2008

\title{
An Archaeological Survey of 3,475 Acres at Camp Swift, Bastrop County, Texas: 2005
}

\author{
David L. Nickels \\ Jessica L. Hurley \\ Center for Archaeological Studies \\ C. Britt Bousman \\ Department of Anthropology, Texas State University
}

Follow this and additional works at: https://scholarworks.sfasu.edu/ita

Part of the American Material Culture Commons, Archaeological Anthropology Commons, Environmental Studies Commons, Other American Studies Commons, Other Arts and Humanities Commons, Other History of Art, Architecture, and Archaeology Commons, and the United States History Commons

Tell us how this article helped you.

This Article is brought to you for free and open access by the Center for Regional Heritage Research at SFA ScholarWorks. It has been accepted for inclusion in Index of Texas Archaeology: Open Access Gray Literature from the Lone Star State by an authorized editor of SFA ScholarWorks. For more information, please contact cdsscholarworks@sfasu.edu. 
An Archaeological Survey of 3,475 Acres at Camp Swift, Bastrop County, Texas: 2005

\section{Creative Commons License}

\section{(c) (1) (8)}

This work is licensed under a Creative Commons Attribution-NonCommercial 4.0 International License 


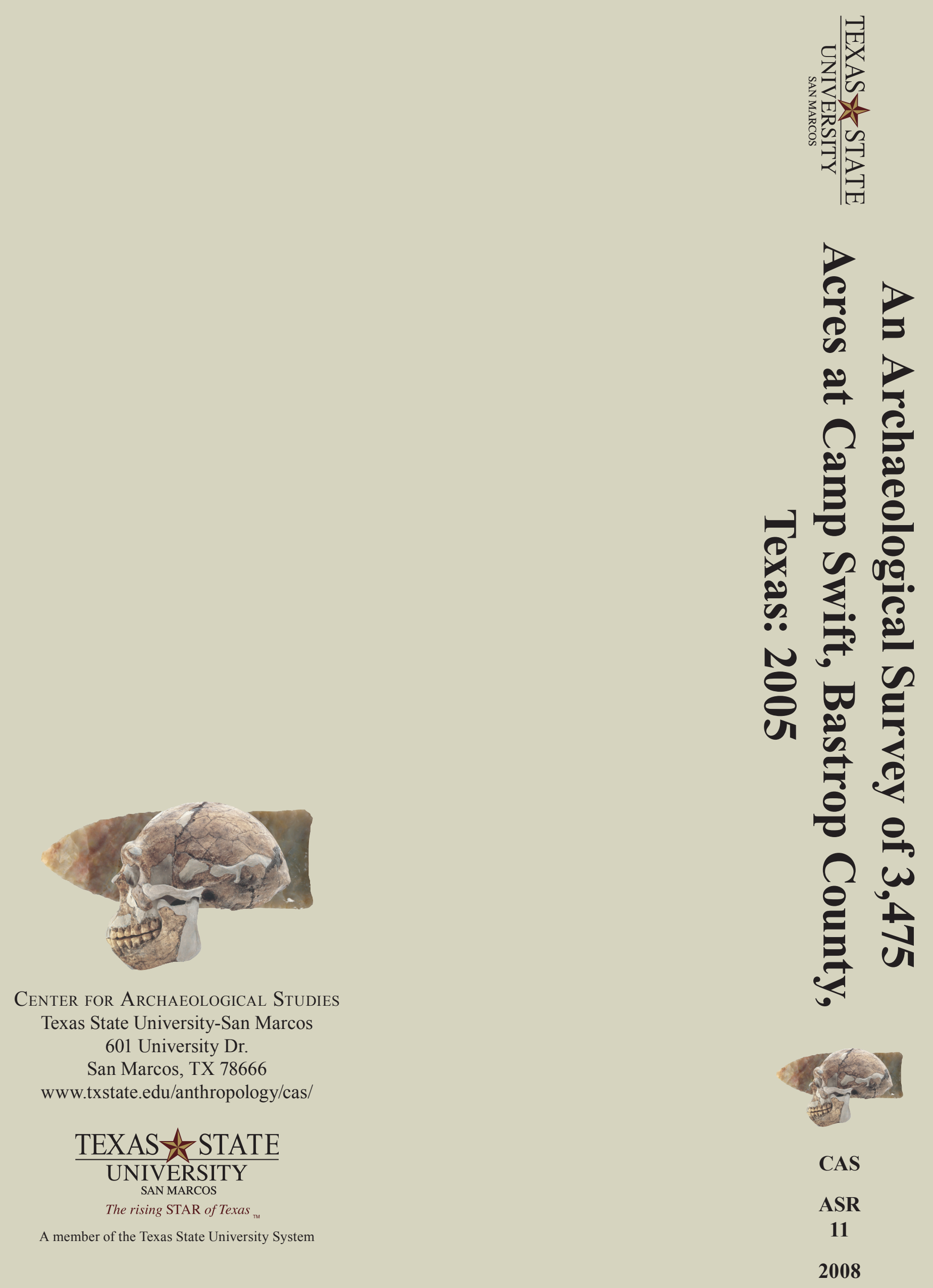

\section{An Archaeological Survey of 3,475 Acres at Camp Swift, Bastrop County, Texas: 2005}

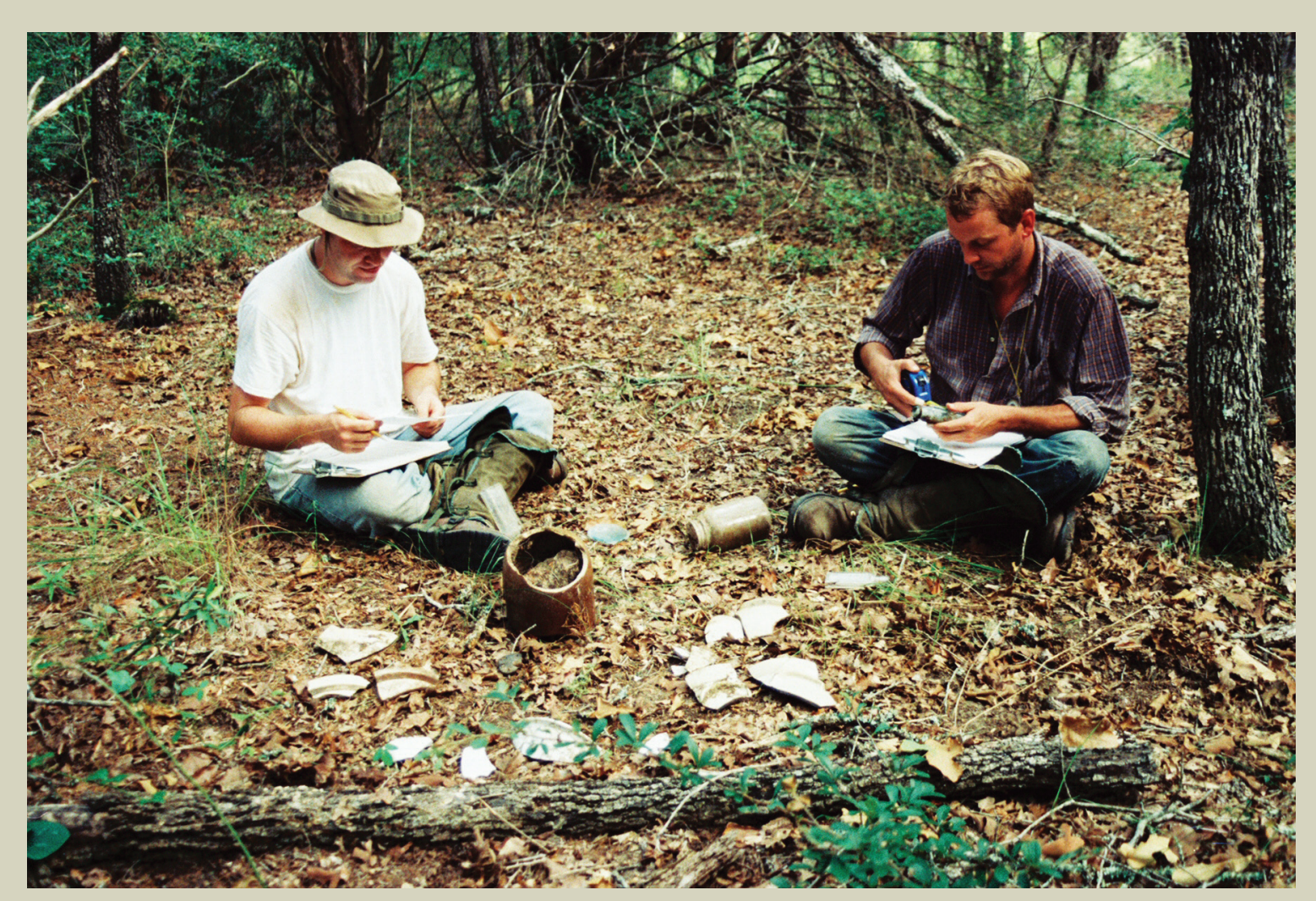

Assembled By David L. Nickels, Jessica L. Hurley, and C. Britt Bousman with contributions by C. Britt Bousman, Jessica L. Hurley, Jon C. Lohse, David L. Nickels, Damon P. Stone, Bob Wishoff, and D. Emory Worrell Principal Investigator: C. Britt Bousman

Archaeological Studies Report No. 11

Center for Archaeological Studies Texas State University-San Marcos 2008 


\title{
An Archaeological Survey of 3,475 Acres at Camp Swift, Bastrop County, Texas: 2005
}

\author{
assembled by
}

David L. Nickels, Jessica L. Hurley and C. Britt Bousman

with contributions by

C. Britt Bousman, Jessica L. Hurley, Jon C. Lohse, David L. Nickels, Damon P. Stone, Bob Wishoff, and D. Emory Worrell

Principal Investigator:

C. Britt Bousman

Archaeological Studies Report No. 11

Center for Archaeological Studies

Texas State University-San Marcos

2008 
The following information is provided in accordance with the General Rules of Practice and Procedures, Title 13, Chapter 26, Texas Administrative Code:

1. Type of investigation: Pedestrian survey with systematic placement of shovel tests.

2. Project name: Swift VI

3. County: Bastrop

4. Principal Investigator: C. Britt Bousman

5. Name and location of sponsoring agency: Texas Military Forces, Adjutant General's Department, P.O. Box 5218, Austin, Texas 78763

6. Published by the Center for Archaeological Studies, Texas State University-San Marcos, 601 University

Drive, San Marcos, Texas, 78666-4616 (2008)

Texas State University-San Marcos is a member of the Texas State University System Copyright (C) 2008 by the Center for Archaeological Studies at Texas State University-San Marcos

All rights reserved.

No part of this book may be reproduced or utilized in any form or by any means,

electronic or mechanical, including photocopying, recording,

or by any information storage and retrieval system

without permission in writing.

For further information on this and other publications by

the Center for Archaeological Studies, please contact:

Center for Archaeological Studies

Texas State University-San Marcos

601 University Drive

San Marcos, TX 78666-4616

www.txstate.edu/anthropology/cas

Editors: Jessica L. Hurley and Maggie McClain

Cover Photograph: Emory Worrell and David Peyton

documenting historic artifacts at $41 B P 490$.

Printed in the United States

by

Ginny’s Printing, Inc., Austin 


\section{Management Summary}

\section{Management Objectives}

The Texas Military Forces (TXMF) conducts military training on Camp Swift, an approximately 11,500-acre tract in northern Bastrop County, Texas. TXMF is responsible for complying with federal legislation regarding the assessment and management of environmental and cultural resources. This cultural resource inventory by the Center for Archaeological Studies (CAS), Texas State UniversitySan Marcos, was conducted between November 2005 and October 2006, under Section 106 and 110 of the National Historic Preservation Act (NHPA). During the survey of 3,475 acres, 168 sites were recorded and 110 of these were newly discovered sites; however, five of these sites were outside of the survey boundary. Fifty-eight sites had been discovered by previous archaeological projects, but four of them could not be relocated. The 54 sites that were relocated were more fully documented in this report. Based on area, the site densities have increased three-fold. These results provide a more accurate inventory of prehistoric and historic sites at Camp Swift and demonstrate that intensive surveys linked with systematic shovel test excavations are the most dependable method for discovering sites at this facility.

\section{Summary and Recommendations}

During this intensive survey, a shovel test was excavated every $30 \mathrm{~m}$, covering 3,475 actual surveyed acres resulting in the excavation of 11,015 transect shovel tests. Of these transect shovel tests, 453 were positive and 10,562 were negative. An additional 16 acres covering site boundaries outside of the survey area were further assessed with shovel tests. This resulted in a total area assessed with shovel tests of approximately 3,491 acres. During this project, CAS archaeologists encountered or searched for 168 sites, discovering 110 new ones and revisiting 54 previously recorded sites; four previously recorded historic sites (41BP164, 41BP167, 41BP434, and 41BP489) could not be relocated. Five sites (41BP124, 41BP381, 41BP771, 41BP775, and 41BP793) were outside of the survey boundary and the latter three are newly discovered. There are 125 prehistoric components and 58 historic components, including four sites that could not be relocated and 15 sites that have both historic and prehistoric components.A total of 12,532 shovel tests were excavated on this project. For the site evaluations, 1,517 shovel tests were excavated within site boundaries in an attempt to evaluate previously recorded sites and establish the boundaries of new sites. Of these, 477 shovel tests were positive and 1040 shovel tests were negative. This survey represents one of the largest investigations of the unique sandy mantle environment in Texas. The Sandy Mantle is a large expanse of surface sandy soils lying above poorly consolidated sandy bedrock deposits that cover approximately one-eighth of the state. Because of this intensive testing, it was possible to develop a detailed map of the sand depths in the mantle at Camp Swift and identify patterns that may correlate with occupation history and site preservation potential. The sandy mantle's greatest depth is found near streams with some deep sands irregularly occurring in uplands. These patterns do not appear to be the result of erosion. In examining site density based on this survey, one site occurs every 21.3 acres with prehistoric sites occurring 1 per 28.3 acres and historic sites 1 per 63.2 acres. When comparing site distribution with water (also area of greatest sand depth), site density is greatest at 20-110 meters from water. Sites are more common in deeper sands 


\section{Management Summary (Continued)}

but it is difficult to draw any conclusions from this initial survey. Based on diagnostic artifacts and radiocarbon dates at Camp Swift, prehistoric occupations began during the Late Pleistocene in low numbers during the Paleoindian Period, dropped during the Middle Archaic (Middle Holocene), and significantly increased during the Late Archaic and Late Prehistoric (Late Holocene). Most historic sites were occupied during late nineteenth century with a secondary surge in occupation during the Depression.

Eighty prehistoric site components are recommended as NOT ELIGIBLE for listing on the National Register of Historic Places (NRHP). Another 45 prehistoric site components are assigned as unknown in terms of NRHP eligibility. CAS recommends that prehistoric site testing include these 45 sites (41BP94, 41BP100, 41BP111, 41BP112, 41BP114, 41BP122, 41BP436, 41BP485, 41BP487, 41BP495, 41BP521, 41BP534, 41BP696, 41BP704, 41BP706, 41BP713, 41BP714, 41BP715, 41BP716, 41BP717, 41BP718, 41BP720, 41BP724, 41BP725, 41BP726, 41BP727, 41BP731, 41BP733, 41BP740, 41BР743, 41BP747, 41BP753, 41BP754, 41BP759, 41BP761, 41BP765, 41BP766, 41BP776, 41BP778, 41BР780, 41BP782, 41BP787, 41BP792, 41BP801, and 41BP802).

Forty-eight historic components are recommended as NOT ELIGIBLE for listing on the NRHP. However, one historic site (41BP159) is recommended as ELIGIBLE, and 9 historic components are of unknown eligibility. It is recommended that further testing be conducted at these ten historic sites (41BP105, 41BP132, 41BP143, 41BP154, 41BP159, 41BP490, 41BP718, 41BP746, 41BP752, and 41BP771). 


\section{Table of Contents}

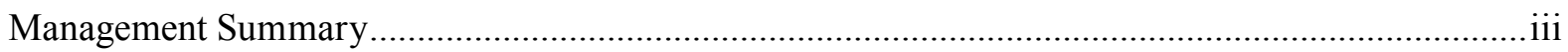

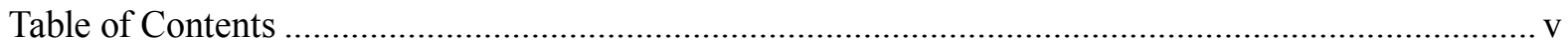

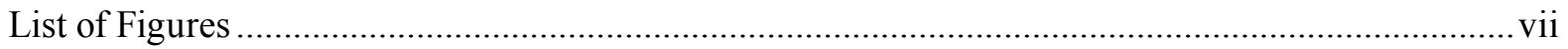

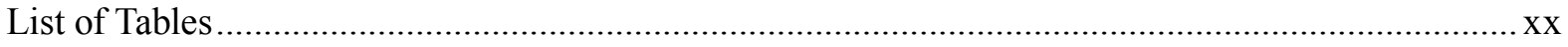

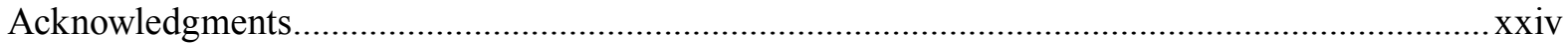

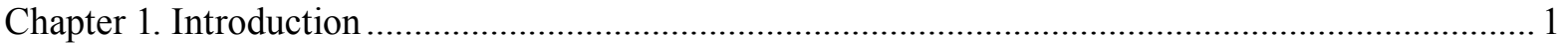

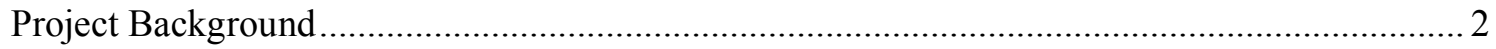

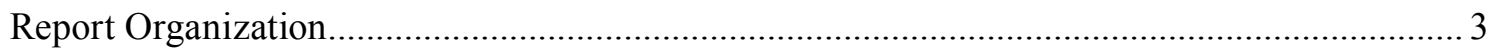

Chapter 2. Project Area Description ......................................................................................... 5

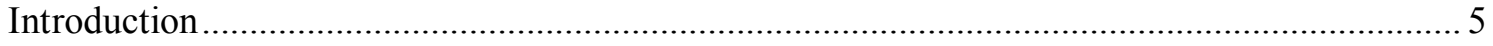

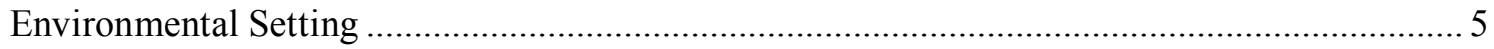

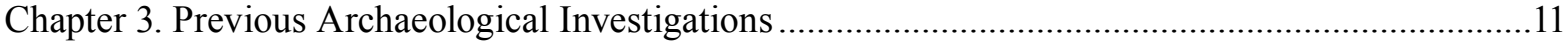

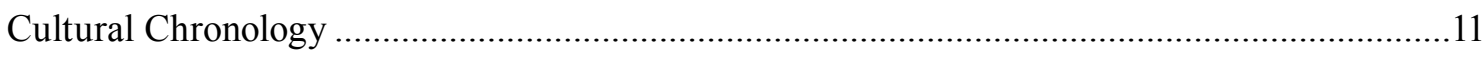

Previous Archaeological Investigations in Bastrop County and Camp Swift ........................... 20

Chapter 4. Research Design and Methods ............................................................................ 25

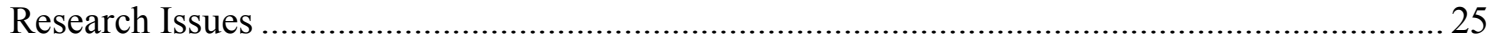

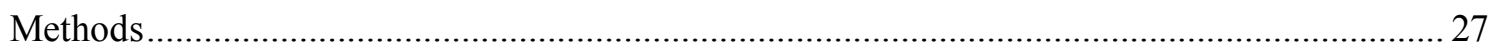

Chapter 5. Prehistoric Component Sites Previously Documented by CAS ........................................ 37

Chapter 6. Prehistoric Component Sites Previously Documented by Other Contractors ................... 63

Chapter 7. New Prehistoric Component Sites.................................................................................. 97

Chapter 8. Previously Documented Historic Component Sites....................................................... 241

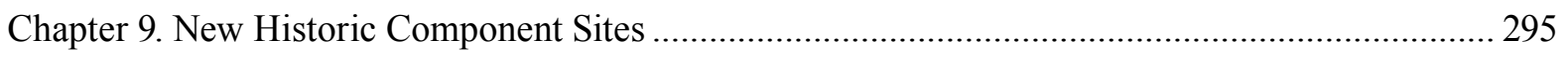

Chapter 10. Prehistoric and Historic Isolated Finds ............................................................... 347

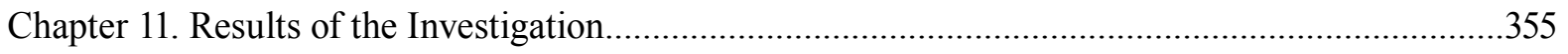

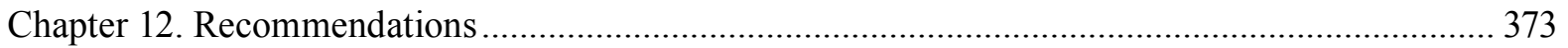

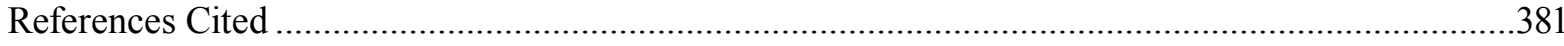

Appendix A. Swift VI Project Site Boundaries (RESTRICTED ACCESS)................. inside back cover

Appendix B. Swift VI Project Isolated Finds (RESTRICTED ACCESS) ................... inside back cover 


\section{Table of Contents (continued)}

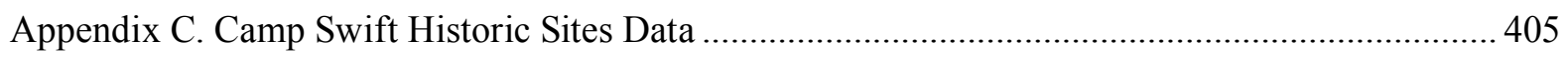




\section{List OF Figures}

1-1. Bastrop County is located in north-central Bastrop County, Texas .......................................... 1

2-1. Location of Bastrop County within the physiographic regions of Texas................................... 5

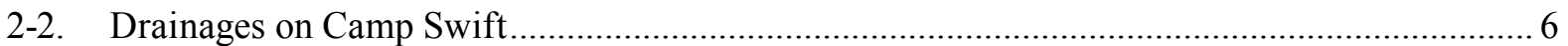

2-3. Deeply incised streams are common on Camp Swift........................................................... 6

2-4. Camp Swift is located within the Post Oak Savannah vegetation region.................................... 8

2-5. Camp Swift lies within the Texan biotic province................................................................ 9

2-6. In addition to Western Diamondbacks, copperheads were commonly seen during

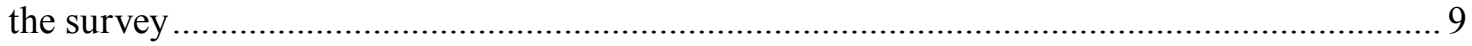

3-1. Cultural chronologies pertinent to the Camp Swift area .................................................... 12

4-1. Areas that are commonly perceived as high probability areas where prehistoric

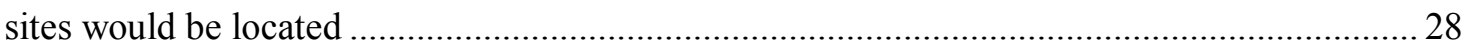

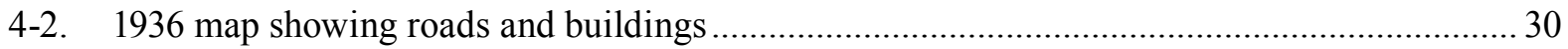

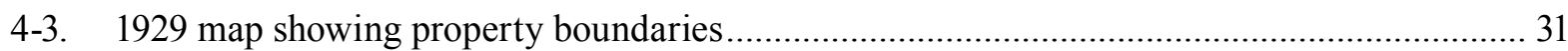

4-4. Emory Worrell and David Peyton documenting historic artifacts at 41BP490 ....................... 34

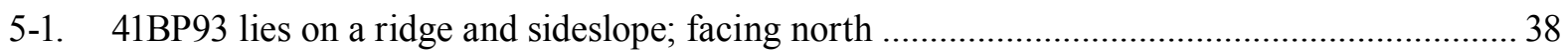

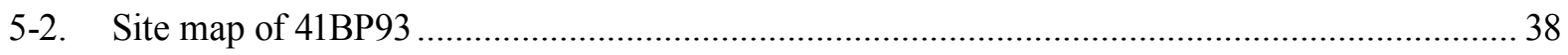

5-3. 41BP94 lies on an old field terrace at the confluence of an intermittent tributary

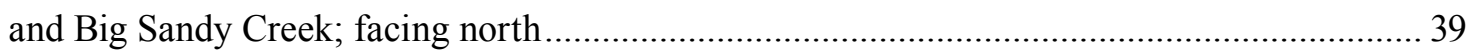

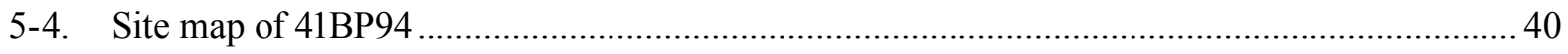

5-5. 41BP100 spans an old field footslope adjacent to McLaughlin Creek; facing southwest .......... 42

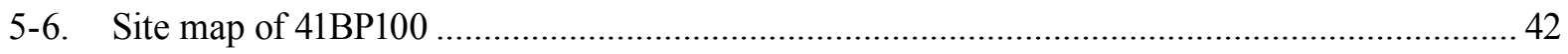

5-7. 41BP105 is a lower terrace site along Big Sandy Creek; facing west ...................................... 44

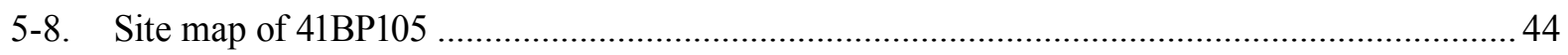

5-9. 41BP111 sets on a wooded ridge and sideslope; facing northwest........................................... 46

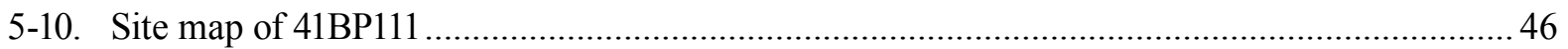

5-11. 41BP112 lies on wooded and grassland sides of an intermittent drainage; facing east ............. 48

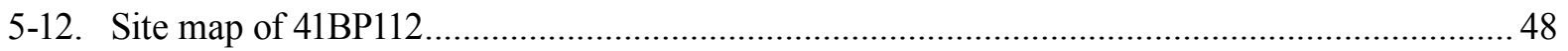

5-13. 41BP121 is situated on a gentle sideslope; photo taken facing north ..................................... 50

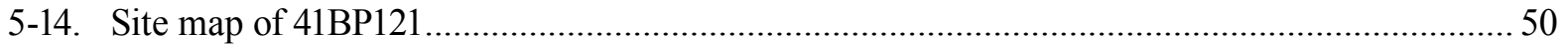

5-15. 41BP123 sets on a wooded, gentle sideslope above a tributary of McLaughlin Creek;

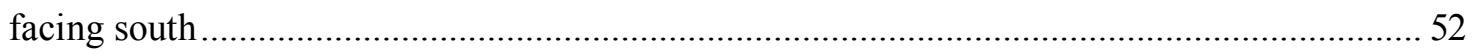

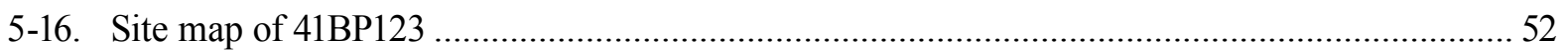

5-17. 41BP127 sets on a grassy, upper terrace adjacent to Dogwood Branch; facing west................ 53

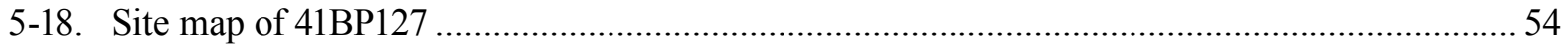

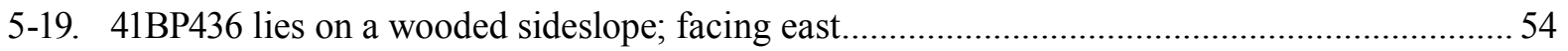

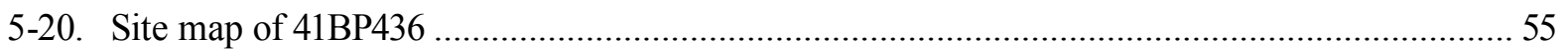

$5-21$. This is the lower, southern portion of 41BP485; facing southwest ....................................... 56

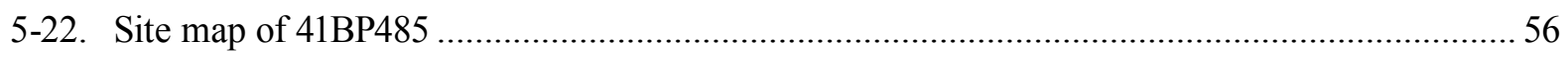

5-23. 41BP491 lies in a wooded upland setting, adjacent to 41BP495, a multi-component

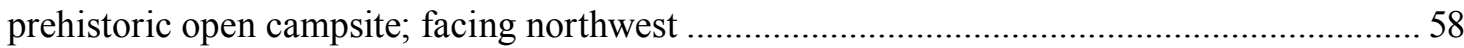




\section{List OF Figures (CONTinued)}

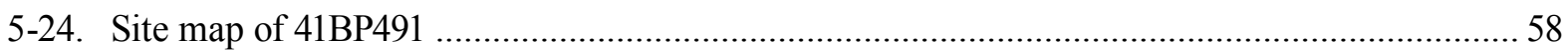

5-25. 41BP495 is an open campsite in a wooded, upland setting; facing east ................................... 60

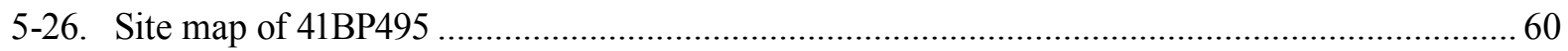

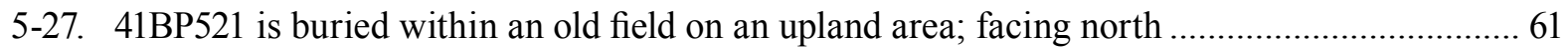

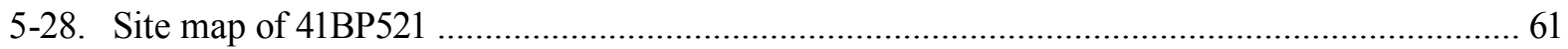

6-1. 41BP95 is a prehistoric open campsite in both a wooded area and an adjoining

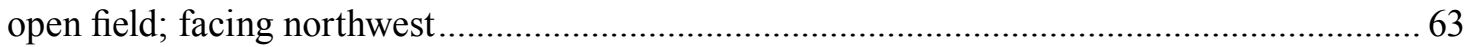

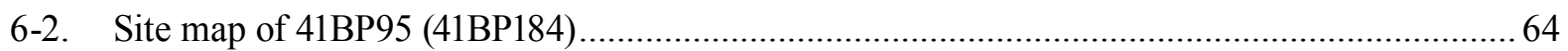

6-3. Chert cobbles are eroding out on a drainage slope at 41BP96; facing south ............................ 66

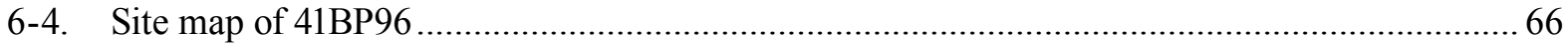

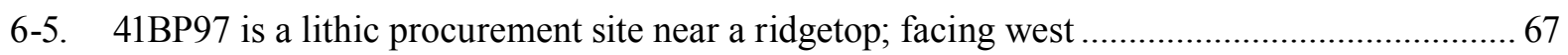

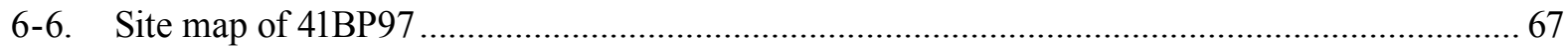

6-7. $41 \mathrm{BP} 99$ is a lithic procurement site north of McLaughlin Creek; facing southeast .................. 68

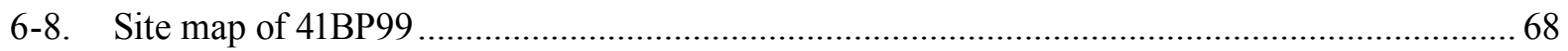

6-9. 41BP101 is a lithic procurement site north of McLaughlin Creek; facing east......................... 69

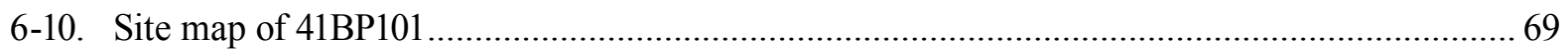

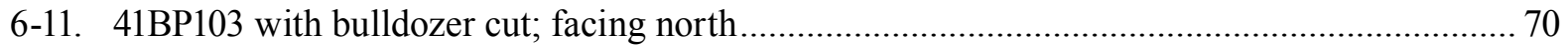

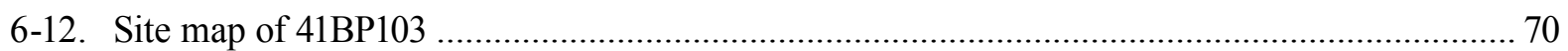

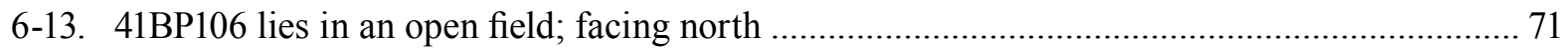

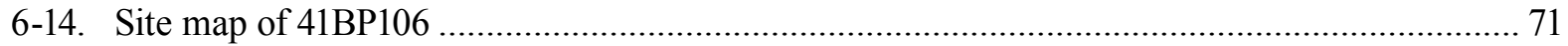

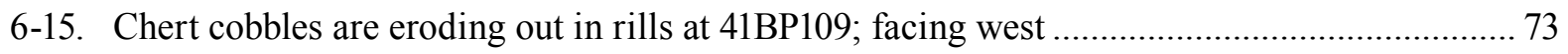

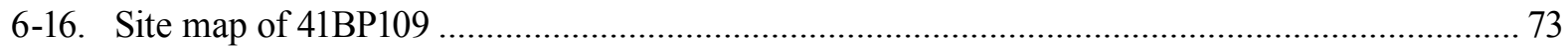

6-17. 41BP114 is an open campsite near the confluence of two streams; facing east ....................... 74

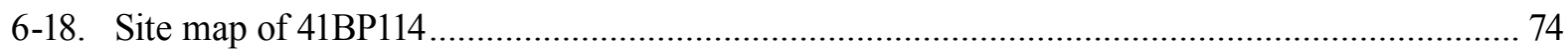

6-19. 41BP119 is an open campsite on the lower slopes of a knoll; facing north.............................. 75

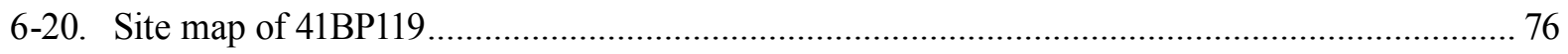

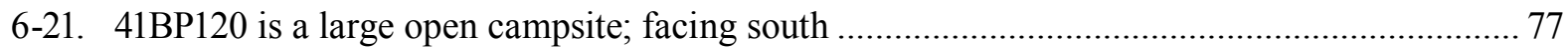

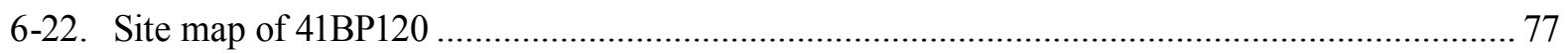

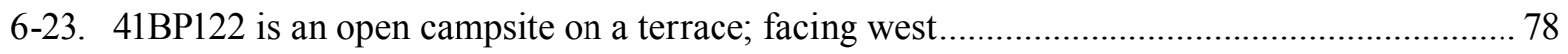

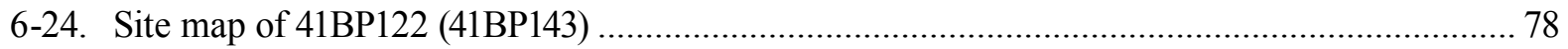

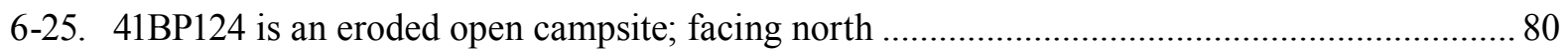

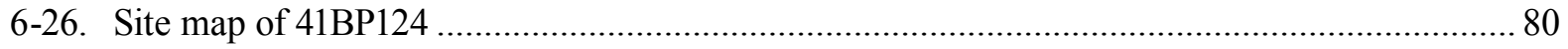

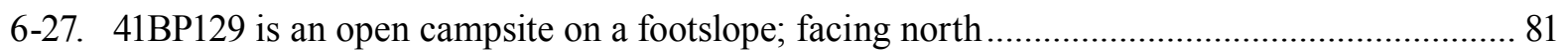

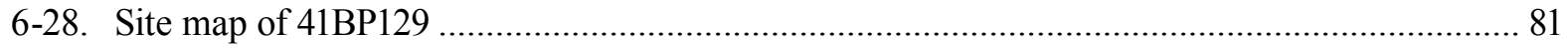

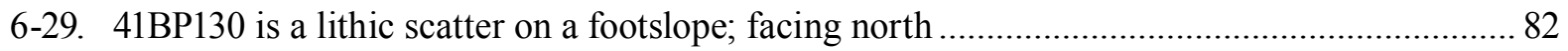

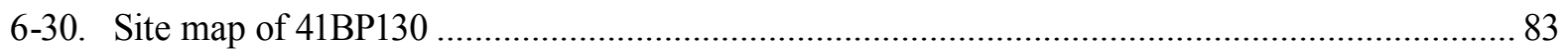

6-31. 41BP131 is an open campsite on the north side of Dogwood Branch; facing southwest........... 84

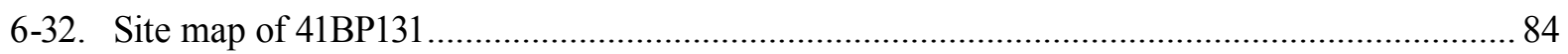

6-33. 41BP366 is an open campsite along a tributary of Harris Creek; facing south ....................... 85

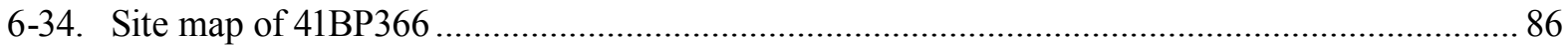




\section{List OF Figures (CONTinued)}

6-35. $41 \mathrm{BP} 367$ is another open campsite along a tributary of Harris Creek; facing south................ 87

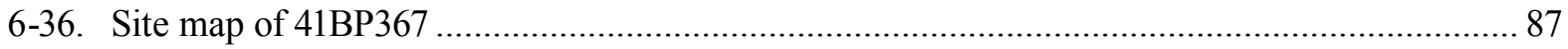

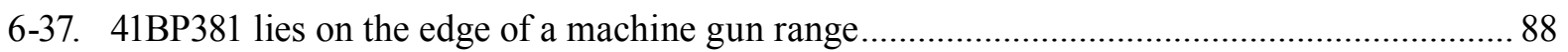

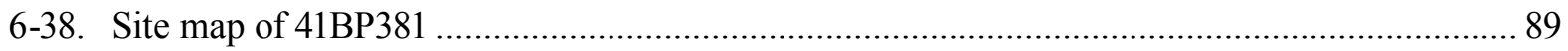

6-39. The eroded eastern slope at 41BP433 has a few prehistoric artifacts; facing north ................. 89

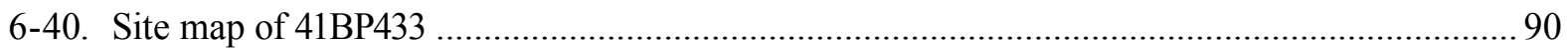

6-41. $41 \mathrm{BP} 472$ is a lithic scatter above Big Sandy Creek; facing west ........................................... 90

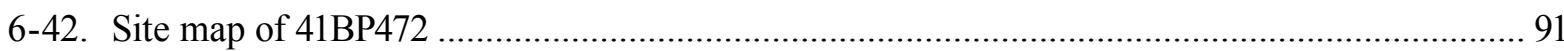

6-43. Cultural remains at $41 \mathrm{BP} 487$ are buried in this T2 terrace adjacent to Big Sandy

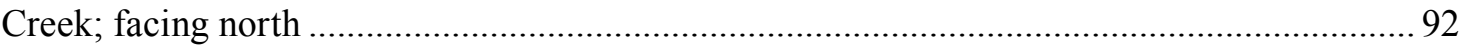

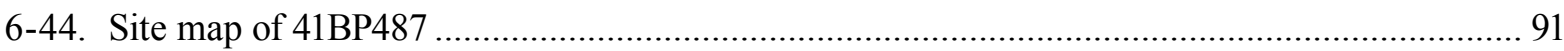

6-45. A scatter of flakes and heat spalls make up the lithic assemblage at 41BP494;

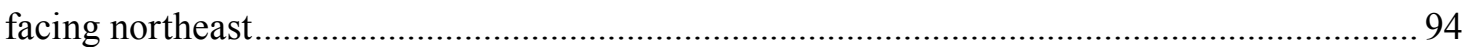

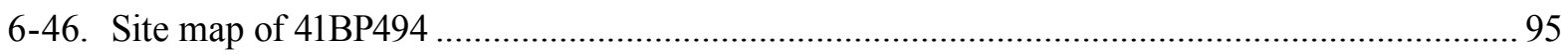

7-1. $\quad$ 41BP534 lies on a cleared field in an upland and wooded sideslope area; facing southeast...... 98

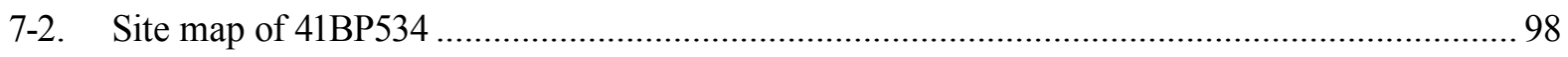

7-3. 41BP695 lies on a heavily wooded sideslope; facing southeast ........................................... 100

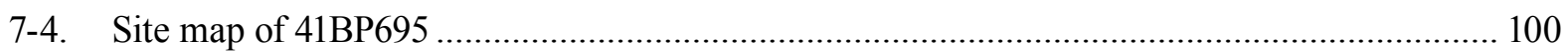

7-5. 41BP696 lies on a partially wooded and partially cleared field upland area;

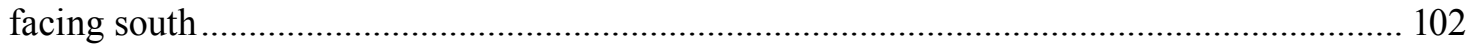

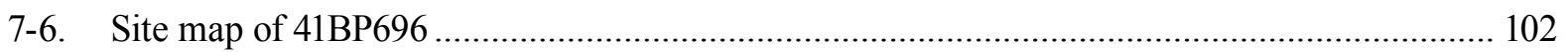

7-7. 41BP697 lies on a ridge end and sideslope; facing southeast ............................................... 104

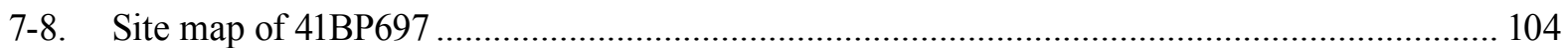

7-9. 41BP699 lies on a semi-wooded sideslope; facing north ...................................................... 105

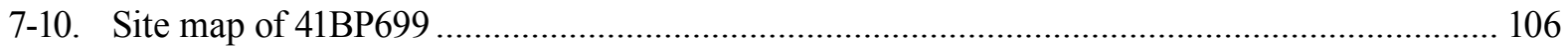

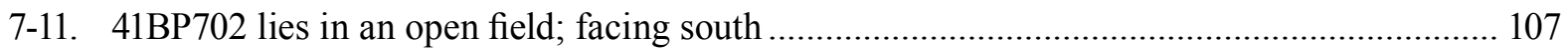

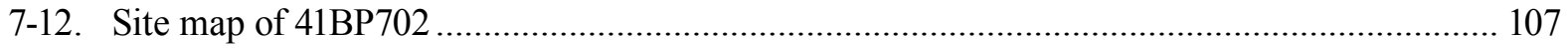

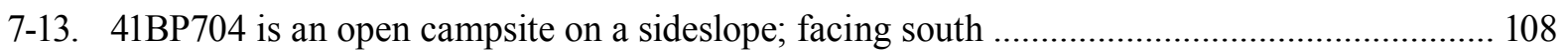

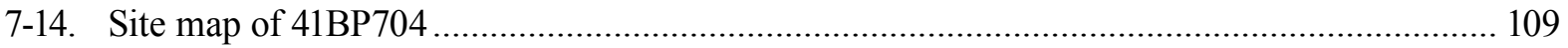

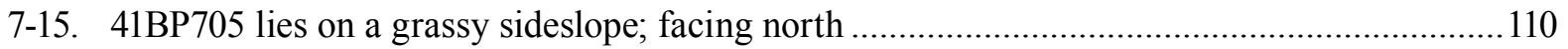

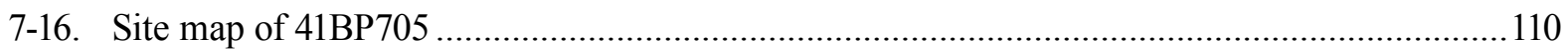

7-17. 41BP706 lies on a lower terrace adjacent to the floodplain of Big Sandy Creek;

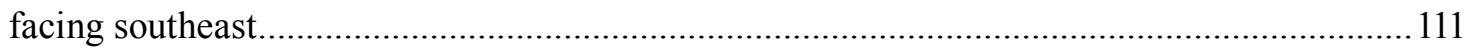

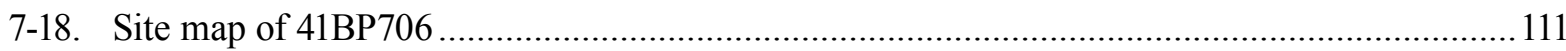

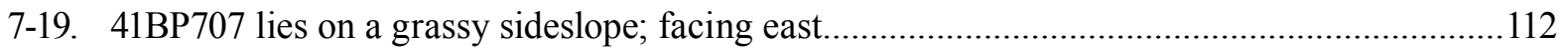

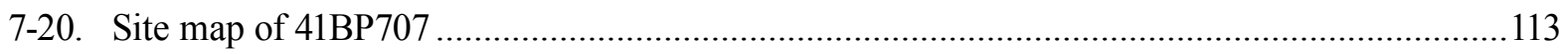

7-21. 41BP708 lies on a partially wooded sideslope; facing northeast ............................................. 114

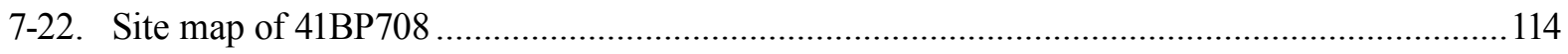

7-23. 41BP709 lies on a semi-wooded sideslope; facing south ....................................................115

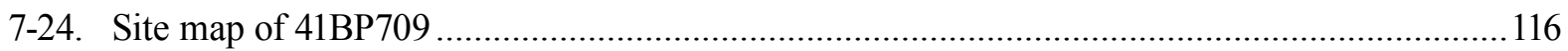




\section{List OF Figures (CONTinued)}

7-25. 41BP710 lies on a heavily wooded sideslope along Spring Branch; facing east......................117

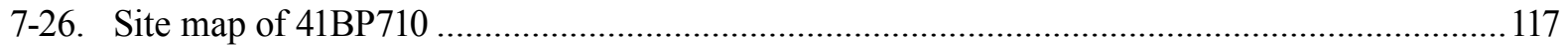

7-27. $41 \mathrm{BP713}$ is an open campsite on a wooded sideslope; facing south .......................................118

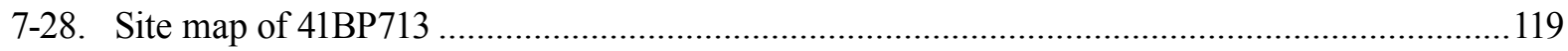

7-29. 41BP714 lies on a wooded upland and sideslope setting; facing west ................................... 120

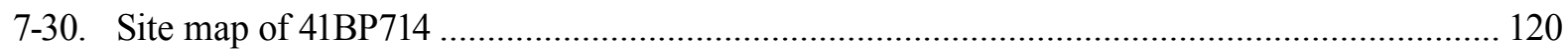

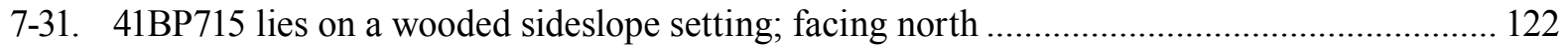

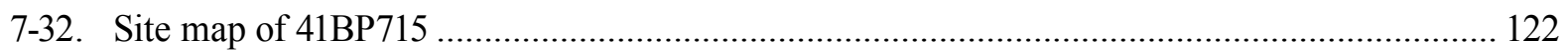

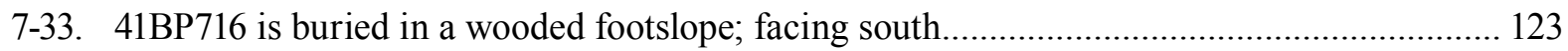

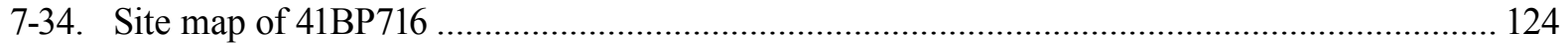

7-35. 41BP717 is buried in a wooded upland ridge; facing southeast ............................................ 125

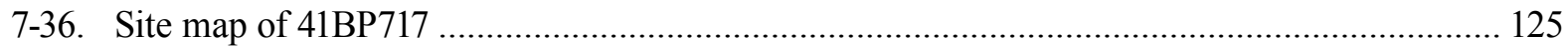

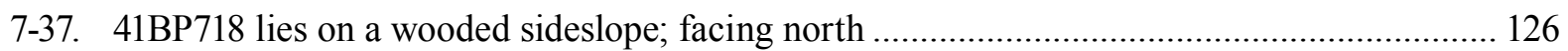

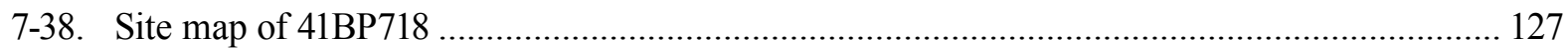

7-39. 41BP719 lies on a wooded upland and sideslope setting; facing south................................. 128

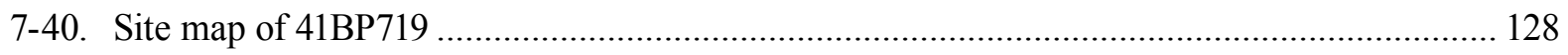

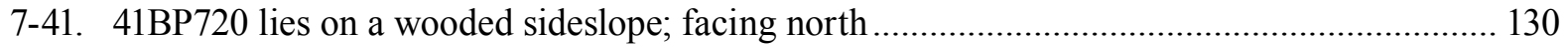

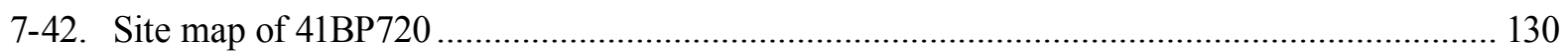

7-43. 41BP721 lies on a lower terrace at the confluence of Big Sandy Creek and an

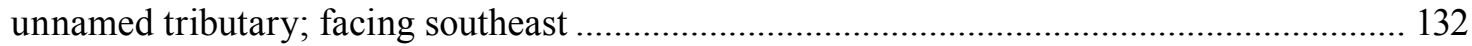

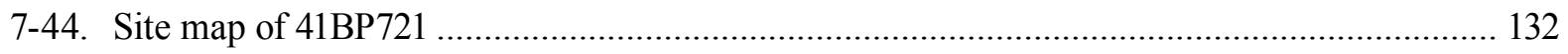

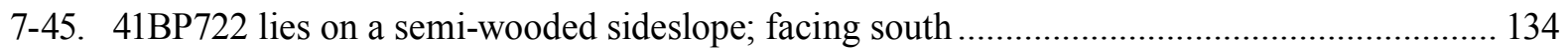

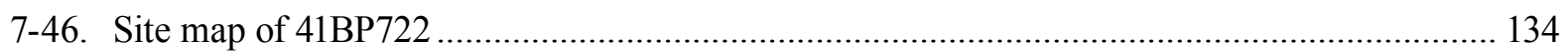

7-47. This Scallorn point was found between 50 and $60 \mathrm{cmbs}$ in ST 13 at $41 \mathrm{BP} 722$.......................135

7-48. 41BP723 lies on a semi-wooded grassland; facing northeast ................................................ 136

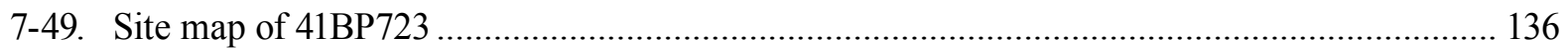

7-50. 41BP724 lies on a broad terrace setting; facing northeast.................................................. 138

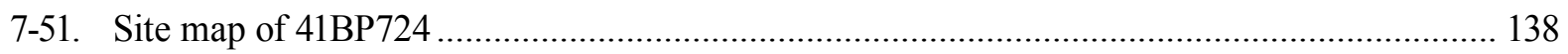

7-52. 41BP725 lies on a ridge end and sideslope; facing southeast ............................................. 139

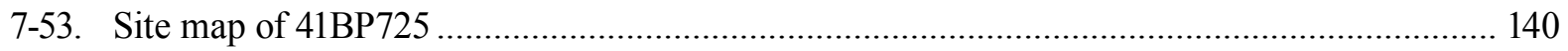

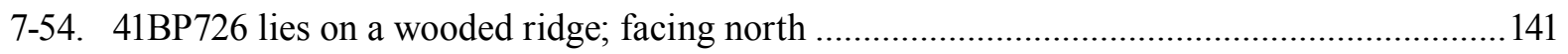

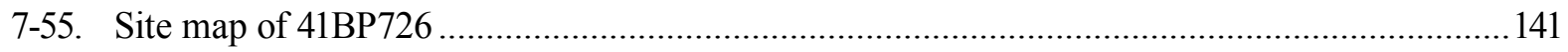

7-56. 41BP727 lies on an upper terrace adjacent to the floodplain of Big Sandy Creek;

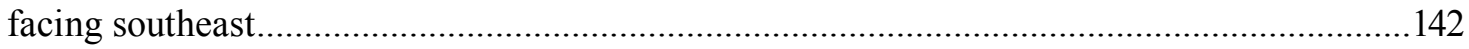

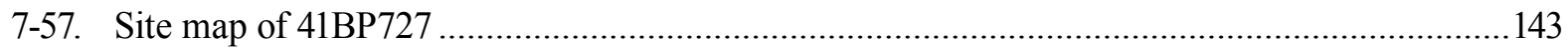

7-58. 41BP728 lies on a partially wooded footslope; facing northeast .......................................... 144

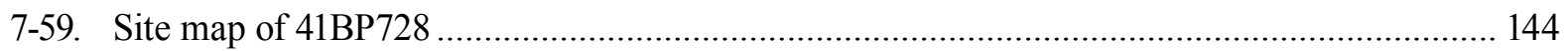

7-60. Quartzite hammerstone/mano, petrified wood chopping tool, and large flake found

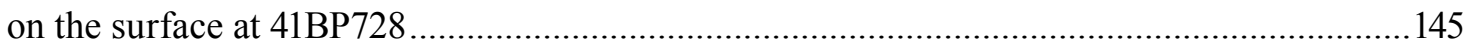

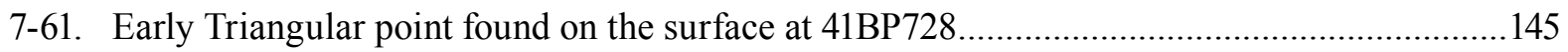




\section{List OF Figures (Continued)}

7-62. 41BP730 spans a grassy ridge and wooded sideslope; facing southwest.............................. 146

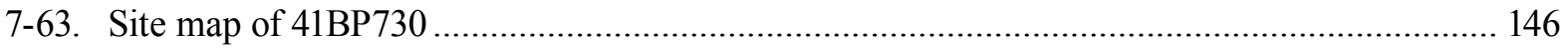

7-64. 41BP731 lies on a T1 terrace adjacent to Big Sandy Creek; facing north .............................. 148

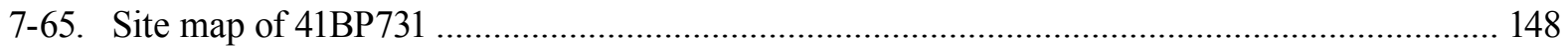

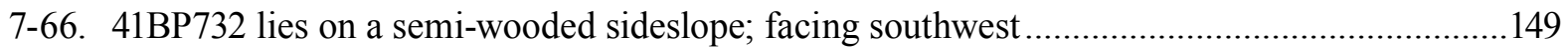

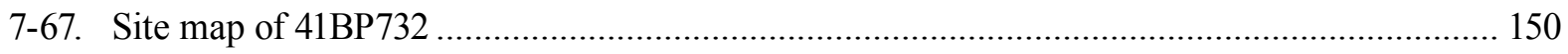

7-68. 41BP733 lies on a wooded and partially cleared sideslope setting; facing southeast..............151

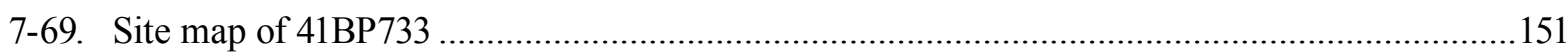

7-70. $41 \mathrm{BP} 734$ is a prehistoric lithic scatter mixed with historic artifacts and

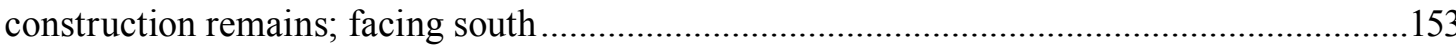

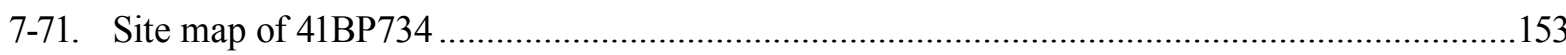

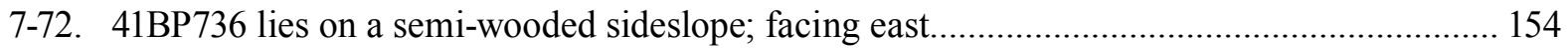

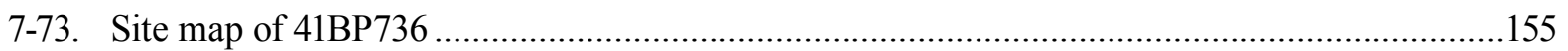

7-74. 41BP737 lies on an eroded, semi-wooded sideslope; facing east ......................................... 156

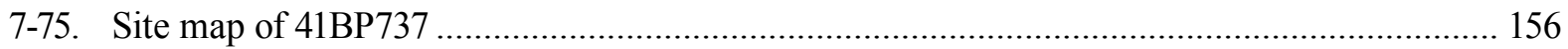

7-76. 41BP738 lies on a heavily disturbed, semi-wooded sideslope; facing north .........................157

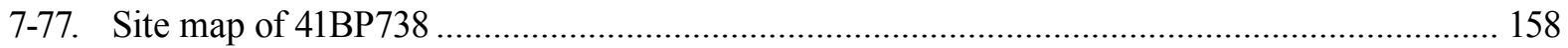

7-78. $41 \mathrm{BP} 739$ is in a semi-wooded grassy field; facing northeast.............................................. 159

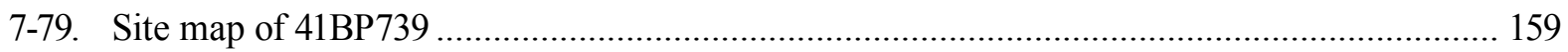

7-80. 41BP740 lies on broad footslope with deep, fine sand; facing northeast................................. 160

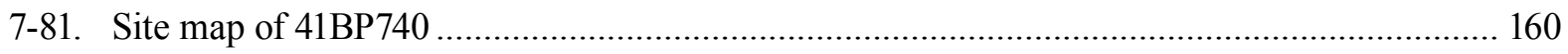

7-82. 41BP742 lies on a narrow ridge that has been cleared, plowed, and occupied as a

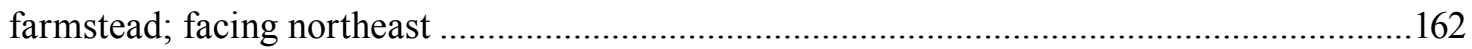

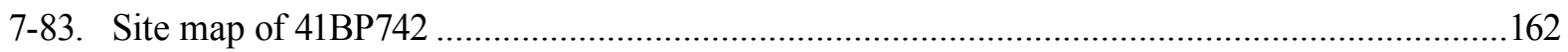

7-84. 41BP743 lies on a lower footslope near McLaughlin Creek; facing east..................................163

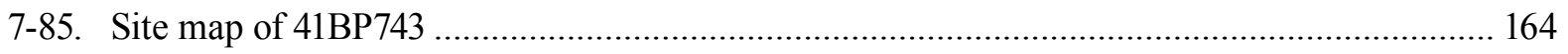

7-86. 41BP744 lies on a heavily disturbed, semi-wooded sideslope; facing north ...........................165

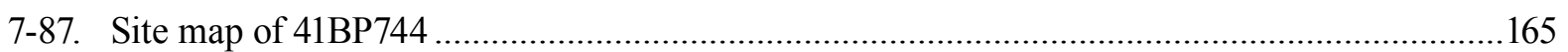

7-88. 41BP745 lies on a lower terrace area that has been partially bulldozed and has a

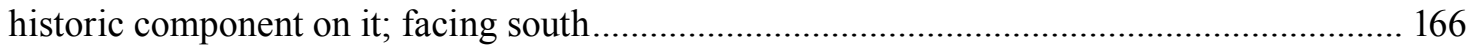

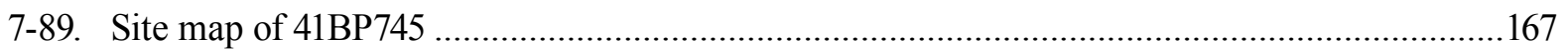

7-90. $41 \mathrm{BP} 147$ is an open campsite in a heavily wooded area along an intermediate tributary to its confluence with McLaughlin Creek; facing north ........................................................ 168

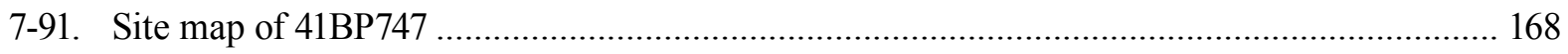

7-92. 41BP748 is a small open campsite that has apparently been disturbed by the

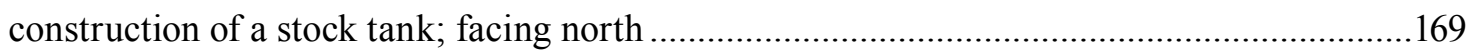

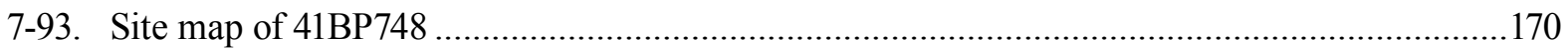

7-94. $41 B P 749$ is an open campsite that lies in an old field above the McLaughlin Creek

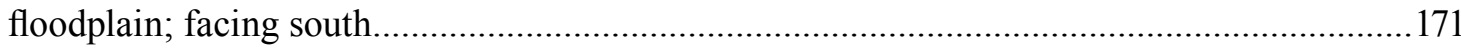

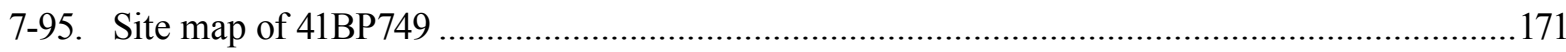




\section{List OF Figures (Continued)}

7-96. 41BP750 is an open campsite that lies in an old field above the McLaughlin Creek

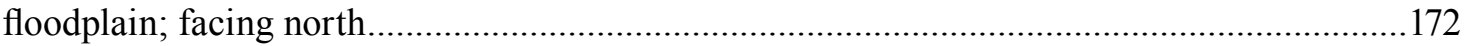

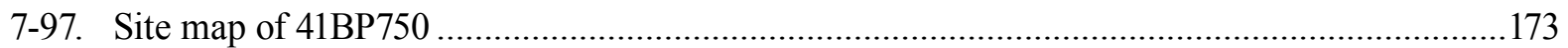

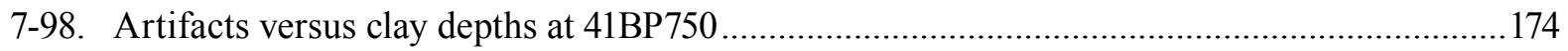

7-99. 41BP753 is an open campsite on a heavily wooded sideslope above a McLaughlin

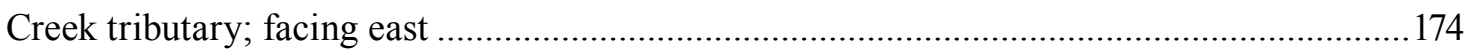

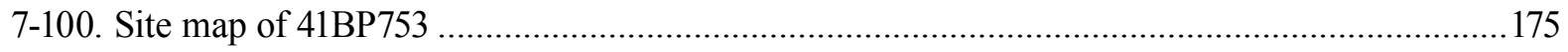

7-101. 41BP754 is another open campsite on a heavily wooded sideslope above a tributary

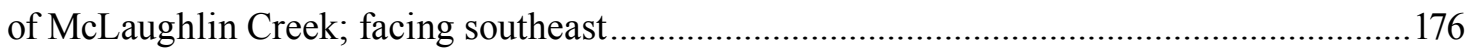

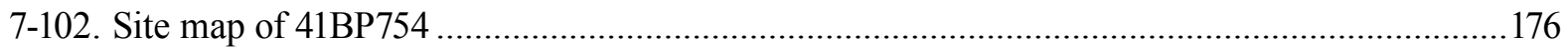

7-103. 41BP755 is an open campsite on an old field and wooded area adjacent to an

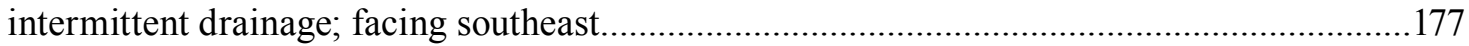

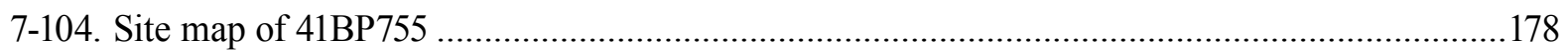

7-105. 41BP756 is a small open campsite on an upland sideslope; facing northeast ..........................179

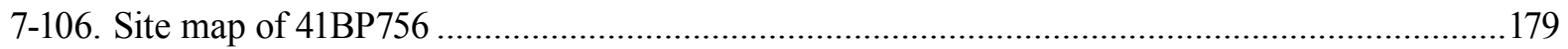

7-107. 41BP757 is a large open campsite on an upland ridge and sideslope; facing east .................. 180

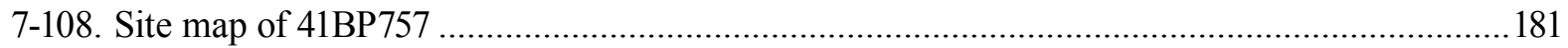

7-109. 41BP758 is a large open campsite on an upland ridge and sideslope; facing southeast............182

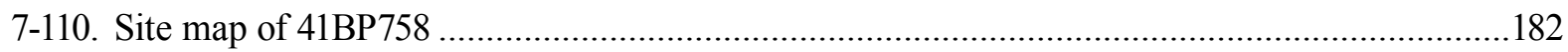

7-111. 41BP759 is an open campsite on an upland ridge and sideslope; facing southeast...................183

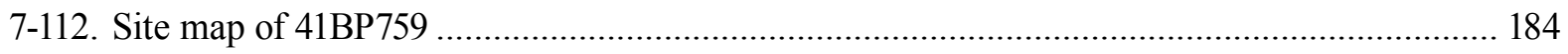

7-113. 41BP761 is an open campsite on a wooded footslope; facing east.........................................185

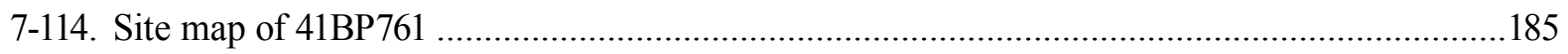

7-115. 41BP762 is an open campsite on a wooded sideslope; facing southwest............................... 186

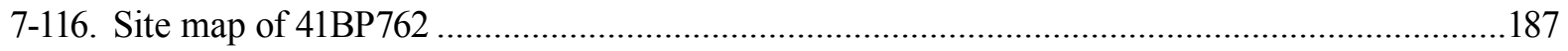

7-117. 41BP763 is an open campsite on a wooded sideslope; facing northeast................................ 188

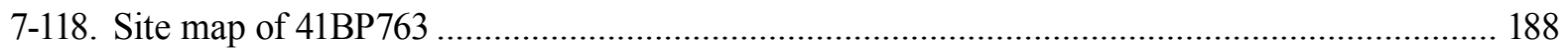

7-119. 41BP764 is an ephemeral lithic scatter just south of McLaughlin Creek; facing northeast.....189

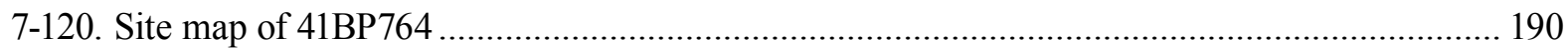

7-121. 41BP765 is a very large open campsite with at least one buried hearth; facing northwest ......191

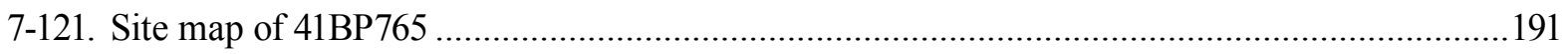

7-123. 41BP766 is a very large open campsite with two scattered surface hearths and

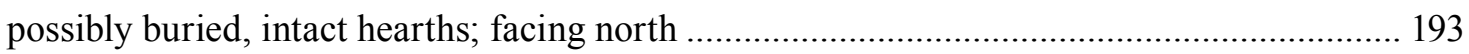

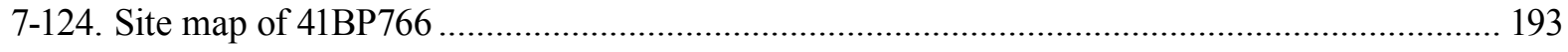

7-125. A sparse scatter of lithic debitage constitutes 41BP768; facing east ..................................... 195

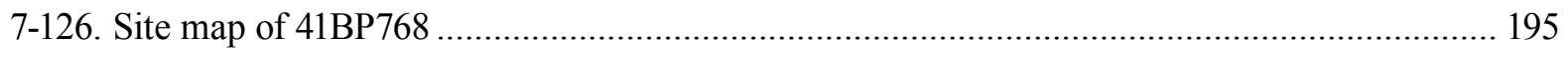

7-127. 41BP769 is an open campsite on a sideslope $400 \mathrm{~m}$ west of McLaughlin Creek;

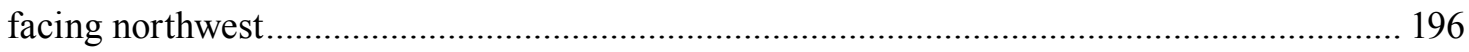

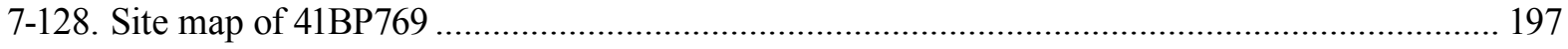

7-129. 41BP770 is a lithic scatter adjacent to McLaughlin Creek; facing southeast ........................ 198 


\section{List OF Figures (Continued)}

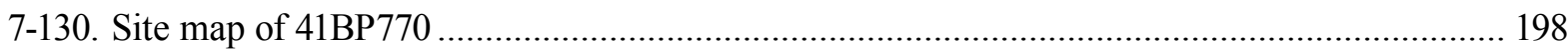

7-131. A bladed right-of-way has exposed burned rocks and flakes at 41BP772; facing north.......... 199

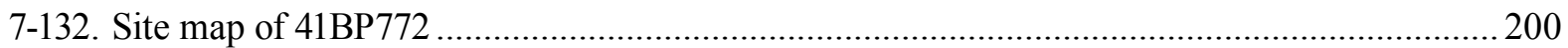

7-133. 41BP774 is an open campsite near the confluence of Dogwood Branch Creek and an

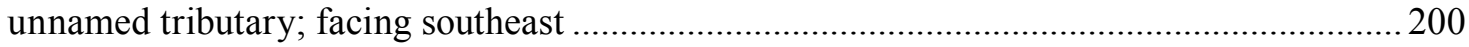

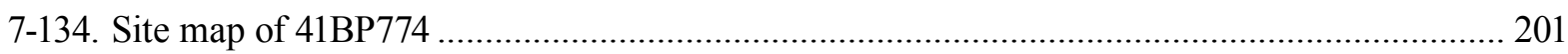

7-135. 41BP776 is an open campsite that borders Dogwood Branch Creek; facing south ................ 202

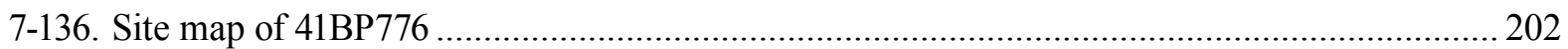

7-137. 41BP777 is small lithic scatter $60 \mathrm{~m}$ west of a tributary of Dogwood Branch Creek;

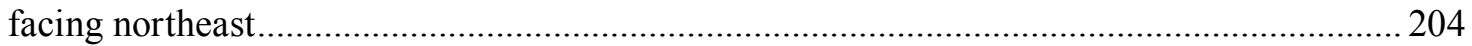

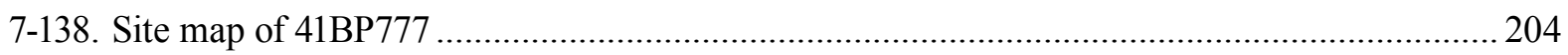

7-139. 41BP778 is a small open campsite on the edge of a powerline right-of-way; facing

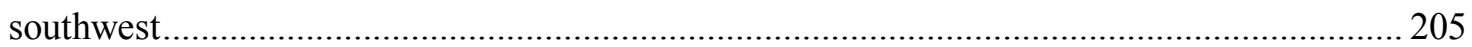

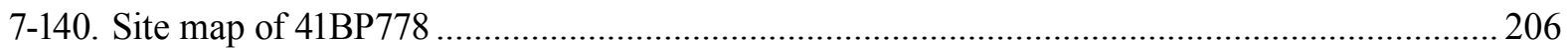

7-141. 41BP779 is another small lithic scatter just west of a tributary of Dogwood Branch

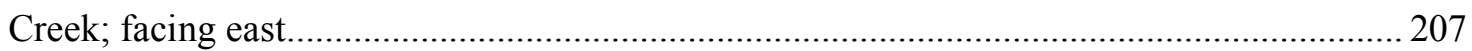

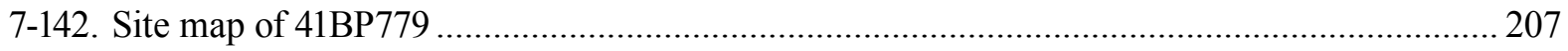

7-142. 41BP780 is an open campsite in an upland setting, $90 \mathrm{~m}$ from a tributary of

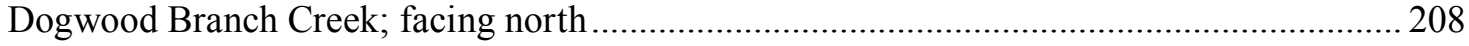

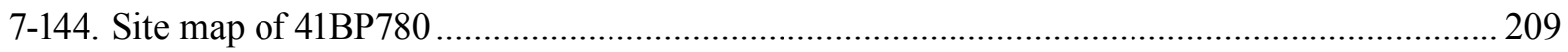

7-145. 41BP781 is an eroded open campsite on a sideslope near a tributary of Dogwood

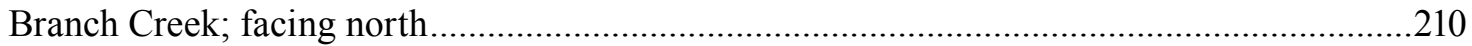

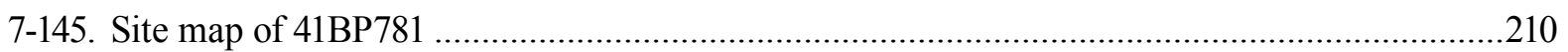

7-147. 41BP782 is a very large open campsite on an inside meander of Dogwood Branch

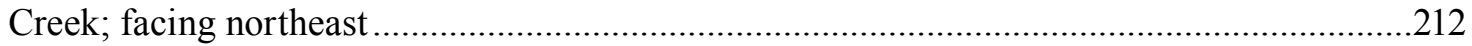

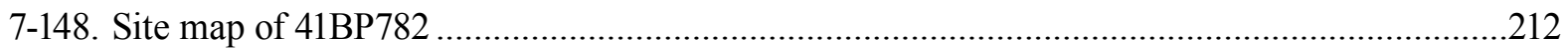

7-149. 41BP783 is an eroded open campsite on a lower terrace and floodplain of

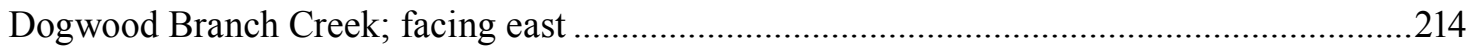

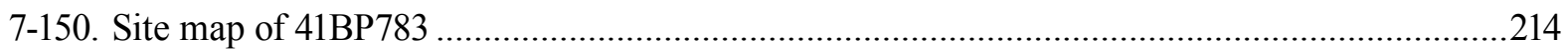

7-151. 41BP784 is an eroded open campsite on a knoll and slope south of Dogwood Branch

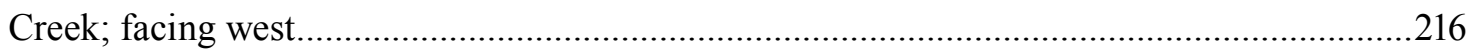

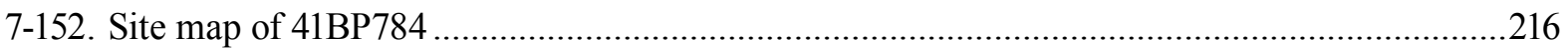

7-153. 41BP786 is a large open campsite bordering on Big Sandy Creek; facing west .....................218

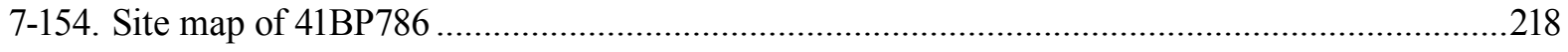

7-155. 41BP787 is an open campsite on a heavily wooded footslope by Spring Branch;

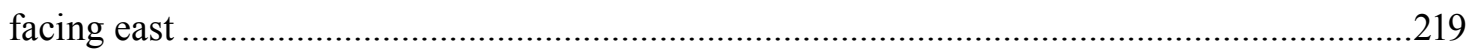

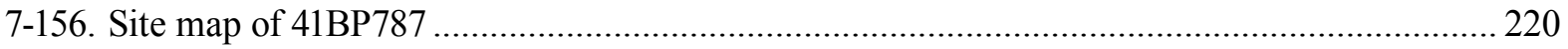

7-157. 41BP788 is an open campsite on a footslope and floodplain alongside Dogwood Branch Creek; facing north. 


\section{List OF Figures (CONTINued)}

7-158. Site map of 41BP788

7-159. 41BP789 is a small open campsite on a lower terrace of Dogwood Branch Creek;

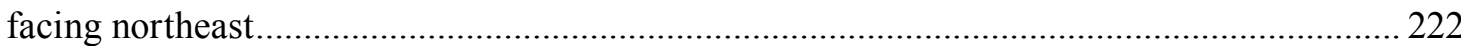

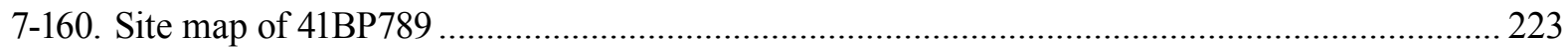

7-161. 41BP790 is a lithic scatter on an inside meander of Dogwood Branch Creek; facing

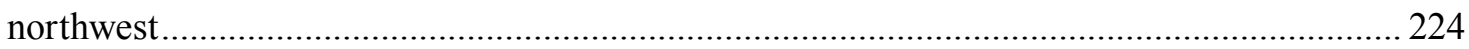

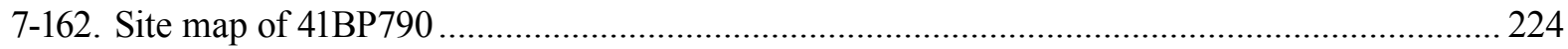

7-163. 41BP792 is an open campsite along Dogwood Branch Creek; facing east............................ 225

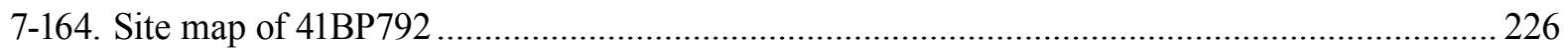

7-165. This sandstone mano/metate was found on the surface at 41BP792 _.................................. 226

7-166. 41 BP796 is an open campsite on a low ridge above Dogwood Branch Creek; facing

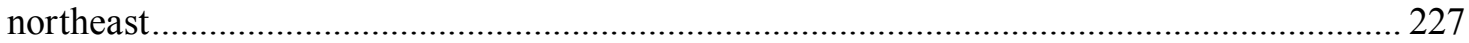

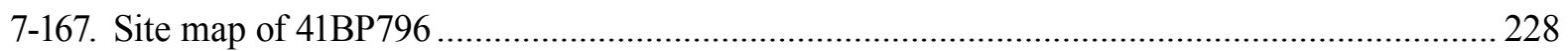

7-168. 41BP797 is an open campsite on a sideslope near Dogwood Branch Creek; facing north...... 229

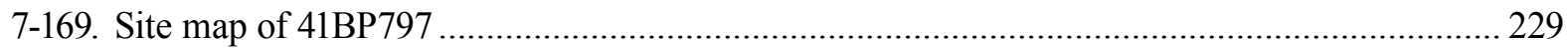

7-170. 41BP798 is a small lithic scatter on a sideslope $70 \mathrm{~m}$ from Dogwood Branch Creek;

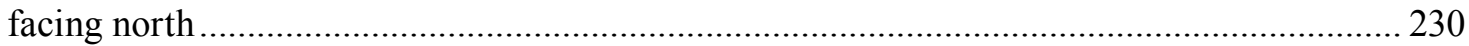

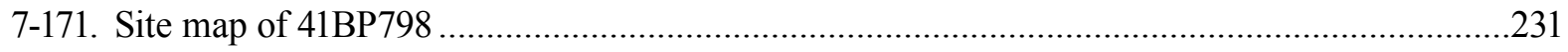

7-172. 41BP799 is a lithic scatter on a heavily wooded footslope; facing north ............................ 232

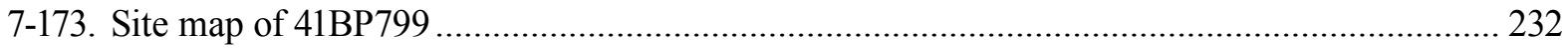

7-174. 41BP800 is an open campsite in a heavily wooded area; facing east ................................... 233

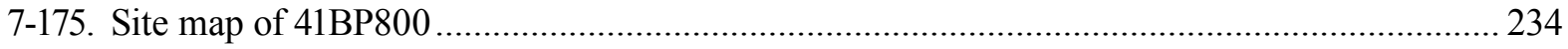

7-176. 41BP801 is an open campsite in a semi-wooded area; facing west ...................................... 235

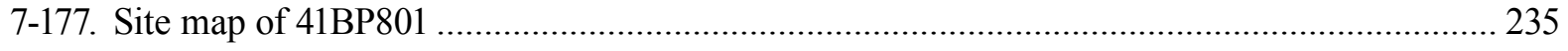

7-178. 41BP802 is an open campsite in a cleared area; facing northeast .......................................... 236

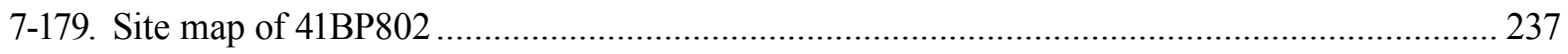

7-180. 41BP804 is an ephemeral lithic scatter on a heavily disturbed sideslope area;

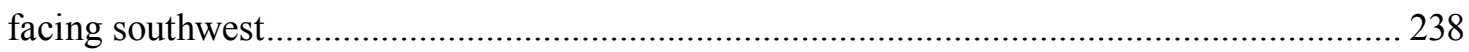

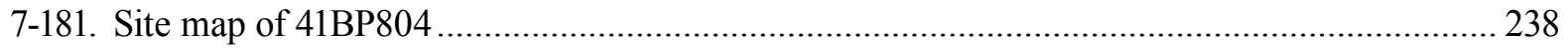

8-1. Historic trash is washing down an intermittent drainage between $41 \mathrm{BP} 132$ and

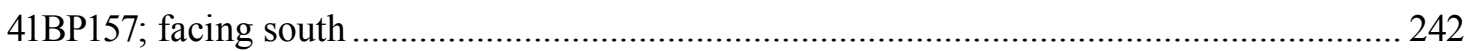

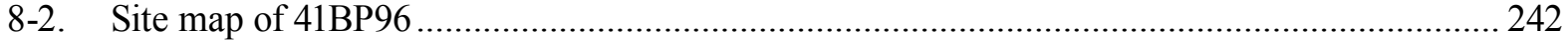

8-3. Lower grape field of Antoine Aussilloux (41BP105); facing west ........................................ 243

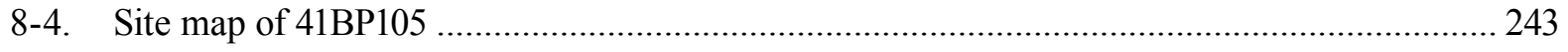

8-5. This sandstone irrigation column is in the middle of Antoine Aussilloux's lower

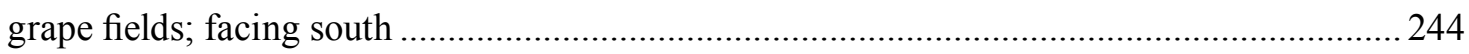

8-6. Site map of 41BP132 ........................................................................................... 245

8-7. Remains of the chimney in the James and Cynthia Floyd house; it is near the intersection of McLaughlin Loop and Sandy Creek Loop roads.......................................... 245

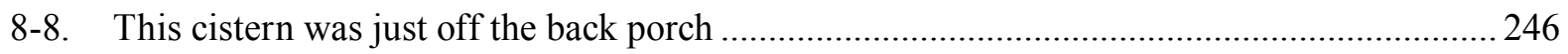




\section{List OF Figures (CONTinued)}

8-9. Sketch of soldered hole-in-top can.

8-10. Selected artifacts found on the surface are from right to left: a soldered hole-in-top

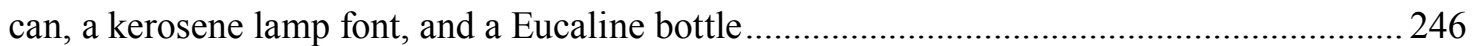

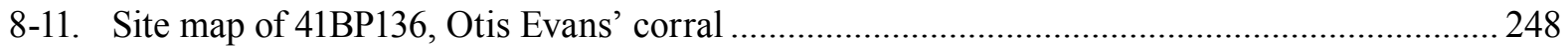

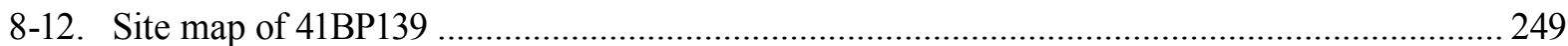

8-13. Selected artifacts found on the surface at 41BP139, from right to left: butter churn lid, Ball screw top condiment bottle, purple goblet glass shards........................................ 250

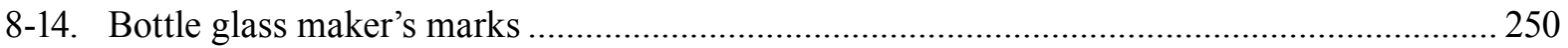

8-15. This house site at 41BP142 may be related to the farmstead just south at 41BP143;

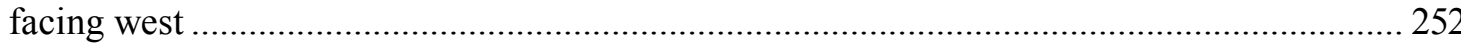

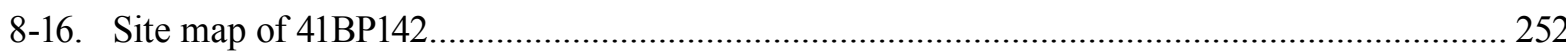

8-17. This farmstead and old fort site is located on both sides of an old two-track road

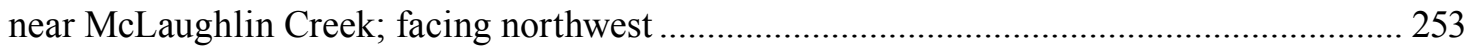

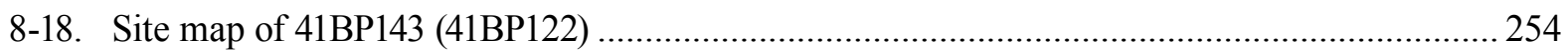

8-19. Texas camps and forts established for protection against Native American hostilities.......... 259

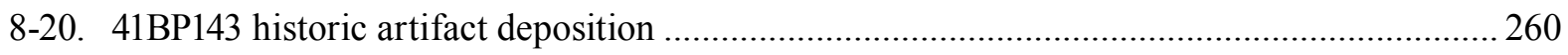

8-21. This house site lies adjacent to McLaughlin Loop jeep road; facing northwest ................... 261

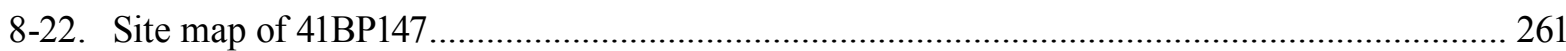

8-23. This house site lies north of the old Sayers to McDade Road road; facing north .................. 262

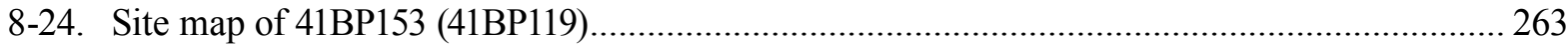

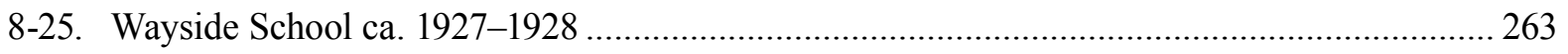

8-26. 41BP154 is the site of the one-room Wayside School alongside the Sayersville-

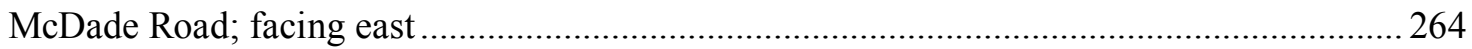

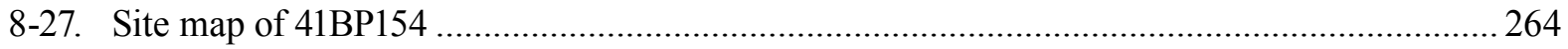

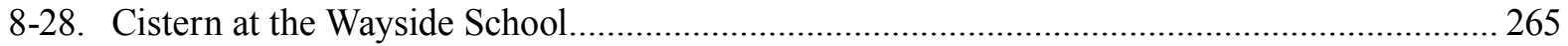

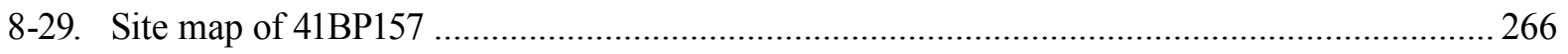

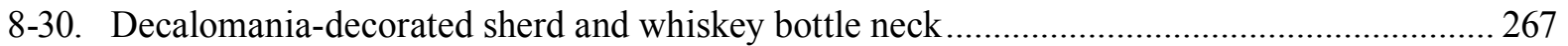

8-31. Ironstone china sherd with British Royal Arms backstamp .................................................... 267

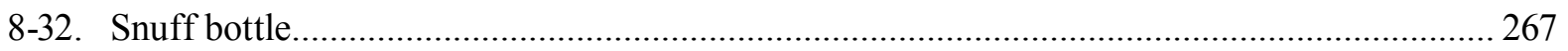

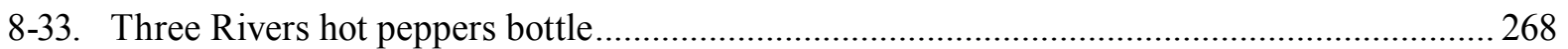

8-34. Metal-lined cistern at the Frank and Mary (Floyd) Scott house ........................................... 268

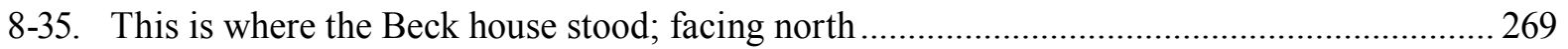

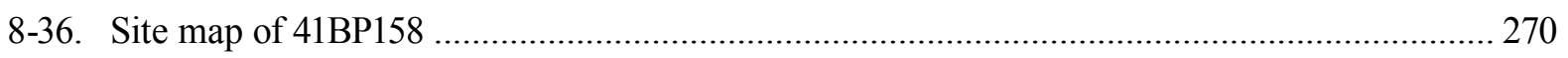

8-37. Whiteware with a Charles Meakin, Hanly, Staffordshire, England maker's mark

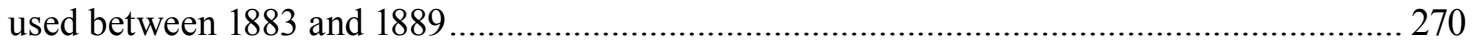

8-38. These fireplace and chimney remains are from the Eschberger house; facing north............. 271

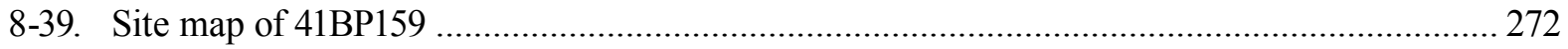

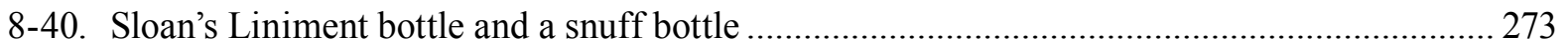

8-41. Lamp chimney upper rim fragment made of unleaded glass ........................................... 273

8-42. 41BP161 may have been the Cottle house site along Oak Hill Road; facing south ................ 274 


\section{List OF Figures (CONTinued)}

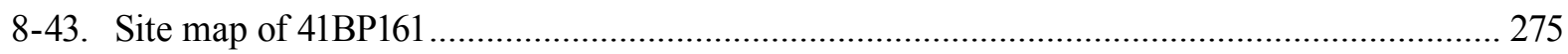

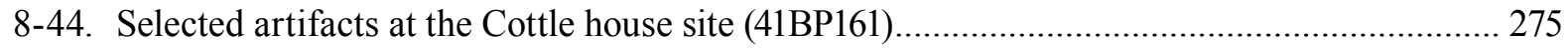

8-45. $41 \mathrm{BP} 162$ is the bulldozed Scruggs house site along Oak Hill Road; facing west.................... 276

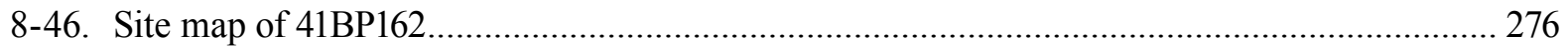

8-47. Stoneware, bricks, sandstone, and metal remain at 41BP171, a bulldozed house site south of the old Sayersville to McDade Road; facing southeast............................................. 279

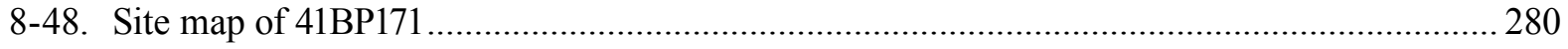

8-49. $41 \mathrm{BP} 172$ is a bulldozed house site adjacent to a powerline right-of-way; facing north........... 281

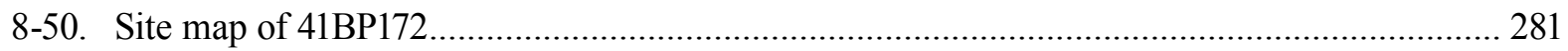

8-51. 41BP185 (41BP95) is an old house site that lies in this open field; facing northwest .............. 282

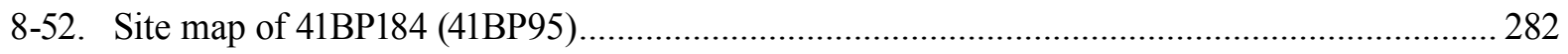

8-53. Bricks and artifacts at 41BP433 are scattered on this wooded slope; facing south ................ 284

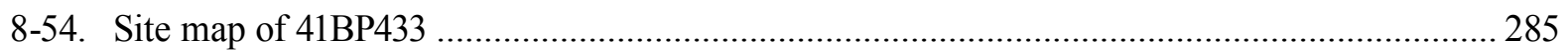

8-55. 41BP487 lies in an old field on a terrace adjacent to Big Sandy Creek; facing south ............ 286

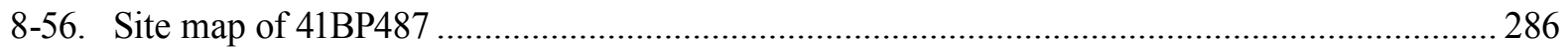

8-57. The entryway to B. C. and Jettie Daughtry's house at 41BP490; facing north...................... 287

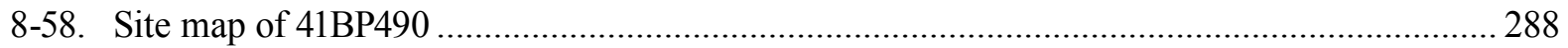

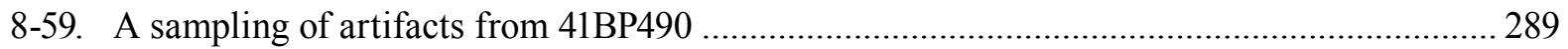

8-60. Brick-lined well on the B. C. and Jettie Daughtry place (41BP490) ..................................... 289

8-61. 41BP492 is the third trash dump on the Daughtry property; facing south ............................. 290

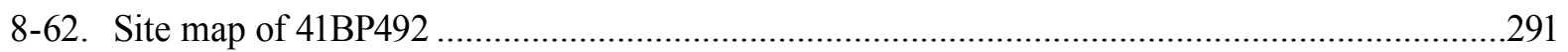

8-63. Discarded bottles, tin cans, jars, and stoneware found at 41BP492 .....................................291

8-64. Sandstone foundation stones and a trash scatter were found at 41BP534; facing north.......... 292

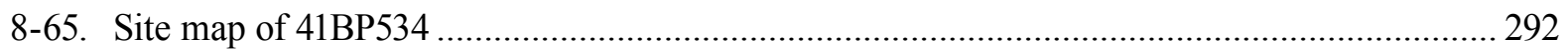

8-66. Bottle neck from ST 1 and ceramic button from ST 5 at 41BP534 _.................................... 294

9-1. This farmstead site fronting Scott Falls Road belonged to Jackson Morgan before

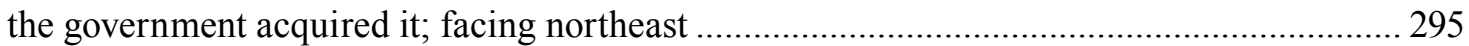

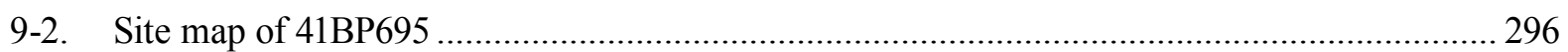

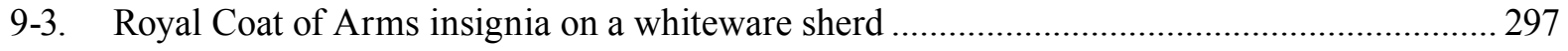

9-4. The Elgin bricks at this site were made between 1891 and 1910; facing southeast ................ 298

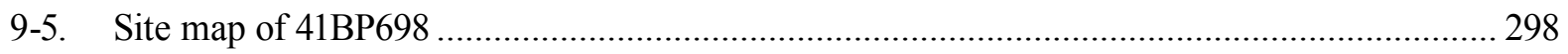

9-6. 41BP700 is a collapsed bridge across Big Sandy Creek; facing southeast ............................ 299

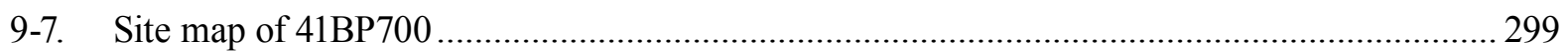

9-8. This collapsed bridge is one of five documented on Big Sandy Creek; facing north.............. 300

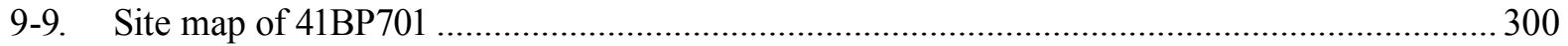

9-10. This is the site of an old farmstead alongside Big Sandy Loop Road; facing northeast ......... 301

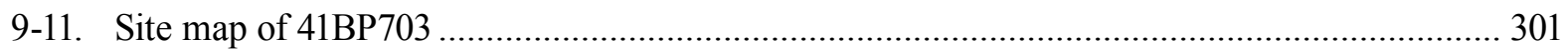

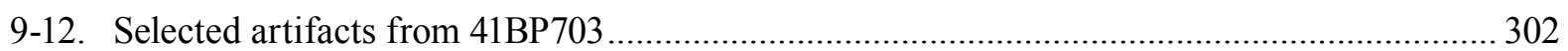

9-13. 41BP711 is one of three trash dumps on property belonging to the Daughtry family; facing north 


\section{List OF Figures (Continued)}

9-14. Site map of 41BP711 304

9-15. 41BP712 is a second trash dump on property belonging to the Daughtry family; facing north 305

9-16. Site map of 41BP712 . 305

9-17. A sandstone slab and artifacts are located in what was the extreme eastern corner of C. R. "Nick" and Louisa May Branton's property; facing north ............................................ 306

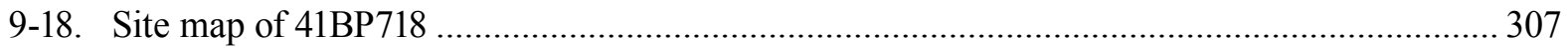

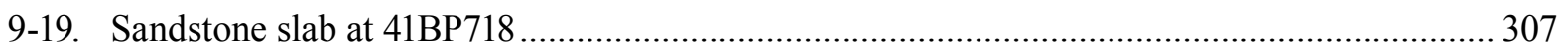

9-20. These wooden piers are all that remain of a bridge across Big Sandy Creek; facing

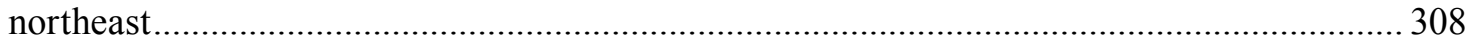

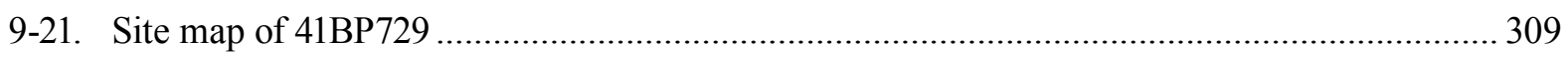

9-22. A brick chimney base is the only intact structural remains of the David Scott home;

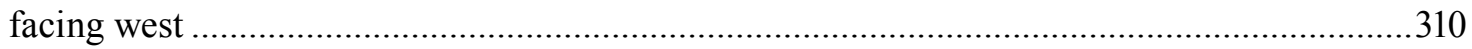

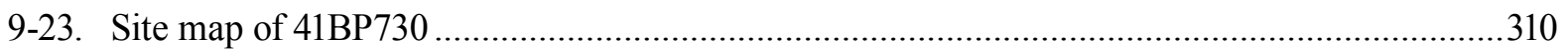

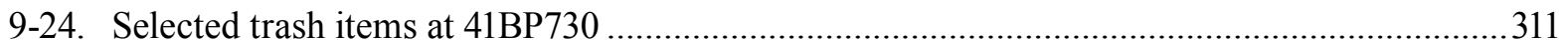

9-25. An old fence and corral are all that is above ground at what may have been the

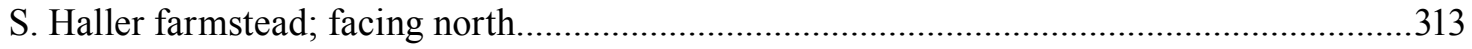

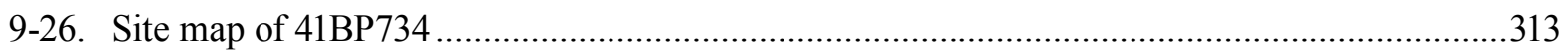

9-27. The house site of the Jones family was on this site adjacent to the old Sayersville-

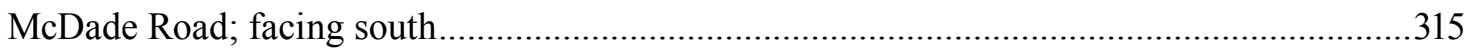

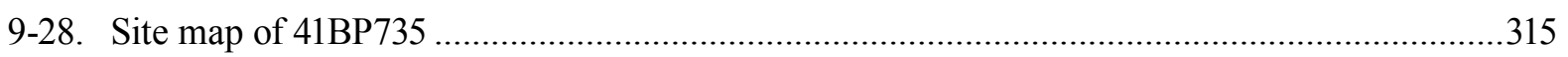

9-29. A spike in an oak tree and a trash scatter make up 41BP741; facing southwest......................317

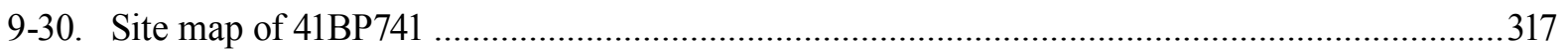

9-31. A pile of brick, sandstone slabs, and artifacts are on 41BP742, what was the J. Evans

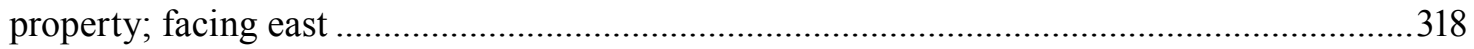

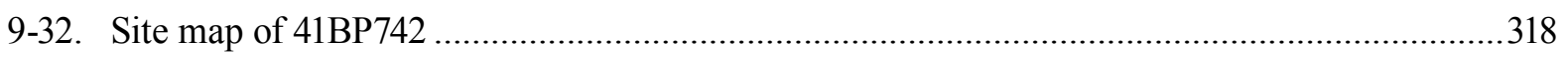

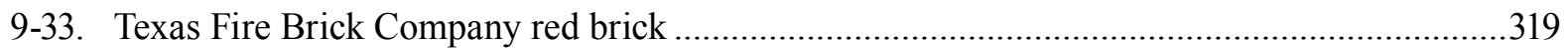

9-34. A push pile with historic construction materials and artifacts lies near McLaughlin

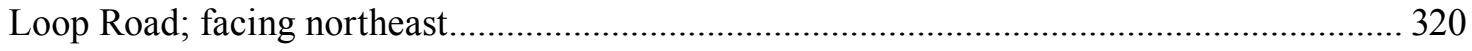

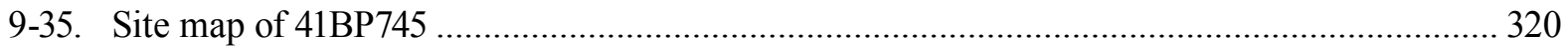

9-36. 41BP746 is a collapsed bridge across McLaughlin Creek; facing southwest ..........................321

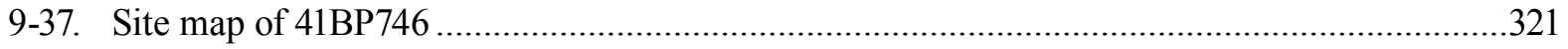

9-38. Selected items from 41BP751, a trash dump on the floodplain of McLaughlin Creek ............ 322

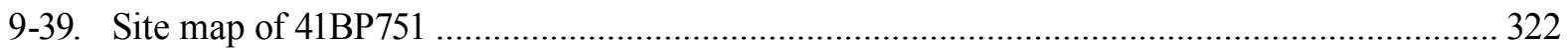

9-40. 41BP752 is a house site possibly occupied as early as 1880 ; facing east ............................... 324

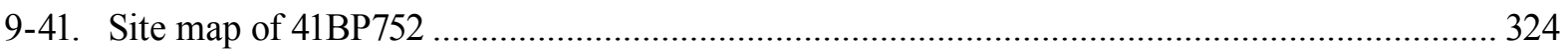

9-42. For this photograph, archaeologists set the 3-gallon stoneware crock pot made by McDade Pottery on a foundation stone at the site; note the blue maker's mark near 


\section{List OF Figures (CONTINUed)}

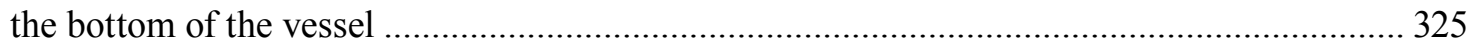

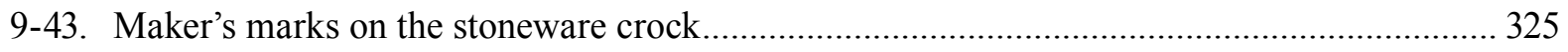

9-44. A sandstone bedrock ledge has been quarried at 41BP760; facing north.............................. 325

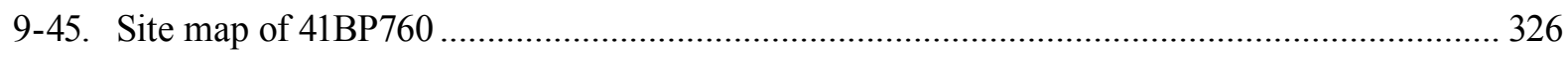

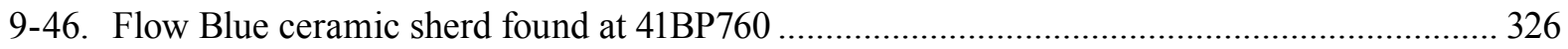

9-47. $41 \mathrm{BP} 767$ is composed of farmstead remains; facing south................................................... 327

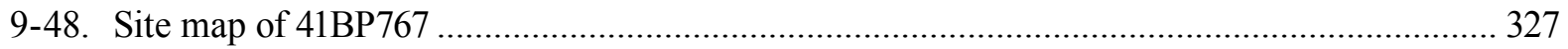

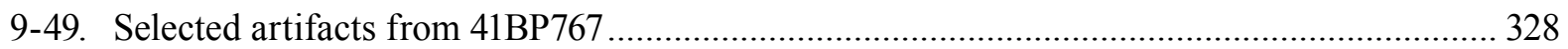

9-50. 41BP771 is a bulldozed house site on property owned by J. Evans; facing northwest............ 329

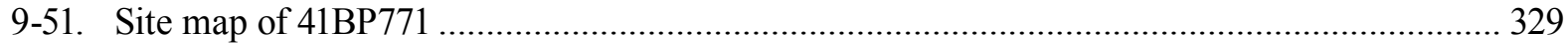

9-52. A dark brown applied and crudely tooled double ring bottle lip with a small section

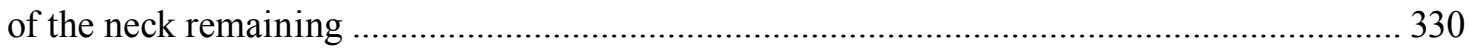

9-53. White Fancy Pearl Agate button from a shirt or blouse ......................................................331

9-54. 41BP773 consists of scattered house remains; facing west ................................................. 332

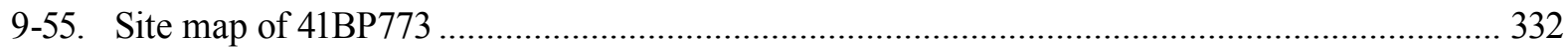

9-56. Horse bit half from 41BP773, along with replicated advertisement from the 1895

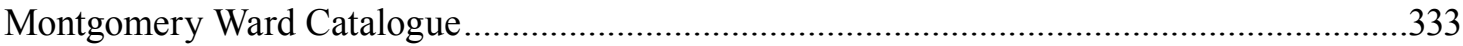

9-57. 41BP775 may be the house remains of Uriah Foster; facing west ......................................... 334

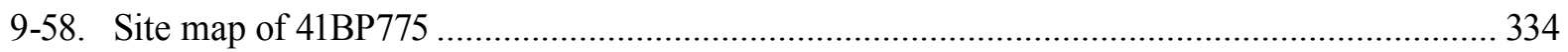

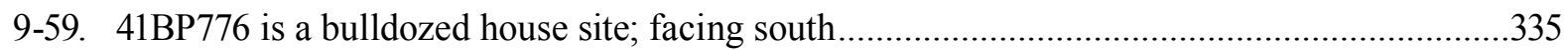

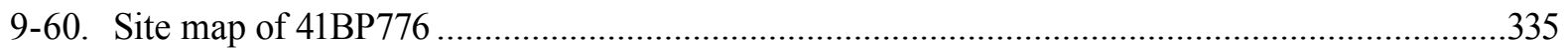

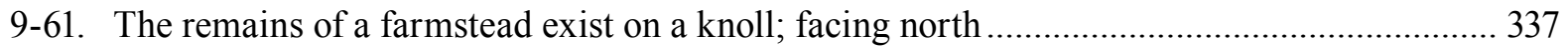

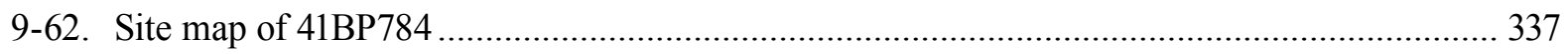

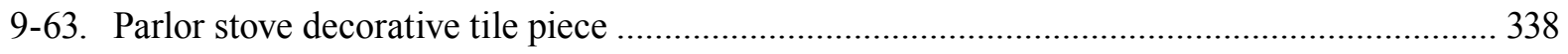

9-64. The remains of a house site constitute 41BP785; facing northeast.......................................... 339

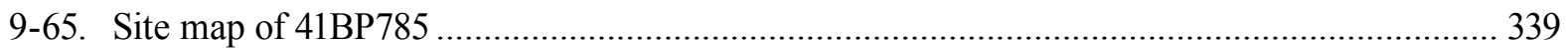

9-66. The remains of a farmstead on land owned by Joe Owen before it was acquired by the government in 1942 is designated as 41BP791; facing east ................................................ 340

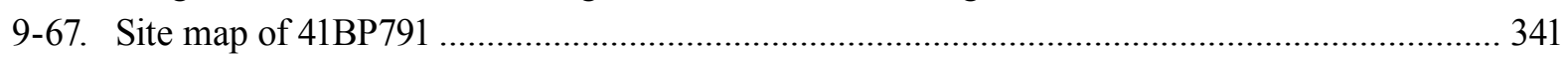

9-68. The remains of a barbed wire corral constitute 41BP793; facing northwest ......................... 341

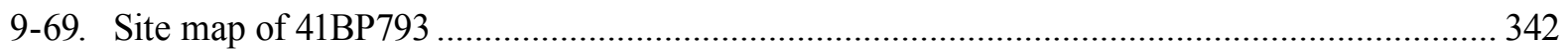

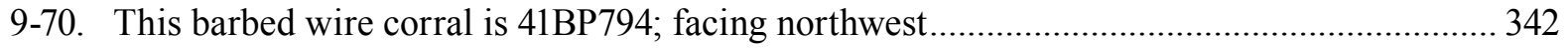

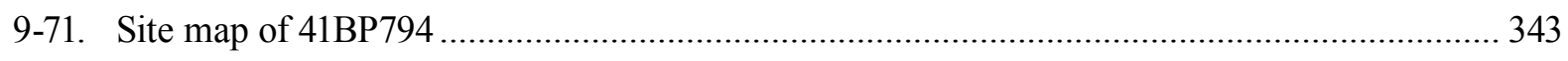

9-72. A lone fence post stands around the house that may have been occupied by

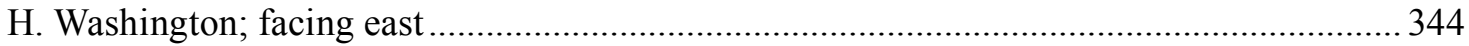

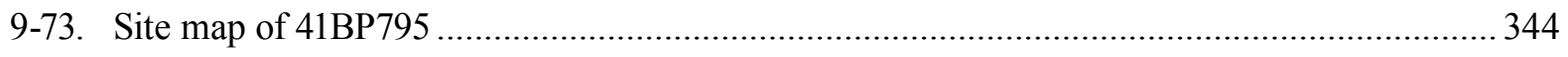

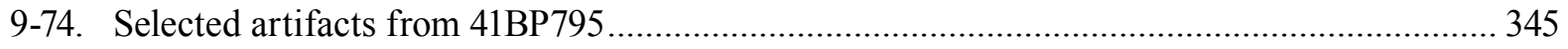

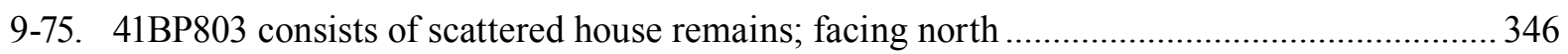

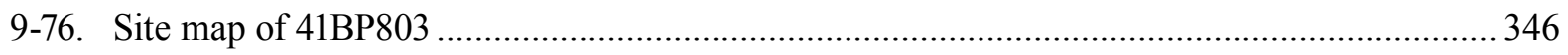

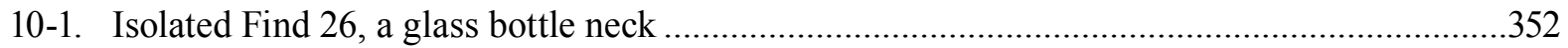




\section{List OF Figures (CONTinued)}

11-1. Map showing the distribution of soil series and streams at Camp Swift 360

11-2. Distribution of soil series covered by archaeological sites at Camp Swift calculated by the percent of coverage .361

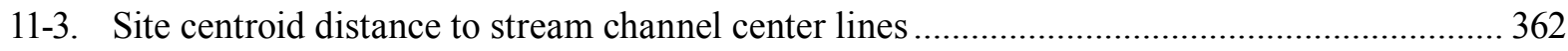

11-4. Map of the depth zones and streams in the Swift VI survey area ........................................... 363

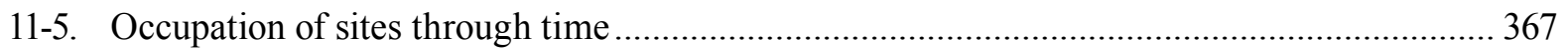

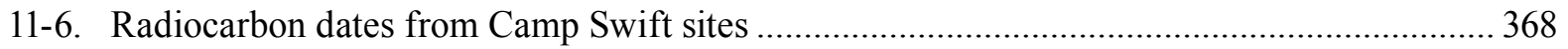

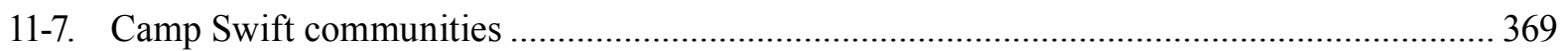

11-8. Ages of historic house sites discovered thus far on Camp Swift.......................................... 371

11-9. Bar chart illustrating the beginning occupation date for all known historic sites at

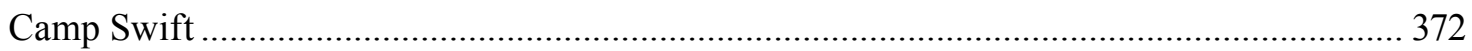

11-10. Decreasing farmstead sizes on Camp Swift through time ................................................... 372 


\section{LIST OF TABLES}

1-1. Prehistoric component sites on Camp Swift ......................................................................... 2

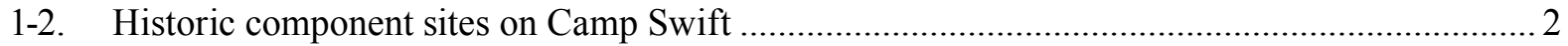

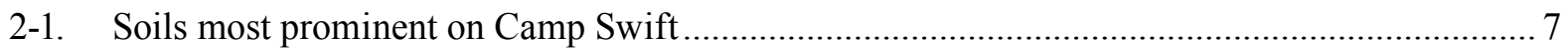

2-2. Common vegetation within various plant communities on Camp Swift (Tera Corporation

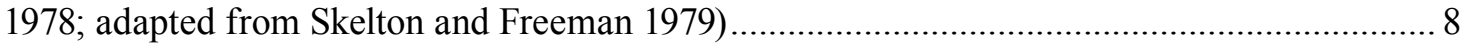

2-3. Animals found in the project area.................................................................................. 10

5-1. Prehistoric components previously documented by CAS whose boundaries were

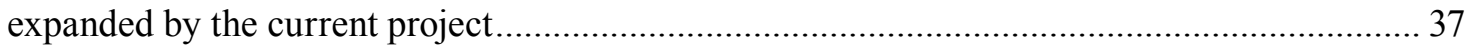

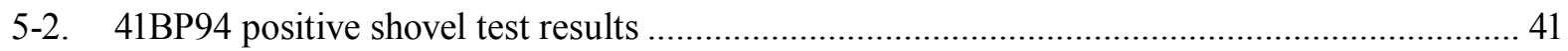

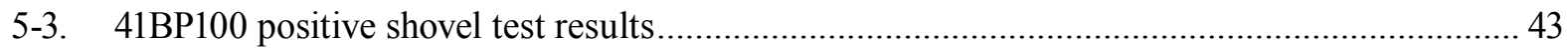

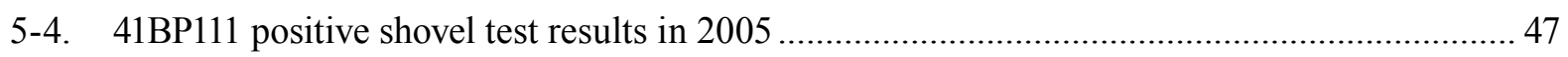

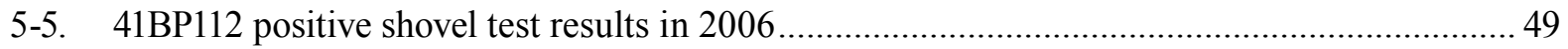

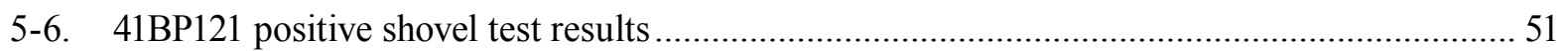

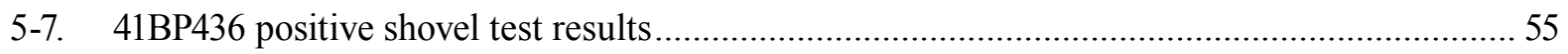

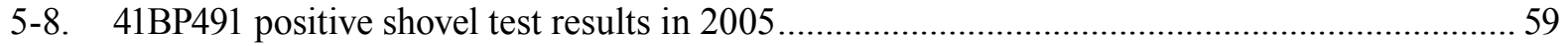

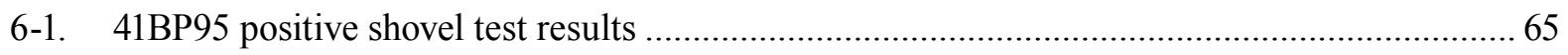

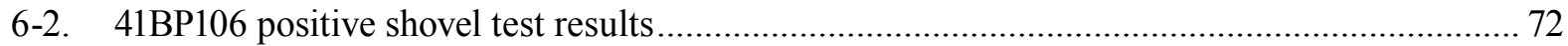

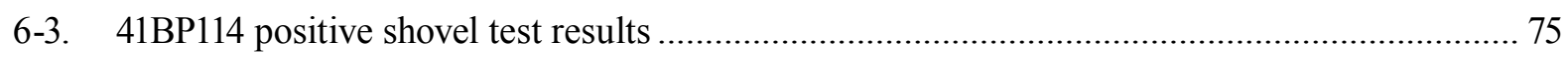

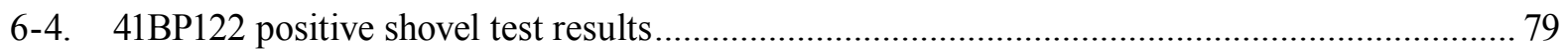

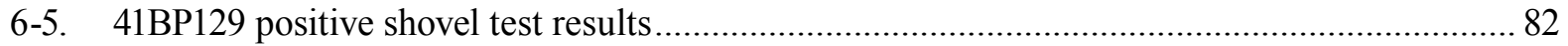

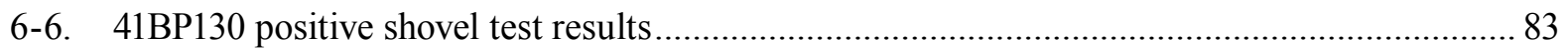

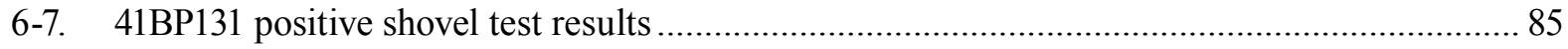

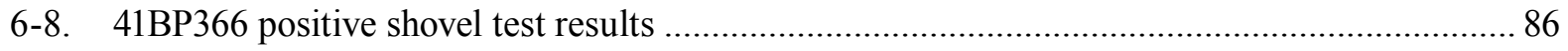

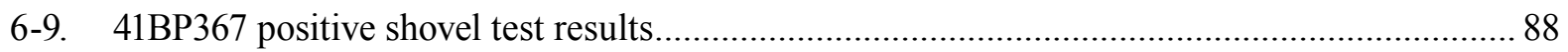

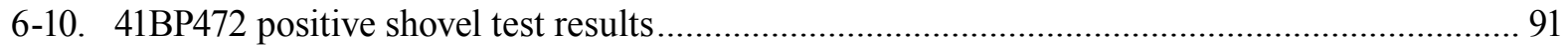

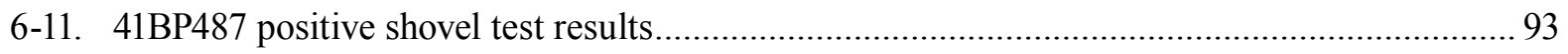

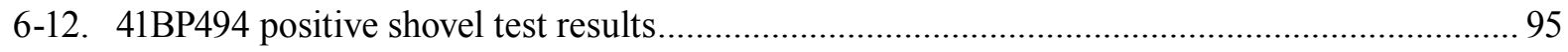

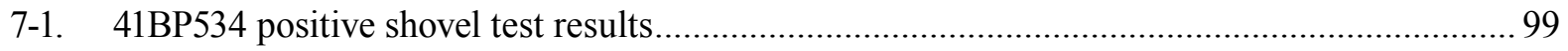

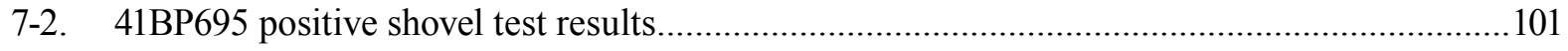

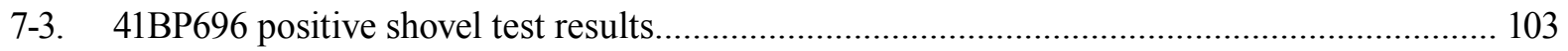

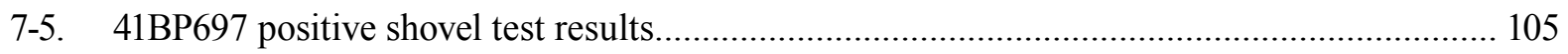

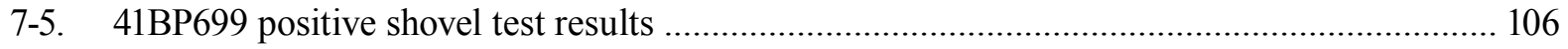

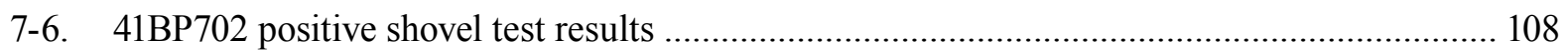

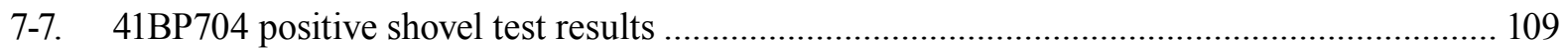

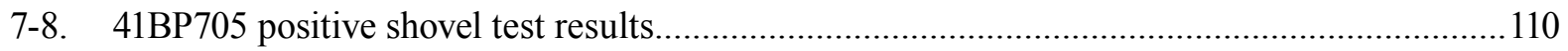

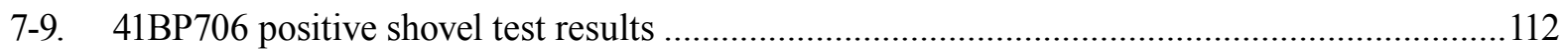

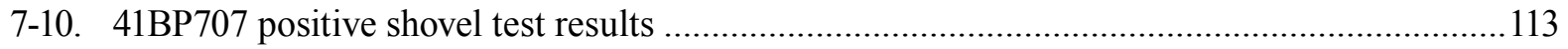

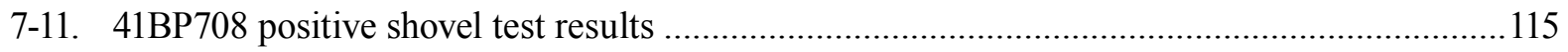

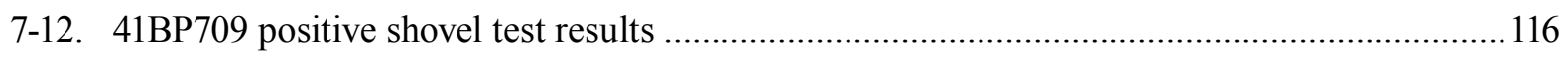

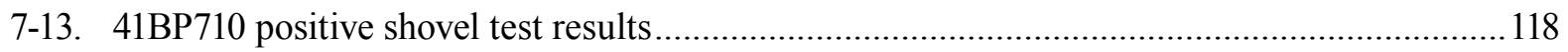




\section{List of Tables (Continued)}

7-14. 41BP713 positive shovel test results

7-15. 41BP714 positive shovel test results

7-16. 41BP715 positive shovel test results 123

7-17. 41BP716 positive shovel test results 124

7-18. 41BP717 positive shovel test results 126

7-19. 41BP718 positive shovel test results 127

7-20. 41BP719 positive shovel test results 129

7-21. 41BP720 positive shovel test results 131

7-22. 41BP721 positive shovel test results .133

7-23. 41BP722 positive shovel test results 135

7-24. 41BP723 positive shovel test results 137

7-25. 41BP724 positive shovel test results 139

7-26. 41BP725 positive shovel test results 140

7-27. 41BP726 positive shovel test results 142

7-28. 41BP727 positive shovel test results 143

7-29. Artifacts on the surface at 41BP728 145

7-30. 41BP728 positive shovel test results 145

7-31. 41BP730 positive shovel test results 147

7-32. 41BP731 positive shovel test results 149

7-33. 41BP732 positive shovel test results 150

7-34. 41BP733 positive shovel test results 152

7-35. 41BP734 positive shovel test results 154

7-36. 41BP736 positive shovel test results 155

7-37. 41BP737 positive shovel test results 157

7-38. 41BP738 positive shovel test results 158

7-39. 41BP740 positive shovel test results 161

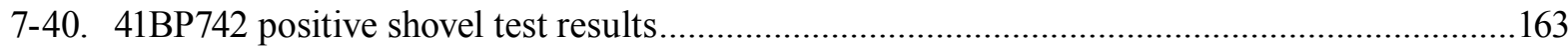

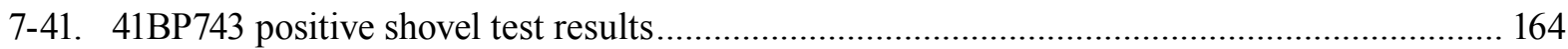

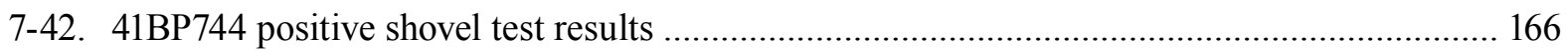

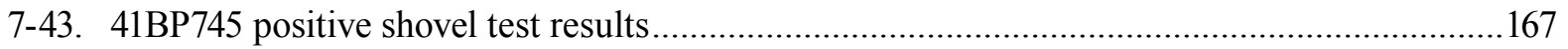

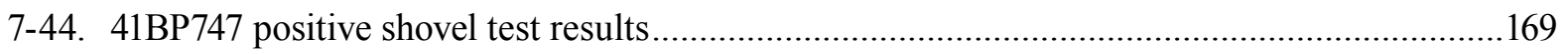

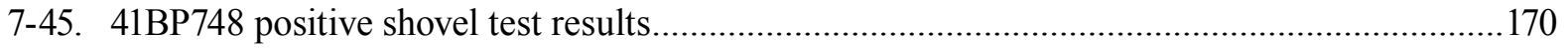

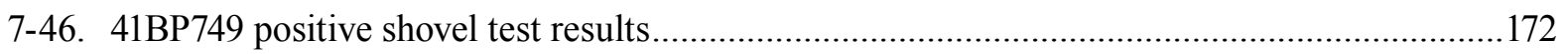

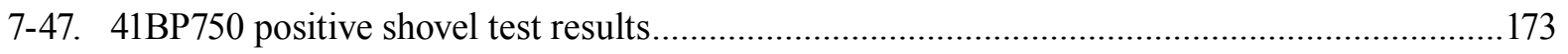

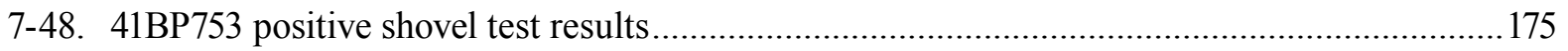

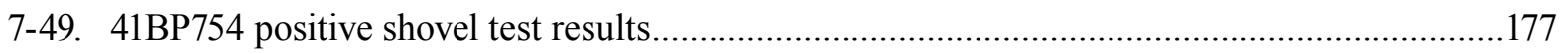

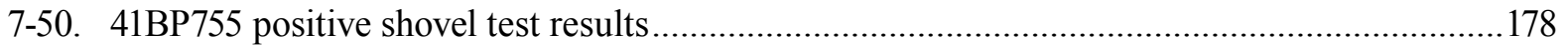

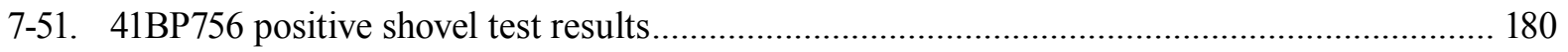

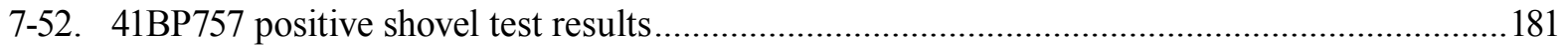

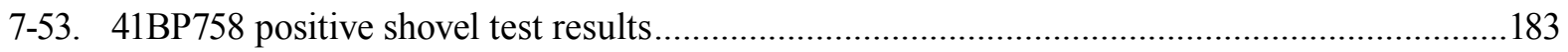




\section{List OF TABLES (Continued)}

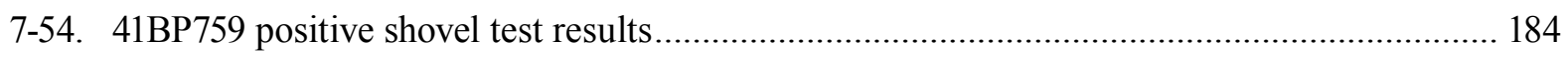

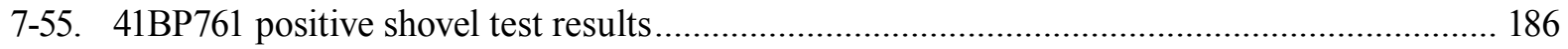

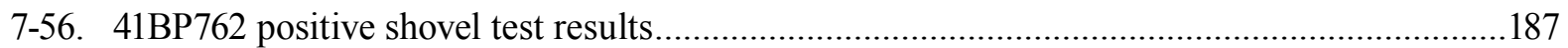

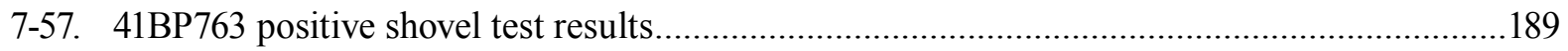

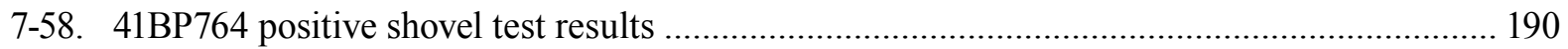

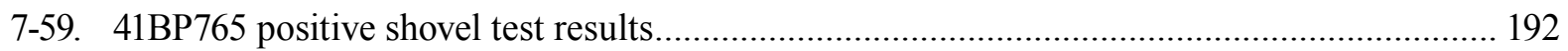

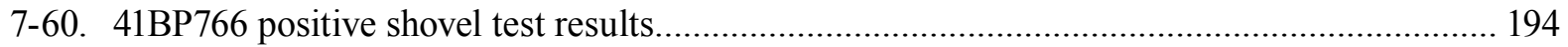

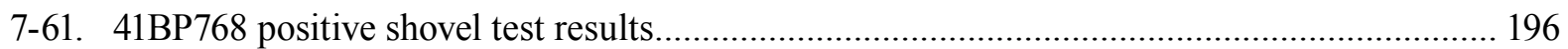

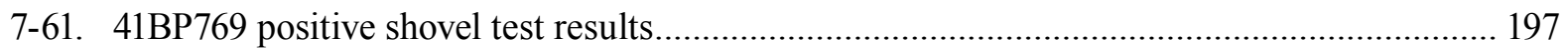

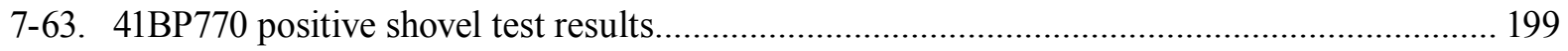

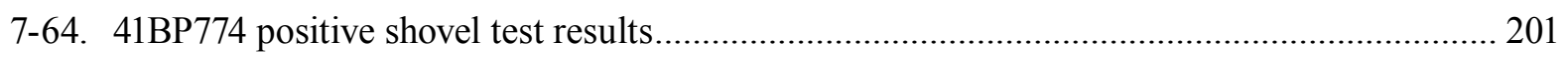

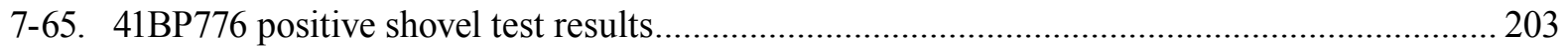

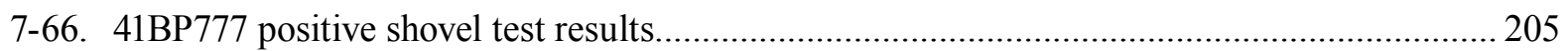

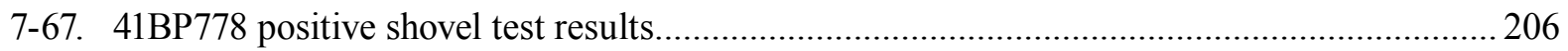

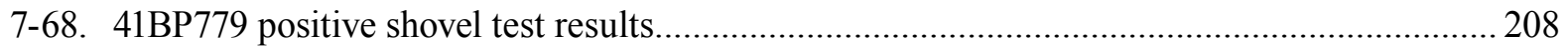

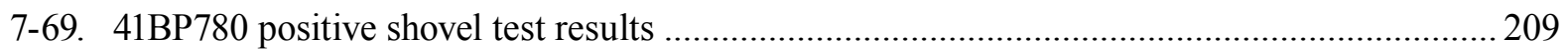

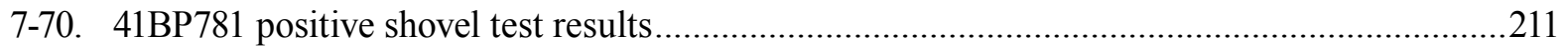

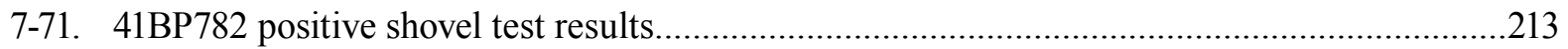

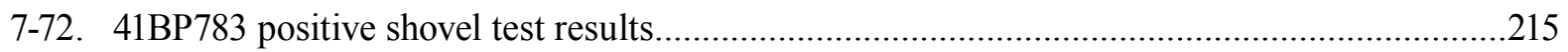

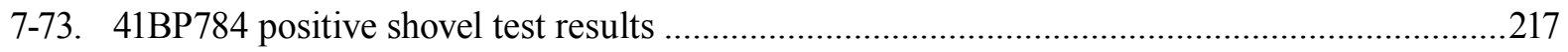

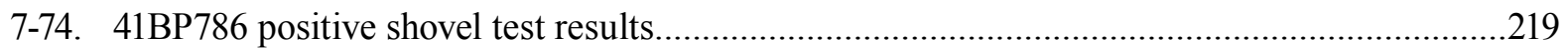

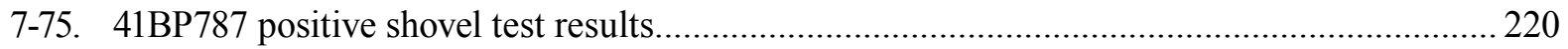

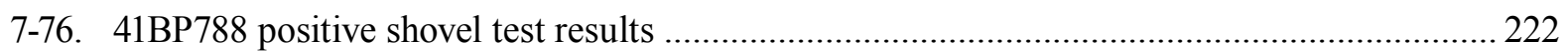

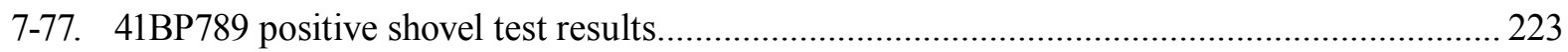

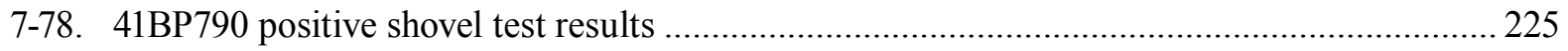

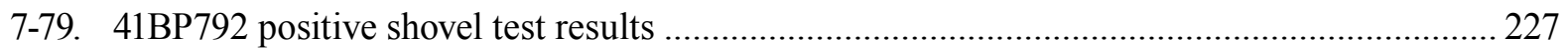

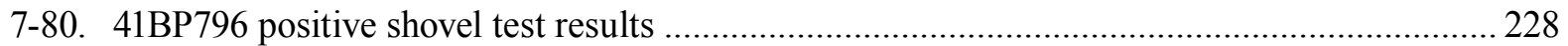

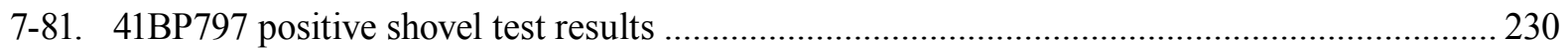

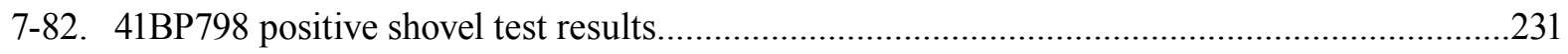

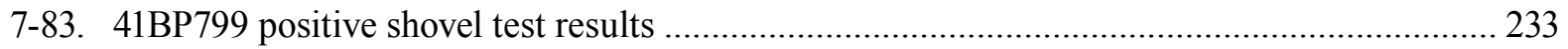

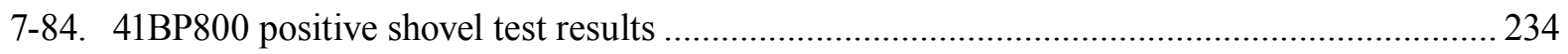

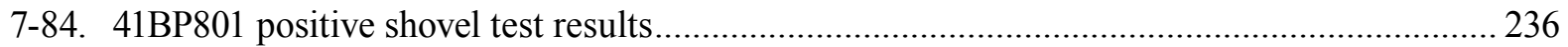

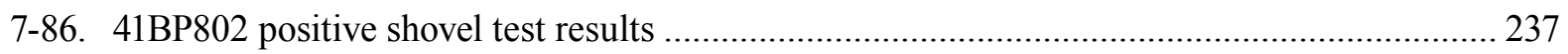

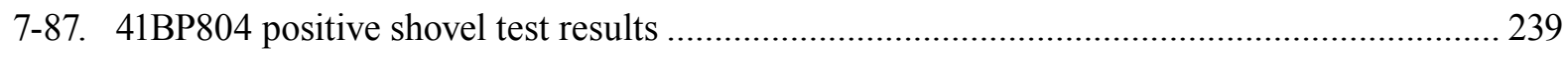

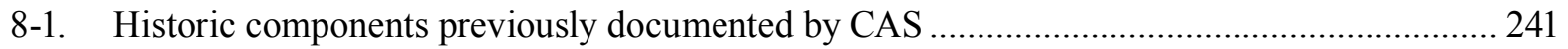

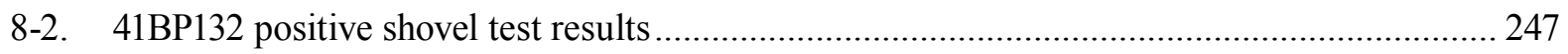

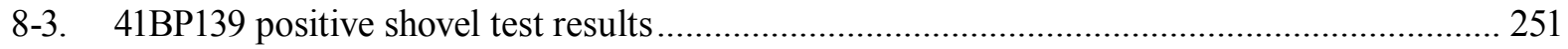

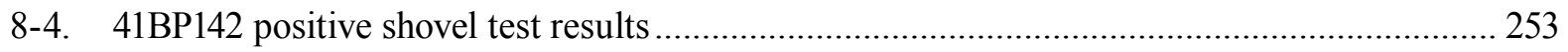

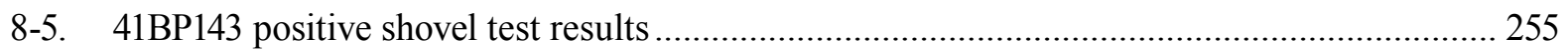

8-6. Historic artifacts from 41BP143 shovel tests according to approximate ages ....................... 256 


\section{List OF TABLes (Continued)}

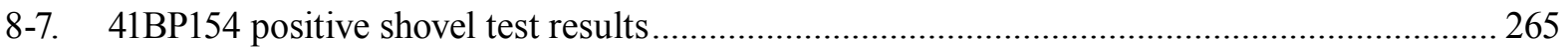

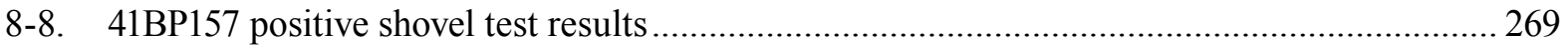

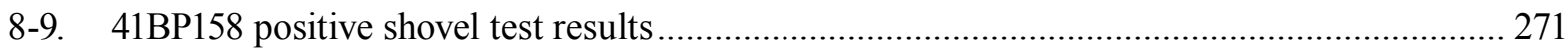

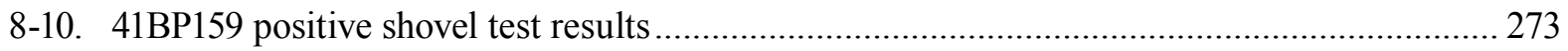

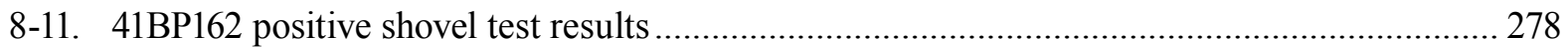

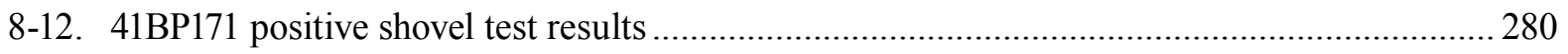

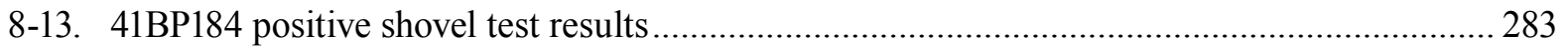

8-14. $41 \mathrm{BP} 490$ positive shovel test results.................................................................................... 288

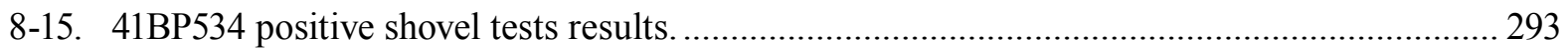

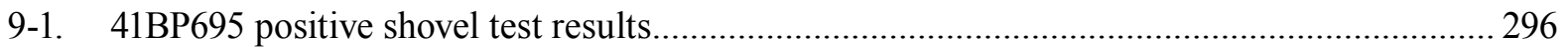

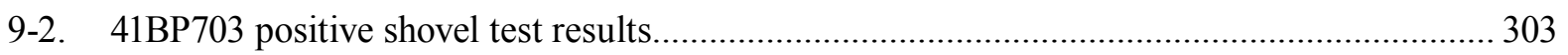

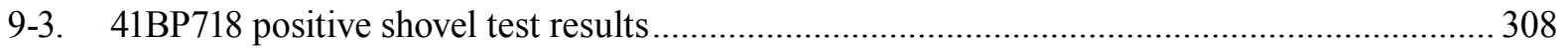

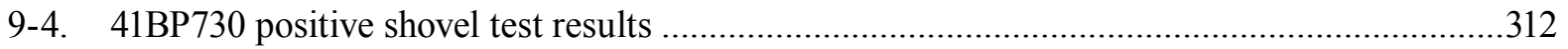

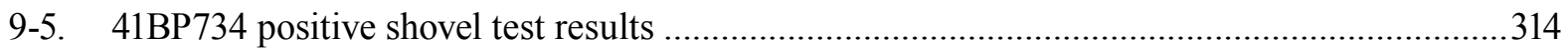

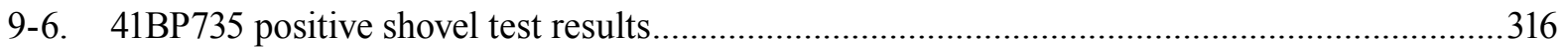

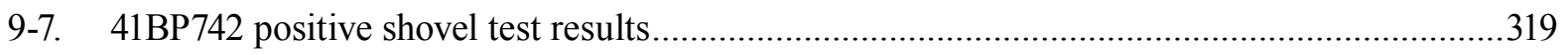

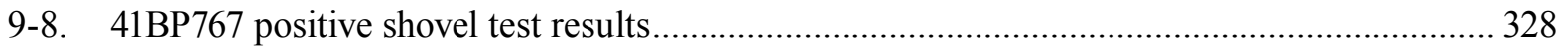

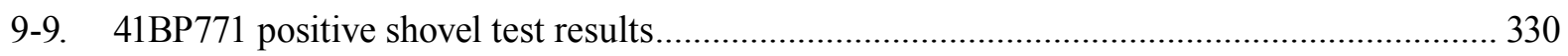

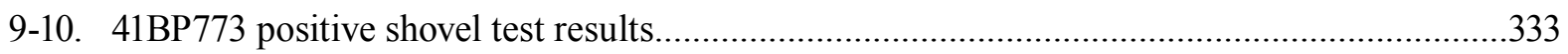

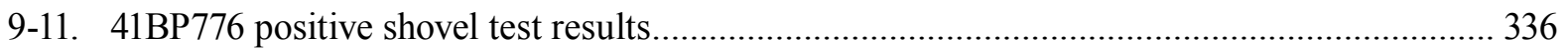

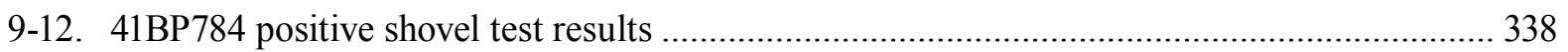

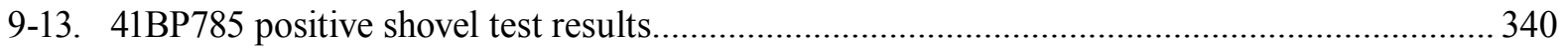

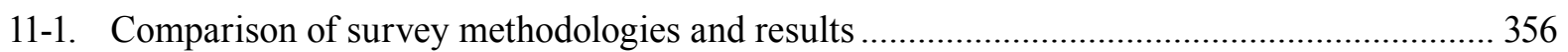

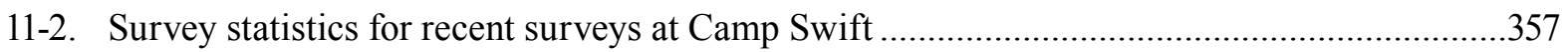

11-3. Contingency table of prehistoric and historic components by survey area, including

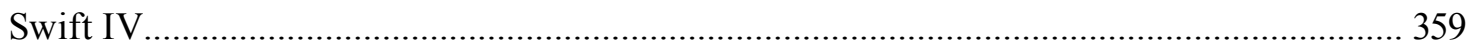

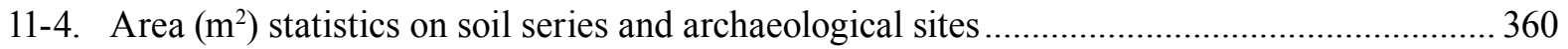

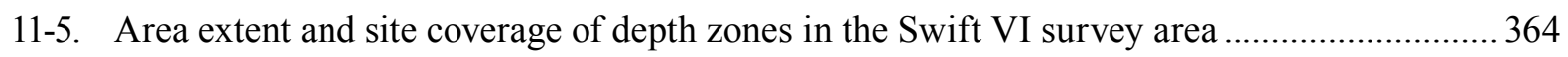

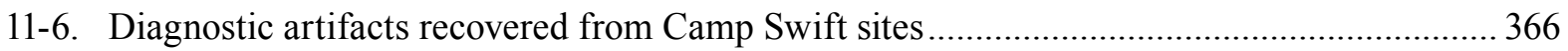

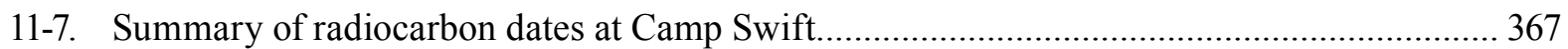

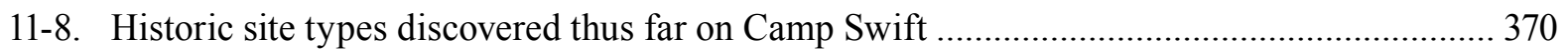

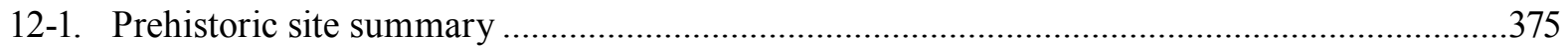

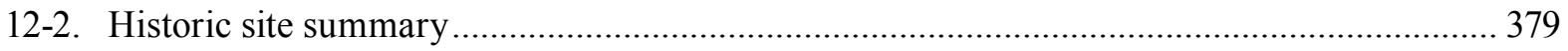




\section{ACKNOWLedgments}

CAS wishes to thank Ms. Shellie Sullo and Ms. Kristen Wenzel, the previous and current Cultural Resource Managers for the Texas Military Forces. They recognized a need for this work and facilitated its completion. Master Sergeant Robert West, the Camp Swift Facility Manger, coordinated with the survey crew daily to ensure our survey project integrated with and did not disrupt the military training schedules and activities. The survey was directed by David Nickels and the crew consisted of D. Emory Worrell, David Peyton, and Matt Stotts. These individuals worked long and hard to discover and record the sites documented in this report. Additional assistance in the field was provided by Marc Beherec, Logan Ralph, Antonio Padilla, and Abbey Peyton (nee Weinstein). GIS and mapping was conducted by Damon Stone, Britt Bousman, Eric Oksanen and Matt Melancon. Jessica Hurley edited the report with initial editing assistance by Maggie McClain. Carole Leezer provided administrative support, and Britt Bousman served as PI. For a portion of this project David Nickels also served as Co-PI. 


\section{Chapter 1}

\section{INTRODUCTION}

\section{By David L. Nickels, C. Britt Bousman, and Jessica L. Hurley}

This report documents an archaeological survey by the Center for Archaeological Studies (CAS) at Texas State University-San Marcos of approximately 3,475 acres at Camp Swift in northcentral Bastrop County, Texas (Figure 1-1). The field work was conducted from November 2005 until October 2006. Camp Swift is managed by the Texas Military Forces (TXMF) and encompasses approximately 11,500 acres. Camp Swift's headquarters are located 8 miles north of Bastrop and 8 miles south of Elgin. Members of all military services, several civilian law enforcement agencies, and other state entities use the land for tracked and wheeled vehicle maneuvers, dismounted (on-foot) military training, and weapons firing.

Although all 11,500 acres have been surveyed over a period of 25 years, they were accomplished in varying degrees of intensity. Previous archaeological investigations conducted at Camp Swift are discussed in Chapter 3. Camp Swift is divided into military training areas designated for certain types of training, e.g., foot patrols, tracked vehicle, Texas. earth moving equipment, etc. The current survey focused on what would be considered high probability areas in central, east-central, and southeast Texas. That is, CAS focused on drainages and terrain features associated

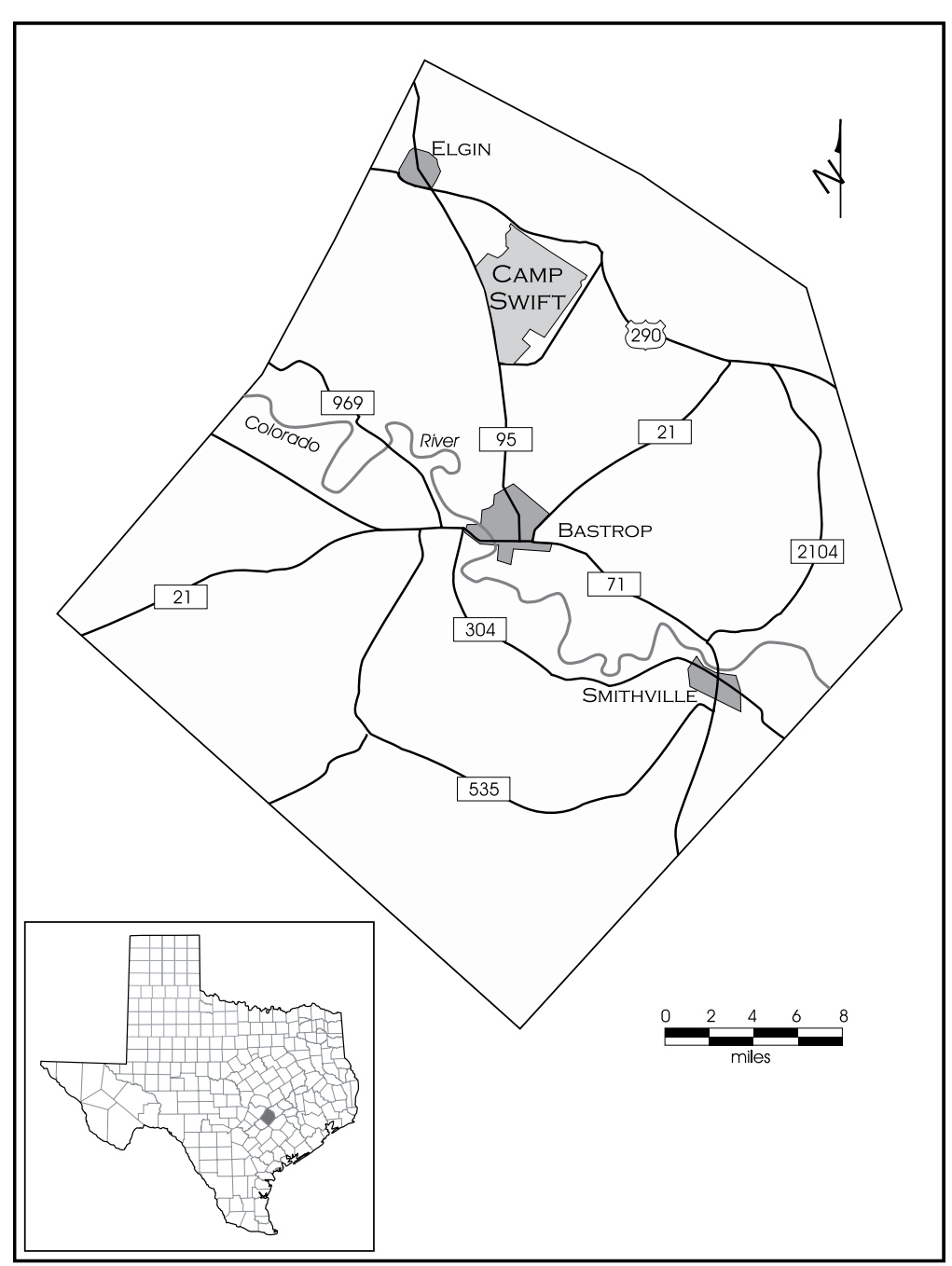

Figure 1-1. Bastrop County is located in north-central Bastrop County, 
with drainages, although no formal predictive modeling was employed. Common terms for these terrain features are terraces, footslopes, sideslopes, finger ridges, and ridges between the confluences of drainages. The outline of high probability areas within those training areas designated as high priority for military training constituted the 3,475 acres surveyed during this project.

During this intensive survey, we targetted a shovel test to be excavated every $30 \mathrm{~m}$, covering 3,475 actual surveyed acres and resulting in the excavation of 11,015 transect shovel tests. Of these transect shovel tests, 453 were positive and 10,562 were negative. For the site evaluations, 1,517 additional shovel tests were excavated within site boundaries in an attempt to determine the horizontal and vertical extent of archaeological deposits, the vertical extent and severity of disturbance present, and to develop a preliminary understanding of the nature of the soils and depositional history at the site. Of these, 477 shovel tests were positive and 1040 shovel tests were negative. In total, 12,532 shovel tests were excavated on this project. In addition to the 3,475 acres covered by the transect survey, 16 acres covering site boundaries outside of the survey area were further assessed with shovel tests. This resulted in a total area assessed with shovel tests of approximately 3,491 acres.

During this project, CAS archaeologists encountered or searched for 168 sites, discovering 110 new sites and revisiting 54 previously recorded sites; four previously recorded historic sites (41BP164, 41BP167, 41BP434, and 41BP489) could not be relocated. Of the 168 recorded sites, 125 prehistoric components and 58 historic components (including the four missing historic sites and 15 multi-component sites) have been recorded. Eighty-eight prehistoric and 31 historic new components were discovered.
With the discovery of 88 additional new prehistoric components during this project, there are now 200 known and documented prehistoric components (Table 1-1). With the discovery of 31 additional historic components, there are now 123 known and documented historic components at Camp Swift (Table 1-2). The addition of the newly discovered sites brings the total number of sites on Camp Swift to 292 (32 of these have both prehistoric and historic components).

Although all prehistoric artifacts were recorded, only diagnostic prehistoric artifacts were collected from either shovel tests or the surface. All historic artifacts discovered were recorded, but only unique items were collected. Collected artifacts are housed at the Texas Archeological Research Laboratory (TARL) at The University of Texas at Austin.

\section{Project Background}

The TXMF Environmental Division Resources Management Office is charged with cultural resource management for Camp Swift. This survey project was undertaken to meet requirements under Sections 106 and 110 of the National Historic Preservation Act (NHPA). The National Register of Historic Places (NRHP) and the Advisory Council for Historic Preservation were created by the NHPA. Under Sections 106 and 110 of the NHPA, the protection of cultural resources is related to their eligibility for inclusion in the NRHP, which is in turn dependent on their NRHP significance as defined in 36 CFR Part

Table 1-1. Prehistoric component sites on Camp Swift.

\begin{tabular}{|c|c|}
\hline Site Type & Number of Sites \\
\hline Lithic Procurement & 12 \\
\hline Lithic Scatter & 47 \\
\hline Open Campsite & 141 \\
\hline Total & $\mathbf{2 0 0}$ \\
\hline
\end{tabular}


Table 1-2. Historic component sites on Camp Swift.

\begin{tabular}{|c|c|}
\hline Site Type & Number of Sites \\
\hline Agricultural (Irrigation) & 1 \\
\hline Brick Scatter & 1 \\
\hline Bridge & 6 \\
\hline Cemetery & 3 \\
\hline Corral & 5 \\
\hline House or Farmstead & 67 \\
\hline House/Fort & 1 \\
\hline House/Winery & 1 \\
\hline Industrial & 1 \\
\hline Isolated Grave & 1 \\
\hline Mine and Residences & 1 \\
\hline Outbuilding and Dam & 1 \\
\hline Quarry & 1 \\
\hline Trash Dumps/Scatters & 28 \\
\hline School & 1 \\
\hline Well & 4 \\
\hline Total & $\mathbf{1 2 3}$ \\
\hline
\end{tabular}

60. The NHPA Amendments of 1992 clarified Section 110 and directed federal agencies to establish preservation programs corresponding to their activities and effects on historic properties. Under Section 110, federal agencies may evaluate the significance of cultural resources not currently threatened to assist with the development of preservation planning. The federal regulatory process is described in detail in 36 CFR Part 800. Section 106 specifies that the Advisory Council on Historic Preservation (ACHP) must be given the opportunity to comment on those cultural resources (in this case, archaeological sites) that may be eligible for listing on the NHRP. In turn, the State Historic Preservation Officer (SHPO) at the Texas Historical Commission (THC) Department of Antiquities Protection advises TXMF regarding their obligations under Sections 106 and 110. In compliance with the fore mentioned laws and regulations, the TXMF has developed an Integrated Cultural Resource Management Plan (ICRMP). It is under the authority of the aforementioned laws, regulations, and the ICRMP that this survey project was undertaken.

\section{Report Organization}

This report is divided into twelve chapters, including this introductory chapter. An overview of the environment, geology, and soils is presented in Chapter 2, while Chapter 3 synthesizes the cultural chronology and previous archaeological research in the region. Chapter 4 includes the research design, encompassing both prehistoric and historic assets. It further describes the field and laboratory methodologies employed to address the cultural contexts and issues for the sites tested. Chapters 5-10 provide a site-by-site description, a description of isolated finds, and the levels and results of work conducted, followed by the conclusions and recommendations for each site individually. Specifically, Chapter 5 discusses prehistoric component sites previously tested by CAS, Chapter 6 covers prehistoric component sites documented by other contractors, and Chapter 7 presents prehistoric component sites that were discovered during this survey. Chapter 8 deals with previously documented historic component sites, which CAS revisited for this project, while Chapter 9 presents historic component sites discovered during this survey. Chapter 10 lists the prehistoric and historic isolated finds. Chapter 11 discusses what has been learned based upon our research design and methods. Finally, recommendations are presented in Chapter 12.

Enclosed in an envelope at the end of this publication are Appendix A, a combined USGS Quadrangle map showing the site locations, and Appendix B, a combined USGS Quadrangle map showing the isolated finds, both of which are therefore restricted to a limited number of copies to authorized individuals and institutions. 
In addition to these project and site-specific data sets, Texas archaeological site forms were completed for all 110 newly recorded sites, as well as for those 58 revisited sites. These are available at TARL in Austin. 


\section{Chapter 2}

\section{Project Area Description}

By David L. Nickels

\section{Introduction}

Camp Swift is located in north-central Bastrop County, approximately eight miles north of the city of Bastrop and eight miles south of the city of Elgin. Camp Swift is composed of approximately 11,500 acres, reduced from its original WWII-era 52,982 acres. The acreage is generally rolling woodlands and open grasslands previously cleared for farming in historic times. Numerous streams and short order tributaries dissect the landscape from the higher elevations in the northeast toward the lower elevations in the southwestern portion before ultimately joining the Colorado River valley to the east.

\section{Environmental Setting}

Bastrop County is situated approximately $30 \mathrm{~km}$ east of the Balcones Escarpment, dominated by oak-hickory forests with a relict, Lost Pine Forest in its central section. The county's northwestern boundary is on the edge of the Blackland Prairie (Figure 2-1). The topography is described as rolling interfluves and hills, with broad alluvial terraces along the Colorado River valley, which runs from northwest to southeast through the center of the county. Elevations within the county range from 400 to 600 feet above mean sea level (ft amsl). The 891-mile ${ }^{2}$ county comprises approximately 25 percent farmland, of which approximately one-third is used for cattle grazing, while a little over 33 percent is forested (Baker 1979; Marks 2008a).

Camp Swift is composed of rolling uplands, ridges, their associated slopes, and bottomlands dissected by both steadily flowing and intermittent streams, all which were encountered while

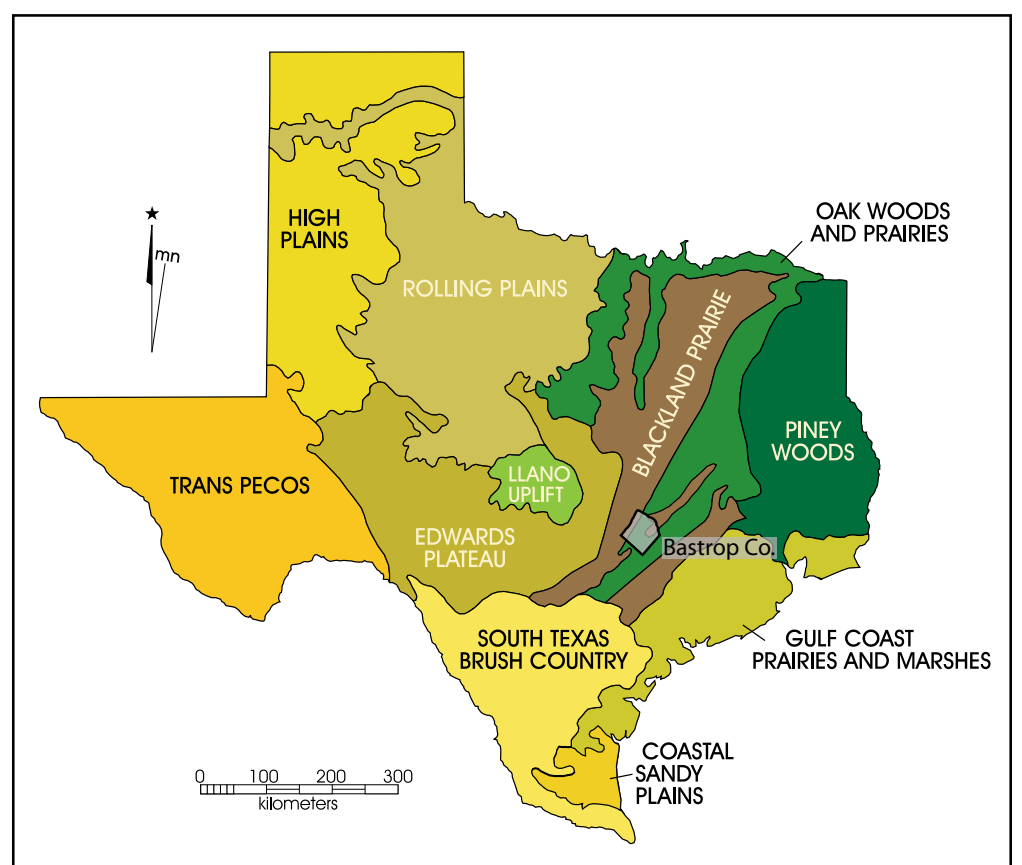

Figure 2-1. Location of Bastrop County within the physiographic regions of Texas. 
conducting this survey. Many streams are deeply incised and criss-cross throughout (Figures 2-2 and 2-3). Most streams and creeks flow intermittently through Camp Swift, although Big Sandy Creek flows in some areas, and pools in many others before the waters intermittently sink into areas of sand strata and Spring Branch (also known as Scott Falls Creek) flows permanently. The headwaters of Big Sandy Creek originate in western Lee County and flow through the project area in the northeastern portion of Camp Swift, eventually dumping into the Colorado River approximately $13 \mathrm{~km}$ to the southwest (Prochnow 2001; Texas State Historical Association 2001). Within Camp Swift, other intermittent streams (e.g., McLaughlin Creek, Dogwood Branch, and Dogwood Creek) accommodate rapid runoff during heavy rainfall.

\section{Physiography}

Camp Swift comprises six physiographic zones: active floodplains, terraces, uplands, ridges, footslopes, and sideslopes. Floodplains are low-lying and easily flooded during less severe, above normal runoffs. They occur in

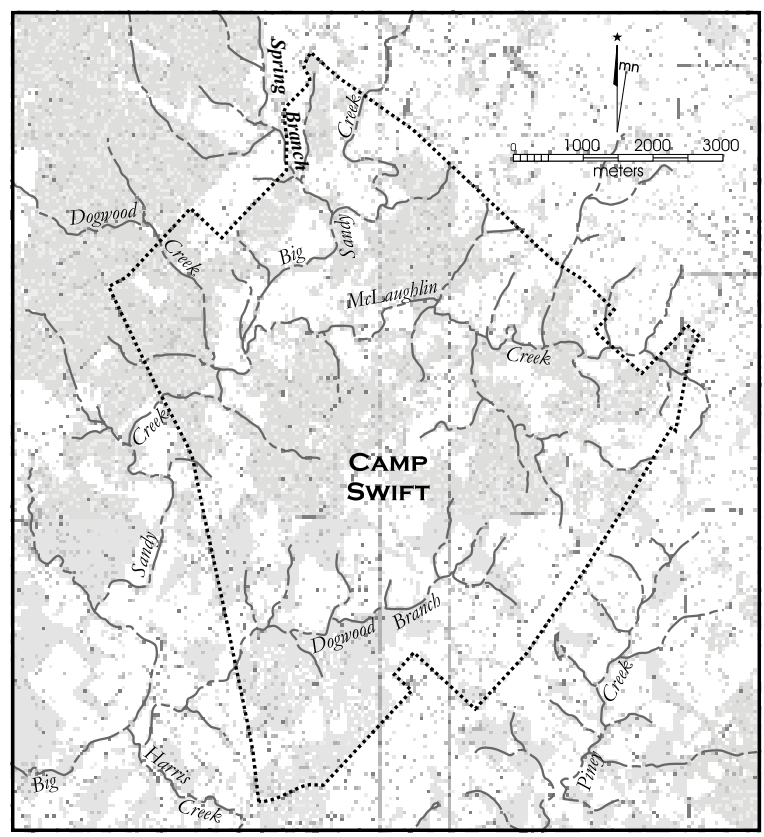

Figure 2-2. Drainages on Camp Swift. large meanders, as over-bank sediment deposits along low water channels. Floodplain deposits on Camp Swift have been described by Prochnow (2001:35) as massive channel margin sands, with wavy, sandy clay lamellae representing the flooding episodes through time.

Also occurring along low water channels are terraces; although created by floodwaters, they are now further away and above active, aggrading floodplains. According to Prochnow (2001:31), terraces generally occur 3-5 m above modern stream channel beds, in modern meander belts and outer valley margins.

Higher land forms separating major drainages and beyond the alluvial terraces are: uplands, ridges, and associated sideslopes. These

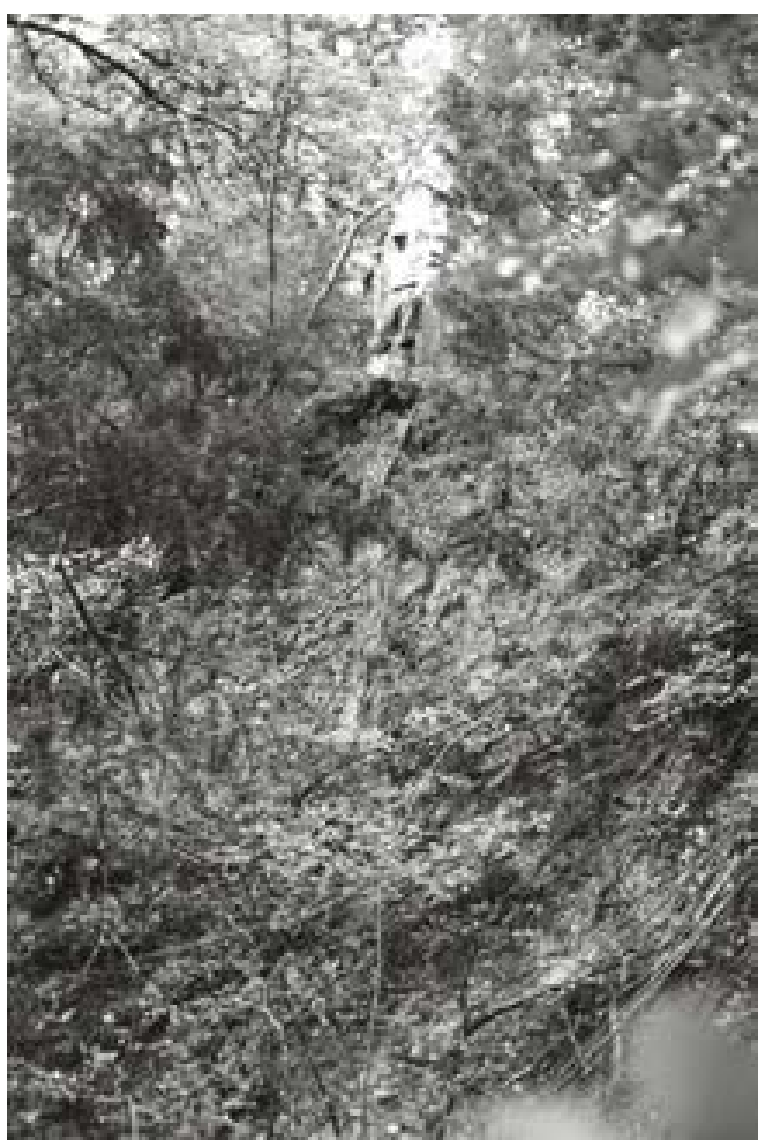

Figure 2-3. Deeply incised streams are common on Camp Swift. 
are usually covered with sandy loam soils. The formation processes of these sandy loams are debatable, as either depositional or pedogenic (see for example, Bruseth and Martin 2001; Frederick and Bateman 2001). Generally, the fine sands are underlain by clay $(\mathrm{Bt})$ horizons (Prochnow 2001).

\section{Geology and Soils}

Camp Swift's geological stratigraphy is composed of more recent sediments and soils that overlay sandstone, and light grey to yellowish brown mudstone beds with various lignite and ironstone inclusions (Barnes 1974). These beds form the Wilcox Group. The Wilcox Group is subdivided into three formations: 1) Calvert Bluff formation, 2) Simsboro formation, and 3) Hooper formation. Camp Swift is located on the Calvert Bluff formation of the Wilcox group (Barnes 1974). These beds weather into red buffcolored sands, confining dense lignite beds up to nine feet thick (Sellards et al. 1932:530, 584586; Wilmarth 1938:321). According to Judson and Kauffman (1990), the Calvert Bluff formed between approximately 37 and 58 million years ago. The mudstone and sandstone beds are found throughout Camp Swift. Mudstone beds are found on slopes and in valleys, and sandstone bed caps are commonly found in the uplands. Sandstone is less likely to erode, thus producing more narrow and steep valleys, while mudstone, a fragile sediment, allows for broader and less

Table 2-1. Soils most prominent on Camp Swift.

\begin{tabular}{|c|c|c|}
\hline Soils & Settings & Surface Textures \\
\hline Axtell series & $\begin{array}{c}\text { Stream terraces and } \\
\text { uplands }\end{array}$ & Fine sandy loam \\
\hline Demona series & $\begin{array}{c}\text { Ridgetops, sideslopes, } \\
\text { upland drainageways }\end{array}$ & Loamy fine sand \\
\hline Patilo series & Uplands & Fine sand \\
\hline Siltsid series & Uplands & Loamy fine sand \\
\hline Tabor series & Broad uplands & Fine sandy loam \\
\hline Gowen series & Floodplains, bottomlands & Clay loam \\
\hline
\end{tabular}

steep valleys. The Big Sandy Creek valley is a good example of this process. As Big Sandy Creek enters the northeastern portion of Camp Swift, it is constricted to a width of approximately $396 \mathrm{~m}$, and as it cuts through the mudstone before exiting the northwestern portion of the Camp, it broadens to about $853 \mathrm{~m}$ (Prochnow 2001:31).

The soil types commonly found at Camp Swift are shown in Table 2-1 (Baker 1979; Prochnow 2001). Soils most prominent at Camp Swift are classified as entisols or mollisols on floodplains and terraces, and alfisols in the uplands and on slopes (Baker 1979). Entisols form during pedogenic processes in temperate regions from coarse parent materials such as quartzite sands. They are commonly found on flooded, eroded, and truncated unstable surfaces or in areas that have been disturbed by humans. Floodplains, sand dunes, mining areas, and otherwise disturbed lands contain entisols (Wilding 2000:E-180). Mollisols are found in both boreal and temperate regions, usually beneath prairie grass in North America (Wilding 2000:E-181-182). Alfisols are found in humid climates in deciduous forest areas, and are "...formed, at least in part, by movement of clay from overlying horizons into the subsoil" (Wilding 2000:E-182).

\section{Climate}

Bastrop County has a subtropical humid climate, with cool winters and hot summers.

The coolest month is January, with a mean temperature of $40^{\circ}$ $\mathrm{F}$, and the warmest is July, with a mean maximum of $96^{\circ} \mathrm{F}$. The annual mean precipitation is 36.82 inches. All these factors combined allow for an annual growing season of 206 days (Marks 2008a). 


\section{Flora}

As shown in Figure 2-4, Camp Swift is located within the vegetation region of Texas known as the Post Oak Savannah (Oak Woods and Prairies) (Gould 1975). This region stretches from northeast Texas, southwesterly adjacent to the Blackland Prairie, and along the base of the Balcones Escarpment. While conducting an environmental study of Camp Swift in anticipation of a portion of it being leased for lignite mining, Tera Corporation identified common vegetation within plant communities presented in Table 2-2.

\section{Fauna}

Camp Swift lies within the Texan biotic province (Figure 25) defined by Blair (1950). Along with the wide variety of flora that exists within the 11,500 acres of Camp Swift, a very diverse animal population also inhabits the area (Figure 2-6). Table 2-3 shows those animals likely to migrate through or make Camp Swift their permanent habitat (Nightengale and Moncure 1996; Tera Corporation 1978). Over the 12-month course of the current survey, virtually all of the animals listed in Table 2-3 were observed.

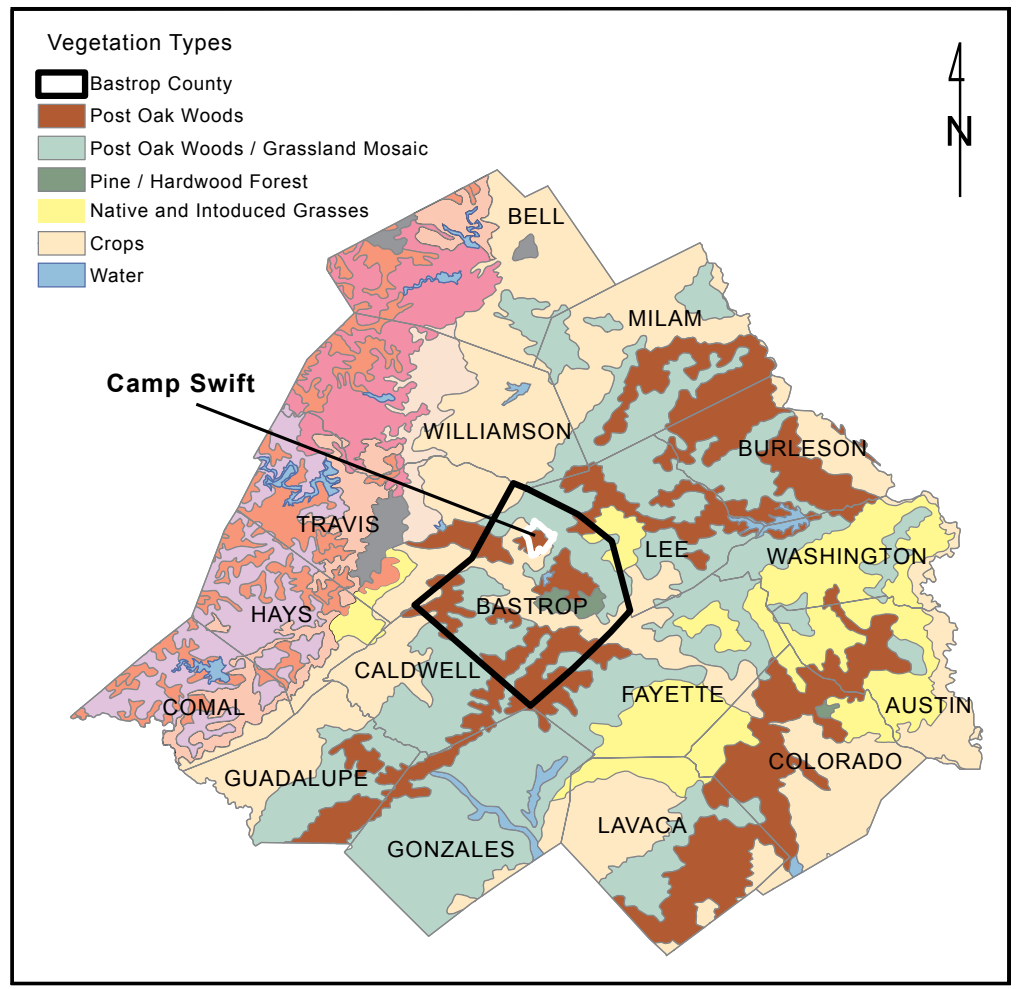

Figure 2-4. Camp Swift is located within the Post Oak Savannah vegetation region.

Table 2-2. Common vegetation within various plant communities on Camp Swift (Tera Corporation 1978; adapted from Skelton and Freeman 1979).

\begin{tabular}{|c|c|c|}
\hline $\begin{array}{c}\text { Plant } \\
\text { Community }\end{array}$ & Vegetation & Settings \\
\hline $\begin{array}{c}\text { Post Oak- } \\
\text { Red Cedar } \\
\text { Woodlands }\end{array}$ & Post oaks, red cedar & $\begin{array}{c}\text { Upper valley } \\
\text { margins, upland } \\
\text { divides, sandy soils }\end{array}$ \\
\hline $\begin{array}{c}\text { Mesquite } \\
\text { Brushland }\end{array}$ & $\begin{array}{c}\text { Mesquite, red cedar, } \\
\text { netleaf hackberry, } \\
\text { winged elm }\end{array}$ & $\begin{array}{c}\text { Disturbed slopes and } \\
\text { knolls, soils eroded } \\
\text { to clay }\end{array}$ \\
\hline Old Field & Grasses, weeds & $\begin{array}{c}\text { Floodplains, lower } \\
\text { valley margins, thick } \\
\text { sand }\end{array}$ \\
\hline Riparian & $\begin{array}{c}\text { Red cedar, black willow, } \\
\text { elm, cottonwood, black } \\
\text { hickory, pecan, pot oak, } \\
\text { hackberry }\end{array}$ & Floodplains \\
\hline
\end{tabular}




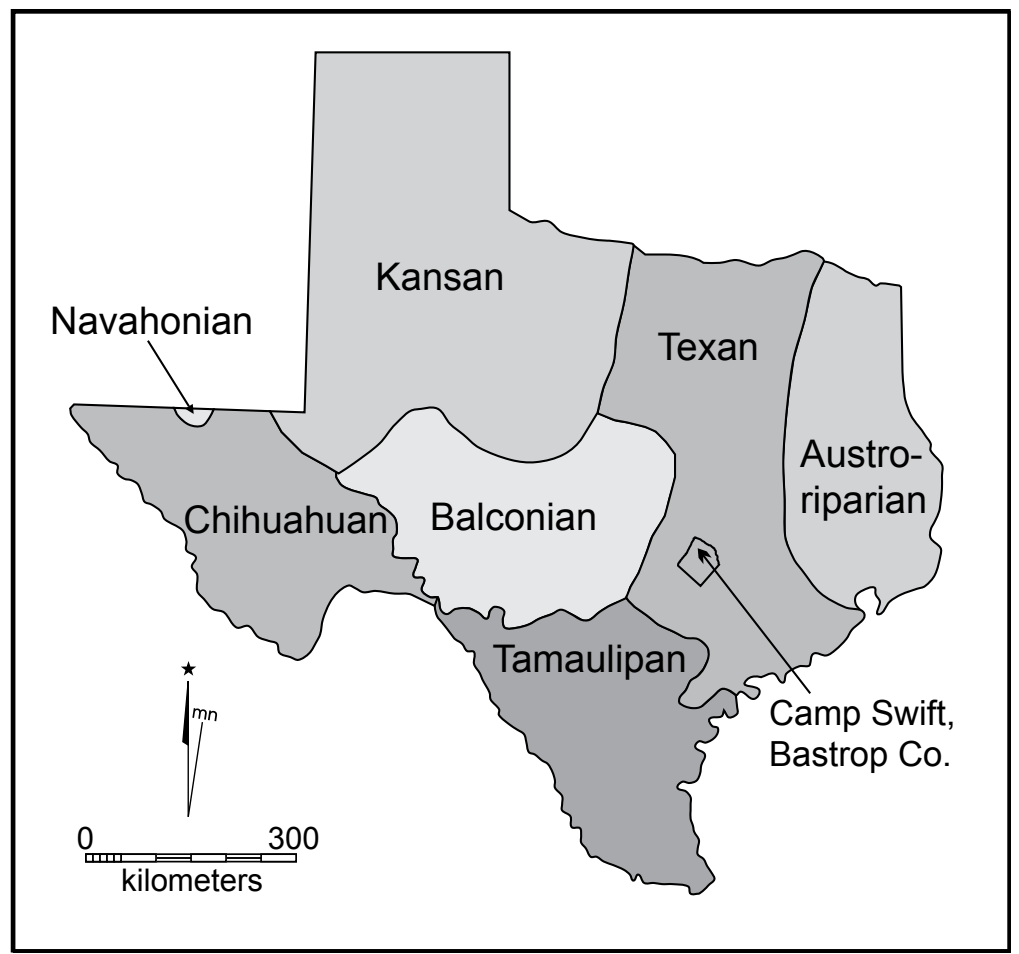

Figure 2-5. Camp Swift lies within the Texan biotic province.

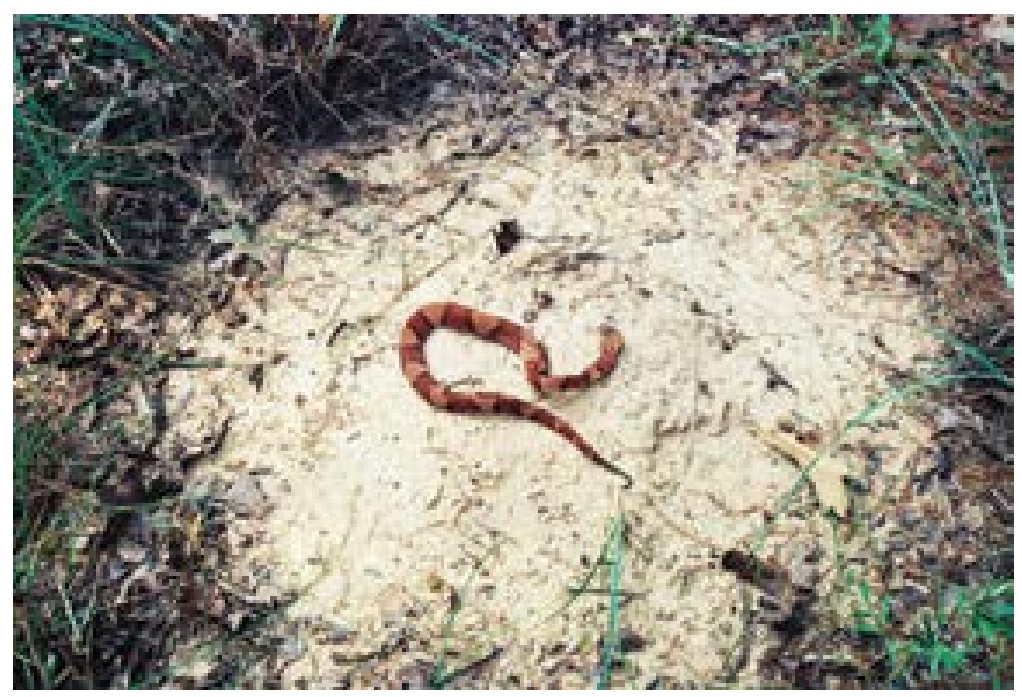

Figure 2-6. In addition to Western Diamondbacks, copperheads were commonly seen during the survey. 
Table 2-3. Animals found in the project area.

\begin{tabular}{|c|c|c|}
\hline Class & Common Name & Scientific Name \\
\hline \multirow{19}{*}{ Mammalia } & White tailed deer & Odocoileus virginianus \\
\hline & Coyote & Canis latrans \\
\hline & Grey fox & Urocyon cinereoargenteus \\
\hline & Bobcat & Lynx rufus \\
\hline & Raccoon & Procyon lotor \\
\hline & Opossum & Didelphis virginiana \\
\hline & Grey squirrel & Sciurus carolinensis \\
\hline & Wild hog & Sus scrofa \\
\hline & Hispid cottonrat & Sigmodon hispidus \\
\hline & White-footed mouse & Peromyscus leucopus \\
\hline & Black tailed jackrabbit & Lepus californicus \\
\hline & Striped skunk & Mephitis mephitis \\
\hline & Eastern cottontail & Sylvilagus flroidanus \\
\hline & Plains pocket gopher & Geomus bursarius \\
\hline & Spotted ground squirrel & Spermophilus spilosoma \\
\hline & Piñon mouse & Peromyscus truei \\
\hline & Nine-banded armadillo & Dasypus novemcinctus \\
\hline & Cougar & Felis concolor \\
\hline & Fulvous harvest mouse & Reithrodontomys fulvescens \\
\hline \multirow{10}{*}{ Reptilia } & Western diamondback rattlesnake & Crotalus atrox \\
\hline & Checkered garter snake & Thamnophis marcianus marcianus \\
\hline & Yellow mud turtle & Kinosternon flavescens \\
\hline & Eastern yellow belly racer (blue racer) & Coluber constricter flaviventris \\
\hline & Common snapping turtle & Chelydra serpentine \\
\hline & Broad-banded copperhead & Agkistrodon contortrixnlaticinctus \\
\hline & Great Plains skink & Eumeces obsoletus \\
\hline & Western cottonmouth & Agkistrodon piscivorus leucostoma \\
\hline & Ornate box turtle & Terrapene ornate \\
\hline & Red eared slider & Trachemys scripta elegans \\
\hline \multirow{15}{*}{ Aves } & Scissor-tailed flycatcher & Muscivora forficata \\
\hline & Red-bellied woodpecker & Centurus carolinus \\
\hline & Carolina chickadee & Parus carolinensus \\
\hline & Brown thrasher & Toxostoma rufum \\
\hline & Painted bunting & Passerine ciris \\
\hline & Turkey vulture & Cathartes aura \\
\hline & Northern bobwhite & Colinus virginianus \\
\hline & Northern cardinal & Cardinalis cardinalis \\
\hline & Red-tailed hawk & Buteo jamaicensis \\
\hline & Western meadowlark & Sturnella neglecta \\
\hline & American robin & Turdus migratorius \\
\hline & Northern mockingbird & Mimus polygottos \\
\hline & Lark sparrow & Chondestes grammacus \\
\hline & Mourning dove & Zenaidura macroura \\
\hline & Greater roadrunner & Geococcyx californianus \\
\hline
\end{tabular}




\title{
Chapter 3
}

\section{Cultural Chronology and Previous Archaeological InVestigations}

\author{
By David L. Nickels, Jon C. Lohse, and Jessica L. Hurley
}

\section{Cultural Chronology}

Bastrop County lies at the convergence of three traditionally recognized and well-described archaeological regions of Texas (Goode 1989). These include Central Texas, East Texas, and the Upper Gulf Coastal area. Early summaries of the cultural record of Central Texas were presented by Suhm (1957), Johnson et al. (1962), Sorrow et al. (1967), Weir (1976), and Prewitt (1981, 1985). More recently, Collins $(1995,2004)$ has reviewed and synthesized archaeological data and aspects of the paleoenvironmental records from Central Texas. Fields (1995) has synthesized the Post Oak Savannah region, which extends into East Texas, though focuses primarily on the record available from study areas located slightly north of Bastrop County. Patterson (1995), following Story (1990), has examined the record found in southeast Texas. Each region - Central, East, and Upper Gulf Coastal - has been distinguished on the basis of diagnostic artifact styles, and together they reflect an increase in the development of well-established regional traditions through time. Below, major periods are discussed as they are represented in the material record of the project area (Figure 3-1). Many of the time-diagnostic points found across Camp Swift are placed in different periods by other researchers; such prevarication is the result of some of these artifact styles having spans as long as a thousand or more years, and also of the regional chronologies that converge in the Camp Swift area.

\section{Paleoindian}

Originally defined as a nomadic way of life reliant on big-game hunting (Wormington 1957), the Paleoindian period corresponds in time with the end of the Pleistocene and very beginning of the Holocene era at approximately 10,000 years ago. Paleoindians were the first Americans, and it is not currently known exactly when they first arrived into the New World. Clovis, the earliest defined material assemblage, is consistent (or nearly so) across the entire North American continent and can be dated to around 11,500 to 10,900 years ago; antecedents to these early settlers are simply referred to as pre-Clovis. Archaeologists understand that Paleoindians in general were highly nomadic; relied heavily though not exclusively on hunting large game animals, many of which became extinct by the end of the Pleistocene; and often exhibited settlement preferences for protected habitats with nearby water and high quality stone for tool-making. For projects where adequate research has been carried out, evidence shows the high degree to which Paleoindians also relied upon small game, including aquatic resources, and indicates the exploitation of plants to the point that it is no longer appropriate to refer to Paleoindians as exclusively big game hunters. Recent summaries of Paleoindian sites and archaeology are available in Bousman et al. (2004), Collins (1998, 2004), and Hester (2004). 


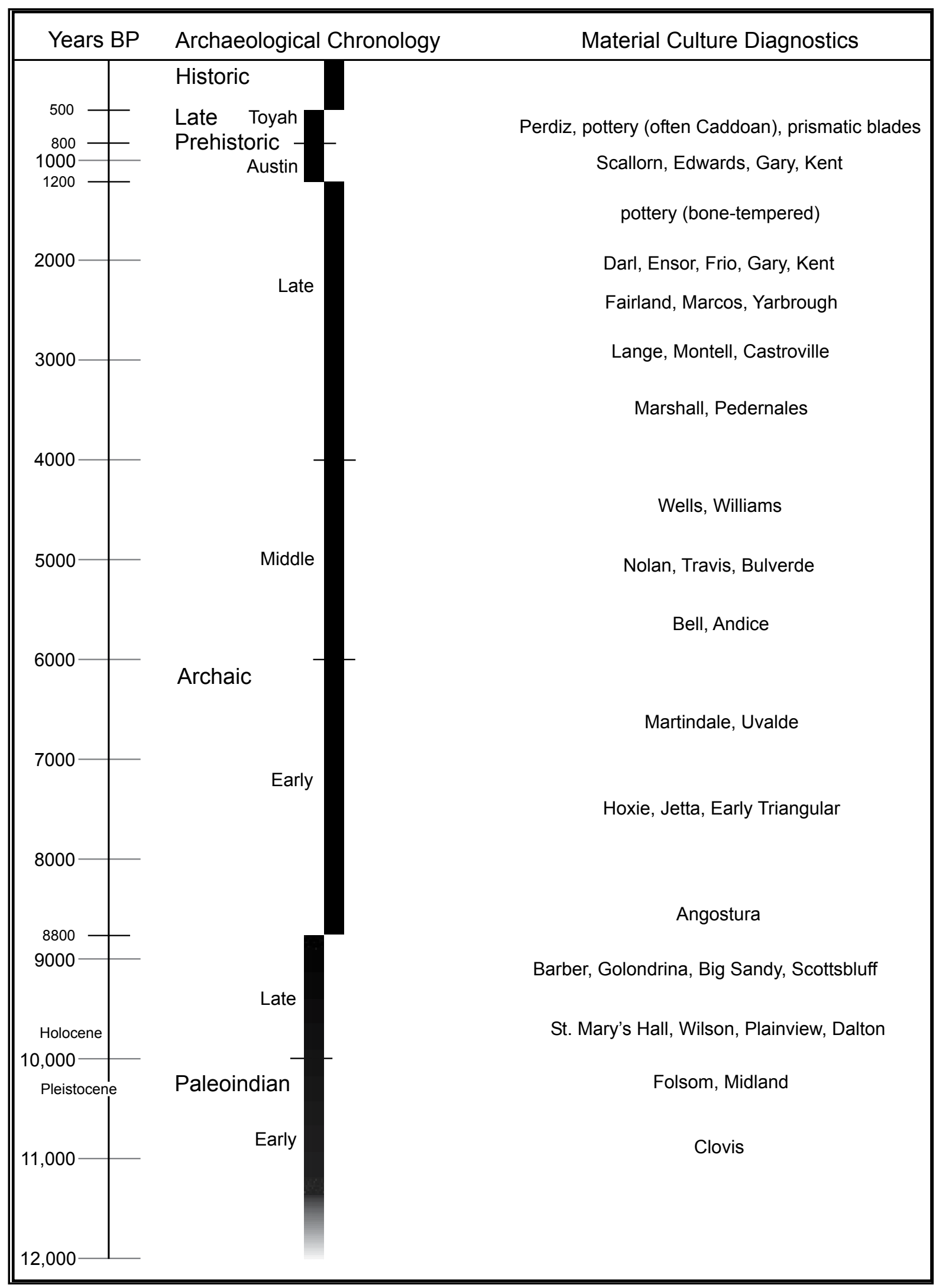

Figure 3-1. Cultural chronologies pertinent to the Camp Swift area. 
The Paleoindian period was one of a dramatically different environment than found today, with much lower average temperatures and generally wetter conditions. By the beginning of the Holocene, sufficient regional variation is evident in toolkits and artifact assemblages to warrant separation of the Paleoindian period into early and late phases. Distinctive Early Paleoindian artifacts include Clovis points and associated assemblages, as well as Folsom and Midland. Late Paleoindian finds indicate a regionalized proliferation of types, suggesting that the degree of residential mobility was diminishing, even if slightly, as populations restricted themselves to smaller seasonal rounds.

Clovis points are lanceolate in shape (as are most Paleoindian point types) and are thinned at the base by removal of one or more channel flakes, or flutes. These are often associated with the remains of mammoth, mastodon, horse, bison, and sometimes camel. Artifacts commonly found with Clovis points include prismatic blades and blade cores; tools on blades such as gravers, scrapers, and serrated cutting tools; and distinctive bifaces. Clovis flaking technology involved the controlled removal of overshot flakes that extended from one side of a biface to the other; when found in discrete assemblages, these flakes are as distinctive of Clovis activity as other tool forms. Clovis sites commonly include campsites, quarries, caches, and kill sites (Collins 1995). With the exception of quarries, these sites are often buried beneath meters of sediment. Many Clovis finds, however, are single artifacts or clusters lying on the surface of deflated landscapes. A single artifact of possible-Clovis manufacture has been found at Camp Swift (Nickels et al. 2005:Table 6-2).

Folsom and Midland points follow Clovis in time, with Midland occurring slightly later though overlapping in certain instances with Folsom.
Folsom points are exquisitely fluted, and are often found with ancient bison remains. Midland points also are extremely well made, showing fine pressure collateral flaking though without fluting. Very thin bifaces, called ultrathins, are commonly found at some Folsom campsites. These bifaces exhibit width-to-thickness ratios of up to 20:1 (Root et al. 1999). Other Pleistocene fauna were extinct by this time, and Folsom peoples are frequently regarded as specialized bison hunters. Many Folsom sites occur as surface scatters, though some deeply buried deposits are known as well from areas in Bell, Goliad, Uvalde, and Williamson Counties (Collins 1995).

Late Paleoindian diagnostic artifact styles proliferate by around 10,000-9,700 years ago, perhaps as a result of dramatic changes as annual temperatures warmed and conditions gradually became wetter in the Early Holocene (Bousman 1998; Collins 1995:Table 2). The change from relatively xeric to mesic conditions was accompanied by gradual shifts in settlement mobility, subsistence practices, technological innovation, and some social practices (Bousman et al. 2004). Important point styles from this period include Wilson, Dalton, St. Mary's Hall, Golondrina, Barber, and Scottsbluff. Each of these exhibits limited distributions compared to Early Paleoindian Clovis and Folsom points, suggesting that populations associated with their production were covering smaller ranges in terms of settlement mobility. Following the end of the Pleistocene, virtually all of the large game animals that were central components of Early Paleoindian diets had become extinct, requiring a shift to expanding populations of smallerbodied animals such as deer and antelope. Bison remained important and diet breadth in general increased as indicated by recovered faunal and botanical evidence. Evidence from Central Texas indicates that groups began experimenting with technological changes, such as crafting stemmed 
dart points, and even burying their dead at campsite locales (Bousman et al. 2002). Late Paleoindian presence at Camp Swift is somewhat problematic. The only possible evidence from this period so far comes from an Angostura point fragment recovered by Robinson (2001:122), though this type is placed by some researchers (Collins 1995) in the Early Archaic (see below).

\section{Archaic}

Distinctions between the Paleoindian and ensuing Archaic stages were established early on by scholars such as Willey and Phillips (1958:107111), who recognized nine primary differences between the two periods. These initially included shifts from large animal hunting and exploitation to a variety of smaller animals, increased plant food use and gathering, increase in use of ground stone tools for processing plants, greater number and variety of chipped stone tools for apparent wood working, manufacture of corner- and sidenotched projectile points that were propelled with an atlatl, greater population stability with less residential mobility, increased reliance on organic materials for tool production, systematic burial of dead, and use of stone for cooking technologies. However, new evidence indicates that some of these transitions occurred over long periods of time (Bousman et al. 2002). The finer distinctions between Late Paleoindian and Early Archaic have become blurred, leading some (Oviatt et al. 2003) to use the term "Paleo-Archaic" to refer to the late Pleistocene-early Holocene interval. Important points for consideration when modeling this dynamic period are environmental shifts and changing climatic conditions that affected regional plant and animal species inventories. In general terms, landscapes became wetter over this interval (with severe oscillations between wet and dry throughout the Holocene), though this process was not synchronous from one region to another and effects were not the same on all local environments. The most detailed
Archaic cultural chronologies for Central Texas and adjacent regions have been proposed and modified by Prewitt $(1981,1985)$.

\section{Early Archaic}

Given these drawn-out transitions, it is difficult to place the beginning of the Archaic with precision. Bousman et al. (2004) suggest it began around 8,000 years ago, while Collins (1995) places it from 8,400 to 8,800 years ago. Angostura points, which exhibit basal grinding distinctive of many Paleoindian point types, seem to span the transition from Late Paleoindian to Early Archaic. Weir (1976) has suggested that Early Archaic populations were small and highly mobile based on the large number of thinly distributed sites and the occurrence of diagnostic types across areas in Texas and New Mexico. However, extensive deposits from this period at sites including Wilson-Leonard (Williamson County), Gault (Bell County), Kennedy Bluffs (Bastrop County), and many others indicate that social groups converged on familiar locales during certain times of the year. Burned rock features appear, and are gradually replaced by middens (at least in some regions) as hot rock cooking techniques are more commonly applied throughout the Archaic (see Black et al. 1997). Diagnostic artifacts include split-stem dart points, such as Gower, Hoxie, and Jetta. Waco Sinkers and grooved stones also appear, suggesting the use of nets as new (or at least newly identified) components of subsistence-related toolkits. Guadalupe and Clear Fork bifaces show wear patterns as gouges and adzes, indicating wood working during this time. Specialized bison hunting weaponry dating to the very end of this period is perhaps represented by Bell and Andice points and their northern counterpart, Calf Creek (Johnson and Goode 1994; Wyckoff 1995). Additionally, while not commonly found, ornamental items such as shell and drilled stone beads provide evidence for personal adornment and perhaps 
for the recognition of social distinctions by age, gender, or role. Elsewhere in North America, the Windover bog site in Florida contains an Early Archaic cemetery, where archaeologists have recovered the remains of at least 168 individuals (Doran 2002). In Victoria County, Texas, another multi-component cemetery with numerous Early Archaic interments has been excavated by Coastal Environments, Inc. and is undergoing analysis by Robert A. Ricklis (Ricklis 2005). Cemeteries such as these provide solid evidence for the association between nomadic groups of people and regional territories. Early Archaic presence in the Camp Swift area is so far limited; Robinson (2001:122) illustrates an Angostura point fragment and Nickels et al. (2005:Table 62) lists an Andice find (which he places in the Early Archaic rather than the Middle Archaic, as shown in Figure 3-1). Camp Swift currently lacks the kinds of extensive heated stone features (burned rock middens) found closer to and above the Edwards Plateau.

\section{Middle Archaic}

The Middle Archaic is thought to have been a time of increasing populations. Food resources like deer and acorn appear to have been hyperabundant and provided much of the basis for seasonal residential mobility patterns (see Black 1989a). Massive middens of burned and firecracked rock, some with intact internal features such as pits and hearths, accumulated as a result of processing these and other resources. While many of these middens have earlier Early and Middle Archaic components underlying them, the majority dates to the Late Archaic extending into the Late Prehistoric period (Black and Creel 1997). Bison are notably absent during the middle to later parts of the Middle Archaic (Dillehay 1974), though are present in other periods. This absence corresponds with a dramatic drying of climate, described by Collins (1995:384) as "what appears from the record to have been the onset of the most xeric conditions ever experienced by humans in Central Texas." The effects of this dry spell are significant for the prehistoric cultural record of Camp Swift. Occupants of the region would have had to adapt to these changing conditions through modifications of tool design and/or subsistence procurement technologies. Perhaps more important, though, are the impacts of this climate change on processes of sediment deposition and erosion. Currently, no cultural components at Camp Swift can be firmly dated to the Middle Archaic (see Nickels et al. 2005: Table 6-2, Figure 6-1). It is conceivable that landforms from this period that contained artifact materials have been lost through severe erosion as protective groundcover dried up, exposing loose sandy sediments to wind and/or episodic rainfall events. Diagnostic artifact types from this period include stemmed dart points such as Nolan, Travis, Wells, and Williams. While Prewitt (1985) describes Bulverde as Middle Archaic, Collins (1995:384) places the type at the very beginning of the Late Archaic, and the specimen reported in Nickels et al. (2005:Table 6-2) is considered a Late Archaic find; however, it probably spans the interval between these periods.

\section{Late Archaic}

The Late Archaic was a substage of additional population growth, increased use of hot-rock cooking technology, and continued diversification of point types and regionally defined settlementsubsistence patterns (Story 1985). Johnson and Goode (1994) observe influences from culture groups from the eastern part of the continent, particularly in terms of religious expression and social organization evidenced in group cemeteries (e.g., Hall 1981). Some researchers (Black 1989b) have argued that subsistence bases grew increasingly diverse, referred to as broad spectrum, though with reduced emphasis on acorns. Bison disappeared again from the Central Texas region (Dillehay 1974). The large 
number of Late Archaic diagnostic points is partly a reflection of the length of this period compared with the preceding Middle Archaic. Styles include Pedernales, Montell, Castroville, and others. The presence of Yarbrough in project areas near Camp Swift is likely to be evidence of influence from eastern parts of the state. At Camp Swift, illustrated types include Ensor, Frio, and Pedernales (Lehman et al. 2003; Robinson 2001).

\section{Late Prehistoric}

The Late Prehistoric represents an important and highly dynamic transition out of "Archaic" ways of life to substantially changed subsistencerelated technologies and perhaps even patterns of social movements and interactions across the landscape. Divided into two phases (Jelks 1962) termed Austin and Toyah (Prewitt 1981), the Late Prehistoric is defined by distinctive traits that include bow-and-arrow technology, ceramic manufacture, and, in some regions, agricultural practices. As Collins (1995:385) notes, this last trait was of only minor importance across some parts of the state. The Austin phase is commonly seen as merely a continuation of the Late Archaic (Johnson and Goode 1994). The most important changes are the appearance of small arrow point types such as Edwards and Scallorn, indicating a shift away from use of the atlatl. These types replace the smaller dart point forms that trend from Late Archaic into the Austin phase, including Darl, Ensor, Frio, Gary, Kent, and others. Burned rock middens are occasionally found associated with these dart point forms, as well as Edwards and Scallorn points (e.g., Houk and Lohse 1993). Ground and pecked stone artifacts for plant processing, which appear much earlier in the Archaic, are relatively common by this time. Dillehay (1974) has noted that bison are not present in the region during the Austin phase, though additional work (Huebner 1991) has suggested that bison might only have been reduced in number and distribution, not entirely absent. Perhaps two of the most important developments at this time include the introduction of bone-tempered pottery along the Upper Gulf Coast and East Texas (Story 1985; Story 1990) as early as AD 300-500, and evidence for social conflict. A number of individual burials dating to the Austin phase have been exhumed that show signs of arrow point penetration (e.g., Meissner 1991; Prewitt 1974; see Black 1989a), suggesting that populations had increased to the point where regional territorial disputes emerged over available resources.

Perdiz points, characterized by long contracting stems and flaring barbed shoulders, appear in the archaeological record of Central Texas and nearby areas around AD 1200. Kelley (1947a, 1947b) associated these with what he called the Toyah Focus, and they have remained the central element of material assemblages from the later portion of the Late Prehistoric. Prismatic blades, blade cores, and scrapers-on-blades occur and are thought to be parts of specialized Toyah bison hunting and processing toolkits (Black and McGraw 1985; Huebner 1991; Ricklis 1994). More importantly, in terms of the social composition of Toyah groups, is the wide variety of ceramic styles and influences that are seen across Toyah assemblages. Some vessels found at sites from this period evidence Caddo-style decorations, while others are coated or decorated with asphaltum from the Texas Gulf Coast. Still other design elements are from West Texas and show Jornada Mogollon influences. Johnson (1994) has argued that Toyah is the material remains of a single group that sprawled across these vast areas, while Ricklis (1994) has described it more as a constellation of traits that moved through relatively stable regional populations (a technocomplex). More recently, John Arnn (2005) has considered the drift of ceramic styles into and out of Toyah "core areas" as signifying the 
movements of small groups of people who moved between different populations established in these regions. Perdiz points, long thought to be at the core of Toyah material culture, are also noted in much later contexts, including an example made of glass recovered from American Indian neophyte residential contexts at the San Antonio de Valero mission in San Antonio (e.g., Lohse 1999:268). The relationships of Toyah peoples with their regional neighbors and their lingering material record are among the more intriguing topics of study in late Texas prehistory.

\section{Protohistoric/Historic}

The end of the Late Prehistoric and beginning of the Historic period in East, Northeast, Southeast, and Central Texas is characterized by written accounts of European contact with indigenous groups. The Protohistoric period begins in 1528 when Spanish explorer Cabeza de Vaca traversed parts of Southeast Texas and left a diary of his five years spent traveling among the hunter-gatherers of Texas and northern Mexico (Covey 1961). In 1542, Coronado entered the Texas Panhandle with hopes of finding riches (Winship 1973 [1896]). That same year, after assuming command from Hernando de Soto, Spanish explorer Luis de Moscoso Alvarado ventured into Northeast Texas, and perhaps beyond, encountering Caddoan-speaking groups before turning back. In 1568, Englishman David Graham returned from Mexico to Nova Scotia, passing inland along the Texas Gulf Coast (Cutrer 1985:7-12).

By the 1540s and 1550s, Spanish ranchers had established large ranches with several hundred thousand cattle in northern Mexico, using Indian slaves as labor. Large mining ventures in northern Mexico did the same. This encroachment from the south forced Native Americans to escape into the south-Central Texas region. The Spanish pushed into New Mexico, and made Santa Fe the capital in 1598. Their harsh treatment of the natives led to the Pueblo Rebellion of 1680 . The Spanish and a few loyal native groups fled to the El Paso area, establishing Isleta Pueblo, but left behind thousands of horses, providing mobility that would significantly disrupt groups in south-Central Texas. Although a few daring Apache had escaped slavery in New Mexico before the rebellion, they now owned a means of transportation that would allow them to hunt and raid unimpeded. By the mid-1700s they had encroached through the plains of the Texas Panhandle and were taking over hunting grounds in Central Texas. By that time the French and English were encroaching from the east, and establishing trade relations with the natives up and down the Red River (Morris 1970:80-81).

Although the advent of Spanish missions around San Antonio and East Texas in the late 1600 s and early 1700 s resulted in records of neophyte conversions and general life inside the missions, the Protohistoric period is a time when few, scant written documents exist detailing Native American life outside the missions. The Historic period that follows is generally thought to begin in the 1700 s, or ca. $260 \mathrm{BP}$ in Central Texas (Collins 1995:386-387) and is best documented by the records of Spanish priests in charge of the missions. The Spanish launched several expeditions or entradas into New Spain (Texas) in order to either inspect the missions or its politically fragile frontier. Early Spanish entradas through Bastrop County include those of Domingo Terán de los Rios in 1691, Pedro de Aguirre in 1709, and Louis Juchereau St. Denis in 1714. And in 1804, a small Spanish fort named Puesta de Colorado was built at the Camino Real crossing on the Colorado River (Leffler 2001).

By 1827, Mexico had gained its independence from Spain and European settlers were moving into the Bastrop area in Stephen F. Austin's "Little 
Colony." As an empresario, Austin established four colonies of settlers. This was the third colony he settled, moving 100 families east of the Colorado River to present-day Bastrop County (Barker 1949:126). However, Native American hostilities impeded further westward settlement toward the Camp Swift area until around 1836, when Texas gained its independence from Mexico and the Texas Rangers offered better protection (Leffler 2001). Although peace was declared under a treaty with the Comanche in 1845, continued Native American hostilities occurred in the area to Anglo settlers who took farm and ranchlands that were once hunting grounds (e.g., Wilbarger 1985 [1889]).

In the decade after Texas gained statehood and again following the Civil War, waves of settlers moved into Bastrop County along McLaughlin, Big Sandy, Dogwood, and Piney Creeks (Sitton 2006). During the 1850s and 1860 s, families "arranged themselves into informal, dispersed rural communities"; some communities, such as Oak Hill, gave "rise to a characteristic infrastructure of church, school, and graveyard" (Sitton 2006:13). The population in the area continued to increase as the construction of railroads in the early 1870 s prompted the establishment of the towns of McDade and Elgin (Marks 2008b; 2008c). Railroad construction also led to the creation of the Sayers(ville) community and depot stop in 1886 (Buder 1996). New waves of settlers continued to arrive in the area in the 1880s and 1890s, often joining relatives living in the existing communities of Oak Hill, Piney, Wayside, and Sayers, as well as others (Sitton 2006).

Among the most prominent early settlers and farmers of the Camp Swift area was Antoine Aussilloux, a French immigrant who became a naturalized U.S. citizen in 1875 . Antoine came to the United States with his brother A. Cologne, and in the 1870s was living in Bastrop County as a stonemason. In 1876, Aussilloux bought 60 acres on the north bank of Big Sandy Creek with a partner, Frank Gorton, to establish a winemaking business. Aussilloux is perhaps the most notable early settler of Camp Swift. Remains of his industry include the ruined limestone cellar of his two-story house (recorded as site 41BP138), the Scott Falls dam across Spring Branch (also called Scott Falls Creek) crafted of hand-chiseled limestone and sandstone blocks, and remnants of an irrigation system that carried water from the dam (see Chapter 8, 41BP108) to his grape fields located almost a mile away (Nickels and Lehman 2004b:72-89). Upon the passage of the Prohibition amendment in 1919, Aussilloux was forced to close his winery operation. He was found dead in his front yard by a neighbor in 1924, and soon after local authorities burned his property and remaining buildings because of their unsanitary condition. The homestead remained in this condition until 1942 when Camp Swift was created and U.S. Army officials acquired the 100 -acre estate for $\$ 477$ (Leffler 2001:18).

In addition to the Aussilloux winery, another significant early business in the area now occupied by Camp Swift was the Sayers lignite mine. Operated by Frank Dennison under a lease with Mrs. Mary C. Young, the Sayers Mine extracted over 200 railroad cars of lignite a year between 1915 and about 1924, when the operation was damaged by fire. Dennison rebuilt his operation, but closed for good in 1928 after a second fire. Stipulations of the Dennison-Young lease called for the removal of all buildings and improvements from the property when and if the mine was no longer active. Remains from this operation at Camp Swift include sump ponds corresponding with old mining shafts, surface scatters of artifacts, spoil piles, and a cemetery for Mexican workers 
(41BP170) who died while working at the mine (Leffler 2001).

In 1920, about 350 families lived on properties within the triangular 87 square miles of countryside that would become Camp Swift (Sitton 2006). Early settlers in and around this area typically planted cotton as a money crop and corn as a subsistence crop, but cotton production in Bastrop County peaked in 1900 and by 1920 area farmers had begun to diversify their crops to include alternative cash crops such as melons, peanuts, and sweet potatoes. Some families also raised turkeys and collected chicken eggs, which could be sold for cash or bartered for items they were unable to produce, like sugar, flour, coffee, and kerosene. In addition to corn for household consumption, people depended on vegetables produced in house gardens, wild plants and vegetables, cattle for dairy products, and pork (Sitton 2006). People also worked part-time in the nearby mines, brickyards, or for government projects (during the Depression years), in addition to subsistence farming and cash cropping. Nevertheless, farming in the sandy soils of Bastrop County proved to be a difficult existence.

However arduous life may have been for those farming families, preparations for America's entrance into World War II further complicated the lives of a portion of the local population. Near the outset of World War II in 1940, the United States Army received a proposal from business and civic leaders in Austin, Bastrop, Elgin, and nearby smaller towns to acquire land for the construction and operation of a military training base near Bastrop. The area was deemed ideal for a number of reasons, including the relatively low fertility and agricultural productivity of the sandy soils; existing nearby highways, rail lines, and power and gas lines; abundant well water; and the projected low cost per acre of acquiring the necessary property (Leffler 2001:25). In January of 1941 the War Department privately approved the proposed Army plan to build a military camp in northern Bastrop County.

On December 18, 1941, eleven days after the attack on Pearl Harbor and almost a year after approval by the War Department, Lyndon Baines Johnson, then a U. S. congressman, publicly announced the War Department's decision to have government attorneys "start the process for taking legal possession of 425 tracts of privately owned land that totaled 52,162 acres" in northern Bastrop County (Sitton 2006:87). Land owners were paid low prices for their land and were informed that any buildings or improvements on the land could be removed but within 30 days after purchase by the government or they would be demolished. Construction of Camp Swift began in March of 1942 while people were still moving or in the process of preparing to move. Army training began in May, and all roads were closed to the public on June 15 (Sitton 2006). Camp Swift's pre-war design included 2,750 buildings with accommodations for 44,000 troops, but reached a maximum of 90,000 troops during the war (Leatherwood 2008). After the war, nearly half of the land that comprised Camp Swift was sold back to the public, but not always to the original landowners, many of whom could not afford to repurchase the land and construct new houses and related buildings (Bousman 2006).

Today, the TXMF retains 11,500 acres of Camp Swift land, which is used for various military training exercises. The TXMF Environmental Division Resources Management Office oversees the cultural resource management (CRM) of Camp Swift. A number of CRM projects have been undertaken (see Previous Archaeological Investigations below) at Camp Swift, and this current project is one of these. An oral history project conducted in 2004 provided 
further insight into the lives and experiences of those families who lived on the land immediately prior to the construction of Camp Swift (Freeman et al. 2006; Sitton 2006). Eighteen former occupants of Camp Swift spoke of both the difficulties and rewards of life in the sandy hills of northern Bastrop County, as well as how the government takeover affected their lives. These individuals were able to identify site locations, occupants, activities, and other relevant sources of information at these historical archaeological sites. Their recollections were critically important to our archival, historical, and archaeological investigations.

\section{Previous Archaeological Investigations in Bastrop County and Camp Swift}

The first archaeological work in the Bastrop County was a survey along the central portion of the Colorado River in Travis, Bastrop, and Fayette counties by A. M. Wilson. Wilson (1930) recorded six prehistoric sites in Bastrop County; however, due to poor documentation, the site descriptions and localities are vague. In 1953, T. N. Campbell and E. B. Jelks excavated two Late Prehistoric burials at the Goodwin Site (41BP1). The skeletal remains were observed in direct association with ceramic sherds and Scallorn arrow points (Texas Archeological Site Data Form [TASDF], on file at the Texas Archeological Research Laboratory [TARL]).

\section{0-1970}

In 1962, the University of Texas Anthropological Society (UTAS) conducted archaeological investigations within Bastrop County that documented previously unrecorded sites. During this survey, UTAS (Davis 1964) documented two Late Prehistoric burials (and associated artifacts) at the McCormick Site (41BP43) and a Late Prehistoric campsite (41BP55) southeast of Sayersville (Brown 1966; Hester 1966). 41BP55 lies in a plowed field near the confluence of Harris Creek and Big Sandy Creek, and was considered to have good potential for further investigations (TASDF). In 1968, UTAS conducted excavations on 41BP62, 41BP63, and 41BP64, and from all three recovered cultural materials associated with the Archaic through Late Prehistoric periods (Malone 1968).

\section{0-1980}

In the mid-1970s, the Texas Archeological Survey (now TARL) at The University of Texas at Austin undertook investigations in Bastrop County, including a survey in 1975 of 160 acres on Camp Swift that recorded 41BP68, a prehistoric chert scatter (Fawcett 1975). Subsequent surveys by TARL within Bastrop County in 1976 and 1979 were limited to a reconnaissance level (Dibble 1976; Dillehay 1979).

In 1979, at the request of the Lower Colorado River Authority (LCRA), Skelton and Freeman (1979) investigated 4,000 acres to be impacted by a proposed lignite surface mine within Camp Swift. During this intensive survey Skelton and Freeman discovered 42 prehistoric sites and 43 historic sites. According to Skelton and Freeman, the majority of sites at Camp Swift that were located on upper terraces and active floodplains had a higher degree of integrity than sites located on valley margins and upland divides. Skelton and Freeman's 1979 survey forms the basis for Camp Swift archaeological site data, from which past and present archaeological work draws.

\section{0-1990}

The Center for Archaeological Research (CAR) at The University of Texas at San Antonio performed a reconnaissance-level survey of 1,900 acres in northern Bastrop County and a small part of Lee County during July of 1980. CAR conducted the survey for City Public Service 
(CPS) of San Antonio to locate any cultural resources that would be impacted by proposed lignite mining. During this investigation, CAR discovered five prehistoric sites (41BP199, 41BP204, 41BP205, 41BP206, and 41LE63) and four historic sites (41BP200, 41BP201, 41BP202, and 41BP203) (Kelly and Roemer 1981).

In May and June of 1983, CAR conducted a 117-acre pedestrian survey within the CPS Butler Lignite Prospect for the City of San Antonio. During this survey, five prehistoric sites were recorded. Two of these sites contained mixed prehistoric and historic materials. Three of the five sites (41LE73, 41BP265, and 41BP264) were recorded along hill ridges approximately $80-400$ $\mathrm{m}$ from intermittent drainages. The remaining two (41LE74 and 41LE75) are located along ephemeral drainages within $50 \mathrm{~m}$ of Willow Creek. One site (41BP264), located along a ridge $250 \mathrm{~m}$ from an intermittent drainage, produced tools that span the Late Archaic to Paleoindian periods (i.e., Plainview, Pedernales, and Clear Fork Tool).

In 1984, CAR initiated an intensive cultural resources survey for the City of San Antonio on 2,433 acres of the CPS Butler Lignite Prospect in northern Bastrop and southern Lee Counties (Taylor 1987). Fourteen sites were investigated, including three prehistoric sites consisting of light lithic scatters located in upland environments along intermittent drainages. These three sites were tested using shovel probes, which provided no evidence of intact deposits. The three prehistoric sites (41BP271, 41BP272, and 41LE85) were considered disturbed due to the lack of intact cultural features and heavily eroded surfaces (Taylor 1987).

In 1987, Espey, Huston \& Associates, Inc. (EH\&A) surveyed a 2.8-mile long, 7.6-m wide right-of-way on the inside of the western perimeter fence along Highway 95 for a proposed water line running from Bastrop to Elgin (Voellinger 1987). The 2.8-mile section ran from approximately the halfway point of the Camp to its northern boundary. They excavated 14 shovel tests along that portion and found no sites. Because the southern 2.5 miles of right-of-way along the fence ran through a portion of the 4,000-acre surveyed in 1979 by Skelton and Freeman (1979), EH\&A did not re-survey that lineal stretch, but did revisit 41BP139, a site recorded by Skelton and Freeman (1979).

From April to May of 1989, LCRA conducted a survey and geomorphological investigation within a proposed 780-acre expansion to the Powell Bend II Lignite Prospect, the fourth investigation of this nature performed on this property. The 780 -acre project area, which is adjacent to Camp Swift, is similar to Camp Swift in prehistoric cultural deposits and geomorphological and paleoenvironmental records. Nine sites were recorded during the survey, two historic and seven prehistoric. Two of the prehistoric sites (41BP332 and 41BP335) were located along opposing flood terraces of Harris Creek, which is an intermittent tributary of Dogwood Creek. The remaining five prehistoric sites (41BP330, 41BP331, 41BP333, 41BP334, and 41BP338) are located along upland divides overlooking Harris Creek, and minor tributaries of Harris Creek. 41BP332, 41BP335, and 41BP331 were recommended for further work based on the cultural material recovered from shovel tests and the presence of a Late Archaic, Ensor dart point found on the surface of 41BP332 (Nightengale et al. 1992).

\section{0-2005}

In 1990 and 1991, LCRA undertook archaeological investigations on 350 acres of property and 4.5 miles of conveyance lines for the Camp Swift Regional Wastewater Project 
on land managed by the LCRA. During these investigations, fourteen sites were recorded, consisting of ten prehistoric and four historic sites. Four of the prehistoric sites (41BP359, 41BP360, 41BP366, and 41BP367) are located along tributary banks, two on terraces (41BP363 and 41BP364), two on a bluff/knoll setting (41BP358 and 41BP365), and two sites (41BP361 and 41BP362) are located on upland terrain. According to Nightengale and Moncure (1996), all the sites recommended for avoidance (i.e., 41BP358, 41BP359, 41BP360, 41BP363, and 41BP364) contained intact buried deposits and thus should be regarded as highly significant.

In the 1990s, TXMF staff archaeologists did a series of special surveys on Camp Swift to provide clearance for proposed training activities and facilities (Leshley 1994, 1996; Stringer and Wormser 1996; Sullo and Wormser 1996; Wormser 1993a, 1993b, 1994; Wormser and Leshley 1995). In August and September of 1995, EH\&A conducted a cultural resources survey of ten seismic lines in advance of a seismic exploration project for KCS Resources, Inc. During this project, a total of 520 shovel tests were excavated and seven new archaeological sites were discovered (Schmidt et al. 1995).

In 1995, EH\&A surveyed the linear rightof-way for a $138-\mathrm{kv}$ transmission line rebuilding project that ran from south to north through the western portion of Camp Swift (Nash et al. 1995). Six new sites were discovered during this project.

In April 1996, EH\&A surveyed 52.3 acres on Camp Swift for KCS Resources, Inc. This investigation consisted of: (1) a systematic pedestrian survey and (2) placement of shovel tests in areas with low surface visibility (less than 25 percent). The purpose of this investigation was to determine if the proposed construction of four wellpads and connecting roads would adversely impact cultural resources. Since no archaeological sites were recorded within the proposed construction area, cultural resource clearance was recommended (Nash et al. 1996).

From November 1996 to July 1997, TXMF conducted a pedestrian survey of 5,000 acres on Camp Swift. During this investigation, 1,000 acres that had been previously surveyed by Skelton and Freeman in 1979 were revisited (Robinson 2001). An assessment of previously recorded prehistoric and historic sites for NRHP eligibility that warranted further testing was included in this project. In addition to the TXMF pedestrian survey, during September of 2000 CAR excavated shovel tests on $41 \mathrm{BP} 485$ and 41BP487, and acquired GPS locations of 28 previously recorded sites (Robinson et al. 2001). Geomorphological investigations during the 2000 survey included recording data from 12 backhoe trenches and using previously recorded data (Lim et al. 2000; Prochnow 2001).

According to Prochnow (2001), the deposits within the project area on Camp Swift generally have a low potential to contain buried intact archaeological deposits, adding that Late Holocene erosion and high-energy deposits along with intense bioturbation are some factors that contribute to these conclusions. In 2001, Mauldin (2001) developed eligibility recommendations for all 168 sites within the Camp Swift boundaries. Twenty-two sites recorded during the $1997 \mathrm{TXMF}$ pedestrian survey and 37 previously recorded sites were considered potentially eligible for the NRHP, and therefore warranted further testing (Mauldin 2001). However, additional shovel tests defining horizontal and vertical boundaries were warranted before potentially eligible sites could be recommended for NRHP nomination. 
In November and December of 2001, the Center for Archaeological Studies (CAS) at Texas State University-San Marcos (formerly known as Southwest Texas State University) evaluated 39 previously recorded sites within Camp Swift for TXMF. The primary goals of this project were site relocation, mapping, and determining site parameters, integrity, and significance. Nine of the sites contained both prehistoric and historic components, and the remaining thirty sites had prehistoric components. Sites were classified as having minimal potential $(n=19)$, moderate potential $(n=8)$, or high potential $(n=11)$ (Nickels et al. 2003). These classifications were based on the presence or absence of stratified, intact deposits that possibly contain datable features, and can contribute significant information toward recent research issues. All of the sites determined to have high potential were located in upland, ridge and or sideslope environments. Five out of eight of the moderate potential sites were located in upland environments, with the remaining three sites located along terraces and a drainageway.

In December 2002 and January 2003, the CAS revisited 20 previously recorded sites at Camp Swift. After placement of shovel tests and additional mapping, CAS assessed one site as eligible for the NRHP, eight sites as ineligible, and 11 as potentially eligible, but further investigations beyond shovel tests were required (Nickels and Lehman 2004).

In June through August 2002, CAS conducted Phase II testing to evaluate 20 archaeological sites on Camp Swift to be impacted directly or indirectly by military training. A total of 120 excavation units and 48 shovel tests were placed on the 20 sites. In addition, geoarchaeological investigations were accomplished by opening six backhoe trenches to examine the underlying stratigraphy and to collect soil samples (Nickels
2007). That report of investigations has not yet been published.

In September through November 2003, CAS conducted a Phase I archaeological survey on 307 acres at Camp Swift (Nickels et al. 2005). A total of 11 new archaeological sites with nine prehistoric and four historic components were discovered. In addition, nine isolates were recorded. CAS assessed four of the nine prehistoric components as insignificant with no further work recommended; the remaining five required additional investigations to determine their integrity. Three of the four historic components were assessed as insignificant, with the fourth warranting additional investigations.

In September 2005, CAS archaeologists returned to Camp Swift and excavated 25 backhoe trenches on eight prehistoric sites previously recommended for further investigations by Nickels and Lehman (2004). Based upon the discovery of burned rock features and apparent stratified lithic deposits, further investigations were recommended on three of the eight (Lohse and Bousman 2006).

As of March 21, 2006, there were 585 prehistoric and historic sites in Bastrop County (Texas Historical Commission 2006), and prior to this current project, there were 182 known sites within the Camp. With the discovery of 110 additional sites during this current project, there are now 292 known sites within the boundaries of Camp Swift. 


\title{
Chapter 4
}

\section{Research Design and Methods}

\author{
By David L. Nickels, C. Britt Bousman, and Jessica L. Hurley
}

The current project represents the sixth cultural resources investigation undertaken by the Center for Archaeological Studies (CAS) for the Texas Military Forces (TXMF) Environmental Division Office. The first project was an assessment of 39 previously recorded sites (Nickels et al. 2003). The second project was a testing project involving 20 previously recorded sites (Nickels 2008b). The third project involved relocating and conducting evaluations at an additional 20 known sites (Nickels and Lehman 2004). The fourth project consisted of a survey of 307 acres (actually 312 acres) in the northern portion of Camp Swift where 11 new sites were recorded and evaluated (Nickels et al. 2005). The fifth project at Camp Swift was an investigation that evaluated eight sites with limited backhoe trenches (Lohse and Bousman 2006). These Swift Projects are referred to by sequential number (Swift I-V); the current project is called Swift VI. During the course of these investigations, numerous research issues and problems have been identified. Some issues have been addressed and others remain unresolved.

\section{Research Issues}

One of the long-standing issues with cultural resources at Camp Swift is the nature and accuracy of the Camp Swift site inventory. The first study undertaken was published in 1979, and it consisted of a pedestrian site survey and archival study (Skeleton and Freeman 1979). This study identified 83 sites in approximately 4000 acres.
No significant cultural resource investigations were undertaken in the 1980s. The TXMF Environmental Division Office began surveying Camp Swift in 1994, and they identified and recorded an additional 14 sites by 1997. During this period, Espey, Huston and Associates conducted two surveys, one for a proposed seismic line (Schmidt and Cruse 1995) and the other for an electrical transmission line (Nash et al. 1995); these projects recorded an additional 14 sites. In the late 1990s Dave Robinson directed a TXMF survey crew that inspected 1000 acres previously surveyed by Skeleton and Freeman (1979) and surveyed an additional 3000 acres. This study was published by the Center for Archaeological Research (CAR) (Robinson et al. 2001). They recorded an additional 58 sites, bringing the total for Camp Swift to 169 sites. Archaeologists from CAR at UTSA relocated 28 previously recorded sites and excavated a series of backhoe trenches for geoarchaeological assessments in 2000 but no new sites were recorded (Robinson et al. 2001). These studies formed the basis of the cultural resources inventory until the CAS survey in 2004 (Nickels et al. 2005). After the 2004 Camp Swift IV survey was completed, it was recognized that a portion of this area had been surveyed by the TXMF staff, but no sites were discovered. The CAS Camp Swift IV survey recorded 11 new sites, and it was clear that the inventory was probably incomplete for the remainder of Camp Swift. This current study is an initial attempt to address this problem. 
During the course of the CAS Camp Swift studies, a number of research issues have been addressed and will continue to be addressed. The current study was designed to address inventory gaps, but these other issues were always an integral part of the project formulation. These issues are identified and discussed below.

\section{Prehistoric Site Density, Distribution, and Characteristics}

Today's survey standards and techniques are more stringent than those of 20 or even 10 years ago. Advances in technologies and methods allow for improved site identification and documentation. For example, the development of fairly inexpensive and accurate Global Positioning System (GPS) hand-held receivers has revolutionized the recording of site spatial parameters and distributional studies. GPS receivers have been used at Swift since 2001, and the spatial data will be useful in examining settlement patterns and site distribution. Despite possible shortcomings of earlier surveys that have been overcome by intensive excavation of shovel tests, the previous survey information from Camp Swift combined with results of this project provides an excellent site database. This allows archaeologists to better assess changing patterns of occupational distributions and site preservation. As with the site density and distribution issues discussed above, we should be able to examine the similarities and differences in site size, features, artifact assemblage (technology), and inferred activities associated with prehistoric occupations through time. Furthermore, the distributions can be used to predict site locations for future studies.

\section{Depths of the Sandy Mantle}

Camp Swift is located in a portion of Texas that is covered by an extensive surface occurrence of loose sandy soils and deposits known informally as the Sandy Mantle. There is a great debate regarding the origin and formation of this Sandy Mantle and the nature of archaeological materials contained in these sandy deposits (see for example, Bruseth and Martin 2001; Frederick and Bateman 2001). Two divergent hypotheses have been presented on this issue. The first argues that the Sandy Mantle is the result of in situ weathering of underlying sandy Eocene bedrock deposits and the formation of sandy soils. This model suggests that there has been little or no deposition of sediments and burial of archaeological materials. All subsurface archaeological materials are the result of the movement of materials down into the soil column from the surface via the processes of pedoturbation and bioturbation. The second hypotheses argues that in certain cases deposition has occurred through colluvial, fluvial, and even aeolian processes during the period of human occupation in North America and that some archaeological materials are truly in place in a proper geological context. This hypothesis also recognizes the in situ weathering of sandy Eocene deposits to form sandy soils, but that in certain cases those sandy soils have been eroded and redeposited. This has been a long-standing debate that involves many convoluted complexities and conflicting evidence, and no single study is likely to resolve the issue in a simple manner. The current study at Camp Swift is concerned with the more general issue of how the Sandy Mantle was formed, and its major contribution was to focus on the geometry of the sand body, itself, by determining the depth of the Sandy Mantle over various landforms. The results from this survey project will add to the existing site database, and aid in attaining the ultimate goal of refining a predictability model of site distribution and site integrity.

\section{Historic Site Spatial Relationships and Economic Activities}

Additional historic sites were expected to be found during the survey. The archaeological 
and archival investigations of these sites should help clarify the spatial relationships of Anglo American farming, ranching, and industrial activities in Bastrop County. The Camp Swift area was first settled beginning in the ca. 1850s. With the new site survey, insight can be gained into settlement patterns in the Camp Swift area through the beginning of WWII. Earlier research indicates many historic structures were destroyed when Camp Swift was created, although stone foundations could still be extant, especially if structures were abandoned before WWII and covered by dense vegetation characteristic of the area. Artifact assemblages typically include ceramics, glass, and metal. Evidence obtained by careful documentation of structural remains and artifact assemblages can be used to infer the probable economic scale of the occupants. Placed within context, we should be able to better interpret the living habits of pre-Camp Swift landowners.

\section{Methods}

The methods employed during this project were designed to address the above research issues, and exceeded THC standards for archaeological surveys.

\section{Prefield Planning}

Before the project began, the Principle Investigators discussed research issues, field methodologies, and analysis strategies with the TXMF Environmental Division Office. Prior to initiation of actual fieldwork, CAS studied archival documents, soil surveys, geology and topographic maps, and aerial photographs to better understand the site potential in the project area. To insure systematic recording procedures, the Co-Principal Investigator/Project Archaeologist met with each crew member before the fieldwork to review artifact classifications and recording procedures. Reports of previous surveys conducted were reviewed, and a copy of the recommendations and conclusions synthesizing the various surveys and other archaeological investigations at Camp Swift were examined in detail. In addition, a review was conducted of the current literature for the North, Central, and Northeast Texas Archaeological Regions. The TXMF Environmental Division Office sent the final project proposal to interested tribes for review. CAS also met with the Texas SHPO. These meetings assisted all parties in agreeing on acceptable and required standards of reporting and fieldwork within the scope of the project. Texas Army National Guard's Cultural Resources Office was to conduct all Tribal consultations.

Initially, an estimate of the remaining areas was prepared and reviewed with the TXMF Environmental Division Office. It was decided that Camp Swift should be divided into high and low site probability areas, and only the high probability areas would be surveyed. High probability areas at Camp Swift were defined by the Project Archaeologist by inspecting the known distribution of sites among landforms, stream courses, and soil types. A combination of these types of information was used to define the proposed survey boundaries. Normally, high probability areas where prehistoric sites should be found include floodplains and terraces. However, previous investigations at Camp Swift have indicated that these areas are possibly the least likely places to contain prehistoric sites. A map was prepared that identified not only the floodplain and terrace areas, but also the footslope, sideslope, and ridge areas where higher densities of prehistoric sites were believed to occur (Figure 4-1). Three areas were isolated. The largest was in the northern portion of Camp Swift, and two others were in the southern portion of Camp Swift. The smallest area was the southernmost. As the survey proceeded a small portion of the northern area was eliminated 


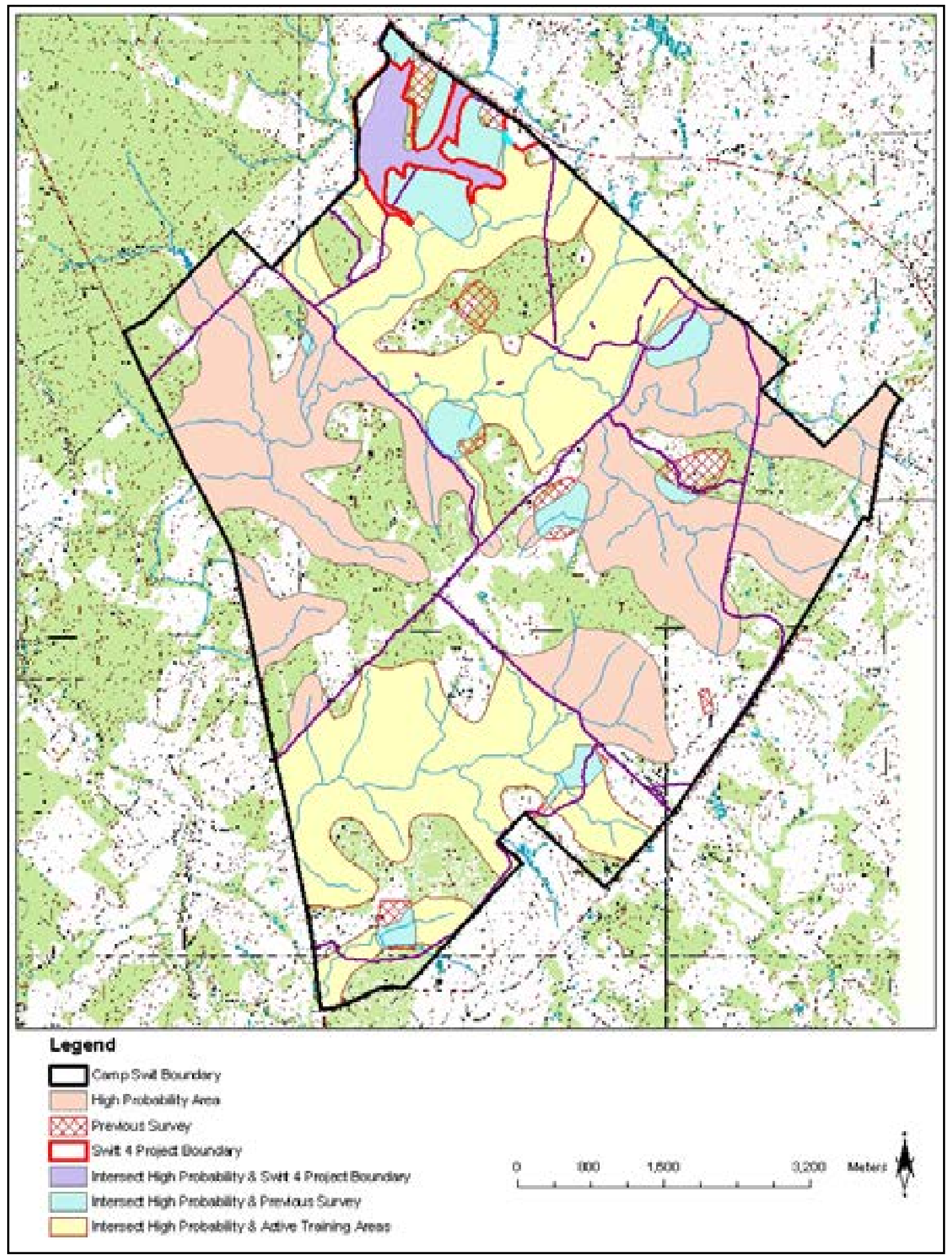

Figure 4-1. Areas that are commonly perceived as high probability areas where prehistoric sites would be located. 
for two reasons. This area was a thin leg that flanked a small stream in the southern part of the Northern Area below a previously survey section. The first reason for dropping this area was that few sites were found near to streams, and this was unlikely to produce as many sites as the surrounding uplands were not in the survey area. Second, the survey had already exceeded the contracted amount of surveyed acres. A second map showing the locations of historic dwellings and roads was overlaid onto a topographic map (Figure 4-2). A third map showing pre-WWII property owners was overlaid onto a topographic map (Figure 4-3). High probability areas were estimated from these sources, and boundaries were prepared. These boundaries were input into Trimble GPS handheld units and used in the field to help control survey areas.

Prehistoric sites are classified as open campsites, villages, lithic procurement sites, lithic scatters, or Native American burials. Open campsites often contain varying quantities of firecracked rock from possible small-hearth features and lithic scatters, suggesting an occupational episode. Villages could be identified by either stacked stone or pit depressions, generally associated with ground stone and/or Native American ceramics. Lithic procurement sites are those characterized by the presence of lithic raw materials; often at Camp Swift these sites consist of exposed gravels. Exploitation of a lithic source is indicated by a light to heavy scatter of chipped stone debris, including artifacts such as cores, quarry blanks, preforms, flakes, and (rarely) informal or formal tools. Native American burials are usually not marked and are often discovered either in an erosional context from cutbanks or around disturbed rock cairns or low earthen mounds. CAS would not disturb Native American human remains if encountered. Upon locating such a site, CAS personnel would avoid further impacts to that location and would immediately notify the Environmental Division of the TXMF, who in turn, would contact appropriate tribes regarding potential burial.

Historic sites include log cabins and farmsteads, water wells, shaft and open pit mines, trash dumps, isolated graves, cemeteries, and early historic trails, roads, and bridges. Archival documents such as maps and oral history interviews (Freeman et al. 2006) were used to help identify the possible locations of historic sites including historic farmsteads and roads. The identification of historic sites was based on the evidence observed in the field and these archival documents. Evidence of historic farmsteads consist of historic artifact scatters that represent domestic and farm activities, and occasional evidence of historic structures. As noted above, most of the historic structures at Camp Swift were raised when the Army took possession of the land at the beginning of World War II, and standing structures are not usually preserved. Thus, standing log cabins would not be expected, but unlikely to be overlooked if present. However, remnants of historic buildings, such as foundations or dispersed architectural materials, could be present. Also present could be stone or cement lined water wells. These would usually be located at farmsteads, but isolated wells could be present. Excavated coal mine shafts were known to occur at Camp Swift at the Sayersville mine, and it was considered possible that other mines could be found. Historic trash dumps were the most likely type of historic site expected after farmsteads. These consist of concentrations of historic artifacts, often in some type of erosion feature such as a gully. Isolated graves and cemeteries would be marked by one or more grave stones. Known cemeteries had been mapped and further documented by archival study, but other unmapped graves or cemeteries could be expected. Surface evidence for historic roads, trails or bridges were rare. Previously, evidence 


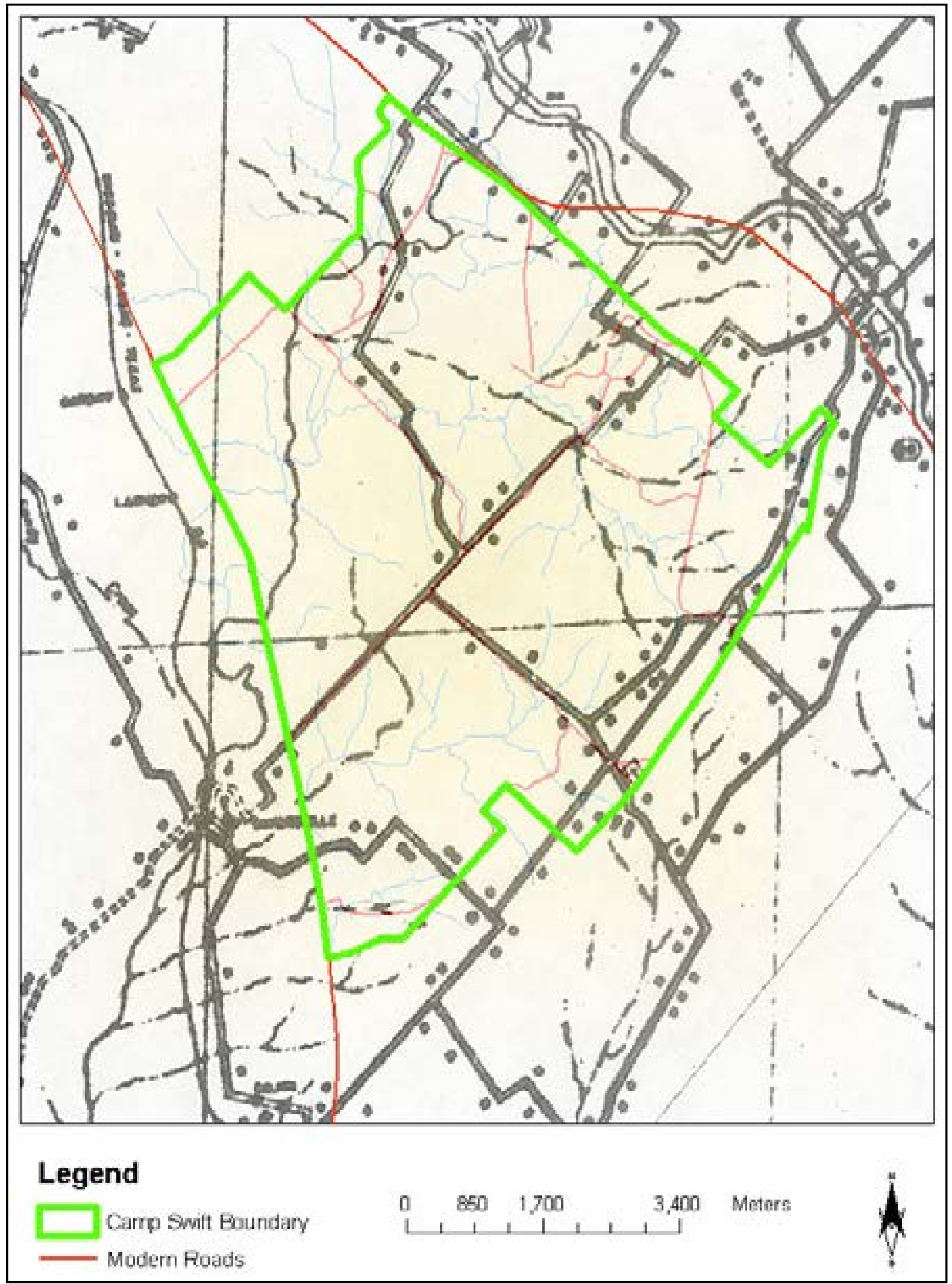

Figure 4-2. 1936 map showing roads and buildings. 


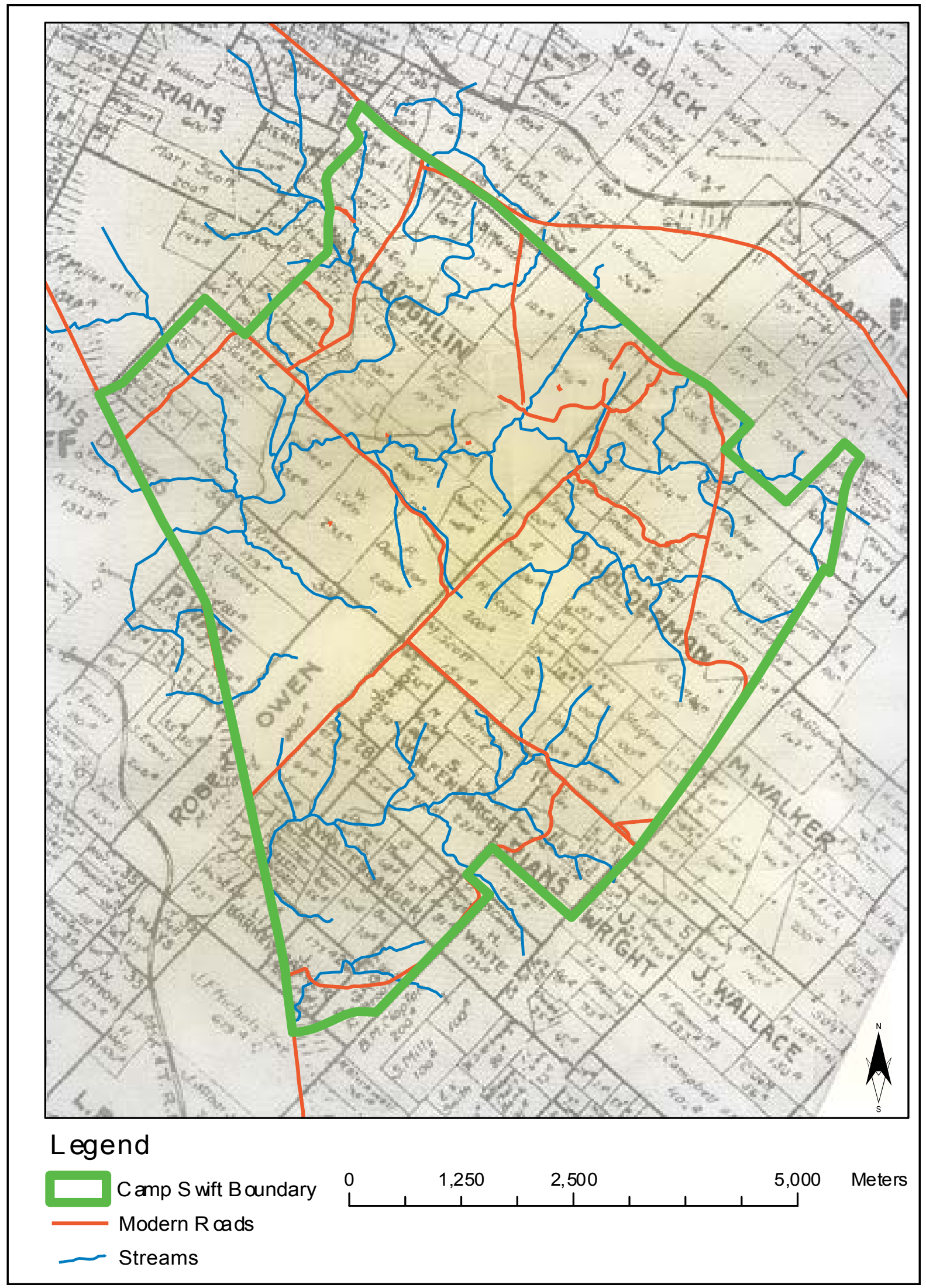

Figure 4-3. 1929 map showing property boundaries. 
for an irrigation system was discovered and determined to be related to Antoine Aussilloux's winery (Lohse and Bousman 2006; Nickels and Lehman 2004). Archival records such as maps were consulted and the field crew searched for subtle surface evidence such as unusual tree clearings or slight surface modifications.

Historic artifacts were identified to the most detailed level possible in the field. Glass was identified as to vessel/object form and color using standard catalogues and online resources (IMACS 1992; Lindsey 2005; Munsey 1970; Toulouse 1969, 1971). Pottery was identified and attributes described including surface/paste treatments, vessel/object form, makers marks (when present), and other attributes according to standard procedures and catalogues (Kovel and Kovel 1986). Other artifacts, including metal artifacts, were identified to as detailed level as possible. Standard catalogues were consulted when possible (Montgomery Ward \& Co. 1969; Nelson 1968; Sears, Roebuck and Co. 1993). In all these artifact identifications, the experience of the surveyor was complemented by the extensive experience and knowledge of the Co-Principal Investigator/Project Archaeologist.

\section{Fieldwork}

The fieldwork was conducted by staff archaeologists under the direct supervision of the projects' Co-Principal Investigator/Project Archaeologist. The fieldwork consisted of a 100 -percent pedestrian survey in areas of high probability and active training areas. Other fieldwork tasks included excavations of shovel tests, limited collecting, recording surface inventories, and complete site documentation.

In adhering to a limited collection policy, only diagnostic prehistoric artifacts were collected. Otherwise, artifacts were collected only when they were required in the laboratory for additional analysis, drawing, or photography that would assist in interpreting the site and its eligibility for the NRHP. Diagnostic historic artifacts were fully documented, but were only collected if additional study in the lab could result in significant information not otherwise obtainable through the current archaeological record or archival research.

CAS archaeologists dug shovel tests and fully documented all recovered cultural material, but only collected significant diagnostic artifacts. Artifacts that were redundant in the archaeological record, such as lithic debitage, non-diagnostic stone tools, or non-diagnostic historic artifacts, were not collected but after recording their attributes and photographing or sketching them, artifacts were placed back into the top 10 centimeters $(\mathrm{cm})$ of the shovel test when backfilled.

\section{Survey Strategy and Shovel Tests}

CAS personnel excavated shovel tests in systematic transects across the project area at 30$\mathrm{m}$ intervals. The northern and southern survey areas were divided into subareas and transects layed out within each subarea. The transects were labeled by letters within each subarea. Shovel tests were numbered consecutively for each lettered transect, e.g., A1, A2, etc. If more than 26 transects were surveyed the letters were duplicated and shovel tests numbered as before, e.g., AA1, AA2, etc.

Shovel tests were dug on each archaeological site to test for subsurface cultural materials and examine the geomorphology. A sufficient number of shovel tests were excavated within the site to determine the horizontal and vertical extent of the archaeological deposit, the vertical extent and severity of disturbance present, and to develop a preliminary understanding of the nature of the soils and depositional history at the site. The 
Project Archaeologist determined the number of on-site shovel tests, taking into consideration site size, artifact frequency over the site surface, and topographical variation over the site surface. Shovel tests were plotted on a site sketch map and numbered consecutively to distinguish from survey transect shovel tests that are labeled by letters and numbers. The results were analyzed to evaluate the potential for buried, intact cultural deposits below any cultural material exposed on the surface.

All shovel test locations were recorded using a hand-held Trimble GPS receiver. These data were differentially corrected in the lab to increase the accuracy of known shovel test locations. A shovel test was defined as a $30-\mathrm{cm}$ diameter unit, excavated, screened, collected, and recorded in levels no more than $10 \mathrm{~cm}$ in thickness to a standardized depth of at least 70 $\mathrm{cm}$ below surface (cmbs) on prehistoric sites and $50 \mathrm{cmbs}$ on historic sites, unless bedrock or culturally sterile sediments were encountered. Additional levels were removed if artifacts were encountered in the bottom $10-\mathrm{cm}$ level and the potential for subsurface cultural strata was deemed high, as in alluvial or thicker, sandy sediments. In deep, sandy soils, shovel tests were generally terminated between 70 and 140 cmbs. All sediment was screened through $1 / 4$-inch wire mesh, and the results of shovel tests were recorded on standardized forms. All artifacts collected from shovel tests were placed in bags that were labeled with their appropriate field provenience, and then transported to CAS for analysis and temporary curation. As noted above, most artifacts were placed back into the shovel test and not collected.

\section{Documenting Sites}

An archaeological site was defined as having at least two artifacts in a $25-\mathrm{m}^{2}$ area, or at least two positive shovel tests in the same area, or at least one cultural feature. Once a site was discovered, crew members intensively examined the ground surface, flagged artifacts if any, and noted any high-density concentrations. If artifacts were present on the surface, site boundaries were initially established according to surface artifact distribution. Later, if shovel tests confirmed the presence of subsurface cultural material, the boundaries were adjusted accordingly; if sites were discovered through systematic shovel tests, the same rules applied. Crew members then rotated through the various tasks of properly documenting the site. Notes were made regarding site disturbance, vegetation, features, and pertinent landmarks visible from the site datum.

To establish the site datum, a large nail was hammered into a tree at the site's center or the best vantage point. USGS 7.5' topographic maps and a GPS receiver were used to determine UTM coordinates. In addition to taking a reading from the site's datum, CAS surveyors recorded GPS projections of all features such as hearths, roads, and fences, from enough points along the perimeter to define the estimated site boundary. These data were then differentially corrected and GPS software-generated site maps were plotted by CAS staff every evening while in the field to check for complete and accurate data.

\section{Site Surface Observation Areas}

When visible, a 100-percent inventory of prehistoric artifacts was recorded. Each artifact was recorded on a standard form, specifying prehistoric flake types, cores, tested cobbles, bifaces, utilized and retouched pieces, ceramics, and diagnostic artifacts. On historic component sites, notes were made regarding structural remains and artifacts; diagnostic attributes were also noted (Figure 4-4). 


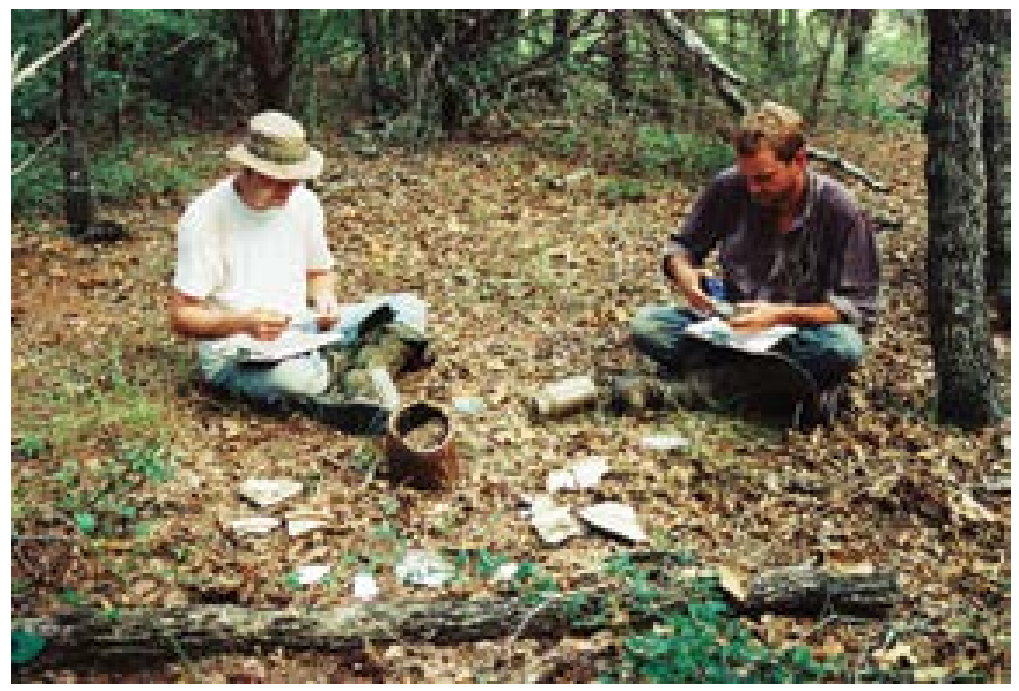

Figure 4-4. Emory Worrell and David Peyton documenting historic artifacts at 41BP490.

\section{Site Mapping}

Sketch maps were made of each site, whether newly discovered or revisited. The sketch maps indicated magnetic north, scale, visible features, shovel tests, and roads, streams, or landforms that would help in relocating the site. Sites were plotted on 7.5' Series USGS quadrangles.

Site locations were recorded with a GPS receiver that is capable of sub-meter accuracy. For each site, CAS took a reading from the centroid of the site and from enough points along the perimeter to define the estimated site boundary. These data were differentially corrected. The GPS data was downloaded and exported into a GIS, ArcView Shapefile. All GIS data is Federal Geographic Data Committee (FGDC) compliant metadata. The FGDC metadata is in XML format. The projection of the GIS data is in UTM Zone 14 and NAD83 datum was used.

\section{Photography}

Site and artifact photographs included 35 mm black and white prints and color slides. Both types of media were archival. Views included, at minimum, two general overview shots of the site to illustrate the site setting (terrain, vegetation, etc.). Additionally, photos of surface and subsurface features were taken. Photo logs for both film types were maintained, and a photo log database was developed and provided to TXMF in a digital format, as well as archived with other project records at TARL.

\section{Laboratory Methods}

Any artifacts collected were accounted for daily while in the field. Upon returning to the CAS lab in San Marcos, cultural materials recovered during the project were inventoried. All artifacts were then identified and analyzed. Artifacts and samples were separated by artifact type and recovery context to facilitate analysis. Processing of recovered artifacts began with washing and sorting into appropriate categories. These data were then entered into an Excel spreadsheet.

At the CAS lab, all cultural material collected was prepared for storage in accordance with federal regulation 36 CFR part 79 , and in accordance with current guidelines of TARL. Lithics, metal, and ceramic artifacts processed in the CAS laboratory were washed, air-dried, and stored in archival-quality bags. Acid-free labels were placed in all artifact bags. Each bag was labeled with a provenience or corresponding bag number. Artifacts larger than a dime and all tools were labeled with permanent ink and covered by a clear coat of acrylic. Other artifacts were separated by class and stored in acid-free boxes with standard labels.

\section{Site Forms and Mapping}

The information recorded in the field and preliminary analysis data derived in the lab was 
transferred to TexSite software "initial visit" and "revisit" forms for filing with TARL. Revisit forms were filled out when a previously recorded site was relocated. If a site could not be found, then a revisit form was not submitted. Site and artifact data used in analyses was provided in database form compatible with Microsoft Excel. In addition to the general maps to be included in the final report, an additional set of maps of the project area was prepared for the TXMF. These show the locations and site boundaries for all cultural resources in the inventory area, plotted on 7.5' Series USGS quadrangles.

\section{Chipped Stone Analysis}

Chipped stone pieces were categorized functionally. In this case, only two projectile points were collected. They were assigned to a type based on the commonly accepted point typology developed for Central Texas (e.g. Turner and Hester 1999), but also with consideration of numerous published reports from the surrounding regions.

\section{GIS Analysis}

The recording and processing of GPS data were undertaken in evenings in the field and in the CAS Laboratory after the commencement of field work. All GPS files were differentially corrected using the TxDOT Bastrop base station data. Shovel test and site information was analyzed using ArcView software. All information was double-checked independently and added to the Swift GIS database. This database will be recorded on $\mathrm{CD}$, and the information provided to the TXMF Environmental Division Office staff and the Texas Historical Commission staff. In addition to shovel test locations and site information, a variety of environmental data that includes streams, soils, topography, roads, survey area boundaries and the previous surveys area boundaries are included on this CD.

\section{Curation}

Finally, all collected cultural material, field notes, shovel test forms for shovel tests placed on sites, photographs, drawings, a copy of the final report on acid-free paper, and computer disks pertaining to this project are stored in acid-free boxes at TARL. 


\title{
Chapter 5
}

\section{Prehistoric Component Sites Previously DoCUMENTED bY CAS}

\author{
By David L. Nickels and D. Emory Worrell
}

During this project, 88 new prehistoric components were documented (see Chapter 7). Nineteen prehistoric site components were previously documented by CAS in the Swift 6 survey area. During the current project, CAS archaeologists excavated shovel tests in transects to within $30 \mathrm{~m}$ of the boundaries previously defined for those 19 sites. The boundaries of 14 of the 19 sites were expanded based upon positive transect shovel tests (Table 5-1) while the boundaries of the remaining five did not change. The five sites with unchanged boundaries are: 41BP128, 41BP138, 41BP384, 41BP435, and 41BP484. The test results and NRHP eligibility recommendations for these five sites remain unchanged; therefore, no discussion of these five is included in the following chapters. As Table 5-1 shows, the data recovered during the current project have not substantially added to the research potential of the expanded 14 sites. In most cases, their NRHP eligibility remains unchanged. Although these sites have been discussed in the references shown, an overview of previous results and additional data obtained during this project are provided below. In presenting the 2005 results, the total number of shovel tests refers to transect and site-specific shovel tests excavated within the final site boundaries (as defined by this study and previous work).

Table 5-1. Prehistoric components whose boundaries were expanded by the current project and previously documented by the Center for Archaeological Studies, Texas State University-San Marcos.

\begin{tabular}{|c|c|c|c|}
\hline Site & CAS Publication & $\begin{array}{c}\text { Previous NRHP } \\
\text { Recommendation }\end{array}$ & $\begin{array}{c}\text { Revised NRHP } \\
\text { Eligibility } \\
\end{array}$ \\
\hline $41 \mathrm{BP} 93$ & Nickels and Lehman 2004 & Not Eligible & No Change \\
\hline 41BP94 & Nickels and Lehman 2004 & Unknown & No Change \\
\hline 41BP100 & Nickels and Lehman 2004 & Unknown & No Change \\
\hline 41BP105 & Nickels and Lehman 2004 & Unknown & Not Eligible \\
\hline 41BP111 & Nickels and Lehman 2004 & Unknown & No Change \\
\hline 41BP112 & Nickels et al. 2003 & Unknown & No Change \\
\hline 41BP121 & Nickels and Lehman 2004 & Unknown & Not Eligible \\
\hline $41 \mathrm{BP} 123$ & Nickels and Lehman 2004 & Not Eligible & No Change \\
\hline $41 \mathrm{BP} 127$ & Nickels et al. 2003 & Not Eligible & No Change \\
\hline $41 \mathrm{BP} 436$ & Nickels and Lehman 2004 & Not Eligible & Unknown \\
\hline $41 \mathrm{BP} 485$ & Nickels et al. 2003 & Unknown & No Change \\
\hline 41BP491 & Nickels and Lehman 2004 & Unknown & Not Eligible \\
\hline 41BP495 & Nickels et al. 2003 & Unknown & No Change \\
\hline 41BP521 & Nickels et al. 2003 & Unknown & No Change \\
\hline
\end{tabular}




\section{$41 B P 93$}

\section{Description}

$41 \mathrm{BP93}$ (Figures 5-1 and 5-2) is a 7,591- $\mathrm{m}^{2}$ prehistoric open campsite ranging in elevation from 420 to $430 \mathrm{ft}$ amsl. The site is situated on a wooded knoll and sideslope above the floodplain of McLaughlin Creek. Patilo complex (PaE) and Silstid loamy fine sand $(\mathrm{SkC})$ cover the area and support scattered stands of oak, cedar, and open grasslands. The sandy loam soil is generally shallow, and the underlying red and orange clays were exposed in many areas in the central and western portions of the site. There is a gravel outcrop located approximately $20 \mathrm{~m}$ north, and there are two open areas to the east and west. The nearest natural water source is McLaughlin Creek, approximately $100 \mathrm{~m}$ to the south. Disturbances observed included a bladed trail, a fence post, and five military foxholes. Surface visibility was approximately 60 percent. The site datum is marked with a nail and aluminum tag in an oak tree.

\section{Levels of Work and Results}

When the site was originally recorded in 1979 by Skelton and Freeman, six small interior flakes, one flake core, and a few small fragments of fire-cracked limestone were recovered from shovel tests. In 2002, CAS personnel excavated 19 shovel tests (see Figure 5-2, shovel tests 1-19) and collected five small $(<1$ inch) pieces of fire-cracked rock, three larger ( $>1$ inch) pieces of fire-cracked rock, one utilized flake, two exterior flakes, and two bullets (Nickels and Lehman 2004). Although the knoll was eroded, no artifacts or features were observed on the surface.

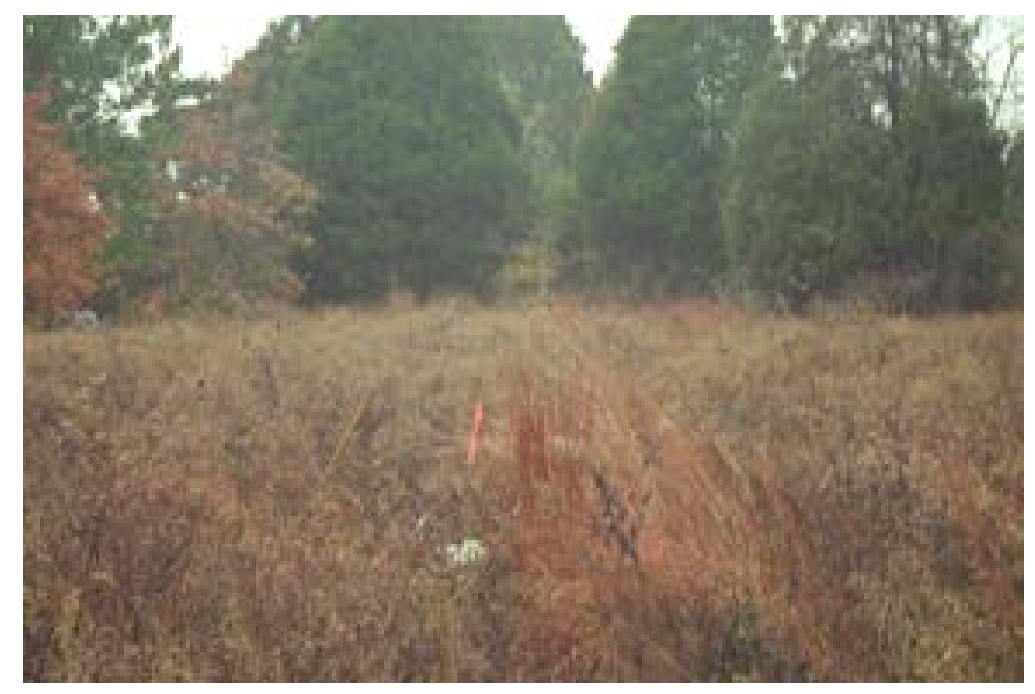

Figure 5-1. 41BP93 lies on a ridge and sideslope; facing north.

FIGURE 5-2. REDACTED

Figure 5-2. Site map of 41BP93. 
When CAS archaeologists excavated shovel tests at the site in 2002, they found shallow soils on the eroded western and northern portions of the site and recovered bullets from two of the tests. Many shovel tests contained angular bedrock fragments in a continuum from top to bottom, suggesting colluvial deposition from the knoll. The few pieces of fire-cracked rock recovered from the sideslope shovel tests were all less than one inch in size and were considered to be in a secondary context (Nickels and Lehman 2004). Figure 5-2 illustrates shovel test locations from 2002 and the current project. CAS personnel excavated two transect shovel tests during the current project, both of which were positive, resulting in an expansion of the boundary by $2,616 \mathrm{~m}^{2}$. A small fire-cracked rock was found at $0-10 \mathrm{cmbs}$ in transect ST A3, and a heat spall was recovered at $40-50 \mathrm{cmbs}$ in ST B5.

\section{Conclusions/Recommendations}

CAS archaeologists postulated that this site was probably used as a short-term open campsite where limited lithic reduction activities occurred (Nickels and Lehman 2004). Cultural materials recovered from the shovel tests were either from shallow, eroded, and mixed contexts, or within secondary, colluvial deposits. Nickels and Lehman assessed the research value of this site as minimal, and that its value would increase only slightly when considered in context with other small open campsites in the region. Nickels and Lehman recommended no further testing in 2002, and based upon the results from shovel tests in 2005 , that recommendation has not changed. The site is not eligible for nomination to the NRHP.

\section{BP94}

\section{Description}

Site 41BP94 (Figures 5-3 and 5-4) is a prehistoric open campsite approximately 12,500 $\mathrm{m}^{2}$ in size that ranges in elevation from 430 to $435 \mathrm{ft}$ amsl. The site is situated on a terrace that overlooks the floodplain of McLaughlin Creek to the south. The area is generally wooded with moderately dense stands of oak and juniper, and to the east is an old field, an open area that consists mainly of tall grasses supported by Axtell fine sandy loam. The site is bisected by an intermittent drainage of McLaughlin Creek. West of this drainage is a raised roadbed and erosional gully, intersected by a fence line that runs northwestsoutheast. Surface visibility was approximately 10 percent. The site datum is marked with a nail and aluminum tag in an oak tree.

\section{Levels of Work and Results}

In 1979, Skelton and Freeman found two pieces of modified silicious wood, and also noted two concentrations of fire-cracked quartzite and limestone exposed in the erosional gully near the eastern portion of the site. Upon revisit in 1997, CAR archaeologists found two flakes in a single

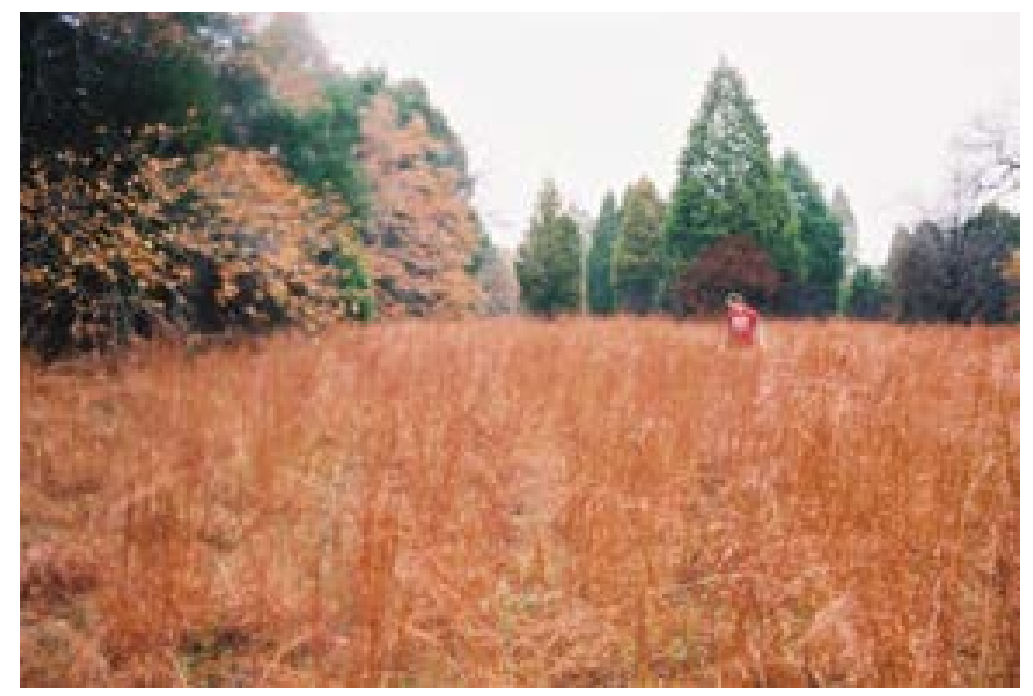

Figure 5-3. 41BP94 lies on an old field terrace at the confluence of an intermittent tributary and Big Sandy Creek; facing north. 
probe and nine pieces of burned rock, three flakes, and an Ensor point in shovel tests (Robinson et al. 2001).

In 2002, CAS excavated 18 shovel tests and recovered 51 small $(<1$ inch) pieces of firecracked rock, 17 larger $(>1$ inch) pieces of fire-cracked rock, 26 interior flakes, seven utilized flakes, two pieces of lithic shatter, one hammerstone, and a piece of milk glass. One crude biface was observed on the surface, and a fire-cracked rock hearth feature was observed in the eastern cutbank of the drainage (Nickels and Lehman 2004).

Figure 5-4 illustrates shovel FIGURE 5-4. REDACTED test locations from the 2002 (118) and 2005 (J, K, L, M and N) projects. Seven of nine systematic shovel tests excavated in 2005 produced 14 flakes, and 12 pieces of fire-cracked rocks. An intrusive shard of modern clear glass was also found. Table 52 presents positive shovel test results from the 2002 and 2005 projects. The site boundary was expanded to the west, increasing the size of the site by $4,777 \mathrm{~m}^{2}$, from $7,723 \mathrm{~m}^{2}$ to $12,500 \mathrm{~m}^{2}$.

\section{Conclusions/Recommendations}

An Ensor point recovered from a shovel test during an earlier survey project suggests a Late Archaic occupation. In addition to hearth features partially buried in the cutbank, shovel tests excavated by CAS in 2002 provided evidence of possibly intact features as deep as 100 cmbs. Additional shovel tests during the current project indicate that the cultural deposits are more extensive than previously known. Such deposits may yield information regarding the

paleoenvironment and site formation processes, and can infer past subsistence and mobility patterns when applied to theoretical models. Thus, CAS recommends excavation of two 1-x1-m units over the hearth feature(s) eroding from the cutbank, seven 1-x-1-m units in the immediate areas of STs 1-4 and L4-L6 on the west side of the drainage, and three 1-x-1-m units on the east side of the drainage around STs 8,12 , and 15 to detemine the eligibility of the site.

\section{BP100}

41BP100 (Figures 5-5 and 5-6) is a prehistoric open campsite covering approximately 18,070 $\mathrm{m}^{2}$ adjacent to McLaughlin Creek. Ranging in elevation from 420 to $430 \mathrm{ftamsl}$, the site is located on an open footslope and wooded area along the creek. Patilo complex loose fine sand $(\mathrm{PaE})$ and Axtell fine sandy loam (AfC2) support tall grasses in the open field and moderately dense stands of pine and cedar in the wooded area. Disturbances 


\begin{tabular}{|c|c|c|c|c|c|c|c|c|c|c|c|c|c|}
\hline$\overline{2} 2$ & & & & & & 逽 & & & & & & & \\
\hline$\hbar \sim$ & \pm & 留五 & & $\frac{\mathrm{I}}{\mathrm{d}}$ & & & & & & & & & \\
\hline$t_{2}$ & & & & & & \pm & & & $\begin{array}{l}\bar{Z} \\
\bar{n} \\
\bar{n}\end{array}$ & & & & \\
\hline 战 & 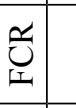 & 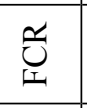 & & 我总 & & I & & & & & & & \\
\hline 的 & & $\Xi$ & & & & 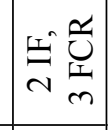 & 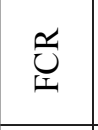 & & 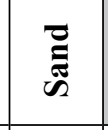 & & & & \\
\hline $5 s$ & & & & 画 & & & 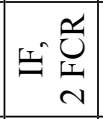 & \pm & & 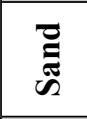 & & & \\
\hline 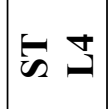 & & 8 & $\bar{q}$ & & & 莡 & & 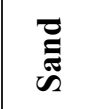 & & & & & \\
\hline $\operatorname{ts}=$ & 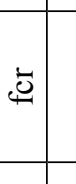 & & 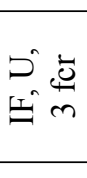 & & 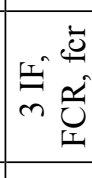 & \begin{tabular}{|l}
0 \\
0 \\
0 \\
0
\end{tabular} & & & 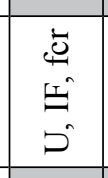 & 啨 & $\frac{\vec{m}}{\mathrm{~d}}$ & & \\
\hline $\bar{\omega}_{2} \pm$ & & & & 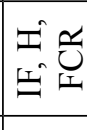 & & $\Xi$ & & 胥 & & & & & \\
\hline$\overline{2} 2$ & & & & & & & $\Phi$ & & 里 & & 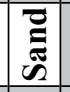 & & \\
\hline $\bar{t}_{2} \simeq$ & & $\pm \frac{10}{4}$ & & $\stackrel{\text { 呈 }}{\underline{\underline{y}}}$ & & 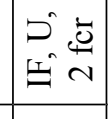 & 总 & 莞 & & & & & \\
\hline$t_{2}=$ & $\begin{array}{l}\overrightarrow{2} \\
\Leftrightarrow\end{array}$ & & & & $\begin{array}{l}\text { E. } \\
\text { sim }\end{array}$ & & & & $\stackrel{\vec{m}}{\mathrm{~d}}$ & & & & \\
\hline $\bar{n} \Omega$ & & & & & $\frac{\substack{0 \\
n}}{n}$ & 里总 & & & & & 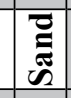 & & \\
\hline $\bar{E}$ & & & & 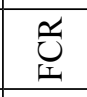 & & & $\frac{\pi}{E}$ & & & & & & \\
\hline $5 \infty$ & & $\ddot{\vec{u}}$ & & & & & \begin{tabular}{|l|}
\multirow{2}{*}{} \\
\end{tabular} & & & & 焉 & & \\
\hline $\bar{y}^{2}$ in & \pm & 宝 & & 䍡 & & & & & & & & & \\
\hline$\vec{s}+$ & & & & & & $\stackrel{\text { 崩 }}{\sim}$ & & 粮总 & $\hat{\tilde{z}}$ & & 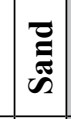 & & \\
\hline $\bar{n} \mathrm{~m}$ & & $\overrightarrow{0}$ & & $\stackrel{\text { 팍 }}{\sim}$ & & 产 & & 节产 & 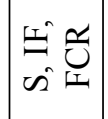 & & 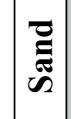 & & \\
\hline $\bar{s} \sim$ & & & & & 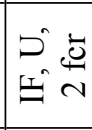 & & $\stackrel{\vec{s}}{i}$ & Е & & & 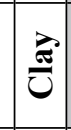 & & \\
\hline$t_{n}-$ & | & $\begin{array}{l}\text { 总 } \\
\underline{\omega}\end{array}$ & & & $\begin{array}{l}\tilde{J} \\
\text { U. } \\
\text { N }\end{array}$ & 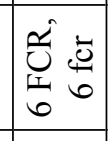 & $\stackrel{2}{2}$ & & & 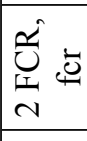 & & 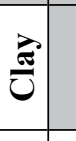 & \\
\hline 言兽 & & 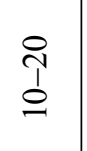 & \} $&{\begin{array}{l}\text { वे } \\
\text { d }\end{array}} &{\begin{array}{l}0 \\
\vdots \\
q\end{array}} &{\begin{array}{l}0 \\
\vdots \\
0 \\
i\end{array}} &{\begin{array}{l}8 \\
0 \\
0 \\
0\end{array}} &{\text { 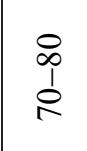 }} &{\begin{array}{l}8 \\
0 \\
0\end{array}} &{\frac{8}{8}} &{\begin{array}{l}\stackrel{0}{1} \\
\vdots \\
\varrho\end{array}} &{\text { 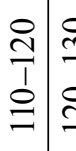 }} &{ } \\
$\hline
\end{tabular}


such as military tank tracks and a plowed firebreak have slightly impacted this site. Surface visibility in 2005 was approximately 20 percent. The site datum is marked with a nail and aluminum tag in an oak tree.

\section{Levels of Work and Results}

When Skelton and Freeman first recorded the site in 1979, they did not collect anything, but noted two hearth features eroding out of the cutbank of the creek. The features were approximately $90 \mathrm{~cm}$ and $1.75 \mathrm{~m}$ below the edge of the cutbank. These features were also noted in 1997 by CAR archaeologists, along with some burned rock recovered from three of their six shovel tests (Robinson et al. 2001).

In 2003, CAS personnel excavated 18 shovel tests (118) and from 8 positive shovel tests collected seven small $(<1$ inch) pieces of fire-cracked rock, 16 larger ( $>1$ inch) pieces of fire-cracked rock, 23 interior flakes, three exterior flakes, one utilized flake, one biface that is a probable arrow point tip, and a pottery sherd from the surface. A very ephemeral scatter of lithic debitage was observed across the site, except for a slightly heavier scatter along the sides and bottom of the firebreak trench. CAS also observed a scattered fire-cracked rock hearth feature in the bottom of the recently cut firebreak

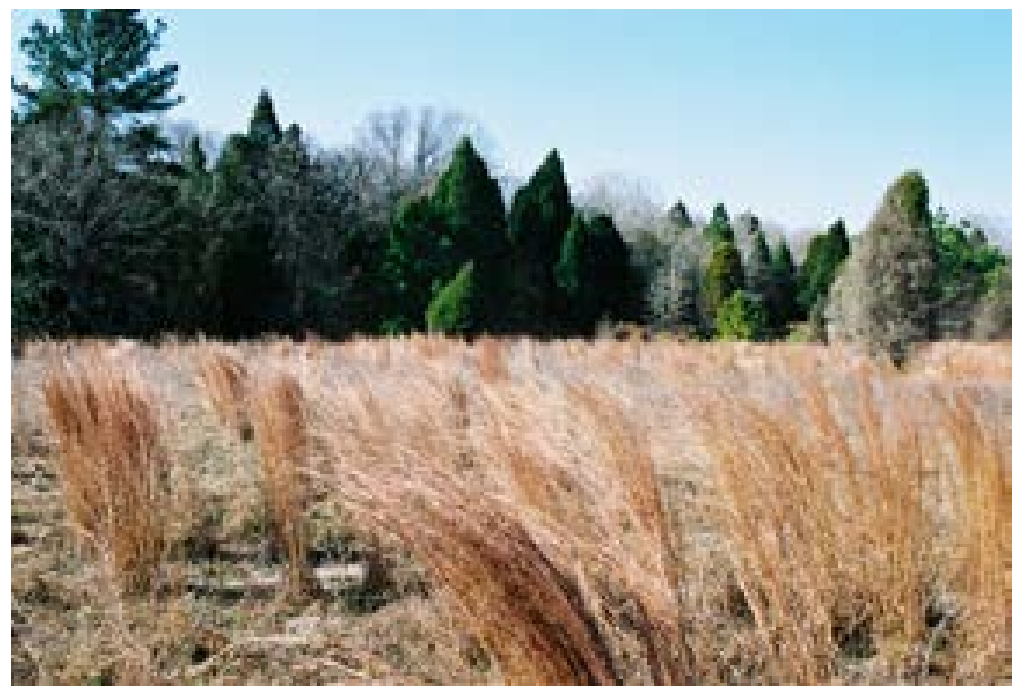

Figure 5-5. 41BP100 spans an old field footslope adjacent to McLaughlin Creek; facing southwest.

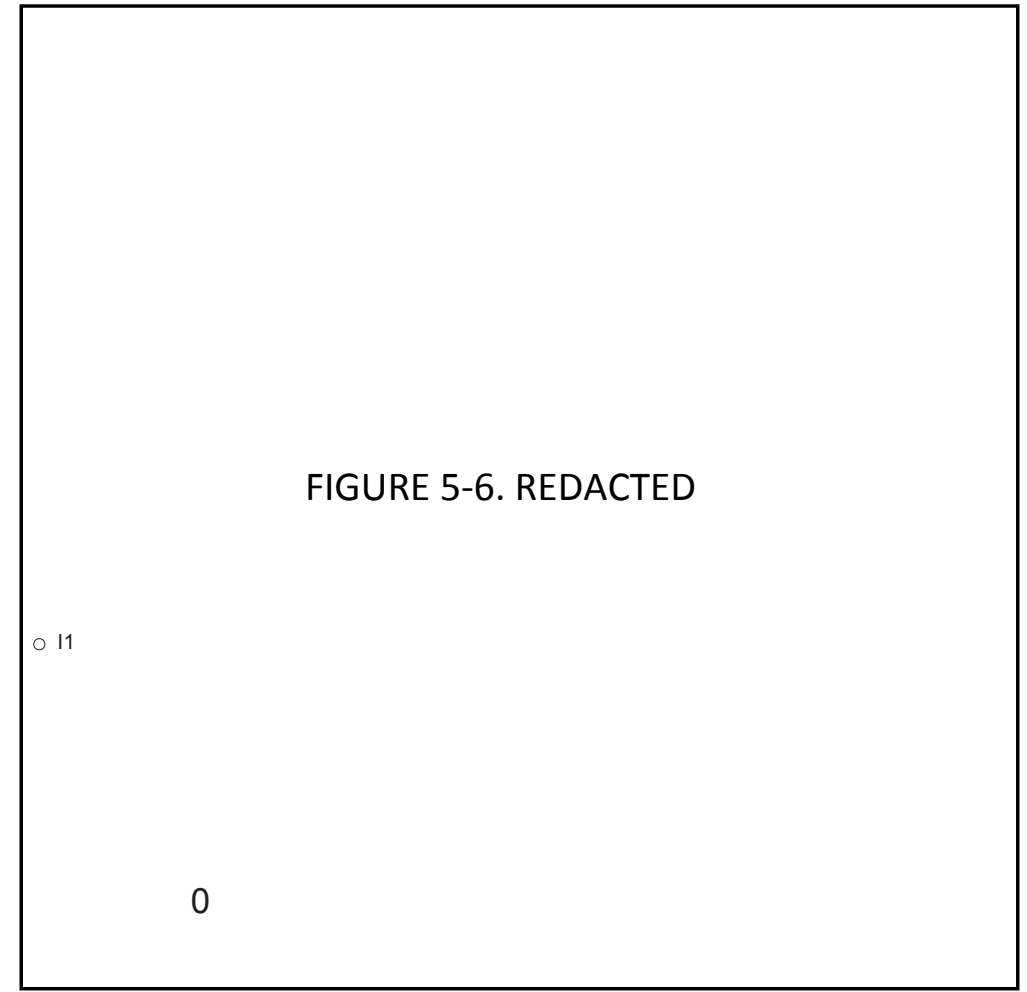

Figure 5-6. Site map of 41BP100.

trench, approximately $50 \mathrm{~cm}$ deep, just north of McLaughlin Creek (Nickels and Lehman 2004).

In 2005, CAS archaeologists did not see any artifacts on the surface, but two of the five systematic shovel tests excavated on the site 
contained a total of one flake and one fire-cracked rock. Table 5-3 presents positive shovel test results from the 2003 and 2005 projects, while shovel test locations from 2003 and the current project are presented in Figure 5-6. The discovery of additional cultural material in these two shovel tests resulted in expanding the site's boundary toward the east. The size of the site is now 18,070 $\mathrm{m}^{2}$, compared with $11,050 \mathrm{~m}^{2}$ in 2003 .

\section{Conclusions/Recommendations}

The results from shovel tests in 2003 suggested two probable isolable components: an upper component between 0 and $30 \mathrm{cmbs}$, and a lower component between 70 and 110 cmbs. The recovery of a pottery sherd and probable arrow point tip indicated a probable Late Prehistoric component in the upper 30 cmbs. Although military usage had moderately disturbed the area, it still appeared to be about 70 percent intact (Nickels and Lehman 2004). The amount of artifacts and depths at which they were encountered indicated possibly intact cultural features buried deep below the surface. The additional artifacts found during the current project corroborate the presence of buried cultural material over an extended area.

Burned rock features may yield significant information about the paleoenvironment and site formation processes and can infer past subsistence and mobility patterns when applied to theoretical models. Therefore, the research value and the NRHP eligibility of this site is unknown without further investigations beyond the scope of this inventory survey. CAS recommends excavating one 1-x-1-m unit adjacent to the scattered firecracked rock found in the bottom of the trench,

Table 5-3. 41BP100 positive shovel test results.

\begin{tabular}{|c|c|c|c|c|c|c|c|c|c|c|}
\hline $\begin{array}{l}\text { Depth } \\
\text { (cmbs) }\end{array}$ & $\begin{array}{c}\text { ST } \\
1\end{array}$ & $\begin{array}{c}\text { ST } \\
2\end{array}$ & $\begin{array}{c}\text { ST } \\
3\end{array}$ & $\begin{array}{c}\text { ST } \\
6\end{array}$ & $\begin{array}{c}\text { ST } \\
7\end{array}$ & $\begin{array}{c}\text { ST } \\
8\end{array}$ & $\begin{array}{l}\text { ST } \\
11\end{array}$ & $\begin{array}{l}\text { ST } \\
14\end{array}$ & $\begin{array}{c}\text { ST } \\
\text { N17 }\end{array}$ & $\begin{array}{c}\text { ST } \\
\text { N19 }\end{array}$ \\
\hline $0-10$ & & & $\begin{array}{l}2 \mathrm{IF} \\
\mathrm{B}, \mathrm{fcr}\end{array}$ & & & & & IF & & \\
\hline $10-20$ & & 3 IF & & IF & $\begin{array}{c}4 \mathrm{IF}, \\
\text { FCR, fcr }\end{array}$ & & & & & IF \\
\hline $20-30$ & $\begin{array}{l}\text { IF, } \\
3 \mathrm{FCR}\end{array}$ & $\begin{array}{l}\text { FCR, } \\
\text { fcr }\end{array}$ & & & & & & & & \\
\hline $30-40$ & IF & & & & & & & & & \\
\hline $40-50$ & $\mathrm{EF}$ & & & & IF & & & & & \\
\hline $50-60$ & IF & & & & & & & & & \\
\hline $60-70$ & $2 \mathrm{IF}$ & & & & $\begin{array}{l}\text { IF, FCR, } \\
\text { fcr }\end{array}$ & & FCR & & FCR & \\
\hline $70-80$ & fcr & & IF, FCR & & & & & & & \\
\hline $80-90$ & FCR & & & IF & & & & & Sand & Sand \\
\hline 90-100 & $\mathrm{U}, \mathrm{fcr}$ & & Water & $\begin{array}{l}2 \mathrm{FCR}, \\
\mathrm{fcr}\end{array}$ & $\begin{array}{l}\text { EF, IF, } \\
\text { FCR }\end{array}$ & IF & & FCR & & \\
\hline $100-110$ & $\begin{array}{l}\text { IF, } \\
\text { FCR }\end{array}$ & Sand & & & EF & $2 \mathrm{FCR}$ & Sand & IF & & \\
\hline $110-120$ & Sand & & & Sand & Sand & Sand & & Sand & & \\
\hline $120-130$ & & & & & & & & & & \\
\hline \multicolumn{11}{|c|}{$\begin{array}{l}\text { Key: EF-exterior flake; IF-interior flake; B-biface; U-uniface; } \\
\text { FCR-fire-cracked rock }>1 \text { inch; fcr-fire-cracked rock }<1 \text { inch }\end{array}$} \\
\hline
\end{tabular}


one 1-x-1-m unit in the wooded area near the creekbank, and nine 1-x-1-m units in the immediate areas of STs $1-3,6-8,11,14$, and N17.

\section{$41 \mathrm{BP} 105$}

\section{Description}

41BP105 (Figures 5-7 and 58 ) is a prehistoric open campsite with scattered historic trash (see Chapter 8: New Historic Component Sites for a discussion of the historic component). The prehistoric component covers approximately $7,312 \mathrm{~m}^{2}$ and ranges in elevation from 410 to $420 \mathrm{ft}$ amsl. The area is located in an open field on a lower terrace just west of the confluence of a spring-fed stream and Big Sandy Creek. The open field was the location of a historic vineyard, with a possible irrigation channel along its northwestern portion. Sayers fine sandy loam (Sa) now supports small isolated oak and mesquite trees in the field, as well as thicker riverine trees and brush along the edges of both creeks. Remnants of grapevines are also present in the open field amidst tall grasses. Surface visibility in 2005 was approximately 20 percent. The site datum is marked with a nail and aluminum tag in an oak tree.

\section{Levels of Work and Results}

Initial investigations at the site were conducted by Skelton and Freeman in 1979. No

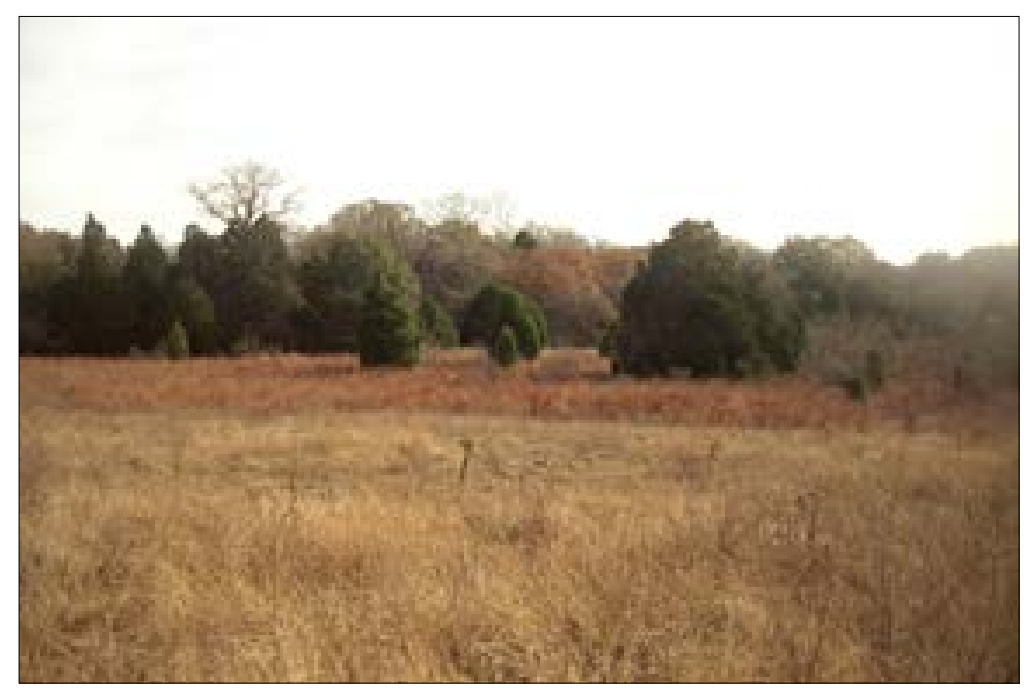

Figure 5-7. 41BP105 is a lower terrace site along Big Sandy Creek; facing west.

FIGURE 5-8. REDACTED

Figure 5-8. Site map of 41BP105.

cultural material was collected; however, they did note a rock hearth exposed in a channel cutbank. The cluster of rock was one meter in length and consisted of a single layer of fire-cracked chert, quartzite, and limestone. The feature was situated 
one meter above the water level and $50 \mathrm{~cm}$ below the surface of the terrace.

In 2002, CAS personnel excavated 19 shovel tests (1-19). Fifteen of the nineteen shovel tests were positive, with deposits as deep as $100 \mathrm{cmbs}$. Grey clay and the water table were encountered at $40 \mathrm{cmbs}$ on the western portion of the site. A historic pottery sherd was uncovered in ST 14 at $60-70 \mathrm{cmbs}$, and a bullet casing and piece of glass were found in the upper $30 \mathrm{cmbs}$ of STs 2 and 17, respectively (Nickels and Lehman 2004).

Artifacts collected from 2002 shovel tests included 14 small $(<1$ inch) pieces of fire-cracked rock, six larger ( $>1$ inch) pieces of fire-cracked rock, four utilized flakes, 30 interior flakes, four exterior flakes, one piece of lithic shatter, one bullet casing, a piece of clear glass, one charred hull, and the piece of historic pottery. No artifacts were observed on the surface (Nickels and Lehman 2004).

Jon Lohse returned to the site in 2005 and dug four backhoe trenches as recommended by Nickels and Lehman (2004). Lohse found no evidence of intact features, recommended no further work be conducted at the site, and recommended that the prehistoric component be considered not eligible for the NRHP (Lohse and Bousman 2006).

Two systematic shovel tests were excavated on the site in transect intervals in 2005 (CC7 and EE3). CAS archaeologists found a single interior flake at $20-30 \mathrm{cmbs}$ in ST CC7. This effectively expands the boundary on this site by $3,467 \mathrm{~m}^{2}$, from $3,845 \mathrm{~m}^{2}$ as determined in 2002 to $7,312 \mathrm{~m}^{2}$ after this project. Shovel test locations from 2002 and the current project, as well as backhoe trench locations from 2005, are illustrated in Figure 58.

\section{Conclusions/Recommendations}

After the 2002 project, CAS determined that although the upper $30 \mathrm{cmbs}$ was likely disturbed due to cultivation, a potentially intact layer from 70 to $90 \mathrm{cmbs}$ contained flakes, larger firecracked rock, and a charred hull. The presence of deeply buried fire-cracked rock found in shovel tests, coupled with Skelton and Freeman's (1979) observation of an eroding hearth, indicated intact cultural features buried deep below the surface. Therefore, the research value of this site was considered high, but in order to further evaluate its integrity, CAS recommended four backhoe trenches be excavated around STs 3, 4, 8-9, and 14 , and that if potentially intact features were encountered during trenching operations, 1-x$1-m$ units should then be excavated to further evaluate the overall significance of the site. As stated above, Lohse found no evidence of intact features when he returned to the site in 2005 . No evidence was discovered during this current testing project that would change his overall assessment of this site; therefore, CAS concurs that the prehistoric component of the site is not eligible for nomination to the NRHP.

\section{BP111}

\section{Description}

41BP111 (Figures 5-9 and 5-10) is a prehistoric open campsite with fire-cracked rock and an associated lithic scatter. The site covers approximately $53,607 \mathrm{~m}^{2}$ and ranges in elevation from 450 to $475 \mathrm{ft}$ amsl. It straddles a heavily wooded ridge and sideslope, with Patilo complex loose, fine sand $(\mathrm{PaE})$ supporting dense stands of post oak, black walnut, hickory, and juniper. The ridge slopes in a southeasterly direction toward an intermittent, upper tributary of McLaughlin Creek. Except for a bladed firebreak, surface visibility in 2005 was less than five percent. The site datum is marked with a nail and aluminum tag in an oak tree. 


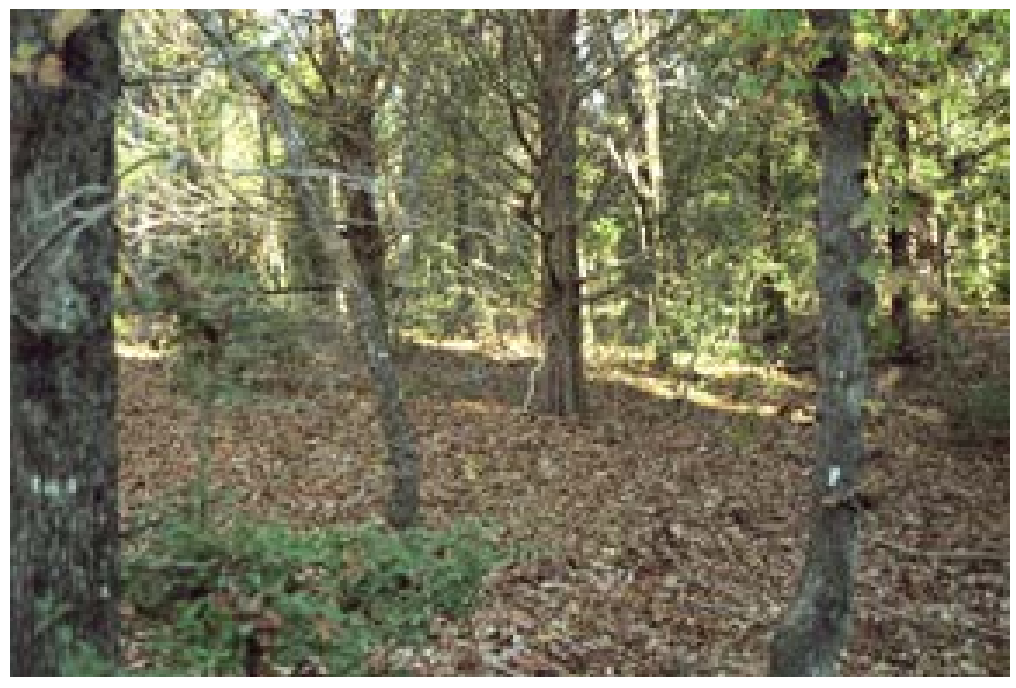

Figure 5-9. 41BP111 sets on a wooded ridge and sideslope; facing northwest.
FIGURE 5-10. REDACTED

Figure 5-10. Site map of 41BP111.

\section{Levels of Work and Results}

This site was originally recorded by Skelton and Freeman in 1979. At that time, they observed remnants of two fire-cracked rock hearths in a cutbank profile at 25 and 35 cmbs, respectively, as well as five flakes in the upper $25 \mathrm{cmbs}$. Both features appeared to be remnants of prehistoric hearths constructed of chert, quartzite, hematite, and silicious wood. They subsequently excavated a single 1-x-1-m test unit and recovered one core fragment, 116 pieces of fire-cracked rock, six secondary flakes, 26 tertiary flakes, and six chips.

In 2002 and 2003, no artifacts were observed on the surface, but CAS personnel excavated 40 shovel tests and collected 22 small ( $<1$ inch) pieces of firecracked rock, 21 large ( $>1$ inch) pieces of fire-cracked rock, 21 interior unmodified flakes, four exterior unmodified flakes, three utilized flakes, one retouched flake, and one piece of lithic shatter (Nickels and Lehman 2004). STs 1-23 were placed on the upper portion of the ridge (Area A), while STs 24-40 were placed on the sideslope (Area B) along an intermittent drainage (see Figure 5-10).

Even though Skelton and Freeman's test unit could not be located; from their description (1979:34-38) it appears that the site was located adjacent to the intermittent drainage along the eastern portion of CAS's designated Area B (see Figure 5-10). CAS archaeologists' 2003 inspection of the cutbank in that area 
revealed no evidence of buried hearth remnants or isolated artifacts. However, they did encounter deep sands, deeply buried artifacts, and 10 larger $(>1$ inch) pieces of buried fire-cracked rock in that area (Nickels and Lehman 2004).

Of the 34 shovel tests excavated on the site during the current project, nine were positive (Figure 5-10 and Table 5-4). Ten flakes and four fire-cracked rocks were recovered from the positive shovel probes. CAS archaeologists also observed a large quartzite and sandstone firecracked rock hearth feature eroding from the side of a bulldozed firebreak road and the adjacent cutbank on the eastern portion of the site (see Figure 5-10). These investigations resulted in expanding the size of the site some $30,558 \mathrm{~m}^{2}$, from $23,049 \mathrm{~m}^{2}$ to $53,607 \mathrm{~m}^{2}$.

Jon Lohse returned to the site in 2005 and dug five backhoe trenches as recommended by Nickels and Lehman (2004). Although no intact features were found in the backhoe trenches, he also noted the eroding hearth feature and recommended that two test units be placed in the immediate area (Lohse and Bousman 2006). Shovel test locations from 2002 and the current project, as well as backhoe trenches from 2005, are illustrated in Figure 5-10 (Nickels and Lehman 2004; Lohse and Bousman 2006).

\section{Conclusions/Recommendations}

A large hearth eroding from the side of a firebreak trench and adjacent cutbank is evidence that intact hearth features and associated cultural remains are buried at this site. This report concurs with Lohse and Bousman's 2006 recommendation that two 1-x-1-m units should be hand-excavated in the immediate area of the eroding heath feature in order to further evaluate the unknown significance of the site.

\section{$41 B P 112$}

\section{Description}

41BP112(Figures 5-11 and 5-12) is a prehistoric open campsite with fire-cracked rock and an associated lithic scatter. The site is approximately $21,622 \mathrm{~m}^{2}$, and the elevation ranges from 450 to $460 \mathrm{ft}$ amsl. The site is intersected by a ca. 5-m deep intermittent drainage that joins McLaughlin Creek. The eastern portion is heavily wooded with evidence of recent cedar clearing and temporary military encampment. Its western portion lies in a partially open, old field area on a sideslope 30 $\mathrm{m}$ west of the intermittent drainage. Numerous

Table 5-4. 41BP111 positive shovel test results in 2005.

\begin{tabular}{|c|c|c|c|c|c|c|c|c|c|}
\hline $\begin{array}{c}\text { Depth } \\
\text { (cmbs) }\end{array}$ & $\begin{array}{c}\text { ST } \\
\text { J1 }\end{array}$ & $\begin{array}{c}\text { ST } \\
\text { K6 }\end{array}$ & $\begin{array}{c}\text { ST } \\
\text { K10 }\end{array}$ & $\begin{array}{c}\text { ST } \\
\text { L4 }\end{array}$ & $\begin{array}{c}\text { ST } \\
\text { L7 }\end{array}$ & $\begin{array}{c}\text { ST } \\
\text { L8 }\end{array}$ & $\begin{array}{c}\text { ST } \\
\text { L16 }\end{array}$ & $\begin{array}{c}\text { ST } \\
\text { M15 }\end{array}$ & $\begin{array}{c}\text { ST } \\
\text { N18 }\end{array}$ \\
\hline $0-10$ & IF & & FCR & & & fcr & & & \\
\hline $10-20$ & & & IF, FCR & & & & & & \\
\hline $20-30$ & & & & & & & & & EF \\
\hline $30-40$ & & IF & Clay & & IF, FCR & & IF & & \\
\hline $40-50$ & & & & IF & & & IF & IF & \\
\hline $50-60$ & Clay & & & & & & & IF & \\
\hline $60-70$ & & & & & & & & & \\
\hline $70-80$ & & Sand & & Sand & Sand & Sand & Sand & Sand & Sand \\
\hline $80-90$ & & & & & & & & & \\
\hline $90-100$ & & & & & & & & & \\
\hline
\end{tabular}




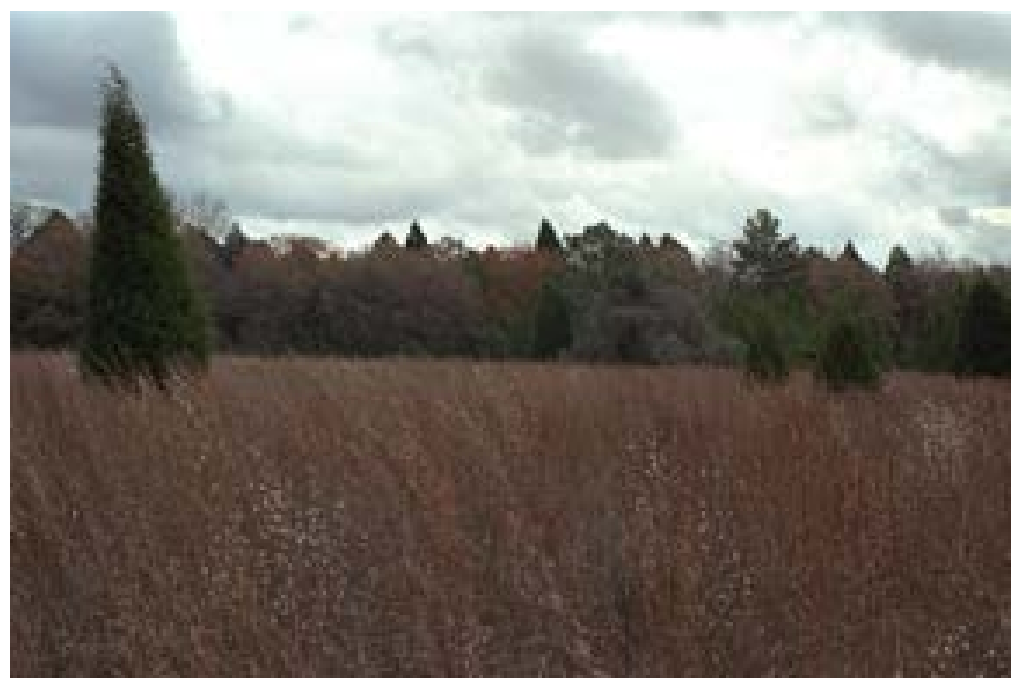

Figure 5-11. 41BP112 lies on wooded and grassland sides of an intermittent drainage; facing east. tank tracks are present on the site, and a ca. $70 \mathrm{~cm}$ trench has been cut along the woodline on the western edge of the drainage. Demona loamy fine sand $(\mathrm{DeC})$ supports dense stands of oak, pine, and mesquite that surround tall grasses on the eastern side of the drainage, and Axtell fine sandy loam in one to five percent slopes (AfC) supports tall grasses on the western side. Surface visibility in April 2005 was less than five percent. The site datum is marked with a nail

FIGURE 5-12. REDACTED

Figure 5-12. Site map of 41BP112. 
and an aluminum tag in a large pine tree on the western portion of the site.

\section{Levels of Work and Results}

The site was originally recorded by Skelton and Freeman in 1979 and later revisited by CAR archaeologists in 1997. Skelton and Freeman's surface observations included burned rock fragments and four flakes (Skelton and Freeman 1979). In 1997, CAR collected three flakes from shovel tests (Robinson et al. 2001). In 2001, CAS personnel excavated fifteen shovel tests in the open field on the western portion of the site, and collected seven pieces of fire-cracked rock, two interior flakes, one piece of lithic shatter, and two charcoal samples. The shovel test results further indicated either a buried ridge under the area of STs 9-12, or possible cut-and-fill deposition on both sides of this area (see Figure 5-12). Although a thorough examination of the surface was conducted, no cultural material was observed (Nickels et al. 2003).

In August 2002, CAS archaeologists excavated 16 shovel tests on the eastern portion of the site and collected six pieces of small ( $>1$ inch) fire-cracked rock, 13 pieces of larger $(<1$ inch) fire-cracked rock, six interior flakes, five exterior flakes, one piece of shatter, and a crushed gravel. Based on the results from shovel tests, seven 1-x1-m units were excavated on the site, two on the eastern portion, and five on the western portion (see Figure 5-12). All seven units were dug to the underlying clay/caliche deposits. The data from these seven units indicated that the soils at this site are shallow. Only one of the excavation units yielded adequate data for analysis, and there appeared to be little if any stratigraphic integrity within that unit. An examination of the resulting datasets indicated that there is no clearly discrete human occupation zone at the site; rather, the combined datasets suggested that turbation has vertically displaced both cultural and noncultural materials. In addition, no diagnostic artifacts, stone tools, preserved charcoal, faunal, or ethnobotanical remains were recovered, and no features were encountered (Nickels 2008).

As part of the current project, CAS archaeologists excavated shovel tests around the site in survey transect intervals in April 2006. Out of five shovel tests placed on the site, three positive shovel tests were recorded along its northern portion (Figure 5-12 and Table 5-5). Therefore, the site boundary was extended in that direction, increasing the site size by $418 \mathrm{~m}^{2}$, from 21,204 $\mathrm{m}^{2}$ to $21,622 \mathrm{~m}^{2}$. Although five fire-cracked rocks were found in ST E1, four of them were lying on the $\mathrm{Bt}$ horizon within roots and rounded gravels. Figure 5-12 illustrates shovel tests results from 2001, 2002, and the current project, as well as the locations of hand-excavated units from 2002.

\section{Conclusions/Recommendations}

This site has been intensively tested, and seven units were hand-excavated in 2002. All investigations failed to provide evidence of intact features or cultural deposits. Although currently unpublished, and therefore, not approved by

Table 5-5. 41BP112 positive shovel test results in 2006.

\begin{tabular}{|c|c|c|c|}
\hline $\begin{array}{c}\text { Depth } \\
\text { (cmbs) }\end{array}$ & ST E1 & ST E2 & ST D11 \\
\hline $0-10$ & FCR & 2 IF & \\
\hline $10-20$ & & & EF \\
\hline $20-30$ & & & \\
\hline $30-40$ & 4 FCR & & \\
\hline $40-50$ & Clay & EF & \\
\hline $50-60$ & & & \\
\hline $60-70$ & & IF & \\
\hline $70-80$ & & Sand & Sand \\
\hline $80-90$ & & & \\
\hline $90-100$ & & & \\
\hline \multicolumn{4}{|c|}{ Key: EF-exterior flake; IF-interior flake; } \\
FCR-fire-cracked rock $>1$ inch \\
\hline
\end{tabular}


THC, CAS assessed the research value of this site as minimal, and it was assessed as not eligible for nomination to the NRHP (Nickels 2008). The three positive shovel tests discovered during the current project do not affect that recommendation.

\section{BP121}

\section{Description}

The size of this open campsite (Figures 5-13 and 5-14) is 51,510 $\mathrm{m}^{2}$, and the siteranges in elevation

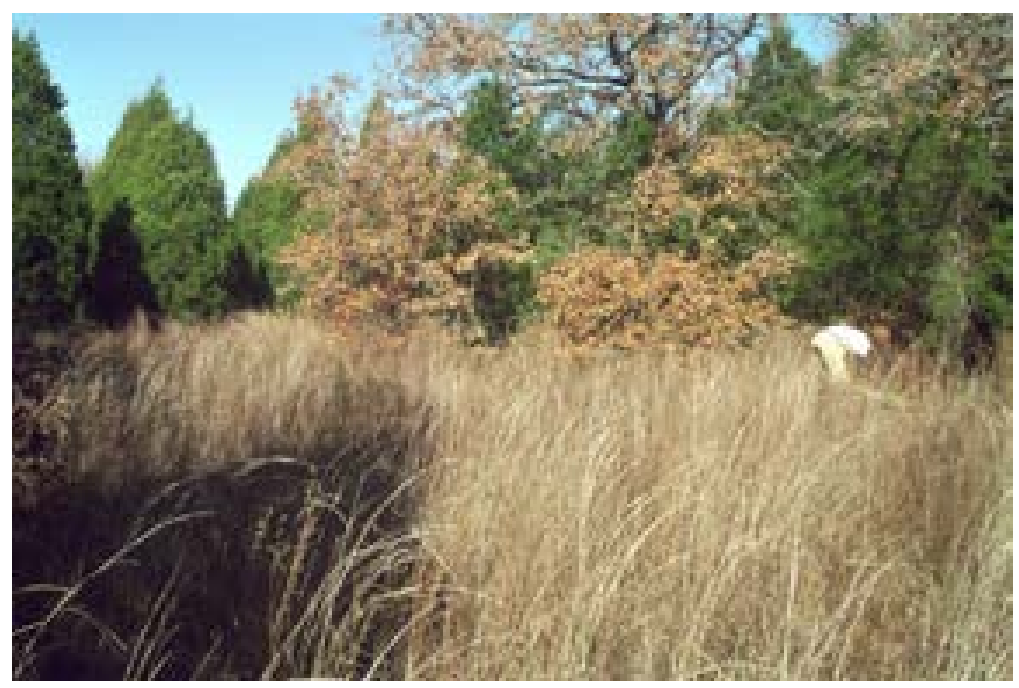

Figure 5-13. 41BP121 is situated on a gentle sideslope; photo taken facing north.

from 455 to $465 \mathrm{ft}$ amsl. Shovel

tests from the current project indicate that it is associated with and overlaps the historic component at 41BP142 (discussed later in Chapter 8). 41BP121 is situated on a sideslope in a semi-wooded area with Demona loamy fine sand (DeC) that supports stands of juniper, oak, and mesquite. New Road runs through the center of the site. Soils on the northern portion are generally eroded, exposing shallow deposits of red and grey clay, while the soils on the southern portion FIGURE 5-14. REDACTED are deeper. Surface visibility in May 2005 was less than five percent. The site datum is a nail and an aluminum tag in a large oak tree.

\section{Levels of Work and Results}

The site was initially recorded by Skeleton and Freeman in 1979 and revisited by CAR

Figure 5-14. Site map of 41BP121; overlaps with 41BP142. 
archaeologists in 1997. In 1979, a 1-x-2-m excavation unit that was dugin 25 -cmlevelsyielded 377 pieces of fire-cracked rock, 383 unmodified flakes, five utilized flakes, one Montell-like dart point, 13 cores, and one hammerstone. Although rodent burrows were observed, the presence of a hearth feature near the bottom of Level 3 (50-75 cmbs) suggested that portions of the site were intact (Skelton and Freeman 1979). During their 1997 revisit, CAR archaeologists found flakes and two pieces of burned rock in one of three shovel tests excavated (Robinson et al. 2001).

Although SkeltonandFreemanhad noted lithic debitage on the surface, no artifacts were observed on the surface in 2002 when CAS personnel initially visited the site for relocation purposes (Nickels and Lehman 2004). When CAS revisited the site in 2003 and designated Areas A and B, numerous gravels were observed in a newly bladed road, cut 50-60 $\mathrm{cm}$ deep through the center of the site. Among the gravels were a bifacial core and a light scatter of flakes. The only other artifacts observed on the surface were a fire-cracked rock and a flake on a gopher mound, both in Area B (Nickels and Lehman 2004). In 2003, CAS personnel excavated a total of 30 shovel tests across the site. Eight small $(<1$ inch) pieces of fire-cracked rock, five large ( $>1$ inch) pieces of firecracked rock, 15 interior flakes, seven exterior flakes, three utilized flakes, one potlid, two pieces of clear glass, and two pieces of brown glass were recovered from shovel test probes.
During this project, CAS archaeologists observed an Archaic-like dart point fragment in the road. Shovel tests dug in systematic transects around the site resulted in expanding the boundary toward the south, north, and east. Thus, the estimated size of the site increased by $19,928 \mathrm{~m}^{2}$, from $37,582 \mathrm{~m}^{2}$ to $51,510 \mathrm{~m}^{2}$. In fact, this extensive shovel test project has expanded the

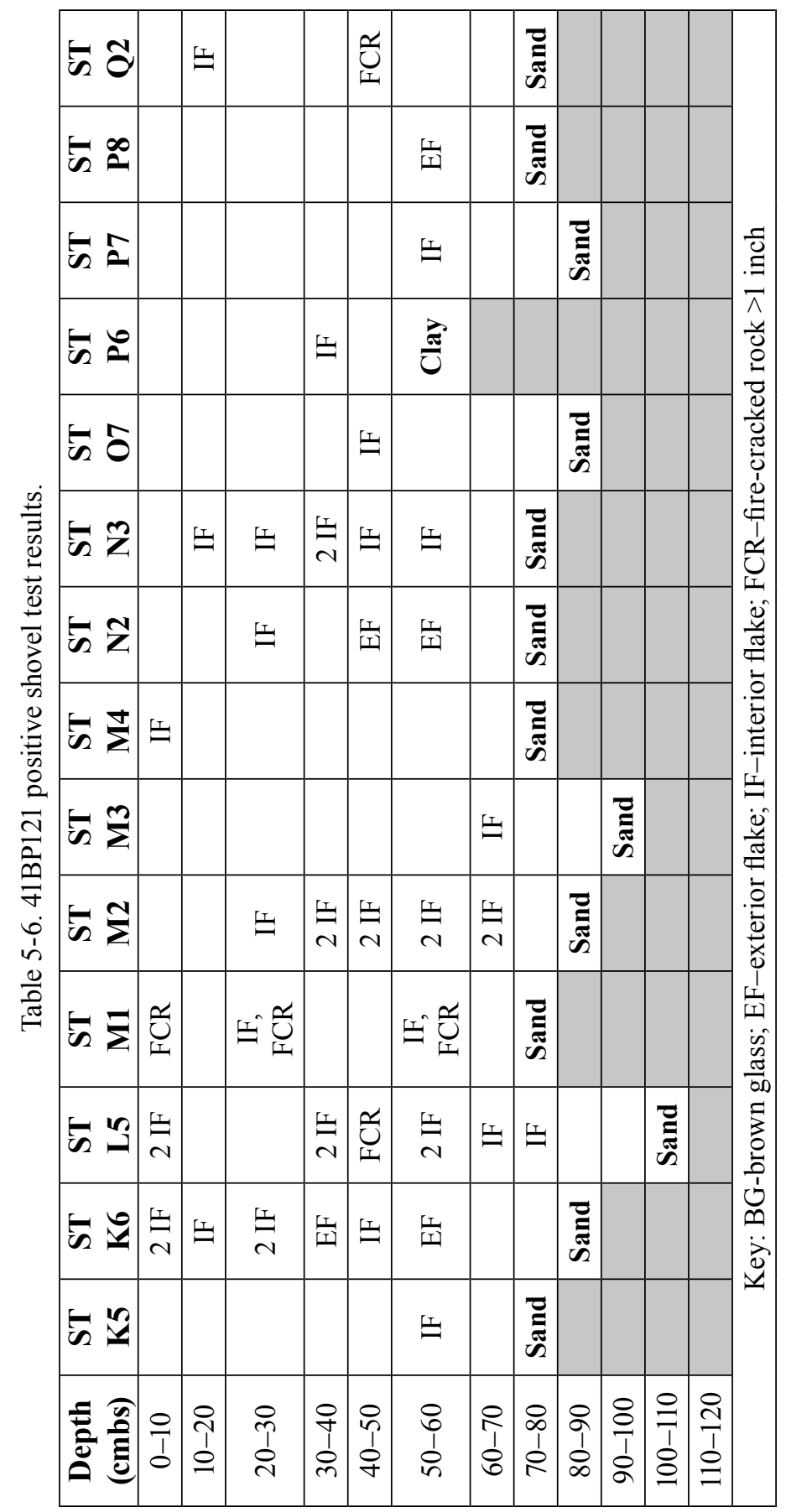


boundaries of 41BP121 so that it now appears that 41BP121 and 41BP122 (an open campsite to the west) could be the same site (see Appendix A for proximity of the two sites). This expansion has also created an overlap with 41BP142, a historic site, sampled independently. Some of the shovel tests excavated for 41BP142 produced prehistoric artifacts and are reported in Chapter 8. In all cases, separate site numbers and boundaries have been maintained so that the sites can be traced throught the various reports.

Table 5-6 lists the artifacts recovered from the 2005 transect shovel tests. Also in 2005, Jon Lohse excavated three backhoe trenches on the site based on Nickels and Lehman's 2004 recommendations. Figure 5-14 illustrates the locations of the shovel tests excavated in 2002 and during the current project, as well as the backhoe trenches excavated in 2005. Lohse found no evidence of intact features within the three trenches (Lohse and Bousman 2006).

\section{Conclusions/Recommendations}

Extensive excavations of shovel tests have resulted in an expansion of the site's boundary, but neither shovel tests nor backhoe trenches have exposed any intact hearth features in addition to the one documented by Skelton and Freeman in 1979. Therefore, CAS concurs with Lohse and Bousman (2006) that no additional work is recommended. The site is not eligible for nomination to the NRHP.

\section{BP123}

\section{Description}

41BP123 (Figures 5-15 and 516) is a prehistoric open campsite that covers approximately 3,584 $\mathrm{m}^{2}$ and ranges in elevation from 450 to $460 \mathrm{ft}$ amsl. It lies in a mixed pine and cedar woodland, interspersed with open grassy areas supported by Demona loamy fine sand $(\mathrm{DeC})$. The area is located on a sideslope overlooking the floodplain of a tributary of McLaughlin Creek. A bulldozed road has been cut through the site, and intensive tree clearing has occurred. Surface visibility in April 2005 was approximately five percent. The site datum is a nail and an aluminum tag in an elm tree along a cutbank on the northern portion of the site.

\section{Levels of Work and Results}

A 1-x-1-m test unit excavated in 1979 by Skelton and Freeman yielded 60 flakes and chips, 72 pieces of burned rock, and four cores. However, most were recovered either from within disturbed deposits or lying on gravelly clay. In 2002 CAS personnel excavated a total of 16 shovel tests (1$16)$, but found only five small pieces $(<1$ inch) of fire-cracked rock. In 2003 CAS archaeologists returned, excavated another nine shovel tests (17-25), and found two additional small pieces ( $<1$ inch) and one larger piece ( $>1$ inch) of firecracked rock, two flakes, and a modern brown glass shard (Nickels and Lehman 2004:47-49).

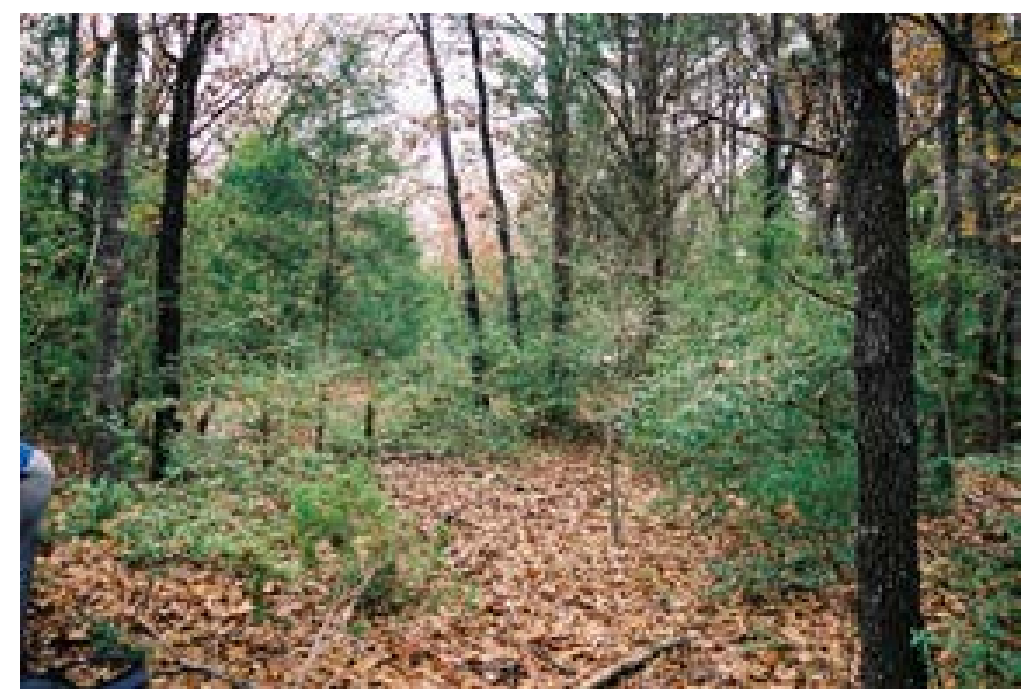

Figure 5-15. 41BP123 sets on a wooded, gentle sideslope above a tributary of McLaughlin Creek; facing south. 


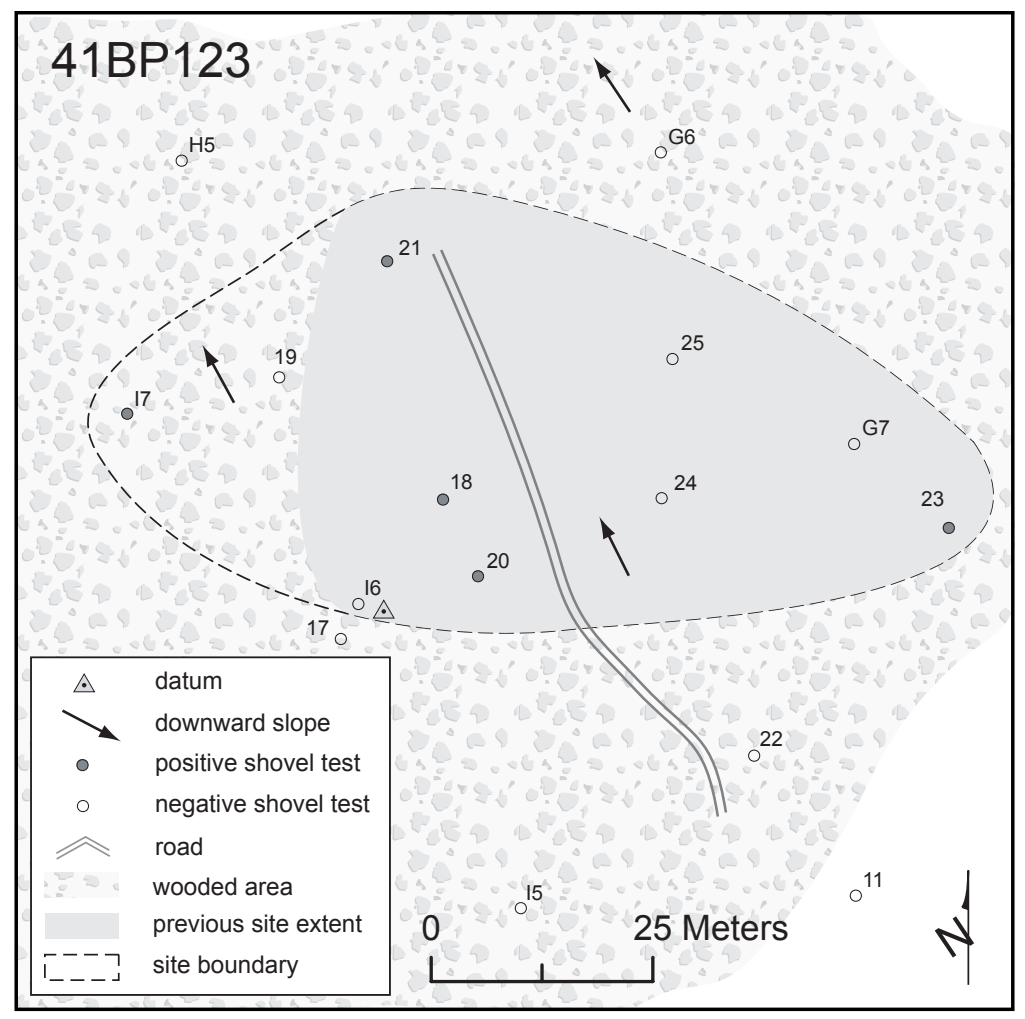

Figure 5-16. Site map of 41BP123.

Figure 5-16 illustrates shovel test locations from 2003 and the current project. During the current project, one out of three systematic shovel tests (I7) excavated on the site contained a fire-cracked rock at 50-60 cmbs, effectively causing the boundary to expand westward beyond ST 19. The size of the site increased by $1,184 \mathrm{~m}^{2}$, from $2,400 \mathrm{~m}^{2}$ to $3,584 \mathrm{~m}^{2}$.

\section{Conclusions/ \\ Recommendations}

Based upon shovel test results in 2003 (Nickels and Lehman 2004), and again during the current project, the research value of this site is minimal. Therefore, CAS's assessment of the ability of this site to provide further significant information to the prehistory of the region is the same as it was in 2003 (Nickels and Lehman 2004); it is minimal, no further testing is recommended, and it is not eligible for nomination to the NRHP.

\section{BP127}

\section{Description}

41BP127 (Figures 5-17 and 5-18) is a $775-\mathrm{m}^{2}$ lithic procurement site situated on a terrace along an intermittent drainage named Dogwood Branch. Ranging in elevation from 460 to $465 \mathrm{ft}$ amsl, the site lies in a partially cleared area with scattered stands of oak and juniper supported by Axtell fine sandy loam (AfC2). Having been heavily disturbed by machinery, there are numerous push piles and bladed lanes on the site. Surface visibility in March 2005 was less than five percent. The site datum is a nail and aluminum tag in an oak tree.

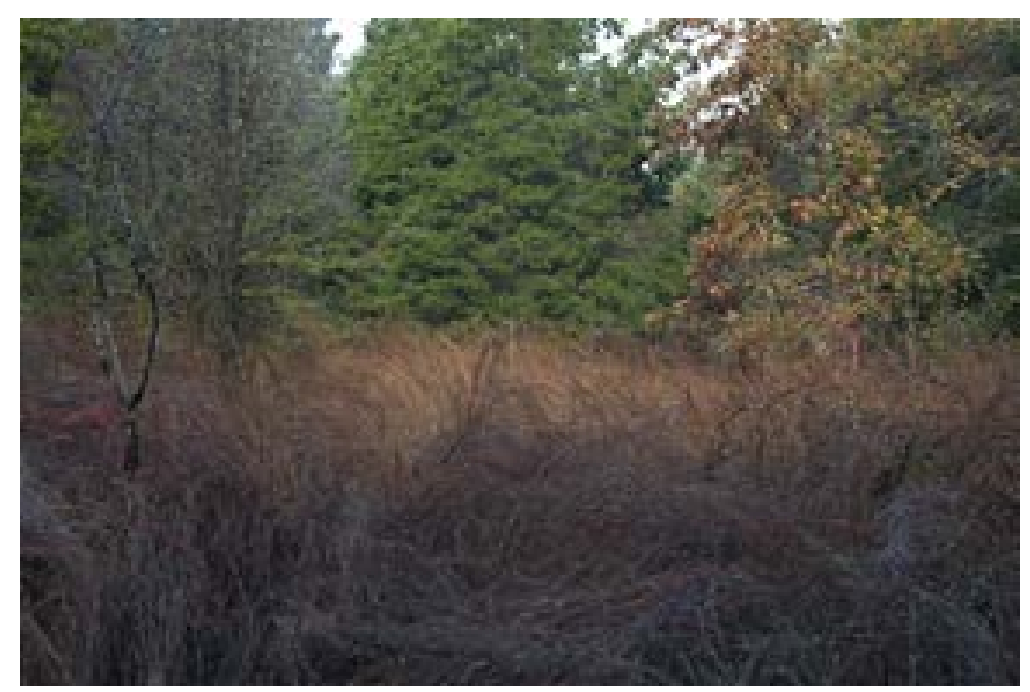

Figure 5-17. 41BP127 sets on a grassy, upper terrace adjacent to Dogwood Branch; facing west. 


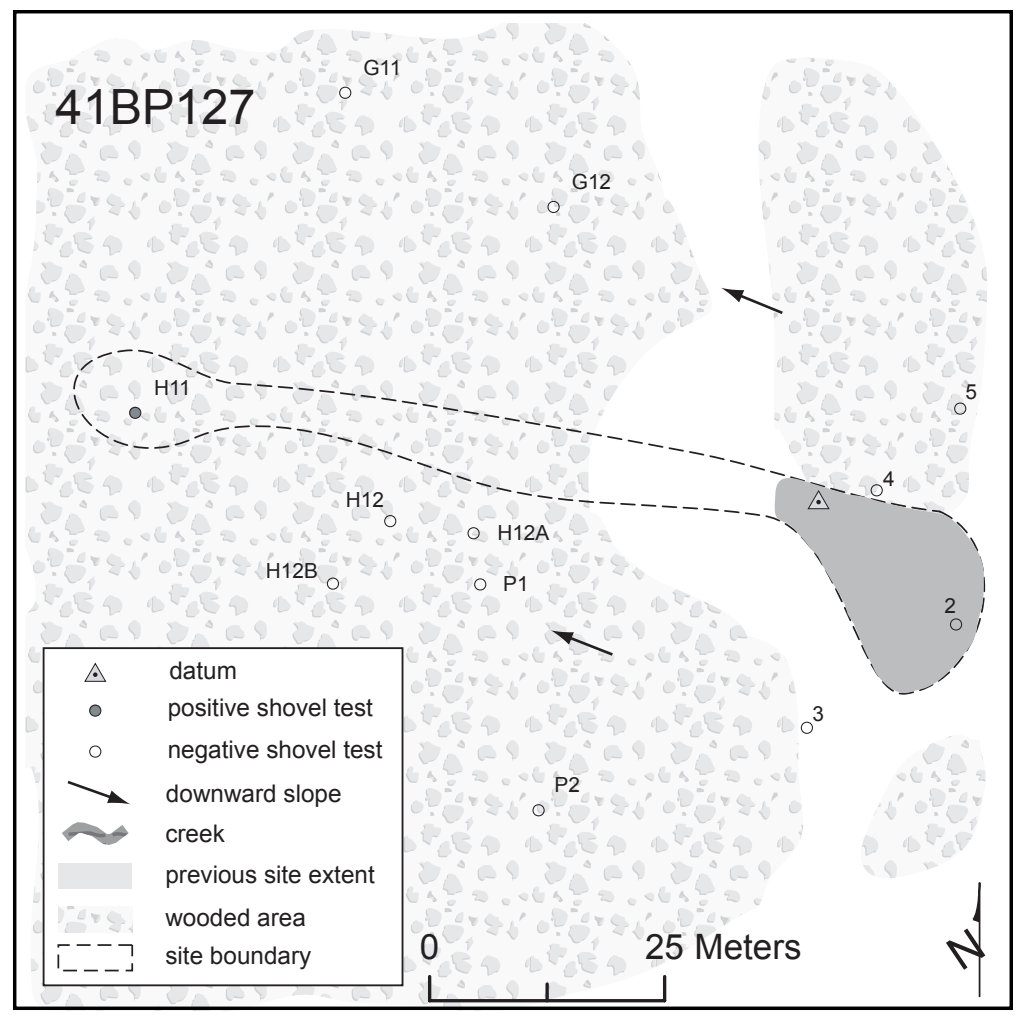

Figure 5-18. Site map of 41BP127.

\section{Levels of Work and Results}

The site was originally recorded in 1979 by Skelton and Freeman and revisited in 1997 by CAR archaeologists. Skelton and Freeman observed two core fragments and several flakes on the surface (Skelton and Freeman 1979), while CAR archaeologists found nothing on the surface, but found a single flake near the surface in a shovel test (Robinson et al. 2001). Neither of the investigators collected any cultural materials, and both described the site's surface as deflated and eroded. In 2001, CAS personnel carefully examined the surface and excavated five shovel tests; however, no cultural materials were located (Nickels et al. 2003).
The locations of excavated shovel tests from 2001 and the current project are illustrated in Figure 5-18. One shovel test excavated on the site during the current project was positive. An interior flake was found in ST H11 at 4050 cmbs. This caused the site's boundary to be expanded toward the west, and increased its size by $535 \mathrm{~m}^{2}$, from $240 \mathrm{~m}^{2}$ to 775 $\mathrm{m}^{2}$.

\section{Conclusions/ Recommendations}

This site lies in a heavily eroded area with push piles and downed trees. From previous investigations it appears the site may have been a small procurement locale where limited lithic reduction activities occurred. However, it has been heavily impacted by erosion, bioturbation, and military training activities (push piles, downed trees, and bladed areas). The single positive

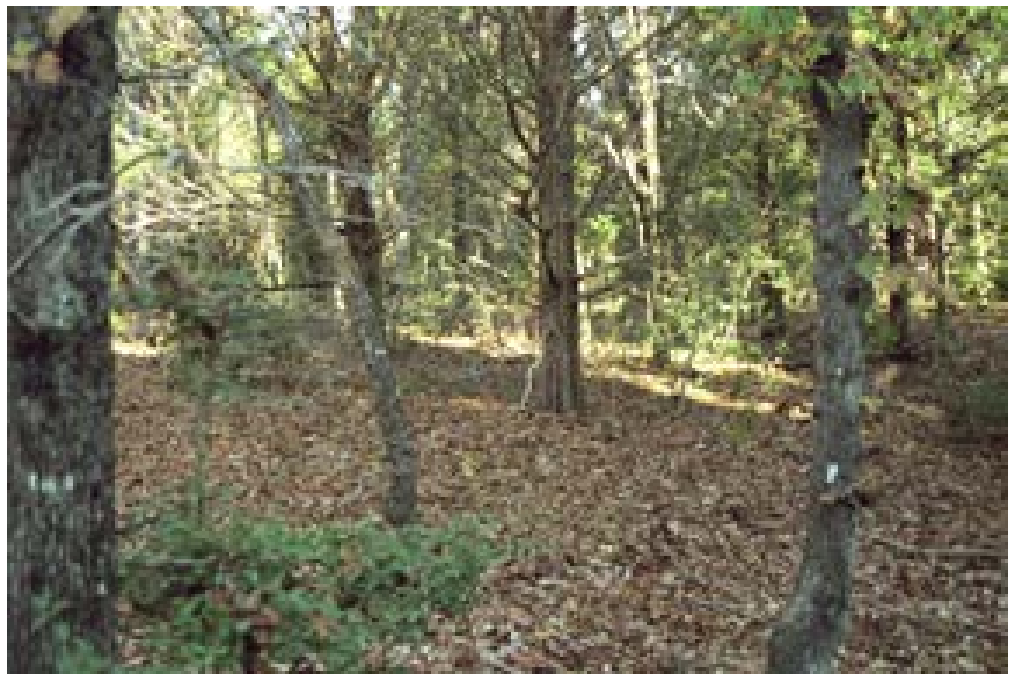

Figure 5-19. 41BP436 lies on a wooded sideslope; facing east. 
shovel test in 2005 does not affect its research value. As evaluated in 2003 by Nickels et al., its research value is minimal, no further investigations are recommended, and the site is not eligible for nomination to the NRHP.

\section{BP436}

\section{Description}

41BP436 (Figures 5-19 and 5-20) is a prehistoric open campsite with burned rock and an associated lithic scatter. The approximate site size is $8,709 \mathrm{~m}^{2}$, and it is located near the confluence of McLaughlin Creek and an unnamed tributary. Ranging in elevation from 480 to $490 \mathrm{ft}$ amsl, the site is situated on a sideslope in a small opening, with Axtell fine sandy loam (AfC2) supporting moderately dense stands of pine, cedar, and tall grasses. Surface visibility in 2005 was approximately 10 percent. The site datum is a nail and an aluminum tag in an oak tree.

\section{Levels of Work and Results}

When Schmidt, Cruse, and Brownlow initially recorded this site in 1995, they did not comment on whether or not artifacts were visible on the surface. At that time, they dug ten shovel tests and found a total of five chert flakes, three quartzite fire-cracked rocks, and several pieces of charcoal. They noted that clay was encountered between 70 and
FIGURE 5-20. REDACTED

Figure 5-20. Site map of 41BP436.

Table 5-7. 41BP436 positive shovel test results.

\begin{tabular}{|c|c|c|c|c|c|c|c|}
\hline $\begin{array}{c}\text { Depth } \\
\text { (cmbs) }\end{array}$ & $\begin{array}{c}\text { ST } \\
\mathbf{3}\end{array}$ & $\begin{array}{c}\text { ST } \\
\text { U13 }\end{array}$ & $\begin{array}{c}\text { ST } \\
\text { V9 }\end{array}$ & $\begin{array}{c}\text { ST } \\
\text { V10 }\end{array}$ & $\begin{array}{c}\text { ST } \\
\text { W3 }\end{array}$ & $\begin{array}{c}\text { ST } \\
\text { X2 }\end{array}$ & $\begin{array}{c}\text { ST } \\
\text { X3 }\end{array}$ \\
\hline $0-10$ & & & & & & & FCR \\
\hline $10-20$ & & & fcr & FCR & & IF & \\
\hline $20-30$ & fcr & $\begin{array}{c}\text { IF, } \\
6 \text { fcr }\end{array}$ & & & & & \\
\hline $30-40$ & EF & FCR & FCR & FCR & & & FCR \\
\hline $40-50$ & & FCR & fcr & FCR & $\begin{array}{c}\text { EF, } \\
\text { FCR }\end{array}$ & & \\
\hline $50-60$ & & FCR & FCR & 2 FCR & FCR & IF & \\
\hline $60-70$ & & FCR & FCR & & & & \\
\hline $70-80$ & Clay & Sand & Clay & Sand & Sand & Sand & Sand \\
\hline $80-90$ & \multicolumn{7}{|c|}{ Key: EF-exterior flake; IF-interior flake; } \\
\hline \multicolumn{7}{|c|}{ FCR-fire-cracked rock >1 inch; fcr-fire-cracked rock $<1$ inch } \\
\hline
\end{tabular}

$80 \mathrm{cmbs}$ (Schmidt et al. 1995). In 2002, CAS personnel excavated an additional ten shovel tests (1-10) and collected only one piece of fire-cracked rock and one exterior flake (see ST 3 in Table 5-7) (Nickels and Lehman 2004). No cultural 
material was observed on the surface in 2002 . Based upon those two investigations, the site's western boundary was mapped as approximately $115 \mathrm{~m}$ from McLaughlin Creek. In this current project seven additonal transect shovel tests were excavated. Six positive shovel tests, located to the southwest of the previously recorded site, expanded the site's size by $6,618 \mathrm{~m}^{2}$, from 2,091 $\mathrm{m}^{2}$ to $8,709 \mathrm{~m}^{2}$. Combined, the positive shovel tests contained 24 fire-cracked rocks and four flakes. Concentrations of fire-cracked rocks were encountered generally between 30 and $60 \mathrm{cmbs}$. Figure 5-20 illustrates the locations of the shovel tests excavated in 2002 and during the current project, while Table 5-7 presents positive shovel test results from 2002 and the current project. These findings vary significantly from those in the previous two investigations. Minor disturbances in the form of a few roots were encountered in two of the shovel tests.

\section{Conclusions/Recommendations}

Contrasting sharply with the findings in 1995 and 2002, the extension of testing in an area closer to the confluence of two streams has yielded additional and significant data. When restricted to the site as mapped in 2002, shovel test results provided little evidence that intact features and/or other cultural material may be present below the surface. Based upon that limited data, the site was recommended as not eligible for the NRHP (Nickels and Lehman 2004). However, as listed in Table 5-8, the 2005 results argue exactly the opposite. Therefore, CAS cannot now assess the ability of this site to provide further significant information to the prehistory of the region, and thus its NRHP eligibility, without additional work beyond southwest. the scope of this inventory survey. In order to do so, CAS recommends excavation of four 1-x-1$m$ units, one each in the immediate areas of STs U13, V9, V10, and W3.

\section{$41 B P 485$}

\section{Description}

41BP485 (Figures 5-21 and5-22) is aprehistoric open campsite spread over approximately 23,058 $\mathrm{m}^{2}$ of a ridge and its sideslope. The site ranges in elevation from 425 to $440 \mathrm{ftamsl}$. Big Sandy Creek runs approximately $40 \mathrm{~m}$ from the southeastern edge of the site, and an intermittent drainage forms the northern-most boundary. The eastern edge of the site has been significantly impacted by the construction of Scott Falls Road, a turnaround area, and bulldozed mounds. Demona loamy fine sand (DeC) supports the growth of a stand of cedar near the center of the site, with oak and cedar woodlands on its northeastern edge. Surface visibility in January 2005 was less than five percent. The site datum is marked with a nail and an aluminum tag in a cedar tree on the southwestern portion of the site.

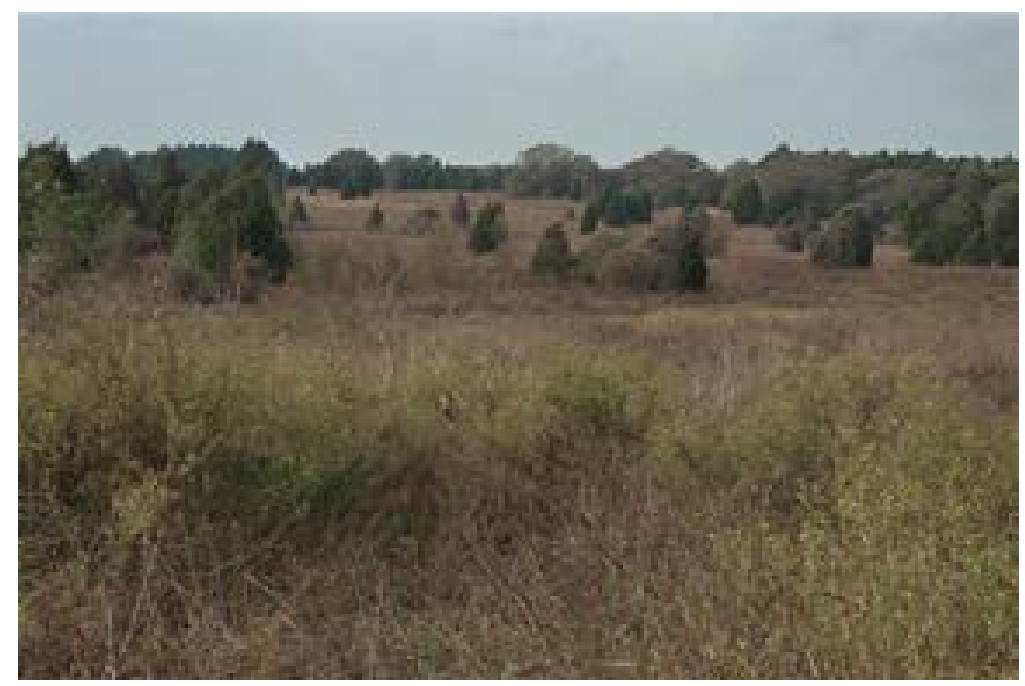

Figure 5-21. This is the lower, southern portion of 41BP485; facing 


\section{Levels of Work and Results}

When this site was initially recorded by CAR archaeologists in 1997, a proximal fragment of an Angostura point and the distal section of an untypable, but Archaic-like dart point were found on the surface. They also excavated two shovel tests and found a single piece of burned rock in the upper $20 \mathrm{cmbs}$ of one of them. Two shovel tests placed at the site in 2001 by CAR archaeologists yielded only a single piece of firecracked rock in the upper $20 \mathrm{cmbs}$ (Robinson et al. 2001). In 2001, CAS personnel conducted a 100 -percent surface inventory and found flakes, a core, pieces of fire-cracked rocks, and historic whiteware sherds. In addition, CAS personnel excavated 38 shovel tests. That data indicated cultural deposits buried in a continuum as deep as $100 \mathrm{cmbs}$ (Nickels et al. 2003).

In the summer of 2002, CAS archaeologists returned to the site and excavated 14 1-x-1-m units and a single backhoe trench. In addition to the Angostura and Archaic-like point fragment found on the surface during previous investigations, CAS recovered a Late Archaic Ellis point, three untypable Late Archaic points, a Pedernales point, and one other untypable dart point from excavation units. Two burned rock features were discovered and 60 charcoal samples were collected. Other unique items included a smoothed stone (possible boiling stone), a silicified wood tool, and a hammerstone. Intrusive modern material included bullets, an ammunition clip, glass, plastic, whiteware, and a metal fragment. Ten of the 14 modern pieces were found in the upper $30 \mathrm{cmbs}$, and all 14 were found above $60 \mathrm{cmbs}$. Faunal remains were scarce. Flotation samples and macrobotanical samples revealed the presence of charred hickory nut and oak wood. Wood charcoal samples submitted for assay yielded radiocarbon dates of $2430 \pm 40 \mathrm{BP}$ and $490 \pm 40$ BP (Nickels 2008).

Subsequent excavation of two positive shovel tests (out of five excavated) near the eastern edge of the site during the current project indicates that the site's boundary should be extended in that direction to a steep slope along an intermittent drainage. One flake was found in ST A44 at $10-20 \mathrm{cmbs}$, and a flake was found in ST A46 at the same depth. By including these two shovel tests within the expanded boundary, it increases the size of the site by $10,000 \mathrm{~m}^{2}$, from $13,058 \mathrm{~m}^{2}$ to $23,058 \mathrm{~m}^{2}$. The extension of the site's boundary and the locations and results of shovel tests excavated in 2001 and the current project, as well

Figure 5-22. Site map of 41BP485. 
as locations of units from 2002 , are illustrated in Figure 5-22.

\section{Conclusions/ \\ Recommendations}

In sum, limited excavations in 2002 yielded evidence of intact deposits, datable charcoal, diagnostic stone tools, good ethnobotanical preservation, and probable faunal preservation (Nickels 2008). Therefore, portions of this site have the potential to further yield significant information about the prehistoric economy and technology of the region. Although currently unpublished, and thus not yet approved by THC, the assessment was that the site is eligible for nomination to the NRHP and should be placed off-limits to military training (Nickels 2008). The two positive shovel tests discovered during the current project do not affect that recommendation.

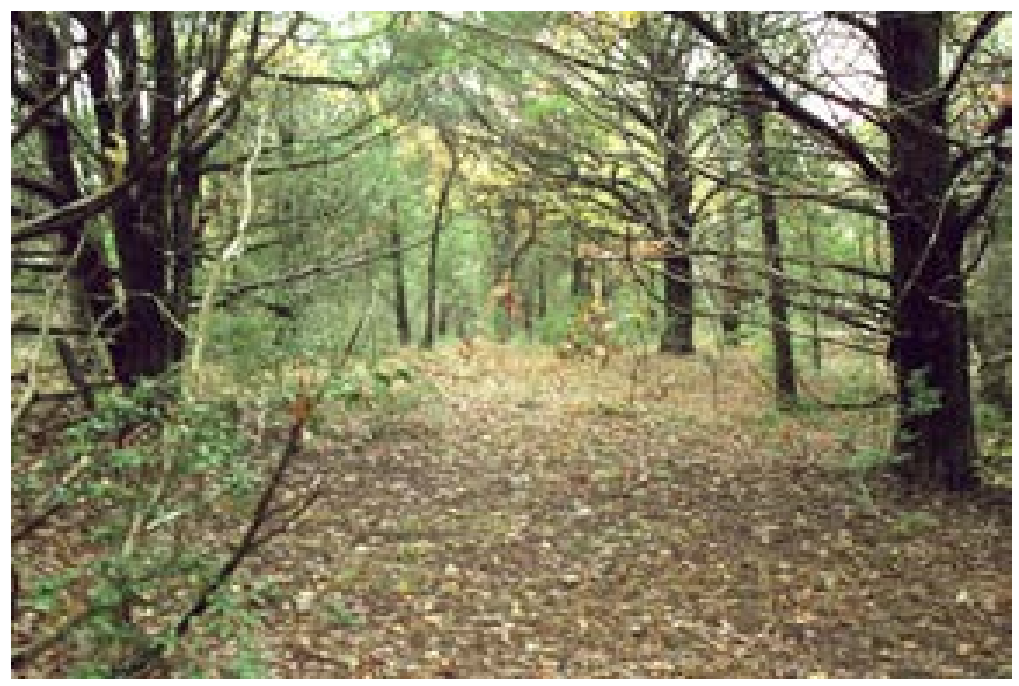

Figure 5-23. 41BP491 lies in a wooded upland setting, adjacent to 41BP495, a multi-component prehistoric open campsite; facing northwest.

FIGURE 5-24. REDACTED

\section{BP491}

\section{Description}

41BP491 (Figure 5-23 and 5-24) is a prehistoric open campsite with fire-cracked rock and associated lithic debitage. The site covers approximately $7,717 \mathrm{~m}^{2}$, and ranges in elevation from 458 to $473 \mathrm{ft}$ amsl. The Figure 5-24. Site map of 41BP491. nearest natural water source is an intermittent tributary of Big generally dense stands of oak and cedar. 41BP495, Sandy Creek $65 \mathrm{~m}$ to the northeast. The site is located in an upland setting in a generally wooded area, and Silstid loamy fine sand ( $\mathrm{SkC}$ ) supports

a multi-component prehistoric open campsite, lies approximately $30 \mathrm{~m}$ to the southeast (Nickels and Lehman 2004). Surface visibility during 
CAS's 2005 visit was less than five percent. The site datum is a nail and an aluminum tag in an oak tree.

\section{Levels of Work and Results}

When CAR archaeologists initially recorded this site in 1997, they dug three shovel tests and recovered flakes and/or burned rocks as deep as $80 \mathrm{cmbs}$ (Robinson et al. 2001). In 2002, CAS personnel excavated 23 shovel tests and also found deeply-buried flakes and fire-cracked rock. No artifacts or features were observed on the surface during either visit to the site. The only disturbances noted were a few rodent burrows and uprooted trees. An upper component between 40 and $60 \mathrm{cmbs}$ and a lower component between 70 and $90 \mathrm{cmbs}$ were discerned from the shovel test data (Nickels and Lehman 2004). The discrete vertical distribution of artifacts recovered was very similar to that of adjacent site $41 \mathrm{BP} 495$. Based upon recommendations made by Nickels and Lehman in 2004, Jon Lohse returned to the

Table 5-8. 41BP491 positive shovel test results in 2005.

\begin{tabular}{|c|c|c|}
\hline $\begin{array}{c}\text { Depth } \\
\text { (cmbs) }\end{array}$ & ST H4 & ST J8 \\
\hline $0-10$ & & 2 CC, IF \\
\hline $10-20$ & & \\
\hline $20-30$ & IF & \\
\hline $30-40$ & & \\
\hline $40-50$ & & \\
\hline $50-60$ & & \\
\hline $60-70$ & & Sand \\
\hline $70-80$ & Sand & \\
\hline $80-90$ & & \\
\hline \multicolumn{2}{|c|}{ Key: CC-chert chip; IF-interior flake } \\
\hline
\end{tabular}

site in 2005 and excavated three backhoe trenches. However, no evidence of intact features was found (Lohse and Bousman 2006). During the current project, CAS archaeologists discovered two positive shovel tests out of four excavated on the site. The recovered artifacts are listed in Table 5-8. Figure 5-24 illustrates the locations of excavated shovel tests from 2002 and the current project, as well as backhoe trench locations from the 2005 project.

\section{Conclusions/Recommendations}

Although the shovel test data indicated there were likely discretely separate components at this site, no features were discovered in subsequent backhoe trenches. Therefore, Lohse and Bousman (2006) recommended that no further work be done and the site is not eligible for nomination to the NRHP. The two additional positive shovel tests dug during the current project effectively increased the size of the site by $3,335 \mathrm{~m}^{2}$, from $4,382 \mathrm{~m}^{2}$ to $7,717 \mathrm{~m}^{2}$, but the data have no effect on Lohse and Bousman's recommendations.

\section{$41 B P 495$}

\section{Description}

41 BP495 (Figures 5-25 and 5-26) is a prehistoric open campsite with burned rock features, diagnostic projectile points, and good organic preservation. It is located in an oak/cedar woodlands area with deep Patilo complex sand $(\mathrm{PaE})$. Situated on the edge of a gently sloping upland area, it ranges in elevation from 475 to $480 \mathrm{ft}$ amsl, covers approximately $8,688 \mathrm{~m}^{2}$, and overlooks intermittent drainages to the northwest and northeast. Observed surface disturbances include a fallen tree in the middle of the site, and three military foxholes (see Figure 5-26). Surface visibility was about 5 percent in 2005. The site datum is marked by a nail and an aluminum tag in an oak tree.

\section{Levels of Work and Results}

This site was initially investigated by CAR archaeologists in 1997 (Robinson et al. 2001) 
and revisited by CAS in 2001 . Systematic shovel tests yielded fire-cracked rock, burned clay, and charcoal as evidence of possibly intact cultural features and associated deposits as deep as $110 \mathrm{cmbs}$ (Nickels et al. 2003). CAS returned to the site in 2002 and excavated ten 1-x-1$m$ units in the immediate areas of the most productive shovel tests. In addition, two backhoe trenches were dug as part of the geomorphological investigation (Nickels 2008).

One fire-cracked rock feature was encountered in a hand-excavated unit, and two others were clipped by the backhoe. Three Scallorn points, a Darl point, and a Clovis preform were found in the excavation units. A total of 76 charcoal samples were collected. The only faunal remains found were an unidentified element of a mammal, and the tarsometatarsus of a bobwhite quail. Four flotation samples from two burned features revealed charred hickory nut fragments and charred oak wood (Nickels 2008). One positive shovel test was dug during the current project just outside the northern boundary as previously mapped.

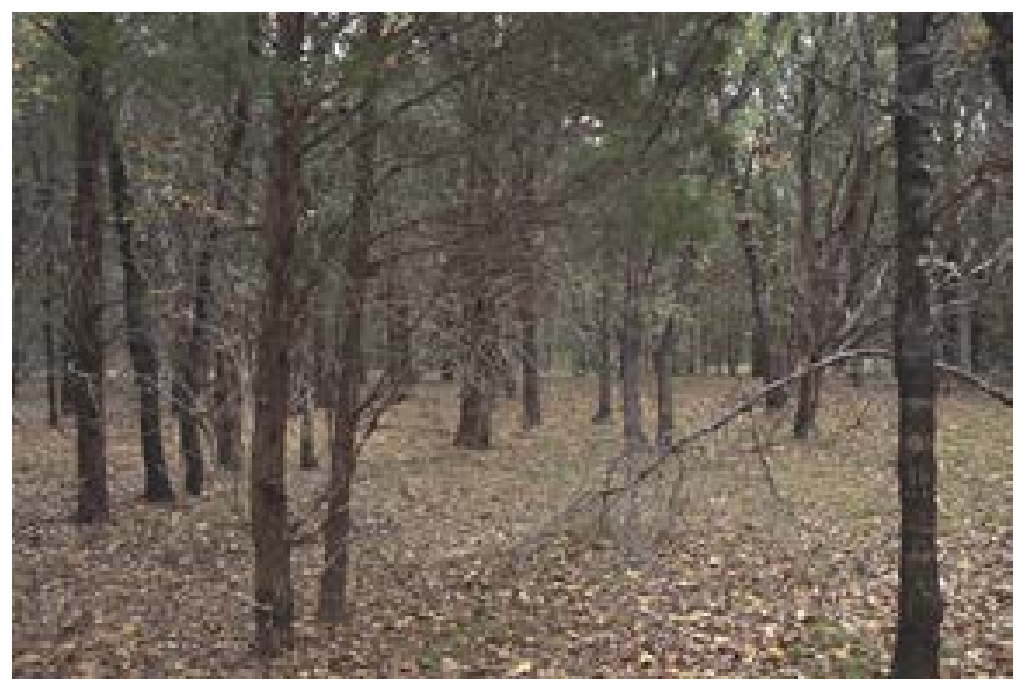

Figure 5-25. 41BP495 is an open campsite in a wooded, upland setting; facing east.

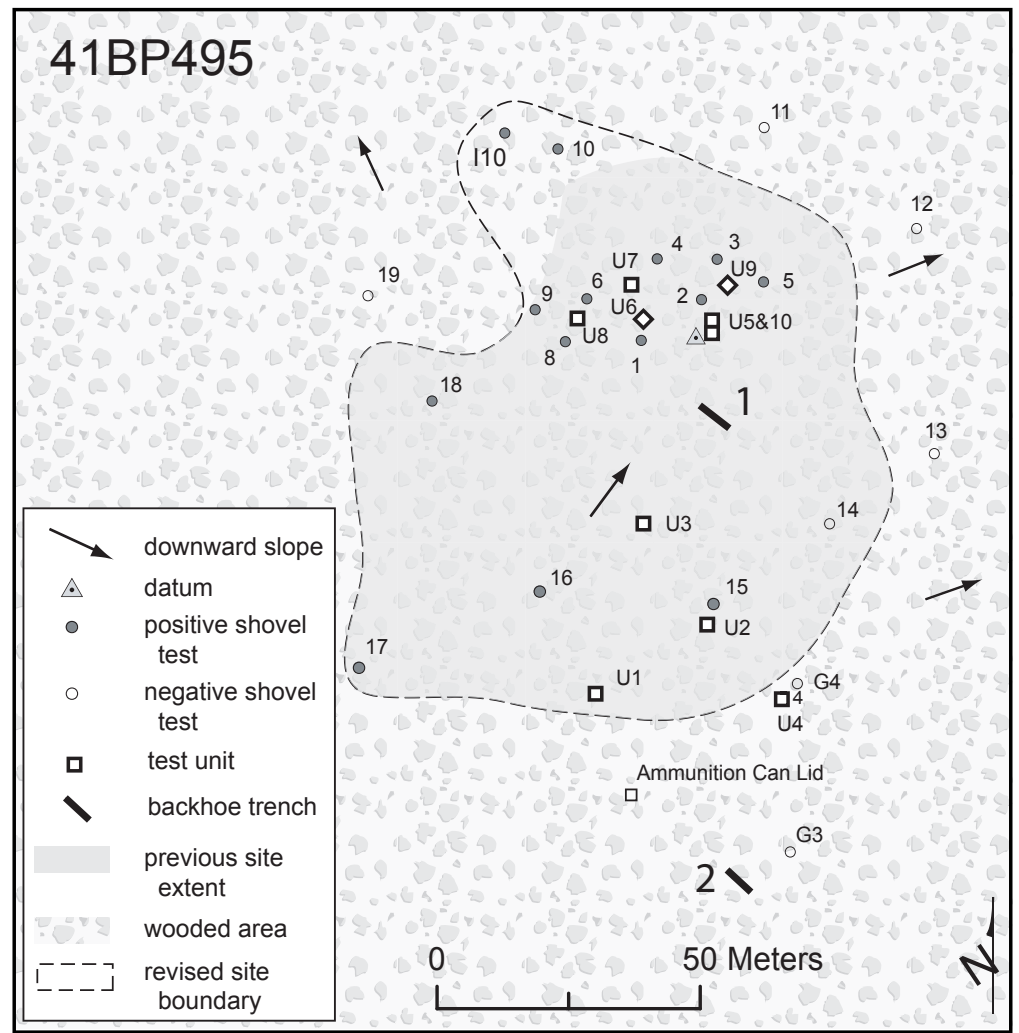

Figure 5-26. Site map of 41BP495. ST I10 had one interior flake at $40-50 \mathrm{cmbs}$. The one positive shovel test during the current project gives cause to expand the site's boundary, increasing the site's the current project are illustrated in Figure 5-26, as are the locations of backhoe trenches and 1-x1-m units from the 2002 project. 


\section{Conclusions/ \\ Recommendations}

Based upon the excavation data gathered during the 2002 excavations, the site is eligible for nomination to the NRHP(Nickels 2008). The limited excavations have yielded evidence of intact cultural features with associated diagnostic stone tools and debitage. In addition, because organic preservation is good, charcoal for dating and ethnobotanical remains that provide information on prehistoric subsistence have been recovered. Although the 2002 findings are not yet published, and thus not approved by THC, CAS assessed that this site has provided sufficient data to demonstrate it has a greater potential to yield further significant information regarding prehistoric subsistence and settlement patterns. Therefore, it is recommended as eligible for nomination to the NRHP, and should be placed off-limits to military training. The positive shovel test discovered during the current project does not affect this recommendation.

\section{BP521}

\section{Description}

41BP521 (Figures 5-27 and 5-28) is an open campsite with fire-cracked rock and lithic scatter, set on a nearly flat upland area. The site covers approximately $9,656 \mathrm{~m}^{2}$ and ranges in elevation from 425 to 431 $\mathrm{ft}$ amsl. Old field growth in Patilo complex sand

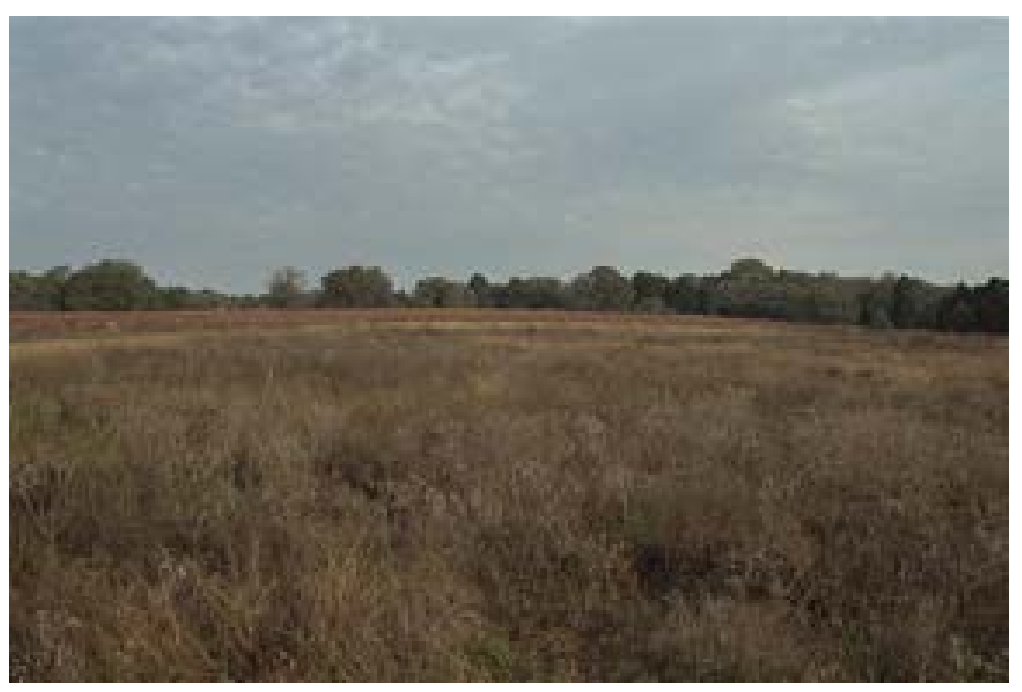

Figure 5-27. 41BP521 is buried within an old field on an upland area; facing north.

FIGURE 5-28. REDACTED

Figure 5-28. Site map of 41BP521.

$(\mathrm{PaE})$ consists of moderately dense grasses. The nearest natural water source is Big Sandy Creek, $200 \mathrm{~m}$ to the east. Modern disturbances include Wine Cellar Road, which cuts through the western edge of the site, and a jeep road cutting 
through its eastern edge. In addition to numerous rodent burrows observed, the surface is very hummocky, indicative of either plowing or heavy machinery (probably tanks) churning up the soil. Surface visibility in January 2005 was less than five percent. The site datum is marked by a nail and an aluminum tag in a pine tree on the southern portion of the site.

\section{Levels of Work and Results}

The site was initially recorded by CAR archaeologists in 1997. A single shovel test produced stone tools, flakes, and fire-cracked rock as deep as $60 \mathrm{cmbs}$ (Robinson et al. 2001). In 2001, CAS revisited the site and collected a Late Archaic Ensor point from the surface of Wine Cellar Road. Also in 2001, CAS archaeologists excavated an additional 16 shovel tests, from which they collected deeply buried fire-cracked rock and flakes (Nickels et al. 2003).

In 2002, CAS excavated seven 1-x-1-m units in the immediate areas of the most productive shovel tests. Two scattered fire-cracked rock features were encountered, and Granbury, Scallorn, and Castroville points were found. In addition, baked clay, a piece of incised hematite, four bifaces, two cores, three battered stones, one ground and battered stone, and 810 flakes were recovered. CAS obtained a wood charcoal date of $1180 \pm 40 \mathrm{BP}$ and an oxidizable carbon ratio (OCR) date of $2516 \pm 75$ BP. Faunal remains consisted of five unidentified elements of mammals, a rat snake vertebra, and a black bear incisor. Charred hickory nut fragments and charred oak wood were identified in a flotation sample (Nickels 2008). During the current project CAS personnel excavated two transect shovel tests on the site. A flake was recovered from transect ST V2 at 40-50 cmbs, just south of the boundary mapped during previous investigations. The positive shovel test during the current project expands the site boundary so that the size of the site increases by $3,159 \mathrm{~m}^{2}$, from $6,497 \mathrm{~m}^{2}$ to 9,656 $\mathrm{m}^{2}$. The locations and results of excavated shovel tests from 2001 and the current project, and the locations of 1-x-1-m units from the 2002 project, are illustrated in Figure 5-28.

\section{Conclusions/Recommendations}

Overall, the 2002 excavations indicate that the site has a greater potential to yield further significant information regarding prehistoric subsistence and settlement patterns. Therefore, although not yet published, it was recommended as eligible for nomination to the NRHP and should be placed off-limits to military training (Nickels 2008). The one positive shovel test discovered during the current project does not affect that recommendation. 


\title{
Chapter 6
}

\section{Previously Documented Prehistoric Component Sites}

\author{
By David L. Nickels, D. Emory Worrell and C. Britt Bousman
}

Twenty-three prehistoric site components were previously documented by various archaeological projects at Camp Swift but never visited by CAS archaeologists until this current project. NRHP eligibility determinations are listed in Table 6-1. CAS excavated shovel tests in transects on all 23 previously recorded sites and additional shovel tests were excavated at most sites. No site specific shovel tests were excavated at 41BP97, 41BP109 and 41BP120 because of lack of material or density of transect shovel tests. Positive shovel tests producing prehistoric artifacts were obtained at 15 of the 23 sites. Eight sites (41BP96, 41BP97, 41BP99,

Table 6-1. Summary of sites and National Register of Historic Places eligibility recommendations.

\begin{tabular}{|c|c|c|c|}
\hline Site & Publications & $\begin{array}{c}\text { Previous NRHP } \\
\text { Eligibility }\end{array}$ & $\begin{array}{c}\text { Revised NRHP } \\
\text { Eligibility }\end{array}$ \\
\hline 41BP95 (184) & Skelton \& Freeman 1979; Robinson et al. 2001 & Not Eligible & No Change \\
\hline 41BP96 & Skelton \& Freeman 1979; Robinson et al. 2001 & Not Eligible & No Change \\
\hline 41BP97 & Skelton \& Freeman 1979; Robinson et al. 2001 & Not Eligible & No Change \\
\hline 41BP99 & Skelton \& Freeman 1979; Robinson et al. 2001 & Not Eligible & Not Eligible \\
\hline 41BP101 & Skelton \& Freeman 1979; Robinson et al. 2001 & Not Eligible & No Change \\
\hline 41BP103 & Skelton \& Freeman 1979; Robinson et al. 2001 & Not Eligible & No Change \\
\hline 41BP106 & Skelton \& Freeman 1979; Robinson et al. 2001 & Not Eligible & No Change \\
\hline 41BP109 & Skelton \& Freeman 1979; Robinson et al. 2001 & Not Eligible & No Change \\
\hline 41BP114 & Skelton \& Freeman 1979; Robinson et al. 2001 & Not Eligible & Unknown \\
\hline 41BP119 & Skelton \& Freeman 1979; Robinson et al. 2001 & Not Eligible & No Change \\
\hline 41BP120 & Skelton \& Freeman 1979; Robinson et al. 2001 & Not Eligible & No Change \\
\hline 41BP122 (143) & Skelton \& Freeman 1979; Robinson et al. 2001 & Not Eligible & Unknown \\
\hline 41BP124 & Skelton \& Freeman 1979; Robinson et al. 2001 & Not Eligible & No Change \\
\hline 41BP129 & Skelton \& Freeman 1979; Robinson et al. 2001 & Not Eligible & No Change \\
\hline 41BP130 & Skelton \& Freeman 1979; Robinson et al. 2001 & Not Eligible & No Change \\
\hline 41BP131 & Skelton \& Freeman 1979; Robinson et al. 2001 & Not Eligible & No Change \\
\hline 41BP366 & Nightengale \& Moncure 1996 & Not Eligible & No Change \\
\hline 41BP367 & Nightengale \& Moncure 1996 & Not Eligible & No Change \\
\hline 41BP381 & Wormser 1994; Robinson et al. 2001 & Not Eligible & No Change \\
\hline 41BP433 & Schmidt et al. 1995 & Not Eligible & No Change \\
\hline 41BP472 & Sullo and Wormser 1996 & Not Eligible & No Change \\
\hline 41BP487 & Haslouer-Kay et al. 1997; Robinson et al. 2001 & Not Eligible & Unknown \\
\hline 41BP494 & Haslouer-Kay et al. 1997; Robinson et al. 2001 & Not Eligible & No Change \\
\hline
\end{tabular}


41BP101, 41BP103, 41BP109, 41BP381 and 41BP433) did not produce prehistoric artifacts from these shovel test excavations. Based on previous results the NRHP eligibility of all 23 sites was classified as "Not Eligible." However, three sites were reclassified as "Unknown Elibibility" based on the results of this current project (see Table 6-1). Even though these sites have been discussed in the references shown in Table 6-1, an overview of previous results and additional data obtained during this project are provided below. In presenting the current results, the total number of shovel tests refers to transect and site-specific shovel tests excavated within the final site boundaries (as defined by this study and previous work).

\section{$41 B P 95$ (41BP184)}

\section{Description}

Skelton and Freeman (1979) identified the prehistoric component here as 41BP95, and the historic component as 41BP184. Subsequent investigations indicate that it should be designated as one large site with both prehistoric and historic components. The historic component is discussed in Chapter 8: Previously Documented Historic Component Sites. The prehistoric component consists of scattered burned rocks and lithic debitage spread across 12,670 $\mathrm{m}^{2}$ (Figures 6-1 and 6-2). Axtell fine sandy loam (AfC2) covers the site. The northern portion is covered with oaks, elms and cedars, while the southern portion is mostly open grassland. Obvious disturbances include the historic structure and the old field that was likely plowed. The surface slopes from 452 to
$440 \mathrm{ft}$ amsl toward McLaughlin Creek, $50 \mathrm{~m}$ to the south. Surface visibility averaged less than five percent across the entire site area. The datum is marked with a nail and aluminum tag on a $30-\mathrm{cm}$ diameter oak tree in the open field.

\section{Levels of Work and Results}

This site was initially recorded by Skelton and Freeman (1979), and later revisited by CAR archaeologists (Robinson et al. 2001). Skelton merely commented on the historic component as an occupation site, and Robinson et al. (2001) commented only on the prehistoric component. Skelton reported seeing flakes and burned rocks in gopher mounds. Robinson recovered a chert core between 20 and $40 \mathrm{cmbs}$ in one of two shovel tests. When CAS returned to the site in August 2005, archaeologists saw only one exterior flake on the surface in the open field area. Subsequent positive shovel tests extended into the woods and expanded the boundary of the site in that direction. Table 6-2 lists the artifacts found in 17 of 23 shovel tests dug on the site. Historic artifacts were mixed with prehistoric artifacts in STs 1-7 on the southern portion of the site

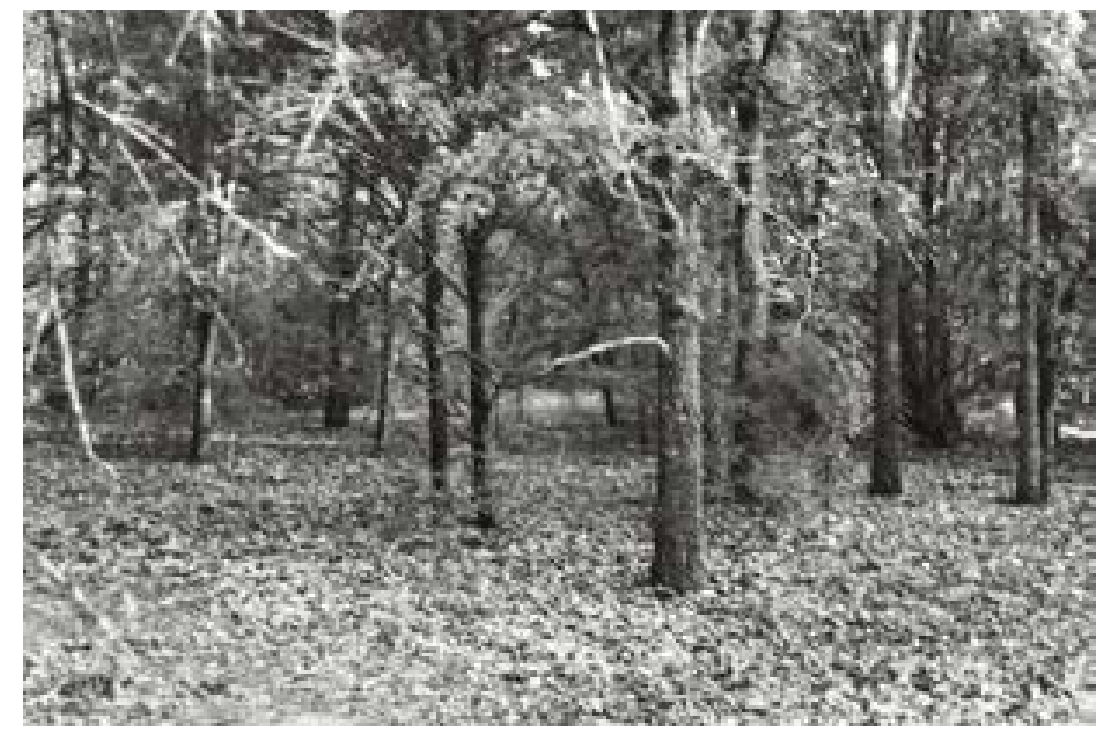

Figure 6-1. 41BP95 is a prehistoric open campsite in both a wooded area and an adjoining open field; facing northwest. 


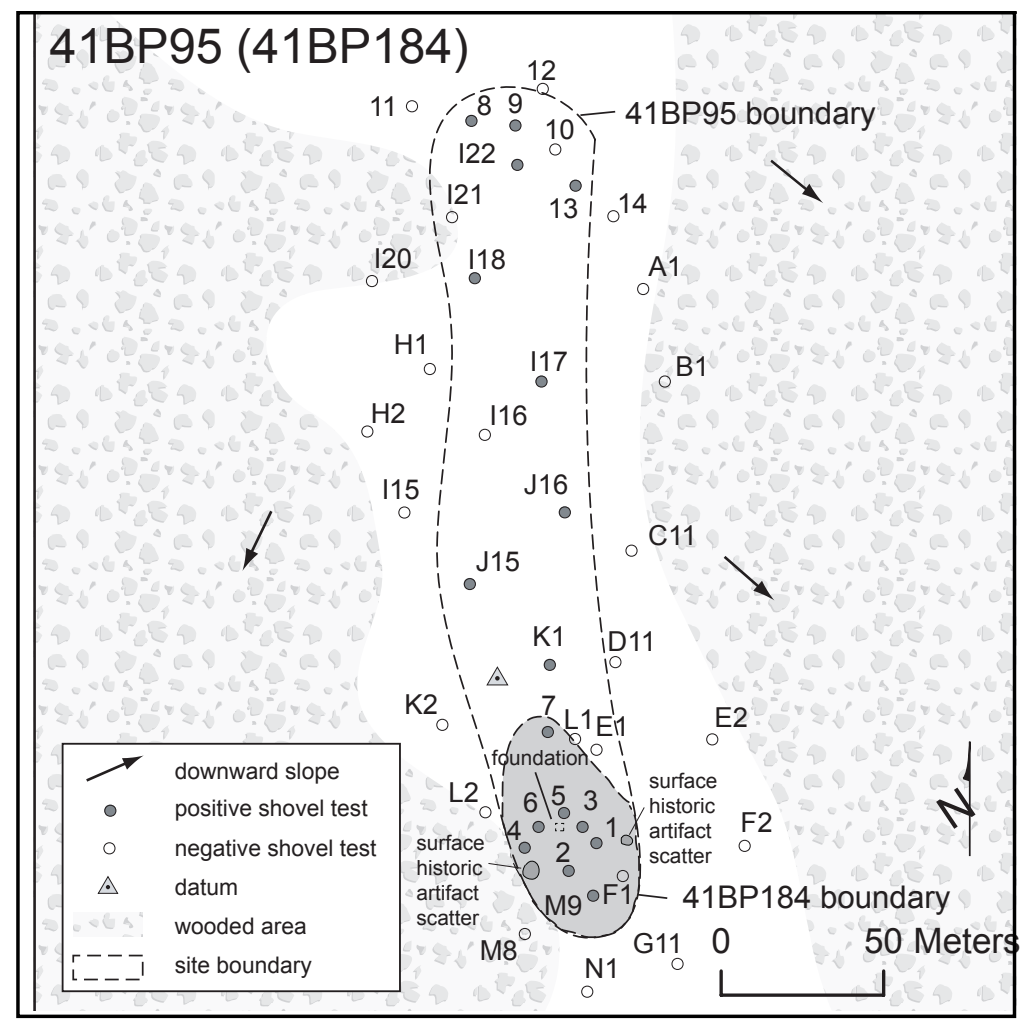

Figure 6-2. Site map of 41BP95 (41BP184).

and this reflects disturbance during the historic occupation.

\section{Conclusions/Recommendations}

It appears that the southern portion of this site may have had the greatest potential for prehistoric research if the historic component had not significantly disturbed it. Although no historic artifacts were found in the northern, wooded area, the soils and artifacts there are generally shallow and sparse. Therefore, CAS recommends no further work be conducted on the prehistoric component. CAS concurs with Mauldin (2001) that the prehistoric component has minimal research potential and is not eligible for nomination to the NRHP.

\section{$41 B P 96$}

\section{Description}

This is an open campsite located on the eastern edge of an intermittent tributary draining to the south and into McLaughlin Creek (Figures 6-3 and 6-4). There is also a historic trash scatter in the drainage; it is described in Chapter 8: Previously Documented Historic Component Sites. Woods extend 15-18 $\mathrm{m}$ east of the drainage, giving way to a grass-covered open field. There is a dam across the drainage $100 \mathrm{~m}$ north of the site. The extent of exposed cobbles along the drainage covers about $1,590 \mathrm{~m}^{2}$. Vegetation along the drainage includes many large oaks, smaller cedars, and assorted shrubs. The terrain slopes to the south from 453 to $447 \mathrm{ft}$ amsl. Axtell fine sandy loam (AfC) soils cover the sideslope. Surface visibility at the time of the August 2005 visit was approximately 15 percent in the open field and about 25 percent along the drainage. The site 


\begin{tabular}{|c|c|c|c|c|c|c|c|c|c|c|}
\hline is $\bar{\Sigma}$ & & 壱 & & & $\frac{\vec{\pi}}{U}$ & & & & & \\
\hline $\bar{\infty} \bar{v}$ & & & 行 & & & $\frac{\vec{Z}}{U}$ & & & & 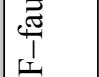 \\
\hline 部 & & & & 艺 & $\frac{\vec{J}}{U}$ & & & & & $\stackrel{\vec{\Xi}}{.} \frac{y}{\vec{J}}$ \\
\hline$\forall \stackrel{n}{=}$ & 土 & & & & & 㝳 & & है & & 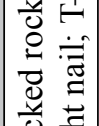 \\
\hline $\bar{\infty} \tilde{I}$ & & & & 荘 & $\frac{\vec{\sigma}}{U}$ & & & & & $\begin{array}{ll}0 & 0 \\
0 & 0 \\
0 & 0 \\
\vdots & 3\end{array}$ \\
\hline$\dot{\omega} \stackrel{\infty}{=}$ & 土 & & & & & 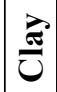 & & & & $\begin{array}{ll} & \\
0 & 3 \\
\because & =\end{array}$ \\
\hline 的气 & & 氠 & & & & $\frac{\vec{\Xi}}{U}$ & & & & 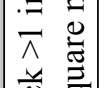 \\
\hline$\dot{\omega} \cong$ & 贡 & & $\frac{\vec{\Xi}}{U}$ & & & & & & & 苾文 \\
\hline is $a$ & & $\Xi$ & & $\frac{\vec{J}}{U}$ & & & & & & 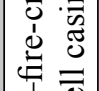 \\
\hline $\bar{n}_{\infty} \infty$ & & 岌 & & $\frac{\vec{\Xi}}{0}$ & & & & & & $\left|\begin{array}{cc}\vec{r} & \overline{1} \\
1 & 0 \\
\dot{v} & -\infty\end{array}\right|$ \\
\hline$\sqrt{\infty} r$ & 土 & $\begin{array}{l} \pm \\
\sim \\
\sim\end{array}$ & 罣 & ن & & & & $\begin{array}{l}\bar{\Xi} \\
\text { ตี }\end{array}$ & & 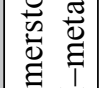 \\
\hline$\sqrt{5} 6$ & 土 & & $\mid$\begin{tabular}{|c|}
0 \\
0 \\
-1
\end{tabular} & & 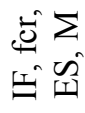 & & & 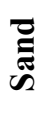 & & 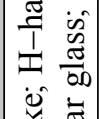 \\
\hline$v_{n}$ n & z & ڤ્ & 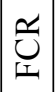 & $\stackrel{\bullet}{\breve{\mu}}$ & 岌 & & & 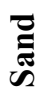 & & 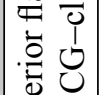 \\
\hline$E_{\infty}+$ & & 里 & 里 & $\begin{array}{l}\hat{0} \\
\text { z } \\
\text { 出 }\end{array}$ & & & $\frac{\vec{a}}{U}$ & & & 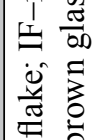 \\
\hline Es m & & $\left|\begin{array}{l}\Sigma \\
\underbrace{-}\end{array}\right|$ & $\frac{\vec{E}}{U}$ & & & & & & & 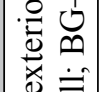 \\
\hline$\overline{v i s}_{2}$ & 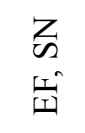 & 里 & $\Sigma$ & $\begin{array}{ll}\underbrace{}_{0} \\
0 \\
0 \\
0\end{array}$ & 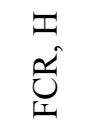 & 全 & & & & 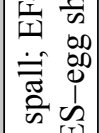 \\
\hline $5-$ & घં & $\stackrel{ \pm}{\sim}$ & & & & & & $\begin{array}{l}\bar{E} \\
\text { है }\end{array}$ & & $\begin{array}{l}0 \\
1 \\
2 \\
2\end{array}$ \\
\hline 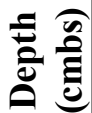 & $\frac{0}{1}$ & $\begin{array}{l}0 \\
\hat{T} \\
0\end{array}$ & 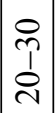 & $\begin{array}{l}\text { P } \\
1 \\
\text { O }\end{array}$ & $\begin{array}{l}8 \\
i \\
i\end{array}$ & $\begin{array}{l}8 \\
0 \\
1 \\
0 \\
n\end{array}$ & $\begin{array}{l}\text { ? } \\
8 \\
8\end{array}$ & $\begin{array}{l}8 \\
\infty \\
1 \\
2\end{array}$ & 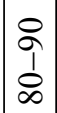 & 离 \\
\hline
\end{tabular}




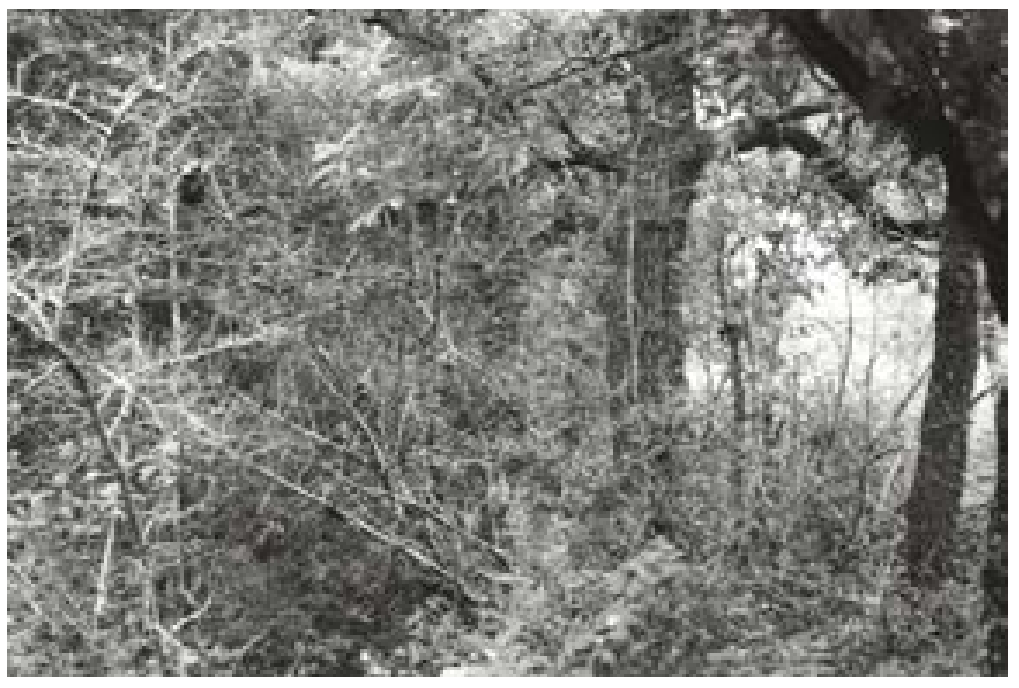

Figure 6-3. Chert cobbles are eroding out on a drainage slope at 41BP96; facing south.

FIGURE 6-4. REDACTED

Figure 6-4. Site map of 41BP96. datum is marked with a nail and an aluminum tag in a large oak tree.

\section{Levels of Work and Results}

When Skelton and Freeman (1979) initially documented this site, they described it as a cobble procurement site or quarry with cobbles scattered across an eroded surface near the drainage. They noted that a few cores and flakes were found among the cobbles. An unknown number of shovel tests failed to recover artifacts in a buried context. During CAS's return visit, archaeologists did see chert cobbles along the drainage slope and cutbank, and an additional three pieces of fire-cracked rock in the drainage bottom; thus, CAS now categorizes this as an open campsite. CAS archaeologists dug seven shovel tests on the site but none of them contained artifacts. The average depth to the Bt horizon was less than 25 cmbs.

\section{Conclusions/ Recommendations}

As observed both in 1979 and 2005, the surface is eroded, and no artifacts were found below the surface. CAS concurs with Mauldin (2001) that the 
prehistoric component at this site has little if any research potential and is not eligible for nomination to the NRHP.

\section{BP97}

\section{Description}

41BP97 is a disturbed lithic procurement site covering approximately $15,647 \mathrm{~m}^{2}$ near the top of an eroded ridge (Figures 6-5 and 6-6). Demona loamy fine sand $(\mathrm{DeC})$ soils at the site support the growth of scattered cedars, oaks, and mesquites, with tall grasses and weeds as understory. McLaughlin Creek lies $500 \mathrm{~m}$ to the southwest. The terrain slopes to the south from 483 to $492 \mathrm{ft}$ amsl. Surface visibility at the time of the August 2005 visit averaged 20 percent. The site datum is marked with a nail and an aluminum tag in an oak tree.

\section{Levels of Work and Results}

Skelton and Freeman (1979:70) described this site as a cobble procurement site that was "....severely eroded, with numerous gullies and rills..." and a few cores and flakes. An unknown number of shovel tests failed to recover artifacts in a buried context. During CAS's return visit, archaeologists did see chert cobbles but no prehistoric artifacts. The 15 shovel tests excavated on the site were all negative.

\section{Conclusions/Recommendations}

As observed both in 1979, and then again in 2005, the surface is eroded and no artifacts were found below the surface. CAS concurs

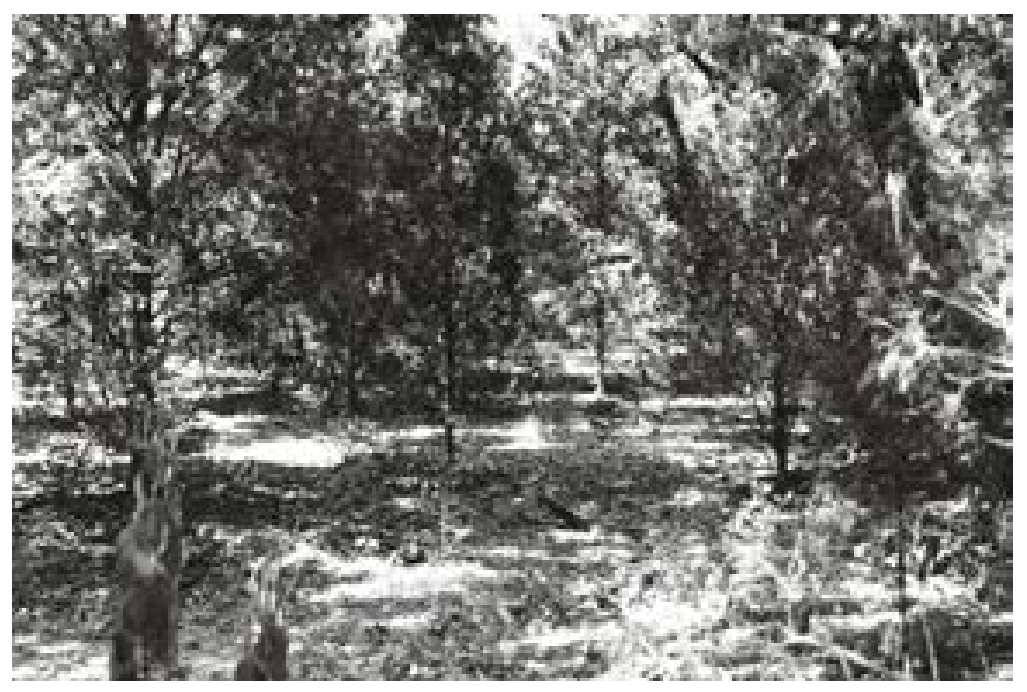

Figure 6-5. 41BP97 is a lithic procurement site near a ridgetop; facing west.

FIGURE 6-6. REDACTED

Figure 6-6. Site map of 41BP97. 
with Mauldin (2001) that the site has little if any research potential and is not eligible for nomination to the NRHP.

\section{$41 B P 99$}

\section{Description}

41BP99 is another lithic procurement site (Figures 6-7 and 6-8). It is on a sideslope 250 m north of McLaughlin Creek, ranges in elevation from 435 to $445 \mathrm{ft}$ amsl, and covers $4,590 \mathrm{~m}^{2}$. McLaughlin Loop Jeep Road runs along its eastern edge. The predominant vegetation includes large oaks and elms, smaller cedars and mesquites, and tall grasses. Axtell fine sandy loam (AfC2) soils at the site are eroded and shallow. Surface visibility at the time of the August 2005 visit averaged less than five percent except for the numerous push piles, heavy machinery ruts, and a bulldozer cut. The site datum is marked with a nail and an aluminum tag in an oak tree.

\section{Levels of Work and Results}

Skelton and Freeman (1979:70) described this site as a cobble procurement site with exposed gravels along numerous rills and gullies. They also noted that the eastern portion of the site had bulldozer cuts in it. They observed cores, flakes, and two quartzite hammerstones. They found no subsurface artifacts in an unrecorded number of shovel tests. When CAS revisited the site in 2005, archaeologists did not see any artifacts but did observe chert cobbles. The seven shovel tests excavated on the site by CAS archaeologists were all negative.

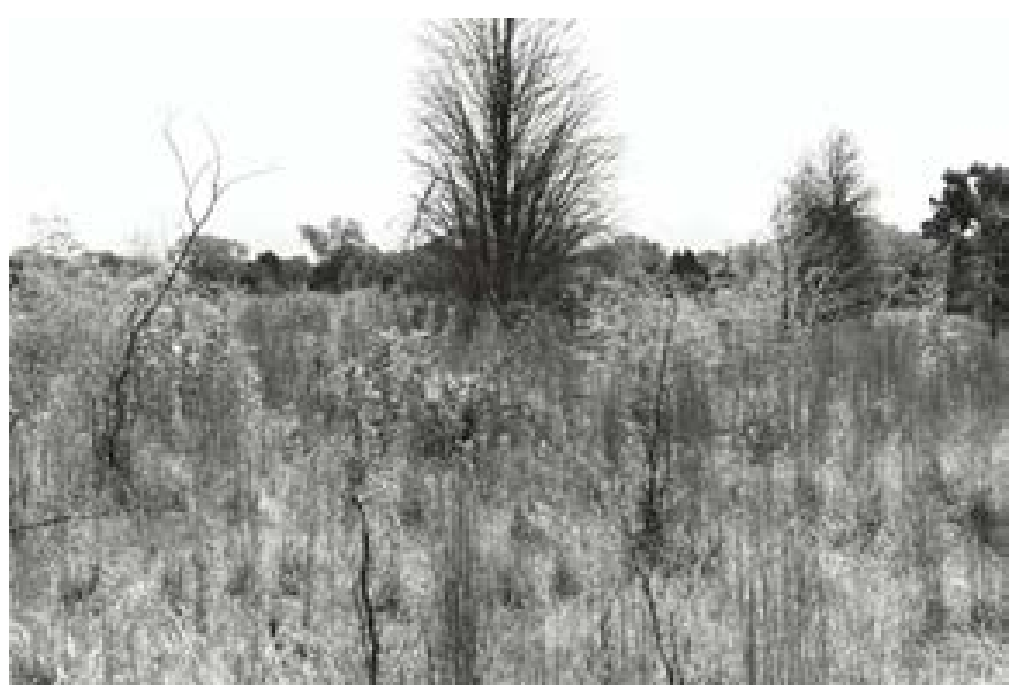

Figure 6-7. 41BP99 is a lithic procurement site north of McLaughlin Creek; facing southeast.

FIGURE 6-8. REDACTED

Figure 6-8. Site map of 41BP99. 


\section{Conclusions/Recommendations}

CAS agrees with Skelton and Freeman (1979), and with Mauldin (2001) that this site is heavily disturbed, it lacks significant research potential, and it is not eligible for nomination to the NRHP.

\section{$41 \mathrm{BP} 101$}

\section{Description}

41BP101 is the third lithic procurement site (see also, 41BP96 and 41BP99) recorded by Skelton and Freeman (1979) along the northern sideslopes and intermittent drainages north of McLaughlin Creek (Figures 6-9 and 6-10). The slope from north to south is 450 to $442 \mathrm{ft}$ amsl. The site size is $4,426 \mathrm{~m}^{2}$. Eroded Axtell fine sandy loam (AfC) soils allowed for between five and ten percent surface visibility. Machinery tracks and numerous rills were observed. Vegetation consists of mesquites, cedars, and oaks, with prickly pears and grasses. A deeper, intermittent drainage splits the western edge of the site. The site datum is marked with a nail and an aluminum tag in an oak tree.

\section{Levels of Work and Results}

Skelton and Freeman (1979:70) observed flakes and cores in a small arroyo, and a slope with ironstones and petrified wood on eroded loam and clays. A few cores and flakes were mixed with the chert cobbles. They found no subsurface artifacts in an unrecorded number of shovel tests. When CAS revisited the site in 2005, archaeologists did not see any artifacts, but did observe chert cobbles. The six shovel tests excavated on the site by CAS archaeologists were all negative.

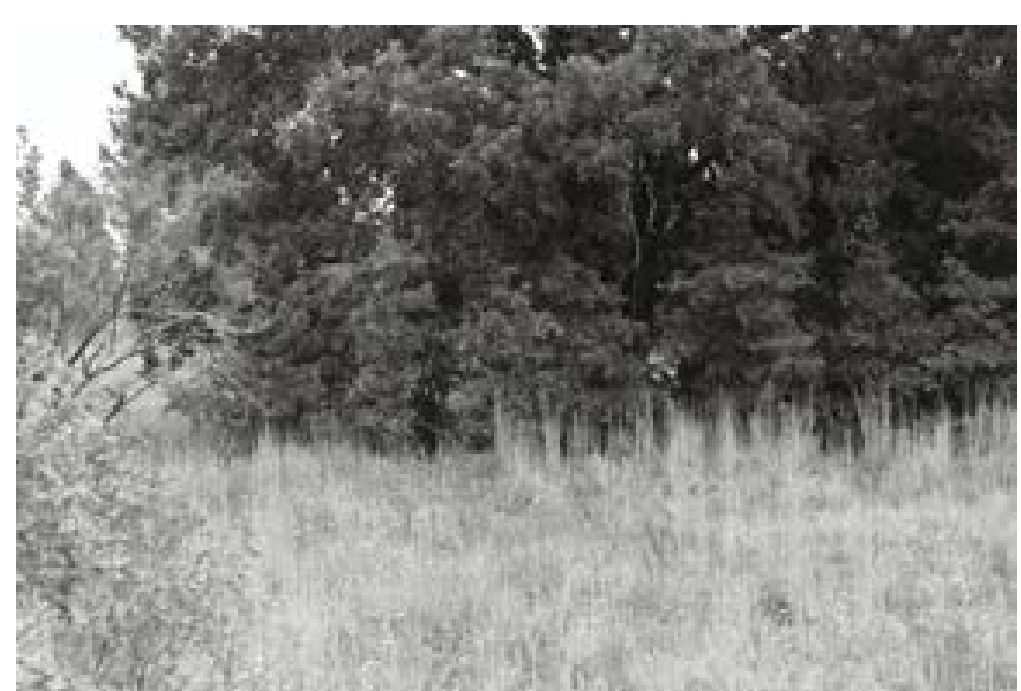

Figure 6-9. 41BP101 is a lithic procurement site north of McLaughlin Creek; facing east.

FIGURE 6-10. REDACTED

Figure 6-10. Site map of 41BP101. 


\section{Conclusions/Recommendations}

CAS agrees with Skelton and Freeman (1979), and with Mauldin (2001) that this site is heavily disturbed. It has minimal research potential; and is not eligible for nomination to the NRHP. to transect shovel tests excavated around the site, CAS archaeologists excavated three shovel tests on the site; all were negative. The surface inventory totaled two interior flakes and two exterior flakes, but no fire-cracked rocks were recovered. The average depth of sandy loam over

\section{BP103}

\section{Description}

41BP103 (Figures 6-11 and 6-12) is a heavily eroded open campsite on a steep slope at the northern end of a ridge at $450 \mathrm{ft}$ amsl. Big Sandy Creek is $90 \mathrm{~m}$ to the north but is $15 \mathrm{~m}$ below the site. A bulldozed road has been cut through the site and military training has been conducted on it. An ephemeral scatter of lithic debitage is scattered over approximately $181 \mathrm{~m}^{2}$ of a heavily eroded surface. The shallow soil here is Tabor fine sandy loam (TfB). The dense vegetation consists of oak and cedar trees, beautyberry bushes, greenbrier, weeds, and grasses. The surface visibility was nearly 100 percent along the bulldozed road, but less than 10 percent off the road. The site datum is marked with a nail and aluminum tag on an oak tree.

\section{Levels of Work and Results}

Skelton and Freeman discovered this site in 1979 and found ten flakes and a few firecracked rocks (1979:73-74). They excavated an unrecorded number of shovel tests at the site but found only shallow soils with no artifacts. In addition

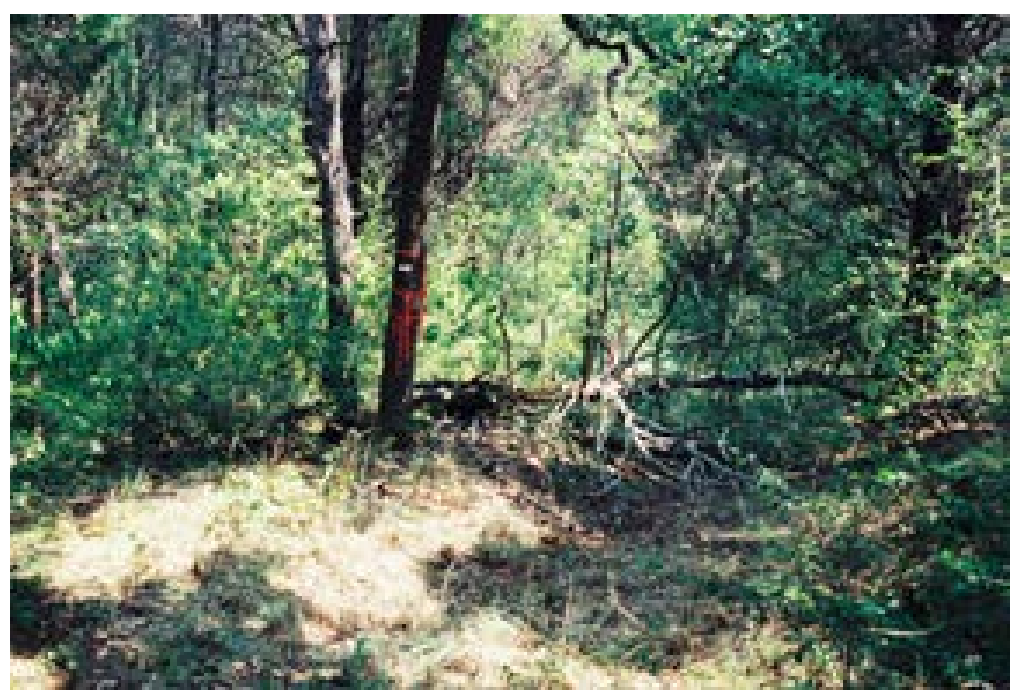

Figure 6-11. 41BP103 with bulldozer cut; facing north.

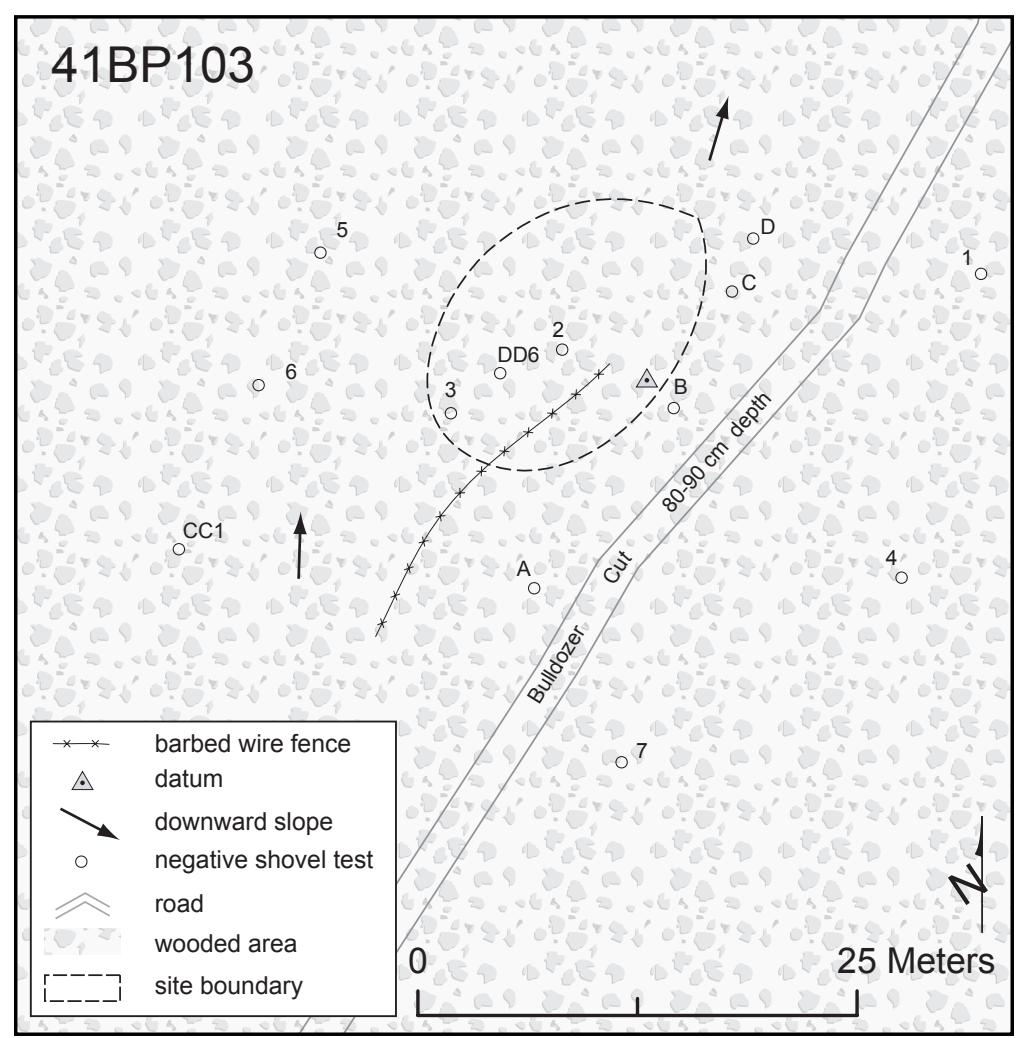

Figure 6-12. Site map of 41BP103. 
the underlying $\mathrm{Bt}$ horizon was 7 cmbs.

\section{Conclusions/ \\ Recommendations}

Because of the heavily disturbed nature of this site, CAS agrees with Mauldin (2001:175-186) that the research value of this site is minimal. CAS recommends that no further work be conducted. The site is not eligible for nomination to the NRHP.

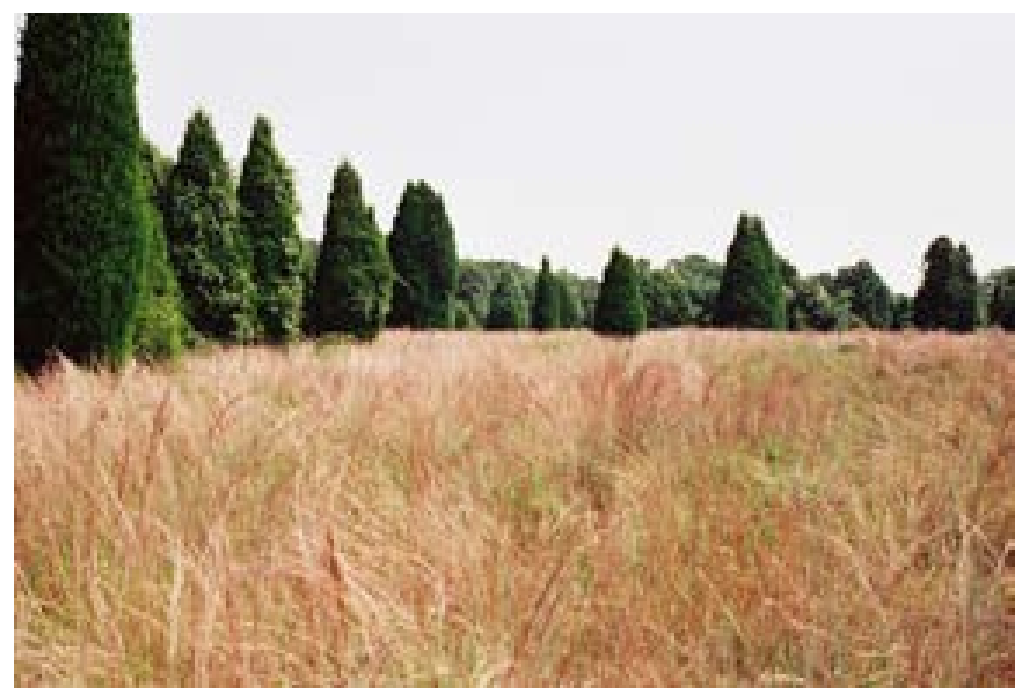

Figure 6-13. 41BP106 lies in an open field; facing north.

\section{BP106}

\section{Description}

41BP106 (Figures 6-13 and 6-14) covers approximately $8,767 \mathrm{~m}^{2}$. It lies in an open field spanning an upland ridge and sideslope. The presence of firecracked rocks and lithic debitage suggests it was used as an open campsite. Demona loamy fine FIGURE 6-14. REDACTED sand $(\mathrm{DeC})$ and Patilo complex fine sand $(\mathrm{PaE})$ support a sparse scatter of cedar trees amidst grapevines, prickly pear, yucca, bull nettle, and dense grasses over 90 percent of the site. Around ST RR10, the surface is broken by numerous gullies incising a steeper sloping surface and the cedar trees are more numerous. The surface visibility was less than 10 percent during CAS's July 2005 site visit. In addition to eroded gullies causing site disturbance, gopher burrows were sparsely present across most of the site. The grassy area is relatively level compared to the steeper slopes around ST RR10; elevation ranges

from $446 \mathrm{ft}$ amsl along its southern edge to 432 $\mathrm{ft}$ amsl on its northern node. The channel of Big Sandy Creek lies is $160 \mathrm{~m}$ to the northeast of the site. The site datum is marked with a nail and aluminum tag on an oak tree $20 \mathrm{~m}$ from ST 10. 


\section{Levels of Work and Results}

When Skelton and Freeman (1979:73-74) initially recorded this site, they noted that the area had been cleared and observed cores, bifaces, flakes, and fire-cracked rocks in an eroded area. The extent to which they excavated shovel tests is unknown; "Minor shovel probes failed to locate buried occupational residues" (Skelton and Freeman 1979:74). In 2005, CAS archaeologists examined the gullies on the lower, northeastern portion of the site and observed chert cobbles and petrified wood fragments, but no artifacts. CAS archaeologists dug 22 shovel tests on the site, which 10 contained artifacts. A total of nine flakes and seven pieces of firecracked rock were recovered from the 10 positive shovel tests (Table 6-3). Although it could not be discerned in soil profiles, it is obvious from the historic material found in the shovel tests that the site has been disturbed. In addition to the bullet and metal fragment listed in Table 6-3 (ST 11), metal fragments were found in STs 9, 17, and 19 as deep as $40 \mathrm{cmbs}$.

\section{Conclusions/Recommendations}

In his assessment of Camp Swift sites, Mauldin (2001:175-186) placed 41BP106 in a grouping of sites not eligible for the NRHP.
The testing in 2005 discovered a buried portion of the site not previously documented, but also identified intrusive historic material that has negatively impacted the overall site integrity. Therefore, CAS considers its research value to be minimal and recommends that no further work be conducted. CAS concurs with Mauldin that the site is not eligible for nomination to the NRHP.

\section{BP109}

\section{Description}

41BP109 (Figures 6-15 and 6-16) is an open campsite located on the east edge of an intermittent tributary that drains to the south and into Big Sandy Creek. The area is heavily wooded with oaks, elms, cedars, and hackberries. Cobbles are exposed along the steep drainage slope. The site as described by Skelton and Freeman in 1979 covers approximately $2,503 \mathrm{~m}^{2}$. The terrain slopes to the south from 460 to $445 \mathrm{ft}$ amsl. Axtell fine sandy loam (AfC) soils cover the sideslope. Surface visibility at the time of the February 2005 visit was approximately 15 percent.

\section{Levels of Work and Results}

When Skelton and Freeman (1979) initially documented this site, he reported observing a few

Table 6-3. 41BP106 positive shovel test results.

\begin{tabular}{|c|c|c|c|c|c|c|c|c|c|c|}
\hline $\begin{array}{c}\text { Depth } \\
\text { (cmbs) }\end{array}$ & $\begin{array}{c}\text { ST } \\
\mathbf{4}\end{array}$ & $\begin{array}{c}\text { ST } \\
\mathbf{6}\end{array}$ & $\begin{array}{c}\text { ST } \\
\mathbf{7}\end{array}$ & $\begin{array}{c}\text { ST } \\
\mathbf{8}\end{array}$ & $\begin{array}{c}\text { ST } \\
\mathbf{1 0}\end{array}$ & $\begin{array}{c}\text { ST } \\
\mathbf{1 1}\end{array}$ & $\begin{array}{c}\text { ST } \\
\text { MM10 }\end{array}$ & $\begin{array}{c}\text { ST } \\
\text { OO10 }\end{array}$ & $\begin{array}{c}\text { ST } \\
\text { QQ11 }\end{array}$ & $\begin{array}{c}\text { ST } \\
\text { RR10 }\end{array}$ \\
\hline $0-10$ & & & & & & IF, Bu & IF & & & IF \\
\hline $10-20$ & & & & & & & & & & \\
\hline $20-30$ & & & & & & & & & IF & \\
\hline $30-40$ & & & & FCR & 2 FCR & M & & & & \\
\hline $40-50$ & & fcr & IF & & fcr & IF, fcr & & & IF & \\
\hline $50-60$ & IF & & FCR & & & & & & & Clay \\
\hline $60-70$ & & & & & & & Water & IF & & \\
\hline $70-80$ & Sand & Sand & Sand & Sand & Sand & Sand & & & & \\
\hline $80-90$ & & & & & & & & Water & Sand & \\
\hline $90-100$ & & & & &
\end{tabular}




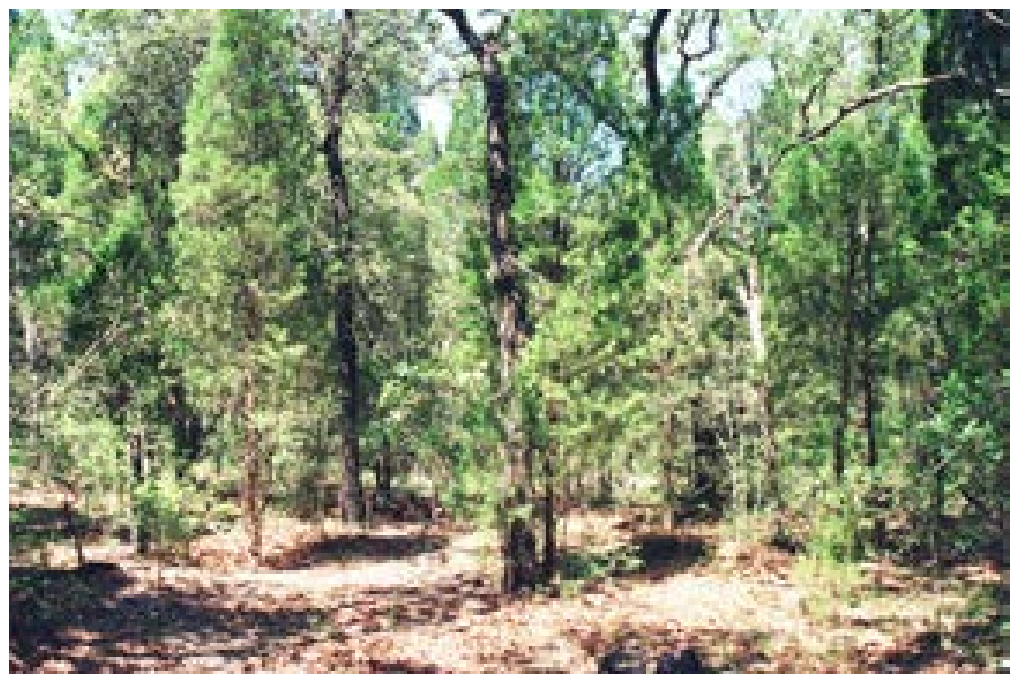

Figure 6-15. Chert cobbles are eroding out in rills at 41BP109; facing west.

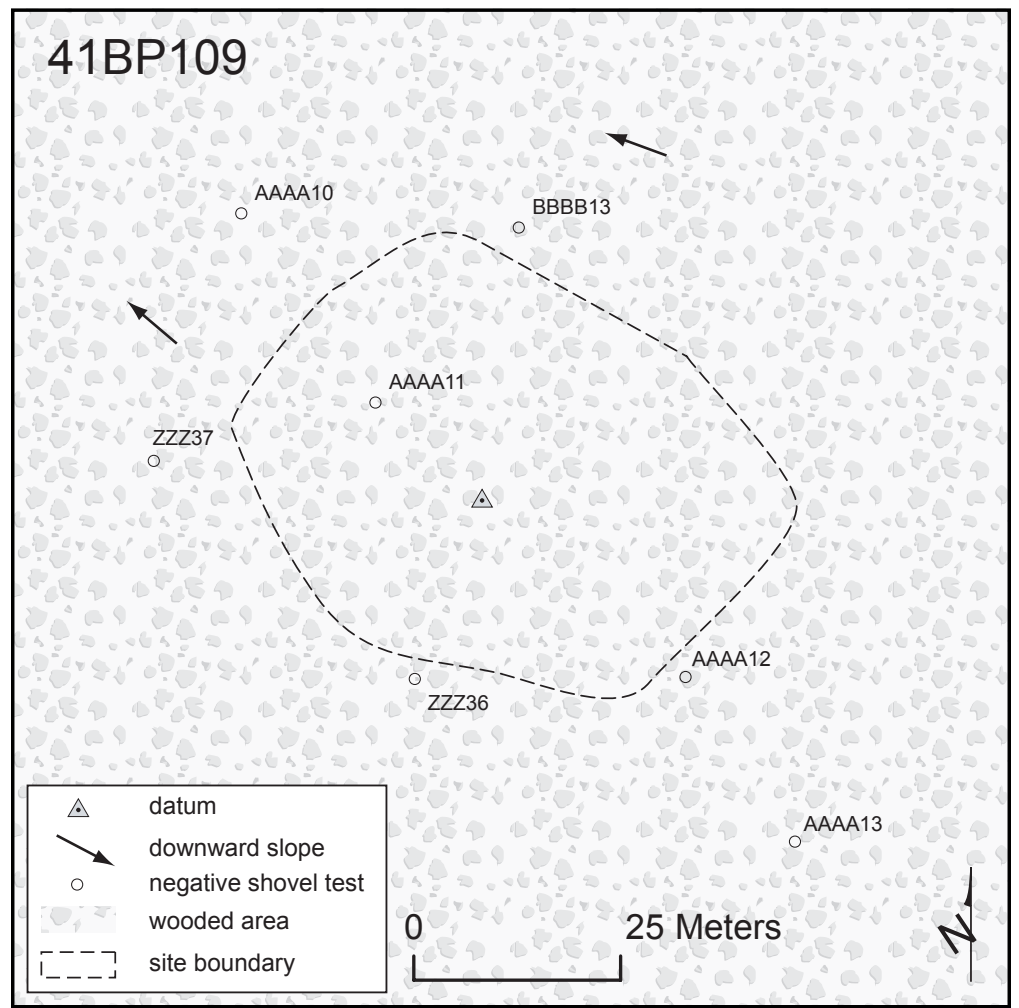

Figure 6-16. Site map of 41BP109.

flakes and fire-cracked rock fragments exposed in rills and rodent disturbances. His few shovel probes confirmed that the deflated soils on the site were about $10 \mathrm{~cm}$ thick. During CAS's return visit archaeologists did see chert cobbles along the drainage slope and cutbank, but no prehistoric artifacts. One transect shovel test excavated on the site was negative. The average depth to the Bt horizon based on shovel tests conducted on and around the site was less than $20 \mathrm{cmbs}$.

\section{Conclusions/ Recommendations}

As observed both in 1979 and in 2005, the surface is eroded and no artifacts were found below the surface. CAS concurs with Mauldin (2001) that the prehistoric component at this site has little, if any, research potential, and is not eligible for nomination to the NRHP.

\section{BP114}

\section{Description}

41BP114 is an open campsite located on a footslope and lower terrace near the confluence of an intermittent drainage and McLaughlin Creek (Figures 6-17 and 6-18). The southern edge of the site borders on the drainage floodplain. It is buried in Patilo complex (PaE) soils on an old plowed field. The field is now overgrown with grapevines, bull nettles, cacti, and tall grasses. Otherwise, there are scattered pines, oaks, and cedars. Based upon shovel test results, the site covers approximately $5,854 \mathrm{~m}^{2}$. The terrain slopes to the east from 435 to $430 \mathrm{ft}$ amsl. Surface visibility at the time of the August 2005 visit was approximately 15 percent. Rodent burrows were observed and plowing likely occurred during past use. An oak 


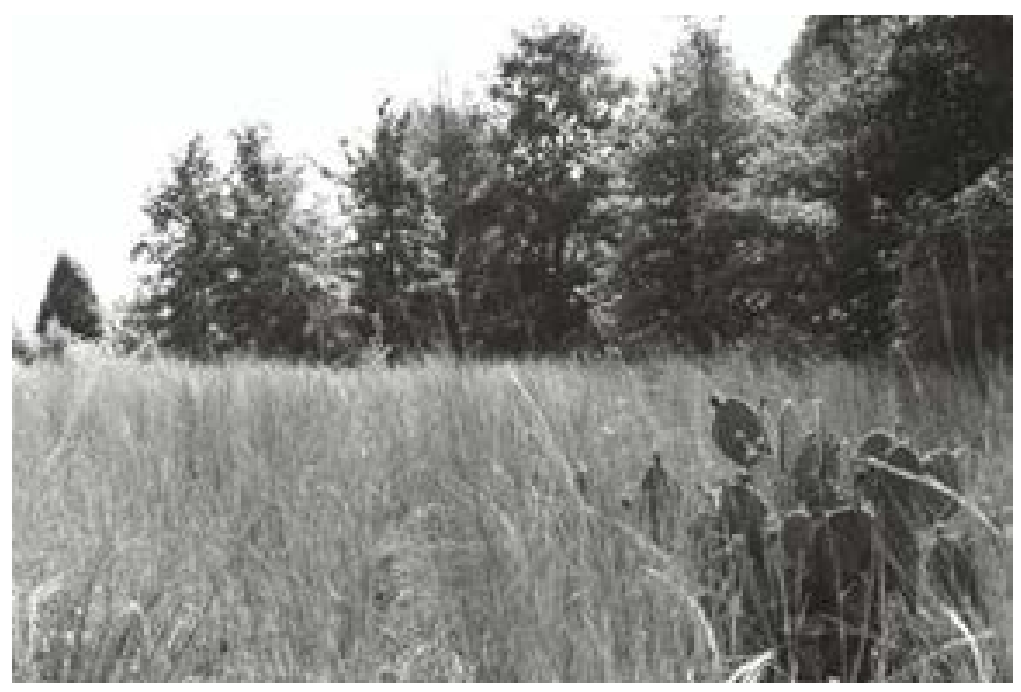

Figure 6-17. 41BP114 is an open campsite near the confluence of two streams; facing east.

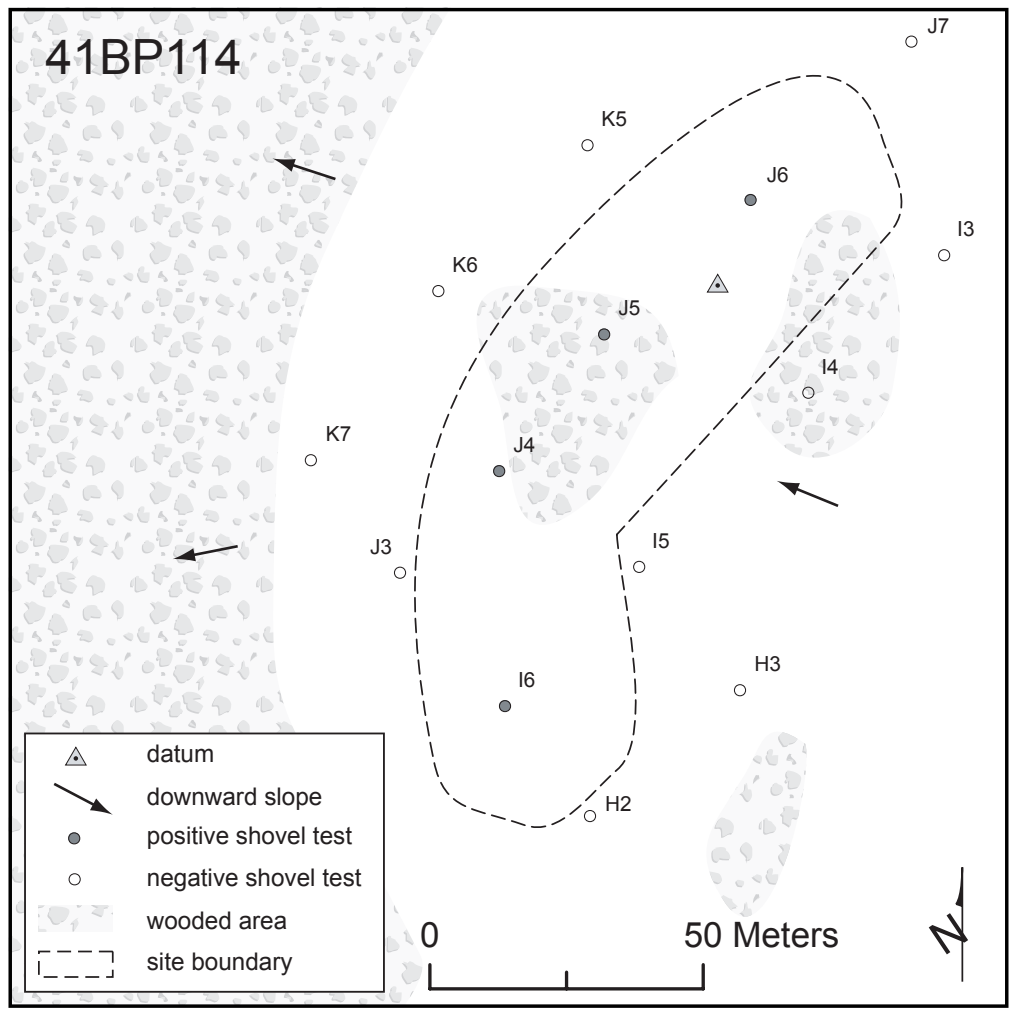

Figure 6-18. Site map of 41BP114.

tree $12 \mathrm{~cm}$ in diameter was established as the site datum with a nail and an aluminum tag.

\section{Levels of Work and Results}

Skelton and Freeman (1979) observed flakes and fire-cracked rocks on rodent burrow backdirt and erosional rills, dug an unknown number of shovel tests, and excavated a 1-x-1-m unit. He recovered 26 flakes, nine chips, and 29 pieces of fire-cracked rocks. Skelton and Freeman (1979) offered an opinion that some of the cultural material laying on the $\mathrm{Bt}$ horizon at $55 \mathrm{cmbs}$ got there by downward movement. CAR archaeologists returned to the site in 1997, dug ten shovel probes, and found two flakes and three fire-cracked rocks from two of them (Robinson et al. 2001). During CAS's visit in 2005, archaeologists did not see any artifacts on the surface. As listed in Table 6-4, a chert chip, two flakes, and six pieces of firecracked rocks were found in the four shovel tests excavated on the site. The only evidence of disturbance noted in any of the tests was angular ironstones in ST I6.

\section{Conclusions/ Recommendations}

After hand-excavating a unit to $55 \mathrm{cmbs}$ and the underlying clay, Skelton and Freeman (1979) recommended no further work be done at this site. After CAR archaeologists dug five shovel probes, they also recommended that no further work be done, because it was assessed as a sparse lithic scatter (Mauldin 2001; Robinson et al. 2001:132). However, the results 
Table 6-4. 41BP114 positive shovel test results.

\begin{tabular}{|c|c|c|c|c|}
\hline $\begin{array}{c}\text { Depth } \\
\text { (cmbs) }\end{array}$ & ST I6 & ST J4 & ST J5 & ST J6 \\
\hline $0-10$ & & & & \\
\hline $10-20$ & & & & IF \\
\hline $20-30$ & & fcr & & \\
\hline $30-40$ & CC & & & \\
\hline $40-50$ & 2 FCR & & & \\
\hline $50-60$ & Clay & & & \\
\hline $60-70$ & & & IF & $\begin{array}{c}2 \text { FCR } \\
\text { fcr }\end{array}$ \\
\hline $70-80$ & & Sand & & \\
\hline $80-90$ & & & Sand & \\
\hline $90-100$ & & & & \\
\hline $100-110$ & & & & Sand \\
\hline $110-120$ & & & & \\
\hline $\begin{array}{c}\text { Key: CC-chert chip; IF-interior flake; FCR-fire- } \\
\text { cracked rock >1 inch; fcr-fire-cracked rock }<1\end{array}$ \\
inch \\
\hline
\end{tabular}

of the systematic shovel tests in 2005 indicate that the sands are very deep in the upper portion of the site, and there are both fire-cracked rocks and flakes deeply buried, yet not lying on the $\mathrm{Bt}$ horizon. Thus, without further investigations, CAS cannot concur with Skelton's opinion that artifacts have moved downward to rest on the clay. In addition, the data indicate that this site is more than a sparse scatter of lithics. It is an open campsite with potentially intact fire-cracked rock hearth features below a presumed plow zone and/or rodent burrowing. To finally determine the research potential and eligibility of this site, CAS recommends that two 1-x-1-m units be excavated in the upper portion of the site around STs J5 and J6.

\section{$41 B P 119$}

\section{Description}

$41 \mathrm{BP} 119$ is a prehistoric open campsite on the lower slopes of a knoll (Figures 6-19 and 6-20). 41BP153, a historic house site, sits on the knoll, and CAS archaeologists observed a few red brick fragments, glass shards, and metal fragments that have eroded downslope and are now on the edge of 41BP119 (see Chapter 8: Previously Documented Historic Component Sites). The slope in the area of the site ranges in elevation from 461 to $450 \mathrm{ft}$ amsl and is heavily eroded. Small rills in the Sayers fine sandy loam (Sa) soils are numerous, allowing for about 10 percent surface visibility. The $7,018-\mathrm{m}^{2}$ site is covered with cedars, elms, and mesquites, with patches of dense grasses. The site datum is marked with a nail and an aluminum tag in a small oak tree.

\section{Levels of Work and Results}

Skelton and Freeman (1979) noted burned rocks, cores, and flakes eroding from the slope. CAR archaeologists found a core on the surface, noted that the surface was heavily eroded, and after digging 12 shovel probes, found nothing below the surface (Robinson et al. 2001). Artifacts

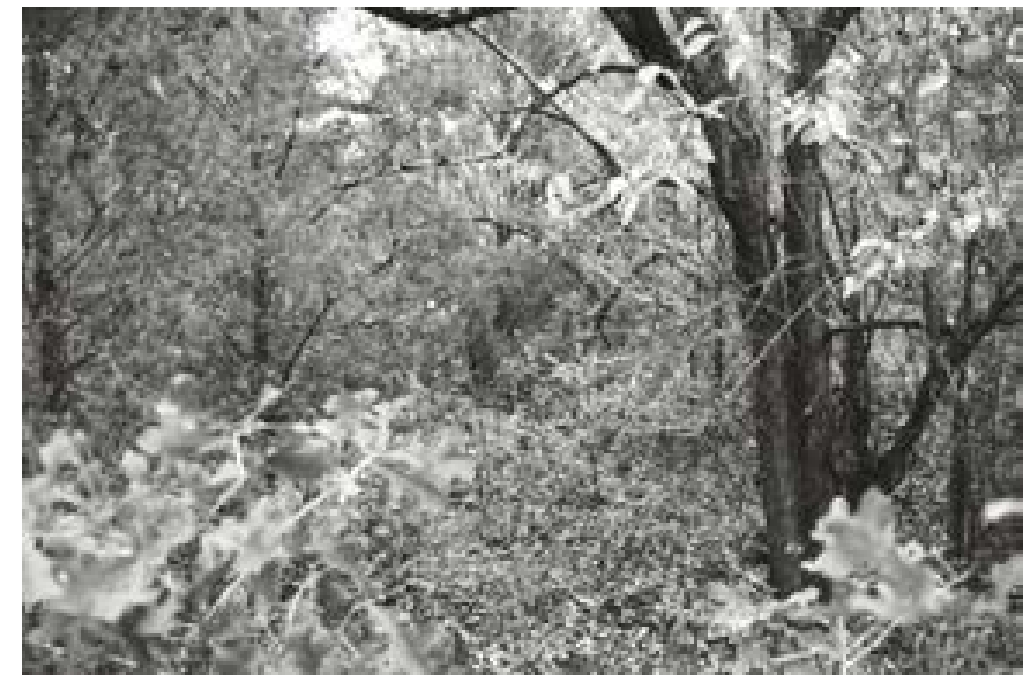

Figure 6-19. 41BP119 is an open campsite on the lower slopes of a knoll; facing north. 


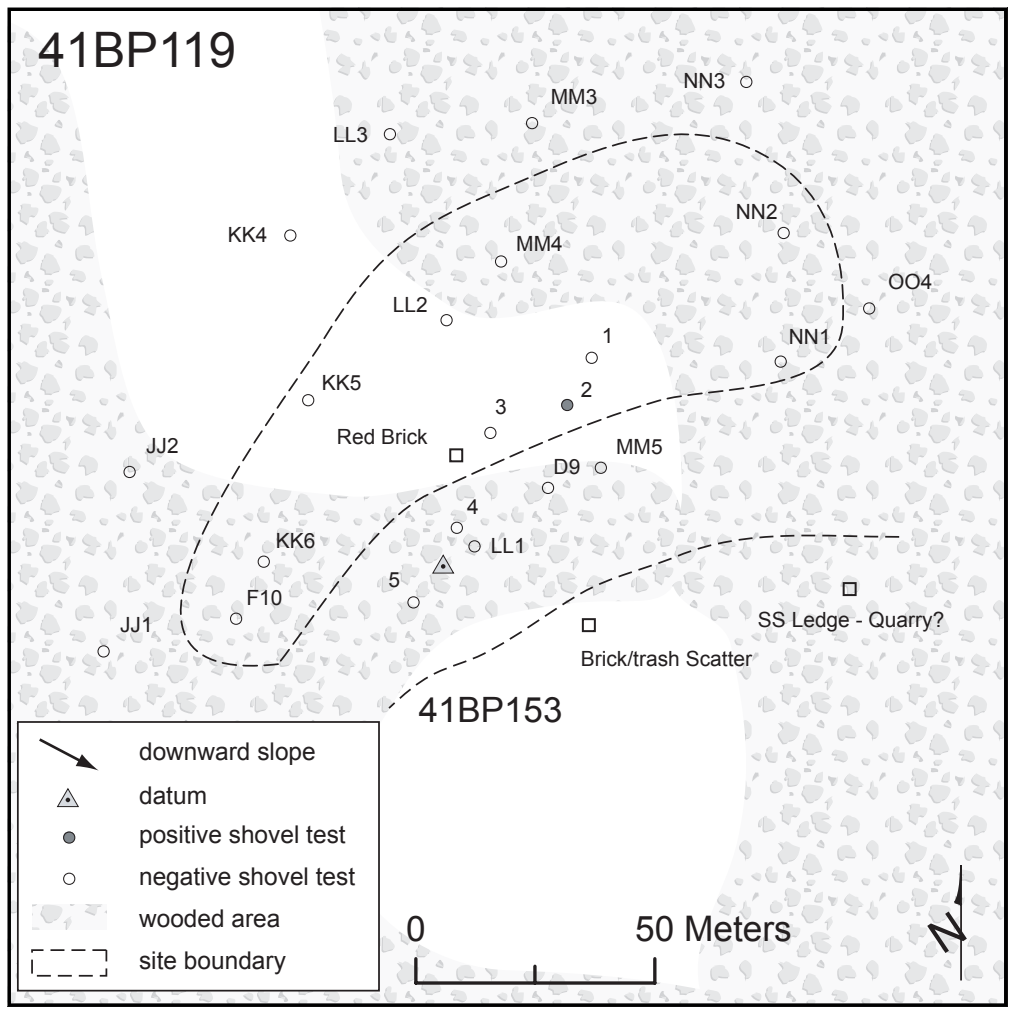

Figure 6-20. Site map of 41BP119.

observed on the surface in 2005 included three chert exterior flakes, two quartzite fire-cracked rocks, one chert core, and a quartzite smoothing stone. CAS archaeologists excavated 10 shovel tests on the site and found only two chert chips in the one positive shovel test (ST 2). The average soil depth across the site was less than 13 cmbs.

\section{Conclusions/Recommendations}

Because of its eroded and heavily disturbed condition, CAS concurs with Mauldin (2001) that the research potential of this site is minimal, no further work is recommended, and the prehistoric component of this site is not eligible for nomination to the NRHP.

\section{BP120}

\section{Description}

41BP120 is a large $\left(40,392 \mathrm{~m}^{2}\right)$ open campsite on a ridge and footslope between two intermittent drainages (Figures 6-21 and 622). The site extends southwest to the low cutbanks along McLaughlin Creek. The overall slope is from 472 to $450 \mathrm{ft}$ amsl. Soil types include Demona loamy fine sand (DeC) and Axtell fine sandy loam (AfC2). When Skelton and Freeman (1979) first recorded this site, they indicated that the area had been cleared of trees, except for riparian vegetation along McLaughlin Creek. However, when CAS archaeologists relocated the site in 2005, oaks, cedars, dense grasses, weeds, and brush covered the site. Therefore, surface visibility was limited to ten percent and less. Just as in 1979, CAS archaeologists observed some erosional rills along the lower, southern portion of the site. In addition, there are some animal burrows and a few tree falls. A bladed, east-west jeep road runs through the northern portion of the site. Archaeologists marked the site datum with a nail and aluminum tag in an oak tree in the center of the ridge on the south side of the jeep road.

\section{Levels of Work and Results}

Shovel probes and two 1-x-1-m test units were excavated on the lower slopes of the site in 1979 (Skelton and Freeman 1979). After recovering 103 pieces of fire-cracked rocks and 75 flakes from the test units, Skelton and Freeman (1979:46) concluded that "the vast majority of cultural material recovered was lying on, or just above, a dense clay zone indicating these materials have been totally displaced, presumably as a result of slopewash which redeposited these residues on the terrace where they were subsequently buried by colluviation." Skelton also noted flakes and 


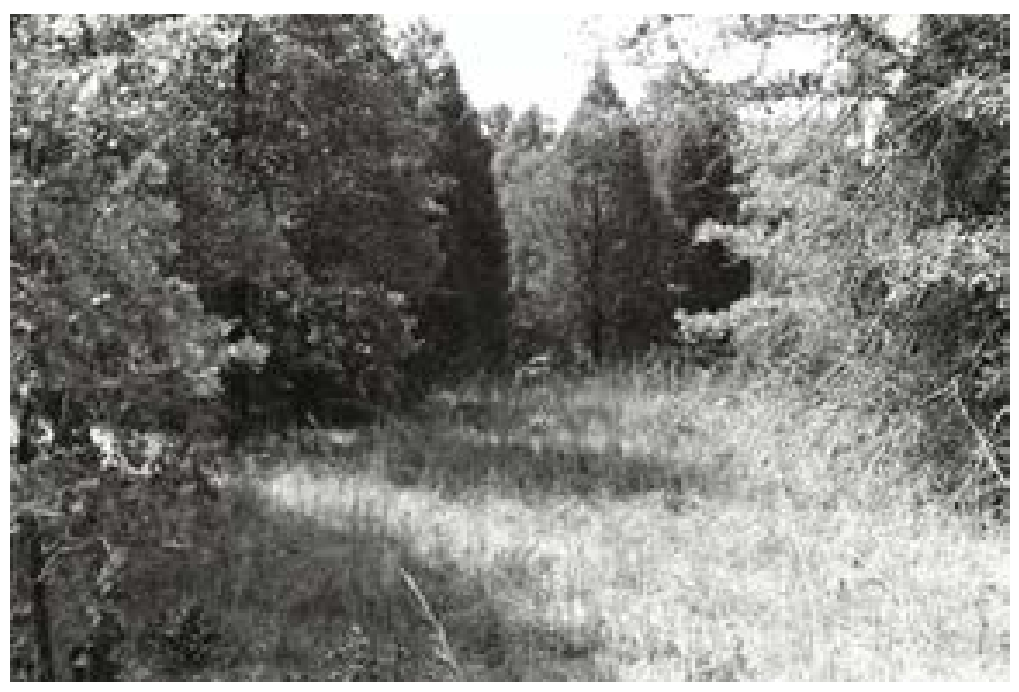

Figure 6-21. 41BP120 is a large open campsite; facing south.

FIGURE 6-22. REDACTED

Figure 6-22. Site map of 41BP120.

fire-cracked rocks on the surface where erosional rills were present. When CAS returned to the site in 2005, no artifacts were seen on the surface. Only chert cobbles were observed in some erosional rills and along the jeep road. Only one shovel test was positive although 33 were placed on the site. The positive shovel test (ST A5) contained a crudely flaked biface mixed with large cobbles between 0 and $10 \mathrm{cmbs}$.

\section{Conclusions/ Recommendations}

The testing across the site in 2005 produced no additional evidence that would change the recommendation made in 1979 when Skelton and Freeman (1979:46) stated that "No further work is warranted at this site." Mauldin (2001) recommended the same and CAS concurs. The site is not eligible for nomination to the NRHP.

\section{BP122 (41BP143)}

\section{Description}

This is an open campsite located on a terrace on the north edge of McLaughlin Creek (Figure 6-23 and 6-24). It also is the site of at least one house and possibly an old fort. The historic component at this site is discussed in Chapter 8: Previously Documented Historic Component Sites. Additionally, this extensive shovel test project has expanded the boundaries of 41BP121 (an open campsite to the east) so that it now appears that $41 \mathrm{BP} 121$ and $41 \mathrm{BP} 122$ are likely one and the same site (see Appendix A for proximity of the two sites). Roughly covering $12,344 \mathrm{~m}^{2}$, the prehistoric component at 41BP122 is situated on a sandy terrace on the north side of McLaughlin Creek, and an old jeep road that has now been improved 


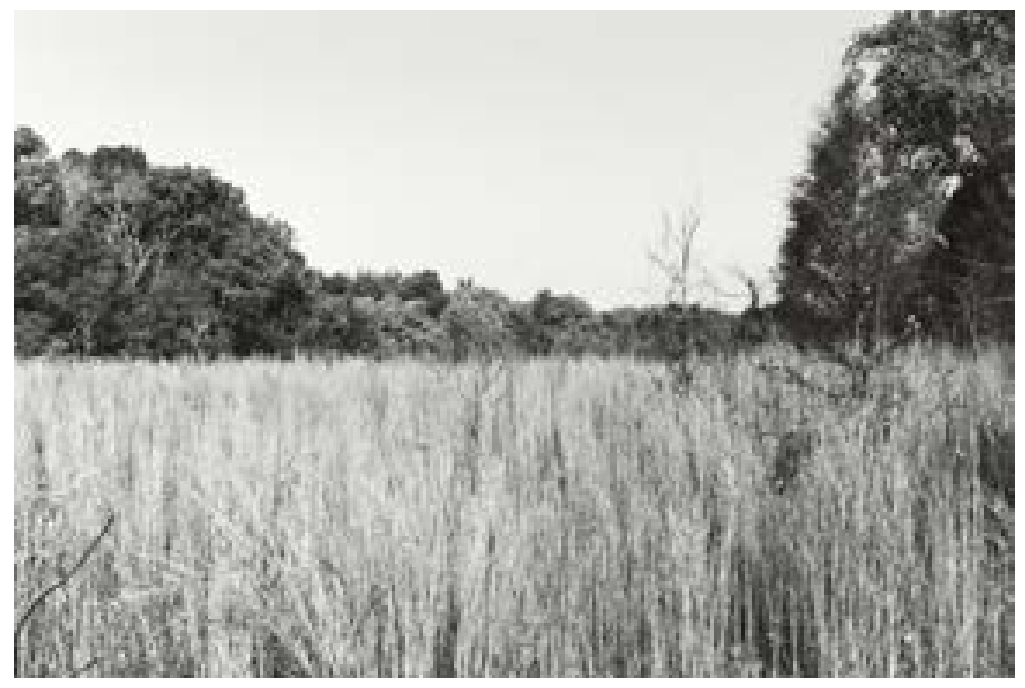

Figure 6-23. 41BP122 is an open campsite on a terrace; facing west.
Figure 6-24. Site map of 41BP122 (41BP143).

and renamed "New Road" cuts through the center of the site (see Figures 6-23 and 6-24). The area north of New Road is a cleared open field with woods further north, while the area south of the road is generally cleared with woods on the extreme southern end of the site. The fields are now overgrown with dense grasses, prickly pear, bull nettles, and poison ivy. What appears to be a machinecontoured drainage ditch with a berm alongside runs through the site from north to south, and the overall surface is hummocky. Based upon shovel test results, a house and/or fort may have stood in a small mott of elm, oak, and cedar trees on the south side (see Figure 6-24). The surface slopes toward the southwest from 457 to $438 \mathrm{ft}$ amsl. The terrace is composed of Demona loamy fine sand $(\mathrm{DeC})$ and Sayers fine sandy loam ( $\mathrm{Sa}$ ) soils. Other than in the road, surface visibility was less than five percent. The site datum is marked with a nail and aluminum tag on an oak tree near the center of the site, just east of the drainage.

\section{Levels of Work and Results}

As discussed in Chapter 8 , there is a minor discrepancy in the plotted location for the historic component (41BP143). Nevertheless, Robinson et al. (2001:133) lump 41BP122 and 41BP143 together and states, "the prehistoric (BP122) and historic (BP143) components of this site were given different site numbers." When Skelton and Freeman (1979) first recorded this site, he noted that it had been extensively damaged by erosion. He observed a few flakes and fire-cracked rocks on the eroded surface, but nothing was found below the surface in his shovel probes. When CAR archaeologists returned to 


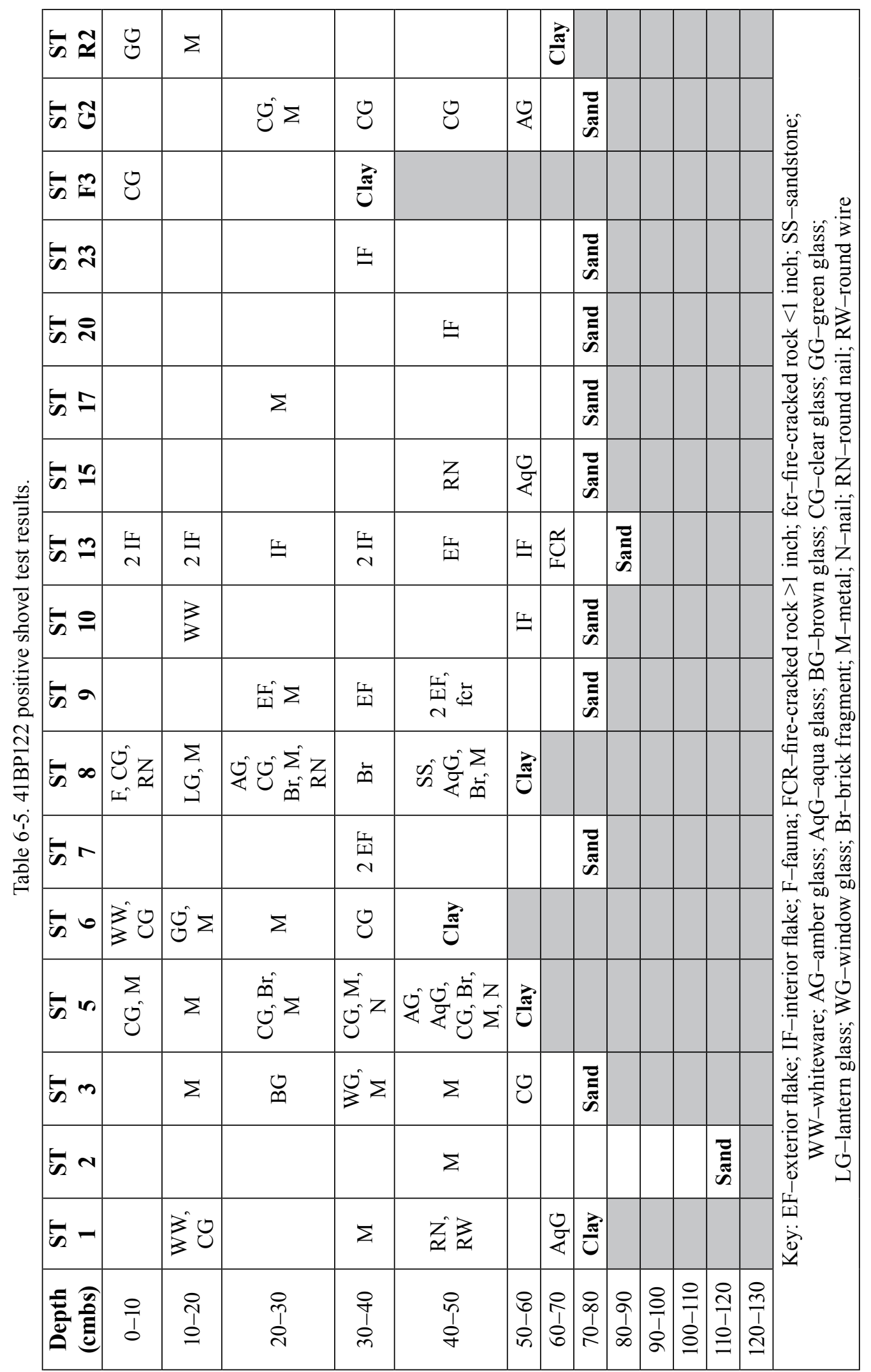


the site in 1997, they found only historic artifacts in two of their shovel tests (Robinson et al. 2001:133).

Although 17 of 35 shovel tests placed on the site in 2005 contained artifacts, only five produced prehistoric artifacts, including 18 flakes and 2 fire-cracked rocks (Table 6-5). Only in ST 13 was there a continuous distribution of prehistoric artifacts that had not mixed with historic artifacts. ST 13 is in on a lower terrace with large oak trees, approximately $5 \mathrm{~m}$ from McLaughlin Creek. Therefore, it does not appear to have been disturbed by the historic occupation.

\section{Conclusions/ \\ Recommendations}

The recovery of a relatively large quantity of flakes and a burned rock deeply buried suggests there may be intact features with associated cultural material. To verify that, levels of effort beyond the scope of this inventory survey are required before CAS can make any NRHP eligibility recommendation for the prehistoric compoent at this site. Two 1-x-1-m units should be excavated on the terrace remnant where ST 13 is located.

\section{$41 \mathrm{BP} 124$}

\section{Description}

According to Skelton and Freeman (1979), this disturbed open campsite was scattered over an area of about $335 \mathrm{~m}^{2}$.
However, there are conflicting UTM coordinates for the site as given by Skelton and TARL. TARL's plot for the site is $168 \mathrm{~m}$ west of Skelton's. CAS archaeologists navigated to both areas using a GPS and the site description provided by Skelton generally matches both areas. Both areas are

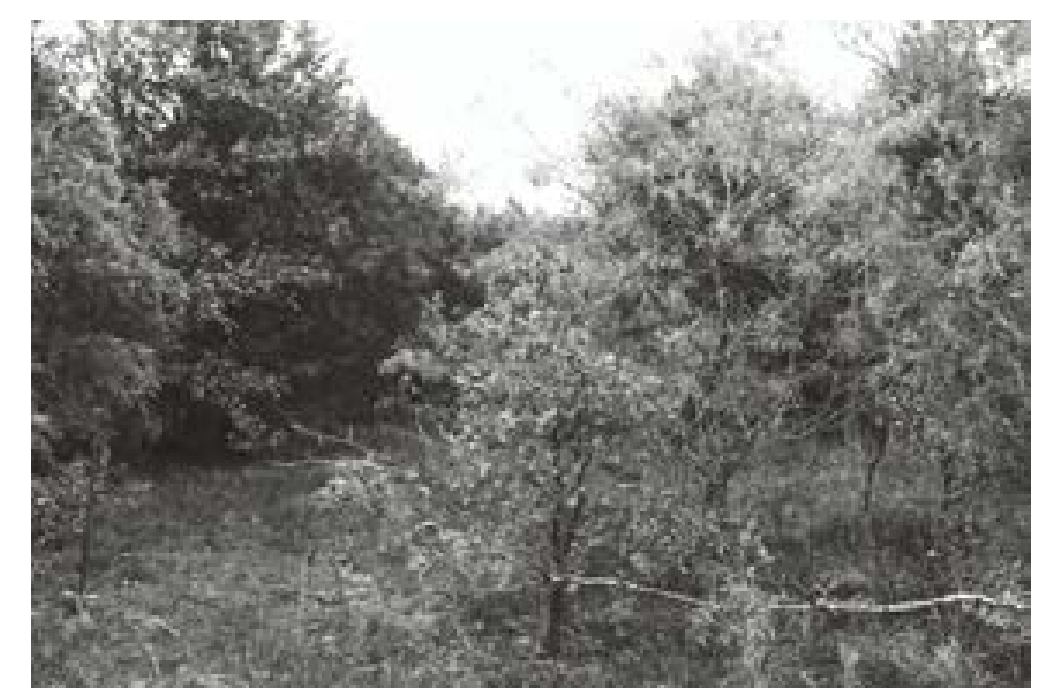

Figure 6-25. 41BP124 is an eroded open campsite; facing north.

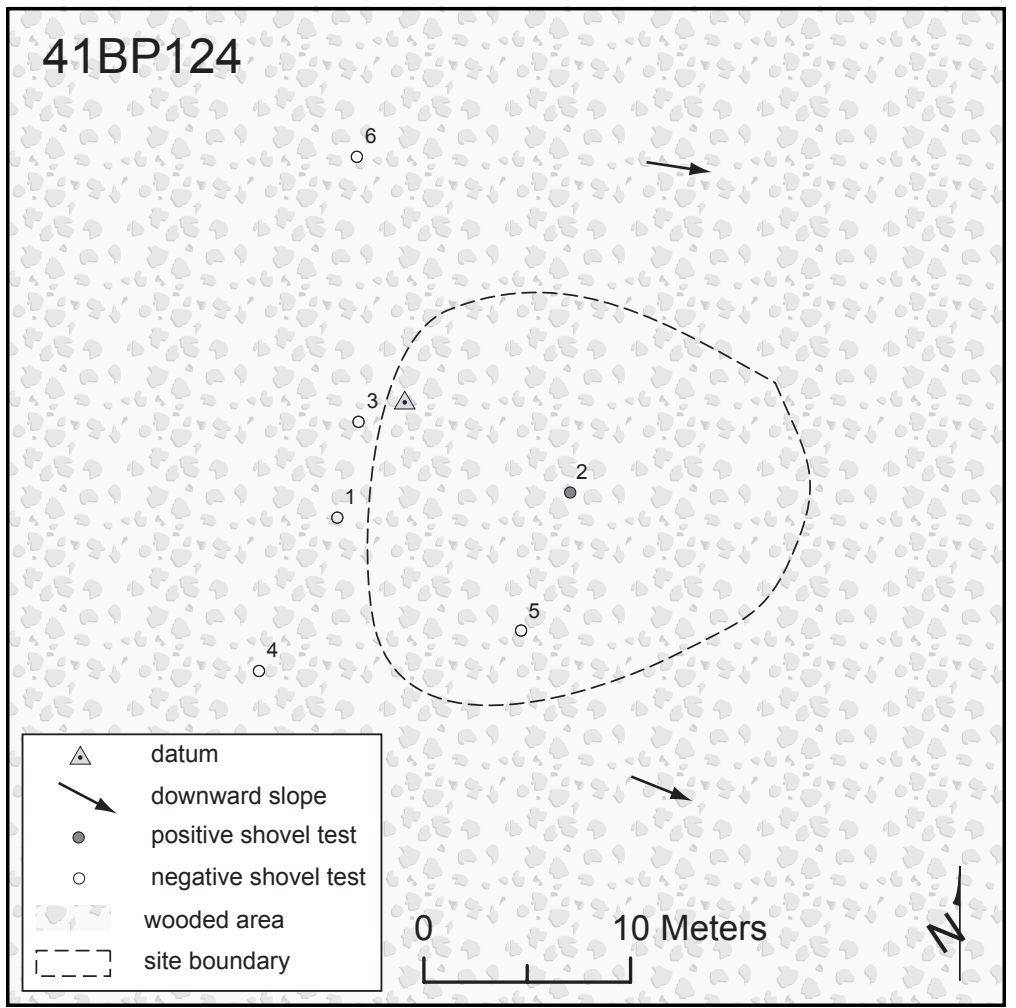

Figure 6-26. Site map of 41BP124. 
heavily disturbed, and dense vegetation includes

\section{BP129}

mesquites, oaks, cedars, elms, shrubs, and grasses. Surface visibility in both areas is about five percent. Shovel tests were excavated in both areas, and the only positive test was in the area where Skelton had the site plotted. Therefore, CAS presumes this to be the right area (Figures 6-25 and 6-26). It has Axtell fine sandy loam (AfC2) soils and slopes toward the west between 477 and $475 \mathrm{ft}$ amsl. A tributary of Harris Creek is 120 $\mathrm{m}$ to the north. The site datum is a nail and an aluminum tag in an oak tree $15 \mathrm{~cm}$ in diameter.

\section{Levels of Work and Results}

Skelton and Freeman (1979) saw 12 flakes, a few fire-cracked rocks, petrified wood, and hematite on eroded surfaces. He noted very shallow soils in his shovel tests and no artifacts. In 2005, CAS archaeologists did not see any artifacts on the surface, and in the two shovel tests excavated on the site found only one flake (ST 2, 0-10 cmbs). The average soil depth across the site was less than $16 \mathrm{cmbs}$.

\section{Conclusions/ Recommendations}

Due to the eroded surfaces and minimal number of artifacts documented, the site has little if any research potential, and CAS concurs with Mauldin (2001) that the site is not eligible for nomination to the NRHP.

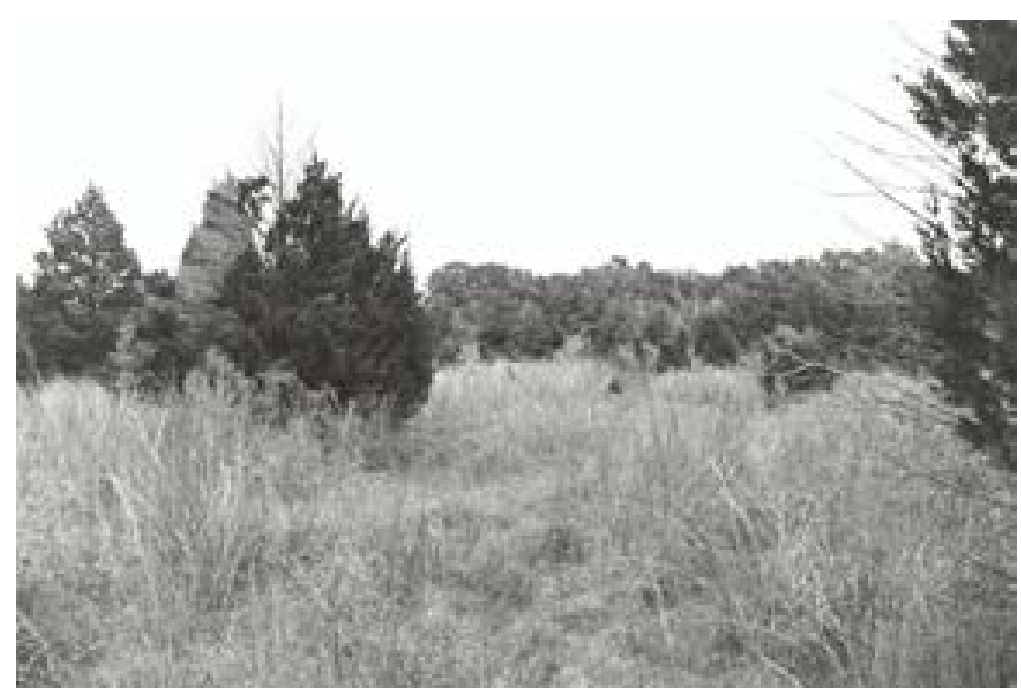

Figure 6-27. 41BP129 is an open campsite on a footslope; facing north.

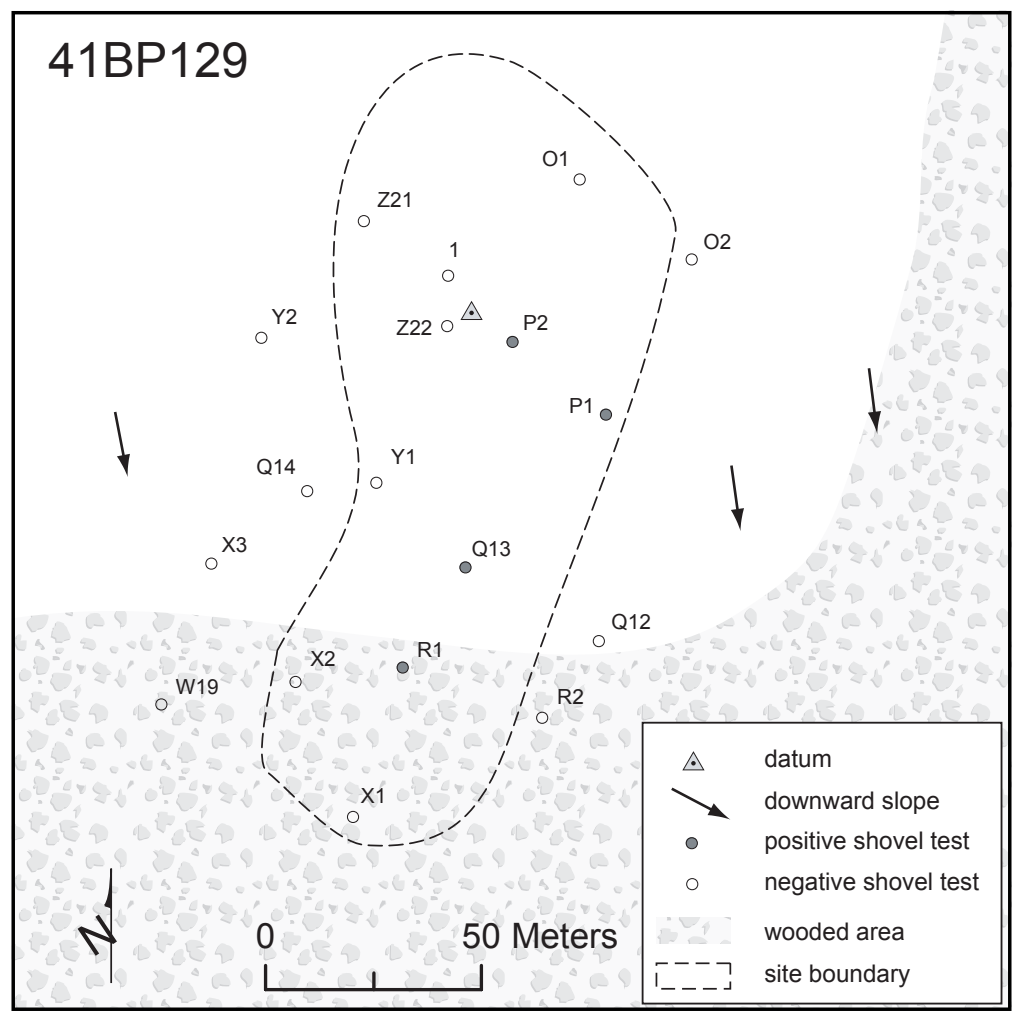

Figure 6-28. Site map of 41BP129. 
Dogwood Branch Creek. Skelton and Freeman (1979) stated that the area was cleared of most trees, but what was once a cleared field is now covered with cedars, mesquite brush, oaks, and dense grasses. Axtell fine sandy loam (AfC2) soils cover the overall slope from 458 to $440 \mathrm{ft}$ amsl. Robinson (2001) noted that the area was more heavily wooded, and as noted by Skelton 18 years earlier, there was wide spread disturbance caused by military training. In 2005, CAS archaeologists observed numerous tank ruts and eroded rills across the entire site. Surface visibility in October 2005 was less than five percent. The site datum was marked with a nail and an aluminum tag in a small oak tree.

\section{Levels of Work and Results}

Skelton and Freeman (1979) observed numerous flakes and cores, along with a few fire-cracked rocks in the tank ruts and eroded rills. However, none were visible on the surface in 2005. Skelton excavated shovel tests on the site and found only two flakes on the southern portion of the site. In 1997, CAR archaeologists dug 13 shovel tests and found only one flake at 20-30 cmbs (Robinson et al. 2001). Artifacts were recovered from four shovel tests out of 11 excavated in 2005 on the site, and they are listed in Table 6-6. As with the previous two investigations, CAS archaeologists observed significant surface disturbance, shallow soils, and a superficial scatter of flakes and fire-cracked rocks below the surface.

\section{Conclusions/ Recommendations}

Because of its eroded and disturbed condition, CAS concurs with Skelton and Freeman (1979) and Mauldin (2001) and recommends no
Table 6-6. 41BP129 positive shovel test results.

\begin{tabular}{|c|c|c|c|c|}
\hline $\begin{array}{c}\text { Depth } \\
\text { (cmbs) }\end{array}$ & ST P1 & ST P2 & ST Q13 & ST R1 \\
\hline $0-10$ & & $\begin{array}{l}2 \text { IF, } \\
\text { FCR }\end{array}$ & IF & IF \\
\hline $10-20$ & & & Sand & IF \\
\hline $20-30$ & IF & & & \\
\hline $30-40$ & & & & \\
\hline $40-50$ & & Clay & & Clay \\
\hline $50-60$ & Clay & & & \\
\hline $60-70$ & \multicolumn{5}{|c|}{ Key: IF-interior flake; } \\
\hline \multicolumn{5}{|c|}{ FCR-fire-cracked rock >1 inch } \\
\hline
\end{tabular}

further work; the site is not eligible for nomination to the NRHP.

\section{BP130}

\section{Description}

41BP130 is a $1,174-\mathrm{m}^{2}$ lithic scatter on a footslope between two intermittent drainages of Dogwood Branch Creek (Figures 6-29 and 6-30). In September 2005, CAS archaeologists noted that the area had likely been cleared in historic times, but was then covered with oaks, cedars, mesquite brush, elms, loblolly pines, cacti, and dense grasses. Axtell fine sandy loam (AfC) soils

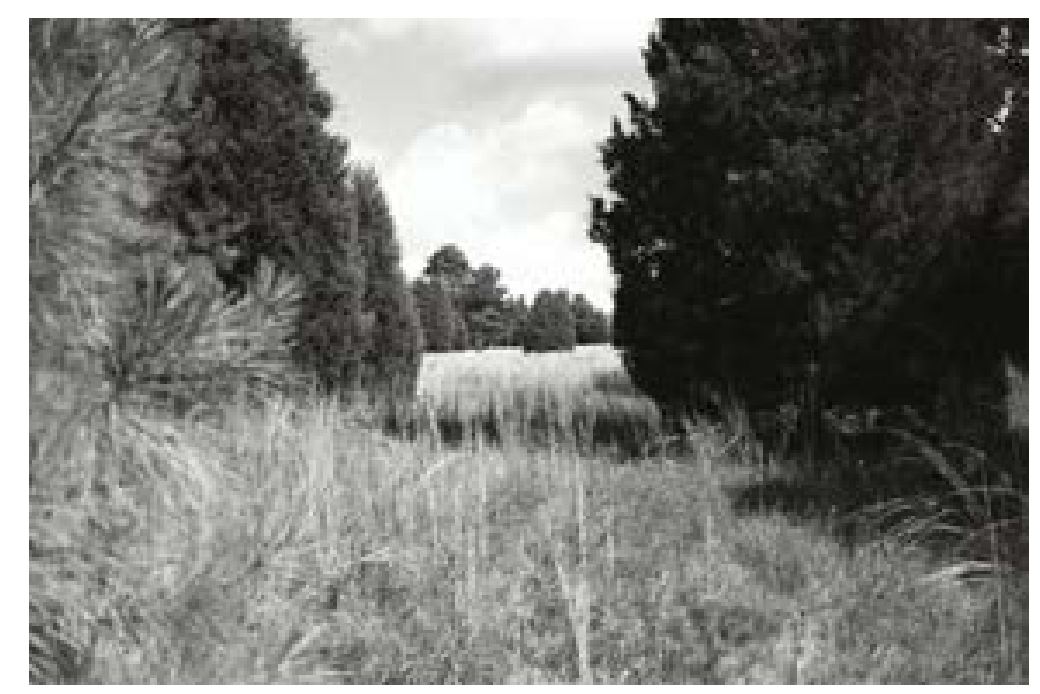

Figure 6-29. 41BP130 is a lithic scatter on a footslope; facing north. 


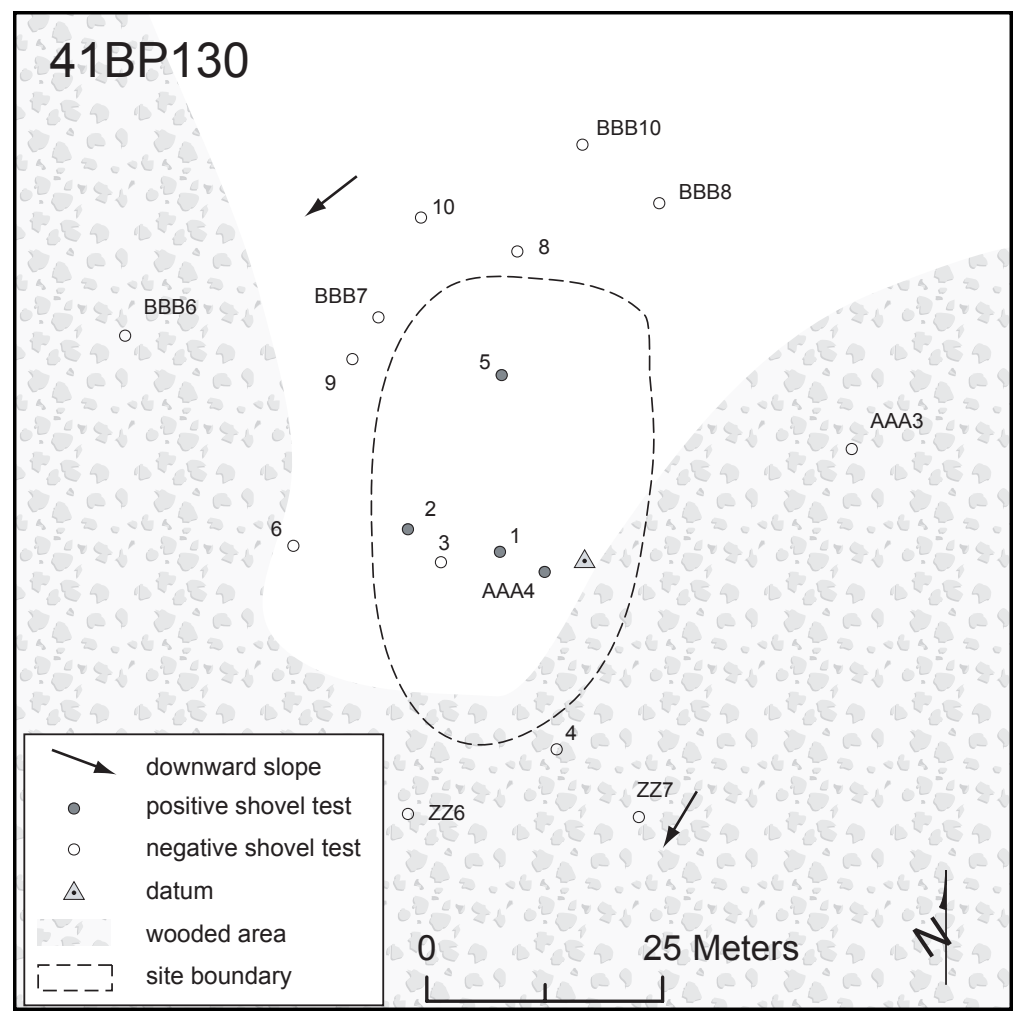

Figure 6-30. Site map of 41BP130.

cover the overall slope. The slope across the site ranges from 432 to $421 \mathrm{ft}$ amsl. Surface visibility was less than five percent. Disturbances included a few tree falls and gopher holes. The site datum

Table 6-7. 41BP130 positive shovel test results.

\begin{tabular}{|c|c|c|c|c|}
\hline $\begin{array}{c}\text { Depth } \\
\text { (cmbs) }\end{array}$ & ST 1 & ST 2 & ST 5 & ST AAA4 \\
\hline $0-10$ & & $\mathrm{Bu}$ & & \\
\hline $10-20$ & $\mathrm{IF}$ & & & IF \\
\hline $20-30$ & $\mathrm{H}$ & & & \\
\hline $30-40$ & & & & \\
\hline $40-50$ & & & IF & \\
\hline $50-60$ & & EF & IF & \\
\hline $60-70$ & & IF & & \\
\hline $70-80$ & Sand & & Sand & Clay \\
\hline $80-90$ & & & & \\
\hline $90-100$ & & Sand & & \\
\hline $100-110$ & & & & \\
\hline \multicolumn{5}{|c|}{ Key: EF-exterior flake; IF-interior flake; } \\
\hline
\end{tabular}

was marked with a nail and an aluminum tag in a pine tree 60 $\mathrm{cm}$ in diameter.

\section{Levels of Work and Results}

Skelton and Freeman (1979) observed five flakes and a core in rodentanderosionaldisturbances, and commented that the artifacts were likely in secondary context. Surface visibility was less than five percent in September 2005, and archaeologists could see no artifacts on the surface. Four shovel tests out of five excavated on the site in 2005 (Table 6-7) produced six flakes, a quartzite hammerstone, and a spent bullet casing.

\section{Conclusions/ Recommendations}

The absence of features and/or evidence of organic preservation at this site significantly lessens its research potential. CAS concurs with Mauldin (2001) that no further work is warranted at this site, and it is not eligible for nomination to the NRHP.

\section{BP131}

\section{Description}

41BP131 is a $6,185-\mathrm{m}^{2}$ open campsite on a low footslope between two intermittent drainages of Dogwood Branch Creek (Figures 631 and 6-32). The southern portion of the site is on the floodplain of Dogwood Branch. The site is covered with oaks, cedars, mesquite brush, elms, loblolly pines, cacti, and dense grasses. Frequently flooded Uhland (Uh) soils cover the overall slope. The slope across the site ranges from 425 to $420 \mathrm{ft}$ amsl. Surface visibility was approximately ten percent. Disturbances included 


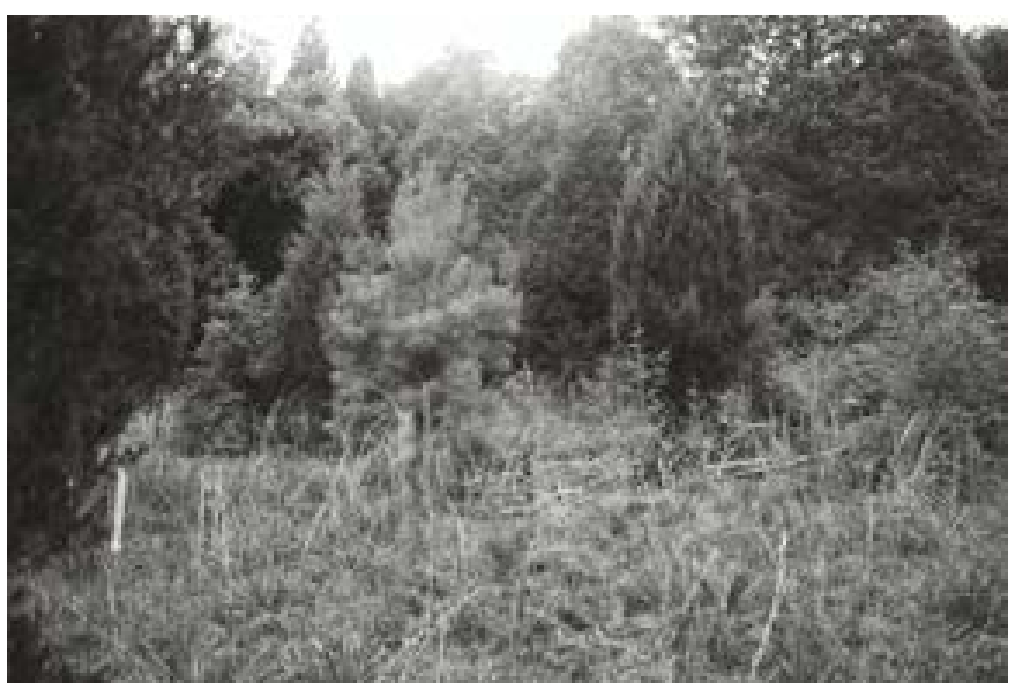

Figure 6-31. 41BP131 is an open campsite on the north side of Dogwood Branch; facing southwest.

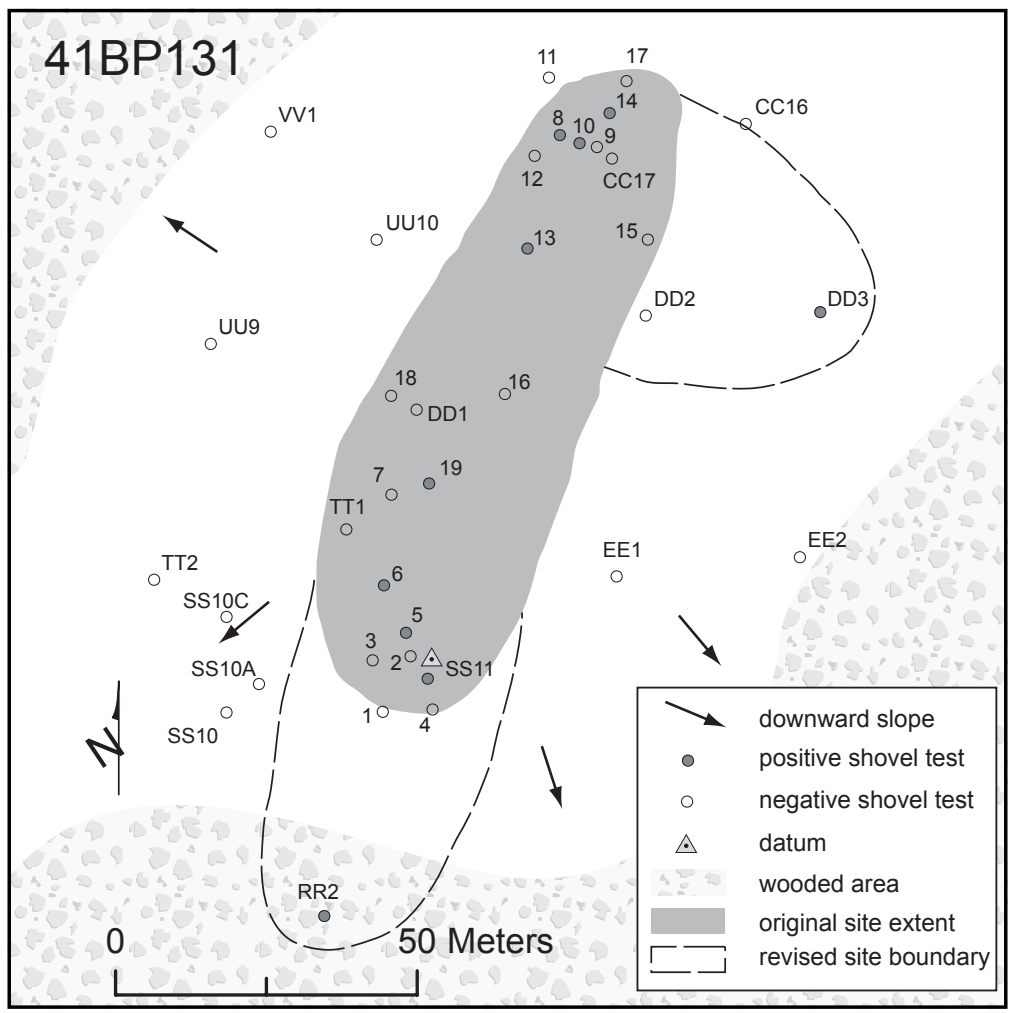

Figure 6-32. Site map of 41BP131.

a few tree falls and some eroded rills. The site datum was marked with a nail and an aluminum to the NRHP.

\section{Levels of Work and Results}

When Skelton and Freeman (1979) first recorded this site, he noted ten flakes and a few small burned rocks on the surface around rodent burrows and eroded rills; no artifacts were found below the surface in shovel tests. Skelton noted that there was a historic site in the area. CAS discovered 41BP775 and $41 \mathrm{BP} 776$ (discussed in Chapters 7 and 9) upslope from 41BP131. That may explain why archaeologists found a whiteware sherd and an unidentifiable metal fragment in ST 10 (Table 6-8). The average soil depth across the site was $32 \mathrm{cmbs}$, and angular ironstones and/or petrified wood chunks were commonly found below the surface. Of the 24 shovel tests dug on the site, 10 contained prehistoric artifacts (see Table 6-8).

\section{Conclusions/ Recommendations}

Although buried firecracked rocks and flakes were found in shovel tests, they were all in shallow soils and within colluvial deposits, and in one case (ST 10) historic items were found. CAS concurs with Mauldin (2001) that no further work is warranted at this site and it is not eligible for nomination

tag in a cedar tree $37 \mathrm{~cm}$ in diameter. 
Table 6-8. 41BP131 positive shovel test results.

\begin{tabular}{|c|c|c|c|c|c|c|c|c|c|c|}
\hline $\begin{array}{c}\text { Depth } \\
\text { (cmbs) }\end{array}$ & $\begin{array}{c}\text { ST } \\
\mathbf{5}\end{array}$ & $\begin{array}{c}\text { ST } \\
\mathbf{6}\end{array}$ & $\begin{array}{c}\text { ST } \\
\mathbf{8}\end{array}$ & $\begin{array}{c}\text { ST } \\
\mathbf{1 0}\end{array}$ & $\begin{array}{c}\text { ST } \\
\mathbf{1 3}\end{array}$ & $\begin{array}{c}\text { ST } \\
\mathbf{1 4}\end{array}$ & $\begin{array}{c}\text { ST } \\
\mathbf{1 9}\end{array}$ & $\begin{array}{c}\text { ST } \\
\text { DD3 }\end{array}$ & $\begin{array}{c}\text { ST } \\
\text { RR2 }\end{array}$ & $\begin{array}{c}\text { ST } \\
\text { SS11 }\end{array}$ \\
\hline $0-10$ & IF & EF & IF & M & EF & & & EF & & EF \\
\hline $10-20$ & & 3 FCR & IF & $\begin{array}{c}\text { CC, } \\
\text { WW }\end{array}$ & & & FCR & & & \\
\hline $20-30$ & & & & IF & & IF & Clay & Clay & IF & \\
\hline $30-40$ & & Clay & & Clay & Clay & Clay & & & & Clay \\
\hline $40-50$ & Clay & & Clay & & & & & & & \\
\hline $50-60$ & & & & & & & & & & \\
\hline $60-70$ & & & & & & & & & & \\
\hline $70-80$ & & & & & & & & & \\
\hline $80-90$ & & & & & & & & & \\
\hline \multicolumn{7}{|c|}{ Key: CC-chert chip; EF-exterior flake; IF-interior flake; } \\
\hline
\end{tabular}

\section{BP366}

\section{Description}

41BP366 is a $1,866-\mathrm{m}^{2}$ prehistoric open campsite on a footslope along an intermittent drainage of Harris Creek (Figures 6-33 and 6-34). A steep, 5-m cutbank forms its eastern boundary. The Axtell fine sandy loam (AfC2) supports a dense growth of oaks, cedars, elms, and pecans along the cutbank. However, most of the site had been cleared for the

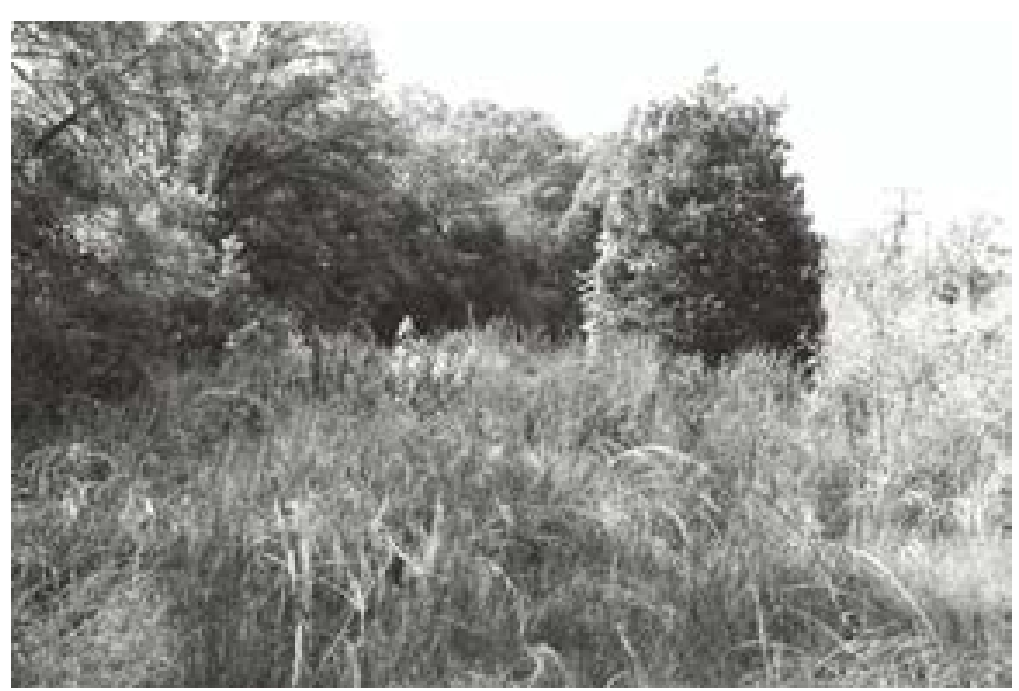

Figure 6-33. 41BP366 is an open campsite along a tributary of Harris Creek; facing south. construction of water and sewer systems. Artificial disturbance is significant, and stream erosion continues to undercut the eastern edge of the site. The surface slopes from 442 to $428 \mathrm{ft}$ amsl. Surface visibility is approximately 30 percent in the cleared areas and less than five percent in the wooded areas. The site datum is a nail and an aluminum tag in an oak tree $12 \mathrm{~cm}$ in diameter.

\section{Levels of Work and Results}

This site was initially recorded by Bruce Nightengale and Henry Moncure during a 19901991 survey for an LCRA wastewater line right-ofway. At that time they observed cultural material on bulldozed push piles and track ruts from an adjacent water line right-of-way. All six shovel tests they dug in the LCRA right-of-way were negative (Nightengale and Moncure 1996). When CAS returned to the site in 2005, archaeologists observed a few flakes on the bladed surfaces, and 


\section{Conclusions/ Recommendations}

Because of the significant disturbance that has occurred here, CAS recommends that no further work is warranted at this site and it is not eligible for nomination to the NRHP.

Figure 6-34. Site map of 41BP366.

Table 6-9. 41BP366 positive shovel test results.

\begin{tabular}{|c|c|c|c|c|}
\hline $\begin{array}{c}\text { Depth } \\
\text { (cmbs) }\end{array}$ & ST 1 & ST 4 & ST 6 & ST A10 \\
\hline $0-10$ & & & & \\
\hline $10-20$ & EF & & IF, fcr & \\
\hline $20-30$ & & FCR & 3 IF & \\
\hline $30-40$ & Clay & FCR & & IF \\
\hline $40-50$ & & Clay & Clay & Clay \\
\hline $50-60$ & & & & \\
\hline $\begin{array}{l}\text { Key: EF-exterior flake; IF-interior flake; FCR- } \\
\text { fire-cracked rock >1 inch; fcr-fire-cracked rock } \\
<1 \text { inch }\end{array}$ \\
\hline
\end{tabular}

recovered six flakes and three fire-cracked rocks from four out of six shovel tests placed on the site (Table 6-9). The only positive shovel test in a relatively undisturbed portion of the site was ST 6 . The average depth of remaining soil across the site was $28.5 \mathrm{cmbs}$.

\section{BP367}

\section{Description}

41BP367 is an open campsite $120 \mathrm{~m}$ north of 41BP366, on the same footslope and intermittent tributary of Harris Creek (Figures 6-35 and 6-36). Shovel test results indicate it covers about $2,672 \mathrm{~m}^{2}$. The cutbanks that form its northern and eastern boundaries are approximately 5$6 \mathrm{~m}$ deep, and have undercut the site. Water and sewer line rightsof-way have been cut along its western edge, there are numerous push piles, much of the site has been cleared, and the overall surface is very hummocky. Where not cleared, Axtell fine sandy loam (AfC2) supports a dense growth of oaks, cedars, and elms. The surface slopes from 440 to $428 \mathrm{ft}$ amsl. Surface visibility is approximately 10 percent in the cleared areas, and less than five percent in the wooded areas. CAS established a site datum with a nail and an aluminum tag in an oak tree $30 \mathrm{~cm}$ in diameter.

\section{Levels of Work and Results}

As with 41BP366, this site was also recorded by Bruce Nightengale and Henry Moncure during the 1990-1991 LCRA wastewater line right-ofway survey. At that time, they observed cultural material on bulldozed push piles and track ruts from an adjacent water line right-of-way, as 


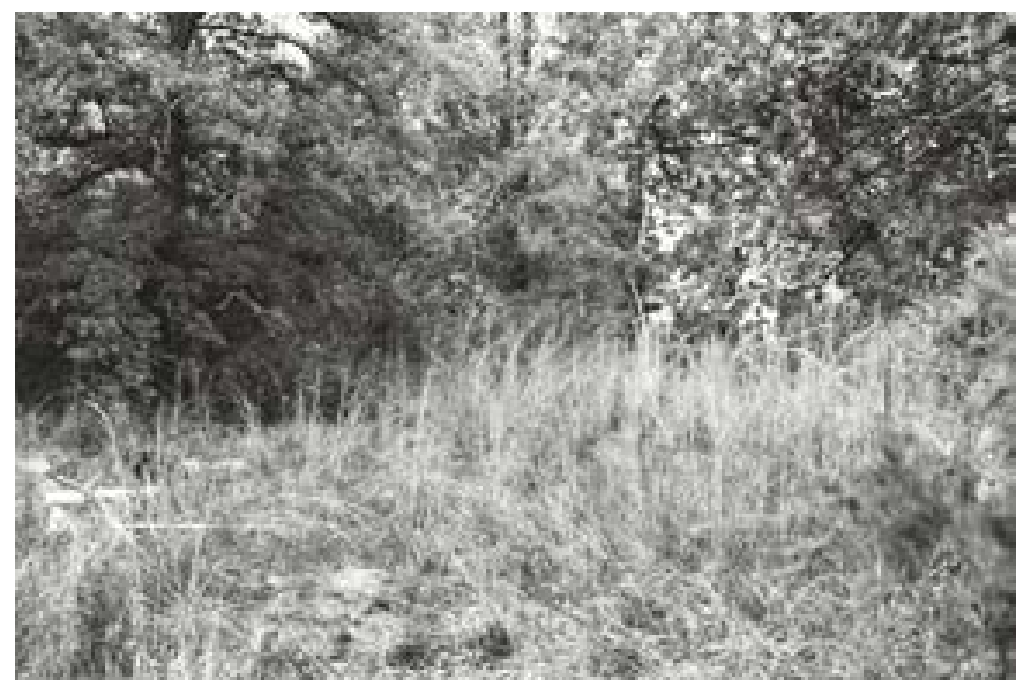

Figure 6-35. 41BP367 is another open campsite along a tributary of Harris Creek; facing south.

\section{FIGURE 6-36. REDACTED}

Figure 6-36. Site map of 41BP367.

well as five hearthstones eroding from $10 \mathrm{cmbs}$ in the cutbank along the site's northern edge. The shovel tests they dug in the LCRA right-of- way were negative (Nightengale and Moncure 1996). When CAS returned to the site in 2005 , archaeologists did not see any fire-cracked rocks and/or flakes either on the upper surface or within the cutbanks. A tiny fire-cracked rock fragment, 
Table 6-10. 41BP367 positive shovel test results.

\begin{tabular}{|c|c|c|c|c|c|c|}
\hline $\begin{array}{c}\text { Depth } \\
\text { (cmbs) }\end{array}$ & ST 2 & ST 3 & ST 4 & ST A5 & ST A6 & ST B5 \\
\hline $0-10$ & IF & & & & & \\
\hline $10-20$ & IF, fcr & & & & & IF \\
\hline $20-30$ & & IF, U & & & & \\
\hline $30-40$ & Clay & & & & IF & Clay \\
\hline $40-50$ & & & & & Clay & \\
\hline $50-60$ & & Clay & IF & IF, U & & \\
\hline $60-70$ & & & Clay & Clay & & \\
\hline $70-80$ & & & & & & \\
\hline \multicolumn{7}{|c|}{ Key: IF-interior flake; U-uniface; } \\
FCR-fire-cracked rock >1 inch; fcr-fire-cracked rock $<1$ inch \\
\hline \multicolumn{7}{|l}{} \\
\hline
\end{tabular}

two unifaces, and seven flakes were found in six shovel tests out of seven excavated on the site (Table 6-10). The uniface in ST 3 was a snapped chert flake with utilization scars on its distal end. The uniface in ST A5 was a chert blade with a utilized edge.

\section{Conclusions/Recommendations}

Although a possible hearth feature was observed eroding from the northern cutbank in 1997, there was no evidence of it to be seen in 2005. The presence of fire-cracked rocks potentially representing buried, intact hearths, and associated stone tools would ordinarily increase the research potential at this site. However, because of the significant artificial and erosional disturbances that have occurred, CAS now assesses the site's potential as minimal. Therefore, CAS recommends that no further work is warranted at this site and it is not eligible for nomination to the NRHP.

\section{BP381}

\section{Description}

41BP381 (Figures 6-37 and 6-38) is an open campsite on the edge of a .50-caliber machine gun range that covers $2,237 \mathrm{~m}^{2}$. The area has been bladed to clay and artificially bermed, and is now mowed. Artifacts were observed on the eroded surface of a two-track road running along the edge of the range. Dense grasses, trees, and brush are growing along the site's western edge. It ranges in elevation from 468 to $472 \mathrm{ft}$ amsl, and thin layers of Axtell fine sandy loam and Tabor fine sandy loam (TfB) exist where the clay has not been exposed. An intermittent drainage is $100 \mathrm{~m}$ to the south. A nail and aluminum tag attached to an oak tree serves as the site datum.

\section{Levels of Work and Results}

This site was originally recorded in 1994 by TXMF archaeologist Alan Wormser, and subsequently revisited in 1997 by CAR

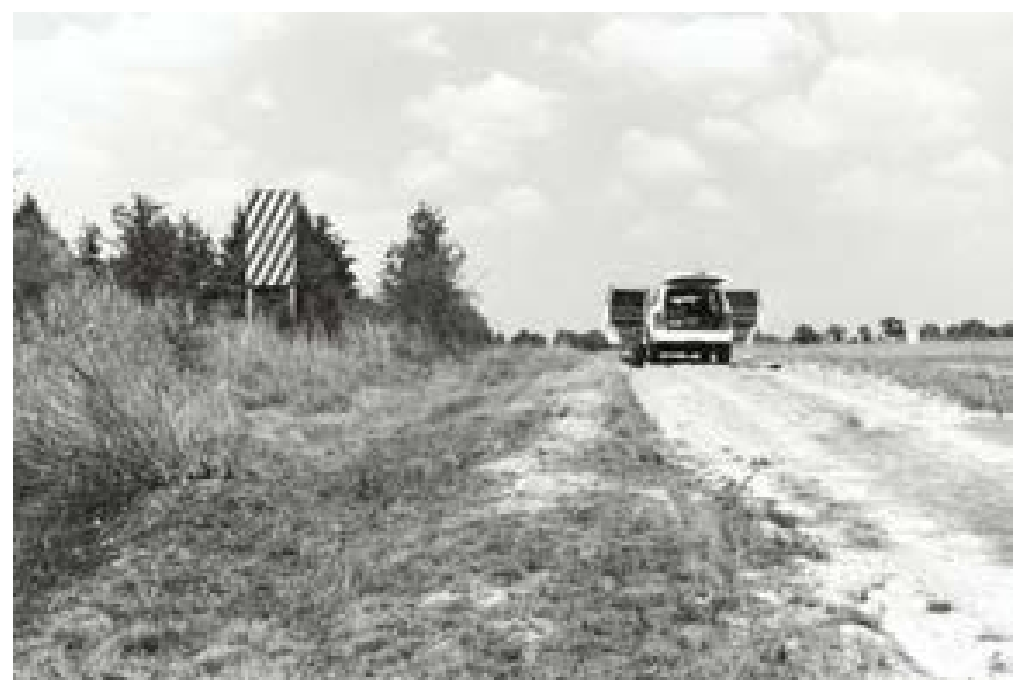

Figure 6-37. 41BP381 lies on the edge of a machine gun range. 
flakes on the surface. Six shovel tests dug on the site were all negative.

FIGURE 6-38. REDACTED

\section{Conclusions/ \\ Recommendations}

As with the two previous visits, CAS's observation is that the site has been significantly impacted by the construction of the machine gun range. The site has little potential for yielding significant prehistoric information. Therefore, CAS concurs with the two previous investigators that no further work is warranted at this site and it is not eligible for nomination to the NRHP.

Figure 6-38. Site map of 41BP381.

\section{BP433}

archaeologists. The range had already been constructed by 1994, and the area had been recently plowed, allowing for very good surface visibility. At that time a mano and a core were collected and three flakes were observed, all resting on the surface (Wormser 1994). In 1997, a Bulverde dart point base and a ground stone were collected from the surface. A total of four flakes were found in two shallow shovel tests and a probe excavated on the site (Robinson et al. 2001). In 2005, CAS archaeologists encountered the site while walking down the two-track road en route to one of the survey areas. Archaeologists observed three pieces of sandstone and quartzite fire-cracked rocks, a quartzite hammerstone, and eight chert

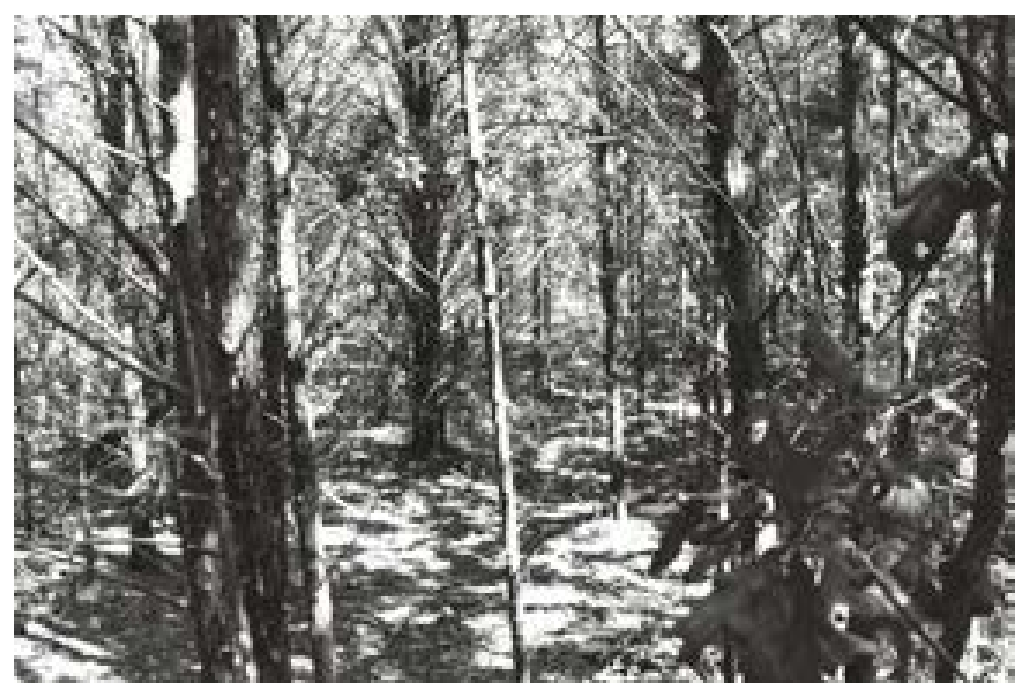

Figure 6-39. The eroded eastern slope at 41BP433 has a few prehistoric artifacts; facing north. 


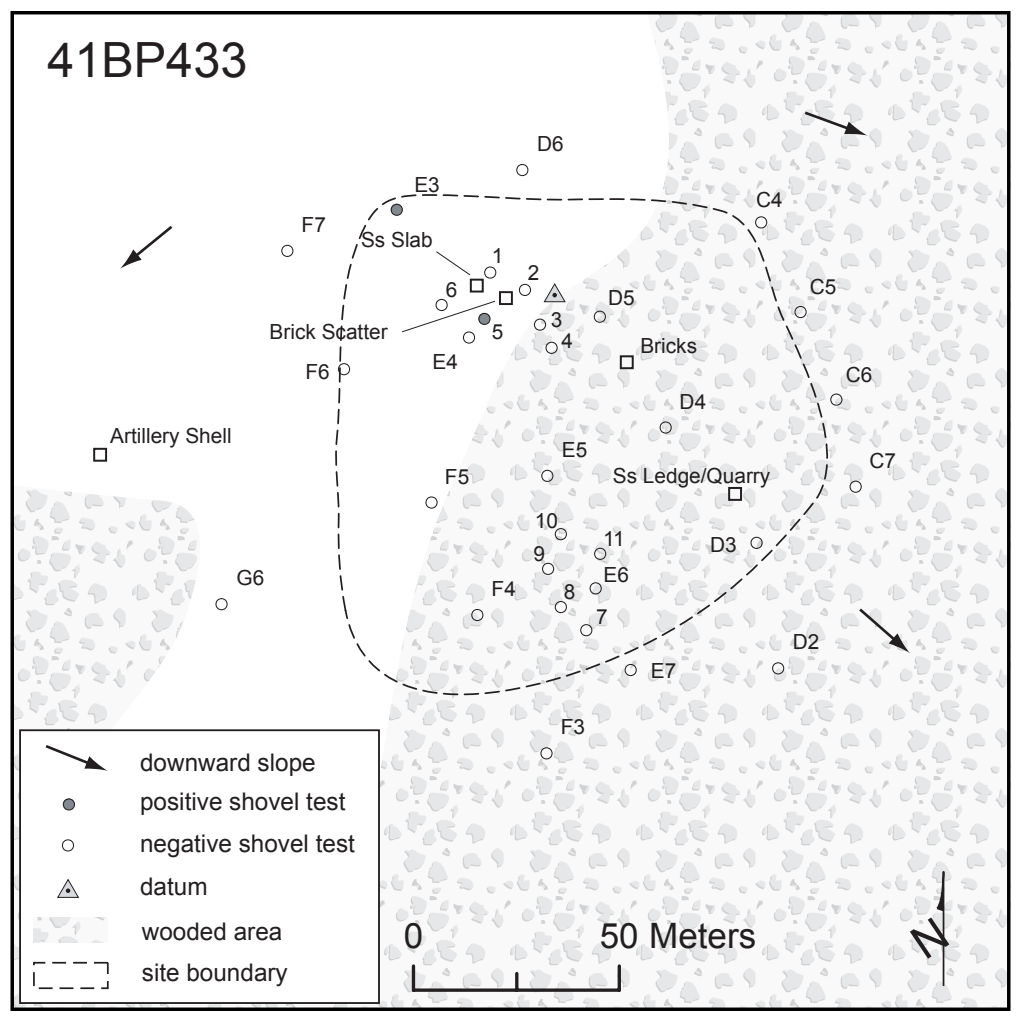

Figure 6-40. Site map of 41BP433. while conducting a 1995 survey for EH\&A, but noted the historic component only (Schmidt et al. 1995). When CAS revisited the site in 2005, archaeologists observed a single bifacial chopper and three fire-cracked rocks on the eroded slope. Although ST 5 and E3 contained historic artifacts, none of the 21 shovel tests excavated on the site contained prehistoric artifacts. The average soil depth in that area was less than $5 \mathrm{cmbs}$.

\section{Conclusions/ Recommendations}

The hearthstones are scattered and the soils are very shallow, negating any research potential the prehistoric component may have held. Therefore, CAS recommends that no further work is warranted and the prehistoric component of the site is not eligible for nomination to the NRHP.

the site that is discussed in Chapter 8: Previously Documented Historic Component Sites. Even though the entire site encompasses about 11,935 $\mathrm{m}^{2}$ and artifacts are highly visible on a generally sloping and eroded surface (468-448 ft amsl), the prehistoric component is limited to a $3,000-\mathrm{m}^{2}$ area on the eastern portion within a dense stand of cedar trees. McLaughlin Creek is $210 \mathrm{~m}$ east. Axtell fine sandy loam (AfC2) covers this sideslope setting. An old deer stand was still partially attached to a large oak tree in the eastern portion of the site. The site datum is marked with a nail and aluminum tag on an 8-inch diameter oak tree.

\section{Levels of Work and Results}

Schmidt, Cruse, and Brownlow first recorded this site

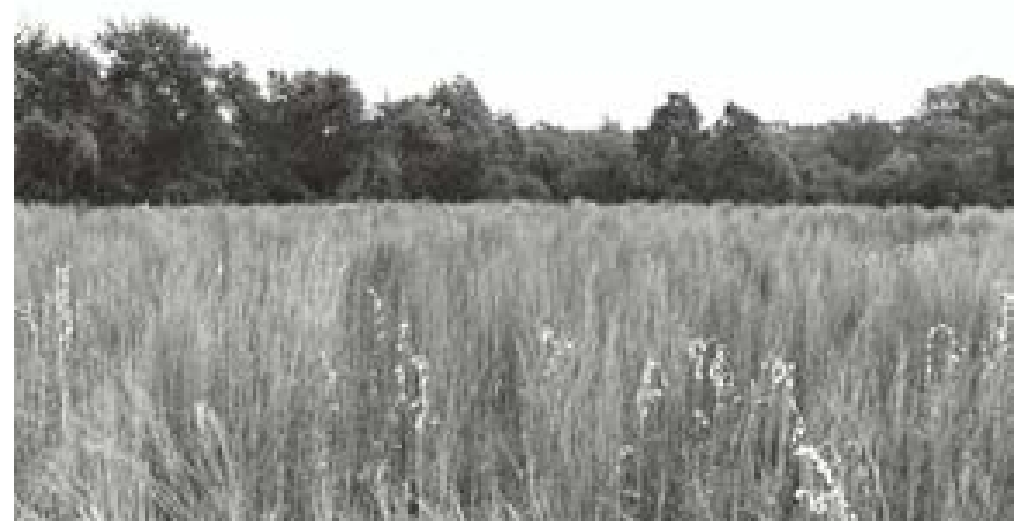

Figure 6-41. 41BP472 is a lithic scatter above Big Sandy Creek; facing west. 


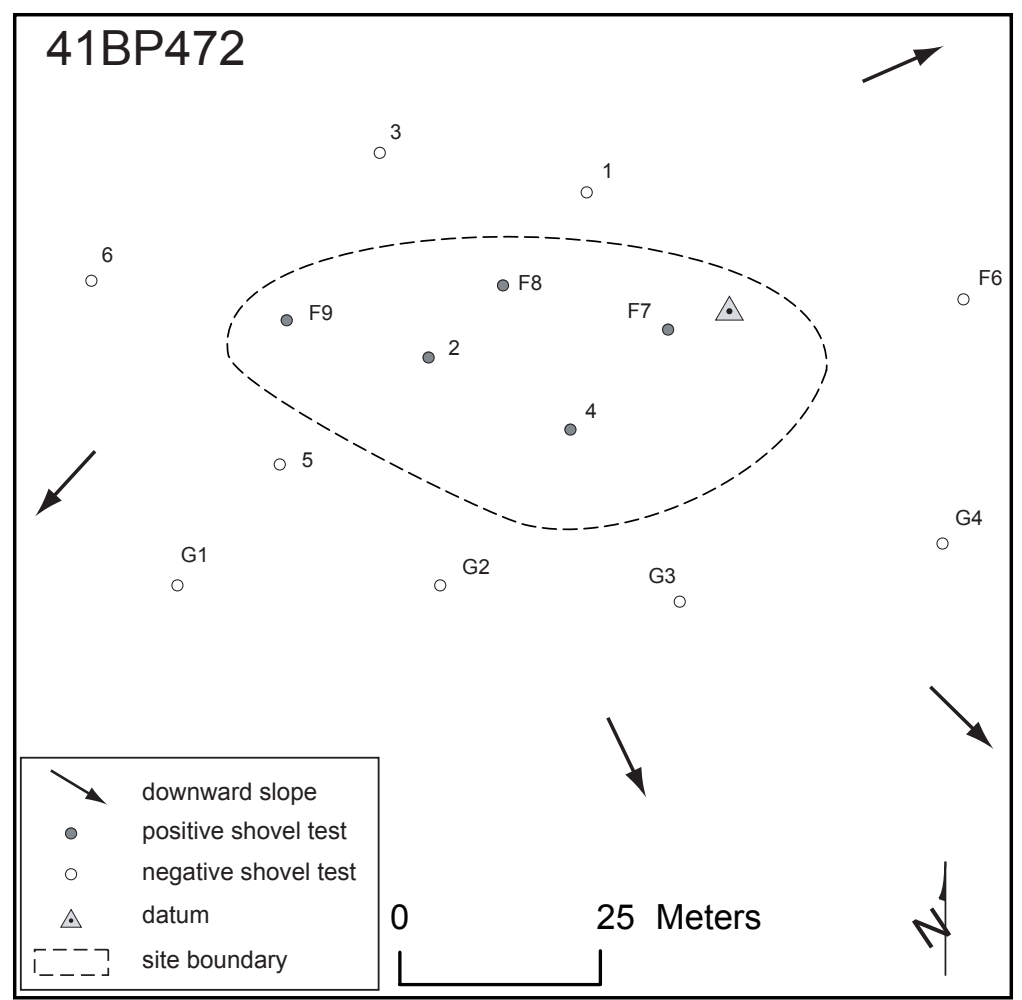

Figure 6-42. Site map of 41BP472.

\section{$41 \mathrm{BP} 472$}

\section{Description}

$41 \mathrm{BP} 472$ is a $1,908-\mathrm{m}^{2}$ lithic scatter (Figures 6-41 and 6-42) located on a sideslope that ranges from 445 to $440 \mathrm{ft}$ amsl. The site has been cleared

Table 6-11. 41BP472 positive shovel test results.

\begin{tabular}{|c|c|c|c|c|c|}
\hline $\begin{array}{c}\text { Depth } \\
\text { (cmbs) }\end{array}$ & $\begin{array}{c}\text { ST } \\
\mathbf{2}\end{array}$ & $\begin{array}{c}\text { ST } \\
\mathbf{4}\end{array}$ & $\begin{array}{c}\text { ST } \\
\text { F7 }\end{array}$ & $\begin{array}{c}\text { ST } \\
\text { F8 }\end{array}$ & $\begin{array}{c}\text { ST } \\
\text { F9 }\end{array}$ \\
\hline $0-10$ & & & & & \\
\hline $10-20$ & & HS & & IF & IF \\
\hline $20-30$ & & & & & \\
\hline $30-40$ & EF, IF & & EF & & \\
\hline $40-50$ & & IF & Clay & & \\
\hline $50-60$ & & & & & Clay \\
\hline $60-70$ & & IF & & & \\
\hline $70-80$ & Clay & & & Sand & \\
\hline $80-90$ & & Clay & & & \\
\hline $90-100$ & \multicolumn{7}{|c|}{} & & & \\
\hline Key: HS-heat spall; EF-exterior flake; IF-interior \\
flake \\
\hline
\end{tabular}

of trees and only tall grasses and grapevines are present. The Demona loamy fine sand (DeC) soil's surface is very hummocky, and tank ruts are very common across the area. Surface visibility was about 5-10 percent during the September 2005 visit. The site sits high in elevation on an inside meander of Big Sandy Creek, $200 \mathrm{~m}$ to the south.

\section{Levels of Work and Results}

Shellie Sullo and Alan Wormser first recorded this site during a survey of potential Bradley Fighting Vehicle training areas. They described it as very sparse lithic scatter heavily disturbed by track vehicle training. Two of their shovel tests were positive, but a piece of metal was found below one of the flakes (Sullo and Wormser 1996). CAS relocated the site in 2005 and found no artifacts on the surface. The five shovel tests excavated on the site were all positive. A total of seven flakes and one heat spall were recovered (Table 6-11) from the five positive shovel tests. Although no metal was found, animal burrows were noted in two of the tests.

\section{Conclusions/Recommendations}

Based upon Sullo and Wormser's findings and the results of CAS's shovel tests and observations, it appears that this site has been heavily disturbed by both track vehicles and bioturbation. Coupled with the absence of features and/or evidence of organic preservation, CAS concurs with Sullo and Wormser that the site has little potential to yield significant scientific data. Therefore, CAS recommends that no further work is warranted 
at this site and it is not eligible for nomination to the NRHP.

\section{BP487}

\section{Description}

41BP487 (Figures 6-43 and 6-44) is an open campsite buried over an $10,561-\mathrm{m}^{2}$ area in deep Sayers fine sandy loam (Sa) on a T2 terrace on the south edge of Big Sandy Creek. This area is an open field that was plowed through 1941 (Abner Scott, personal communication 16 January 2002). The surface slopes gently from 420 to 419 $\mathrm{ft}$ amsl and is now covered with grasses, bull nettles, prickly pear cacti, and grapevines, except for cedar and oak trees in a wooded area along the creek (see Figure 6-44). In addition to plowing, a bladed jeep trail runs along the tree line. Surface visibility was less than 10 percent in August 2005. The site datum is a post oak tree $8 \mathrm{~cm}$ in diameter located in the tree line and is marked with a nail and aluminum tag.

\section{Levels of Work and Results}

This site was initially recorded in 1997 by TXMF archaeologists (Haslouer-Kay et al. 1997). At that time, they observed one flake on the surface Figure 6-44. Site map of 41BP487. and from three shovel tests recovered eight flakes and three burned rocks as deep as $1.2 \mathrm{~m}$ below the surface. Evidence of disturbance in the form of a cast iron stove piece between 20 and $40 \mathrm{cmbs}$ was found. In September 2000, archaeologists from CAR returned to the site. At that time they noted the bladed jeep road and three military foxholes that had been dug to the northeast of the site. They found nothing on the surface, but in one of the three shovel tests excavated they found four flakes and four burned rocks distributed continuously down to 


\begin{tabular}{|c|c|c|c|c|c|c|c|c|c|c|c|c|c|}
\hline is 1 & & & & $\Xi$ & & & & & 駡 & & & & \\
\hline 战齐 & & 王 & & & & 论 & & 岀 & & & 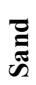 & & \\
\hline 点 2 & & U & & & & & z & & 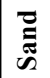 & & & & \\
\hline 的 & & & tr & $\stackrel{\Phi}{ \pm}$ & & & & 芴 & & & & & $\overline{\bar{g}}$ \\
\hline $\sin$ & & 0 & & & & & & 苞 & & & & & 节 \\
\hline $\bar{n} \bar{N}$ & & 止 & & & & $\Phi$ & & 嫣 & & & & & $\begin{array}{l}\bar{j} \\
i \\
\text { zu }\end{array}$ \\
\hline 52 & & & & & 五 & & $\Phi$ & & 赔 & & & & $\begin{array}{l}\frac{0}{0} \\
0 \\
1\end{array}$ \\
\hline $\bar{s}_{\infty} \infty$ & & I & & & & & & 胥 & & & & & $\stackrel{\overline{\mathscr{O}}}{g}$ \\
\hline $5=$ & & 五 & $\stackrel{5}{\sim}$ & 五 & I & I & & 墕 & & & & & $\begin{array}{l}\stackrel{4}{0} \\
0 \\
0\end{array}$ \\
\hline 50 & & & 土 & & 止 & & & 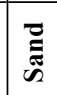 & & & & & 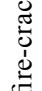 \\
\hline 50 & & & & & 止 & $\Phi$ & & 童 & & & & & 舍 \\
\hline $5=$ & & & $\Xi$ & II & & & & 颉 & & & & & 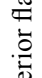 \\
\hline $5_{\infty}=$ & & $\Xi$ & $m$ 总 & 记 & 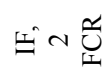 & 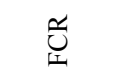 & & & & 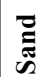 & & & 它 \\
\hline $5 a$ & & & & & & 王 & & 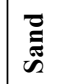 & & & & & 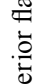 \\
\hline$\sum_{\infty} \infty$ & & I & 幽总 & & I & & & 墕 & & & & & $\begin{array}{l}0 \\
1 \\
y \\
y\end{array}$ \\
\hline is 0 & $\Xi$ & & $\Xi$ & & I & & & 墕 & & & & & $\begin{array}{l}\text { क्रे } \\
\text { एँ }\end{array}$ \\
\hline 5 in & & & $\stackrel{\underline{m}}{m}$ & 留至 & 莡 & & & & 竧 & & & & 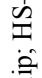 \\
\hline $\bar{n}^{\prime}+$ & & I & & & 五 & & & 墕 & & & & & $\frac{\mathrm{E}}{\mathrm{g}}$ \\
\hline sen & & & & & 纴 & & & $\begin{array}{l}\text { Dू } \\
\text { Dू }\end{array}$ & & & & & $\ddot{\breve{d}}$ \\
\hline $\bar{s}^{2} \mathrm{~N}$ & & & 㝳 & & & & & 䓂 & & & & & \\
\hline $5-$ & \pm & 幽总 & 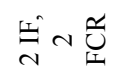 & ઘ & 丽总 & 土઼山总 & 莡 & & & 竧 & & & \\
\hline 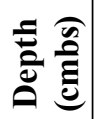 & $\frac{0}{1}$ & 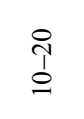 & $\begin{array}{l}\text { ஜे } \\
\text { ஓे }\end{array}$ & $\begin{array}{l}\text { P } \\
1 \\
0 \\
0\end{array}$ & 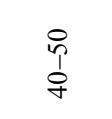 & $\begin{array}{l}8 \\
0 \\
1 \\
1 \\
n\end{array}$ & $\begin{array}{l}2 \\
1 \\
8\end{array}$ & $\begin{array}{l}8 \\
1 \\
1 \\
2\end{array}$ & $\begin{array}{l}8 \\
1 \\
1 \\
\infty\end{array}$ & $\begin{array}{l}8 \\
1 \\
2 \\
2\end{array}$ & $\begin{array}{l}\stackrel{\circ}{7} \\
\stackrel{1}{8}\end{array}$ & $\begin{array}{l}\stackrel{\overbrace{}}{1} \\
\stackrel{1}{=}\end{array}$ & \\
\hline
\end{tabular}


$60 \mathrm{cmbs}$ (Robinson et al. 2001:123). In January and August 2005, CAS archaeologists relocated the site, examined the surface, and dug a total of 30 shovel tests on the site. Out of a combined 21 positive shovel tests (Table 6-12), they found 51 flakes, 18 fire-cracked rocks $>1$ inch in size, two heat spalls, a charred nut shell, and a piece of red ocher 2 inches long and a half-inch thick. Many of the flakes appeared to have been heat treated. Other than the $30-\mathrm{cm}$ plowzone, the only disturbances observed in any of the shovel tests were gopher holes at 20-30 cmbs in ST 22, and $30-40 \mathrm{cmbs}$ in ST 16.

\section{Conclusions/Recommendations}

This site has been classified as a historic trash scatter and prehistoric open campsite. However, CAS only observed a single historic item, the iron stove piece mentioned above. No other historic items have been observed on the surface or found in any of the multitude of shovel tests dug on and around the site. Based on the limited results of six shovel tests conducted by TXMF and CAR in 1997 and 2001, the site was recommended as not eligible for nomination to the NRHP (Mauldin 2001:176-179). However, with the additional data obtained during the current project, CAS believes that a recommendation for eligibility to the NRHP should be further evaluated for the prehistoric component. The recovery of burned rocks, a charred nut shell, ocher, and flakes suggests there may be intact features, additional preserved organic material, and associated artifacts well below any level of obvious disturbance (40 cmbs). To verify that, levels of effort beyond the scope of this inventory survey are required before CAS can make any NRHP eligibility recommendation for the prehistoric component of this site. Five 1-x1-m units should be excavated on this site: one each in the immediate areas of STs 1 and 10, one in the area of ST 5, one in the area of ST 25, and one in the area of ST E14.

\section{BP494}

\section{Description}

41BP494 is a lithic scatter on a low knoll and sideslope in a wooded upland area (Figures 6-45 and 6-46). It is buried over a $10,087-\mathrm{m}^{2}$ area in Patilo complex sand (Pa) soils. The surface slopes gently from 491 to $475 \mathrm{ft}$ amsl, and is covered with large oak, elm, and cedar trees, with vines and grass understory. An intermittent tributary of Big Sandy Creek is $110 \mathrm{~m}$ to the west. Obvious surface disturbances include tree falls and an occasional animal burrow. Surface visibility was less than five percent in July 2005. The site datum is an oak tree marked with a nail and aluminum tag.

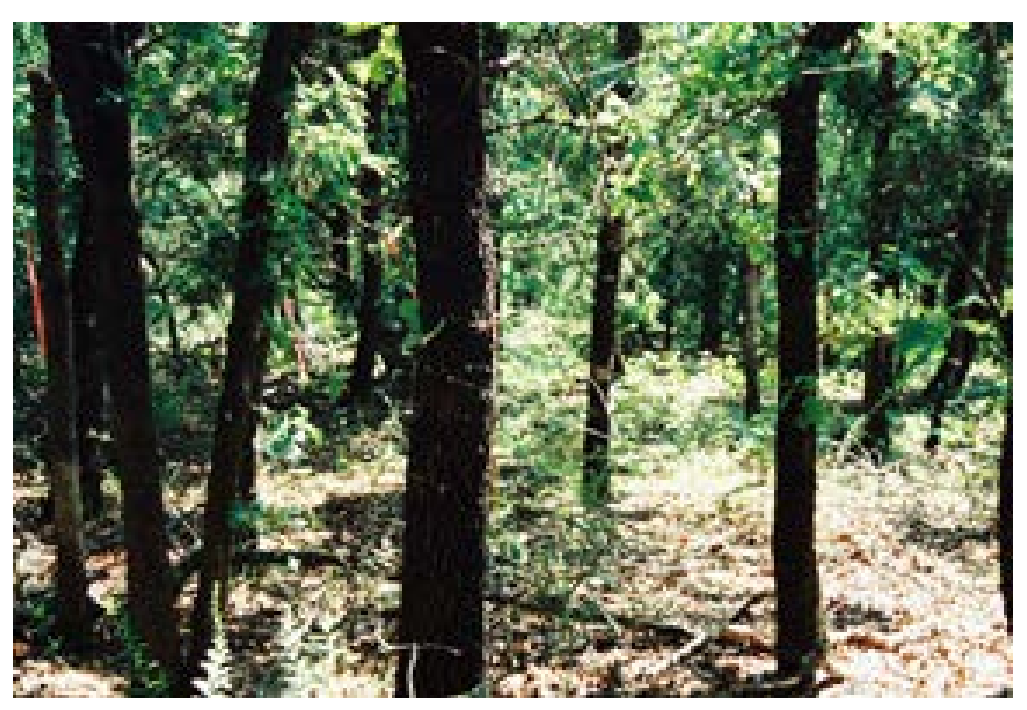

Figure 6-45. A scatter of flakes and heat spalls make up the lithic assemblage at 41BP494; facing northeast. 


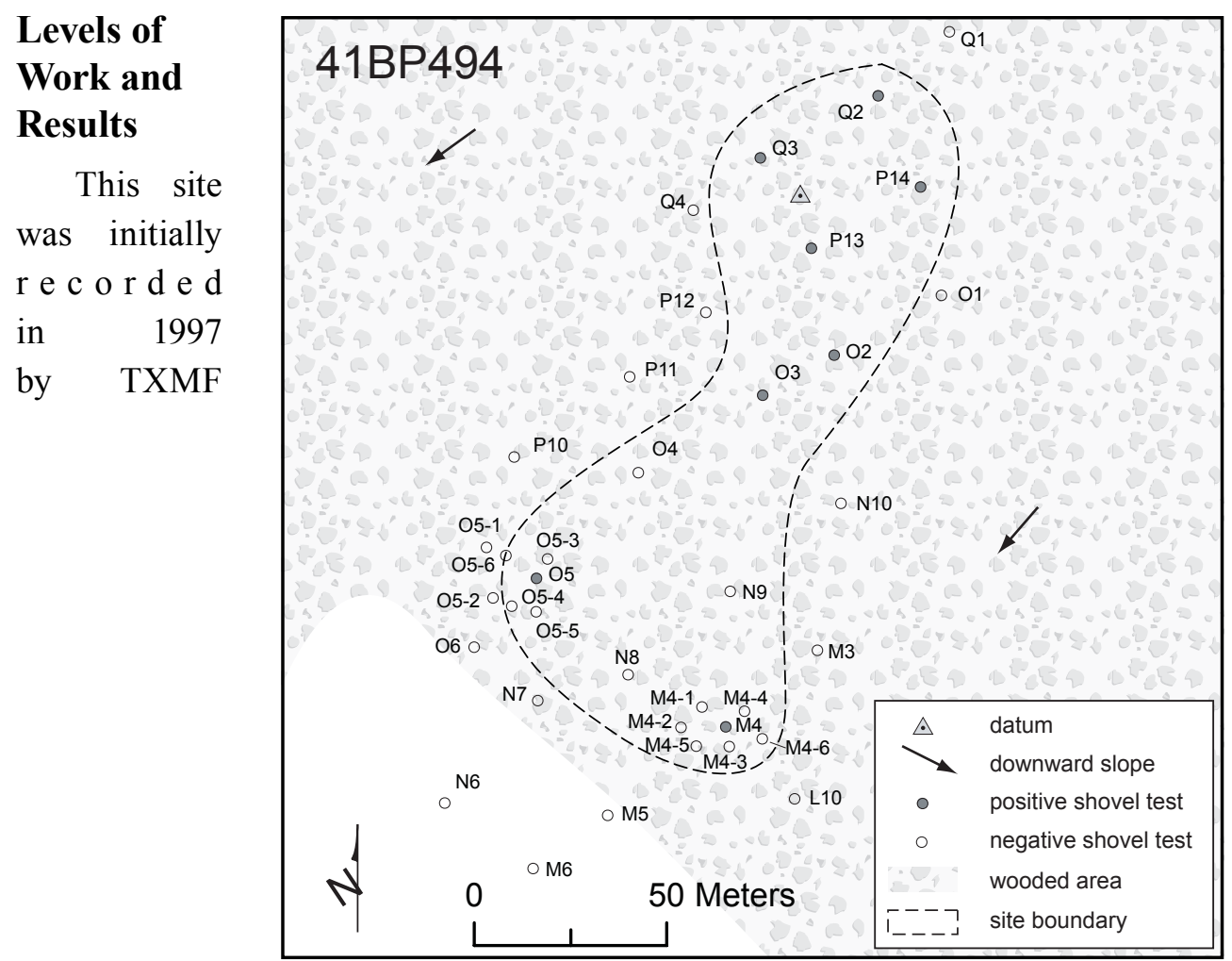

Figure 6-46. Site map of 41BP494.

Table 6-13. 41BP494 positive shovel test results.

\begin{tabular}{|c|c|c|c|c|c|c|c|c|}
\hline $\begin{array}{l}\text { Depth } \\
\text { (cmbs) }\end{array}$ & ST M4 & ST 02 & ST O3 & ST 05 & ST P13 & ST P14 & ST Q2 & ST Q3 \\
\hline $0-10$ & & & HS & IF & & IF & & \\
\hline $10-20$ & $\mathrm{EF}$ & & HS & & & $2 \mathrm{IF}$ & IF & IF \\
\hline $20-30$ & & & & & IF & IF & & \\
\hline $30-40$ & & & & & & $2 \mathrm{IF}$ & & \\
\hline $40-50$ & & IF & & Clay & & IF & & \\
\hline \multicolumn{9}{|l|}{$50-60$} \\
\hline $60-70$ & & & & & & & & IF \\
\hline $70-80$ & Sand & Sand & & & Clay & Sand & & \\
\hline $80-90$ & & & Sand & & & & Sand & Sand \\
\hline $90-100$ & & & & & & & & \\
\hline & & y: HS- & pall; E & xterior $\mathrm{f}$ & re; IF-int & or flake & & \\
\hline
\end{tabular}

archaeologists (Haslouer-Kay et al. 1997). They reported seeing one flake on the surface and found two flakes in two of three shovel tests. In July 2005, CAS archaeologists relocated the site, found no cultural materials on the surface, but recovered two heat spalls and 14 flakes from eight positive shovel tests out of 20 excavated on the site (Table 6-13). Because of the dense woods, roots were commonly encountered in all shovel tests throughout the site. 


\section{Conclusions/Recommendations}

The sands at this site are deep, lithic debitage is generally at shallow depths, and there is an absence of features and/or evidence of organic preservation, all of which indicate that the site has little potential to yield significant scientific data. Therefore, CAS concurs with Mauldin (2001) and recommends that no further work is warranted at this site and it is not eligible for nomination to the NRHP. 


\title{
Chapter 7
}

\section{New Prehistoric Component Sites}

\author{
By David L. Nickels, D. Emory Worrell and C. Britt Bousman
}

\section{INTRODUCTION}

Eightly-seven new prehistoric components were discovered during the current project. Thirtytwo of these sites have great enough integrity to warrant further investigations in order to estabish their eligibility for listing on the NRHP and their eligibility is classified as "Unknown." The remaining 55 components are so poorly

Table 7-1. Summary of new prehistoric components and National Register of Historic Places eligibility recommendations.

\begin{tabular}{|c|c|c|c|c|c|}
\hline Site & $\begin{array}{c}\text { NRHP } \\
\text { Eligibility }\end{array}$ & Site & $\begin{array}{c}\text { NRHP } \\
\text { Eligibility }\end{array}$ & Site & $\begin{array}{c}\text { NRHP } \\
\text { Eligibility }\end{array}$ \\
\hline 41BP534 & Unkown & 41BP730 & Not Elibible & 41BP765 & Unkown \\
\hline 41BP695 & Not Elibible & 41BP731 & Unkown & 41BP766 & Unkown \\
\hline 41BP696 & Unkown & 41BP732 & Not Elibible & 41BP768 & Not Elibible \\
\hline 41BP697 & Not Elibible & 41BP733 & Unkown & 41BP769 & Not Elibible \\
\hline 41BP699 & Not Elibible & 41BP734 & Not Elibible & 41BP770 & Not Elibible \\
\hline 41BP702 & Not Elibible & 41BP736 & Not Elibible & 41BP772 & Not Elibible \\
\hline 41BP704 & Unkown & 41BP737 & Not Elibible & 41BP774 & Not Elibible \\
\hline 41BP705 & Not Elibible & 41BP738 & Not Elibible & 41BP776 & Unkown \\
\hline 41BP706 & Unkown & 41BP739 & Not Elibible & 41BP777 & Not Elibible \\
\hline 41BP707 & Not Elibible & 41BP740 & Unkown & 41BP778 & Unkown \\
\hline 41BP708 & Not Elibible & 41BP742 & Not Elibible & 41BP779 & Not Elibible \\
\hline 41BP709 & Not Elibible & 41BP743 & Unkown & 41BP780 & Unkown \\
\hline 41BP710 & Not Elibible & 41BP744 & Not Elibible & 41BP781 & Not Elibible \\
\hline 41BP713 & Unkown & 41BP745 & Not Elibible & 41BP783 & Not Elibible \\
\hline 41BP714 & Unkown & 41BP747 & Unkown & 41BP784 & Not Elibible \\
\hline 41BP715 & Not Elibible & 41BP748 & Not Elibible & 41BP786 & Not Elibible \\
\hline 41BP716 & Unkown & 41BР749 & Not Elibible & 41BP787 & Unkown \\
\hline 41BP717 & Unkown & 41BP750 & Not Elibible & 41BP788 & Not Elibible \\
\hline 41BP718 & Unkown & 41BP753 & Unkown & 41BP789 & Not Elibible \\
\hline 41BP719 & Not Elibible & 41BP754 & Unkown & 41BP790 & Not Elibible \\
\hline 41BP720 & Unkown & 41BP755 & Not Elibible & 41BP792 & Unkown \\
\hline 41BP721 & Not Elibible & 41BP756 & Not Elibible & 41BP796 & Not Elibible \\
\hline 41BP722 & Not Elibible & 41BP757 & Not Elibible & 41BP797 & Not Elibible \\
\hline 41BP723 & Not Elibible & 41BP758 & Not Elibible & 41BP798 & Not Elibible \\
\hline 41BP724 & Unkown & 41BP759 & Unkown & 41BP799 & Not Elibible \\
\hline 41BP725 & Unkown & 41BP761 & Unkown & 41BP800 & Not Elibible \\
\hline 41BP726 & Unkown & 41BP762 & Not Elibible & 41BP801 & Unkown \\
\hline 41BP727 & Unkown & 41BP763 & Not Elibible & 41BP802 & Unkown \\
\hline 41BP728 & Not Elibible & 41BP764 & Not Elibible & 41BP804 & Not Elibible \\
\hline
\end{tabular}


preserved, have such limited artifact assemblages, or fail to provide evidnece that artifacts or features are preservered in a good geological context, that these sites are considered "Not Eligible" for listing in the NRHP.

\section{BP534}

\section{Description}

41BP534 (Figures 7-1 and

7-2) is a large prehistoric open campsite spanning over 22,797

$\mathrm{m}^{2}$ of upland and sideslope terrain features that range in elevation from 465 to 432 $\mathrm{ft}$ amsl. It also includes the remains of a historic sandstone foundation and historic artifact scatter. The historic component is discussed in Chapter 9: New Historic Component Sites. The prehistoric component's southern and eastern portions extend into heavily wooded areas, while its northern and western portions lie in a cleared field previously used for farming. With the recovery of fire-cracked rocks and lithic debitage, CAS categorizes the prehistoric component as an open campsite.

Spring Branch, the only constantly flowing creek on Camp Swift, is $140 \mathrm{~m}$ to the

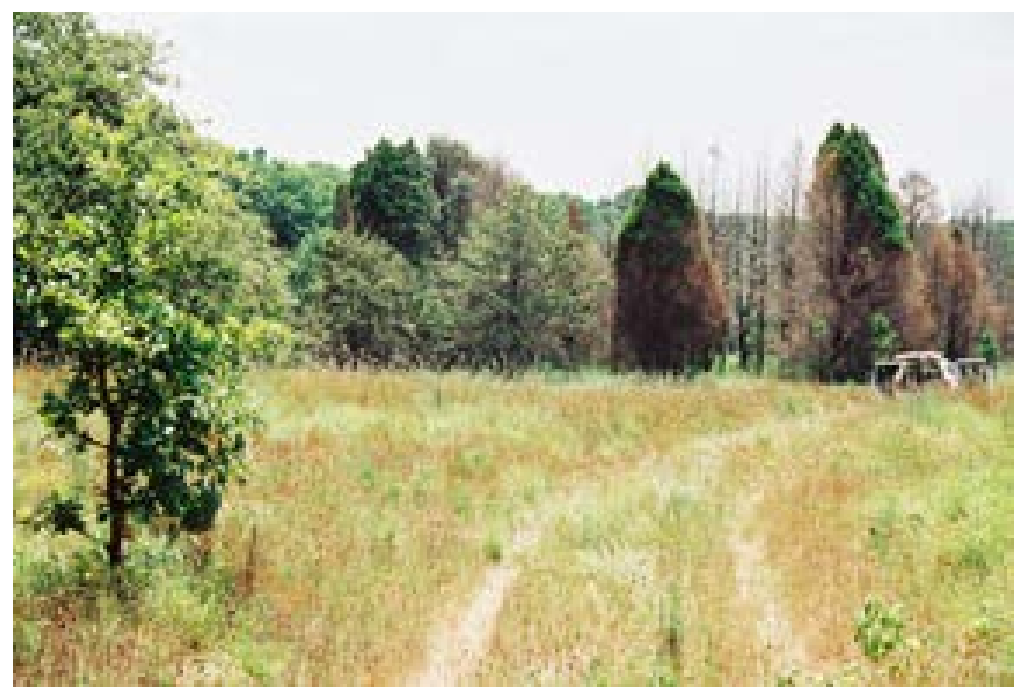

Figure 7-1. 41BP534 lies on a cleared field in an upland and wooded sideslope area; facing southeast.

FIGURE 7-2. REDACTED

Figure 7-2. Site map of 41BP534. northeast. Soil across the entire push pile, and an occasional uprooted tree in the site is Patilo complex fine sand (PaE). Surface disturbances observed in 2005 included gopher burrows, a jeep trail, deep ruts in a hummocky surface in the open field with a bladed road and wooded areas. Surface visibility was less than five percent in most areas. The datum is marked by a nail and aluminum tag in a large oak tree in the northern portion of the site. 


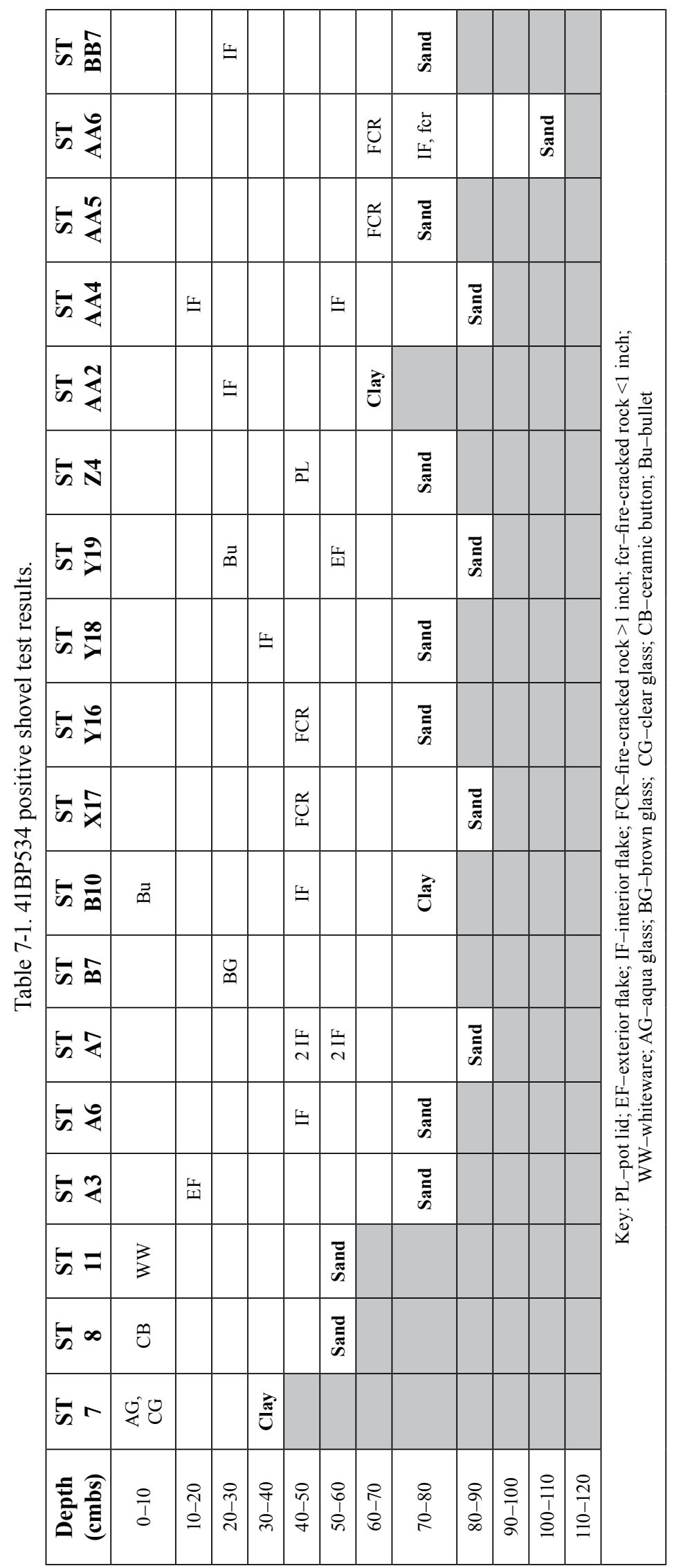




\section{Levels of Work and Results}

The historic component of this site was initially documented in 1997 (Wormser et al. 1997). The prehistoric component was discovered during excavation of systematic transect shovel tests in 2005. No prehistoric artifacts were observed on the surface. Of the 29 shovel tests placed on the site, prehistoric cultural material was recovered from 14 of the 18 positive shovel tests and included 13 flakes, five fire-cracked rocks, and a potlid (Table 7-1). Disturbances included two bullets recovered between 0 and $30 \mathrm{cmbs}$ (STs B10 and Y19), and more compact sands noted below $30 \mathrm{cmbs}$, which corroborate a probable plow zone assumption in the open field.

\section{Conclusions/Recommendations}

Although lithic debitage and fire-cracked rock were recovered below a probable plow zone in shovel tests in the open field area, heavy equipment training and the construction of a jeep road have negatively impacted that area. However, the wooded portion of the site appears to be relatively undisturbed. Specifically, the presence of fire-cracked rocks in STs AA5 and AA6 between 60 and $80 \mathrm{cmbs}$ suggests the possibility of a stratified cultural zone and buried intact hearth features in those immediate areas. Such buried intact cultural deposits have the potential to yield significant information about the paleoenvironment, as well as past human subsistence and mobility patterns. Thus, the research value of the prehistoric component of this site is unknown, and further investigations beyond the scope of an inventory survey are required before a recommendation regarding nomination to the NRHP can be made. At a minimum, CAS recommends that two 1-x-1-m units be excavated on this site, one each in the immediate areas of STs AA5 and AA6.

\section{BP695}

\section{Description}

41BP695 (Figures 7-3 and 7-4) is composed of a prehistoric component adjacent to a historic farmstead. With the recovery of only lithic debitage and no other cultural material, CAS categorizes the prehistoric component as a lithic scatter. The historic component is discussed in Chapter 9: New Historic Component Sites. The entire site covers approximately $4,415 \mathrm{~m}^{2}$ and ranges in elevation from 460 to $440 \mathrm{ft}$ amsl, while the approximately $500-\mathrm{m}^{2}$ prehistoric component makes up the lower, eastern portion of the site. The prehistoric component area is situated on a wooded sideslope above an intermittent first order tributary of Big Sandy Creek. Demona loamy fine sand (DeC) supports predominantly large oak and cedar trees. The prehistoric component area has not been cleared of vegetation and appears to be relatively undisturbed. Surface disturbances observed included small rodent burrows, and an occasional uprooted tree. Surface visibility was

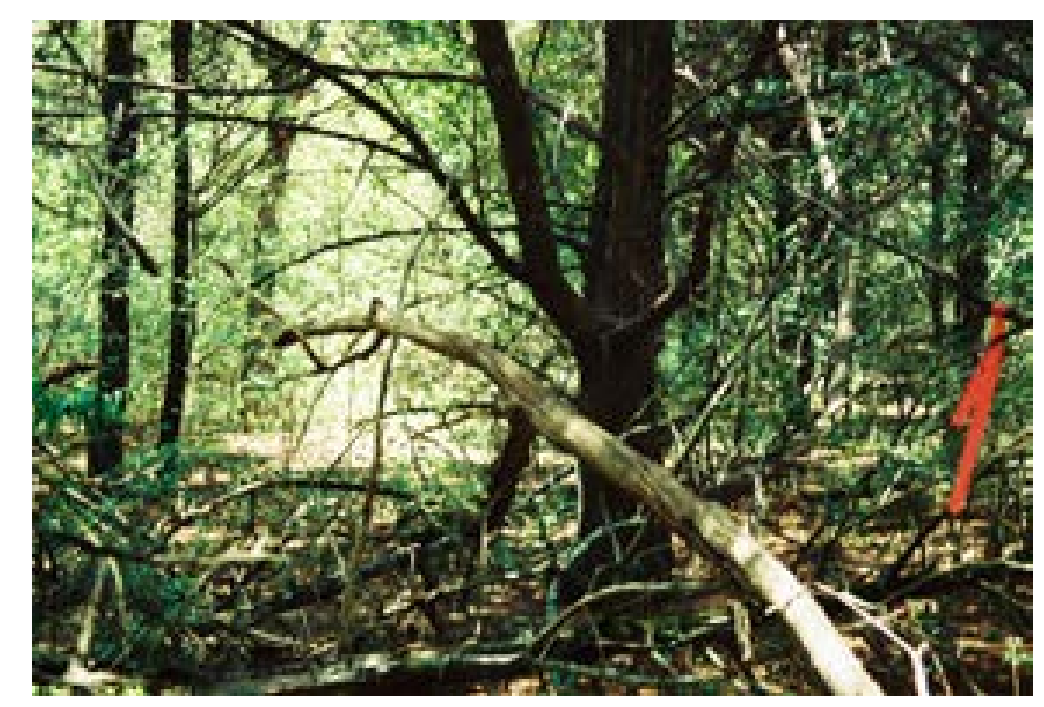

Figure 7-3. 41BP695 lies on a heavily wooded sideslope; facing southeast. 
less than five percent in July 2005.

\section{Levels of Work and Results}

No artifacts or features were observed on the surface, and this site was discovered during systematic excavation of shovel tests (see Figure 7-3). A total of nine shovel tests were dug FIGURE 7-4. REDACTED

within the site's boundaries, of which eight were positive. STs 4-10 focused on the prehistoric component area (see Figure 74). Only three of the shovel test probes contained prehistoric artifacts. A chert chip and three interior chert flakes were recovered from STs 6, 9, and C2 (Table 7-2). Numerous roots were encountered in all shovel tests Figure 7-4. Site map of 41BP695. in the prehistoric component

Table 7-2. 41BP695 positive shovel test results.

\begin{tabular}{|c|c|c|c|c|c|c|c|c|}
\hline $\begin{array}{l}\text { Depth } \\
\text { (cmbs) }\end{array}$ & ST 1 & ST 3 & ST 6 & ST 9 & ST C2 & ST D13 & ST E2 & ST E3 \\
\hline $0-10$ & & & & & & $\mathrm{M}$ & WW, CG & \\
\hline $10-20$ & & & IF & & IF & WW & CG & CG \\
\hline $20-30$ & & $\mathrm{CG}$ & & IF & & $\mathrm{CG}, \mathrm{M}$ & $\mathrm{CG}$ & \\
\hline $30-40$ & CG & & & & & & $\mathrm{R}$ & \\
\hline $40-50$ & & CG & & & $\mathrm{CC}$ & & & \\
\hline $50-60$ & & WW, CG, M, RW & & & & & & \\
\hline $60-70$ & & $\mathrm{AG}, \mathrm{CG}, \mathrm{M}$ & & & & & & \\
\hline $70-80$ & CG & $\begin{array}{l}\text { WW, AG, } \\
\text { CG, M, SN }\end{array}$ & Sand & Sand & Sand & Sand & Sand & Sand \\
\hline $80-90$ & CG & $\begin{array}{c}\text { AG, AqG, BG, } \\
\text { CG, M, SN }\end{array}$ & & & & & & \\
\hline $90-100$ & & $\mathrm{CG}, \mathrm{M}$ & & & & & & \\
\hline $100-110$ & Sand & & & & & & & \\
\hline $110-120$ & & Sand & & & & & & \\
\hline $120-130$ & & & & & & & & \\
\hline
\end{tabular}


area, and angular ironstone and sandstone found in STs 6 and 9 suggests that the artifacts were within colluvial deposits. The site datum is marked by a nail and aluminum tag on a $40-\mathrm{cm}$ diameter cedar tree.

\section{Conclusions/ Recommendations}

CAS's estimation is that the prehistoric component of this site has been disturbed due to a complex root system and a colluvial deposition history. Therefore, its research value is minimal, CAS recommends that no further work is warranted for the prehistoric component at this site, and it is not eligible for nomination to the NRHP.

\section{BP696}

\section{Description}

\section{BP696 (Figures 7-}

5 and 7-6) is the largest prehistoric open campsite thus fardocumented on Camp Swift, spanning over 43,248 $\mathrm{m}^{2}$ of upland and sideslope terrain features, and ranging in elevation from 450 to 420 $\mathrm{ft}$ amsl. Its northern and southern portions extend into heavily wooded areas, while its middle portion lies in a cleared field previously used for farming and heavy equipment training. Big Sandy Creek flows along its southern edge, and its southeastern node is at the confluence of Big Sandy Creek and one of its

first order tributaries. Patilo complex fine sand $(\mathrm{PaE})$ generally underlies the old field and northern woodlands areas, while Demona loamy fine sand 


\begin{tabular}{|c|c|c|c|c|c|c|c|c|c|c|c|c|c|c|c|c|c|c|c|c|c|c|c|c|c|c|}
\hline $\sin \frac{\pi}{4}$ & & & & & & 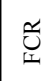 & & & 旋 & & & & & & & & & & & & & & & & & \\
\hline $5 \frac{m}{4}$ & & & & & & $\Xi$ & $\Xi$ & & \pm & & 宸 & & 的 & & & & & $\Xi$ & & & 赔 & & & & & \\
\hline $\sin \frac{7}{4}$ & & & & 茴 & 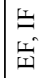 & 丰 & & $\frac{5}{1}$ & 莡 & 莡 & & 离 & 包果 & \pm & & & & & & & 墕 & & & & & \\
\hline $\bar{s} \bar{z}$ & $\stackrel{\Xi}{\sim}$ & \pm & \pm & & \pm & & & 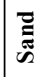 & & & & & 的兄 & & & & & & 里 & & 蔍 & & & & & \\
\hline $\sin ^{\infty}$ & & \pm & & & & 胥 & & & 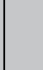 & . & & 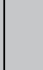 & 战士 & & & & & & 些总 & & & 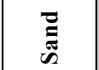 & & & & \\
\hline 公事 & \pm & & \pm & 岀 & 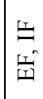 & 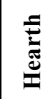 & & & 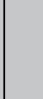 & & & & 频 & 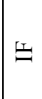 & & & & & 丰 & & & 薝 & & & & \\
\hline 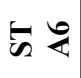 & & & & & & $\begin{array}{l}\text { 㱟 } \\
\text { s. }\end{array}$ & $\Xi$ & 就 & & & & & 的弐 & & \pm & & & & $\Xi$ & & $\begin{array}{l}\bar{E} \\
\tilde{E} \\
\tilde{n}\end{array}$ & & & & & \\
\hline $\sin 2$ & & \pm & & \pm & & & $\frac{\vec{Z}}{\tilde{U}}$ & & & & & & 频 & & \pm & & & & 总 & & & & 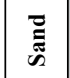 & & & \\
\hline $\tan$ & & & 诘 & & & $\begin{array}{l}\text { f̂ } \\
\text { I } \\
\text { m }\end{array}$ & & 薝 & & & & & 的照 & & \pm & & & Oי & & & $\begin{array}{l}\bar{E} \\
\tilde{n} \\
\mathscr{n}\end{array}$ & & & & & \\
\hline $\bar{\theta} \approx$ & & & $\Xi$ & & 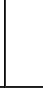 & 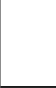 & & 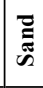 & & & & & 跧獣 & & & $\ddot{\underline{a}}$ & $\Sigma$ & & & & 部 & & & & & \\
\hline $\sin$ & & 出 & & \pm & & & & 赔 & & & & & 数 & \pm & & & & & & & 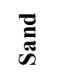 & & & & & \\
\hline$\dot{\omega} \approx$ & \pm & & & & & & & 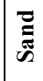 & & & & & 药 $\stackrel{\infty}{\circ}$ & & \pm & & & $\vec{c}$ & & & & 薝 & & & & \\
\hline $\bar{n} \approx$ & & $\Phi$ & & $\Phi$ & & $\Xi$ & $\Xi$ & & 薝 & & & & 的余 & & & & $\Phi$ & $\stackrel{\mid \vec{v}}{\sim}$ & 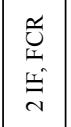 & 些总 & 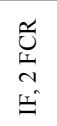 & 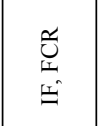 & 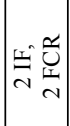 & 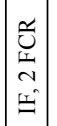 & 芯 & \\
\hline $\bar{v}_{\infty} \infty$ & & & & \pm & & & & 颉 & & & & & 频 & & & & 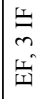 & 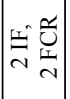 & 象茔 & 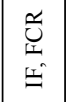 & $\begin{array}{l}\overrightarrow{\vec{c}} \\
\stackrel{4}{=}\end{array}$ & 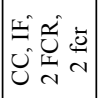 & 吆 & $\ddot{3}$ & 吾 & \\
\hline $\bar{\infty}=$ & & \pm & & & & & $\Xi$ & \pm & O & & 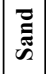 & & 的 & & $\Xi$ & & & & & & 墕 & & & & & \\
\hline $\bar{n}_{2} \cong$ & & & & & & తే & 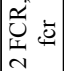 & & 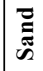 & & & & 战 & & & & & 土 & & & $\begin{array}{l}\bar{E} \\
\text { D̆ }\end{array}$ & & & & & \\
\hline $\bar{n}=$ & & & & & & & 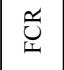 & & & $\begin{array}{l}\text { E. } \\
\text { कू⿹ }\end{array}$ & & & 觇 さ & & & 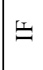 & & & $n$ & & $\frac{\vec{\pi}}{\tilde{U}}$ & & & & & \\
\hline $\bar{n}_{\infty} \infty$ & & ш & & & & 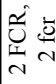 & & & 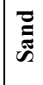 & & & & 的金 & 岌 & & & & 尊 & & & & & & & & \\
\hline 步 0 & & 里 & & & & & & $\begin{array}{l}\bar{E} \\
\text { 荡 }\end{array}$ & & & & & 坫 & \pm & & & & 0 & $\vec{c}$ & 声 & ઘ & 总 & $\underset{\sim}{\stackrel{\Xi}{\sim}}$ & 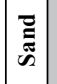 & & \\
\hline$\frac{5}{n}$ in & \pm & & & & & \pm & & & 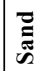 & & & & 阷 $\frac{0}{4}$ & & & 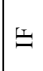 & & & & & & 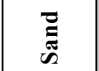 & & & & \\
\hline$\frac{1}{\infty}+$ & \pm & & & & & & & 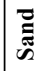 & & & & & $\sin \frac{\pi}{4}$ & & & & & & & ઘ & $\Xi$ & & $\stackrel{\vec{m}}{\mathrm{~d}}$ & & & \\
\hline 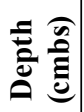 & $\frac{0}{1}$ & 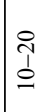 & 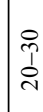 & $\begin{array}{l}\text { o } \\
\text { o } \\
0\end{array}$ & $\begin{array}{l}0 \\
\hat{p} \\
o \\
q\end{array}$ & $\begin{array}{l}8 \\
\vdots \\
0 \\
\text { in }\end{array}$ & $\begin{array}{l}2 \\
0 \\
0 \\
0\end{array}$ & $\begin{array}{l}0 \\
0 \\
0 \\
2\end{array}$ & $\begin{array}{l}8 \\
0 \\
0 \\
\infty\end{array}$ & $\begin{array}{l}\frac{8}{0} \\
\frac{1}{2} \\
2\end{array}$ & $\begin{array}{l}0 \\
\stackrel{1}{1} \\
0 \\
\varrho\end{array}$ & 疍 & 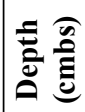 & $\frac{1}{0}$ & $\begin{array}{l}\stackrel{1}{1} \\
\stackrel{0}{=}\end{array}$ & $\begin{array}{l}\text { के } \\
\text { ते }\end{array}$ & $\begin{array}{l}\text { o } \\
9 \\
0\end{array}$ & $\begin{array}{l}0 \\
0 \\
o \\
q\end{array}$ & $\begin{array}{l}0 \\
0 \\
0 \\
\text { n }\end{array}$ & $\begin{array}{l}0 \\
i \\
0 \\
0\end{array}$ & 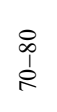 & $\begin{array}{l}\stackrel{0}{0} \\
\grave{1} \\
\infty\end{array}$ & 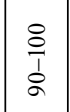 & 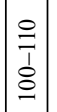 & $\begin{array}{l}\stackrel{9}{T} \\
\stackrel{0}{\Xi}\end{array}$ & 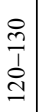 \\
\hline
\end{tabular}


(DeC) generally covers the southern wooded area. The woody vegetation is predominantly large oak and hickory trees, with tall grasses now covering the open field area. The open field was plowed for growing grapes and melons through 1941 (Abner Scott, personal communication January 2001). Disturbances observed in 2005 included a gravel road, deep ruts in a hummocky surface in the open field, with a bladed road and push pile, evidence of military foot training, and an occasional uprooted tree in the wooded areas. Surface visibility was less than five percent in most areas.

\section{Levels of Work and Results}

Although the only artifact observed on the surface was a fire-cracked rock, 41 shovel tests (out of 48 excavated on the site) contained numerous prehistoric artifacts, including 87 flakes, 43 firecracked rocks, three heat spalls, two chert chips, and one core. A hearth was encountered in ST A7 at 50-60 cmbs. Several test locations showed no obvious mixing or significant disturbances (Table 7-3). The exceptions are in STs E3 and E5, where a piece of metal and a green glass shard were found. The primary datum is marked by a nail and aluminum tag in a large oak tree in the southern portion of the site, and a secondary datum was similarly marked in a large oak in the northern portion of the site.

\section{Conclusions/ Recommendations}

The consistent recovery of fire-cracked rock, lithic debitage, and charcoal suggests there may be buried features and associated cultural material still intact in a stratified cultural occupation zone below $50 \mathrm{cmbs}$. In addition, a fire-cracked rock hearth was encountered in ST
A7. Such buried intact cultural deposits have the potential to yield significant information about the paleoenvironment, as well as about past human subsistence and mobility patterns. Thus, the research value of this site is unknown, and further investigations beyond the scope of an inventory survey are required before a recommendation can be made regarding eligibility for nomination to the NRHP. At a minimum, CAS recommends placement of a hand-excavated unit in the immediate area of ST A7, and excavation of a minimum of twelve additional 1-x-1-m units in the areas of STs 8, 11, 13, 15, A12, B6, D5, and D7.

\section{BP697}

\section{Description}

41BP697 (Figures 7-7 and 7-8) is a small (336 $\mathrm{m}^{2}$ ) lithic scatter located in a grassy field with scattered oak motts growing in Patilo complex fine sand $(\mathrm{PaE})$. The terrain gently slopes to the southwest, ranging in elevation from 463 to 460 ft amsl. An intermittent first order tributary of Big Sandy Creek lies $90 \mathrm{~m}$ to the southwest. No obvious disturbances were observed on the surface, and surface visibility was less than five percent in July 2005. The site datum is marked by

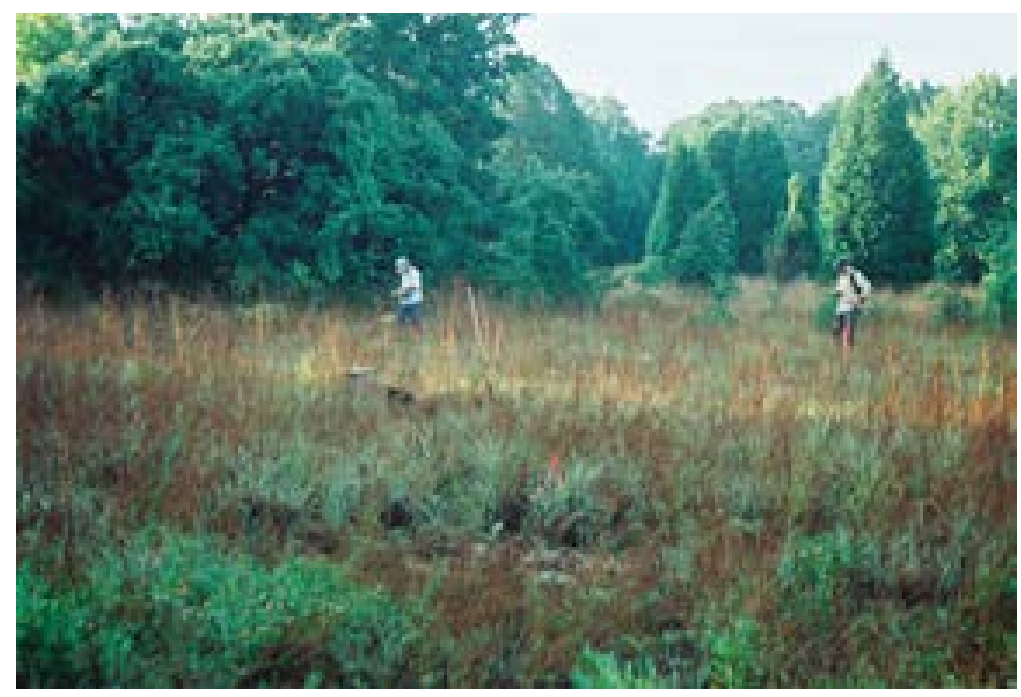

Figure 7-7. 41BP697 lies on a ridge end and sideslope; facing southeast. 


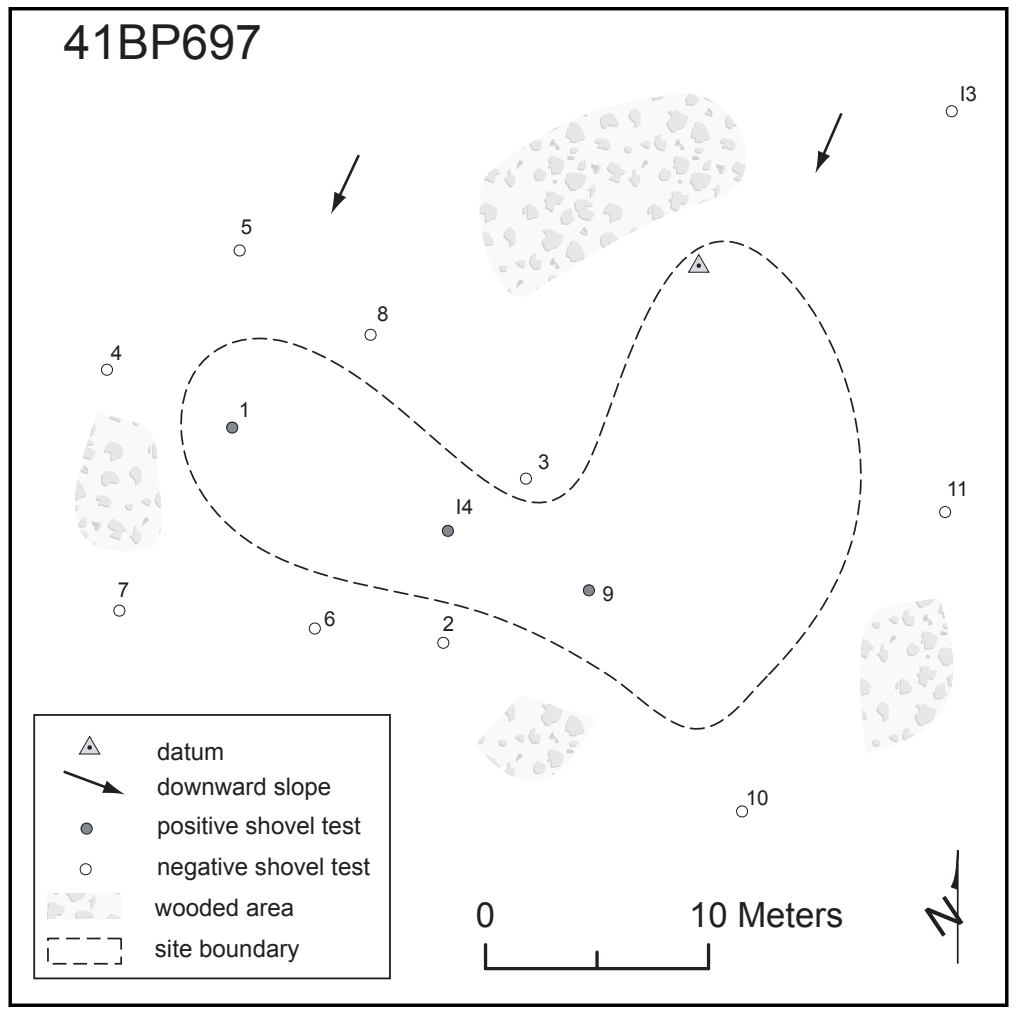

Figure 7-8. Site map of 41BP697.

a nail and aluminum tag on a $20-\mathrm{cm}$ oak tree.

\section{Levels of Work and Results}

A single positive transect shovel test led to the discovery of this site (see Figure 7-8). Although

Table 7-4. 41BP697 positive shovel test results.

\begin{tabular}{|c|c|c|c|}
\hline $\begin{array}{c}\text { Depth } \\
\text { (cmbs) }\end{array}$ & ST 1 & ST 9 & ST I4 \\
\hline $0-10$ & & & \\
\hline $10-20$ & & & \\
\hline $20-30$ & IF & & \\
\hline $30-40$ & & & \\
\hline $40-50$ & & & \\
\hline $50-60$ & & & IF \\
\hline $60-70$ & & EF & \\
\hline $70-80$ & Sand & & Sand \\
\hline $80-90$ & & Sand & \\
\hline $90-100$ & & & \\
\hline \multicolumn{2}{|c|}{ Key: EF-external flake; IF-interior flake } \\
\hline
\end{tabular}

additional shovel tests were placed on and around the site to determine its boundaries and to evaluate its integrity, the three shovel tests excavated within the site's boundaries (ST 1, ST 9, and transect ST I4) produced only three flakes (Table 7-4). Looser sand in the upper $30 \mathrm{cmbs}$ suggests that the field has been plowed. No artifacts or features were observed on the surface.

\section{Conclusions/ Recommendations}

This site appears to be an ephemeral lithic scatter with no evidence of fire-cracked rocks, faunal or organic preservation, or features. Therefore, its research value is minimal. CAS recommends that no further work be conducted and the site is not eligible for nomination to the NRHP.

\section{BP699}

\section{Description}

41BP699 (Figures 7-9 and 7-10) is a small $\left(393 \mathrm{~m}^{2}\right)$ lithic scatter embedded within Patilo complex fine sand (PaE). The semi-wooded grassland surface slopes gently from 442 to $440 \mathrm{ft}$ amsl, and is now covered with oak, hickory, pine and cedar trees, with dense grasses, yucca cacti, and grapevines. It is situated on a sideslope 240 $m$ north of Big Sandy Creek. Surface visibility was approximately 50 percent in July 2005. The immediate area has been disturbed by the blading of firebreak trails and controlled burning. In sharp contrast to the upper $28-30 \mathrm{cmbs}$, the sand below becomes crusty and compact, suggesting that the upper portion has been plowed. In addition, crushed gravels were found in ST 11 between 60 


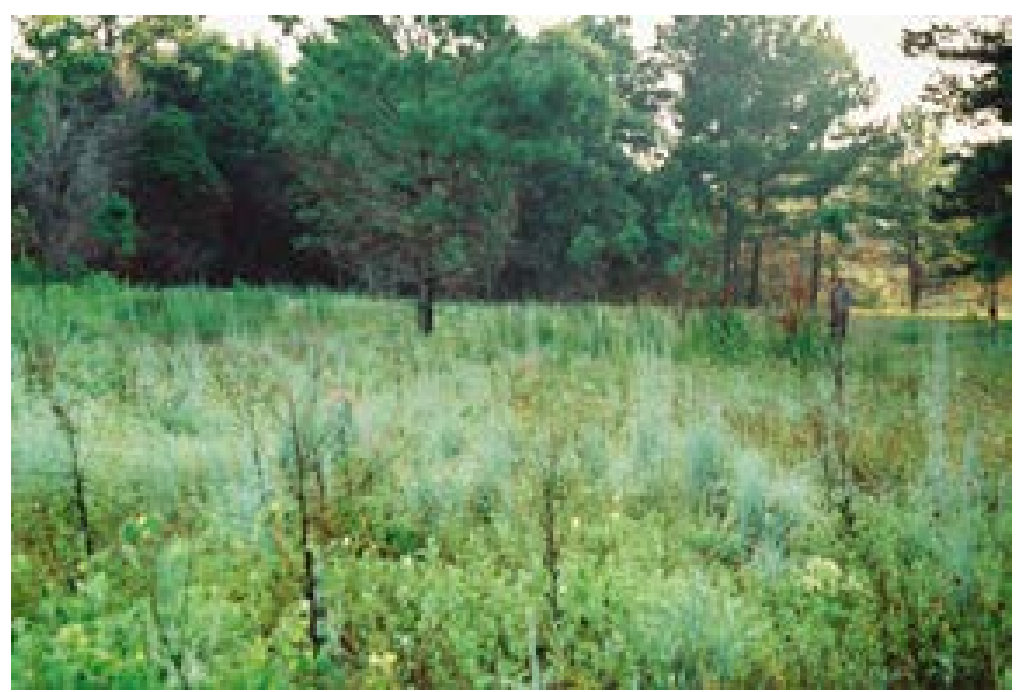

Figure 7-9. 41 BP699 lies on a semi-wooded sideslope; facing north.

\section{Conclusions/ Recommendations}

The paucity of cultural evidence recovered from shovel tests indicates that the site has little to contribute to the prehistory of the region. Therefore, as its research value is minimal, CAS recommends that no further work be conducted, and the site is not eligible for nomination to the NRHP.

\section{BP702}

\section{Description}

41BP702 (Figures 7-11 and 7-12) is 8,134 nail and aluminum tag on a pine tree $30 \mathrm{~cm}$ in diameter.

\section{Levels of Work and Results}

Despite the relatively high surface visibility, no artifacts or features were observed on the surface. The site was discovered during the excavation of Transect ST T3 (see Figure 7-10). Six flakes were recovered from four of the five shovel tests excavated on the site (Table 7-5).

FIGURE 7-10. REDACTED

Figure 7-10. Site map of 41BP699.

\begin{tabular}{|c|c|c|c|c|}
\hline $\begin{array}{c}\text { Depth } \\
\text { (cmbs) }\end{array}$ & ST 2 & ST 4 & ST 9 & ST T3 \\
\hline $0-10$ & & & IF & \\
\hline $10-20$ & & & IF & \\
\hline $20-30$ & & & IF & \\
\hline $30-40$ & & & & \\
\hline $40-50$ & & IF & & \\
\hline $50-60$ & EF & & & IF \\
\hline $60-70$ & & & & \\
\hline $70-80$ & Sand & Sand & Sand & \\
\hline $80-90$ & & & & Sand \\
\hline $90-100$ & & & & \\
\hline
\end{tabular}




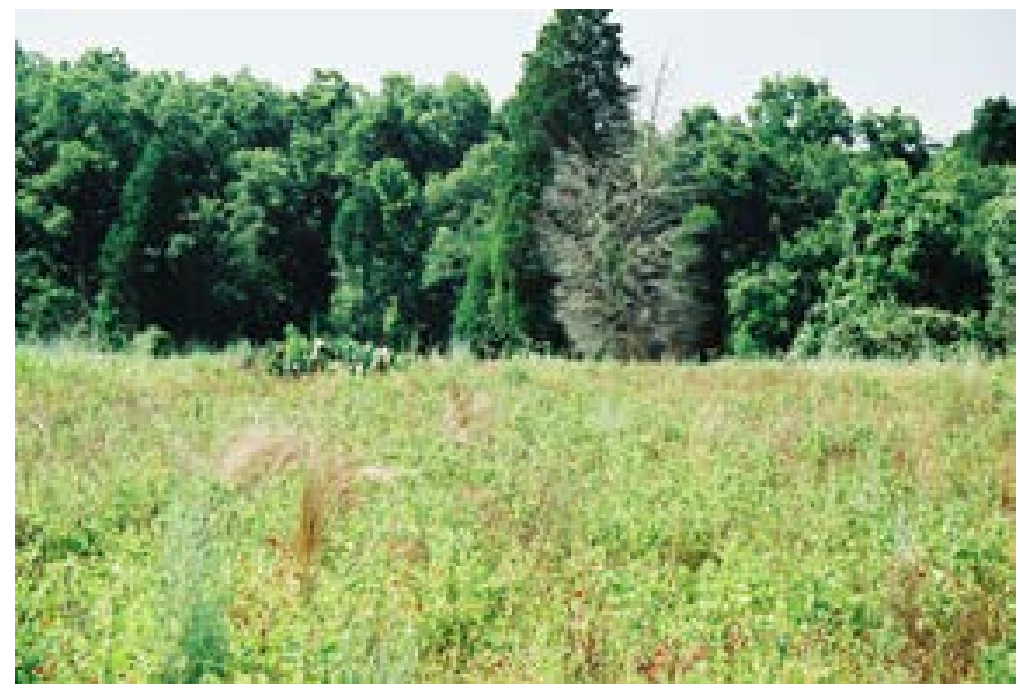

Figure 7-11. 41BP702 lies in an open field; facing south.

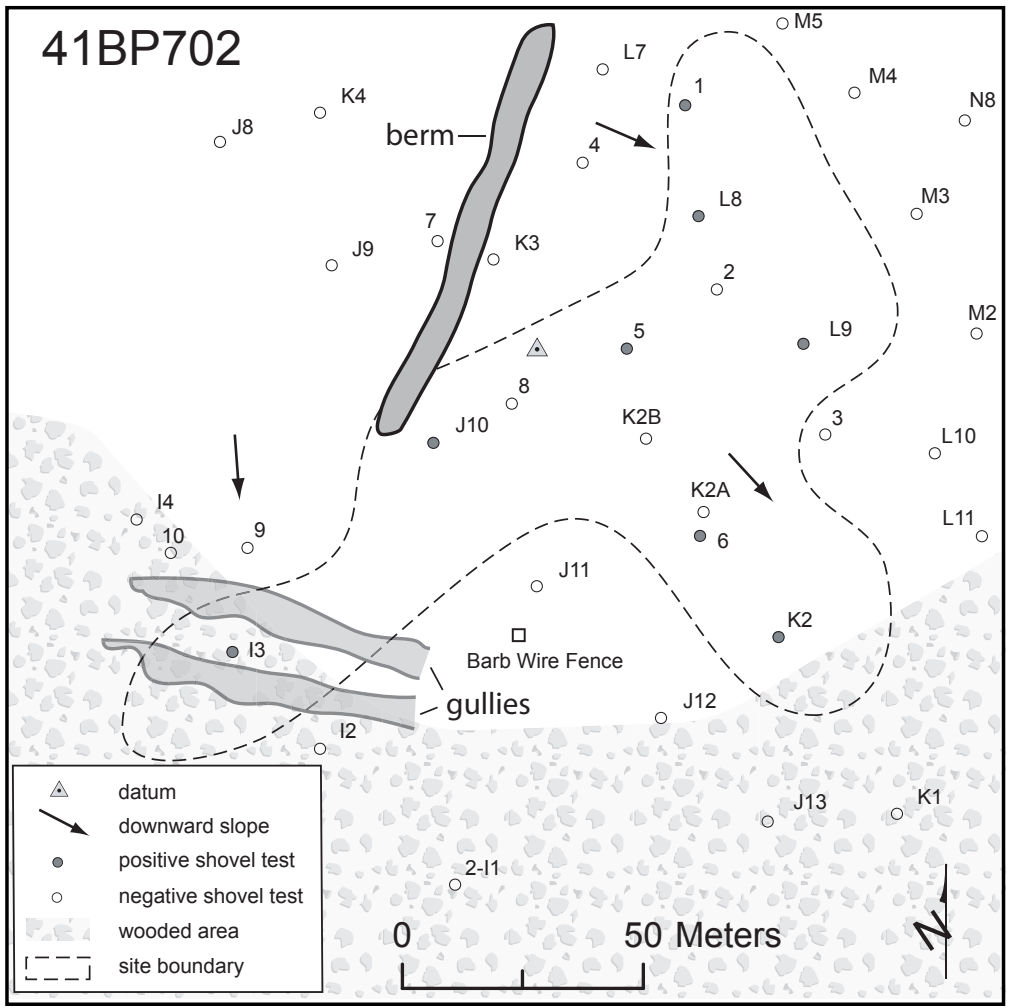

Figure 7-12. Site map of 41BP702.

documentation. Obvious surface disturbances include an artificial berm and eroded gullies (see Figure 7-12). As is discussed in the following paragraph, because it ranges in elevation from 436 to $415 \mathrm{ft}$ amsl, the cultural material has likely been displaced due to colluvial processes. The floodplain of Big Sandy Creek lies 50 meters south of the site. The site datum is marked with a nail and aluminum tag on an oak tree $10 \mathrm{~cm}$ in diameter. 
Table 7-6. 41BP702 positive shovel test results.

\begin{tabular}{|c|c|c|c|c|c|c|c|c|}
\hline $\begin{array}{l}\text { Depth } \\
\text { (cmbs) }\end{array}$ & ST 1 & ST 5 & ST 6 & ST I3 & ST J10 & ST K2 & ST L8 & ST L9 \\
\hline \multicolumn{9}{|l|}{$0-10$} \\
\hline $10-20$ & & 2 IF & & & & & & \\
\hline $20-30$ & IF & & & & & & IF & \\
\hline $30-40$ & & & IF & & & IF & $\mathrm{CC}$ & IF \\
\hline $40-50$ & IF & & Clay & $\begin{array}{l}\text { FCR, } \\
3 \mathrm{fcr}\end{array}$ & HS & & & \\
\hline $50-60$ & & $\mathrm{M}$ & & $3 \mathrm{fcr}$ & & & IF & IF \\
\hline $60-70$ & & & & $2 \mathrm{fcr}$ & & & & \\
\hline $70-80$ & Sand & Sand & & Sand & Sand & Sand & & Sand \\
\hline \multicolumn{9}{|l|}{$80-90$} \\
\hline $90-100$ & & & & & & & Sand & \\
\hline $100-110$ & & & & & & & & \\
\hline
\end{tabular}

\section{Levels of Work and Results}

No artifacts or features were observed on the surface. The site was discovered during systematic transect testing (see Figure 7-12). A total of ten flakes, one piece of fire-cracked rock $>1$ inch in size, eight pieces of fire-cracked rock $<1$ inch in size, a chert chip, and a heat spall were recovered from eight shovel tests out of 12 excavated within the site's boundaries (Table 7-6). Evidence of colluvial deposition in the form of coarse sand, angular ironstones, and fragmented pieces of petrified wood was observed in most shovel tests, and a piece of metal was found at 50 $60 \mathrm{cmbs}$ in ST 5.

\section{Conclusions/ Recommendations}

The preponderance of evidence suggests that this area has been used for heavy equipment training, which has negatively impacted the overall site integrity. In addition, colluvial processes have further negated any research value the site may have possessed. Therefore, CAS considers its research value to be minimal and recommends that no further work be conducted. The site is not eligible for nomination to the NRHP.

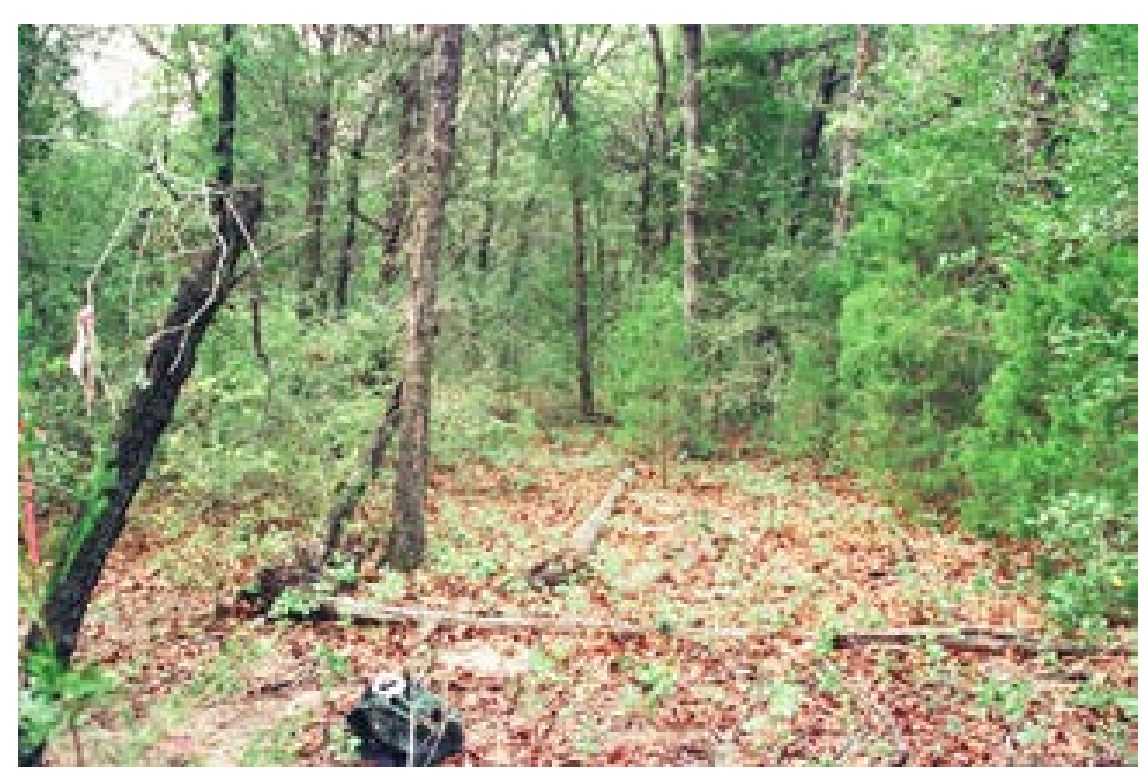

Figure 7-13. $41 \mathrm{BP} 704$ is an open campsite on a sideslope; facing south. 


\begin{abstract}
41BP704
Description

41BP704 is an open campsite on a wooded sideslope $800 \mathrm{~m}$ east of Big Sandy Creek (Figures 7-13 and 7-14). The site covers $507 \mathrm{~m}^{2}$ and ranges in elevation from 500 to $502 \mathrm{ft}$ amsl. Mature oaks and cedars thrive in Patilo complex fine sand (PaE). Surface visibility was less than five percent in May 2006. The only obvious surface disturbances were a few rodent burrows. The site datum is marked with a nail and aluminum tag on an oak tree $28 \mathrm{~cm}$ in diameter.
\end{abstract}

\section{Levels of Work and Results}

No artifacts or features were observed on the surface, but the site was discovered when a flake was found in Transect ST AA3 between 0 and $10 \mathrm{cmbs}$ (see Figure 7-14). The five shovel tests excavated on the site were all positive and contained a total of nine flakes, four pieces of red ochre $<1$ inch in size, a small burned rock $<1$ inch in size, and a small chunk of charcoal (Table 7-7). The only evidence of possible subsurface disturbance was in the form of an occasional root.

\section{Conclusions/Recommendations}

Although no features were encountered, the presence of a small fire-cracked rock and a charcoal chunk suggest that intact burned rock features with datable organic material could exist below the surface. The charcoal and fire-cracked rock were recovered in stratigraphic context with flakes and ocher between 40 and $60 \mathrm{cmbs}$. Based on these data, CAS cannot recommend NRHP nomination eligibility without further investigations beyond the scope of this inventory survey. Therefore, CAS recommends excavation of two 1-x-1-m units in the immediate areas of ST 1 and ST 2.

Table 7-7. 41BP704 positive shovel test results.

\begin{tabular}{|c|c|c|c|c|c|}
\hline $\begin{array}{c}\text { Depth } \\
\text { (cmbs) }\end{array}$ & $\begin{array}{c}\text { ST } \\
\mathbf{1}\end{array}$ & $\begin{array}{c}\text { ST } \\
\mathbf{2}\end{array}$ & $\begin{array}{c}\text { ST } \\
\mathbf{7}\end{array}$ & $\begin{array}{c}\text { ST } \\
\mathbf{8}\end{array}$ & $\begin{array}{c}\text { ST } \\
\text { AA3 }\end{array}$ \\
\hline $0-10$ & & & & IF & IF \\
\hline $10-20$ & & & & EF & \\
\hline $20-30$ & IF & & & & \\
\hline $30-40$ & & & & & \\
\hline $40-50$ & IF, O & $\begin{array}{c}2 \text { EF, } \\
\text { fcr }\end{array}$ & & & \\
\hline $50-60$ & EF & & $\begin{array}{c}\text { IF, } \\
\text { Ch }\end{array}$ & & \\
\hline $60-70$ & Clay & & & & \\
\hline $70-80$ & & Clay & Sand & Sand & Sand \\
\hline $80-90$ & & & & & \\
\hline \multicolumn{2}{|l|}{$\begin{array}{l}\text { Key: fcr-fire-cracked rock<1 inch; EF-exterior } \\
\text { flake; IF-interior flake; Ch-charcoal; O-ocher }\end{array}$} \\
\hline
\end{tabular}




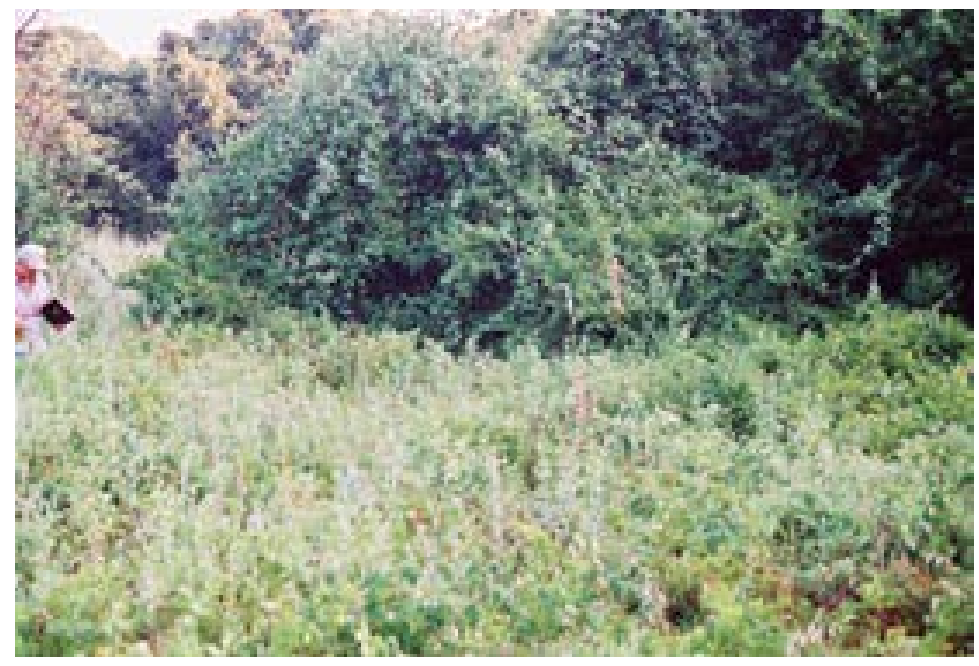

Figure 7-15. 41BP705 lies on a grassy sideslope; facing north.

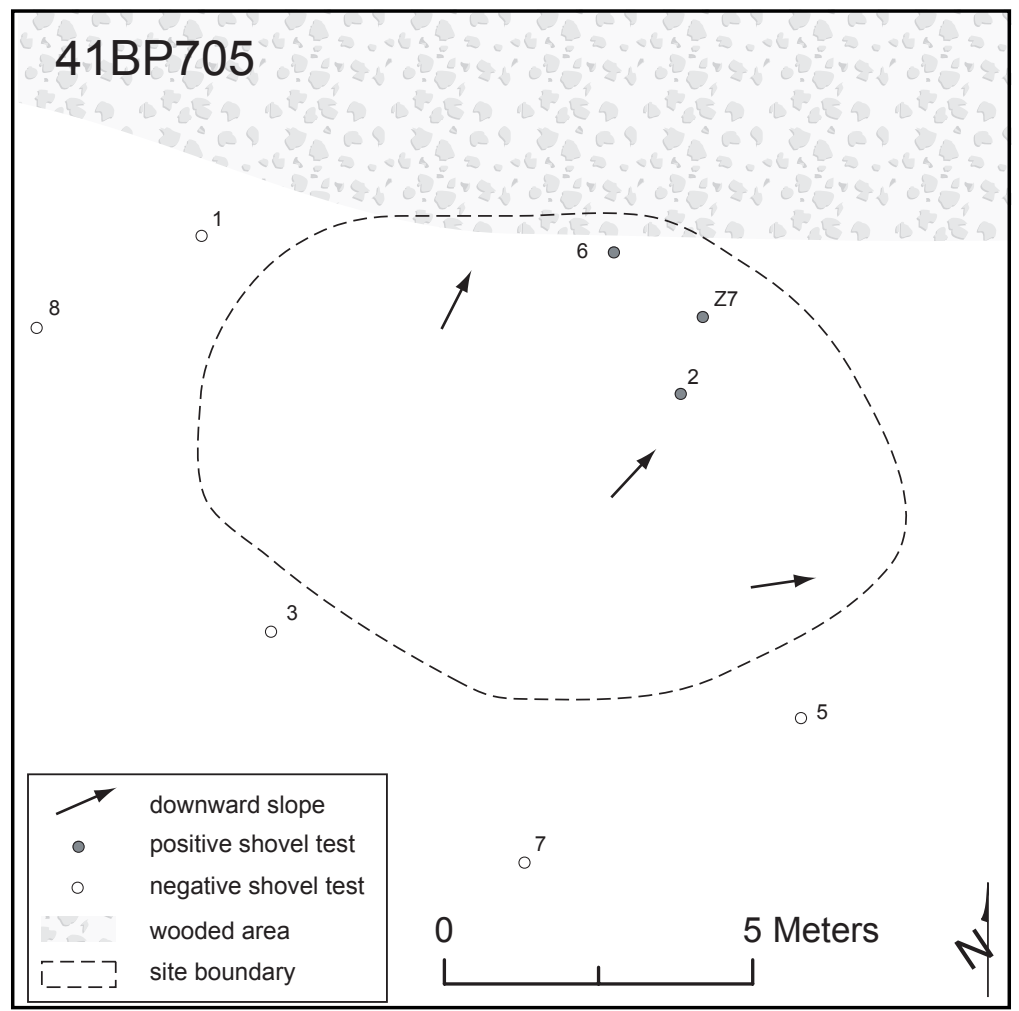

Figure 7-16. Site map of 41BP705.

\section{BP705}

\section{Description}

41BP705 (Figures 7-15 and 7-16) is a small $\left(76 \mathrm{~m}^{2}\right)$ lithic scatter buried in Patilo complex fine sand $(\mathrm{PaE})$. The sideslope grassland surface slopes gently from 433 to $428 \mathrm{ft}$ amsl. An eroded
Table 7-8. 41BP705 positive shovel test results.

\begin{tabular}{|c|c|c|c|}
\hline $\begin{array}{c}\text { Depth } \\
\text { (cmbs) }\end{array}$ & ST 2 & ST 6 & $\begin{array}{c}\text { ST } \\
\text { Z7 }\end{array}$ \\
\hline $0-10$ & & & \\
\hline $10-20$ & & IF & \\
\hline $20-30$ & & IF & \\
\hline $30-40$ & & IF & \\
\hline $40-50$ & IF & & IF \\
\hline $50-60$ & & & \\
\hline $60-70$ & & & \\
\hline $70-80$ & Sand & Sand & Sand \\
\hline $80-90$ & & & \\
\hline \multicolumn{3}{|c|}{ Key: IF-interior flake } \\
\hline
\end{tabular}

gully lies along the site's western edge, and a cutbank overlooking the floodplain of Spring Branch forms its southern boundary. A dense growth of wild grapevines now flourishes amidst tall grasses, along with scattered prickly pear. Along the cutbank are large oak and pecan trees. Surface visibility was less than five percent in July 2005. The site datum is marked with a nail and aluminum tag on a small cedar tree on the north end of the site.

\section{Levels of Work and Results}

No artifacts or features were observed on the surface. The site was discovered during the excavation of Transect ST Z7 (see Figure 7-16). Five flakes were recovered from the three shovel tests excavated on the site (Table 7-8). In sharp contrast to the upper 28-30 cmbs, the sand below becomes crusty and compact, suggesting that the upper portion has been plowed. 


\section{Conclusions/Recommendations}

The paucity of cultural evidence recovered from shovel tests indicates that the site has little to contribute to the prehistory of the region. Therefore, its research value is minimal, CAS

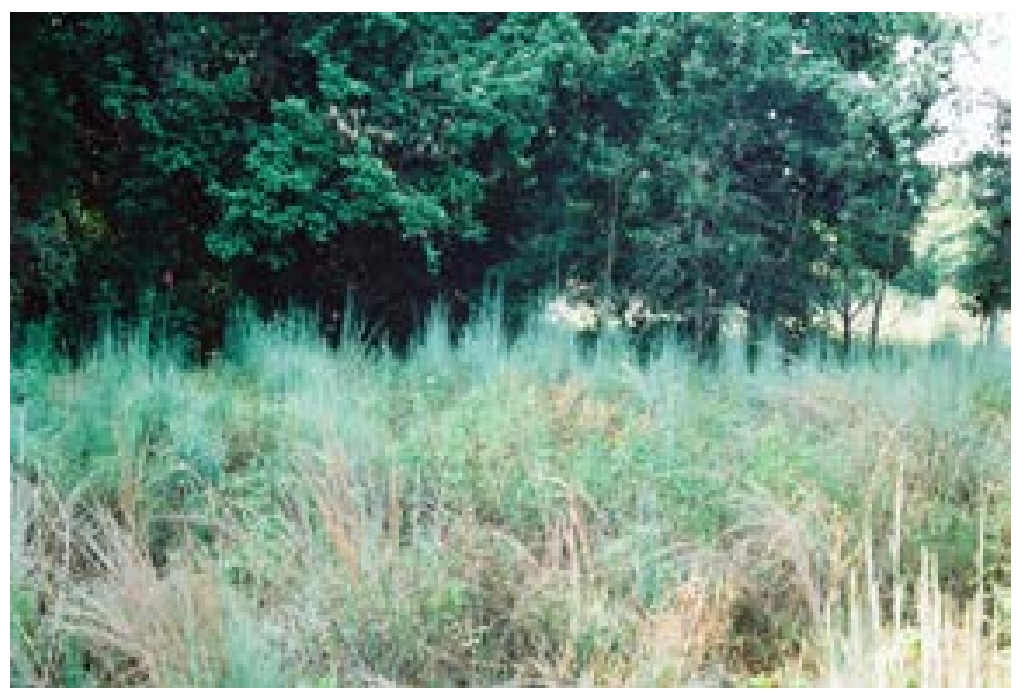

Figure 7-17. 41BP706 lies on a lower terrace adjacent to the floodplain of Big Sandy Creek; facing southeast.

FIGURE 7-18. REDACTED

Figure 7-18. Site map of 41BP706. recommends that no further work be conducted, and the site is not eligible for nomination to the NRHP.

\section{BP706}

\section{Description}

41BP706 (Figures 7-17 and 718) is composed of a prehistoric open campsite partially disturbed by the construction of a livestock shed and pen that appear to date to the $1960 \mathrm{~s}$, when parts of Camp Swift were leased for cattle grazing. The site covers approximately 7,523 $\mathrm{m}^{2}$, and ranges in elevation from 423 to $420 \mathrm{ft}$ amsl. It is situated on a lower terrace with a 2-m cutbank above the floodplain of Big Sandy Creek. The western and grassland half of the site lies within Patilo complex fine sand $(\mathrm{PaE})$, while the eastern, wooded area is composed of Sayers fine sandy loam (Sa). Riparian vegetation consisting of oak, elm, cedar, herbaceous weeds, and greenbrier thrive in the Sayers loam. Other disturbances observed included an eroded gully and a $30-\mathrm{cm}$ deep firebreak trench along the tree line. Surface visibility was less than five percent in July 2005.

\section{Levels of Work and Results}

No prehistoric artifacts or features were observed on the surface, but the site was discovered during excavation of systematic shovel tests (see 
Table 7-9. 41BP706 positive shovel test results.

\begin{tabular}{|c|c|c|c|c|c|c|c|c|c|c|c|c|c|}
\hline $\begin{array}{l}\text { Depth } \\
\text { (cmbs) }\end{array}$ & $\begin{array}{c}\text { ST } \\
1\end{array}$ & $\begin{array}{c}\text { ST } \\
2\end{array}$ & $\begin{array}{c}\text { ST } \\
\mathbf{3}\end{array}$ & $\begin{array}{c}\text { ST } \\
4\end{array}$ & $\begin{array}{c}\text { ST } \\
5\end{array}$ & $\begin{array}{c}\text { ST } \\
7\end{array}$ & $\begin{array}{c}\text { ST } \\
8\end{array}$ & $\begin{array}{l}\text { ST } \\
10\end{array}$ & $\begin{array}{l}\text { ST } \\
\text { Y8 }\end{array}$ & $\begin{array}{l}\text { ST } \\
\text { Y9 }\end{array}$ & $\begin{array}{c}\text { ST } \\
\text { Y10 }\end{array}$ & $\begin{array}{c}\text { ST } \\
\text { Z13 }\end{array}$ & $\begin{array}{c}\text { ST } \\
\text { AA12 }\end{array}$ \\
\hline $0-10$ & IF & IF & & & IF & IF & IF & & IF & & FCR & IF & \\
\hline $10-20$ & & & IF & $\mathrm{BG}$ & & & & & & & & & \\
\hline $20-30$ & WW & WW & IF & & & & & & & $\begin{array}{l}\mathrm{EF}, \\
\mathrm{IF}\end{array}$ & & & \\
\hline $30-40$ & & IF & $\begin{array}{c}\text { FCR, } \\
\text { fcr }\end{array}$ & CG & IF & & IF & & FCR & & & & \\
\hline $40-50$ & IF & & FCR & $\mathrm{Ch}$ & & & IF & & & IF & & & \\
\hline $50-60$ & & $\mathrm{M}$ & IF & FCR & & & & & & & IF & & EF, IF \\
\hline $60-70$ & & M & IF & & Clay & & Clay & IF & & $\begin{array}{l}\text { IF, } \\
\text { Ch }\end{array}$ & & & IF \\
\hline $70-80$ & Sand & & & Sand & & Sand & & & Sand & $\begin{array}{c}\text { FCR, } \\
\text { fer }\end{array}$ & Sand & Sand & IF, O \\
\hline $80-90$ & & Sand & Clay & & & & & Sand & & & & & IF \\
\hline $90-100$ & & & & & & & & & & Sand & & & \\
\hline $100-110$ & & & & & & & & & & & & & Sand \\
\hline $110-120$ & & & & & & & & & & & & & \\
\hline
\end{tabular}

Figure 7-18). Ten additional shovel tests were dug on and around the site to determine site boundaries and evaluate its integrity. Of the 14 shovel tests excavated on the site, 13 contained 27 flakes, eight fire-cracked rocks, two pieces of charcoal, and one piece of ocher. Shovel test results indicate significant disturbance has occurred in the immediate area of the tin structure (STs 1, 2, and 4), with historic material as deep as $70 \mathrm{cmbs}$ in ST 2 (Table 7-9). However, the mixing appears to be restricted to a very small area. Notably, no other historic material was found in any other shovel tests. For example, STs 3 and AA12, placed in close proximity, contained no historic material but were very rich in prehistoric material. Another shovel test in which prehistoric material is deeply buried in apparently unmixed context is ST Y9. Other than a probable plow zone from 0 to $28 \mathrm{cmbs}$ in the open field area, no other disturbances were observable in shovel tests. The

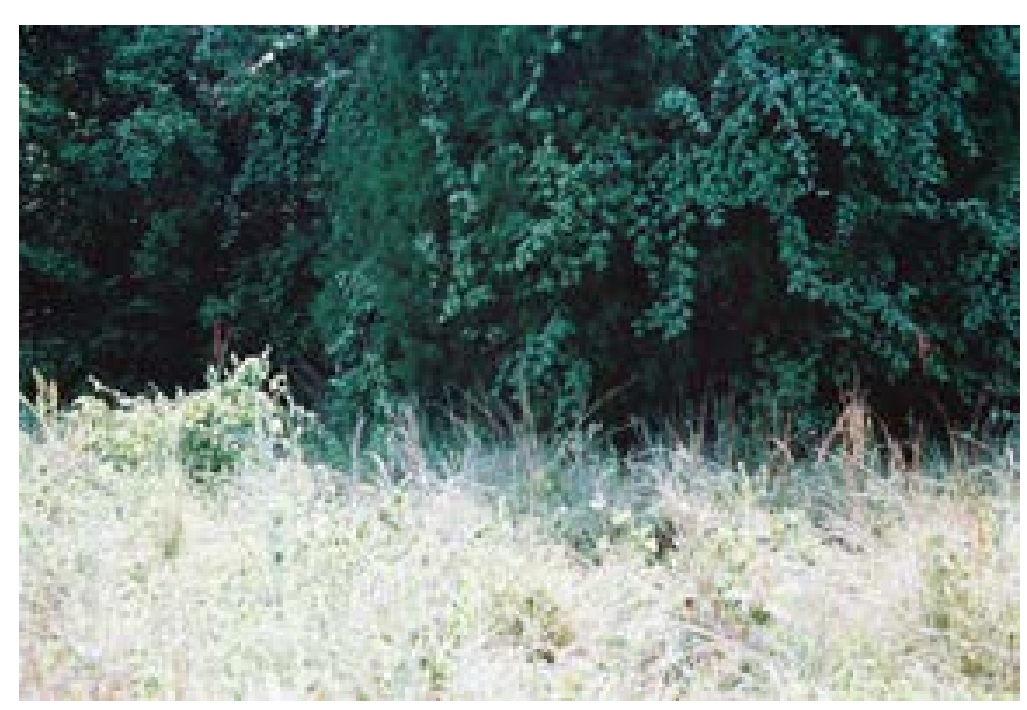

Figure 7-19. 41BP707 lies on a grassy sideslope; facing east. 
three $1-x-1-m$ units in the areas of STs 3, Y9, and AA12.

\section{BP707}

\section{Description}

FIGURE 7-20. REDACTED

Figure 7-20. Site map of 41BP707.

site datum is marked by a nail and aluminum tag on a large oak tree (see Figure 7-18).

\section{Conclusions/Recommendations}

Although obvious mixing of the modern historic and prehistoric component has occurred, it appears to be isolated to a small part of the overall site. Otherwise, fire-cracked rocks, charcoal, ocher, and lithic debitage in the areas of STs 3, Y9, and AA12 are buried in apparently undisturbed contexts. Such buried intact cultural deposits have the potential to yield significant information about the paleoenvironment, as well as about past human subsistence and mobility patterns. Thus, the research value of this site is unknown, and further investigations beyond the scope of an inventory survey are required before a recommendation can be made regarding eligibility for nomination to the NRHP. At a minimum, CAS recommends excavation of
Table 7-10. 41BP707 positive shovel test results.

\begin{tabular}{|c|c|c|}
\hline $\begin{array}{c}\text { Depth } \\
\text { (cmbs) }\end{array}$ & ST 6 & ST Y3 \\
\hline $0-10$ & IF & IF \\
\hline $10-20$ & IF & \\
\hline $20-30$ & & IF \\
\hline $30-40$ & IF & \\
\hline $40-50$ & & Sand \\
\hline $50-60$ & & \\
\hline $60-70$ & & Sand \\
\hline $70-80$ & & \\
\hline $80-90$ & \multicolumn{2}{|c|}{ Key: IF-interior flake } \\
\hline \multicolumn{2}{|l}{}
\end{tabular}

erosion along the floodplain, hog wallows near ST 6 and a firebreak. The site datum is marked with a nail and aluminum tag on a small cedar tree near ST Y3. 


\section{Levels of Work and Results}

No artifacts or features were observed on the surface. The site was discovered during the excavation of Transect ST Y3 (see Figure 720). A total of five flakes were recovered from the two shovel tests (Table 7-10) excavated on the site. Archaeologists observed a plow zone between 28 and $30 \mathrm{cmbs}$ in the grassy area. Notably the two positive shovel tests were situated inside the tree line, suggesting that the artifacts are more likely in primary context.

\section{Conclusions/}

\section{Recommendations}

The paucity of cultural evidence recovered from shovel tests indicates that the site has little to contribute to the prehistory of the region. Therefore, its research value is minimal, CAS recommends that no further work be conducted, and the site is not eligible for nomination to the NRHP.

\section{BP708}

\section{Description}

41BP708 (Figures 7-21 and $7-22)$ is a $2,245-\mathrm{m}^{2}$ lithic scatter in both Patilo complex fine sand $(\mathrm{PaE})$ and Sayers fine sandy loam (Sa). Cedar, pine, oak, assorted cacti, and dense grasses are on and around the site area. Surface visibility in July 2005 was less than five percent. The site is located on a partially wooded sideslope 140 m northwest of Big Sandy Creek, where the surface northeast. slopes gently from 422 to $420 \mathrm{ft}$ amsl. The only obvious surface disturbance was a firebreak trench dug $30 \mathrm{~cm}$ deep along the tree line. The site datum is marked with a nail and aluminum tag on a large pine $2 \mathrm{~m}$ southeast of ST 5 .

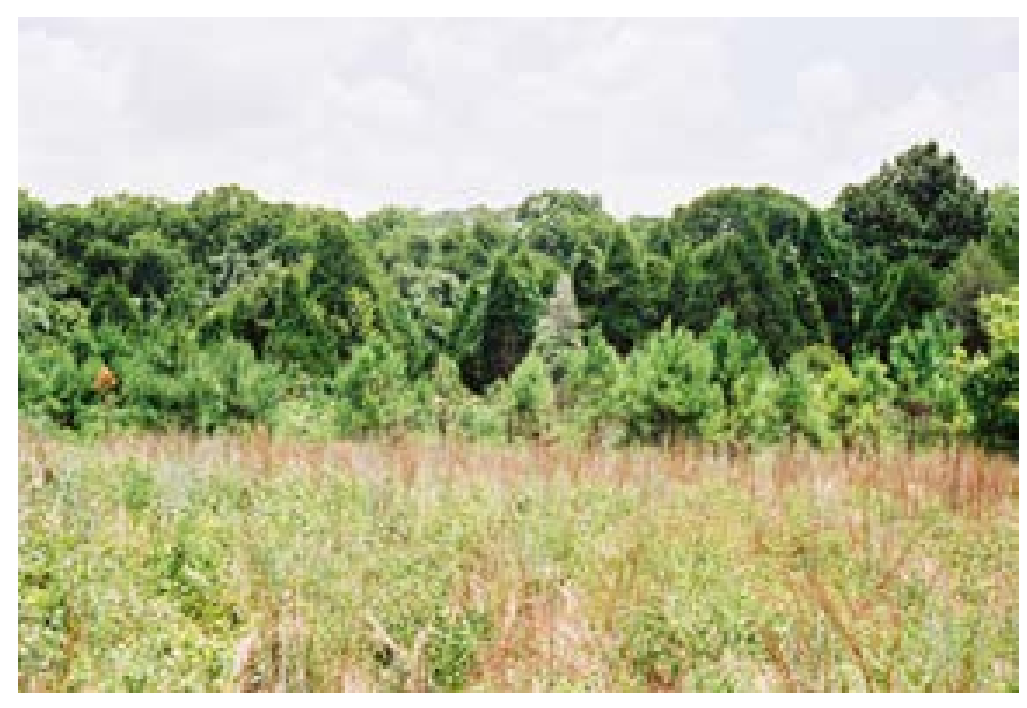

Figure 7-21. 41BP708 lies on a partially wooded sideslope; facing

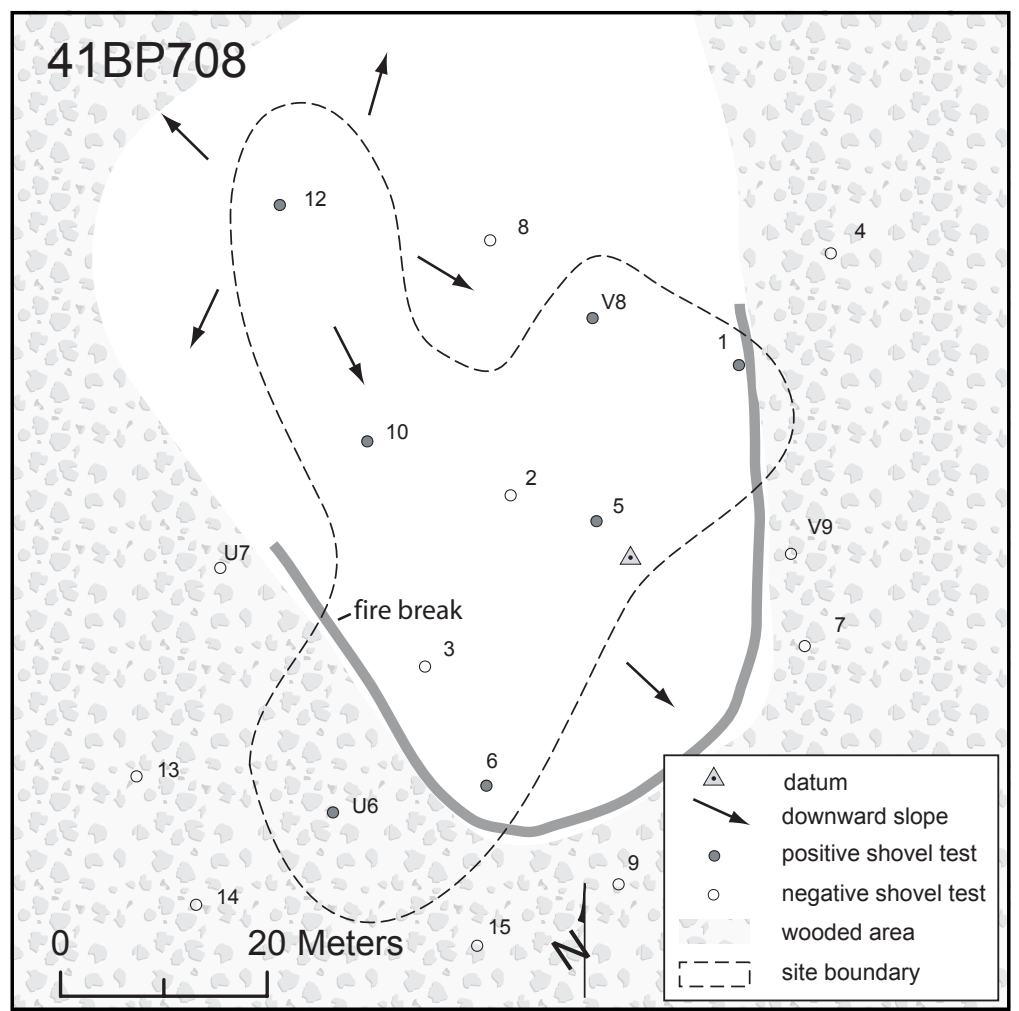

Figure 7-22. Site map of 41BP708. 


\section{Levels of Work and Results}

No artifacts or features were observed on the surface. The site was discovered during the excavation of Transect STs U6 and V8, which each contained an interior flake at 50-60 cmbs (see Figure 7-22). Fifteen additional shovel tests were placed on and around the site to determine the site's boundary and degree of integrity. Eleven flakes and a tested cobble were recovered from seven of nine shovel tests excavated on the site (Table 7-

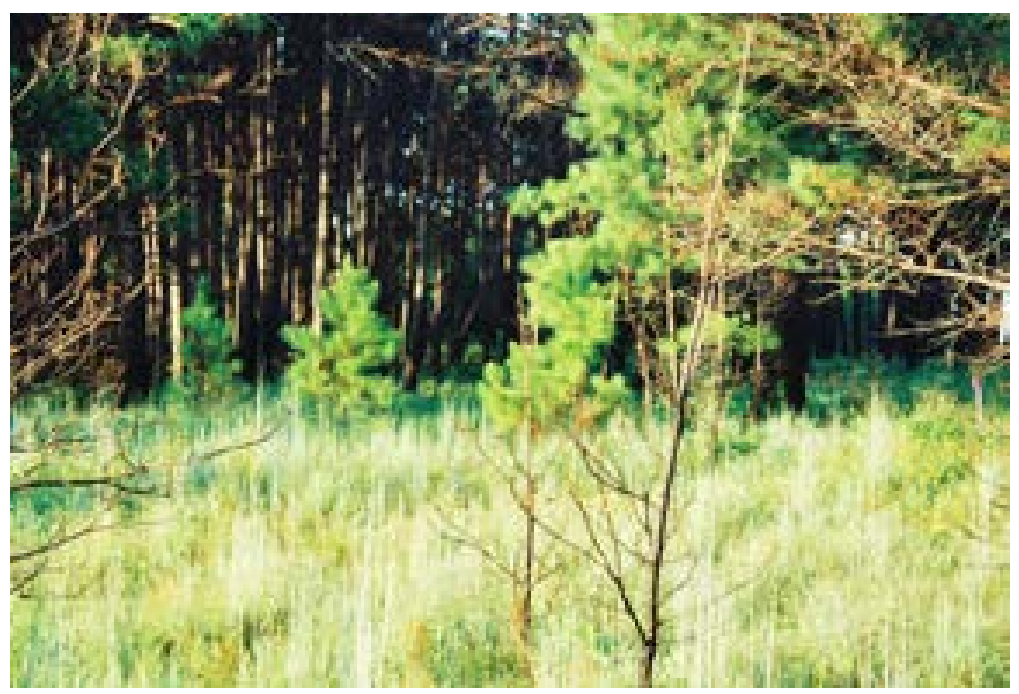

Figure 7-23. 41BP709 lies on a semi-wooded sideslope; facing south.
11). Archaeologists observed a

plow zone between 28 and $30 \mathrm{cmbs}$ in the grassy area.

\section{Conclusions/Recommendations}

Although cultural material was found fairly consistently between 50 and $60 \mathrm{cmbs}$, suggesting a possibly intact, stratified cultural zone, no evidence was found of datable material or organic preservation. Therefore, the site is not of moderate or high research value to the prehistory of the region, CAS recommends that no further work be conducted, and the site is not eligible for nomination to the NRHP.

\section{BP709}

\section{Description}

$41 B P 709$ (Figures 7-23 and 7-24) is a small $\left(230 \mathrm{~m}^{2}\right)$ open campsite located amidst tall grasses, bull nettles, and herbaceous weeds between a pine forest and oak motts. Patilo complex fine sand $(\mathrm{PaE})$ covers a sideslope that gently slopes to the northeast between from 420 to $418 \mathrm{ft}$ amsl. Big Sandy Creek lies 240 $\mathrm{m}$ to the east. Obvious surface disturbances include bladed twotrack firebreak trails and recent burning. Surface visibility was less than five percent in July 2005. The site datum is marked by a nail and aluminum tag on a small oak tree.

\section{Levels of Work and Results}

No artifacts or features were observed on the surface, but a single positive shovel test during excavation of systematic shovel tests led to the discovery of this 


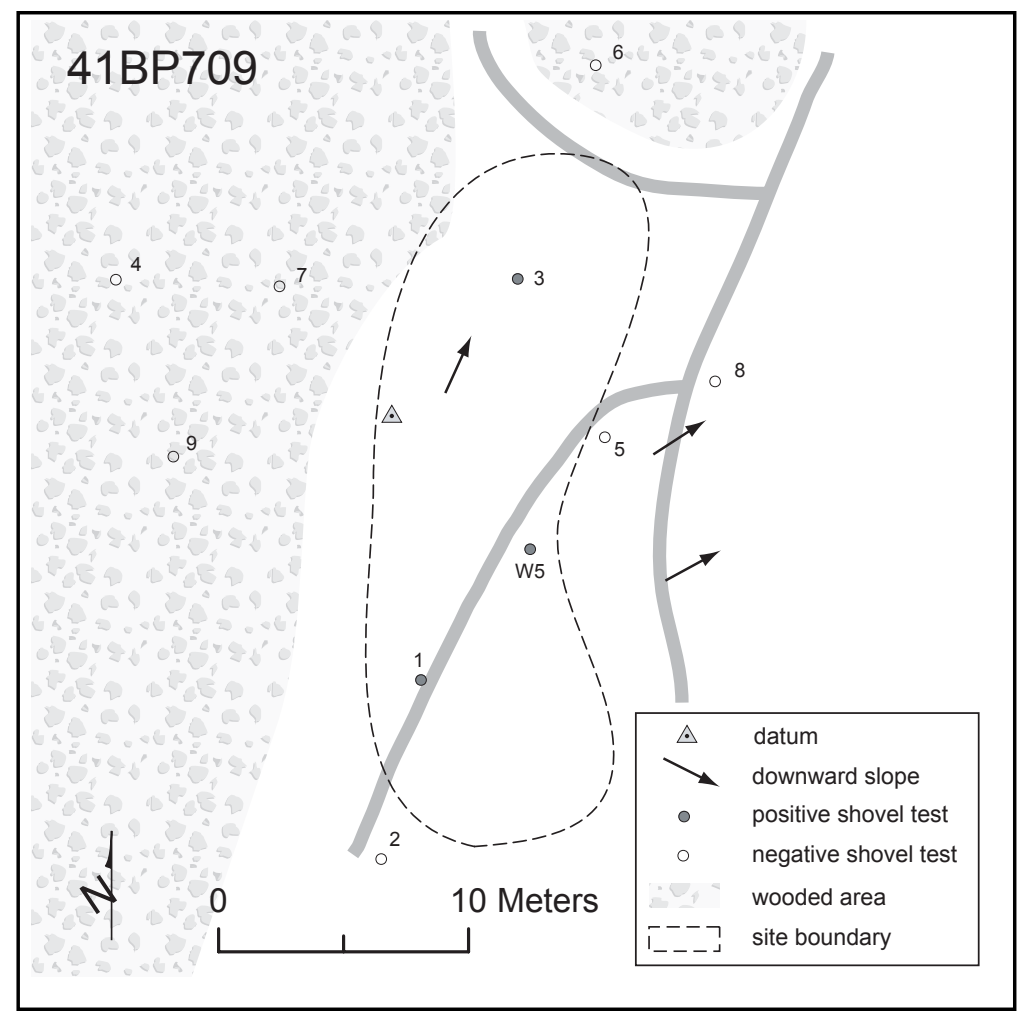

Figure 7-24. Site map of 41BP709.

site (see Figure 7-24). Although nine additional shovel tests were placed on and around the site, a total of only two flakes and a fire-cracked rock were recovered from the three shovel tests excavated on the site (Table 7-12). Looser sand in

Table 7-12. 41BP709 positive shovel test results.

\begin{tabular}{|c|c|c|c|}
\hline $\begin{array}{c}\text { Depth } \\
\text { (cmbs) }\end{array}$ & ST 1 & ST 3 & ST W5 \\
\hline $0-10$ & & & \\
\hline $10-20$ & & & IF \\
\hline $20-30$ & & & \\
\hline $30-40$ & & & \\
\hline $40-50$ & & FCR & \\
\hline $50-60$ & IF & & \\
\hline $60-70$ & & & \\
\hline $70-80$ & Sand & Sand & \\
\hline $80-90$ & & & Sand \\
\hline $90-100$ & & & \\
\hline Key: IF-interior flake; FCR-fire-cracked rock $>1$ \\
inch \\
\hline
\end{tabular}

the upper $30 \mathrm{cmbs}$ suggests that the area has been plowed.

\section{Conclusions/ \\ Recommendations}

This site appears to be an open campsite, but with no evidence of faunal or organic preservation or features discovered, its research value is minimal. Therefore, CAS recommends that no further work be conducted and that the site is not eligible for nomination to the NRHP.

\section{BP710}

\section{Description}

41BP710 (Figures 7-25 and $7-26)$ is a small $\left(115 \mathrm{~m}^{2}\right)$ lithic scatter on a steep sideslope that ranges in elevation from 430 to $420 \mathrm{ft}$ amsl. Sayers fine sandy loam (Sa) supports a dense forest of cedar, oak and hickory trees, with dense shrubs, Virginia creeper, and poison ivy understory. The site lies $20 \mathrm{~m}$ south of Spring Branch. The western edge of the site has been negatively impacted by the construction of Wine Cellar Road and a large earthen berm at some point in the historic past. Surface visibility was less than five percent in July 2005. The site datum is marked by a nail and aluminum tag on a large oak tree $50 \mathrm{~cm}$ in diameter.

\section{Levels of Work and Results}

Dense leaf and brush cover obscured any artifacts that may have been on the surface in the woods, and although the eroded, clay surface along the road's edge was carefully examined, no artifacts were found on the surface. Positive Transect ST CC1 led to the discovery of this site (see Figure 7-26). Two other shovel tests placed 


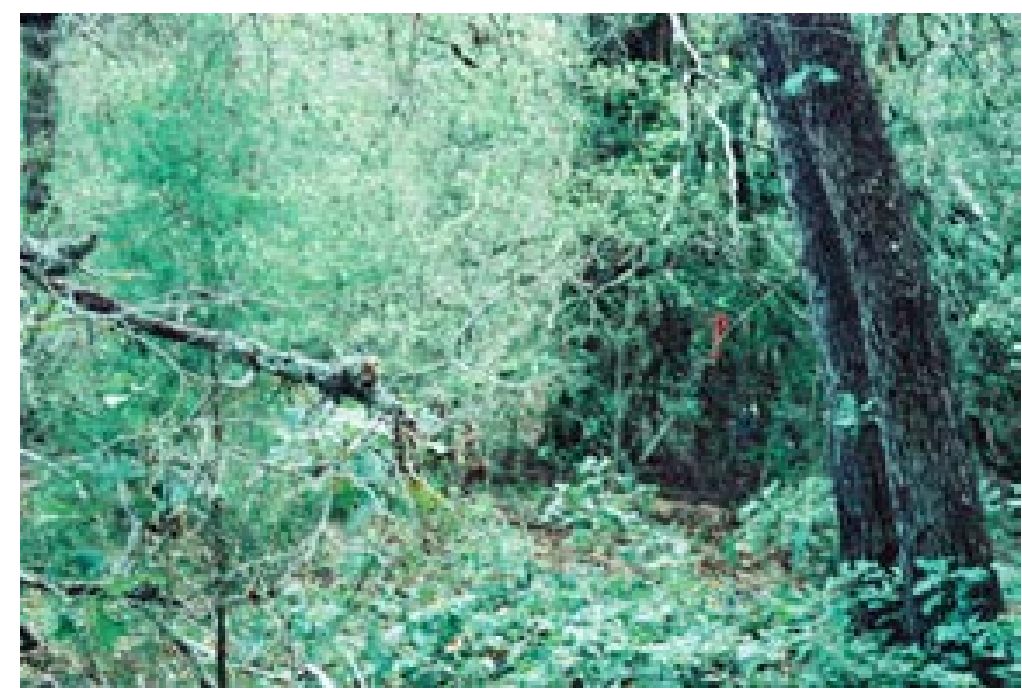

Figure 7-25. 41BP710 lies on a heavily wooded sideslope along Spring Branch; facing east.

FIGURE 7-26. REDACTED

Figure 7-26. Site map of 41BP710.

on the site, ST 3 and ST 8, were positive. In total, four flakes and a bullet were recovered from the three positive shovel tests excavated on the site.
A bullet found below a flake in ST 8 attests to the obvious disturbance that has occurred to this small site (Table 7-13). 
Table 7-13. $41 \mathrm{BP} 710$ positive shovel test results.

\begin{tabular}{|c|c|c|c|}
\hline $\begin{array}{c}\text { Depth } \\
\text { (cmbs) }\end{array}$ & ST 3 & ST 8 & ST CC1 \\
\hline $0-10$ & & & \\
\hline $10-20$ & & IF & IF \\
\hline $20-30$ & IF & Bu & \\
\hline $30-40$ & IF & & \\
\hline $40-50$ & & & \\
\hline $50-60$ & & & \\
\hline $60-70$ & & & \\
\hline $70-80$ & Sand & Sand & \\
\hline $80-90$ & & & Sand \\
\hline $90-100$ & & & \\
\hline \multicolumn{2}{|l|}{ Key: IF-interior flake; Bu-bullet } \\
\hline
\end{tabular}

\section{Conclusions/Recommendations}

With only four flakes recovered, no evidence of faunal or organic preservation, no features discovered, and the obvious road-related disturbance that has occurred, the research value of this site is minimal. Therefore, CAS recommends that no further work be conducted and that the site is not eligible for nomination to the NRHP.

\section{$41 B P 713$}

\section{Description}

41BP713

(Figures

$7-27$ and 7-28) is an open campsite buried in Patilo fine sand $(\mathrm{PaE})$ on a heavily wooded sideslope. Based upon shovel test results, the site encompasses $3,370 \mathrm{~m}^{2}$ and ranges in elevation from 486 to $495 \mathrm{ft}$ amsl. The forest

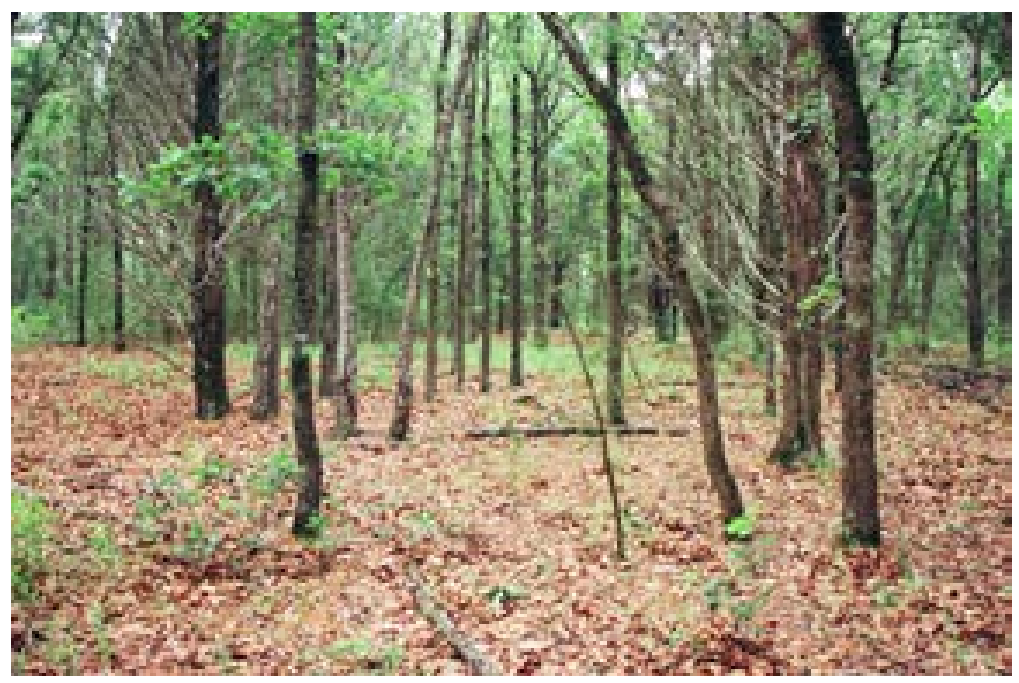

Figure 7-27. 41BP713 is an open campsite on a wooded sideslope; facing south. the only surface disturbances noted. Surface visibility was less than five percent in May 2006. The site datum is marked by a nail and aluminum tag on a large oak tree $25 \mathrm{~cm}$ in diameter.

\section{Levels of Work and Results}

No artifacts were found on the surface. However, one fire-cracked rock, a piece of shattered chert, and 22 flakes were recovered from 11 of 17 shovel tests excavated on the site (Table 7-14). The only subsurface disturbances observed were in the form of small roots.

\section{Conclusions/Recommendations}

The presence of a quartzite fire-cracked rock and lithic debitage in generally deep sands suggest that a buried, intact burned rock hearth with associated cultural material could exist at this site. Therefore, the research value of this site is unknown and further investigations beyond the scope of an inventory survey are required is made up of cedar, oak and hickory trees, with moderately dense shrubs as understory. An intermittent drainage of Big Sandy Creek is $45 \mathrm{~m}$ to the north. An occasional treefall and mammal burrow were

before a recommendation can be made regarding eligibility for nomination to the NRHP. At a minimum, CAS recommends excavation of two 1-x-1-m units in the areas of STs 7 and 16. 


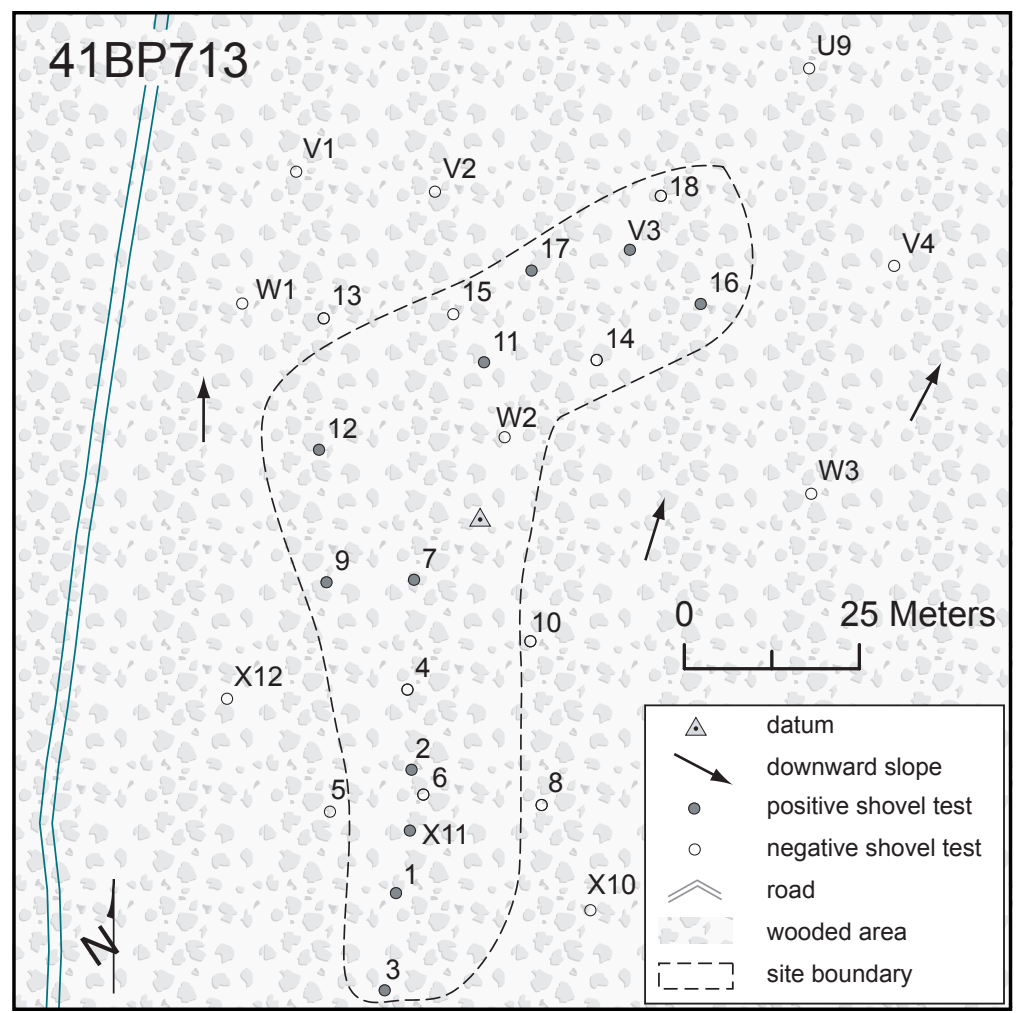

Figure 7-28. Site map of 41BP713.

Table 7-14. 41BP713 positive shovel test results.

\begin{tabular}{|c|c|c|c|c|c|c|c|c|c|c|c|}
\hline $\begin{array}{l}\text { Depth } \\
\text { (cmbs) }\end{array}$ & $\begin{array}{c}\text { ST } \\
1\end{array}$ & $\begin{array}{c}\text { ST } \\
2\end{array}$ & $\begin{array}{c}\text { ST } \\
3\end{array}$ & $\begin{array}{c}\text { ST } \\
7\end{array}$ & $\begin{array}{c}\text { ST } \\
9\end{array}$ & $\begin{array}{l}\text { ST } \\
11\end{array}$ & $\begin{array}{l}\text { ST } \\
12\end{array}$ & $\begin{array}{l}\text { ST } \\
16\end{array}$ & $\begin{array}{l}\text { ST } \\
17\end{array}$ & $\begin{array}{l}\text { ST } \\
\text { V3 }\end{array}$ & $\begin{array}{c}\text { ST } \\
\text { X11 }\end{array}$ \\
\hline $0-10$ & & IF & & & & & & & IF & & \\
\hline $10-20$ & & & & & & IF & & & & EF & \\
\hline $20-30$ & & & & $2 \mathrm{~S}, \mathrm{EF}$ & & & IF & & & & IF \\
\hline $30-40$ & & & & & & IF & & & Clay & & \\
\hline $40-50$ & IF & & & & & & & & & IF & IF \\
\hline $50-60$ & & & IF & & & & & EF, FCR & & & IF \\
\hline $60-70$ & & 2 IF & & $2 \mathrm{EF}$ & IF & EF, IF & & & & & \\
\hline $70-80$ & Sand & & & & & & Sand & Sand & & Sand & Sand \\
\hline $80-90$ & & Sand & Clay & Sand & IF & Clay & & & & & \\
\hline \multicolumn{12}{|l|}{$90-100$} \\
\hline $100-110$ & & & & & Sand & & & & & & \\
\hline $110-120$ & & & & & & & & & & & \\
\hline \multicolumn{12}{|c|}{ Key: S-shatter; EF-exterior flake; IF-interior flake; FCR-fire-cracked rock $>1$ inch } \\
\hline
\end{tabular}

\section{BP714}

\section{Description}

41BP714 (Figures 7-29 and 7-30) is a 4,977$\mathrm{m}^{2}$ open campsite in a wooded upland/sideslope setting. It slopes from 482 to $458 \mathrm{ft}$ amsl over its 129-m (141 ft) length. The floodplain of an intermittent tributary of Big Sandy Creek lies along its northwestern edge, and its southern 
boundary is defined by a $4-\mathrm{m}$ deep gully. Demona loamy fine sand $(\mathrm{DeC})$ supports the growth of oak, cedar, elm, prickly pear cacti, and assorted shrubs and grasses. In addition to the gully and floodplain disturbed areas, eroded clay was observed on the surface adjacent to a smaller gully in the lower, western portion, a modern trash dump and rodent burrows were present across the upper, eastern portion of the site, and an old barbwire fence cuts through its southern portion (see Figure 7-30). Other than in the heavily eroded areas, surface visibility was less than ten percent across the site. The datum is marked by a nail and aluminum tag in an oak tree 25 $\mathrm{cm}$ in diameter.

\section{Levels of Work and Results}

Although eroded surfaces and cutbanks were examined, no artifacts were observed on the surface. However, 12 positive shovel tests out of 14 excavated on the site contained 18 flakes and two pieces of fire-cracked rock as deep as $50 \mathrm{cmbs}$. Obvious mixing has occurred around ST 17, where a piece of metal was found below a flake (Table 715). The steeper portion of this site lies south of the datum.

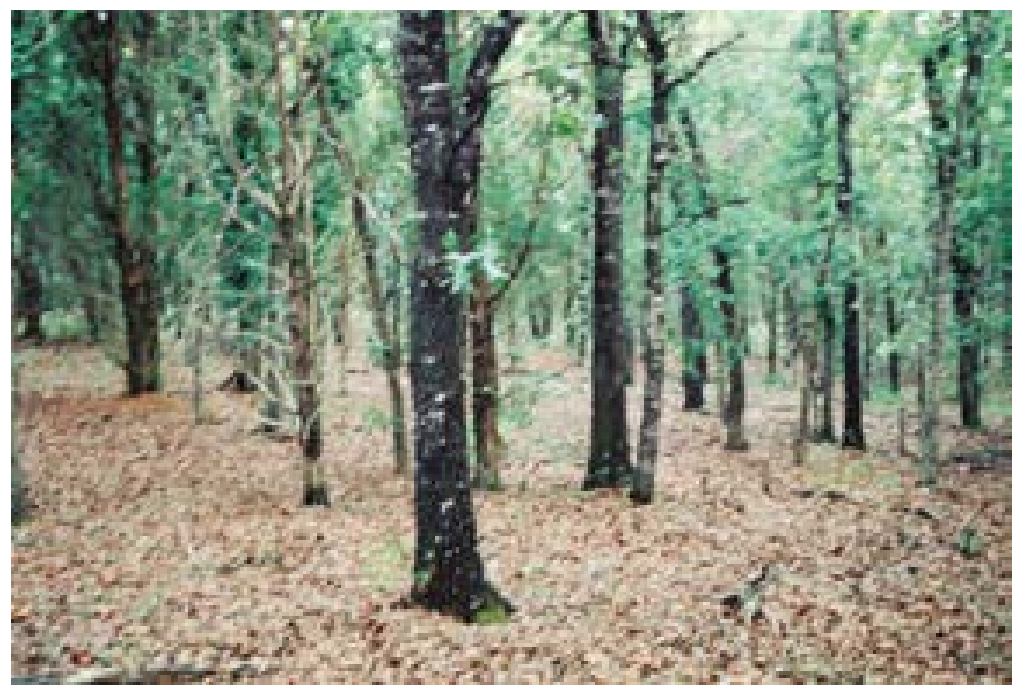

Figure 7-29. 41BP714 lies on a wooded upland and sideslope setting; facing west.

FIGURE 7-30. REDACTED

Figure 7-30. Site map of 41BP714.

Attesting to the likely erosion that has occurred, sands on the site upslope and south of the datum averaged over $70 \mathrm{cmbs}$ in depth, while sands downslope and north of the datum averaged only $29 \mathrm{cmbs}$.

\section{Conclusions/Recommendations}

Although this site has been heavily impacted by erosional gullies and modern activities, it is not unlike similar sites at Camp Swift that contain 
Table 7-15. 41BP714 positive shovel test results.

\begin{tabular}{|c|c|c|c|c|c|c|c|c|c|c|c|c|}
\hline $\begin{array}{l}\text { Depth } \\
\text { (cmbs) }\end{array}$ & $\begin{array}{c}\text { ST } \\
1\end{array}$ & $\begin{array}{c}\text { ST } \\
2\end{array}$ & $\begin{array}{c}\text { ST } \\
\mathbf{3}\end{array}$ & $\begin{array}{c}\text { ST } \\
5\end{array}$ & $\begin{array}{l}\text { ST } \\
10\end{array}$ & $\begin{array}{l}\text { ST } \\
11\end{array}$ & $\begin{array}{l}\text { ST } \\
13\end{array}$ & $\begin{array}{l}\text { ST } \\
15\end{array}$ & $\begin{array}{l}\text { ST } \\
17\end{array}$ & $\begin{array}{c}\text { ST } \\
\text { QQQ5 }\end{array}$ & $\begin{array}{c}\text { ST } \\
\text { SSS17 }\end{array}$ & $\begin{array}{c}\text { ST } \\
\text { SSS19 }\end{array}$ \\
\hline $0-10$ & & & $2 \mathrm{IF}$ & IF & & & IF & & & & IF & \\
\hline $10-20$ & & IF & & & & IF & & IF & & IF & M & \\
\hline $20-30$ & IF & IF & & & & FCR & Clay & & & & & \\
\hline $30-40$ & IF & & & Clay & $\mathrm{EF}$ & IF & & FCR & & & Clay & \\
\hline $40-50$ & IF & & Clay & & & & & IF & IF & & & IF \\
\hline $50-60$ & & & & & & & & Clay & & & & \\
\hline $60-70$ & & & & & & & & & & & & \\
\hline $70-80$ & Sand & Sand & & & Sand & Sand & & & Sand & Sand & & Sand \\
\hline $80-90$ & & & & & & & & & & & & \\
\hline
\end{tabular}

discrete areas where there still may be intact deposits. Specifically, no evidence of disturbance was observed in ST 11, where two flakes and a fire-cracked rock were found between 10 and 40 cmbs. ST 11 is situated on the upper portion of the site where the sands are deeper and the slope is rather gentle. Thus, there is a possibility of a buried feature and associated cultural material still intact in a stratified cultural occupation zone in that area. Such buried intact cultural deposits have the potential to yield significant information about the paleoenvironment, as well as about past human subsistence and mobility patterns. Thus, the research value of this site is unknown and further investigations beyond the scope of an inventory survey are required before a recommendation can be made regarding nomination to the NRHP. At a minimum, CAS recommends excavation of two $1-x-1-m$ units in the area around ST 1.

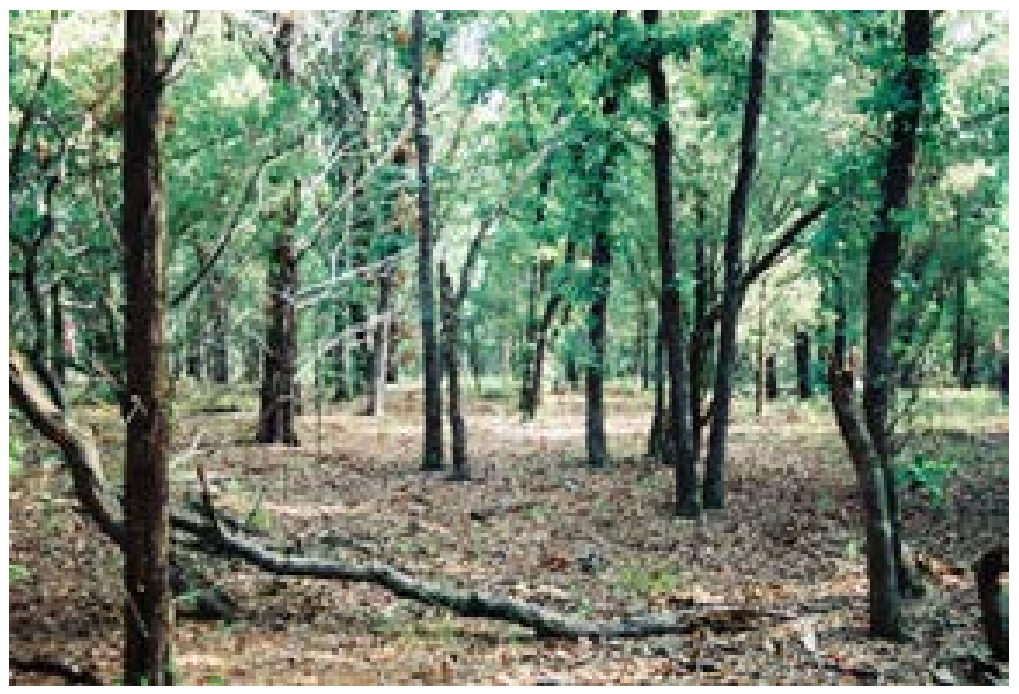

Figure 7-31. 41BP715 lies on a wooded sideslope setting; facing north. 


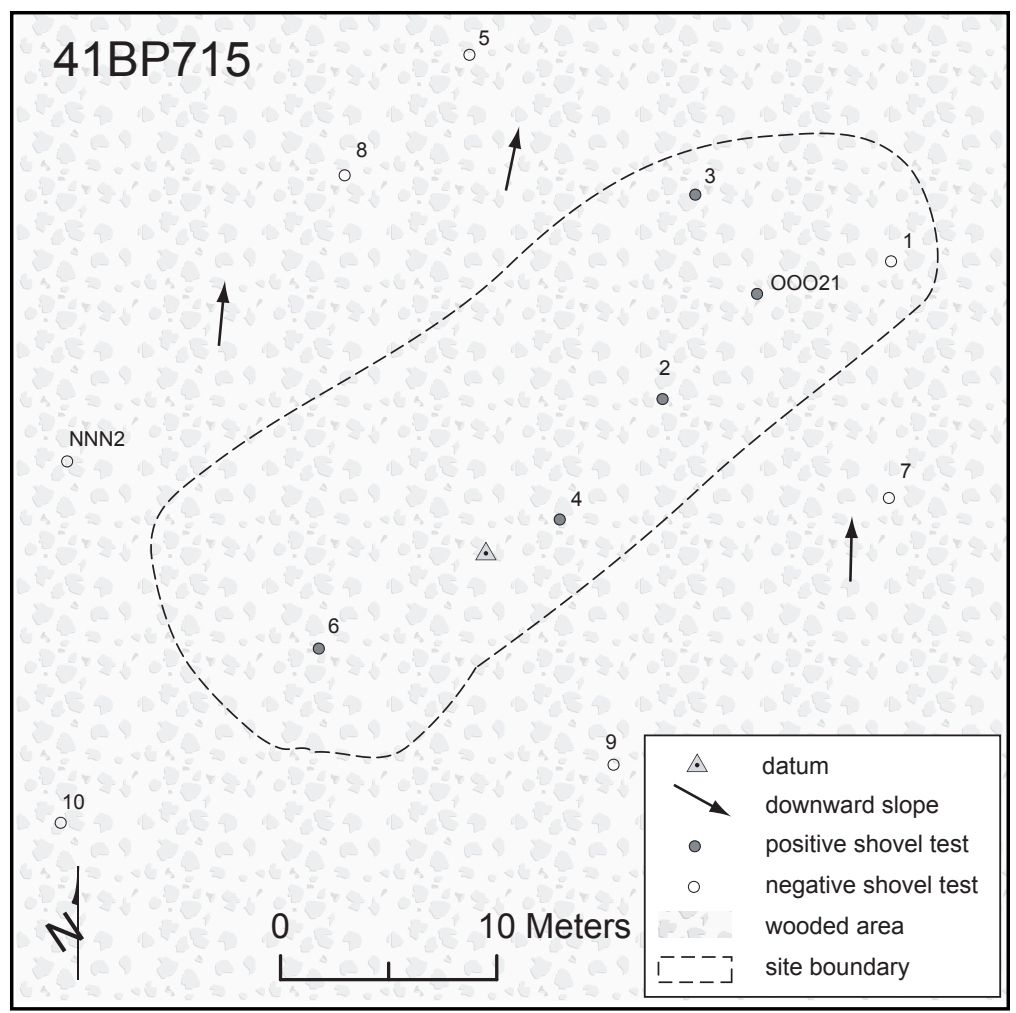

Figure 7-32. Site map of 41BP715.

and with little understory. No surface disturbances were obvious in the immediate area of the site (see Figure 7-32). Because of heavy leaf cover, surface visibility was less than ten percent across the site. The datum is marked by a nail and aluminum tag in a large oak tree.

Table 7-16. 41BP715 positive shovel test results.

\begin{tabular}{|c|c|c|c|c|c|}
\hline $\begin{array}{c}\text { Depth } \\
\text { (cmbs) }\end{array}$ & $\begin{array}{c}\text { ST } \\
\mathbf{2}\end{array}$ & $\begin{array}{c}\text { ST } \\
\mathbf{3}\end{array}$ & $\begin{array}{c}\text { ST } \\
\mathbf{4}\end{array}$ & $\begin{array}{c}\text { ST } \\
\mathbf{6}\end{array}$ & $\begin{array}{c}\text { ST } \\
\text { OOO21 }\end{array}$ \\
\hline $0-10$ & & & & & \\
\hline $10-20$ & IF & & Ch & & \\
\hline $20-30$ & & & & & \\
\hline $30-40$ & & & Ch & & \\
\hline $40-50$ & & & & Ch & \\
\hline $50-60$ & & IF & & & IF \\
\hline $60-70$ & & & & & \\
\hline $70-80$ & Sand & Sand & Sand & Sand & Sand \\
\hline $80-90$ & & & & & \\
\hline \multicolumn{7}{|c|}{ Key: IF-interior flake; Ch-charcoal } \\
\hline
\end{tabular}

\section{Levels of Work and Results}

No artifacts were observed on the surface, but five shovel tests out of 6 excavated on the site contained either charcoal or flakes (Table 7-16). No obvious mixing was observed in any of the shovel tests placed on and around the site, only roots causing possible disturbance. The only shovel test in which clay was reached was in ST 5 at 50 cmbs; all other shovel tests were excavated to $70 \mathrm{cmbs}$ in sand. Although no fire-cracked rocks were recovered, charcoal was found in two shovel tests (STs 4 and 6), and there was no evidence that the charcoal was the result of root burning.

\section{Conclusions/ \\ Recommendations}

CAS is unable to fully evaluate the potential of this site without further investigations. The fact that there is evidence of organic preservation and datable material suggests that, if intact, buried cultural deposits at this site have the potential to yield significant information about the paleoenvironment, as well as about past human subsistence and mobility patterns. Thus, the research value of this site is unknown, and further investigations beyond the scope of an inventory survey are required before a recommendation can be made regarding NRHP eligibility. At a minimum, CAS recommends excavation of two 1-x-1-m units in the immediate areas of STs 4 and 6. 


\begin{abstract}
41BP716
Description

$41 \mathrm{BP} 716$

(Figures

$7-33$

and 7-34) is an open campsite covering $2,160 \mathrm{~m}^{2}$ on a wooded footslope; the landform is similar to a finger ridge. Oak and cedar, grasses, and a few prickly pear cacti thrive in the deep Demona loamy fine sand $(\mathrm{DeC})$. There is a gentle slope ranging from 480 to $477 \mathrm{ft}$ amsl, the same elevation as potentially intact deposits discovered at 41BP714 and 41BP715. The floodplain of an intermittent tributary of Big Sandy Creek lies $30 \mathrm{~m}$ to the north. No surface disturbances were obvious in the immediate area of the site. Because of heavy leaf cover surface visibility was less than ten percent across the site.
\end{abstract}

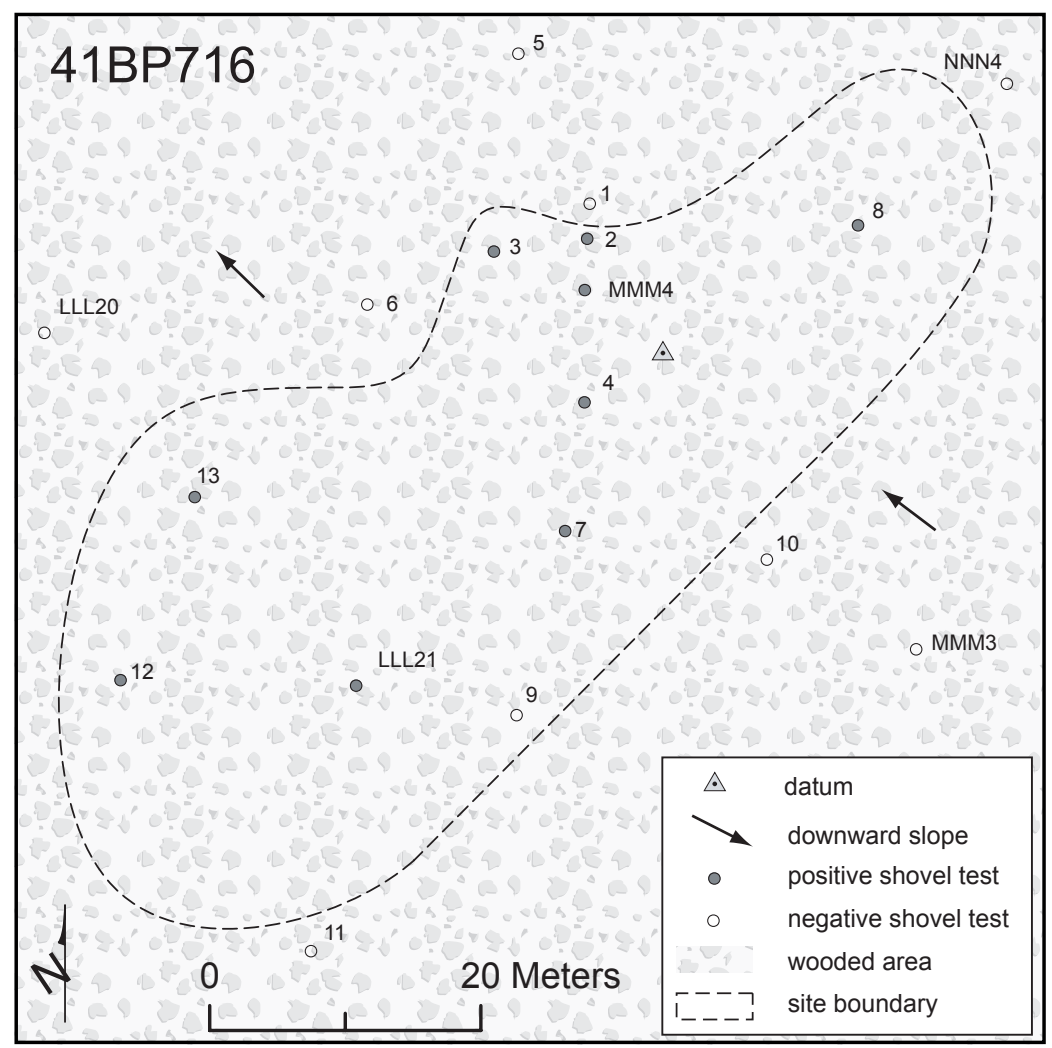

Figure 7-34. Site map of 41BP716.

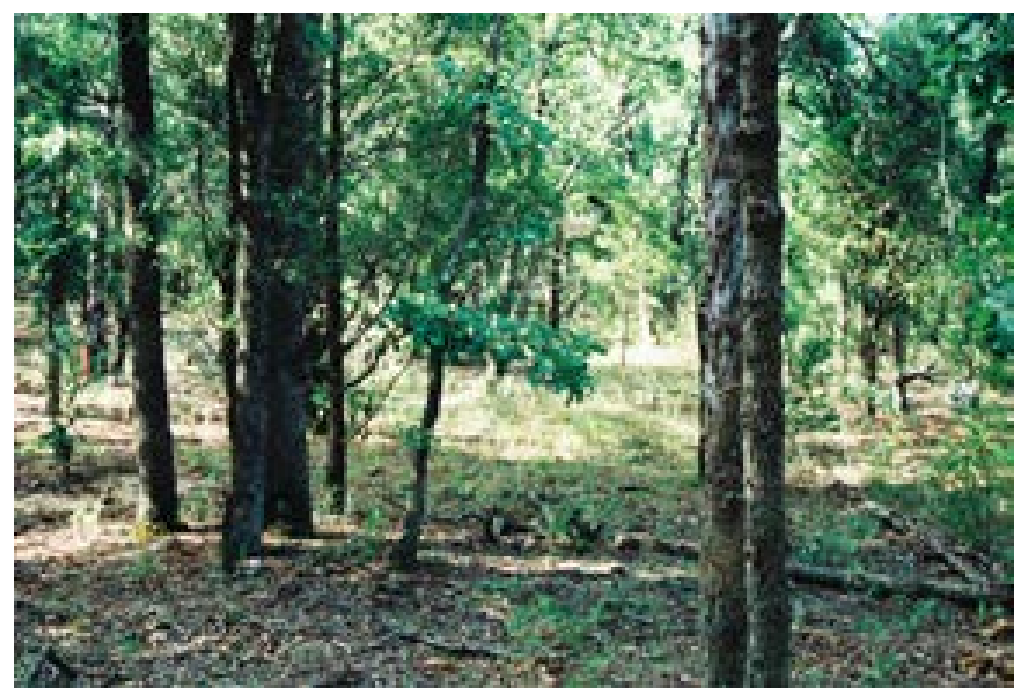

Figure 7-33. 41BP716 is buried in a wooded footslope; facing south.

The datum is marked by a nail and aluminum tag in a small oak tree.

\section{Levels of Work and Results}

No artifacts were observed on the surface, but 13 flakes and a fire-cracked rock were recovered from nine shovel tests out of 10 excavated within the site's boundaries (Table 7-17). The interior flake between 50 and $60 \mathrm{cmbs}$ in ST 8 had been heated. A few roots were the only source of disturbance observed in any of the shovel tests placed on and around the site. ST 5, closest to the floodplain, was terminated at $50 \mathrm{cmbs}$ on clay. Otherwise all shovel tests were excavated to $70 \mathrm{cmbs}$ in sand.

\section{Conclusions/ \\ Recommendations}

CAS is unable to fully evaluate the potential of this site without further investigations. The presence 
Table 7-17. 41BP716 positive shovel test results.

\begin{tabular}{|c|c|c|c|c|c|c|c|c|c|}
\hline $\begin{array}{c}\text { Depth } \\
(\mathbf{c m b s})\end{array}$ & ST 2 & ST 3 & ST 4 & ST 7 & ST 8 & ST 12 & ST 13 & ST LLL21 & ST MMM4 \\
\hline $0-0$ & IF & & & & & & & IF & \\
\hline $10-20$ & & & & IF & & & & & \\
\hline $20-30$ & & IF & & & & IF & IF & FCR & \\
\hline $30-40$ & & & & & IF & & & & \\
\hline $40-50$ & & IF & EF & & & & & & IF \\
\hline $50-60$ & & & IF & & IF-h & & & & \\
\hline $60-70$ & & IF & & & & & & & Sand \\
\hline $70-80$ & Sand & & Sand & Sand & Sand & Sand & Sand & Sand & \\
\hline $80-90$ & & & & & & & & & \\
\hline $90-100$ & & Sand & & & & & & & \\
\hline $100-110$ & & & & & & & & \\
\hline \multicolumn{7}{|l|}{ Key: EF-exterior flake; IF-interior flake; FCR-fire-cracked rock $>1$ inch; h-heated } \\
\hline
\end{tabular}

of a fire-cracked rock and a heated chert flake suggests the potential exists for discovering an intact hearth feature with further work at the site. If intact, such buried cultural deposits at this site have the potential to yield significant information about the paleoenvironment, as well as about past human subsistence and mobility patterns. Thus, the research value of this site is unknown and further investigations beyond the scope of an inventory survey are required

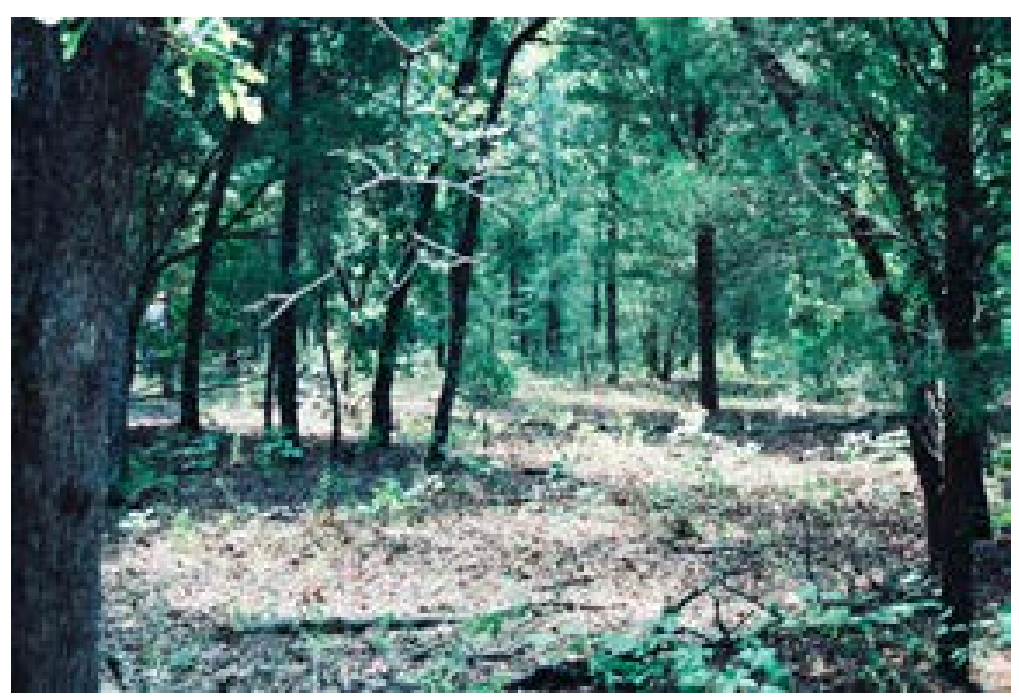

Figure 7-35. 41BP717 is buried in a wooded upland ridge; facing southeast. before a recommendation can be made regarding eligibility for nomination to the NRHP. At a minimum, CAS recommends excavation of two 1-x-1-m units in the areas around STs 3, 4, 8, and LLL21.

\section{BP717}

\section{Description}

41BP717 (Figures 7-35 and 7-36) is a small open campsite covering $907 \mathrm{~m}^{2}$ on a wooded upland ridge. Demona loamy fine sand $(\mathrm{DeC})$ supports oak and cedar, grasses and a few prickly pear cacti on a gentle slope ranging from 490 to $487 \mathrm{ft}$ amsl. An intermittent tributary of Big Sandy Creek lies 270 m to the north. Obvious surface disturbances in the immediate area of the site included a few rodent burrows and uprooted trees. Because of heavy leaf cover, surface visibility was less than ten percent across the site. The datum is marked by a nail 


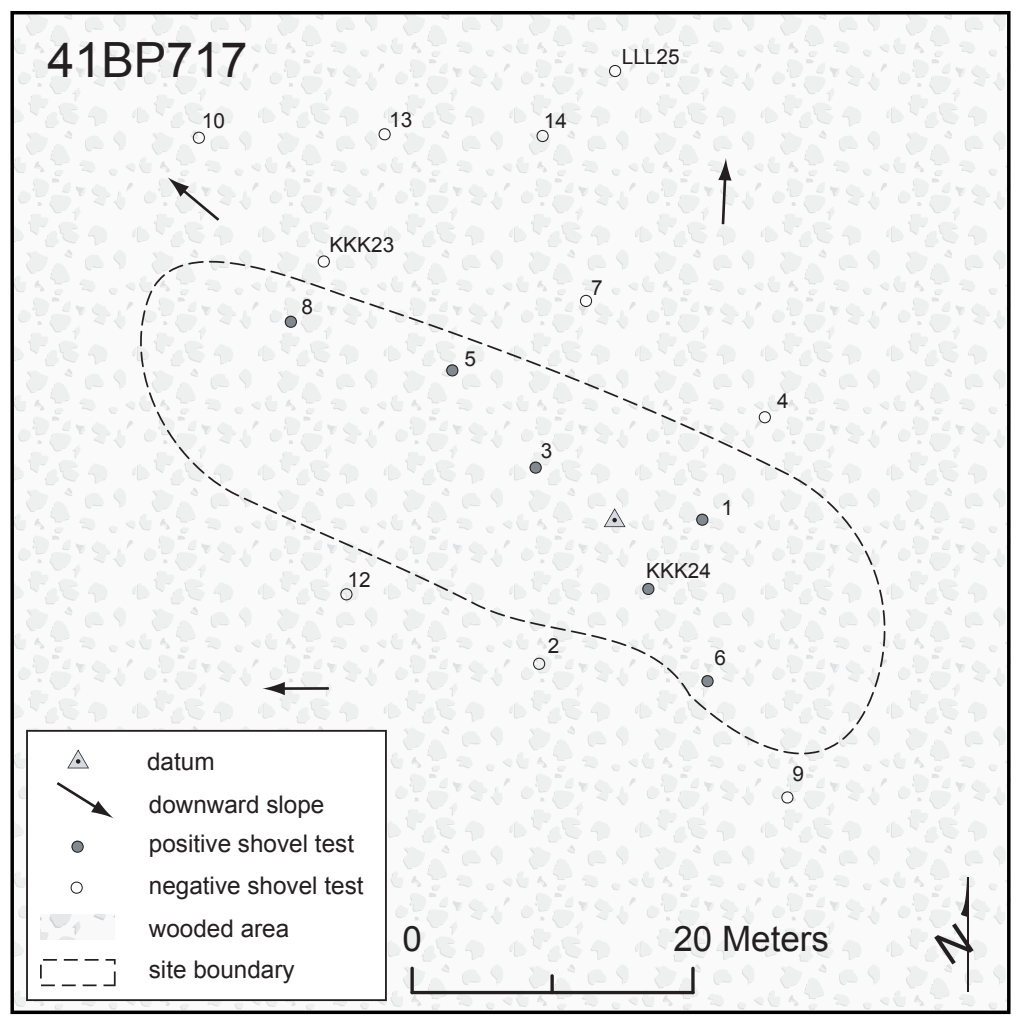

Figure 7-36. Site map of 41BP717.

and aluminum tag in a small oak tree $10 \mathrm{~cm}$ in diameter.

\section{Levels of Work and Results}

A total of ten flakes and a small fire-cracked rock were recovered from the six positive shovel

Table 7-18. 41BP717 positive shovel test results.

\begin{tabular}{|c|c|c|c|c|c|c|}
\hline $\begin{array}{c}\text { Depth } \\
\text { (cmbs) }\end{array}$ & ST 1 & ST 2 & ST 5 & ST 6 & ST 8 & ST KKK24 \\
\hline $0-10$ & & & & & & \\
\hline $10-20$ & & & IF & & & IF \\
\hline $20-30$ & & & & IF & & \\
\hline $30-40$ & & & & & & \\
\hline $40-50$ & IF & fcr & & & & IF \\
\hline $50-60$ & IF & & & & IF & 3 IF \\
\hline $60-70$ & & & & & & \\
\hline $70-80$ & Sand & Sand & Sand & Sand & Sand & \\
\hline $80-90$ & & & & & & Sand \\
\hline $90-100$ & & & & & & \\
\hline \multicolumn{7}{|l}{ Key: IF-interior flake; fcr-fire-cracked rock $<1$ inch } \\
\hline
\end{tabular}

tests excavated on the site (Table 7-18). One interior flake between 50 and $60 \mathrm{cmbs}$ in KKK24 had been heated. A few roots were the only source of disturbance observed in any of the shovel tests placed on and around the site. All shovel tests were excavated to at least $70 \mathrm{cmbs}$ in sand.

\section{Conclusions/ Recommendations}

A review of Table 7-18 indicates the presence of flakes and a small fire-cracked rock between 40 and $60 \mathrm{cmbs}$, suggesting a stratified cultural zone may exist across the site. If intact and if associated with a burned rock feature, such buried cultural deposits may have the potential to yield significant information about the paleoenvironment, as well as about past human subsistence and mobility patterns. Thus, the research value of this site is unknown and further investigations beyond the scope of an inventory survey are required before a recommendation can be made regarding eligibility for nomination to the NRHP. At a minimum, CAS recommends excavation of two 1-x-1-m units in the areas around STs 1, 2, and KKK24.

\section{BP718}

\section{Description}

41BP718 (Figures 7-37 and $7-38)$ is a $4,063-\mathrm{m}^{2}$ prehistoric open campsite with a historic component on the upper, southern 


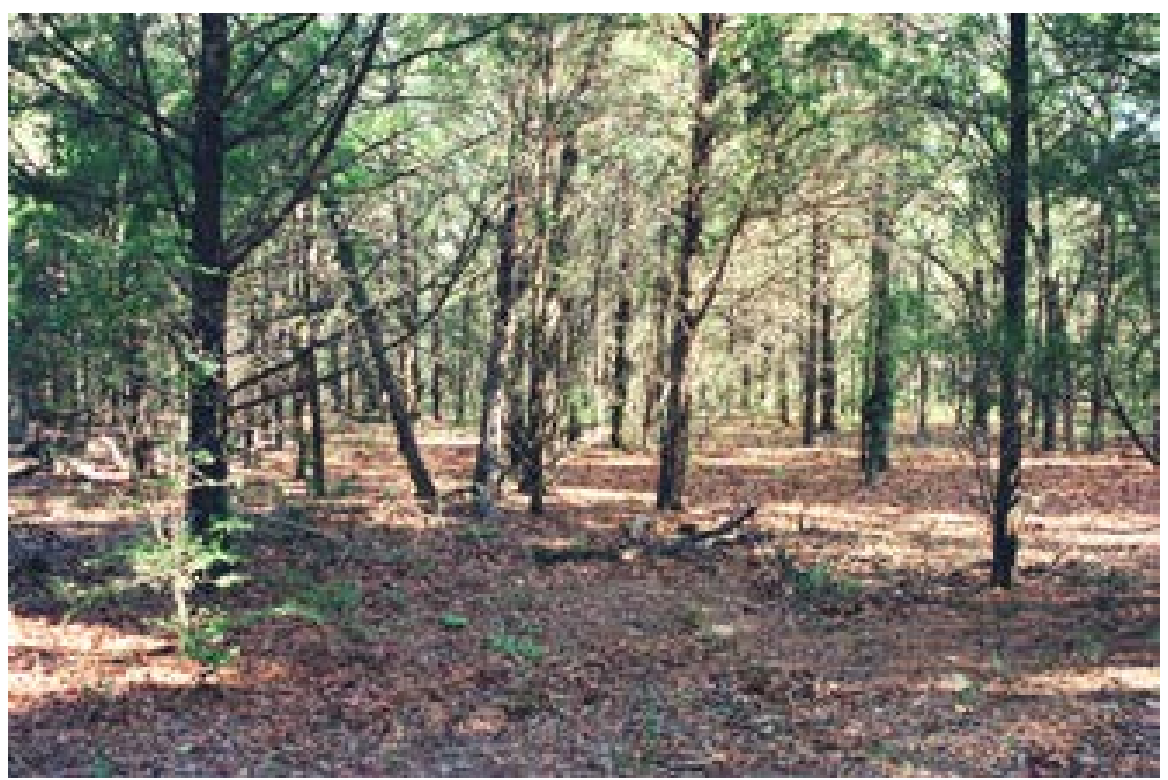

Figure 7-37. 41BP718 lies on a wooded sideslope; facing north.

the lower portion

contains more riparian vegetation, with greenbrier, brush, and weeds. Surface visibility was less than five percent in July 2005. The datum is marked by a nail and aluminum tag in a large oak tree.

\section{Levels of Work and Results}

Because of the dense leaf cover, no prehistoric artifacts were observed on the

portion of the site. In addition to historic artifacts found in shovel tests, a large sandstone slab, bone fragments, and a piece of slate were found on the surface. The historic component is discussed in Chapter 9: New Historic Component Sites. Its rather steep sideslope terrain setting ranges in elevation from 490 to $450 \mathrm{ft}$ amsl. The southern portion of the prehistoric component has obviously been negatively impacted by a historic occupation. An intermittent tributary of Big Sandy Creek is $100 \mathrm{~m}$ to the northwest. Demona loamy fine sand $(\mathrm{DeC})$ covers all but the extreme southern portion of the site where the historic component is also located. There, the soil is Patilo complex fine sand (PaE). The upper portion of the site consists of woody predominantly large oak and hickory trees, with sparse grasses underneath, while

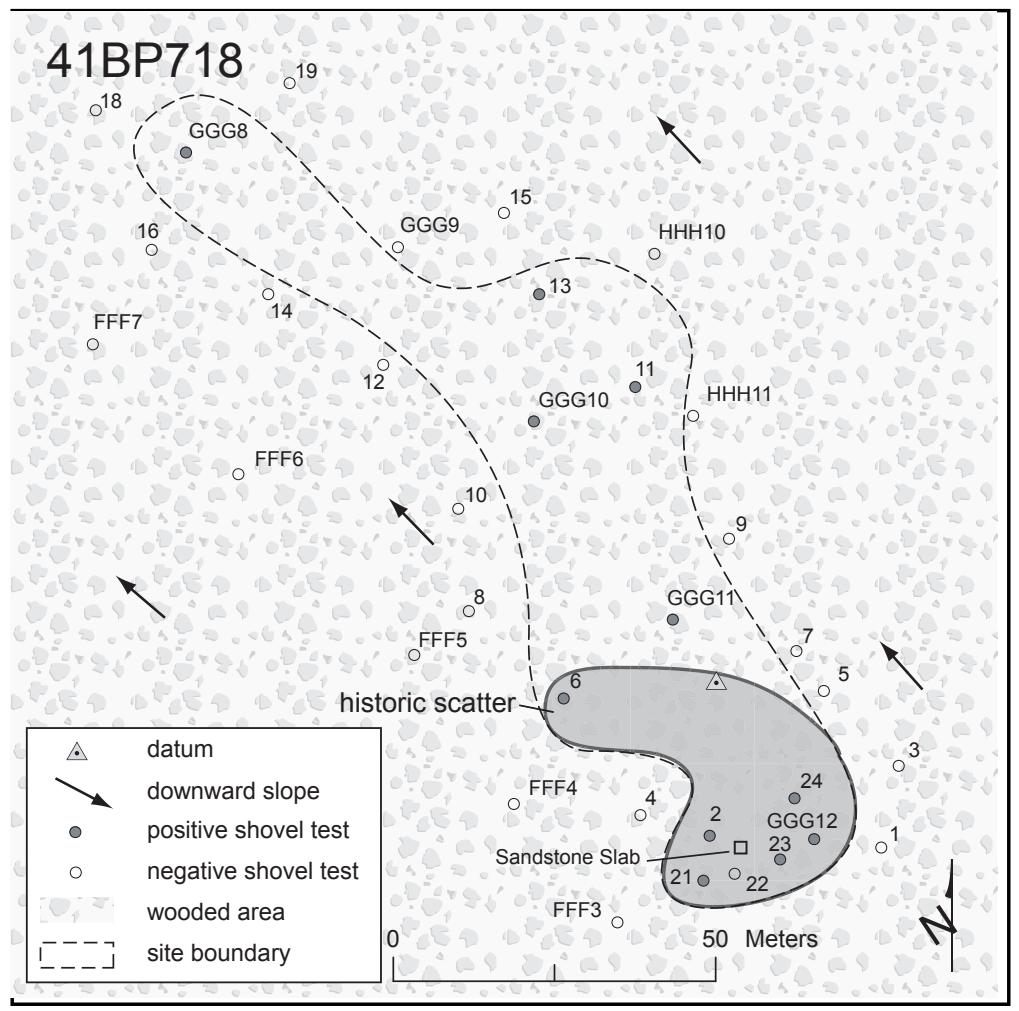

Figure 7-38. Site map of 41BP718. 
Table 7-19. 41BP718 positive shovel test results.

\begin{tabular}{|c|c|c|c|c|c|c|c|c|c|c|c|}
\hline $\begin{array}{c}\text { Depth } \\
\text { (cmbs) }\end{array}$ & $\begin{array}{c}\text { ST } \\
\mathbf{2}\end{array}$ & $\begin{array}{c}\text { ST } \\
\mathbf{6}\end{array}$ & $\begin{array}{c}\text { ST } \\
\mathbf{1 1}\end{array}$ & $\begin{array}{c}\text { ST } \\
\mathbf{1 3}\end{array}$ & $\begin{array}{c}\text { ST } \\
\mathbf{2 1}\end{array}$ & $\begin{array}{c}\text { ST } \\
\mathbf{2 3}\end{array}$ & $\begin{array}{c}\text { ST } \\
\mathbf{2 4}\end{array}$ & $\begin{array}{c}\text { ST } \\
\text { GGG8 }\end{array}$ & $\begin{array}{c}\text { ST } \\
\text { GGG10 }\end{array}$ & $\begin{array}{c}\text { ST } \\
\text { GGG11 }\end{array}$ & $\begin{array}{c}\text { SG } \\
\text { GG12 }\end{array}$ \\
\hline $0-10$ & $\begin{array}{c}\text { GG, } \\
\text { SN }\end{array}$ & & & & BG & & SN & & & & \\
\hline $10-20$ & GG & & & & & F & & IF & & & \\
\hline $20-30$ & CG & BG & & & & & & & & & \\
\hline $30-40$ & 4 FCR & & & & & 2 F & & & IF & & \\
\hline $40-50$ & Hearth & & EF & Ch & & & & & IF & & \\
\hline $50-60$ & & & & & & & & & & & \\
\hline $60-70$ & & & & & & & & & & IF & CB \\
\hline $70-80$ & & Sand & Sand & Sand & Sand & Sand & Sand & Sand & Sand & & \\
\hline $80-90$ & & & & & & & & & & Clay & Sand \\
\hline $90-100$ & & & & & & & & & \\
\hline \multicolumn{7}{|c|}{ Key: EF-exterior Flake; IF-interior Flake; FCR-fire-cracked rock $>1$ inch; F-faunal; } \\
BG-brown glass; CG-clear glass; GG-green glass; CB-ceramic button; SN-square nail
\end{tabular}

is the presence of a fire-cracked rock hearth feature at $40-50 \mathrm{cmbs}$ in ST 2. Excavation was halted at that level to preserve the remainder of the feature. This area of the site is relatively flat compared to the major, northern portion of the site, and thus is less subject to erosion. However, the age and integrity of the hearth feature is unclear. Because of its proximity to historic artifacts directly above, it may be historic in age. On the other hand, if prehistoric, it may have been disturbed by historic activities. All positive shovel tests were dug to at least $70 \mathrm{cmbs}$ with the exception of STs 2 and 13. ST 13 was terminated between 40 and $50 \mathrm{cmbs}$, when a large mass of charcoal exceeding two handfuls came out in one shovel load. Away from the immediate area of the historic component, flakes are deeply buried with no obvious disturbances observed in the shovel tests. However, the contexts of downslope prehistoric cultural material is questionable because of the steepness of the slope noted above. The long and narrow shape of this site suggests the prehistoric cultural material distribution has been influenced by erosional activity, and thus may be in a secondary context.

\section{Conclusions/Recommendations}

Although faunal remains, charcoal, firecracked rock, and lithic debitage were all recovered from this site, as discussed in the preceding paragraph, their context is of questionable integrity. One exception may be the hearth feature encountered in ST 2 on a relatively level portion of the site. Additionally, the charcoal mass discovered in ST 13 should be further investigated. Without further investigations to access the age and integrity of both the firecracked rock feature and the charcoal mass, the potential of this site to address important prehistoric issues is unknown. Therefore, further investigations beyond the scope of this inventory survey are required before a recommendation can be made regarding eligibility for nomination of the prehistoric component to the NRHP. At a minimum, CAS recommends excavation of two 1-x-1-m units in the immediate areas of STs 2 and 13 to expose and document the two features. 


\section{BP719}

\section{Description}

41BP719 (Figures 7-39 and 740 ) is a $3,220-\mathrm{m}^{2}$ open campsite in a wooded upland/sideslope setting. It slopes rather steeply to the north from 510 to $485 \mathrm{ft}$ amsl, with Big Sandy Creek 375 $\mathrm{m}$ to the northwest. Demona loamy fine sand (DeC) and Patilo complex fine sand $(\mathrm{PaE})$ supports the growth of oak, cedar, elm, prickly pear, Virginia creeper, poison ivy, and assorted shrubs and grasses. Rodent burrows and a few treefalls were observed. Visibility was less than ten percent across the site. The datum is marked by a nail and aluminum tag in an oak tree $25 \mathrm{~cm}$ in diameter.

\section{Levels of Work and Results}

No artifacts were observed on the surface. However, 15 shovel tests out of 21 excavated on the site contained prehistoric artifacts. Sixteen

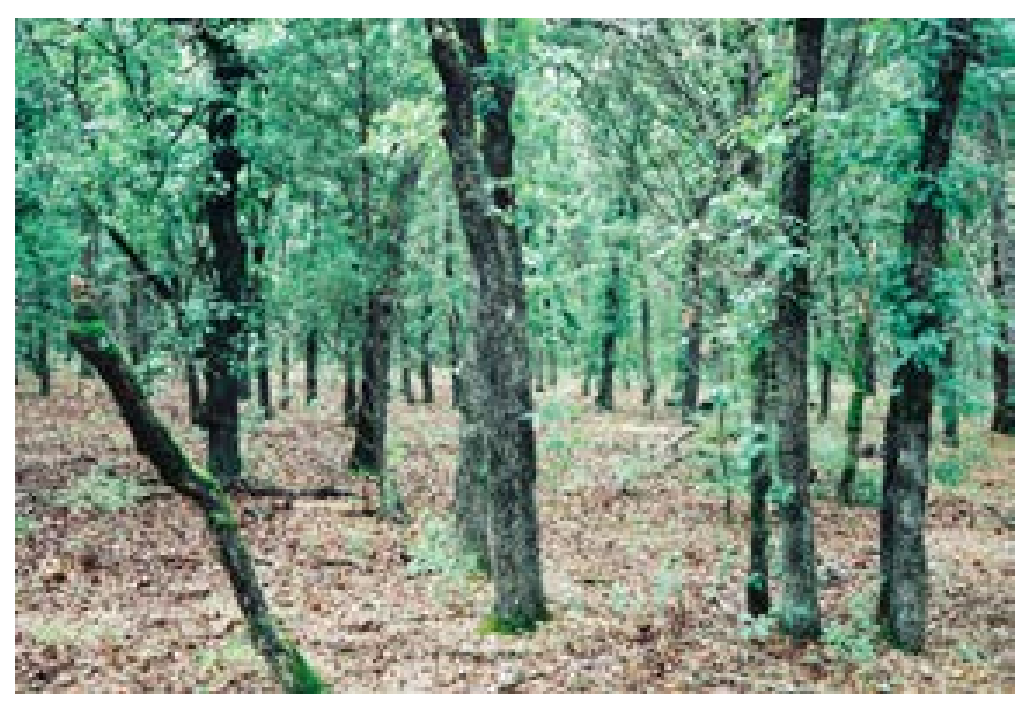

Figure 7-39. 41BP719 lies on a wooded upland and sideslope setting; facing south.

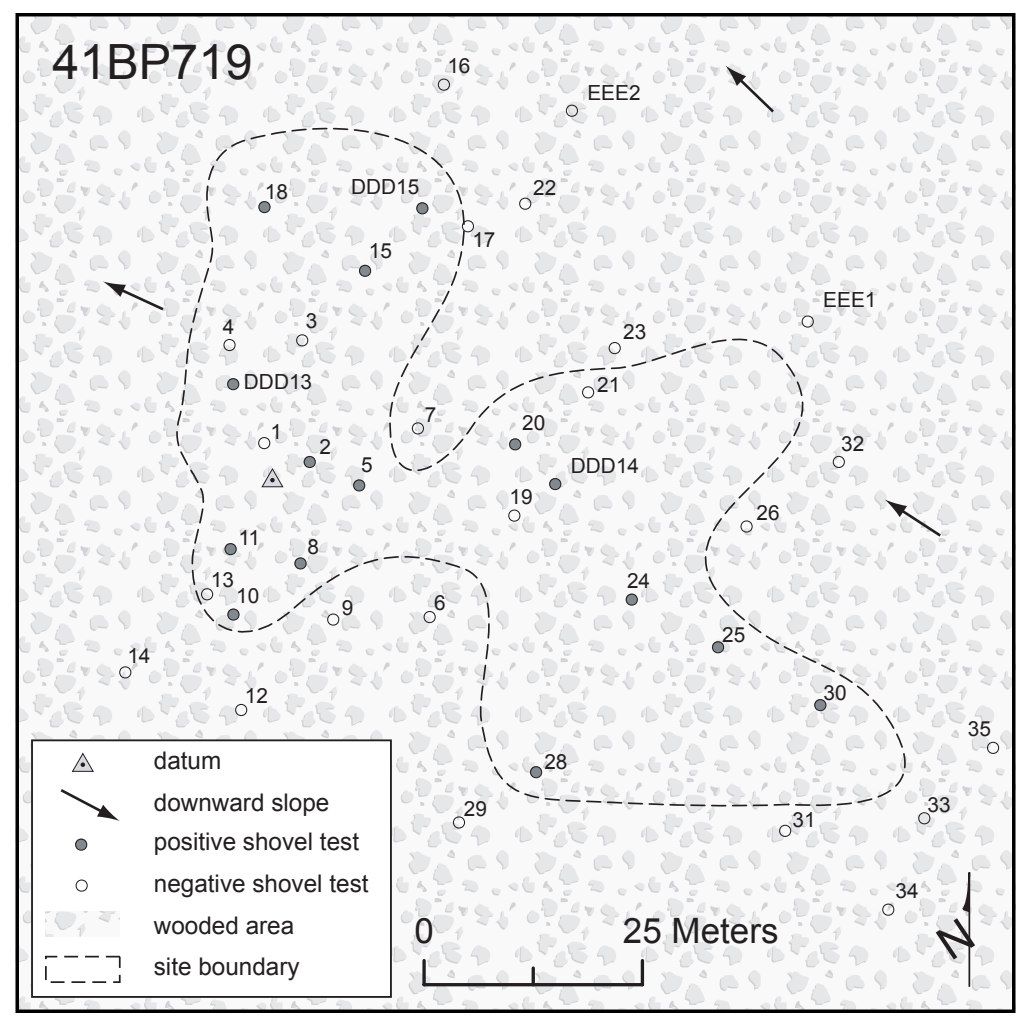

Figure 7-40. Site map of 41BP719.

flakes, two chert chips, and three fire-cracked rocks were recovered from as deep as $70 \mathrm{cmbs}$. Three flakes had been heated and/or spalled. Obvious mixing has occurred around ST 28, where a piece of metal shrapnel was found with a flake (Table 7-20), and another piece of shrapnel was found in ST 11 between 20 and 30 cmbs. The only disturbance that could be discerned from shovel tests was caused by roots. However, the relative steepness and uniformity of slope at this site strongly indicate that colluvial processes have moved cultural material downslope. In several cases, adjoining shovel tests varied significantly in depth to clay, attesting to the likely gullying that has occurred. 


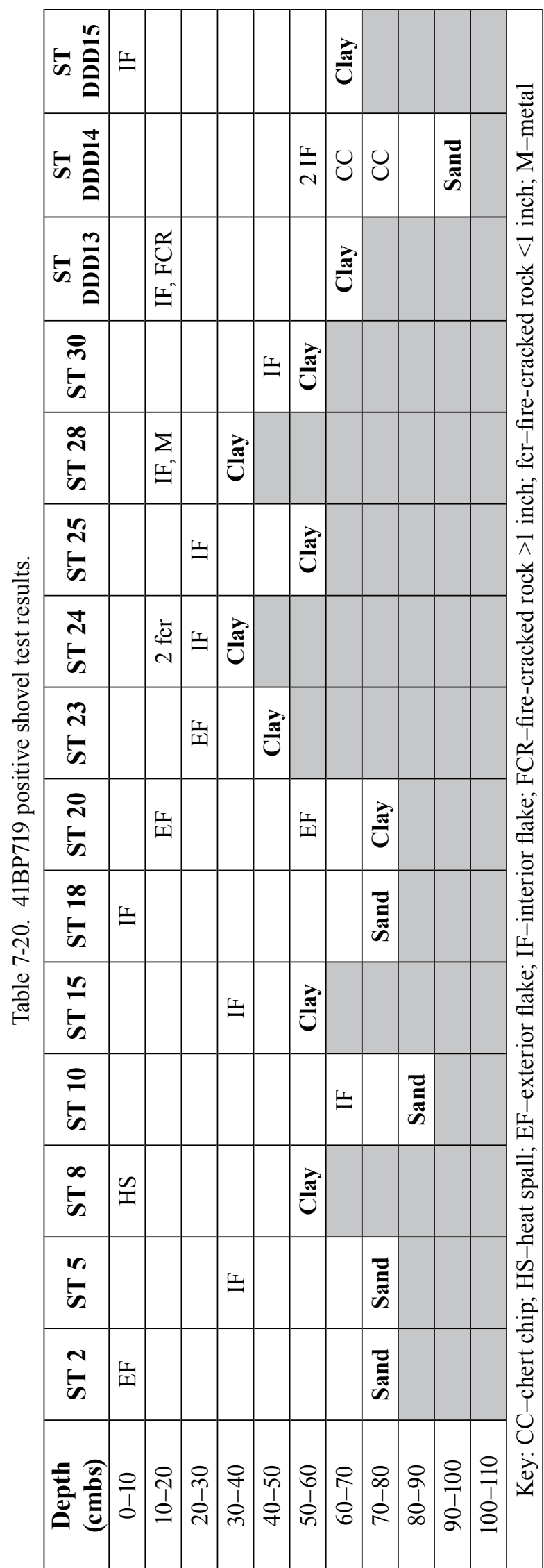

\section{Conclusions/Recommendations}

Unlike 41BP714, which is also set on a generally steep slope, but likely contains a discrete area where there still may be intact deposits, CAS does not believe that is the case at 41BP719. In addition to probable disturbance due to erosion, two pieces of metal shrapnel were found in shovel tests. Therefore, the research value of this site is minimal, CAS recommends that no further work be conducted, and the site is not eligible for nomination to the NRHP.

\section{BP720}

\section{Description}

41BP720 (Figures 7-41 and 7-42) is a $3,767-\mathrm{m}^{2}$ open campsite located on a wooded sideslope covered with oak, cedar, prickly pear cacti, and dense grasses. The Demona loamy fine sand $(\mathrm{DeC})$ surface slopes to the northwest from 471 to $462 \mathrm{ft}$ amsl. The floodplain of Big Sandy Creek lies along the northwest edge of the site. Surface visibility was less than five percent in July 2005. The site datum is marked by a nail and aluminum tag on a small oak tree.

\section{Levels of Work and Results}

No artifacts or features were observed on the surface, but two positive transect shovel tests (Transect STs BBB1 and DDD10) led to the discovery of this site (see Figure 7-42). Seventeen shovel tests out of 26 excavated on the site were positive. A total of 19 flakes, a biface, a chert chip, five fire-cracked rocks, a chunk of charcoal, and a piece of ocher was recovered (Table 7-21). The biface is a crude scraper made from chert. Problematic with the context of the charcoal and scraper is the discovery of a piece of metal shrapnel just above the two (see ST DDD10 in Table 7-21). A piece of shrapnel was also found in 


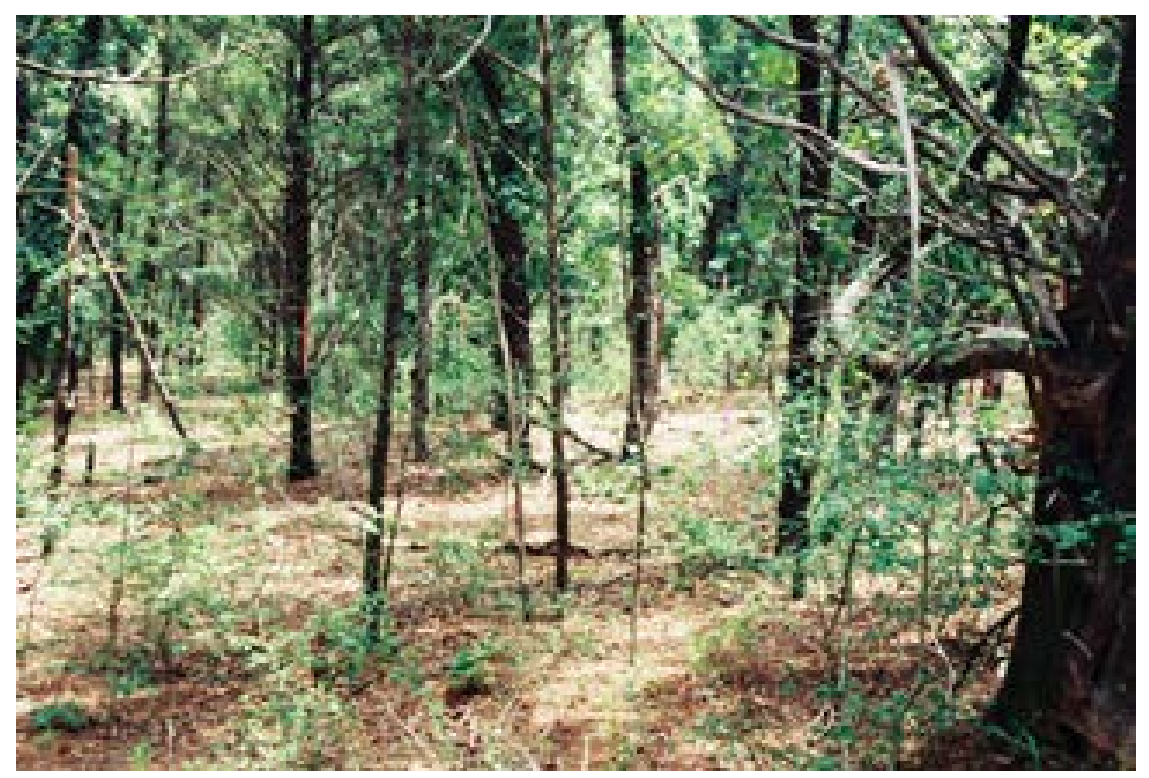

Figure 7-41. 41BP720 lies on a wooded sideslope; facing north.

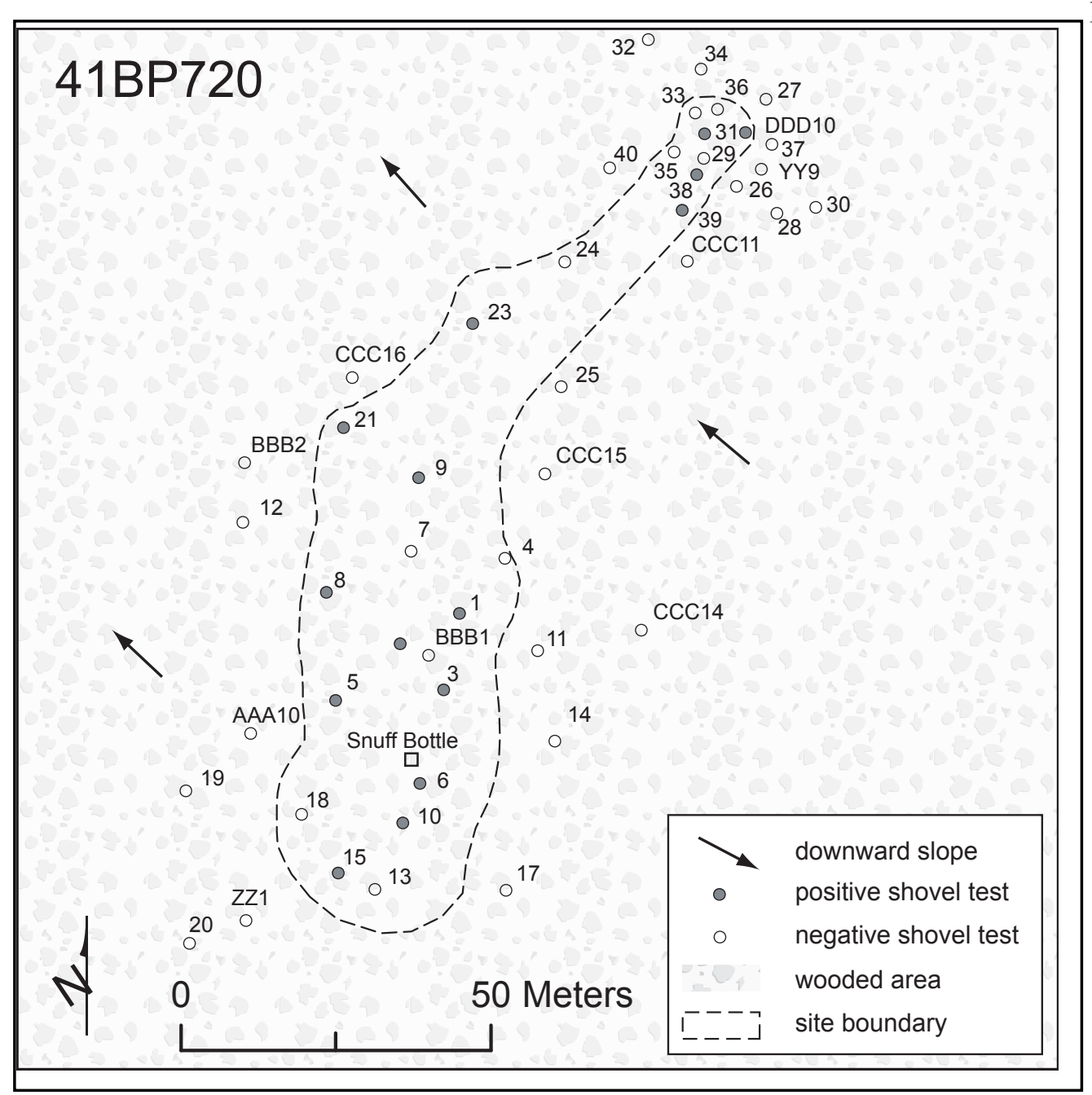

percent in July 2005 . The site datum is marked by a nail and

Figure 7-42. Site map of 41BP720. 


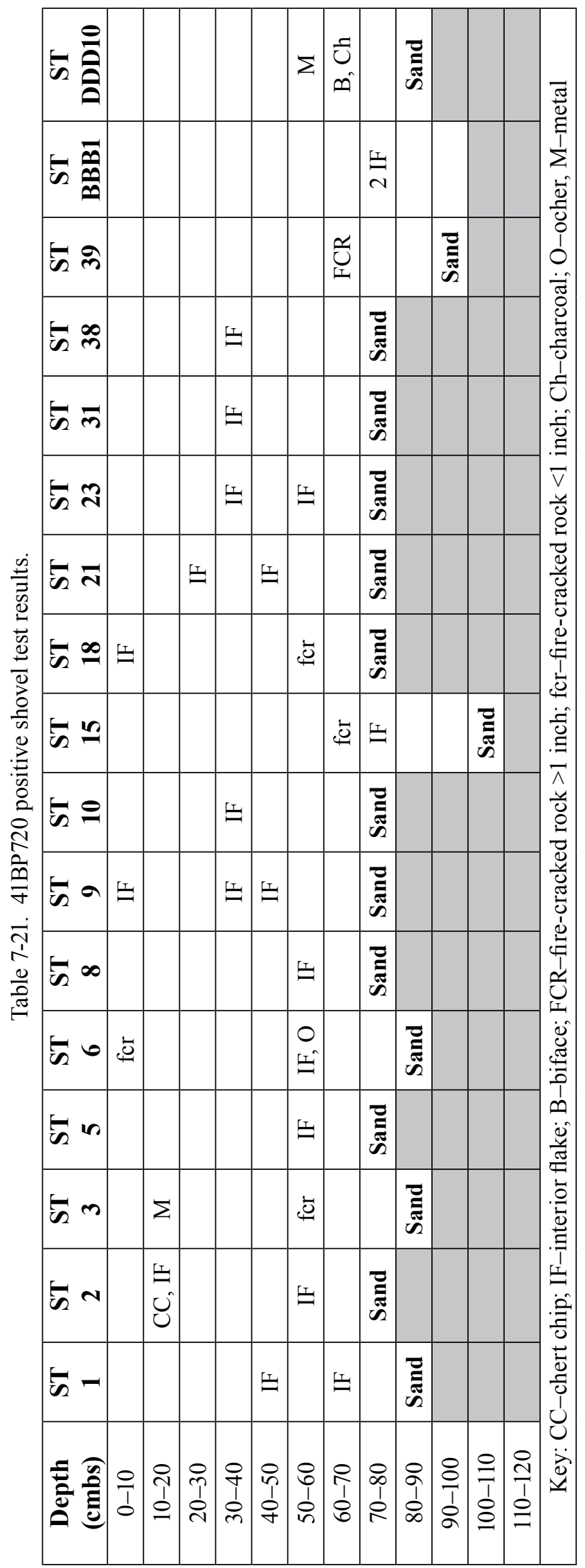

ST 3 between 10 and $20 \mathrm{cmbs}$ and in ST 37 between 0 and $10 \mathrm{cmbs}$.

\section{Conclusions/Recommendations}

This site appears to be an open campsite and has a crude tool, organic preservation in the form of datable charcoal, firecracked rock, and lithic debitage. However, the integrity of the biface and charcoal in ST DDD10 on the lower, northern portion of this site is doubtful because of the depth at which shrapnel was also found. On the other hand, the consistent presence of firecracked rocks, ocher, and lithic debitage below $50 \mathrm{cmbs}$ in the southern portion of the site in deep sands suggests that a stratified cultural zone with intact features potentially exists in that area. Therefore, further investigations beyond the scope of this inventory survey are required before a recommendation can be made regarding eligibility for nomination to the NRHP. At a minimum, CAS recommends excavation of four 1-x-1-m units, one each in the areas around STs 2, 6, 15, and 18 .

\section{BP721}

\section{Description}

41BP721 (Figures 7-43 and 7-44) is an open campsite on a lower terrace at the confluence of Big Sandy Creek and an unnamed tributary. An apparent shift in the channel of the unnamed tributary has now isolated the site on an "island." The results of shovel tests indicate the site covers approximately $4,715 \mathrm{~m}^{2}$ buried in Sayers fine sandy loam (Sa). All but the eastern end of the site is covered with dense grasses, wild grapevines, bull nettle, assorted cacti, and scattered cedar and oak trees. The surface slopes to the north from 430 to 420 $\mathrm{ft}$ amsl. Surface visibility was less than five 


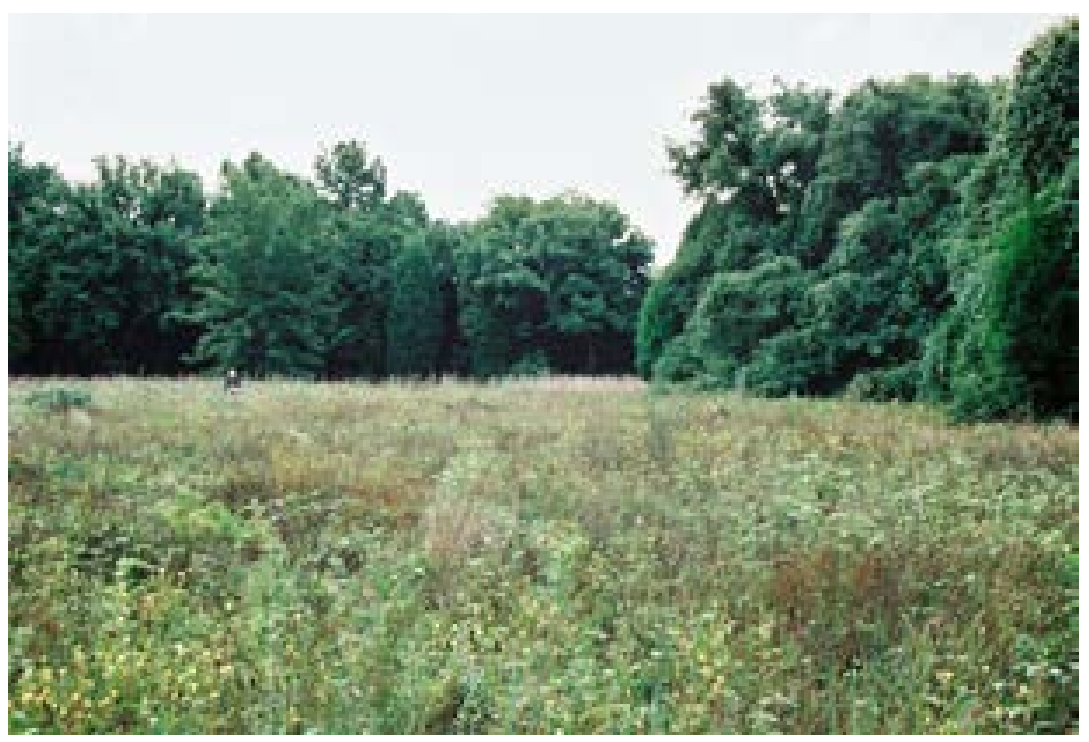

Figure 7-43. 41BP721 lies on a lower terrace at the confluence of Big Sandy Creek and an unnamed tributary; facing southeast.

FIGURE 7-44. REDACTED

Figure 7-44. Site map of 41BP721.

aluminum

Levels

tag on a

small oak tree.

and Results

of Work 
Table 7-22. 41BP721 positive shovel test results.

\begin{tabular}{|c|c|c|c|c|c|c|c|c|c|c|c|}
\hline $\begin{array}{l}\text { Depth } \\
\text { (cmbs) }\end{array}$ & ST 1 & ST 2 & ST 3 & ST 6 & ST 7 & ST 8 & ST 12 & ST 16 & $\begin{array}{c}\text { ST } \\
\text { VV8 }\end{array}$ & $\begin{array}{c}\text { ST } \\
\text { XX3 }\end{array}$ & $\begin{array}{c}\text { ST } \\
\text { ZZ8 }\end{array}$ \\
\hline $0-10$ & & IF, M & & & & & & & & $2 \mathrm{IF}$ & \\
\hline $10-20$ & IF & & & & IF & & $\mathrm{M}$ & & IF & & \\
\hline $20-30$ & & & $\mathrm{M}$ & & IF & $4 \mathrm{IF}$ & & $\mathrm{EF}$ & & & \\
\hline $30-40$ & IF & & & & IF & $\mathrm{M}$ & & & & & \\
\hline $40-50$ & & & PL & $2 \mathrm{IF}$ & & $\mathrm{EF}$ & & & & & \\
\hline $50-60$ & & & & & & & & & IF & & \\
\hline $60-70$ & & & & IF & & & & & IF & FCR & IF \\
\hline $70-80$ & Sand & Sand & Sand & $\mathrm{EF}$ & Sand & Sand & & Sand & & & \\
\hline \multicolumn{12}{|l|}{$80-90$} \\
\hline $90-100$ & & & & Sand & & & & & Sand & Sand & Sand \\
\hline $100-110$ & & & & & & & & & & & \\
\hline \multicolumn{12}{|c|}{ Key: PL-pot lid, EF-exterior flake; IF-interior flake; FCR-fire-cracked rock $>1$ inch; M-metal } \\
\hline
\end{tabular}

No surface artifacts or features were observed, but 11 positive shovel tests out of 15 placed on the site yielded 22 flakes, one firecracked rock, and a chert potlid (Table 7-22). However, three pieces of metal shrapnel were also found, one in ST 2 at $0-10 \mathrm{cmbs}$, one in ST 3 at $20-30 \mathrm{cmbs}$, and one in ST 12 at $10-20 \mathrm{cmbs}$. Other evidence of disturbance observed in the shovel tests was a plow zone in the grassy field and angular ironstones in ST 12 between 0 and $70 \mathrm{cmbs}$, which suggest a colluvial deposit in that area.

\section{Conclusions/Recommendations}

Although this open campsite has firecracked rock and lithic debitage, the evidence for disturbance in the form of colluvium and buried shrapnel negatively influence the integrity of the prehistoric cultural deposits. Therefore, the research value of this site is minimal, CAS recommends that no further work be conducted, and the site is not eligible for nomination to the NRHP.

\section{BP722}

\section{Description}

41BP722 (Figures 7-45 and 7-46) is a lithic scatter on a semi-wooded sideslope adjacent to the floodplain of an intermittent drainage of Big Sandy Creek. The site covers approximately 2,526 $\mathrm{m}^{2}$ buried in Demona loamy fine sand $(\mathrm{DeC})$. Vegetation includes dense grasses, Virginia creeper, assorted cacti, poison ivy, and scattered cedar and oak trees. The surface slopes to the north from 455 to $443 \mathrm{ft}$ amsl. Obvious surface disturbances include eroded swales and gullies, and a few uprooted trees. Surface visibility was less than five percent in July 2005. The site datum is marked by a nail and aluminum tag on an oak tree $25 \mathrm{~cm}$ in diameter.

\section{Levels of Work and Results}

Archaeologists recovered a Late Prehistoric Scallorn arrow point (Figure 7-47) made of pinkish-tan, fine-grained chert and eight flakes from eight of nine shovel tests excavated on the site (Table 7-23). However, no artifacts or features were observed on the surface. Three pieces of metal shrapnel were also found, two listed in Table 7-23 and another found in ST 14 between 0 


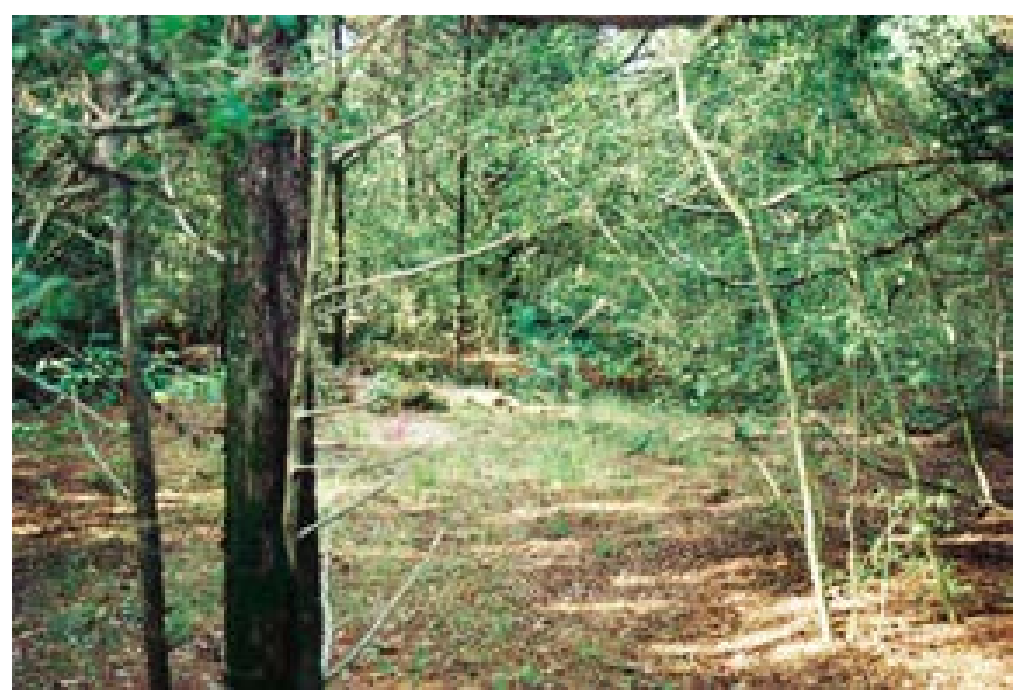

Figure 7-45. 41BP722 lies on a semi-wooded sideslope; facing south.

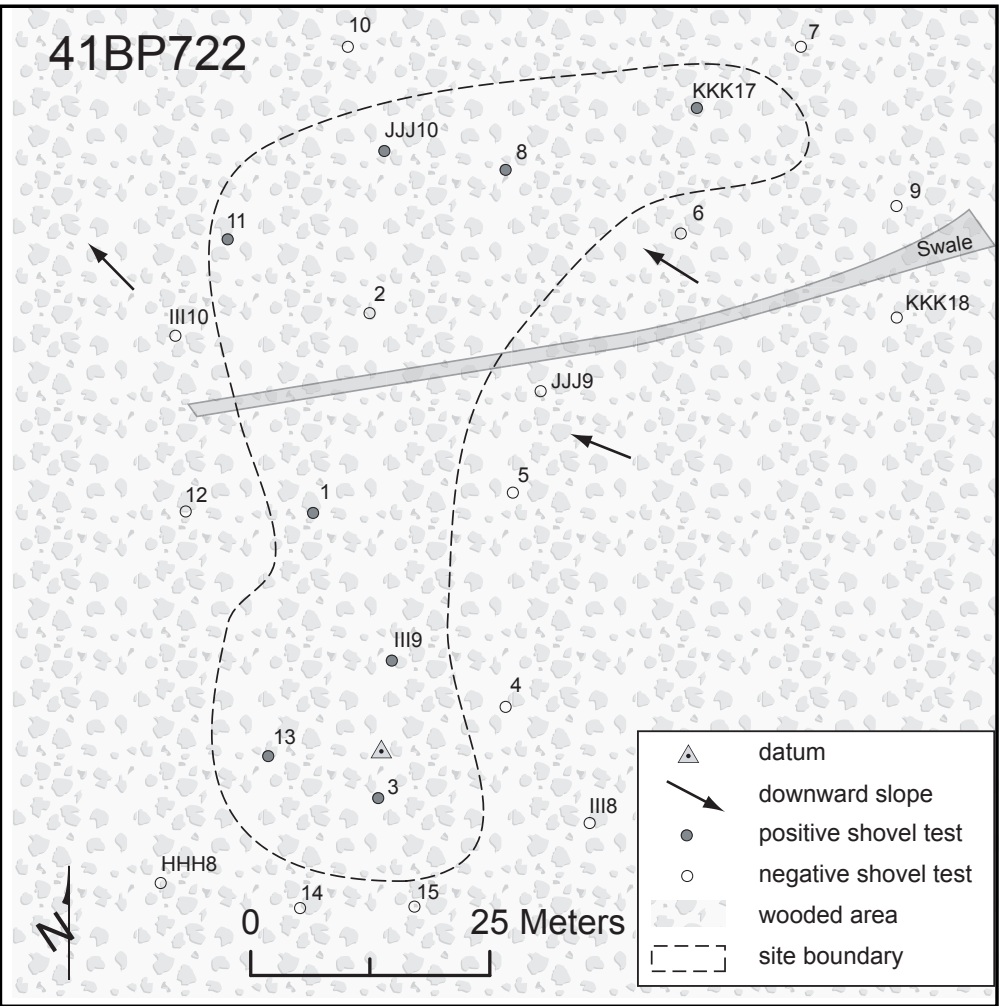

Figure 7-46. Site map of 41BP722.

and $10 \mathrm{cmbs}$. Notably, the piece in ST JJJ10 was found below a flake and on the same level as the Scallorn point was in ST 13.

\section{Conclusions/Recommendations}

Although this lithic scatter has a timediagnostic artifact, the evidence for disturbance 


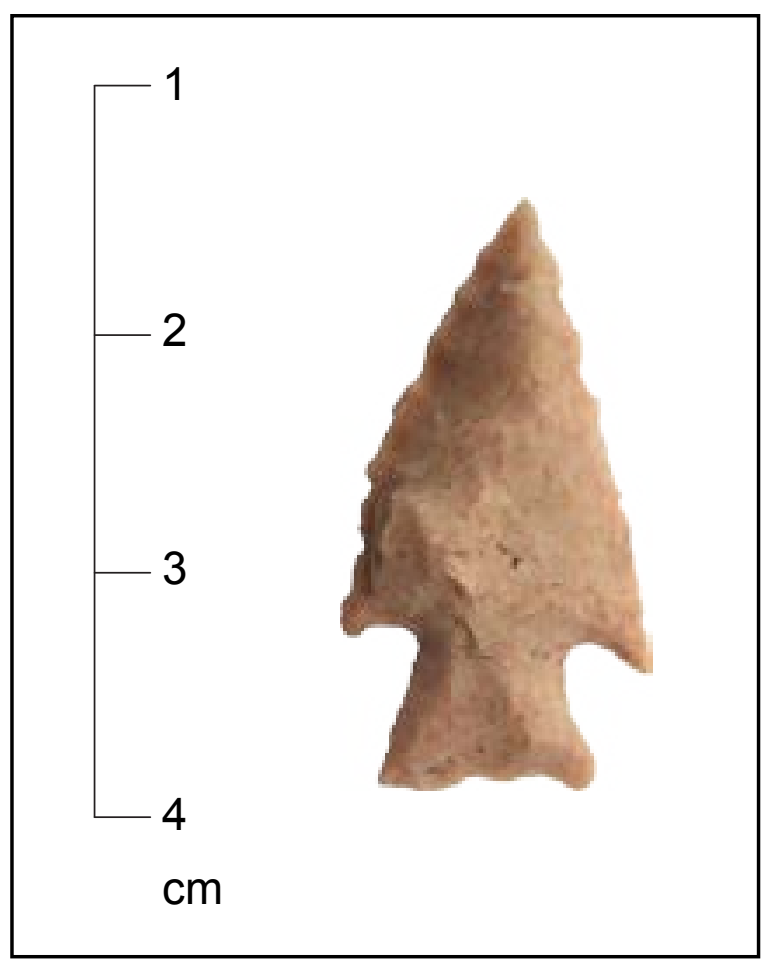

Figure 7-47. This Scallorn point was found between 50 and $60 \mathrm{cmbs}$ in ST 13 at 41BP722.

Table 7-23. 41BP722 positive shovel test results.

\begin{tabular}{|c|c|c|c|c|c|c|c|c|}
\hline Depth (cmbs) & ST 1 & ST 3 & ST 8 & ST 11 & ST 13 & ST III9 & ST JJJ10 & ST KKK17 \\
\hline $0-10$ & & IF & & & $\mathrm{M}$ & IF & & \\
\hline \multicolumn{9}{|l|}{$10-20$} \\
\hline \multicolumn{9}{|l|}{$20-30$} \\
\hline $30-40$ & & $\mathrm{EF}$ & & & & & & IF \\
\hline $40-50$ & IF & & & & & & IF & \\
\hline $50-60$ & & & IF & & SP & & $\mathrm{M}$ & \\
\hline $60-70$ & & & & IF & & & & Clay \\
\hline $70-80$ & Sand & Sand & Sand & & & Sand & Sand & \\
\hline $80-90$ & & & & Sand & Sand & & & \\
\hline $90-100$ & & & & & & & & \\
\hline \multicolumn{9}{|c|}{ Key: EF-exterior flake; IF-interior flake; SP-Scallorn point; M-metal } \\
\hline
\end{tabular}

in the form of severe erosion, uprooted trees, and buried shrapnel negatively influence the integrity of the prehistoric cultural deposits. Therefore, the research value of this site is minimal, CAS recommends that no further work be conducted, and the site is not eligible for nomination to the NRHP. 


\section{BP723}

\section{Description}

41BP723 (Figures 7-48 and 7-49) is a small $\left(195 \mathrm{~m}^{2}\right)$ lithic scatter located in a semi-wooded grassy field with bull nettle, assorted cacti,

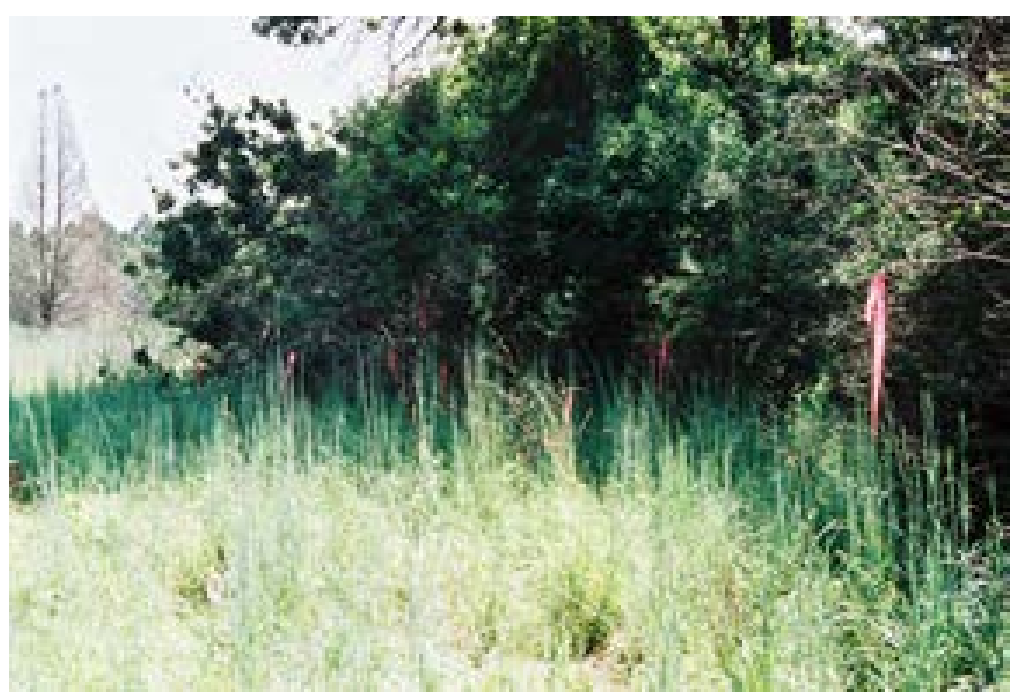

Figure 7-48. 41BP723 lies on a semi-wooded grassland; facing northeast.

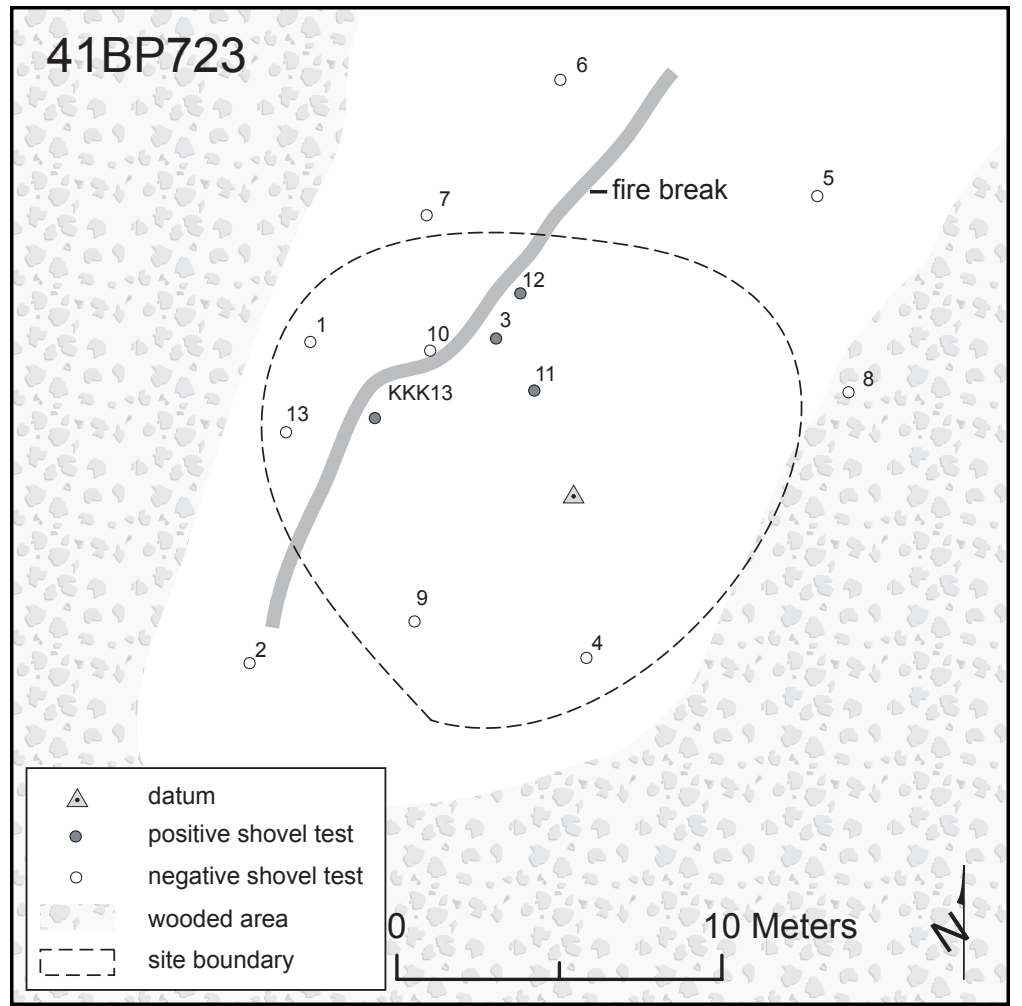

Figure 7-49. Site map of 41BP723. poison ivy and surrounded by pine, oak, and cedar woods. The site lies at the juncture of two soil types: Patilo complex fine sand $(\mathrm{PaE})$ in its western half, and Axtell fine sandy loam (AfC) in its eastern half. The terrain gently slopes to the south, ranging in elevation from 430 to 428 feet. The floodplain of an intermittent first order tributary of Big Sandy Creek lies $10 \mathrm{~m}$ to the east. A $30-\mathrm{cm}$ deep firebreak trench has been cut through the site. Surface visibility was less than five percent in July 2005. The site datum is marked by a nail and aluminum tag on a small oak tree.

\section{Levels of Work and Results}

A single positive shovel test (Transect ST KKK13) led to the discovery of this site (see Figure 7-49). Of the nine shovel tests excavated on the site, only five flakes were recovered from four positive shovel tests (Table 724). In addition to the firebreak penetrating the surface, a piece of unidentifiable metal was found at $0-10 \mathrm{cmbs}$ in ST 13.

\section{Conclusions/ Recommendations}

This site appears to be an ephemeral lithic scatter with no evidence of fire-cracked rocks, faunal or organic preservation, or features. Therefore, its research value is minimal, CAS recommends that no further work be conducted, and the site is not eligible for nomination to the NRHP. 
Table 7-24. 41BP723 positive shovel test results.

\begin{tabular}{|c|c|c|c|c|}
\hline $\begin{array}{c}\text { Depth } \\
\text { (cmbs) }\end{array}$ & $\begin{array}{c}\text { ST } \\
\mathbf{3}\end{array}$ & $\begin{array}{c}\text { ST } \\
\mathbf{1 1}\end{array}$ & $\begin{array}{c}\text { ST } \\
\mathbf{1 2}\end{array}$ & $\begin{array}{c}\text { ST } \\
\text { KKK13 }\end{array}$ \\
\hline $0-10$ & IF & & IF & \\
\hline $10-20$ & & & & \\
\hline $20-30$ & & & & \\
\hline $30-40$ & & IF & & \\
\hline $40-50$ & & & & \\
\hline $50-60$ & & & & \\
\hline $60-70$ & & & IF & IF \\
\hline $70-80$ & Sand & Sand & & \\
\hline $80-90$ & & & & Sand \\
\hline $90-100$ & & & Sand & \\
\hline $100-110$ & & & & \\
\hline \multicolumn{5}{|r|}{ Key: IF-interior flake } \\
\hline
\end{tabular}

\section{BP724}

\section{Description}

41BP724 (Figures 7-50 and 7-51) is a 1,355$\mathrm{m}^{2}$ open campsite under open grassland with bull nettles and cacti, as well as a wooded area with pine, oak, and cedar trees. The broad terrace it is situated on gently slopes toward the south from 436 to $435 \mathrm{ft}$ amsl. Big Sandy Creek lies $160 \mathrm{~m}$ to the west. The soil type at this site is Patilo complex fine sand $(\mathrm{PaE})$. Surface visibility was less than five percent across the site, and there were no obvious disturbances in the immediate area. The datum is marked by a nail and aluminum tag in a large pine tree.

\section{Levels of Work and Results}

No artifacts were observed on the surface, but six shovel tests out of eight excavated on the site contained either fire-cracked rocks or interior flakes for a total of eight flakes and two firecracked rocks (Table 7-25). Rodent burrows were noted in ST 6 between 0 and 20 cmbs. Upper and lower soil zones were consistently observed across the site in virtually all shovel tests. The upper $50-\mathrm{cm}$ zone (on average) consisted of tan, loose sand, while a lower zone to $70 \mathrm{cmbs}$ consisted of tan, loose sand with red, coarse sand mottling. The derivation of these two zones is unknown. However, a review of the data in Table 7-25 indicates a possibly stratified cultural component between 50 and $60 \mathrm{cmbs}$.

\section{Conclusions/Recommendations}

Without further investigations, CAS is unable to fully evaluate the potential of this site. The consistent vertical distribution of firecracked rocks and flakes between 50 and 60 cmbs, coincidental with a buried soil zone, suggests that there may be buried burned rock features and associated material. In addition, the clearly defined differentiations in soil zones make this site and landform amenable to a geomorphological study. Thus, the research value of this site is unknown and further investigations beyond the scope of an inventory survey are required before a recommendation can be made regarding eligibility for nomination to the NRHP. At a minimum, CAS recommends excavation of two 1-x-1-m units, one each in the areas around STs 3 and 7. The geomorphological study should consist of two backhoe trenches. Trench walls should be profiled and described, with soil samples collected for possible further analysis in conjunction with sandy mantle formation issues. The trenches should be carefully excavated in $3-5-\mathrm{cm}$ levels in a scraping fashion so that if features or preserved faunal material are encountered, they can then be excavated by hand during a Phase II testing program. 


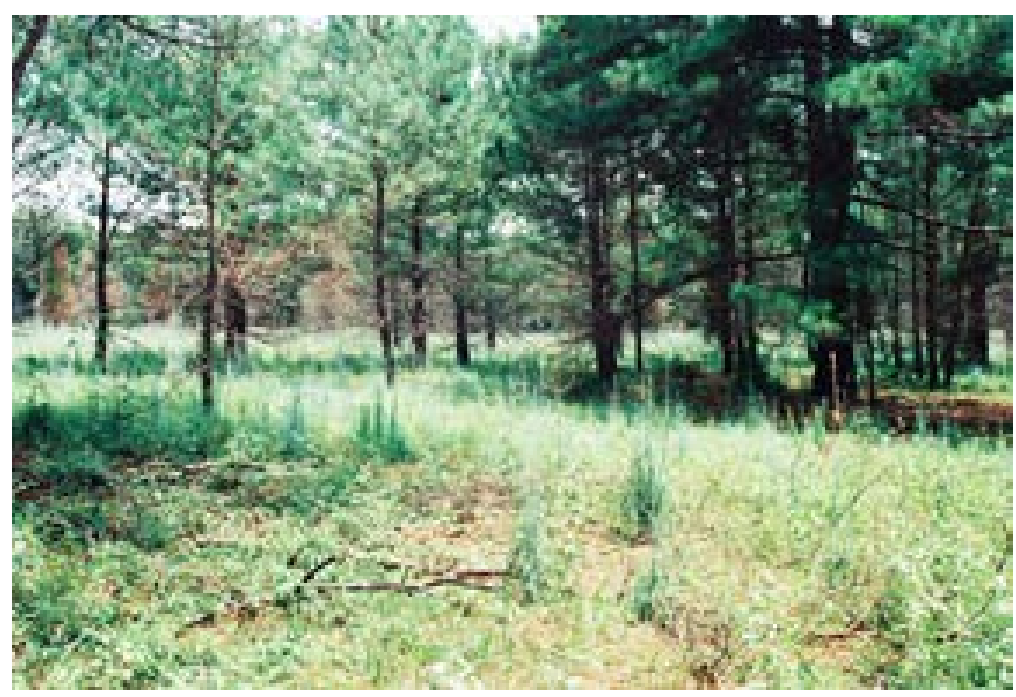

Figure 7-50. 41BP724 lies on a broad terrace setting; facing northeast.

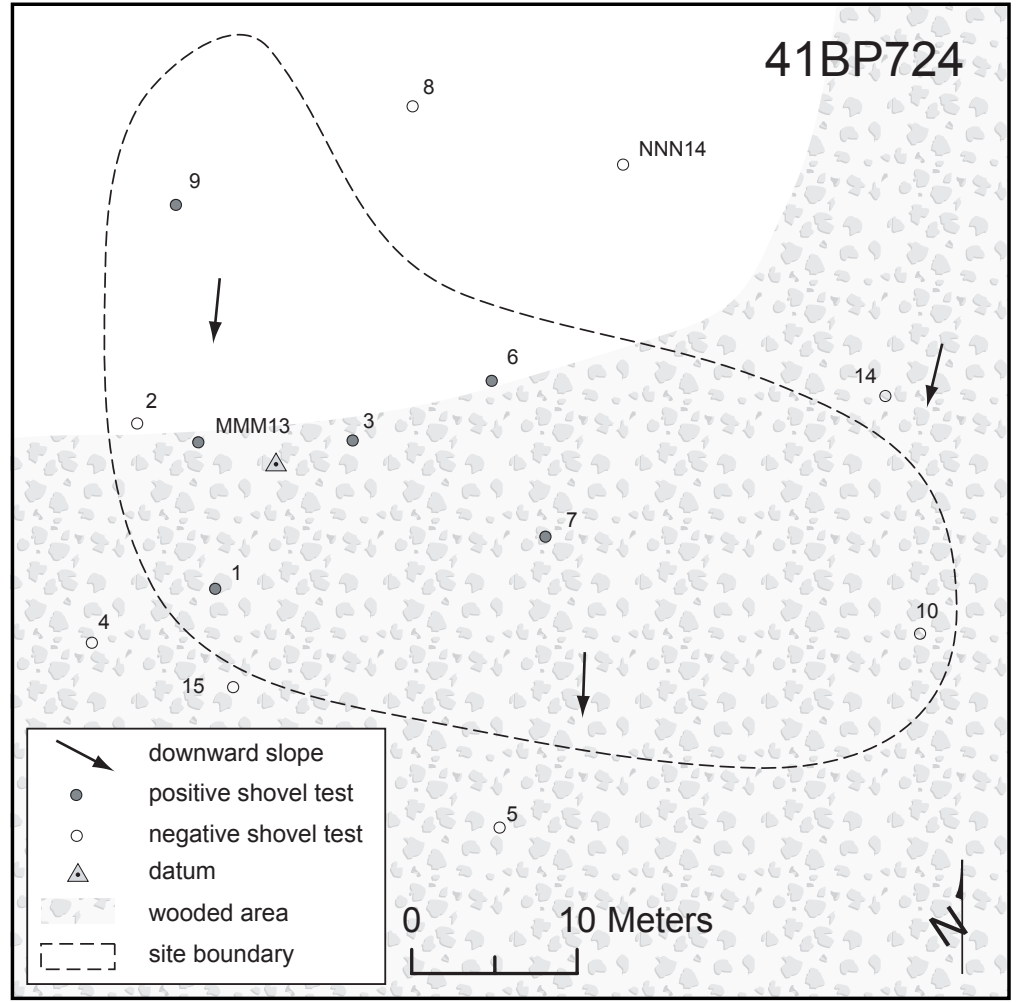

Figure 7-51. Site map of 41BP724. 
Table 7-25. 41BP724 positive shovel test results.

\begin{tabular}{|c|c|c|c|c|c|c|}
\hline $\begin{array}{c}\text { Depth } \\
\text { (cmbs) }\end{array}$ & ST 1 & ST 3 & ST 6 & ST 7 & ST 9 & $\begin{array}{c}\text { ST } \\
\text { MMM13 }\end{array}$ \\
\hline $0-10$ & IF & & IF & & & \\
\hline $10-20$ & IF & & & & & \\
\hline $20-30$ & & & & & & IF \\
\hline $30-40$ & & & & & IF & \\
\hline $40-50$ & & & & & & \\
\hline $50-60$ & & FCR & IF & FCR & IF & \\
\hline $60-70$ & & & IF & & & \\
\hline $70-80$ & Sand & Sand & & Sand & & Sand \\
\hline $80-90$ & & & & & Sand & \\
\hline $90-100$ & & & Sand & & & \\
\hline $100-110$ & & & & & & \\
\hline \multicolumn{7}{|l}{ Key: IF-interior flake; FCR-fire-cracked rock $>1$ inch } \\
\hline
\end{tabular}

small fragment of fire-cracked chert and nine small interior flakes were recovered from nine shovel tests out of 17 excavated on the site (Table 7-26). Tree roots presented the only readily apparent causes of disturbances observed in the shovel tests. Although evidence of colluvial deposition could not be detected within the shovel tests, the data indicate that in general, artifacts are buried deeper downslope (see Figure 7-53 and Table 7-26). No artifacts or features were observed on the surface.

\section{BP725}

\section{Description}

41BP725 (Figures 7-52 and 7-53) is a large $\left(18,421 \mathrm{~m}^{2}\right)$ prehistoric open campsite ranging in elevation from 505 to $460 \mathrm{ft}$ amsl. The site is situated on a wooded ridge end and sideslope above an intermittent first order tributary of Big Sandy Creek. Demona loamy fine sand (DeC) and Patilo complex fine sand $(\mathrm{PaE})$ cover the area and support predominantly oak and cedar trees. Disturbances observed included a bladed push pile, small rodent burrows, and an occasional uprooted tree. Surface visibility was less than five percent in July 2005. The datum is marked by a nail and aluminum tag on a large oak tree.

\section{Levels of Work and Results}

This site was discovered during excavation of systematic transect shovel tests (see Figure 7-53). One additional shovel test (ST 1) was placed on the site. A

\section{Conclusions/Recommendations}

CAS's estimation is that this site is approximately 80 percent intact. However, without further investigations beyond the scope of this inventory survey, its research value is unknown. CAS recommends excavation of five $1-x-1-m$ units in the areas of the nine positive shovel tests to further assess the integrity and NRHP eligibility of this site.

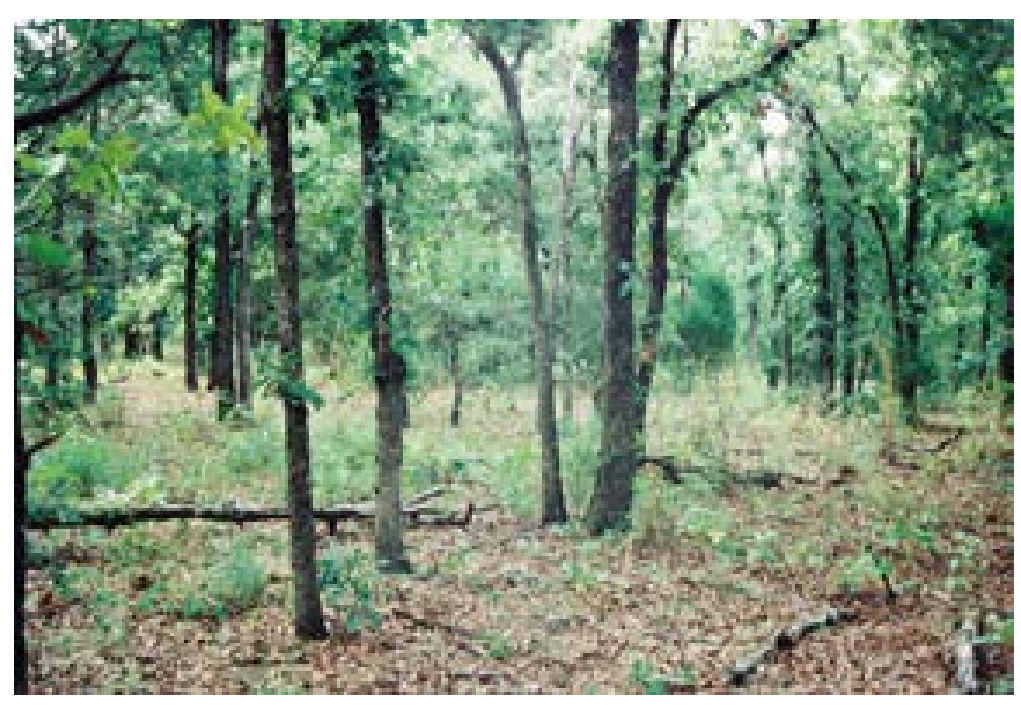

Figure 7-52. 41BP725 lies on a ridge end and sideslope; facing southeast. 
FIGURE 7-53. REDACTED

Figure 7-53. Site map of 41BP725.

Table 7-26. 41BP725 positive shovel test results.

\begin{tabular}{|c|c|c|c|c|c|c|c|c|c|}
\hline $\begin{array}{c}\text { Depth } \\
\text { (cmbs) }\end{array}$ & $\begin{array}{c}\text { ST } \\
\text { 1 }\end{array}$ & $\begin{array}{c}\text { ST } \\
\text { TTT13 }\end{array}$ & $\begin{array}{c}\text { ST } \\
\text { UUU8 }\end{array}$ & $\begin{array}{c}\text { ST } \\
\text { VVV5 }\end{array}$ & $\begin{array}{c}\text { ST } \\
\text { WWW18 }\end{array}$ & $\begin{array}{c}\text { ST } \\
\text { WWW22 }\end{array}$ & $\begin{array}{c}\text { ST } \\
\text { XXX17 }\end{array}$ & $\begin{array}{c}\text { ST } \\
\text { XXX19 }\end{array}$ & $\begin{array}{c}\text { ST } \\
\text { ZZZ4 }\end{array}$ \\
\hline $0-10$ & & & & & IF & & & & \\
\hline $10-20$ & & & & & & & & & \\
\hline $20-30$ & S & & & & & & & IF & \\
\hline $30-40$ & & & & & & & IF & & \\
\hline $40-50$ & & & & IF & & HS & & & IF \\
\hline $50-60$ & & & IF & IF & fcr & & & & \\
\hline $60-70$ & IF & IF & & & & & & & \\
\hline $70-80$ & & & Sand & Sand & & Sand & Sand & Sand & Sand \\
\hline $80-90$ & Sand & Sand & & & & & & & \\
\hline $90-100$ & & & & & & & & & \\
\hline
\end{tabular}




\begin{abstract}
41BP726
Description

41BP726 (Figures 7-54 and 7-55) is situated on an oak and cedar ridge with Demona loamy fine sand $(\mathrm{DeC})$. It is apparently a small $\left(521 \mathrm{~m}^{2}\right)$ open campsite buried under a surface that gently slopes toward the north from 505 to $504 \mathrm{ft}$ amsl. The nearest drainage is an intermittent tributary of Big Sandy Creek some $250 \mathrm{~m}$ to the southeast. No surface disturbances were obvious in the immediate area of the site. Because of heavy leaf cover, surface visibility was less than five percent across the site except in a $20-\mathrm{cm}$ deep roadcut that runs along its southern edge. The datum is marked by a nail and aluminum tag in a large oak tree.
\end{abstract}

\section{Levels of Work and Results}

No artifacts were observed on the surface, but six of nine shovel tests excavated on the site contained either charcoal or flakes (Table 7-27). No obvious mixing, only roots causing possible disturbances, were observed in any of the shovel tests placed on and around the site. Although no fire-cracked rocks were recovered, charcoal was found at similar depths in STs 6, 12, and 13 .

\section{Conclusions/Recommendations}

This site is situated on a similar landform and elevation, with similar vegetation to that of

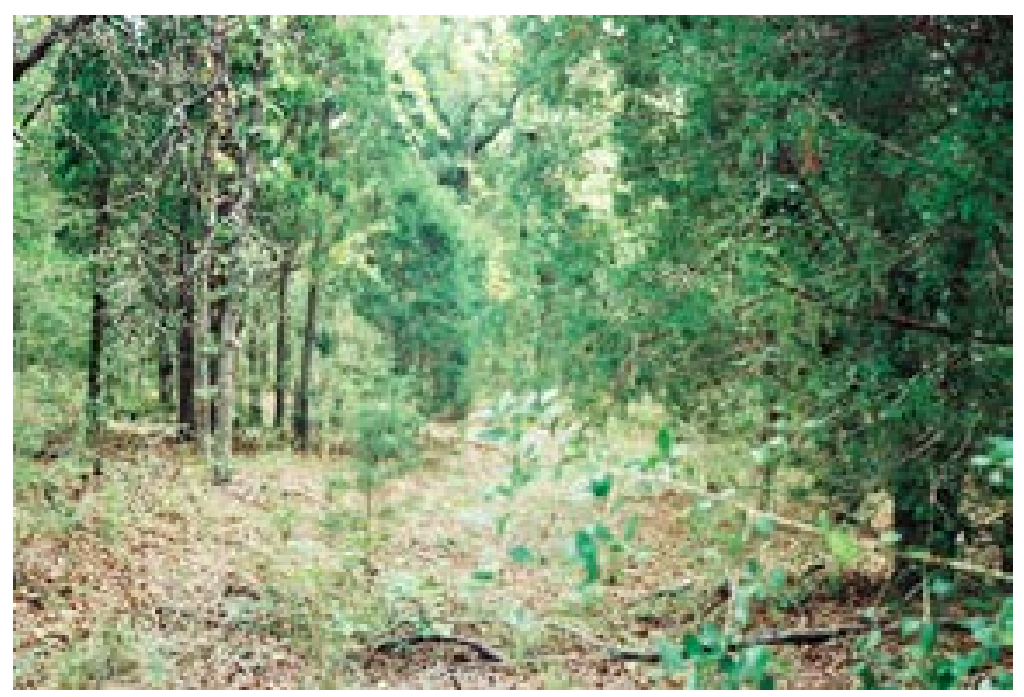

Figure 7-54. 41BP726 lies on a wooded ridge; facing north.

FIGURE 7-55. REDACTED

Figure 7-55. Site map of 41BP726.

41BP529, an intact Early Archaic open campsite on the opposite side of a large intermittent drainage. However, without further investigations, CAS is unable to fully evaluate the potential of this site. Evidence of organic preservation and datable material suggests that, if intact, buried 
Table 7-27. 41BP726 positive shovel test results.

\begin{tabular}{|c|c|c|c|c|c|c|}
\hline $\begin{array}{l}\text { Depth } \\
\text { (cmbs) }\end{array}$ & $\begin{array}{c}\text { ST } \\
5\end{array}$ & $\begin{array}{c}\text { ST } \\
6\end{array}$ & $\begin{array}{l}\text { ST } \\
8\end{array}$ & $\begin{array}{l}\text { ST } \\
12 \\
\end{array}$ & $\begin{array}{l}\text { ST } \\
13\end{array}$ & $\begin{array}{c}\text { ST } \\
\text { BBBB21 }\end{array}$ \\
\hline \multicolumn{7}{|l|}{$0-10$} \\
\hline \multicolumn{7}{|l|}{$10-20$} \\
\hline $20-30$ & & $\mathrm{Ch}$ & $\mathrm{EF}$ & & & \\
\hline $30-40$ & & & & $\mathrm{Ch}$ & $\mathrm{Ch}$ & IF \\
\hline $40-50$ & IF & & & & & \\
\hline \multicolumn{7}{|l|}{$50-60$} \\
\hline $60-70$ & & & & & Clay & \\
\hline $70-80$ & & & Sand & Sand & & Sand \\
\hline $80-90$ & Sand & Sand & & & & \\
\hline $90-100$ & & & & & & \\
\hline
\end{tabular}

cultural deposits at this site have the potential to yield significant information about the paleoenvironment, as well as about past human subsistence and mobility patterns. Thus, the research value of this site is unknown and further investigations beyond the scope of an inventory survey are required before a recommendation can be made regarding eligibility for nomination to the NRHP. At a minimum, CAS recommends excavation of two 1-x-1-m units in the immediate areas of STs 6 and 12 .

\section{BP727}

\section{Description}

41BP727 (Figures 7-56 and 757 ) is composed of a prehistoric open campsite on an upper terrace partially disturbed by clearing, plowing, and the construction of a historic fence. The entire site covers approximately 1,657 $\mathrm{m}^{2}$, and ranges in elevation from 432 to $428 \mathrm{ft}$ amsl. The site is situated on an upper terrace with its western edge adjoining a 2-m cutbank above the floodplain of Big Sandy Creek. Patilo complex fine sand $(\mathrm{PaE})$ comprises the soil type. Riparian vegetation consisting of oak, elm, cedar, herbaceous weeds, and greenbrier thrive along its western edge; dense grasses cover its middle portion; and dense woods of oak, cedar, and pines cover its eastern portion. Surface visibility was less than five percent in July 2005 . The site datum is marked by a nail and an aluminum tag on a large oak tree.

\section{Levels of Work and Results}

No prehistoric artifacts or features were observed on the surface. The prehistoric component was discovered during excavation of transect shovel tests. Twenty-one additional shovel tests were dug on and around the site to determine site boundaries and evaluate its integrity. Of the 12 shovel tests excavated on the site, nine flakes, a chert heat spall, three fire-cracked rocks, and bits of charcoal were recovered from 10 positive shovel tests (Table 7-28). Notably, the fire-

Figure 7-56. 41BP727 lies on an upper terrace adjacent to the floodplain of Big Sandy Creek; facing southeast. 


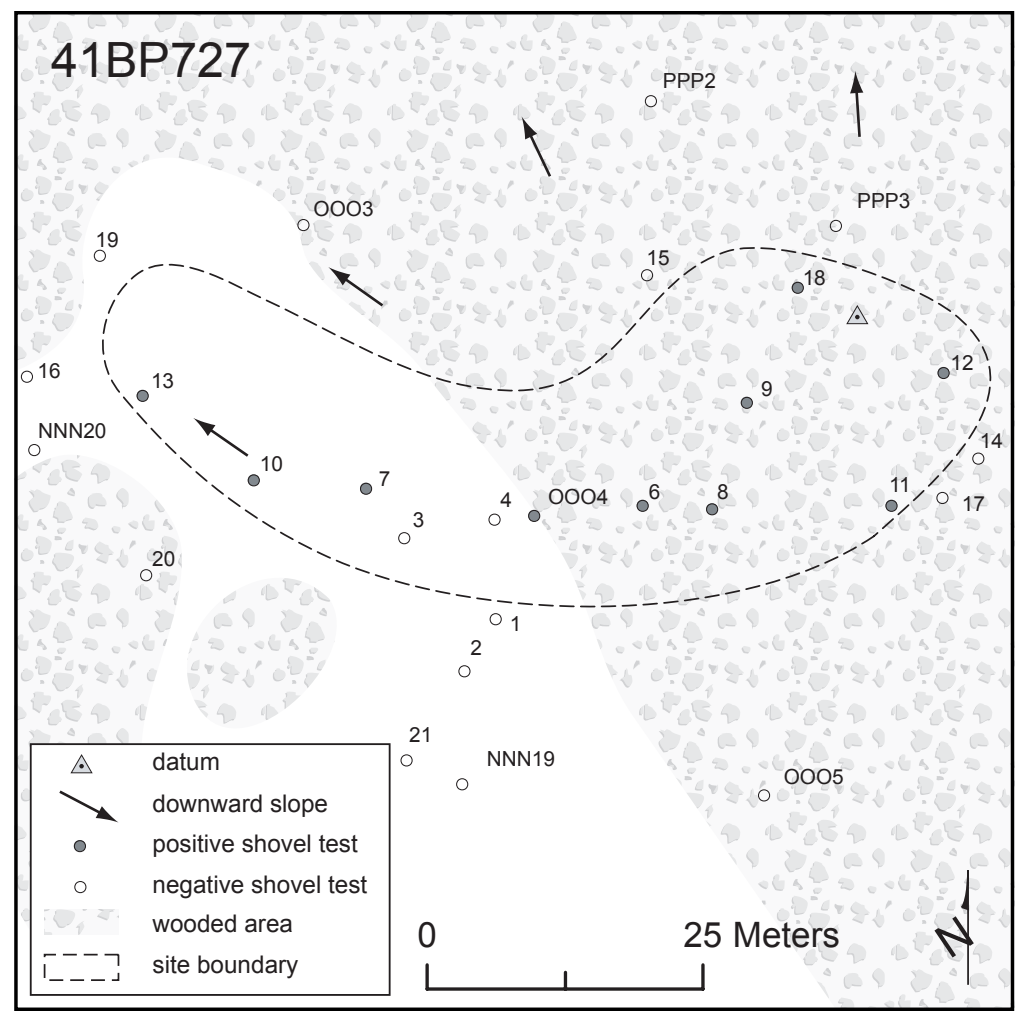

Figure 7-57. Site map of 41BP727.

Table 7-28. 41BP727 positive shovel test results.

\begin{tabular}{|c|c|c|c|c|c|c|c|c|c|c|}
\hline $\begin{array}{c}\text { Depth } \\
\text { (cmbs) }\end{array}$ & ST 6 & ST 7 & ST 8 & ST 9 & ST 10 & ST 11 & ST 12 & ST 13 & ST 18 & ST OOO4 \\
\hline $0-10$ & & & & & & & & & & \\
\hline $10-20$ & & & & IF & EF & & & IF & & \\
\hline $20-30$ & IF & IF & & & & & & & IF & \\
\hline $30-40$ & & & & & & & IF & & & \\
\hline $40-50$ & & & & & & FCR & & FCR & & IF \\
\hline $50-60$ & & HS & Ch & & FCR & & & & & \\
\hline $60-70$ & & IF & & Clay & & & & & & \\
\hline $70-80$ & Sand & & Sand & & & Sand & Sand & Sand & Sand & Sand \\
\hline $80-90$ & & Sand & & & Sand & & & & & \\
\hline $90-100$ & \multicolumn{7}{|c|}{ Key: HS-heat spall; EF-exterior flake; IF-interior flake; } \\
\hline \multicolumn{7}{|c|}{ FCR-fire-cracked rock >1 inch; Ch-charcoal } \\
\hline
\end{tabular}

cracked rock, charcoal, and heat spall seem to be horizontally comparable, between 40 and 60 cmbs. Other than a probable plow zone from 0 to $28 \mathrm{cmbs}$ in the open field area, no other disturbances were observable in shovel tests. The site datum is marked by a nail and aluminum tag on a large oak tree. 


\section{Conclusions/ \\ Recommendations}

Fire-cracked rocks and charcoal appear to be buried in relatively undisturbed contexts in a stratified zone between 40 and $60 \mathrm{cmbs}$ in the areas of STs 8, 10, 11, and 13. Such buried intact cultural deposits have the potential to yield significant information about the paleoenvironment, as well as about past human subsistence and mobility patterns. However, without further investigations beyond the scope of this inventory survey, its research potential is unknown, and no recommendation can be made regarding its eligibility for nomination to the NRHP. At a minimum, CAS recommends excavation of four 1-x-1-m units in the areas of STs 8, 10, 11, and 13.

\section{$41 B P 728$}

\section{Description}

41BP728 (Figures 7-58 and $7-59$ ) is a $2,014-\mathrm{m}^{2}$ lithic scatter in both Axtell fine sandy loam (AfC) and Demona loamy fine sand (DeC). Cedar, elm, oak, mesquite, dense grasses, poison ivy, Virginia creeper, and various types of brush are on and around the site area. Surface visibility in July 2005 was less than five percent in the wooded and grassy areas, but approximately 80 percent in the heavily eroded area. The site is located on a partially wooded footslope adjacent to an intermittent tributary of northeast.

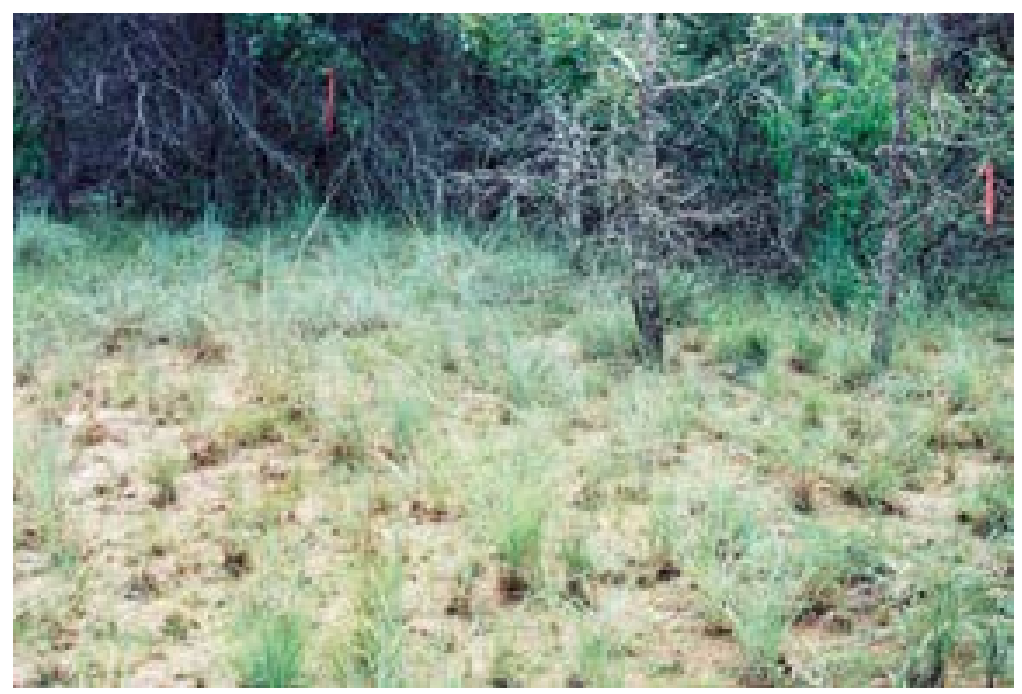

Figure 7-58. 41BP728 lies on a partially wooded footslope; facing

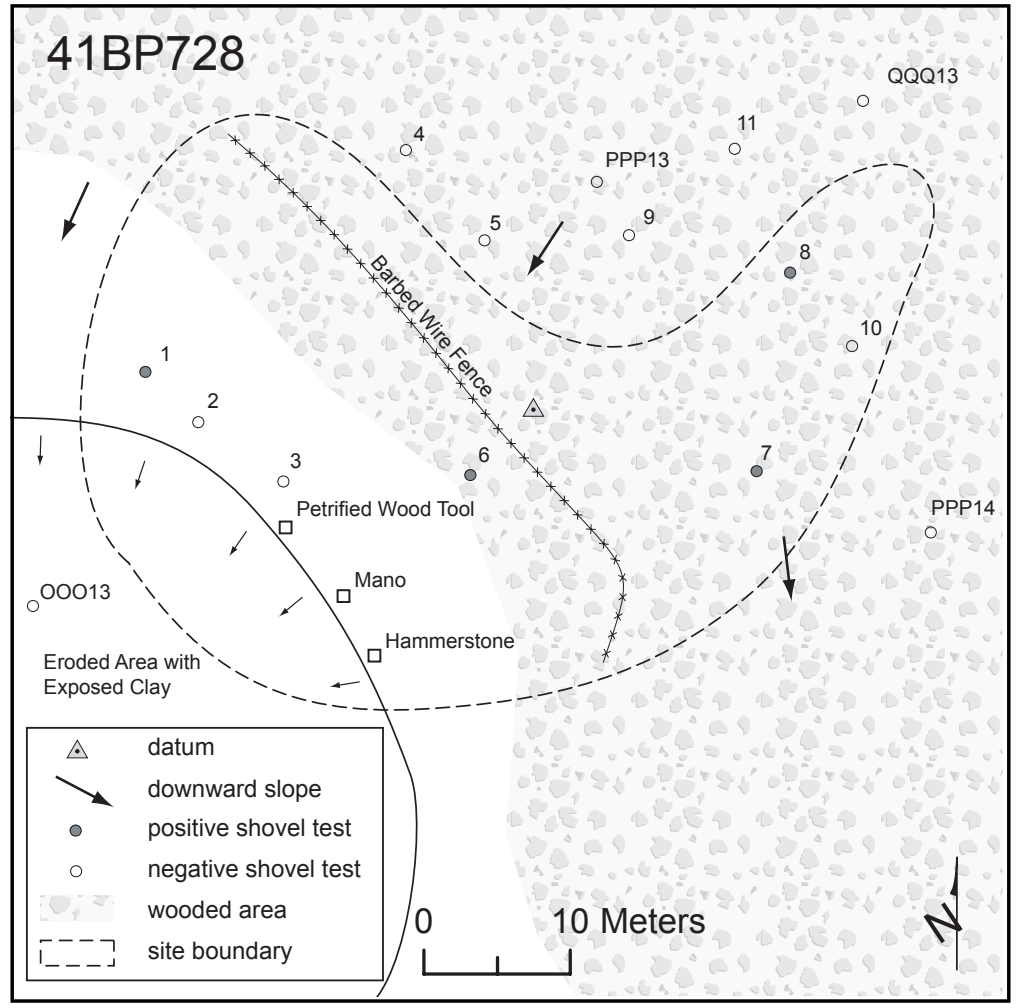

Figure 7-59. Site map of 41BP728.

Big Sandy Creek, where the surface slopes from 455 to $448 \mathrm{ft}$ amsl. Obvious surface disturbances included a barb wire fence and erosion along the southwestern portion of the site (see Figure 7-59). The site datum is marked with a nail and 


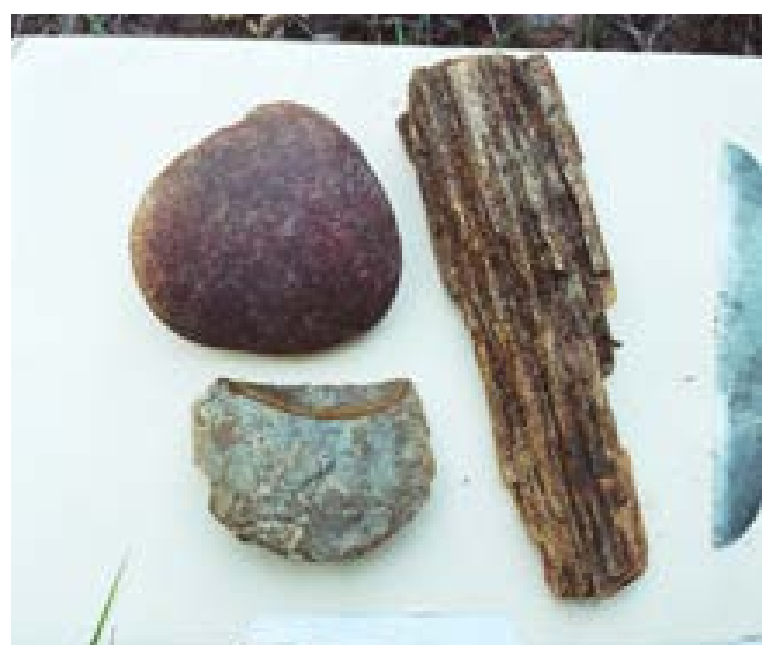

Figure 7-60. Quartzite hammerstone/mano, petrified wood chopping tool, and large flake found on the surface at 41BP728.

Table 7-29. Artifacts on the surface at 41BP728.

\begin{tabular}{|c|c|}
\hline Artifact Found & Material \\
\hline Early Triangular point & chert \\
\hline Hammerstone & quartzite \\
\hline Utilized flake & chert \\
\hline Blade flake & chert \\
\hline Mano & quartzite \\
\hline Chopping tool & petrified wood \\
\hline 2 Interior flakes & chert \\
\hline
\end{tabular}

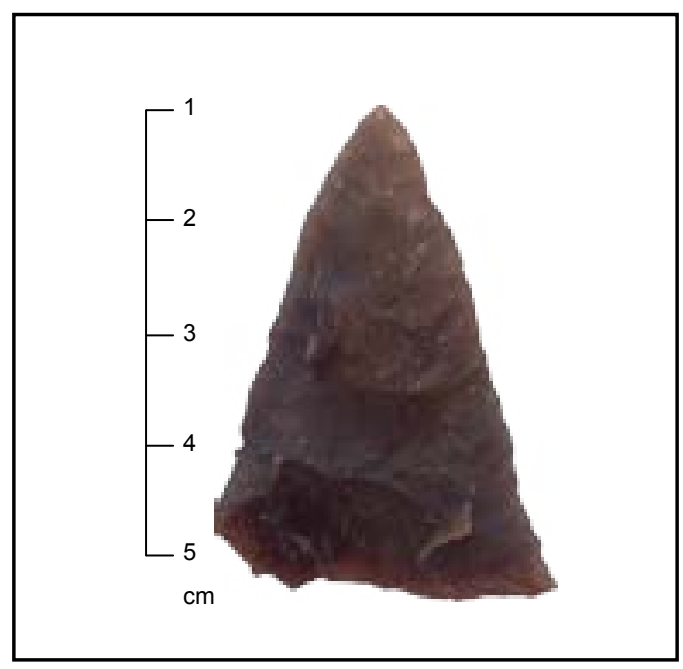

Figure 7-61. Early Triangular point found on the surface at 41BP728. aluminum tag on an oak tree $37 \mathrm{~cm}$ in diameter near ST 6.

\section{Levels of Work and Results}

The site was discovered when a quartzite hammerstone was found on the surface (Figure 7-60). A further examination revealed those artifacts listed in Table 7-29. All were exposed on the southwestern, eroded portion of the site. The interior flakes are bifacial manufacturing flakes. A diagnostic Early Triangular point was among the unique items found (Figure 7-61), and was the only one collected. Although not well defined, Early Triangular points are thought to date to around 5,700-5,600 BP (Turner and Hester 1999:108-110).

The petrified wood tool is $120 \mathrm{~mm}$ long, 37 mm wide, and $19 \mathrm{~mm}$ thick. It is very similar in morphology to those observed on two other prehistoric campsites at Camp Swift, 41BP485 and 41BP667 (Nickels et al. 2005:45; Nickels 2007). Choppers and pressure flakers fashioned from petrified wood have been documented at the Chesser Site in nearby Lee County (Rogers and Kotter 1995:109-112). A bifacial chopping or cutting tool was uncovered at 41GM224 in Grimes County to the northeast (Rogers 1994), and a silicified wood tool identified as a hammerstone was found at the Kennedy Bluffs Site in Bastrop County (Bement 1989:147-148).

Table 7-30. 41BP728 positive shovel test results.

\begin{tabular}{|c|c|c|c|c|c|}
\hline $\begin{array}{c}\text { Depth } \\
\text { (cmbs) }\end{array}$ & $\begin{array}{c}\text { ST } \\
\mathbf{1}\end{array}$ & $\begin{array}{c}\text { ST } \\
\mathbf{6}\end{array}$ & $\begin{array}{c}\text { ST } \\
\mathbf{7}\end{array}$ & $\begin{array}{c}\text { ST } \\
\mathbf{8}\end{array}$ & $\begin{array}{c}\text { ST } \\
\text { OOO12 }\end{array}$ \\
\hline $0-10$ & & FCR & IF & IF & IF \\
\hline $10-20$ & & & Clay & & \\
\hline $20-30$ & & & & Clay & \\
\hline $30-40$ & IF & & & & Clay \\
\hline $40-50$ & Clay & Clay & & & \\
\hline $50-60$ & \multicolumn{5}{|c|}{} \\
\hline Key: IF-interior flake; FCR-fire-cracked rock $>1$ \\
inch \\
\hline
\end{tabular}


Only four flakes and a single fire-cracked rock were recovered from five shovel tests out of 10 excavated on this site (Table 730). Four of the five artifacts were in the upper $10 \mathrm{cmbs}$. Soils were deeper in the wooded area, with the deepest test dug to 35 cmbs before encountering the underlying $\mathrm{Bt}$ horizon. The overall average depth for all shovel tests was just over 25 cmbs.

\section{Conclusions/ Recommendations}

If it could be ascertained that the Early Triangular point is clearly associated with the other tools and debitage at the site, then a surface collection and subsequent more in-depth artifact analysis could contribute to the poorly understood Early Archaic occupation at Camp Swift. However, they were all found on an eroded and deflated surface. Soils on the site are generally shallow and shovel tests failed to produce evidence of organic preservation or deeply buried features. Therefore, the site is not considered to be of moderate or high research value to the prehistory of the region, CAS recommends that no further work be conducted, and the site is not eligible for nomination to the NRHP.

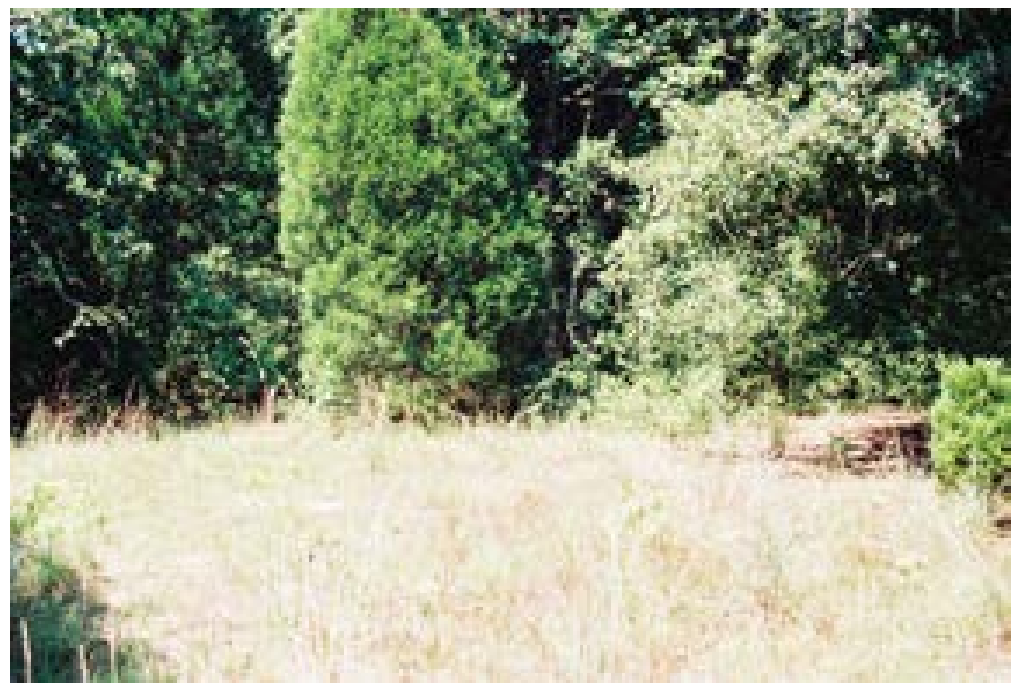

Figure 7-62. 41BP730 spans a grassy ridge and wooded sideslope; facing southwest.

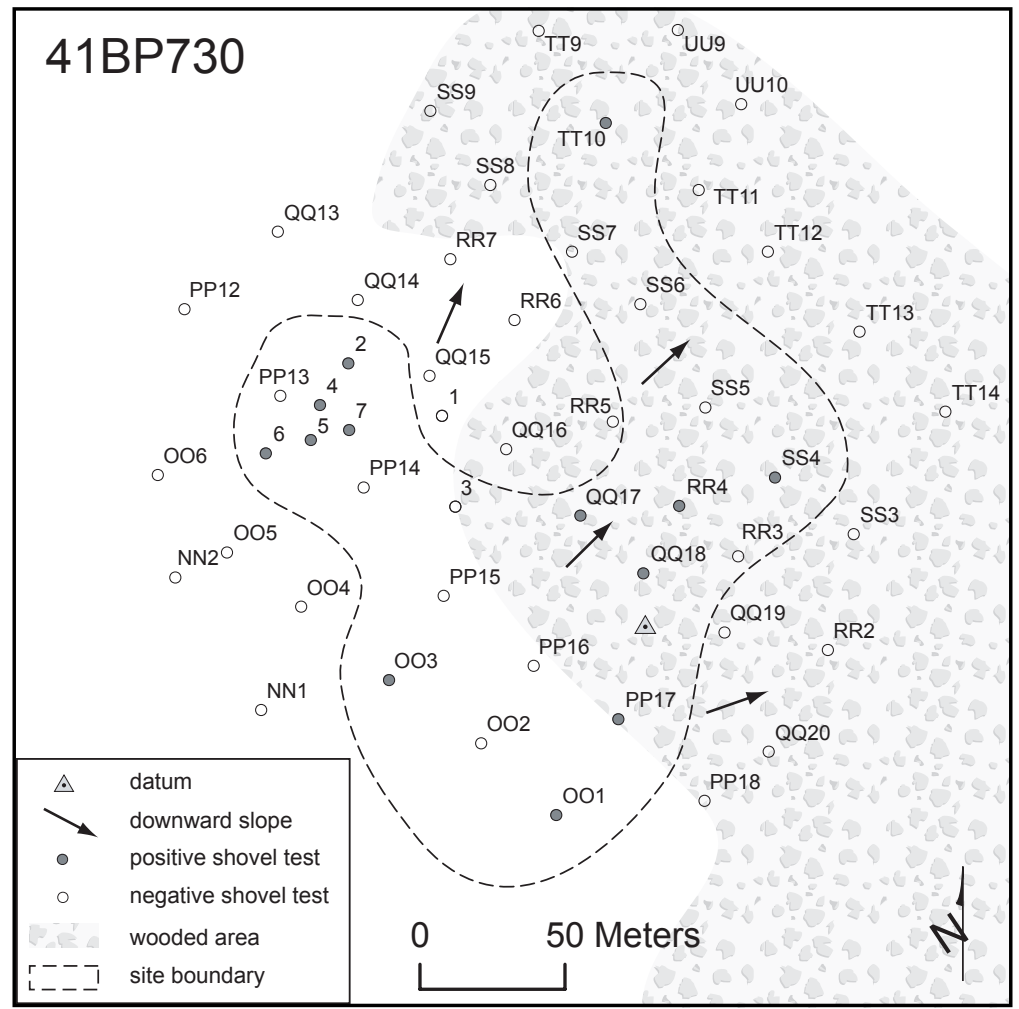

Figure 7-63. Site map of 41BP730.

\section{BP730}

\section{Description}

41BP730 (Figures 7-62 and 7-63) is composed of a large prehistoric open campsite with a historic farmstead and trash dump on it. The historic 
component is discussed in Chapter 9: New Historic Component Sites. The entire site covers approximately $23,401 \mathrm{~m}^{2}$, and ranges in elevation from 455 to $427 \mathrm{ft}$ amsl. It is situated on a grassy ridge and wooded sideslope sloping to the northeast so that its northern end reaches to the floodplain of Big Sandy Creek. Vegetation and disturbances vary considerably across the site. In the upper, more level southern portion soils are deep, the land has been cleared for farming, and the area now consists of dense grasses encroached upon by cedar and oak motts. In the more sloping and lower northern half, it is wooded with cedar, oak, and elm. Soils in the northern half are much shallower, small gullies are present, and clay is exposed in some areas. Demona loamy fine sand $(\mathrm{DeC})$ makes up the northern one-third and is mapped so that it generally coincides with the contour intervals (Baker 1979). The southern twothirds are composed of Patilo complex fine sand $(\mathrm{PaE})$. Accordingly, surface visibility in July 2005 varied from approximately 50 percent in the northern half to less than five percent in the grassy southern half. The site datum is marked by a nail and aluminum tag on a $30-\mathrm{cm}$ diameter oak tree.

\section{Levels of Work and Results}

As shown in Figure 7-63, a scattered hearth and lithic debitage were recorded on the more heavily eroded northern portion of the slope. Six fire-cracked rocks (five quartzite, one chert), a tested chert cobble, an exterior chert flake, and a petrified wood core with two flake scars were observed. Out of the 23 shovel tests excavated on the site, 13 flakes and a heat spall were recovered from nine of the 13 positive shovel tests (Table 7-31).

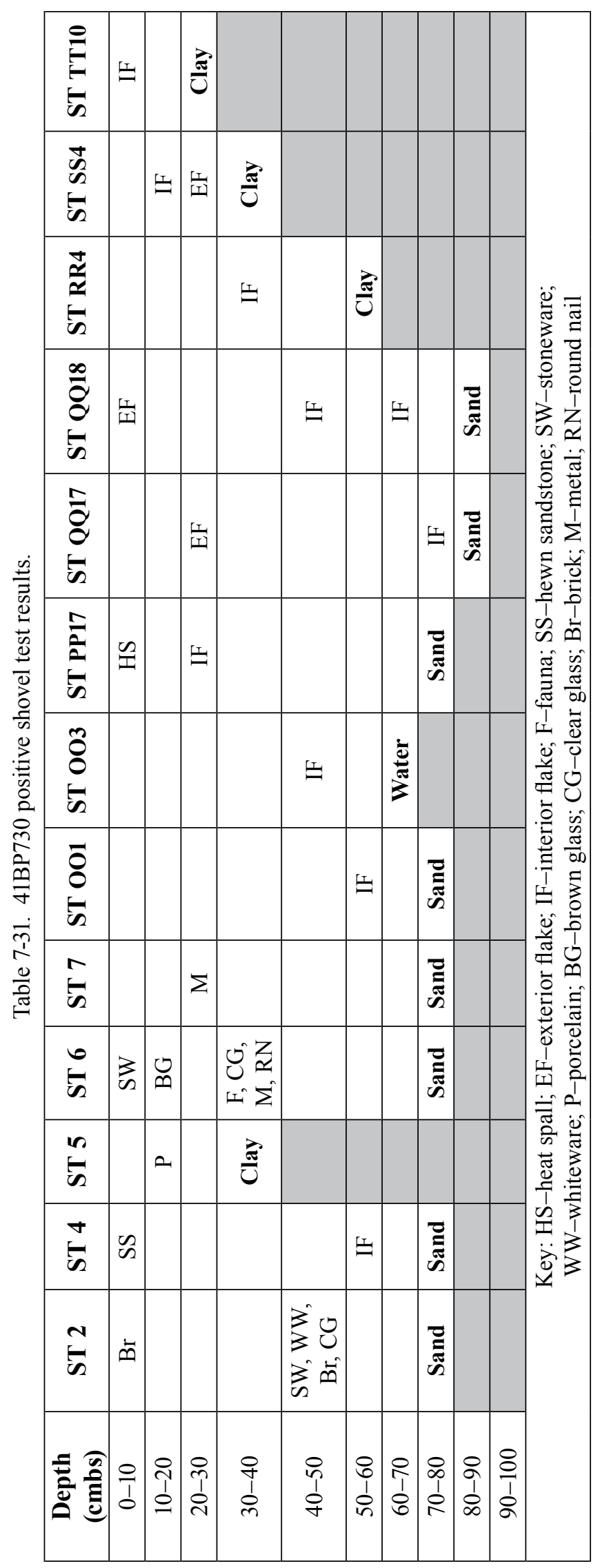




\section{Conclusions/ \\ Recommendations}

Thirteen of fourteen flakes were retrieved from shovel tests in the upper, plowed field area. Their vertical distribution shows no apparent stratigraphic conformity, which suggests they may have been disturbed by historic activities. The absence of fire-cracked rocks or any other prehistoric items in this area suggests it was used for limited lithic reduction only. While the northern portion of the site contains fire-cracked rocks and lithic debitage, with no evidence of intact features, or faunal or organic preservation, the research value of the prehistoric component of this site is minimal. CAS recommends that no further work be conducted on the prehistoric component of the site and the site is not eligible for nomination to the NRHP.

\section{BP731}

\section{Description}

This prehistoric open campsite (Figures 7-64 and 7$65)$ is buried in Sayers fine sandy loam $(\mathrm{Sa})$ on the first terrace (T1) on the south side of Big Sandy Creek. A 2-m cutbank at the creek forms its western boundary. It then slopes upward to the east from 420 to $430 \mathrm{ft}$ amsl.

Shovel tests indicate the site covers $1,002 \mathrm{~m}^{2}$. The vegetation here is typical, thick riparian, with oak, cedar, greenbrier, and beautyberry. The area has been used as a training area for the military,

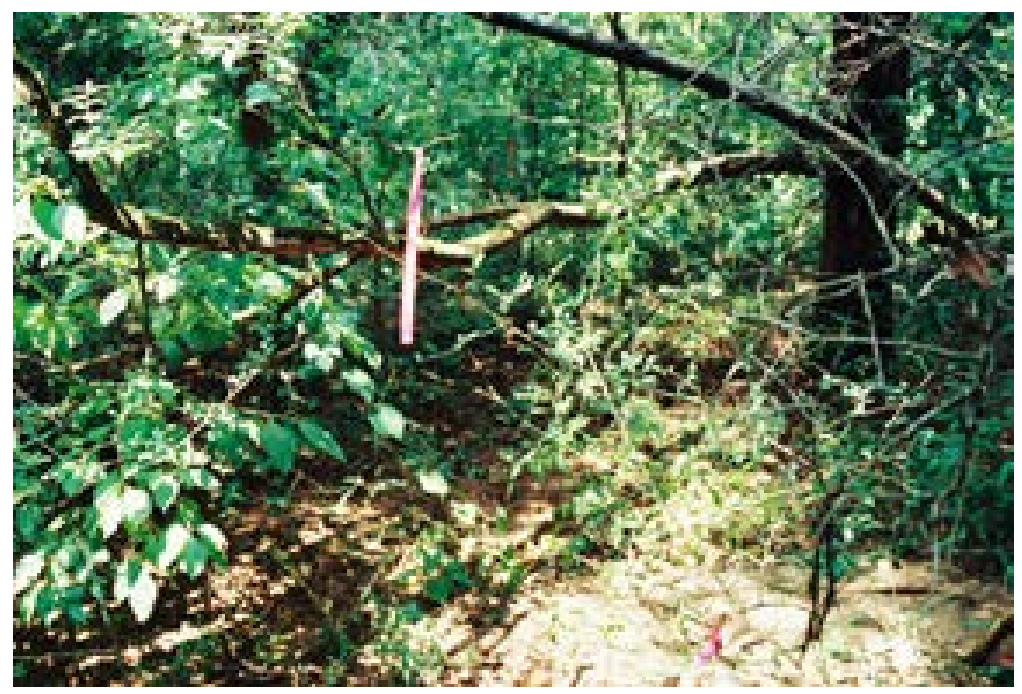

Figure 7-64. 41BP731 lies on a T1 terrace adjacent to Big Sandy Creek; facing north.

FIGURE 7-65. REDACTED
Figure 7-65. Site map of 41BP731.

probably in the 1960s and 1970s, as evidenced by raised huts similar to those constructed in Vietnamese villages. Two have been built on the eastern edge of the site (see Figure 7-65). Surface visibility was less than five percent in July 2005. 
Table 7-32. 41BP731 positive shovel test results.

\begin{tabular}{|c|c|c|c|c|c|c|c|c|c|}
\hline $\begin{array}{c}\text { Depth } \\
\text { (cmbs) }\end{array}$ & ST 1 & ST 2 & ST 3 & ST 7 & ST 8 & ST 9 & ST 11 & ST CC4 & ST DD3 \\
\hline $0-10$ & & IF & FCR & & & & & & \\
\hline $10-20$ & & & & & & & & & IF \\
\hline $20-30$ & & FCR & Ch, EF & IF & & & & & Hearth \\
\hline $30-40$ & & & FCR & & Ch & & & & 4 FCR \\
\hline $40-50$ & & & & & & & FCR & & \\
\hline $50-60$ & FCR & & & & & EF & & & \\
\hline $60-70$ & & & IF & & & & & & \\
\hline $70-80$ & Sand & Clay & & Sand & Sand & Sand & Sand & Sand & Sand \\
\hline $80-90$ & & & & & & & & & \\
\hline $90-100$ & & & & & & & & & \\
\hline
\end{tabular}

The datum is marked by a nail and aluminum tag in a large oak tree.

\section{Levels of Work and Results}

The cutbank along Big Sandy Creek was examined, but no artifacts were observed eroding out, and if there were any surface artifacts, they were covered with duff. As shown in Figure 7-65 and Table 7-32, all nine shovel tests dug on the site contained artifacts and/or charcoal. In addition to a hearth found in ST DD3 with more than a dozen golfball-to-softball sized fire-cracked rocks encountered between 20 and $30 \mathrm{cmbs}$, six flakes, nine fire-cracked rocks, and two chunks of charcoal were recovered from all shovel tests. The only likely subsurface disturbances observed in shovel tests would be due to the root system in this environment.

\section{Conclusions/ \\ Recommendations}

Without investigations CAS presumes that all fire-cracked rocks, charcoal, and lithic debitage here are prehistoric in origin. However, because of the mock village and simulated cultural activities that may have occurred here, CAS does not rule out the possibility that the cultural material remains could be modern in origin. If prehistoric in age, the available evidence indicates that organic preservation is good, and potentially intact burned rock features exist. Without further investigations to access these age and integrity issues, the research potential of this site is unknown, and

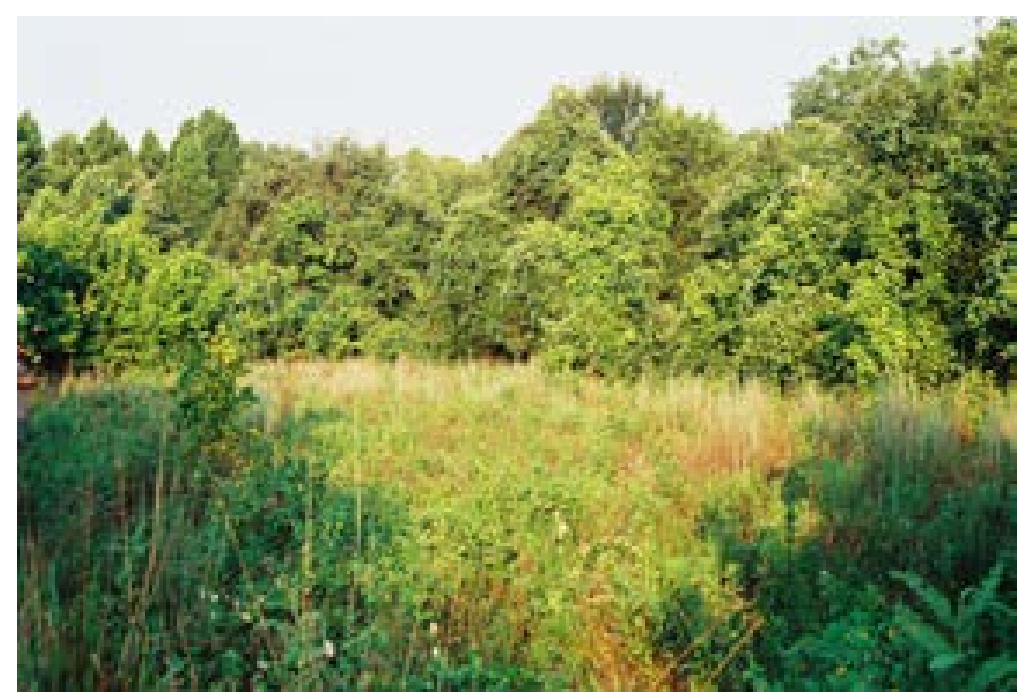

Figure 7-66. 41 BP732 lies on a semi-wooded sideslope; facing southwest. 
FIGURE 7-67. REDACTED

Figure 7-67. Site map of 41BP732.

further work beyond the scope of this inventory survey is required before a recommendation can be made regarding eligibility for nomination to the NRHP. Because this site is situated on a narrow, lower terrace and is relatively small, CAS recommends that a backhoe is not the mechanism best suited to test this site. Instead, at a minimum, CAS recommends excavation of two hand-excavated units in the immediate areas of ST DD3 to document the known hearth feature, and near ST 3 to gather additional data.

\section{BP732}

\section{Description}

CAS categorizes $41 \mathrm{BP} 732$ as a lithic scatter (Figures 7-66 and 7-67). Only lithic debitage was discovered and no fire-cracked rocks, charcoal, or any other cultural material that would indicate this site was used as a campsite was evident . It is situated on a lower terrace adjacent to a cutbank along Big Sandy Creek. As with 41BP731 upstream, Sayers fine sandy loam (Sa) makes up the terrace here. Scattered cedar and hackberry, and dense grasses and weeds in a previously cleared field now cover most of its 650$\mathrm{m}^{2}$ with oak trees along Big Sandy Creek. The surface slopes toward the creek from 423 to 415 $\mathrm{ft}$ amsl. The site was plowed, and a barbwire fence and iron T-posts are present. Surface visibility was less than five percent in July 2005. The site datum is marked by a nail and aluminum tag on a small oak tree.

\section{Levels of Work and Results}

After excavating two positive transect shovel tests, CAS archaeologists excavated an additional 13 shovel tests on and around the site, of which only one was positive. Of the six shovel tests excavated within the site's boundaries, three positive shovel tests

Table 7-33. 41BP732 positive shovel test results.

\begin{tabular}{|c|c|c|c|}
\hline Depth (cmbs) & ST 7 & ST Y3 & ST Z2 \\
\hline $0-10$ & & & \\
\hline $10-20$ & & & \\
\hline $20-30$ & & & \\
\hline $30-40$ & CC & IF & \\
\hline $40-50$ & & & EF \\
\hline $50-60$ & & & \\
\hline $60-70$ & & & \\
\hline $70-80$ & & Sand & Sand \\
\hline $80-90$ & Sand & & \\
\hline $90-100$ & & & \\
\hline \multicolumn{4}{|c|}{ Key: CC-chert chip; } \\
\hline \multicolumn{5}{|c|}{ EF-exterior flake; IF-interior flake } \\
\hline
\end{tabular}


produced two flakes and a chert chip (Table 7-33). No artifacts or features were observed on the surface. Looser sand in the upper $30 \mathrm{cmbs}$ suggests that the area has been plowed, and a gopher burrow was encountered in ST 1 between 30 and 40 cmbs.

\section{Conclusions/ \\ Recommendations}

The paucity of data obtained from an adequate number of shovel tests, coupled with the disturbance that has occurred at this site, indicate that it possesses minimal research value. Therefore, CAS recommends that no further work be conducted and the site is not eligible for nomination to the NRHP.

\section{$41 B P 733$}

\section{Description}

Apparently intensively used, this prehistoric open campsite (Figures 7-68 and 7-69) lies buried within Patilo complex fine sand $(\mathrm{PaE})$ on a sideslope. Ninety percent of the site is wooded with cedar and oak, while the northern 10 percent is now a cleared grassy field. It covers $3,789-\mathrm{m}^{2}$ and is buried in Patilo complex fine sand (PaE). It slopes from 494 to 474 ft amsl toward an intermittent drainage along its western tip. That drainage empties into Big Sandy Creek some $90 \mathrm{~m}$ to the west. Recent disturbances to the site include the digging of a military foxhole, the blading of a two-track road, animal burrows,

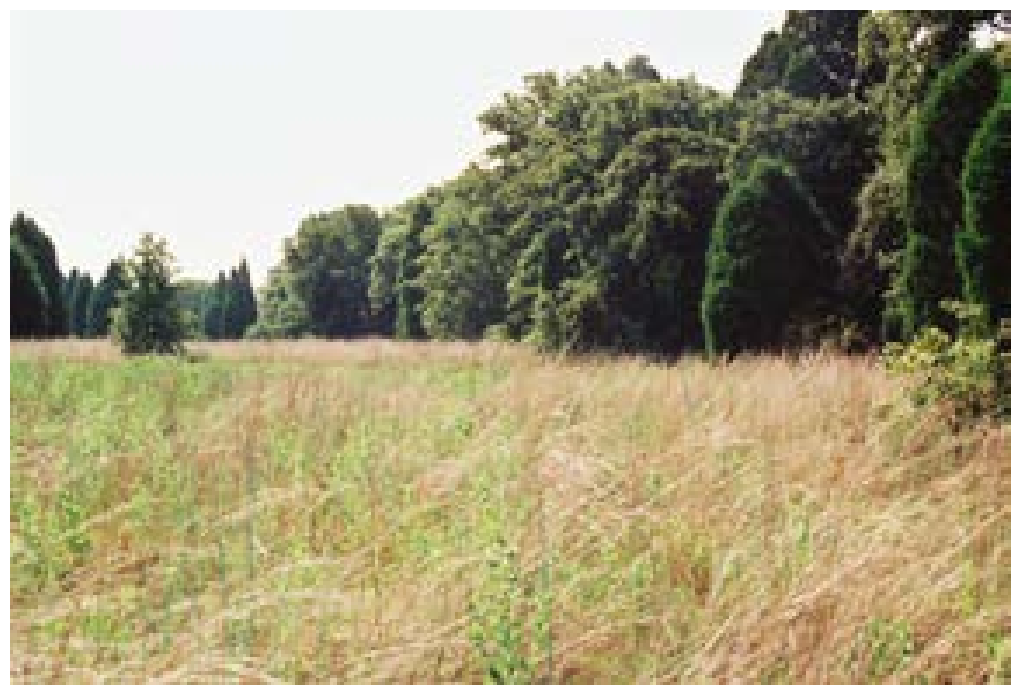

Figure 7-68. 41BP733 lies on a wooded and partially cleared sideslope setting; facing southeast.

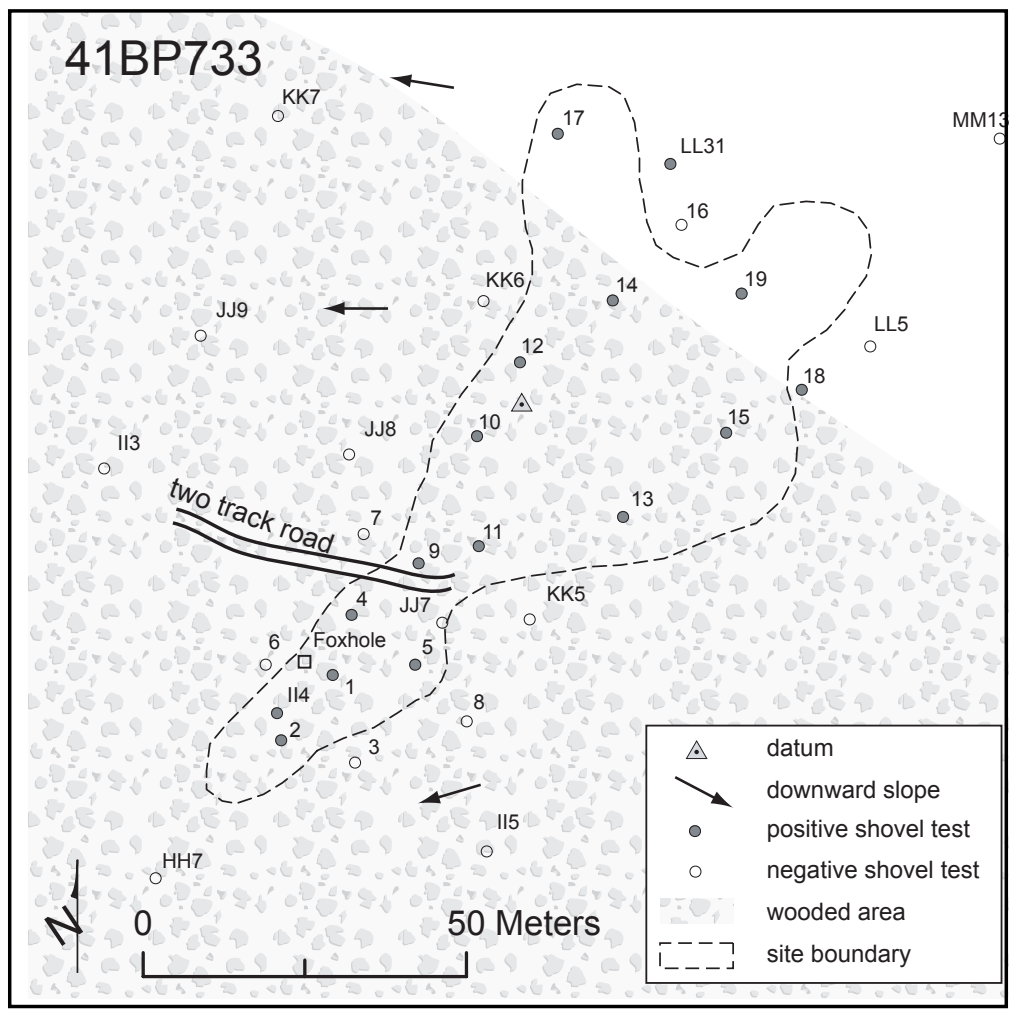

Figure 7-69. Site map of 41BP733.

and plowing in the open field (see Figure 7-69). Surface visibility across the site was generally less than five percent. The datum is marked by a nail and aluminum tag in a large oak tree $45 \mathrm{~cm}$ in diameter. 


\begin{tabular}{|c|c|c|c|c|c|c|c|c|c|c|c|c|}
\hline$\underset{E}{\Xi}$ & & & & 岀 & & & & 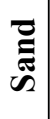 & & & & \\
\hline$\frac{a}{2}$ & & & & & & & 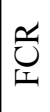 & & & V & & \\
\hline$\frac{5}{5}$ & & & 壬 & & 㝳 & & & 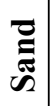 & & & & \\
\hline$\frac{n}{n}$ & 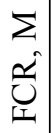 & 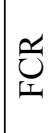 & 幽 & $\Xi$ & $\underset{\text { d }}{0}$ & & & 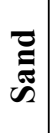 & & & & \\
\hline$\underset{D}{ \pm}$ & & & 生 & $\stackrel{\Xi}{m}$ & 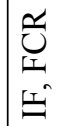 & 芯 & & 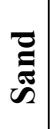 & & & & 5 \\
\hline$\frac{n}{n}$ & $\underset{\underbrace{}}{\approx}$ & 苂 & 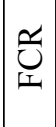 & $\begin{array}{l}\underset{才}{I} \\
\text { N }\end{array}$ & 壬 & 岶 & & 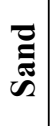 & & & & 5 \\
\hline$\frac{\mathfrak{Z}}{5}$ & & & 壬 & 幽 언 & & İ & $\frac{\pi}{U}$ & & & & & \\
\hline$\vec{\nabla}$ & $\Sigma$ & & 壬 & & & & & $\begin{array}{l}\bar{\Xi} \\
\bar{n} \\
\end{array}$ & & & & \\
\hline$\stackrel{\theta}{\stackrel{\theta}{n}}$ & & & & 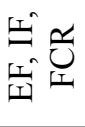 & $\frac{\vec{E}}{U}$ & & & & & & & 8 \\
\hline a) & & 预 & 坐 & & & & & 胥 & & & & $\pi$ \\
\hline 旾 & & & 㝳 & $\frac{\vec{\Xi}}{U}$ & & & & & & & & 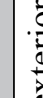 \\
\hline$\underset{⿱ 亠 凶}{\Delta}$ & & & 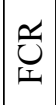 & & & $\underset{\underbrace{}}{ِ ્ ય}$ & & 胥 & & & & \pm \\
\hline$\stackrel{N}{n}$ & & & & & & છِ & & 离 & & & & \\
\hline$\vec{\sigma}$ & & & & & & 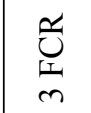 & & 预 & & & & \\
\hline 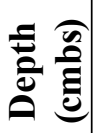 & $\begin{array}{l}0 \\
1 \\
0\end{array}$ & 오 & 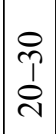 & $\begin{array}{l}\text { P } \\
\text { 1 } \\
\text { on }\end{array}$ & $\begin{array}{l}\stackrel{0}{n} \\
\text { 1 } \\
\dot{+}\end{array}$ & $\begin{array}{l}8 \\
0 \\
1 \\
0 \\
n\end{array}$ & 요 & $\begin{array}{l}\curvearrowright \\
\infty \\
1 \\
2\end{array}$ & $\begin{array}{l}8 \\
\frac{1}{1} \\
\infty\end{array}$ & $\frac{\varrho}{\varrho}$ & I & \\
\hline
\end{tabular}

\section{Levels of Work and Results}

A single transect shovel test with one flake led to the discovery of this fairly large open campsite with a high ubiquity of buried fire-cracked rock. Fourteen positive shovel tests (out of 15 excavated on the site) contained 21 fire-cracked rocks and 22 chert flakes (Table 7-34). No artifacts were observed on the surface. Disturbances noted in shovel tests were rodent burrows in ST 6 at 50-60 cmbs deep, metal in the upper $10 \mathrm{cmbs}$ of ST 11 , a c-ration can in ST 15 at $0-10 \mathrm{cmbs}$, and shrapnel in ST 16 at $0-10$ cmbs. Otherwise, roots were encountered at various levels across much of the site. Angular ironstones, coarse sands, and/or petrified wood fragments were not present, which suggests colluvial processes were not a major contributor to site formation.

\section{Conclusions/Recommendations}

Based upon field observations and shovel test results, it appears this site is not as heavily disturbed as many others on Camp Swift. Notably, fire-cracked rocks occur in deep sands in STs 1, 2, $4,12,13,14$, and 15. CAS recommends excavation of seven 1-x-1-m test units, one each in the immediate areas of STs $1,2,4,12,13,14$, and 15. Until then, the research value of this site is unknown, and further investigations beyond the scope of an inventory survey are required before a recommendation can be made regarding eligibility for nomination to the NRHP. 


\section{BP734 \\ Description}

41BP734 (Figures 7-70 and 7-71) is composed of a prehistoric component mixed with historic artifacts and the construction remains of a historic farmstead. With the recovery of only lithic debitage and no other cultural material, CAS categorizes the prehistoric component as a lithic scatter. The historic component is discussed in Chapter 9: New Historic Component Sites. The entire site covers approximately $8,688 \mathrm{~m}^{2}$ of an upland ridge, and ranges in elevation from 510 to $504 \mathrm{ft}$ amsl. Demona loamy fine sand $(\mathrm{DeC})$ supports large oak and cedar trees, with dense grasses now prevalent in the cleared field areas. The site area has been very heavily disturbed by the construction of a bladed road and berm, a fenced and tinned corral, and numerous tank ruts. Surface visibility was about 10 percent in August 2005. The site datum is marked by a nail and aluminum tag on a 25 $\mathrm{cm}$ diameter oak tree.

\section{Levels of Work and Results}

No prehistoric artifacts or features were observed on the surface, but the prehistoric component was discovered while excavating a shovel test around an old corral. CAS archaeologists excavated 15 shovel tests on the site, of which 10 were positive. Of the 10 positive shovel tests, only four contained prehistoric artifacts. As

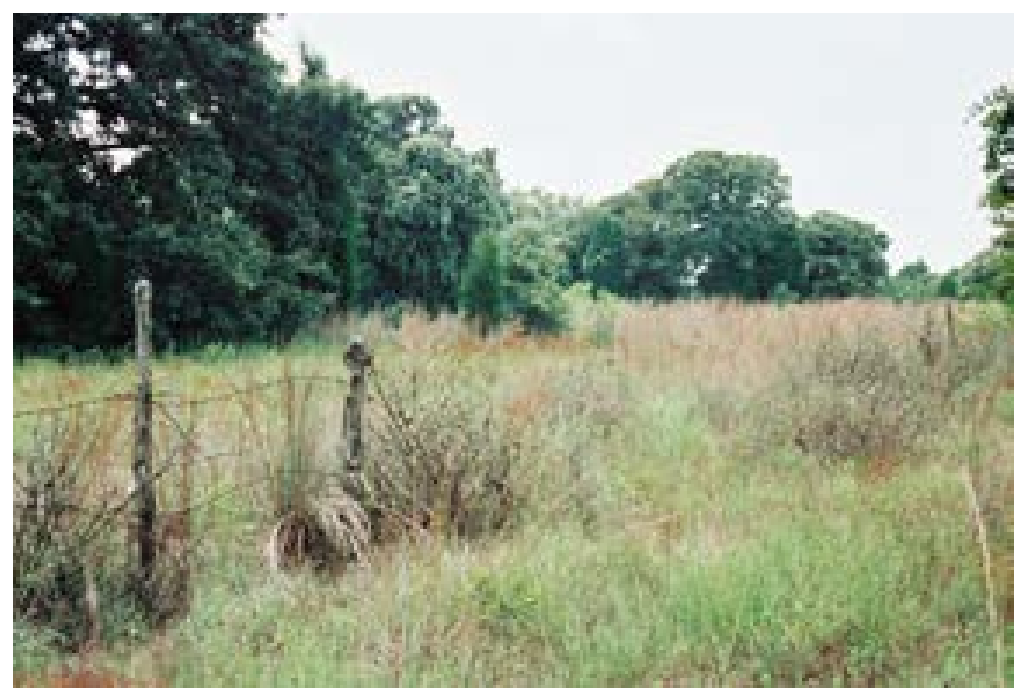

Figure 7-70. 41BP734 is a prehistoric lithic scatter mixed with historic artifacts and construction remains; facing south.

FIGURE 7-71. REDACTED 
Table 7-35. 41BP734 positive shovel test results.

\begin{tabular}{|c|c|c|c|c|c|c|c|c|c|c|}
\hline $\begin{array}{l}\text { Depth } \\
\text { (cmbs) }\end{array}$ & ST 3 & ST 4 & ST 6 & ST 7 & ST 8 & ST 9 & ST C2 & ST D3 & ST E5 & ST F2 \\
\hline $0-10$ & & $\mathrm{AG}$ & & & & CG & $\mathrm{RS}$ & & $\mathrm{AG}$ & \\
\hline $10-20$ & $\mathrm{Br}$ & $\mathrm{CG}, \mathrm{EF}$ & & $\mathrm{Br}$ & & & & & CG & $\mathrm{BG}$ \\
\hline $20-30$ & & & & $\mathrm{RN}$ & $\mathrm{Br}$ & & & & & \\
\hline $30-40$ & IF & & $3 \mathrm{IF}$ & & $\mathrm{Br}$ & & & & Clay & \\
\hline $40-50$ & Clay & $\mathrm{LG}$ & Clay & Clay & & & & IF & & $\mathrm{Br}$ \\
\hline $50-60$ & & & & & & Clay & $\mathrm{AG}$ & Clay & & \\
\hline \multicolumn{11}{|l|}{$60-70$} \\
\hline $70-80$ & & Sand & & & Sand & & & & & Sand \\
\hline \multicolumn{11}{|l|}{$80-90$} \\
\hline $90-100$ & & & & & & & Sand & & & \\
\hline $100-110$ & & & & & & & & & & \\
\hline Key: & $\begin{array}{r}\text { xteri } \\
\text { LG }\end{array}$ & $\begin{array}{l}\text { ake; IF } \\
\text { ntern gl }\end{array}$ & terio & ke; A & $\begin{array}{l}\text {-amber } \\
\text { nent; } \mathrm{R}\end{array}$ & lass; B & $\begin{array}{l}\text {-brown } \\
\text { ail; RS- }\end{array}$ & $\begin{array}{l}\text { ass; } \mathrm{CG}_{-} \\
\text {fle shell }\end{array}$ & ear gla & \\
\hline
\end{tabular}

in generally shallow soils either on or just above the underlying $\mathrm{Bt}$ horizon.

\section{Conclusions/Recommendations}

CAS's estimation is that the prehistoric component of this site has been disturbed due to historic construction, occupation, and heavy equipment operations. Therefore, its research value is minimal, CAS recommends that no further work be conducted, and the prehistoric component of the site is not eligible for nomination to the NRHP.

\section{BP736}

\section{Description}

41 BP736 (Figures 7-72 and 7-73) is a small $\left(352 \mathrm{~m}^{2}\right)$ lithic scatter in eroded and shallow Axtell fine sandy loam (AfC2). It is on a semi-wooded sideslope surface that ranges in elevation from 444 to $431 \mathrm{ft}$ amsl. Dogwood Branch Creek is 220 $\mathrm{m}$ to the southeast. Vegetation

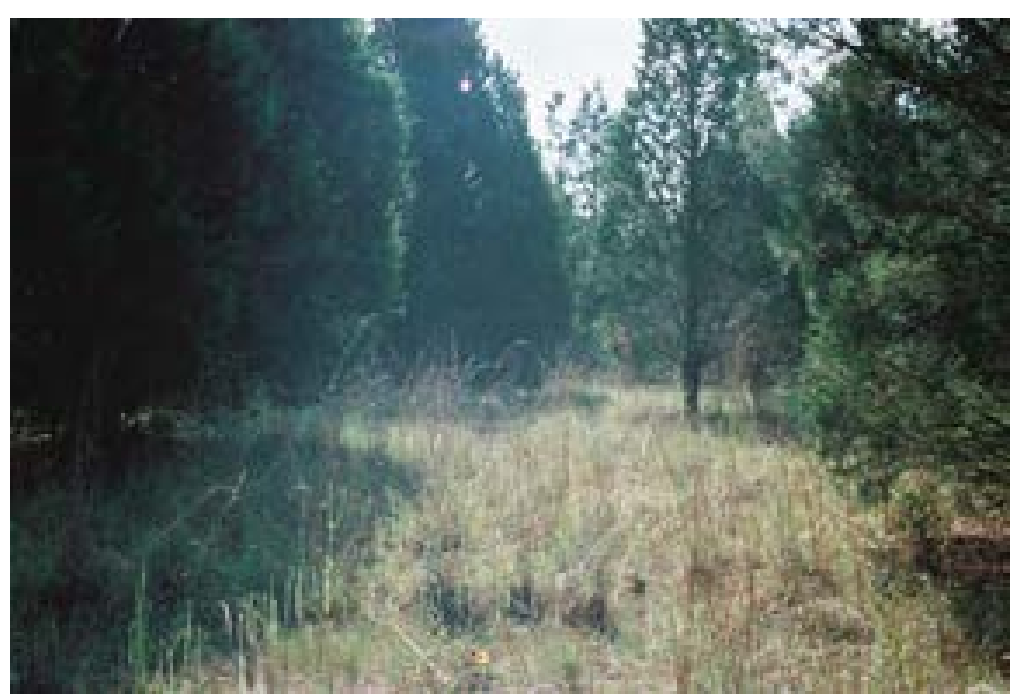

Figure 7-72. 41BP736 lies on a semi-wooded sideslope; facing east. consists of mimosa, oak, elm, and cedar trees, with native grasses, weeds, and cacti. Along the cutbank are large oak and pecan trees. Surface visibility was less than five percent in August 2005. The site datum is marked with a nail and aluminum tag on a small oak tree.

\section{Levels of Work and Results}

No artifacts or features were observed on the surface. The site was discovered during the 


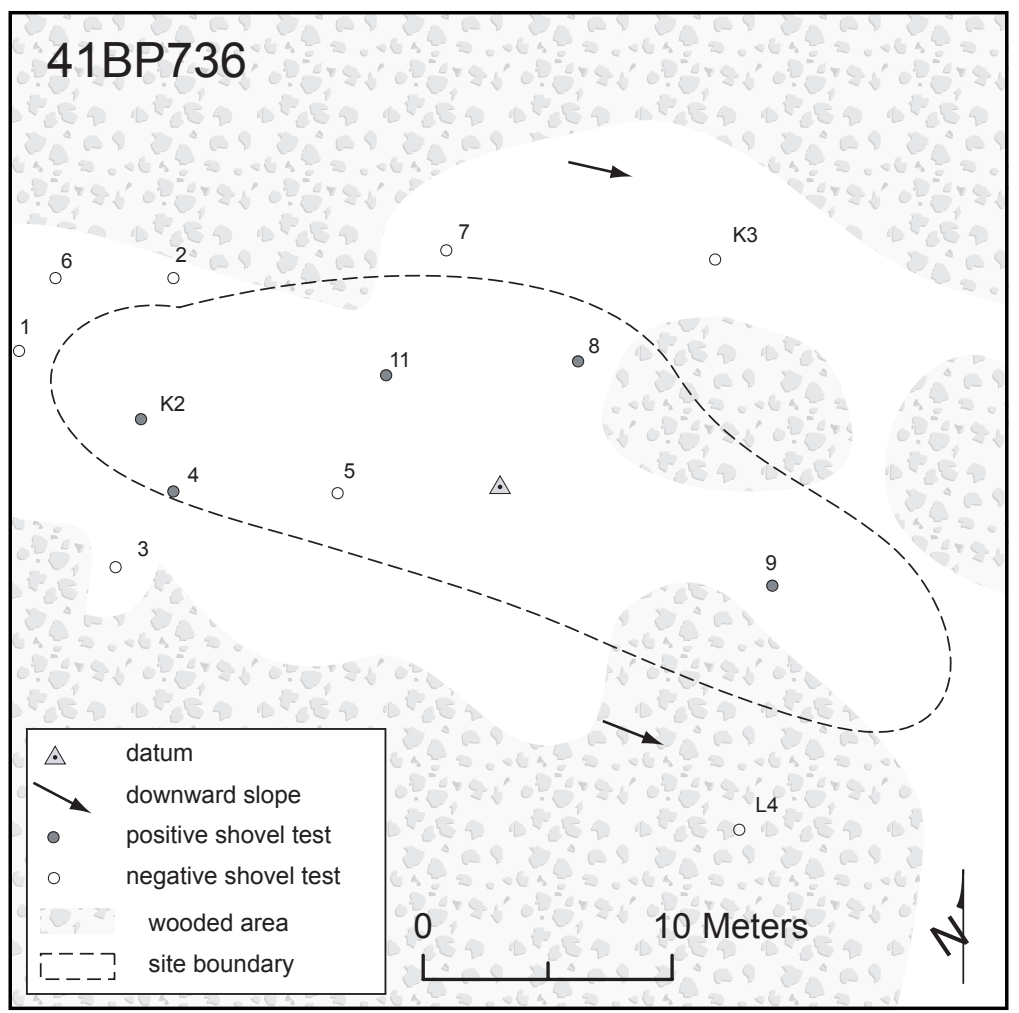

Figure 7-73. Site map of 41BP736.

Table 7-36. 41BP736 positive shovel test results.

\begin{tabular}{|c|c|c|c|c|c|}
\hline $\begin{array}{c}\text { Depth } \\
\text { (cmbs) }\end{array}$ & $\begin{array}{c}\text { ST } \\
\mathbf{4}\end{array}$ & $\begin{array}{c}\text { ST } \\
\mathbf{8}\end{array}$ & $\begin{array}{c}\text { ST } \\
\mathbf{9}\end{array}$ & $\begin{array}{c}\text { ST } \\
\mathbf{1 1}\end{array}$ & $\begin{array}{c}\text { ST } \\
\text { K2 }\end{array}$ \\
\hline $0-10$ & & & & & IF \\
\hline $10-20$ & & & IF & & \\
\hline $20-30$ & IF & IF & Clay & EF & \\
\hline $30-40$ & & & & & \\
\hline $40-50$ & Clay & Clay & & & \\
\hline $50-60$ & & & & Clay & Clay \\
\hline $60-70$ & \multicolumn{5}{|c|}{} \\
\hline \multicolumn{7}{|c|}{ Key: EF-exterior flake; IF-interior flake; } \\
\hline
\end{tabular}

excavation of transect shovel test K2 (see Figure 7-73). Of the six shovel tests excavated on the site, five were positive. One flake was recovered from each of the positive shovel tests (Table 736). The underlying Bt horizon was encountered no deeper than $50 \mathrm{cmbs}$ across the site.

\section{Conclusions/ Recommendations}

The paucity of cultural evidence recovered from shovel tests indicates that the site has little to contribute to the prehistory of the region. Therefore, its research value is minimal, CAS recommends that no further work be conducted, and the site is not eligible for nomination to the NRHP.

\section{BP737}

\section{Description}

41BP737 (Figures 7-74 and $7-75)$ is a small $\left(653 \mathrm{~m}^{2}\right)$ lithic scatter embedded within frequently flooded Uhland soils (Uh). The semi-wooded grassland surface slopes from 414 to 406 amsl toward the southeast, and the surface is now covered with oak, elm, and cedar trees, with dense grasses and scattered prickly pear. It is situated on a sideslope 40 m west of Dogwood Branch Creek. Surface visibility was approximately five percent in August 2005. The immediate area has been disturbed by a gully along its western edge and general soil erosion. The datum is marked with a nail and aluminum tag on an elm tree in the center of the site.

\section{Levels of Work and Results}

No artifacts or features were observed on the surface. The site was discovered during the excavation of transect shovel test T5 (see Figure 7-75). CAS archaeologists excavated eight shovel tests on the site. In total, four flakes and a heat spall were recovered from four of five positive shovel tests. A whiteware sherd recovered from 40 to $50 \mathrm{cmbs}$ in ST 5 and the presence of angular 


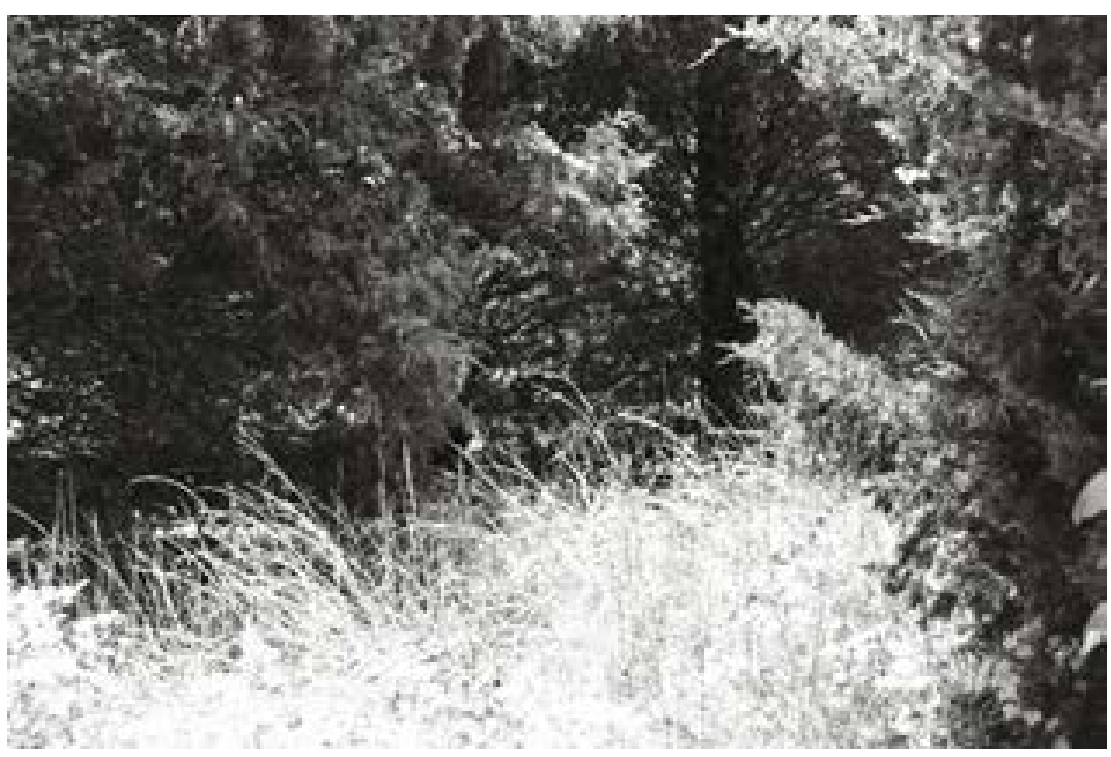

Figure 7-74. 41BP737 lies on an eroded, semi-wooded sideslope; facing east.

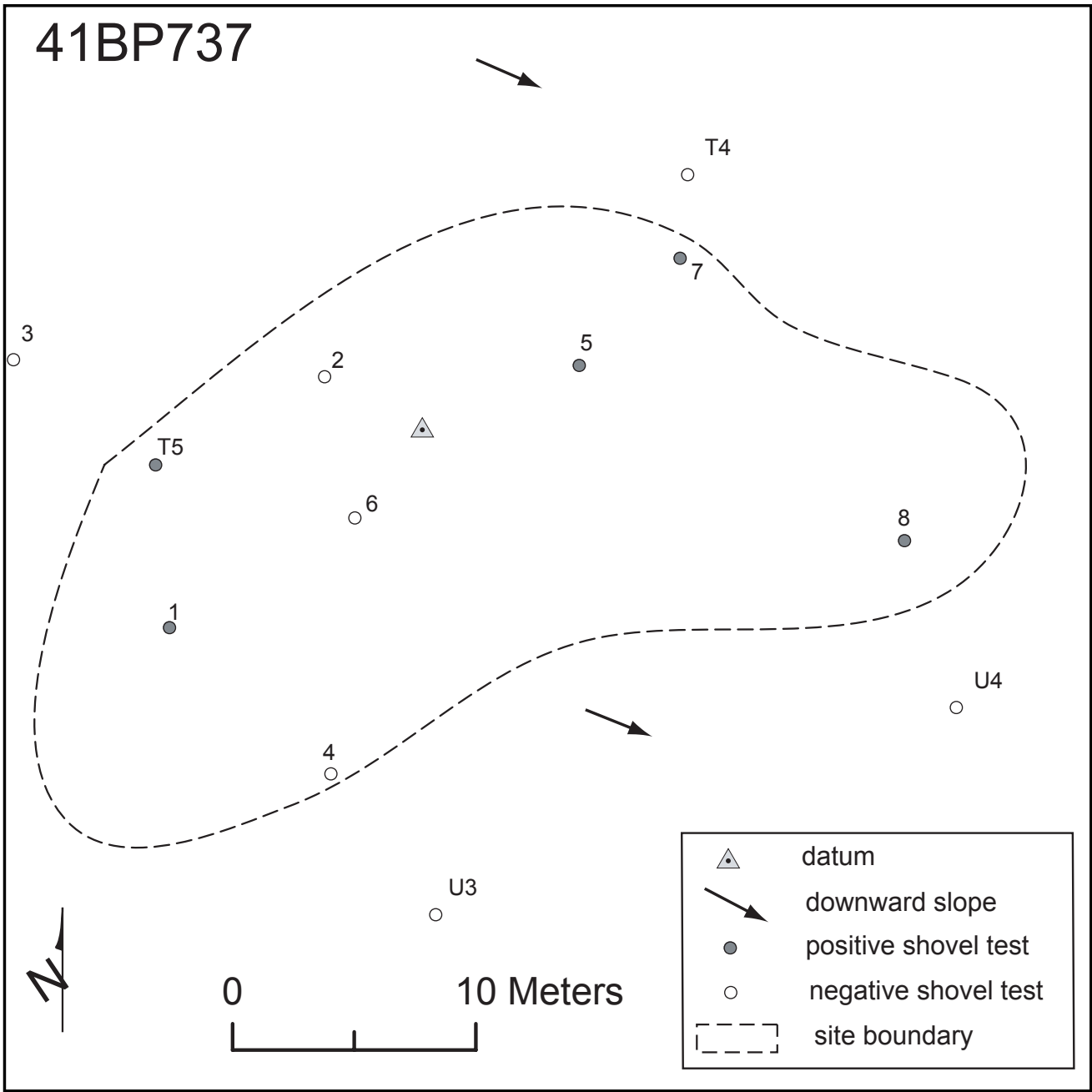

Figure 7-75. Site map of 41BP737. 
Table 7-37. 41BP737 positive shovel test results.

\begin{tabular}{|c|c|c|c|c|c|}
\hline $\begin{array}{l}\text { Depth } \\
\text { (cmbs) }\end{array}$ & $\begin{array}{c}\text { ST } \\
1\end{array}$ & $\begin{array}{c}\text { ST } \\
5\end{array}$ & $\begin{array}{c}\text { ST } \\
7\end{array}$ & $\begin{array}{c}\text { ST } \\
8\end{array}$ & $\begin{array}{l}\text { ST } \\
\text { T5 }\end{array}$ \\
\hline \multicolumn{6}{|l|}{$0-10$} \\
\hline $10-20$ & IF & & IF & & \\
\hline $20-30$ & & & & IF & IF \\
\hline $30-40$ & & & & & HS \\
\hline $40-50$ & & WW & & & \\
\hline \multicolumn{6}{|l|}{$50-60$} \\
\hline $60-70$ & & & Clay & & \\
\hline $70-80$ & Sand & Sand & & Sand & Sand \\
\hline $80-90$ & & & & & \\
\hline \multicolumn{6}{|c|}{$\begin{array}{l}\text { Key: HS-heat spall; IF-interior flake; } \\
\text { WW-whiteware }\end{array}$} \\
\hline
\end{tabular}

ironstones in all shovel tests corroborate the colluvially disturbed nature of the site (Table 7-37). The sherd most likely washed downslope from a historic house site documented during this project (41BP139) (see Chapter 8 Previously Documented Historic Component Sites for detailes on 41BP139 and Appendix A for site proximity).

\section{Conclusions/Recommendations}

With very little evidence of prehistoric cultural evidence, and obvious disturbance recorded from shovel tests, the site has little to contribute to the prehistory of the region. Therefore, its research value is minimal, CAS recommends that no further work be conducted, and the site is not eligible for nomination to the NRHP.

\section{BP738}

\section{Description}

41BP738 (Figures 7-76 and 7-77) is a prehistoric lithic scatter covering $4,599 \mathrm{~m}^{2}$ of a semi-wooded sideslope about $60 \mathrm{~m}$ northwest of Dogwood Branch Creek. The western 85 percent of the site contains Demona loamy fine sand $(\mathrm{DeC})$, while on its southeastern node contains Uhland soils (Uh). Its surface slopes from 430 to 418 amsl toward the southeast, and is covered with post oaks, mesquites, and cedars, moderately dense grasses, grapevines, and weeds. Surface visibility was less than five percent in August 2005. Heavy equipment has disturbed the area, resulting in a hummocky surface throughout, and a large push pile runs almost half the length of the site (see Figure 7-77). The datum is marked with a nail and aluminum tag on a $50-\mathrm{cm}$ diameter post oak tree in the northwestern portion of the site.

\section{Levels of Work and Results}

This site was discovered when a biface fragment and two flakes were recovered from three contiguous transect shovel tests (P3, Q3, and Q4, respectively). STs 4 and 6 each contained a single flake as well. In total, CAS archaeologists excavated nine shovel tests on the site, of which six were positive. Five of the six contained prehistoric artifacts. Subsurface disturbance

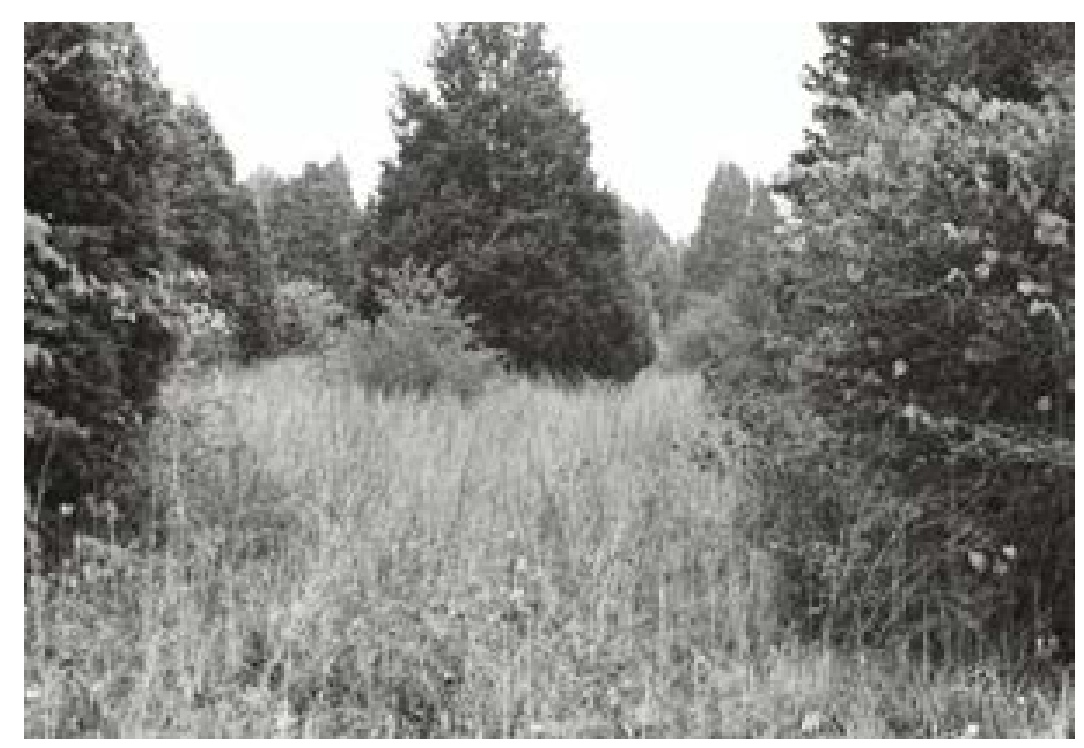

Figure 7-76. 41BP738 lies on a heavily disturbed, semi-wooded sideslope; facing north. 


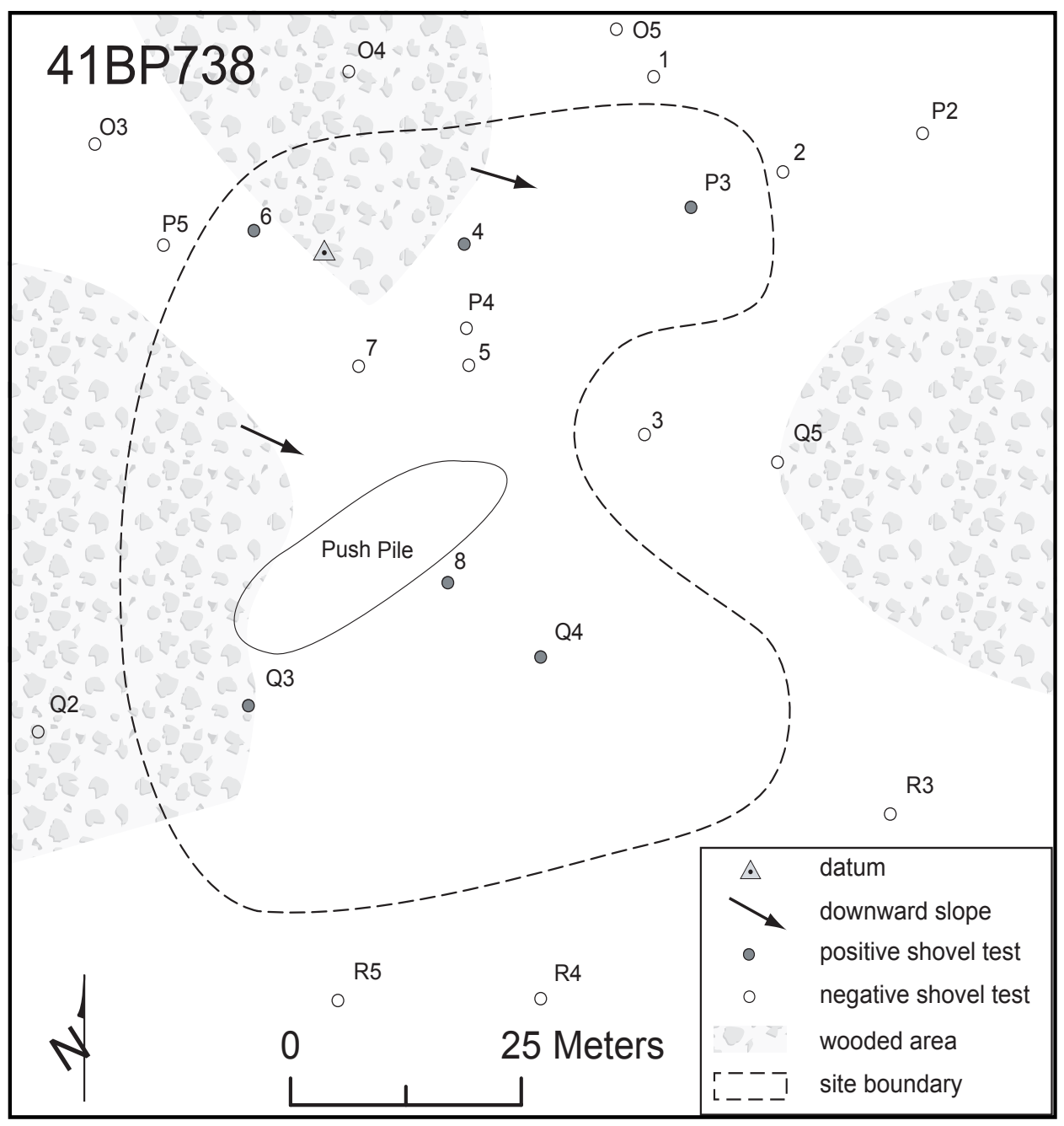

Figure 7-77. Site map of 41BP738.

Table 7-38. 41BP738 positive shovel test results.

\begin{tabular}{|c|c|c|c|c|c|c|}
\hline $\begin{array}{c}\text { Depth } \\
\text { (cmbs) }\end{array}$ & ST 4 & ST 6 & ST 8 & ST P3 & ST Q3 & ST Q4 \\
\hline $0-10$ & & & & & & \\
\hline $10-20$ & & & & & & \\
\hline $20-30$ & & IF & & & & \\
\hline $30-40$ & & & & & & \\
\hline $40-50$ & & & 2 CG & & & \\
\hline $50-60$ & IF & & & & & IF \\
\hline $60-70$ & Clay & & & B & IF & \\
\hline $70-80$ & & Clay & Sand & & & Sand \\
\hline $80-90$ & & & & Sand & Clay & \\
\hline $90-100$ & & & & & & \\
\hline \multicolumn{7}{|c|}{ Key: IF-Interior Flake; B-Biface; CG-Clear Glass } \\
\hline
\end{tabular}


was confirmed from shovel tests with the recovery of two clear glass shards in ST 8, and angular ironstones and petrified wood fragments found in others (Table 7-38). No artifacts or features were observed on the surface. The clear glass is presumably from 41BP139, a historic house site upslope and $30 \mathrm{~m}$ to the west (see Chapter 8 Previously Documented Historic Component Sites and Appendix A for site proximity).

\section{Conclusions/}

\section{Recommendations}

Because of the obvious disturbance recorded during surface observations and in shovel tests, this site has little to contribute to the prehistory of the region. Therefore, its research value is minimal, CAS recommends that no further work be conducted, and the site is not eligible for nomination to the NRHP.

\section{BP739}

\section{Description}

41BP739 (Figures 7-78 and $7-79)$ is a small $\left(121 \mathrm{~m}^{2}\right)$ lithic scatter located in a semi-wooded grassy field with cedar, oak, and native grasses. The site lies in eroded Crockett soils (CsC2) on a sideslope sloping to the west from 423 to 418 feet. The floodplain of Dogwood Branch Creek lies $30 \mathrm{~m}$ to the southwest. Surface

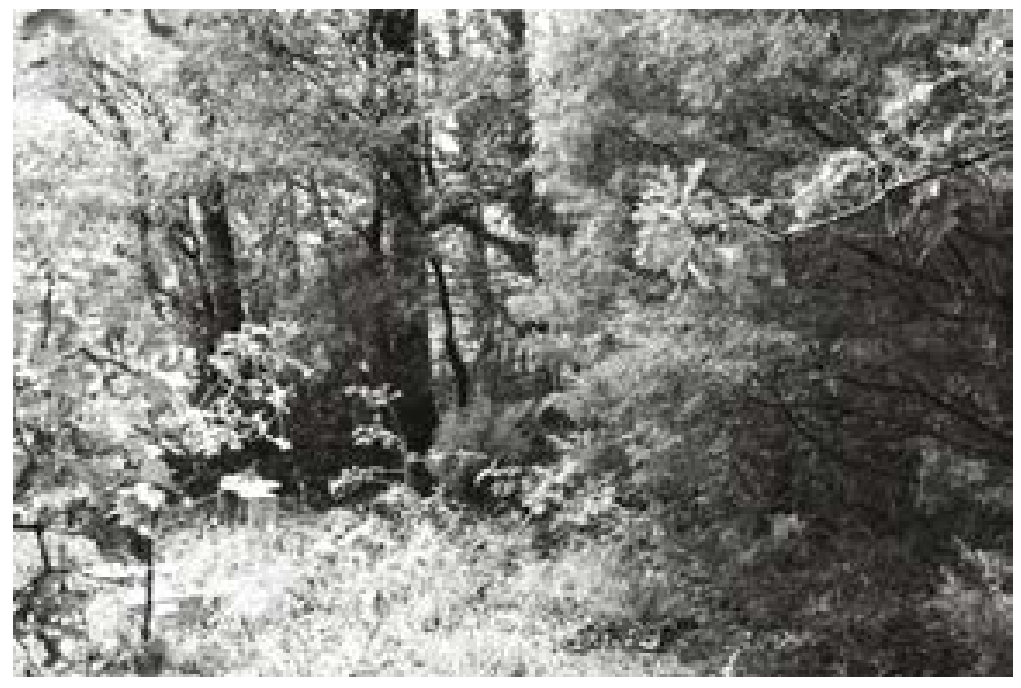

Figure 7-78. 41BP739 is in a semi-wooded grassy field; facing northeast.

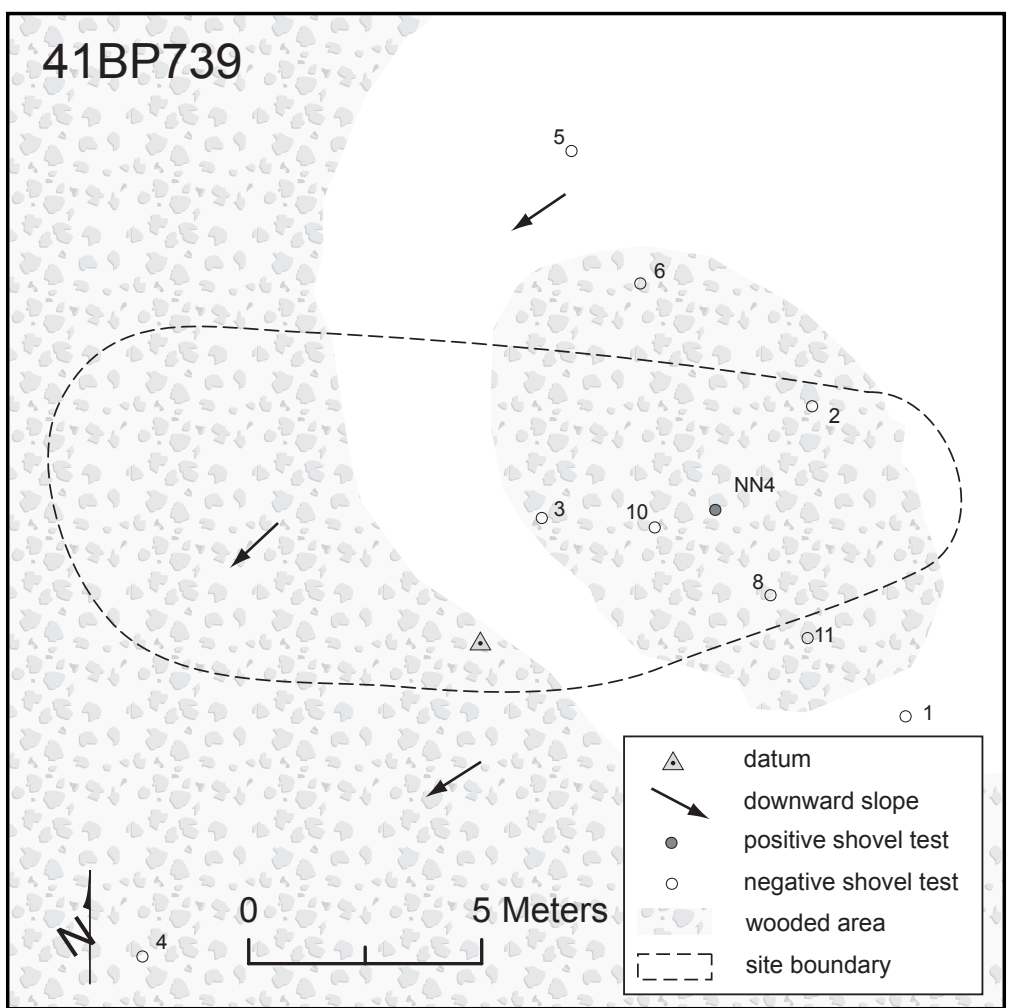

Figure 7-79. Site map of 41BP739.

visibility was less than five percent in August 2005. The site datum is marked by a nail and aluminum tag on an oak tree near ST 5. 


\section{Levels of Work and Results}

A single positive transect shovel test (Transect ST NN4) led to the discovery of this site (see Figure 7-79). Two interior flakes were found between 10 and 30 cmbs. Although six shovel tests were excavated within the site's boundaries, no other cultural material was recovered. The average depth of Crockett soils over the underlying $\mathrm{Bt}$ horizon is $29 \mathrm{cmbs}$.

\section{Conclusions/ Recommendations}

This site appears to be an ephemeral lithic scatter with no evidence of fire-cracked rocks, faunal or organic preservation, or features. Therefore, its research value is minimal, CAS recommends that no further work be conducted, and the site is not eligible for nomination to the NRHP.

\section{BP740}

\section{Description}

41BP740 (Figures 7-80 and 7-81) is a large $(12,274$ $\mathrm{m}^{2}$ ) prehistoric open campsite ranging in elevation from 435 to $422 \mathrm{ft}$ amsl. The site is situated on a broad footslope that has apparently been cleared and farmed in historic times. Its

semi-circular western and southern edges follow the shape of an outside meander on McLaughlin Creek. Patilo complex fine sand (PaE) covers the

Figure 7-81. Site map of 41BP740.

landform, and supports dense grasses, weeds, grapevines, prickly pear cacti, bull nettles, a few scattered cedar trees, and a pine grove (see Figure 7-81). Other than an old fence post near the creek, no disturbances were observed on the surface, but visibility was less than five percent in August 


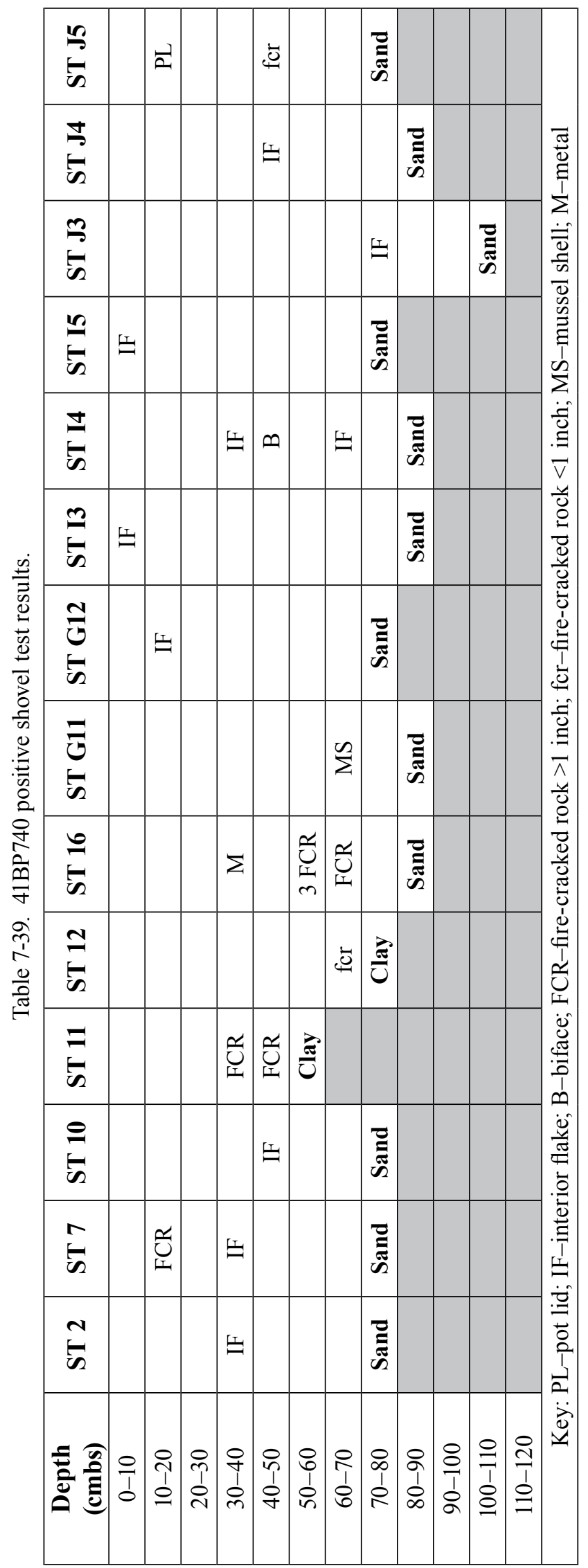

2005. The datum is marked by a nail and an aluminum tag on a large pine tree.

\section{Levels of Work and Results}

This site was discovered while excavating transect shovel tests (see Figure 7-81). Fourteen of 21 shovel tests excavated on the site resulted in the recovery of a bifacial preform exhibiting middle-late stage reduction, 10 flakes, a potlid, a mussel shell fragment, and nine pieces of fire-cracked rocks. In addition to a metal washer found in ST 16 between 30 and 40 cmbs, archaeologists detected a probable plow zone as deep as $30 \mathrm{cmbs}$ in the open field (Table 7-39). No artifacts or features were observed on the surface.

\section{Conclusions/Recommendations}

Our estimation is that this site is approximately 80 percent intact below the 30 -cmbs plow zone. However, without further investigations beyond the scope of this inventory survey, its research value is unknown. Notably, larger pieces of firecracked rocks were found in STs 11 and 16, suggesting that intact burned rock hearth features may be present in those areas. Although only a single mussel shell fragment was found, its mere presence suggests that additional subsistence information may also be found. CAS recommends excavation of four 1-x-1-m units, one each in the immediate areas of STs 11, 16, G11, and I4.

\section{BP742}

\section{Description}

41BP742 (Figures 7-82 and 7-83) is a 4,171- $\mathrm{m}^{2}$ prehistoric open campsite that has been disturbed by the occupation of, and tilling around, a historic farmstead. The 


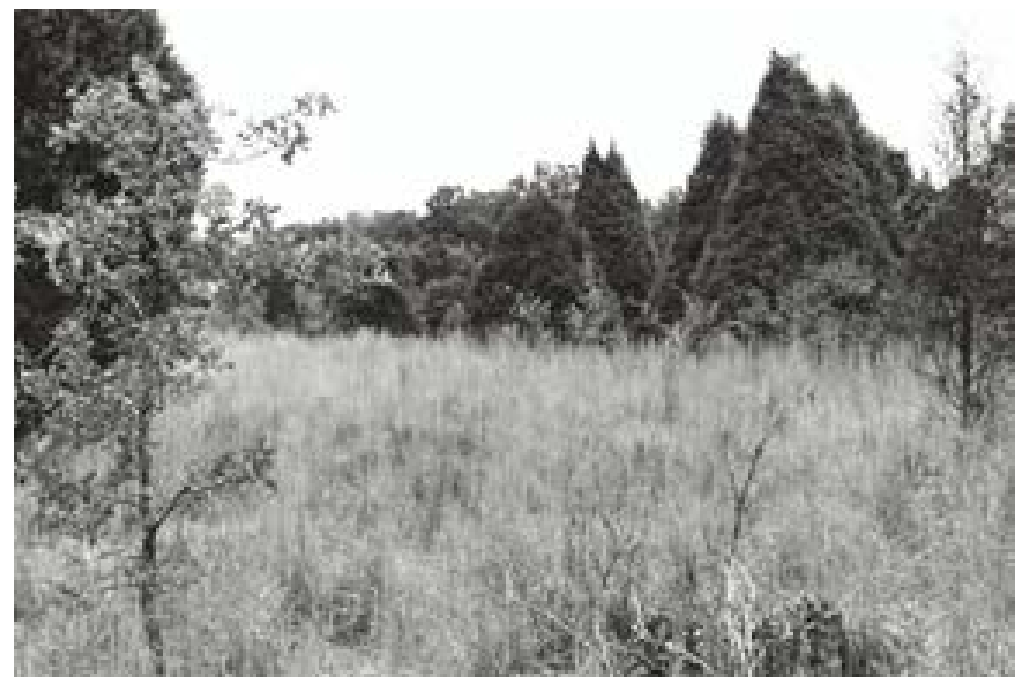

Figure 7-82. 41BP742 lies on a narrow ridge that has been cleared, plowed, and occupied as a farmstead; facing northeast.

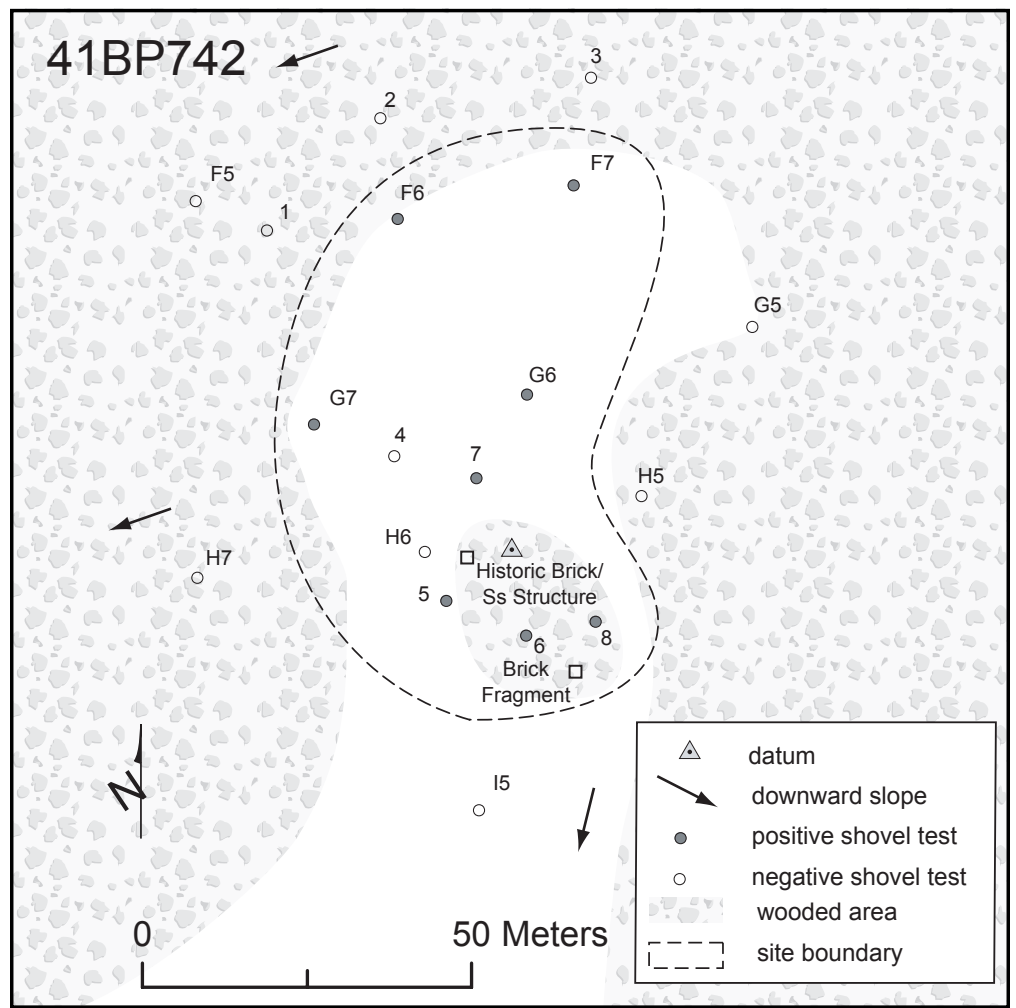

Figure 7-83. Site map of 41BP742.

site is in an old plowed field on a narrow ridge, with an intermittent tributary of McLaughlin Creek beyone its western edge. The old field with Axtell fine sandy loam (AfC2) is now overgrown with dense grasses and scattered cedar trees. The immediate area of the historic component has large oak and elm trees. The historic component is further discussed in Chapter 9: New Historic Component Sites. Overall, the site's surface slopes from about 442 feet in the north to $435 \mathrm{ft}$ amsl in the south. Perhaps because of the dense vegetation, no prehistoric artifacts were observed on the surface. The site datum is marked by a nail and aluminum tag on one of the large oak trees near the old farmhouse.

\section{Levels of Work and Results}

The prehistoric component was discovered during the excavation of transect shovel tests (see Figure 7-83). Eight additional shovel tests were dug on and around the site to determine site boundaries and evaluate its integrity (Table 740). A total of 10 shovel tests were excavated within the site's boundaries, of which eight were positive. Of the eight positive shovel tests, six contained prehistoric artifacts. Shovel test results (STs 6 and 8) indicate that significant historic disturbance has occurred in the immediate area of the historic structure. In the open field area, archaeologists detected a plow zone extending to nearly $30 \mathrm{cmbs}$, and a large metal pin found in the upper 20 cmbs of ST G7. A formally retouched uniface and two flakes were found in the upper $30 \mathrm{cmbs}$ (STs 5,6 , and 8), and three pieces of fire-cracked rock 
Table 7-40. 41BP742 positive shovel test results.

\begin{tabular}{|c|c|c|c|c|c|c|c|c|}
\hline $\begin{array}{c}\text { Depth } \\
\text { (cmbs) }\end{array}$ & ST 5 & ST 6 & ST 7 & ST 8 & ST F6 & ST F7 & ST G6 & ST G7 \\
\hline $0-10$ & IF & & WW & & & & & \\
\hline $10-20$ & & CG & & & & & & M \\
\hline $20-30$ & FCR & U, M, BC & MG & IF, CG & & & & \\
\hline $30-40$ & & & & & & C & FCR & Clay \\
\hline $40-50$ & FCR, fcr & & & & FCR & & & \\
\hline $50-60$ & & & & & Clay & & & \\
\hline $60-70$ & & Clay & & & & & & \\
\hline $70-80$ & Sand & & Sand & Clay & & & & \\
\hline $80-90$ & & & & & & Sand & Sand & \\
\hline $90-100$ & & & & & & & \\
\hline
\end{tabular}

and a petrified wood core were found below 30 cmbs (STs 5, F6, F7, G6).

\section{Conclusions/Recommendations}

Mixing of the historic and prehistoric components has occurred, and the mixing is most intensive and clear in the upper $30 \mathrm{cmbs}$. However, the integrity of five artifacts found below $30 \mathrm{cmbs}$ is questionable and these mostly consist of only fire-cracked rock. Therefore, CAS does not believe further work on the prehistoric component of this site will provide credible data and recommends that the prehistoric component is not eligible for nomination to the NRHP.

\section{BP743}

\section{Description}

This prehistoric open campsite is buried in Sayers fine sandy loam (Sa) on a lower footslope $100 \mathrm{~m}$ north of McLaughlin Creek. It slopes upward to the north from 428 to $433 \mathrm{ft}$ amsl. Shovel tests indicate the site covers $706 \mathrm{~m}^{2}$. The vegetation here is typical of a previously cleared open field now overgrown with dense grasses, weeds, and wild grapevines (Figures 7-84 and 7-85). Surface visibility was less than five percent in August 2005. The datum is marked by a nail and aluminum tag in a small oak tree.

\section{Levels of Work and Results}

CAS archaeologists placed seven shovel tests within the site's boundaries, of which four were

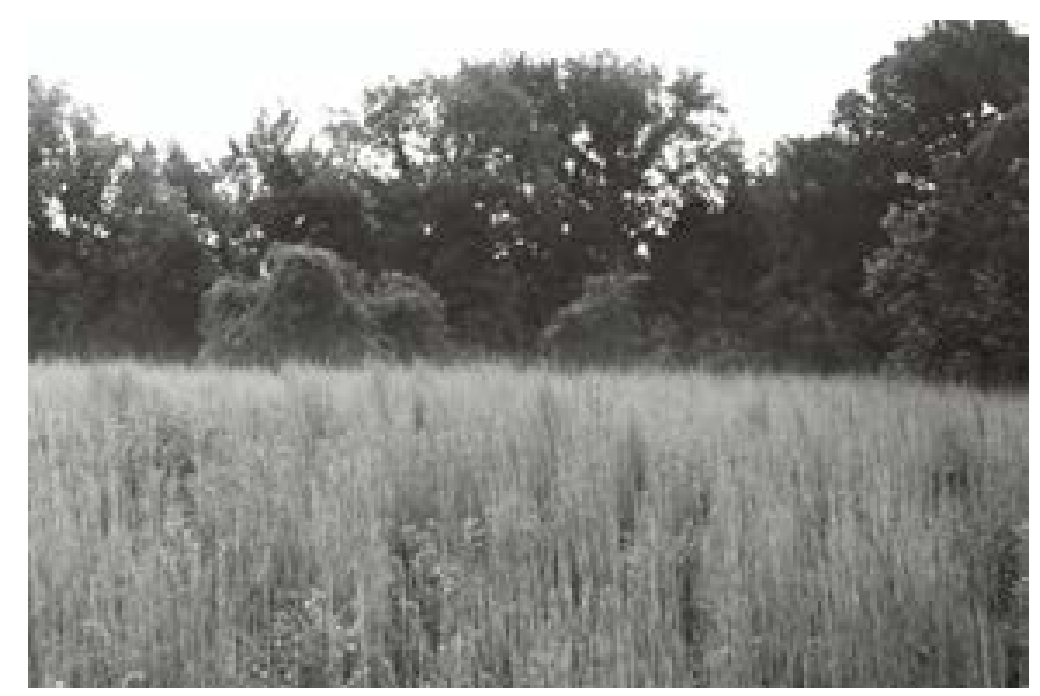

Figure 7-84. 41BP743 lies on a lower footslope near McLaughlin Creek; facing east. 


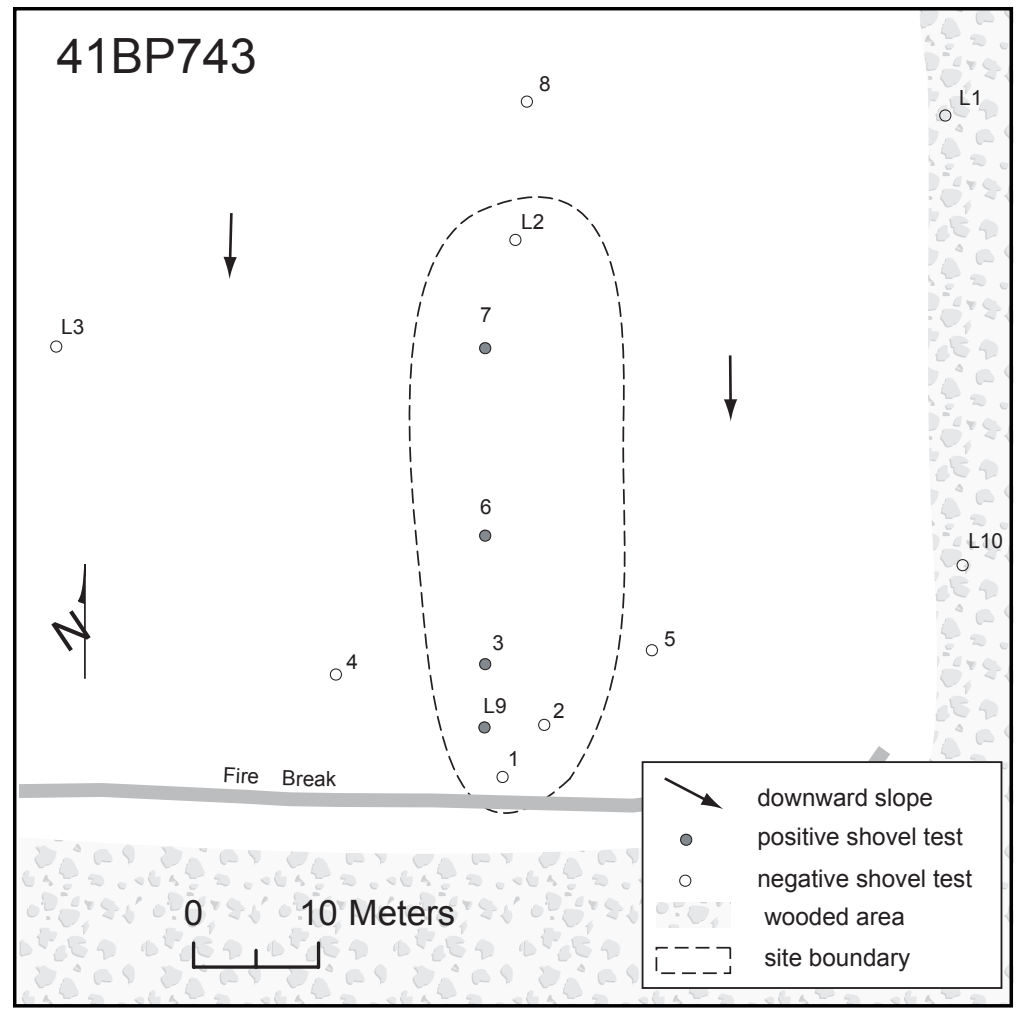

Figure 7-85. Site map of 41BP743.

Table 7-41. 41BP743 positive shovel test results.

\begin{tabular}{|c|c|c|c|c|}
\hline $\begin{array}{c}\text { Depth } \\
\text { (cmbs) }\end{array}$ & ST 3 & ST 6 & ST 7 & ST L9 \\
\hline $0-10$ & & & & \\
\hline $10-20$ & IF & IF & & \\
\hline $20-30$ & & & & \\
\hline $30-40$ & & IF & & \\
\hline $40-50$ & FCR & fcr & IF & \\
\hline $50-60$ & & $\begin{array}{c}\text { IF, } \\
2 \text { FCR, } \\
\text { fcr }\end{array}$ & & \\
\hline $60-70$ & & 2 FCR & & IF \\
\hline $70-80$ & Sand & Hearth & Sand & Water \\
\hline $80-90$ & & & & \\
\hline $\begin{array}{c}\text { Key: IF-interior flake; FCR-fire-cracked rock }>1 \\
\text { inch; fcr-fire-cracked rock }<1 \text { inch }\end{array}$ \\
\hline
\end{tabular}

positive (see Figure 7-85). ST 6 was terminated $75 \mathrm{cmbs}$ when a sandstone and quartzite burned rock hearth was encountered. As shown in Table 7-41, a total of six flakes and seven fire-cracked rocks were recovered from the four positive shovel tests. No artifacts were on the surface, but that may be due to the dense vegetation. Unlike most open field sites, no plow zone was detected in shovel tests at this site, suggesting it may have been cleared for grazing only.

\section{Conclusions/ Recommendations}

Due to the presence of a possibly intact hearth and other cultural material found, the research potential of this site is unknown without further investigations beyond the scope of this inventory survey. Therefore, more work is required before a recommendation can be made regarding eligibility for nomination to the NRHP. At a minimum, a hand excavated unit should be placed in the immediate area of ST 6 to document the known hearth feature. In addition, CAS recommends excavation of a 1-x-1-m unit near ST 3 to gather additional data.

\section{BP744}

\section{Description}

41BP744 (Figures 7-86 and 7-87) is a prehistoric open campsite covering $5,434 \mathrm{~m}^{2}$ of a semi-wooded sideslope with the floodplain of McLaughlin Creek along its northern edge. The southern 80 percent of the site contains Demona loamy fine sand $(\mathrm{DeC})$, while its northern portion has Uhland soils (Uh). Its swale and gully-incised surface slopes rather steeply from 458 to 442 amsl toward the creek, and is covered with post oaks, mesquites, cedars, dense grasses, grapevines, cacti, and weeds. Surface visibility was less than five percent in August 2005. The site datum is 


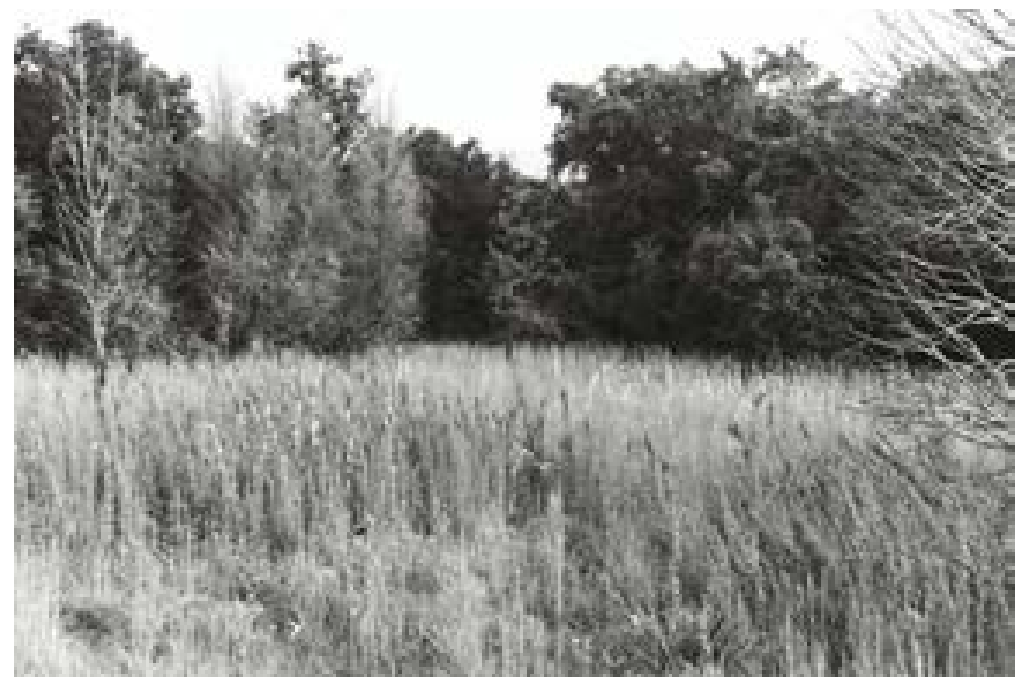

Figure 7-86. 41BP744 lies on a heavily disturbed, semi-wooded sideslope; facing north.

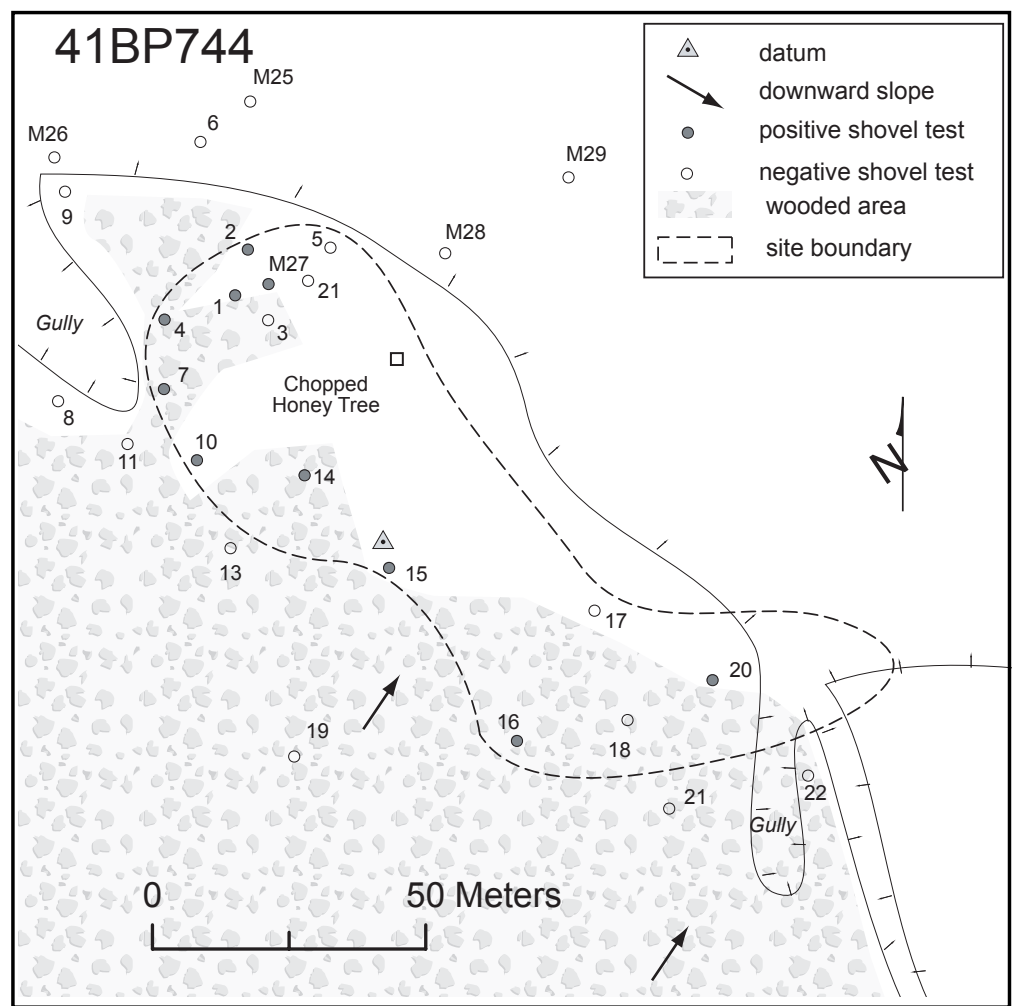

Figure 7-87. Site map of 41BP744.

marked with a nail and aluminum tag on a 50$\mathrm{cm}$ diameter post oak tree in the northwestern portion of the site.

\section{Levels of Work and Results}

This site was discovered when three flakes were recovered from Transect ST M27. A total of nine flakes, a chert chip, and two pieces of firecracked rocks were recovered from nine of the 15 
Table 7-42. 41BP744 positive shovel test results.

\begin{tabular}{|c|c|c|c|c|c|c|c|c|c|c|}
\hline $\begin{array}{l}\text { Depth } \\
\text { (cmbs) }\end{array}$ & ST 1 & ST 2 & ST 4 & ST 7 & ST 10 & ST 14 & ST 15 & ST 16 & ST 20 & ST M27 \\
\hline $0-10$ & & & & & & & IF & & & \\
\hline $10-20$ & & & & & & $\mathrm{CC}$ & & & & \\
\hline $20-30$ & & $\mathrm{Bu}$ & & & & & & & & \\
\hline $30-40$ & & & & & & & & & IF & \\
\hline $40-50$ & & & & IF & IF & & & & & IF \\
\hline $50-60$ & FCR & fcr & $\mathrm{EF}$ & & & Clay & & IF & & IF \\
\hline $60-70$ & & & & & & & & & & IF \\
\hline $70-80$ & Sand & Clay & Sand & Sand & Sand & & Sand & Sand & Sand & Sand \\
\hline $80-90$ & & & & & & & & & & \\
\hline & & $\begin{array}{l}\mathrm{Bu}-\mathrm{l} \\
\mathrm{C}-\mathrm{f}\end{array}$ & . & ert c & $\begin{array}{l}E F-e \\
c h ; f c\end{array}$ & $\begin{array}{l}\text { rior } \mathrm{fl} \\
\text { îre-cr }\end{array}$ & $\begin{array}{l}\text {; IF-in } \\
\text { ed rock }\end{array}$ & $\begin{array}{l}\text { ior flak } \\
1 \text { inch }\end{array}$ & & \\
\hline
\end{tabular}

shovel tests placed on the site. Spent .50-caliber bullets were found in ST 2 at $20-30 \mathrm{cmbs}$ (Table 7-42), and in ST 5 at 10-20 cmbs. Archaeologists also noted the presence of angular sandstone and coarse sand in many of the shovel tests, suggesting colluvial deposition. A single, interior flake was observed on an eroded gully surface in the eastern portion of the site.

\section{Conclusions/Recommendations}

Because of the obvious disturbance recorded during surface observations and in shovel tests,

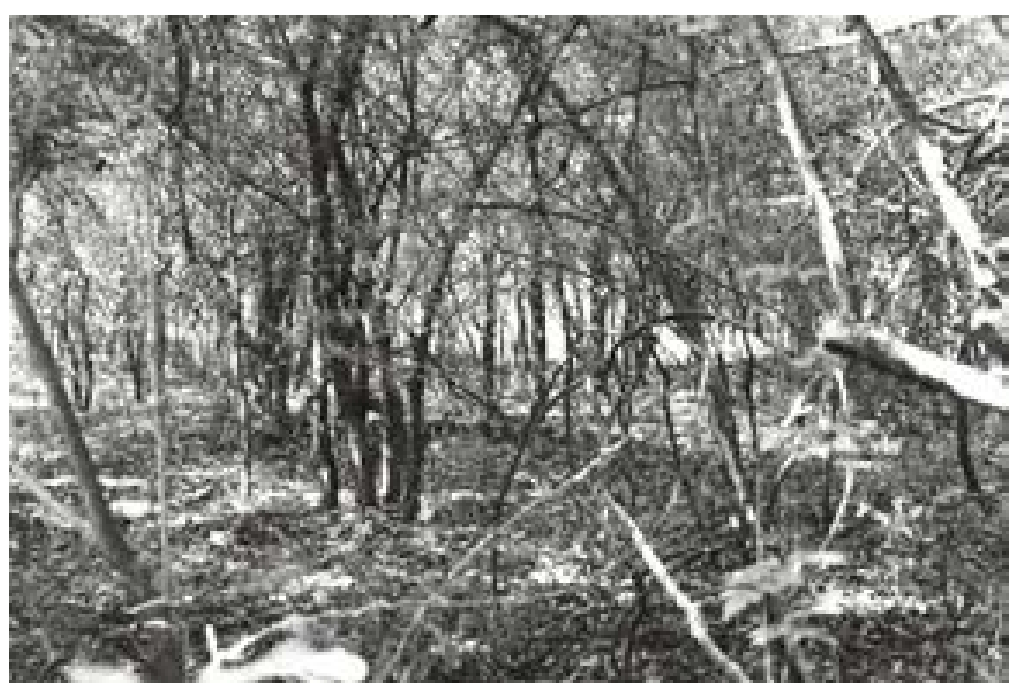

Figure 7-88. 41BP745 lies on a lower terrace area that has been partially bulldozed and has a historic component on it; facing south. this site has little to contribute to the prehistory of the region. Therefore, its research value is minimal, CAS recommends that no further work be conducted, and the site is not eligible for nomination to the NRHP.

\section{BP745}

\section{Description}

$41 \mathrm{BP} 745$ (Figures 7-88 and 7-89) is a $716-\mathrm{m}^{2}$ prehistoric lithic scatter on a lower terrace (T1) with Uhland soils (Uh) adjacent to McLaughlin Creek. Bricks and sandstone have been pushed into a pile on the southern portion of the site, and a dense thicket of thorny scrub brush in marked contrast to surrounding vegetation suggests that the soil in the immediate area has also been pushed with heavy equipment. Otherwise, the sloping surface (435-430 $\mathrm{ft}$ amsl) is covered with cedars, elms, and dense grasses. The historic component is further discussed in Chapter 9: New Historic Component Sites. Perhaps because of the dense 
FIGURE 7-89. REDACTED

Figure 7-89. Site map of 41BP745.

Table 7-43. 41BP745 positive shovel test results.

\begin{tabular}{|c|c|c|c|c|c|c|c|}
\hline $\begin{array}{c}\text { Depth } \\
\text { (cmbs) }\end{array}$ & $\begin{array}{c}\text { ST } \\
\mathbf{1}\end{array}$ & $\begin{array}{c}\text { ST } \\
\mathbf{2}\end{array}$ & $\begin{array}{c}\text { ST } \\
\mathbf{3}\end{array}$ & $\begin{array}{c}\text { ST } \\
\mathbf{5}\end{array}$ & $\begin{array}{c}\text { ST } \\
\mathbf{6}\end{array}$ & $\begin{array}{c}\text { ST } \\
\mathbf{8}\end{array}$ & $\begin{array}{c}\text { ST } \\
\text { N1 }\end{array}$ \\
\hline $0-10$ & & & & & & & \\
\hline $10-20$ & IF & & & & & & \\
\hline $20-30$ & IF & & & & & & \\
\hline $30-40$ & IF & IF & & & IF & IF & \\
\hline $40-50$ & & & & IF & & & IF \\
\hline $50-60$ & IF & & IF & & & & Bedrock \\
\hline $60-70$ & & & & & Clay & & \\
\hline $70-80$ & Sand & Sand & Sand & Sand & & & \\
\hline $80-90$ & & & & & & Sand & \\
\hline $90-100$ & & & & & & & \\
\hline \multicolumn{7}{|c|}{ Key: IF-interior flake } \\
\hline
\end{tabular}

vegetation, no prehistoric artifacts were observed on the surface. The site datum is marked by a nail and aluminum tag on a large elm tree.

\section{Levels of Work and Results}

The prehistoric component was discovered during excavation of transect shovel tests (see Figure 7-89). Of the seven shovel tests placed on the site, a total of ten flakes were found (Table 7-43). The only subsurface disturbances detected from shovel tests were caused by roots. Notably, no historic material was found below the surface.

\section{Conclusions/ \\ Recommendations}

Although the subsurface disturbances at this site appear to be minimal, the absence of burned rock, stone tools, and/or evidence of organic preservation significantly lessens the research potential of this site. Therefore, CAS does not recommend that further work at this site will provide credible data, and the prehistoric component is not eligible for nomination to the NRHP.

\section{BP747}

\section{Description}

41BP747 (Figures 7-90 and 7-91) is a large $\left(14,156-\mathrm{m}^{2}\right)$ prehistoricopencampsiteranging in elevation from 460 to $432 \mathrm{ft}$ amsl. The site lies on a sideslope and footslope alongside an intermittent drainage and McLaughlin Creek, which is 30 meters to the north. Elevation varies greatly, from $460 \mathrm{ft}$ amsl in the northern portion to 438 feet on the lower bluff overlooking McLaughlin Creek to the 
south. Today, a 7-m cutbank on the intermittent drainage forms the site's eastern boundary. The eastern and southern portions are heavily wooded with oaks, pines, and cedars, while the western portion is semi-wooded, with dense grasses and predominantly cedar motts. Soils mapped on the site include Uhland (Uh) on its southern tip, Silstid loamy fine sand $(\mathrm{SkC})$ on its western portion, Tabor fine sandy loam (TfB) in its upper, northwestern portion, and Sayers fine sandy loam (Sa) in its eastern area. Surface visibility in August 2005 was less than five percent, but obvious disturbances are a firebreak trench along the main tree line (see Figure 7-91), with some rodent burrowing and treefalls in the heavily wooded area. The datum is marked by a nail and an aluminum tag on a large oak tree.

\section{Levels of Work and Results}

This site was discovered during excavation of transect shovel tests. Eight of 13 shovel tests excavated within the boundaries of the site were positive (see Figure 7-91). A total of four flakes and six pieces of fire-cracked rocks were recovered (Table 7-44). No artifacts or features were observed on the surface, and although archaeologists walked the intermittent drainage and McLaughlin Creek, leaf fall, moss, and brush precluded a thorough examination of their cutbanks. The only disturbances detected

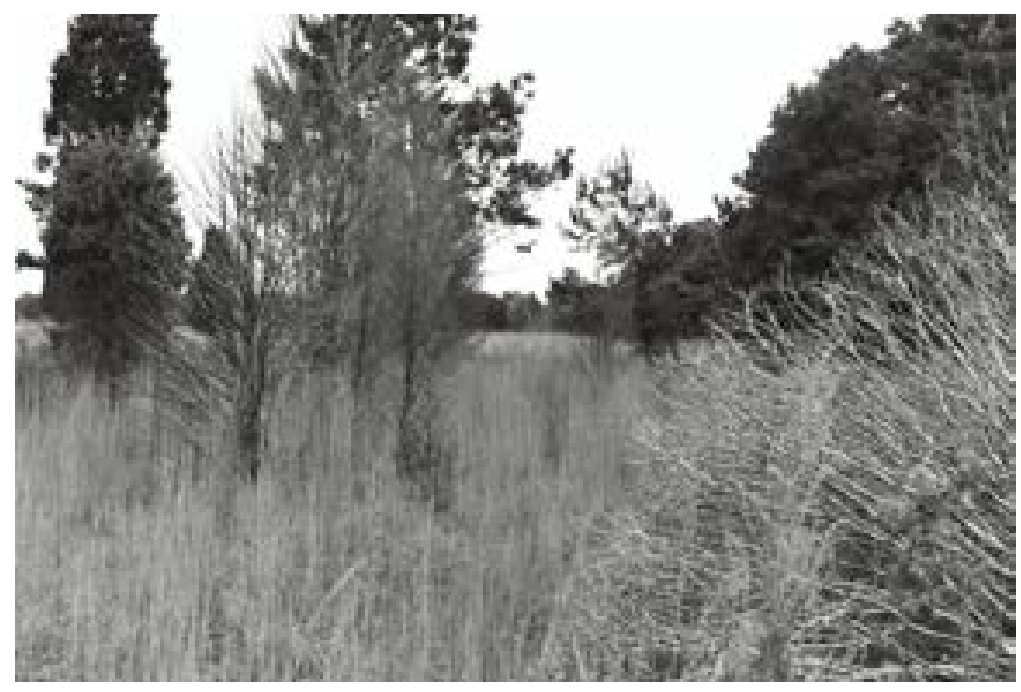

Figure 7-90. 41BP147 in an open campsite in a heavily wooded area along an intermediate tributary to its confluence with McLaughlin Creek; facing north.

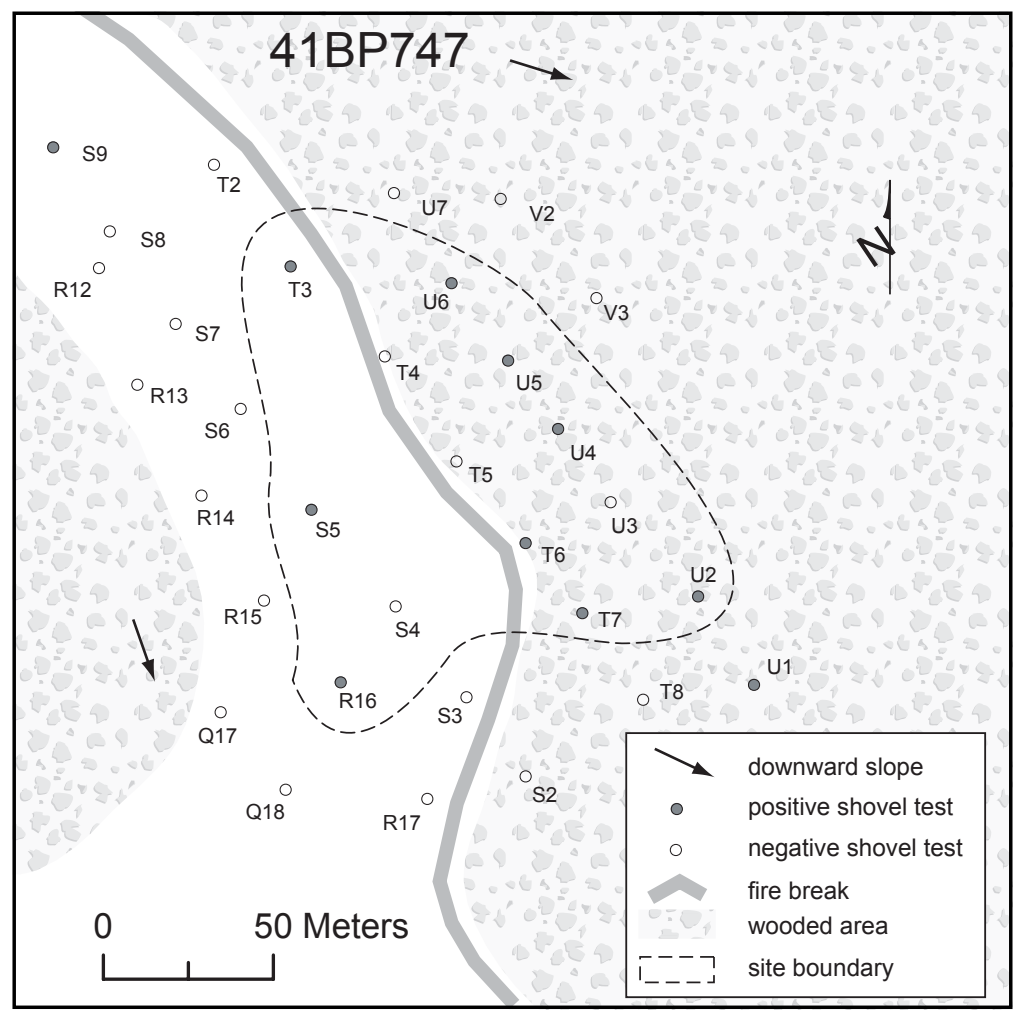

Figure 7-91. Site map of 41BP747. from shovel tests were caused by roots in the heavily wooded area. 
Table 7-44. 41BP747 positive shovel test results.

\begin{tabular}{|c|c|c|c|c|c|c|c|c|}
\hline $\begin{array}{l}\text { Depth } \\
\text { (cmbs) }\end{array}$ & ST R16 & ST S5 & ST T3 & ST T6 & ST U2 & ST U4 & ST U5 & ST U6 \\
\hline \multicolumn{9}{|l|}{$0-10$} \\
\hline $10-20$ & & & & & FCR & & $2 \mathrm{FCR}$ & IF \\
\hline $20-30$ & IF & & fcr & & & fcr & FCR & \\
\hline \multicolumn{9}{|l|}{$30-40$} \\
\hline $40-50$ & & & & IF & & & & \\
\hline $50-60$ & & & & & Clay & & & \\
\hline $60-70$ & & $\mathrm{EF}$ & & & & & & \\
\hline $70-80$ & Sand & & Sand & & & Sand & Sand & Sand \\
\hline $80-90$ & & Sand & & Sand & & & & \\
\hline 90-100 & & & & & & & & \\
\hline
\end{tabular}

\section{Conclusions/ \\ Recommendations}

Shovel test results indicate that the high bluff along the intermittent drainage was most likelyused as the main occupation area. Buried pieces of firecracked rock and lithic debitage in that area suggest that there is a potential for intact burned rock features and associated cultural material to also exist. However, further investigations beyond the scope of this inventory survey are necessary to confirm their

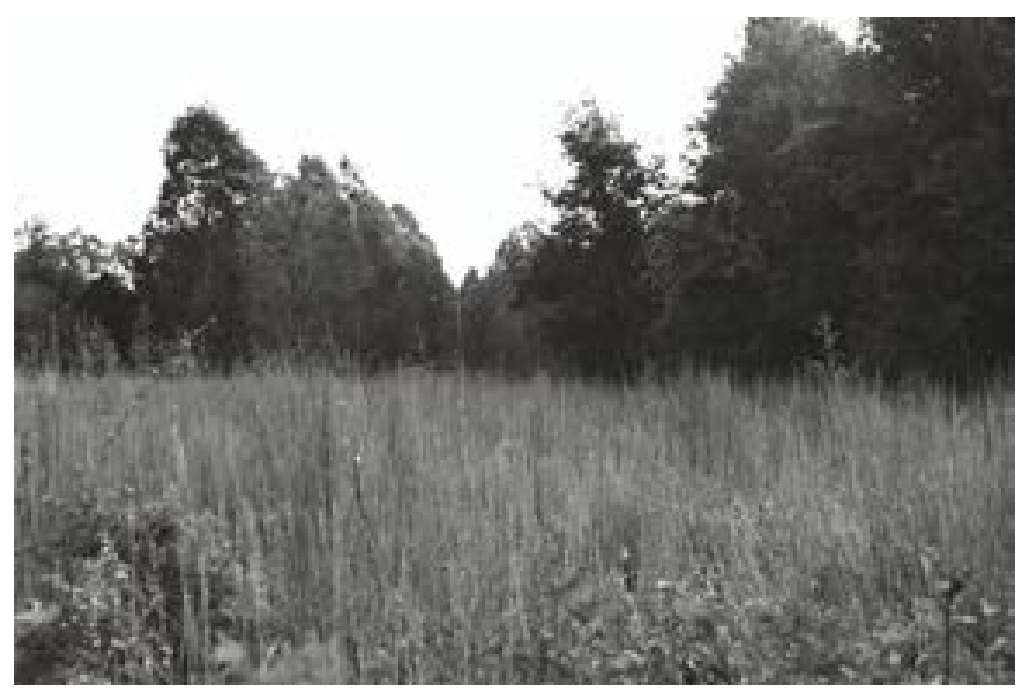

Figure 7-92. 41BP748 is a small open campsite that has apparently been disturbed by the construction of a stock tank; facing north. presence/absence and determine the eligibility of the site. Until that can be done, the research value of this site is unknown. CAS recommends excavation of four 1-x-1-m units along the intermittent drainage on a line between STs U2 and U6.

\section{$41 B P 748$}

\section{Description}

41BP748 (Figures 7-92 and 7-93) is a small open campsite in disturbed Silstid loamy fine sand (SkC) and Tabor fine sandy loam (TfB) soils. It

now covers approximately $332 \mathrm{~m}^{2}$ adjacent to an ephemeral drainage. It is situated on a sideslope between 435 and $439 \mathrm{ft}$ amsl. A stock tank exists behind an earthen dam constructed across the drainage. Artifacts, as well as crushed gravels, are present in an open grassland area below the dam. Red clay is exposed to the surface northeast of ST E2. The site is otherwise partially surrounded by stands of oak trees covered with vines. The datum is marked with a nail and an aluminum tag in an oak tree southeast of ST E2. 
FIGURE 7-93. REDACTED

Figure 7-93. Site map of 41BP748.

Table 7-45. 41BP748 positive shovel test results.

\begin{tabular}{|c|c|c|c|}
\hline $\begin{array}{c}\text { Depth } \\
\text { (cmbs) }\end{array}$ & ST 1 & ST 9 & ST E2 \\
\hline $0-10$ & & & \\
\hline $10-20$ & & & \\
\hline $20-30$ & & & EF \\
\hline $30-40$ & & 2 IF & \\
\hline $40-50$ & & & \\
\hline $50-60$ & FCR, fcr & & \\
\hline $60-70$ & & Clay & \\
\hline $70-80$ & Sand & & Sand \\
\hline $80-90$ & & & \\
\hline $\begin{array}{l}\text { Key: EF-exterior flake; IF-interior flake; FCR- } \\
\text { fire-cracked rock >1 inch; fcr-fire-cracked rock } \\
<1 \text { inch }\end{array}$ \\
\hline \multicolumn{4}{|c|}{} \\
\hline
\end{tabular}

\section{Levels of Work and Results}

No artifacts were observed on the surface, only a few crushed gravels likely caused by construction of the dam. Two pieces of firecracked rock and three flakes were found in three of the four shovel tests excavated on the site (Table 7-45). Angular ironstones and/or petrified wood were noted in five of the shovel tests, and a crushed cobble was found in ST 9 at $30-40 \mathrm{cmbs}$.

\section{Conclusions/}

\section{Recommendations}

The surface observations and minimal number of artifacts recovered from shovel tests indicate that this small site has been heavily disturbed by the construction of a stock tank. Therefore, its research value is minimal, no further work is recommended, and the site is not eligible for nomination to the NRHP.

\section{BP749}

\section{Description}

41BP749 (Figures 7-94 and 7-95) is an open campsite spread across $1,139 \mathrm{~m}^{2}$ of a semiwooded sideslope adjacent to McLaughlin Creek. Uhland soils (Uh) support the growth of a loblolly pine mott, surrounded by an old cleared field. Bull nettles, blackberry vines, grapevines, prickly pear, shrubs, and grasses have overtaken the field, while the heavily wooded surrounding areas consist of oak, cedar, elm, chinaberry, and sumac. Surface visibility in August 2005 was less than five percent. Small rills and larger swales are common across the 10-degree sloping surface. An old barb wire fence runs along the northeastern portion of the site. The site datum is marked by a nail and an aluminum tag in a $25-\mathrm{cm}$ diameter oak tree. 


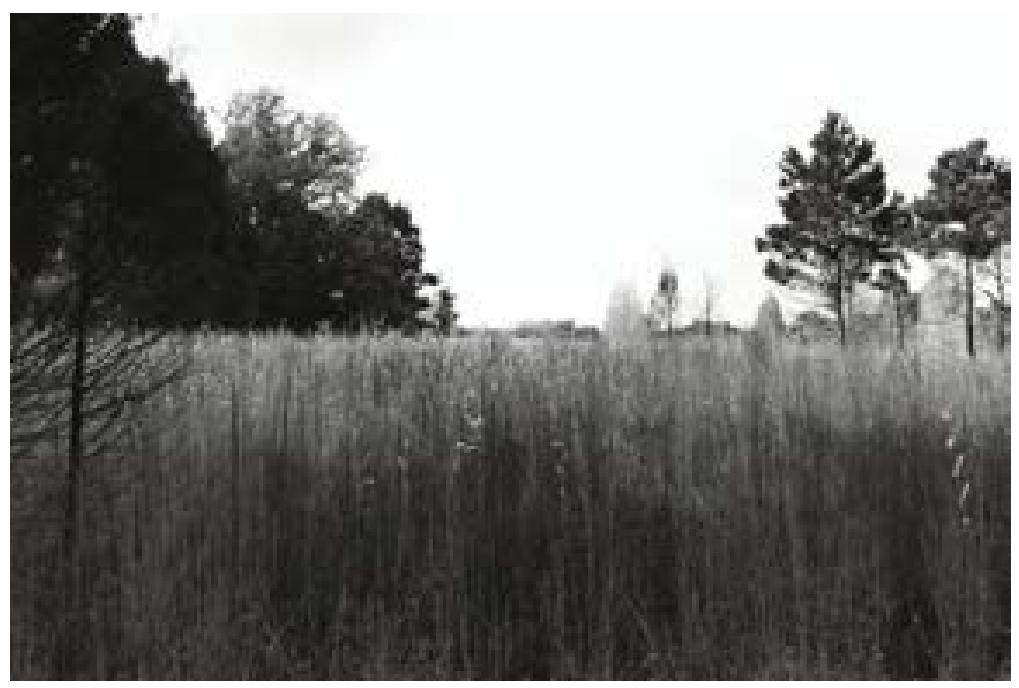

Figure 7-94. 41BP749 is an open campsite that lies in an old field above the McLaughin Creek floodplain; facing south.

FIGURE 7-95. REDACTED

Figure 7-95. Site map of 41BP749.

\section{Levels of Work and Results}

No artifacts were observed on the surface, but a total of two buried fire-cracked rocks and five flakes were found in six of eight shovel tests excavated within the boundaries of the site (Table 7-46). A plow zone was detected between 20 and 
Table 7-46. 41BP749 positive shovel test results.

\begin{tabular}{|c|c|c|c|c|c|c|}
\hline $\begin{array}{c}\text { Depth } \\
\text { (cmbs) }\end{array}$ & ST 5 & ST 7 & ST 9 & ST 10 & ST 12 & ST M11 \\
\hline $0-10$ & & & & & & \\
\hline $10-20$ & & & & & IF & \\
\hline $20-30$ & & & & & & \\
\hline $30-40$ & IF, FCR & & FCR & IF & Clay & \\
\hline $40-50$ & Clay & & & & & IF \\
\hline $50-60$ & & & & Clay & & \\
\hline $60-70$ & & IF & & & & \\
\hline $70-80$ & & & Sand & & & Sand \\
\hline $80-90$ & & Sand & & & & \\
\hline $90-100$ & & & & & & \\
\hline \multicolumn{7}{|c|}{ Key: IF-interior flake; FCR-fire-cracked rock $>1$ inch } \\
\hline
\end{tabular}

$30 \mathrm{cmbs}$ in some shovel tests, and deep sands in STs 1-4, 6, 7, and M11 contrasted sharply with the shallower sands $(16-45 \mathrm{cmbs})$ in the shovel tests to the north and south of that group, suggesting possible gullying perpendicular to McLaughlin Creek. Angular ironstones noted in STs 5 and 8 indicate probable colluvium.

\section{Conclusions/Recommendations}

Although buried fire-cracked rocks and flakes could suggest intact features and

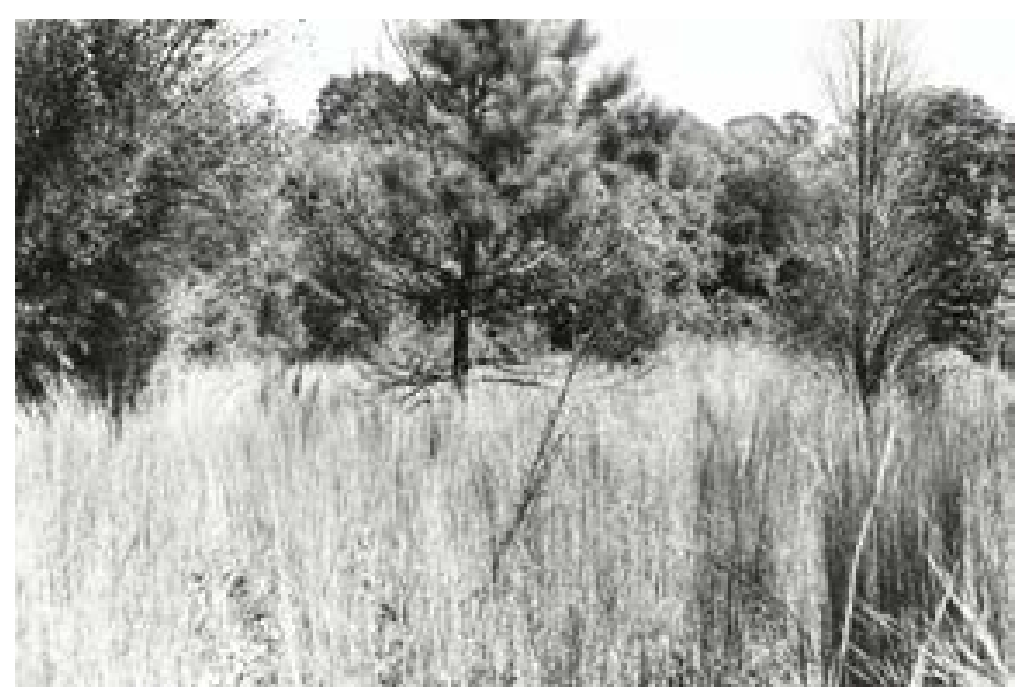

Figure 7-96. 41BP750 is an open campsite that lies in an old field above the McLaughin Creek floodplain; facing north. associated cultural material, the results from shovel tests suggest otherwise. For example, the firecracked rock and flake found in ST 5 were lying just above the $\mathrm{Bt}$ horizon under $40 \mathrm{~cm}$ of probable colluvial deposits. Because of the erosion that has apparently occurred at this site, the research value is minimal, no further work is recommended, and the site is not eligible for nomination to the NRHP.

\section{BP750}

\section{Description}

Very hummocky ground and tank ruts characterize the disturbance that has occurred at this open campsite on a sideslope $80 \mathrm{~m}$ south of the McLaughlin Creek floodplain (Figure 7-96). Patilo complex fine sand (PaE) covers the slope. The site's $1,379-\mathrm{m}^{2}$ elongated shape perpendicular to the creek, and running down the 10-degree slope (Figure 7-97) causes a suspicion that erosional forces have negatively impacted its cultural integrity. The once-cleared field now has dense grasses, bull nettles, grapevines, prickly pears, and assorted shrubs. Surface visibility in August 2005 was less than five percent. Loblolly pine trees, along with oaks, cedars, sumacs, and beautyberries surround the open field area. The site datum is marked with a nail and an aluminum tag in a $20-\mathrm{cm}$ diameter pine tree near ST 6.

\section{Levels of Work and Results}

No artifacts were observed on the surface. Shovel tests indicate that the average depth of 


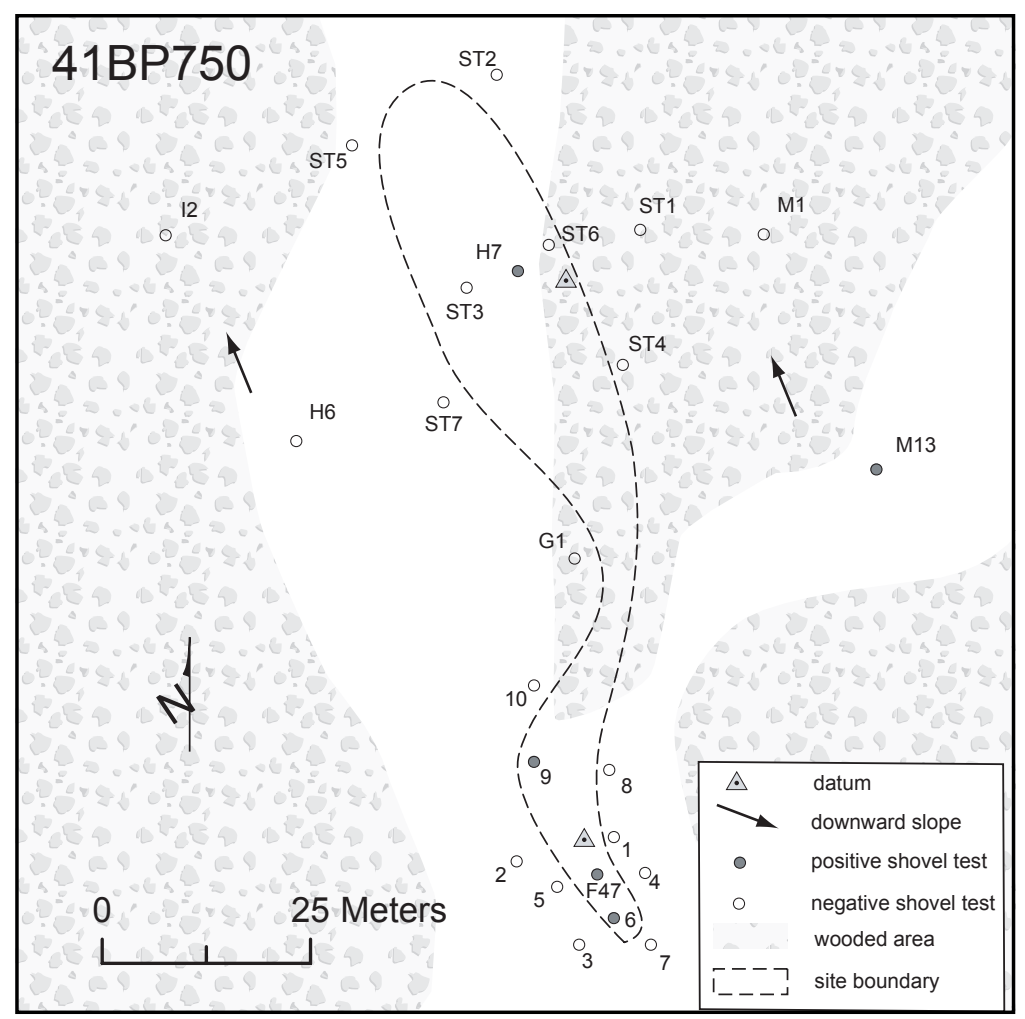

Figure 7-97. Site map of 41BP750.

Table 7-47. 41BP750 positive shovel test results.

\begin{tabular}{|c|c|c|c|c|c|c|c|c|c|}
\hline $\begin{array}{c}\text { Depth } \\
(\mathbf{c m b s})\end{array}$ & ST 2 & ST 3 & ST 4 & ST 5 & ST 6 & ST 13 & ST 16 & ST F47 & ST H7 \\
\hline $0-10$ & & & & & IF & & & & \\
\hline $10-20$ & & & & & & & & & \\
\hline $20-30$ & & EF & EF & & & & IF & & FCR \\
\hline $30-40$ & & & & & & IF & IF & FCR & \\
\hline $40-50$ & FCR & & Clay & & & Clay & Clay & & \\
\hline $50-60$ & & & & IF & & & & & Clay \\
\hline $60-70$ & Gravel Bed & & & Clay & Clay & & & Clay & \\
\hline $70-80$ & & Sand & & & & & & & \\
\hline $80-90$ & & & & & & & & & \\
\hline \multicolumn{7}{|l}{ Key: EF-exterior flake; IF-interior flake; FCR-fire-cracked rock $>1$ inch } \\
\hline
\end{tabular}

sand at the site is just over $44 \mathrm{cmbs}$. The deepest sand was found in ST 5 and a dense gravel layer was found in ST 2 (Table 7-47), downslope and nearest the McLaughlin floodplain. A total of seven flakes and three fire-cracked rocks were found in the 9 shovel tests placed on the site: an ephemeral concentration was found on the lower, northern portion of the site (STs 2-6, H7), and another concentration on the upper, southern portion (STs 13, 16, F47).

Figure 7-98 orders the shovel tests according to their relative elevations on the site, with ST 13 as the highest on the landscape and ST 5 


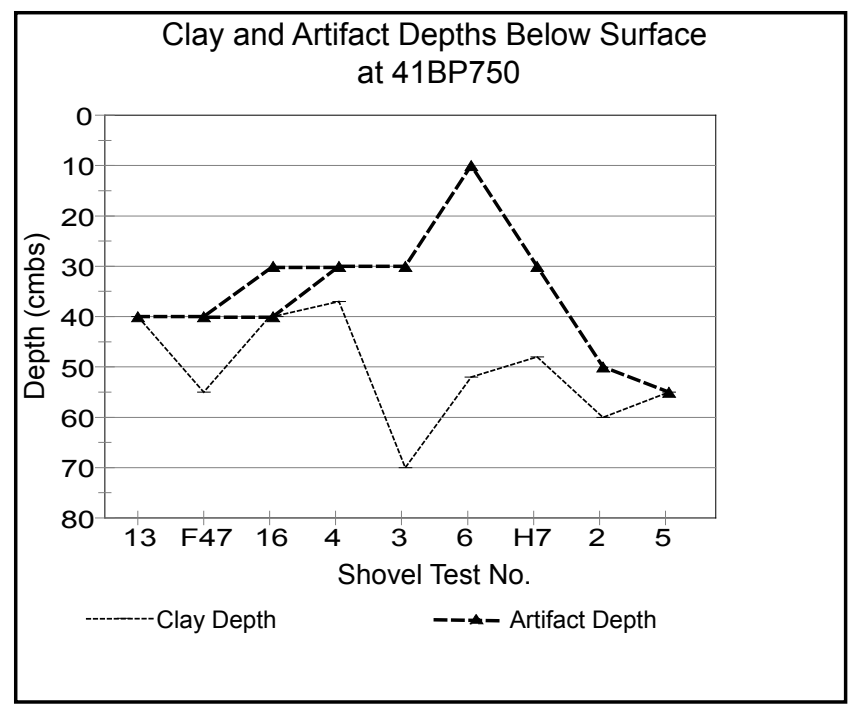

Figure 7-98. Artifacts versus clay depths at 41BP750. Note that a gravel bed was encountered in ST2 and clay was not reached in ST 3.

as the lowest. The lines on the graph illustrate the maximum depths of the artifacts relative to the underlying Bt horizon and/or a gravel bed (ST 2). Note the congruity in depths between the two datasets in the upper portion (STs 13, F47, and 16) versus the disparity in the lower portion. In other words, the sands are generally deeper in the upper portion, and the artifacts in that area are on or near the clay, but in the lower portion of the site the artifacts are generally more shallowly buried in the sands. Though not conclusive, CAS interprets these data as corroborating evidence indicating that downslope erosion of both sands and artifacts has occurred.

\section{Conclusions/ \\ Recommendations}

Although colluvial deposits could not be discerned from shovel tests, the data obtained indicate that the artifacts found are likely in a secondary context due to slope erosion. Therefore, the research value is minimal, no further work is recommended, and the site is not eligible for nomination to the NRHP.

\section{BP753}

\section{Description}

This $5,754-\mathrm{m}^{2}$ open campsite (Figures 7-99 and 7-100) lies on a sideslope of Patilo complex fine sand $(\mathrm{PaE})$ and parallels a secondary intermittent drainage of McLaughlin Creek, some $120 \mathrm{~m}$ to the south. The site ranges in elevation from 469 to 490 feet, is heavily wooded with oaks and cedars, and has predominantly Virginia creeper, beautyberry, and poison ivy understory. Surface visibility in August 2005 was less than five percent. Shallow rills, an occasional animal burrow, and some tree falls appear to be the primary sources of disturbance. The site datum is marked with a nail and aluminum tag in an oak tree measuring $30 \mathrm{~cm}$ in diameter.

\section{Levels of Work and Results}

If any artifacts were on the surface, they would have been covered with leaves and duff.

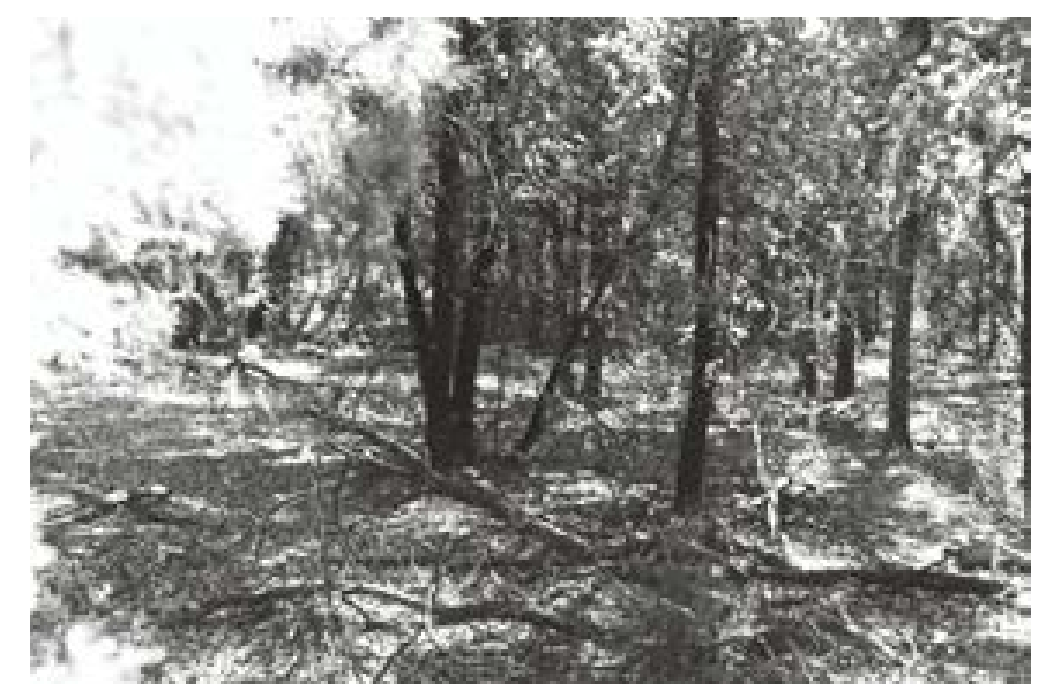

Figure 7-99. 41BP753 is an open campsite on a heavily wooded sideslope above a McLaughlin Creek tributary; facing east. 


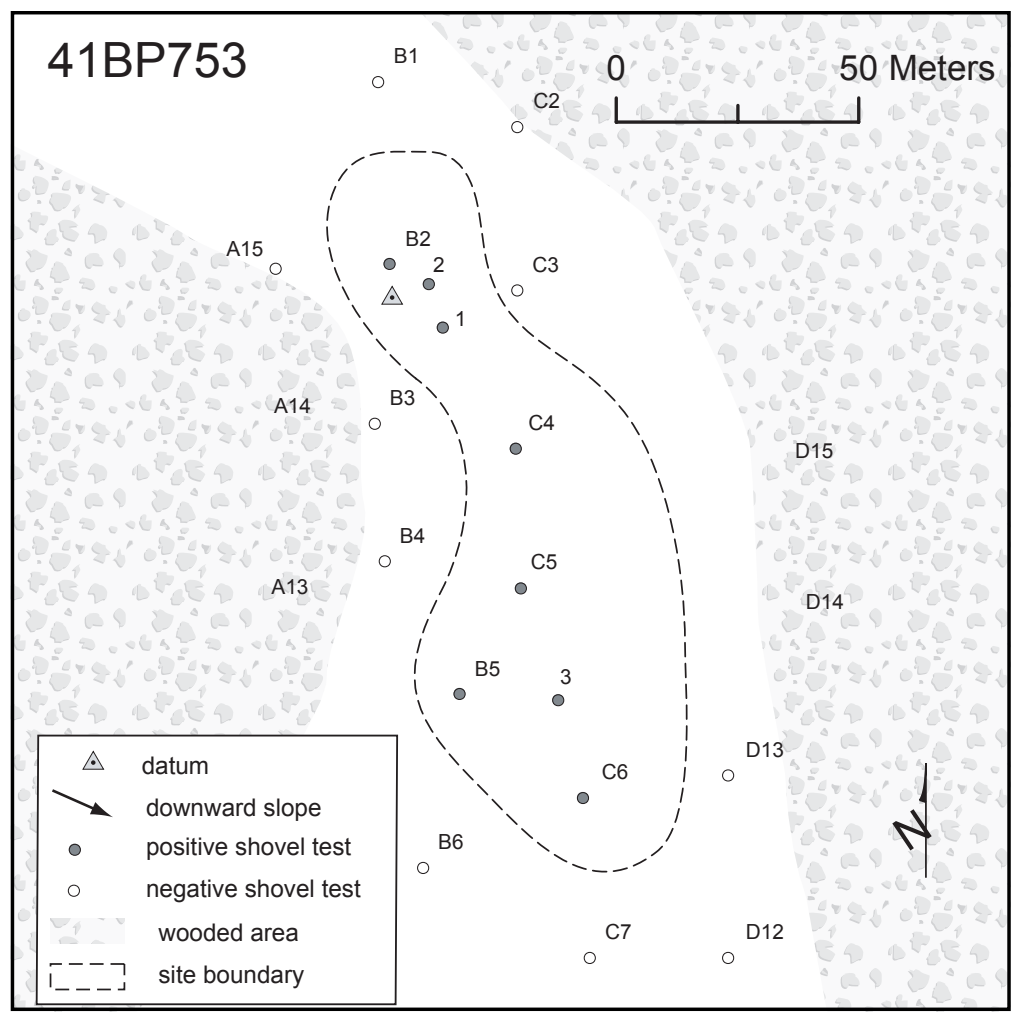

Figure 7-100. Site map of 41BP753.

Table 7-48. 41BP753 positive shovel test results.

\begin{tabular}{|c|c|c|c|c|c|c|c|c|}
\hline Depth (cmbs) & ST 1 & ST 2 & ST 3 & ST B2 & ST B5 & ST C4 & ST C5 & ST C6 \\
\hline $0-10$ & & & & & & & & \\
\hline $10-20$ & & IF & & & & & & \\
\hline $20-30$ & & EF & Ch & IF & EF, IF & & fcr & \\
\hline $30-40$ & & & EF & & & IF & & \\
\hline $40-50$ & EF & fcr & Ch & & & FCR & & IF \\
\hline $50-60$ & & & & & 2 IF & & & \\
\hline $60-70$ & & & & & & & & \\
\hline $70-80$ & Sand & Sand & Sand & Sand & Sand & Sand & Sand & Sand \\
\hline $80-90$ & & & & & & & \\
\hline \multicolumn{7}{|c|}{ Key: EF-exterior flake; IF-interior flake; } \\
\hline
\end{tabular}

As indicated in Table 7-48, the sands at this site are deeper than $70 \mathrm{cmbs}$. The only disturbances noted from shovel tests were in the form of roots.
A total of 11 flakes, three pieces of burned rock, and five chunks of charcoal ranging from dime to quarter-size were found in the 8 positive shovel tests excavated within the boundaries of the site (Table 7-48). 


\section{Conclusions/Recommendations}

Notably, nine of the 11 flakes, the three burned rocks, and all of the charcoal were recovered from 20 to $50 \mathrm{cmbs}$, suggesting a stratified and possibly intact cultural zone occurs at those depths. The presence of burned rocks further suggests that buried and possibly intact features also exist. Finally, the recovery of charcoal presumes a good potential for organic preservation at the site. However, further investigations beyond the scope of this inventory survey are necessary to confirm such a presence or absence. Until that can be done, the research value of this site is unknown. CAS recommends excavation of two $1-x-1-m$ units, one each in the immediate areas of STs 3 and C4 to determine the eligibilty of the site to be listed on the NRHP.

\section{BP754}

\section{Description}

41BP754 (Figures 7-101 and $7-102)$ is located at $460-470$ $\mathrm{ft}$ amsl on the same wooded sideslope as 41BP753, $70 \mathrm{~m}$ north of a first order intermittent tributary of McLaughlin Creek. Based upon shovel test results, the site measures approximately 1,556 $\mathrm{m}^{2}$. Patilo complex fine sand $(\mathrm{PaE})$ encompasses this area of the slope. It is also generally heavily wooded with oaks and cedars, and has predominantly Virginia creeper, beautyberry, and poison ivy understory. Otherwise, a small area of open grassland is on the southern portion of the site. Surface visibility in August 2005 was less than five percent. Shallow rills and some tree falls appear to be the primary sources of disturbance. The site datum is marked with a nail

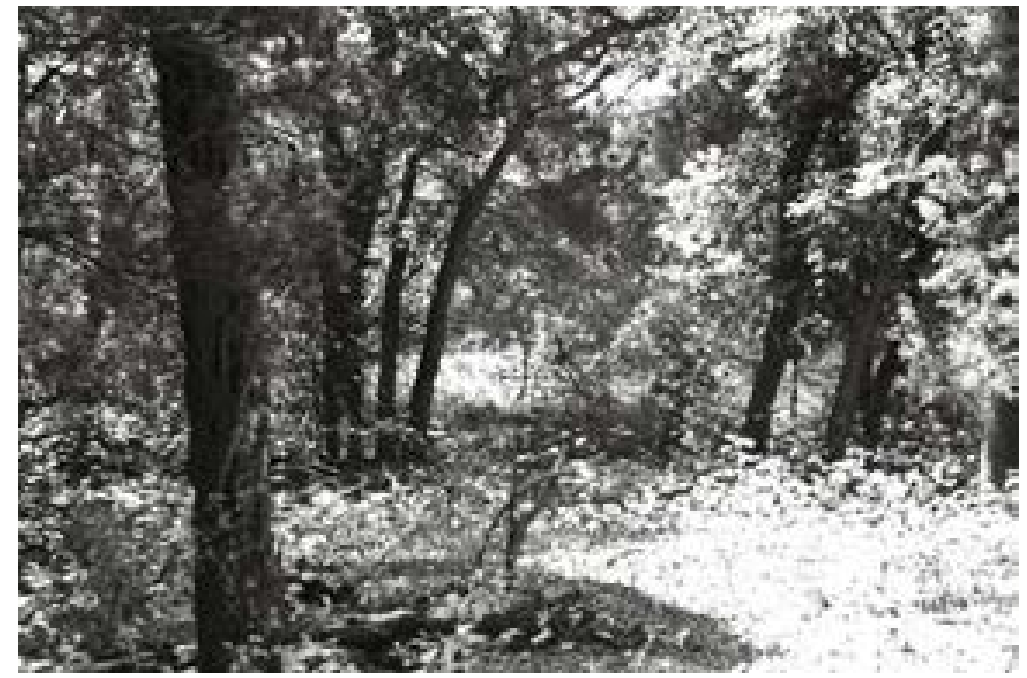

Figure 7-101. 41BP754 is another open campsite on a heavily wooded sideslope above a tributary of McLaughlin Creek; facing southeast.

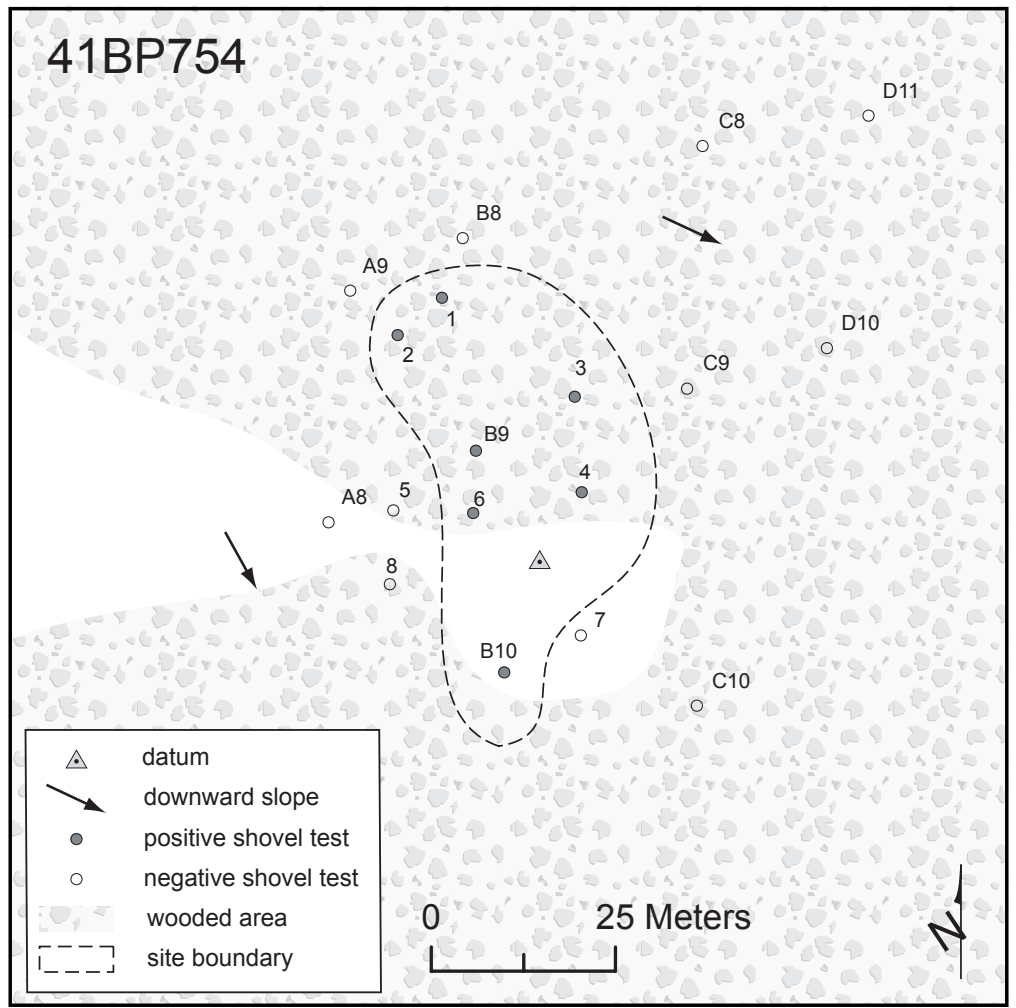

Figure 7-102. Site map of 41BP754. 
Table 7-49. 41BP754 positive shovel test results.

\begin{tabular}{|c|c|c|c|c|c|c|c|}
\hline $\begin{array}{l}\text { Depth } \\
\text { (cmbs) }\end{array}$ & $\begin{array}{c}\text { ST } \\
1 \\
\end{array}$ & $\begin{array}{c}\text { ST } \\
2 \\
\end{array}$ & $\begin{array}{c}\text { ST } \\
3 \\
\end{array}$ & $\begin{array}{c}\text { ST } \\
4 \\
\end{array}$ & $\begin{array}{c}\text { ST } \\
6 \\
\end{array}$ & $\begin{array}{l}\text { ST } \\
\text { B9 }\end{array}$ & $\begin{array}{c}\text { ST } \\
\text { B10 } \\
\end{array}$ \\
\hline \multicolumn{8}{|l|}{$0-10$} \\
\hline \multicolumn{8}{|l|}{$10-20$} \\
\hline \multicolumn{8}{|l|}{$20-30$} \\
\hline $30-40$ & & & fcr & & & & \\
\hline $40-50$ & & & fcr & fcr & & & \\
\hline $50-60$ & & IF & & & & & $\begin{array}{c}\mathrm{CC}, \\
\text { IF }\end{array}$ \\
\hline $60-70$ & IF & & & & EF & EF & $\begin{array}{l}\text { IF, } \\
\text { fcr }\end{array}$ \\
\hline $70-80$ & & Sand & Sand & Sand & 2 FCR & & \\
\hline $80-90$ & Sand & & & & $\begin{array}{c}\mathrm{EF}, \\
3 \mathrm{fcr}\end{array}$ & Sand & \\
\hline $90-100$ & & & & & fcr & & \\
\hline $100-110$ & & & & & Sand & & Sand \\
\hline $110-120$ & & & & & & & \\
\hline $\begin{array}{r}\text { Key: } \\
\text { FCR- }\end{array}$ & rrac & hip; & $\begin{array}{l}\text {-ext } \\
\text { inch }\end{array}$ & of fla & $\begin{array}{l}\text {; IF-in } \\
\text { cracke }\end{array}$ & or $\mathrm{fl}$ & \\
\hline
\end{tabular}

and aluminum tag in an oak tree measuring 21 $\mathrm{cm}$ in diameter.

\section{Levels of Work and Results}

No artifacts could be seen on the heavily vegetated surface, and as indicated in Table 749, all artifacts were at depths below 30 cmbs. Seven shovel tests were excavated on the site, all of which were positive. A total of ten pieces of fire-cracked rock, seven flakes, and a chert chip were found in the seven positive shovel tests (Table 749). The only disturbances noted in shovel tests were in the form of roots.

\section{Conclusions/ Recommendations}

The consistent presence of deeply buried fire-cracked rocks and debitage suggests that there could still be an intact hearth feature and associated cultural material at this site. Additional investigations beyond the scope of this inventory survey are necessary to confirm such presence or absence. Until that can be done, the research value of this site is unknown and so is its NRHP eligibility. CAS recommends excavation of four $1-x-1-m$ units, one each in the immediate areas of STs 3, 4, 6, and B10.

\section{BP755}

\section{Description}

41BP755 is an open campsite that spans across $1,309 \mathrm{~m}^{2}$ of an upland sideslope (Figures 7-103 and 7-104). Obvious disturbances include small gullies that have incised the Demona loamy fine sand (DeC) old field surface, a barb wire fence that runs along the eastern edge of the tree line, a few animal burrows, and a few tree falls. The old field

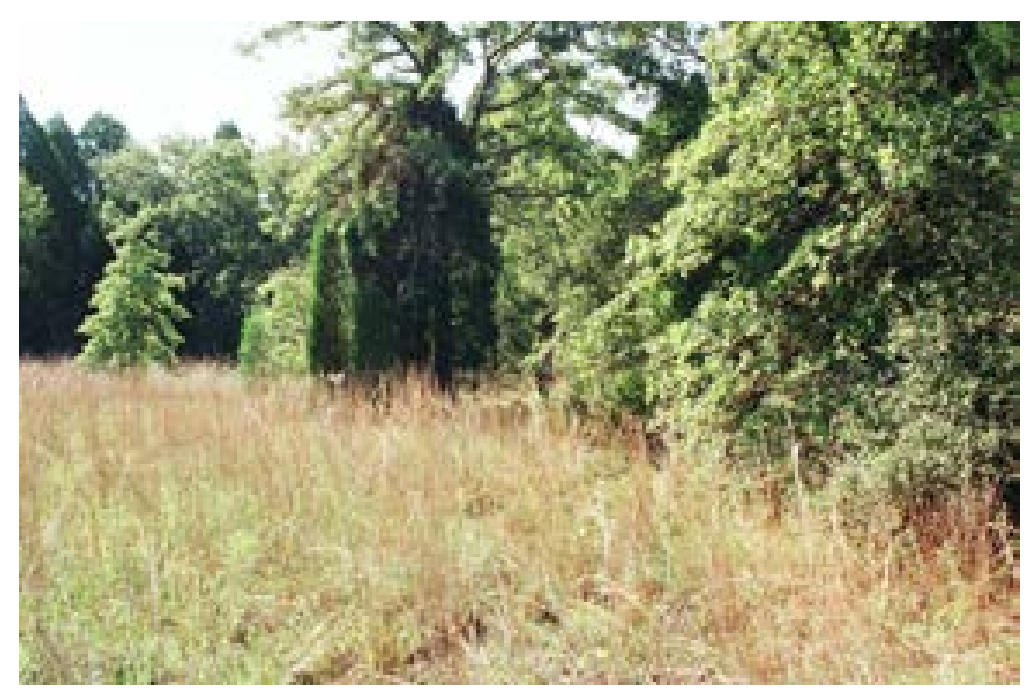

Figure 7-103. 41BP755 is an open campsite on an old field and wooded area adjacent to an intermittent drainage; facing southeast. 


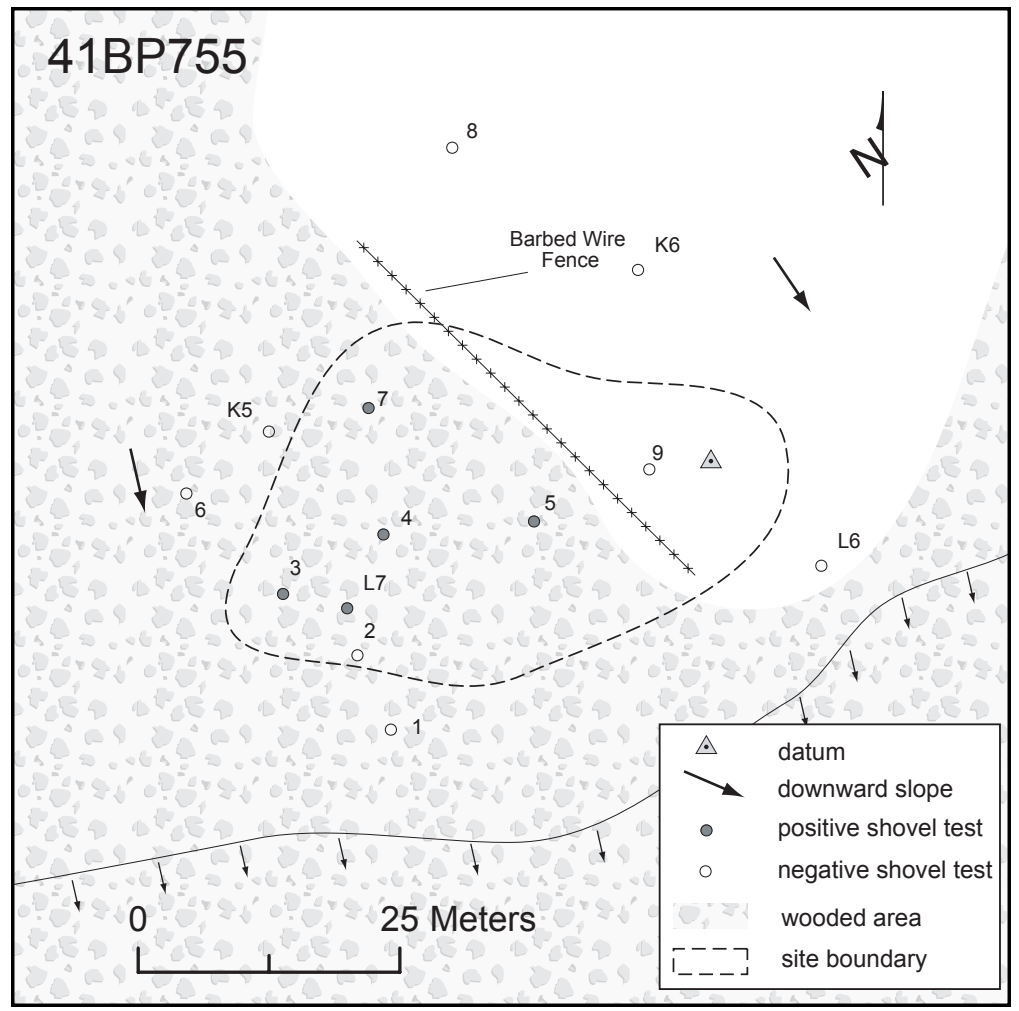

Figure 7-104. Site map of 41BP755.

Table 7-50. 41BP755 positive shovel test results.

\begin{tabular}{|c|c|c|c|c|c|}
\hline $\begin{array}{c}\text { Depth } \\
\text { (cmbs) }\end{array}$ & $\begin{array}{c}\text { ST } \\
\mathbf{3}\end{array}$ & $\begin{array}{c}\text { ST } \\
\mathbf{4}\end{array}$ & $\begin{array}{c}\text { ST } \\
\mathbf{5}\end{array}$ & $\begin{array}{c}\text { ST } \\
\mathbf{7}\end{array}$ & $\begin{array}{c}\text { ST } \\
\text { L7 }\end{array}$ \\
\hline $0-10$ & & & & & \\
\hline $10-20$ & & & & IF & \\
\hline $20-30$ & & & & & IF, fcr \\
\hline $30-40$ & & & & & \\
\hline $40-50$ & IF & & & & \\
\hline $50-60$ & & IF & & & \\
\hline $60-70$ & & & 2 fcr & & \\
\hline $70-80$ & Sand & Sand & & Sand & \\
\hline $80-90$ & & & & & Sand \\
\hline $90-100$ & & & Sand & \\
\hline $100-110$ & \multicolumn{7}{|c|}{ inch } & & \\
\hline Key: IF-interior flake; fcr-fire-cracked rock $<1$ \\
\hline \multicolumn{7}{|c|}{} \\
\hline
\end{tabular}

slopes gently from 482 to $478 \mathrm{ft}$ amsl, but a sharp, 3-m drop to an intermittent drainage channel forms its southern boundary. Vegetation includes vines and dense grasses in the open field, with oaks, cedars, and beautyberries in the wooded areas so that surface visibility in August 2005 was less than five percent. The site datum is marked with a nail and aluminum tag on an oak tree just inside the tree line.

\section{Levels of Work and Results}

Two small pieces of firecracked rocks and four interior flakes were found in five shovel tests out of seven excavated on the site (Table 7-50). The only disturbances observed in shovel tests were from roots. All shovel tests were excavated to at least $70 \mathrm{cmbs}$, and all were terminated in sand.

\section{Conclusions/ \\ Recommendations}

Although lithic debitage and small firecracked rock pieces were found, they were at varying depths, suggesting that there are no stratigraphically intact cultural deposits. Therefore, CAS assesses the site as having little potential to yield significant information, and no further work is recommended. The site is not eligible for nomination to the NRHP.

\section{BP756}

\section{Description}

41BP756 is a small $\left(361 \mathrm{~m}^{2}\right)$ open campsite with an ephemeral scatter of lithic debitage and firecracked rocks. It is located on a wooded, upland sideslope between 472 and $473 \mathrm{ft}$ amsl (Figures 7-105 and 7-106). Cedar, oak, and beautyberry are the prevalent trees and bushes at the site, so surface visibility in August 2005 was less than five percent. A first order intermittent tributary of McLaughlin Creek courses approximately 120 


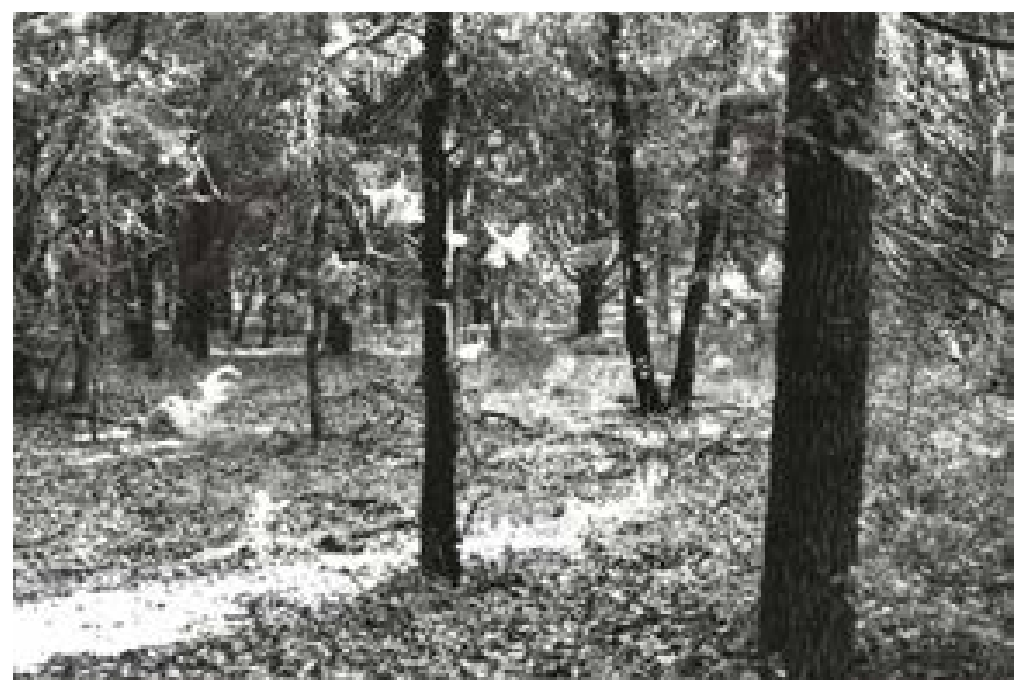

Figure 7-105. 41BP756 is a small open campsite on an upland sideslope; facing northeast.

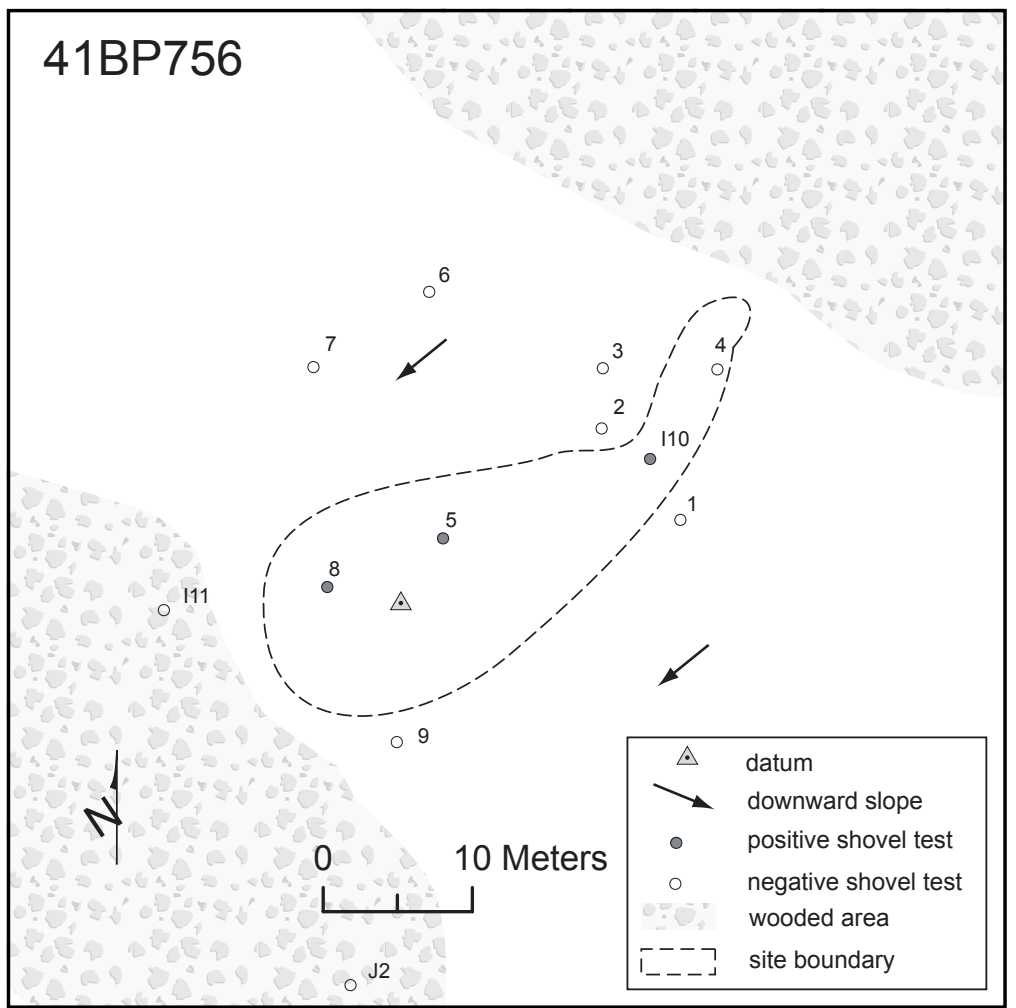

Figure 7-106. Site map of 41BP756. 
Table 7-51. 41BP756 positive shovel test results.

\begin{tabular}{|c|c|c|c|}
\hline $\begin{array}{c}\text { Depth } \\
\text { (cmbs) }\end{array}$ & ST 5 & ST 8 & ST I10 \\
\hline $0-10$ & & & IF \\
\hline $10-20$ & & IF & \\
\hline $20-30$ & & & \\
\hline $30-40$ & & Clay & \\
\hline $40-50$ & 2 FCR & & \\
\hline $50-60$ & Clay & & \\
\hline $60-70$ & & & \\
\hline $70-80$ & & & Sand \\
\hline $80-90$ & & & \\
\hline Key: IF-interior flake; fcr-fire-cracked rock $<1$ \\
inch \\
\hline
\end{tabular}

$\mathrm{m}$ to the west. The only disturbances observed in the Demona loamy fine sand $(\mathrm{DeC})$ surface were caused by tree falls. The site datum is marked with a nail and aluminum tag on an oak tree on the southern portion of the site.

\section{Conclusions/Recommendations}

Although lithic debitage and fire-cracked rock pieces were found, the results of shovel tests indicate the potential for intact features and associated cultural material is limited. Therefore, CAS assesses the site as having little potential to yield significant information, and no further work is recommended. The site should is not eligible for nomination to the NRHP.

\section{BP757}

\section{Description}

41BP757 (Figures 7-107 and 7-108) is a large open campsite that spans $7,976 \mathrm{~m}^{2}$ on an upland ridge and sideslope between 475 and 485 $\mathrm{ft}$ amsl, and $370 \mathrm{~m}$ north of McLaughlin Creek. Demona loamy fine sand supports oaks and cedars on its western half and scattered cedars

\section{Levels of Work and Results}

No artifacts were observed on the surface, but two pieces of fire-cracked rock and two interior flakes were found in three shovel tests out of four excavated on the site (Table 751). The average sand depth across the site is slightly over 52 cmbs. Disturbances observed in shovel tests were from roots and angular ironstones found in two of the shovel tests, which suggest at least some colluvial deposition across the site.

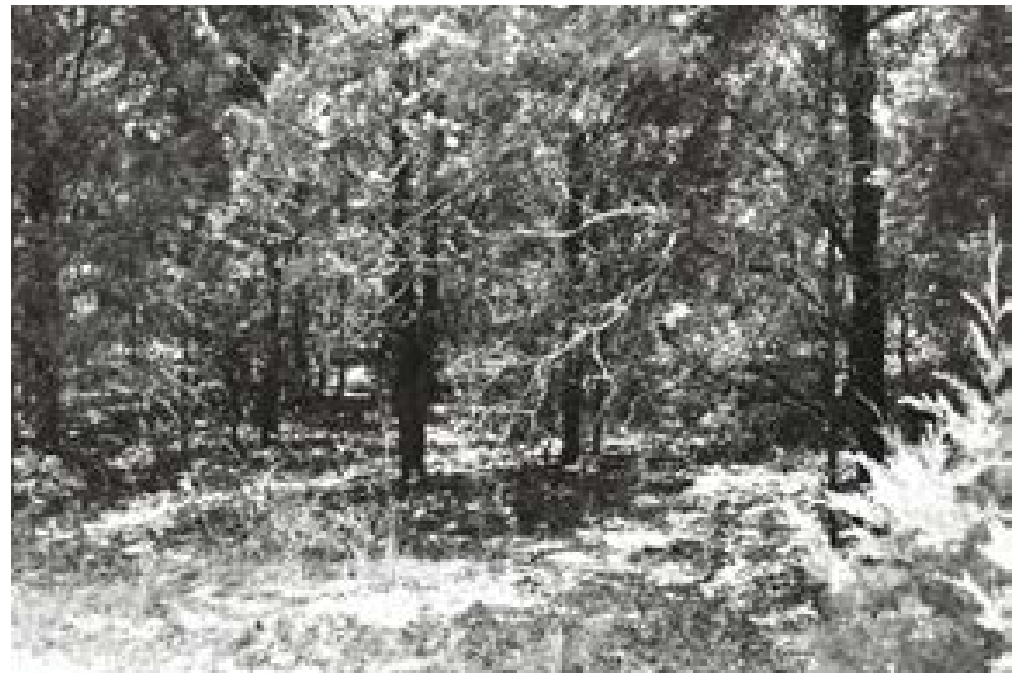

Figure 7-107. 41BP757 is a large open campsite on an upland ridge and sideslope; facing east. 


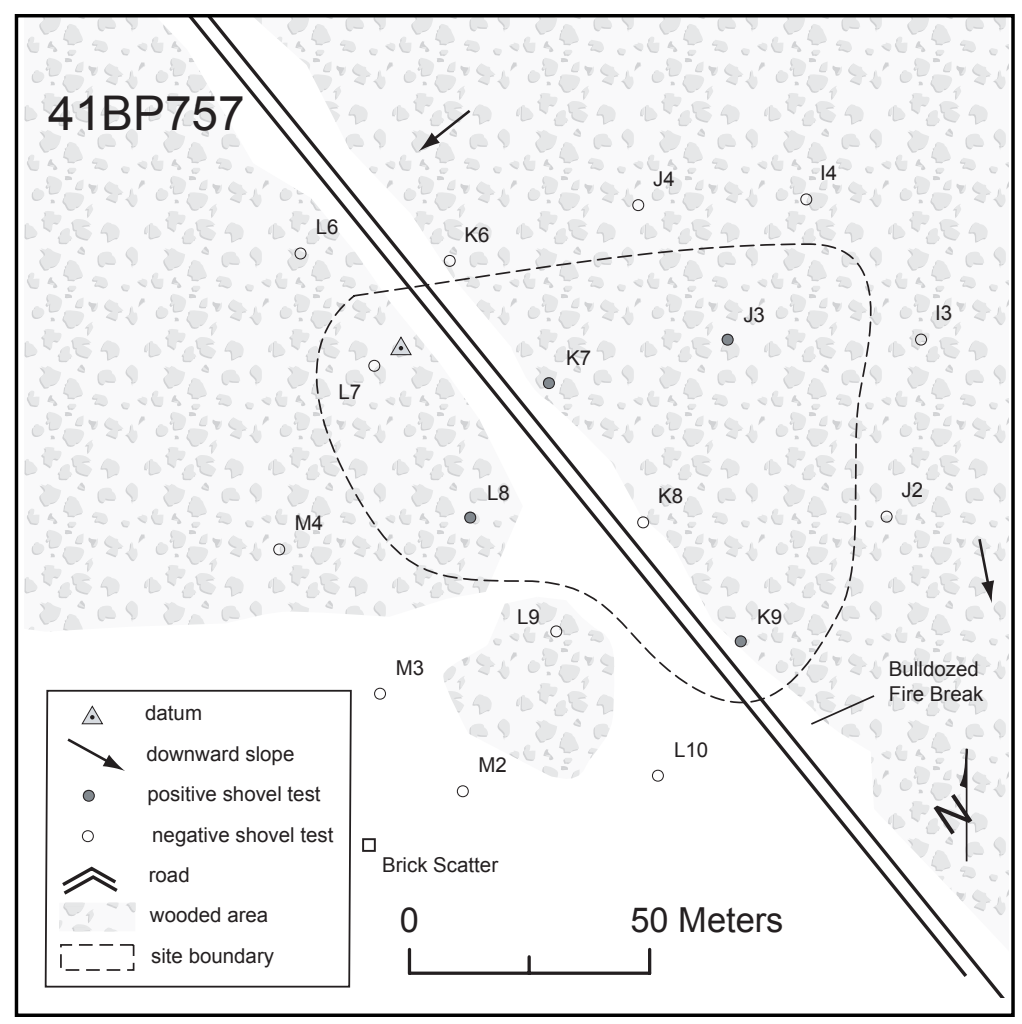

Figure 7-108. Site map of 41BP757.

Table 7-52. 41BP757 positive shovel test results.

\begin{tabular}{|c|c|c|c|c|}
\hline $\begin{array}{c}\text { Depth } \\
\text { (cmbs) }\end{array}$ & $\begin{array}{c}\text { ST } \\
\text { J3 }\end{array}$ & $\begin{array}{c}\text { ST } \\
\text { K7 }\end{array}$ & $\begin{array}{c}\text { ST } \\
\text { K9 }\end{array}$ & $\begin{array}{c}\text { ST } \\
\text { L8 }\end{array}$ \\
\hline $0-10$ & & & & FCR \\
\hline $10-20$ & IF & & & \\
\hline $20-30$ & & FCR & IF & Clay \\
\hline $30-40$ & & FCR & & \\
\hline $40-50$ & EF & Clay & & \\
\hline $50-60$ & & & & \\
\hline $60-70$ & & & Clay & \\
\hline $70-80$ & Sand & & & \\
\hline $80-90$ & & & & \\
\hline \multicolumn{6}{|c|}{ Key: EF-exterior flake; IF-interior flake; } \\
FCR-fire-cracked rock >1 inch \\
\hline
\end{tabular}


amidst tall grasses and bull nettles on its eastern half. Surface visibility in August 2005 was less than ten percent. A bulldozed firebreak road has been put through the western portion of the site, and dozer tracks and push piles are common alongside the road. Other disturbances include a

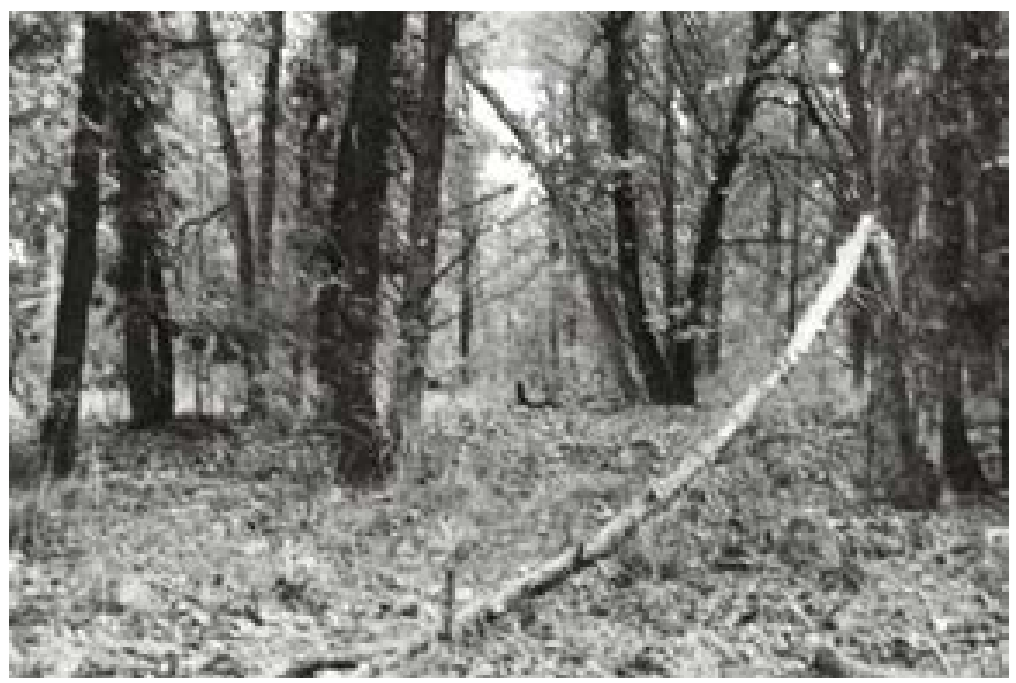

Figure 7-109. 41BP758 is a large open campsite on an upland ridge and sideslope; facing southeast.

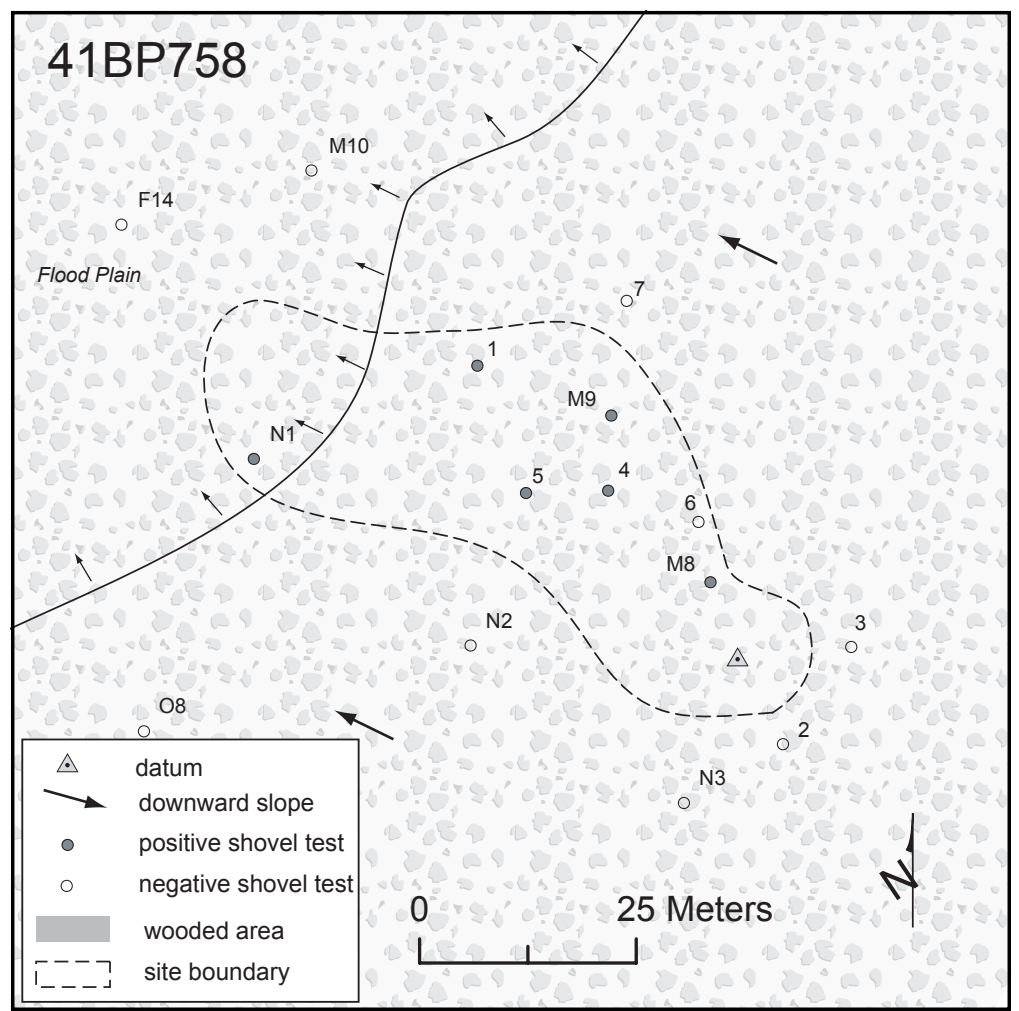

Figure 7-110. Site map of 41BP758. few tree falls. The site datum is marked with a nail and aluminum tag on an oak tree on west side of the firebreak road.

\section{Levels of Work and Results}

Four of the six shovel tests excavated on the site produced three fire-cracked rocks and three interior flakes (Table 752). The average sand depth across the site is slightly over 52 cmbs. Roots were common disturbances observed in almost all shovel tests dug on and around the site. No artifacts were observed on the surface.

\section{Conclusions/ Recommendations}

The disturbances caused by both machine and nature, the generally shallow soils, and the ephemeral distribution of cultural material degrade the overall significance of this site, and indicate that the potential for intact features and associated artifacts is limited. Therefore, CAS recommends that no further work is necessary and the site is not eligible for nomination to the NRHP.

\section{BP758}

\section{Description}

Shallow Demona loamy fine sand $(\mathrm{DeC})$ covers the sideslope where this open campsite is located (Figures 7-109 and 7-110). Its northern edge slopes steeply into the floodplain of a first order tributary of McLaughlin Creek, 
Table 7-53. 41BP758 positive shovel test results.

\begin{tabular}{|c|c|c|c|c|c|c|}
\hline $\begin{array}{c}\text { Depth } \\
\text { (cmbs) }\end{array}$ & ST 1 & ST 4 & ST 5 & ST M8 & ST M9 & ST N1 \\
\hline $0-10$ & $\begin{array}{c}\text { EF, } \\
\text { IF }\end{array}$ & EF & & FCR & & \\
\hline $10-20$ & $\begin{array}{c}\text { EF, } \\
\text { IF }\end{array}$ & & IF & & EF & \\
\hline $20-30$ & Clay & Clay & Clay & Clay & & \\
\hline $30-40$ & & & & & Clay & FCR \\
\hline $40-50$ & & & & & & \\
\hline $50-60$ & & & & & & \\
\hline $60-70$ & & & & & & \\
\hline $70-80$ & & & & & & Clay \\
\hline $80-90$ & \multicolumn{7}{|c|}{ Key: EF-exterior flake; IF-interior flake; } \\
\hline \multicolumn{7}{|c|}{ FCR-fire-cracked rock >1 inch } \\
\hline
\end{tabular}

while its southern edge slopes upward from 445 to $468 \mathrm{ft}$ amsl. The shape of this $1,735-\mathrm{m}^{2}$ site, roughly perpendicular to the creek, suggests that slope erosion has elongated its boundary. The entire slope is heavily wooded with oaks, cedars, and beautyberries. Numerous tree falls and small rills have made for an uneven surface throughout the site, and clay is exposed in some areas. The site datum is marked with a nail and an aluminum tag on an oak tree in the upper, southern portion of the site.

\section{Levels of Work and Results}

Seven shovel tests were placed on the site, of which six were positive. However, the average depth of the underlying $\mathrm{Bt}$ horizon encountered from shovel tests was less than 25 cmbs, and as a result most artifacts were also shallowly buried (Table 7-53). Colluvial gravels and roots were common in nearly all shovel tests. Gravels and cobbles were observed on the surface, but no artifacts.

\section{Conclusions/Recommendations}

Field observations and shovel tests results indicate that erosion has negatively impacted this site beyond any potential research value. Therefore, CAS recommends that no further work be conducted and the site is not eligible for nomination to the NRHP.

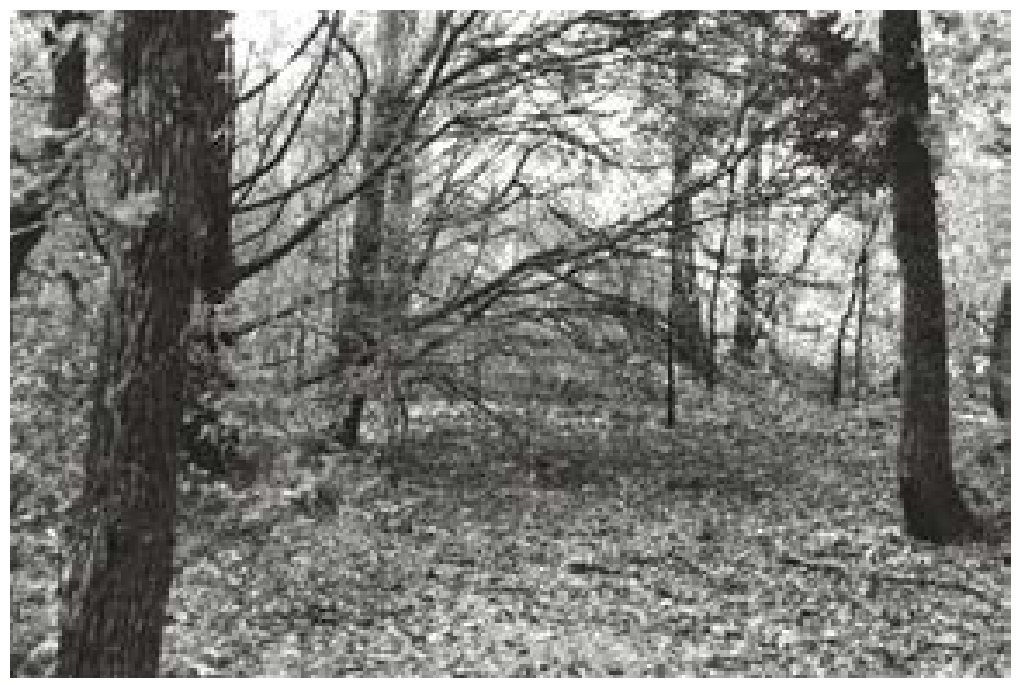

Figure 7-111. 41BP759 is an open campsite on an upland ridge and sideslope; facing southeast.

\section{BP759}

\section{Description}

As with 41BP758, the boundary of open campsite 41BP759 (Figures 7-111 and 7112) has likely been elongated due to slope erosion. It now spans slightly over $4,000 \mathrm{~m}^{2}$ of a semiwooded ridge and sideslope, ranges in elevation from 450 to $475 \mathrm{ft}$ amsl, and its northern boundary ends at the edge of an intermittent drainage floodplain. The drainage confluences with McLaughlin Creek $260 \mathrm{~m}$ to the southwest.Largeoaks and cedars, 


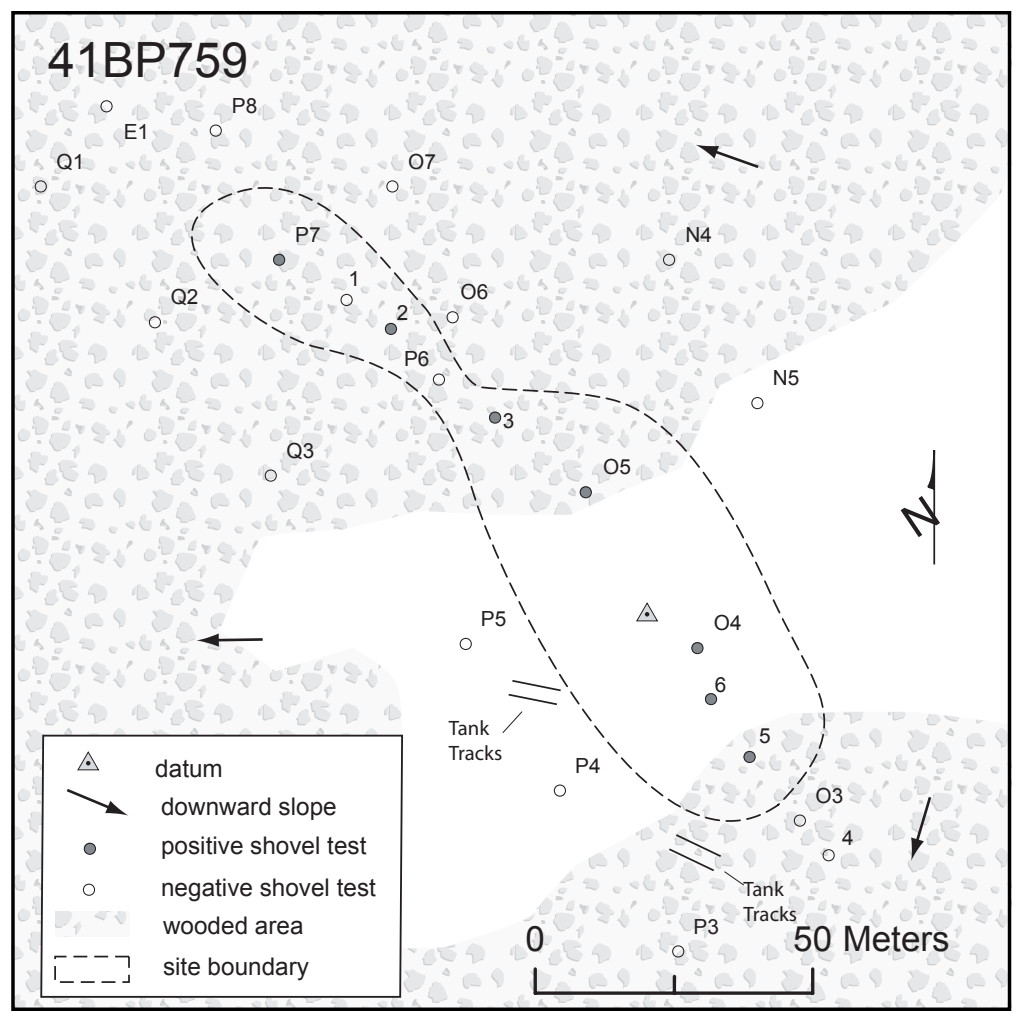

Figure 7-112. Site map of 41BP759.

Table 7-54. 41BP759 positive shovel test results.

\begin{tabular}{|c|c|c|c|c|c|c|c|}
\hline $\begin{array}{c}\text { Depth } \\
\text { (cmbs) }\end{array}$ & $\begin{array}{c}\text { ST } \\
\mathbf{2}\end{array}$ & $\begin{array}{c}\text { ST } \\
\mathbf{3}\end{array}$ & $\begin{array}{c}\text { ST } \\
\mathbf{5}\end{array}$ & $\begin{array}{c}\text { ST } \\
\mathbf{6}\end{array}$ & $\begin{array}{c}\text { ST } \\
\text { O4 }\end{array}$ & $\begin{array}{c}\text { ST } \\
\text { O5 }\end{array}$ & $\begin{array}{c}\text { ST } \\
\text { P7 }\end{array}$ \\
\hline $0-10$ & & & & & & & EF \\
\hline $10-20$ & EF & & & IF & & & \\
\hline $20-30$ & Clay & IF & & IF & & FCR & \\
\hline $30-40$ & & & & & & & Clay \\
\hline $40-50$ & & Clay & & & & & \\
\hline $50-60$ & & & IF & & & & \\
\hline $60-70$ & & & EF & & IF & FCR & \\
\hline $70-80$ & & & & Sand & FCR & Clay & \\
\hline $80-90$ & & & Sand & & & & \\
\hline $90-100$ & & & & & Sand & & \\
\hline $100-110$ & & & & & & & \\
\hline Key: & & & & & & \\
\hline
\end{tabular}

Key: EF-exterior flake; IF-interior flake; FCR-fire-cracked rock $>1$ inch

bull nettles, and dense grasses and weeds cover the area. Demona loamy fine sand $(\mathrm{DeC})$ covers the ridge and sideslope, with Sayers fine sandy loam (Sa) in the floodplain. Surface visibility in August 2005 was less than five percent, but obvious surface disturbances include a shallow 
firebreak trench, heavy machinery tracks, and tree falls.

\section{Levels of Work and Results}

As shown in Table 7-54 (compare to Figure 7-112), the sands are much deeper on the upper, ridge portion of the site, while the underlying Bt horizon was encountered at shallower depths on the sideslope. Firecracked rocks and flakes were found deeply buried on the ridge. As would be expected, colluvial gravels were common in nearly all shovel tests on the sideslope, but not on the ridge. A total of eight flakes and three firecracked rocks were recovered from seven of nine shovel tests excavated on the site. No artifacts were observed on the surface.

\section{Conclusions/ \\ Recommendations}

The results of shovel tests indicate that slope erosion has likely affected the integrity of this site, but the extent of disturbance is unknown. While evidence of colluvium was found on the sideslope, no disturbance could be discerned on the more level ridge. Without additional testing, the known data suggests that there is a potential for deeply buried and intact firecracked rock features and associated cultural material to still exist on the ridge, specifically in the areas of STs O4, O5, and 5. CAS recommends excavation of three 1-x-1-m units, one each in the immediate areas of those three shovel tests to determine NRHP eligibility.

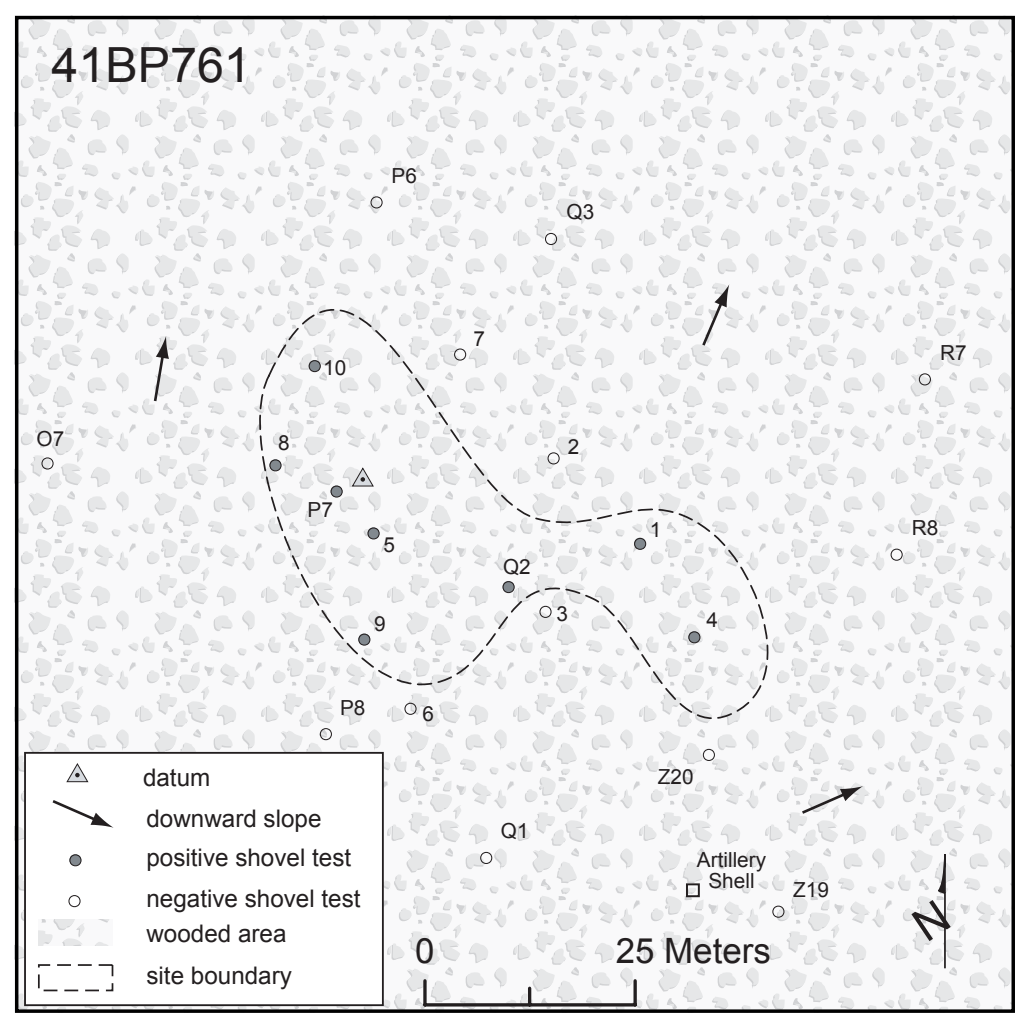

Figure 7-114. Site map of 41BP761.

Figure 7-113. 41BP761 is an open campsite on a wooded footslope; facing east.

41BP761

\section{Description}

This open campsite is situated on a wooded footslope $30 \mathrm{~m}$ west of a first order tributary of McLaughlin Creek (Figures 7-113 and 7-114). 
Table 7-55. 41BP761 positive shovel test results.

\begin{tabular}{|c|c|c|c|c|c|c|c|c|}
\hline $\begin{array}{l}\text { Depth } \\
\text { (cmbs) }\end{array}$ & ST 1 & ST 4 & ST 5 & ST 8 & ST 9 & ST 10 & ST P7 & ST Q2 \\
\hline $0-10$ & & & C, 2 FCR, fcr & & $\mathrm{B}, \mathrm{FCR}$ & & IF, FCR & \\
\hline $10-20$ & & & IF & FCR & Clay & & $\mathrm{CC}$ & \\
\hline $20-30$ & & IF & & & & FCR & $\mathrm{CC}, 3 \mathrm{IF}, \mathrm{fcr}$ & \\
\hline $30-40$ & IF & & & Clay & & $\mathrm{EF}$ & $\mathrm{EF}, 3 \mathrm{IF}$ & \\
\hline $40-50$ & FCR & Clay & IF & & & FCR & $2 \mathrm{IF}$ & FCR \\
\hline $50-60$ & IF & & & & & FCR & & fcr \\
\hline $60-70$ & & & & & & Clay & fcr & \\
\hline $70-80$ & Sand & & Sand & & & & & Sand \\
\hline $80-90$ & & & & & & & Sand & \\
\hline $90-100$ & & & & & & & & \\
\hline & Key: CC & $\begin{array}{l}\mathrm{rt} \mathrm{ch} \\
6 \mathrm{re}\end{array}$ & $\begin{array}{l}\text { F-exterior fla } \\
\text { ed rock }>1 \text { inc }\end{array}$ & $\begin{array}{l}\text {; IF-1 } \\
\text { fcr-1 }\end{array}$ & $\begin{array}{l}\text { or flake; } \\
\text { racked r }\end{array}$ & $\begin{array}{l}\text {-core; } \\
\text { ck }<1 \text { in }\end{array}$ & -biface; & \\
\hline
\end{tabular}

The slope at the site equates to elevations ranging from 450 to $461 \mathrm{ft}$ amsl. Because of the dense growth of oaks, cedars, and beautyberries, leaf litter has degraded surface visibility to less than five percent. The only obvious disturbances have been caused by a few tree falls and animal burrows. Soils consist of Axtell fine sandy loam (AfC2). The shape of the $1,559-\mathrm{m}^{2}$ campsite follows the natural contours paralleling the nearby drainage. The site datum is marked with a nail and an aluminum tag on a large oak tree.

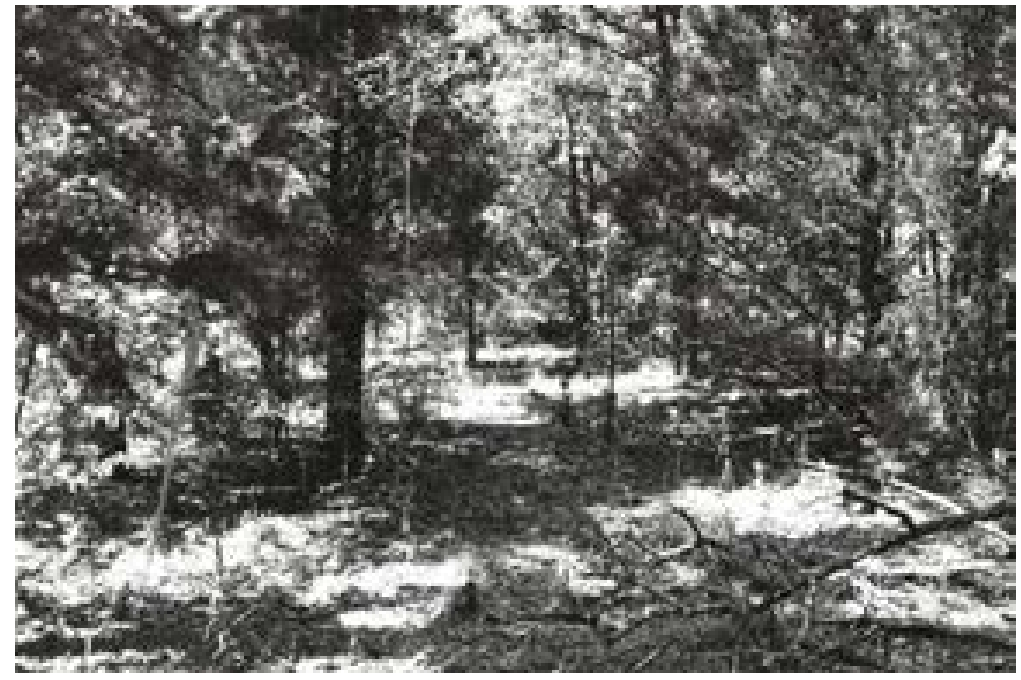

Figure 7-115. 41BP762 is an open campsite on a wooded sideslope; facing southwest.

\section{Levels of Work and Results}

Likely due to the dense vegetation, CAS archaeologists observed no artifacts on the surface. However, buried artifacts were recovered from each of the eight shovel tests excavated within the boundaries of the site (Table 7-55). In positive shovel tests, one large biface, one core, 15 flakes, one chert chip, and 14 pieces of fire-cracked were recovered. Roots were commonly encountered in this wooded environment, and angular sandstone and ironstones implying colluvial deposition were noted in STs 3, 4, and 10.

\section{Conclusions/Recommendations}

The detection of probable colluvial deposition in three shovel tests and the presence of roots present the issue of integrity. The results of shovel tests indicate that slope erosion has likely affected the overall integrity of this site. However, 


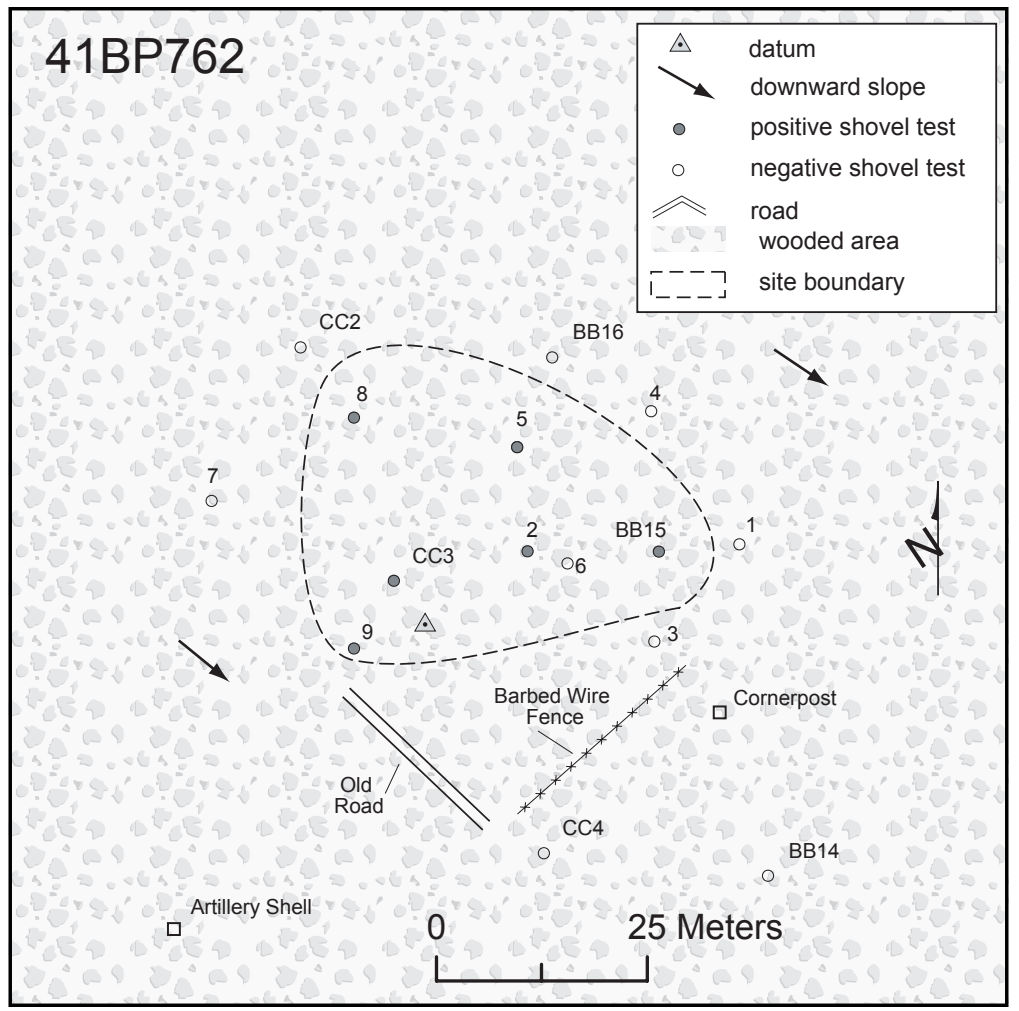

Figure 7-116. Site map of 41BP762.
P7. CAS recommends excavation of two 1-x-1-m units, one each in the immediate area of those two shovel tests to determine NRHP eligibility.

\section{BP762}

\section{Description}

41BP762 is on a wooded sideslope, between 468 and $473 \mathrm{ft}$ amsl, with Axtell fine sandy loam (AfC), and $100 \mathrm{~m}$ west of a first order tributary of McLaughlin Creek (Figures 7115 and 7-116). Leaf litter and a moderately dense stand of oaks, cedars, and beautyberries, with brush and shrub understory obscure the surface visibility to less than five percent. A barbed wire fence has been constructed

the density of artifacts in certain shovel tests where little or no disturbances were noted suggests that certain areas of this site may still be intact. Specifically, STs 10 and $\mathrm{P} 7$ contained concentrations of fire-cracked rocks and lithic debitage. Without additional testing the extent of disturbance is unknown, and CAS has to presume that the potential for deeply buried and intact firecracked rock features and associated cultural material still exist in the areas of STs 10 and

Table 7-56. 41BP762 positive shovel test results.

\begin{tabular}{|c|c|c|c|c|c|c|}
\hline $\begin{array}{c}\text { Depth } \\
\text { (cmbs) }\end{array}$ & ST 2 & ST 5 & ST 8 & ST 9 & $\begin{array}{c}\text { ST } \\
\text { BB15 }\end{array}$ & $\begin{array}{c}\text { ST } \\
\text { CC3 }\end{array}$ \\
\hline $0-10$ & & & & & IF & \\
\hline $10-20$ & & IF & & & & \\
\hline $20-30$ & & & & & & \\
\hline $30-40$ & FCR & EF & FCR & & & \\
\hline $40-50$ & FCR & EF & & & & 2 IF \\
\hline $50-60$ & & & & & Clay & FCR \\
\hline $60-70$ & & & & 3 fcr & & \\
\hline $70-80$ & Sand & Sand & Sand & Clay & & Sand \\
\hline $80-90$ & & & & & & \\
\hline \multicolumn{7}{|c|}{ Key: EF-exterior flake; IF-interior flake; } \\
FCR-fire-cracked rock >1 inch; fcr-fire-cracked rock $<1$ inch \\
\hline
\end{tabular}


next to the 3-m high cutbank that runs along the southern edge of the site, and the remnants of an old road can be seen near its western end. Other obvious surface disturbances are a few tree falls and animal burrows. As with 41BP761, the shape of this $1,345-\mathrm{m}^{2}$ campsite follows the natural

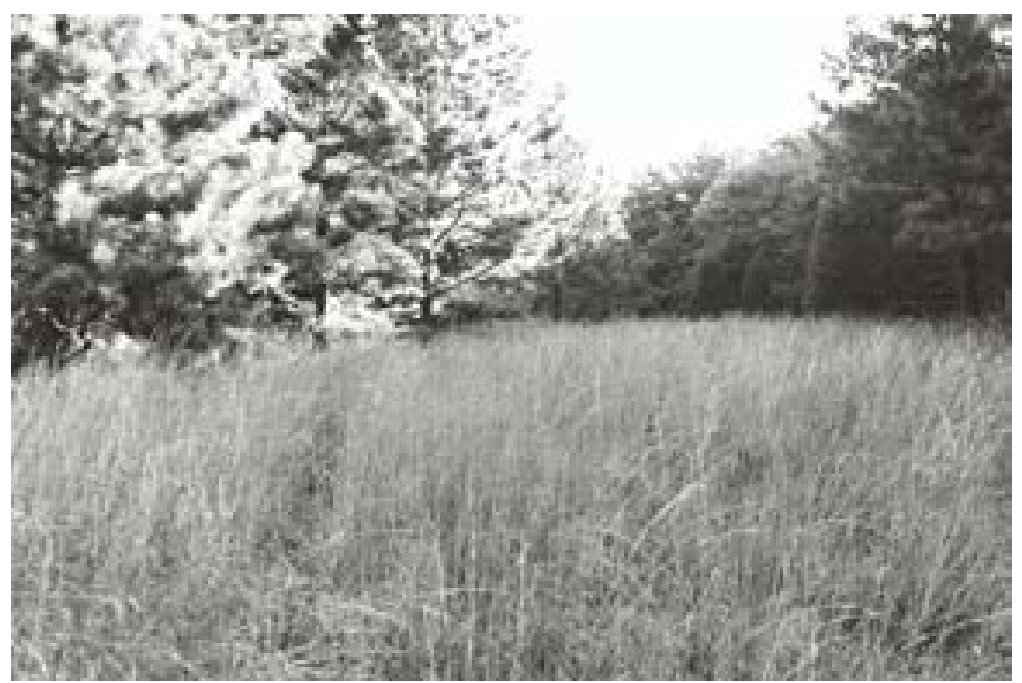

Figure 7-117. 41BP763 is an open campsite on a wooded sideslope; facing northeast.

FIGURE 7-118. REDACTED

Figure 7-118. Site map of 41BP763. contours paralleling the nearby drainage. The site datum is marked with a nail and an aluminum tag on a large oak tree.

\section{Levels of Work and Results}

No artifacts were found on the surface, but seven firecracked rocks and six flakes were recovered from six of seven shovel tests excavated on the site (Table 7-56). Roots were commonly encountered in this wooded environment. In addition, angular sandstone and ironstones, in most cases in a continuum with increasing depths, were noted in all of the shovel tests, suggesting that the 10-degree slope across the site's modern surface is indicative of past landscape evolution.

\section{Conclusions/ Recommendations}

As revealed from shovel tests, colluvial deposition has been the major contributor to the present provenience of the artifacts discovered. Therefore, the site's overall potential to yield credible information is minimal, CAS recommends that no further work be conducted, and the site is not eligible for nomination to the NRHP.

\section{BP763}

\section{Description}

41BP763 (Figures 7-117 and 7-118) is a prehistoric open campsite covering approximately 2,204 $\mathrm{m}^{2}$ of a wooded sideslope. 
Table 7-57. 41BP763 positive shovel test results.

\begin{tabular}{|c|c|c|c|c|c|}
\hline $\begin{array}{c}\text { Depth } \\
(\mathbf{c m b s})\end{array}$ & ST 6 & ST 7 & ST 8 & ST V14 & ST W3 \\
\hline $0-10$ & & & & & FCR \\
\hline $10-20$ & & FCR & & IF & \\
\hline $20-30$ & & Bedrock & fcr & & \\
\hline $30-40$ & IF & & 2 FCR & & \\
\hline $40-50$ & & & & & \\
\hline $50-60$ & & & & & Clay \\
\hline $60-70$ & IF & & Clay & & \\
\hline $70-80$ & & & & Clay & \\
\hline $80-90$ & Sand & & & & \\
\hline $90-100$ & \multicolumn{7}{|c|}{ Key: IF-interior flake; } \\
\hline \multicolumn{7}{|c|}{ FCR-fire-cracked rock >1 inch; fcr-fire-cracked rock $<1$ inch } \\
\hline
\end{tabular}

Because it slopes from 471 to 458 feet in elevation, eroded gullies are present on its western edge, where it borders an intermittent drainage to McLaughlin Creek. Other obvious disturbances have been caused by treefalls and rodent burrows. Demona fine sandy loam supports the growth of pines, cedars, oaks, and beautyberries. Surface visibility in the non-eroded areas is less than five percent. The datum is marked with a nail and aluminum tag in a large oak tree on the upper portion of the site.

\section{Levels of Work and Results}

A loose scatter of firecracked rock was observed on an eroded gully surface along the western edge of the site (see Figure 7-118). In total, three flakes and five pieces of fire-cracked rock were recovered from five of nine shovel tests excavated within the boundaries of the site (Table 7-57). Disturbances observed in shovel tests included angular ironstones (colluvial deposition) in three of the five positive shovel tests; roots were encountered in all shovel tests.

\section{Conclusions/ Recommendations}

Both surface observations and shovel test results indicate that this site has been negatively impacted by erosion and root growth. CAS recommends that no further work be conducted and the site is not eligible for nomination to the NRHP.

\section{BP764}

\section{Description}

41BP764 is an ephemeral lithic scatter spread across approximately 1,056 $\mathrm{m}^{2}$ (Figures 7-119 and 7-120). It is located on a footslope, with the floodplain of McLaughlin Creek approximately $25 \mathrm{~m}$ to the north. The slope at the site is toward the north from 448 to $442 \mathrm{ft}$ amsl. The site surface is mostly covered with tall grasses surrounded by oaks, cedars, elms, and chinaberries, which impeded surface visibility to about five percent in

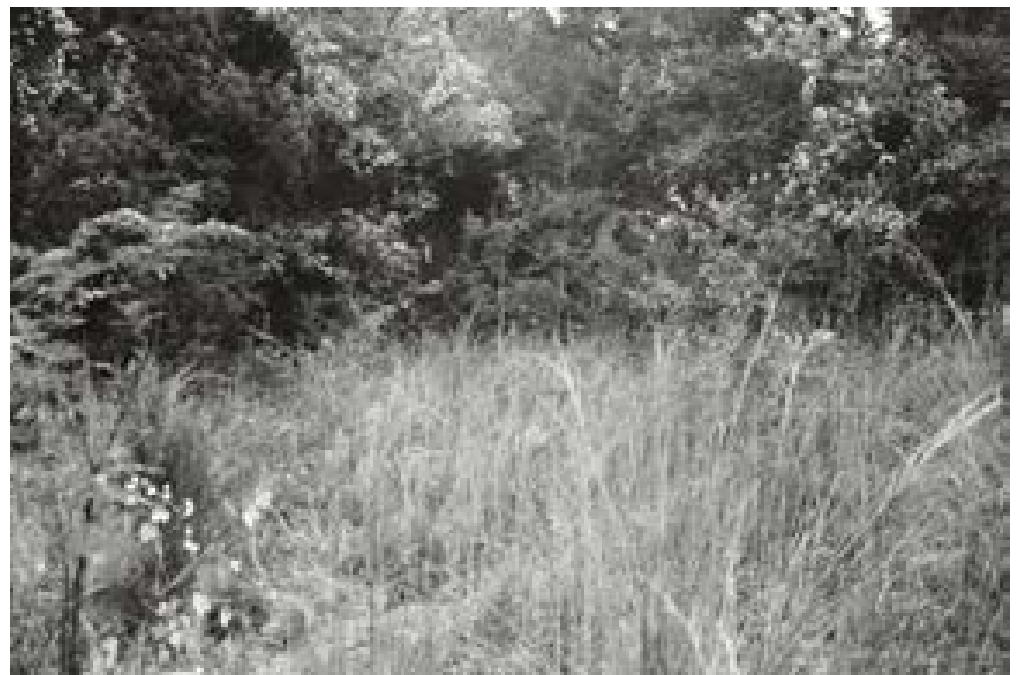

Figure 7-119. 41BP764 is an ephemeral lithic scatter just south of McLaughlin Creek; facing northeast. 


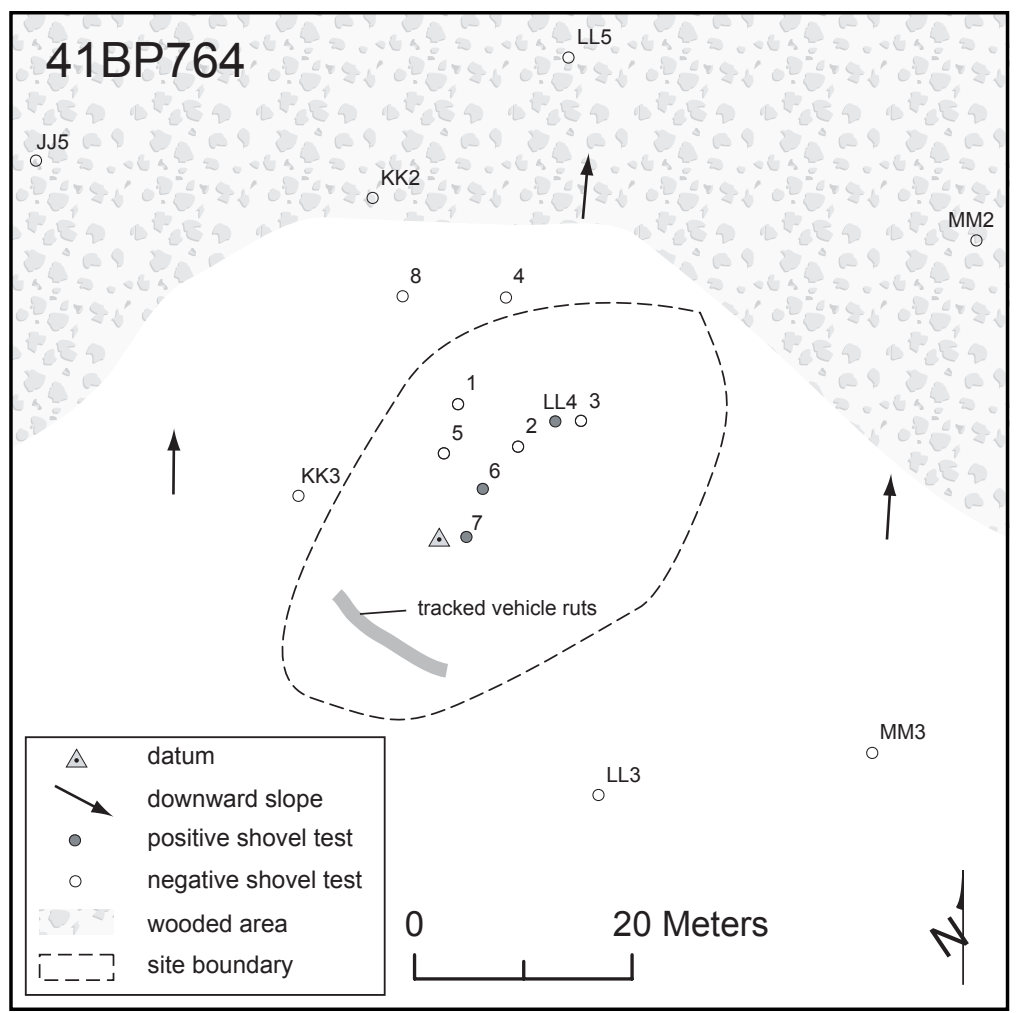

Figure 7-120. Site map of 41BP764.

Table 7-58. 41BP764 positive shovel test results.

\begin{tabular}{|c|c|c|c|}
\hline $\begin{array}{c}\text { Depth } \\
\text { (cmbs) }\end{array}$ & ST 6 & ST 7 & ST LL4 \\
\hline $0-10$ & & & \\
\hline $10-20$ & & & \\
\hline $20-30$ & & & \\
\hline $30-40$ & & & IF \\
\hline $40-50$ & IF & & \\
\hline $50-60$ & & EF & \\
\hline $60-70$ & & & \\
\hline $70-80$ & Sand & Sand & Sand \\
\hline $80-90$ & & & \\
\hline \multicolumn{4}{|l|}{ Key: EF-exterior flake; IF-interior flake } \\
\hline
\end{tabular}


August 2005. Soils on the slope are Sayers fine sandy loam (Sa). The only obvious surface disturbances observed were track vehicle ruts on the southern edge of the site. The site datum is marked with a nail and an aluminum tag in an oak tree 18 $\mathrm{cm}$ in diameter between STs 6 and 7.

\section{Levels of Work and Results}

The site was discovered when an interior flake was found in Transect ST LL4. Three of the seven shovel tests excavated on the site were positive. ST 6 , ST 7, and Transect ST LL4 each contained one flake (Table 7-58). Although the soils here averaged $66 \mathrm{cmbs}$ deep, evidence of colluvium in the form of angular ironstones was found in four of the shovel tests. No artifacts were observed on the surface.

\section{Conclusions/ \\ Recommendations}

Although the flakes were recovered from a zone between 30 and $60 \mathrm{cmbs}$, and would suggest that the zone may be intact, the apparent colluvial deposition that has occurred at this site argues differently. In addition, the apparent absence of hearth features, stone tools, and/ or preserved organic cultural material minimizes its research potential. In sum, CAS recommends no further investigations be conducted and that the site is not eligible for nomination to the NRHP.

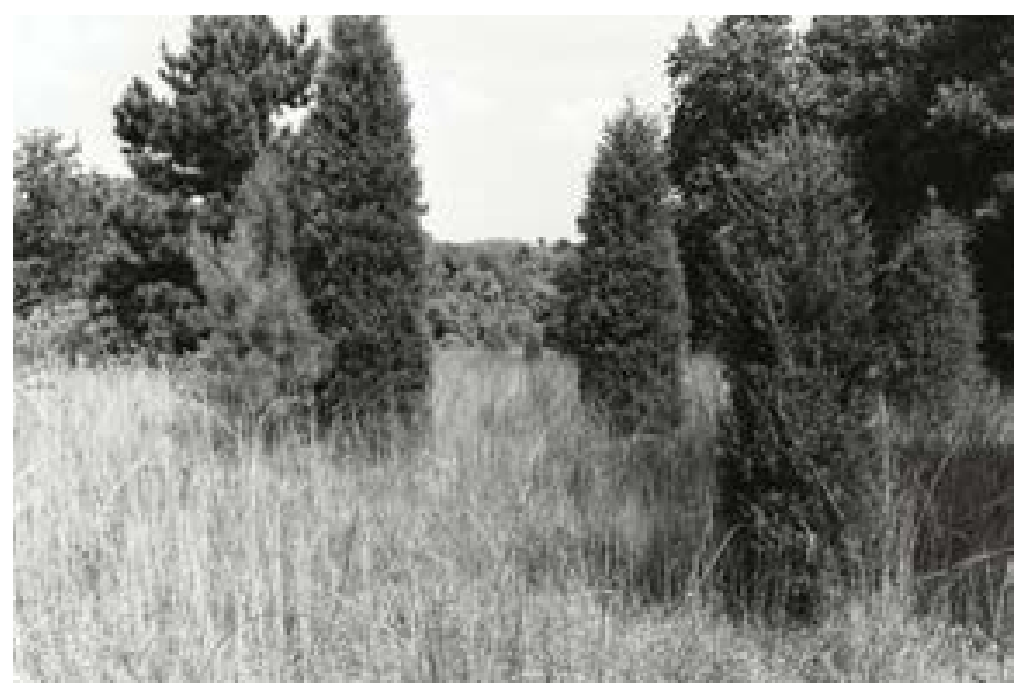

Figure 7-121. 41BP765 is a very large open campsite with at least one buried hearth; facing northwest.

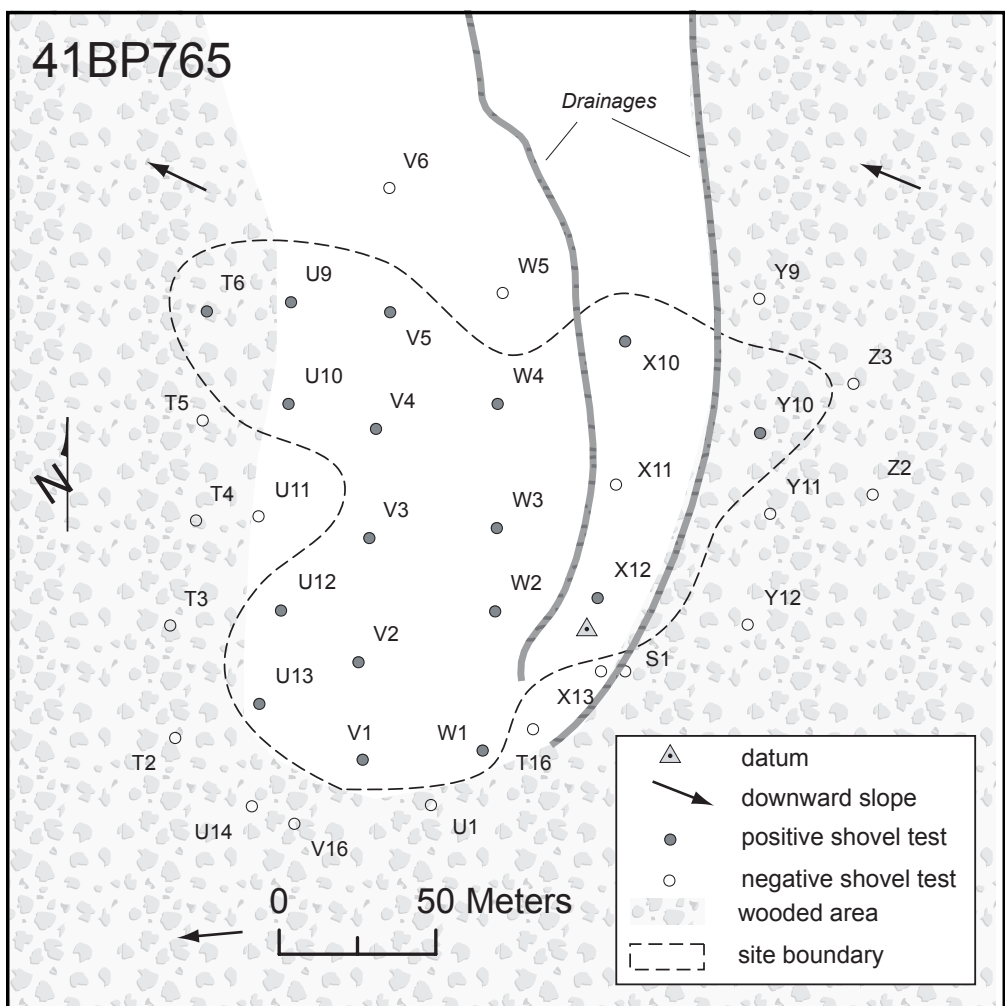

Figure 7-122. Site map of 41BP765.

\section{BP765}

\section{Description}

This site is a very large $\left(21,873-\mathrm{m}^{2}\right)$ open campsite (Figures 7-121 and 7-122) ranging in elevation from 435 to $470 \mathrm{ft}$ amsl on a sideslope. 


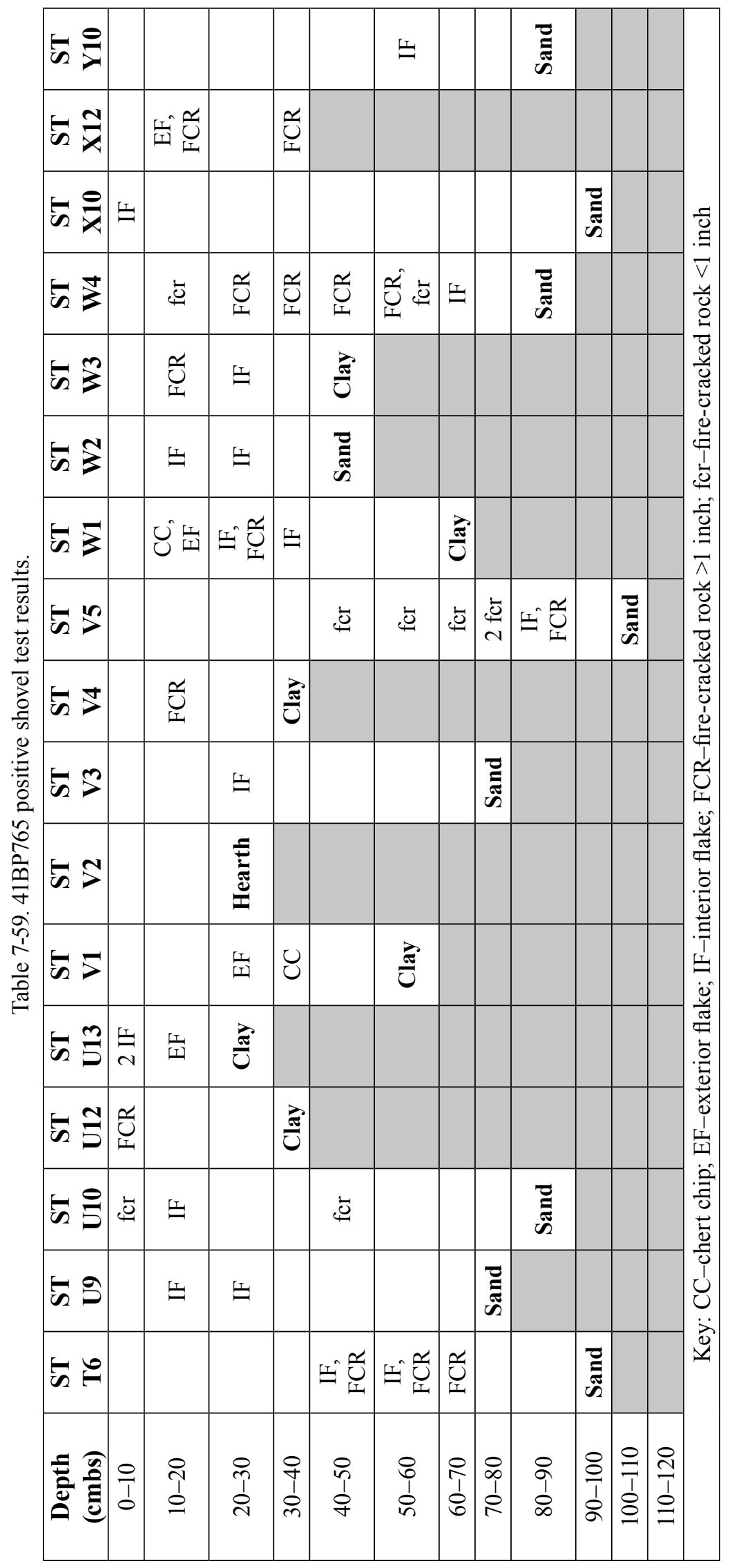

McLaughlin Creek lies $45 \mathrm{~m}$ to the northwest. Spanning both semi-wooded and open field areas, scrub brush, oaks, pines, cedars, mesquites, sumacs, beautyberries, bull nettles, grasses, and weeds are all present on the site. Small drainages have incised the site, and much of the open field area is hummocky, suggesting it has either been plowed orotherwisedisturbed by heavy machinery. Demona loamy fine sand (DeC) covers the upper half of the slope, with Axtell fine sandy loam (AfC2) on the lower portion. The site datum is marked with a nail and an aluminum tag on a large oak tree near ST X12.

\section{Levels of Work and Results}

No artifacts were observed on the surface, but as shown in Table 7-59, 21 flakes, 23 fire-cracked rocks, and two chert chips were recovered from 17 of 18 shovel tests excavated on the site. Additionally, a hearth was encountered in transect ST V2. The excavation of shovel test ST V2 was halted when the hearthstones were encountered. Although there is a maximum of a 35$\mathrm{ft}$ slope across the site, it is also very large, diffusing significant disturbances caused by potential erosion 
and slopewash. The three small drainages shown on the site map were the only obvious surface disturbances, and no evidence of colluvium was readily detected from shovel tests. Roots in some of the wooded areas presented the only evidence for subsurface disturbance.

\section{Conclusions/ \\ Recommendations}

Despite the obviously eroded small drainage areas, the results of shovel tests indicate there are quite likely intact areas on this site. The large quantities of often deeply buried fire-cracked rocks and associated flakes suggest there may be more than one possibly intact hearth that exists at this site, and thus its research potential is unknown. CAS recommends that additional testing be conducted to further assess its research potential. At a minimum to determine NRHP eligibility, CAS recommends that a hand-excavated unit be placed at ST V2 to expose the hearth feature encountered there. CAS further recommends the excavation of three 1-x-1-m units, one in each of the immediate areas of STs T6, V5, and W4.

\section{BP766}

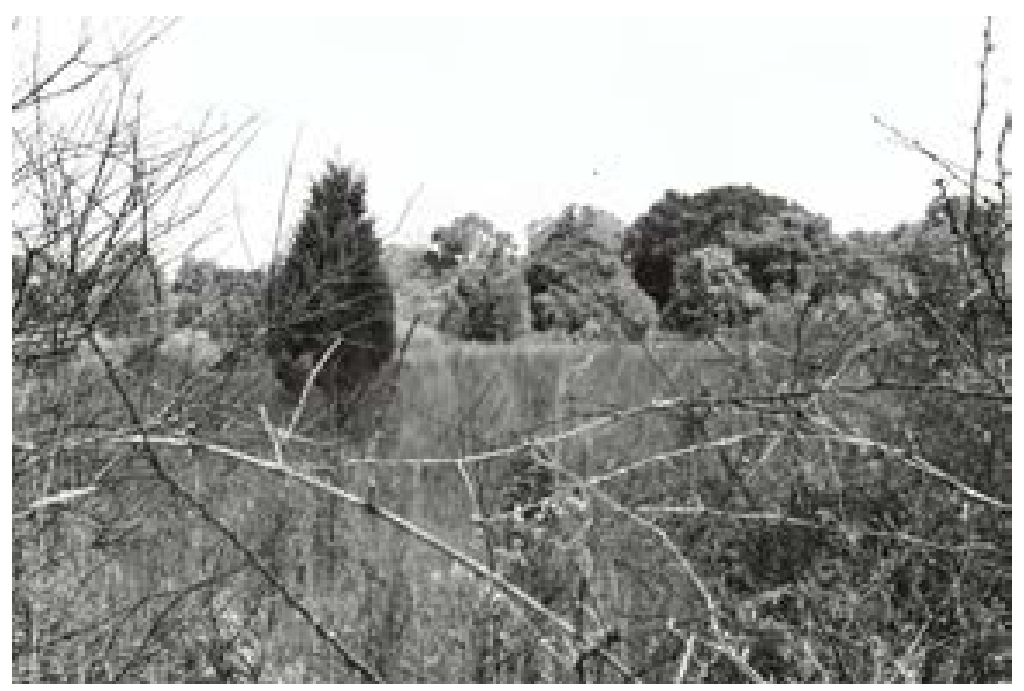

Figure 7-123. 41BP766 is a very large open campsite with two scattered surface hearths and possibly buried, intact hearths; facing north.

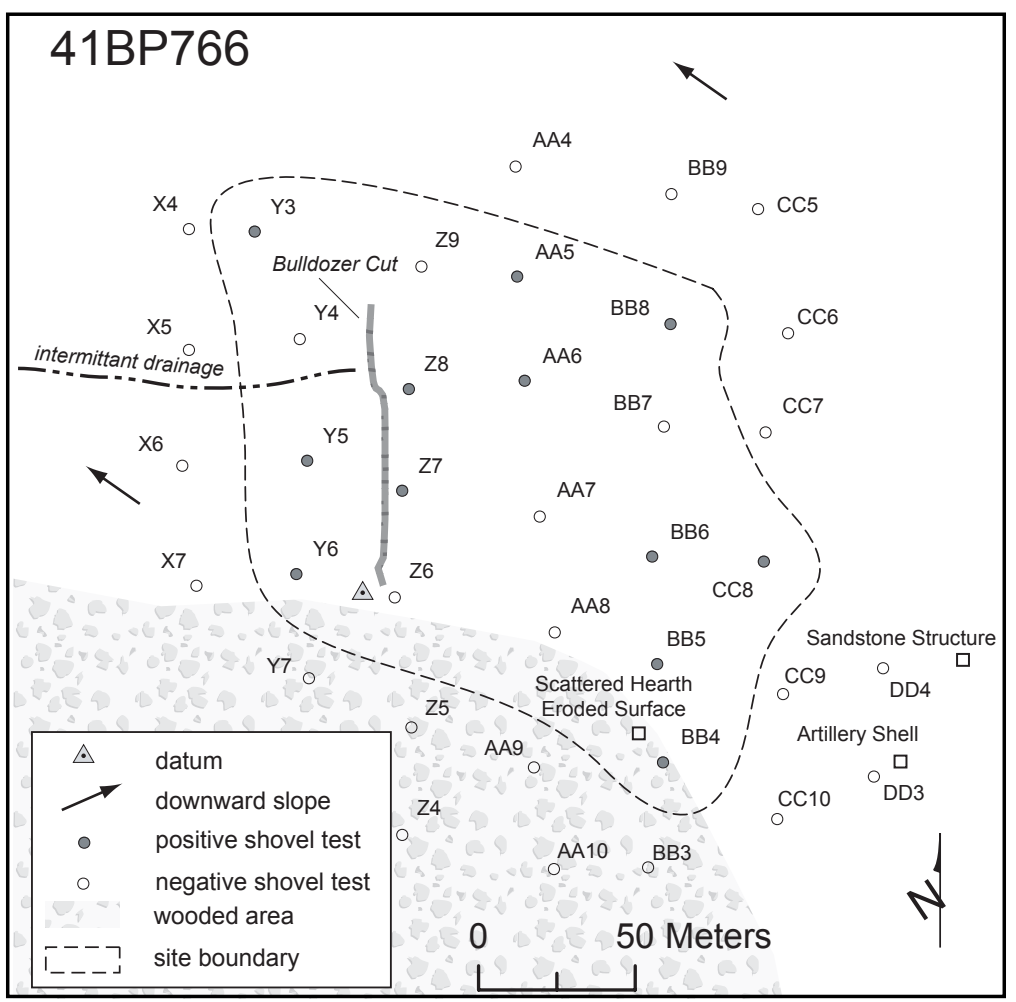

Figure 7-124. Site map of 41BP766.

\section{Description}

As with 41BP765, this open campsite is very large; scattered surface artifacts and positive shovel tests were located over approximately 25,820 $\mathrm{m}^{2}$ (Figures 7-123 and 7-124). It lies in

and on a footslope of Demona loamy fine sand (DeC) sloping some 29 feet from 466 to $437 \mathrm{ft}$ amsl. Its lower portion is situated $30 \mathrm{~m}$ from the floodplain of McLaughlin Creek, near its confluence with one of its larger tributaries. Soils 
Table 7-60. 41BP766 positive shovel test results.

\begin{tabular}{|c|c|c|c|c|c|c|c|c|c|c|c|c|}
\hline $\begin{array}{l}\text { Depth } \\
\text { (cmbs) }\end{array}$ & $\begin{array}{l}\text { ST } \\
\text { Y3 }\end{array}$ & $\begin{array}{l}\text { ST } \\
\text { Y5 }\end{array}$ & $\begin{array}{l}\text { ST } \\
\text { Y6 }\end{array}$ & $\begin{array}{l}\text { ST } \\
\text { Z7 }\end{array}$ & $\begin{array}{l}\text { ST } \\
\text { Z8 }\end{array}$ & $\begin{array}{c}\text { ST } \\
\text { AA5 }\end{array}$ & $\begin{array}{c}\text { ST } \\
\text { AA6 }\end{array}$ & $\begin{array}{c}\text { ST } \\
\text { BB4 }\end{array}$ & $\begin{array}{c}\text { ST } \\
\text { BB5 }\end{array}$ & $\begin{array}{c}\text { ST } \\
\text { BB6 }\end{array}$ & $\begin{array}{c}\text { ST } \\
\text { BB8 }\end{array}$ & $\begin{array}{c}\text { ST } \\
\text { CC8 }\end{array}$ \\
\hline $0-10$ & & & $\begin{array}{l}\text { IF, } \\
\text { M }\end{array}$ & & & & IF & $\begin{array}{c}3 \mathrm{FCR}, \\
\text { fcr }\end{array}$ & & IF & & \\
\hline $10-20$ & & & & fcr & & & IF & Clay & IF & & & $\mathrm{EF}$ \\
\hline $20-30$ & & & & & & & & & & & & \\
\hline $30-40$ & & & & & FCR & & fcr & & & & & Clay \\
\hline $40-50$ & & & & & & fcr & & & & Clay & & \\
\hline $50-60$ & IF & & $3 \mathrm{IF}$ & & & fcr & Clay & & Clay & & $\mathrm{U}$ & \\
\hline $60-70$ & & IF & IF & Clay & Clay & $\begin{array}{c}\mathrm{H}, \\
\text { FCR, } \\
\text { fcr }\end{array}$ & & & & & & \\
\hline $70-80$ & & $\begin{array}{c}\text { FCR, } \\
\text { O }\end{array}$ & & & & $2 \mathrm{IF}$ & & & & & Sand & \\
\hline $80-90$ & Sand & IF & & & & & & & & & & \\
\hline $90-100$ & & & Clay & & & Sand & & & & & & \\
\hline $100-110$ & & Sand & & & & & & & & & & \\
\hline $110-120$ & & & & & & & & & & & & \\
\hline
\end{tabular}

on its upper, extreme southeastern portion are generally shallow. Red clay is exposed in some areas, and mesquite and cacti are the predominant vegetation in the open areas. Soils on the lower, northern and western portions of the site nearer the creek are much deeper. In that area, there are dense grasses, scrub brush, and small cedar motts. For the most part, the area is either open or semi-wooded. Accordingly, surface visibility ranges from less than five percent on the lower portion to perhaps as high as 25 percent on the upper portion. In addition to selected eroded areas on its upper portion, surface disturbances noted include a small intermittant drainage and bulldozer cut on its northwestern edge, and an occasional animal burrow. The datum is marked with a nail and aluminum tag on a large oak tree on the southwestern edge of the site.

\section{Levels of Work and Results}

Scattered fire-cracked rocks from two hearths and a brownish grey chert quarry blank were observed on the upper, southern portion of the site. The bifacially worked quarry blank contained ten percent cortex on its dorsal face, and measured 13-x-8-x-3.5-cm. The burned rock consisted of three quartzite pieces and four sandstone pieces, all ranging in size from one to four inches. Out of 18 shovel tests placed on the site, 12 contained artifacts. Table 7-60 lists the artifacts recovered from the 12 positive shovel tests. In addition to 12 fire-cracked rocks and 15 flakes, three small pieces of red ocher were found in ST Y5, a quartzite hammerstone was found in ST AA5, and a finely worked, formally retouched unifacial tool was found in ST BB8. It was made from tan chert, with formal retouch on its right distal edge, and beveling on its left distal edge. Its proximal end had been snapped off. The only apparent colluvial deposits were noted in the form of angular ironstones, in ST BB4. Otherwise, the only other evidence for disturbance was a piece of metal shrapnel found in the upper $10 \mathrm{cmbs}$ of ST Y6. 


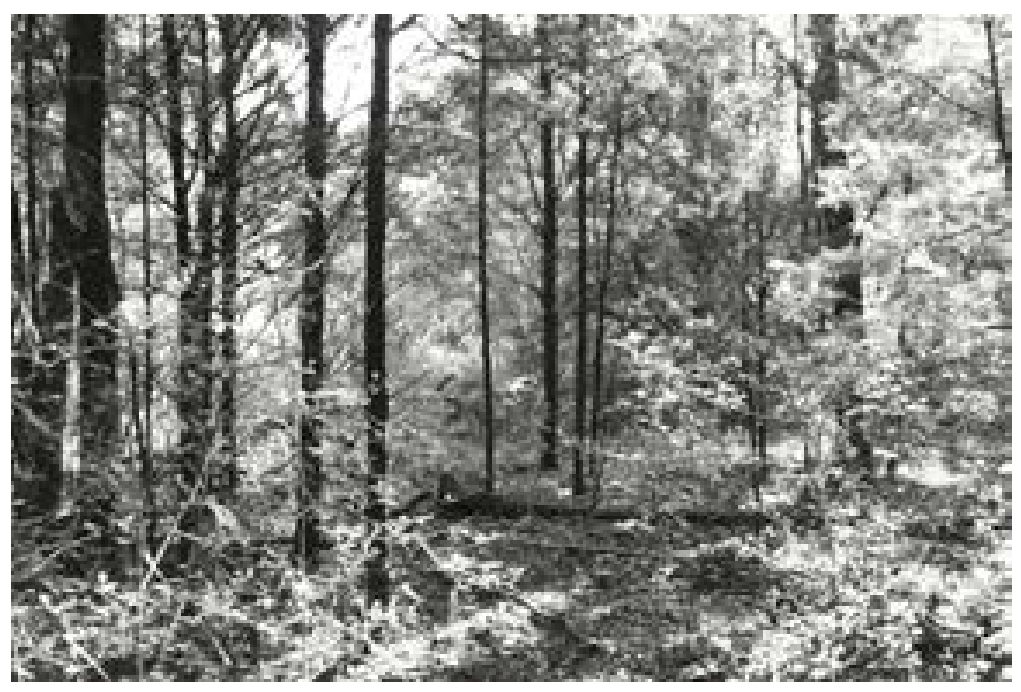

Figure 7-125. A sparse scatter of lithic debitage constitutes 41BP768; facing east.

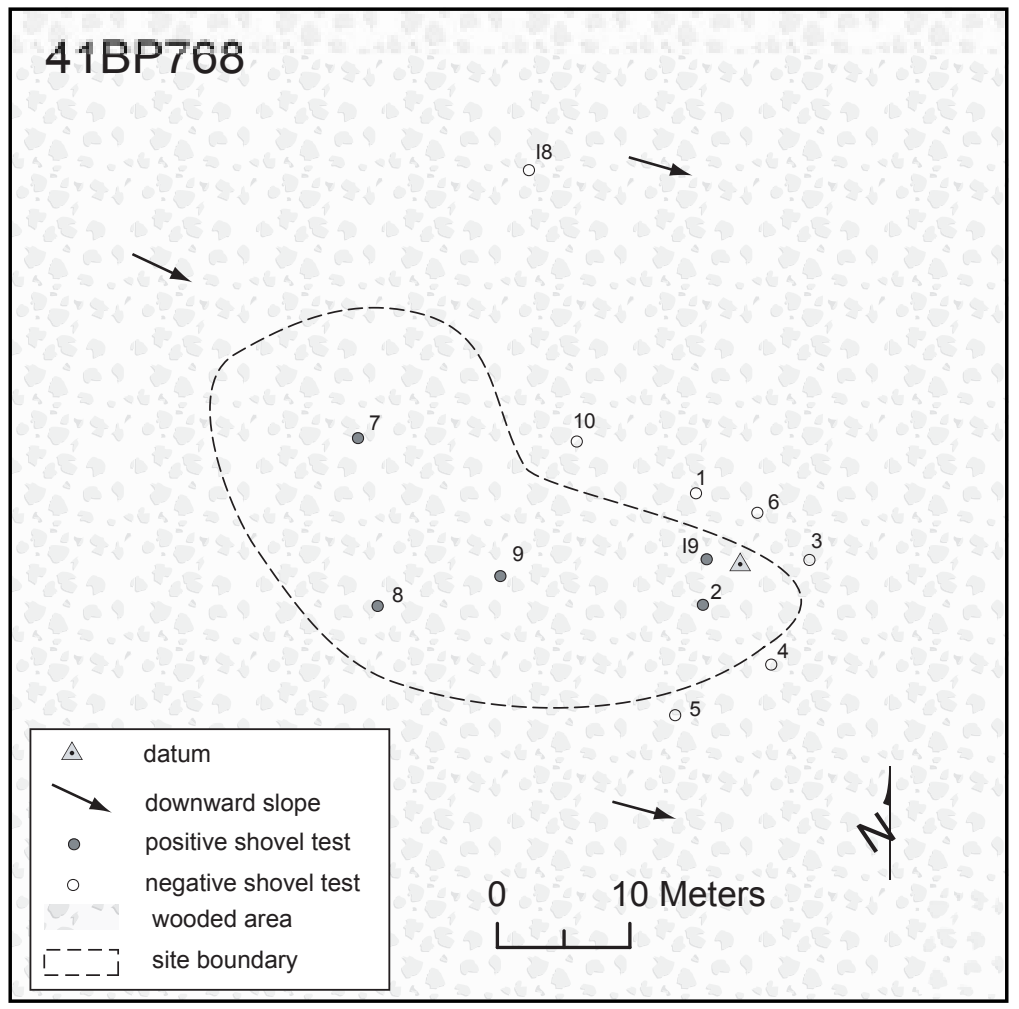

Figure 7-126. Site map of 41BP768.

\section{Conclusions/Recommendations}

With the exception of a small drainage and a bulldozed track, the majority of this site appears to be mostly undisturbed. The presence of buried fire-cracked rocks, stone tools, and ocher in stratigraphic association argues for the potential of intact cultural zones to exist below the surface, and there may be intact hearths. Without additional investigations, the research potential at 41BP766 is unknown. CAS recommends that additional testing be conducted to further assess its research potential. Because of its size, CAS recommends excavation of eight $1-\mathrm{x}-1-\mathrm{m}$ on the western and northern portions of this site: in a semi-circular line extending from the general area of ST Y6, in the immediate area of ST Y5, in the general area of ST Z8, in the immediate area of ST AA5, and in the general area of ST BB8.

\section{$41 B P 768$}

\section{Description}

A sparse scatter of lithic debitage spread over $906 \mathrm{~m}^{2}$ constitutes 41BP768 (Figures 7125 and 7-126). It is on a sideslope, $130 \mathrm{~m}$ west of an intermittent drainage of McLaughlin Creek. The site's surface slopes from 460 to $455 \mathrm{ft}$ amsl, west to east, and is covered with oak and cedar trees, beautyberries, milk weeds, and a few scattered grass clumps. Surface visibility during the August 2005 visit was about five percent. Based upon the number of uprooted trees and angular ironstones found from shovel tests, it appears that the site is heavily disturbed. CAS archaeologists drove a nail in an oak tree on the eastern edge of the site and placed an aluminum tag on it to serve as the site datum. 
Table 7-61. 41BP768 positive shovel test results.

\begin{tabular}{|c|c|c|c|c|c|}
\hline $\begin{array}{c}\text { Depth } \\
\text { (cmbs) }\end{array}$ & $\begin{array}{c}\text { ST } \\
\mathbf{2}\end{array}$ & $\begin{array}{c}\text { ST } \\
\mathbf{7}\end{array}$ & $\begin{array}{c}\text { ST } \\
\mathbf{8}\end{array}$ & $\begin{array}{c}\text { ST } \\
\mathbf{9}\end{array}$ & $\begin{array}{c}\text { ST } \\
\text { I9 }\end{array}$ \\
\hline $0-10$ & & & & & \\
\hline $10-20$ & & & & & \\
\hline $20-30$ & & & EF & IF & \\
\hline $30-40$ & & IF & & & \\
\hline $40-50$ & EF & & & IF & EF \\
\hline $50-60$ & & & & & \\
\hline $60-70$ & Clay & & & & Clay \\
\hline $70-80$ & & Sand & Sand & Sand & \\
\hline $80-90$ & & & & & \\
\hline \multicolumn{7}{|l}{ Key: EF-exterior flake; IF-interior flake } \\
\hline
\end{tabular}

\section{Levels of Work and Results}

No artifacts were observed on the surface, but the site was discovered during excavation of systematic shovel tests when a single flake was found in Transect ST I9. A total of six flakes were recovered from the five shovel tests placed on the site. A review of Table 7-61 indicates that they are stratigraphically congruent between 20 and $50 \mathrm{cmbs}$. However, in addition to angular ironstones suggesting colluvial deposition across the site, large roots were also encountered.

\section{Conclusions/}

\section{Recommendations}

Although the flakes recovered were from a zone between 20 and $50 \mathrm{cmbs}$, and would suggest that the zone is intact, the apparent colluvial deposition and obvious root disturbance that has occurred at this site argue differently. In addition, the apparent absence of hearth features, stone tools, and/or preserved organic cultural material minimizes its research potential. In sum, CAS recommends no further investigations be conducted that the site is not eligible for nomination to the NRHP.

\section{BP769}

\section{Description}

41BP769 is a prehistoric open campsite covering approximately $7,483 \mathrm{~m}^{2}$ of both a wooded and open grassland sideslope, just below a ridge crest (Figures 7-127 and 7-128). Axtell fine sandy loam (AfC2) essentially underlies the open grassland, while the wooded area with oaks, cedars, hickories, and chinaberries has Demona loamy fine sand (DeC). Because of the heavy leaf litter and dense grasses, surface visibility in August 2005 ranged from between five and fifteen percent. At the time archaeologists noted a few tree falls and a push pile from heavy machinery on the western edge of the site. The surface slopes toward the north from 490 to 478 $\mathrm{ft}$ amsl. McLaughlin Creek is $400 \mathrm{~m}$ to the east. A nail and aluminum tag on an oak tree along the western edge of the site serve as a datum.

\section{Levels of Work and Results}

A total of four fire-cracked rocks, a heat spall, and four flakes were recovered from five

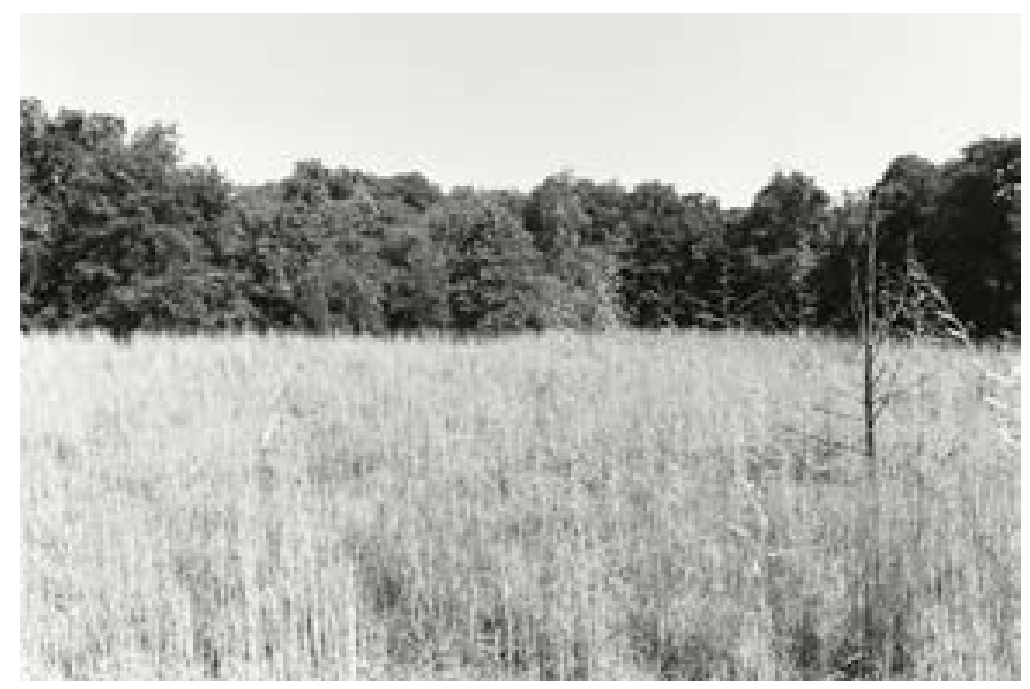

Figure 7-127. 41BP769 is an open campsite on a sideslope $400 \mathrm{~m}$ west of McLaughlin Creek; facing northwest. 


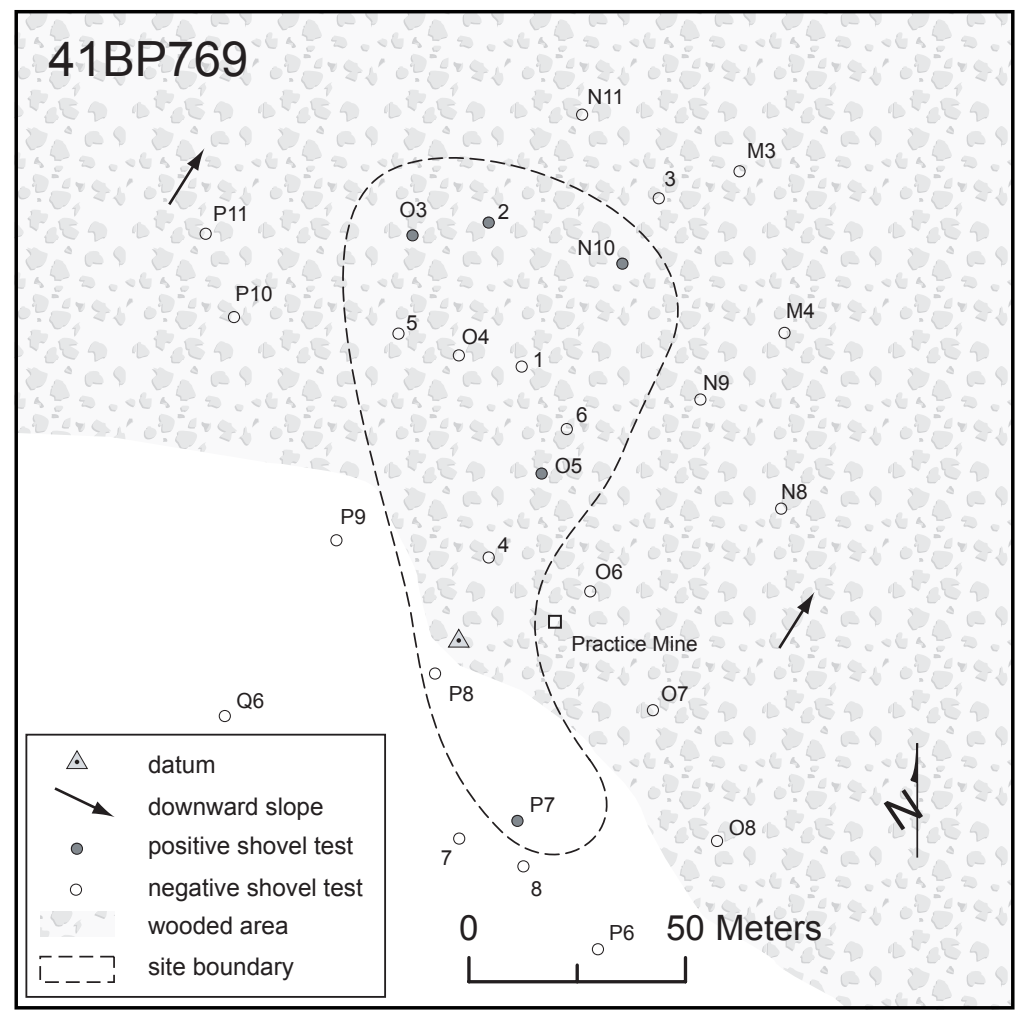

Figure 7-128. Site map of 41BP769.

Table 7-62. 41BP769 positive shovel test results.

\begin{tabular}{|c|c|c|c|c|c|}
\hline $\begin{array}{c}\text { Depth } \\
\text { (cmbs) }\end{array}$ & $\begin{array}{c}\text { ST } \\
\mathbf{2}\end{array}$ & $\begin{array}{c}\text { ST } \\
\text { N10 }\end{array}$ & $\begin{array}{c}\text { ST } \\
\text { O3 }\end{array}$ & $\begin{array}{c}\text { ST } \\
\text { O5 }\end{array}$ & $\begin{array}{c}\text { ST } \\
\text { P7 }\end{array}$ \\
\hline $0-10$ & & & IF & & \\
\hline $10-20$ & IF & & & & \\
\hline $20-30$ & fcr & & & & \\
\hline $30-40$ & & 2 FCR & & HS & IF \\
\hline $40-50$ & Clay & FCR & Clay & IF & \\
\hline $50-60$ & & & & & \\
\hline $60-70$ & & & & & Clay \\
\hline $70-80$ & & Loam & & Sand & \\
\hline $80-90$ & & & & & \\
\hline \multicolumn{7}{|c|}{ Key: HS-heat spall; IF-interior flake, } \\
FCR-fire-cracked rock $>1$ inch \\
\hline
\end{tabular}

shovel tests out of 11 excavated within the site's boundaries (Table 7-62). Notably, the stratigraphic positioning of six of the nine artifacts suggests there may be an intact zone of cultural material between 30 and $50 \mathrm{cmbs}$. However, the northerly, elongated shape of this site runs perpendicular to the contour of the slope, suggesting that artifacts may have been displaced downslope. A review of the forms for those shovel tests dug on and immediately around this site indicates the presence of angular ironstones and other gravels in seven shovel tests. Four others contained both roots and gravels, and in one (ST 6), large cobbles were found lying on clay. All these data suggest considerable erosional processes have likely negatively affected the integrity of the cultural material.

\section{Conclusions/ Recommendations}

Both surface observations and shovel test results indicate that this site has been negatively impacted by erosion and root growth. At sites with this degree of disturbance, little opportunity exists for significant in situ archaeological deposits, and it is highly unlikely here. CAS recommends that no further work be conducted and the site is not eligible for nomination to the NRHP.

\section{BP770}

\section{Description}

41BP770 (Figures 7-129 and 7-130) is a small $\left(646 \mathrm{~m}^{2}\right)$ lithic scatter on a terrace and floodplain $30 \mathrm{~m}$ north of McLaughlin Creek. Soils on the terrace are Demona loamy fine sand $(\mathrm{DeC})$ and Sayers fine sandy loam on the floodplain. The slope across the site from north to south is 444 to $440 \mathrm{ft}$ amsl. The area appears to have been cleared in historic times, but surface visibility in the semi-wooded and grassy areas was less than five percent in September 2005. Vegetation now includes cedars, oaks, chinaberries, and 


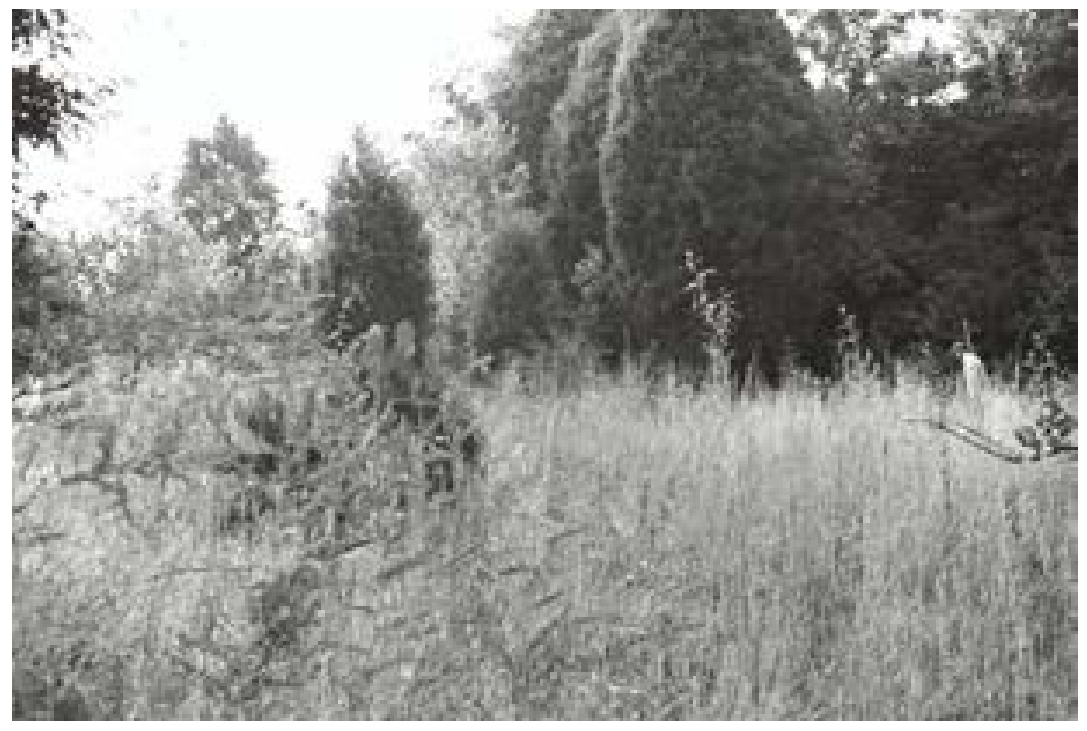

Figure 7-129. 41BP770 is a lithic scatter adjacent to McLaughlin Creek; facing southeast.

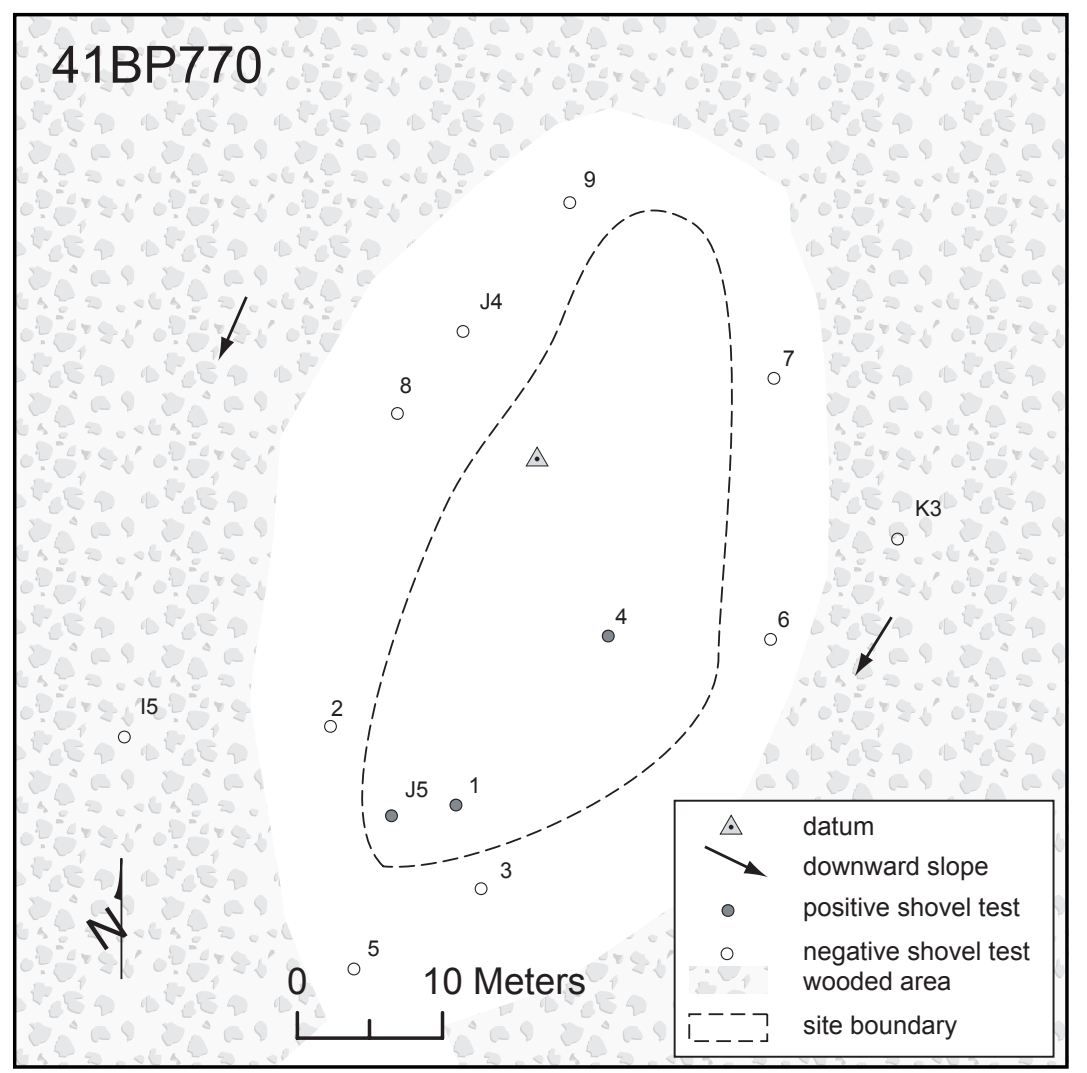

Figure 7-130. Site map of 41BP770. assorted cacti. Orange clay is exposed to the surface in the floodplain. A nail and aluminum tag on an oak tree along the western edge of the site serve as a datum.

\section{Levels of Work and Results}

No artifacts could be seen on the surface, but the three shovel tests placed on the site contained seven flakes in total (Table 763). Angular ironstones indicating probable colluvial deposition were found in four shovel tests. Others contained roots and large gravels lying on clay. All these data suggest considerable erosional processes have likely negatively affected the integrity of the cultural material.

\section{Conclusions/ Recommendations}

Our shovel test results indicate that this site has been negatively impacted by colluvial processes. In addition, archaeologists found no evidence to suggest there are buried features and/ or preserved organic or faunal materials here. Therefore, CAS recommends that no further work be conducted and the site is not eligible for nomination to the NRHP. 
Table 7-63. 41BP770 positive shovel test results.

\begin{tabular}{|c|c|c|c|}
\hline $\begin{array}{c}\text { Depth } \\
\text { (cmbs) }\end{array}$ & ST 1 & ST 4 & ST J5 \\
\hline $0-10$ & EF, IF & 2 IF & \\
\hline $10-20$ & & & \\
\hline $20-30$ & EF, IF & & \\
\hline $30-40$ & & & IF \\
\hline $40-50$ & Clay & & \\
\hline $50-60$ & & Clay & \\
\hline $60-70$ & & & \\
\hline $70-80$ & & & Sand \\
\hline $80-90$ & & & \\
\hline \multicolumn{2}{|c|}{ Key: EF-exterior flake; IF-interior flake } \\
\hline
\end{tabular}

\section{BP772}

\section{Description}

A bladed powerline right-of-way has exposed scattered fire-cracked rocks and flakes over a 903$\mathrm{m}^{2}$ area that constitutes 41BP772 (Figures 7-131 and 7-132). Bladed to the underlying red clay, the right-of-way is steep and heavily eroded in this sideslope location, sloping from 443 to 438 feet across the site. A gully cut into the right-of-way has exposed grey clay underneath the red clay. Silstid loamy fine sand (SkC) covers the slope outside the right-of-way, all the way to an intermittent drainage of Dogwood Branch Creek, $45 \mathrm{~m}$ to the north. Both sides of the rightof-way are heavily wooded with oaks, mesquites, and cedars, and surface visibility in those areas is less than five percent. The site datum is marked with a nail and an aluminum tag in an oak tree on the southwestern portion.

\section{Levels of Work and Results}

One chert fire-cracked rock, three sandstone fire-cracked rocks, and four chert flakes were found on the eroded right-of-way surface in no discernible pattern. Five shovel tests were excavated along the right-of-way within the boundaries of the site. No artifacts were found in any of the shovel tests excavated along the edge of the right-of-way, where soils over the underlying Bt horizon were an average $14 \mathrm{cmbs}$ deep.

\section{Conclusions/Recommendations}

Both surface observations and shovel test results indicate that this site has been negatively impacted by heavy equipment and erosion. The limited number and depth of artifacts suggests that subsurface materials are derived through bioturbation and/or anthropogenic activities. CAS recommends that no further work be conducted and the site is not eligible for nomination to the NRHP.

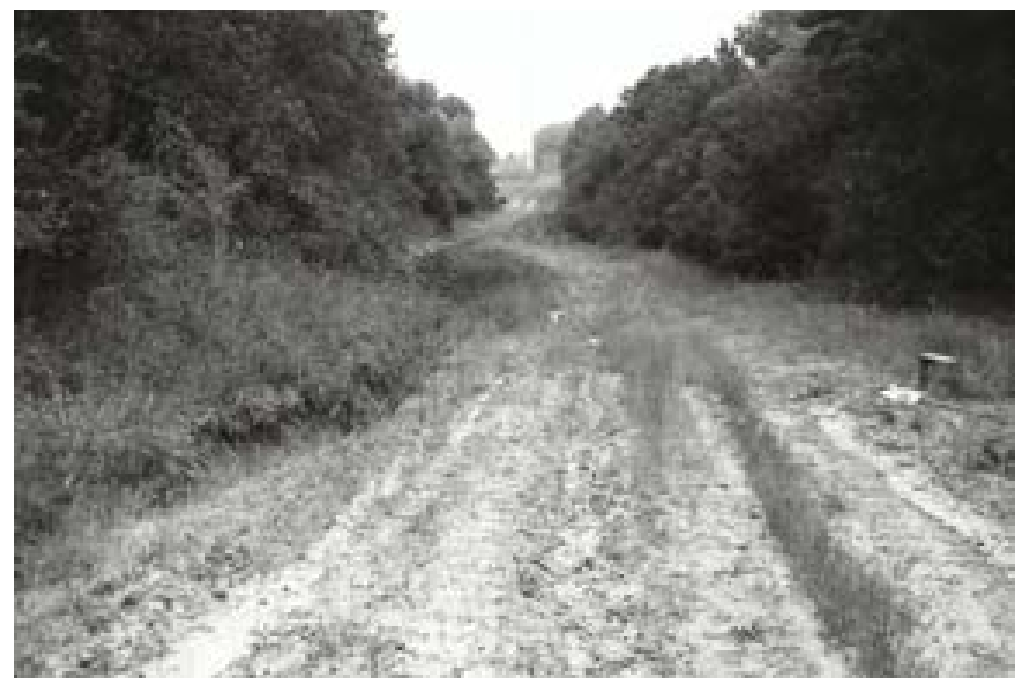

Figure 7-131. A bladed right-of-way has exposed burned rocks and flakes at 41BP772; facing north. 
FIGURE 7-132. REDACTED

Figure 7-132. Site map of 41BP772.

\section{BP774}

\section{Description}

A very small $\left(73 \mathrm{~m}^{2}\right)$ open campsite was discovered on a footslope $90 \mathrm{~m}$ from the confluence of Dogwood Branch Creek and an intermittent tributary (Figures 7-133 and 7-134). Oaks, cedars, loblolly pines, elms, poison ivy, and Virginia creepers thrive in the Uhland soils (Uh) that cover the area. Surface visibility during the September 2005 visit was less than five percent. The site's surface gently slopes from the northwest to the southeast, from 419 to $418 \mathrm{ft}$ amsl, and is hummocky due to erosion and treefall. The datum is marked with a nail and an aluminum tag in a $15-\mathrm{cm}$ diameter elm tree on the northeastern portion of the site.

\section{Levels of Work and Results}

No artifacts were found on the surface, and two of three shovel tests placed on the site contained only three artifacts (Table 7-64). Although they were buried between 50 and $70 \mathrm{cmbs}$, angular ironstones, petrified wood pieces, and roots were consistently found at depth in nearly all shovel tests on and around the site.

\section{Conclusions/ Recommendations}

Because of the limited number of observed artifacts and the obvious disturbances, it appears that any cultural material at this site is likely in a mixed or derived context, negating any significant research potential. Therefore, CAS recommends that no further work be conducted and the site is not eligible for nomination to the NRHP.

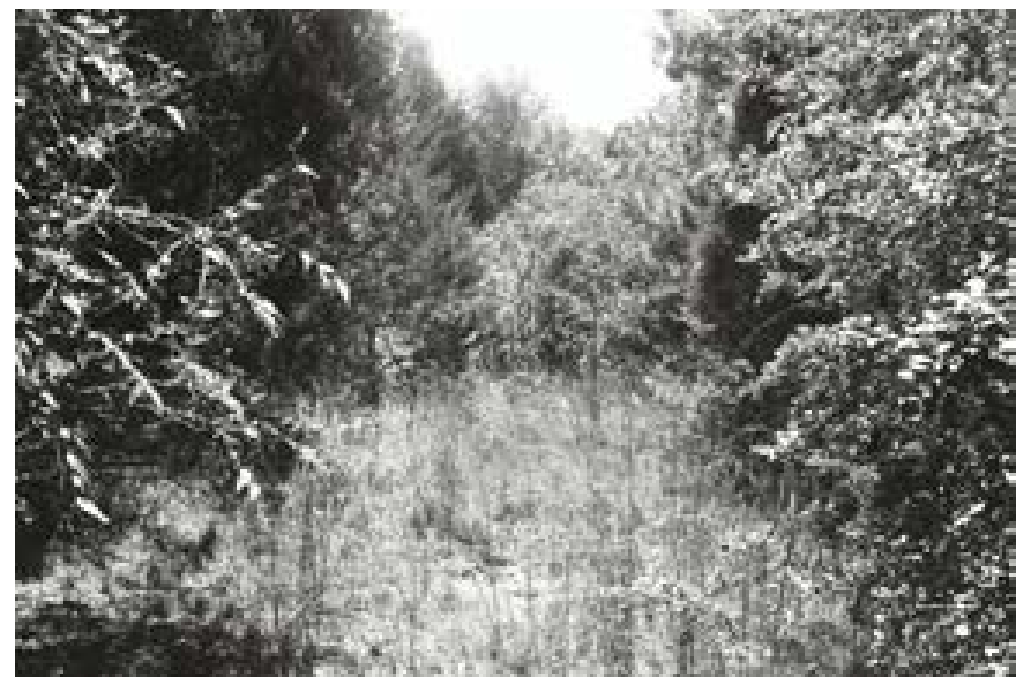

Figure 7-133. 41BP774 is an open campsite near the confluence of Dogwood Branch and an unnamed tributary; facing southeast. 


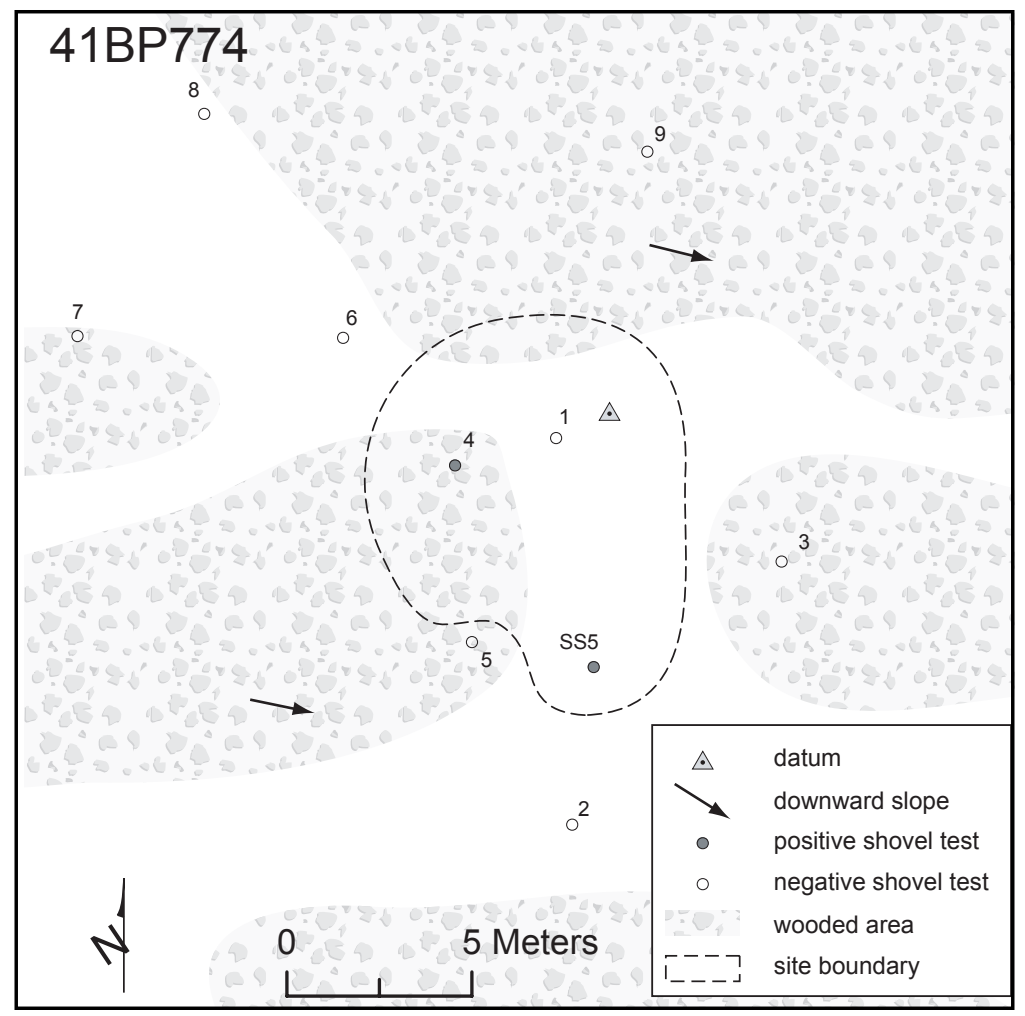

Figure 7-134. Site map of 41BP774.

Table 7-64. 41BP774 positive shovel test results.

\begin{tabular}{|c|c|c|}
\hline Depth (cmbs) & ST 4 & ST SS5 \\
\hline \multicolumn{3}{|l|}{$0-10$} \\
\hline \multicolumn{3}{|l|}{$10-20$} \\
\hline \multicolumn{3}{|l|}{$20-30$} \\
\hline \multicolumn{3}{|l|}{$30-40$} \\
\hline \multicolumn{3}{|l|}{$40-50$} \\
\hline $50-60$ & & IF \\
\hline $60-70$ & 2 FCR & \\
\hline $70-80$ & & Sand \\
\hline $80-90$ & Sand & \\
\hline $90-100$ & & \\
\hline \multicolumn{3}{|c|}{$\begin{array}{c}\text { Key: IF-interior flake; } \\
\text { FCR-fire-cracked rock }>1 \text { inch }\end{array}$} \\
\hline
\end{tabular}

\section{BP776}

\section{Description}

This prehistoric open campsite (Figures 7-135 and 7-136) also has a historic farmstead component that is discussed in Chapter 9: New
Historic Component Sites. The prehistoric component lies on the southern portion of the site and spans some 23,590 $\mathrm{m}^{2}$ of a footslope that is both wooded and semi-wooded/open grassland. Vegetation consists of oaks, cedars, elms, mesquites, bull nettles, grapevines, and tall grasses. Surface visibility is less than five percent. The prehistoric component area slopes from about 438 to $420 \mathrm{ft}$ amsl, and its southern tip is at the bank of an intermittent drainage of Dogwood Branch Creek. Although the open grassland area has likely been cleared in historic times, no evidence of that was apparent on the surface. Treefall in the wooded areas was not significant at the time of the visit in September 2005. The site datum is an aluminum tag and nail in a $30-\mathrm{cm}$ diameter oak tree in the idle of the prehistoric component.

\section{Levels of Work and Results}

No artifacts were observed on the surface at this site. Of the 25 shovel tests excavated on the site, 17 were positive. Eight shovel tests contained prehistoric artifacts, which included 20 flakes, seven fire-cracked rocks, a chert chip, and a bifacially flaked chert quarry blank. Prehistoric artifacts were found as deep as $80 \mathrm{cmbs}$ (Table 7$65)$. With the exception of ST X5, which contained petrified wood pieces between 40 and $50 \mathrm{cmbs}$, none of the archaeologists noted any evidence of colluvium or other disturbance in those positive shovel tests in the prehistoric component area. 


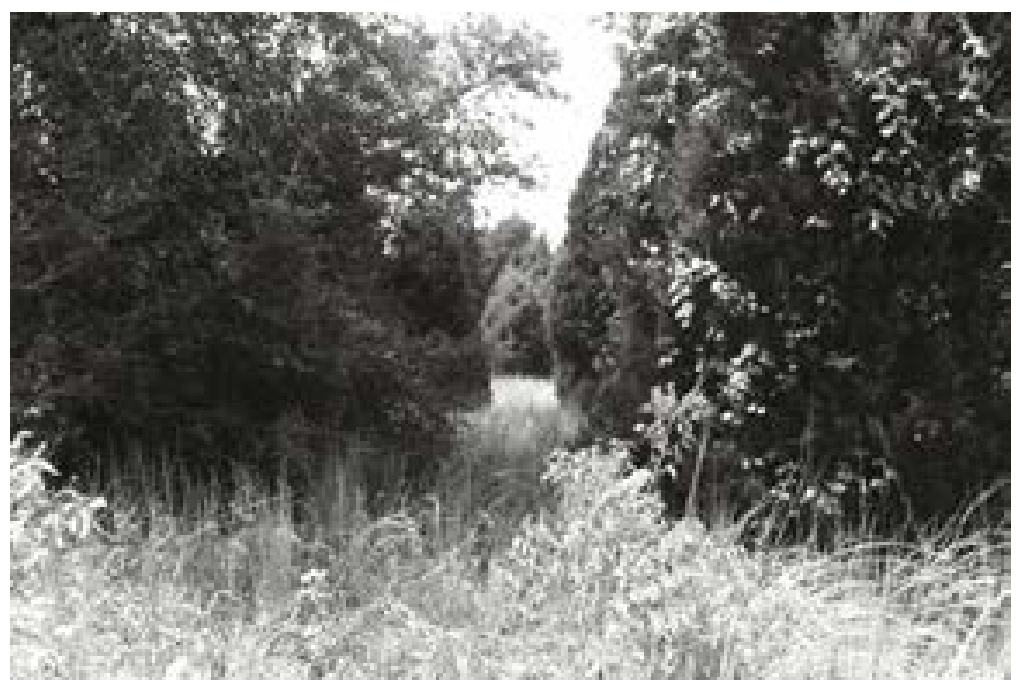

Figure 7-135. 41BP776 is an open campsite that borders Dogwood Branch Creek; facing south.

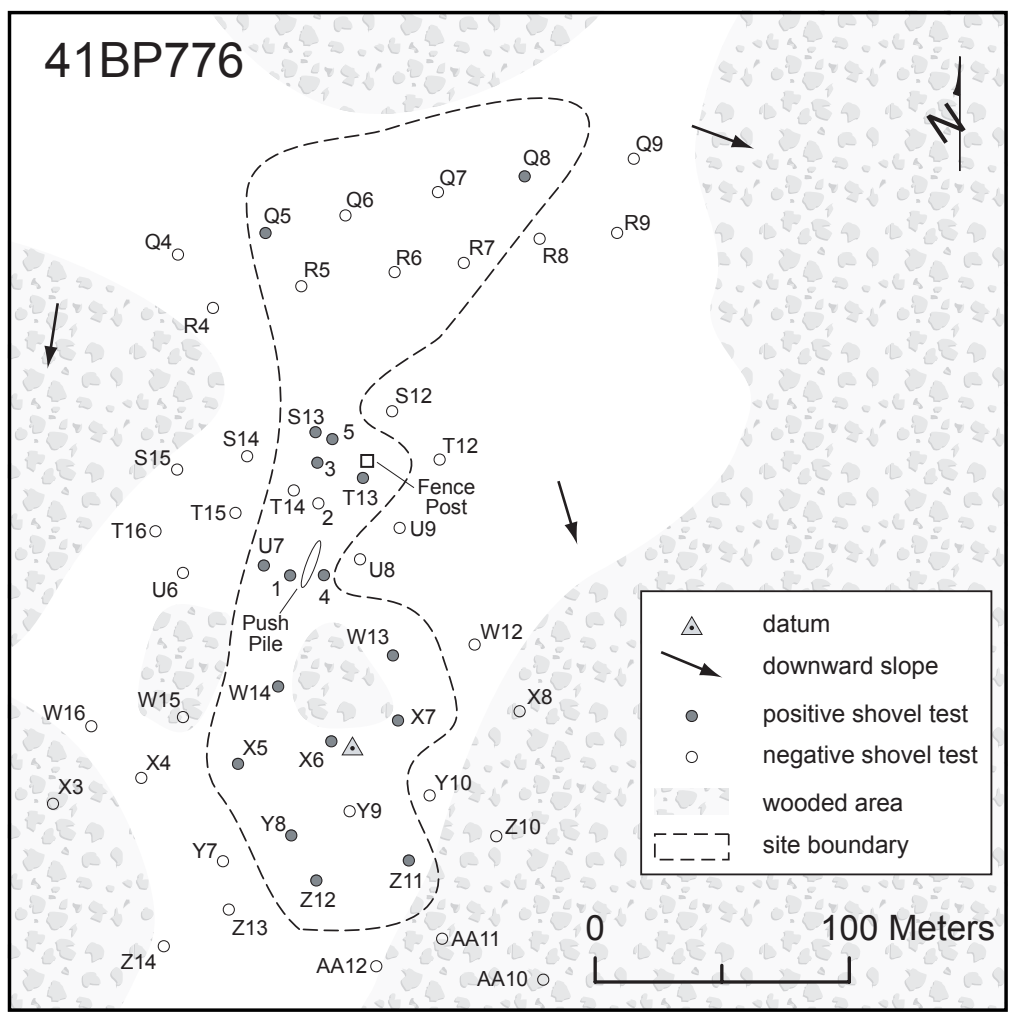

Figure 7-136. Site map of 41BP776.

\section{Conclusions/Recommendations}

With rare exception, the prehistoric component at this site appears to be undisturbed, but the potential for discovering buried and intact features is unknown without further investigations beyond the scope of this inventory survey. The ubiquity of burned rocks and lithic debitage warrant the excavation of three 1-x-1-m units, one in each of the immediate areas of STs X5, X6, and Z11 to determine NRHP eligibility. 


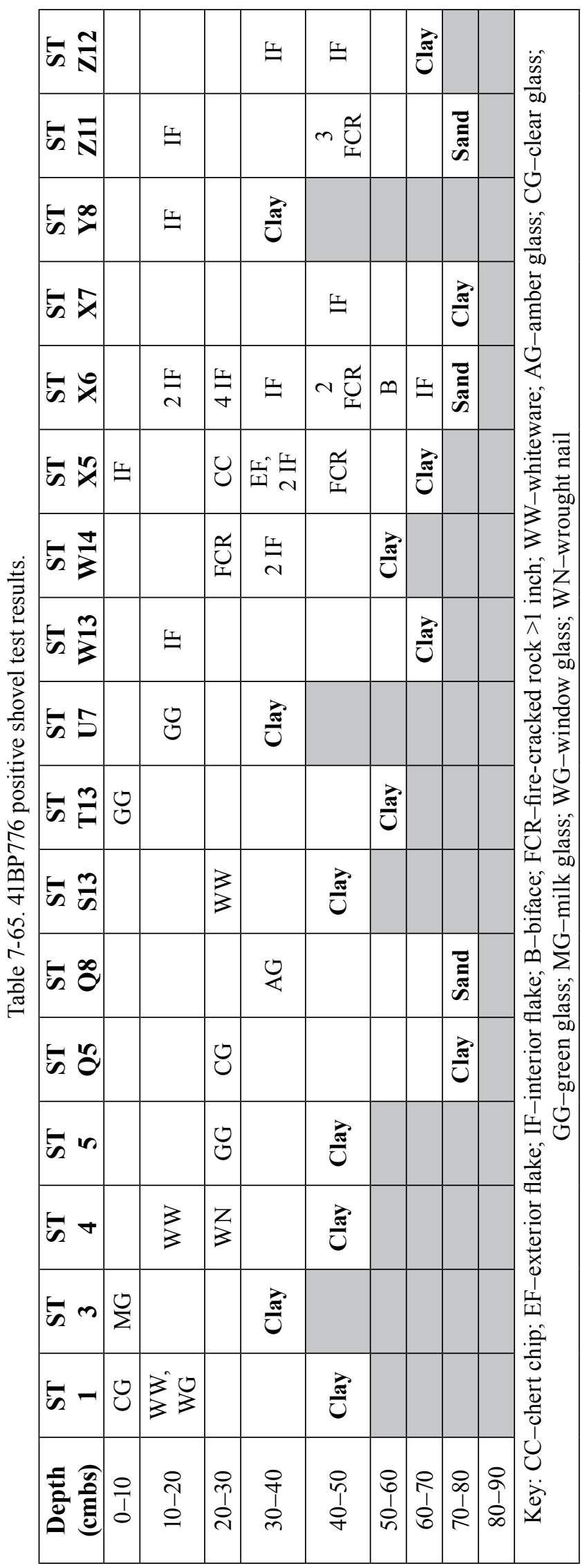

\section{BP777}

\section{Description}

41BP777 (Figures 7-137 and 7-138) is a small $\left(283 \mathrm{~m}^{2}\right)$ ephemeral lithic scatter on a wooded sideslope that slopes from 430 to $429 \mathrm{ft}$ amsl toward an intermittent drainage of Dogwood Branch Creek, 60 $\mathrm{m}$ to the east. Uhland soils (Uh) support the growth of oak and cedar woodlands, with beautyberries, shrubs and grasses as understory. Generally, surface visibility was less than five percent. Surface disturbances observed included an occasional treefall and a barbed wire fence. An old plow tine was also found on the surface. The datum is marked with a nail and an aluminum tag in a $15-\mathrm{cm}$ diameter oak tree on the site's northern portion.

\section{Levels of Work and Results}

No artifacts were found on the surface. Three flakes were found in the five shovel tests dug on the site (Table 7-66). Four shovel tests were positive, but only three contained prehistoric material. Angular ironstones were found at depth in seven of the shovel tests, petrified wood pieces were found in ST 6, a fence staple was found in ST 8 at $0-10 \mathrm{cmbs}$, and red clay mottling was found in ST 2 to $45 \mathrm{cmbs}$. The average depth across the site to the underlying $\mathrm{Bt}$ horizon was less than $36 \mathrm{cmbs}$.

\section{Conclusions/Recommendations}

Generally shallow soils, colluvial deposition, and possible plowing have disrupted the integrity of any cultural material at this site, thus significantly reducing its research potential. Therefore, CAS recommends that no further work be conducted and the site is not eligible for nomination to the NRHP. 


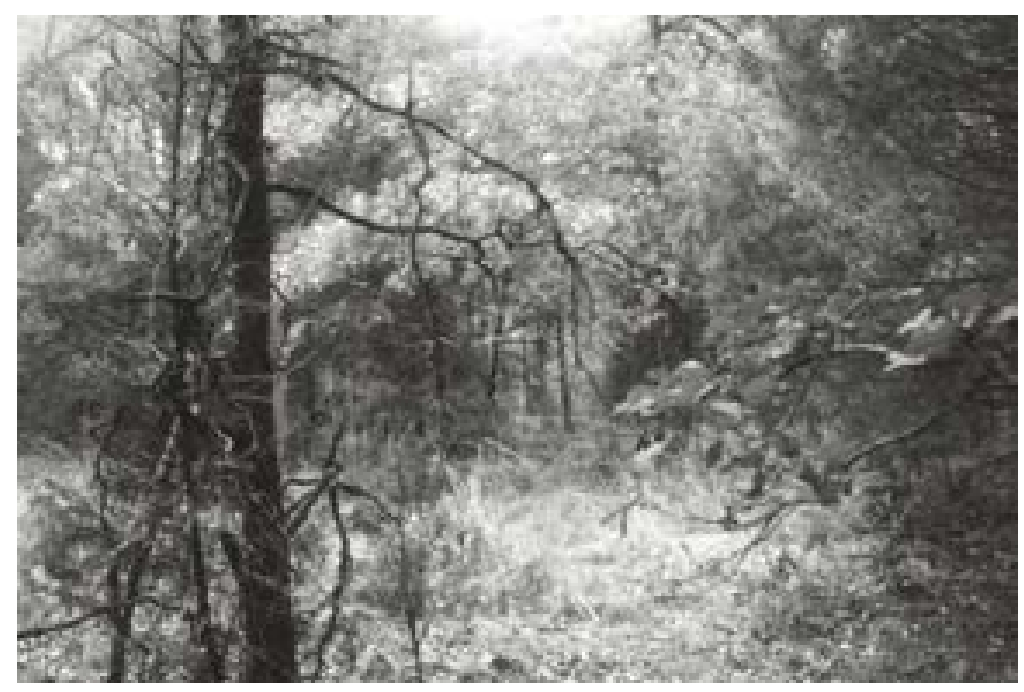

Figure 7-137. 41BP777 is small lithic scatter $60 \mathrm{~m}$ west of a tributary of Dogwood Branch Creek; facing northeast.

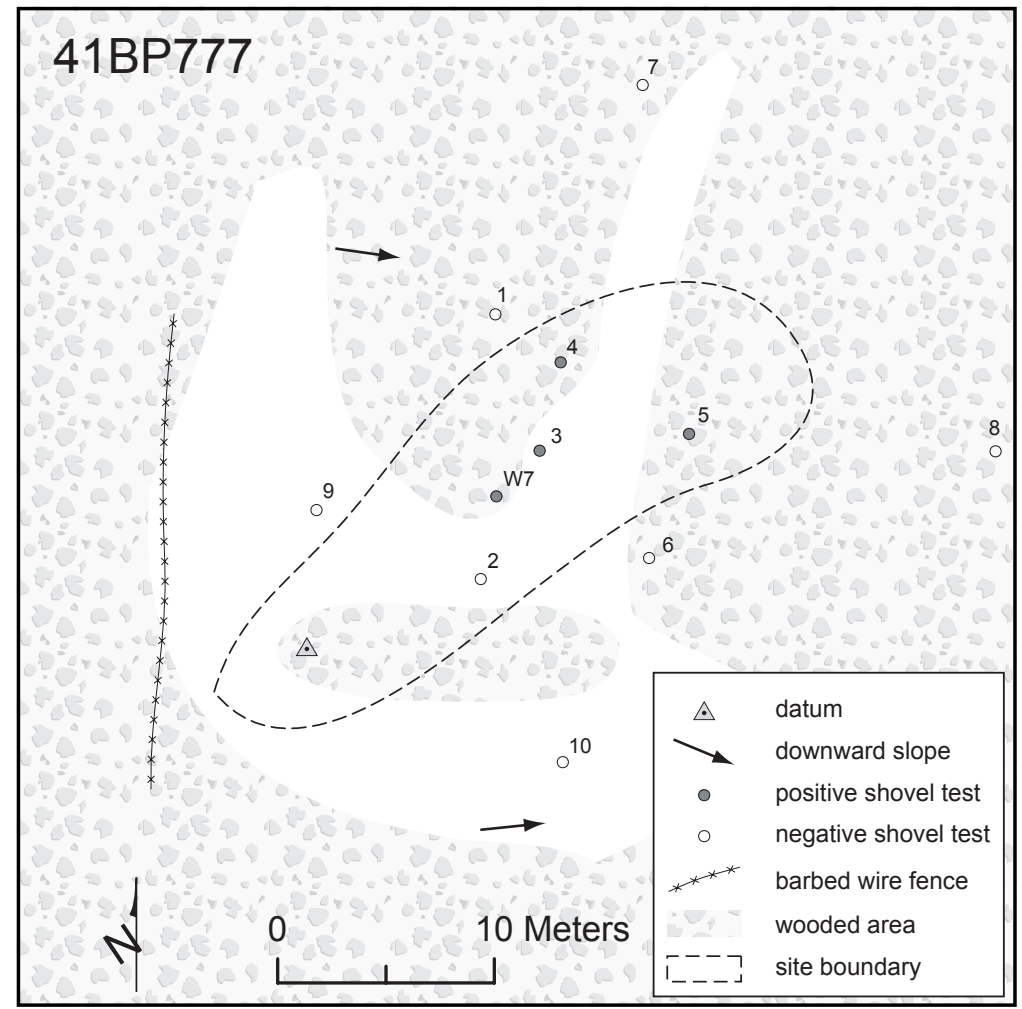

Figure 7-138. Site map of 41BP777. 
Table 7-66. 41BP777 positive shovel test results.

\begin{tabular}{|c|c|c|c|c|}
\hline $\begin{array}{c}\text { Depth } \\
\text { (cmbs) }\end{array}$ & ST 3 & ST 4 & ST 5 & $\begin{array}{c}\text { ST } \\
\text { VV7 }\end{array}$ \\
\hline $0-10$ & & & IF & M \\
\hline $10-20$ & & & & \\
\hline $20-30$ & & & & \\
\hline $30-40$ & & EF & Clay & \\
\hline $40-50$ & IF & & & \\
\hline $50-60$ & & & & \\
\hline $60-70$ & & Clay & & \\
\hline $70-80$ & Sand & & & \\
\hline $80-90$ & & & & \\
\hline \multicolumn{2}{|l|}{ Key: EF-exterior flake; IF-interior flake; M-metal } \\
\hline
\end{tabular}

\section{BP778}

\section{Description}

This small open campsite (Figures 7-139 and 7-140) lies in a semi-wooded and open field alongside a powerline right-of-way. It can be described as being located on a sideslope setting, $130 \mathrm{~m}$ west of an intermittent tributary of Dogwood Branch Creek. Vegetation across the site's gentle slope (443-441 ft amsl) consists of oaks, cedars, sumacs, grapevines, prickly pears, bull nettles, poison ivy, Virginia creeper, with assorted shrubs and tall grasses. Surface visibility in September 2005 was less than five percent, even where the powerline rightof-way was not recently bladed. Based upon shovel tests, the site covers about $648 \mathrm{~m}^{2}$. The soil on the site is Demona loamy fine sand (DeC). Other than the right-of-way along its western edge, it appears that the site has been cleared in historic times, and a barbed wire fence runs along its northeastern edge. The datum is marked with a nail and aluminum tag on an oak tree 12 $\mathrm{cm}$ in diameter.

\section{Levels of Work and Results}

No artifacts were observed on the surface, but two pieces of firecracked rock and three flakes were found in four of five shovel tests excavated on the site (Table 7-67). In ST 3, archaeologists found evidence of disturbance in the form of mottled clay and angular sandstone, presumably from the nearby rightof-way cut. Otherwise, few gravels and/or roots were encountered throughout.

\section{Conclusions/Recommendations}

Although only two burned rocks were found in ST 1, no evidence of disturbance could be discerned there. Stratigraphically, it conforms to a single flake found in ST 7. The ephemeral nature of artifacts at this small site does not negate the possibility that they represent a single, short occupation with discretely intact cultural deposits. Until further investigations, the research potential here is unknown. CAS recommends excavation of two 1-x-1-m excavation units in

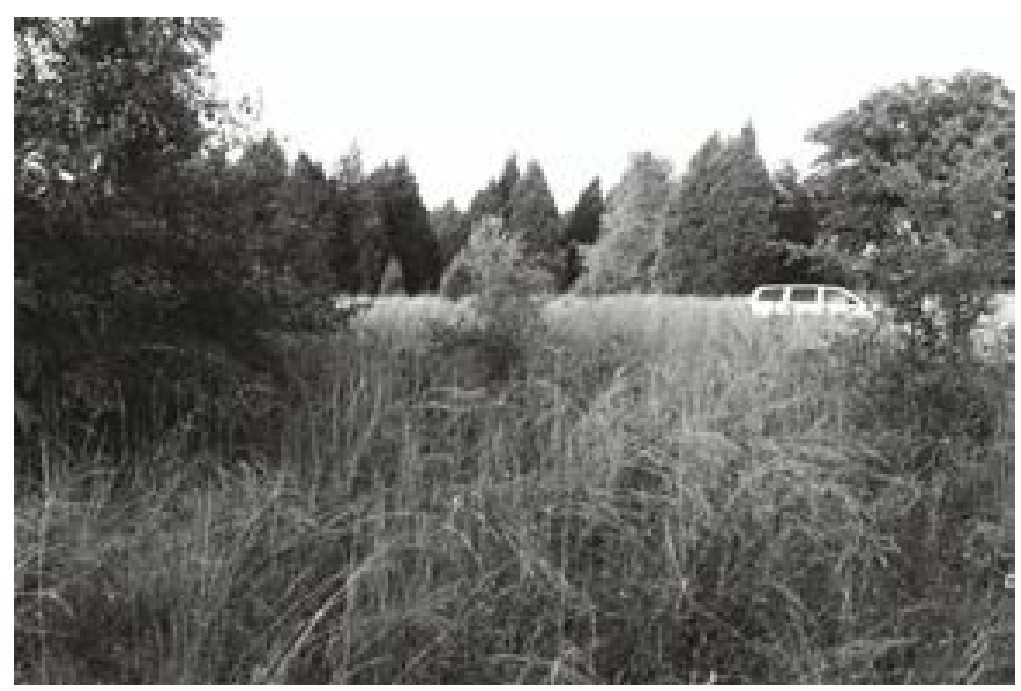

Figure 7-139. 41BP778 is a small open campsite on the edge of a powerline right-of-way; facing southwest. 
e ach

of the

FIGURE 7-140. REDACTED

Figure 7-140. Site map of 41BP778.

Table 7-67. 41BP778 positive shovel test results.

\begin{tabular}{|c|c|c|c|c|}
\hline $\begin{array}{c}\text { Depth } \\
\text { (cmbs) }\end{array}$ & ST 1 & ST 3 & ST 7 & ST YY1 \\
\hline $0-10$ & & & & \\
\hline $10-20$ & & IF & & \\
\hline $20-30$ & & & & IF \\
\hline $30-40$ & & & & \\
\hline $40-50$ & FCR & & EF & \\
\hline $50-60$ & FCR & & & \\
\hline $60-70$ & & & & \\
\hline $70-80$ & Sand & Sand & Sand & Sand \\
\hline $80-90$ & & & & \\
\hline Key: EF-exterior flake; IF-interior flake, FCR- \\
fire-cracked rock >1 inch \\
\hline
\end{tabular}


immediate areas of STs 1 and 7 to determine NRHP elibibility.

\section{BP779}

\section{Description}

Like 41BP777, 41BP779 (Figures 7-141 and 7-142) is another small $\left(190 \mathrm{~m}^{2}\right)$ ephemeral lithic scatter on a wooded sideslope. This site slopes from 429 to $428 \mathrm{ft}$ amsl toward the same intermittent drainage of Dogwood Branch Creek, 45 m to the east. Silstid loamy fine sand (SkC) covers the slope here and oaks, cedars, beautyberries, shrubs, and tall grasses prevail. Obvious surface disturbances include an occasional treefall and a few gopher holes. Overall, surface visibility was about 20 percent in September 2005. The datum is marked with a nail and an aluminum tag in a $20-\mathrm{cm}$ diameter oak tree on the northern portion of the site.

\section{Levels of Work and Results}

No artifacts were found on the surface, but a total of five flakes were found in the two shovel tests excavated on the site (Table 7-68). Angular ironstones were found in a continuum to 70 cmbs in STs 1, 4, and 7. Otherwise, roots and gravels were noted in all other shovel tests. As shown in Table 7-68, four flakes were found deeply buried in ST YY5; however, they were with small rounded gravels.

\section{Conclusions/Recommendations}

With only five pieces of lithic debitage, and no evidence of features, diagnostic tools, and/ or organic preservation at this site, its research potential is minimal. In addition, apparent

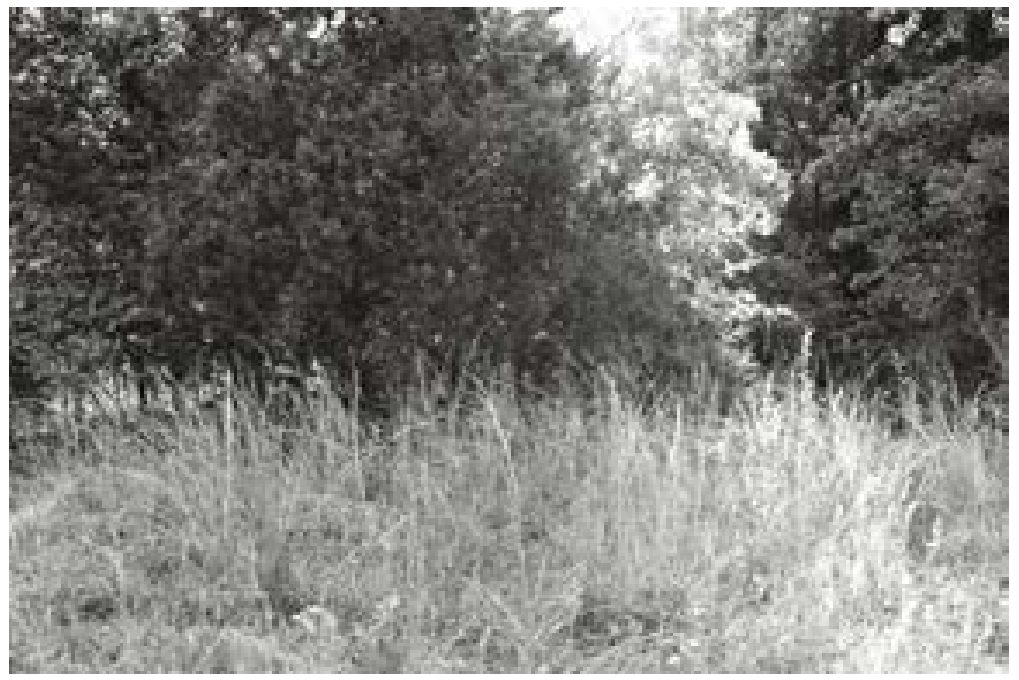

Figure 7-141. 41BP779 is another small lithic scatter just west of a tributary of Dogwood Branch Creek; facing east.

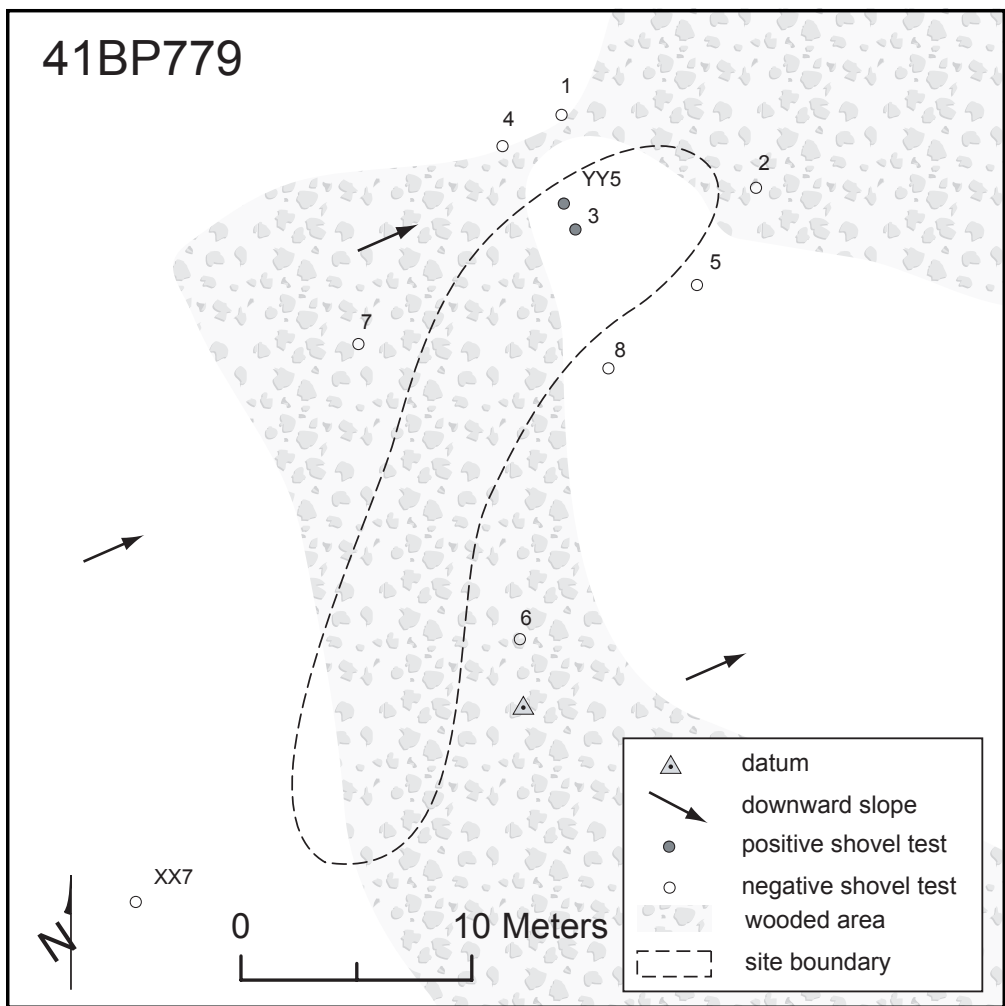

Figure 7-142. Site map of 41BP779. 
Table 7-68. 41BP779 positive shovel test results.

\begin{tabular}{|c|c|c|}
\hline $\begin{array}{c}\text { Depth } \\
\text { (cmbs) }\end{array}$ & ST 3 & ST YY5 \\
\hline $0-10$ & & \\
\hline $10-20$ & & \\
\hline $20-30$ & & \\
\hline $30-40$ & & \\
\hline $40-50$ & IF & \\
\hline $50-60$ & & \\
\hline $60-70$ & & IF \\
\hline $70-80$ & Sand & IF \\
\hline $80-90$ & & IF \\
\hline $90-100$ & & IF \\
\hline $100-110$ & & Sand \\
\hline $110-120$ & & \\
\hline \multicolumn{2}{|c|}{ Key: IF-interior flake } \\
\hline
\end{tabular}

colluvial deposition has disrupted the integrity of the debitage. Therefore, CAS recommends that no further work be conducted and the site is not eligible for nomination to the NRHP.

\section{BP780}

Although this field was likely plowed in the past, no obvious disturbances could be seen on the surface. The datum is marked with a nail and an aluminum tag in a $7-\mathrm{cm}$ diameter oak tree on the northern portion of the site.

\section{Levels of Work and Results}

No artifacts were found on the surface. Three fire-cracked rocks, five flakes, and a chert chip were found in seven shovel tests out of 11 excavated on the site (Table 7-69). Angular ironstones were found in a continuum to $70 \mathrm{cmbs}$ in ST DDD6, but not in any others. Otherwise, the only evidence for likely disturbance was in the form of a few roots in some shovel tests; no plow zone was discernible.

\section{Conclusions/Recommendations}

With the presence of buried fire-cracked rocks and minimal disturbance detected from shovel tests, the potential exists for intact hearths to exist below the surface. But without further investigations beyond the scope of this inventory survey, the research potential at this site is

\section{Description}

This open campsite is situated in an upland setting $90 \mathrm{~m}$ east of an intermittent drainage to Dogwood Branch Creek (Figures 7-143 and 7-144). It slopes gently to the west from 443 to $437 \mathrm{ft}$ amsl, and covers approximately $6,017 \mathrm{~m}^{2}$. An old field is now overgrown with cedars, pines, oaks, grapevines, bull nettles, shrubs, and tall grasses. Deep, Axtell fine sandy loam (AfC) covers the area. Surface visibility was less than five percent in September 2005.

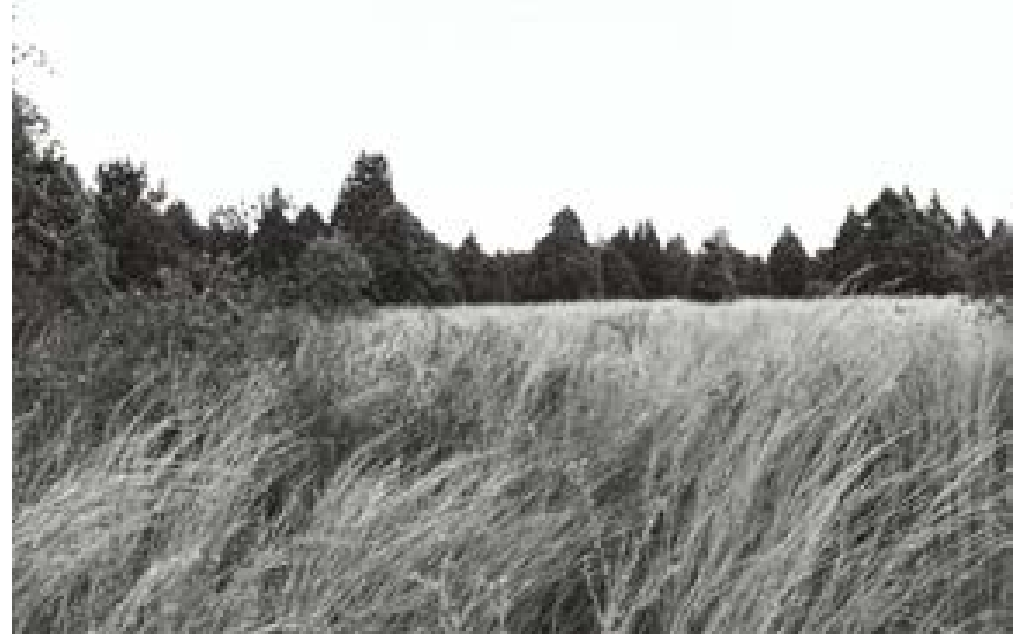

Figure 7-143. 41BP780 is an open campsite in an upland setting, $90 \mathrm{~m}$ from a tributary of Dogwood Branch Creek; facing north. 


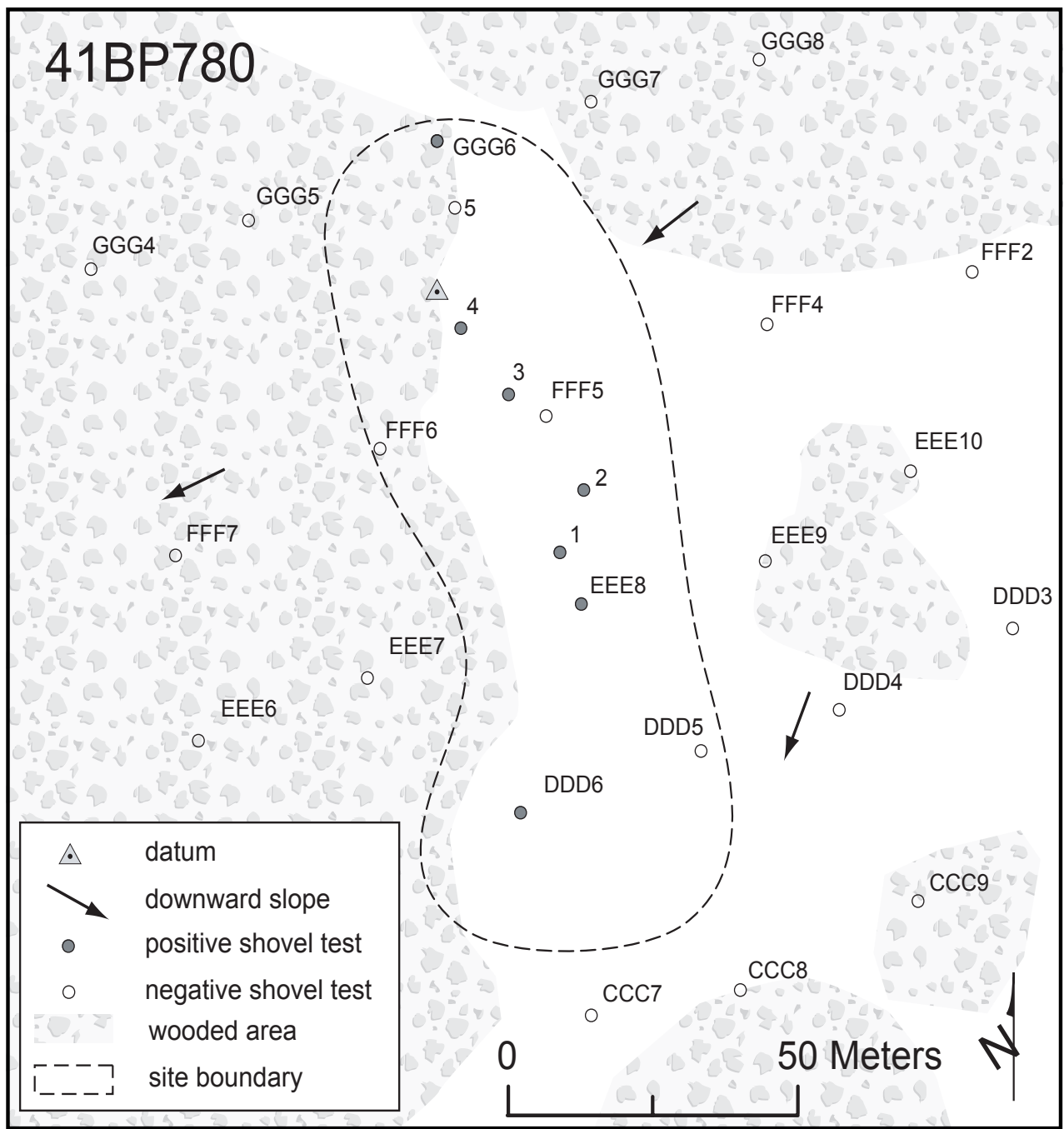

Figure 7-144. Site map of 41BP780.

Table 7-69. 41BP780 positive shovel test results.

\begin{tabular}{|c|c|c|c|c|c|c|c|}
\hline $\begin{array}{c}\text { Depth } \\
\text { (cmbs) }\end{array}$ & ST 1 & ST 2 & ST 3 & ST 4 & $\begin{array}{c}\text { ST } \\
\text { DDD6 }\end{array}$ & $\begin{array}{c}\text { ST } \\
\text { EEE8 }\end{array}$ & $\begin{array}{c}\text { ST } \\
\text { GGG6 }\end{array}$ \\
\hline $0-10$ & & & & & & & \\
\hline $10-20$ & & & & & & & \\
\hline $20-30$ & FCR & & & & & IF & IF \\
\hline $30-40$ & & & FCR & IF & & IF & \\
\hline $40-50$ & & & & Clay & & & \\
\hline $50-60$ & & IF & Clay & & FCR & & \\
\hline $60-70$ & & & & & & CC & \\
\hline $70-80$ & Sand & Sand & & & Sand & & \\
\hline $80-90$ & & & & & & Sand & Clay \\
\hline $90-100$ & & & & & & & \\
\hline \multicolumn{7}{|l}{ Key: CC-chert chip; IF-interior flake; FCR-fire-cracked rock $>1$ inch } \\
\hline
\end{tabular}


unknown. CAS recommends excavation of three 1-x-1-m units, one each in the immediate area of STs 1, 3, and DDD6 to determine NRHP eligibility.

\section{BP781}

\section{Description}

41BP781 (Figures 7-145 and 7-146) is a small $\left(532 \mathrm{~m}^{2}\right)$ open campsite located on a semi-wooded sideslope $80 \mathrm{~m}$ east of an intermittent tributary of Dogwood Branch Creek. It slopes nine feet (470-461 ft amsl) across its 47-m length, and its elongated shape is perpendicular to the creek and natural contours, suggesting that artifacts may have eroded downslope. Vegetation at the site includes oaks, cedars, chinaberries, beautyberries, grapevines, Virginia creepers, poison ivy, and tall grasses. The soil type here is Demona loamy fine sand (DeC). Surface visibility was less than five percent in September 2005. Obvious disturbances that could be seen on the surface included heavy erosion on the eastern portion of the site. The datum is marked with a nail and an aluminum tag in a $15-\mathrm{cm}$ diameter oak tree on the western portion of the site.

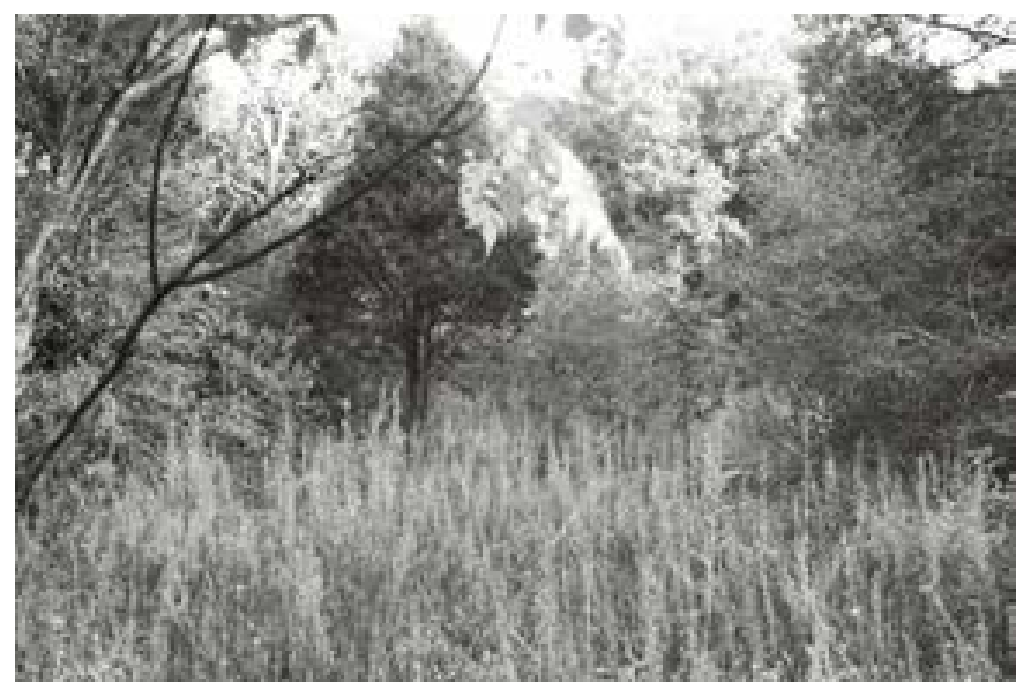

Figure 7-145. 41BP781 is an eroded open campsite on a sideslope near a tributary of Dogwood Branch Creek; facing north.

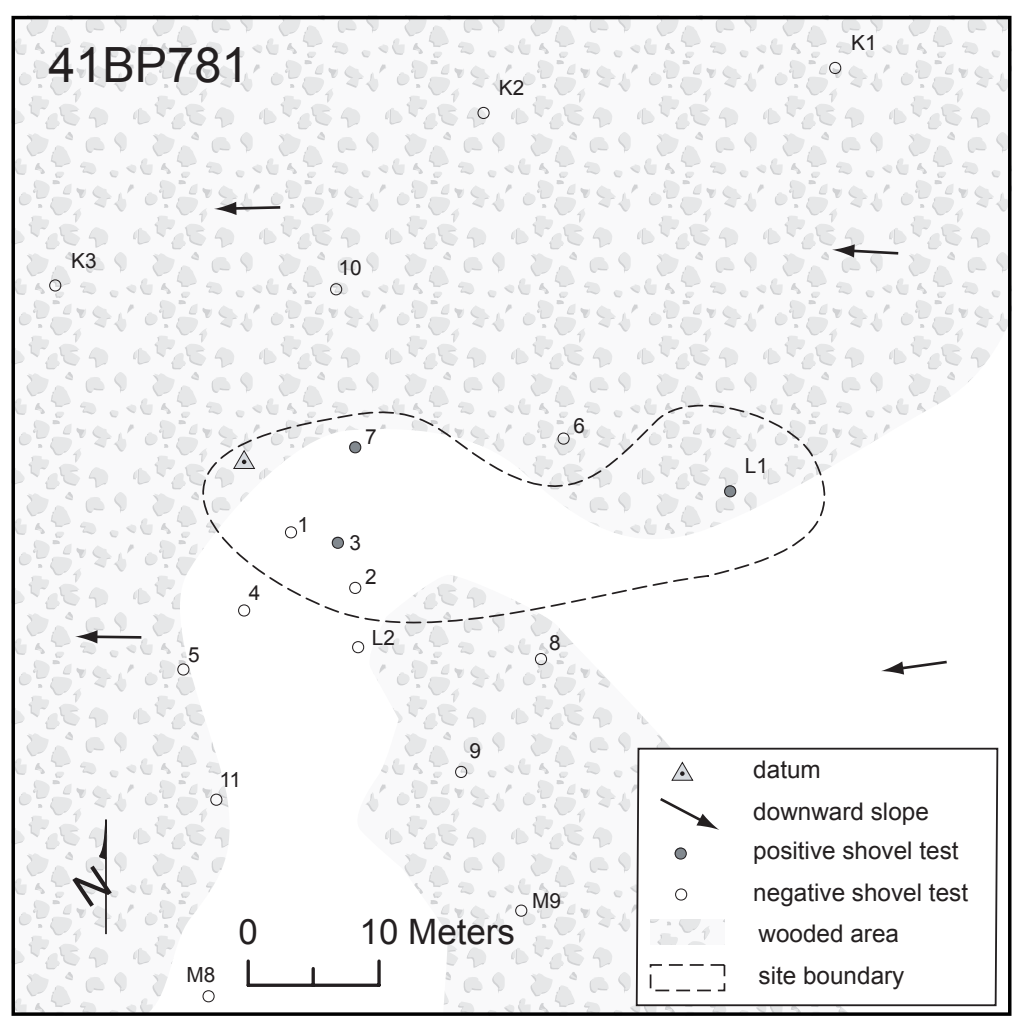

Figure 7-146. Site map of 41BP781.

\section{Levels of Work and Results}

No artifacts were seen on the surface, but a single fire-cracked rock and three flakes were found in three of five shovel tests excavated on the site (Table 7-70). Small rounded pebbles and small roots were found in virtually all shovel tests 
Table 7-70. 41BP781 positive shovel test results.

\begin{tabular}{|c|c|c|c|}
\hline $\begin{array}{c}\text { Depth } \\
\text { (cmbs) }\end{array}$ & ST 3 & ST 7 & ST L1 \\
\hline $0-10$ & & & \\
\hline $10-20$ & & & \\
\hline $20-30$ & & IF & \\
\hline $30-40$ & IF & FCR & IF \\
\hline $40-50$ & & & \\
\hline $50-60$ & & Clay & \\
\hline $60-70$ & & & \\
\hline $70-80$ & Sand & & Sand \\
\hline $80-90$ & & & \\
\hline Key: IF-interior flake; FCR-fire-cracked rock $>1$ \\
inch \\
\hline
\end{tabular}

at the site, and reddish loam was interspersed with tan sand in STs 3 and 6. The depth to clay encountered in shovel tests varies erratically from north to south, indicating probable gullying.

\section{Conclusions/Recommendations}

An eroded surface on the eastern, upper portion of the site, the minimal number of artifacts recovered, and the results of shovel tests indicate this site has been significantly disturbed by erosion. Therefore, its research potential is minimal, and CAS recommends that no further work be conducted. The site is not eligible for nomination to the NRHP.

\section{BP782}

\section{Description}

Covering approximately $34,760 \mathrm{~m}^{2}$, this open campsite (Figures 7-147 and 7-148) spans a broad sideslope on an inside meander of Dogwood Branch Creek. The soil type here is Axtell fine sandy loam (AfC2). The area appears to have been cleared at one time in the past, but today there is a variety of vegetation, predominantly oaks, pines, cedars, sumacs, mesquites, cacti, beautyberries, and tall grasses. The slope over the area is gentle, ranging from 442 to $430 \mathrm{ft}$ amsl. Surface visibility varied from less than five percent to about 10 percent. Treefalls were noted sporadically throughout the area, an occasional push pile was observed, and a shallow firebreak trench was noted along some treelines. The datum is marked with a nail and an aluminum tag on an elm tree on the northeastern portion of the site.

\section{Levels of Work and Results}

No artifacts were found on the surface. However, as shown in Table 7-71, numerous buried artifacts were found in 14 positive shovel tests. In total, 25 flakes, six fire-cracked rocks, one uniface, and two heat spalls were recovered from 14 of the 27 shovel tests excavated on the site. A formally retouched uniface was found at $0-10 \mathrm{cmbs}$ in ST L3, and a thin blade-like interior flake was found in the same shovel test at 10-20 cmbs. Angular ironstones indicating probable colluvial deposition were noted in STs H2, K5, and M9. Otherwise, the only evidence for likely disturbance was in the form of roots in some shovel tests. The average soil depth across the site was just over $41 \mathrm{cmbs}$. Notably, as shown in Table 7-71, all shovel tests that contained fire-cracked rocks encountered clay at shallow depths. The deeper tests (STs M9, LL2, and NN19) contained no fire-cracked rocks.

\section{Conclusions/Recommendations}

As stated above, this site is extremely large, and although dozens of shovel tests were placed on and around it, CAS does not believe that shovel tests every $30 \mathrm{~m}$ or more have been adequate to fully evaluate this site. The presence of fire-cracked rocks and stone tools suggests that there may be undiscovered intact hearths with associated stone tools and charcoal. Problematic with the burned rocks found is that they were at relatively shallow depths. In order to further evaluate the research potential of this site, CAS recommends excavation of a series of eight 1-x- 


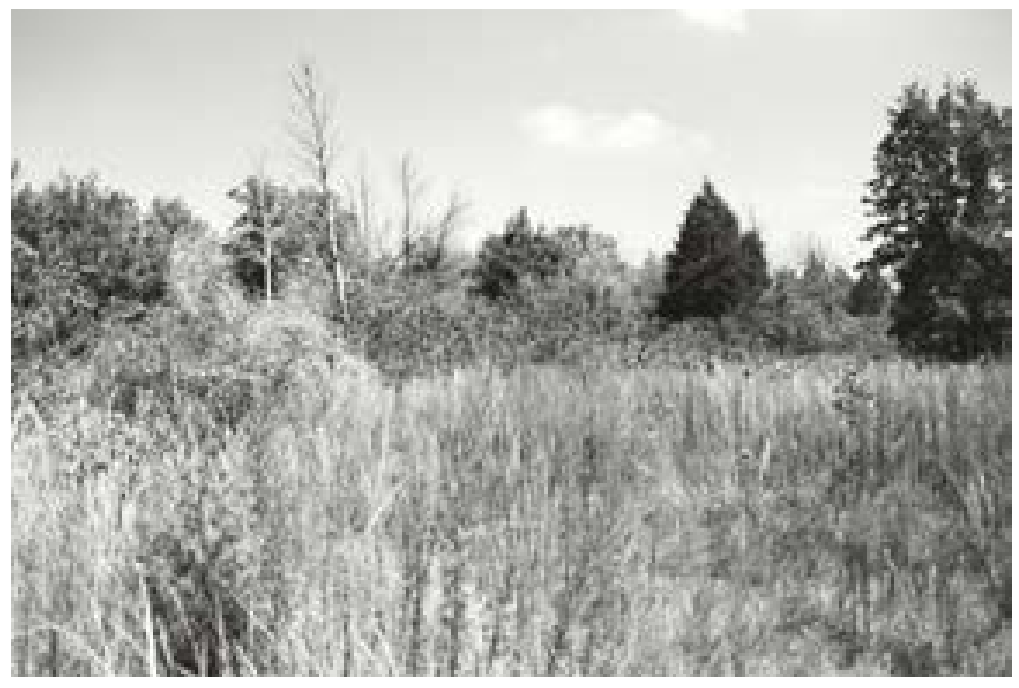

Figure 7-147. 41BP782 is a very large open campsite on an inside meander of Dogwood Branch Creek; facing northeast.

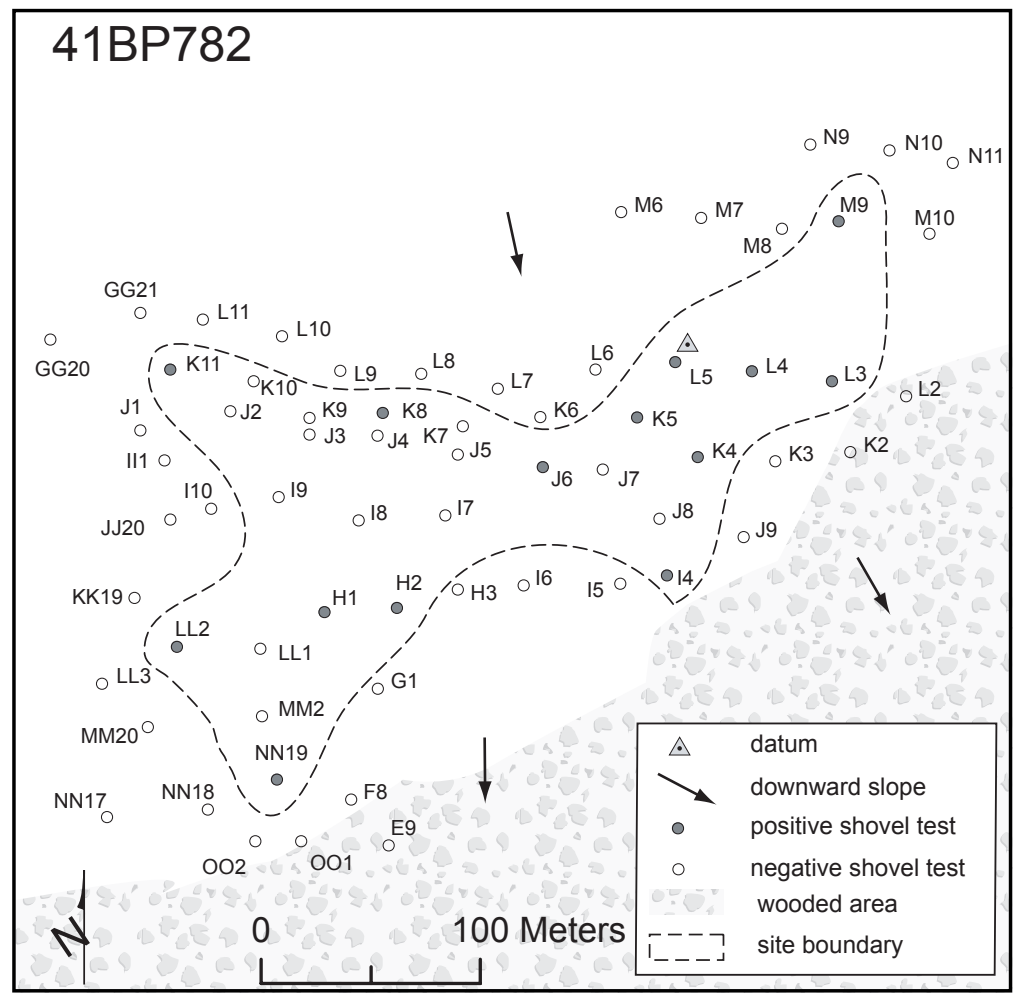

Figure 7-148. Site map of 41BP782. 


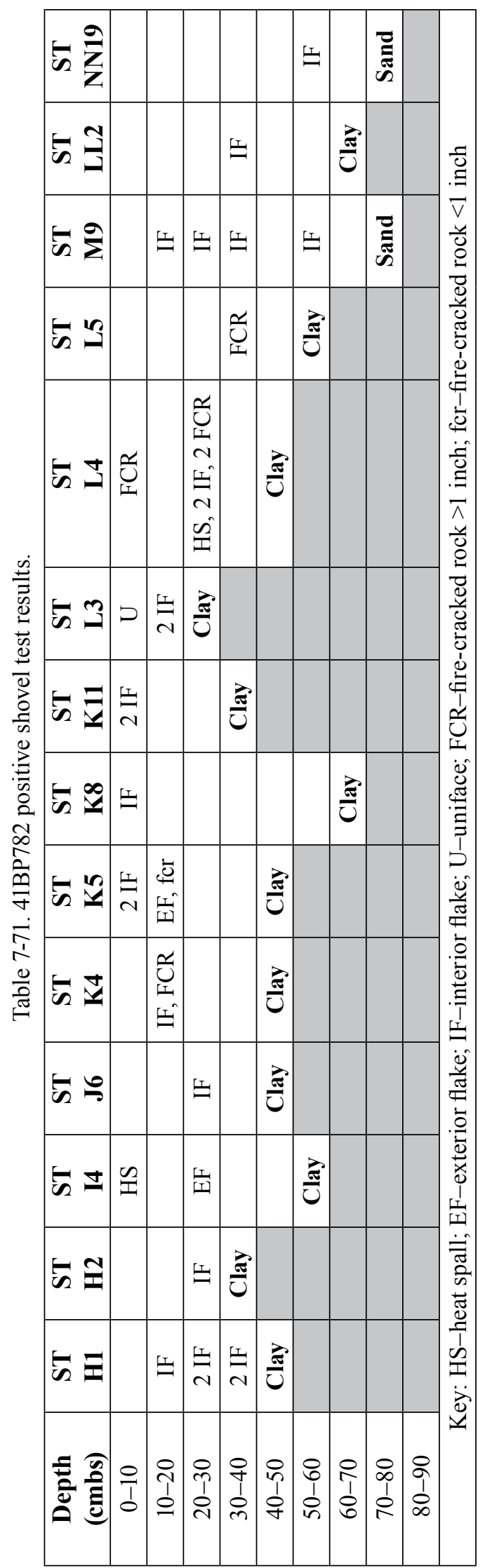

1-m units along the eastern portion of this site, where the ubiquity of burned rocks and lithic debitage is generally greater, specifically in the areas of STs K4, K5, L4, L5, and M9 to determine NRHP eligibility.

\section{BP783}

\section{Description}

A few flakes and a burned rock compose the artifact assemblage found at this open campsite. Covering about $1,048 \mathrm{~m}^{2}$ of a lower terrace, its northern boundary is formed by the floodplain of Dogwood Branch Creek (Figures 7-149 and 7-150). Vegetation includes oaks, cedars, elms, mesquites, beautyberries, Virginia creeper, poison ivy, assorted shrubs, and tall grasses. The surface slopes toward the creek from 422 to $417 \mathrm{ft}$ amsl. Surface visibility was less than five percent in September 2005. The soil type at this site is Uhland (Uh), a clay loam typically found along the floodplains of creeks in this area. Obvious disturbances that could be seen on the surface included typical floodplain erosion, and a few small animal burrows. The datum is marked with a nail and an aluminum tag in an 8 -cm diameter oak tree on the northeastern portion of the site.

\section{Levels of Work and Results}

No artifacts were found on the surface, and only two flakes and a fire-cracked rock were recovered from three out of seven shovel tests excavated on the site (Table 7-72). Colluvial deposition in the form of angular ironstones and sandstones was observed in many of the shovel tests, and the average depth across the site of the Bt horizon is $29 \mathrm{cmbs}$.

\section{Conclusions/Recommendations}

Because of the paucity of artifacts, evidence of colluvial deposition, and shallow soils at this site, its research potential is minimal. CAS recommends that no further work be conducted 


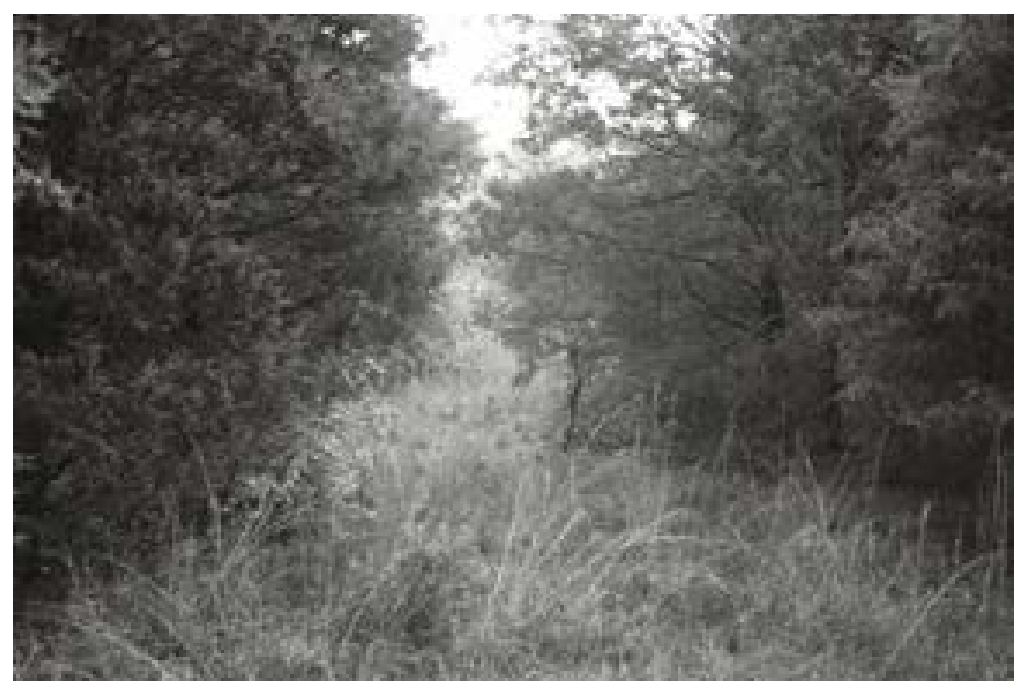

Figure 7-149. 41BP783 is an eroded open campsite on a lower terrace and floodplain of Dogwood Branch Creek; facing east.

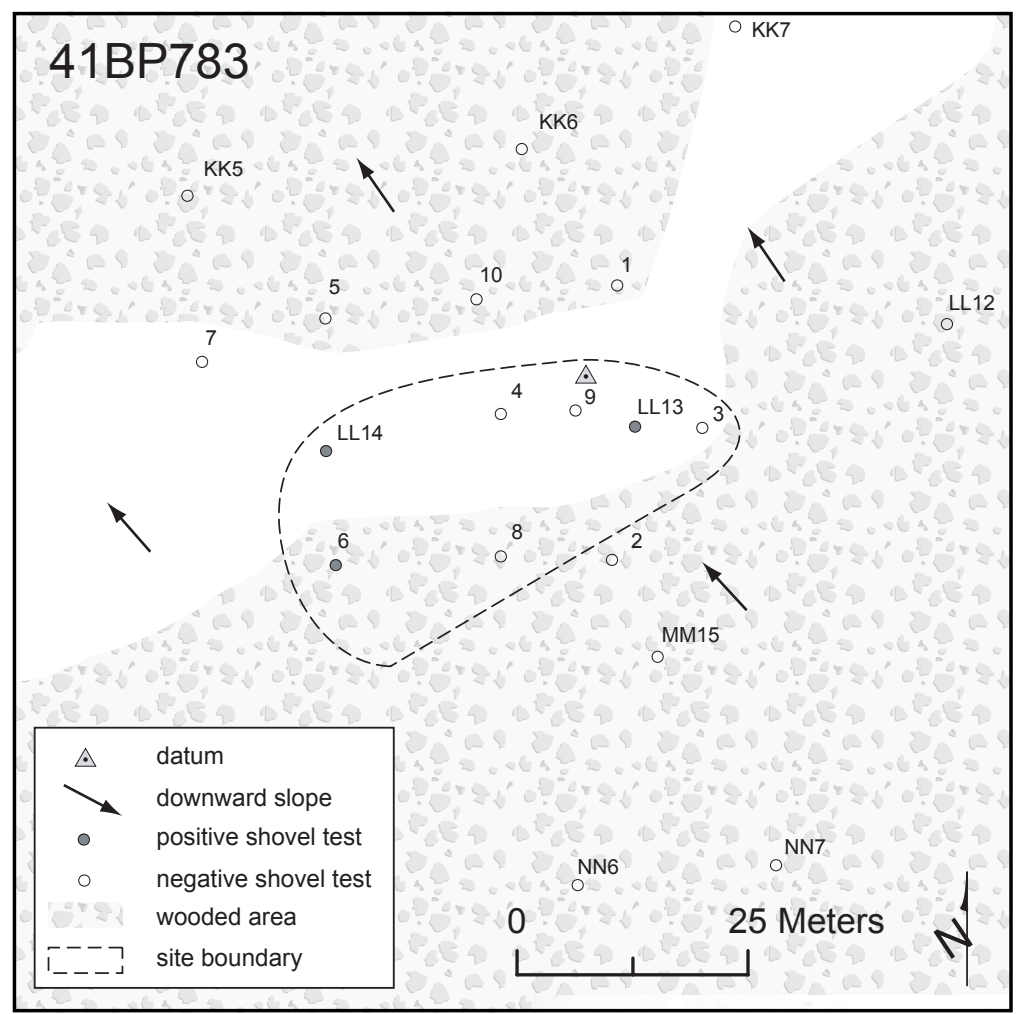

Figure 7-150. Site map of 41BP783. 
Table 7-72. 41BP783 positive shovel test results.

\begin{tabular}{|c|c|c|c|}
\hline $\begin{array}{c}\text { Depth } \\
\text { (cmbs) }\end{array}$ & ST 6 & ST LL13 & ST LL14 \\
\hline $0-10$ & & & \\
\hline $10-20$ & FCR & & \\
\hline $20-30$ & & EF & \\
\hline $30-40$ & Clay & & \\
\hline $40-50$ & & & \\
\hline $50-60$ & & & IF \\
\hline $60-70$ & & Clay & \\
\hline $70-80$ & & & Clay \\
\hline $80-90$ & & & \\
\hline \multicolumn{3}{|c|}{ Key: EF-exterior flake; IF-interior flake; } \\
\hline \multicolumn{4}{|c|}{ FCR-fire-cracked rock >1 inch } \\
\hline
\end{tabular}

and that the site is not eligible for nomination to the NRHP.

\section{BP784}

\section{Description}

41BP784 (Figures 7-151 and 7-152) is composed of a prehistoric component mixed with the remains of a historic farmstead. The historic component is discussed in Chapter 9: New Historic Component Sites. The entire site covers approximately $8,961 \mathrm{~m}^{2}$, and ranges in elevation from 461 to $438 \mathrm{ft}$ amsl. It is situated on a semi-wooded knoll and sideslope $100 \mathrm{~m}$ south of Dogwood Branch Creek. Crockett soils (CsD3) and Uhland soils (Uh) support predominantly large oak, elm, and cedar trees with beautyberry, poison ivy, and prickly pear cacti. Crockett soils are prevalent on fairly steep slopes and are commonly heavily eroded (Baker 1979). Surface visibility was about 15 percent in September 2005. Open areas of the site have been heavily bladed with machinery, push piles are present, some trees have been knocked down, and small animal burrows appear sporadically across the surface. The site datum is marked with a nail and an aluminum tag in a large oak tree $75 \mathrm{~cm}$ in diameter.

\section{Levels of Work and Results}

Although only 15 percent of the surface was visible, two flakes were found on the surface. Table 7-73 lists the prehistoric artifacts found below the surface. Of the 16 shovel tests excavated on the site, 11 were positive. Eight of the 11 positive shovel tests contained prehistoric artifacts. Two of the eight shovel tests with prehistoric artifacts also had historic artifacts in them at the same or nearly the same depths. Five out of eight shovel tests with only prehistoric artifacts were located in a discrete area on the northern portion of the site, but the soils there are generally shallow.

\section{Conclusions/Recommendations}

Because of the mixing of prehistoric and historic artifacts, heavy equipment damage, and shallow soils at this site, the research potential of the prehistoric component is minimal. CAS recommends that no further work be conducted 


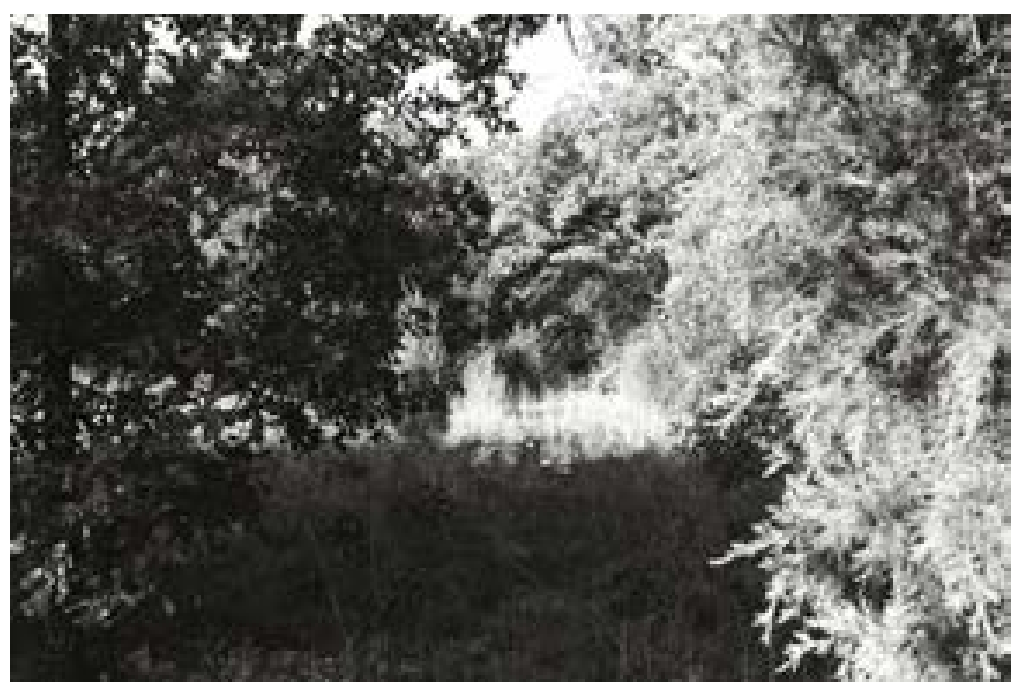

Figure 7-151. 41BP784 is an eroded open campsite on a knoll and slope south of Dogwood Branch Creek; facing west.

FIGURE 7-152. REDACTED

Figure 7-152. Site map of 41BP784. 


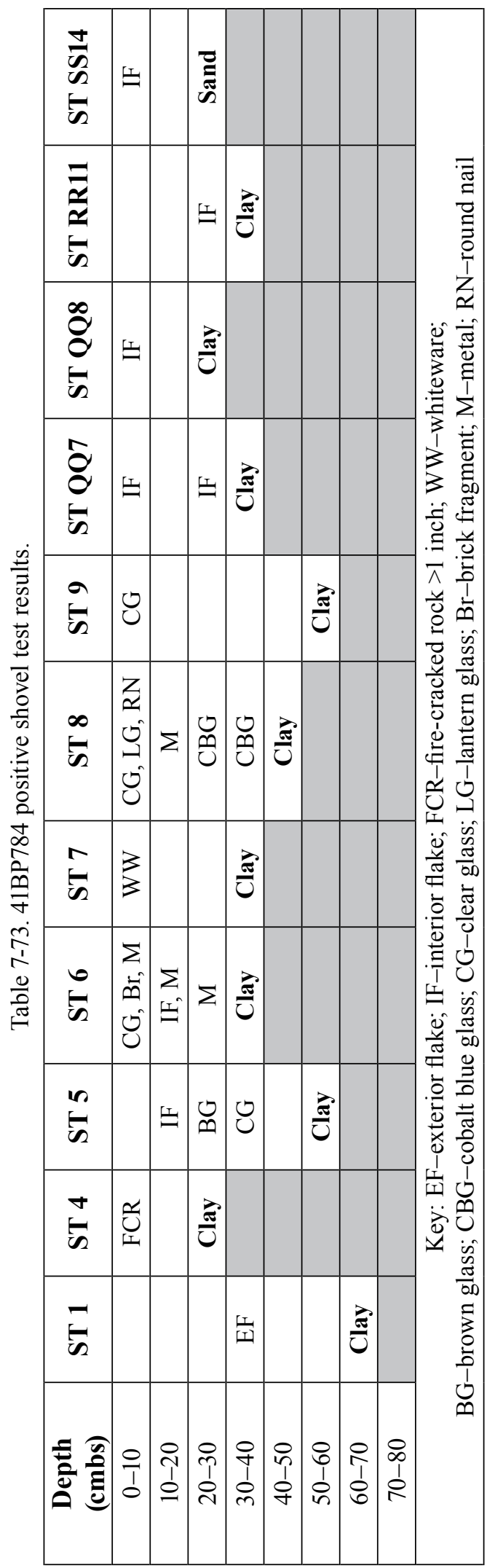

on the prehistoric component of the site and the prehistoric component is not eligible for nomination to the NRHP.

\section{$41 B P 786$}

\section{Description}

An ephemeral scatter of lithic debitage was found in shovel tests on a sideslope, footslope, and lower terrace along Big Sandy Creek, covering an area some 13,682 $\mathrm{m}^{2}$ in size (Figures 7-153 and 7154). It is mostly open field with dense grasses, grapevines, and weeds. Surrounding trees include oaks, cedars, elms, and pecans. The overall slope ranges from 432 to $418 \mathrm{ft}$ amsl. Demona loamy fine sand covers the upper, northern portion while Sayers fine sandy loam (Sa) covers the lower southern portion. Numerous heavy vehicle tracks crisscross the site and significant disturbance to the area is evident in the form of dense patches of prickly pear and pencil cacti, plants which are considered invader species and prefer disturbed habitats. In addition, a 2-m high artificial berm parallels the southern portion of the site, likely sand pushed from the site area. Overall surface visibility was less than five percent in September 2005. The site datum is marked with a nail and an aluminum tag in an oak tree $60 \mathrm{~cm}$ in diameter.

\section{Levels of Work and Results}

No artifacts were observed on the surface, and as shown in Table 7-74, only seven flakes were recovered from six of the 12 shovel test probes excavated within the site's boundaries. Attesting to the widespread disturbances observed on the surface, unidentifiable metal fragments were found in two of the six positive shovel tests. Roots were also encountered in two of the positive shovel tests.

\section{Conclusions/Recommendations}

Because of the obvious disturbance, lack of cultural features and stone tools, and paucity of 


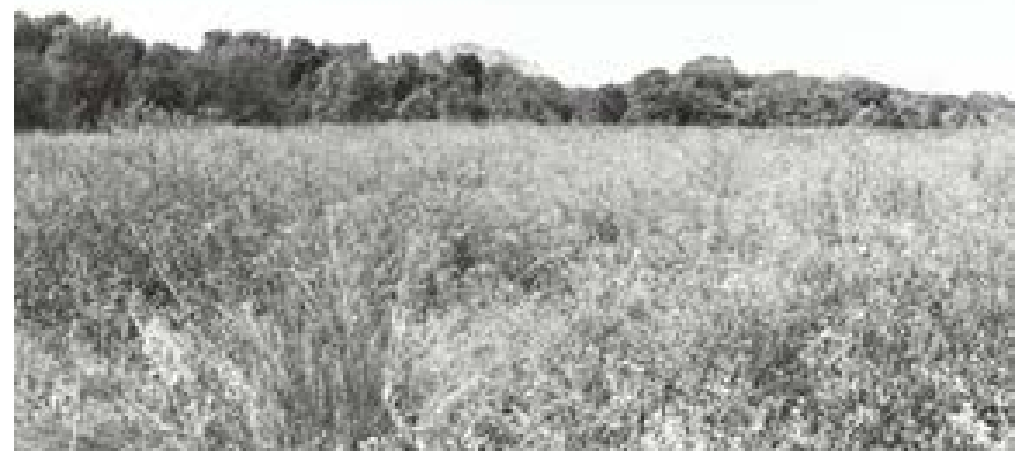

Figure 7-153. 41BP786 is a large open campsite bordering on Big Sandy Creek; facing west.

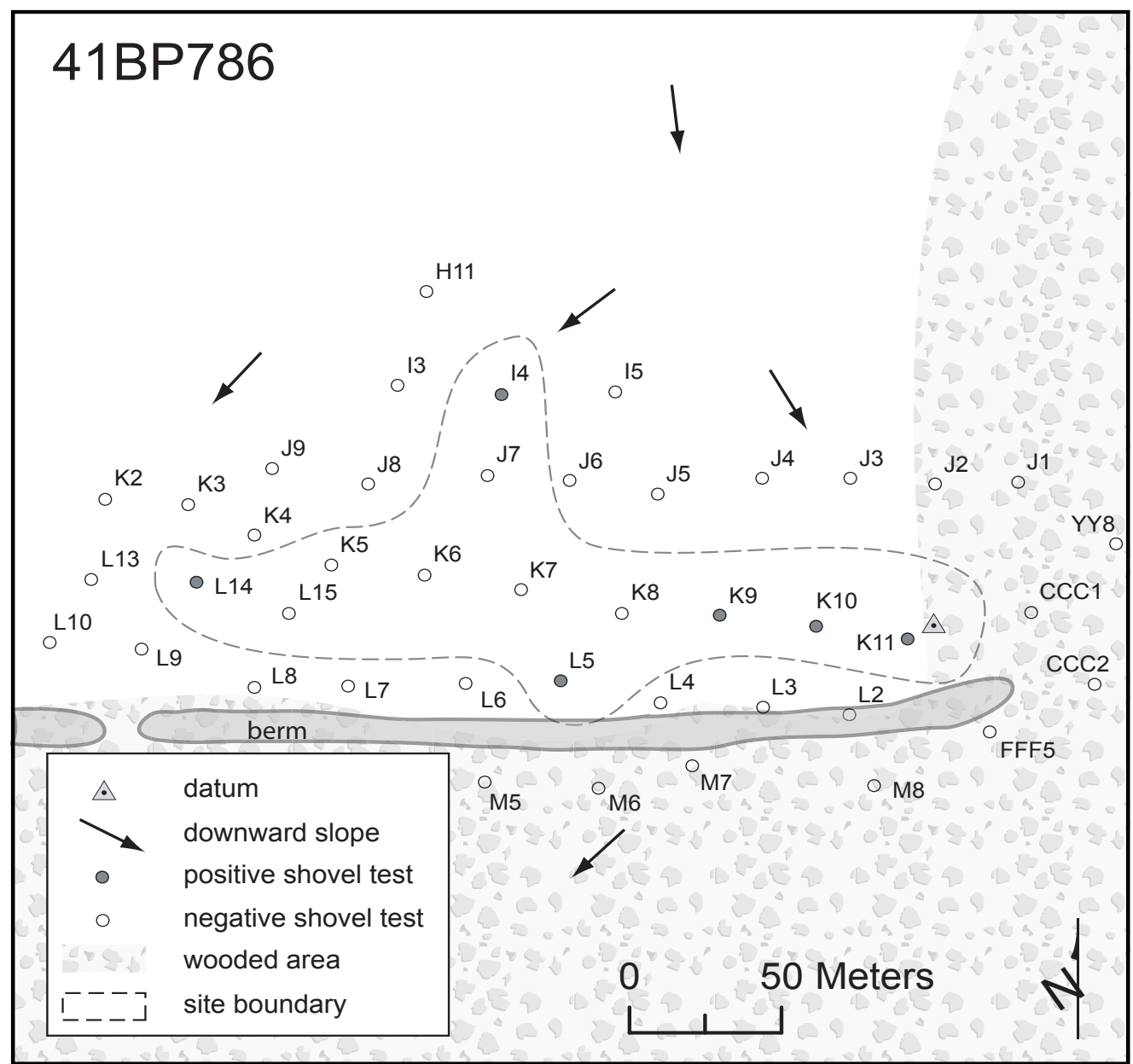

Figure 7-154. Site map of 41BP786. 
Table 7-74. 41BP786 positive shovel test results.

\begin{tabular}{|c|c|c|c|c|c|c|}
\hline $\begin{array}{c}\text { Depth } \\
\text { (cmbs) }\end{array}$ & $\begin{array}{c}\text { ST } \\
\text { I4 }\end{array}$ & $\begin{array}{c}\text { ST } \\
\text { K9 }\end{array}$ & $\begin{array}{c}\text { ST } \\
\text { K10 }\end{array}$ & $\begin{array}{c}\text { ST } \\
\text { K11 }\end{array}$ & $\begin{array}{c}\text { ST } \\
\text { L5 }\end{array}$ & $\begin{array}{c}\text { ST } \\
\text { L14 }\end{array}$ \\
\hline $0-10$ & & & & & & IF, M \\
\hline $10-20$ & EF & & & IF & & \\
\hline $20-30$ & & & M & & & \\
\hline $30-40$ & & & & & & \\
\hline $40-50$ & & 2 IF & & & & \\
\hline $50-60$ & & & & & IF & \\
\hline $60-70$ & & & IF, M & & & \\
\hline $70-80$ & Sand & Sand & & Sand & Sand & Sand \\
\hline $80-90$ & & & Sand & & & \\
\hline $90-100$ & & & & & & \\
\hline \multicolumn{7}{|l|}{ Key: EF-exterior flake; IF-interior flake; M-metal } \\
\hline
\end{tabular}

debitage, the research potential here is minimal. CAS recommends that no further work be conducted and that the site is not eligible for nomination to the NRHP.

\section{BP787}

\section{Description}

The western edge of this open campsite (Figures 7-155 and 7-156) lies next to the 4-m steep slope and cutbank of Spring Branch Creek, the only constantly flowing creek on Camp Swift. A few artifacts have apparently eroded down the slope so that now the entire site drops from 441 feet in its northern portion to $420 \mathrm{ft}$ amsl in its southern, floodplain portion. Based upon shovel test results, the site is approximately 4,667 $\mathrm{m}^{2}$ in size. It is heavily wooded with elms, oaks, and cedars, and with beautyberries and thorny vines as understory. Uhland soils (Uh) cover this footslope setting.
Surface visibility was less than five percent in September 2005. Obvious surface disturbances included some treefalls, a few medium-size animal burrows, erosion along the steep slope by Spring Branch, and barbed wire strand on the eastern edge of the site. The datum is marked with a nail and an aluminum tag in an oak tree with double trunks, both $40 \mathrm{~cm}$ in diameter.

\section{Levels of Work and Results}

No artifacts were found on the surface. The area has obviously been a good hunting area in historic times because two spent shotgun shells were found in shovel tests, the deepest at 20-30 cmbs. Finding them at that depth is problematic, but fire-cracked rock and flakes (with no historic items) were found stratigraphically consistent between 30 and $60 \mathrm{cmbs}$ in eight of the 10 positive shovel tests (Table 7-75). A total of seven

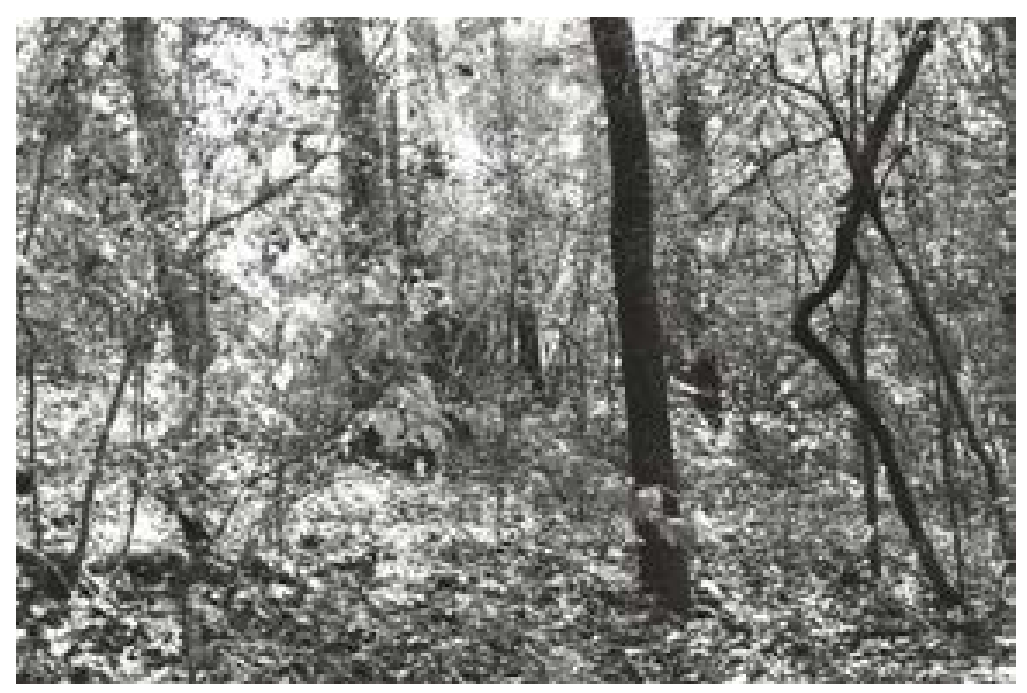

Figure 7-155. 41BP787 is an open campsite on a heavily wooded footslope by Spring Branch; facing east. 
FIGURE 7-156. REDACTED

Figure 7-156. Site map of 41BP787.

Table 7-75. 41BP787 positive shovel test results.

\begin{tabular}{|c|c|c|c|c|c|c|c|c|c|c|}
\hline $\begin{array}{c}\text { Depth } \\
\text { (cmbs) }\end{array}$ & ST 1 & ST 2 & ST 3 & ST 4 & ST 5 & ST 6 & ST 7 & ST G1 & ST G3 & ST J4 \\
\hline $0-10$ & & & & & & & & & & SG \\
\hline $10-20$ & & & IF & & & & IF, FCR & & & \\
\hline $20-30$ & & FCR & & & & & SG & & & \\
\hline $30-40$ & & & & & & & & & IF & IF, FCR \\
\hline $40-50$ & & Clay & & & & IF & & FCR & & \\
\hline $50-60$ & FCR & & & EF & FCR & & FCR & & & IF \\
\hline $60-70$ & & & & & & & & & & \\
\hline $70-80$ & Sand & & Sand & Sand & Sand & Sand & Sand & Sand & Sand & Sand \\
\hline $80-90$ & & & & & & & & & & \\
\hline \multicolumn{2}{|l|}{ Key: EF-exterior flake; IF-interior flake; FCR-fire-cracked rock >1 inch; SG-shotgun shell } \\
\hline
\end{tabular}

fire-cracked rocks and seven flakes were found in 10 of the 12 shovel tests excavated within the site's boundaries. The only disturbances noted within the shovel tests were from a very active root system.

\section{Conclusions/Recommendations}

With the presence of buried fire-cracked rocks and minimal disturbance detected from shovel tests, the potential exists for intact hearths and associated cultural material to exist below the surface. But without further investigations beyond the scope of this inventory survey, the 
research potential at this site is unknown. CAS recommends excavation of five 1-x-1-m units, one unit in each of the immediate areas of STs 1, 5, 7, G1, and J4 to determine NRHP eligibility.

\section{BP788}

\section{Description}

This open campsite covers an area of 8,650 $\mathrm{m}^{2}$ (Figures 7157 and 7-158) and is situated on a footslope and floodplain on Dogwood Branch Creek. Crockett soils ( $\mathrm{CsC} 2$ ) comprise the southern footslope portion, while Uhland soils (Uh) make up the floodplain area. The overall slope from south to north is from 437 feet to $425 \mathrm{ft}$ amsl. The areas void of trees appear to have recently been cleared with heavy machinery, and machinery tracks are common across the site. Vegetation consists of oaks, cedars, elms, mesquites, sumacs, beautyberries, shrubs, and tall grasses. Accordingly, surface visibility ranges from less than five percent in the woods to perhaps as high as 20 percent in the clearings. The datum is marked with a nail and aluminum tag on an oak tree 10 $\mathrm{cm}$ in diameter.

\section{Levels of Work and Results}

Raw materials in the form of chert and sandstone cobbles were seen occasionally on the surface, but no artifacts were seen on the surface. Table 7-76 lists the artifacts found in five shovel test probes out of seven placed

Figure 7-158. Site map of 41BP788.

Figure 7-157. 41BP788 is an open campsite on a footslope and floodplain alongside Dogwood Branch Creek; facing north.

\section{FIGURE 7-158. REDACTED}

on the site. Although seven flakes were found in ST II2, they were mixed with angular ironstones, angular sandstones, and pieces of petrified wood, suggesting that they were in a colluvial deposition context. The same is true for STs KK4 and LL3. 
Table 7-76. 41BP788 positive shovel test results.

\begin{tabular}{|c|c|c|c|c|c|}
\hline $\begin{array}{c}\text { Depth } \\
\text { (cmbs) }\end{array}$ & $\begin{array}{c}\text { ST } \\
\text { II2 }\end{array}$ & $\begin{array}{c}\text { ST } \\
\text { JJ3 }\end{array}$ & $\begin{array}{c}\text { ST } \\
\text { JJ4 }\end{array}$ & $\begin{array}{c}\text { ST } \\
\text { KK4 }\end{array}$ & $\begin{array}{c}\text { ST } \\
\text { LL3 }\end{array}$ \\
\hline $0-10$ & & & & IF & \\
\hline $10-20$ & & IF & $\begin{array}{c}\text { EF, IF, } \\
4 \text { FCR }\end{array}$ & & \\
\hline $20-30$ & 2 IF & & 4 FCR & & \\
\hline $30-40$ & EF, IF & Clay & Clay & Clay & \\
\hline $40-50$ & 2 IF & & & & \\
\hline $50-60$ & IF & & & & IF \\
\hline $60-70$ & & & & & \\
\hline $70-80$ & Sand & & & & Sand \\
\hline $80-90$ & \multicolumn{5}{|c|}{} \\
\hline \multicolumn{7}{|c|}{ Key: EF-exterior flake; IF-interior flake; } \\
FCR-fire-cracked rock >1 inch \\
\hline
\end{tabular}

Although eight fire-cracked rocks and 2 flakes were found in ST JJ4, the soils in that area are generally shallow and likely mixed.

\section{Conclusions/Recommendations}

The cultural material at this site has been negatively impacted by heavy machinery and colluvial movement, and is within shallow soils which could be easily mixed by the above

recommends that no further investigations are warranted and the site is not eligible for nomination to the NRHP.

\section{$41 B P 789$}

\section{Description}

41BP789 (Figures 7-159 and $7-160)$ is a small $\left(555 \mathrm{~m}^{2}\right)$ open campsite that lies on a lower terrace adjacent to Dogwood Branch Creek, between 432 and $430 \mathrm{ft}$ amsl. Maneuver Road runs along its eastern boundary, and there are heavy equipment

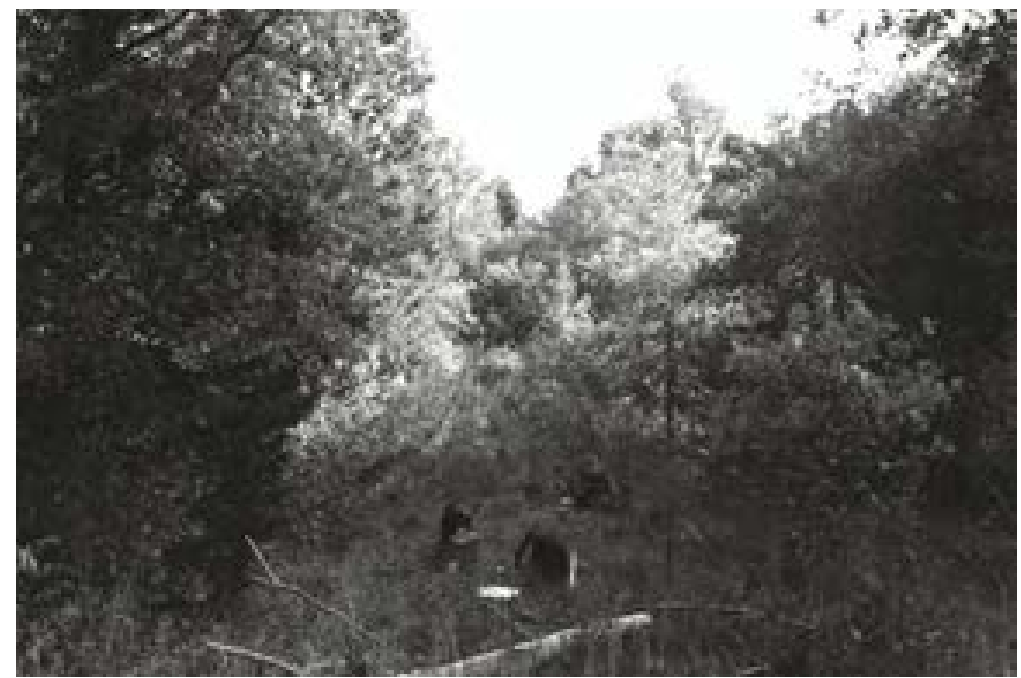

Figure 7-159. 41BP789 is a small open campsite on a lower terrace of Dogwood Branch Creek; facing northeast. 
FIGURE 7-160. REDACTED

Figure 7-160. Site map of 41BP789.

Table 7-77. 41BP789 positive shovel test results.

\begin{tabular}{|c|c|c|c|}
\hline $\begin{array}{c}\text { Depth } \\
\text { (cmbs) }\end{array}$ & ST 3 & ST 5 & ST FF6 \\
\hline $0-10$ & IF & & \\
\hline $10-20$ & & HS & \\
\hline $20-30$ & & IF & \\
\hline $30-40$ & Clay & IF & EF, IF \\
\hline $40-50$ & & Clay & IF \\
\hline $50-60$ & & & FCR \\
\hline $60-70$ & & & Clay \\
\hline $70-80$ & & & \\
\hline $\begin{array}{r}\text { Key: HS-heat spall; EF-exterior flake; } \\
\text { IF-interior flake; FCR-fire-cracked rock }>1 \text { inch }\end{array}$ \\
\hline
\end{tabular}


colluvial movement. Therefore, CAS recommends that no further investigations are warranted and the site is not eligible for nomination to the NRHP.

\section{BP790}

\section{Description}

With only lithic debitage and no firecracked rocks, CAS categorizes this 2,212- $\mathrm{m}^{2}$ site as a lithic scatter (Figures 7-161 and 7-162). It is approximately 60 meters

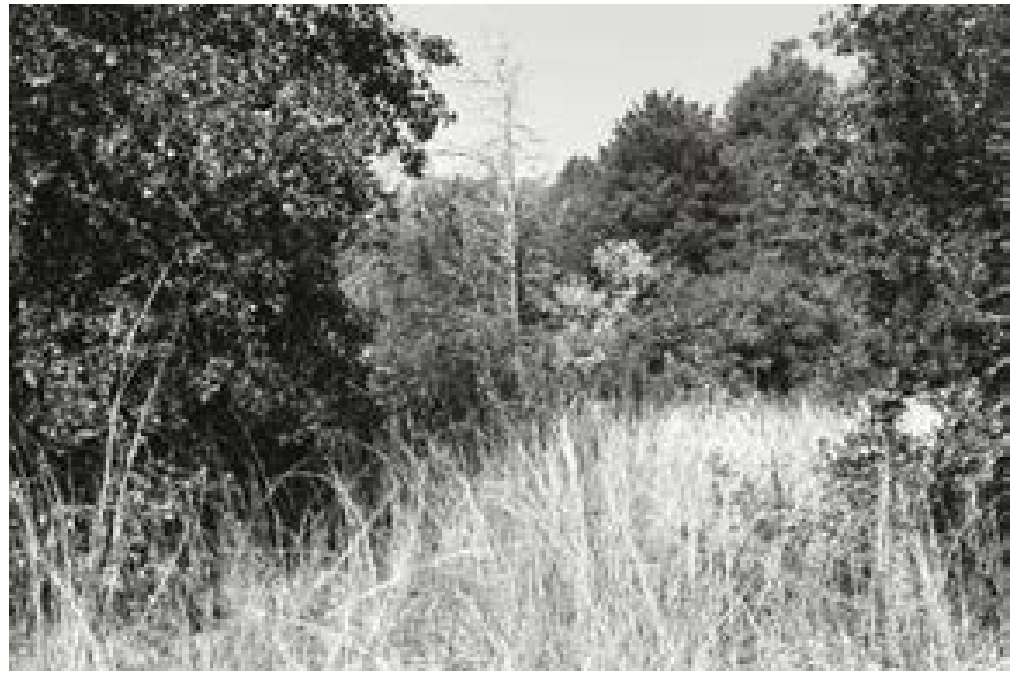

Figure 7-161. 41BP790 is a lithic scatter on an inside meander of Dogwood Branch Creek; facing northwest.

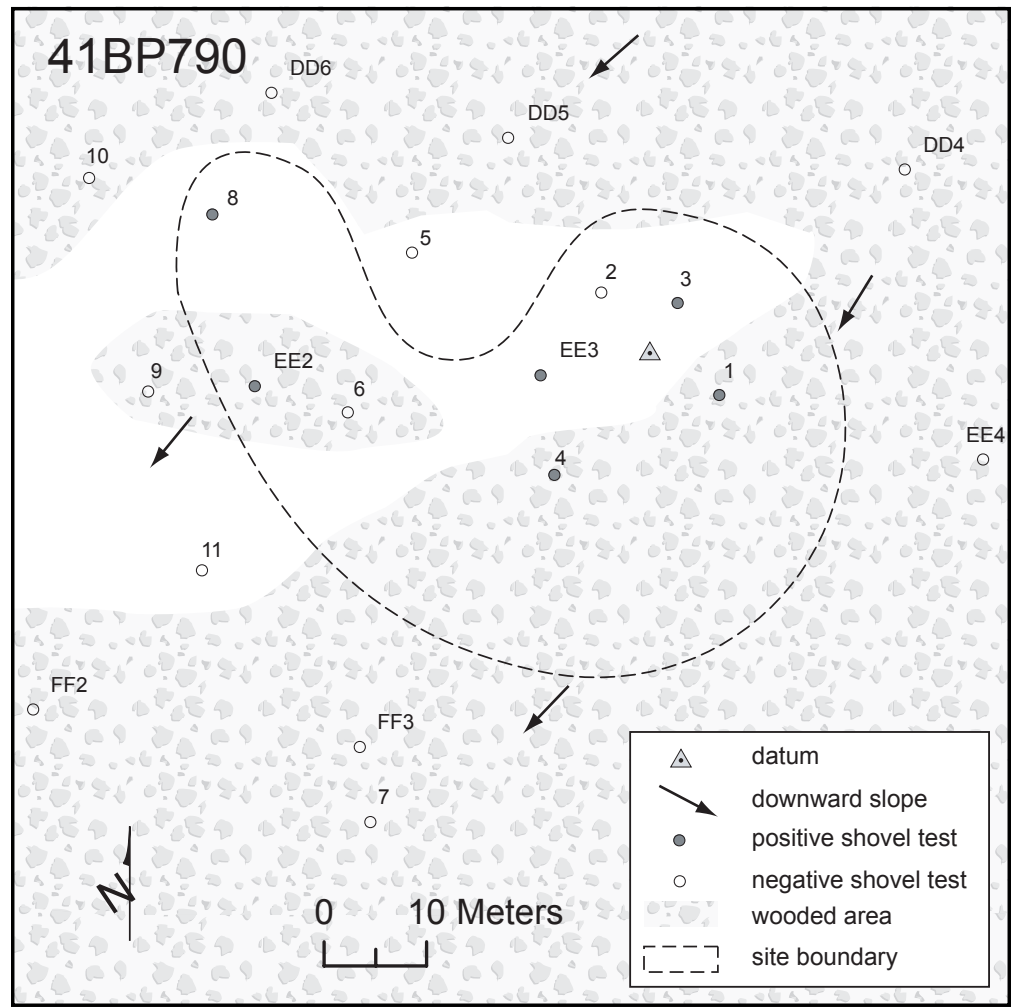

Figure 7-162. Site map of 41BP790. northwest of 41BP789, and is located on an inside meander of Dogwood Branch on a lower footslope. Its southern edge skirts the floodplain of the creek. Soils representing the footslope and floodplain conjoin; the upper, northern 90 percent of the site is covered with Demona loamy fine sand $(\mathrm{DeC})$, and the lower 10 percent is covered with Uhland soils (Uh). There is a gentle slope here, between 436 and $433 \mathrm{ft}$ amsl. The area may have been cleared at one time, but today there are cedars, oaks, elms, sumacs, chinaberries, beautyberries, poison ivy, ferns, and assorted shrubs and grasses. Surface visibility was less than five percent in September 2005. The datum is marked with a nail and aluminum tag on an oak tree $30 \mathrm{~cm}$ in diameter.

\section{Levels of Work and Results}

No artifacts were seen on the surface. Based upon shovel test results, the average soil depth across the site is $40 \mathrm{cmbs}$. A chert chip and seven flakes were found in six out of eight shovel tests excavated on the site (Table 7-78). Angular ironstones were noted in STs 2, 5, 8, and EE3, and angular sandstones 
Table 7-78. 41BP790 positive shovel test results.

\begin{tabular}{|c|c|c|c|c|c|c|}
\hline $\begin{array}{c}\text { Depth } \\
\text { (cmbs) }\end{array}$ & ST 1 & ST 3 & ST 4 & ST 8 & ST EE2 & ST EE3 \\
\hline $0-10$ & & EF & & & & \\
\hline $10-20$ & EF & & EF & IF & CC, IF & \\
\hline $20-30$ & IF & Clay & & Clay & & IF \\
\hline $30-40$ & Clay & & Clay & & & Clay \\
\hline $40-50$ & & & & & Clay & \\
\hline $50-60$ & & & & & & \\
\hline \multicolumn{7}{|c|}{ Key: CC-chert chip; EF-exterior flake; IF-interior flake } \\
\hline
\end{tabular}

with petrified woods were observed in ST EE2. Otherwise, roots were commonly found in all shovel tests.

\section{Conclusions/Recommendations}

Without evidence of intact features, good organic preservation, or diagnostic stone tools, the research potential at this site is minimal. Additionally, colluvial disturbance in generally shallow soils has apparently affected the integrity of the lithic debitage discovered. In sum, CAS recommends that no further investigations are warranted and the site is not eligible for nomination to the NRHP. likely cleared in historic times. There are a few tree falls and animal burrows both on the site and in the surrounding area. The soil type on this footslope terrain feature is of the Crockett Series (CsC2). The surface slopes north to south from 451 to $441 \mathrm{ft}$ amsl. Surface visibility was less than five percent in September 2005. The datum is marked with a nail and aluminum tag on an oak tree $22 \mathrm{~cm}$ in diameter.

\section{Levels of Work and Results}

The only artifact seen on the surface was a sandstone, dual purpose mano/metate measuring $11 \mathrm{~cm}$ long x $9 \mathrm{~cm}$ wide x $3 \frac{1}{2} \mathrm{~cm}$ thick (Figure 7165). Superficial grinding on its concave ventral surface suggests that it was used as a metate, while grinding on its convex dorsal surface suggests its use as a mano. A total of six fire-cracked rocks and 13 flakes were found in seven of the eight shovel tests placed on the site (Table 7-79).

Although archaeologists noted angular ironstones in STs N5 and P17, unlike many sites close to

\section{BP792}

\section{Description}

Near the confluence of an intermittent drainage and Dogwood Branch Creek is a $3,607-\mathrm{m}^{2}$ open campsite designated as 41BP792 (Figures 7-163 and 7-164). The channel of Dogwood is $50 \mathrm{~m}$ to the south. Most of the site is in an open grassy area, but it is surrounded by loblolly pines, oaks, cedars, and mesquites. Much of it appears to be secondary growth, indicating that the area was

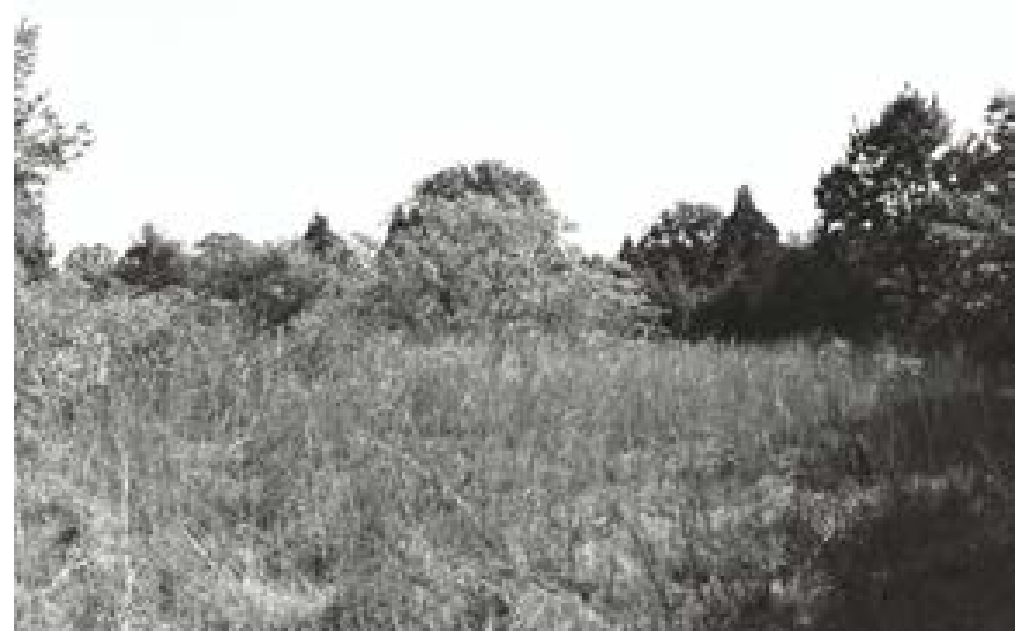

Figure 7-163. 41BP792 is an open campsite along Dogwood Branch Creek; facing east. 


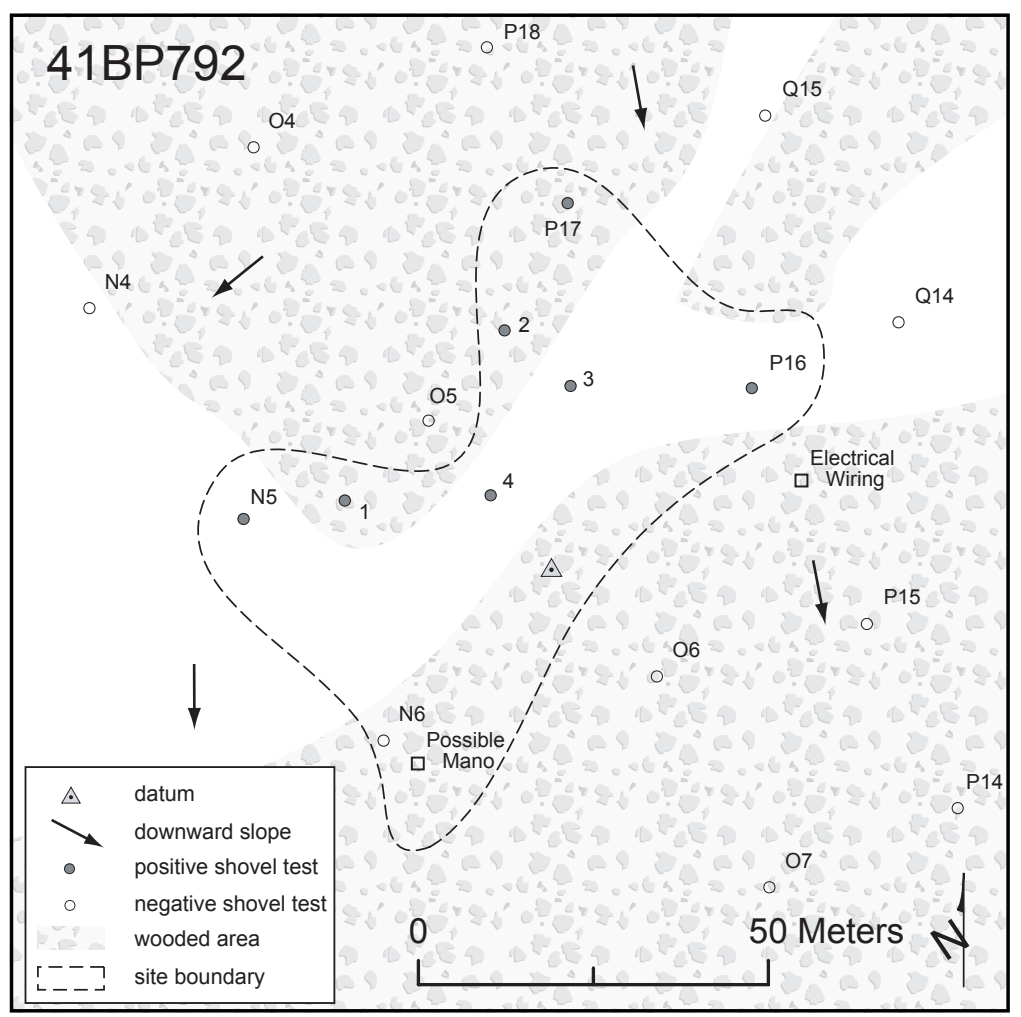

Figure 7-164. Site map of 41BP792.

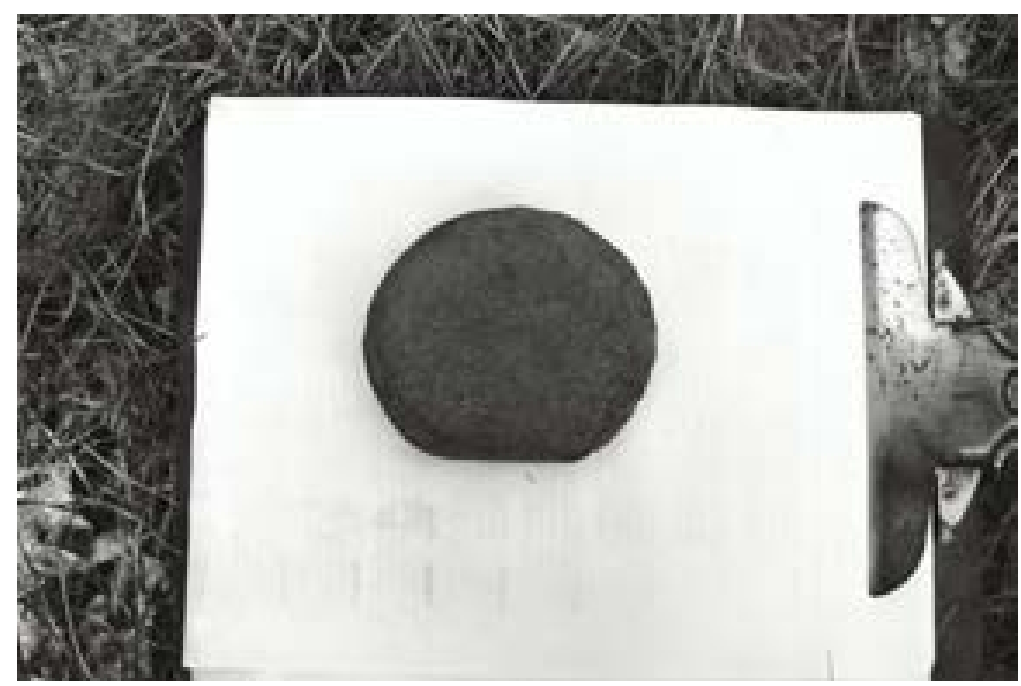

Figure 7-165. This sandstone mano/metate was found on the surface at $41 \mathrm{BP} 792$.

the creeks at

Camp Swift, very little disturbance in the form of colluvial deposits were obvious on this site. The concentration of fire-cracked rocks encountered in ST P16 consisted of one quartzite piece larger than $10 \mathrm{~cm}$ in size and three sandstone pieces larger than $7 \mathrm{~cm}$ in size. 
Table 7-79. 41BP792 positive shovel test results.

\begin{tabular}{|c|c|c|c|c|c|c|c|}
\hline $\begin{array}{c}\text { Depth } \\
\text { (cmbs) }\end{array}$ & ST 1 & ST 2 & ST 3 & ST 4 & $\begin{array}{c}\text { ST } \\
\text { N5 }\end{array}$ & $\begin{array}{c}\text { ST } \\
\text { P16 }\end{array}$ & $\begin{array}{c}\text { ST } \\
\text { P17 }\end{array}$ \\
\hline $0-10$ & & & & & IF & IF & 2 IF \\
\hline $10-20$ & & 3 IF & fcr & & IF & & \\
\hline $20-30$ & & & & EF & & 5 FCR & \\
\hline $30-40$ & IF & & & & Clay & & \\
\hline $40-50$ & IF & EF & & & & & \\
\hline $50-60$ & IF & & & Clay & & & \\
\hline $60-70$ & & & Clay & & & & \\
\hline $70-80$ & Sand & Clay & & & & Clay & Clay \\
\hline $80-90$ & & & & & & & \\
\hline \multicolumn{7}{|c|}{ Key: EF-exterior flake; IF-interior flake; } \\
FCR-fire-cracked rock >1 inch; fcr-firecracked rock $<1$ inch \\
\hline
\end{tabular}

\section{Conclusions/Recommendations}

The results of shovel tests indicate that the majority of this site is likely relatively undisturbed. The concentration of burned rock found in ST P16 suggests that there could be intact hearths with associated stone tools and charcoal below the surface. In order to further evaluate the research potential of this site, CAS recommends excavation of two 1-x-1-m units, one unit in the immediate area of ST P16 and another one in the immediate area of ST 3 to determine NRHP eligibility. from 462 to $461 \mathrm{ft}$ amsl. An open grassland area is surrounded by woods of oaks, cedars, mesquites and sumacs. The estimated surface visibility in October 2005 was ten percent. A bulldozer cut along the eastern edge of the site, and the overall surface across the site is hummocky. The datum is marked with a nail and an aluminum tag on an oak tree $20 \mathrm{~cm}$ in diameter.

\section{Levels of Work and Results}

No artifacts were observed on the surface, but a heat spall, three pieces of fire-cracked rocks, and seven flakes were found in eight out of nine shovel tests excavated on the site (Table 7-80). Evidence of disturbed soils noted in the shovel tests included the presence of petrified wood pieces, roots, and clods (not commonly found in sandy loam on Camp Swift). Also, a spent bullet casing was found in the upper $10 \mathrm{cmbs}$ of ST O14. The average depth of sandy loam across the site is just over 35 cmbs.

\section{BP796}

\section{Description}

41BP796 (Figures 7-166 and 7-167) is an open campsite covering approximately 1,384 $\mathrm{m}^{2}$ on a low ridge of Axtell fine sandy loam (AfC2 and AfE2). The prominent landform extends northwest toward the confluence of an intermittent drainage and Dogwood Branch Creek. Dogwood's channel lies $180 \mathrm{~m}$ to the north. The terrain across the site is nearly level, dropping

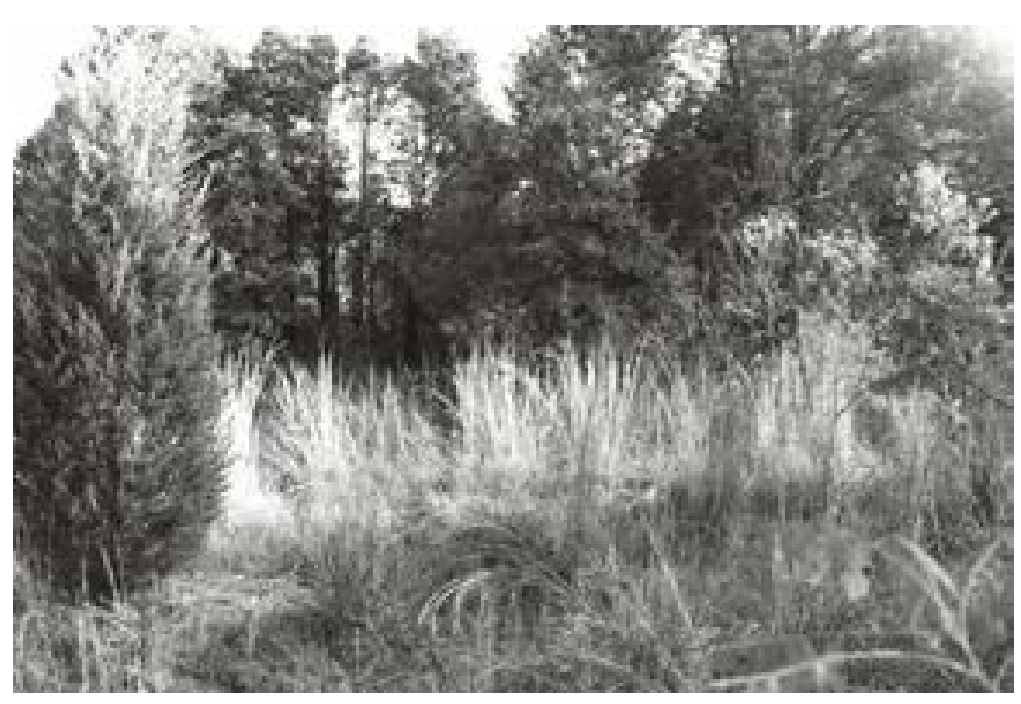

Figure 7-166. 41BP796 is an open campsite on a low ridge above Dogwood Branch Creek; facing northeast. 


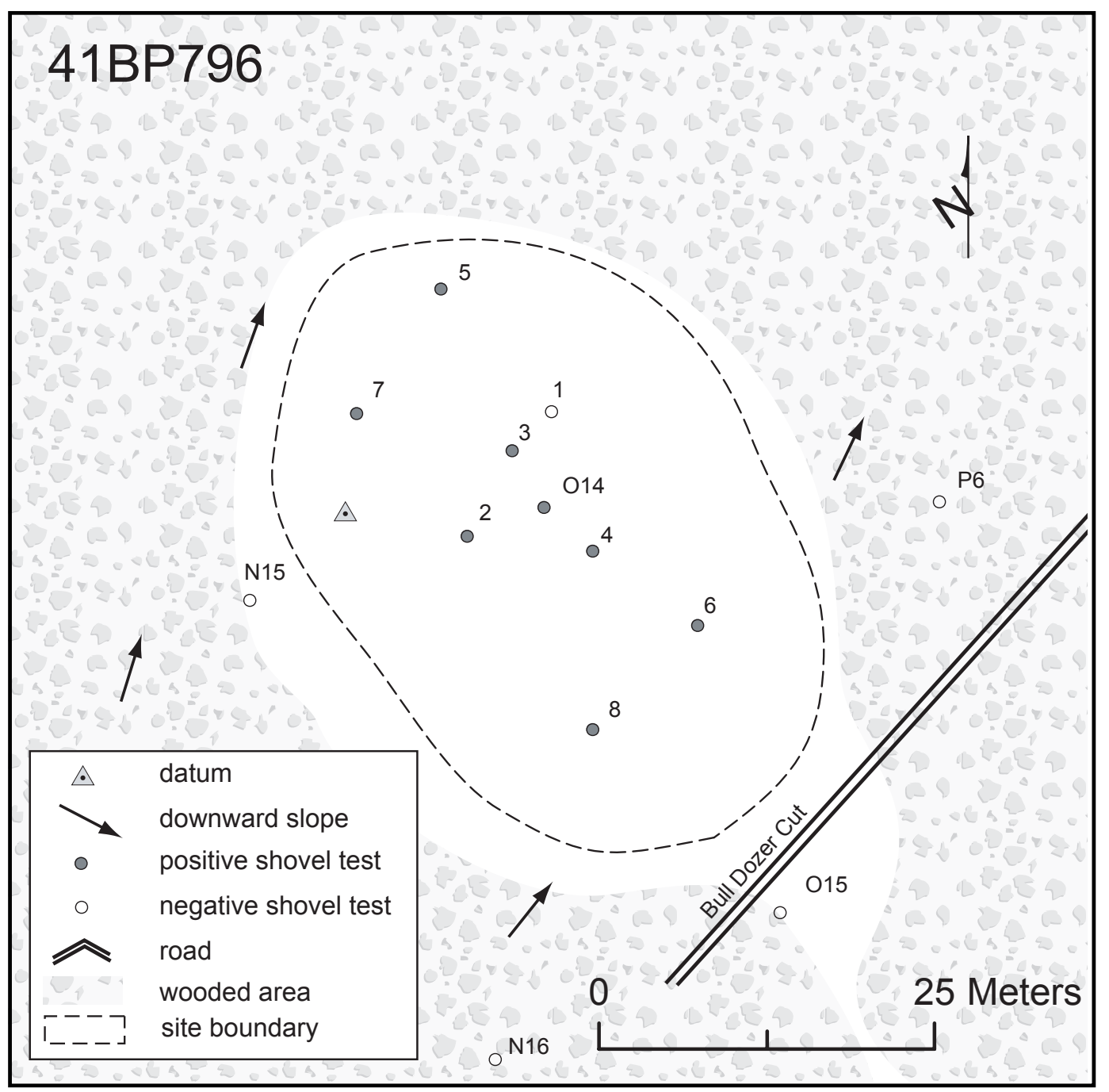

Figure 7-167. Site map of 41BP796.

Table 7-80. 41BP796 positive shovel test results.

\begin{tabular}{|c|c|c|c|c|c|c|c|c|}
\hline Depth (cmbs) & ST 2 & ST 3 & ST 4 & ST 5 & ST 6 & ST 7 & ST 8 & ST O14 \\
\hline $0-10$ & & & & & & 2 IF & & Bu \\
\hline $10-20$ & & IF & FCR & IF & & & IF & \\
\hline $20-30$ & IF & & & & & HS & & \\
\hline $30-40$ & & Clay & & Clay & fcr & Clay & Clay & IF \\
\hline $40-50$ & Clay & & Clay & & Clay & & & FCR \\
\hline $50-60$ & & & & & & & & \\
\hline $60-70$ & & & & & & & & \\
\hline $70-80$ & & & & & & & & Loam \\
\hline $80-90$ & & & & & & & & \\
\hline
\end{tabular}

Key: HS-heat spall; IF-interior flake; FCR-fire-cracked rock $>1$ inch; fcr-fire-cracked rock $<1$ inch; $\mathrm{Bu}-$ bullet 


\section{Conclusions/ \\ Recommendations}

Even though the firecracked rock suggests that a burned rock hearth was present at this site, the results of shovel tests indicate that subsurface disturbances have occurred, as well as disturbances on the surface. Thus, the integrity of cultural material has been negatively impacted to the extent that the research potential at this site is minimal. Therefore, CAS recommends that no further investigations are warranted and the site is not eligible for nomination to the NRHP.

\section{BP797}

\section{Description}

Situated on a sideslope, 41BP797 (Figures 7-168 and 7169) is an open campsite covering approximately $6,584 \mathrm{~m}^{2}$. It is semi-open woodland, with oaks, cedars, mesquites, and pines growing in Axtell fine sandy loam (AfC). The southern tip of the site borders an intermittent drainage of Dogwood Branch Creek. The surface slopes to the west, from 472 to $450 \mathrm{ft}$ amsl. The estimated surface visibility in October 2005 was about 10 percent. There were no obvious site disturbances visible on the surface. The datum is marked with a nail and an aluminum tag on an oak tree $15 \mathrm{~cm}$ in diameter.

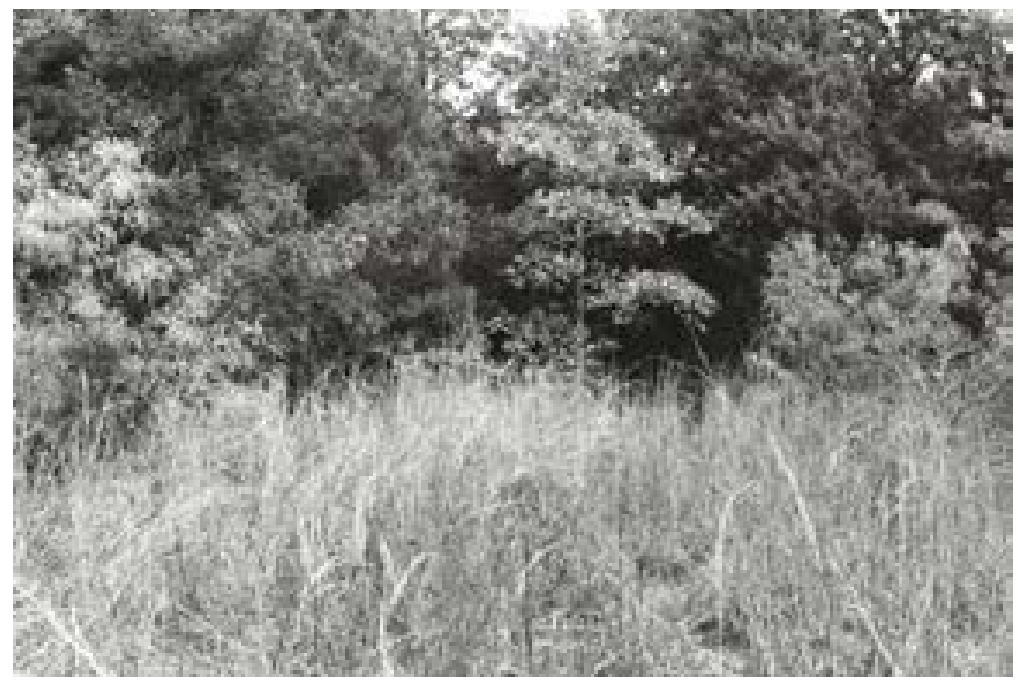

Figure 7-168. 41BP797 is an open campsite on a sideslope near Dogwood Branch Creek; facing north.

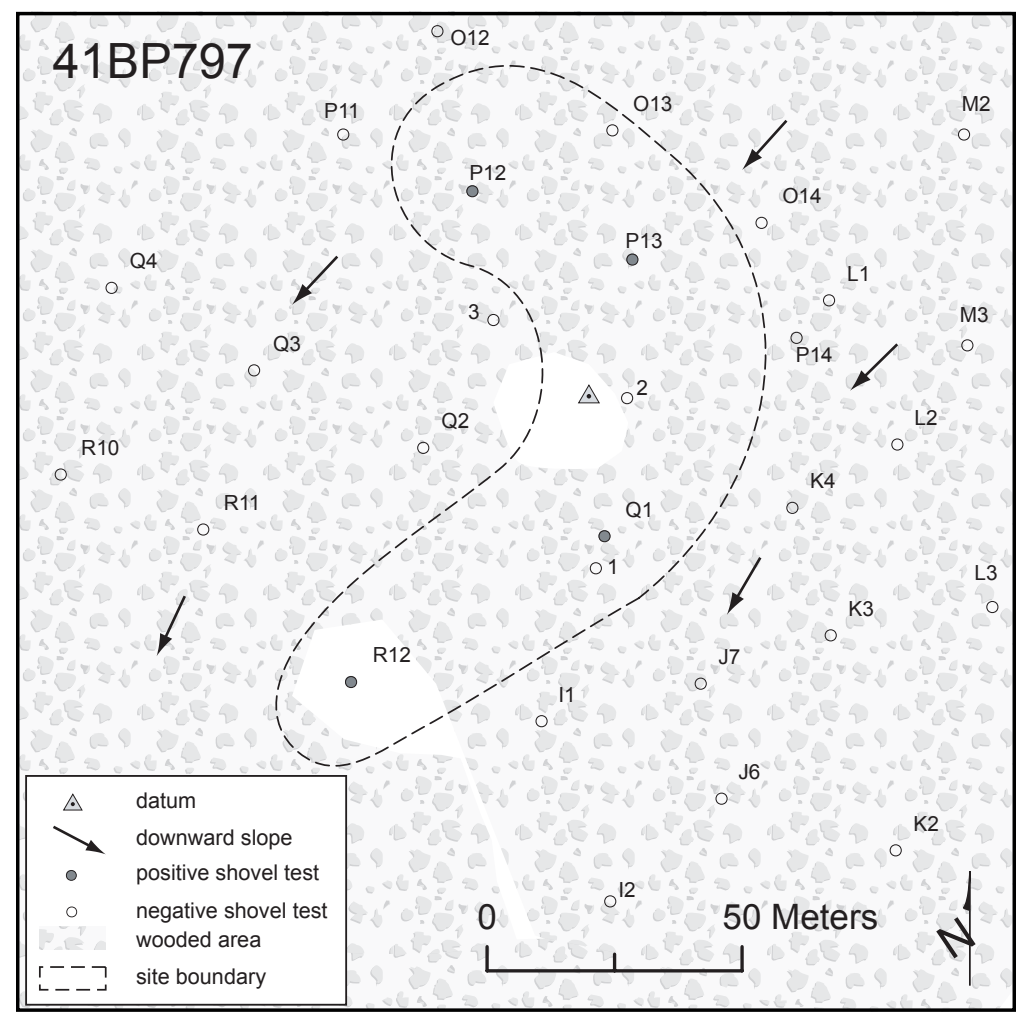

Figure 7-169. Site map of 41BP797.

\section{Levels of Work and Results}

No artifacts were observed on the surface. A tiny piece of fire-cracked rock, a blade with a unifacially utilized edge, and seven flakes were found in four of the seven shovel tests placed on 
Table 7-81. 41BP797 positive shovel test results.

\begin{tabular}{|c|c|c|c|c|}
\hline $\begin{array}{l}\text { Depth } \\
(\mathrm{cmbs})\end{array}$ & $\begin{array}{c}\text { ST } \\
\text { P12 } \\
\end{array}$ & $\begin{array}{c}\text { ST } \\
\text { P13 } \\
\end{array}$ & $\begin{array}{l}\text { ST } \\
\text { Q1 }\end{array}$ & $\begin{array}{c}\text { ST } \\
\text { R12 } \\
\end{array}$ \\
\hline $0-10$ & & & & IF \\
\hline $10-20$ & & IF, U, fcr & & IF \\
\hline $20-30$ & & & IF & \\
\hline $30-40$ & & & Clay & Clay \\
\hline $40-50$ & IF & & & \\
\hline $50-60$ & EF & & & \\
\hline $60-70$ & IF & & & \\
\hline $70-80$ & Clay & Clay & & \\
\hline $80-90$ & & & & \\
\hline $\begin{array}{l}\text { Key: } \\
\text { U-u1 }\end{array}$ & $f$ & lake; IF & erior & \\
\hline
\end{tabular}

the site (Table 7-81). Other than a few roots, there was no evidence of significantly disturbed soils noted from shovel tests. The average depth of sandy loam across the site is just over $51 \mathrm{cmbs}$.

\section{Conclusions/ Recommendations}

Although there is little evidence of disturbance at this site, the paucity of burned rock suggests that it is primarily a lithic scatter, with a low probability that there are intact hearths below the surface. Therefore, CAS recommends that no further investigations are warranted and the site is not eligible for nomination to the NRHP.

\section{$41 B P 798$}

\section{Description}

An ephemeral lithic scatter on a sideslope constitutes 41BP798 (Figures 7-170 and 7-171). Oaks and cedars cover the site in Axtell fine sandy loam (AfE2). Its elongated shape encompasses $774 \mathrm{~m}^{2}$. Dogwood Branch lies $70 \mathrm{~m}$ to the north. The site's surface is hummocky and slopes to the north, from 478 to $465 \mathrm{ft}$ amsl. Surface visibility was less than five percent in October 2005. There were no obvious site disturbances visible on the surface. The datum is marked with a nail and an aluminum tag on an oak tree $15 \mathrm{~cm}$ in diameter.

\section{Levels of Work and Results}

No artifacts were observed on the surface, and only an interior flake and a unifacially utilized flake were found in two out of the three

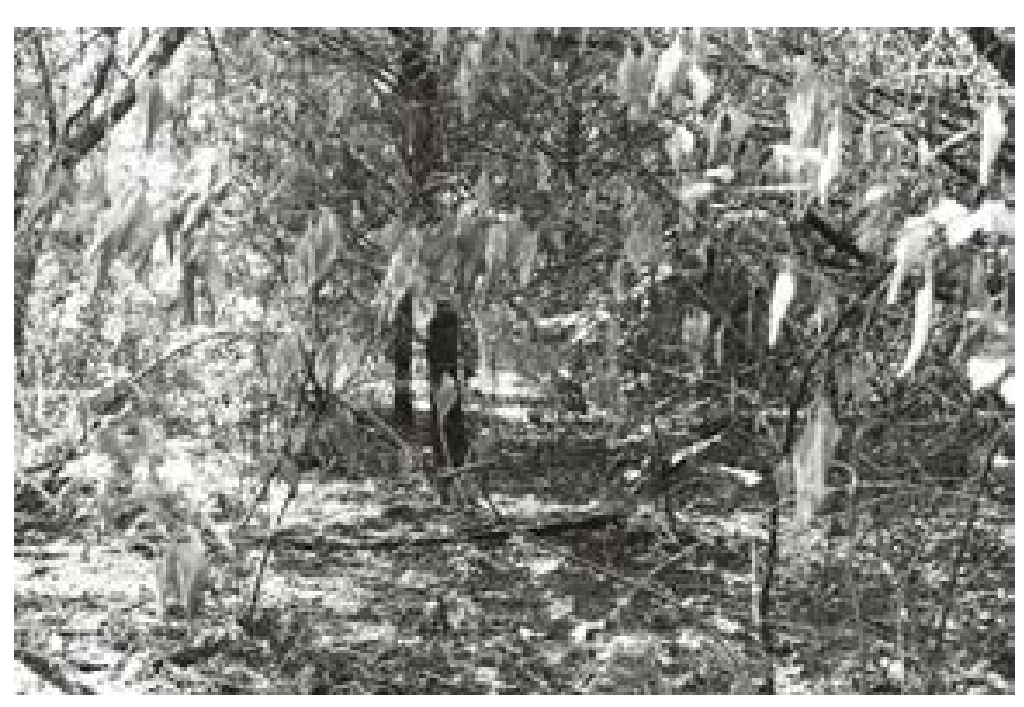

Figure 7-170. 41BP798 is a small lithic scatter on a sideslope $70 \mathrm{~m}$ from Dogwood Branch Creek; facing north. 


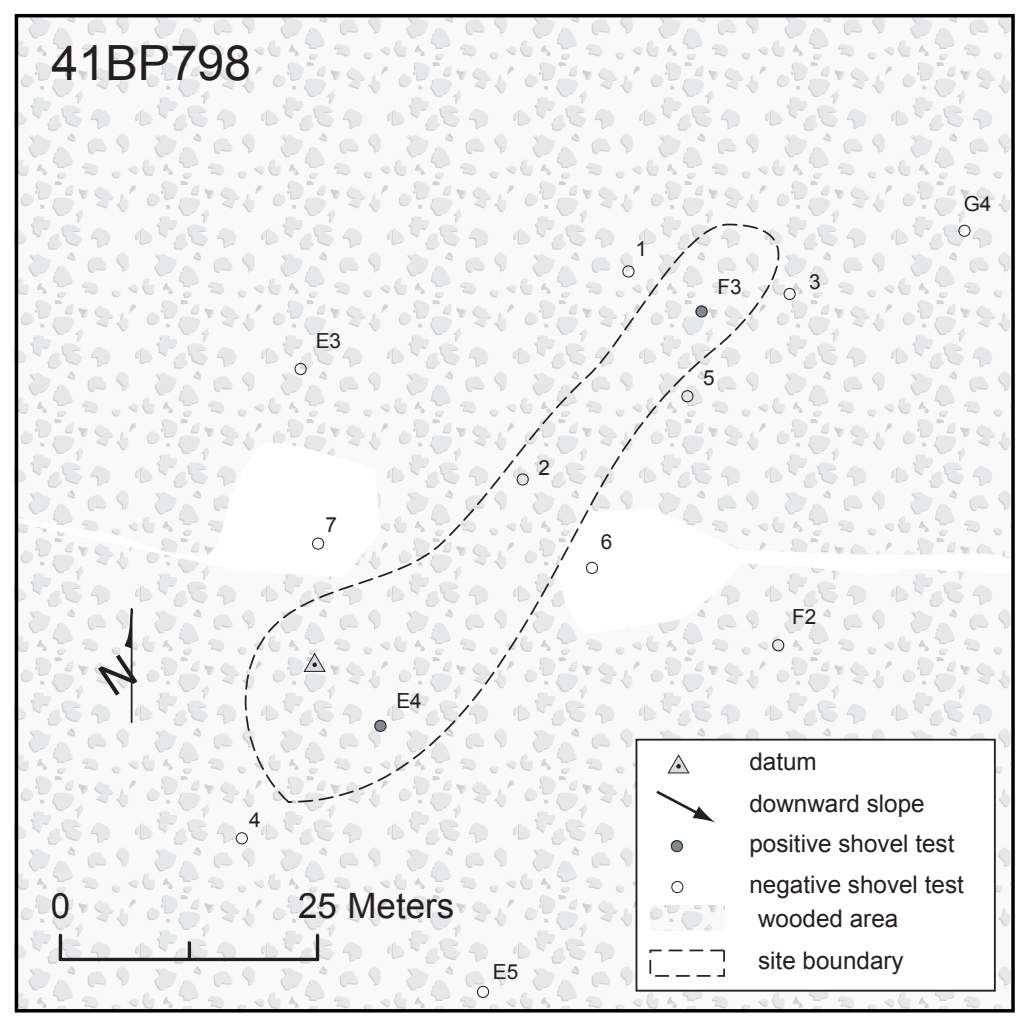

Figure 7-171. Site map of 41BP798.

Table 7-82. 41BP798 positive shovel test results.

\begin{tabular}{|c|c|c|}
\hline $\begin{array}{c}\text { Depth } \\
\text { (cmbs) }\end{array}$ & ST E4 & ST F3 \\
\hline $0-10$ & & \\
\hline $10-20$ & & \\
\hline $20-30$ & & IF \\
\hline $30-40$ & U & \\
\hline $40-50$ & & Clay \\
\hline $50-60$ & & \\
\hline $60-70$ & Clay & \\
\hline $70-80$ & & \\
\hline \multicolumn{2}{|c|}{ Key: IF-interior flake; U-uniface } \\
\hline
\end{tabular}


shovel tests dug on the site (Table 7-82). Disturbances in the form of roots, angular sandstones, and a rodent burrow were noted in the shovel tests, and it is likely that artifact positions were altered.

\section{Conclusions/ \\ Recommendations}

The paucity of lithic debitage, and absence of evidence of diagnostic artifacts, features, and organic preservation minimizes the research potential of this site. The added possibility of vertical mixing further diminishes the research potential. Therefore, CAS recommends that no further investigations are warranted and the site is not eligible for nomination to the NRHP.

\section{BP799}

\section{Description}

This lithic scatter (Figures 7-172 and 7-173) is in shallow Axtell fine sandy loam (AfC2) on a footslope $100 \mathrm{~m}$ west of Dogwood Branch. Oaks, cedars, elms, and mesquites cover the $1,522-\mathrm{m}^{2}$ site. The site's surface slopes from 455 to $452 \mathrm{ft}$ amsl toward the southwest. Surface visibility was approximately five percent in October 2005. There

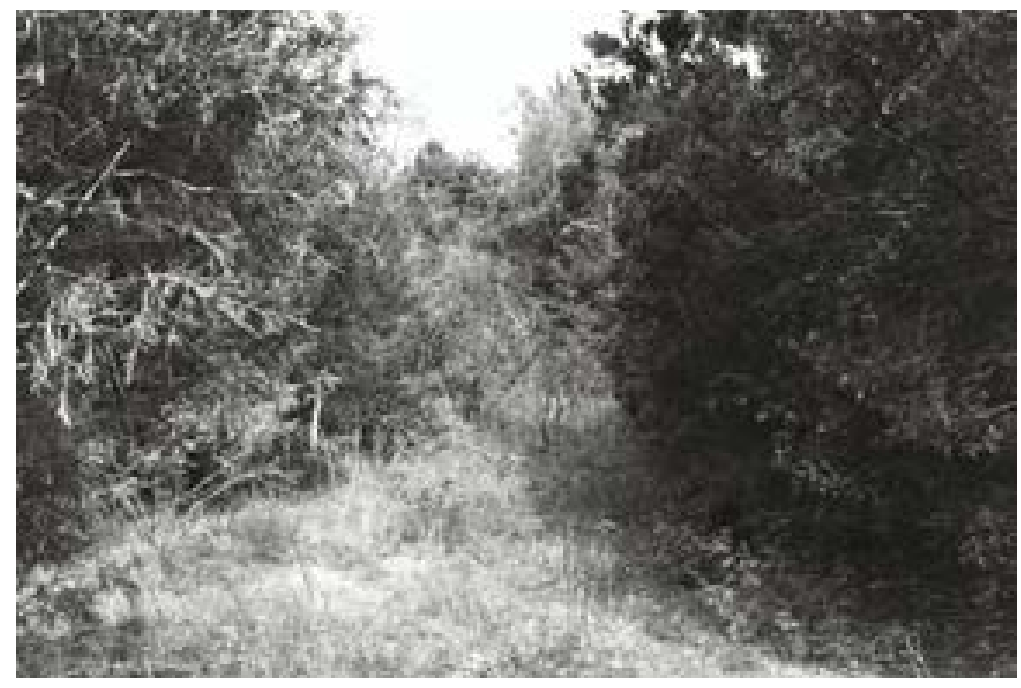

Figure 7-172. 41BP799 is a lithic scatter on a heavily wooded footslope; facing north.

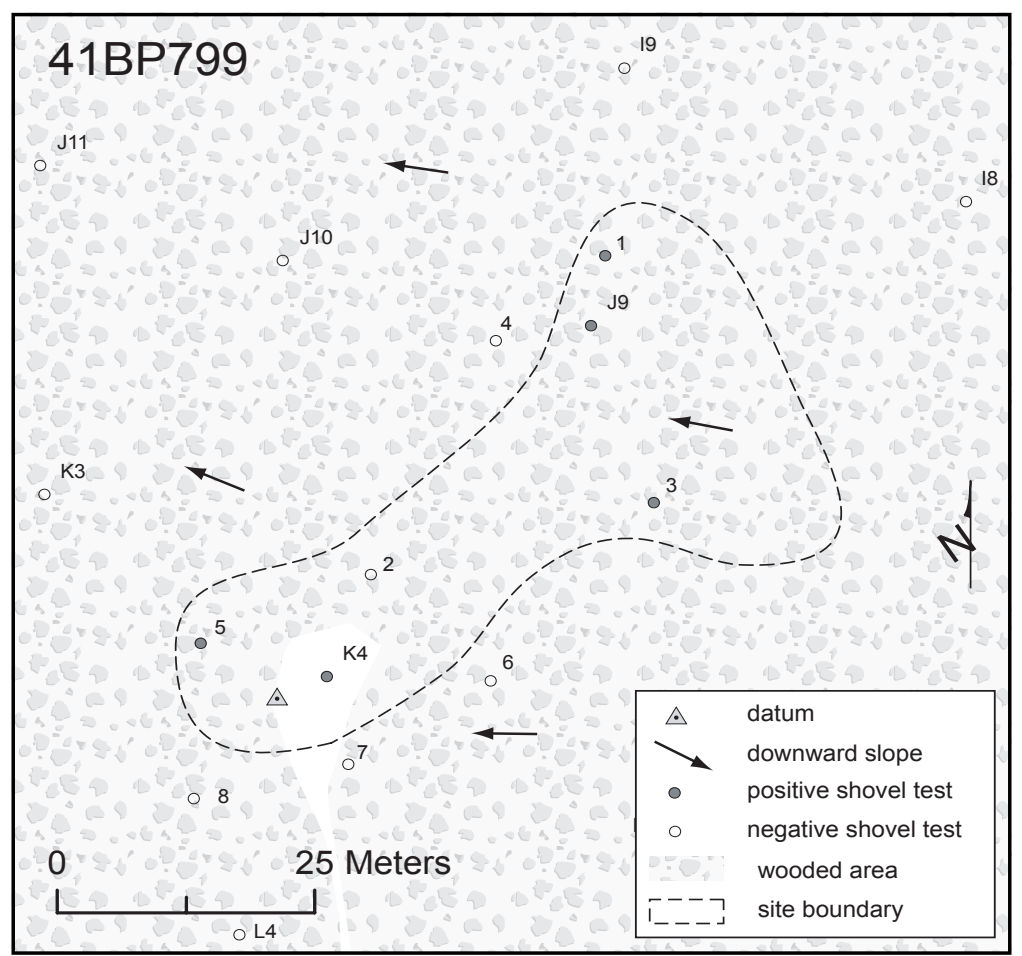

Figure 7-173. Site map of 41BP799. were no obvious site disturbances visible on the surface. The datum is marked with a nail and an aluminum tag on an oak tree $12 \mathrm{~cm}$ in diameter.

\section{Levels of Work and Results}

No artifacts were observed on the surface. As listed in Table 7-83, six flakes and one fire-cracked rock were found in five out of six shovel tests 
Table 7-83. 41BP799 positive shovel test results.

\begin{tabular}{|c|c|c|c|c|c|}
\hline $\begin{array}{c}\text { Depth } \\
\text { (cmbs) }\end{array}$ & $\begin{array}{c}\text { ST } \\
\mathbf{1}\end{array}$ & $\begin{array}{c}\text { ST } \\
\mathbf{3}\end{array}$ & $\begin{array}{c}\text { ST } \\
\mathbf{5}\end{array}$ & $\begin{array}{c}\text { ST } \\
\text { J9 }\end{array}$ & $\begin{array}{c}\text { ST } \\
\text { K4 }\end{array}$ \\
\hline $0-10$ & & & IF & IF & 2 EF \\
\hline $10-20$ & & IF & & & \\
\hline $20-30$ & IF & Clay & FCR & Clay & \\
\hline $30-40$ & Clay & & Clay & & Clay \\
\hline $40-50$ & & & & & \\
\hline \multicolumn{6}{|c|}{ Key: EF-exterior flake; IF-interior flake; } \\
FCR-fire-cracked rock $>1$ inch \\
\hline
\end{tabular}

excavated within the established site boundary. The soils at the site are shallow; the average depth to the underlying Bt horizon is $21 \mathrm{cmbs}$. Often, such shallow soils suffer disturbances through bioturbation.

\section{Conclusions/Recommendations}

The shallow soils and absence of evidence of diagnostic artifacts, features, and/or organic preservation minimizes the research potential of this site. Therefore, CAS recommends that no further investigations are warranted and the site is not eligible for nomination to the NRHP.

\section{BP800}

\section{Description}

41BP800 is an open campsite located on a sideslope $30 \mathrm{~m}$ east of an intermittent drainage of Dogwood Branch (Figures 7-174 and 7-175). The predominant vegetation is oak, cedar, and mesquite trees in Axtell fine sandy loam (AfC2). The site's surface slopes from 472 to $465 \mathrm{ft}$ amsl and covers $1,592 \mathrm{~m}^{2}$. Surface visibility was less than five percent in October 2005. There were no obvious site disturbances visible on the surface. The datum is marked with a nail and an aluminum tag on a large oak tree $65 \mathrm{~cm}$ in diameter.

\section{Levels of Work and Results}

No artifacts were observed on the surface. A large cobble flake with a utilized edge, two firecracked rocks, and five flakes were found in the four shovel tests excavated on the site (Table 7-84).

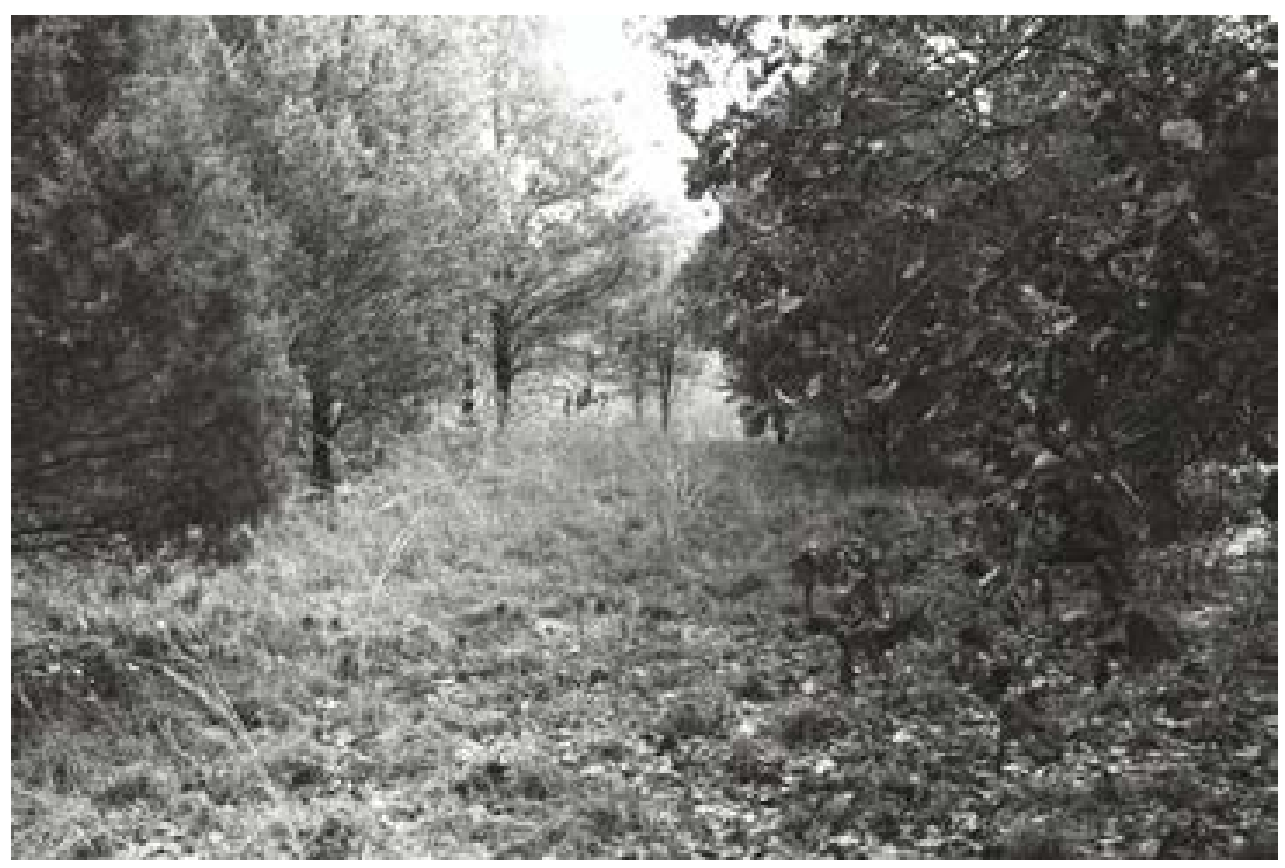

Figure 7-174. 41BP800 is an open campsite in a heavily wooded area; facing east. 
FIGURE 7-175. REDACTED

Figure 7-175. Site map of 41BP800.

Table 7-84. 41BP800 positive shovel test results.

\begin{tabular}{|c|c|c|c|c|}
\hline $\begin{array}{c}\text { Depth } \\
\text { (cmbs) }\end{array}$ & ST 5 & ST 7 & ST C4 & ST C5 \\
\hline $0-10$ & & $\begin{array}{c}\text { IF, } \\
\text { FCR }\end{array}$ & & EF \\
\hline $10-20$ & IF & & & U \\
\hline $20-30$ & & $\begin{array}{c}\text { IF, } \\
\text { FCR }\end{array}$ & IF & Clay \\
\hline $30-40$ & & & Clay & \\
\hline $40-50$ & & Clay & & \\
\hline $50-60$ & & & & \\
\hline $60-70$ & & & & \\
\hline $70-80$ & Clay & & & \\
\hline $80-90$ & & & & \\
\hline \multicolumn{2}{|l|}{$\begin{array}{l}\text { Key: EF-exterior flake; IF-interior flake; U- } \\
\text { uniface; FCR-fire-cracked rock }>1 \text { inch }\end{array}$} \\
\hline
\end{tabular}


Angular sandstones found in seven of the shovel tests indicate colluvial deposition processes have likely negatively impacted the integrity of the cultural material. The average depth of loam above the underlying $\mathrm{Bt}$ horizon is $30 \mathrm{cmbs}$.

\section{Conclusions/ \\ Recommendations}

The shallow soils and colluvial depositional processes lessen the integrity and minimize the research potential of this site. Therefore, CAS recommends that no further investigations are warranted and the site is not eligible for nomination to the NRHP.

\section{BP801}

\section{Description}

This open campsite buried in Axtell fine sandy loam (AfC2) and Silstid loamy fine sand (SkC) covers $4,670 \mathrm{~m}^{2}$ of a sideslope $90 \mathrm{~m}$ west of an intermittent drainage of Dogwood Branch (Figures 7-176 and 7-177). It is semi-wooded, with scattered oaks, mesquites, and sumacs surrounded by tall grasses and grapevines. The surface slopes from 488 to $471 \mathrm{ft}$ amsl, and red clay is exposed on the heavily eroded eastern portion of the site. Other than in that area and along a bladed trail, surface visibility was less than five percent across the site. When viewing the surface, the site looks to have been heavily disturbed by blading, erosion, and fence construction across

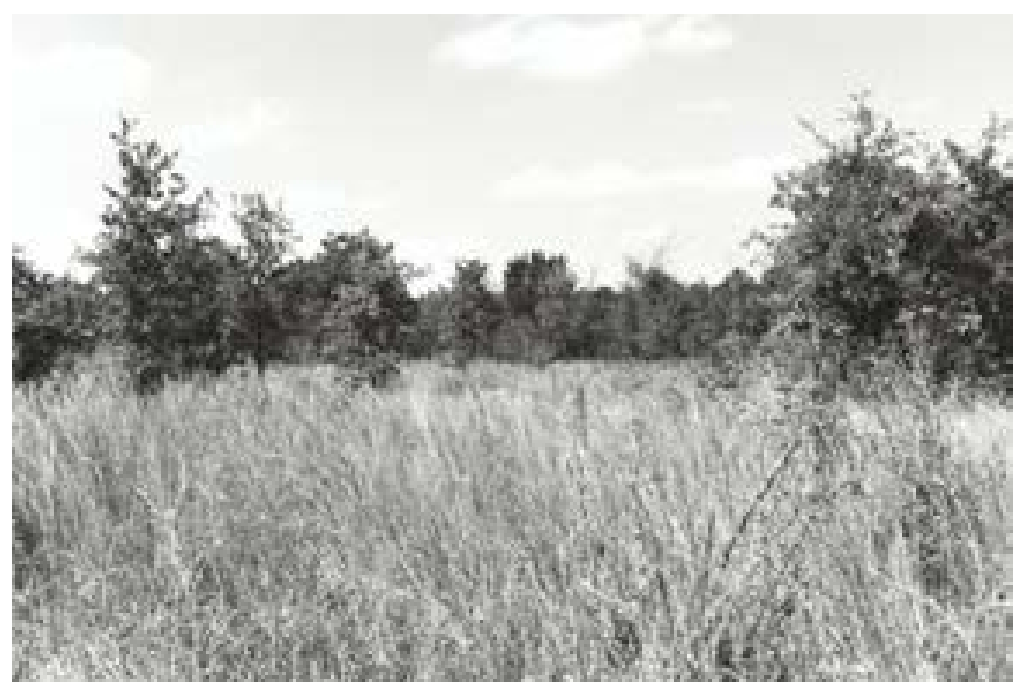

Figure 7-176. 41BP801 is an open campsite in a semi-wooded area; facing west.

Figure 7-177. Site map of 41BP801.

\section{FIGURE 7-177. REDACTED}

its northern edge, and the surface in the grassy area is generally hummocky, presumably caused by heavy machinery. A nail and an aluminum tag were attached to an oak tree $15 \mathrm{~cm}$ in diameter. 
Table 7-85. 41BP801 positive shovel test results.

\begin{tabular}{|c|c|c|c|}
\hline $\begin{array}{l}\text { Depth } \\
\text { (cmbs) }\end{array}$ & F1 & G1 & I 2 \\
\hline $0-10$ & & $\mathrm{EF}$ & $2 \mathrm{EF}, \mathrm{IF}, \mathrm{fcr}$ \\
\hline $10-20$ & & & IF \\
\hline $20-30$ & & Clay & $5 \mathrm{IF}, 2$ FCR \\
\hline $30-40$ & IF & & $\begin{array}{c}2 \text { IF, EF, FCR, } \\
\text { fcr }\end{array}$ \\
\hline $40-50$ & & & $\begin{array}{c}6 \text { IF, } 5 \text { FCR, } 4 \\
\text { fcr }\end{array}$ \\
\hline $50-60$ & & & $8 \mathrm{IF}, 5 \mathrm{FCR}$ \\
\hline $60-70$ & & & FCR \\
\hline $70-80$ & Sand & & Clay \\
\hline $80-90$ & & & \\
\hline \multicolumn{4}{|c|}{$\begin{array}{l}\text { Key: EF-exterior flake; IF-interior flake; FCR- } \\
\text { fire-cracked rock }>1 \text { inch; fcr-fire-cracked rock } \\
\qquad<1 \text { inch }\end{array}$} \\
\hline
\end{tabular}

\section{Levels of Work and Results}

A single flake was seen on the eroded surface on the eastern end of the site. Twenty-eight flakes and 20 fire-cracked rocks were recovered from three of four shovel tests dug on the site (Table 7-85). A prolific quantity of cultural material was found in ST I2, which contained all 20 firecracked rocks and 26 of the 28 flakes. ST I2 was located upslope where the soils are generally deeper. Evidence of disturbance in the forms of angular ironstones and/or tabular sandstone bedrock fragments were encountered in many of the shovel tests, but not in ST I2. Instead, sandy loam with no intrusive items other than cultural material were found.

\section{Conclusions/ Recommendations}

The results of shovel tests indicate that the majority of this site is likely disturbed. However, the area immediately around ST I 2 may be one discrete area that is still relatively undisturbed. The concentration of burned rocks and lithic debitage there suggests that there could be intact hearths with associated stone tools and charcoal below the surface. In order to further evaluate the research potential of this site and determine NRHP eligibility, CAS recommends excavation of two 1-x-1-m units in the immediate area of ST I2.

\section{$41 \mathrm{BP802}$}

\section{Description}

41BP802 (Figures 7-178 and 7-179) is a 5,827$\mathrm{m}^{2}$ open campsite lying buried in an old field surrounded by oaks and cedars. A single large pine tree is on the southern portion of the site and two dense brush thickets are on the northern portion. A bladed road runs along a firing range $45 \mathrm{~m}$ west of the site, and judging by the surface, the site area has been negatively impacted. The thickets likely resulted from the soils being disturbed, there is a push pile and depression on the site, numerous track vehicle ruts, and the overall surface is hummocky. The surface slopes from 473 to $465 \mathrm{ft}$ amsl toward an intermittent drainage of Harris Creek, $25 \mathrm{~m}$ to the south. The soil type here is Tabor fine sandy loam (TfB).

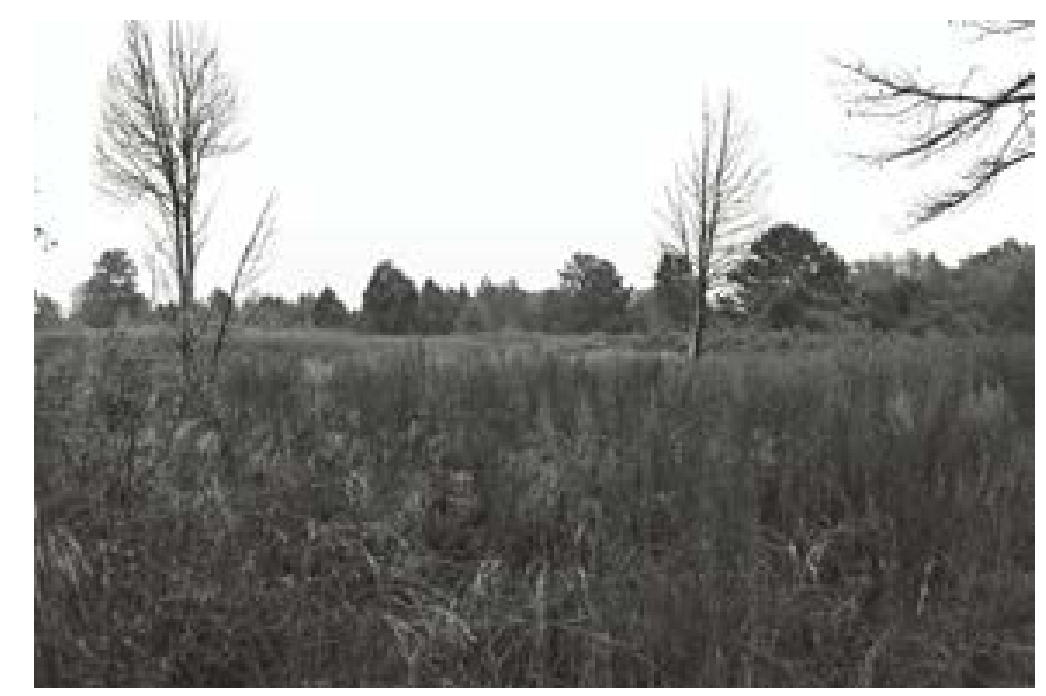

Figure 7-178. 41BP802 is an open campsite in a cleared area; facing northeast. 
Surface visibility was less than five percent during the October 2005 documentation of the site. A nail in the large pine tree and attached aluminum tag serves as the site datum.

\section{Levels of Work and Results}

No artifacts were visible on the surface. The artifacts recovered from nine of the ten shovel tests excavated on the site are listed in Table 7-86. In addition to eight fire-cracked rocks and 16 flakes, a chert core tool, or "chopper," and four small pieces of red ocher were found. Interestingly, the data indicate that a discrete zone of cultural material is buried between 40 and $80 \mathrm{cmbs}$ across the site. In contrast to surface observations, which indicated the upper portion of the site had been disturbed, the only indication of potential disturbance below the surface were roots encountered in ST Q4. Otherwise, fine sandy loam with no intrusions was found in all shovel tests. The average shovel test depth was

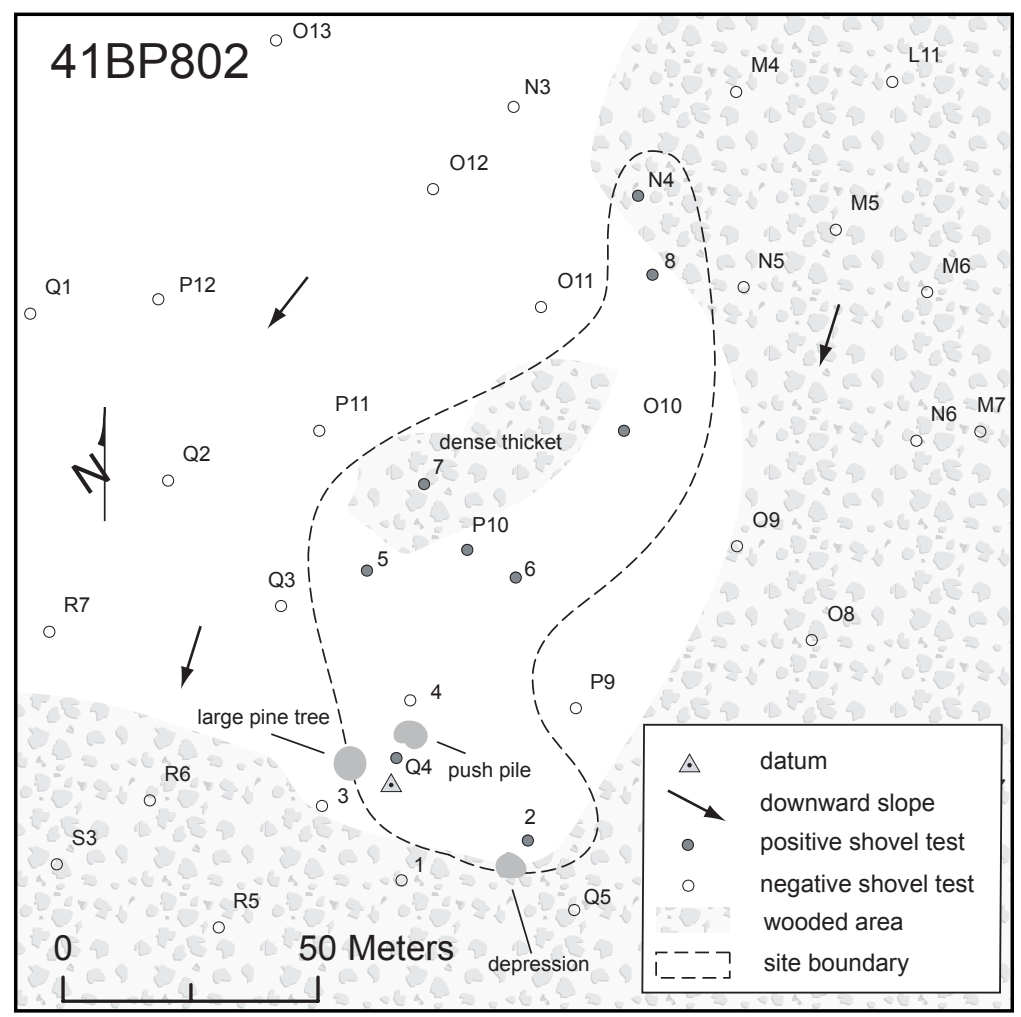

Figure 7-179. Site map of 41BP802.

Table 7-86. 41BP802 positive shovel test results.

\begin{tabular}{|c|c|c|c|c|c|c|c|c|c|}
\hline $\begin{array}{l}\text { Depth } \\
\text { (cmbs) }\end{array}$ & ST 2 & ST 5 & ST 6 & ST 7 & ST 8 & ST N4 & ST 010 & ST P10 & ST Q4 \\
\hline $0-10$ & & & & IF, fcr & & & & & \\
\hline $10-20$ & & & & fcr & & & & & \\
\hline $20-30$ & & & & IF, fcr & & & & & \\
\hline $30-40$ & & & IF & & & & & & \\
\hline $40-50$ & & IF & & & FCR & & & & \\
\hline $50-60$ & FCR & & IF & & IF & & $4 \mathrm{IF}, \mathrm{CT}, \mathrm{O}$ & IF & fcr \\
\hline $60-70$ & Clay & Clay & IF, FCR & & & IF & IF & & Clay \\
\hline $70-80$ & & & FCR & Sand & Sand & & $2 \mathrm{IF}$ & & \\
\hline $80-90$ & & & & & & Sand & & & \\
\hline $90-100$ & & & & & & & & Sand & \\
\hline $100-110$ & & & Sand & & & & Sand & & \\
\hline $110-120$ & & & & & & & & & \\
\hline
\end{tabular}


just over $72 \mathrm{cmbs}$, with the underlying Bt horizon reached in only four of them.

\section{Conclusions/Recommendations}

The results of shovel tests indicate that the deeply buried cultural material is likely undisturbed in a discrete stratigraphic zone between 40 and $80 \mathrm{cmbs}$. However, without further investigations beyond the scope of this inventory

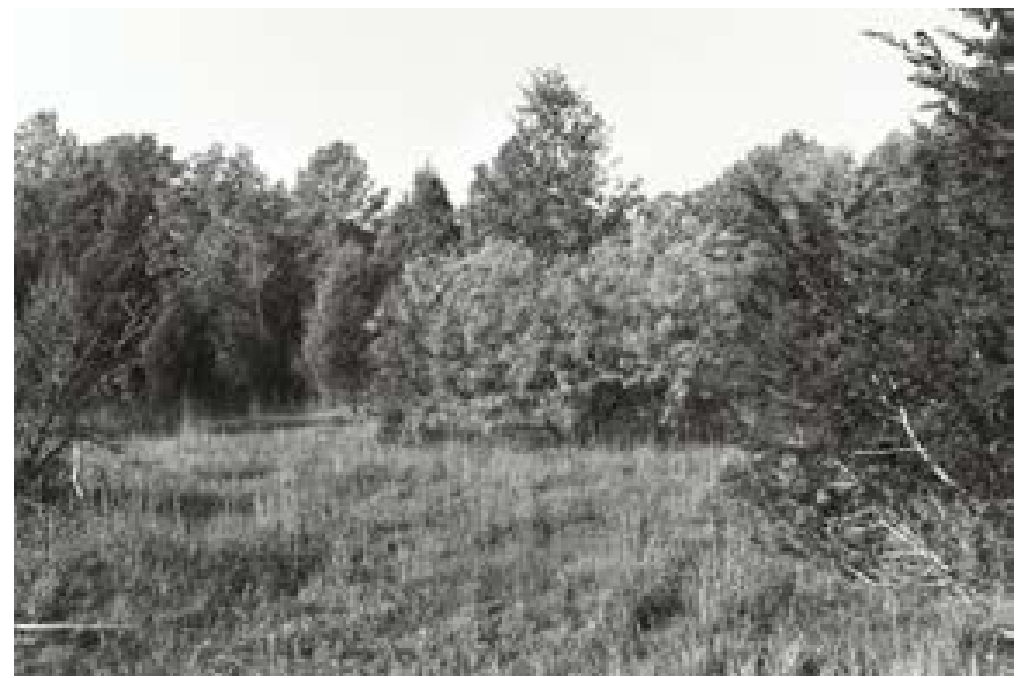

Figure 7-180. 41BP804 is an ephemeral lithic scatter on a heavily disturbed sideslope area; facing southwest.

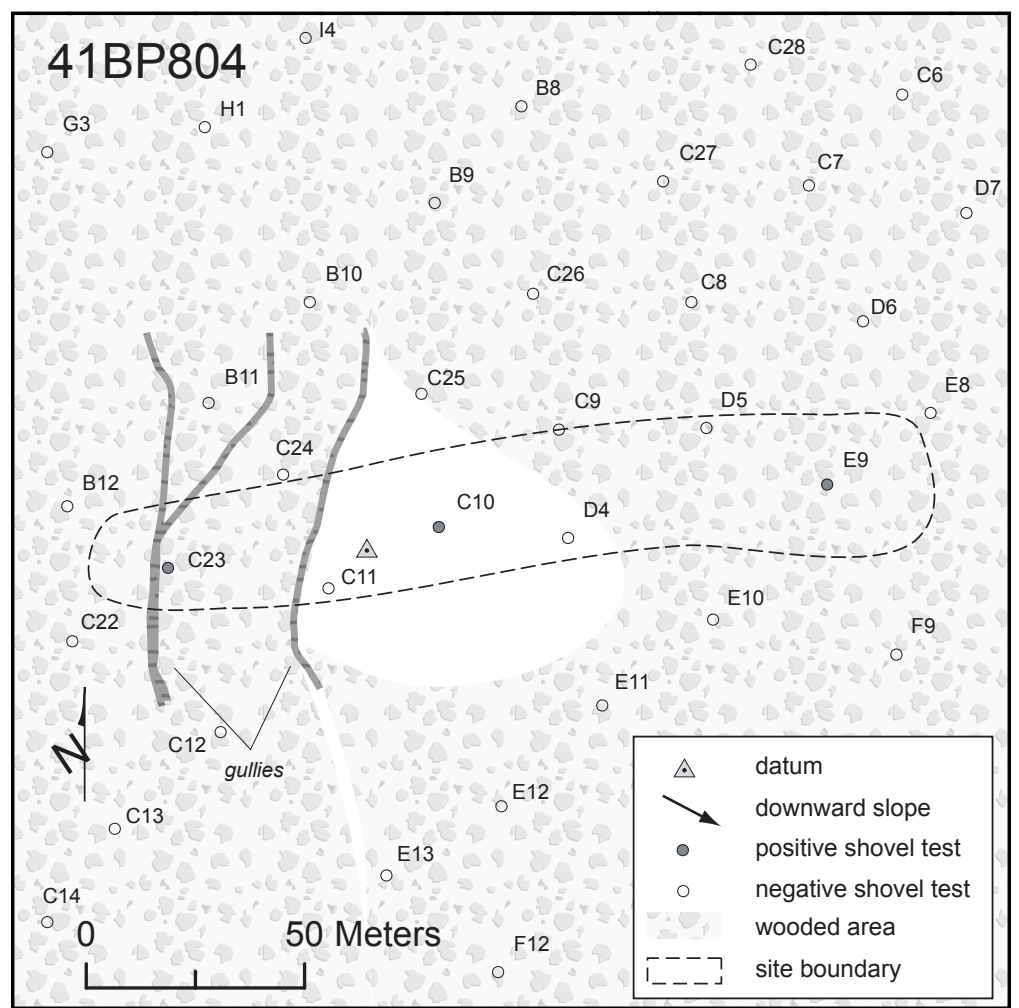

Figure 7-181. Site map of 41BP804. survey, the research potential of this site is unknown. Before a recommendation can be made regarding NRHP eligibility, three 1-x-1-m units should be dug on the site, one each in the immediate areas of STs 6,8 , and O10.

\section{BP804}

\section{Description}

41BP804 (Figures 7-180 and 7-181) is an ephemeral lithic scatter found in a $5,675-\mathrm{m}^{2}$ area on a semi-wooded sideslope above an intermittent drainage of Dogwood Branch, $15 \mathrm{~m}$ to the west. The surface is gullied and sloping from 496 to $474 \mathrm{ft}$ amsl. Vegetation consists primarily of cedars, pines, oaks, mesquites, and tall grasses. Numerous track vehicle ruts and downed trees remained after a recent cedarclearing operation. The two soil types are Axtell fine sandy loam (AfC2) on the upper, northern portion, and Tabor fine sandy loam on the lower, southern portion. Other than in the deeply eroded gullies, surface visibility on the more stable surfaces was less than ten percent. The datum was marked with a nail and an 
aluminum tag in a small oak tree.

\section{Levels of Work and Results}

No artifacts were observed either on the surface or in the eroded gully areas. Of six shovel tests placed on the site, three contained a flake each (Table 7-

Table 7-87. 41BP804 positive shovel test results.

\begin{tabular}{|c|c|c|c|}
\hline $\begin{array}{c}\text { Depth } \\
\text { (cmbs) }\end{array}$ & ST C10 & ST C23 & ST E9 \\
\hline $0-10$ & & & \\
\hline $10-20$ & IF & & IF \\
\hline $20-30$ & Clay & & \\
\hline $30-40$ & & & \\
\hline $40-50$ & & IF & \\
\hline $50-60$ & & Clay & Clay \\
\hline $60-70$ & & & \\
\hline \multicolumn{4}{|c|}{ Key: IF-interior flake } \\
\hline
\end{tabular}

Conclusions/ Recommendations

The absence of cultural features, stone tools, and/or evidence of organic preservation, along with the colluvial deposits and erosion at this site, significantly lessens its integrity and minimizes its research potential. Therefore, CAS recommends that no further investigations are warranted and the site is not eligible for nomination to the NRHP. 


\title{
Chapter 8
}

\section{Previously Documented Historic Component Sites}

\author{
By David L. Nickels, D. Emory Worrell, and Jessica L. Hurley
}

Within the areas surveyed during the current project, there were 27 historic components that had previously been documented. Of those, CAS had tested only three during past projects: 41BP105, 41BP138, and 41BP484 (Table 8-1). During the current project, CAS personnelexcavated shovel tests in transects to within at least $30 \mathrm{~m}$ of the boundaries previously defined for those three sites. Although the boundaries of the three sites did not change, sandstone architecture was identified for the first time at 41BP105. Therefore, 41BP138 and 41BP484 will be excluded from the discussion below and 41BP105 will be discussed only in brevity. The NRHP eligibility recommendations for these three sites have not changed (see Nickels et al. 2003:156; Nickels and Lehman 2004:130-132).

\section{$41 B P 96$}

\section{Description}

A historic trash washing down an intermittent drainage constitutes the historic component at 41BP96 (Figures 8-1 and 8-2). The prehistoric component of this site was discussed in Chapter 6: PreviouslyDocumentedPrehistoric Component Sites. The drainage eventually dumps into McLaughlin Creek, about $300 \mathrm{~m}$ downstream. Woods extend 15 to $18 \mathrm{~m}$ east of the drainage, giving way to a grass-covered open field. There is a dam across the drainage $100 \mathrm{~m}$ north of the site. Vegetation along the drainage includes many large oaks, smaller cedars, and assorted shrubs. Surface visibility at the time of the August 2005 visit was approximately 15 percent in the open field and about 25 percent along the drainage. The site datum is marked with a nail and an aluminum tag in a large oak tree.

\section{Levels of Work and Results}

Skelton and Freeman recorded the prehistoric lithic procurement component in 1979, but did not mention the presence of historic artifacts. In 2005, CAS archaeologists returned to further document the prehistoric component, but then observed bottle glass, whiteware sherds, and brick fragments that had washed downstream from south of the dam. Skelton and Freeman excavated shovel tests on the site but found only shallow soils with no artifacts. The 2005 results were the same. None of the six shovel tests excavated on the site contained artifacts. The average depth to the Bt horizon was less than 25 


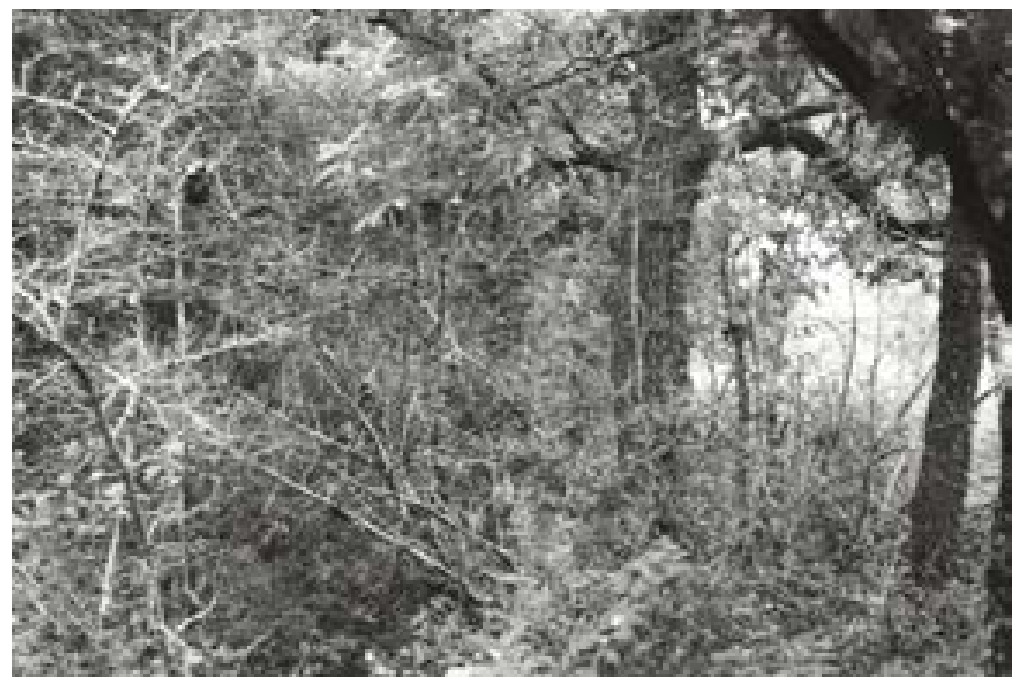

Figure 8-1. Historic trash is washing down an intermittent drainage between 41BP132 and 41BP157; facing south.

FIGURE 8-2. REDACTED

Figure 8-2. Site map of 41BP96.

cmbs. Artifacts observed along the streambed included a brown glass shard, a whiteware sherd, a barbed wire strand, a red brick fragment, and a ca. post-1900 brown snuff bottle with three dots (Munsey 1970:77).

\section{Conclusions/ Recommendations}

The historic trash is probably associated with either the Jim and Cynthia Floyd house (41BP132) or the Frank and Mary Scott house (41BP157). Both are upslope from this trash scatter, and both houses were occupied through 1942 according to former resident Abner C. Scott (personal communication 16 February 2006). CAS assesses the historic component at this site as having little research potential given the absence of subsurface deposits. No further work is recommended and the historic component is not eligible for nomination to the NRHP.

\section{BP105}

\section{Description}

This is the site of winemaker Antoine Aussilloux's lower grape field (Figures 8-3 and 84). It also has a prehistoric open campsite component that was previously documented by CAS and recommended for further testing (Nickels and Lehman 2004). At that time, the historic component consisted of the field itself; a stoneware sherd, similar to French Beauvasisis; and a piece of clear glass. During the current project, archaeologists discovered a rectangular sandstone irrigation column in the field extending 2-3 inches above the modern surface (Figure 8$5)$. Because of the dense vegetation, it had been unobserved during past visits. 


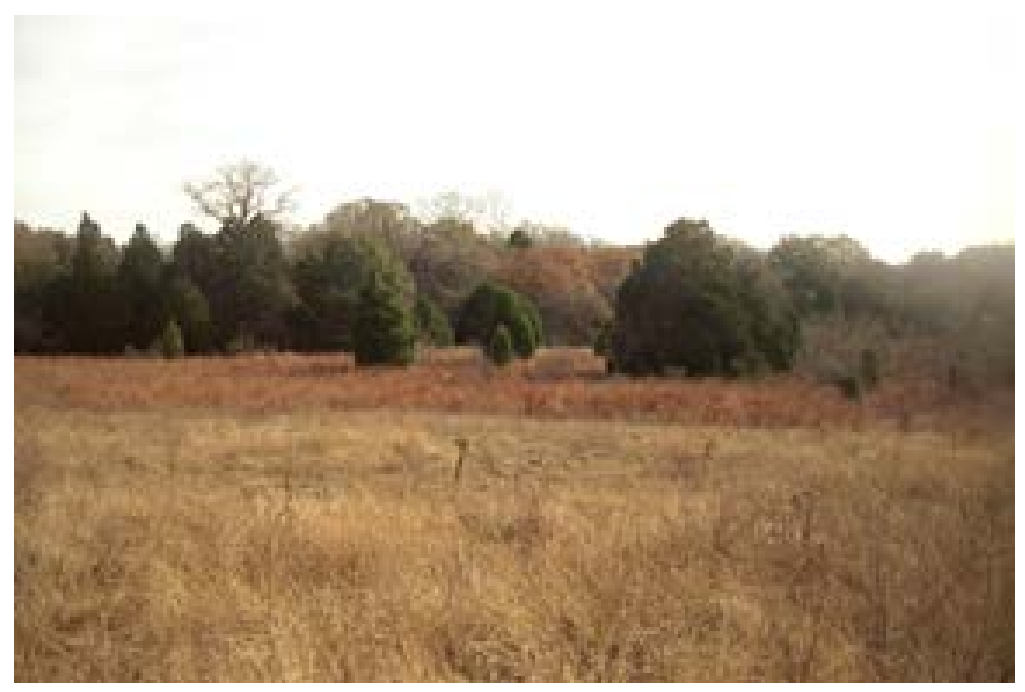

Figure 8-3. Lower grape field of Antoine Aussilloux (41BP105); facing west. interior opening measuring 7-x11.5-inches. CAS archaeologists conducted shovel probes around all four sides of the sandstone columnand discovered stoneware pipes extending from three directions. A 7.5-inch exterior diameter stoneware pipe with a light orange burnished surface extends from the north side, its top being 18 inches below the top of the stone column and 15 to 16 inches below the surface. The stoneware pipe extends out 12 inches from the column, and the opening in the stone column around the pipe is sealed with pasty mortar. An iron pipe 6.5 inches in exterior diameter and 16 inches long fits into the opposite, female end of the stoneware pipe and the connection is sealed with pasty mortar. A second section of iron pipe fits into the female end of the 16-inch section, and that connection is also sealed with pasty mortar. The length of this second section is unknown, as further probing was not conducted.

A brown glazed stoneware pipe 5 inches in exterior diameter extends from the eastern face of the column, 8 inches below its top and 6 to 7 inches below the surface. A second, brown glazed, 5-inch exterior diameter stoneware pipe extends from

\section{Levels of Work and Results}

The sandstone column is constructed of 1- to 2-inch sandstone slabs with sharp corners, and is molded together with pasty mortar. Its exterior dimensions are 23-x-26-inches, and it has an the column's western face, its top being 5 inches below the top of the column and approximately 3 to 4 inches below the surface. There is no pipe extending from the column's southern face. The 


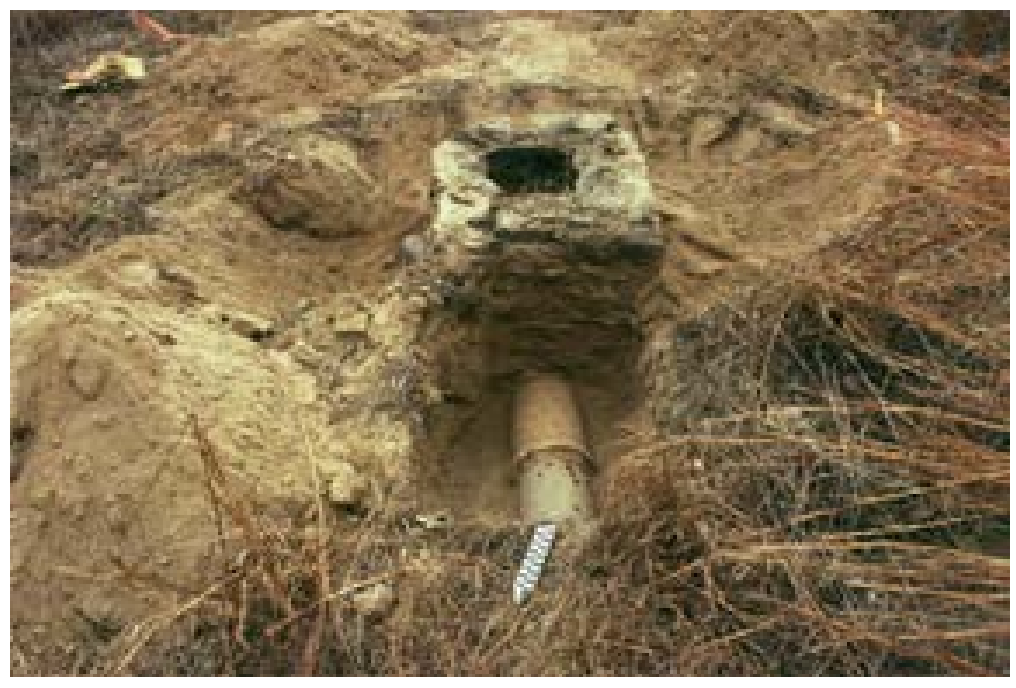

Figure 8-5. This sandstone irrigation column is in the middle of Antoine Aussilloux's lower grape fields; facing south.

base of the sandstone column was not determined, as shovel probes terminated shallow enough so that the overall structure would not become destabilized. After documenting the architecture as described above, the probes were backfilled. Shovel test locations from 2002, two transect shovel test probes from the current project, and a backhoe trench location from 2005 are illustrated in Figure 5-8. As the landscape is today, the pipe's course would have traversed through the higher elevation of the field area, and then across a lowlying edge of the adjacent floodplain. However, no evidence of a pipe and/or ditch was found in the low-lying area. It could be that if the iron pipe extended into that area, it was scavenged for the WWII effort.

\section{Conclusions/Recommendations}

It appears that this architecture represents the terminus of Aussilloux's irrigation ditch, which originated at Scott Falls Dam and followed the contours of Spring Branch Creek until just north of the lower grape fields. However, the fields are slightly higher in elevation than what was likely the end of the open ditch. The discovery of this unique artesian-powered device indicates that Aussilloux solved this problem by using the gravity-fed design to force the water flow into the constricted iron and stoneware pipes buried below the surface. Once the water reached the stoneware structure, it was forced upward into the rectangular opening, and then flowed out of the smaller pipes, and likely into furrows between the rows of grapevines.

In 2004, CAS recommended that $41 \mathrm{BP} 105$ be placed offlimits until the significance of the prehistoric component was determined, and that a Determination of Effect should be submitted to THC before military training was conducted on the lower grape field (Nickels and Lehman 2004:89). The discovery of the irrigation column now adds another dimension to the significance of the historic component of this site and enhances its research value. Therefore, CAS recommends that the historic component be placed off-limits for military training until the site's eligibility can be determined through further investigations. Six hand excavations should be conducted to determine the full extent of the irrigation pipe(s) and the depth of the sandstone column. In addition, CAS recommends a magnetometer study be conducted across the site to identify anomalies that may represent additional buried architecture and/or irrigation channels.

\section{BP132}

\section{Description}

This house site (Figure 8-6) belonged to J. and C. Floyd before the government acquired it and the surrounding 197 acres from them in 1942 (Bastrop County 1929; Skelton and Freeman 1979). It lies near the intersection of 
McLaughlin Loop and Sandy Creek Loop roads in a grove of large oak trees, with scattered cedars, mesquites, cacti, weeds, and grasses. The site has been leveled and bulldozed so that only a few foundation stones, chimney bricks, and fence posts remain in place. Artifacts are scattered from the house site area to the south and downslope into a heavily wooded area.

\section{Levels of Work and Results}

An outline of the house and probable attached porch was still discernible from foundation stones and bricks (see Figure 8-6). The remains of the house foundation consist of hand-hewn sandstone, and the chimney bricks are red with a pasty mortar. The bricks were not uniform, exhibited rough edges, and appeared to be poorly made. The fireplace remnants along the southeast end of the structure were uncovered, measured, and photographed (Figure 8-7). Approximately 10 feet south of the corner of the structure was a tin, mortar-lined cistern, with riveted seams, and a ribbed top (Figure 8-8). The circumference of the cistern was 61.5 inches, the wall was .25 of an inch thick, and the depth was 80 inches to the bottom,. It was filled with leaf litter, a tin can, and a brick fragment. Several bullet holes were observed in the cistern. A pile of whole and fragmented bricks and a wooden beam with round nails were located next to the cistern. Loop roads.

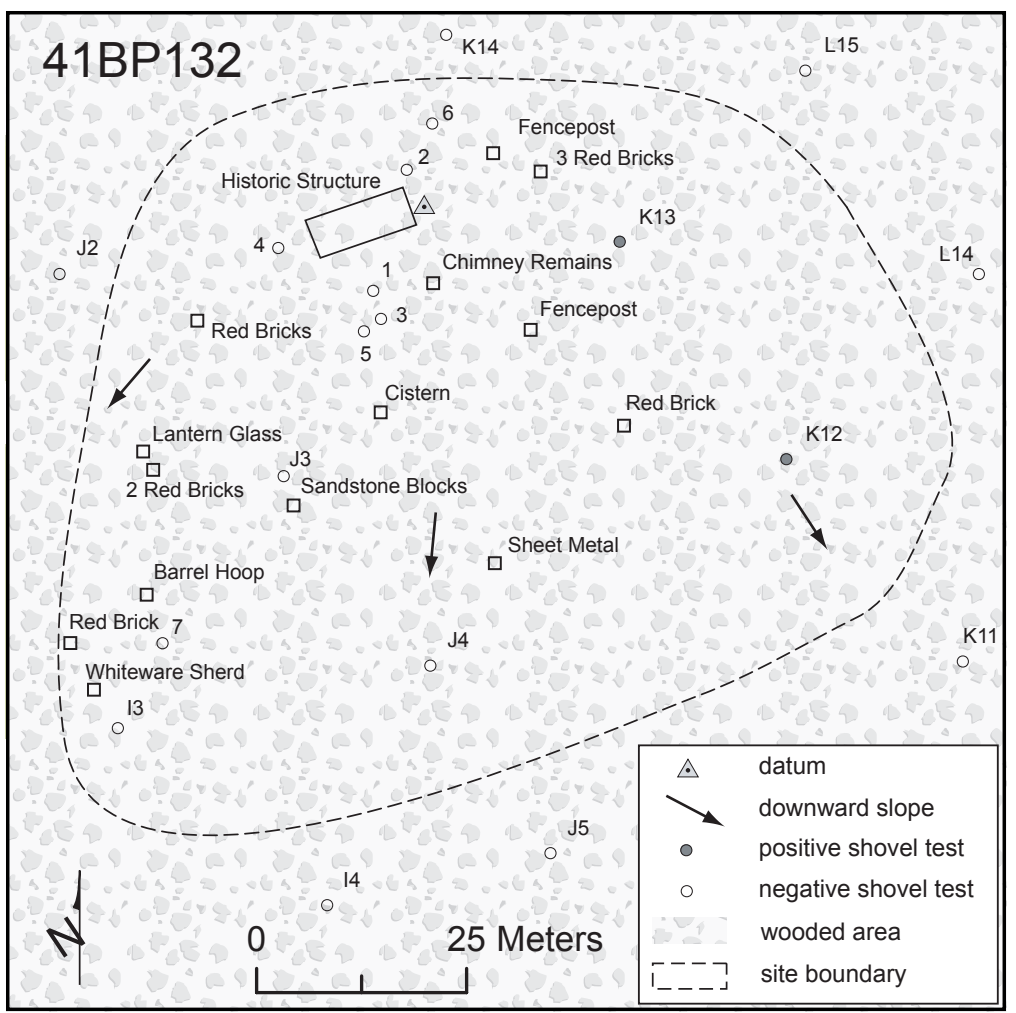

Figure 8-6. Site map of 41BP132.

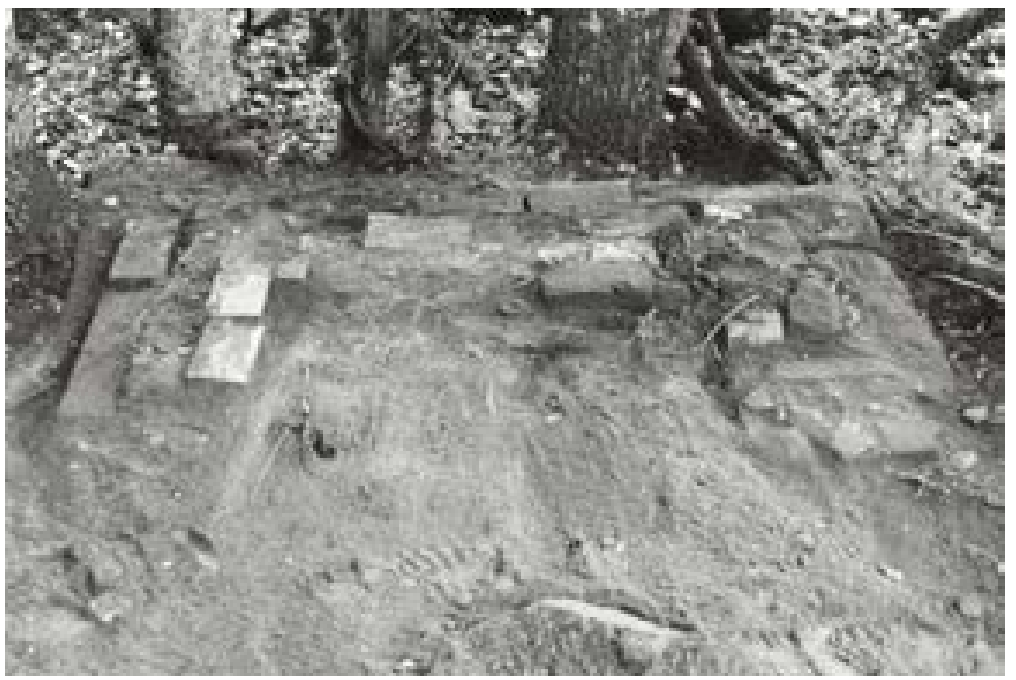

Figure 8-7. Remains of the chimney in the James and Cynthia Floyd house; it is near the intersection of McLaughlin Loop and Sandy Creek

Artifacts found on the surface include a barrel hoop, two red brick fragments, three rusted tin cans with crimped sides and hole-in-top lids (Figure 8-9; ca. mid-1800s to early 1900s), and purple glass with a scale pattern (ca. 1880-1915), 


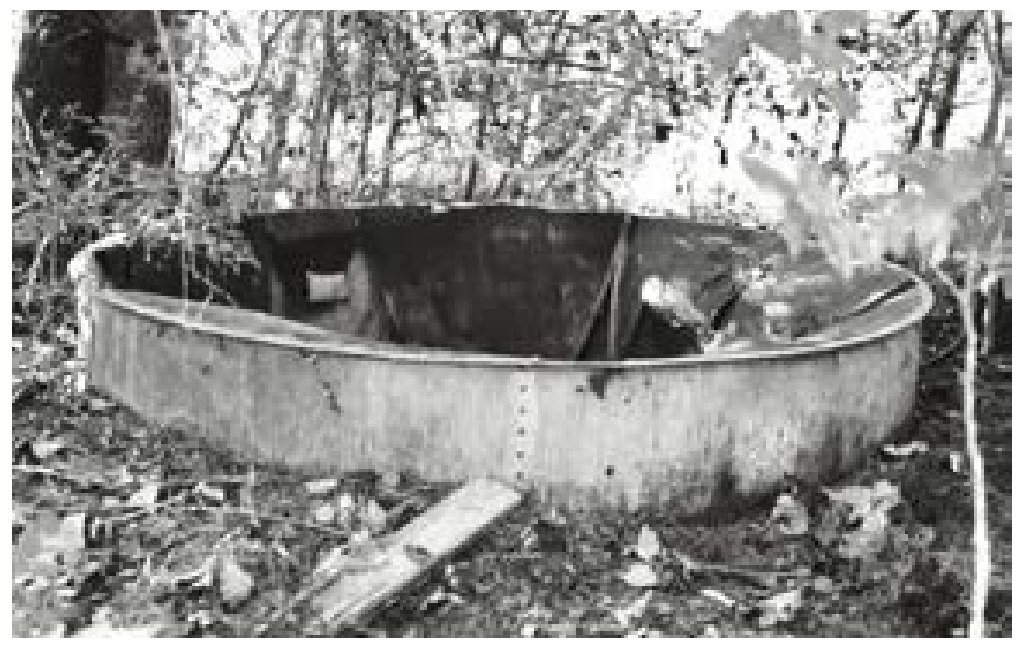

Figure 8-8. This cistern was just off the back porch.

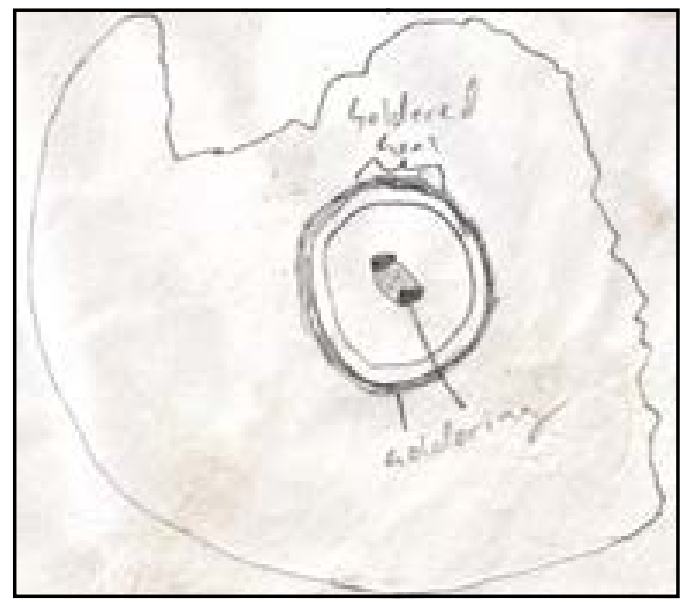

Figure 8-9. Sketch of soldered hole-in-top can.

most likely from a kerosene lamp. Termed the font, this purple glass fragment was probably the basin of the lamp, which held fuel (Woodhead et al. 1984:39). A clear glass bottle with no hue and mold seams extending onto the lip, which was designed for a stopper top, was embossed with the word "Eucaline," and exhibited light patina (ca. post-1930); it was found on the surface. Eucaline was a brand name used for perfumes or medicines (Figure 8-10).

Milk glass with a blue trim was also found on the surface. Milk glass was commonly used in the production of cosmetic bottles, toiletry bottles, and ointment/cream jars from the 1870 s to the mid-twentieth century (Lindsey 2005). Finally, a pink granite rock that measured 17-x-8.5-x-9inches was found on the surface next to ST 7. It is obviously out of context, but why it is there is unknown.

Artifacts found in six of the 12 shovel tests dug on the site (Table 8-2) include:

ST 2: an unidentifiable metal fragment

ST 4: a medium thick clear glass shard with no hue (ca. post-1930)

ST 6: a piece of threaded iron with rivets that may have been wagon hardware, which measures 14 inches long, 1 inch wide, and tapers from $1 / 2$ to $3 / 4$ inches thick; a heavily scratched, clear glass rim shard with no hue (ca. post-1930); red brick fragments; and an unidentifiable bullet casing with a "L 35 S" headstamp.

ST 7: a brown glass snuff bottle rim (ca. pre1900); two brown glass shards possibly associated with the snuff bottle (ca. pre1900); one clear glass fragment with an aqua hue and embossed with "U.S." (ca. pre-1900); one clear glass fragment with no hue and medium patina (ca. post-1930); and a clear glass, molded rim fragment with an amethyst hue (ca. 1880-1915)

ST K12: one clear glass shard with no hue (ca. post-1930)

ST K13: one undecorated whiteware sherd (ca. 1850-present)

Historic glass artifacts in a variety of types and colors were recovered from the surface and shovel test probes at this historic site and others on Camp Swift. CAS archaeologists carefully inspected and recorded diagnostic features 


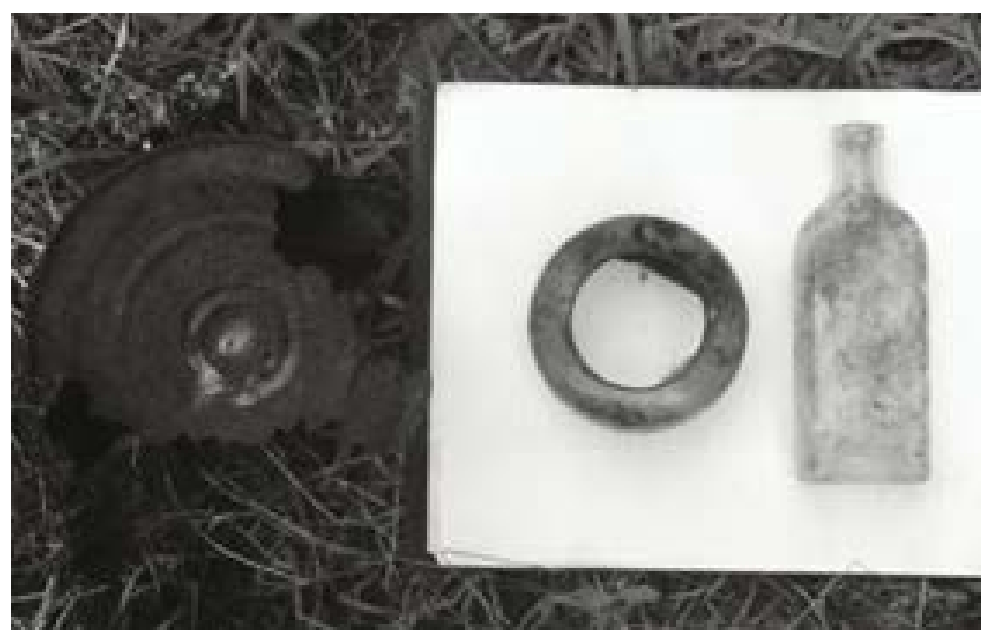

Figure 8-10. Selected artifacts found on the surface are from right to left: a soldered hole-in-top can, a kerosene lamp font, and a Eucaline bottle.

present on glass fragments and bottles that would assist in dating the artifacts. Glass color was also considered when approximating a general time frame for manufacture. Although dating glass by color can be problematic, some glass colors were produced more commonly than others as innovations in manufacturing processes and changes in popular opinion occurred over time. For example, aqua-colored glass and other shades of green were the predominant glass colors prior to the 1920s, when a preference for clear glass for presentation purposes arose (Lindsey 2005). Furthermore, glassmakers began to make a colorless glass around 1880 by adding manganese to bleach out the natural green tinge of glass when produced with sand containing iron. However, manganese additives cause colorless glass that is exposed to ultraviolet rays for an extended period to develop a purple hue, such as that seen in the fragment in ST 7 at this site.

Important for estimating the time of manufacture, a reduction in the use of manganese as a decolorizer(and thus the production of amethyst-hued glass) occurred around 1915. Some authors attribute the change to Germany cutting off its manganese supply to the United States during World War I (Kendrick 1966; Munsey 1970). However, Lindsey (2005) maintains that manganese as a decolorizer fell into decline with the development of automatic bottle machines, which mostly used open glass tanks in which selenium was a superior decolorizer. The addition of selenium caused the clear glass to have a straw or amber colored hue rather than the amethyst color produced by the addition of manganese. While clear glass with an amethyst hue likely dates from 1880 to 1915 , clear glass with a straw or amber hue is representative of the period from the mid1910s to the mid-1950s. Although diagnostic characteristics such as distinct bottle morphology, makers marks, and embossing provide the most accurate dating information, glass color can be a useful determinant in the absence of these features, especially if the color is associated with a specific time period.

Table 8-2. 41BP132 positive shovel test results.

\begin{tabular}{|c|c|c|c|c|c|c|}
\hline $\begin{array}{l}\text { Depth } \\
\text { (cmbs) }\end{array}$ & $\begin{array}{c}\text { ST } \\
2\end{array}$ & $\begin{array}{c}\text { ST } \\
4\end{array}$ & $\begin{array}{c}\text { ST } \\
6\end{array}$ & $\begin{array}{c}\text { ST } \\
7\end{array}$ & $\begin{array}{c}\text { ST } \\
\text { K12 }\end{array}$ & $\begin{array}{c}\text { ST } \\
\text { K13 }\end{array}$ \\
\hline $0-10$ & $\mathrm{M}$ & $\mathrm{CG}$ & $\mathrm{Br}, \mathrm{M}$ & $\mathrm{BG}, \mathrm{CG}$ & $\mathrm{CG}$ & WW \\
\hline $10-20$ & & & $\mathrm{Br}, \mathrm{RS}$ & & & \\
\hline $20-30$ & Clay & Clay & & Clay & & Clay \\
\hline $30-40$ & & & Clay & & & \\
\hline \multicolumn{7}{|l|}{$40-50$} \\
\hline $50-60$ & & & & & Clay & \\
\hline $60-70$ & & & & & & \\
\hline \multicolumn{7}{|c|}{$\begin{array}{l}\text { Key: WW-whiteware; BG-brown glass; CG-clear glass; } \mathrm{Br} \text {-brick } \\
\text { fragment; } \mathrm{M} \text {-metal; RS-rifle shell }\end{array}$} \\
\hline
\end{tabular}




\section{Archival Research}

In 1979, former residents Ina Fay Scott and Harlan Scott told Martha Freeman that this was the Cynthia and Jim Floyd house site. In January 2006, Abner C. Scott was driven to the site and he confirmed that Cynthia Floyd did indeed live there right up until 1942. Cynthia's brother, James (Jim) Floyd, lived with Cynthia until he died in 1934 (Skelton and Freeman 1979:97). They lived there with a nephew named Earnest Scott. He was the son of Frank Scott and Mary (Floyd) Scott, who lived just east of the Floyds (at 41BP157). Abner confirmed that the house sat as it is mapped, except it was T-Shaped, with the " $T$ " being in the front, a half-porch on the front corner, and a back porch. The drain for the cistern was across the front only.

\section{Conclusions/Recommendations}

The artifacts support the statements of Freeman's informants that this site was occupied from the last quarter of the nineteenth century and continued through the early twentieth century by the Floyd family. Although the architecture is severely damaged, some of its integrity still remains.. Mauldin (2001:175-186) concluded that the site has minimal research potential. However, the results reported here and the solid archival evidence can be used to recommend further investigations are warranted to determine if the site is eligible for nomination to the NRHP. CAS recommends that $51-x-$ $1-m$ units be excavated near the foundations and near the cistern.

\section{BP136}

\section{Description}

This is a twentieth-century corral constructed of lumber, posts, wire, and corrugated tin (Figure 8-11). According to Freeman's informants, it was used by Otis Evans before he relinquished the title to the government in 1942 (Skelton and Freeman 1979). Although it has been overtaken with dense vegetation, it is still relatively sound (Abner C. Scott, personal communication 25 January 2006). It was used again when parts of the Camp were leased out for cattle grazing in the 1960s. A large oak shade tree stands in the middle of it.

\section{Levels of Work and Results}

The one shovel test excavated within the site boundary was negative; all transect shovel tests around it were also negative. The only surface artifacts were two brown bottles that likely held disinfectant and a few clear glass jars with no hue. The corral has cedar posts with woven wire along

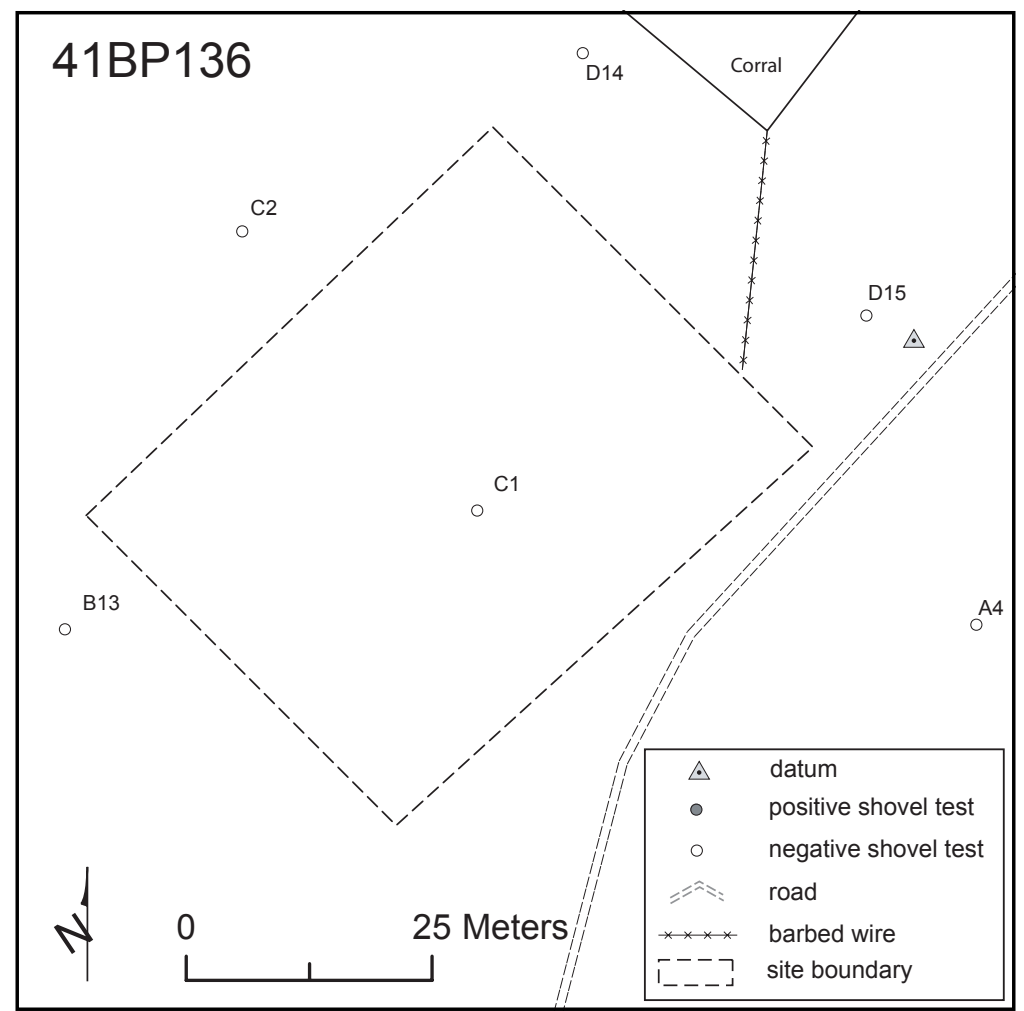

Figure 8-11. Site map of 41BP136, Otis Evans' corral. 
its western, southwestern, and northeastern sides, corrugated tin in its northern corner, cedar posts and 2-x-4 lumber along its southwestern side, and cedar posts with woven wire and corrugated tin along its southern and southeastern sides. A cedar lined loading and/or vaccination chute has been constructed in its southern portion.

\section{Archival Research}

Freeman indicates that this corral was "built by Otis Evans after World War II when he leased the land from the government for cattle grazing" (Skelton and Freeman 1979:96). Abner C. Scott (personal communication 16 January 2006) confirmed that Otis leased several hundred acres from the government for cattle grazing in the 1950s and 1960s. This corral was used as a staging area for shipping cattle.

\section{Conclusions/Recommendations}

Corrals are commonly found on Camp Swift,
Russell house site (Skelton and Freeman 1979), located near the community of Sayersville, and just south of the Sayersville to McDade Road (now Impact Road). Highway 95, the Camp Swift perimeter fence, and a sewer pipeline right-ofway now border the site on its western edge. Scattered bricks and artifacts, a few fence posts, some decorative vegetation, and a cattle watering trough are the only evidence that remain of the Russell occupation (Figure 8-12). The immediate area that likely constituted the house, yard, and fenced corral area are now moderately wooded with mesquite, cedar, and oak, with much thicker brush and trees surrounding it. The site datum is marked with a nail and an aluminum tag in a large oak tree.

\section{Levels of Work and Results}

Freeman examined the scattered bricks, a cistern, ceramics, glass, and metal and opined that they probably represented a first part of

but this one is in relatively good condition compared to the vast majority. Cattle operations of varying sizes existed in this area of the county from early settlement through the 1960s. Although interesting in its design and use of an assortment of materials in construction, it is not eligible for nomination to the NRHP because of its young age, i.e., post WWII and disassociation with habitation occupations. Also, it is unlikely to preserve significant subsurface deposits.

\section{BP139}

\section{Description}

Informants of Freeman indicated that this was the

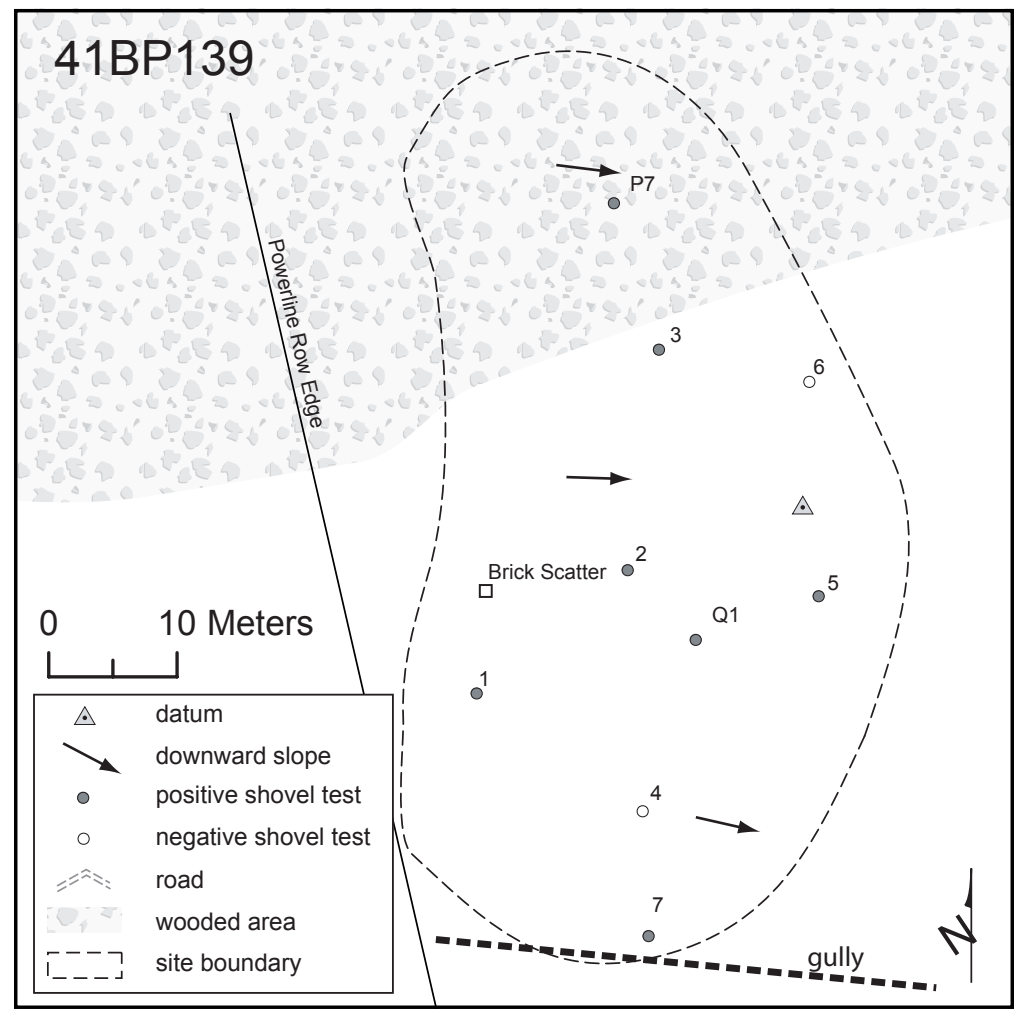

Figure 8-12. Site map of 41BP139. 
the twentieth century occupation. Schmidt, Cruse, and Brunlow later looked at the site in conjunction with an archaeological survey in advance of construction of the sewer line. They noted basically the same cultural remains as did Freeman, except for a cistern, but also an ornamental narcissus flower (Schmidt et al. 1995). In August, 2005 CAS archaeologists relocated the site and conducted a surface survey along with shovel test excavations. Cultural material on the surface included red chimney bricks in the densely treed portion alongside the right-of-way. All were red and mostly well made, and some were still together, three bricks high, forming the 20 -inch exterior of the chimney. Other than that, there were both red and yellow bricks scattered about in the same general area. Sandstone blocks scattered in this same area suggest that this was the location of the house and chimney. The round, metal watering trough is located north of the house, and may be the cistern referred to by Freeman.

The artifacts were scattered from the house area and downslope into a small gully (Figure 8-13). Bottle glass on the surface included a partial one with clear glass and an amethyst hue (ca. 1880-1915) that was manufactured by the

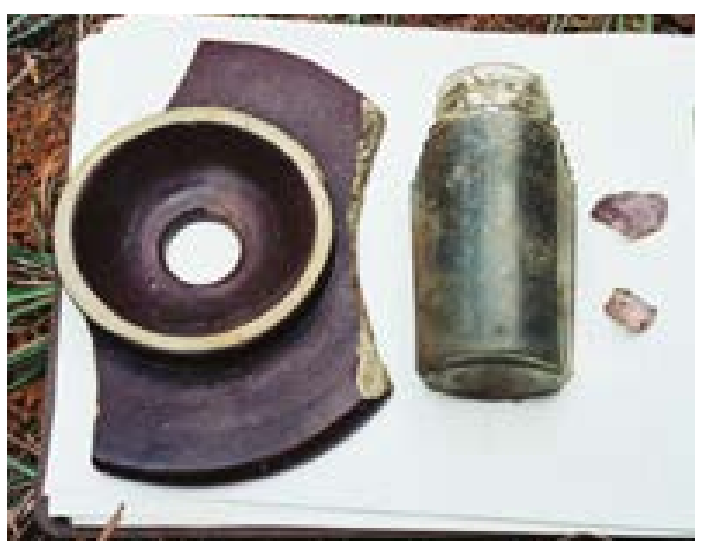

Figure 8-13. Selected artifacts found on the surface at 41BP139, from right to left: butter churn lid, Ball screw top condiment bottle, purple goblet glass shards.
Austin Bottling Works (Figure 8-14). Other glass included: a Ball perfect mason jar, 1-quart, with clear glass and a screw top (ca. post 1930); another Ball ribbed design condiment bottle of clear glass (ca. post-1930); a bottle neck of clear glass with an amethyst hue, cork stopper type neck, and an applied and smoothed lip (ca. 1880-1915); and purple glass shards from what may have been a goblet (ca. 1880-1915).

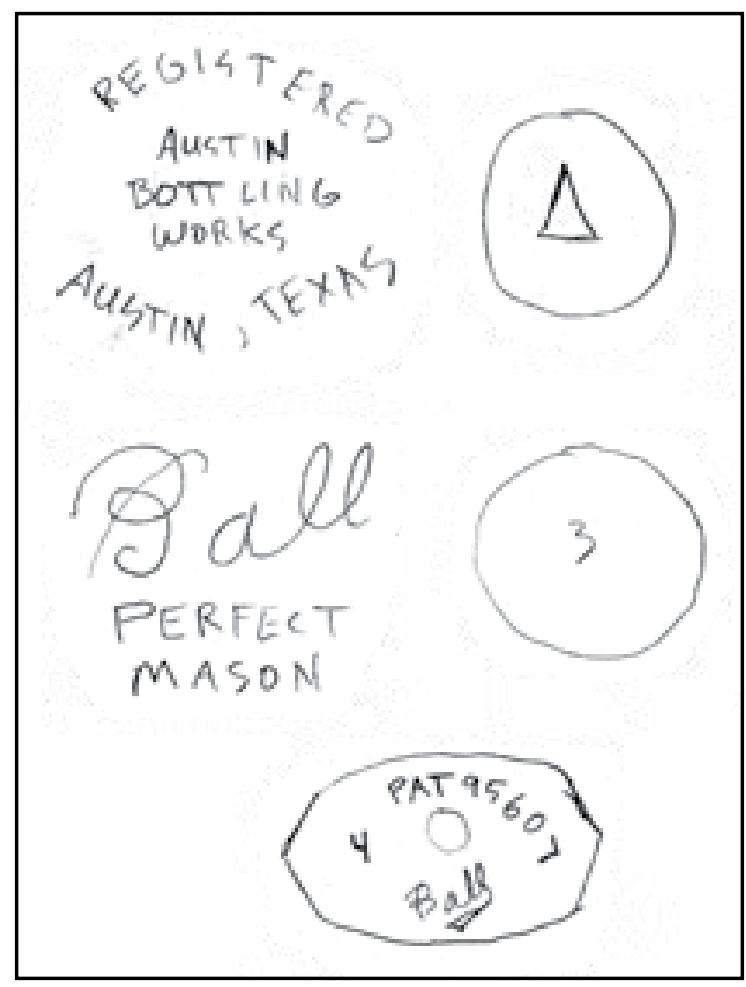

Figure 8-14. Bottle glass maker's marks.

Metal items included scattered sheet metal, a rusted bucket, and barbed wire strands of both two and four prongs. In addition to two undecorated whiteware sherds (ca. 1850-present), the top of a stoneware butter churn was found. It has a Leon slipped (ca. 1875-1900) dorsal surface and an unslipped/unglazed ventral surface.

Seven of nine shovel tests excavated on the site contained artifacts. Artifacts found in the shovel tests (Table 8-3) are as follows: 
Table 8-3. 41BP139 positive shovel test results.

\begin{tabular}{|c|c|c|c|c|c|c|c|}
\hline $\begin{array}{c}\text { Depth } \\
\text { (cmbs) }\end{array}$ & ST 1 & ST 2 & ST 3 & ST 5 & ST 7 & ST P7 & ST Q1 \\
\hline $0-10$ & CG & WW, CG & & CG, SN & & & WW, CG \\
\hline $10-20$ & CG, Mo & CG, LB, M & & SW, BG, CG & & WW & SW, WW, CG \\
\hline $20-30$ & Mo, SN & WW, CG & CG & BG, CG & CG & & WW, BG, CG \\
\hline $30-40$ & Clay & WW, CG & Clay & Clay & Clay & Clay & Clay \\
\hline $40-50$ & & AqG, CG & & & & & \\
\hline $50-60$ & & Clay & & & & & \\
\hline $60-70$ & \multicolumn{7}{|c|}{ glass; Mo-mortar; M-metal; SN-square nail } \\
\hline Key: SW-stoware; WW-whiteware; AqG-aqua glass; BG-brown glass; CG-clear glass; LB-light bulb \\
\hline
\end{tabular}

ST 1: Clear glass with no hue (ca. post-1930); aqua glass with thick patina (ca. pre-1900); mortar chunks; square-cut nail (ca. pre-1900)

ST 2: Clear glass (ca. post-1930); clear glass with amethyst hue (ca. 1880-1915); aqua glass (ca. pre-1900); undecorated whiteware (ca. 1850-present); light bulb glass; undecorated ironstone with a Royal Ironstone China, A. J. Wilkinson Ltd. Maker's mark, which indicates it could have been manufactured as early as 1896 (Kovel and Kovel 1986:12); and the metal base of an electric light bulb

ST 3: Clear glass with heavy patina (ca. post1930)

ST 5: Clear glass with amethyst hue (ca. 18801915); thick brown glass with milky patina (ca. pre-1900); square-cut nail (ca. pre-1900); clear glass with no hue (ca. post-1930)

ST 7: Clear glass with no hue (ca. post-1930)

ST P7: Undecorated whiteware (ca. 1850 present)

ST Q1: Undecorated whiteware (ca. 1850present); stoneware (ca. 1900); clear glass with no hue (ca. post-1930); thin brown glass (ca. post-1930)

\section{Conclusions/Recommendations}

As stated above, the Russell family lived here before Camp Swift was established. On February 8, 2006, Fay Pannell (personal communication) confirmed that Mr. Bill Russell lived here until the government acquired the land. He owned property on both sides of what is now Highway 95, and he moved across the highway in 1942. A review of the approximate ages of artifacts indicates a potential occupation period from about 1880 through 1942, when the Russells moved off the property. A further review indicates that when approximate ages are considered, the artifacts are somewhat mixed. The soils are mainly brown sandy loams but common angular ironstone fragments and unusually loose sediments were observed, suggesting a degree of mixing may be present. CAS assesses the additional research value of the historic component at this site as minimal; no further investigations are recommended, and the historic component is not eligible for nomination to the NRHP.

\section{BP142}

\section{Description}

This historic house site lies just northeast of 41BP143 (Figures 8-15 and 8-16), and as Freeman noted when she first recorded the site (Skelton and Freeman 1979), the two may be related. Both 


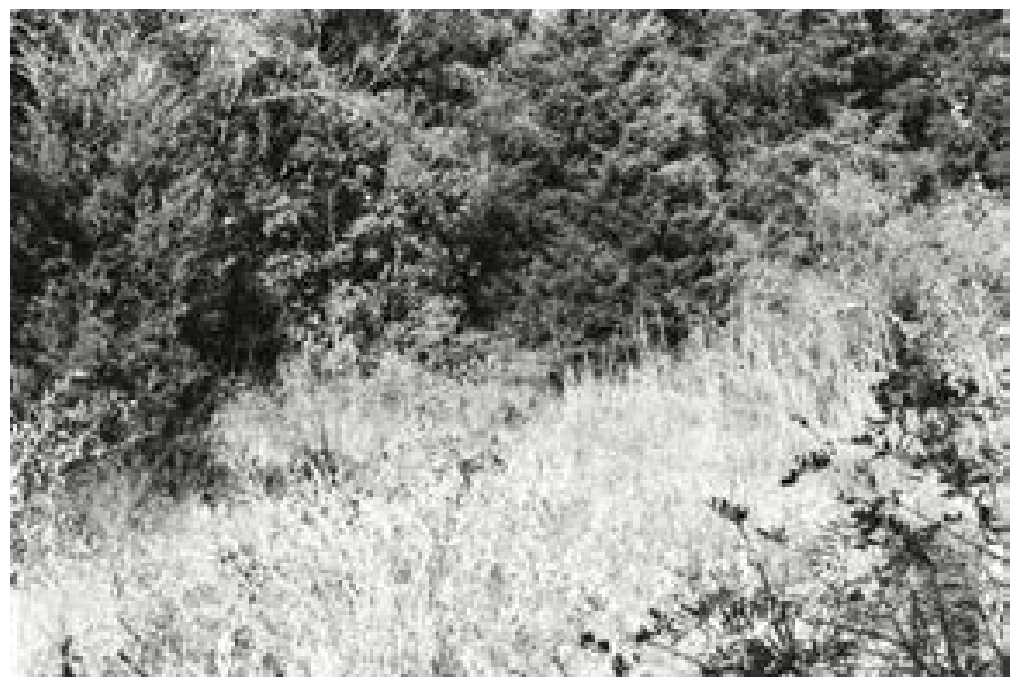

Figure $8-15$. This house site at $41 \mathrm{BP} 142$ may be related to the farmstead just south at 41BP143; facing west.

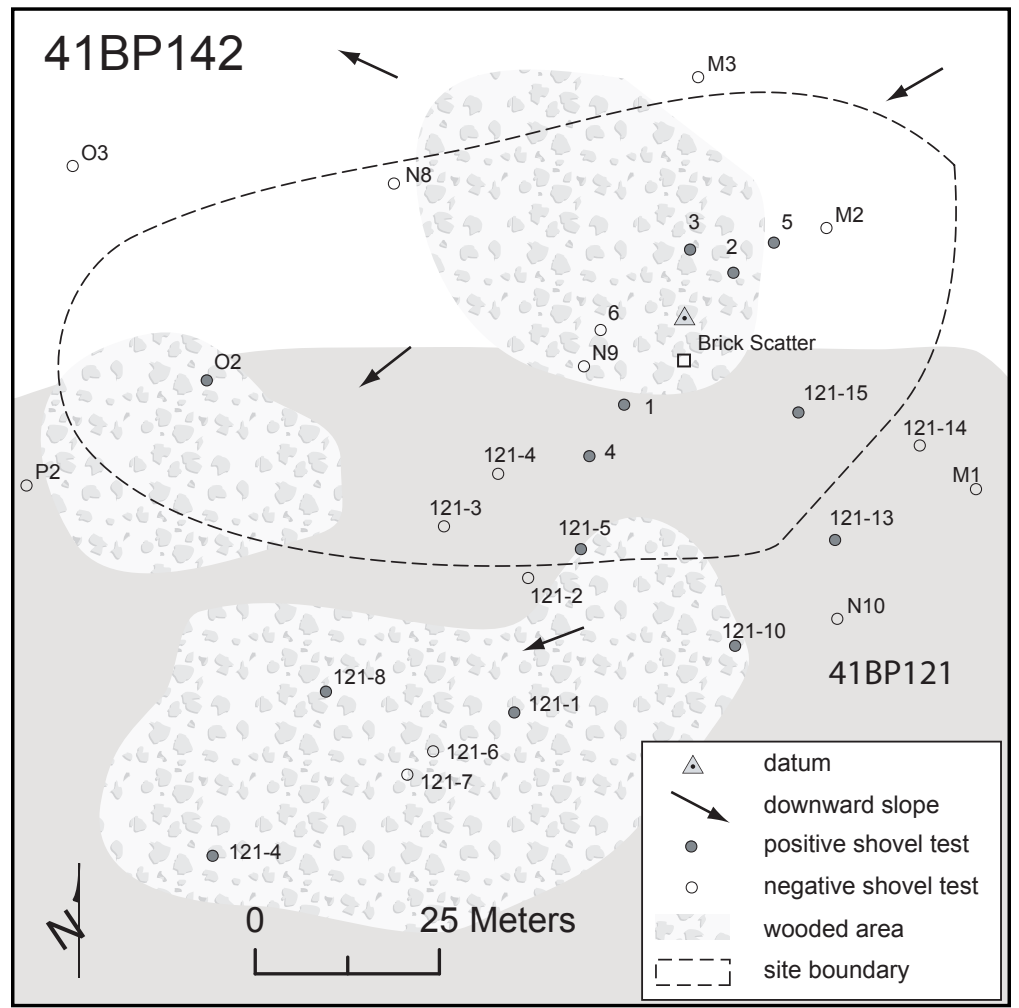

Figure 8-16. Site map of 41BP142.

which is a prehistoric site, but the original site numbers have been retained. Vegetation consists of oak, mesquite, cedar, hackberry, elm, prickly pear, blackberry, and grapevines. The site datum is marked with a nail and aluminum tag on a $15-\mathrm{cm}$ diameter oak tree.

\section{Levels of Work and Results}

When Freeman saw the site in 1979, she noted that it was composed of twentiethcentury bricks, ceramics, and glass. When CAS archaeologists returned in 2005, they observed bricks, whiteware sherds, and an unidentifiable metal piece on the surface. Of the 10 shovel tests excavated on the site, six contained artifacts. Positive shovel tests are listed in Table 8-4.

ST 1: Clear glass with pinkish hue (ca. 1880-1915)

ST 2: Pink and green flower transferware (ca. 1880-1900); undecorated whiteware (ca. 1850-present); square nail (ca. pre-1890); thick, dark brown glass with heavy patina (ca. pre1900)

ST 3: Thick, dark brown glass (ca. pre-1900)

ST 4: Clear glass with aqua hue

are on a 676-acre tract previously owned by C. Westbrook (Bastrop County 1929). It consists of scattered bricks, glass, and nails on a clay surface that has been heavily disturbed by bulldozing. The site also overlaps significantly with 41BP121,

\section{(ca. pre-1900)}

ST 5: Yellow brick fragment, fairly well fired; thick, dark brown glass (ca. pre-1900)

ST O2: Dark brown glass (ca. pre-1900) 
Table 8-4. 41BP142 positive shovel test results.

\begin{tabular}{|c|c|c|c|c|c|c|}
\hline $\begin{array}{c}\text { Depth } \\
\text { (cmbs) }\end{array}$ & $\begin{array}{c}\text { ST } \\
\mathbf{1}\end{array}$ & $\begin{array}{c}\text { ST } \\
\mathbf{2}\end{array}$ & $\begin{array}{c}\text { ST } \\
\mathbf{3}\end{array}$ & $\begin{array}{c}\text { ST } \\
\mathbf{4}\end{array}$ & $\begin{array}{c}\text { ST } \\
\mathbf{5}\end{array}$ & $\begin{array}{c}\text { ST } \\
\text { O2 }\end{array}$ \\
\hline $0-10$ & CG & WW & & CG & & \\
\hline $10-20$ & CG & $\begin{array}{c}\text { WW, } \\
\text { SN }\end{array}$ & BG & Clay & $\begin{array}{c}\text { BG, } \\
\text { Br }\end{array}$ & BG \\
\hline $20-30$ & Clay & $\begin{array}{c}\text { WW, } \\
\text { BG }\end{array}$ & & & & \\
\hline $30-40$ & & Clay & Clay & & & \\
\hline $40-50$ & & & & & & \\
\hline $50-60$ & & & & & Clay & \\
\hline $60-70$ & & & & & & \\
\hline \multicolumn{7}{|c|}{ Key: WW-whiteware, BG-brown glass; CG-clear glass; } \\
Br-brick fragment; SN-square nail \\
\hline
\end{tabular}

Sediments observed in shovel tests indicated a significant level of disturbance. Evidence for disturbance includes gravel lenses and angular ironstone fragments at depth.

\section{Conclusions/Recommendations}

The artifacts found during this survey imply an occupation period of about 1880-1900, if not later. Because the structure has been bulldozed and soils have also been disturbed, CAS assesses the research value of the historic component at this site as minimal, no further investigations are recommended, and the historic component is not eligible for nomination to the NRHP.

\section{$41 \mathrm{BP} 143$ (41BP122) \\ Description}

This is the site of a farmstead on a corner of C. Westbrook's 676-acre tract (Bastrop County 1929), located on Tract D-133 near the northeast corner of Tract D-146 (discussed further below). It is also believed to have been the site of an early fort.
The prehistoric component at this site has been discussed in Chapter 7: New Prehistoric Component Sites-41BP122. It is situated on a sandy terrace on the north side of McLaughlin Creek, and an old jeep road that has now been improved and renamed "New Road" cuts through the center of the site (Figures 8-17 and $8-18)$. The area north of New Road has both dense woods and a cleared open field, while the area south of the road is generally cleared. Otherwise, the fields are now overgrown with dense grasses, prickly pear, bull nettles, and poison ivy. What appears to be a machine contoured drainage ditch with a berm alongside runs through the site from north to south, and the overall surface is hummocky. A depression north of the road may be a filled-in well or cistern, and based upon shovel test results, a house and/or fort may have stood in a small mott of elm, oak, and cedar trees on the south side (see Figure 817). The site datum is marked with a nail and aluminum tag on an oak tree near the center of the site, just east of the drainage.

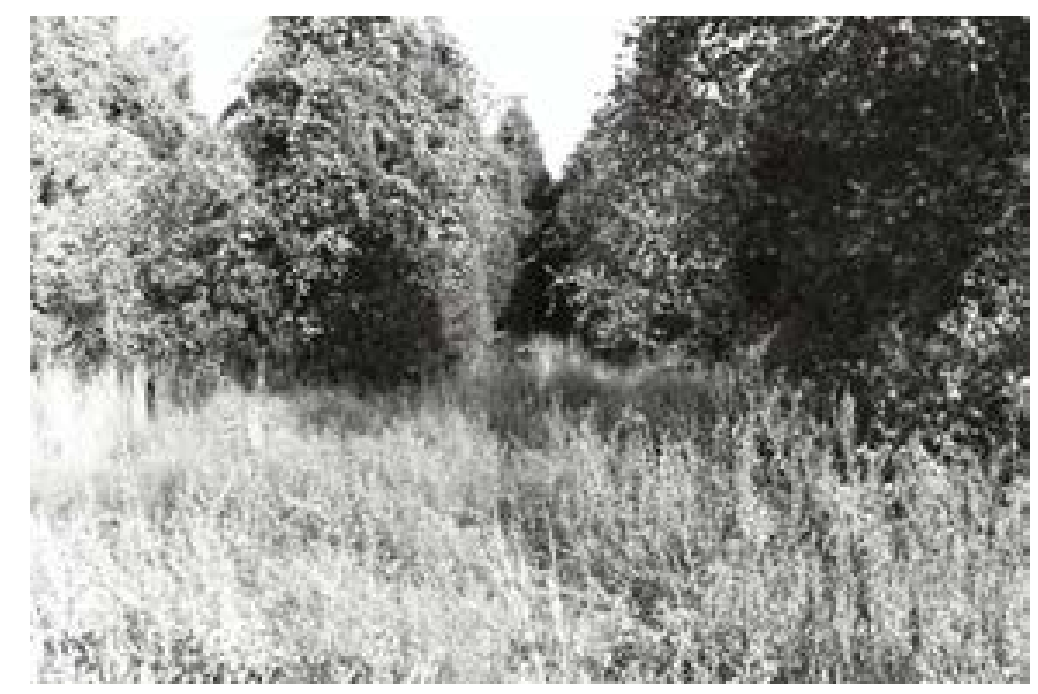

Figure 8-17. This farmstead and old fort site is located on both sides of an old two-track road near McLaughlin Creek; facing northwest. 
FIGURE 8-18. REDACTED

Figure 8-18. Site map of 41BP143 (41BP122).

\section{Levels of Work and Results}

A review of the site location on THC's Atlas site indicates that it is plotted approximately $85 \mathrm{~m}$ northeast from the actual site location. However, using WGS83/84 datum coordinates, the site digitization UTMs provided by TARL more accurately plot the site. Robinson et al. (2001:133) lump 41BP122 and 41BP143 together and state, "the prehistoric (41BP122) and historic (41BP143) components of this site were given different site numbers." There is no question that the historic component (41BP143) was located during this survey. It is as described by Freeman. When she visited this site in 1979 , she stated that "the site is situated unusually close to McLaughlin Creek and is cut by a historic road...It seems to be comprised of at least three discrete, collapsed buildings and areas of disturbed, mounded earth" (Skelton and Freeman 1979: Table 5). The old road she refers to has been re-routed and is now called "New Road." New Road cuts through 41BP143 just south of where the old road was.

In 1997, CAR archaeologists excavated six shovel probes and recovered a brown snuff bottle that dated before 1903, aqua glass, brown glass, and two cut nails (Robinson et al. 2001:133). In 2005, CAS archaeologists could not discern any discrete areas of collapsed buildings on the surface, only an occasional brick or sandstone fragment. Bottle glass shards found on New Road consisted of thick aqua (ca. pre-1900); thick, dark brown (ca. pre-1900); clear with a pinkish hue (ca. 1880-1915); milk glass (ca. 1870-1920); thick amber (ca. post-1915); and clear with no hue (ca. post-1930). Of the 35 shovel tests excavated on the site, thirteen of the seventeen positive shovel tests contained historic artifacts that could date from as early as 1830 through the present (Table 8-5).

Table 8-6 shows on a gross scale the earliest and latest date for the manufacture and/or use of the historic artifacts found in the shovel tests. Thirty-nine diagnostic artifacts could be associated with a general time frame, but 26 could not. The 39 datable items are sorted according to the earliest date of possible use, and then divided into three general periods: 1850 and earlier; 1850-1900; and 1900 and later. Interestingly, 18 of 39 items (46 percent) potentially date to 1850 or earlier, and 16 of those 18 ( 89 percent) were recovered in a small area focused on STs $1-8$ and G2 (see Figure 8-18). At the same time, all 12 items potentially dating to $1850-1900$ and seven of nine items that could date from 1900-present 


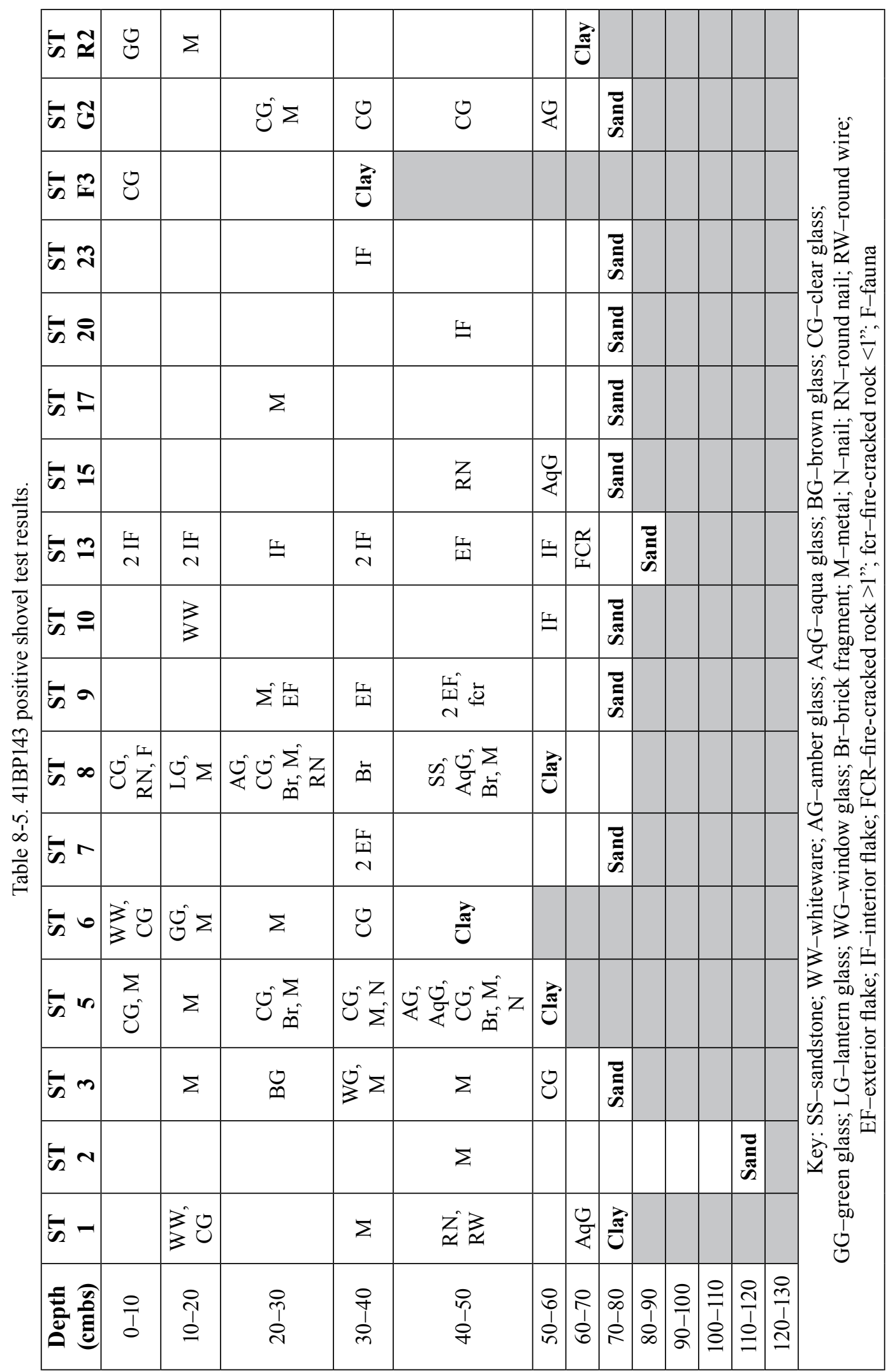




\begin{tabular}{|c|c|c|c|c|c|c|c|c|c|c|c|c|c|c|c|c|}
\hline 莺 & § & § & 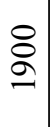 & ‡ & $\begin{array}{l}\overrightarrow{0} \\
\overrightarrow{0} \\
0 \\
0 \\
0 \\
0\end{array}$ & $\S$ & 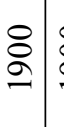 & $\stackrel{8}{\S}$ & 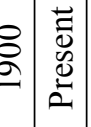 & 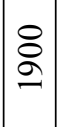 & ஓ & 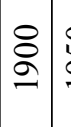 & 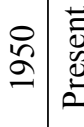 & 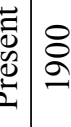 & 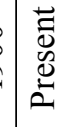 & 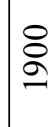 \\
\hline 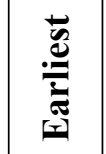 & $\underset{\mathscr{\infty}}{\stackrel{\infty}{\infty}}$ & $\underset{\mathscr{\infty}}{\stackrel{\infty}{\infty}}$ & $\begin{array}{l}\stackrel{\oplus}{\infty} \\
\infty\end{array}$ & $\begin{array}{l}\stackrel{\infty}{\infty} \\
\infty \\
-1\end{array}$ & $\begin{array}{l}\stackrel{0}{ } \\
\infty \\
\infty\end{array}$ & $\begin{array}{l}0 \\
\wp \\
\infty\end{array}$ & \begin{tabular}{l|l}
$\stackrel{0}{\infty}$ & \\
$\infty$ &
\end{tabular} & \begin{tabular}{l|l}
0 & \multicolumn{2}{c}{} \\
$\infty$ & $\alpha$ \\
$\infty$ & $\alpha$
\end{tabular} & \begin{tabular}{l|l}
$\stackrel{0}{0}$ \\
$\infty$ \\
$\infty$ & $\infty$ \\
0
\end{tabular} & $\left|\begin{array}{c}0 \\
\infty \\
\infty\end{array}\right|$ & $\begin{array}{c}0 \\
\infty \\
\infty\end{array}$ & \begin{tabular}{|l|l}
$\stackrel{0}{\infty}$ & \\
$\infty$ & $\vdots$
\end{tabular} & 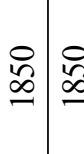 & \begin{tabular}{l|l}
$:$ & 0 \\
0 & $\infty$ \\
0 & $\infty$ \\
\end{tabular} & $\begin{array}{l}\stackrel{0}{\infty} \\
\infty\end{array}$ & $\begin{array}{l}\mathscr{\infty} \\
\ddot{\infty}\end{array}$ \\
\hline$\frac{\grave{\Xi}}{0}$ & & & & & & & & & & & & & & & & \\
\hline 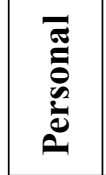 & & & & & & & & & & & & & & & $x$ & \\
\hline 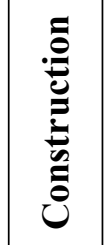 & $x$ & $x$ & $x$ & $x$ & & & & & & & & & $x$ & & & \\
\hline 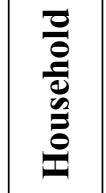 & & & & & $x$ & $x=$ & $x$ & $x / y$ & $x \mid x$ & $x$ & $x \mid$ & $x$ & $x$ & $x \mid x$ & & $x$ \\
\hline$\stackrel{\Xi}{\Xi}$ & 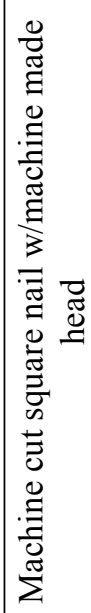 & 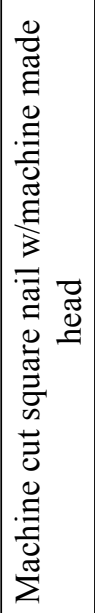 & 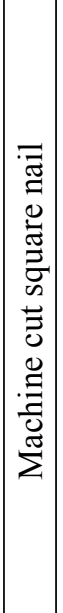 & 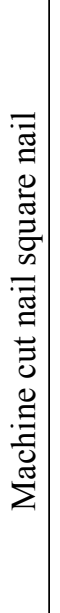 & 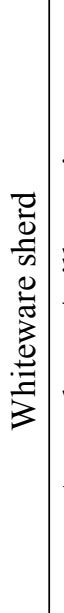 & 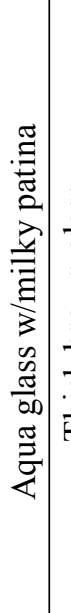 & 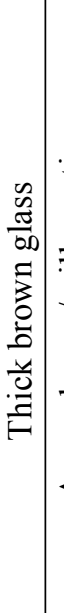 & 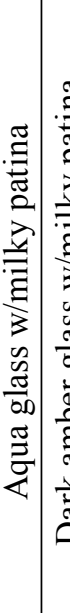 & 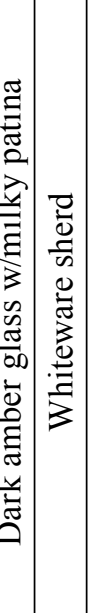 & 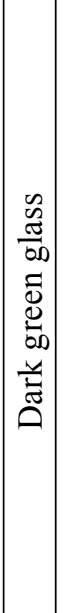 & 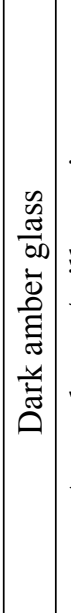 & 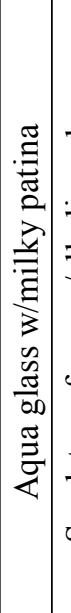 & 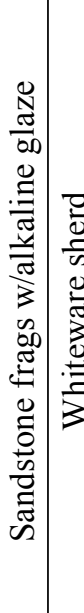 & 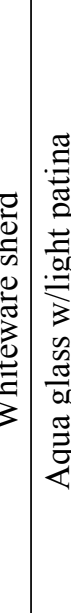 & 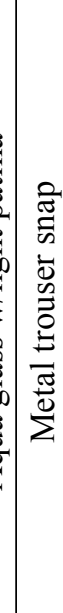 & 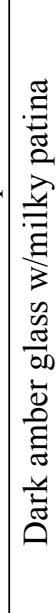 \\
\hline 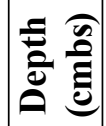 & $\begin{array}{l}\text { P } \\
1 \\
0 \\
0\end{array}$ & $\begin{array}{l}\stackrel{p}{1} \\
\text { p } \\
\text { + }\end{array}$ & $\begin{array}{l}0 \\
1 \\
0\end{array}$ & $\begin{array}{l}8 \\
1 \\
0 \\
\text { N }\end{array}$ & $\begin{array}{l}\stackrel{\imath}{1} \\
\stackrel{\theta}{ }\end{array}$ & 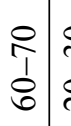 & 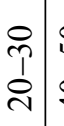 & \begin{tabular}{l|l}
0 & \multicolumn{1}{c}{} \\
1 & 4 \\
0 & \\
+ & 5
\end{tabular} & 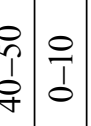 & $\begin{array}{l}\stackrel{1}{1} \\
\hat{0}\end{array}$ & 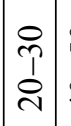 & 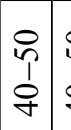 & 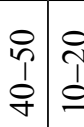 & 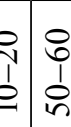 & i & $\begin{array}{l}8 \\
0 \\
1 \\
0\end{array}$ \\
\hline 部 & $n$ & $n$ & $\infty$ & $\infty$ & - & -1 & $m$ & $n$ & $n$ & 0 & $\infty$ & $\infty$ & $\infty \quad \subseteq$ & $\theta \cong$ & $\mathcal{O}$ & $\widetilde{O}$ \\
\hline 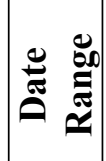 & \multicolumn{16}{|c|}{ 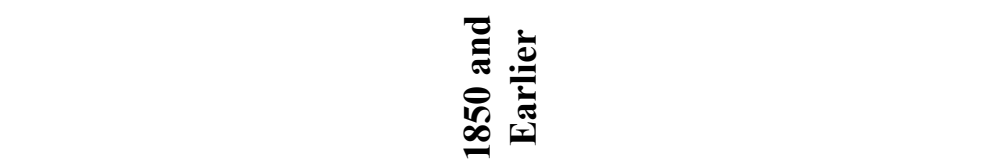 } \\
\hline
\end{tabular}




\begin{tabular}{|c|c|c|c|c|c|c|c|c|c|c|c|c|c|c|c|c|c|c|c|c|}
\hline 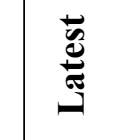 & $\frac{n}{2}$ & $\frac{n}{2}$ & $\frac{n}{a}$ & $\frac{n}{2}$ & $\frac{n}{2}$ & $\frac{n}{2}$ & $\frac{n}{a}$ & $\frac{n}{2}$ & ڤ & $\frac{n}{\sigma}$ & $\frac{n}{2}$ & 옹 & 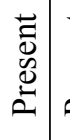 & 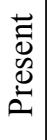 & 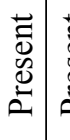 & 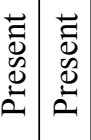 & $\mid \begin{array}{l}\overrightarrow{0} \\
0 \\
0 \\
0 \\
0\end{array}$ & $\begin{array}{l}\overrightarrow{0} \\
\overrightarrow{0} \\
0 \\
\dot{0}\end{array}$ & & $\begin{array}{l}\overrightarrow{0} \\
0 \\
0 \\
0 \\
=\end{array}$ \\
\hline 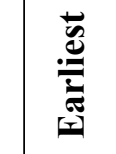 & $\begin{array}{l}0 \\
\infty \\
\infty \\
-1\end{array}$ & $\begin{array}{l}\infty \\
\infty \\
\infty \\
-1\end{array}$ & $\begin{array}{l}\infty \\
\infty \\
\infty\end{array}$ & $\begin{array}{l}\infty \\
\infty \\
\infty\end{array}$ & $\begin{array}{l}\infty \\
\infty \\
\infty\end{array}$ & $\begin{array}{l}\infty \\
\infty \\
\infty\end{array}$ & $\begin{array}{l}0 \\
\infty \\
\infty\end{array}$ & $\begin{array}{l}\infty \\
\infty \\
\infty \\
-1\end{array}$ & $\begin{array}{l}\stackrel{0}{\infty} \\
\infty \\
=\end{array}$ & $\begin{array}{l}\infty \\
\infty \\
\infty\end{array}$ & $\begin{array}{l}0 \\
\infty \\
\infty \\
\infty\end{array}$ & $\begin{array}{l}2 \\
\infty \\
\infty \\
\infty\end{array}$ & $\stackrel{2}{\circ}$ & 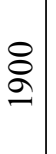 & ఏ & 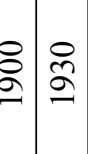 & হু & $\stackrel{\sigma}{\sigma}$ & 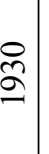 & $\begin{array}{l}0 \\
\check{2}\end{array}$ \\
\hline$\frac{\grave{\Xi}}{\overline{0}}$ & & & & & & & & & & & & & $x$ & & & & & & & \\
\hline $\begin{array}{l}\bar{\sigma} \\
\overline{0} \\
0 \\
0 \\
0 \\
0\end{array}$ & & & & & & & & & & & & & & & & & & & & \\
\hline 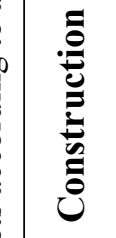 & & & & & & & & & & & & & & $x$ & $x$ & & & & & \\
\hline $\begin{array}{l}\frac{\pi}{0} \\
\frac{0}{0} \\
0 \\
0 \\
0\end{array}$ & $x \mid$ & $x$ & $x$ & $x$ & $x$ & $x$ & $x$ & $x$ & $x$ & $x \mid$ & $x$ & $x$ & & & & $x \mid x$ & $x$ & $x=$ & $x$ & $x$ \\
\hline$\stackrel{\Xi}{\Xi}$ & 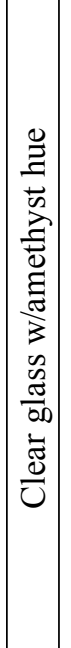 & 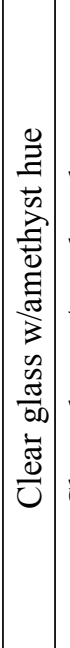 & 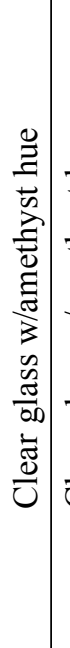 & 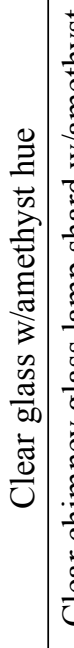 & 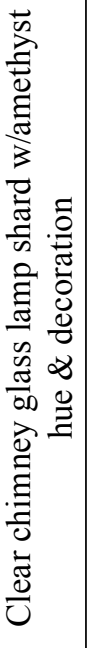 & 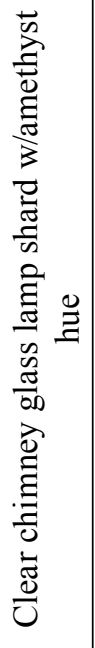 & 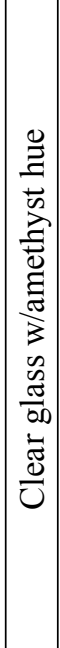 & 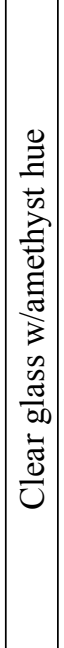 & 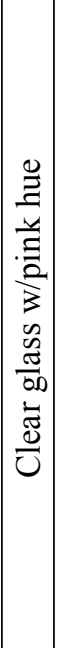 & 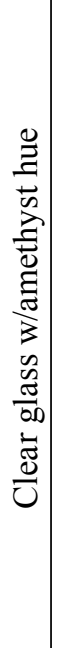 & 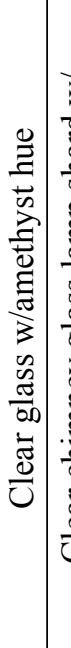 & 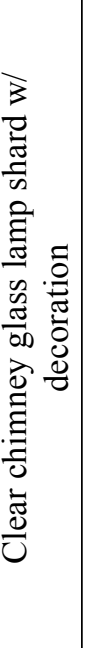 & 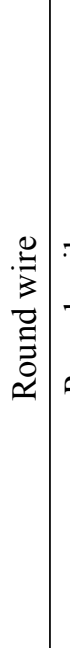 & 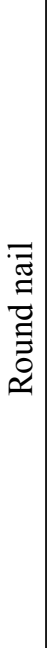 & 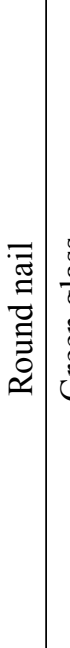 & 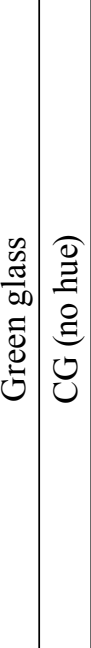 & 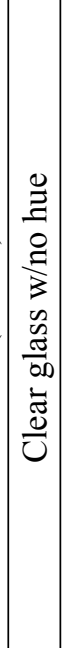 & 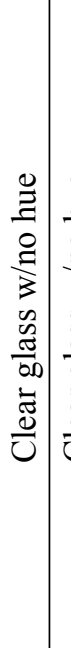 & 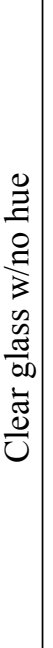 & 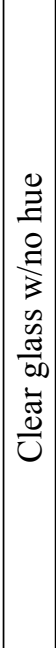 \\
\hline 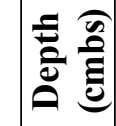 & $\begin{array}{l}0 \\
1 \\
0\end{array}$ & $\begin{array}{l}0 \\
\tilde{1} \\
\hat{\lambda}\end{array}$ & \begin{tabular}{c}
0 \\
$f$ \\
1 \\
0 \\
\hdashline
\end{tabular} & $\begin{array}{l}0 \\
\stackrel{1}{1} \\
o \\
+\end{array}$ & $\frac{0}{1}$ & $\stackrel{\text { Iิ }}{\text { Iิ }}$ & 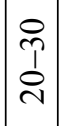 & 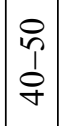 & $\mid \begin{array}{l}0 \\
1 \\
0 \\
q\end{array}$ & $\begin{array}{l}o \\
q \\
0 \\
\varnothing\end{array}$ & $\begin{array}{l}0 \\
i \\
o \\
+\end{array}$ & $\stackrel{0}{1}$ & $\begin{array}{l}8 \\
0 \\
1 \\
0 \\
n\end{array}$ & $\begin{array}{l}8 \\
0 \\
1 \\
0 \\
n\end{array}$ & \begin{tabular}{ll}
0 & \multicolumn{1}{c}{} \\
1 & \\
$o$ &
\end{tabular} & \begin{tabular}{l|l}
0 & $\stackrel{1}{1}$ \\
& 1 \\
0 & 0
\end{tabular} & $\begin{array}{l}8 \\
0 \\
1 \\
0 \\
\text { n }\end{array}$ & $\begin{array}{l}\text { Pे } \\
1 \\
\stackrel{r}{r}\end{array}$ & $\frac{0}{1}$ & $\begin{array}{l}0 \\
\tilde{n} \\
1 \\
\text { సे }\end{array}$ \\
\hline 舟 & in & in & in & in & $\infty$ & $\infty$ & $\infty$ & $\infty$ & $\infty$ & ठิ & త & 6 & -1 & - & 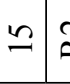 & $\approx-$ & $m$ & 0 & $\tilde{I}$ & ठิ \\
\hline 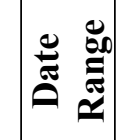 & \multicolumn{12}{|c|}{$\begin{array}{l}1 \\
\stackrel{1}{10} \\
0 \\
0\end{array}$} & \multicolumn{8}{|c|}{ 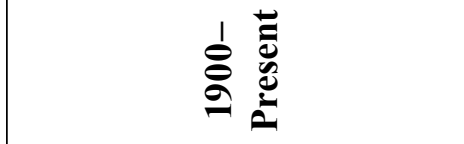 } \\
\hline
\end{tabular}




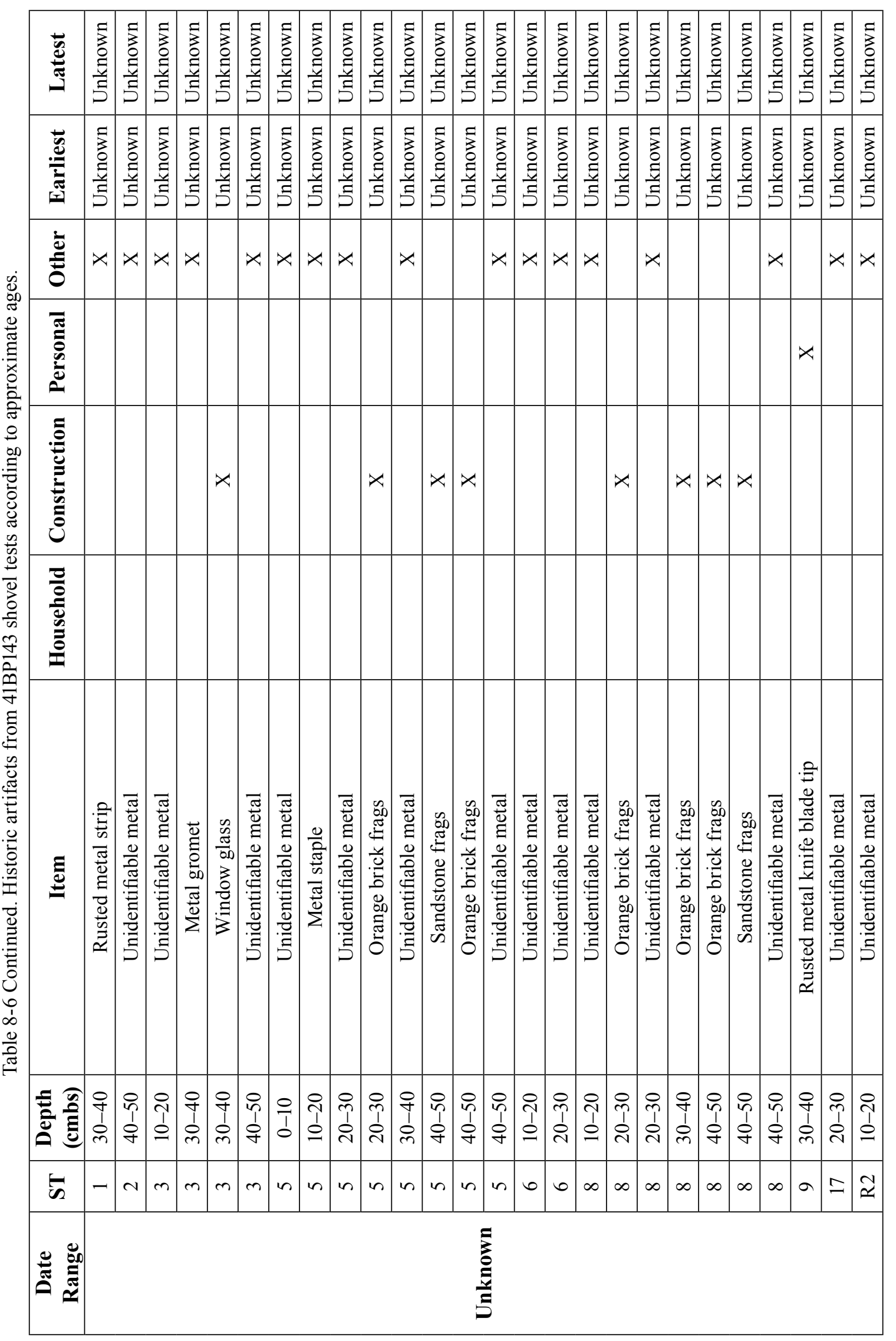


were recovered from the same area. Fourteen of 15 items that are typically related to construction were in that area.

\section{The Old Fort}

Native American hostilities in Texas ebbed and flowed with the westward expansion of Anglo Americans, influenced by (among other things) Texas Independence, headstrong ambitions for new land, new trails through Native American hunting lands to the western goldfields, the Civil War, and political bickering between the Bureau of Indian Affairs and the army. The New Handbook of Texas (Tyler 1996) identifies no less than 75 Texas forts and camps, both private and government sponsored, that were established to provide protection against Indian depredations (Figure 8-19). Bastrop County was no exception when it came to retaliatory attacks from both whites and Native Americans (Fehrenbach 1974; Richardson 1991; Wilbarger 1985 [1889]).

In his 1933 master's thesis, William Korges (1933:81) describes two such family forts built by Austin's Colony pioneers and located southeast of Bastrop:

A fort was built here and the seven families built $\log$ cabins within the fort. In the beginning the Indians were more of an annoyance than of danger, being content to steal horses, cattle, and other property. The families locating at this fort were: Cottle, Craft, Grimes, Highsmith, Parks, Ridgeway, and White. Later Ridgeway became dissatisfied, moved east about ten miles, and built Ridgeway Fort on Ridgeway Prairie where Paige is now located. However, the Indians became very troublesome, and he was glad to move back to the settlement. The fort built by them was constructed by splitting eight-foot logs and setting them edgewise in the ground. The fort enclosed about an acre. After its abandonment by Ridgeway, the Indians kept their stolen horses in it for safe keeping.

Skelton and Freeman (1979:98) indicated that two District Court cases, 2080 and 2081, which decided lawsuits over the ownership of Tract D146 between John D. Floyd, David McLaughlin, Abner Scott, Jonathan D. Floyd, Silas Floyd, and John Hampshire, mentions an "Old Fort" on the northwest bank of McLaughlin Creek. These two cases were decided in 1872 and 1874, respectively, with the land confirmed to the Floyds in both cases. The fact that the lawsuits mention an old fort on the northwest bank of McLaughlin Creek is significant. Although 41BP143 is not on Tract $\mathrm{D}-146$, it is in fact located at the adjoining corner of Tract D-133 - the C. Westbrook property.

CAS archaeologists obtained a copy of the survey description from the TXMF office at Camp Mabry for Tract D-146, filed in February 1943. Specifically, the description mentions a survey stake on the northwest bank of McLaughlin Creek at the old fort. CAS then obtained a copy of the bearings, metes, and bounds prescribed

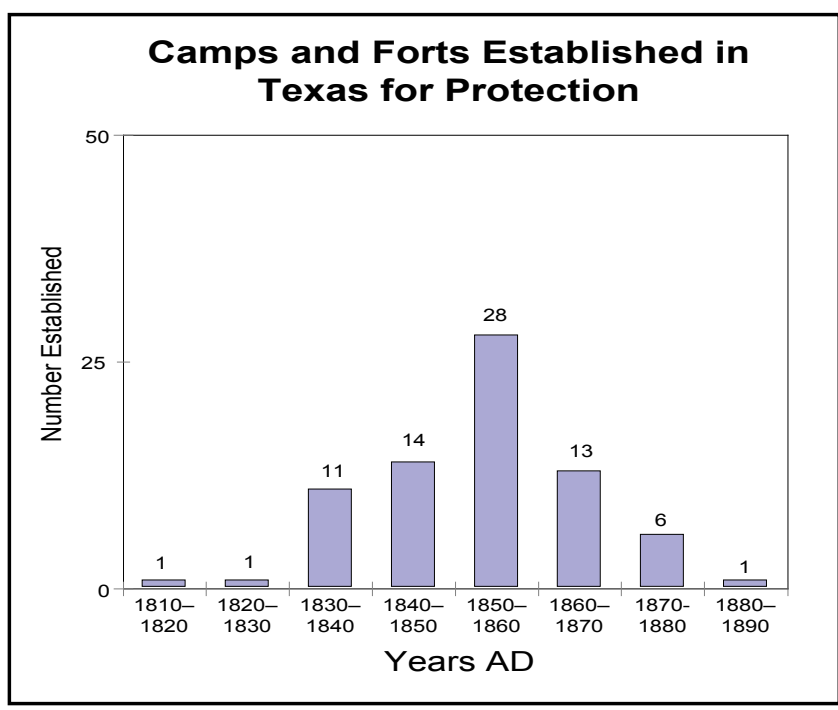

Figure 8-19. Texas camps and forts established for protection against Native American hostilities. 
for Tract D-146, apparently digitized for the Texas National Guard in March 1980. Using these data, archaeologists identified the northeast corner of Tract D-146 on McLaughlin Creek, where according to the 1943 survey description and District Court cases 2080 and 2081, the old fort was supposedly located. The 1980 document gave the Texas State Plane coordinates for the northeast corner. CAS archaeologists then converted the state plane coordinates to UTM coordinates and used them to navigate to the northeast corner of Tract D146 with a GPS.

The exact corner is located on a slight rise above and adjacent to the McLaughlin Creek floodplain, approximately $110 \mathrm{~m}$ (363 feet) southwest of the artifact concentration found in STs $1-8$ and G2 (see Figure 8-18). However, as the terrain exists today, it seems like an improbable place to locate any type of structure. It is subjected to periodic flooding from McLaughlin Creek. A more likely location would be upslope in the locale of STs $1-8$ and G2.

\section{Conclusions/Recommendations}

The artifacts recovered from shovel tests imply occupations could have begun before 1850 through possibly as late as 1942 , when the government acquired the property. However, this site has yielded significantly more early artifacts than are commonly found at other historic sites on Camp Swift. The earliest possible date as ascertained from the square nails is 1830 . One possible interpretation is that 46 percent of the historic items could have been discarded at this site between 1830-1850. It is also possible that these artifacts date to a later period, but mostly before 1900. Figure 8-20 shows that most of the artifacts, when the full time-span is illustrated, date between 1850 and 1910 with a likely peak

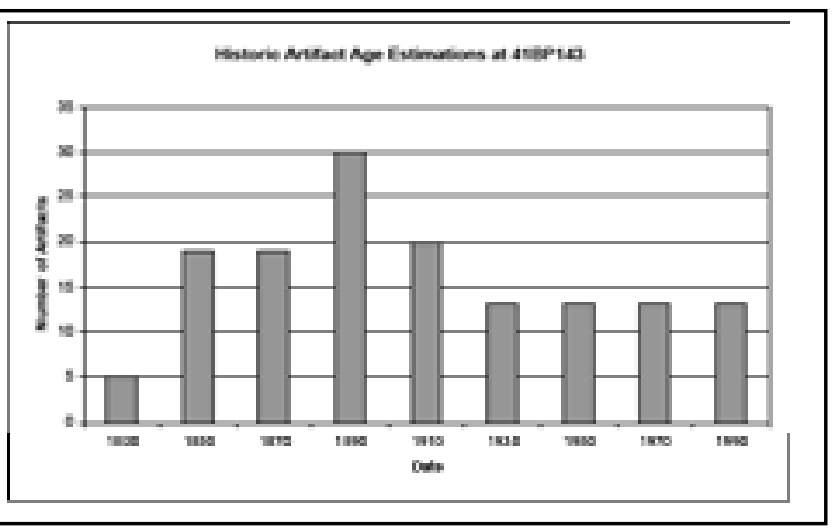

Figure 8-20. 41BP143 historic artifact deposition.

near 1890. It is most probable that the most intense occupation was in the later half of the nineteenth century, but a mid-nineteenth century occupation cannot be refuted.

In sum, the artifact ubiquity in that locale implies a comparatively intensive occupation starting perhaps as early as 1850, and could possibly represent a temporary fort-like structure and occupation. A cursory review of deed records indicates there were no fewer than 30 transactions on land in the surrounding area prior to 1860. Although no intact structural remains were discovered during this project, the ages of artifacts suggest some may be contemporaneous with the construction of a fort. However, before such a determination can be made, CAS recommends four test units be hand-excavated to gather additional data. If the data reveal potentially intact deposits, then a more comprehensive plan should be developed to determine the dimensions of the structure if possible. In addition, CAS recommends that more in-depth archival investigations be conducted to determine if and when the possible fort was likely constructed, who may have constructed it, and how long it may have been used. In the meantime, the historic component's NRHP eligibility at this site is unknown. 


\section{BP147}

\section{Description}

41BP147 is a bulldozed house site straddling the McLaughlin Loop jeep road (Figures 8-21 and 8-22). Although outside the survey areas prescribed for this project, CAS archaeologists observed whiteware and glass shards on the jeep road while walking to a survey area. The house site is on 2,084 $\mathrm{m}^{2}$ of property owned by Otis and Oval Evans before the military purchased the surrounding 227 acres for $\$ 800$ on March 7, 1940

(Bastrop County Deed Records, Book 103, Pages 171-172). It is now so extremely overgrown with dense thickets of pencil cactus and mesquite brush that some areas are nearly impenetrable, and the Axtell fine sandy loam (AfE2) is heavily eroded. Past tank and troop activities have extensively disturbed the area.

\section{Levels of Work and Results}

When Skelton and Freeman initially recorded this site in 1979, they described it as the remains of a nineteenth- and twentieth-century house site and ranching activity site. Remnants included a collapsed ironstone chimney with lime based mortar, stoneware sherds, and a small corral covering approximately 15 acres (Skelton and Freeman 1979). They also mentioned that one informant indicated that there was once a log cabin on the property, but remnants of it were not located then, or in subsequent revisits by other archaeologists. Wormser and Leshley (1995) relocated the site and observed remnants of the house, a trash scatter, and animal pens.

When CAS archaeologists revisited the site in August 2005, they observed sandstone slabs on 
both sides of the road, and glass and undecorated whiteware mostly in the road (see Figure 8-22). Unlike Skelton and Freeman, they did not see any sandstone with lime mortar on it, but it's likely that after 26 years the vegetation is much thicker and has obscured much of the material from view.

Four shovel tests were placed within the site's boundaries but none contained artifacts. The oldest glass observed was aqua and could date from pre-1900 to the 1920 s, when colorless glass production increased. The clear glass fragments did not exhibit any significant degree of hue, and likely post-date the 1910s, when automatic bottle machines began producing colorless glass regularly (Lindsey 2005). The undecorated whiteware could date to as early as 1850 or as late as the present (Fox et al. 1989).

\section{Conclusions/Recommendations}

Due to historical disturbances, in its present condition, this site does not merit nomination to the NRHP, nor does it in any way appear to possess the integrity necessary for it to contribute to the significance of properties with a similar cultural theme within the area. The lack of early diagnostic artifacts also fails to provide a clear temporal estimate to the occupation. Therefore, CAS agrees with Mauldin's assessment (2001) that the research value of this site is minimal; no further investigations are recommended, and it is not eligible for nomination to the NRHP.

\section{$41 \mathrm{BP} 153$}

\section{Description}

This house site is on a prominent knoll north of the old Sayers to McDade Road (Figures 823 and 8-24). On the lower slopes of the knoll north of 41BP153 is 41BP119, a prehistoric site. Archaeologists observed that a few red brick fragments have eroded downslope and are now on the surface of the edge of 41BP119. This is noted in the discussion of 41BP119 in Chapter 6: Previously Documented Prehistoric Component Sites. Surrounding the knoll are 676 acres, which were owned by $\mathrm{C}$. Westbrook. The site and area in general have been heavily disturbed by earthmoving equipment. The surface on the knoll is heavily eroded and overgrown with dense grasses, oak, cedar, mesquite, prickly pear and pencil cactus. A sandstone ledge along the eastern edge of the knoll appears to have been quarried.

\section{Levels of Work and Results}

Freeman initially recorded this site in 1979 and described it as the remains of two discrete buildings, with Elgin and unmarked bricks and ironstone footings (Skelton and Freeman 1979). When CAS archaeologists revisited the site in August 2005, they observed over 40 bricks with no maker's mark. No ironstone footings were visible on the surface. Artifacts were washing off the knoll to the north on generally eroded

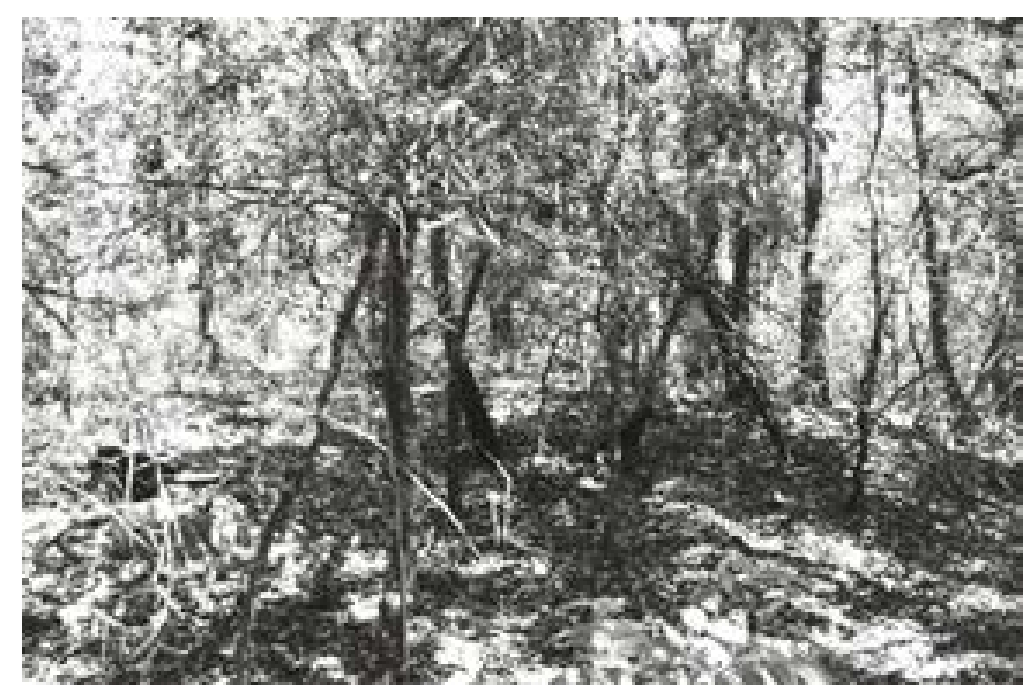

Figure 8-23. 41BP153 lies north of the old Sayers to McDade Road road; facing north. 


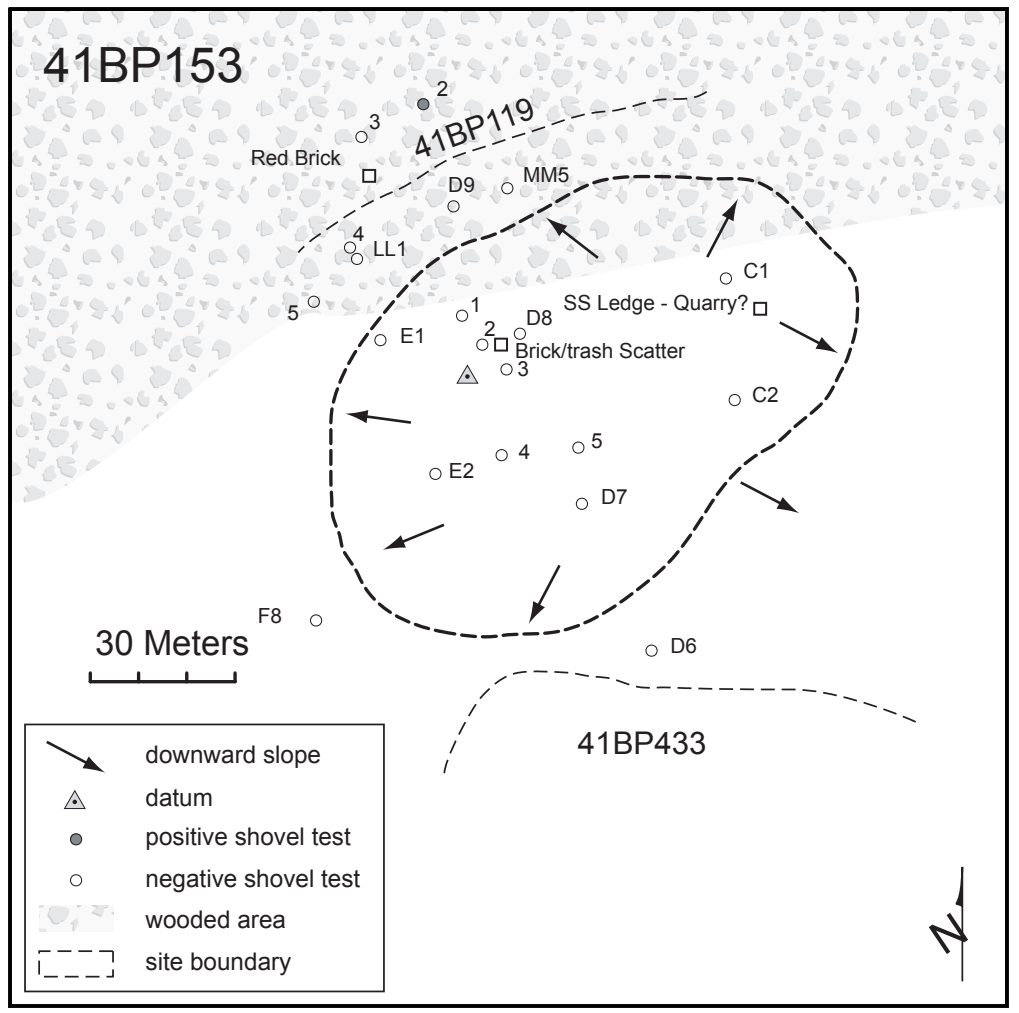

Figure 8-24. Site map of 41BP153.

clay and archaeologists observed clear glass fragments with an amethyst hue (ca. 1880-1915), thick brown glass (ca. pre-1900), and an iron skillet. Twelve shovel tests were excavated on the site but they were all negative. not report any ironstone, only about 20 bricks, and no other historic artifacts (this seems to describe 41BP153). When CAR archaeologists revisited what they believed was $41 \mathrm{BP} 153$ in 1997 (Robinson et al. 2001:137), they reported whiteware, bottle glass, bricks, and ironstone structure footings (this seems to describe 41BP433).

Nevertheless, as with 41BP433, 41BP153 has been bulldozed, archival research has provided no evidence of occupants significant to the nation's history, and the historic component of this site is not eligible for nomination to the NRHP.

\section{BP154}

\section{Description}

This is the site of the one-room Wayside School (Figure 8-25). All that remains are ironstone

\section{Conclusions/}

\section{Recommendations}

We believe that somehow sites 41BP153 and 41BP433 have been mistaken for each other over the years. They are less than $50 \mathrm{~m}$ from each other. The description by Skelton and Freeman in 1979 for 41BP153 sounds very similar to that of 41BP433, with two distinct structure areas (see site description for 41BP433 below). When Schmidt, Cruse, and Brownlow recorded 41BP433 for EH\&A in 1995, they did

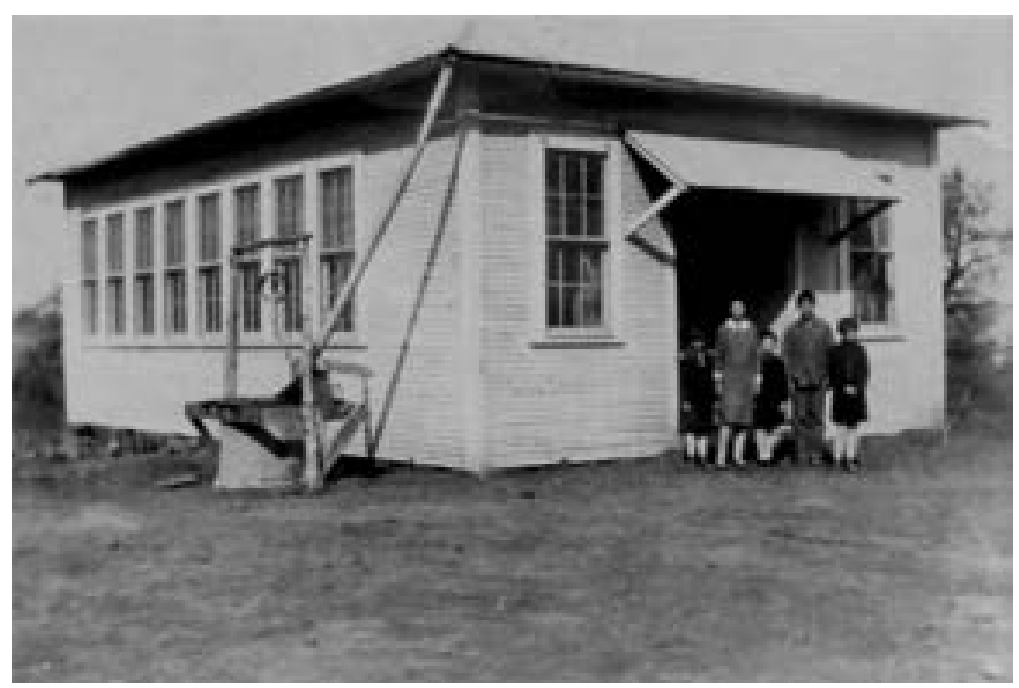

Figure 8-25. Wayside School ca. 1927-1928. (photo courtesy of Jonathon C. Fleming, McDade, Texas) 
footings and a cistern (Figures 8-26 and 8-27). A shallow depression, likely from an uprooted tree, is on the southwestern portion of the site. It lies on the west side of the old Sayersville-McDade Road (now called East Center Road), and an intermittent drainage of McLaughlin Creek is about $30 \mathrm{~m}$ to the west. B. P. and Bennie (wife) Jones donated two acres in 1902 to the Wayside School Trustees so they could build the school there (Skelton and Freeman 1979:99). The site datum was marked with a nail and an aluminum tag in a $16-\mathrm{cm}$ diameter oak tree.

\section{Levels of Work and Results}

Skelton and Freeman initially recorded this site in 1979, and informants indicated that this was the Wayside School site. In 2006, Abner C. Scott took CAS archaeologists to the site and confirmed the same. The site has changed little since Freeman first documented it, when CAR archaeologists re-visited it in 1997 (Robinson et al. 2001), and when CAS archaeologists further documented it in 2006. A surface examination revealed scattered sandstone foundation stones, and yellow and red chimney bricks with pasty mortar. Orange chimney flue pieces are still within the chimney bricks, as well as scattered about. The beehive shape opening in the top of the brick, mortar-lined cistern shown in Figures 8-25 and 8-28 measures 32 inches in diameter, and is an estimated 22 feet deep. It is lined with mortar, with rip- rap construction seams every two feet apart up the wall. Artifacts found in five of the seven shovel tests dug on the site include clear glass with no hue (ca. post-1930), heavily burned aqua glass (ca. pre-1900), and round nails (Table 8-7).

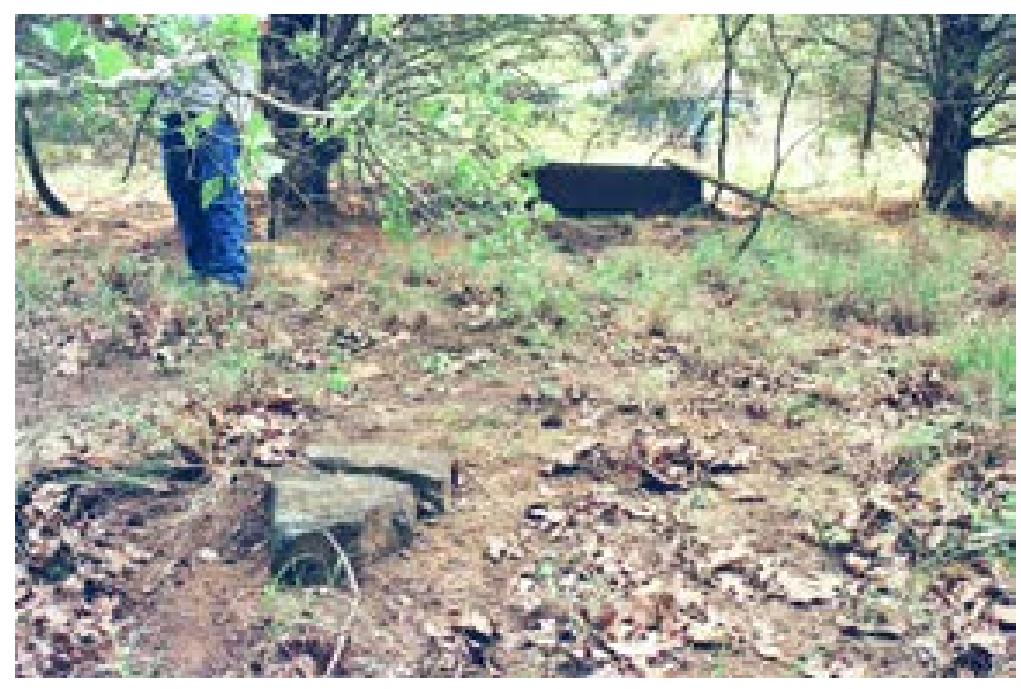

Figure 8-26. 41BP154 is the site of the one-room Wayside School alongside the Sayersville-McDade Road; facing east.

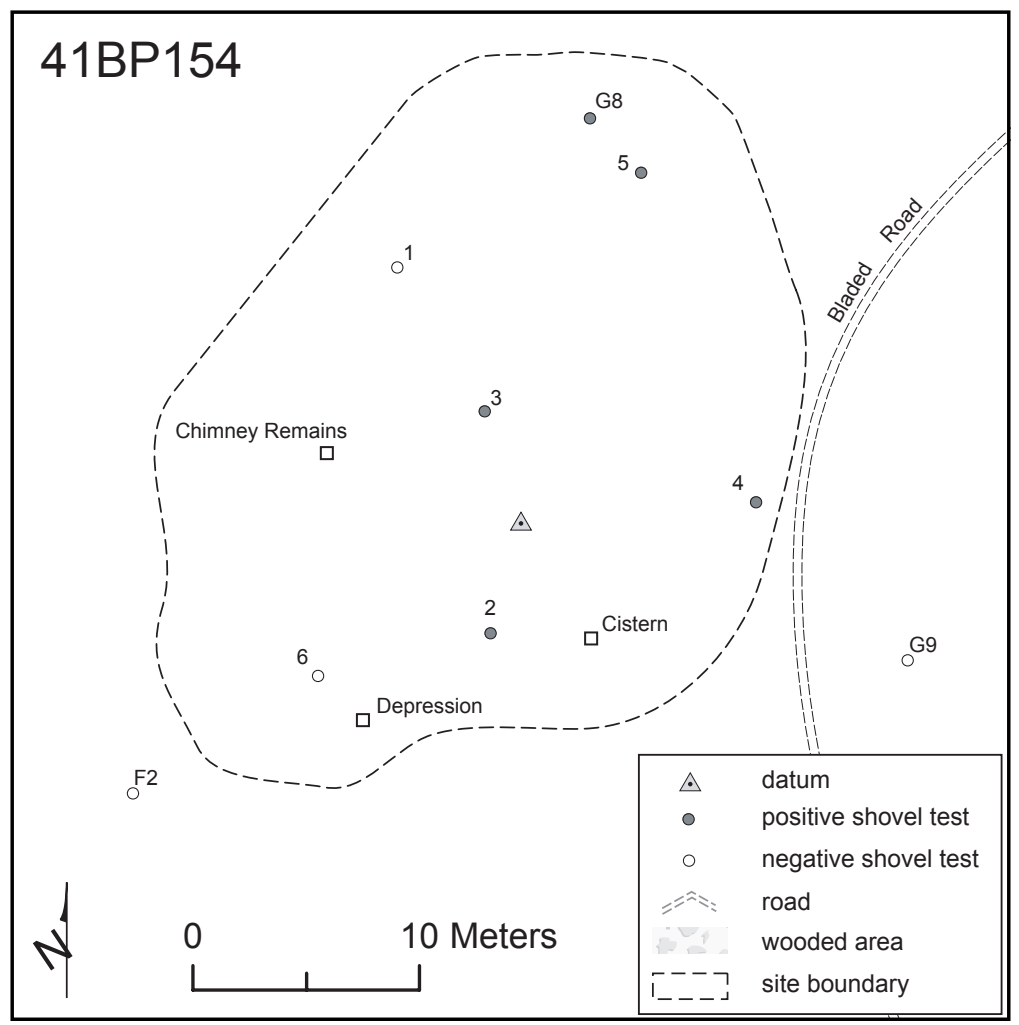

Figure 8-27. Site map of 41BP154. 


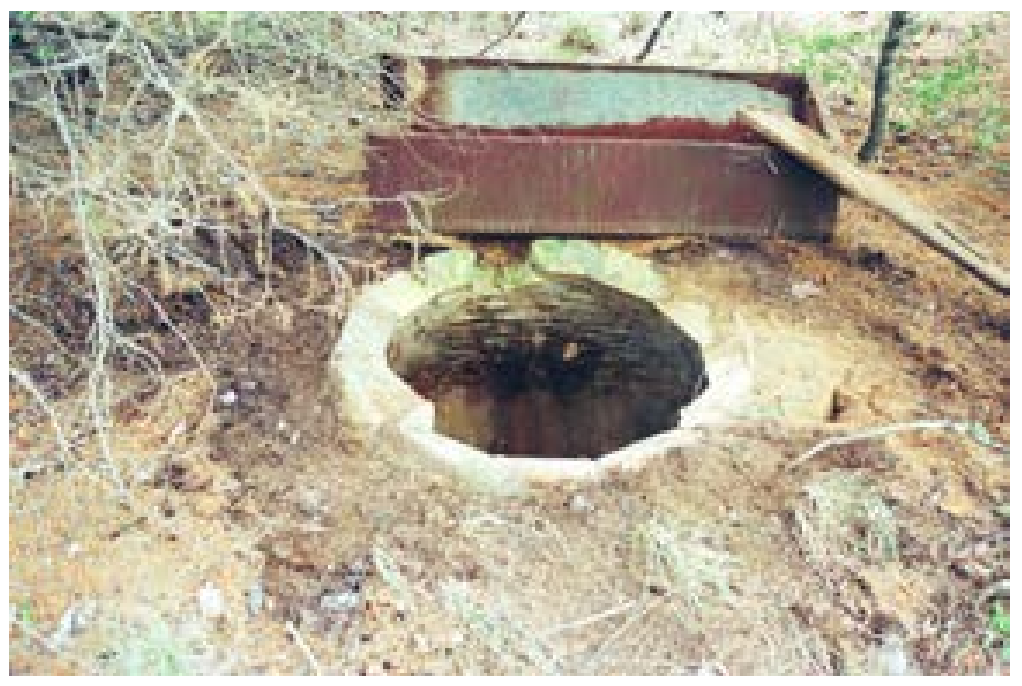

Figure 8-28. Cistern at the Wayside School.

Table 8-7. 41BP154 positive shovel test results.

\begin{tabular}{|c|c|c|c|c|c|}
\hline $\begin{array}{c}\text { Depth } \\
\text { (cmbs) }\end{array}$ & $\begin{array}{c}\text { ST } \\
\mathbf{2}\end{array}$ & $\begin{array}{c}\text { ST } \\
\mathbf{3}\end{array}$ & $\begin{array}{c}\text { ST } \\
\mathbf{4}\end{array}$ & $\begin{array}{c}\text { ST } \\
\mathbf{5}\end{array}$ & $\begin{array}{c}\text { ST } \\
\text { G8 }\end{array}$ \\
\hline $0-10$ & CG & & CG & & $\begin{array}{c}\text { CG, } \\
\mathrm{Bu}\end{array}$ \\
\hline $10-20$ & & CG & $\begin{array}{c}\text { AqG, } \\
2 \mathrm{RN}\end{array}$ & & \\
\hline $20-30$ & Clay & & $3 \mathrm{RN}$ & & \\
\hline $30-40$ & & & CG & $\mathrm{Bu}$ & \\
\hline $40-50$ & & Clay & & & \\
\hline $50-60$ & & & Sand & Sand & \\
\hline $60-70$ & & & & & \\
\hline $70-80$ & & & & & Sand \\
\hline $80-90$ & & & & & \\
\hline \multicolumn{7}{|c|}{ Key: AqG-Aqua Glass; CG-Clear Glass; } \\
RN-Round Nail; Bu-Bullet \\
\hline
\end{tabular}

\section{Conclusions/Recommendations}

All that remains are dispersed foundation stones, a cistern, and scattered artifacts. However, very limited archival investigations indicate that beginning in the 1840 s or 1850 s, there were four other schools within the confines of the current Camp Swift that preceded the Wayside School's location and construction; they were all within three miles or less of the Wayside School. The fifth school in the area, the Wayside School, was constructed here in 1902, burned in 1923, was rebuilt, and then closed in 1931 (Korges 1933:136-137). Schools, churches, and cemeteries bound communities together. CAS believes more extensive archival research will reveal significant information regarding the settlement of this area that is heretofore unknown. Therefore, CAS does not concur with Mauldin (2001) and recommends that the site has an unknown eligibility for nomination to the NRHP and needs further archival research.

\section{BP157}

\section{Description}

The remains of a farmstead cover $6,479 \mathrm{~m}^{2}$ of a wooded sideslope just south of Sandy Creek Loop Road, and are on property owned by J. and C. Floyd before the military assumed ownership in 1942 (Bastrop County 1929). It was initially documented during this project as Field Site 59, as it was within the designated survey area and no historic site was mapped at this location. However, after documenting the site, archaeologists noted that it sounded very much like the site description for 41BP157, a site to the east and outside of the survey area. 41BP157 was initially recorded by Skelton and Freeman (1979), and later revisited by CAR archaeologists in 1997 (Haslouer-Kay 1997; Robinson et al. 2001:138). Large oak trees tower over the cistern and house remains (Figure 8-29). To the west is the wooded slope, and to the east and south are cleared, grassy fields. A gully runs north-south just to the east of the site, and another, larger intermittent drainage located 150 $\mathrm{m}$ to the west has been dammed to make a stock tank. Traces of a clearing and an old two-track road through the woods toward the tank are still visible. 


\section{Levels of Work and Results}

A review of the site's trinomial form in the THC Atlas database indicates that Skelton and Freeman listed the UTM coordinates $121 \mathrm{~m}$ east and $23 \mathrm{~m}$ north of where CAS documented this site, while the digitized UTM coordinates given by TARL places the site $140 \mathrm{~m}$ to the east and $59 \mathrm{~m}$ to the north. CAS archaeologists plotted both sets of UTM coordinates provided on a topographic map, and using both a GPS and the topographic map, navigated to both locations, walked the areas, and found no evidence of a historic occupation. However, the site description provided by Skelton and Freeman nearly matches whatCAS archaeologists observed. In sum, CAS believes that $41 \mathrm{BP} 157$ has been mistakenly misplotted, and the UTMs obtained during this project using a GPS and the North American Datum 1927 are correct.

When Skelton and Freeman initially recorded this site in 1979, they described it as the remains of a twentieth-century house site with a well or cistern, scattered brick, recent glass, ceramics, and a child's metal toy (Skelton and Freeman 1979). When CAS archaeologists revisited the site in August 2005, artifacts were washing downslope to the west on generally eroded clay and the following were observed on the surface:

Bricks - one whole brick, several fragments, all poorly made, low fired, and sandy.

Metal - corrugated tin, a water tank for animals, barrel hoops, numerous tin cans of all sizes, a \#3 washtub, and a metal piece of farm hardware strap with holes.

Ceramics - several pieces of undecorated whiteware (ca. 1850-present). One decalcomania-decorated sherd with a pink rose and light green leaf pattern (Figure 8-30) and one ironstone china sherd with a maker's mark (Figure 8-31). The decalcomania technique became popular by 1850 , but not until about 1910 for the rose pattern (Durrenberger 1965:66; Kovel and Kovel 1986:257). Although the manufacturer's identification was not present on the broken ironstone china piece, it did have the British Royal Arms on the backstamp, and part of the word "WARRANTED" underneath, indicating it was manufactured sometime after about 1890 (Kovel and Kovel 1986:234, 267). Despite the best efforts of CAS staff, no clear association between the backstamp and the manufacturer could be ascertained.

Bottle Glass - a few shards of clear glass with no hue (post-1930), brown, and depression blue. 
Also, one whole, square, dark brown snuff bottle was found with a flared lip, and no dots on the base (Figure 8-32). It would have had a paper label, and its lack of dots on the bottom suggests a late 1800s date (Munsey 1970:76-80). One whole clear glass bottle was found with a ringed design and a Three Rivers maker's mark on its base (Figure 833). The Three Rivers Glass Company was in operation in Three Rivers, Texas, from 1922 through 1937. This specimen would have had a paper label and held hot peppers (Smith 1989). When the crew cleaned the dirt out of the inside of it at the site, it still had an oily, fishy smell to it. A clear glass whiskey bottle neck with a cork stopper neck was also found (see Figure 8-30).

Miscellaneous - soles from what was probably a pair of small female shoes.

The metal and mortar-lined cistern is still fairly intact and unlike most cisterns and wells on Camp Swift, it hasn't been filled in (Figure 8-

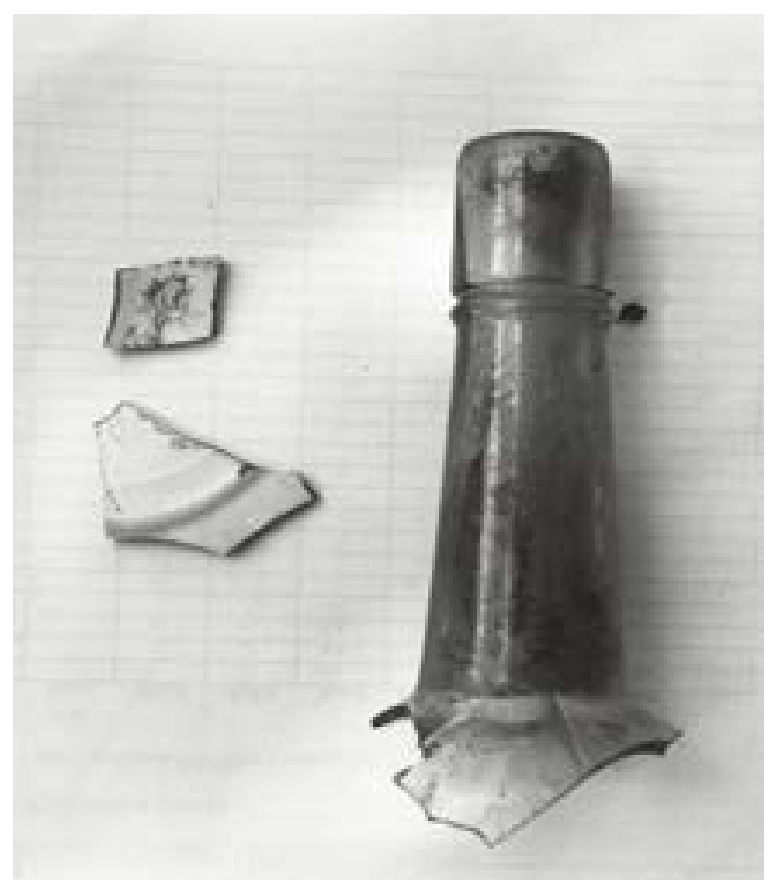

Figure 8-30. Decalomania-decorated sherd and whiskey bottle neck.
34). Its metal and mortar construction is the kind rarely seen on Swift historic sites. Normally, they are either sandstone or brick-lined. In general, the sandstone and brick construction appear to represent an earlier occupation at sites.

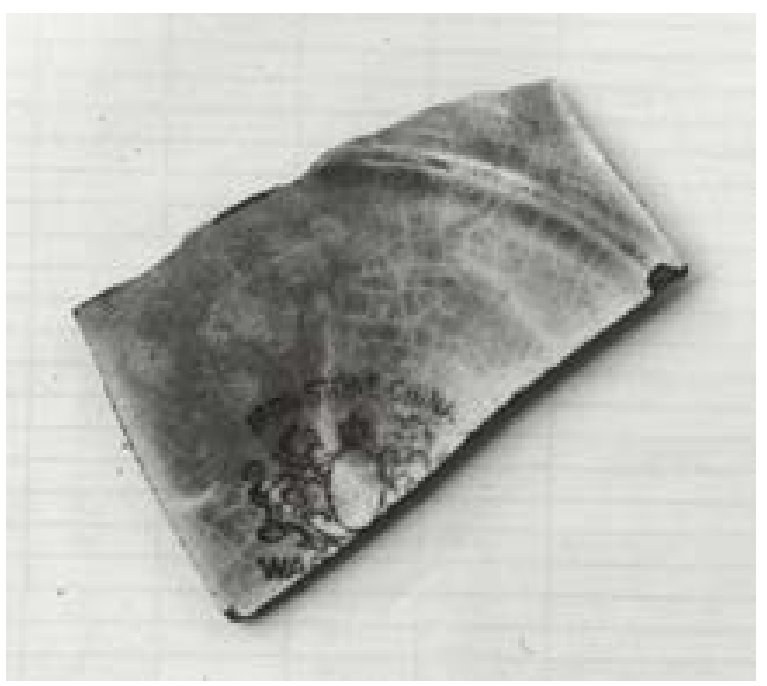

Figure 8-31. Ironstone china sherd with British Royal Arms backstamp.

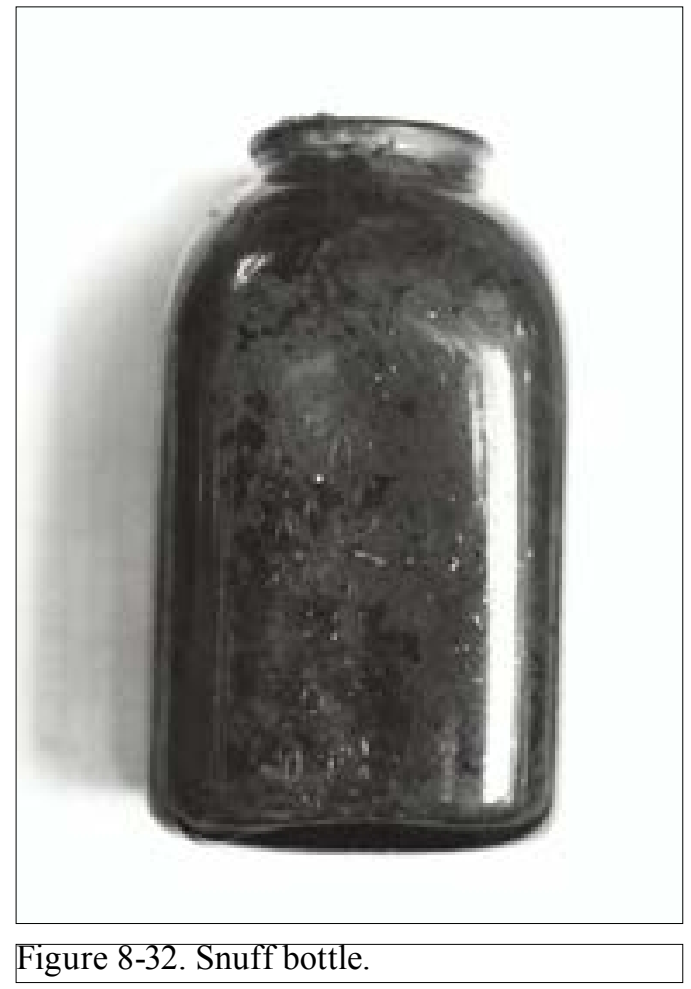


Four of the 11 shovel tests excavated on the site contained artifacts (Table 8-8). Artifacts were found to $30 \mathrm{cmbs}$ and the sands were generally shallow. Material recovered included many thin, unidentifiable metal fragments, several clear glass bottle shards with light patina (one with a screw top), one milk glass shard (ca. 1870-1920), one brown glass shard, one amber glass shard, red brick fragments, undecorated whiteware sherds, the base of a spent shotgun shell, and a square nail. The shotgun shell's stamp identifies it as a Winchester, New Rival 12 gauge. This type was manufactured beginning in 1929. All shovel test artifacts are generally of the approximate ages as the surface artifacts described above, although the square nail could be somewhat earlier (Nelson 1968).

\section{Archival Research}

According to Abner C. Scott (personal communication 16 February 2006), Frank and Mary (Floyd) Scott lived here. Frank and Mary were sharecroppers, and as such, they moved around a lot, but would always return to live in the house. And for a time, their son Earnest lived here with them until he went to live with his aunt and uncle, Jim and Cynthia Floyd, just to the west (at 41BP132).

\section{Conclusions/ \\ Recommendations}

Overall, the artifacts and construction materials here suggest occupation occurred between 1910 and 1941. Frank and Mary Scott and their son Earnest lived here during that period. After reviewing various publications on Bastrop County and Texas history, CAS could not identify the names of any of the previous landowners that were associated with events that have made a significant contribution to the broad patterns of history as defined by Criterion B. The site fails to meet Criterion A, C, or D for nomination to the NRHP also, nor does it possess the integrity necessary for it to contribute to the significance of properties with a similar cultural

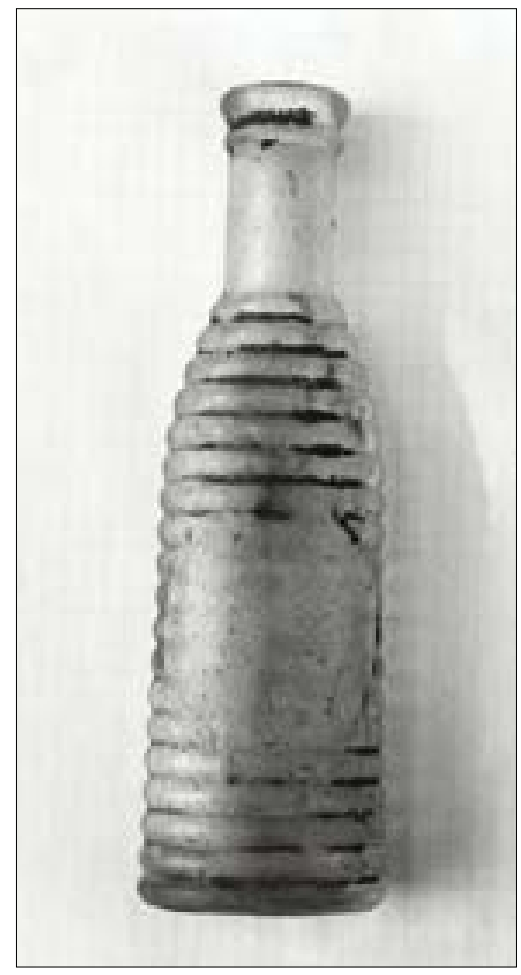

Figure 8-33. Three Rivers hot peppers bottle.

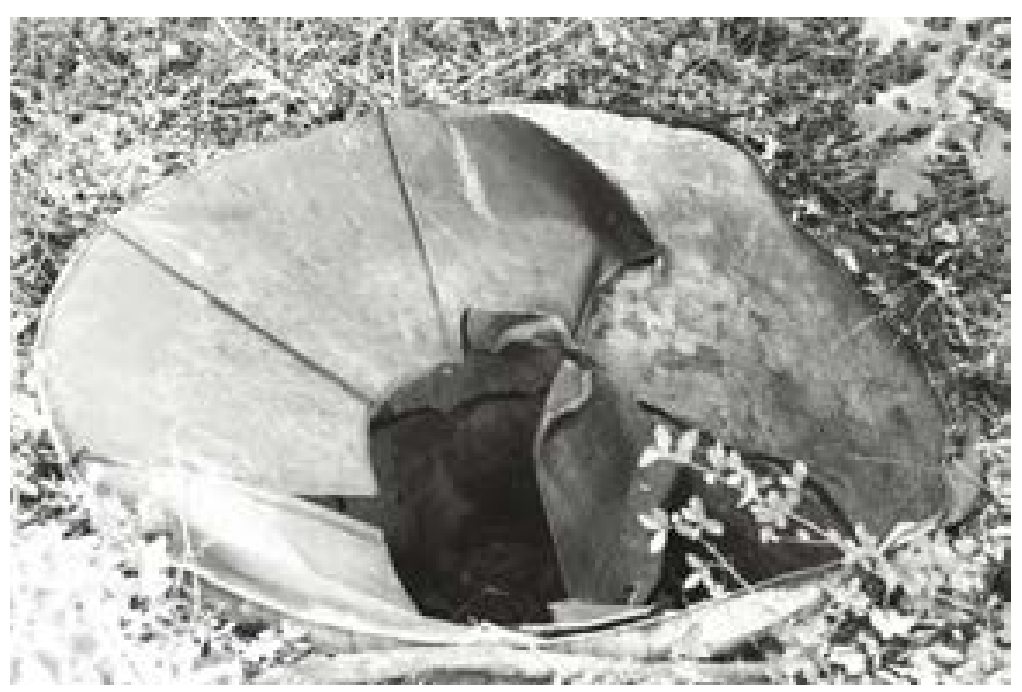

Figure 8-34. Metal-lined cistern at the Frank and Mary (Floyd) Scott house. 
Table 8-8. 41BP157 positive shovel test results.

\begin{tabular}{|c|c|c|c|c|}
\hline $\begin{array}{c}\text { Depth } \\
\text { (cmbs) }\end{array}$ & ST 1 & ST 2 & ST 3 & ST 6 \\
\hline $0-10$ & CG, Br & M & & $\begin{array}{c}\text { BG, CG, } \\
\text { PG }\end{array}$ \\
\hline $10-20$ & CG & CG, M & WW & $\begin{array}{c}\text { WW, AG, } \\
\text { BG, SG }\end{array}$ \\
\hline $20-30$ & & & & MG, SN \\
\hline $30-40$ & Gravel Bed & Gravel Bed & Clay & Clay \\
\hline $40-50$ & & & & \\
\hline Key: WW-whiteware; AG-amber glass; BG-brown glass; \\
CG-clear glass; MG-milk glass; PG-pink glass; \\
Br-brick fragment; M-metal; SN-square nail; SG-shotgun shell \\
\hline
\end{tabular}

theme within the area. Therefore, CAS assesses the research value of the historic component at this site as minimal; no further investigations are recommended, and the historic component is not eligible for nomination to the NRHP.

\section{$41 B P 158$}

\section{Description}

41BP158 comprises house construction materials, a generally intactcistern, fencerows, and an artifact scatter across a $1,830-\mathrm{m}^{2}$ area (Figures 8-35 and 8-36). Artifacts are plentiful and highly visible on Maneuver Road, some $40 \mathrm{~m}$ from the house site. The cistern is located just north of the house remains. The site is densely vegetated with cacti, mesquites, elms, and hackberries, and significantly disturbed by heavy machinery. The site datum is marked with a nail and aluminum tag on a 10 -inch diameter mesquite tree. In 1979, informants of Freeman indicated that this was the site of the Beck house (Skelton and Freeman 1979: Table 5).

\section{Levels of Work and Results}

This site was initially recorded by Skelton and Freeman (1979: Table 5), and later revisited by TXMF archaeologists in 1997 (Robinson et al. 2001:138). Both times archaeologists observed two brick lined and plastered cisterns, two loci of ironstone structure footings, and scattered brick, but only one whiteware sherd artifact on the surface. Skelton and Freeman also mention a fenced corral to the northeast of the house site. The corral is actually $220 \mathrm{~m}$ from the house site, is apparently not on the Owen property, and has been documented during this project as 41BP793 (see Chapter 9: New Historic Component Sites).

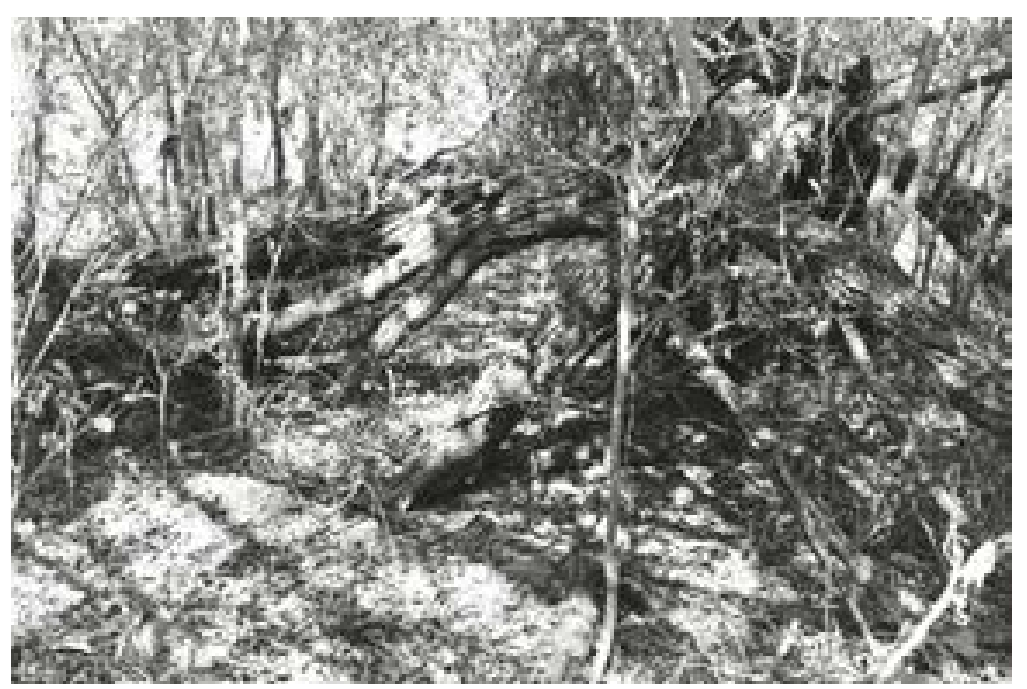

Figure 8-35. 41BP158 is where the Beck house stood; facing north.
During the 2005 revisit, CAS archaeologists observed significant disturbance from earth moving equipment. Push piles and shallow trenches were common. As shown in Figures 8-35 and 8-36, one cistern remains, as well as scattered ironstone slabs and bricks. The cistern is bell-shaped, and is constructed of two types of red brick, with some exhibiting salt glazed faces. Its interior has been covered with cement and 


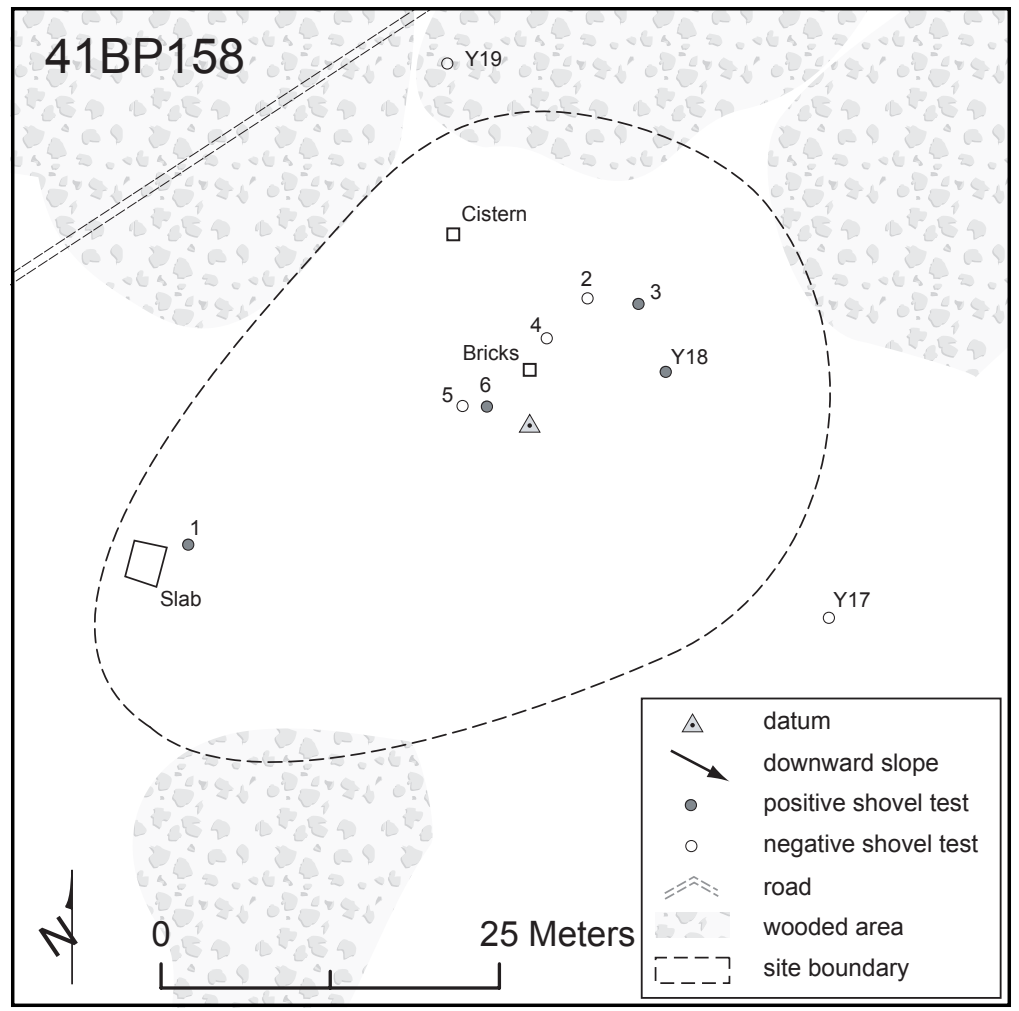

Figure 8-36. Site map of 41BP158.

then a layer of plaster applied. The unique tabby construction technique used to plaster the interior is evidenced by circular pour lines approximately 12 inches apart. The bottom is filled with debris to 42 inches below the ground surface. Its opening is 44 inches in diameter, and expanding to 80 inches at the top of the fill.

No artifacts were observed in the densely vegetated area around the house and cistern, but 46 artifacts extending some 180 linear meters were inventoried on Maneuver Road. They include:

Bottle Glass - clear with an amethyst hue (ca. 1880-1915); aqua (pre-1900); brown (probably post-1900); white (1870-1920); clear with an amber hue (ca. 1915-1930); clear with no hue (ca. post-1930).

Ceramics - undecorated whiteware (ca. 1850present); whiteware with a Charles Meakin,
Hanley, Staffordshire, England maker's mark (Figure 8-37), used between 1883 and 1889 (Kovel and Kovel 1986:10h).

Stoneware-Leon slip interior and exterior (ca. 1875-1900); Bristol glaze interior and exterior (post-1920).

In addition to a transect shovel test dug on the site, six shovel tests were placed within the site's boundaries; five around the house and one adjacent to a single square sandstone slab under a large cedar shade tree. The sandstone slab seemed out of context, which prompted staff archaeologists to excavate a shovel test there. More artifacts were recovered near the slab in ST 1 than were recovered around the house (Table 8-9). Notable artifacts recovered below the surface in ST 1 include a horseshoe, five clear glass shards with an amethyst hue (ca. 1880-1915), aqua

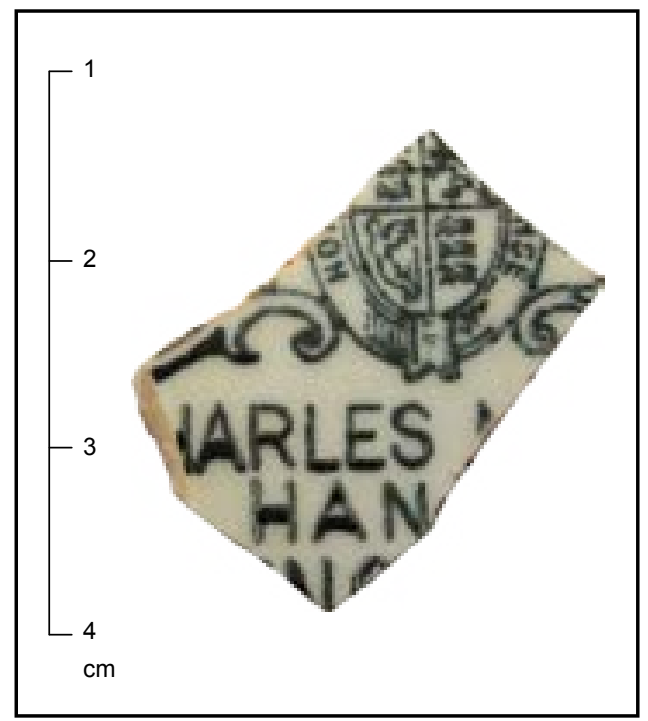

Figure 8-37. Whiteware with a Charles Meakin, Hanley, Staffordshire, England maker's mark used between 1883 and 1889 . 
Table 8-9. 41BP158 positive shovel test results.

\begin{tabular}{|c|c|c|c|c|}
\hline $\begin{array}{c}\text { Depth } \\
\text { (cmbs) }\end{array}$ & ST 1 & ST 3 & ST 6 & ST Y18 \\
\hline $0-10$ & AqG, CG, M & CG, Br & Br & WW \\
\hline $10-20$ & $\begin{array}{c}\text { SW, WW, AqG, } \\
\text { BG, CG, M, MuS }\end{array}$ & Clay & Clay & Clay \\
\hline $20-30$ & Clay & & & \\
\hline $30-40$ & & & & \\
\hline \multicolumn{3}{|c|}{$\begin{array}{l}\text { Key: SW-stoneware; WW-whiteware; AgG-aqua glass; } \\
\text { BG-brown glass; CG-clear glass; Br-brick fragment; } \\
\text { M-metal; MuS-mule shoe }\end{array}$} \\
\hline \multicolumn{5}{|c|}{} \\
\hline
\end{tabular}

glass shards (ca. pre-1900), Flow Blue-decorated whiteware (ca. pre-1900), and stoneware with Leon slip interior and exterior (ca. 1875-1900). The average depth of soil at the site is less than 10 cmbs. Artifacts recovered from the four positive shovel tests are temporally coeval with artifacts found on the road.

\section{Conclusions/Recommendations}

In 1979, Ms. Fay Pannell told Freeman that this was the Beck house site. Overall, the age of the artifacts suggest an occupation period from about 1880 to 1942 , when the government acquired the property. The cistern is one of few remaining on Camp Swift, and is unique because of its bell-shaped, brick, concrete, and plaster, tabby technique construction. Nevertheless, it makes up a small fraction of the original architecture. Additionally, the surviving artifacts have clearly been disturbed and little remains of the internal site structure. What artifacts do remain are in very shallow sediments and probably bioturbated, thus the site's overall research value to the history of the area is of minimal significance. Therefore, it is not eligible for nomination to the NRHP.

\section{BP159}

\section{Description}

The remains of a large, elaborate sandstone and brick fireplace and chimney still partially stand at $41 \mathrm{BP} 159$ (Figures 8-38 and 8-39). Other scattered bricks and sandstone represent either an outbuilding or an extension of the house. A depression likely marks a filled-in well or cistern. Artifacts are scattered across a $1,332-\mathrm{m}^{2}$ area that is now densely vegetated with cacti, mesquites, elms, and hackberries. The site datum is marked with a nail and aluminum tag on a 10 -inch diameter mesquite tree. An old, narrow road cut and "Y" intersection can be seen along a southern property line about $90 \mathrm{~m}$ and 190 degrees south of the house site. Minnie Shelton owned an 88acre tract here in 1941. A corral (41BP793) that may have belonged to either her or $\mathrm{H}$. Washington (41BP794 and 41BP795) lies along the southern portion of this and J. Owen's property line, some

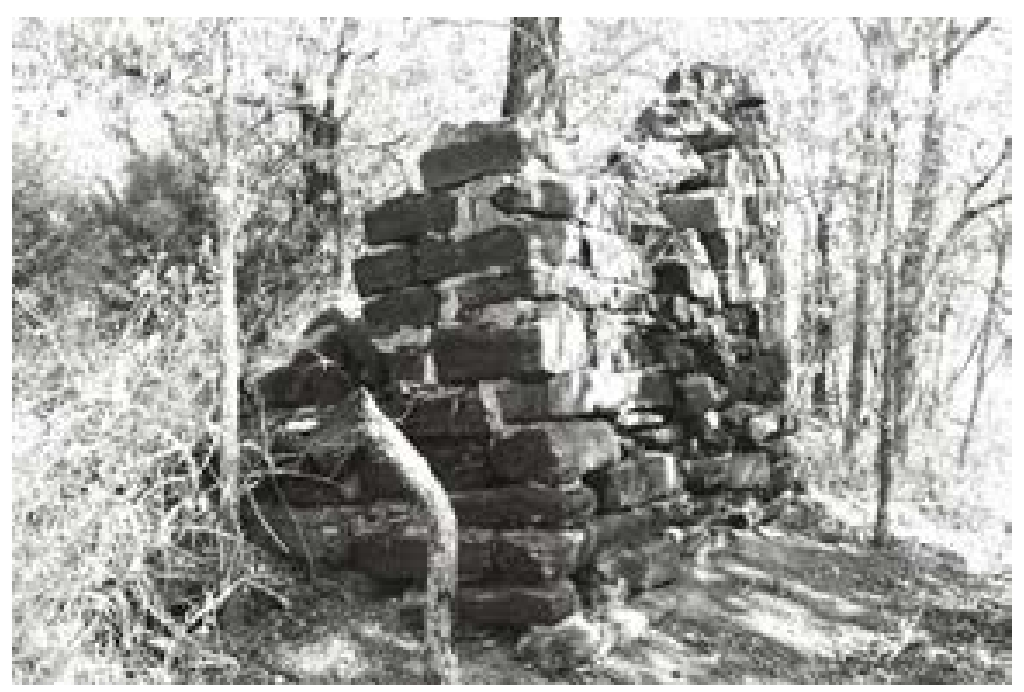

Figure 8-38. These fireplace and chimney remains are from the Eschberger house at 41BP159; facing north. 
$100 \mathrm{~m}$ north of Maneuver Road.

However, as discussed below, a family named 'Eschberger' lived in the house.

\section{Levels of Work and Results}

Although one could have been ten feet away from the large fireplace and chimney and not have seen it because of the dense brush and trees, this site was discovered when archaeologists were laying out a survey area boundary, and then later returned to excavate shovel tests and conduct a surface survey. With a single opening to the west, the fireplace obviously represents the eastern end of the house. The fireplace is constructed of large hewn sandstone slabs and is 72

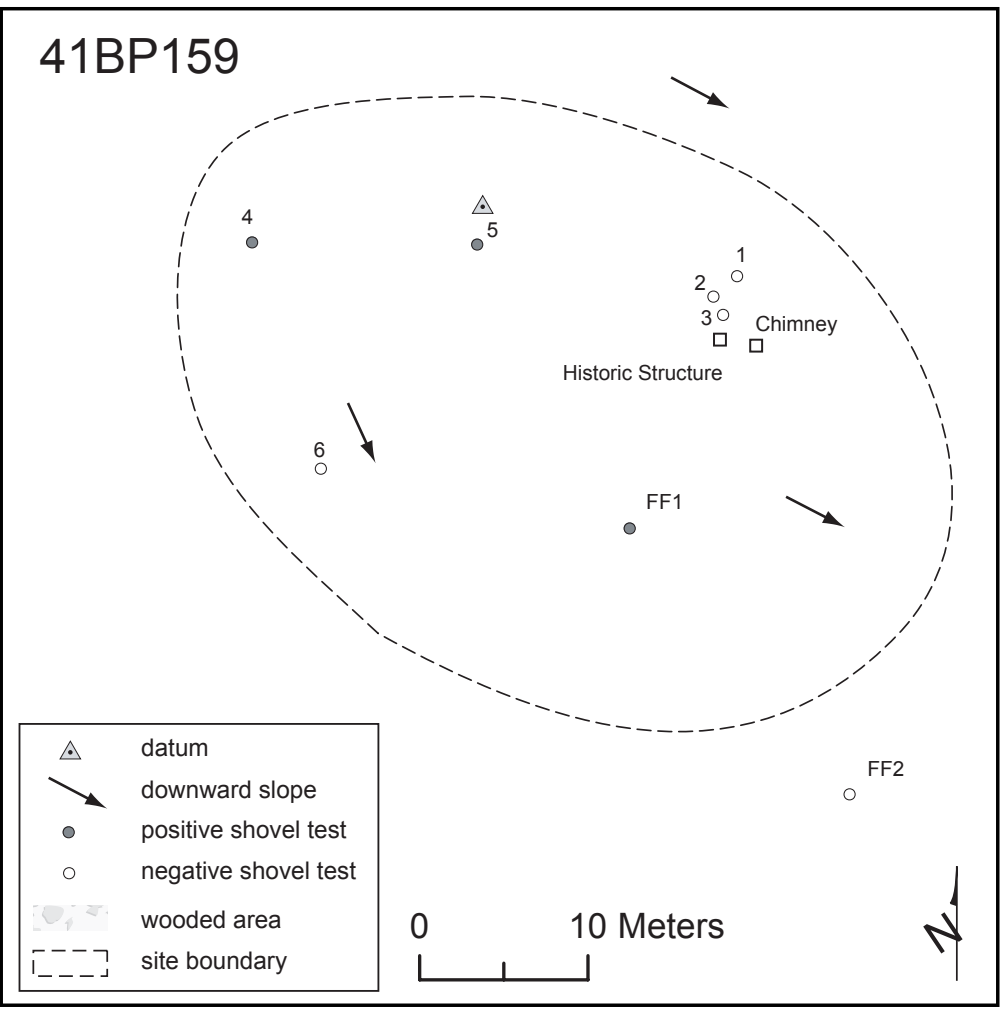

Figure 8-39. Site map of 41BP159. inches wide and 80 inches long, with a 51-inch wide internal hearth area supported at the front with a thick iron lintel. A sandstone foundation juts out two inches wider all around the fireplace's base. Above the fireplace, red bricks project to 81 inches above ground at their highest point. Brick and sandstone rubble is scattered around the structure, and in two push piles. Grey, coarse mortar was used to fill in the gaps between the sandstone slabs, and is still on many of the brick faces. Some red bricks with "Texas" and a symbol stamped on their faces are highly fired, finely made, and measure 3.75 inches wide by 2.25 inches thick. These were manufactured by Texas Press Brick Company in Ellis County in the late 1920s (Steinbomer 1982: Plate 221). Most red bricks though, have no markings and are rather poorly made, suggesting they may be older.

A 78-inch-wide depression 23 feet east of the fireplace that has a railroad tie in it was most

likely where a well or cistern was located. CAS surmises that it was probably a well because cisterns in general have been found closer to the house to catch rainwater in eave gutters. Fay Pannell (personal communication 16 February 2005) said there was a well some distance from the house, near a creek bank. Because of the 52foot distance from the fireplace, a second scatter of bricks and hewn sandstone likely represents a second structure. Three of seven shovel tests excavated on the site were positive but were in very shallow soils. A piece of window glass, clear and amber glass bottle shards, and an undecorated whiteware sherd were found (Table 8-10).

In addition to three \#3 metal washtubs scattered around, archaeologists observed:

Glass - a brown snuff bottle with four dots, indicating it was made after about 1900 (Munsey 1970:77); a clear glass Sloan's 
Liniment bottle with embossed lettering and a screw top, indicating it was made after about 1930 (Figure 8-40); a clear glass Mason jar mouth; two clear glass unidentifiable bottles; a lamp chimney upper rim fragment made of unleaded glass (Figure 8-41) that does not fluoresce under ultraviolet light (post-1864) and with a beaded decoration indicating it was made after 1883 (Woodhead et al. 1984:61-62).

Ceramics - a stoneware sherd with Bristol glaze interior and exterior, indicating it was likely produced after about 1920 (Greer 1999:212); a large undecorated whiteware sherd that although could date to the 1850 s, is probably temporally coeval with the other ceramics and glass at the site.

When Skelton and Freeman (1979) first recorded this house site, Ms. Fay Pannell was their informant. At that time Ms. Pannell told her that this was the Eschberger house site. On February 8, 2006, CAS archaeologists drove Ms. Pannell to Camp Swift. She confirmed that there was a family named Eschberger that lived here before the government acquired the property. At that time Ms. Pannell was nearly 90 years old, and as far back as she could remember, the Eschbergers owned the property, but she couldn't remember which Eschberger, although Gus Eschberger owned property around the area. His daughter married a man by the last name of Wilford, and Gus Eschberger gave this property to her. Ms. Pannell didn't know whether the house was there, or if they built the house. Wilford and Gus's daughter had a son named Oswald, and when the boy was only 5 or 6 years old, Ms. (Eschberger) Wilford died. Ms. Pannell thought that ownership of the property then went to Oswald, not to Mr. Wilford. Mr. Wilford then married a woman by the last name of Miller. They had a daughter named Ora Lea, and when Ora Lea was

Table 8-10. 41BP159 positive shovel test results.

\begin{tabular}{|c|c|c|c|}
\hline $\begin{array}{c}\text { Depth } \\
\text { (cmbs) }\end{array}$ & ST 4 & ST 5 & ST FF1 \\
\hline $0-10$ & WG & CG & WW, AG \\
\hline $10-20$ & Clay & Clay & \\
\hline $20-30$ & & & Clay \\
\hline $30-40$ & & & \\
\hline \multicolumn{3}{|c|}{ Key: WW-whiteware; AG-amber glass; } \\
CG-clear glass; WG-window glass \\
\hline
\end{tabular}

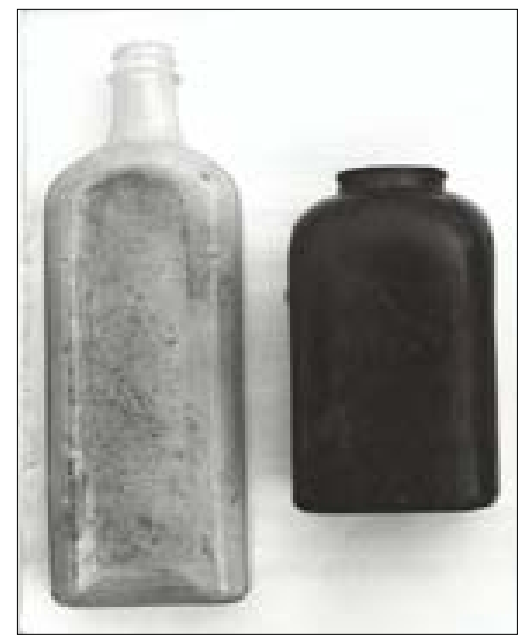

Figure 8-40. Sloan's Liniment bottle and a snuff bottle.

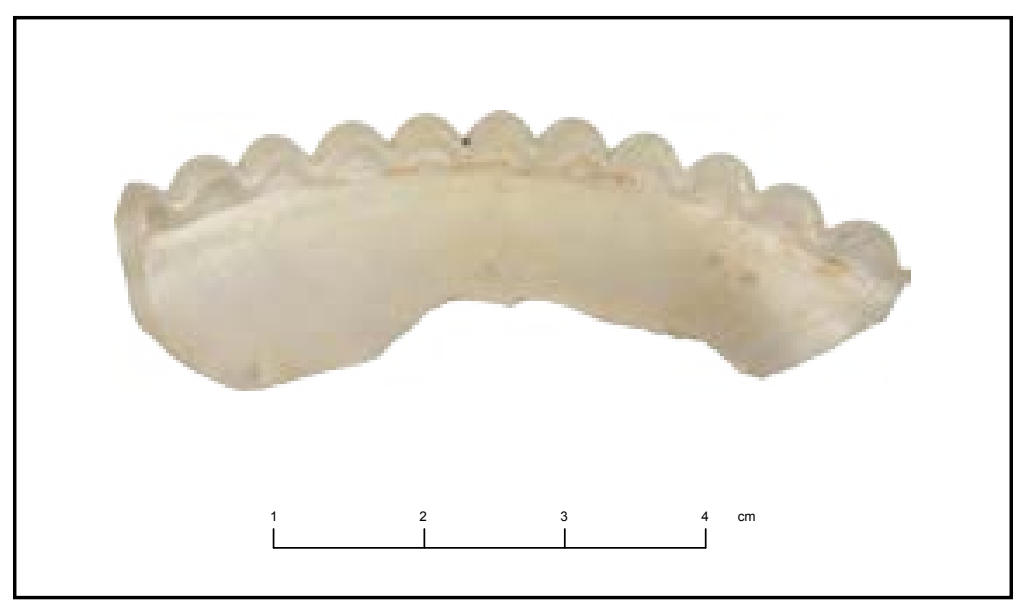

Figure 8-41. Lamp chimney upper rim fragment made of unleaded glass. 
about 8 years old, Ms. (Miller) Wilford died. Mr. Wilford worked for the railroad and was gone a lot, so his mother lived there and took care of the children for several years. Mr. Wilford eventually remarried, and they moved to San Antonio. Then some of the other Wilfords lived in the house. Ms. Pannell said it was always known as the Eschberger place, and it supposedly belonged to Oswald, but she didn't know if it was that way before the government acquired the land. She thought it was either rented out or some of the Wilfords lived there just before that.

Although she admitted she could not find it now, she knew that in about 1925, when it was so dry, some men were cleaning out a well by the creek. She said that one of the Wilford men was in the well and hollered to the men on top to bring him to the surface because he couldn't breathe. However, when he got to the top and was hit with fresh air, he lost his hold, fell back into the well, and broke his neck; he died.

Ms. Pannell confirmed that the road that is now called Maneuver Road was not there when the government acquired the land. There was an old road that went in a generally straight line from just north of a small drainage on Oak Hill Cemetery Road to the Eschberger house, then went straight on to the Wilford house (41BP158), and no further.

\section{Conclusions/ Recommendations}

Overall, the age of the artifacts suggest an occupation period from about 1920 to about 1942, when the government acquired the property. The fireplace and chimney remains are massive compared to other non-militaryhistoric architecture observed, and are an example of some of the best preserved architecture remaining at Camp Swift. In many cases a site of this recent historical age and with this degree of destruction would not be considered eligible for listing on the National Register, but in this context and considering the overwhelming lack of intact standing historic structures at Camp Swift, CAS recommends that this structure be preserved by considering it eligible at a moderate scale for listing on the National Register. Additional work could be focused on more archival research and limited testing to search for any surviving features. Two 1-x-1-m units are recommended.

\section{BP161}

\section{Description}

This house site lies along the southern edge of Oak Hill Road. Freeman's informants in 1979 thought that a family named "Cottle" may have lived here (Skelton and Freeman 1979). Bulldozer piles and ruts along the road are common, and the site is densely overgrown with oak, cedar, mesquite, elm, hackberry, greenbrier, cacti, and grasses. The site faces an intermittent drainage along its western edge (Figures 8-42 and 8-43).

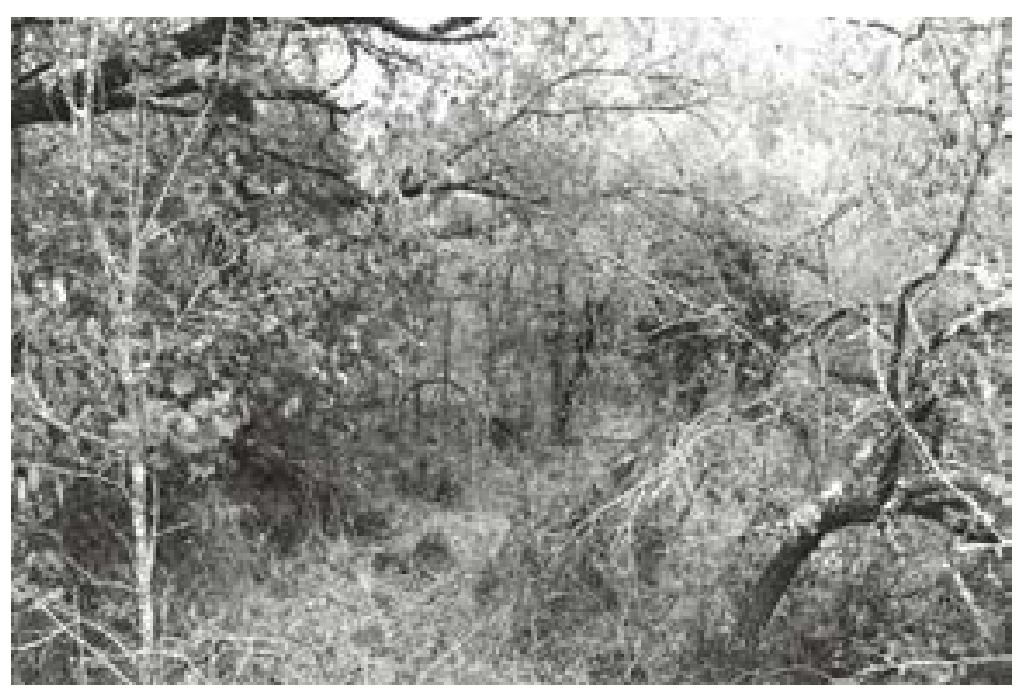

Figure 8-42. 41BP161 may have been the Cottle house site along Oak Hill Road; facing south. 
FIGURE 4-83. REDACTED

Figure 8-43. Site map of 41BP161. glass wine bottle with screw top; clear glass with raised molded pattern; two clear glass jars with screw tops made by Hazel-Atlas Glass Company after 1920 (see Figure 8-44); a clear glass Ball jar with screw top (see Figure 844); a brown bottle with a raised flower motif (all glass appears to be post-1930).

Ceramics - whiteware sherd with molded design; three other undecorated whiteware sherds (see Figure 8-44); 5-gallon stoneware jug with a hole drilled in its bottom center, Bristol glaze interior and exterior, ca. post1920 (see Figure 8-44).

Metal-Chamber pot, enameled tinware, white with blue rim (see

\section{Levels of Work and Results}

In her description of the site, Freeman noted a depression that was likely a cistern not far from collapsed chimney bricks, twentieth-century glass and ceramics, and corrals to the southeast. In 2005, CAS archaeologists also found bricks, glass, ceramics, and fence posts, but no depression. No artifacts were found in any of the 11 shovel tests dug on the site, and red clay was normally encountered $5 \mathrm{cmbs}$. A surface inventory of artifacts included:

Glass-blue jar base (Figure 8-44); clear glass jug base; whole clear glass condiment bottle with screw top; green

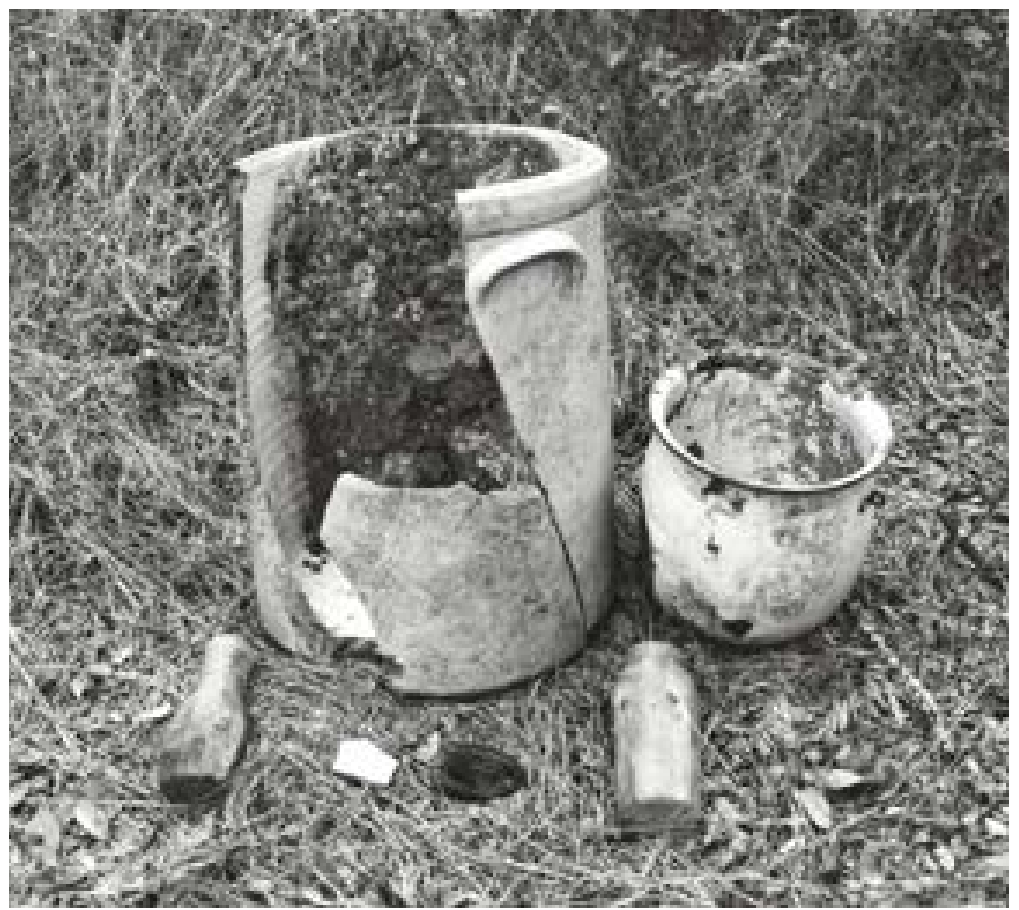

Figure 8-44. Selected artifacts at the Cottle house site (41BP161). Back row: 5-gallon stoneware crock, chamber pot. Front row (left to right): Hazel Atlas condiment bottle, whiteware sherd, blue glass jar base, Ball condiment bottle. 
Figure 8-44); metal bucket with blue paint and with a 12-inch elm tree growing through the center of it; small milk pail; two barrel hoops; tin sheet metal; round nails in fence posts.

Construction material-Red brick fragments, well made, with mortar; yellow brick fragment, well made; rounded sandstone block.

\section{Conclusions/}

\section{Recommendations}

The artifacts suggest an occupation period of ca. post-1920. The site has been bulldozed and it is clear that the spatial integrity has been severely compromised, and archival research indicates no persons of historical significance were associated with the property. Without a reasonable expectation of research potential or the lack of intact architecture or significant archival evidence, CAS recommends that no further work be conducted and the site is not eligible for nomination to the NRHP.

\section{BP162}

\section{Description}

According to informants of Freeman, this house site belonged to the Scruggs family before the government purchased it (Skelton and Freeman 1979). It is located beside Oak Hill Road near the confluence of Dogwood Branch Creek and one of its tributaries. The house remains, a filled-in well, and scattered artifacts are all that remain among hackberries, cedars, tasajillo, prickly pear cacti, and dense weeds and grasses (Figures 8-45 and 8-46). An exception, and in sharp contrast to the surrounding vegetation, was a small clump of yucca-like plants growing

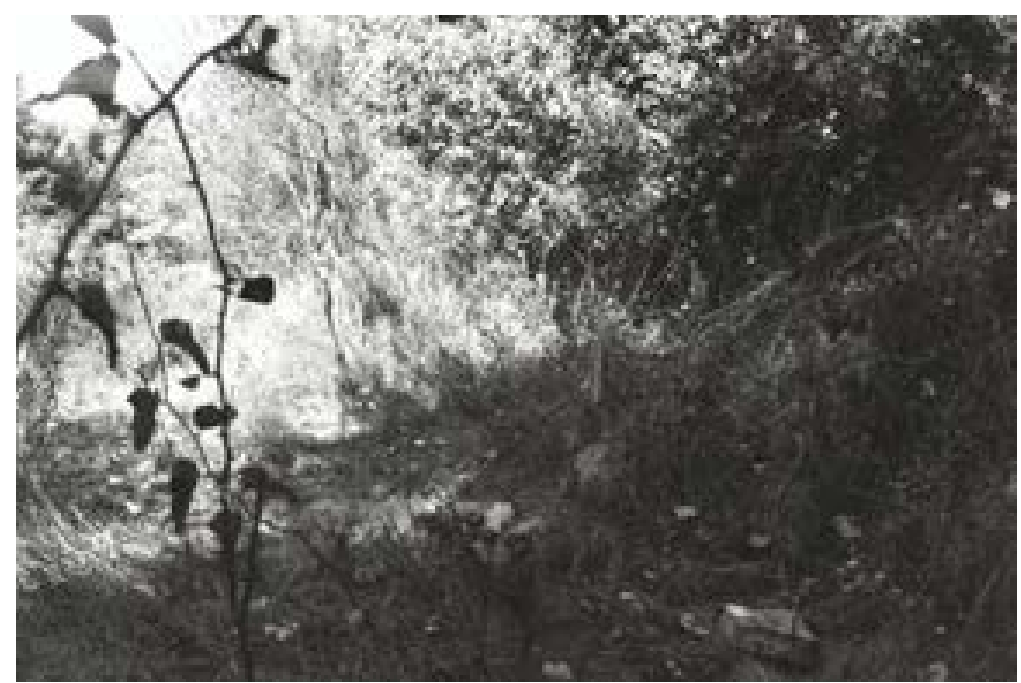

Figure 8-45. 41BP162 is the bulldozed Scruggs house site along Oak Hill Road; facing west.

FIGURE4-86. REDACTED

Figure 8-46. Site map of 41BP162. 
in the filled-in well. Numerous push piles were observed.

\section{Levels of Work and Results}

Freeman observed stone house footings, bricks around the well, and scattered artifacts (Skelton and Freeman 1979). The condition of the site was about the same when revisited by CAR archaeologists in 1997 (Robinson et al. 2001:139), except that a series of monitor wells had been drilled on the site. When CAS relocated it in 2005 , tubing from the well drilling operation was on the southern portion of the site. In addition to sandstone footings and mortared bricks, CAS archaeologists noted: a clear glass shard with light green hue; a half-gallon metal bucket with numerous "Church Key" punches, ca. post 1935 (Intermountain Antiquities Computer System [IMACS] 2001a), suggesting that it was used as a heating element; a one-quart coffee can, also with numerous "Church Key" perforations around its lower portion, suggesting it also was used as some sort of heating utensil; and red bricks mortared together that formed a semi-circular shape and were plastered on the interior, suggesting they were likely from the filled-in well. Table 8-11 lists artifacts recovered from six of eight shovel tests excavated on the site, which includes:

\section{ST 1}

0-10 cmbs: clear glass with light green hue (ca. post-1910)

10-20 cmbs: mortar fragments

20-30 cmbs: unidentifiable metal fragments

\section{ST 2}

0-10 cmbs: tan glazed earthenware

\section{ST 3}

0-10 cmbs: light bulb glass, electric light pull chain, and incandescent light bulb with copper filament
10-20 cmbs: clear glass (ca. post-1930), light bulb glass, and clear glass with light green hue (ca. post-1910)

20-30 cmbs: milk glass (ca. 1870-1920), unidentifiable metal fragments, red brick fragments, and round nail

30-40 cmbs: a crown bottle cap with 21 crimps, ca. pre-1920 (Bender 1986:22-25), unidentifiable metal fragments, brown glass, and red brick fragments

40-50 cmbs: round nail, electric light pull chain, brown glass, clear glass with light green hue (ca. post-1910), clear glass with an amethyst hue (ca. 1880-1915), clear glass with an amber hue (ca. mid-1910s-mid-1950s), unidentifiable metal fragments, red brick fragments, and plastic

\section{ST 5}

0-10 cmbs: .12 gauge shotgun shell

10-20 cmbs: clear glass (ca. post-1930)

20-30 cmbs: clear glass (ca. post-1930)

30-40 cmbs: clear glass (ca. post-1930), small animal bone fragment

\section{ST A9}

0-10 cmbs: clear glass with painted labeling (post1933) (Lindsey 2005), red brick fragments, brown glass, crazed (burned) whiteware (ca. 1850-present)

10-20 cmbs: clear glass, stoneware with Leon slip interior and exterior (ca. 1875-1900), stoneware with Leon slip interior and plain exterior (ca. 1875-1900)

\section{ST B4}

0-10 cmbs: whiteware (ca. 1850-present), clear glass (ca. post-1930)

10-20 cmbs: clear glass (ca. post-1930), green glass 
Table 8-11. 41BP162 positive shovel test results.

\begin{tabular}{|c|c|c|c|c|c|c|}
\hline $\begin{array}{l}\text { Depth } \\
\text { (cmbs) }\end{array}$ & ST 1 & ST 2 & ST 3 & ST 5 & ST A9 & ST B4 \\
\hline $0-10$ & $\mathrm{CG}$ & EW & $\mathrm{M}$ & SG & WW, Br, CG & WW, CG \\
\hline $10-20$ & Mo & & $\mathrm{CG}, \mathrm{LB}, \mathrm{M}$ & $\mathrm{CG}$ & SW, CG & \\
\hline $20-30$ & M & Clay & $\mathrm{MG}, \mathrm{Br}, \mathrm{M}, \mathrm{RN}$ & CG & & $\mathrm{CG}$ \\
\hline $30-40$ & Clay & & $\mathrm{BG}, \mathrm{CG}, \mathrm{Br}, \mathrm{M}$ & $\mathrm{CG}, \mathrm{F}$ & & GG \\
\hline $40-50$ & & & $\mathrm{BG}, \mathrm{CG}, \mathrm{M}, \mathrm{RN}, \mathrm{P}$ & & Clay & Clay \\
\hline $50-60$ & & & & Sand & & \\
\hline $60-70$ & & & Sand & & & \\
\hline $70-80$ & & & & & & \\
\hline \multicolumn{7}{|c|}{$\begin{array}{l}\text { Key: EW-earthenware; SW-stoneware; WW-whiteware; BG-brown glass; CG-clear glass; } \\
\text { GG-green glass; MG-milk glass; LB-light bulb glass; Br-brick fragment; Mo-mortar; } \\
\text { M-metal; RN-round nail; SG-shotgun shell; P-plastic; F-fauna }\end{array}$} \\
\hline
\end{tabular}

\section{Conclusions/Recommendations}

With the exception of a few pieces of milk glass, amethyst hued bottle glass, the crimped bottle cap, and the stoneware that was commonly a useful heirloom, the artifacts suggest an occupation period of ca. post-1920, and CAS is informed that the site was occupied through the beginning of WWII. Archival research indicates no persons of historical significance were associated with the property, and other than the well, the architecture has been destroyed beyond recognition. CAS recommends that no further work be conducted, and the site is not eligible for nomination to the NRHP.

\section{BP164}

\section{Description}

This site was recorded by Freeman in 1979. She indicated that it appeared "...to date from the late nineteenth century, with brick, a collapsed ironstone chimney, the depression of what was probably a cistern, and what appeared to be locally-manufactured pottery sherds. One house pier, still in place, was made from part of a telephone pole" (Skelton and Freeman 1979: Table 5). The site size was estimated at $900 \mathrm{~m}^{2}$.

\section{Levels of Work and Results}

This site could not be relocated during this survey, even though another house site (41BP773) was found about $100 \mathrm{~m}$ southwest of where this site was supposed to be. After surveying the area in systematic $3-\mathrm{m}$ intervals, in a second attempt to find the site, CAS archaeologists used a handheld GPS to navigate to the UTMs provided by TARL on the ATLAS website, as well as the UTMs provided by Skelton and Freeman on their Trinomial Form submission. Given that in some cases global datums are not standardized, the field crew used both NAD 27 and NAD 83 datums (even though Freeman's survey was before 1983). During the second attempt, three archaeologists systematically inspected the area within $100-\mathrm{m}$ diameter circles around the supposed site locations. In a third attempt, after examining aerial photographs, the site location map published in Skelton and Freeman (1979), and plotting the UTM locations on a quad map, two archaeologists returned to the locations and walked the areas in close order transects.

\section{Conclusions/Recommendations}

This is one of four sites that could not be relocated during this survey (see also, 41BP167, 41BP434, 41BP489). It could be that this site has 
been misplotted, it may be completely obscured by dense vegetation, or, has been covered with dirt. When this area is scheduled for controlled burning, CAS recommends another attempt be made to find it. Nevertheless, based upon Skelton and Freeman's description, as with all otherhistoric sites at Camp Swift, this site had apparently been bulldozed. Previous investigation determined this site was not eligible for nomination to the NRHP (Mauldin 2001:176-179), and CAS concurs.

\section{BP167}

\section{Description}

When Freeman described this historic house site in 1979 (Skelton and Freeman 1979), she indicated there were whiteware sherds, twentiethcentury machine-manufactured bricks, brown glass, and rock house footings at the site. She noted that it was on a southwestern slope, and had an old road passing through it. The site size was estimated at $580 \mathrm{~m}^{2}$.

\section{Levels of Work and Results}

Although one other house site recorded by Freeman (41BP171) and a newly discovered site (41BP791) were documented in this area during the current survey, 41BP167 could not be located. To no avail, CAS archaeologists followed the same methodologies used in an attempt to find 41BP164 (see above).

\section{Conclusions/ Recommendations}

This is one of four sites that could not be relocated during this survey (see also 41BP164, 41BP434, and 41BP489). After exhausting all avenues, CAS assumes that this site has either been obscured by dense vegetation, has been covered with dirt, or perhaps misplotted. When this area is scheduled for controlled burning, CAS recommends another attempt be made to find it. Regardless, based upon Freeman's description, it appears that 41BP167 was another bulldozed house site. As such, CAS must agree with Mauldin (2001:176-179) that it is not eligible for nomination to the NRHP.

\section{BP171}

\section{Description}

This bulldozed house site (Figures 8-47 and 8-48) is another recorded by Skelton and Freeman (1979). It is on a 91-acre tract of land previously owned by a Mr. Hood and others before the government acquired it. Ms. Fay Pannell stated that they probably didn't live there, just owned the land for investment (personal communication 8 February 2006). The once-cleared field surrounding it is now overgrown with oaks, cedars, mesquites, hackberries, sumacs, chinaberries, grapevines, shrubs, and grasses. The upland setting slopes toward Dogwood Branch Creek to the south. Push piles are common, a firebreak trail has been cut along the eastern edge of the

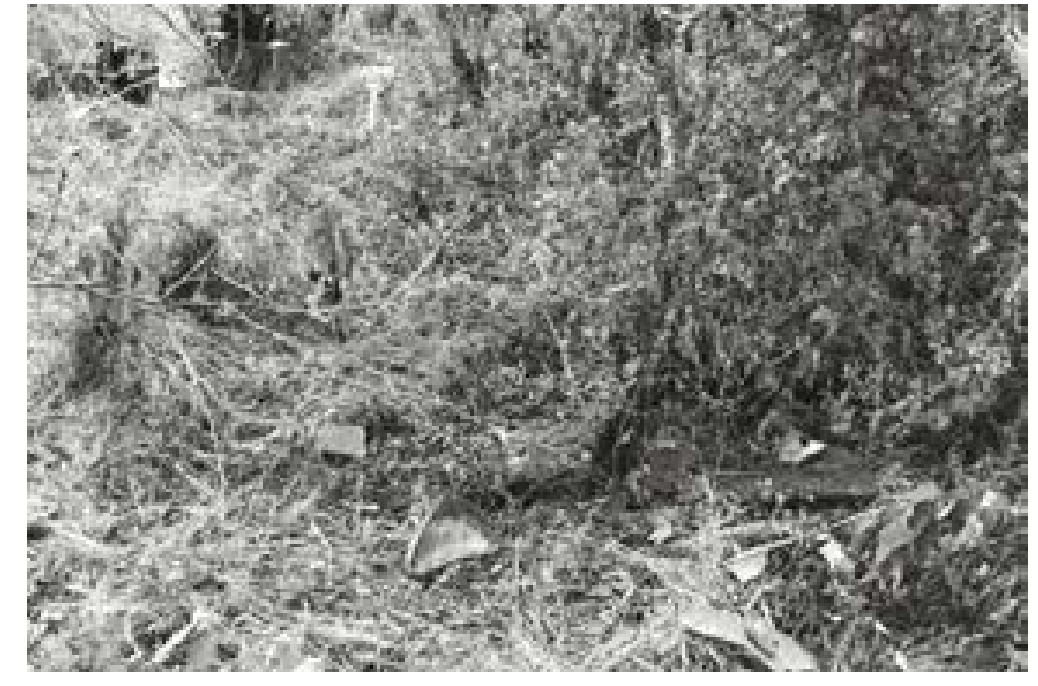

Figure 8-47. Stoneware, bricks, sandstone, and metal remain at 41BP171, a bulldozed house site south of the old Sayersville to McDade Road; facing southeast. 


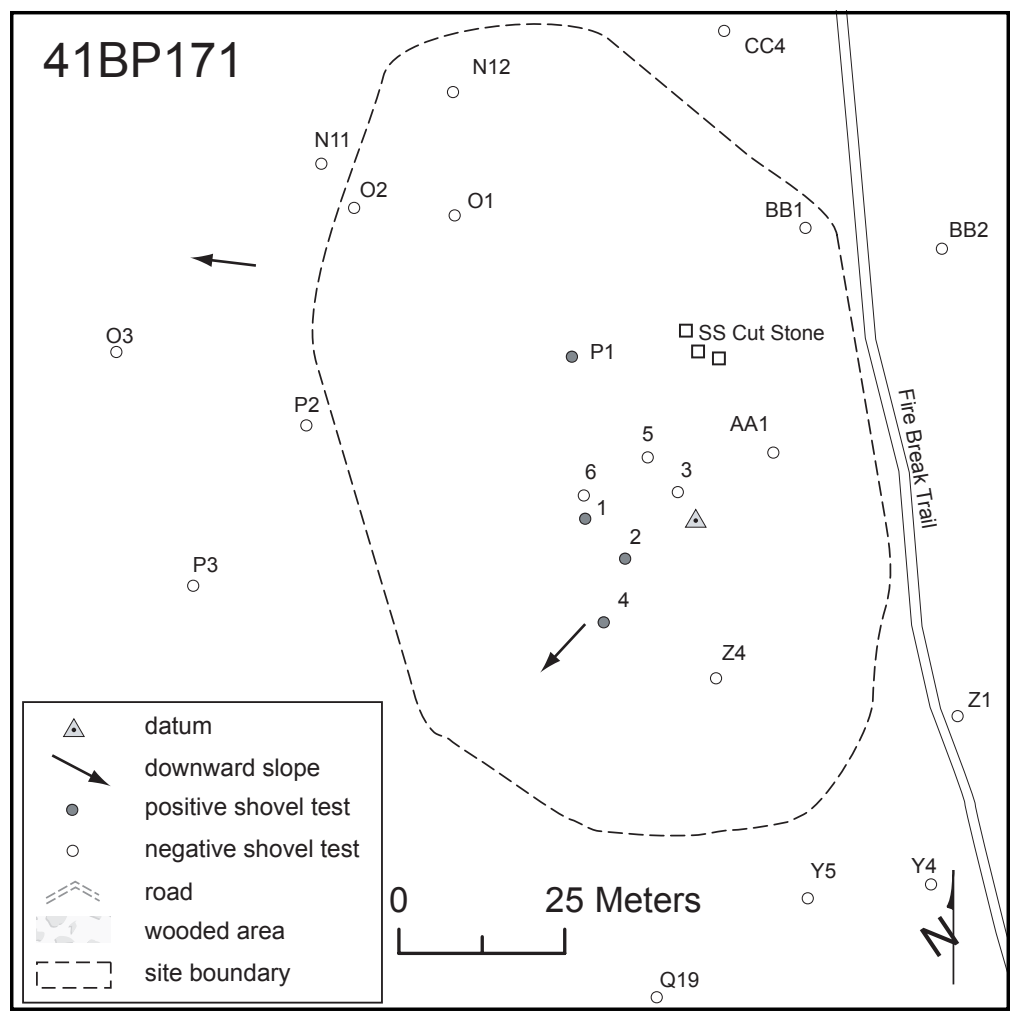

Figure 8-48. Site map of 41BP171.

site, and the surface is hummocky from heavy equipment and wild hog rooting. The datum is marked by a nail and aluminum tag on a $45-\mathrm{cm}$ diameter hackberry tree.

\section{Levels of Work and Results}

When Freeman visited the site, she noted stone house footings, and twentieth-century glass, china, and metal scattered across the surface (Skelton and Freeman 1979). When CAS archaeologists relocated the site in 2005, they observed approximately two dozen yellow, well-made bricks, some with "T. F. B." raised lettering. The Texas Fire Brick Company manufactured this type between 1906 and 1914 (Steinbomer 1982). Three pieces of cut sandstone were also part of the construction remains. A metal \#3 washtub was observed, as well as a metal barrel with numerous perforations in the top that was likely used as a heater. Finally, archaeologists saw an unglazed, thick and flat ceramic piece with numerous perforations that was likely used as a sauerkraut press. Artifacts recovered from four of 13 shovel tests dug on the site include clear glass with an amethyst hue (ca. 1880-1915), thick and dark brown glass with heavy patina (ca. pre-1900), a pink transferware ceramic sherd (ca. 1880-1900), a round wire nail (ca. 1890-present), unidentified metal fragments, and a light bulb shard (Table 812). The soils are shallow, with the average depth to clay less than 9 cmbs.

\section{Conclusions/Recommendations}

The prevalent ages of the artifacts suggest an occupation period from about 1880 through 1920. However, the light bulb probably dates to the late 1930s or early 1940s when electrical lines finally reached this rural area (Abner C. Scott, personal communication 16 January 2002). The historic component has been bulldozed to the extent that it has no significant research value. CAS

Table 8-12. 41BP171 positive shovel test results.

\begin{tabular}{|c|c|c|c|c|}
\hline $\begin{array}{c}\text { Depth } \\
\text { (cmbs) }\end{array}$ & ST 1 & ST 2 & ST 4 & ST P1 \\
\hline $0-10$ & CG & RN & BG, CG & LB \\
\hline $10-20$ & Clay & Clay & WW, BG, CG & \\
\hline $20-30$ & & & BG, M & \\
\hline $30-40$ & & & Clay & Clay \\
\hline $40-50$ & & & & \\
\hline Key: WW-whiteware; BG-brown glass; CG-clear glass; LB-light \\
bulb glass; M-metal; RN-round nail \\
\hline
\end{tabular}


recommends that no further work be conducted and the site is not eligible for nomination to the NRHP.

\section{BP172}

\section{Description}

$41 \mathrm{BP} 172$ is the site of a former house that was initially documented by Skelton and Freeman in 1979 (Skelton and Freeman 1979). Probably bulldozed during WWII, it has been further disturbed by the construction of a powerline rightof-way about $15 \mathrm{~m}$ to the west and heavy equipment operation outside the right-of-way (Figures 8-49 and 8-50). Oak, cedar, greenbrier, dense grasses, and leaves now cover the site, offering less than five percent surface visibility. The site datum is a nail and aluminum tag in a 20-cm diameter oak tree.

\section{Levels of Work and Results}

Freeman described the site as heavily disturbed, but having handmade bricks, some with a thick blue-green glaze. When CAS archaeologists relocated the site in 2005 , they inspected the surface, including push piles and a small drainage, but did not see any bricks, only a single stoneware sherd with a Bristol glaze (ca. 1920-1950) on the surface. One of eight shovel tests dug on the site was positive. ST 1 contained a piece of clear bottle glass between $0-10 \mathrm{cmbs}$. The average depth to the underlying $\mathrm{Bt}$ horizon was less than $9 \mathrm{cmbs}$.

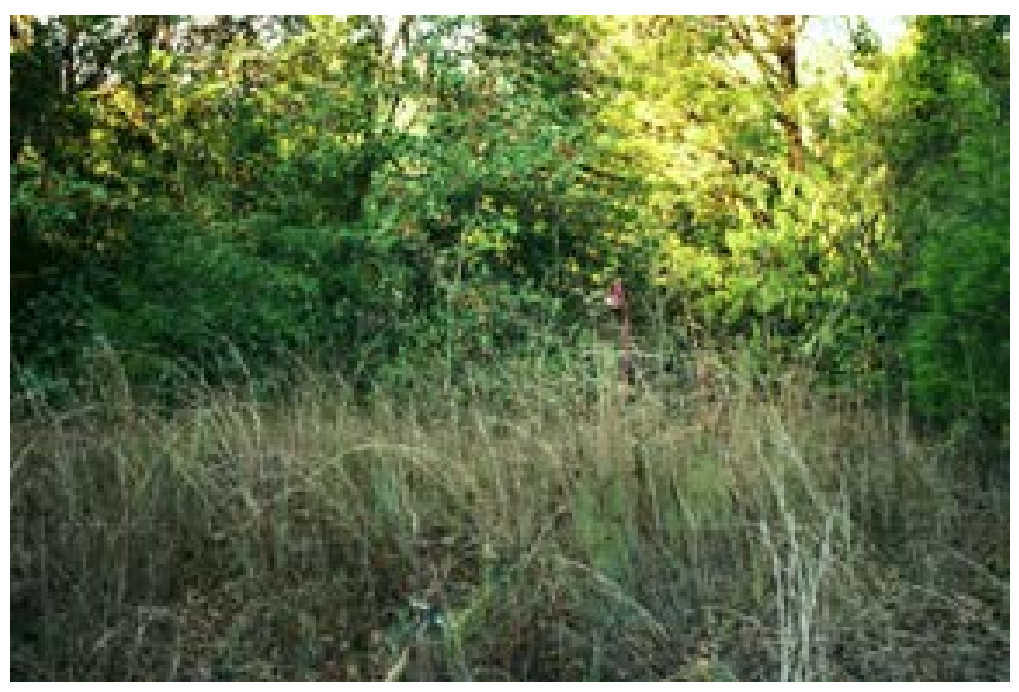

Figure 8-49. 41BP172 is a bulldozed house site adjacent to a powerline right-of-way; facing north.

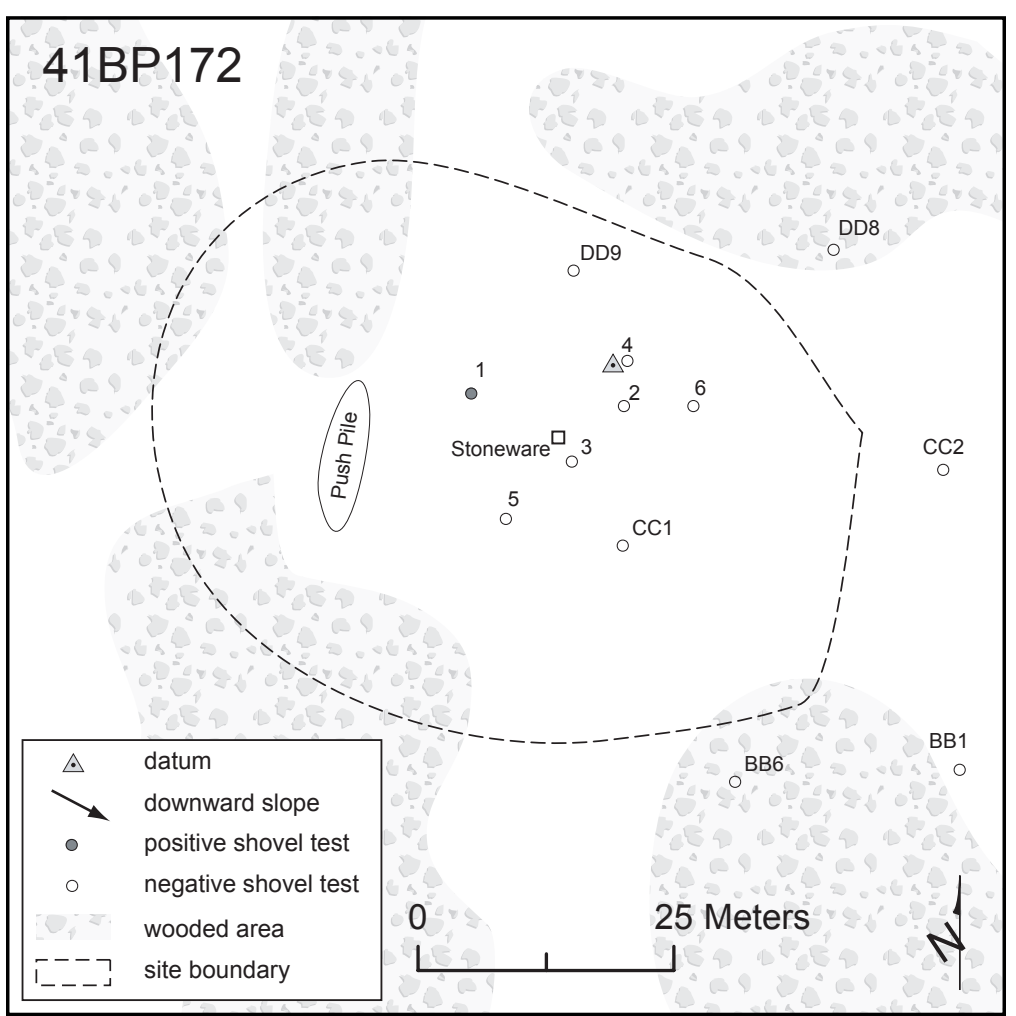

Figure 8-50. Site map of 41BP172.

\section{Conclusions/Recommendations}

The paucity of artifacts found suggests perhaps a post-1930 occupation. The historic component has been bulldozed to the extent that it has no significant research value. Therefore, 
CAS recommends that no further work be conducted and the site is not eligible for nomination to the NRHP.

\section{BP184 (41BP95)}

\section{Description}

Skelton and Freeman (1979) identified the prehistoric component here as 41BP95, and the historic component as 41BP184. Subsequent investigations indicate that it should be designated as one large site with prehistoric and historic components. The prehistoric component has been discussed in Chapter 6: Previously Documented Prehistoric Component Sites. The historic component consists of sandstone foundation stones, bricks, and scattered artifacts. The house site is in an open field area that is now covered with dense grasses and grapevines. A small mott of shade trees now covered with vines grows near the foundation remains (Figures 8-51 and 8-52). The site datum is marked with a nail and aluminum tag on a 30 $\mathrm{cm}$ diameter oak tree in the open field.

\section{Levels of Work and Results}

This site was initially recorded by Skelton and Freeman (1979), and later revisited by CAR archaeologists (Robinson et al. 2001). Skelton and Freeman merely commented on the historic component as an occupation site, and Robinson et al. did not comment on the historic component. When

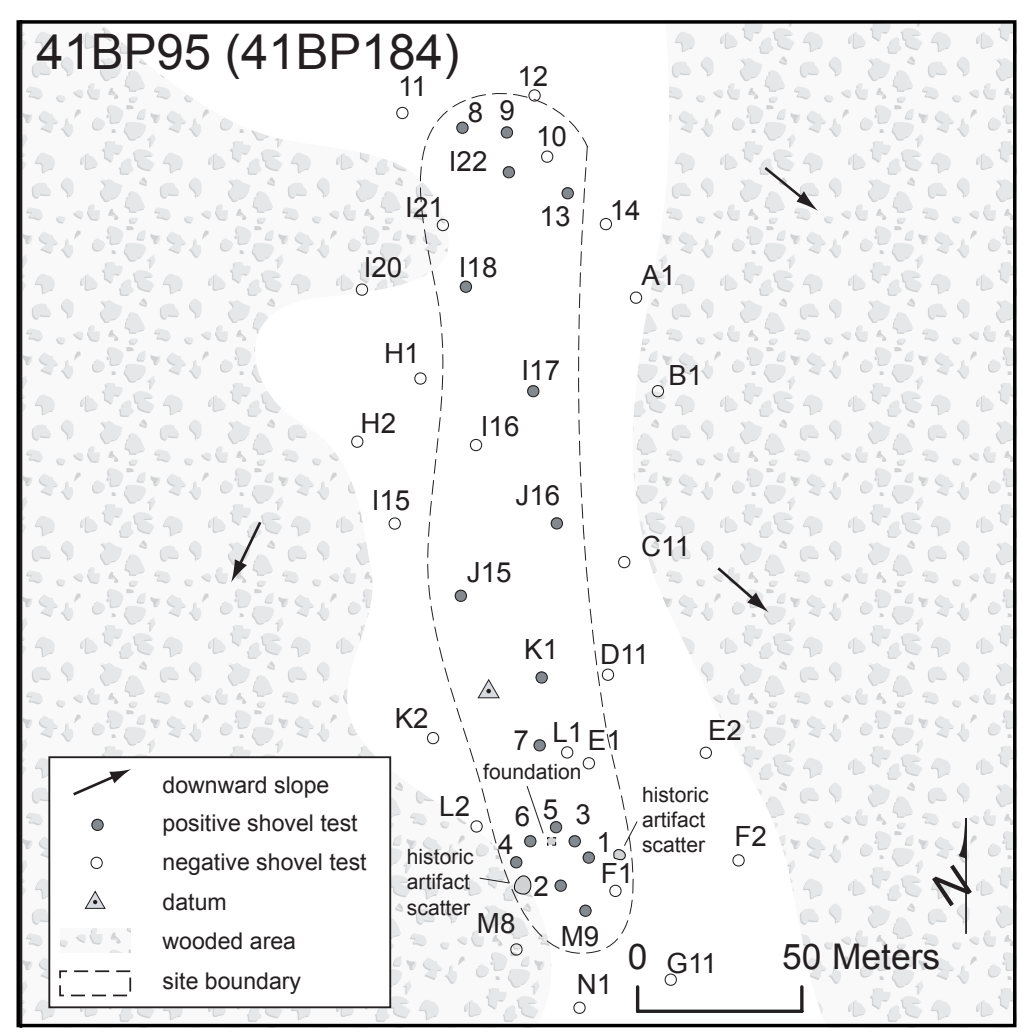

Figure 8-52. Site map of 41BP184 (41BP95).

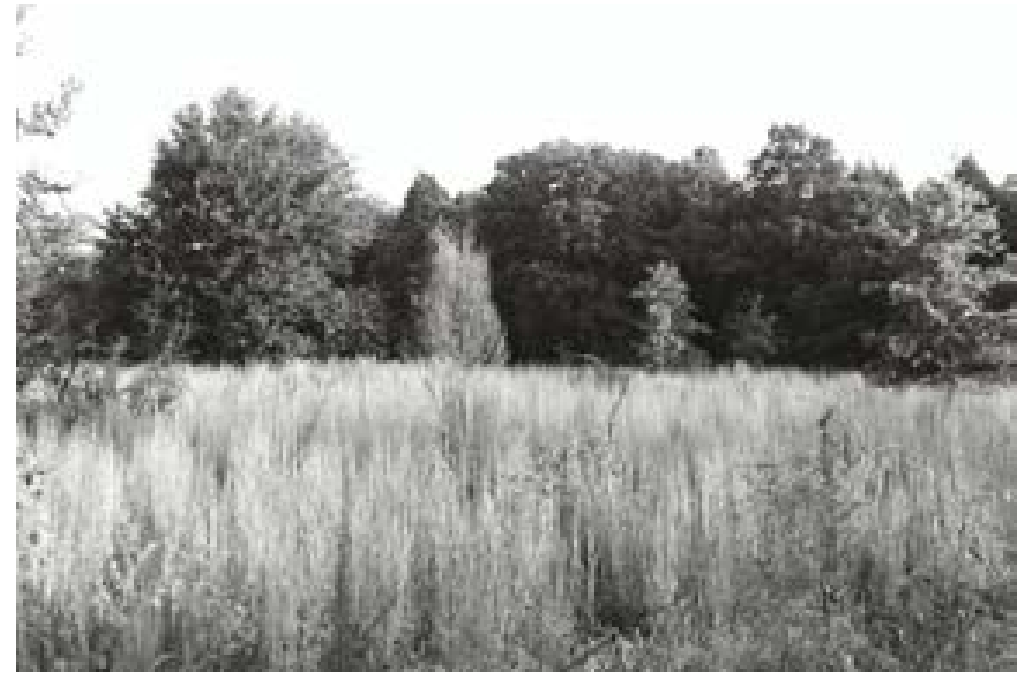

Figure 8-51. 41BP184 (41BP95) lies in this open field; facing northwest.

CAS archaeologists relocated the site in 2005, they observed a thick aqua glass candlestick holder crown shard (ca. pre-1900) on the surface. Glass candlesticks were more commonly used in parlors or dining rooms instead of metal ones used in kitchens and bedrooms. Glass holders 
were considered "middle class," between less expensive pewter or brass and more expensive silver (Woodhead et al. 1984:26). Other historic material on the surface included a few whiteware sherds washing downslope to the south. Sandstone foundation remnants were jutting just above the surface, and a six-foot square was cleared off to reveal more scattered sandstone, as well as a square depression and an intact row of stones (see Figure 8-52).

Out of 23 shovel tests dug on the site, historic artifacts were found in all seven placed around the foundation and vine covered trees (see Figure 8-52, Table 8-13). They include:

Glass - clear with amethyst hue (ca. 18801915) and with no hue (ca. post-1930s); thick, dark brown neck (ca. pre-1900).

Metal-square nails: one wrought (ca. 1850), two cut with machined heads (ca. 18301890) (IMACS 2001b); .30 caliber, short, copper rimfire spent bullet casing with " $\mathrm{H}$ " headstamp, patented in 1871 and used in the Sharps four-barrel derringer as well as the Stevens single shot pistol manufactured ca. 1872-1916 (Logan 1959:64; Savage Arms \& Stevens FAQ 2006; Schroeder 1989:186); a tack from a storage trunk; unidentifiable metal fragments; a chunk of lead.

Fauna - a bovine-like tooth fragment, possible deer bone; hen-sized egg shell fragments

\section{Conclusions/Recommendations}

The house lies in the northern portion of a 200-acre tract, which Otis and Oval Evans owned before the government acquired it in 1942. The mode age of artifacts found implies an occupation period from about 1880 through about 1920. In sum, in its present condition this site does not meet Criteria A, C, or D for nomination to the NRHP,

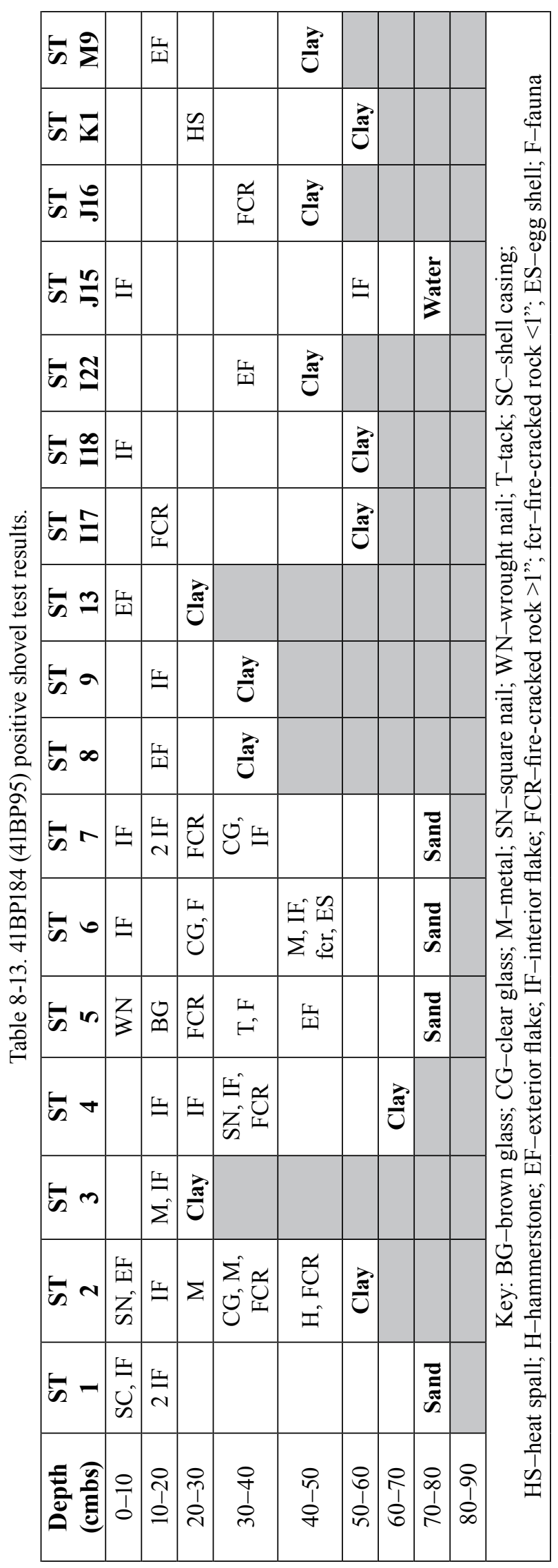


nor does it possess the integrity necessary for it to contribute to the significance of properties with a similar cultural theme within the area (Criterion B). Therefore, CAS assesses the research value of the historic component at this site as minimal; no further investigations are recommended, and the historic component is not eligible for nomination to the NRHP.

\section{BP433}

\section{Description}

House construction materials and a historic artifact scatter compose 41BP433 (Figures 8-53 and 8-54). There is also a prehistoric open campsite on the eastern, wooded portion of the site that has been discussed in Chapter 6: Previously Documented Prehistoric Component Sites. Although the entire site encompasses about $11,935 \mathrm{~m}^{2}$, historic artifacts are spread across about 2,400 $\mathrm{m}^{2}$ and are highly visible on a generally eroded surface within a dense stand of cedar trees on the northern portion, but dense grasses and cacti impede surface visibility in the open areas. An old deer stand was still partially attached to a large oak tree in the eastern portion of the site. Downslope and to the east, a sandstone ledge along the floodplain of McLaughlin Creek appears to have been quarried. The site datum is marked with a nail and aluminum tag on an 8-inch diameter oak tree. The site has been bulldozed, and push piles and heavy machinery tracks are common. C. Westbrook owned a 676-acre tract here in 1929.

\section{Levels of Work and Results}

Schmidt, Cruse, and Brownlow first recorded this site while conducting a survey for EH\&A (Schmidt et al. 1995). They estimated about 20 bricks in the scatter, and observed a .223 caliber

spent bullet casing with military c-ration cans. When CAS archaeologists revisited the site in 2005, they observed sandstone blocks around ST 5 (see Figure 8-54), with a few of the larger ones on the edge of a small mound, and aligned as though they may have been entrance steps. Also on the surface were a metal bucket, red bricks that were coarse and poorly made, two whiteware sherds, a stoneware sherd, the base of a crock pot, and an aqua-colored bottle base with a maker's mark indicating it was made by Adolphus Busch Glass Manufacturing Company in Belleville, Illinois, sometime between 1904 and 1907 (Toulouse 1971:26). Two shovel tests (STs 5 and E3) out of 21 placed on the site contained historic artifacts. ST5 had dozens of small red brick fragments with pasty mortar, a metal bucket handle, clear bottle glass with heavy patina and amethyst hue, window glass, and a .50 caliber bullet recovered between 0 and $30 \mathrm{cmbs}$. The window glass is 27 mm thick. Randy Moir (1988) developed a linear regression formula based on window glass thickness to estimate manufacture data. Even though the formula was designed to be used with a sample of glass fragments and single samples may be very unreliable, we have used Moir's data regression formula to estimate the date of manufacture of the window glass found here. 


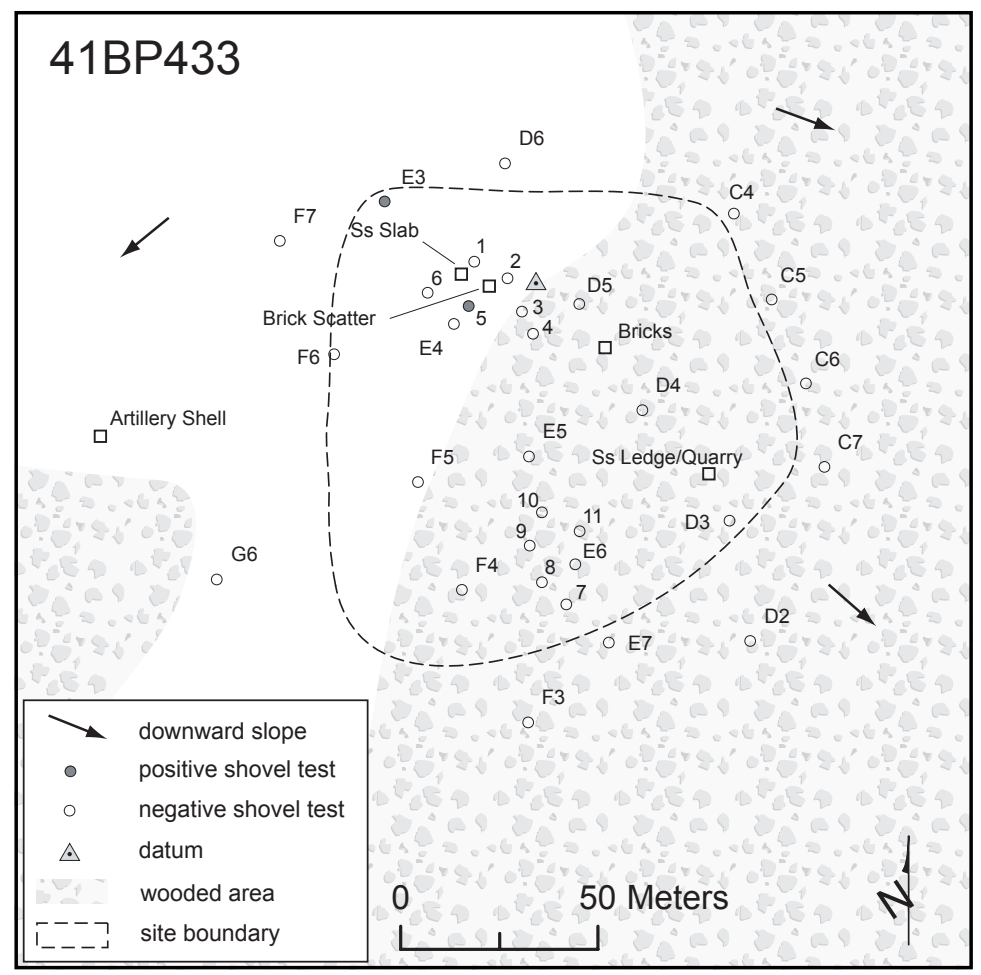

Figure 8-54. Site map of 41BP433.

The estimate is between 1933 and 1947 (Moir 1988:271). Transect ST E3 contained 2 pieces of clear glass with no hue (ca. post 1930) and a stoneware sherd with an Albany slip exterior and no interior slip at $0-10 \mathrm{cmbs}$. One clear glass shard was found in ST E3 at 10-20 cmbs.

\section{Conclusions/Recommendations}

We believe that somehow sites 41BP153 and 41BP433 have been mistaken for each other over the years. They are less than $50 \mathrm{~m}$ from each other. The description by Skelton and Freeman in 1979 for 41BP153 sounds very similar to that of 41BP433, with two distinct structure areas (see above). When EH\&A archaeologists recorded 41BP433 in 1995 (Schmidt et al. 1995), they did not report any ironstone, only about 20 bricks, and no other historic artifacts (this sounds like 41BP153). When CAR archaeologists (Robinson et al. 2001) revisited what they believed was 41BP153 in 1997, they reported whiteware, bottle glass, bricks, and ironstone structure footings (this sounds like 41BP433).

The artifacts suggest that this site was occupied no earlier than the early 1900s, and likely continued though 1941 or 1942. The historic component has been bulldozed to the extent that it has no significant research value, and archival research has provided no proof that persons of historical significance occupied the site. Therefore, CAS recommends that no further work be conducted and the historic component of the site is not eligible for nomination to the NRHP.

\section{BP434}

\section{Description}

This site was discovered during an archaeological survey in advance of a seismic exploration project at Camp Swift (Schmidt et al. 1995). At that time, it was described as a small surface scatter of yellow and red bricks with foundation stone that covered about $100 \mathrm{~m}^{2}$. Clay was observed on the surface and vegetation was very dense. No other artifacts were observed.

\section{Levels of Work and Results}

This site is one of four that could not be relocated during the current survey (see also 41BP164, 41BP167, and 41BP489). After surveying the area in $30-\mathrm{m}$ intervals and not finding the site, CAS archaeologists navigated with a GPS to the UTM coordinates provided by both TARL and EH\&As using both NAD27(CONUS) and NAD83(CONUS). Three archaeologists systematically walked the entire area for about $150 \mathrm{~m}$ around the UTM locations, but could not find the site. CAS once again reviewed aerial 
photographs, the ATLAS site form, and the published report. In May 2006, two archaeologists returned to those same areas, but still could not find the site.

\section{Conclusions/Recommendations}

It should be noted that a sketch map drawn in 1995 shows the site just inside a tree line, with an open meadow west of the site. The UTM coordinates provided led us to the edge of a tree line, but to the west is a heavily wooded drainage and an open meadow is to the east. It appears then, that the site has either been misplotted, or perhaps obliterated by dense vegetation. CAS recommends that when the area surrounding the possible site location is scheduled for controlled burning, that another attempt be made to find it. However, based upon the 1995 evaluation, Mauldin (2001:176179) recommended that the site is not eligible for nomination to the NRHP and CAS concurs.

\section{BP487}

\section{Description/Levels of Effort/Conclusions}

The only historic artifact discovered by CAR archaeologists when they initially documented this site in 1997 was a cast iron stove fragment (Robinson et al. 2001:123). It is also the site of a prehistoric open campsite discussed in Chapter 6: Previously Documented Prehistoric Component Sites.
When CAS returned to the site in 2005, archaeologists conducted a surface survey and excavated 30 shovel tests on the site (Figures 855 and 8-56). No historic artifacts were found either on or below the surface. This area is in an open field that was owned by W. Fleming

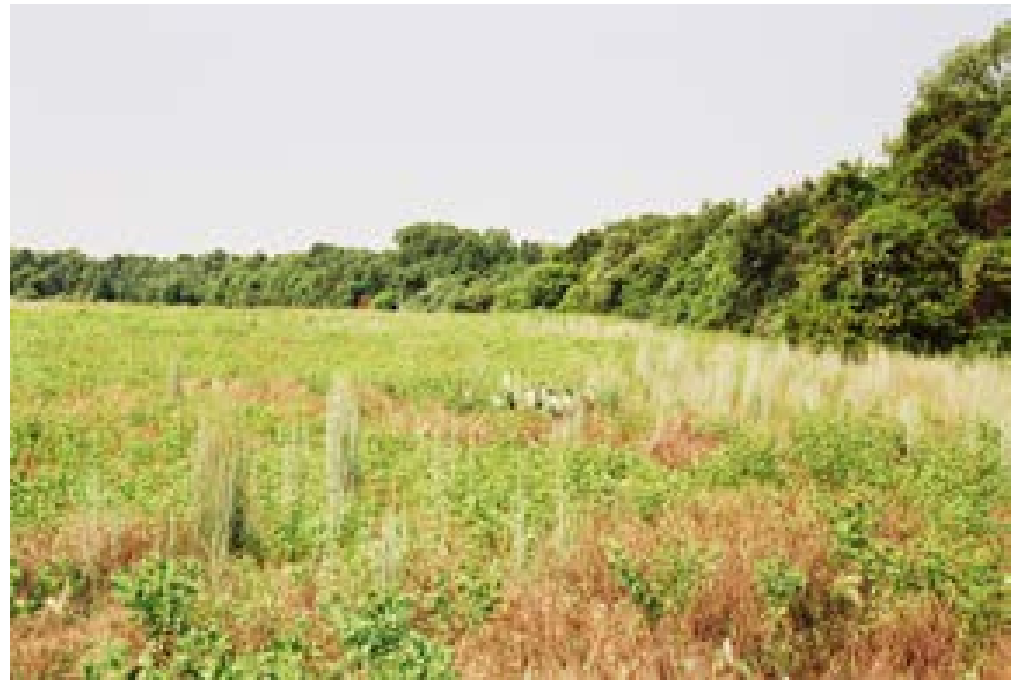

Figure 8-55. 41BP487 lies in an old field on a terrace adjacent to Big Sandy Creek; facing south.

FIGURE 8-56. REDACTED

Figure 8-56. Site map of 41BP487. 
and was plowed through 1941 (Abner C. Scott, personal communication 16 January 2002), but is now covered with grasses, bull nettles, prickly pear cacti, and grapevines, except for cedar and oak trees in a wooded area along the creek. In addition to plowing, a bladed jeep trail runs along the tree line. Surface visibility was less than 10 percent in August 2005. The site datum is a post oak tree $8 \mathrm{~cm}$ in diameter located in the tree line, and is marked with a nail and aluminum tag. CAS archaeologists drove Mr. Scott by the site in January 2006, and he indicated that to his knowledge there was never a building there of any kind; it was always a plowed field, and because of its close proximity to Big Sandy Creek, the field was frequently flooded. Mauldin (2001:176-179) recommended that the historic component of this site, a historic trash scatter, was not eligible for nomination to the NRHP and CAS concurs.

\section{BP489}

\section{Description/Levels of Effort/Conclusions}

This historic installation site consisting of a 2-m diameter scatter of cut sandstone, a stoneware bowl, and a metal bucket was initially recorded in 1997 by CAR archaeologists (Robinson et al. 2001:89). They indicated that the site was moderately wooded and was $45 \mathrm{~m}$ southeast of the northern Camp Swift perimeter fence along County Road 356. CAS archaeologists did not relocate the site during normal transect survey, so they then navigated to specific UTM coordinates provided by TARL, as well as those provided on the ATLAS site form. In 2005, CAS archaeologists observed that an approximately $30-\mathrm{m}$ wide swath had been cleared by heavy machinery along the entire fence line. Large push piles of dirt, large trees, and brush covered much of the area. The field crew saw no cut sandstone or other artifacts in the area. If plotted correctly, the area is on a 60-acre tract that belonged to J. Morgan in 1929 (Bastrop County 1929), but the site has likely been obliterated. This is one of four sites that could not be relocated during this survey (see also 41BP164, 41BP167, and 41BP434). Mauldin (2001:175-186) recommended that the site is not eligible for nomination to the NRHP, and CAS has no reason to disagree.

\section{$41 B P 490$}

\section{Description}

The remains of a bulldozed house and outbuilding, scattered artifacts, and a capped well constitute 41BP490 (Figures 8-57 and 8-58). This site belonged to B. C. and Jettie Daughtry before the military purchased their 187 acres on August 11, 1942 for $\$ 2,875$. It is now just $20 \mathrm{~m}$ south of the Camp Swift perimeter fence and Scott Falls Road. The house and outbuilding with the well are approximately $130 \mathrm{~m}$ apart. Structural remains and artifacts are scattered downslope and cover approximately $4,878 \mathrm{~m}^{2}$.

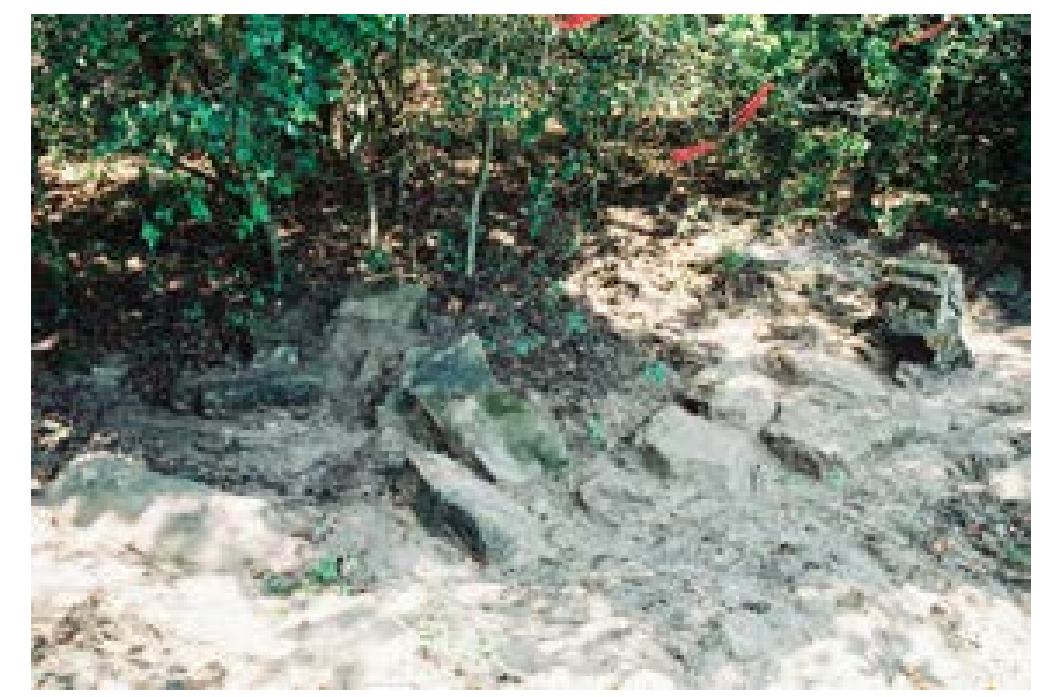

Figure 8-57. The entryway to B. C. and Jettie Daughtry's house at 41BP490; facing north. 


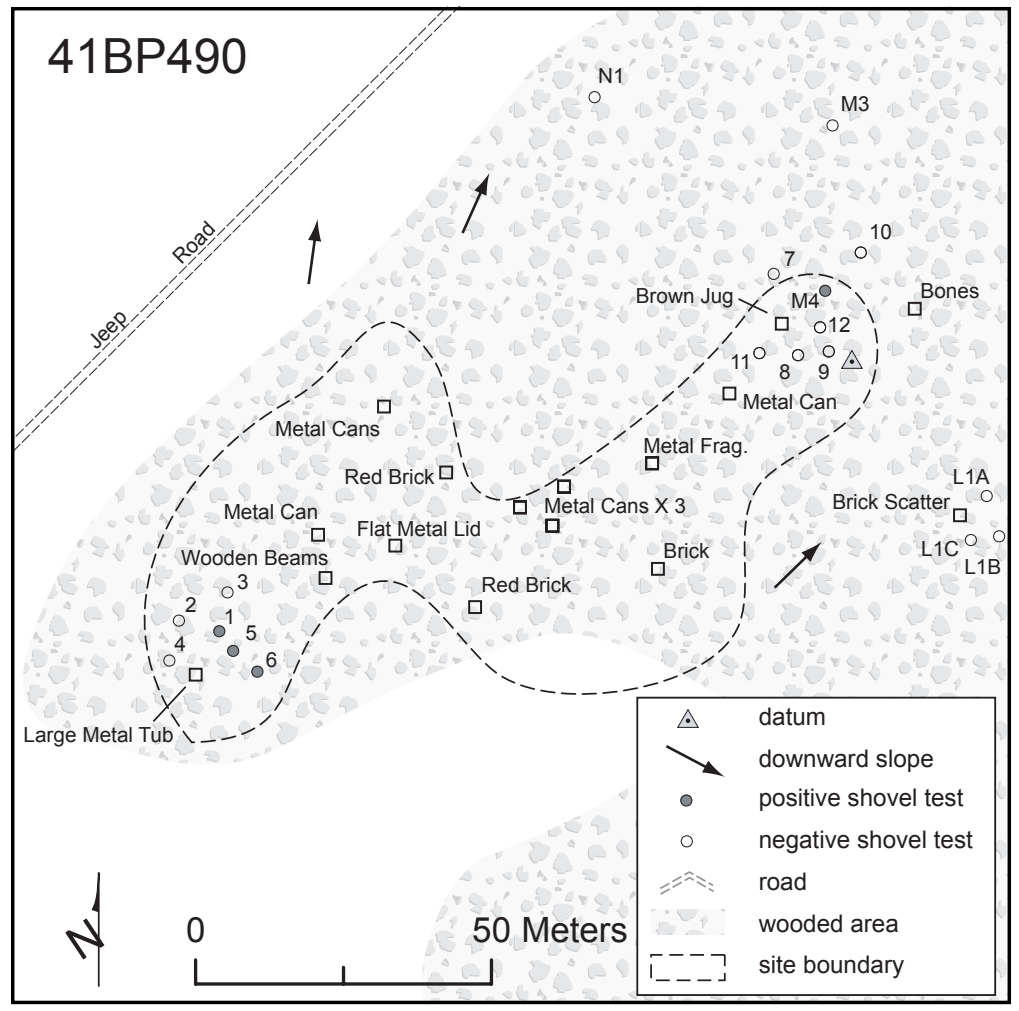

Figure 8-58. Site map of 41BP490.

In the wooded area surface visibility was about 50 percent, but dense grasses around the house remains significantly impeded visibility. The area has been used extensively for military training. The site datum is marked by a nail and aluminum tag on a $30-\mathrm{cm}$ diameter cedar tree.

\section{Levels of Work and Results}

This site was initially recorded by CAR archaeologists in 1997 (Robinson et al. 2001:89). At that time they observed sandstone blocks, scattered artifacts, and a capped well. During the 2005 revisit, CAS archaeologists observed a low mound on the northwestern edge of a cleared field most likely representing where the house stood. Sandstone slabs with mortar just north of the mound appear to be the remains of an entryway (see Figure 8-57). It is not clear whether four large beams lying on the surface northeast of the entryway are related to the house occupation, or whether they represent military usage. Near the house site, three round nails, three square nails, a red brick fragment, unidentified metal, and a piece of round wire were recovered from three of 11 shovel tests that were dug on the site (Table 8-14).

Artifacts are scattered on the surface in a southwest-northeast direction, downslope along an intermittent drainage for approximately $110 \mathrm{~m}$ and span a width of about $50 \mathrm{~m}$. Among the artifacts found are a one-gallon stoneware jug with cord rings observable on the interior and a Leon slip on both the interior and exterior, a porcelain bowl with a square, flat base and ribbed design on it, and a black boot heel, most likely made of rubber. Stoneware sherds from three separate crocks were found. All three have a Bristol glaze interior and exterior. An aqua glass jar bottom was found with "ATLAS," "EZ SEAL," and "TRADE MARK REG." on it (ca. 1896-1964) (Toulouse 1971:55). This was a

Table 8-14. 41BP490 positive shovel test results.

\begin{tabular}{|c|c|c|c|c|}
\hline $\begin{array}{c}\text { Depth } \\
\text { (cmbs) }\end{array}$ & ST 1 & ST 5 & ST 6 & ST M4 \\
\hline $0-10$ & Br, SN & SN & RN & IF \\
\hline $10-20$ & & & M & \\
\hline $20-30$ & & SN & RN & \\
\hline $30-40$ & & & RN & \\
\hline $40-50$ & & & RW & \\
\hline $50-60$ & Sand & Sand & & \\
\hline $60-70$ & & & Sand & \\
\hline $70-80$ & & & & Sand \\
\hline $80-90$ & & & & \\
\hline \multicolumn{2}{|c|}{ Key: Br-brick; M-metal; RN-round nail; SN- } \\
square nail; RW-round wire; IF-interior flake \\
\hline
\end{tabular}


version of the "Lightning" jar, made by the Atlas Glass Co. and is considered to be one of its first products. The Lightning jar was a design adapted from a beverage bottle stopper that used wires to secure the lid to the jar (Toulouse 1969:22). A mason jar with "Kerr," "MASON," "SELF SEALING," and "TRADE MARK REG." embossed on the front was observed. The Kerr Glass Company made this jar from 1903 through at least 1969 (Toulouse 1969:169-170). Two clear glass bottles with metal caps, screw tops, and unidentified marks were found. The first appears to be a half diamond with an eight inside of an oval. To the left of this mark is a "7" and to the right is an "O." The second bottle has a mark with a large diamond inside of a large oval. Just below the oval appears to be a seven. The last item is a clear Three Rivers bottle. The bottom reads "3 RIVERS" with a star to the right and "55 7" below the mark (see Figure 8-59).

Approximately $112 \mathrm{~m}$ southeast of the house area is the well, which measures 45 inches in diameter and is capped with concrete (Figure 8-60). Approximately $20 \mathrm{~m}$ northwest from the well is a trash pile that includes corrugated tin sheets that are 45 inches tall; an electric pole crossbar; a 30gallon drum made by US Steel; possible decorative vitrified tile measuring 113/4 inches long, 4 inches thick, 51/2 inches wide; numerous rolls of barbed wire; fence and gate posts; red brick; a tin can with a snap-top lid and a modern seam; and a tin can with handle measuring $11 \frac{1}{2}$ inches in diameter. The lumber contains round nails. A cleaning product bottle and a clear bottle with a mark of a " $\mathrm{B}$ " within a circle were also observed. This is most likely a Brockway Glass Co. maker's mark, which was copyrighted in 1928 (Toulouse 1971:61). Above the mark is "1740-A," to the left is " 3 ," and below is " $4 . "$

\section{Conclusions/Recommendations}

According to Mr. Abner C. Scott (personal communication 16 February 2006), the Daughtrys

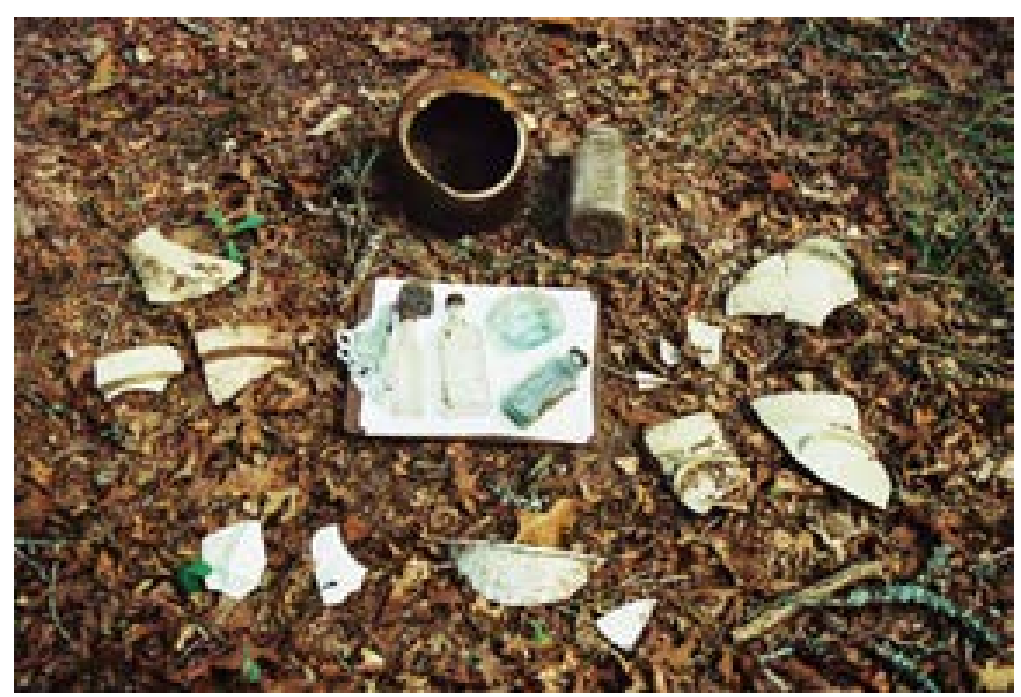

Figure 8-59. A sampling of artifacts from 41BP490.

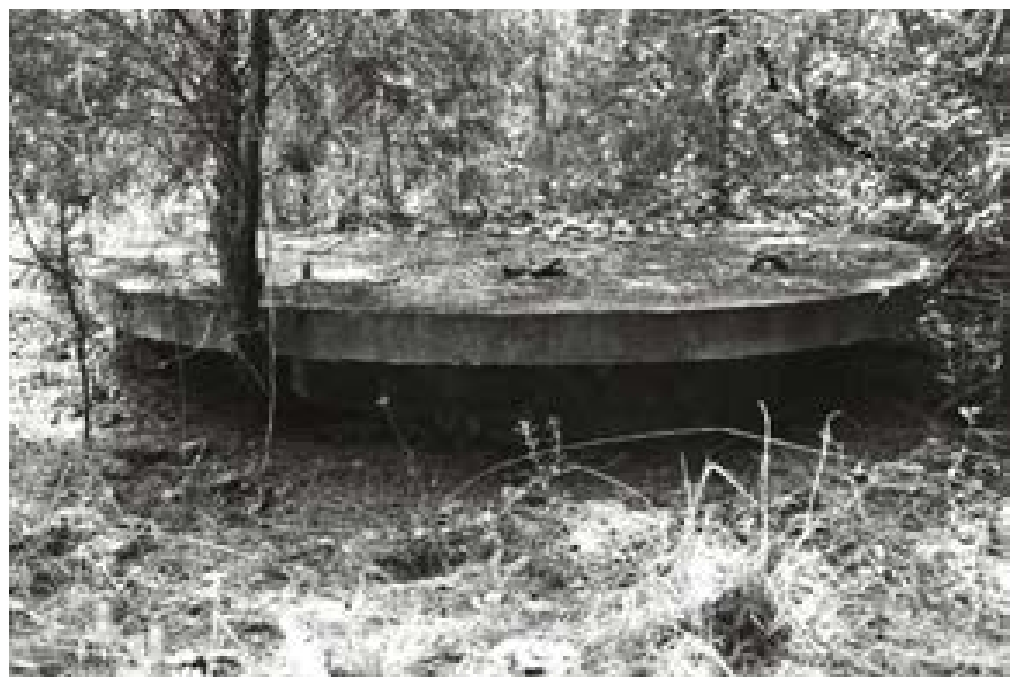

Figure 8-60. Brick-lined well on the B. C. and Jettie Daughtry place (41BP490). 
owned the land for some time, but always lived in Elgin until they got older. They were only on the place for eight or ten years before the government took the land. They owned land all the way between the Aussiloux property along Spring Branch and the Doll Fort property along the west. Their land ran all the way across that open field, across Big Sandy Creek, and extended well to the south of Big Sandy. They kept all their cattle on the south side of Big Sandy, by the Scott place. The land they owned on the north side of Big Sandy was so heavily wooded, and the open field either was farmed or didn't produce much grass. The bottomland on the other side of Big Sandy was more suitable for grazing their cattle.

The artifacts suggest that this site was occupied no earlier than the early 1900s, and likely continued though 1942. The household ceramics and glass, brick-lined well, metal outbuildings, and barbed wire suggest a farmstead household and agricultural use. Like most other historic components on Camp Swift, this site has been bulldozed to a great degree, but with intact architectural features and positive shovel tests there may be a possibility of further intact deposits. Therefore, CAS recommends that additional investigations should be conducted in order to determine if the site is eligible for nomination to the NRHP. Three additional 1-x-1-m test units should be excavated in the area of the entryway and near the positive shovel tests.

\section{$41 B P 492$}

\section{Description}

This is the third trash dump on the Daughtry's 187 acres (see also, 41BP711 and 41BP712). It is strewn on the edge and side of a gully on eroded clay and sandstone bedrock (Figures 8-61 and 8-62), about $45 \mathrm{~m}$ south of the Camp Swift perimeter fence and Scott Falls Road. An old road cut leads into the gully. A nail and aluminum tag on a $30-\mathrm{cm}$ diameter oak tree.

\section{Levels of Work and Results}

This site was initially recorded by CAR archaeologists in 1997. At that time they observed numerous cans and bottles and some ceramics. They collected two shell buttons that likely were produced before 1915, and a whiteware sherds with maker's mark that possibly dated to as early as 1913 (Robinson et al. 2001:92). No shovel tests were dug within the site's boundaries when CAS visited the site in 2005 , but automotive products such as rubber tires and 50- and 60-weight motor oil cans were numerous, and tires were observed further downslope in the creek bed. A white enamel-coated, tin washbasin, one yellow brick fragment, modern looking stoneware with light blue decorative bands, and one with a square base were found. Other debris included the top of a clear glass jar with a screw top, a clear glass shard with a handle, green 7-Up and Coke bottle shards, a light blue glass shard with molded ribbing, a brown bottle with a crown cap, and

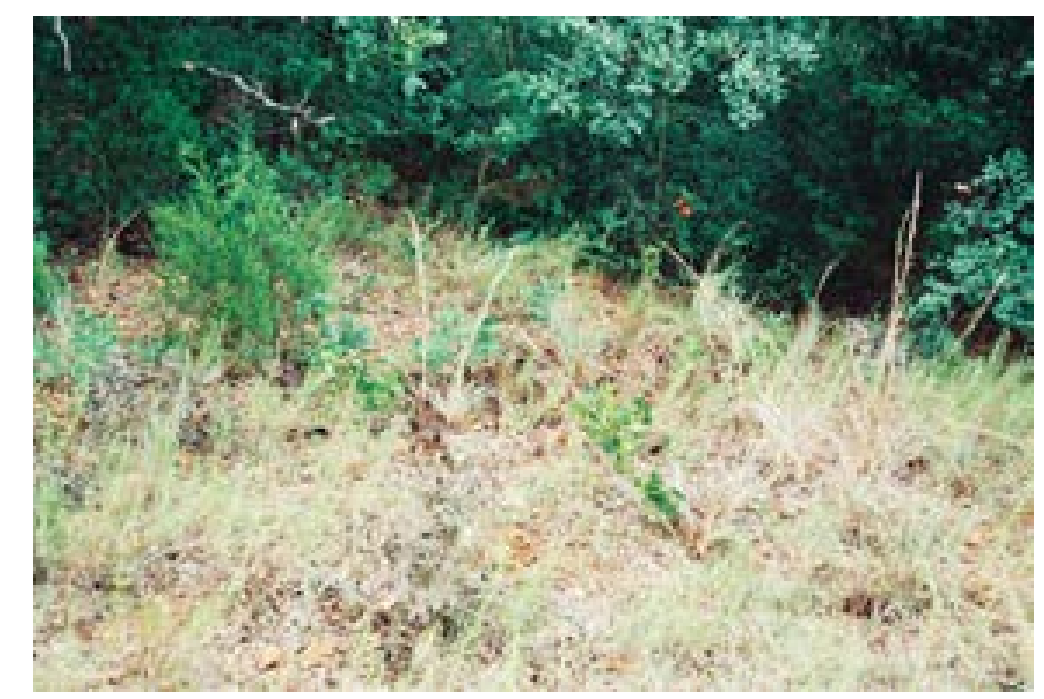

Figure 8-61. 41BP492 is the third trash dump on the Daughtry property; facing south. 


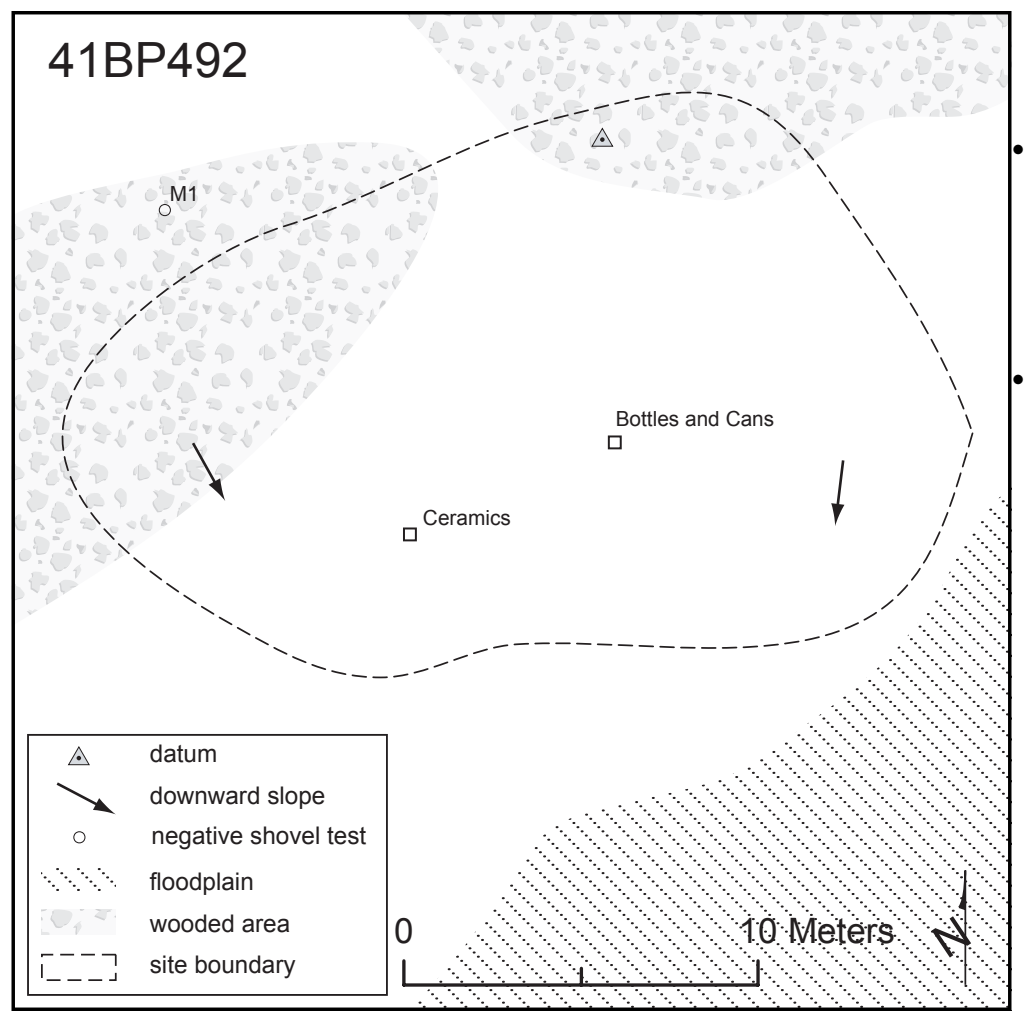

Figure 8-62. Site map of 41BP492. makes the year of production difficult to pinpoint.

a clear glass bottle with ribbing near the top. No mark was observed but the numbers " 31 " and " 1635 " were present.

a clear glass fruit jar embossed with "Ball Perfect Mason" on the front and an " 8 " on the bottom, produced by the Ball Bros. Co., Muncie, Ind., circa 1915 (Toulouse 1969:37, 38).

\section{Conclusions/ Recommendations}

In general, much of the trash at this site appears to have been deposited relatively later than the debris at 41BP711 and 41BP712, both on the Daughtry's property. Robinson concluded that it may have served as a community plate glass (Figure 8-63). Bottles with legible marks include: dump site. Nevertheless, it is of little significance,

- a brown beer bottle with an Owens-Illinois Glass Co. mark, indicating that it was produced in the Streator, Illinois plant in 1940 (Toulouse 1971: 395).

- a brown Purex bleach bottle with an Owens-Illinois Glass Co. mark, indicating that it was either produced in the Okmulgee, Oklahoma or the Waco, Texas plant. This factory number was reassigned to the Texas plant when the Oklahoma plant closed and only the last digit of the year is present, which

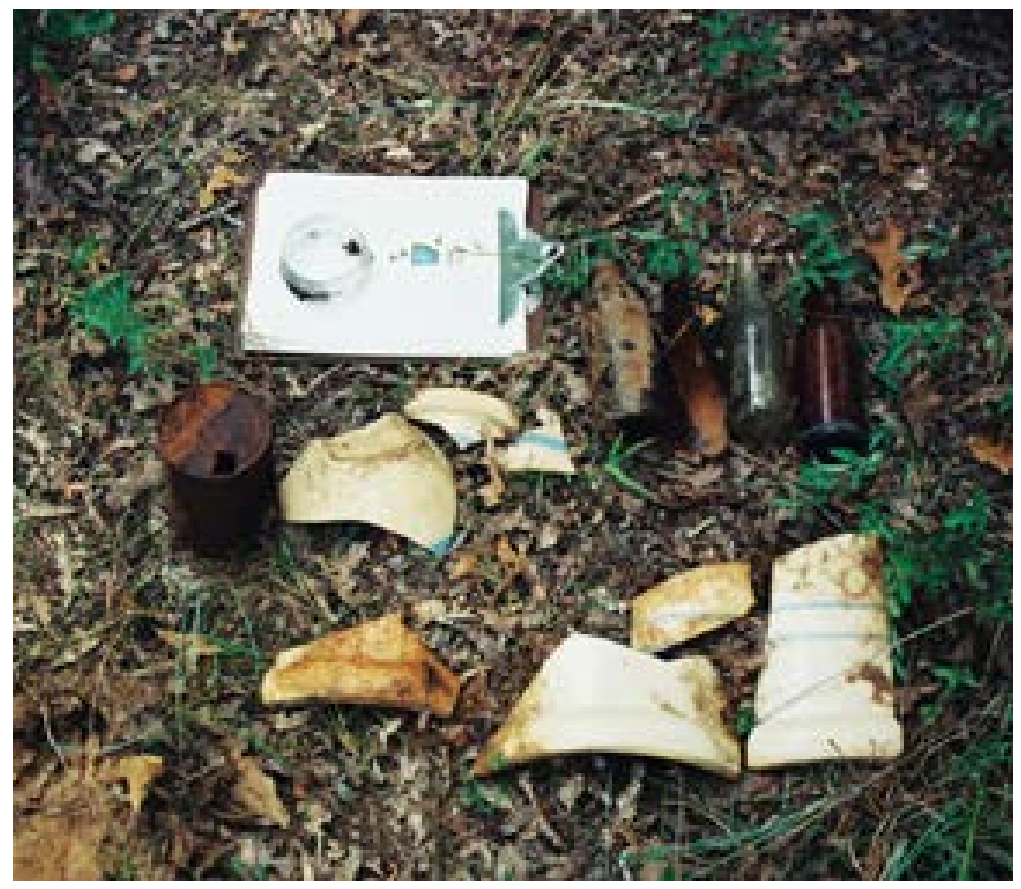

Figure 8-63. Discarded bottles, tin cans, jars, and stoneware found at $41 \mathrm{BP} 492$. 
no further work is warranted, and it is not eligible for nomination to the NRHP.

\section{BP534}

other bottle and window glass, an amethyst glass plate base, whiteware, and porcelain sherds were sparsely scattered through the woods just south of the foundation stones. Also found in the same

\section{Description}

The historic component of this site was initially documented by CAR archaeologists in 1997 (Robinson et al. 2001:117). A prehistoric component was discovered during the current project, and it has been discussed in Chapter 7: New Prehistoric Component Sites. The eastern portion of the site is heavily wooded, but has a cleared road leading to sandstone foundation stones and a scatter of historic artifacts. A barbed wire fence runs along the west and south sides of the foundation area. The western portion is a cleared field (Figures 8-64 and 8-65). A nail and an aluminum tag were placed on an oak tree to mark the site datum.

\section{Levels of Work and Results}

During the July 2005 and January 2006 visits, archaeologists from CAS observed less than six clear glass shards in the open field area, but six possible sandstone foundation stones were found in the eastern, wooded portion of the site. A brown snuff bottle base with no dots dating to ca. pre-1900 (Munsey 1970:77),

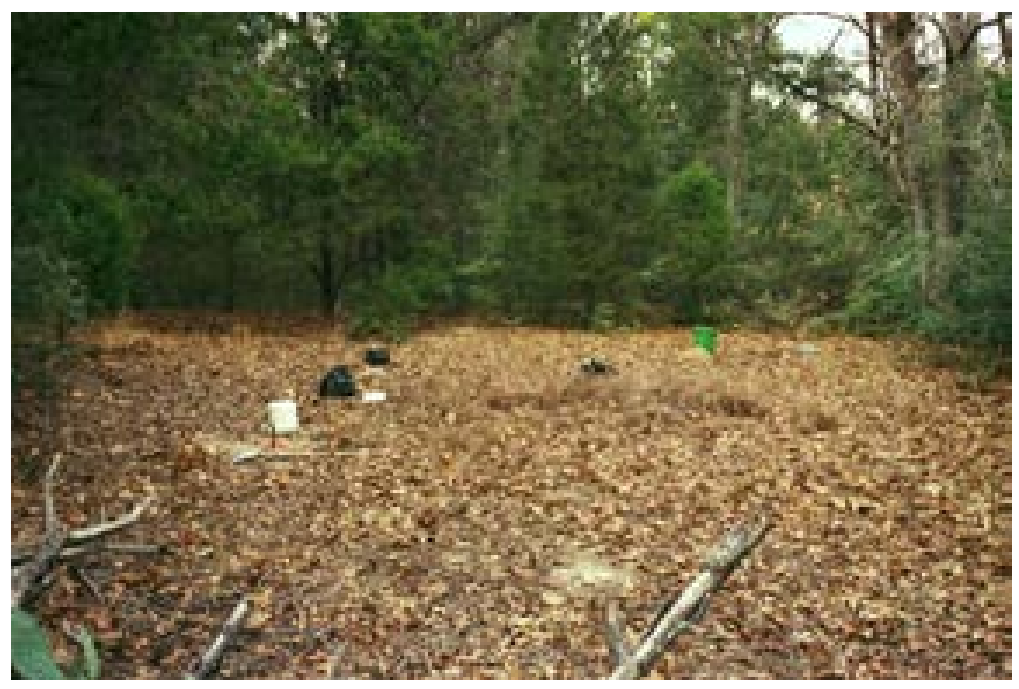

Figure 8-64. Sandstone foundation stones and a trash scatter were found at 41BP534; facing north.

Figure 8-65. Site map of 41BP534. 
general area was a metal bucket, two \#3 washtubs, and two soldered hole-in-top cans (ca. 1850-1920).

Four of 29 shovel tests placed on the site contained historic artifacts (Table 8-15). Transect shovel test B7 contained a modern brown glass fragment at 20-30 cmbs. In addition, three of the six shovel tests placed around the foundation stones included an aqua green medicine bottle neck (ca. pre1900), clear glass with an amethyst hue (ca. 1880-1915), a ceramic button (ca. 1880-1930), and a highly fired whiteware cup sherd (ca. 1850-present). The bottle neck and button are shown in Figure 866.

\section{Conclusions/ Recommendations}

Abner C. Scott, who lived in the area from 1923 through 1942, does not remember anyone ever living at this site (personal communication 16 February 2006). The approximated ages of the artifacts suggest that the site was likely occupied during the period from about 1880 through 1915 . The foundation stones appear to be just inside the Daughtry's property line with Antoine Aussilloux's 40-acre tract.

Regardless, the historic component of this site has been heavily disturbed due to bulldozing. Therefore, its research value is minimal. CAS recommends that no further work be conducted, and the

\begin{tabular}{|c|c|c|c|c|c|c|c|c|c|c|c|c|c|}
\hline 的公 & & & $\Phi$ & & & & & 䏤 & & & & & \\
\hline 的文 & & & & & & & 结 & 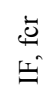 & & & D & & \\
\hline $\sin \frac{1}{4}$ & & & & & & & 颉 & ت्ञ & & & & & \\
\hline 的交 & & 㝳 & & & & 里 & & & Dूँ & & & & \\
\hline $\sin \frac{1}{4}$ & & & $\Phi$ & & & & d & & & & & & $\begin{array}{l}: \Xi \\
\vec{\nabla} \\
\frac{\ddot{v}}{=}\end{array}$ \\
\hline 的 & & & & & $\overrightarrow{2}$ & & & Е్ & & & & & \\
\hline $\sin \frac{\theta}{\lambda}$ & & & $\vec{m}$ & & & 立 & & & 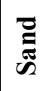 & & & & 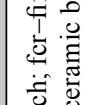 \\
\hline $\sin \frac{\infty}{\lambda}$ & & & & $\Phi$ & & & & 窇 & & & & & 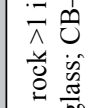 \\
\hline 的 & & & & & త్ & & & 营 & & & & & 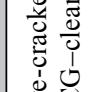 \\
\hline is $\frac{5}{x}$ & & & & & 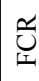 & & & & $\begin{array}{l}\text { 就 } \\
\text { מี }\end{array}$ & & & & \\
\hline 的帛 & $\bar{\emptyset}$ & & & & $\Phi$ & & & $\frac{\pi}{U}$ & & & & & \\
\hline $\bar{\infty} \bar{\infty}$ & & & U & & & & & & & & & & \\
\hline 的车 & & & & & $\underset{\sim}{ \pm}$ & $\underset{\sim}{ \pm}$ & & & 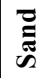 & & & & \\
\hline is $\frac{1}{4}$ & & & & & 里 & & & 尝 & & & & & \\
\hline 部 & & 壵 & & & & & & 咅 & & & & & \\
\hline$v_{n}=$ & 3 & & & & & מี & & & & & & & \\
\hline$\xi_{\infty} \infty$ & జ & & & & & एँ & & & & & & & \\
\hline$\sqrt{2}-$ & ن ن & & & $\frac{\pi}{0}$ & & & & & & & & & \\
\hline 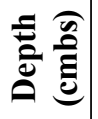 & $\frac{0}{1}$ & $\begin{array}{l}\stackrel{\imath}{1} \\
\stackrel{0}{0}\end{array}$ & $\begin{array}{l}0 \\
\text { 1 } \\
\text { กิ }\end{array}$ & $\begin{array}{l}\text { i } \\
1 \\
0 \\
\text { n }\end{array}$ & $\begin{array}{l}\frac{1}{4} \\
\frac{q}{q}\end{array}$ & $\begin{array}{l}8 \\
0 \\
1 \\
\text { in }\end{array}$ & $\begin{array}{l}8 \\
0 \\
8\end{array}$ & $\begin{array}{l}\infty \\
1 \\
1\end{array}$ & $\begin{array}{l}8 \\
1 \\
1 \\
\infty\end{array}$ & $\begin{array}{l}\frac{8}{1} \\
\frac{1}{2}\end{array}$ & I & 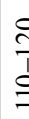 & \\
\hline
\end{tabular}




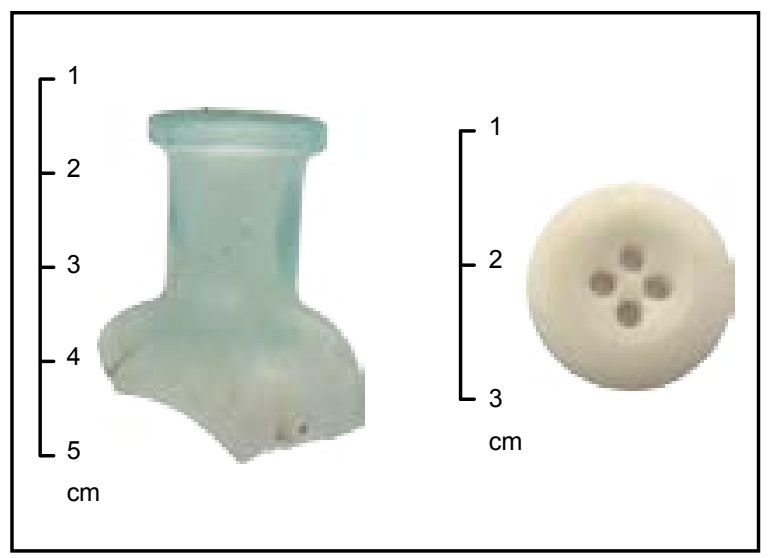

Figure 8-66. Bottle neck from ST 1 and ceramic button from ST 5 at 41BP534. 


\title{
Chapter 9
}

\section{New Historic Component Sites}

\author{
By David L. Nickels and D. Emory Worrell
}

\section{BP695}

\section{Description}

Artifacts and construction material make up the remnants of a farmstead that belonged to Jackson Morgan before his surrounding 60acre tract was purchased by the military (Abner C. Scott, personal communication 16 February 2006). The farmstead lies adjacent to a prehistoric lithic scatter that has been discussed in Chapter 7: New Prehistoric Component Sites. Based upon shovel test results, it appears that the historic material has been distributed by bulldozer across approximately $3,900 \mathrm{~m}^{2}$ of the western, elevated portion of the site. The historic component area is situated on a low knoll that has been deeply cut on its southwestern edge for the construction of Scott Falls Road (Figures 9-1 and 9-2). The area has been cleared except for scattered oak and cedar trees, and is now overgrown with dense grasses, weeds, and wild grapevines. Surface visibility was less than five percent in July 2005. The surface is extremely uneven, and several rodent burrows were observed. The site datum is marked by a nail and aluminum tag on a $40-\mathrm{cm}$ diameter cedar tree.

\section{Levels of Work and Results}

No artifacts or features were observed on the surface, and this site was discovered during excavation of transect shovel tests (see Figure 9-2). STs 1-3 were dug on and around the historic component to determine site boundaries and evaluate its integrity. A total of nine shovel tests were dug within the site's boundaries, of which eight were positive. Historic artifacts were recovered from five of the eight positive shovel tests and included glass, metal fragments, a metal harness, a metal snap, part of a rubber tire, square nails, and whiteware (Table 9-1).

Artifacts found in the shovel tests include clear, clear with a purple hue, amber, aqua, and brown glass. Enough remained of the aqua glass shard to determine that it was a screw top. Although screw top bottles had been used prior to the 1900 s, they were considered specialty items

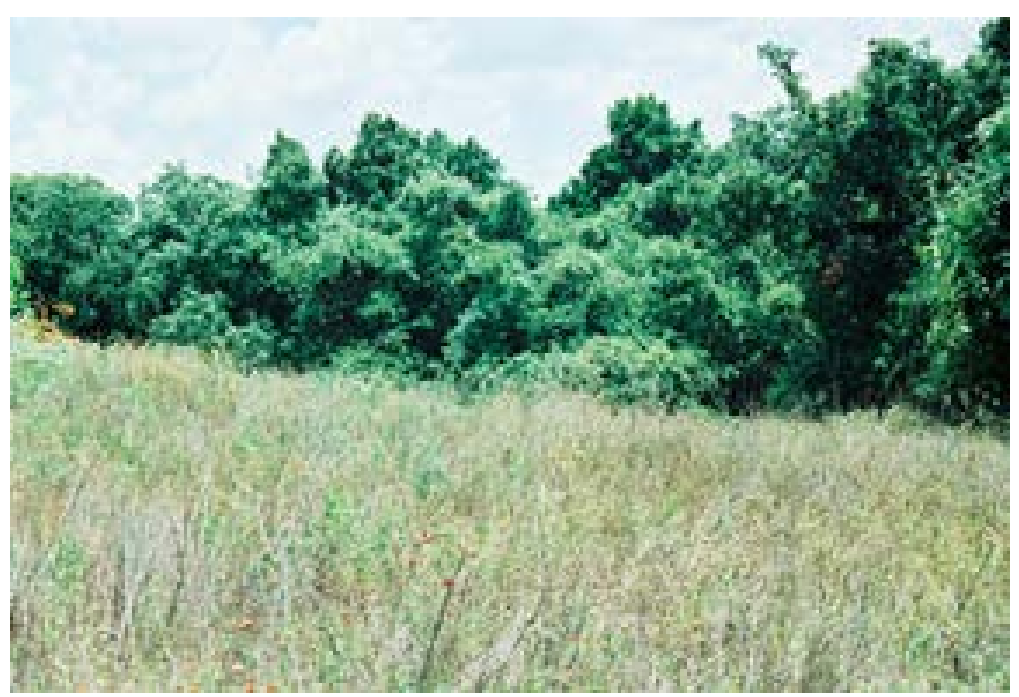

Figure 9-1. This farmstead site fronting Scott Falls Road belonged to Jackson Morgan before the government acquired it; facing northeast. 
FIGURE 9-2. REDACTED

Figure 9-2. Site map of 41BP695. and were not common until about 1924 (Polak 1997:24). A purple hue was observed on one of the clear glass shards, indicating the use of manganese and an approximate date of manufacture between 1880 and 1915. In sum, the glass found here suggests an earliest occupation date of around 1880.

An undecorated whiteware rim sherd and a whiteware sherd with a maker's mark were found in ST 3 (Figure 9-3). The mark is the "Royal Coat of Arms" insignia, which was commonly used by pottery producers both in Britain and America from the early 1800s through the twentieth century (Kovel and Kovel 1986:267). The belt that surrounds the shield on

Table 9-1. 41BP695 positive shovel test results.

\begin{tabular}{|c|c|c|c|c|c|c|c|c|}
\hline $\begin{array}{l}\text { Depth } \\
\text { (cmbs) }\end{array}$ & ST 1 & ST 3 & ST 6 & ST 9 & ST C2 & ST D13 & ST E2 & ST E3 \\
\hline $0-10$ & & & & & & $\mathrm{M}$ & WW, CG & \\
\hline $10-20$ & & & IF & & IF & WW & $\mathrm{CG}$ & $\mathrm{CG}$ \\
\hline $20-30$ & & CG & & IF & & $\mathrm{CG}, \mathrm{M}$ & $\mathrm{CG}$ & \\
\hline $30-40$ & CG & & & & & & $\mathrm{R}$ & \\
\hline $40-50$ & & CG & & & $\mathrm{CC}$ & & & \\
\hline $50-60$ & & WW, CG, M, RW & & & & & & \\
\hline $60-70$ & & $\mathrm{AG}, \mathrm{CG}, \mathrm{M}$ & & & & & & \\
\hline $70-80$ & CG & $\begin{array}{c}\text { WW, AG, CG, } \\
\text { M, SN }\end{array}$ & Sand & Sand & Sand & Sand & Sand & Sand \\
\hline $80-90$ & $\mathrm{CG}$ & $\begin{array}{c}\text { AG, AqG, BG, } \\
\text { CG, M, SN }\end{array}$ & & & & & & \\
\hline $90-100$ & & $\mathrm{CG}, \mathrm{M}$ & & & & & & \\
\hline $100-110$ & Sand & & & & & & & \\
\hline $110-120$ & & Sand & & & & & & \\
\hline $120-130$ & & & & & & & & \\
\hline $\begin{array}{r}\text { Key } \\
\mathrm{M} \\
\end{array}$ & -whit & $\begin{array}{l}\text { re; } \mathrm{AG}-\text { amber gl } \\
\text { fuare nail; RW-ro }\end{array}$ & $\mathrm{Aq}$ & Ia gla & $3 \mathrm{G}-\mathrm{br}$ & $\begin{array}{l}\text { glass; } \\
\text { hin. }\end{array}$ & $\begin{array}{l}\text { clear glas } \\
\text { ior flake }\end{array}$ & \\
\hline
\end{tabular}


the insignia bears the motto of the Order of the Garter, which reads "Hon Y Soit Qui Mal Y Pense," and translates to "Shame to him who evil thinks" (Birks 2005). Although the factory name is regularly found below the insignia, this area was missing from the sherd. An undecorated whiteware cup sherd was recovered from ST D13 and another undecorated whiteware sherd was found in ST E2, suggesting a probable post-1860 date of use, but whiteware was still a common dinnerware in use through 1941 (Fox et al. 1989:45). Overall, the ceramics discovered here suggest an earliest likely occupation date of 1860 .

Three round wire strands, sheet metal protruding from the shovel test wall, three cut nails, and unidentified metal fragments were also found in ST 3. Though the nails were cut it was not possible to determine if the heads were hammered or machine-made. Cut nails were used for nearly two centuries; those with handhammered heads were commonly used between 1790 and 1825, and those with machine-made heads were in use from about 1825 through the mid-twentieth century (Nelson 1968:1-10).

\section{Conclusions/Recommendations}

Jackson W. Morgan lived here from 1929 until the government acquired the land in 1942. He raised four boys and a girl here. The artifacts suggest that this site was occupied no earlier than the mid-nineteenth century and likely continued though 1941. The household ceramics and glass, a metal clothing snap, nails and sheet metal used in construction, a metal harness ring, and a rubber tire piece suggest a farmstead household and agricultural use. Regardless, the historic component of this site has been heavily disturbed due to bulldozing. Therefore, its research value is minimal. CAS recommends that no further work be conducted and the historic component of the site is not eligible for nomination to the NRHP. 


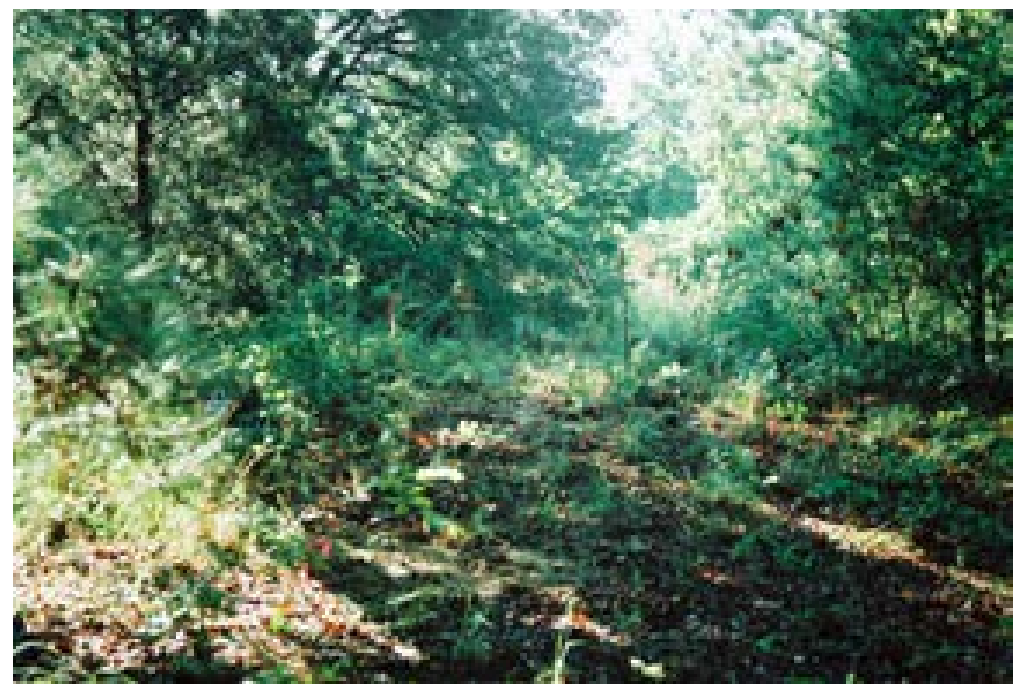

Figure 9-4. The Elgin bricks at this site were made between 1891 and 1910; facing southeast.

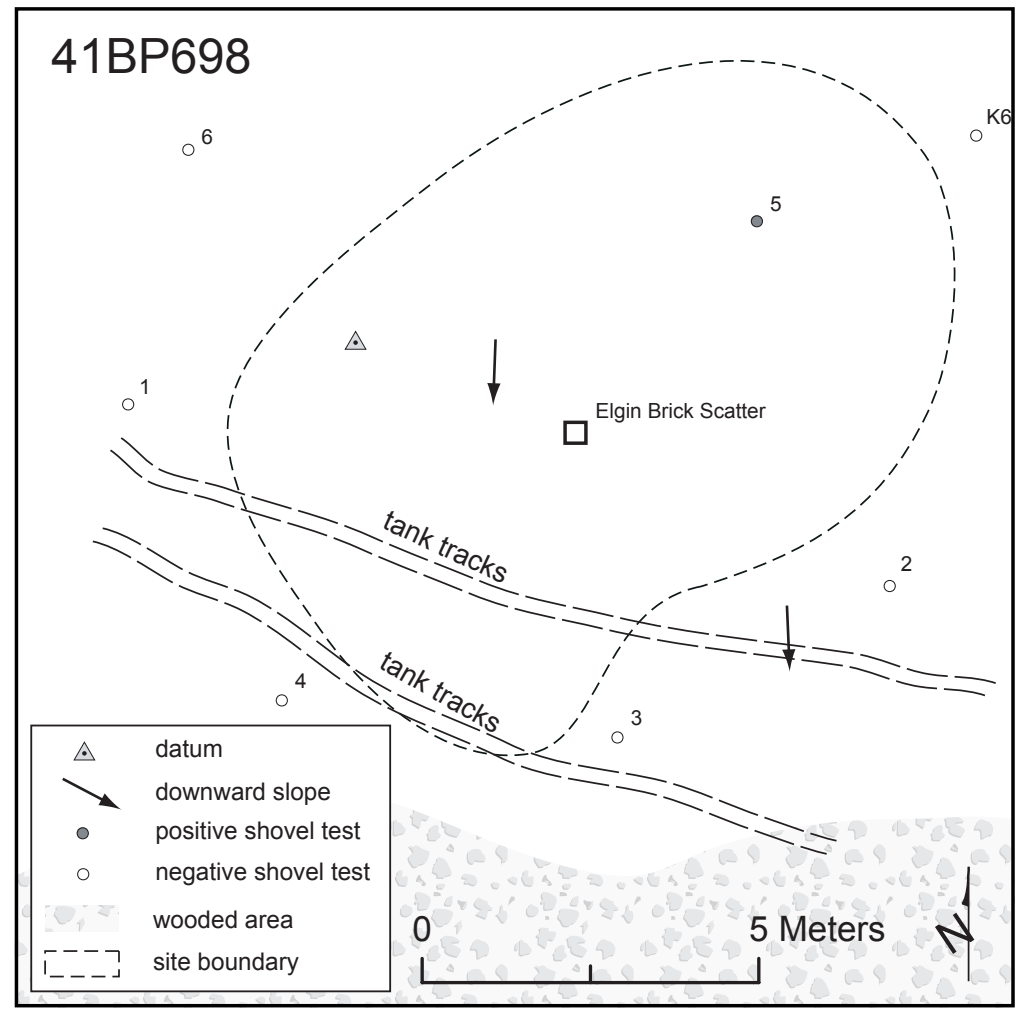

Figure 9-5. Site map of 41BP698.

maker's mark, indicating they were produced by the Elgin Press Brick Co., Bastrop County, with a production date spanning 1891-1910 (Steinbomer 1982). There were no whole bricks, nor mortar traces on any of them. The one shovel test placed on the site (ST 5) contained a metal fence staple at $10-20 \mathrm{cmbs}$. Notably, two other red bricks and an enameled tin washbasin were found on the surface some $90 \mathrm{~m}$ to the north and east of this site.

\section{Conclusions/ Recommendations}

Coupled with the absence of mortar traces on the bricks and the absence of either surface or subsurface artifacts, it appears unlikely that they were used for construction, or that a brick structure existed at this location. The more likely scenario is that they were hauled to this location and dumped. In either case, the research value of this site is minimal, no further work is recommended, and the site is not eligible for nomination to the NRHP.

\section{BP700}

\section{Description}

The remains of an old, narrow, collapsed bridge across Big Sandy Creek constitute 41BP700 (Figures 9-6 and 9-7). It is situated off the northwest end of a long ridge with Scott Hill, and where the Scott homestead (41BP134) was located. The creek meanders here, with a seven-foot cutbank, and a relatively level floodplain on both sides. Typical riparian vegetation includes elm and hickory trees, and coarse grasses. At the time of the July 2005 visit the creek was not flooded and it was only about two feet deep. 


\section{Levels of Work and Results}

Archaeologists looked for traces of a roadcut or a two-track leading to the bridge on both sides of the creek, but none were discernible. A small gate made of barbwire and wood posts was found on the north bank, about $12 \mathrm{~m}$ from the bridge, and the remnants of a barbwire fence with wooden posts was found adjacent to the north bank (see Figure 9-7). The bridge had been constructed of sandstone slabs and bricks. No wooden piers could be seen, but they most likely have been washed away, or were buried within the cutbank as the creek meandered through time. The hand-hewn sandstone slabs were confined to the south bank, were 4 inches thick, and covered about nine feet of the bank leading to the creek's edge. Brick rubble consisting of brown, well-made, rectangular, 3 and 4-hole bricks lay in the creekbed from the end of the sandstone slabs to the northern cutbank. Mixed in also were a few vitrified blocks with faded, aqua-green paint. Judging from the remains, the bridge would have been about eight feet wide.

\section{Conclusions/ Recommendations}

This is one of five historic bridges documented on Big Sandy Creek (see also 41BP481, 41BP482, 41BP701, and 41BP729). 41BP700 and 41BP701 are within $200 \mathrm{~m}$ of each other, while the other three are nearly a mile and more to the north. Like this one, the other four

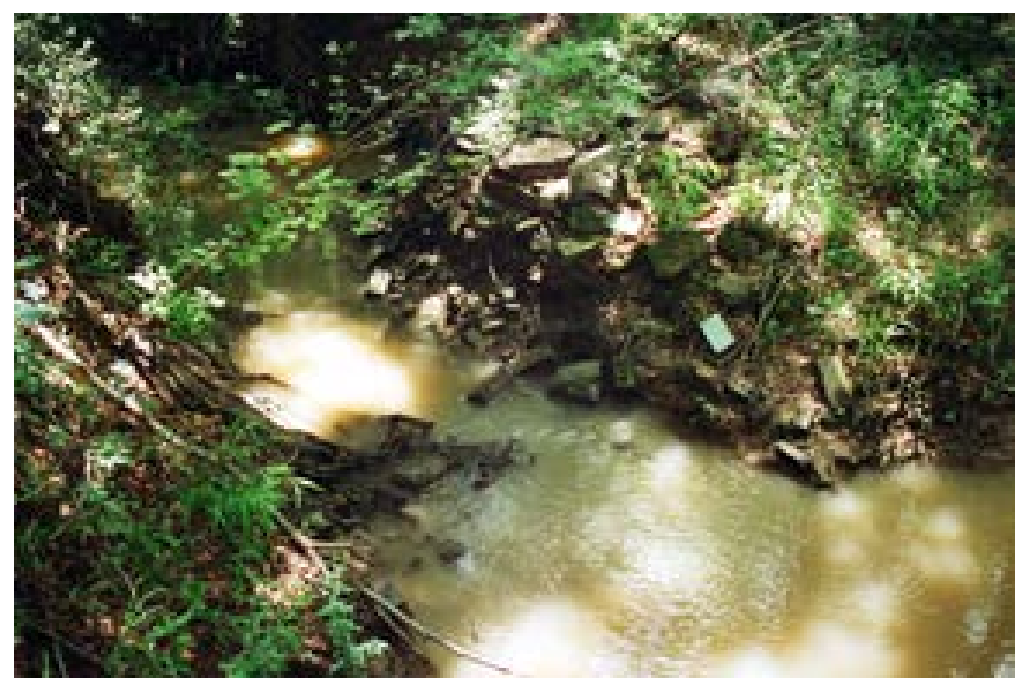

Figure 9-6. 41BP700 is a collapsed bridge across Big Sandy Creek; facing southeast.

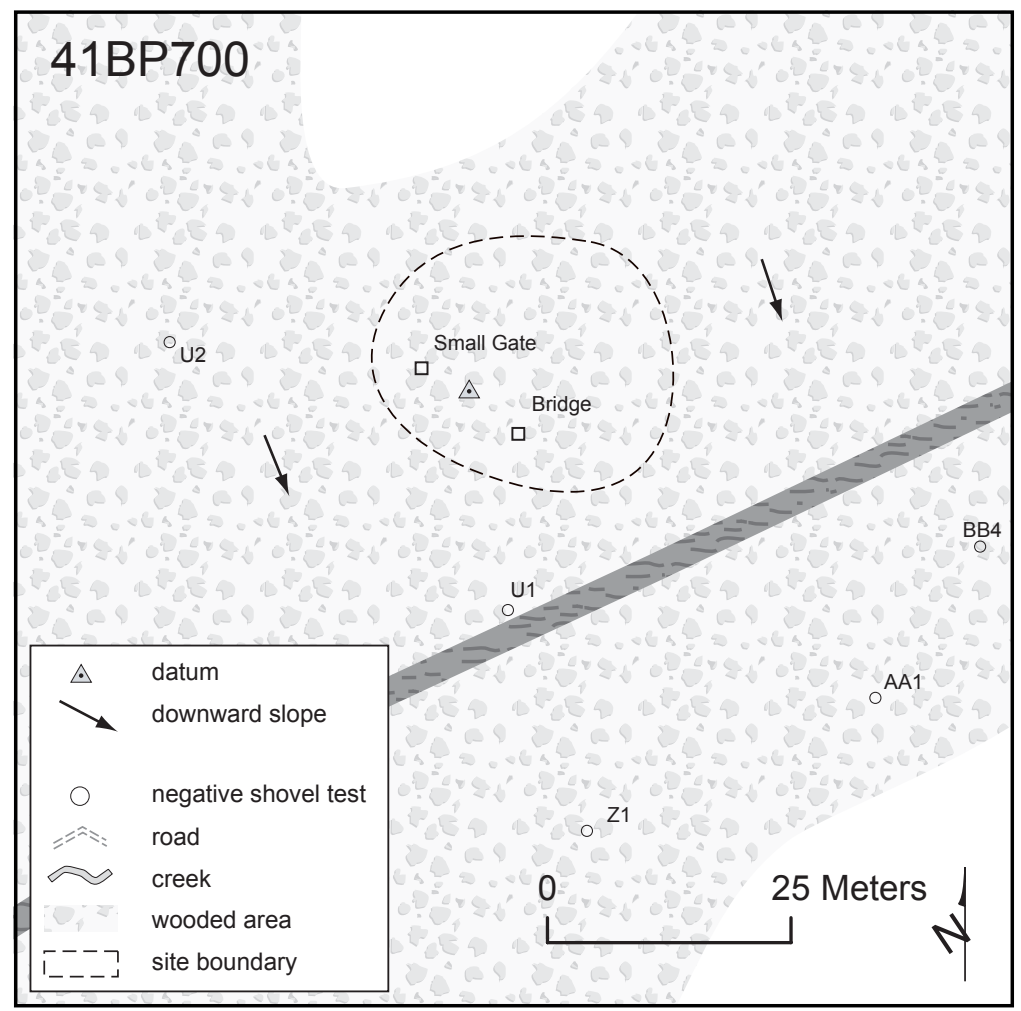

Figure 9-7. Site map of 41BP700. are in disrepair and no longer crossable. The research value of this site is minimal, no further work is recommended, and the site is not eligible for nomination to the NRHP. 


\section{BP701}

\section{Description}

41BP701 (Figures 9-8 and 9-9) is another historic bridge that spanned Big Sandy Creek approximately $200 \mathrm{~m}$ downstream from 41BP700. It has washed out, with remnants only on the north bank. The creek channel is about nine feet deep at this point, with relatively level floodplains on both sides. Water in the creek was only about 18 inches deep during the July 2005 visit. Riparian vegetation includes mostly elms with a few pecan trees. It appears as though the solid, but collapsed structure has caused the creek to widen and meander. A nail and aluminum tag was attached to the middle elm of a cluster of three on the north edge of the creek.

\section{Levels of Work and Results}

No traces of a roadcut or a two-track leading to the bridge were discernible on either side of the creek. This bridge can be described as a two-track, with each track 33 inches wide and constructed of sandstone slabs covered with concrete. In between the tracks are river cobbles and a few bricks. Two of the bricks still had white paint and one still had the aqua-green paint color as seen on some at 41BP700. No wooden piers or beams were seen, but the actual span may have been constructed of stone, as large stone blocks were strewn in the

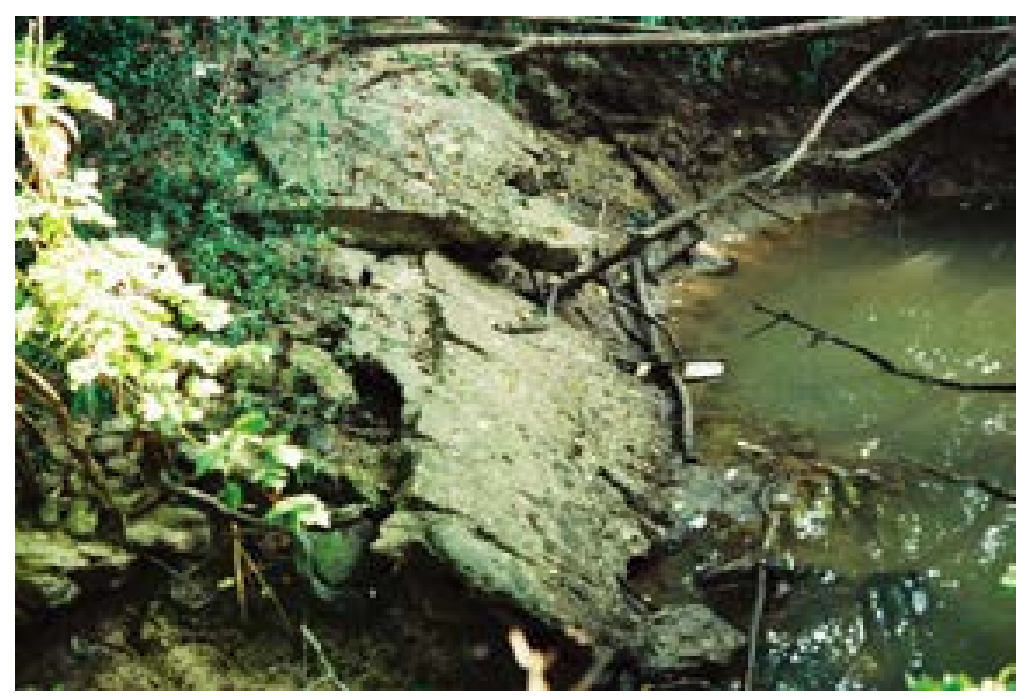

Figure 9-8. This collapsed bridge is one of five documented on Big Sandy Creek; facing north.

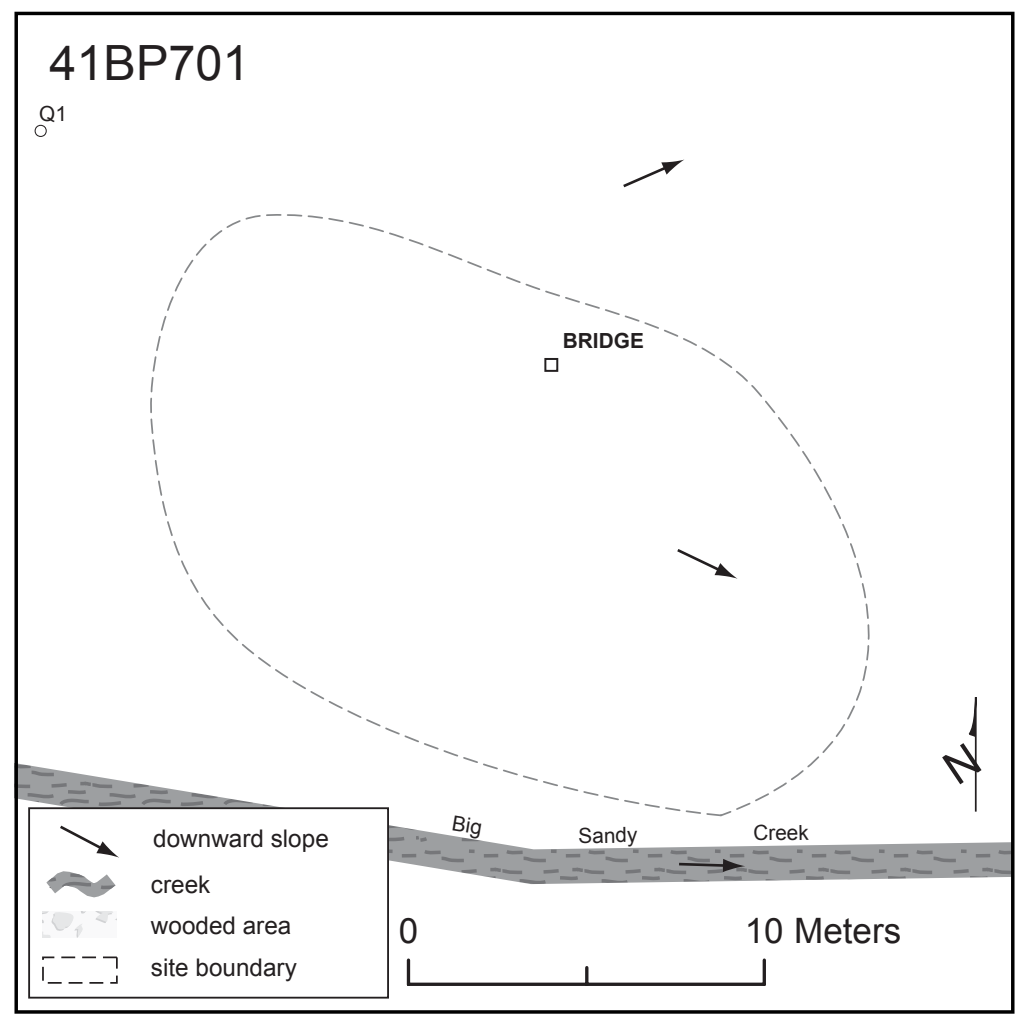

Figure 9-9. Site map of 41BP701.

creek bottom. Judging from the remains, as with 41BP700, this bridge also would have been about eight feet wide. 


\section{Conclusions/Recommendations}

Although interesting, as with 41BP700, the research value of this site is minimal, no further work is recommended, and the site is not eligible for nomination to the NRHP. top closure with continuous threads and exhibiting "neckring seams," which indicates machine manufacture (ca. post-1900); at the conjunction of the side mold seam and the outer neckring seam was what appears to be a mold seam glass extrusion. This characteristic

\section{BP703}

\section{Description}

Bricks, sandstone, and household and farmstead artifacts compose 41BP703 (Figures 910 and 9-11). The site is in the northern portion of a 103-acre tract owned by C. Westbrook before the government acquired the tract in 1942. It is located in an upland area adjacent to Sandy Creek Loop Road. Push piles, secondary mesquite growth, and thickets of pencil cactus indicate that extensive disturbance has occurred. The site datum is marked with a nail and an aluminum tag in a hackberry tree $32 \mathrm{~cm}$ in diameter.

\section{Levels of Work and Results}

Figure 9-12 shows selected artifacts at the site. Artifacts observed on the surface in bladed areas and on push piles include:

- an aqua bottle base with heavy patina and marked with a line above a "C"; the origin of this maker's mark could not be found, but the glass color suggests a pre1920s date of manufacture (Lindsey 2005).

- a container top of clear glass with no hue, screw-

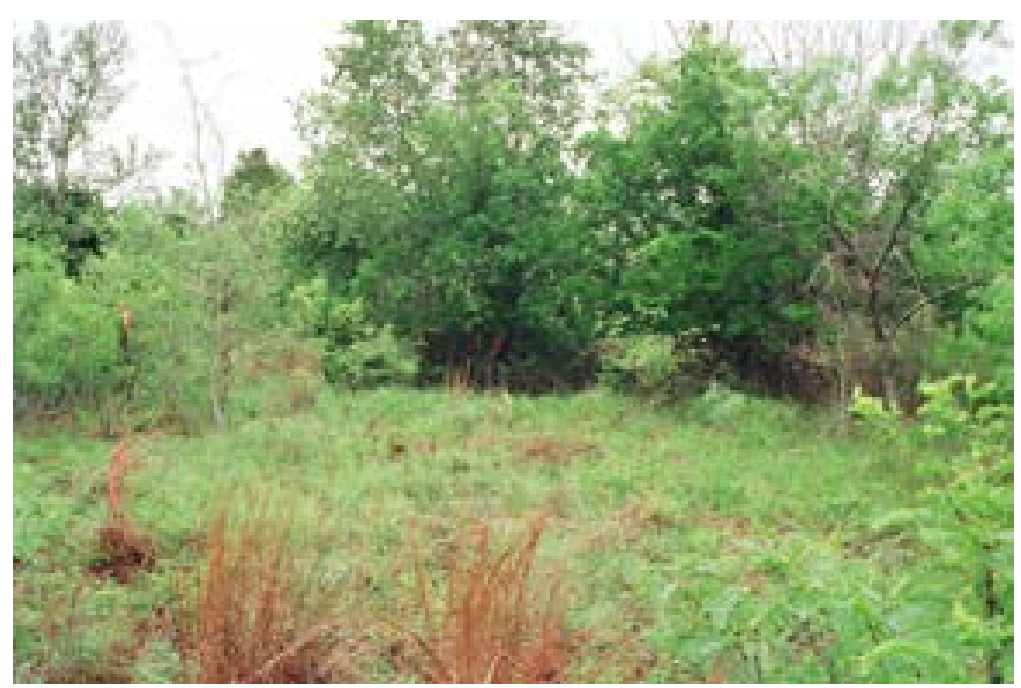

Figure 9-10. This is the site of an old farmstead alongside Big Sandy Loop Road; facing northeast.

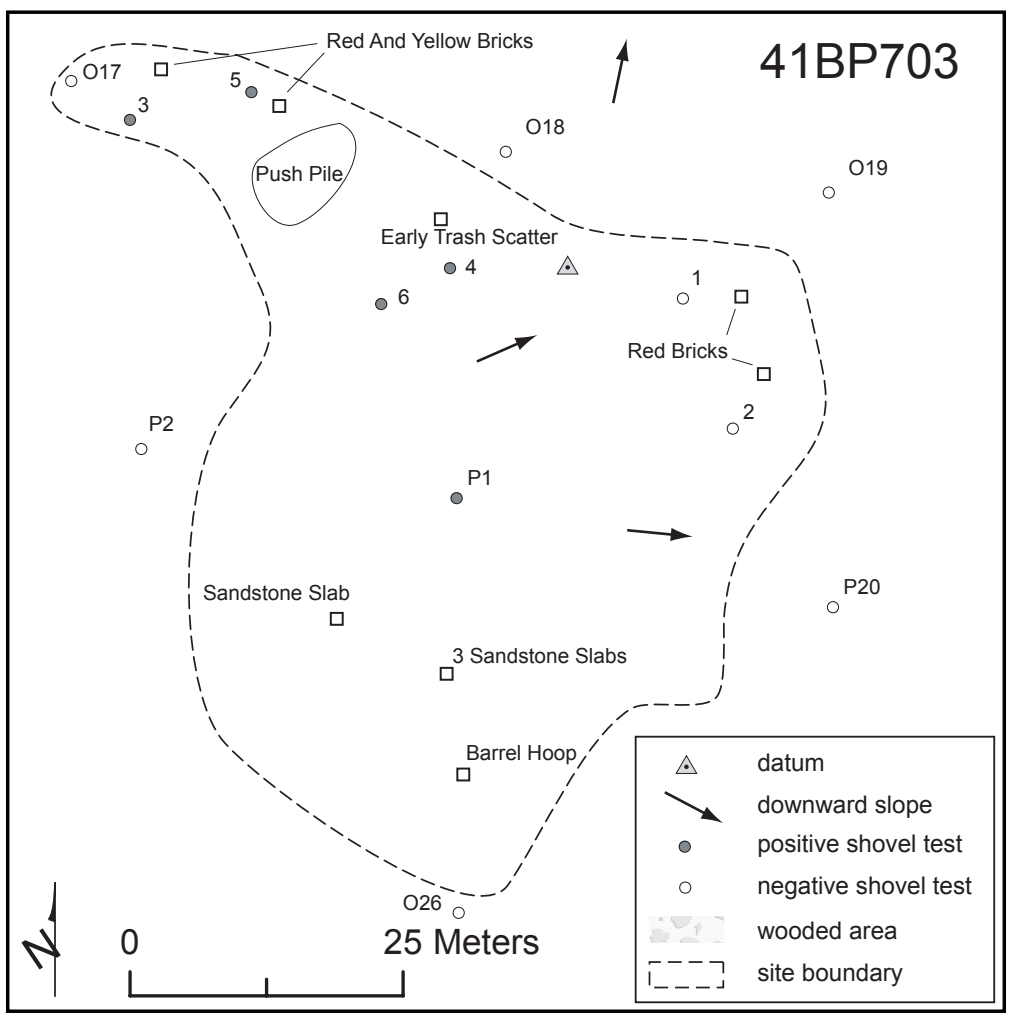

Figure 9-11. Site map of 41BP703. 
is the result of glass being pushed from the seam during manufacture, which usually indicates that the item was mouth-blown (Lindsey 2005). Due to the fact that these are conflicting attributes (machine-made versus blown), one could surmise that the extrusion may have been intentionally formed for the function of the closure.

- several clear glass shards with an amethyst hue (ca. 1880-1915)

- several undecorated whiteware sherds (ca. 1850-present)

- a modern majolica basal sherd with a white undecorated interior and a molded design, and blue/white glaze exterior; modern majolica was popular ca. 1850-1900 (Ray 1974)

- $\quad$ several red and yellow bricks

- a probable cow bone with a sawed end were also found on the push pile.

Five of eight shovel tests excavated on the site were positive (Table 9-2). Artifacts recovered from below the surface include:

ST 3: clear glass with amethyst hue; thin light green glass with heavy patina (ca. pre1900); a thin undecorated whiteware saucer sherd

ST 4: round nail; metal staple; 1-inch diameter brass gear, probably from a clock; ovalshaped horse hardware worn at both ends; medium thick undecorated whiteware sherd

ST 5: red brick fragment

ST 6: an unidentified rusted metal fragment; possible fragment from a stove with a raised ridge; silverware made of nickel, with a flower pattern design and a Wm. A. Rogers mark., which was used as early as 1897. "It became part of Oneida silver around 1929, and Oneida employed the Wm. A. Rogers mark as late as 1978" (Young 2006); stoneware with a Leon slip interior and a salt glaze exterior (ca. 1850-1900); medium thick brown glass (ca. pre-1900); clear glass with an aqua hue (ca. pre-1900); clear glass with an amethyst hue and light patina; medium thick undecorated whiteware

ST P1: clear glass from a medicine bottle (ca. 1900-1930); undecorated whiteware

\section{Archival Research}

Limited archival research indicates D. P. and M. F. Johnson sold this 103-acre tract to Mrs. R. L. P. Biggers (wife of J. J. Guthrie) on August 22, 1904 for $\$ 850$. Mrs. Biggers then sold the parcel to C. Westbrook on January 21, 1930. Mr. Westbrook owned several hundred acres in the area during that time, and he is known to have lived south of this site on a different parcel of land.

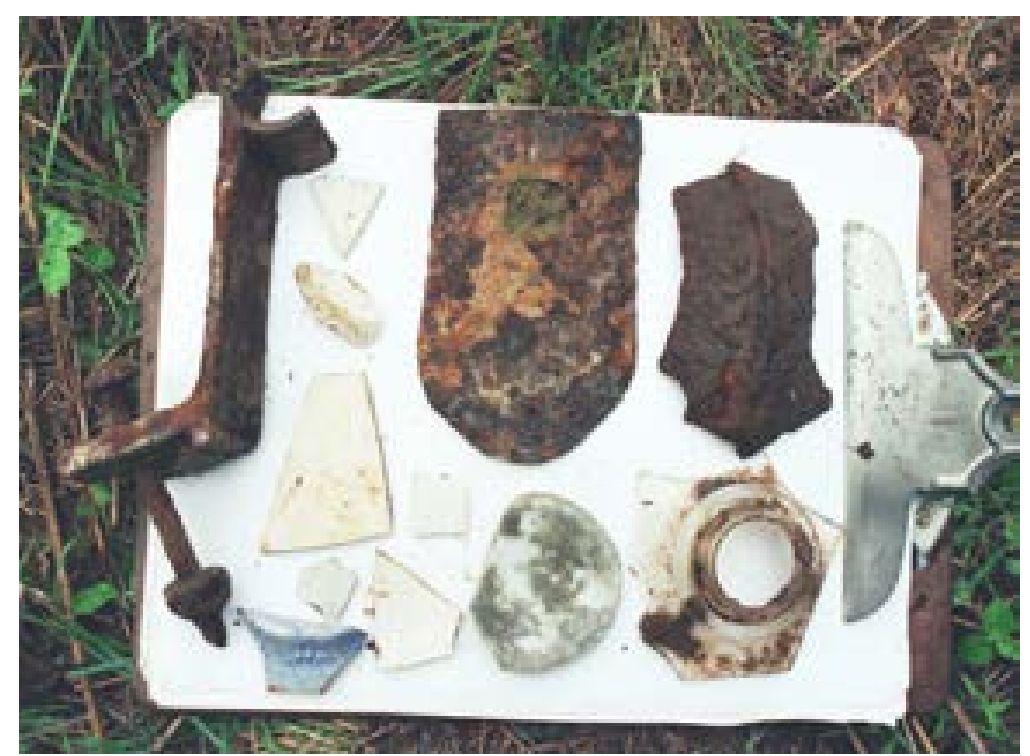

Figure 9-12. Selected artifacts from 41BP703. 
Table 9-2. 41BP703 positive shovel test results.

\begin{tabular}{|c|c|c|c|c|c|}
\hline $\begin{array}{c}\text { Depth } \\
\text { (cmbs) }\end{array}$ & ST 3 & ST 4 & ST 5 & ST 6 & ST P1 \\
\hline $0-10$ & $\begin{array}{c}\text { WW, } \\
\text { CG, GG }\end{array}$ & & $\mathrm{Br}$ & $\mathrm{M}$ & $\mathrm{CG}$ \\
\hline $10-20$ & & Clay & $\begin{array}{c}\text { SW, BG, } \\
\text { CG, M }\end{array}$ & $\begin{array}{c}\text { WW, } \\
\text { CG }\end{array}$ \\
\hline $20-30$ & Clay & $\begin{array}{c}\text { WW, } \\
\text { M, RN }\end{array}$ & & $\begin{array}{c}\text { WW, } \\
\text { CG, TS }\end{array}$ & Clay \\
\hline $30-40$ & & Clay & & Clay & \\
\hline $40-50$ & & & & & \\
\hline \multicolumn{7}{|c|}{$\begin{array}{l}\text { Key: SW-stoneware; WW-whiteware; AqG-aqua glass; } \\
\text { BG--brown glass; CG-clear glass; GG-green glass; } \\
\text { Br-brick; M-metal; RN-round nail; TS-teaspoon }\end{array}$} \\
\hline \multicolumn{7}{|c}{}
\end{tabular}

\section{Conclusions/Recommendations}

The approximated age of the artifacts at this site suggest they were likely discarded during the last quarter of the nineteenth century through the first quarter of the twentieth century. In its bulldozed condition, the research value of this site is minimal, no further work is recommended, and the site is not eligible for nomination to the NRHP.

\section{BP711}

nail and an aluminum tag on an oak tree on the northern end of the site.

\section{Levels of Work and Results}

Although the one shovel test placed on the site contained no artifacts, archaeologists observed cans, bottles, whiteware sherds from a saucer and coffee cup, six barrel hoops, bed springs, an automobile shock, a rubber boot heel, part of a rubber tire, and a one-gallon tin bucket on the surface. Assorted tin cans had held baking powder, soup, black pepper, Pet Milk, pipe tobacco, paint, and Hershey's cocoa. Hershey's began making cocoa in 1894 , and in 1988 switched from metal to plastic cans (Hershey's 2005). One condiment can had "patent 1935" written on it, but its contents are unknown. All of the cans were of the sanitary type, with crimped sides, tops, and bottoms. These were commonly produced beginning in the early 1920 s (Busch 1981:98). Bottle glass with legible maker's marks and/or datable characteristics were:

\section{Description}

41BP711 (Figures 9-13 and 9-14) is one of three historic trash dumps on property previously owned by B. C. and Jettie Daughtry. Unlike many trash dumps on Camp Swift, this one is not in a swale or gully. Covering $276 \mathrm{~m}^{2}$ and containing numerous cans and bottles, it rises approximately eight inches above a northwesterly sloping and moderately wooded surface. The nearest known historic structure was the Daughtry home, about $250 \mathrm{~m}$ to the west. The site datum is marked with a

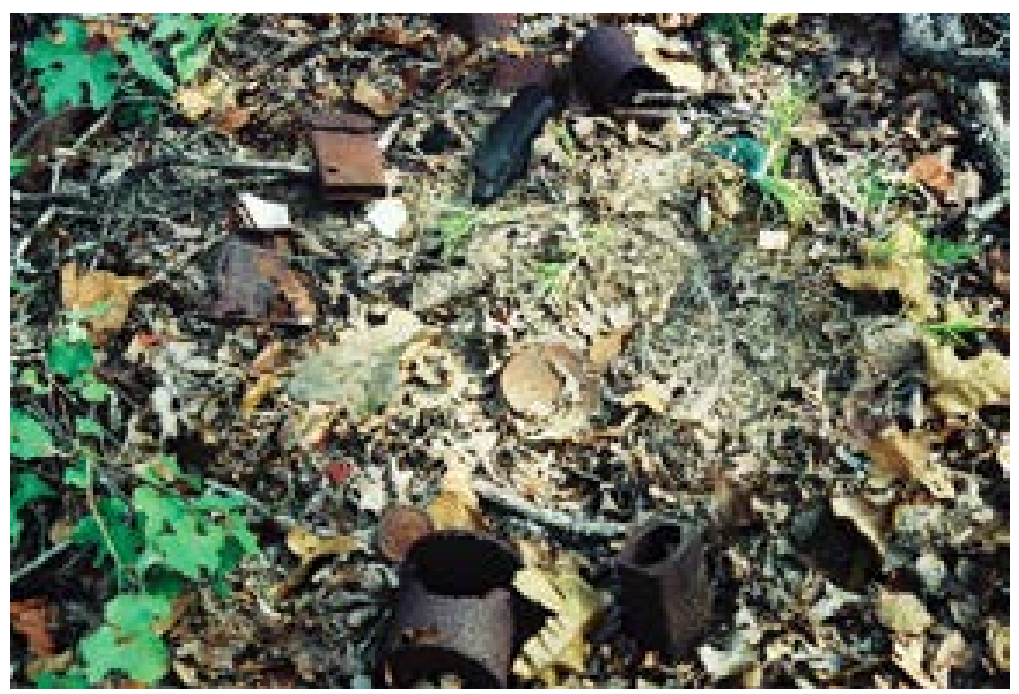

Figure 9-13. 41BP711 is one of three trash dumps on property belonging to the Daughtry family; facing north. 


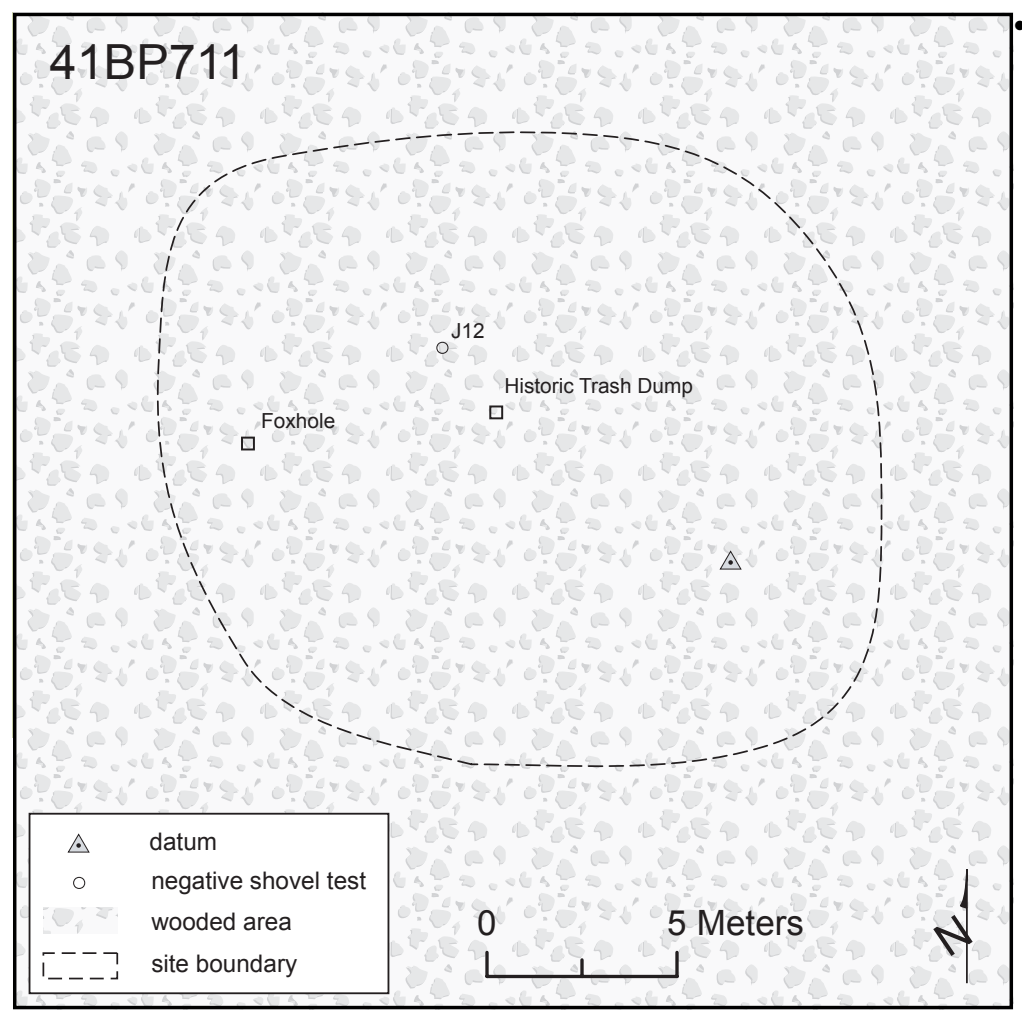

Figure 9-14. Site map of 41BP711.

- a clear glass bottle with no hue and presumably an Illinois Glass maker's mark. The mark consists of a diamond with an "I," yet the "I," which is usually found on the inside of the diamond, was located on the outside. The mark that is most similar to this dates from 1916 to 1929 (Toulouse 1971:264).

- a clear glass bottle with "STEWARTS B...." embossed on it is most likely a Mrs. Stewart's ${ }^{\circledR}$ Bluing bottle. Stewart's bluing, a fabric whitening product, has been manufactured since 1883 (Mrs. Stewart's ${ }^{\circledR}$ Bluing 2005), but the clear glass suggests that this particular bottle was made after 1930 .

- a light green bottle base embossed with "..atlas.. trademark rec" and "E EA" in the middle of the base. This trademark began with the Atlas Glass Co. in 1896 and continued with the Hazel Atlas Glass Co. until 1964 (Toulouse 1971:55). a light green bottle with a screw top. Screw-top bottles were not common until after 1924, when the threads were standardized by the glass industry (Polak 1997:24).

\section{Conclusions/ Recommendations}

The debris on this site most likely represents a trash dump created by the Daughtry family. Until very late in the 20th century, farmers disposed of trashbydumpingnonconsumable items in piles, often burning or burying them. Consumable trash was often fed to dogs or pigs. At this dump, the Pet milk cans and the Hershey's cocoa can are items used in baking, and the whiteware sherds are broken dinnerware pieces. These clearly represent nonconsumable items that had to be discarded from a household. The level of decomposition on the metal objects, the relative dates of the containers, and the organic debris on the trash pile suggest an occupation period near the beginning of the twentieth century through 1942. Overall, the research value of this site is minimal because all artifacts were found on the surface. No further work is recommended and the site is not eligible for nomination to the NRHP.

\section{BP712}

\section{Description}

41BP712 (Figures 9-15 and 9-16) is the second of three historic trash dumps on property previously owned by B. C. and Jettie Daughtry. It is spread across $161 \mathrm{~m}^{2}$ of a wooded, lower slope along an intermittent drainage. It contains mostly cans and bottles. The Daughtry home was located 
about $225 \mathrm{~m}$ to the southwest. The site datum is marked by a nail and aluminum tag on a 30 $\mathrm{cm}$ diameter cedar tree.

\section{Levels of Work and Results}

Included in the trash pile is a rubber boot sole, a sanitarytype soup can with crimped top, side, and bottom, a pipe tobacco can, a tin enamel-coated 1.5quart basin, and several glass containers. The glass containers with maker's marks include:

- a clear glass, pint-sized wine bottle with an aluminum cap and screw top, and heavy patina on its surface. The bottle has an Owens-Illinois Glass Co. mark. "D126" above the mark indicates the container style. "D. S. PA 92901" below the mark designates the mold cavity. The " 55 " numbers to the left of the mark indicate the plant number. Embossing on the front of the bottle reading "Federal Law Forbids the Sale or Re-use of this Bottle" is a statement usually found only on bottles containing alcohol, and was mandated after 1933 with the repeal of prohibition (Polak 1997:27). To the right is " 4 " indicating the year made; thus it could be 1934, 1944, or 1954 (Lockhart 2004).

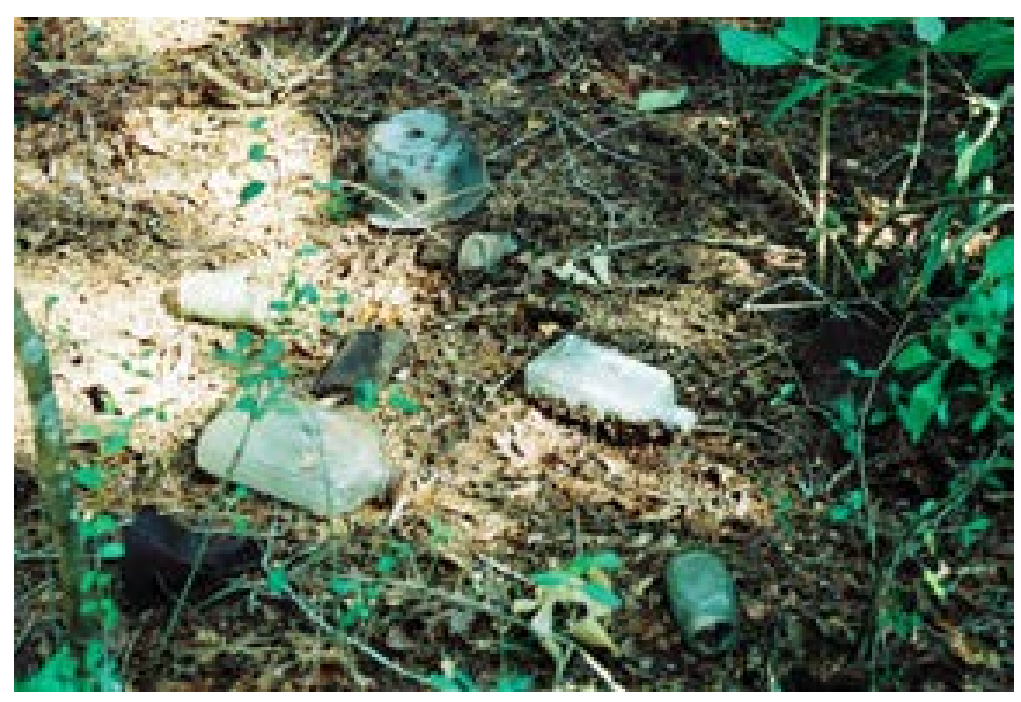

Figure 9-15. 41BP712 is a second trash dump on property belonging to the Daughtry family; facing north.

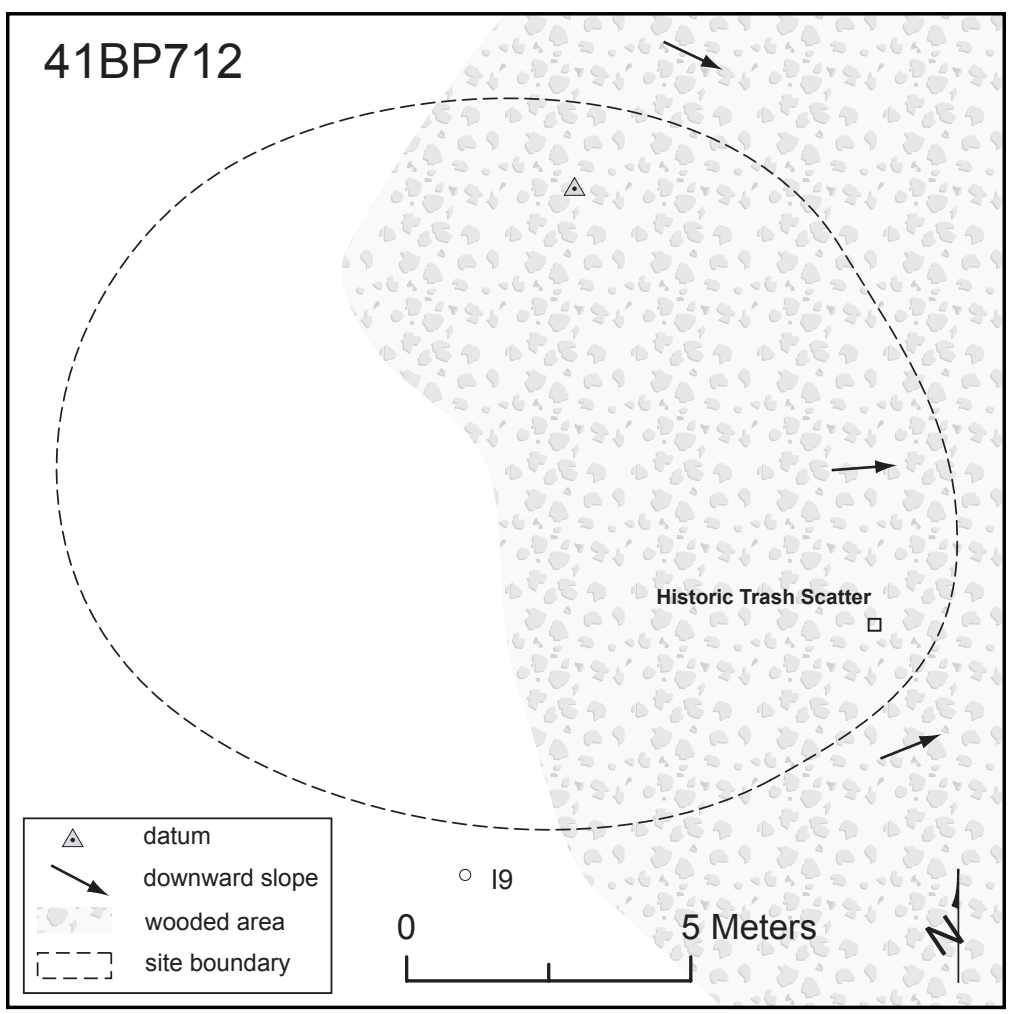

Figure 9-16. Site map of 41BP712.

up the neck. There is an Owens-Illinois Glass Co. mark on the bottom, with a "7" on its left, indicating this bottle was manufactured by the Alton, Illinois plant sometime from after 1929 (Lockhart 2004). 
- a square, clear glass condiment bottle with rounded edges. The bottom bares a " $T$ " within an inverted triangle, a Turner Bros. Co. mark used circa 1905-1930 at the factory in Terre Haute, Indiana. (Insulator Collectors On the Net 2005).

- a light green Tableware item, which was probably an ice cream soda glass. The mark on the bottom indicates it was produced by the Hazel-Atlas Glass Co. ca. 1920-1964 (Toulouse 1971:239).

\section{Conclusions/Recommendations}

The preponderance of evidence derived from the glass bottles here suggests they were likely deposited in the dump sometime from ca. 1905 through 1942, when the military acquired the land. Thus, the use of this site as a trash dump approximates the same time period as that of 41BP711. Why the Daughtry family would use two different locations for dumping trash during the same time period is unknown. It could be that the two dump sites are not of the same period, but the data CAS has been able to obtain is not finegrained enough for determining more precise dates. In any case, as with 41BP711, the research value of this site is minimal, no further work is recommended, and the site is not eligible for nomination to the NRHP.

\section{BP718}

\section{Description}

This apparent house site was discovered when archaeologists observed a large out-of-context sandstone slab on a sandy, wooded slope (Figures 9-17 and 9-18). Two large, rotting oak trees and a large cedar tree in the same condition around the slab also stood in marked contrast to the surrounding younger oaks and cedars. They may have been left for shade or planted. Prehistoric artifacts were found in shovel tests, and that component is documented in Chapter 7: New Prehistoric Component Sites. It is situated in the easternmost corner of a 366-acre tract of land owned by C. B. "Nick" and Louisa May Branton (Abner C. Scott, personal communication 16 January 2002). Surface visibility was less than five percent in July 2005. A medium-sized animal had burrowed under the sandstone, leaving a backdirt pile. The site datum is marked by a nail and aluminum tag on a $20-\mathrm{cm}$ diameter oak tree.

\section{Levels of Work and Results}

As stated previously, the large single piece of sandstone seemed totally out of context. Most historic farmsteads and house sites on Camp Swift have at least some hewn sandstone slabs; however, they are not as massive as this piece (Figure 9-19). It measured 4 inches thick, 20 inches wide, and 52 inches long. One end of the slab was straight and the other was rounded. Pieces as large as this one have been observed covering what is presumed to be a human infant burial on Camp Swift (41BP146; Nickels and Lehman

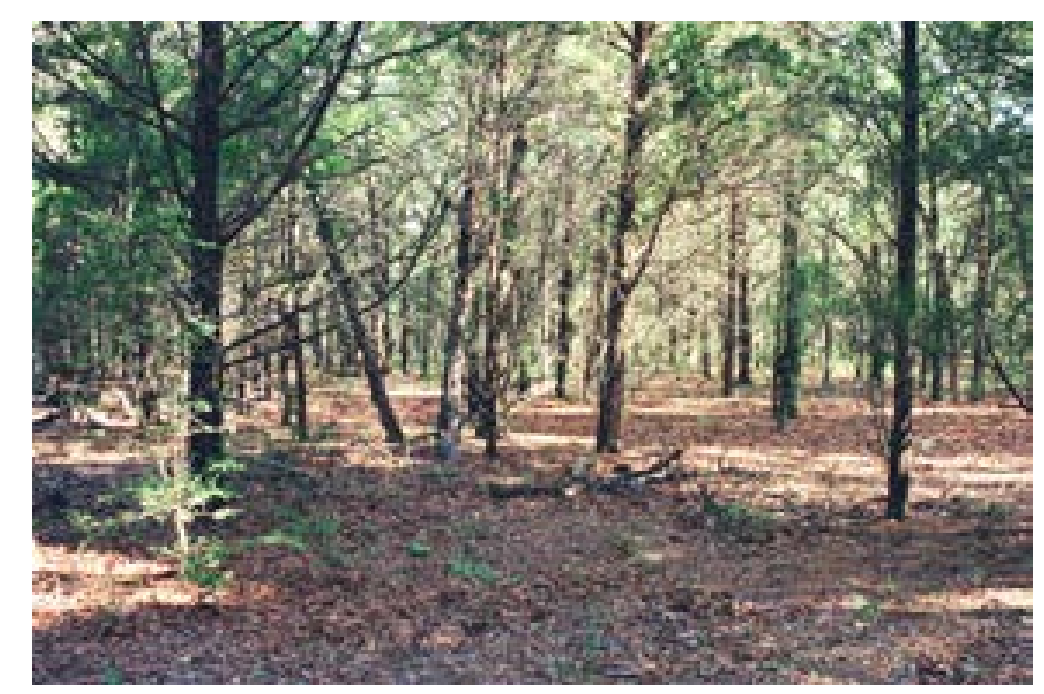

Figure 9-17. A sandstone slab and artifacts are located in what was the extreme eastern corner of C. R. "Nick" and Louisa May Branton's property; facing north. 


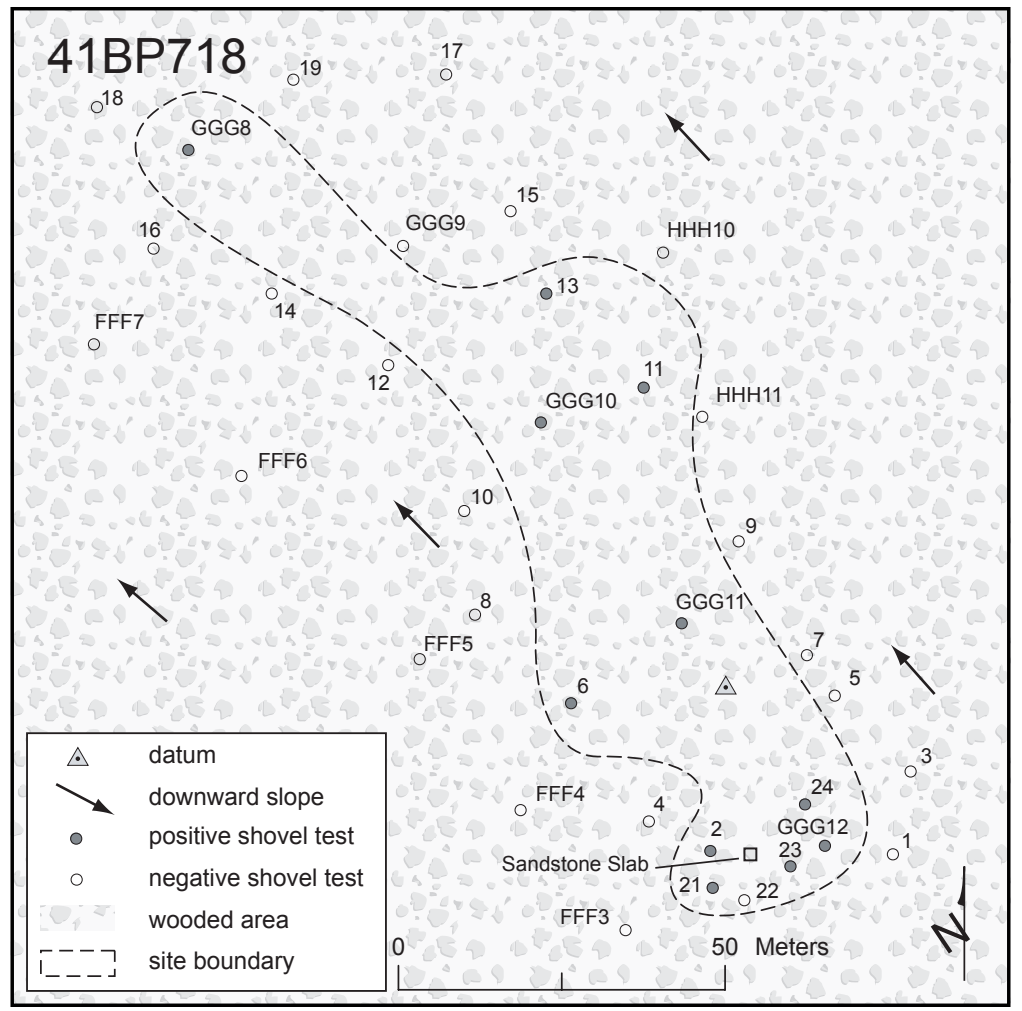

Figure 9-18. Site map of 41BP718.

2004:89-95). Archaeologists initially surmised that it could be an isolated juvenile burial here also. A small fragment of slate was found on top of the slab, and a small white button, glass, and faunal remains were found in nearby shovel tests (Table 9-3). In addition, faunal remains were found on the backdirt from underneath the slab. The sandstone was examined for any sort of inscription, but none was found. The faunal remains from the backdirt as well as one of the shovel tests (ST 23) were submitted to Barbara Meissner and Cindy Munoz at CAR for identification. Their assessment is that they were not human, but were probably deer.

A low earth mound that measured $30 \mathrm{~cm}$ in height and several smaller mounds were observed next to the slab. A few small sandstone chunks and rusted bucket fragments were also found next to the slab. Although eight of 11 shovel tests were positive, historic artifacts were recovered from five shovel tests and included brown, clear, and green glass, a button, and two square nails (see Table 93). The thickness of the brown glass shard, the patina on it, and the square nails suggest an early twentieth century-occupation. The white "sew-through" ceramic (also called agate) button with four holes recovered from ST GGG12 is a "dish type," with an inwardly sloping center (Pool 1987:281-282). Button sizes were usually designated by "lines." This specimen is a line 16 measurement, and was most likely used for a shirt or dress. Ceramic, or agate, buttons are commonly found on late nineteenth- and early twentieth-century sites (Pool 1987:281; see for example Meissner 1997; Nickels 2003).

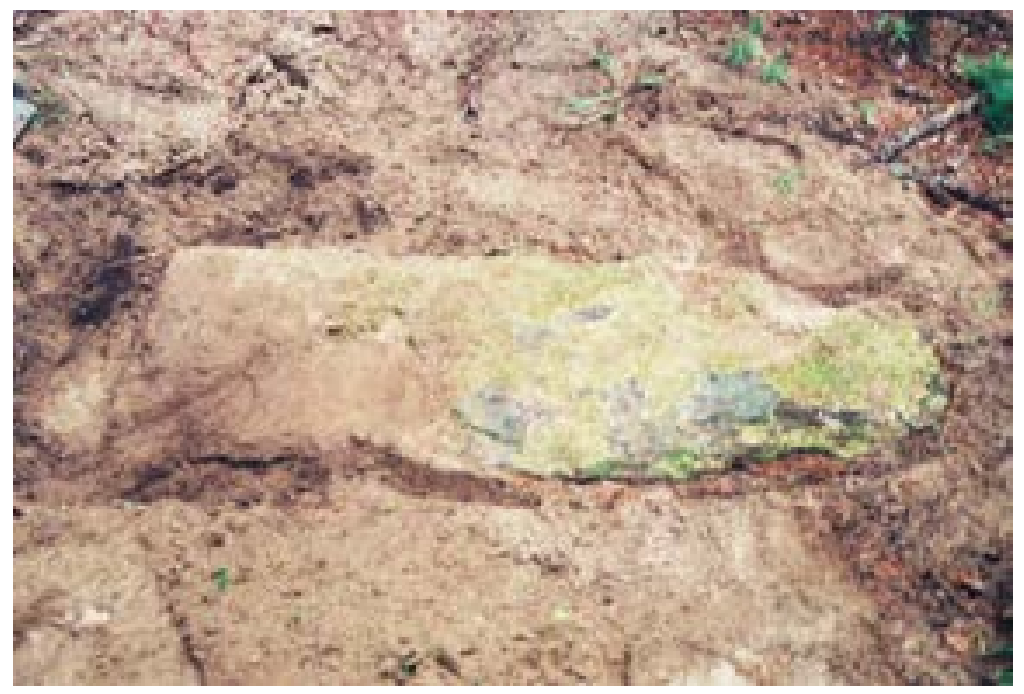

Figure 9-19. Sandstone slab at 41BP718. 
Table 9-3. 41BP718 positive shovel test results.

\begin{tabular}{|c|c|c|c|c|c|c|c|c|c|c|c|}
\hline $\begin{array}{l}\text { Depth } \\
\text { (cmbs) }\end{array}$ & $\begin{array}{c}\text { ST } \\
2 \\
\end{array}$ & $\begin{array}{c}\text { ST } \\
6 \\
\end{array}$ & $\begin{array}{l}\text { ST } \\
11 \\
\end{array}$ & $\begin{array}{l}\text { ST } \\
13 \\
\end{array}$ & $\begin{array}{l}\text { ST } \\
21 \\
\end{array}$ & $\begin{array}{l}\text { ST } \\
23 \\
\end{array}$ & $\begin{array}{l}\text { ST } \\
24 \\
\end{array}$ & $\begin{array}{c}\text { ST } \\
\text { GGG8 }\end{array}$ & $\begin{array}{c}\text { ST } \\
\text { GGG10 } \\
\end{array}$ & $\begin{array}{c}\text { ST } \\
\text { GGG11 } \\
\end{array}$ & $\begin{array}{c}\text { ST } \\
\text { GGG12 }\end{array}$ \\
\hline $0-10$ & $\mathrm{GG}, \mathrm{SN}$ & & & & $\mathrm{BG}$ & & SN & & & & \\
\hline $10-20$ & GG & & & & & $\mathrm{F}$ & & IF & & & \\
\hline $20-30$ & $\mathrm{CG}$ & $\mathrm{BG}$ & & & & & & & & & \\
\hline $30-40$ & $4 \mathrm{FCR}$ & & & & & $2 \mathrm{~F}$ & & & IF & & \\
\hline $40-50$ & Hearth & & $\mathrm{EF}$ & $\mathrm{Ch}$ & & & & & IF & & \\
\hline \multicolumn{12}{|l|}{$50-60$} \\
\hline $60-70$ & & & & & & & & & & IF & $\mathrm{CB}$ \\
\hline $70-80$ & & Sand & Sand & Sand & Sand & Sand & Sand & Sand & Sand & & \\
\hline $80-90$ & & & & & & & & & & Clay & Sand \\
\hline $90-100$ & & & & & & & & & & & \\
\hline
\end{tabular}

\section{Conclusions/Recommendations}

The square nails, glass, button, slate fragment, rusted bucket pieces, sandstone, and large old trees at this site suggest that some sort of an inhabited structure was here. The lack of other items such as horse tack, farm equipment parts, or barbed wire, for example, suggests that it was a house site only and not a farmstead. The possibility of intact architectural remains or features should be investigated by further archival and field work. Therefore, CAS recommends that additional archival research is needed and at least three 1-x1-m units should be excavated to determine if the site is eligible for nomination to the NRHP.

\section{BP729}

\section{Description}

The remains of a pier and beam bridge across Big Sandy Creek constitute 41BP729 (Figures 9-20 and 9-21). It is situated along the property line between C. B. "Nick" Branton and S. Haller (Bastrop County
1929). Typical riparian vegetation on both sides of the creek includes oak trees, greenbrier, and other woody vines. In this case, traces of an old road were visible leading to the bridge from the northeast. The bottom of the creek channel is about eight feet deep here, but there was only about 18 inches of water when CAS archaeologists visited the site in July 2005. Had Big Sandy Creek been near flood stage the piers would have been under water. A nail in an oak tree on the creek

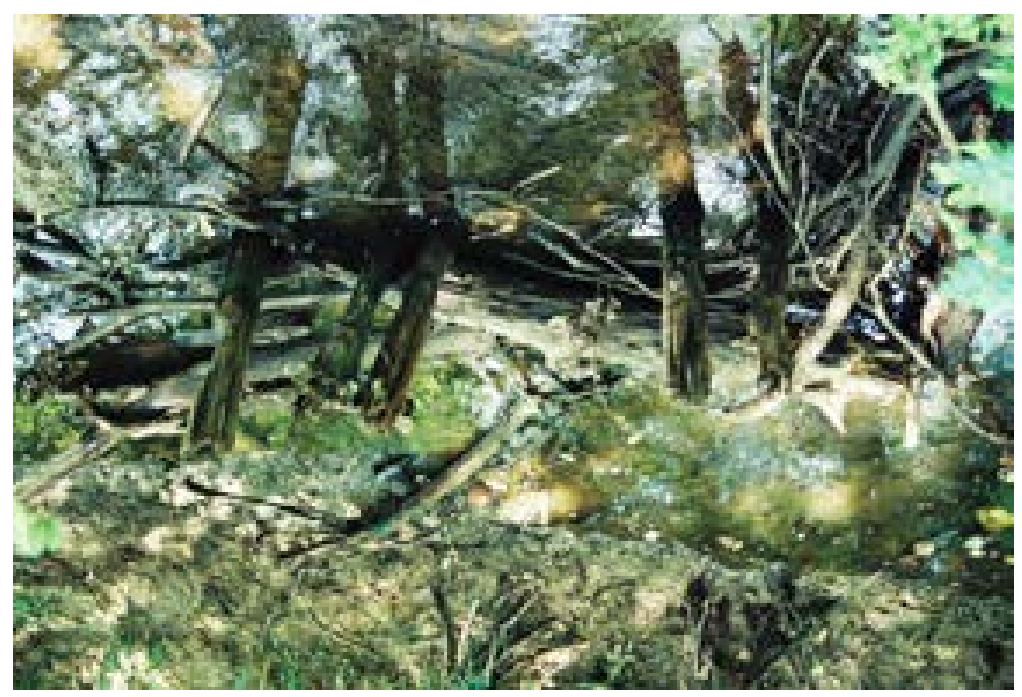

Figure 9-20. These wooden piers are all that remain of a bridge across Big Sandy Creek; facing northeast. 


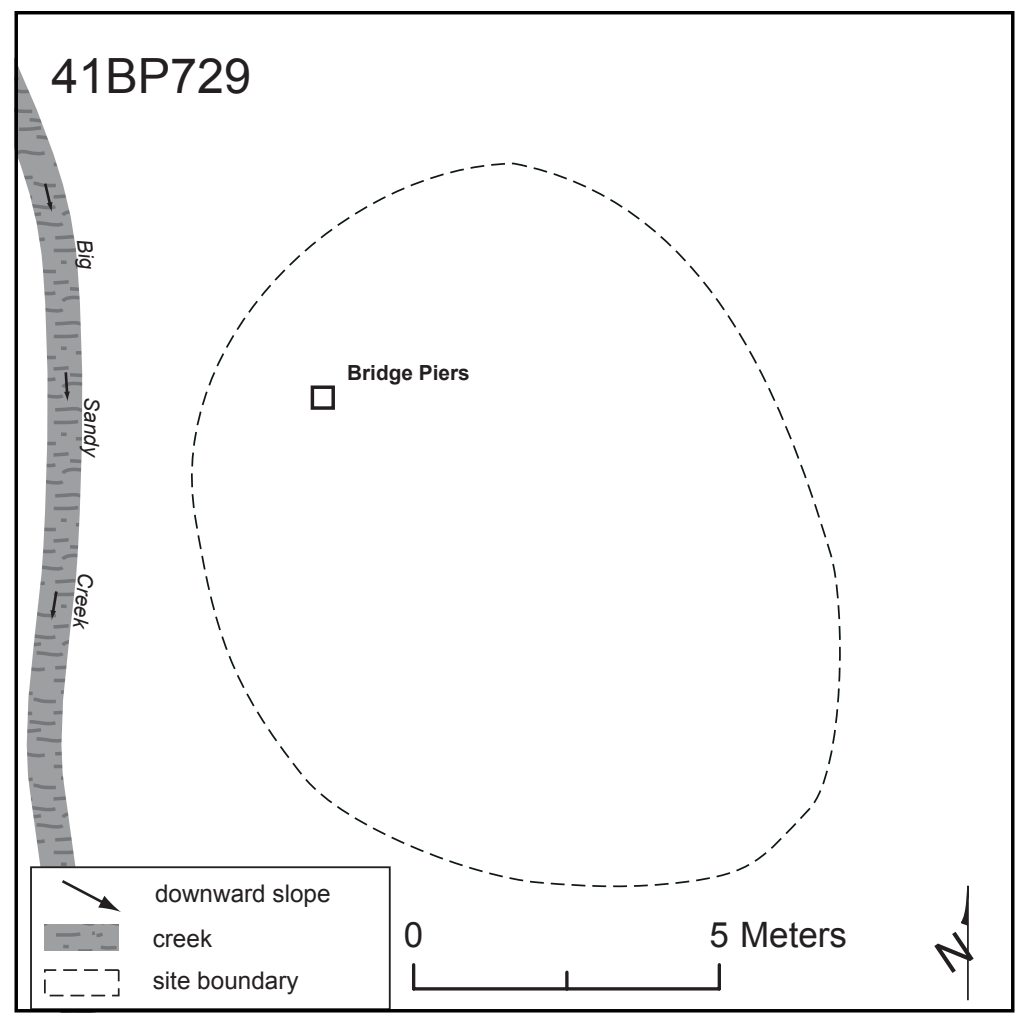

Figure 9-21. Site map of 41BP729.

bank with an aluminum tag on it serves as the site datum.

\section{Levels of Work and Results}

While the eastern side of the creek is more elevated and traces of an old road were visible, the western side is floodplain, and no trace of a road cut or clearing could be seen on that side. About $30 \mathrm{~m}$ west of the creek is a 3-m high steep embankment. Although there are places where a wagon or vehicle could have climbed up it, archaeologists could see no clearly discernible evidence for the same. Five oak posts remain in the center of the creek, and two others are still in place on the east edge of the creek. They varied in size from $3 \frac{1}{2}$ to $61 / 2$ inches thick and extended upward to 3 feet above the waterline. Nutria had gnawed the tops and sides of four of the seven posts remaining. The five posts that remained in the middle of the creek spanned a total of seven feet in width, suggesting that the bridge may have been eight feet wide, about the same as two other bridges documented during this project (41BP700 and 41BP781). Scattered sandstone chunks on the downstream side of the post may be the remains of bridge supports in addition to the posts.

\section{Conclusions/ Recommendations}

This is one of two historic bridges consisting of wooden support posts documented on Big Sandy Creek (see also 41BP481; Robinson et al. 2001:84). Both are in disrepair. The research value of this site is minimal, no further work is recommended, and the site is not eligible for nomination to the NRHP.

\section{BP730}

\section{Description}

41BP730 is a farmstead that belonged to David Scott before the military purchased it (Abner C. Scott, personal communication 16 February 2006). He owned 125 acres bordering Big Sandy Creek. The historic component on this dual-component site consists of the house remains in the middle of an open grassy field, and a trash dump on the side of a gully (Figures 9-22 and 9-23). The prehistoric component is an open campsite, and has been discussed in Chapter 7: New Prehistoric Component Sites. Vegetation and disturbances vary considerably across the site. In the upper, more level southern portion where the house stood, the soils are deep, the land has been cleared for farming, and the area now consists of dense grasses encroached upon by cedar and oak motts. In the more sloping and lower northern 


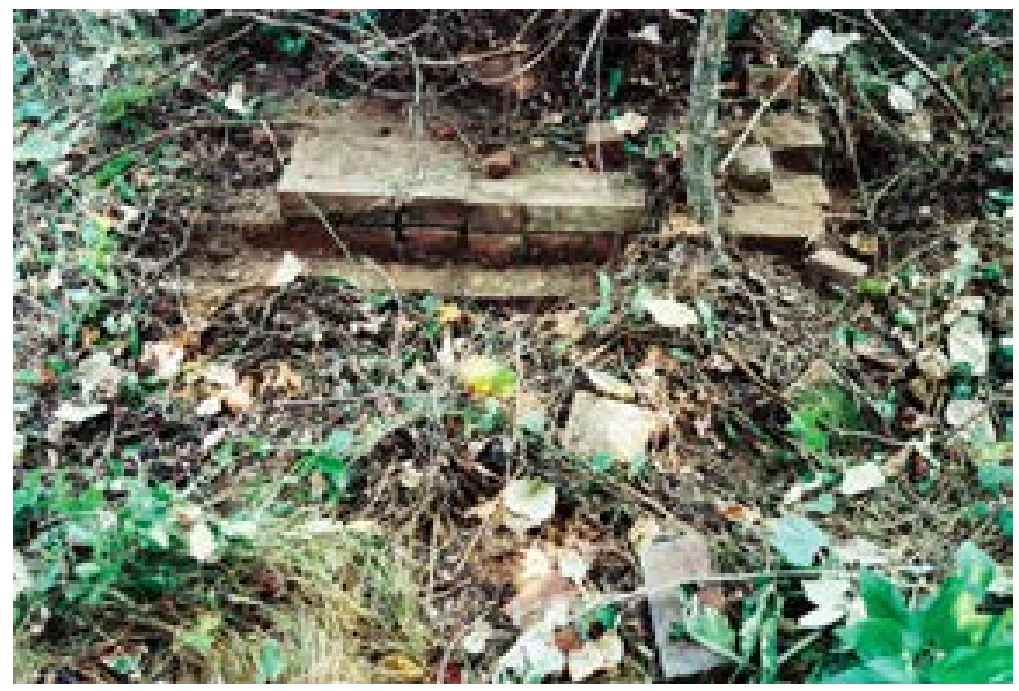

Figure 9-22. A brick chimney base is the only intact structural remains of the David Scott home; facing west.

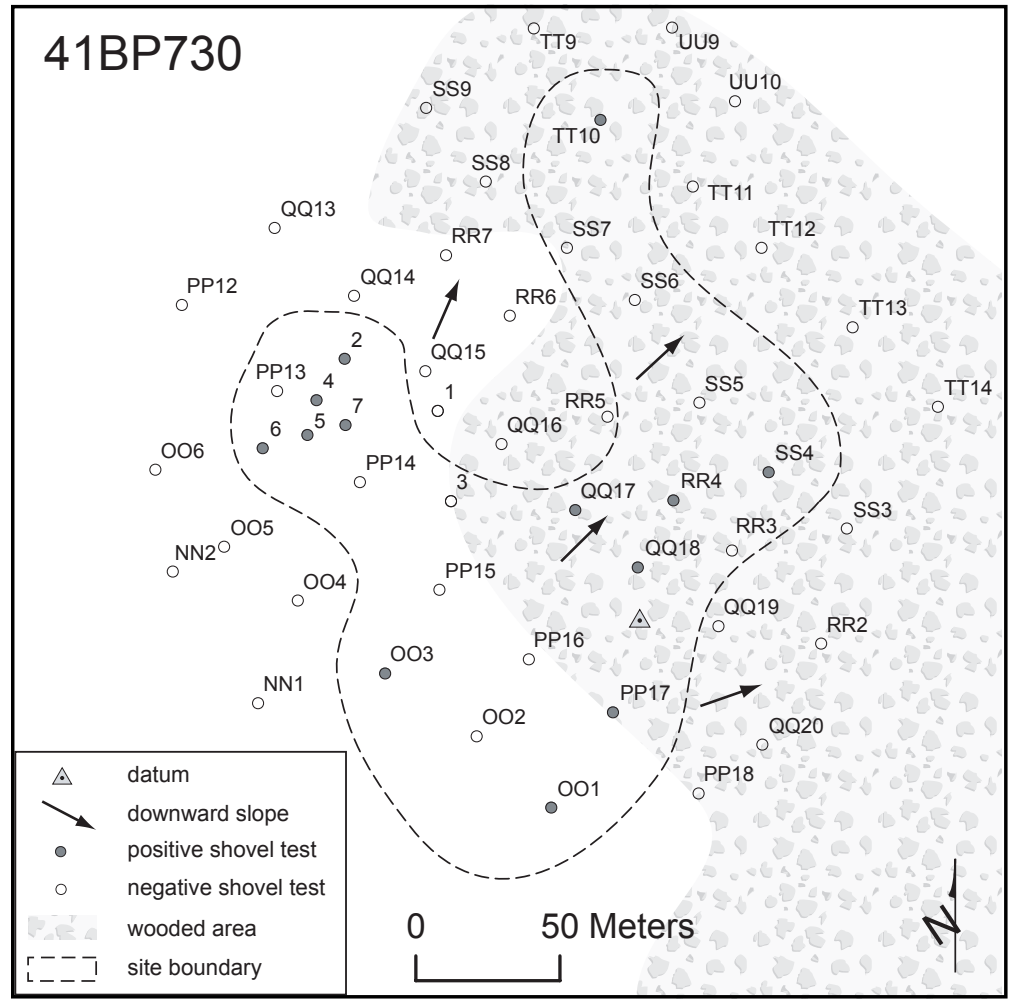

Figure 9-23. Site map of 41BP730.

half, it is wooded with cedar, oak, and elm. Soils in the northern half are much shallower, small gullies are present, and clay is exposed in some areas. Demona loamy fine sand (DeC) makes up the northern, lower slopes and is heavily eroded (Baker 1979). The southern 75 percent is composed of Patilo complex fine sand $(\mathrm{PaE})$. Accordingly, surface visibility in July 2005 varied from approximately 50 percent in the northern half to less than five percent in the grassy southern half. The site datum is marked by a nail and aluminum tag on a 30-cm diameter oak tree.

\section{Levels of Work and Results}

A chimney base was located in a cleared field, near a large oak with large grapevines in the upland portion of the site. The chimney was constructed with well-made red bricks and mortar, but no manufacturer's marks were observed on any of the bricks. Two staggered tiers were noted in the base; the top tier of the chimney measured 48 inches square, and the bottom measured 55 inches square. The dimensions and construction materials of its base are unknown. No other construction material or artifacts were observed on the surface. The trash pile was located approximately 150 meters north of the chimney base, on an eroding sideslope leading down to the creek bed. Ten barrel hoops; a rusted tin pail; part of an iron skillet; a wood burning stove door and unidentified stove part; a rusted bucket; two bed springs; rusted tin cans with crimped sides, tops, and bottoms; two leather shoe soles; a leather horse pack; a red brick measuring $81 / 2-x 4-x-2 \frac{1}{4}-i n c h e s ;$ and two red brick fragments were observed (Figure 9-24). A large piece of a stoneware crock with a handle was also found. It 


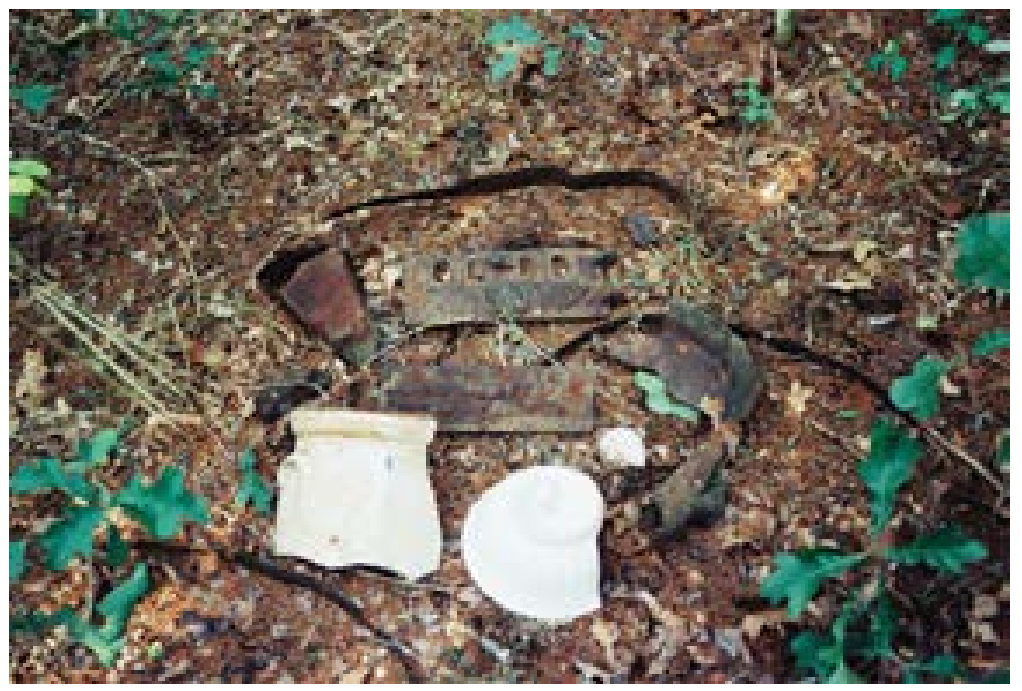

Figure 9-24. Selected trash items at 41BP730.

had a Leon slip interior, a Bristol glaze exterior, and the number " 4 " stenciled in blue on the exterior near the rim. This combination of Leon slip and Bristol glaze was most commonly used in Texas between 1880 and 1920. Cobalt was most likely used to produce the blue number, and the number indicates a four-gallon capacity (Greer 1999:137, 138, 194, 212). A whiteware bowl with a large section missing and a "K.T.\&K." mark was observed. The mark refers to the Knowles, Taylor, and Knowles Pottery Company in East Liverpool, Ohio, which was formed in 1870 and incorporated in 1891. This piece was most likely produced between 1926 and 1931, when the company merged with several others to form the American China Corporation, which failed due to the Depression (Lehner 1988:238, 239).

Of 23 shovel tests placed on the site, 13 were positive. Five of the 13 positive shovel tests contained historic artifacts. Red brick and sandstone fragments, clear glass with no hue, and unidentified metal fragments were found in shovel tests placed around the chimney base. A stoneware sherd with a Leon slip exterior and interior and a whiteware sherd was recovered from ST 2. The Leon and Leon combination was most popular between 1875 and 1900 (Greer 1999:197, 200). A thin white porcelain sherd with no distinguishing marks was observed in ST 5. A stoneware sherd with a Leon slip exterior and a Bristol glaze exterior, an etched brown glass shard, an etched clear glass shard with heavy patina, an undetermined nail type, and two charred bone fragments were recovered from ST 6 (Table 9-4). Etching glass became a common technique beginning in the late 1800s (Munsey 1970:51).

\section{Conclusions/Recommendations}

According to Abner C. Scott (personal communication 16 February 2006), David Scott and his family lived here. They had two sons and two daughters. David Scott is buried at Oak Hill Cemetery, and his grave is marked with a Woodsmen of the World tombstone.

Based upon the approximate ages of the glass and stoneware found, it appears that the David Scott farmstead was occupied from the last quarter of the nineteenth century to around 1942, when the military assumed ownership of the 125-acre tract. As with many other historic sites on Camp Swift, only the chimney base remains intact. Therefore, the research value of the historic component of this site is minimal and no further work is recommended. The historic component is not eligible for nomination to the NRHP. 


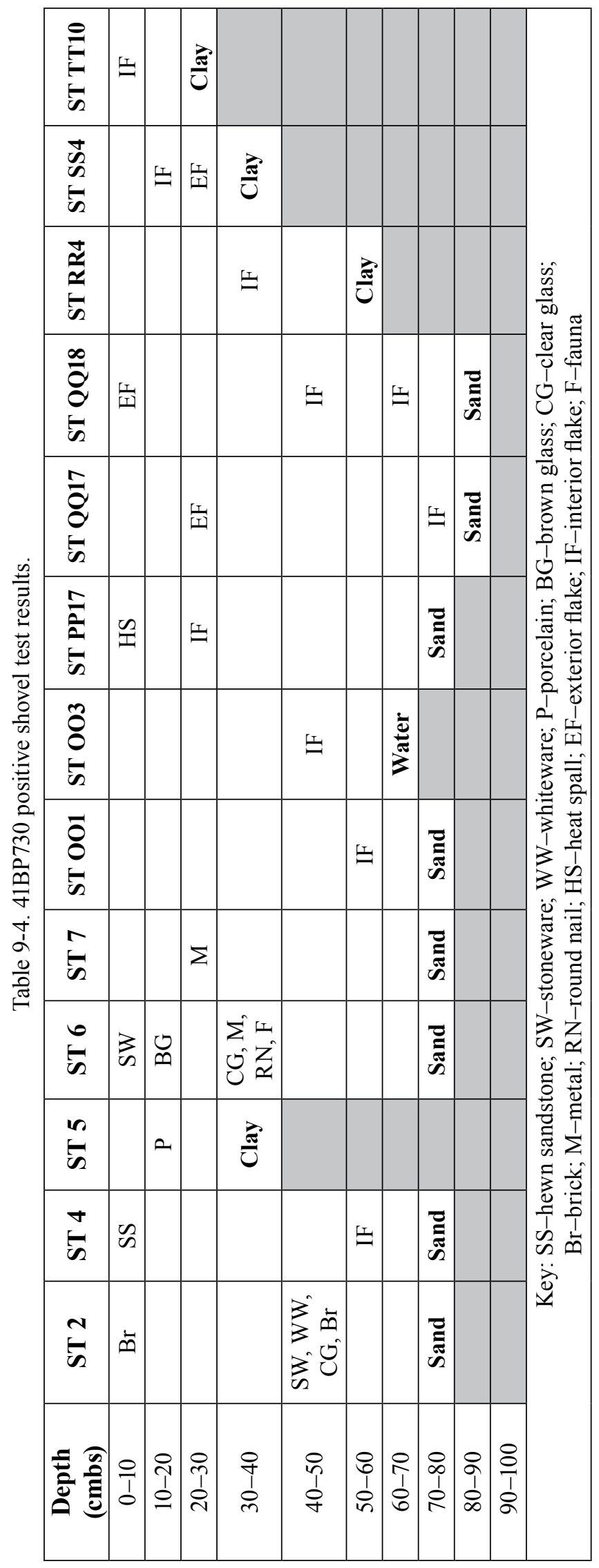

\section{BP734}

\section{Description}

A corral is the only above-ground evidence remaining of what may have been the S. Haller farmstead (Figures 925 and 9-26). The site is on the eastern and most elevated edge of a 177-acre tract owned by Haller in 1929 (Bastrop County 1929). A prehistoric lithic scatter mixed with historic artifacts exists within the Demona loamy fine sand $(\mathrm{DeC})$ at the site. The lithic scatter has been discussed in Chapter 7: New Prehistoric Component Sites. The site covers approximately $8,688 \mathrm{~m}^{2}$ of a knoll on an upland ridge, and ranges in elevation from 510 to $504 \mathrm{ft}$ amsl. Where the area has not been cleared, and is generally very heavily disturbed by heavy machinery, large oak and cedar trees coexist with dense grasses in the fields. An old bladed road and berm and numerous tank ruts were observed on the surface. Surface visibility was about 10 percent in August 2005. The site datum is marked by a nail and aluminum tag on a $25-\mathrm{cm}$ diameter oak tree.

\section{Levels of Work and Results}

The corral consists of cedar posts with barbed and woven wire. Admittedly, a specific type of barbed wire is problematic for determining a not-laterthan date because in many cases it was manufactured for extended periods and its uselife was also extensive. However, a not-earlier-than date can be determined by its patent date. The barbed wire on the east and south side of the corral is double strand with rounded four-barbed wrapped around both strands, and there are 3 inches between barbs. This is most similar to a type known as Glidden's 
Coils, Four-wrap Variation, patented in 1876 (Clifton 1970:145). The barbed wire on the west side of the corral is double strand, has two flat barbs wrapped around one strand, and there are 4 inches between barbs. This is most similar to a type known as Glidden's Barb, Flat Variation, patented in 1874 (Clifton 1970:105). Woven wire observed on the west side of the corral is $2 \frac{1}{4}-\mathrm{x}-4$-inches and woven wire on the south and east side of the corral is $11 \frac{3 / 4}{4}$ $\mathrm{x}$-4-inches. The northern and northwestern corner portions of the corral were constructed of closely spaced cedar staves. Corrugated tin panels were also attached to the fence on the northwest outside corner of the corral.

A child's iron wagon wheel with a diameter of $13 \frac{3}{4}$ inches, $1 / 2$-inch wide, and 1/16-inch thick was found on the surface inside the corral. Its size and style match the front wheels on a Boys' Express Wagon No. 29R68 advertised by Sears, Roebuck \& Co. in its 1902 catalogue (Sears, Roebuck and Co. 1993:912). A metal bucket and a large roll of woven wire were also located on the inside of the corral. A pile

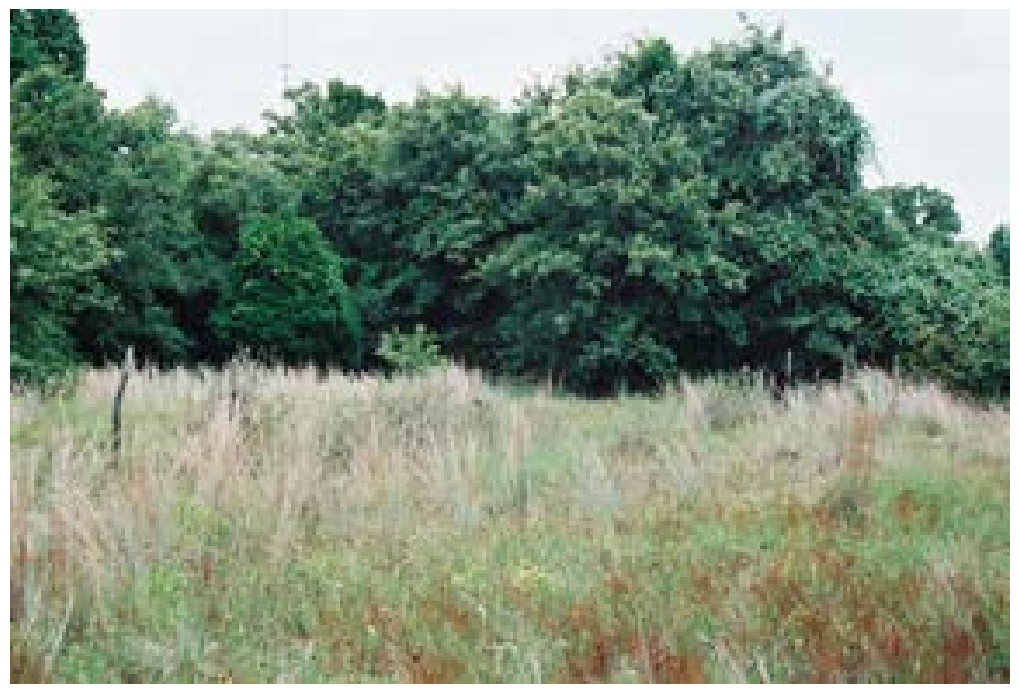

Figure 9-25. An old fence and corral are all that is above ground at what may have been the S. Haller farmstead; facing north.

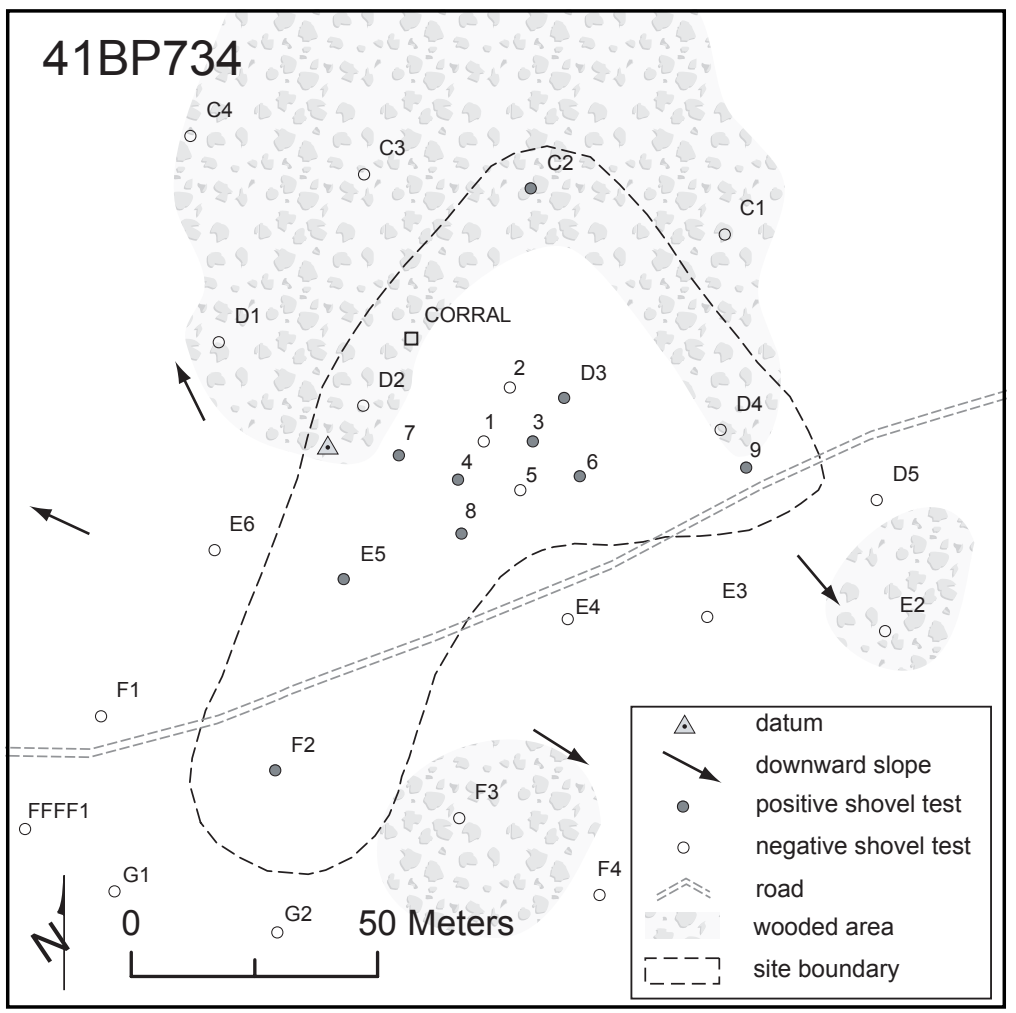

Figure 9-26. Site map of 41BP734.

made brick fragments with grey glaze, six small orange brick fragments, a round nail, and a rifle bullet casing. Two moderately thick amber glass shards were likely manufactured between 1915 and 1930, when selenium was predominantly used 
Table 9-5. 41BP734 positive shovel test results.

\begin{tabular}{|c|c|c|c|c|c|c|c|c|c|c|}
\hline $\begin{array}{c}\text { Depth } \\
\text { (cmbs) }\end{array}$ & ST 3 & ST 4 & ST 6 & ST 7 & ST 8 & ST 9 & ST C2 & ST D3 & ST E5 & ST F2 \\
\hline $0-10$ & & AG & & & & CG & RS & & AG & \\
\hline $10-20$ & Br & CG, EF & & Br & & & & & CG & BG \\
\hline $20-30$ & & & & RN & Br & & & & & \\
\hline $30-40$ & IF & & 3 IF & & Br & & & & Clay & \\
\hline $40-50$ & Clay & LG & Clay & Clay & & & & IF & & Br \\
\hline $50-60$ & & & & & & Clay & AG & Clay & & \\
\hline $60-70$ & & & & & & & & & & \\
\hline $70-80$ & & Sand & & & Sand & & & & & Sand \\
\hline $80-90$ & & & & & & & & & & \\
\hline $90-100$ & & & & & & & & & & \\
\hline $100-110$
\end{tabular}

to decolorize glass (Munsey 1970:55). A piece of a decorated upper rim clear chimney lamp or lantern glass was found in ST 4. The style of decoration is that made from about 1885 through the early twentieth century (Woodhead et al. 1984:61). The other clear glass and two brown glass bottle shards appear to be of more recent origin. The rifle bullet shell casing was a .42 caliber. This caliber of rim fire bullet was manufactured by the Union Metallic Cartridge Co. in Bridgeport Connecticut for the Forehand \& Wadsworth No. 64 single action rifle (Logan 1959:67-68). The Union Metallic Cartridge Co. was organized and began manufacturing cartridges in 1867 (Remington 2005). The Forehand and Wadsworth name was retained until 1890 when Wadsworth retired and the company then became simply the Forehand Arms Company (Spangler 2005). Thus, by process of elimination the .42 caliber casing found at this site had to have been made between 1867 and 1890.

\section{Conclusions/Recommendations}

Judging from the historic artifacts recovered, it appears that this site was most probably occupied from about the last quarter of the nineteenth century through the first quarter of the twentieth century. However, the corral structure appears to have been used later. The corrugated tin, round nails, woven wire, and condition of the cedar staves suggest it was used through 1942, or even perhaps in the 1960s when parts of Camp Swift were leased out as grazing lands. CAS recommends that no further effort is warranted and the historic component of this site is not eligible for nomination to the NRHP due to the continued recent use and clear mixing of historic and prehistoric artifacts from mixing.

\section{BP735}

\section{Description}

41BP735 (Figures 9-27 and 9-28) is a bulldozed house site located adjacent to what used to be the old Sayersville-McDade Road, and is now called Impact Road. By comparison, and probably because of its close proximity to the Sayersville community and the old Bastrop to Elgin Road (now Highway 95), it is on one of the smaller tracts that was acquired for Camp Swift- 17.142 acres. It is now heavily disturbed, and although thick vegetation precluded seeing 
any surface artifacts, the site was discovered during excavation of transect shovel tests. Based upon shovel test results, it appears that the historic material has been distributed by bulldozer over across approximately 3,088 $\mathrm{m}^{2}$. The area is now covered with scattered oak, mesquite, and cedar trees, dense grasses, shrubs, weeds, prickly pear, and wild grapevines. Exceptions include a decorative crepe myrtle tree and mulberry trees that were likely planted by the occupants. An extra large cedar tree probably served as a shade tree at the time the house was occupied. A large pile of cut logs have been placed on the northern portion of the site. The datum is marked by a nail and aluminum tag on an elm tree near ST 3.

\section{Levels of Work and Results}

In addition to red and yellow brick fragments, artifacts found in the seven positive shovel tests (Table 9-6) excavated on the site include:

Glass: the clear glass shards either had no hue, an amethyst hue, or a pink hue. No hue suggests a post1930 manufacturing date, an amethyst hue indicates a date between 1880 and 1915 (Lindsey 2005). The shard with a pink hue had embossed, or raised, lettering, which could date as early as 1869 or as late as 1920. It also has embossed lettering including "G. CO" and "TEX." No information could be found concerning

Figure 9-28. Site map of 41BP735.

the lettering on the glass, though the letters probably correspond to "MFG. CO. TEX."

Ceramics: a spongeware pattern on a Flow Blue sherd was found in ST 5. Flow Blue ceramics were generally produced from 1825 to the early 
1900 s, but the spongeware and Flow Blue techniques together indicates it was likely produced between 1845 and 1900 (Bagdade and Bagdade 1991:325; Greaser and Greaser 1967; Snyder 1992:7). Three "hard fired," undecorated whiteware sherds were recovered. Their finely made attributes would seem to indicate a date of production in the early to mid-twentieth century, considering the refinement of kilns and firing techniques Table 9-6. 41BP735 positive shovel test results.

\begin{tabular}{|c|c|c|c|c|c|c|c|}
\hline $\begin{array}{l}\text { Depth } \\
\text { (cmbs) }\end{array}$ & $\begin{array}{c}\text { ST } \\
\mathbf{1} \\
\end{array}$ & $\begin{array}{c}\text { ST } \\
2 \\
\end{array}$ & $\begin{array}{c}\text { ST } \\
\mathbf{3} \\
\end{array}$ & $\begin{array}{c}\text { ST } \\
4 \\
\end{array}$ & $\begin{array}{l}\text { ST } \\
\text { C3 }\end{array}$ & $\begin{array}{l}\text { ST } \\
\text { E4 }\end{array}$ & $\begin{array}{l}\text { ST } \\
\text { E5 }\end{array}$ \\
\hline $0-10$ & $3 \mathrm{CG}$ & $\begin{array}{c}3 \mathrm{CG}, \\
\mathrm{Br}\end{array}$ & SW & $\mathrm{CG}$ & & & \\
\hline 10-20 & & $\begin{array}{c}\mathrm{SW}, \\
2 \mathrm{CG}\end{array}$ & & & & & \\
\hline $20-30$ & $\mathrm{CG}, \mathrm{M}$ & $\mathrm{M}$ & $\mathrm{CG}$ & $\mathrm{RN}$ & & & \\
\hline $30-40$ & $2 \mathrm{CG}$ & & SW & & & & \\
\hline $40-50$ & $\mathrm{CG}$ & & & $\mathrm{CG}$ & SW & & \\
\hline $50-60$ & & & Clay & WW & & WW & WW \\
\hline $60-70$ & & Clay & & & & & Clay \\
\hline $70-80$ & Sand & & & Clay & Clay & Clay & \\
\hline \multicolumn{8}{|l|}{$80-90$} \\
\hline & $\begin{array}{l}\text { W-stc } \\
\text {-bric } \\
\end{array}$ & rare; & $-\mathrm{wl}$ & $\begin{array}{l}\text { vare } \\
\mathrm{RN}\end{array}$ & $\begin{array}{l}\mathrm{G}-\mathrm{C} \\
\text { roun }\end{array}$ & $\begin{array}{l}\mathrm{rgla} \\
\text { ail } \\
\end{array}$ & \\
\hline
\end{tabular}
in later times. The two stoneware sherds found in ST 3 were a Leon slip interior/Bristol glaze exterior, and a Leon slip exterior/interior piece. The Leon/Bristol combination Bristol glaze became popular by 1920 and is still in use today, while a Leon/Leon combination was most common in the last quarter of the nineteenth century (Greer 1999:197, 212). Finally, an unidentifiable stoneware sherd with a grey exterior and a light brown "ribbed" interior was found in ST C3.

Metal: a rusted metal teaspoon was found in ST 2, a crimped rod in ST 2, and a round nail in ST 4; there were also unidentifiable metal fragments.

\section{Conclusions/Recommendations}

According to Ms. Fay Pannell (personal communication 8 February 2006), a family by the name of Jones lived here. The artifacts suggest that this site could have been occupied from as early as 1869 and possibly continued though 1941 . They suggest a house site, and absent are artifacts that would indicate the use of the site for farming, agriculture, or industry. Regardless, it has been

heavily disturbed by bulldozing. Therefore, its research value is minimal, CAS recommends that no further work be conducted, and the site is not eligible for nomination to the NRHP.

\section{BP741}

\section{Description}

This historic site consists of an ephemeral historic trash scatter and a spike driven into a large, old oak tree. It is situated on an eroded clay upland area, with small drainages to the north and a two-track firebreak to its east (Figures 9-29 and 9-30). The predominant vegetation is oak, cedar, and beautyberry. Otherwise, two open fields exist to the north and south. The property was owned by Cynthia Floyd before the government acquired it (Bastrop County 1929; Abner C. Scott, personal communication 16 February 2006).

\section{Levels of Work and Results}

The square spike is heavily imbedded in an old oak tree that is 54 inches in circumference and is now rotting and broken. The trunk has grown around a strand of barbed wire so that it is now in the middle of the trunk. The wire 
is a double strand, with double pointed barbs spaced every two inches and wrapped around only one of the strands. This is a type that was commonly in use by 1882 (Clifton 1970). Barbed wire strands run 130 degrees-310 degrees from the oak. An examination of the surface in a large area around the oak revealed no evidence of a structure, only assorted historic trash. An aqua glass vase shard, a painted whiteware ceramic sherd with light green leaf pattern, and barrel hoops were found. The aqua glass and the light green leaf-painted shard are both likely pre-1900 (Durrenberger 1965:66; Kovel and Kovel 1986:257; Munsey 1970).

\section{Conclusions/ Recommendations}

The large oak, spike, and barbed wire apparently represent a property boundary between J. Evans and Cynthia Floyd. Judging from the historic artifacts recovered it appears that the trash perhaps accumulated here in the last quarter of the nineteenth century, the same era when the barbed wire was patented. Due to the limited number of artifacts and the lack of subsurface archaeological deposits, no further effort is

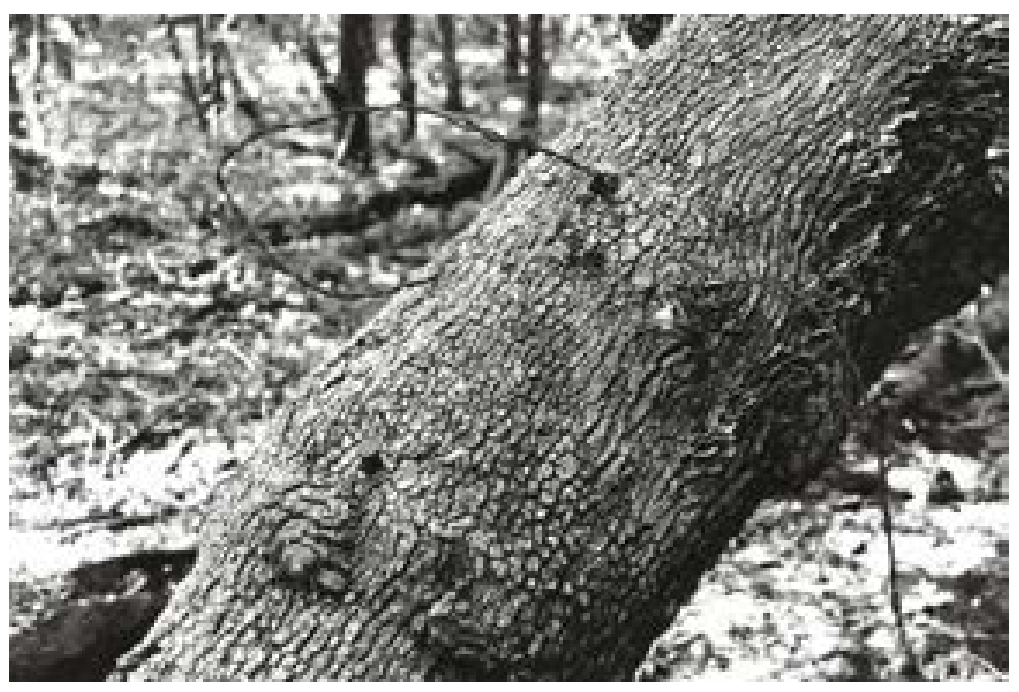

Figure 9-29. A spike in an oak tree and a trash scatter make up 41BP741; facing southwest.

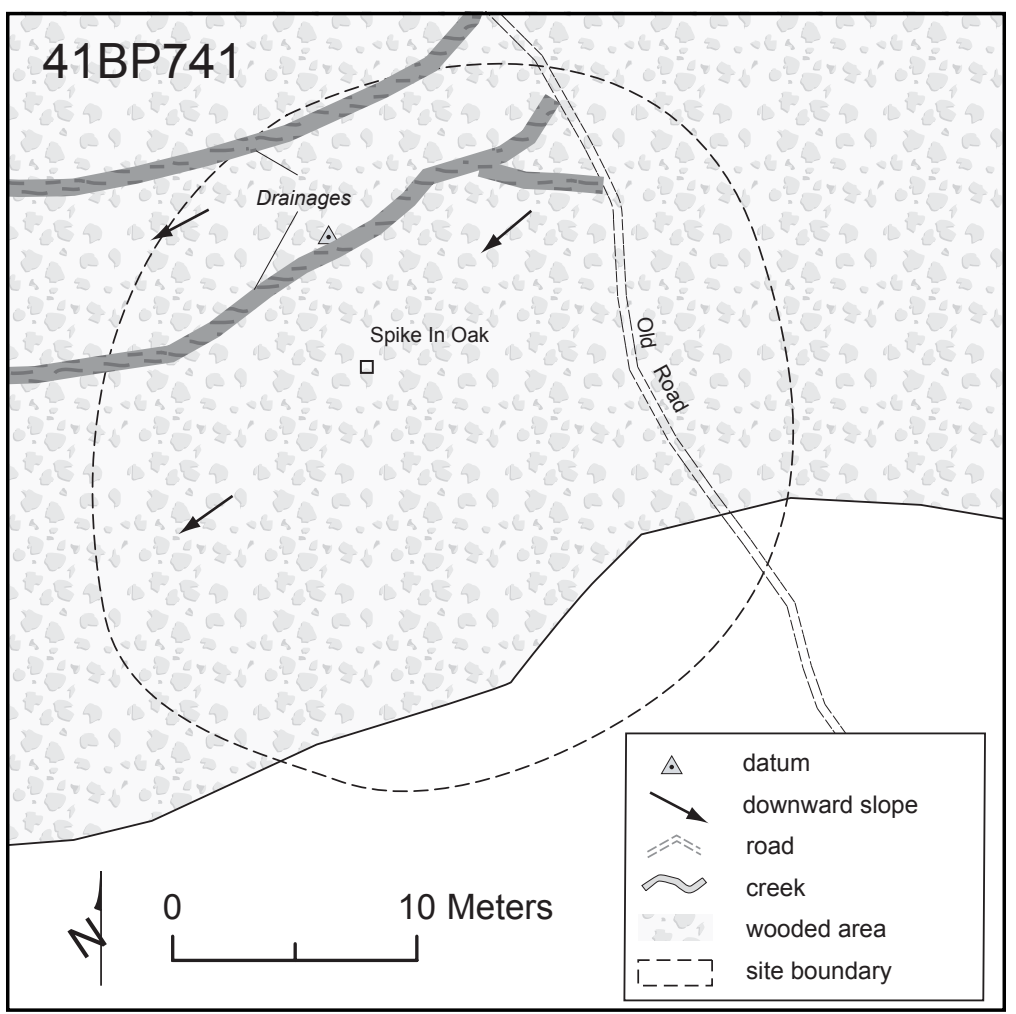

Figure 9-30. Site map of 41BP741. warranted and the historic component of this site is not eligible for nomination to the NRHP.

\section{BP742}

\section{Description}

A mounded brick pile, sandstone slabs, scattered artifacts, and a depression that was likely a well or cistern are what make up the 
historic component of 41BP742.

There is also a prehistoric open campsite component that has been discussed in Chapter 6: Previously Documented Prehistoric Component Sites. The historic component is located in and around an oak mott on the east end of an open field (Figures 9-31 and 9-32). An intermittent drainage joins McLaughlin Creek just south of the site. The property was owned by J. Evans before the government acquired it (Bastrop County 1929). A nail and an aluminum tag on an oak tree mark the site datum.

\section{Levels of Work and Results}

The bricks are orange, grey or tan, are heavily fired and finely made, and have sharp, crisp edges. Some of the red ones have "T F B Co" stamped on them (Figure 9-33); these were made by the Texas Fire Brick Company in Lasher Switch, Bastrop County, Texas between 1906 and 1914 (Steinbomer 1982:242). The scattered sandstone slabs that were likely used as foundation stones measured 7 inches $x 9$ inches $\mathrm{x} 4$ inches. The slight depression that may have been a well or cistern is located east of the house area. Other than bricks and sandstones, no other historic material was observed on the surface.

Although eight of the 10 shovel tests excavated on the site were positive, historic artifacts were

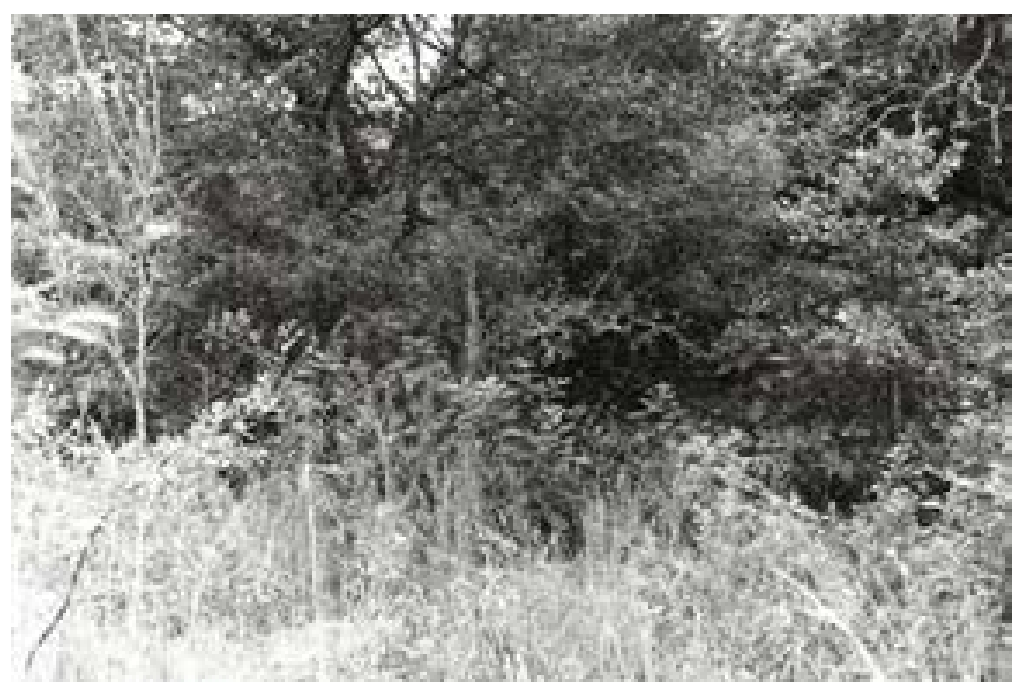

Figure 9-31. A pile of brick, sandstone slabs, and artifacts are on 41BP742, what was the J. Evans property; facing east.

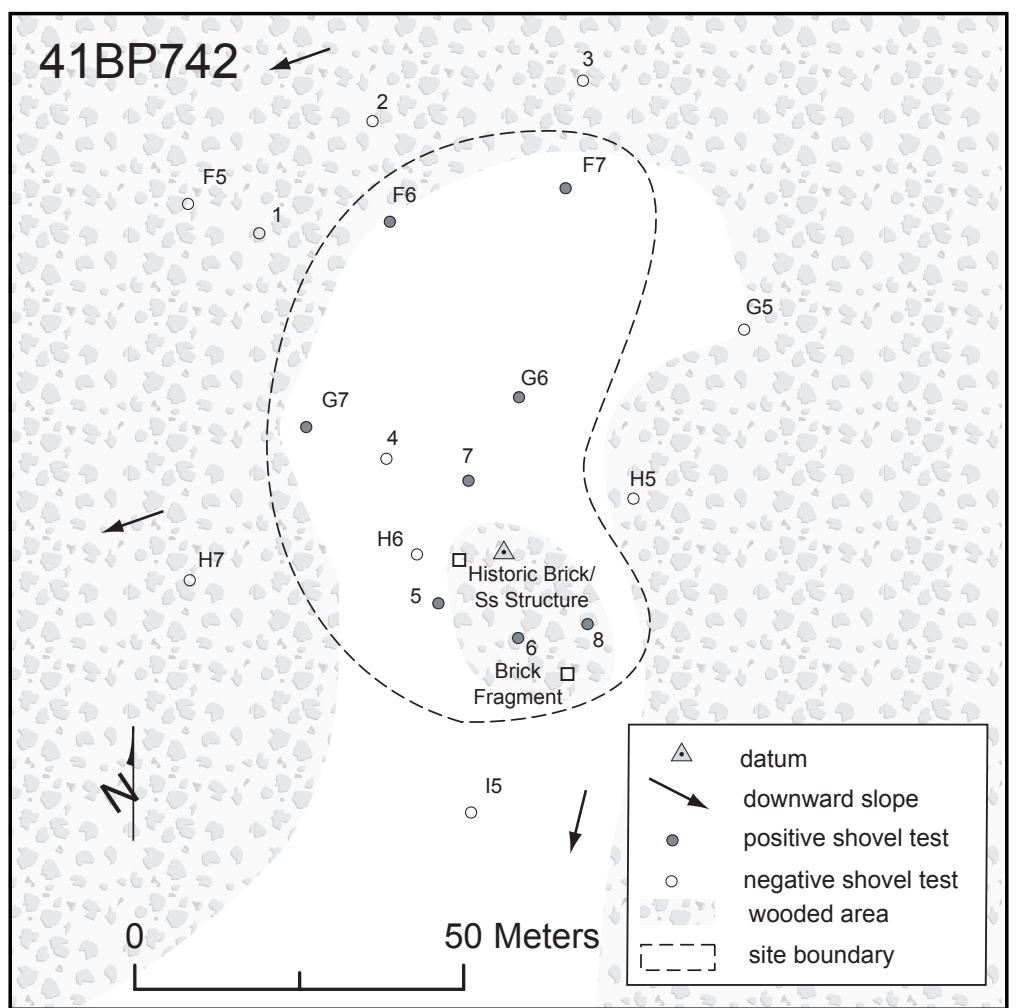

Figure 9-32. Site map of 41BP742.

recovered from four shovel tests (Table 9-7) around the house site and include:

ST 6: thin, clear window glass; half of a crown bottle cap (ca. 1892 [earliest]-present); unidentifiable metal fragment 
ST 7: undecorated whiteware sherd (ca. 1850-present); milk glass shard (ca. 1870s to the mid-twentieth century)

ST 8: clear glass with amethyst hue (ca. 1880-1915)

ST G7: iron rod $3 / 4$-inch thick by $4 \frac{1}{2}$ inches long

\section{Conclusions/ \\ Recommendations}

Judging from the historic artifacts recovered, it appears that the site was occupied from about the last quarter of the nineteenth century through about 1930. The historic component has been bulldozed so it is likely that no intact architecture remains. The bulldozing probably disturbed any subsurface deposits and mixed historic and prehistoric artifacts. Therefore, no further effort is warranted on the historic component and it is not eligible for nomination to the NRHP.

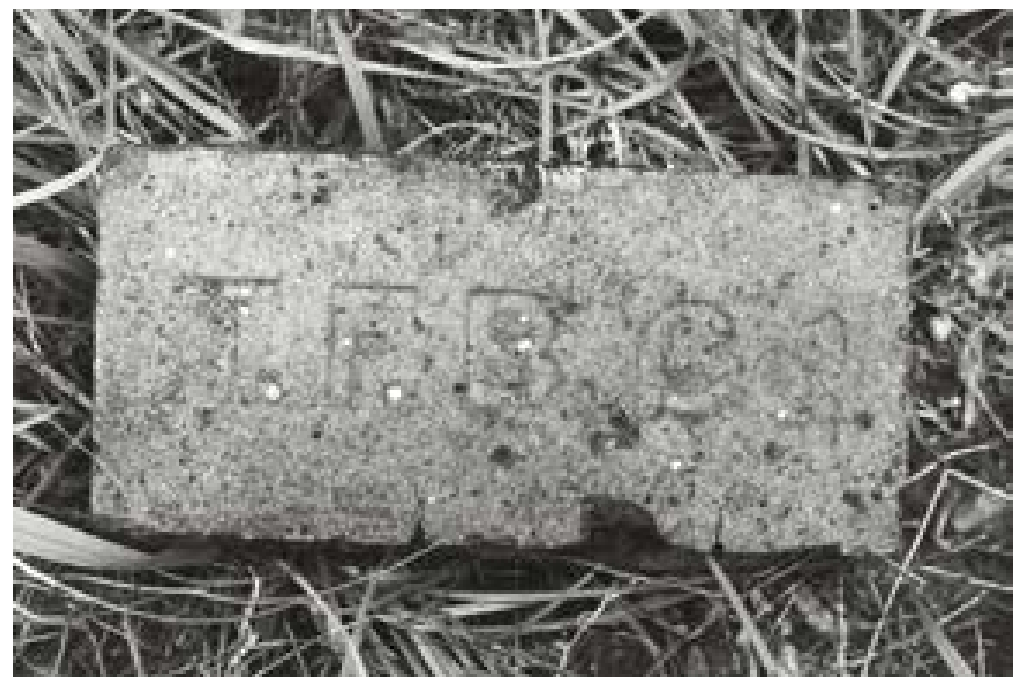

Figure 9-33. Texas Fire Brick Company red brick.

\section{BP745}

\section{Description}

The historic component of 41BP745 consists of a pushed pile of bricks, glass, and hewn sandstone blocks lying on a lower terrace $20 \mathrm{~m}$ west of McLaughlin Jeep Road and $30 \mathrm{~m}$ south of the McLaughlin Creek channel (Figures 9-34 and 9-35). This property belonged to J. Evans before the government acquired it (Bastrop County 1929). A dense thicket of thorny scrub brush just east of the push pile contrasts sharply with

Table 9-7. 41BP742 positive shovel test results.

\begin{tabular}{|c|c|c|c|c|c|c|c|c|}
\hline $\begin{array}{c}\text { Depth } \\
(\mathbf{c m b s})\end{array}$ & ST 5 & ST 6 & ST 7 & ST 8 & ST F6 & ST F7 & ST G6 & ST G7 \\
\hline $0-10$ & IF & & WW & & & & & \\
\hline $10-20$ & & CG & & & & & & M \\
\hline $20-30$ & FCR & M, BC, U & MG & CG, IF & & & & \\
\hline $30-40$ & & & & & & C & FCR & Clay \\
\hline $40-50$ & FCR, fcr & & & & FCR & & & \\
\hline $50-60$ & & & & & Clay & & & \\
\hline $60-70$ & & Clay & & & & & & \\
\hline $70-80$ & Sand & & Sand & Clay & & & & \\
\hline $80-90$ & & & & & & Sand & Sand & \\
\hline $90-100$ & & & & & & & \\
\hline
\end{tabular}


mature mesquite, cedar, and elm trees elsewhere on the site and indicates a probable cleared area. Underlying the historic component is a prehistoric lithic scatter that has been discussed in Chapter 7: New Prehistoric Component Sites. The push pile covers an area about $16 \mathrm{~m}^{2}$ of the $716-\mathrm{m}^{2}$ site. The site datum is marked with a nail and aluminum tag on a small mesquite tree.

\section{Levels of Work and Results}

In addition to the hewn sandstone blocks, there are moderately well-made yellow bricks, both singles and some that are still mortared together. Only one piece of clear glass with no noticeable hue was observed on the push pile. The area surrounding the site was inspected and several similar bricks were observed in the creek bed. Although seven shovel tests placed on the site were positive, none of them contained historic artifacts.

\section{Conclusions/ \\ Recommendations}

This is an unusual location for a historic structure so near the floodplain of McLaughlin Creek. However, CAS believes the push pile represents some sort of structure that was once in the immediate area, and the previously cleared and now overgrown area was likely the location of the original structure. The mortared brick with hewn sandstone are typical construction materials observed on most

Figure 9-35. Site map of 41BP745.

Figure 9-34. A push pile with historic construction materials and artifacts lies near McLaughlin Loop Road; facing northeast.

FIGURE 9-35. REDACTED house sites on Camp Swift. Lacking evidence of farming, agricultural, or industrial use, CAS has designated this as a house site. In any case, the historic component of this site is destroyed and of little research value. No further work is 
recommended and the site's historic component is not eligible for nomination to the NRHP.

\section{BP746}

\section{Description}

41BP746 is a collapsed bridge on McLaughlin Creek 40 m east of McLaughlin Loop Road. The remains consist of hand-hewn sandstone slabs and pier supports (Figures 9-36 and 9-37). It is located on a property line between J. Evans on the south and F. Fleming on the north (Bastrop County 1929). The creek cutbank here is about seven feet, and a relatively level floodplain exists on both sides. Typical riparian vegetation includes oak, elm, and hickory trees, and coarse grasses. At the time of the August 2005 visit, the creek was not flooded and was only about a foot deep.

\section{Levels of Work and Results}

A slight depression and cleared areas on both sides of the creek are apparent traces of a roadcut or a two-track leading to the bridge on both sides of the creek. The bridge support, at least on the west bank of the creek, had been constructed of hand-hewn sandstone slabs between three and six inches thick and cedar piers. Only one pier still remains. The slabs and pier now rise about four feet above the creek bottom. No piers or sandstone could be seen on the west edge,

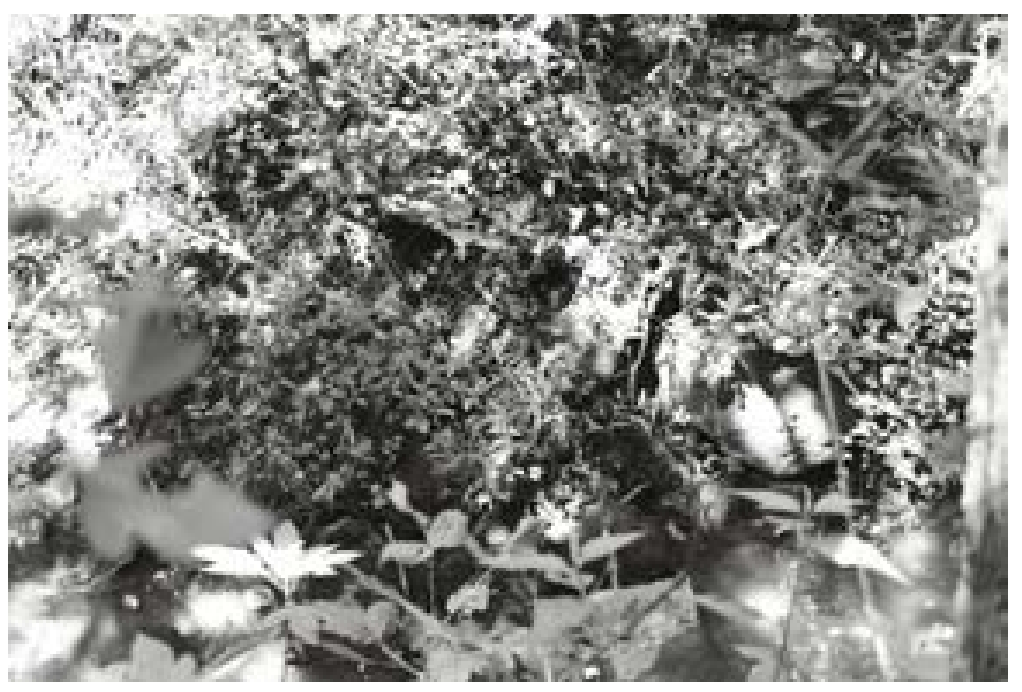

Figure 9-36. 41BP746 is a collapsed bridge across McLaughlin Creek; facing southwest.

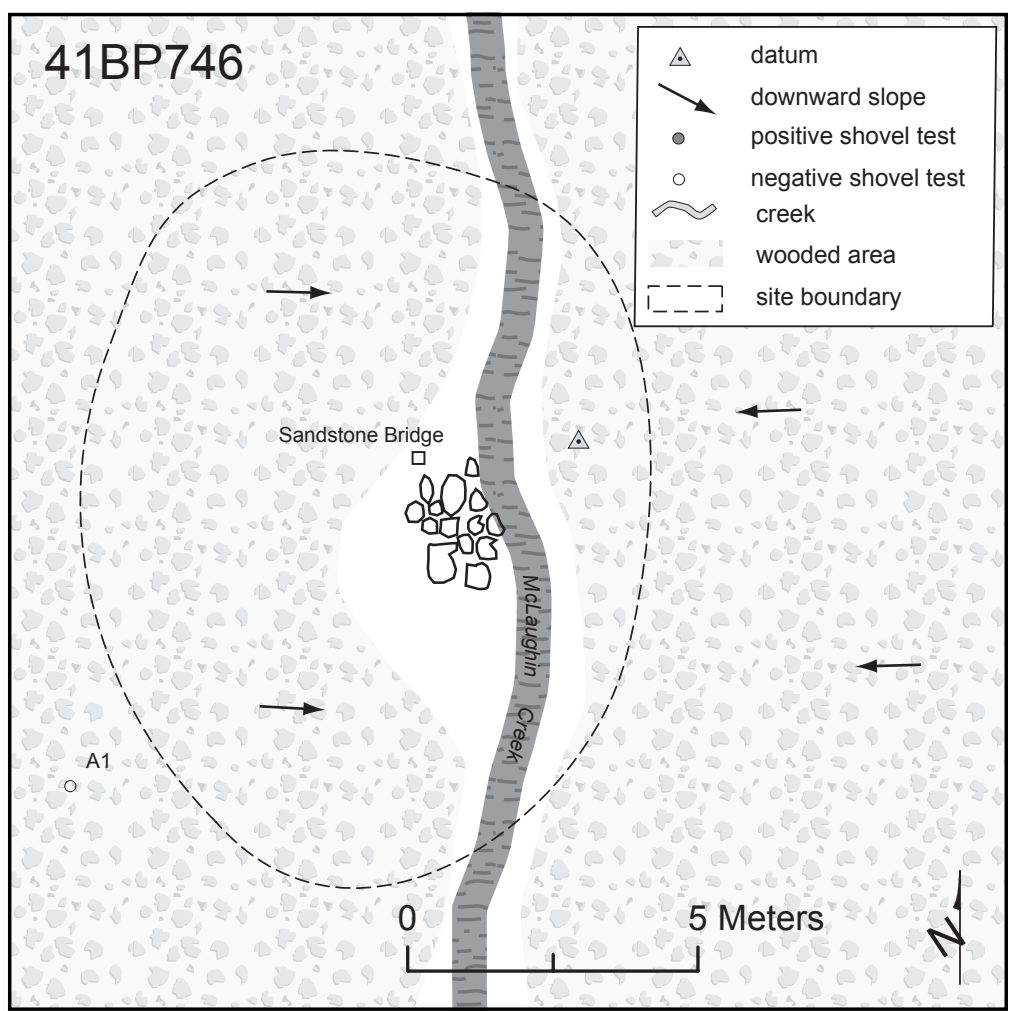

Figure 9-37. Site map of 41BP746.

but they most likely have washed away, or were buried within the cutbank as the creek meandered through time. Judging from the remains, the bridge would have been about eight feet wide. 


\section{Conclusions/ \\ Recommendations}

The age of the bridge is unknown, but it was probably used by both the Evans and Flemings. More archival research could provide an indication of the construction date, the individuals who built the bridge, or those that used the bridge. In its present condition, no further fieldwork is warranted beyond protecting the site from further impacts, but additional archival research is needed to determine if the bridge is eligible for nomination to the NRHP.

\section{BP751}

\section{Description}

41BP751 is a trash dump that contains, among other items, bottles that likely post-date about 1920 (Figure 9-38). It is located approximately $10 \mathrm{~m}$ east of Scott Falls road in the densely wooded floodplain of McLaughlin Creek, and within close proximity to numerous push piles (Figure 939). The site datum is a nail and aluminum tag on an elm tree 30 $\mathrm{cm}$ in diameter. This land was also owned by J. Evans in 1929 (Bastrop County 1929).

\section{Levels of Work and Results}

Objects observed included a one-gallon galvanized bucket, a section of riveted sheet metal, an enamel-coated tin pot, metal parts of a torch that could be rearticulated, part of a lantern, unidentified metal (lead), wire,

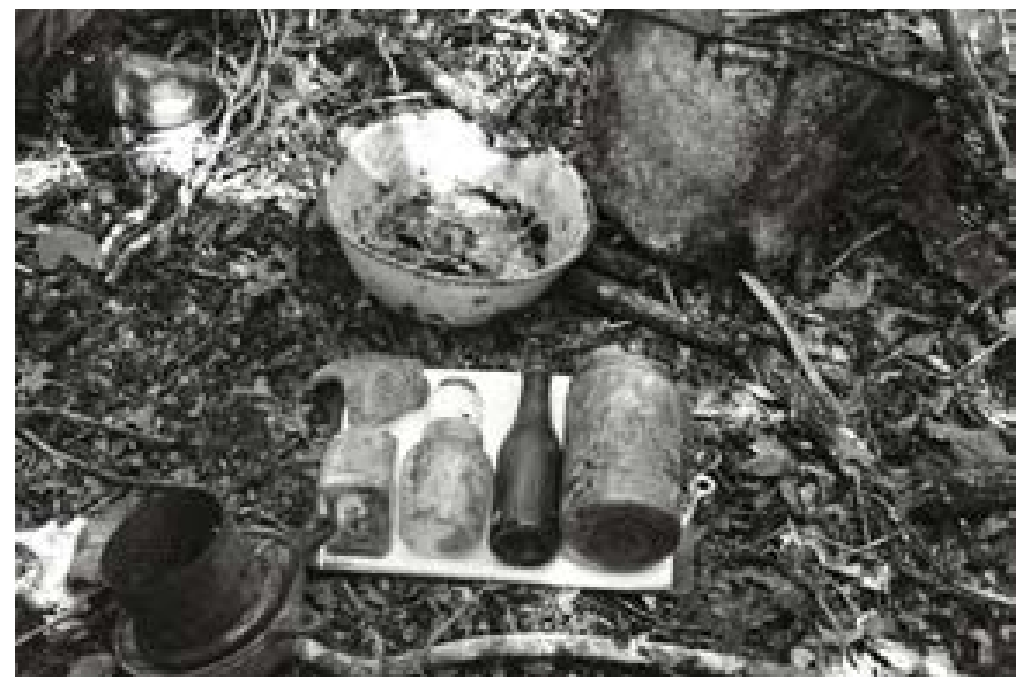

Figure 9-38. Selected items from 41BP751, a trash dump on the floodplain of McLaughlin Creek.

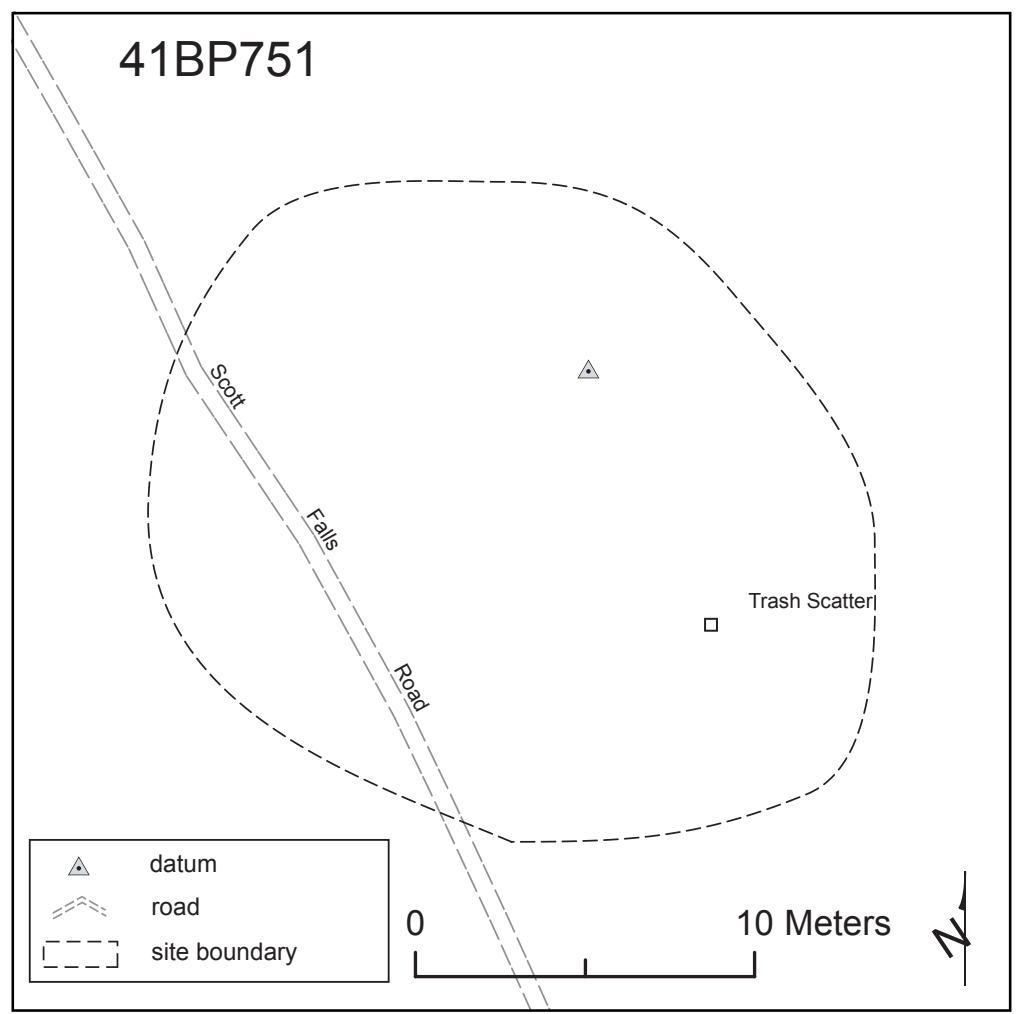

Figure 9-39. Site map of 41BP751. whiteware, and clear glass. Documented glass containers include:

- two green Depression glass fragments with a petal design on the base. Green Depression 
glass dates from the $1920 \mathrm{~s}$ to the $1950 \mathrm{~s}$ (Schroy 2000:13, 14).

- a clear glass jar with no hue and a decorative pattern on the side, consisting of lines within a triangle, and embossed with "21-C," an Obear-Nester Glass Co. mark, and a "7". This mark has been in use from 1915 to present (Toulouse 1971:373, 374).

- two green bottles with crown caps and seams running over the lips. William Painter patented the crown cap in 1892, though it did not gain widespread acceptance until the 1920s (Lindsey 2005). Though only significant when used in conjunction with other bottle characteristics, the mold seams would also suggest a later date of production (Lindsey 2005).

- a clear glass mason jar with no hue, air bubbles in the glass, and embossed on the side with "Kerr," "SELF SEALING," and "WIDE MOUTH MASON." The embossing on the center of the base reads "PAT.6," "AO3," "191 5," and is surrounded by "KERR GLASS MASON SAND SPRINGS OKLA." This mark is most similar to one produced at the Los Angeles plant from 1920 to 1940, though the embossing on the base indicates that it was produced at the Sand Springs, Oklahoma factory (Toulouse 1969:166-171). Although it is common for older glass containers to contain a significant amount of bubbles, this characteristic is considered to be a weak dating indicator (Lindsey 2005).

- a clear glass French's ${ }^{\odot}$ Mustard jar with no hue. French's ${ }^{\odot}$ Mustard was introduced in 1904 (French's $^{\odot}$ 2005).

- a Ponds milk glass jar, which most likely contained cold cream. Milk glass was commonly used for cosmetic containers from the 1870 s to the mid-twentieth century (Lindsey 2005).
Metal items observed in the dump included a torch or heating device that likely used propane gas, a one-gallon galvanized bucket, a white enamel-coated tin wash basin, a section of riveted sheet metal, part of a lantern, unidentifiable lead pieces, and round wire. Mass production of white enamel-coated tinware thrived by the last quarter of the nineteenth century, but it can still be purchased today (Rhodes and Carson 2005). Finally, a few whiteware sherds that could date from the 1850 s through the present were also in the dump.

\section{Conclusions/Recommendations}

The location of the trash pile, in the floodplain and within close proximity to the road, suggests that this was a dump site and not an occupation site. The majority of the artifacts date to no earlier than the beginning of the twentieth century. Its research value is minimal and it is not eligible for nomination to the NRHP.

\section{BP752}

\section{Description}

$41 \mathrm{BP} 752$ is a house site located in the northeastern corner of a 200-acre tract that belonged to J. Evans in 1929 (Bastrop County 1929). The ironstone foundation or chimney remains have been disturbed, and a depression in the middle of them (Figures 9-40 and 9-41) is typical of the bulldozing of historic houses that occurred on Camp Swift during WWII. It is located on a relatively flat area on an otherwise steep slope adjacent to an intermittent drainage. A stock tank is located on the drainage $130 \mathrm{~m}$ to the south. An old road clearing running northsouth is located approximately $15 \mathrm{~m}$ east of the house site.

\section{Levels of Work and Results}

The hand-hewn ironstone slabs appear to be in a rectangular shape and measure 15-x-17-feet. 
The only artifact observed on the surface was a stoneware crock, approximately $20 \mathrm{~m}$ from the sandstone slabs. It had Leon slip on the interior and the top half of the exterior. The bottom half of the vessel was coated with Bristol glaze (Figure 9-42). This combination of glaze and slip was popular from about 1880 through 1920 (Greer 1999:194, 212). It also had a McDade Pottery maker's mark, and the number "3," indicating that it had a three-gallon capacity (Figure 9-43). The McDade Pottery began production in the 1870 s and closed with the advent of WWII (Metcalfe 2001). Two shovel tests were excavated within the boundaries of the site. The only positive shovel test was ST 3; a round nail was found at 10-20 cmbs. Round nails were not the dominant type until the 1890s (Nelson 1968:1-10).

\section{Conclusions/ \\ Recommendations}

Based upon the approximate age of the artifacts at this site, the probable period of occupation was ca. 1880-1920. Even though the surface architecture has been destroyed, the possibility of a well or cistern in a buried context still offers some research potential. Limited additional work to look for buried features is recommended before it can be determined identify additional buried features.

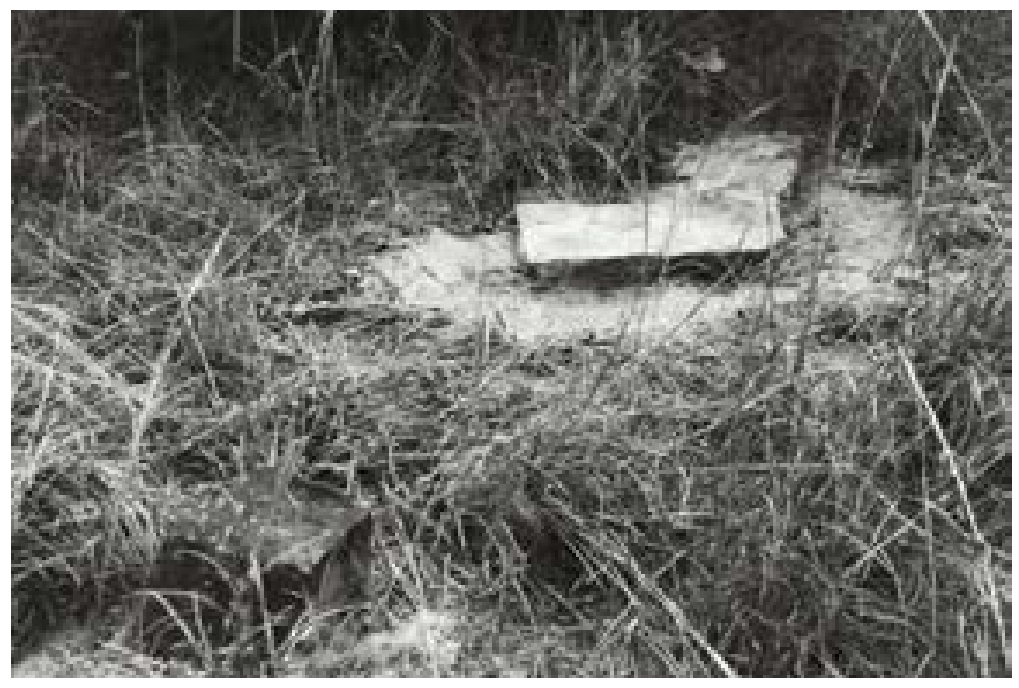

Figure 9-40. 41BP752 is a house site possibly occupied as early as 1880; facing east.

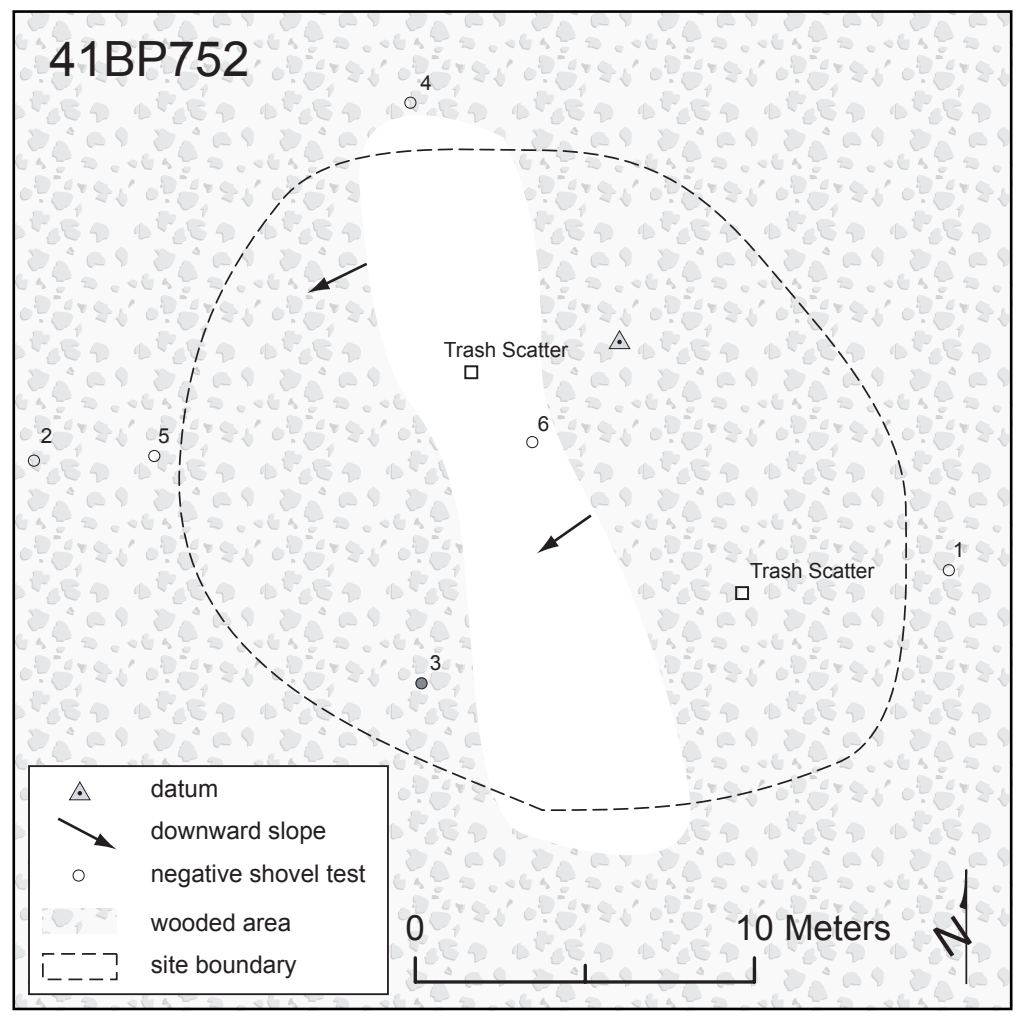

Figure 9-41. Site map of 41BP752. as eligible for nomination to the NRHP. Three 


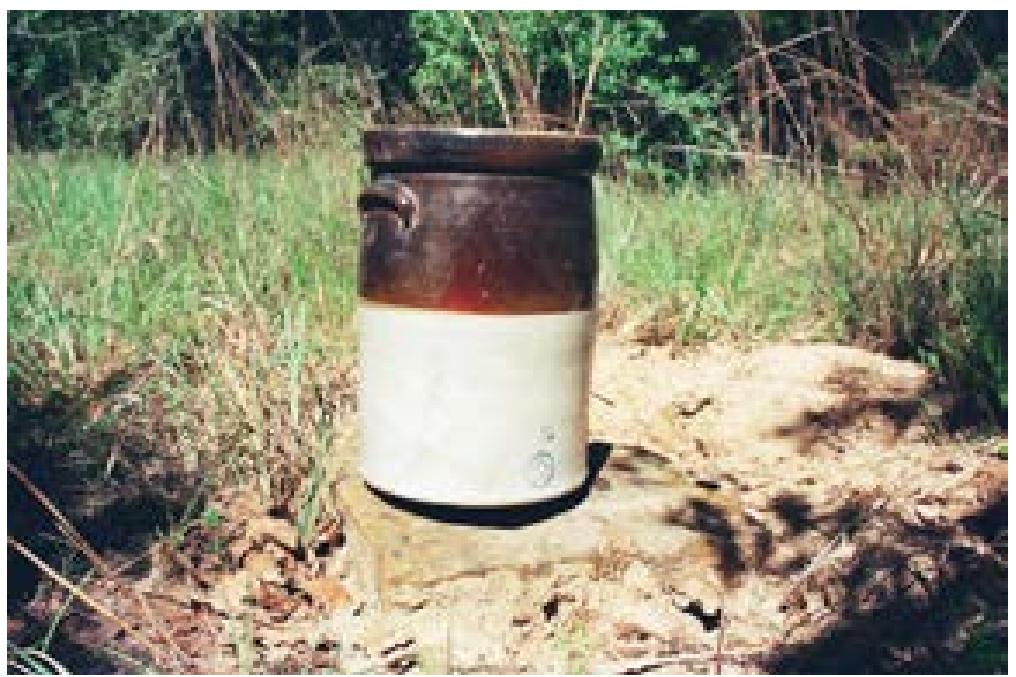

Figure 9-42. For this photograph, archaeologists set the 3-gallon stoneware crock pot made by McDade Pottery on a foundation stone at the site; note the blue maker's mark near the bottom of the vessel.

\section{BP760}

\section{Description}

The discovery of this site began with the recovery of a single ceramic sherd from a shallow shovel test. A subsequent examination of the immediate area led to the documentation and designation of the site as a historic quarry operation with sandstone ledges in an area of about $1,560 \mathrm{~m}^{2}$. Although modern gravel pits are numerous, only a few quarried sandstone outcrops that are presumed to be much older have been observed on Camp Swift. The sandstone bedrock ledge here forms a jutting precipice at the end of a broad ridge. Secondary growth vegetation is so thick with briars, vines, cedars, and mesquites that crawling on hands and knees was often the only effective manner to cover the site (Figures 9-44 and 9-45). It is situated on the eastern portion of a 200 -acre tract owned by J. Evans in 1929 (Bastrop County 1929).

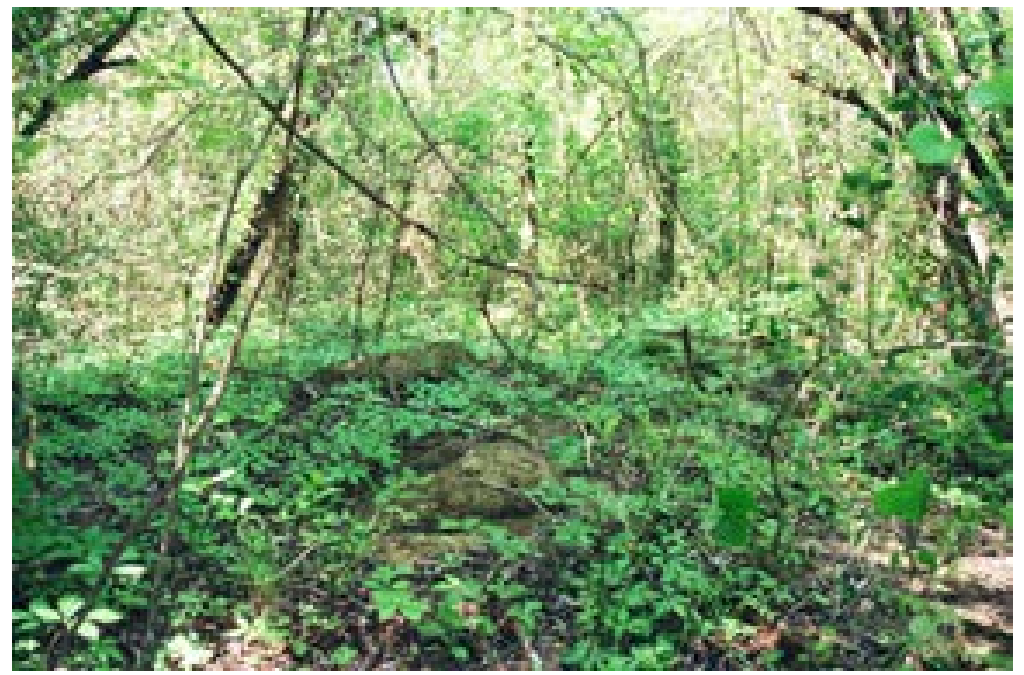

Figure 9-44. A sandstone bedrock ledge has been quarried at 41BP760; facing north.
Figure 9-43. Maker's marks on the stoneware crock.

\section{Levels of Work and Results}

No chisel marks were observed, but apparent hard percussion scars were present on the edges of the ledge, suggesting that it was quarried with a sledge hammer. No artifacts were observed on the surface, and only one shovel test (out of seven placed on the site) contained cultural material. A Flow Blue spongeware sherd (Figure 9-46) and an undecorated whiteware rim sherd with yellowish paste were recovered from ST G3 at $0-10$ cmbs. Flow Blue ceramics were generally produced 


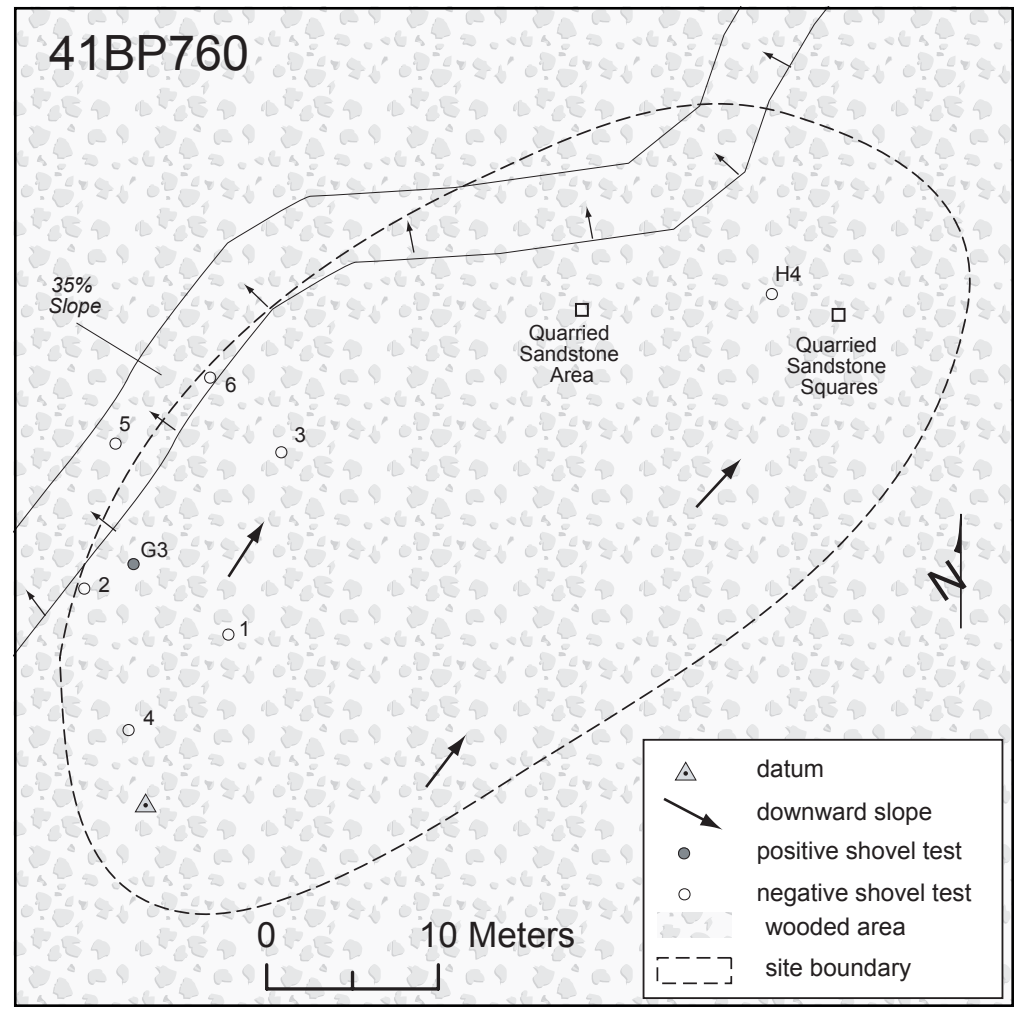

Figure 9-45. Site map of 41BP760.

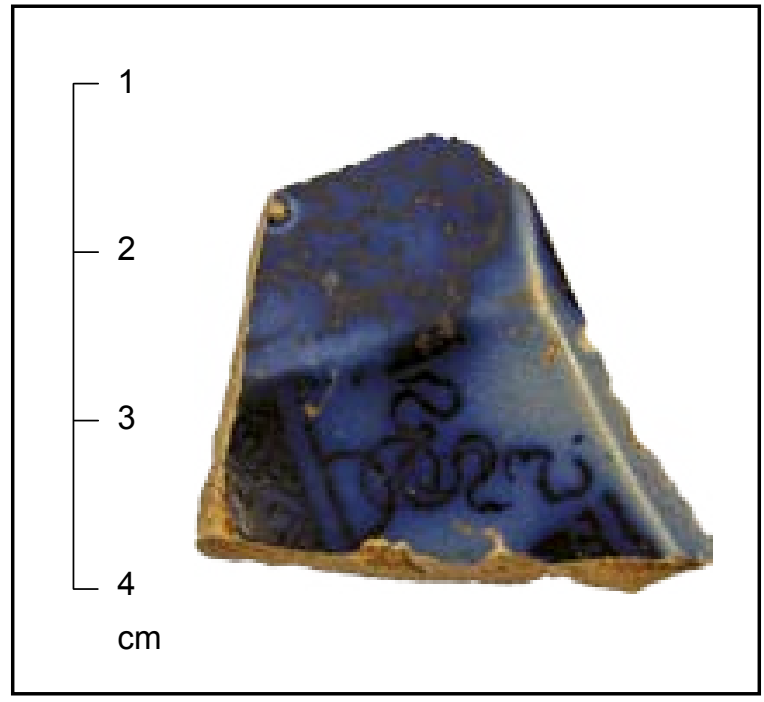

Figure 9-46. Flow Blue ceramic sherd found at 41BP760.

from 1825 to the early 1900s (Snyder 1992:7), but the spongeware technique became popular 20 years later, between 1845 and 1900 (Bagdade and Bagdade 1991:325; Greaser and Greaser 1967). Thus, the combination of the two periods dates this particular specimen to between 1845 and 1900 . Although yellowish, soft paste is generally a characteristic found in older whiteware, it is not a conclusive indicator of antiquity. Average depth to bedrock was 9-10 cmbs.

\section{Conclusions/ Recommendations}

Although two ceramic sherds were found at this site, the absence of other household items implies that this bedrock ridge site was not occupied, but was used primarily as a quarry area. Without the dense vegetation that now covers the ridge, it would have offered a panoramic view of the McLaughlin Creek valley below, and made an ideal place for a picnic. One possibility is that the whiteware was broken while on such an outing. The Flow Blue piece is one of the oldest found on Camp Swift thus far. During the period encompassed by the use of such dinnerware (ca. 1845-1900), the property was owned by members of the Herms and Gest families. A search of pertinent archives and historical accounts of the region failed to produce evidence that any members of these families significantly contributed to history as defined by Department of the Interior Regulations 36 CFR 60, nor does the quarry operation meet those guidelines. Therefore, the research potential of this site is minimal, no further work is recommended, and it is not eligible for nomination to the NRHP. 


\section{BP767}

\section{Description}

41BP767 is a farmstead situated on a semi-open slope on a heavily eroded surface. Ironstone footings, a few bricks, and numerous artifacts are scattered over approximately $452 \mathrm{~m}^{2}$ (Figures 9-47, 9-48, and 9-49). The soils are generally shallow, red clay is exposed in some areas, and incised drainages are present along the southern, sloping portion of the site. Scrub brush, pencil cacti, tall grasses, cedar, mesquite, and oak trees are prevalent, but the house apparently sat nestled within a group of oak and hackberry trees. As with most home sites on Camp Swift, this one has also been bulldozed. An elongated push pile contained many artifacts and sandstone slabs. Many of the artifacts observed on the surface had been exposed by feral hogs rutting. The site sets on a 676acre tract of land owned by $C$. Westbrook (Abner C. Scott, personal communication 25 January 2006).

\section{Levels of Work and Results}

Three pieces of clear glass with amethyst hue (ca. 18801915), a whiteware sherd (ca. 1850-present), a stoneware sherd with Leon slip (ca. 1875-1900), and a crudely-made brick fragment were found in two shovel tests (Table 9-8) out of four placed on the site. Some of the red, yellow, and grey bricks on the surface at the

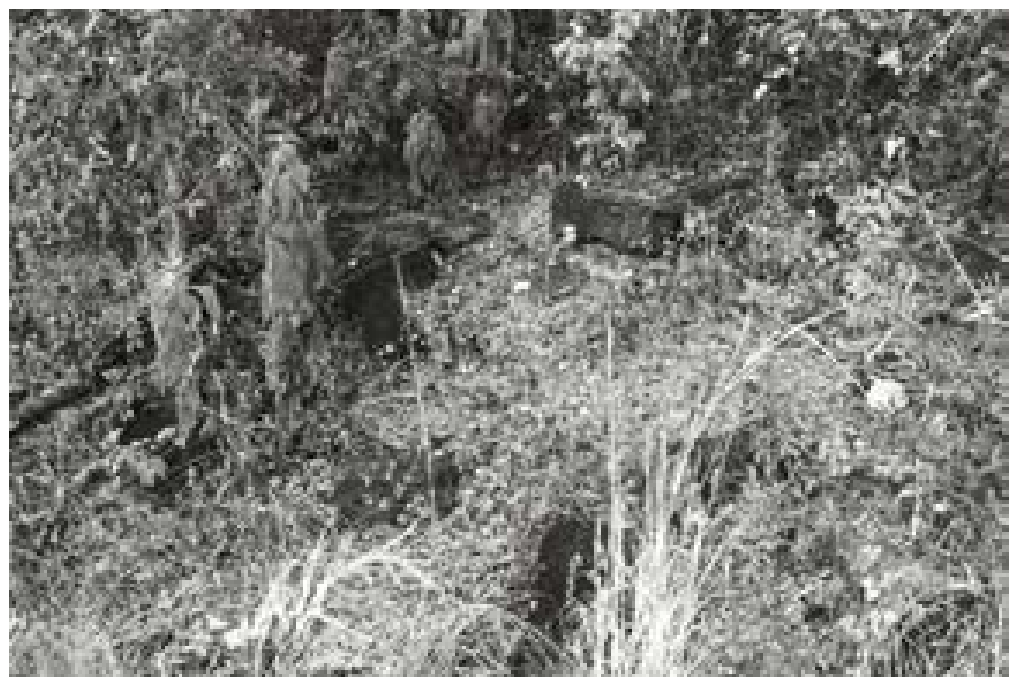

Figure 9-47. 41BP767 is composed of farmstead remains; facing south.

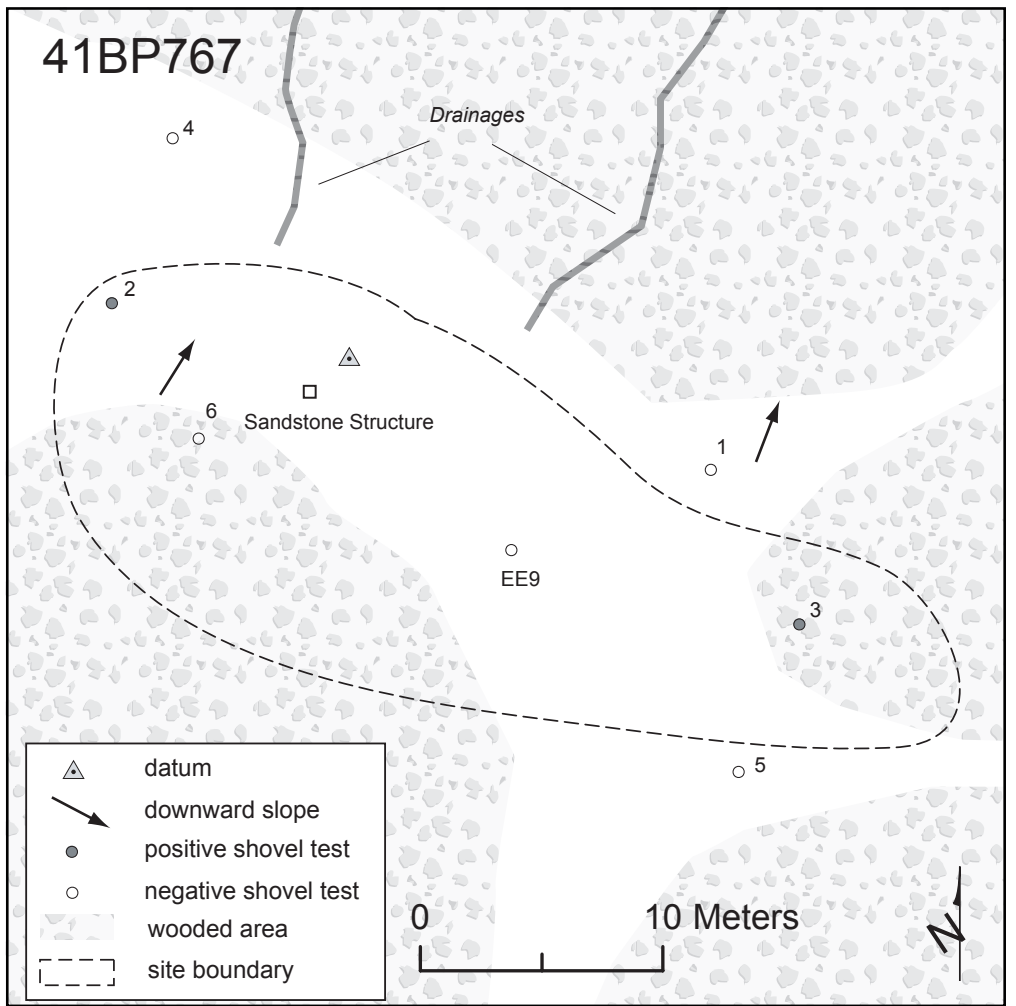

Figure 9-48. Site map of 41BP767.

site were well made with crisp edges, measuring 4 by $2^{1 / 4}$ inches. Others were very poorly made with coarse temper, and were highly fragmented. The grey color may have been from heating. It is possible that these bricks were part of a chimney. Numerous undecorated whiteware sherds, 


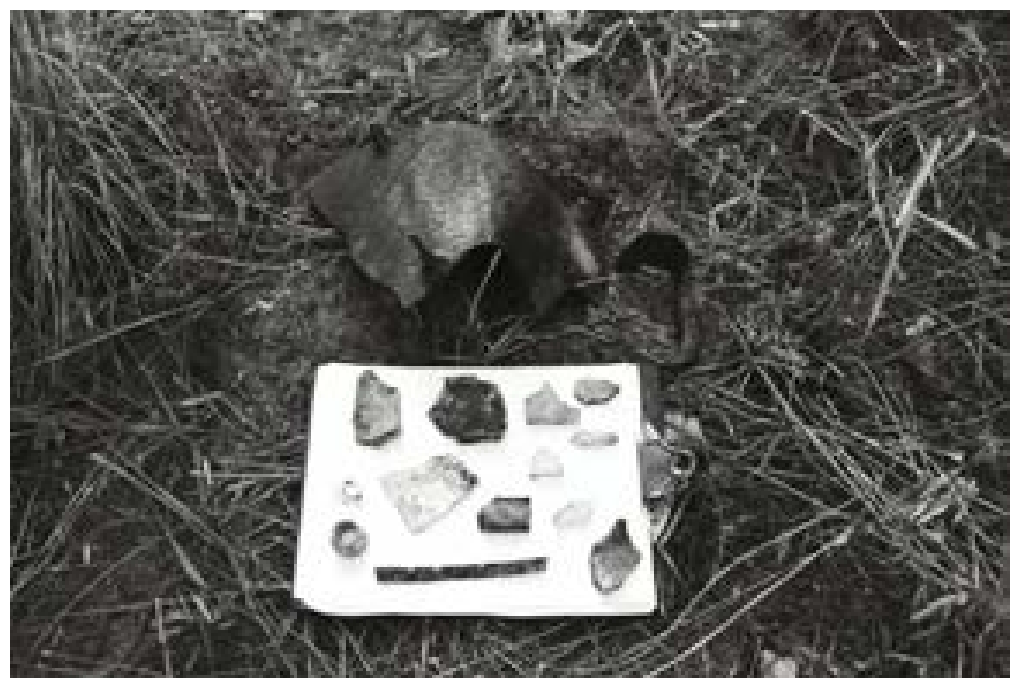

Figure 9-49. Selected artifacts from 41BP767.

Table 9-8. 41BP767 positive shovel test results.

\begin{tabular}{|c|c|c|}
\hline Depth (cmbs) & ST 2 & ST 3 \\
\hline $0-10$ & WW, Br & SW, AG, CG \\
\hline $10-20$ & & CG \\
\hline $20-30$ & & Clay \\
\hline $30-40$ & Clay & \\
\hline $40-50$ & & \\
\hline $\begin{array}{l}\text { Key: SW-stoneware; WW-whiteware; AG-amber } \\
\text { glass; CG-clear glass; Br-brick fragment }\end{array}$ \\
\hline
\end{tabular}

some with a pinkish paste (ca. 1850-present), and unglazed stoneware sherds were found. A whiteware sherd with a Meakin maker's mark was also found on the surface. This family of potters produced several different marks, all bearing the Meakin name. The part of the sherd that would indicate which family member(s) were responsible for the production of this piece was missing. The remaining mark was most similar to one produced by J \& G Meakin (Ltd.), Hanley, Staffordshire, England, ca. 1890 (Kovel and Kovel 1986:11).

Glass observed on the surface included aqua with heavy patina (ca. pre-1900), clear with medium to heavy patina (ca. 1880-1915), pink (ca. 1880-1915), thick brown with heavy patina (ca. pre-1880), thick green with heavy patina (ca. pre-1880), purple with heavy patina (ca. 1880-1915), dark amber with heavy patina (ca. 1880-1915), and a dark brown, applied bottle lip with heavy patina (ca. pre1880). Patination results not from age but from "natural chemical processes of decomposition in both water and the earth" (Lindsey 2005). Over time, these processes obviously affected the appearance of the bottles found at 41BP767.

Metal observed on the site included:

- a hole-in-top style tin can with double crimped and soldered edges and a soldered eight-inch diameter top. Food was stored in these types of cans by pushing it through a small opening in the top. A cap with a little vent hole was then soldered onto the opening. The vent hole was sealed with a drop of solder after the can was heated. This style of canning food was common from the mid-1800s until the early 1900 s, when developments resulted in the improved sanitary can (Busch 1981:96, 97).

- a broken, iron, ten-quart Dutch kettle with three legs and one handle remaining. The iron appeared to be wrought as opposed to cast. Cast iron vessels are formed with a mold; however, the rough and irregular appearance of this kettle suggests that it was hand wrought by a blacksmith. Though kettles of this type were used throughout the nineteenth and twentieth centuries, the fact that a blacksmith formed it by hand would suggest an earlier period of use, most likely from the mid-nineteenth century.

- a piece of wagon hardware, most similar to the center clip hook of a singletree harness. 
Considering the context in which this item was found, one could surmise that it dates from the midnineteenth century as well.

\section{Conclusions/ Recommendations}

The predominance of artifacts on this site suggests that it was occupied from about 1850 through about 1915. It was most certainly a homestead, and the presence of wagon hardware and its rural location would suggest some level of agricultural activities being practiced. The architecture is destroyed and the eroded condition can be used to argue that there is little chance of buried intact features. Therefore, the research potential of this site is minimal, no further work is recommended, and it is not eligible for nomination to the NRHP.

\section{BP771}

\section{Description}

This farmstead site sits in an eastern portion of a 200 -acre tract that belonged to J. Evans. Artifacts are scattered across $1,542 \mathrm{~m}^{2}$, in a disturbed area overgrown with patches of pencil cactus that runs along a bladed track (Figures 9-50 and 9-51). The soils are shallow and red clay is exposed to the surface in some areas. The house apparently sat on the edge of an open field that is now covered with tall grasses and scattered cedars.

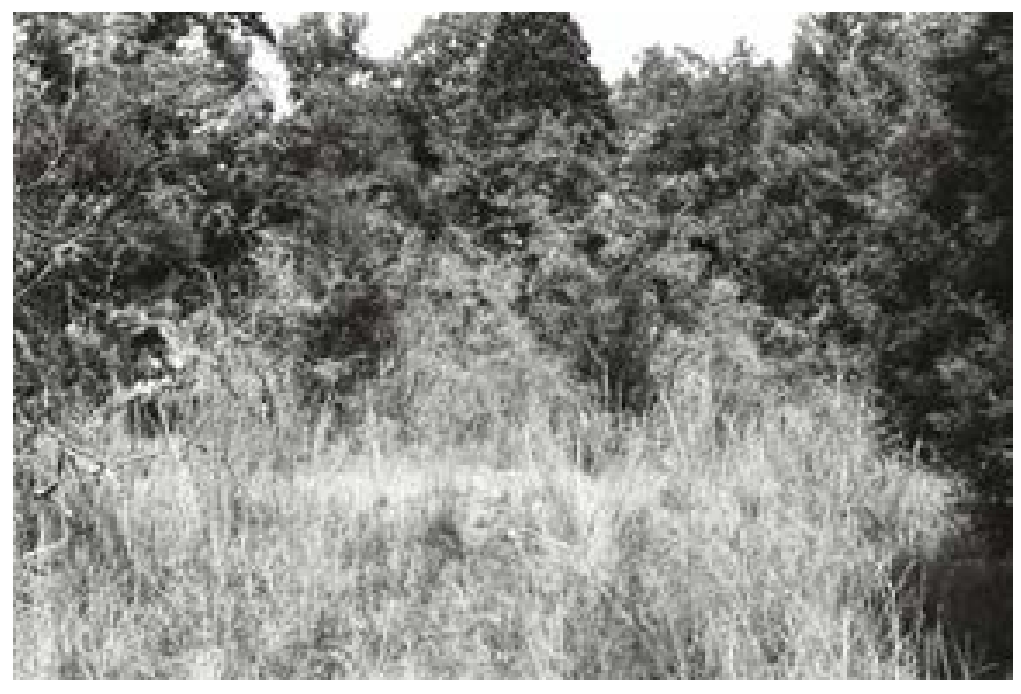

Figure 9-50. 41BP771 is a bulldozed house site on property owned by J. Evans; facing northwest.

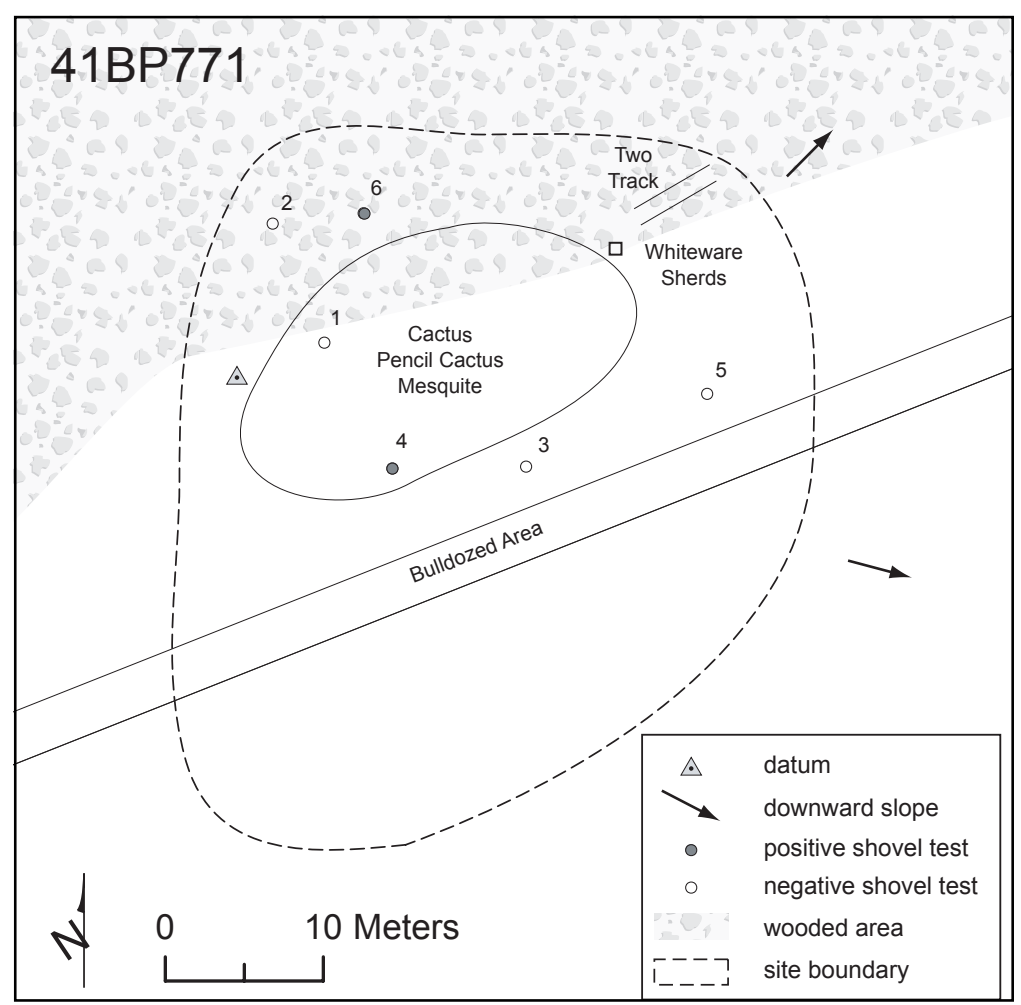

Figure 9-51. Site map of 41BP771.

A two-track cuts north through the woods from where the house was located. The site datum was marked with a nail and an aluminum tag in an oak tree on the western edge of the site. 


\section{Levels of Work and Results}

A metal bucket and two \#3 metal washtubs were found $90 \mathrm{~m}$ northeast of the house at the end of the open field, just inside the tree line. It is unknown whether they are associated with this site or not. Artifacts observed on the surface include:

Glass: an aqua glass shard with heavy patina, and an aqua glass bottle shard with a concave base (ca. pre-1900); a dark aqua glass shard with molded raised ribbing (ca. 1869-1920); a dark purple decorative glass shard (ca. 18401880) (Lindsey 2005); a dark brown, applied and crudely tooled, double ring bottle lip, with a small section of the neck remaining (Figure 9-52). Although a lipping tool was used in the production of this piece, it is considered to be an applied finish and not a "true" tooled finish. A tooled finish employed the use of a mold, which incorporated the forming, or at least the pre-forming, of the finish within the mold. After removal from the mold, the bottle was then "tooled" of its remaining imperfections. This applied and crudely tooled finish, typically just called an "applied" finish, was placed and shaped on

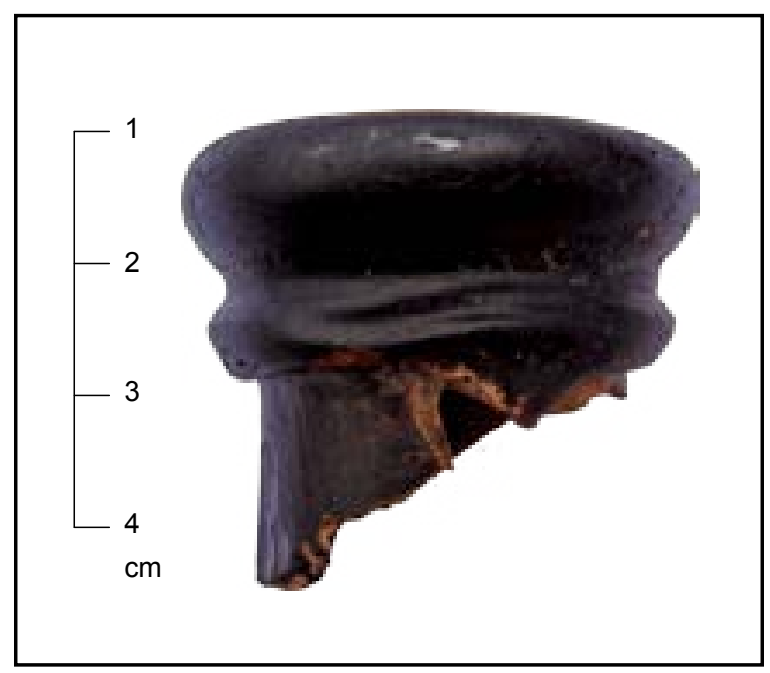

Figure 9-52. A dark brown applied and crudely tooled double ring bottle lip with a small section of the neck remaining. the neck, after the removal from the blowpipe (Lindsey 2005). On this specimen the crudely tooled finish was most likely shaped from shears or tongs rather than a true finishing tool. Finishing tools were not developed in the United States until 1850, which would suggest that this piece was produced prior to this date (Munsey 1970:41).

Ceramics: whiteware sherds with a creamy paste (probably pre-1900); a stoneware sherd with salt glazed exterior and interior (ca. 18501900); a stoneware sherd with an unglazed interior and what appeared to be a burnished exterior (date[s] unknown, could be pre1850).

Six shovel tests were dug within the boundaries of the site. Artifacts recovered from the two positive shovel tests (Table 9-9) include:

ST 4: two squarenails; they were badly deteriorated and it was not possible to determine if they were hand wrought or machine cut. Thus, they can generally be dated to pre-1900. The presence of nails supports the premise that a structure once existed here. Two dark brown glass bottle bases with thick patina, and with concave circular mold seams on their bottoms (ca. pre-1900), were found lying

Table 9-9. 41BP771 positive shovel test results.

\begin{tabular}{|c|c|c|}
\hline $\begin{array}{c}\text { Depth } \\
\text { (cmbs) }\end{array}$ & ST 4 & ST 6 \\
\hline $0-10$ & AqG & WW, BU \\
\hline $10-20$ & 2 SN, F & Clay \\
\hline $20-30$ & BG, F & \\
\hline $30-40$ & F & \\
\hline $40-50$ & BG & \\
\hline $50-60$ & Clay & \\
\hline $60-70$ & & \\
\hline \multicolumn{3}{|c|}{ Key: WW-whiteware; AqG-aqua glass; } \\
BG-brown glass; CG-clear glass; \\
SN-square nail; BU-button; F-fauna \\
\hline
\end{tabular}


on the clay at 39 cmbs. A bovine tooth and possible vertebra fragment were found at the same level.

ST 6: a thick whiteware rim sherd with coarse and very white paste (ca. 1850-present), and a ceramic button ([ca. 1850-1910] [Albert and Kent 1949:35]) were found in ST 6. The button is a sew-through, pie crust type, exhibiting four holes, a concave center, a molded rim with radiating lines, and a narrow ridge edge (Pool 1987:282). It is described as a White Fancy Pearl Agate in the 1895 Montgomery Ward Catalogue and matches closest with the line 14 measurement on the button scale; it likely fell off a shirt or blouse (Figure 9-53).

\section{Conclusions/Recommendations}

Based upon the ages of the artifacts found here, this may be one of the oldest historic occupation sites documented thus far on Camp Swift. Some artifacts likely date before 1850, but most of them date between 1850 and 1900. Even though the architecture appears to be destroyed, the possibility of buried features and the age of the site warrants further work to determine if the site is eligible for nomination to the NRHP. CAS recommends three 1-x-1-m units to search for intact 19th century deposits.

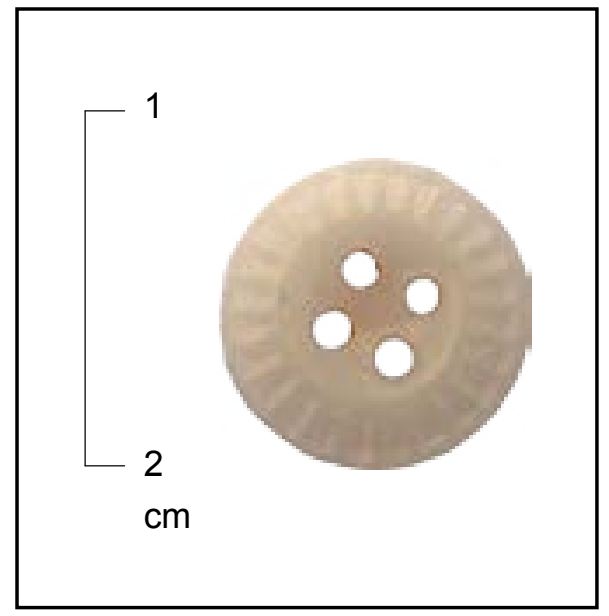

Figure 9-53. White Fancy Pearl Agate button from a shirt or blouse.

\section{BP773}

\section{Description}

41BP773 (Figures 9-54 and 9-55) is a historic farmstead. Only scattered bricks and artifacts remain due to bulldozing activity during WWII. Pencil cacti, tall grasses, cedar, walnut, and oak trees are prevalent so that surface visibility was less than five percent in September 2005. The scattered artifacts and construction materials cover about $1,561 \mathrm{~m}^{2}$. An intermittent drainage courses along the western edge of the site. The site datum is marked with a nail and an aluminum tag in an oak tree.

\section{Levels of Work and Results}

The only items on the surface were red brick fragments. However, a variety of artifacts were found in five of six shovel tests excavated on the site (Table 9-10). They include:

Bottle Glass: aqua glass with medium to thick patina (ca. pre-1900); clear glass with amethyst hue (ca. 1880-1915); clear glass with pinkish hue (ca. 1880-1915); clear glass, molded design (ca. 1869-1920s); thick, dark brown glass (ca. pre-1900)

Metal: horse bit half (Figure 9-56), an "X C Plate Stiff Mount Driving Bit," sold for ten cents in the 1902 Sears and Roebuck Catalogue (1993:420) and the 1895 Montgomery Ward Catalogue (1969:338); spent .44 caliber rimfire bullet casing bearing a headstamp of "WR" "44", indicating it was manufactured by Winchester for commercial (non-military) use in a .44 caliber pistol, and was likely manufactured sometime between 1868 and 1890 (Logan 1959); square nails (cut with hammered heads) that were generally replaced by wire nails in the 1890s (Nelson 1968:1-10); unidentifiable rusted metal fragments 
Ceramics: stoneware sherd with salt glazed exterior and unglazed interior, a technique that generally predates 1850 (Greer 1999:180181); whiteware sherds with crackled surfaces from burning, soft, pinkish paste that suggests possibly a pre1900 era of manufacture

Bricks: fragmented, red, poorly fired; one whole brown, speckled, well made, similar in size and material to those made by Elgin Brick Company in the early 1900s (Steinbomer 1982)

Button: shell, two-hole, most popular between 1880 and 1920 , peaked in popularity around $1900 \quad$ (Pool 1987:277-293), a 22-line size appropriate for use on cloaks, jackets, or dresses (Sears, Roebuck and Co. 1993)

Fauna: burned, small, and fragmented faunal remains, likely deer

\section{Conclusions/ Recommendations}

The ages of the artifacts found here suggest a likely occupation period from around the last

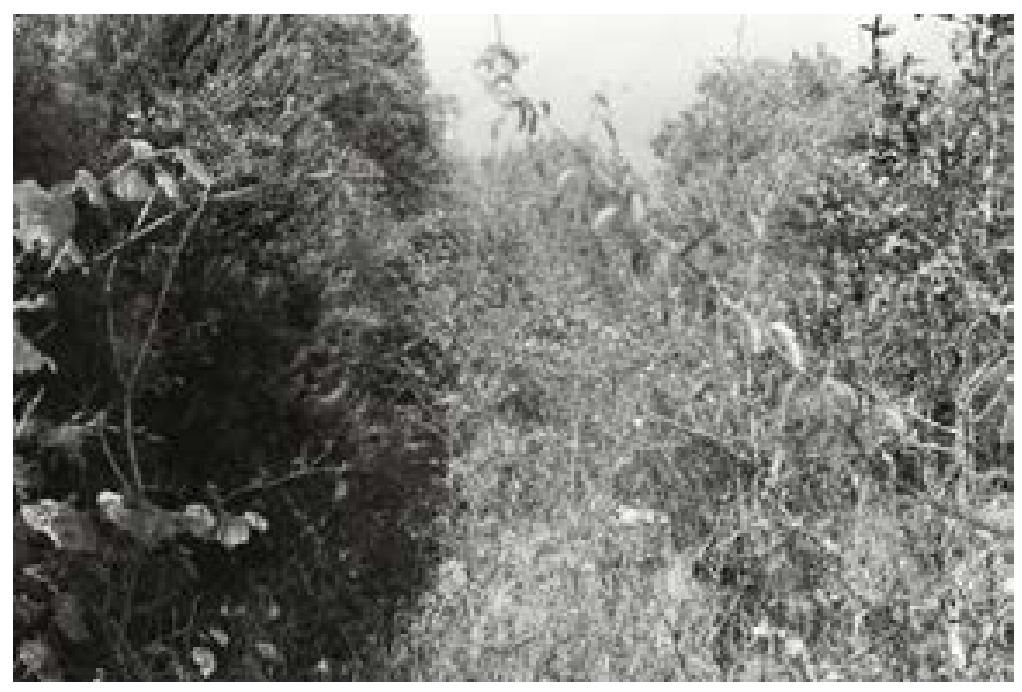

Figure 9-54. 41BP773 consists of scattered house remains; facing west.

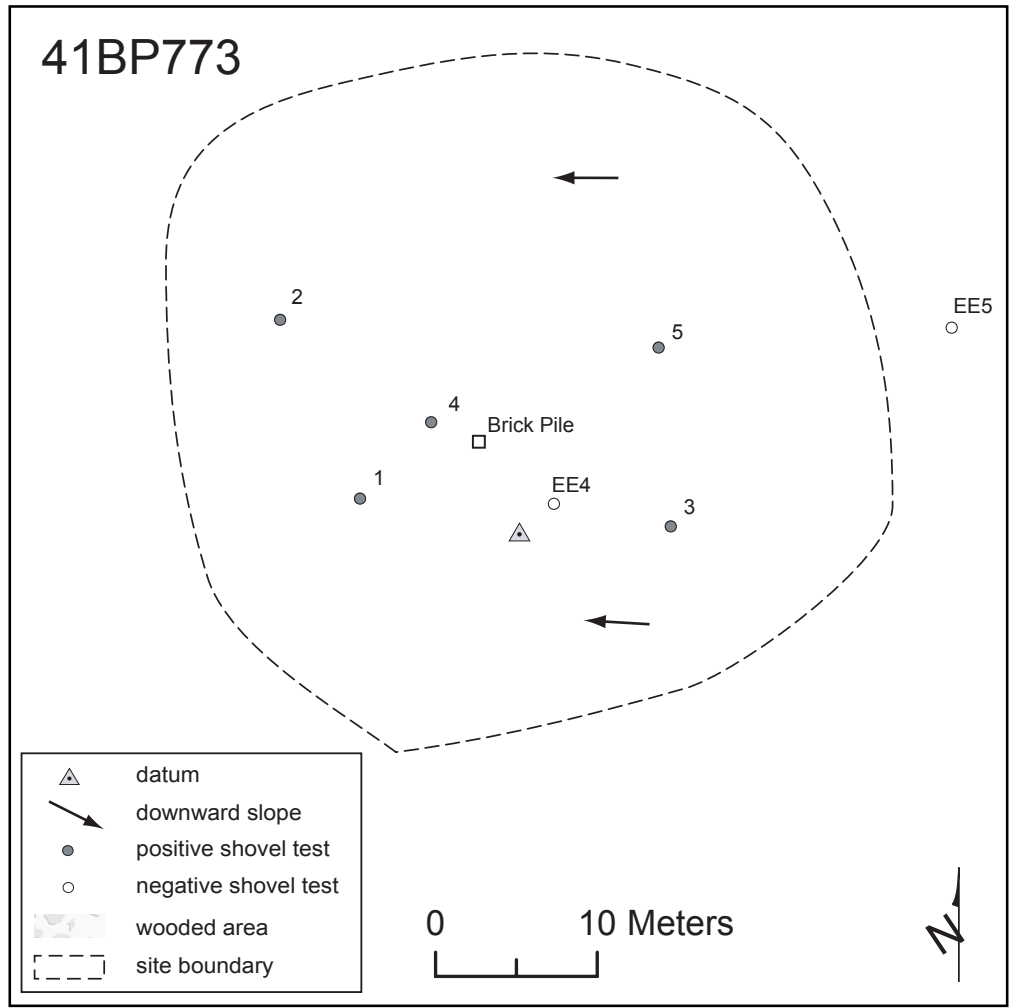

Figure 9-55. Site map of 41BP773. quarter of the nineteenth century through perhaps the first quarter of the twentieth century. However, the architecture is destroyed. minimal, no further work is recommended, and it is not eligible for nomination to the NRHP. 
Table 9-10. 41BP773 positive shovel test results.

\begin{tabular}{|c|c|c|c|c|c|}
\hline $\begin{array}{c}\text { Depth } \\
\text { (cmbs) }\end{array}$ & ST 1 & ST 2 & ST 3 & ST 4 & ST 5 \\
\hline $0-10$ & & & CG & CG, Br & CG \\
\hline $10-20$ & & WW, AqG, F & M & AqG, CG, Br, 2 SN & AG, CG \\
\hline $20-30$ & AqG & & CG & WW, CG, 2 Br, M, SN & SW, CG, RS \\
\hline $30-40$ & & Clay & & WW, CG, M, BU & SN \\
\hline $40-50$ & & & & Clay & Clay \\
\hline $50-60$ & & & Clay & & \\
\hline $60-70$ & Clay & & & & \\
\hline $70-80$ & & & & & \\
\hline \multicolumn{6}{|l}{ Key: SW-stoneware; WW-whiteware; AG-amber glass; AqG-aqua glass; BG-brown glass; } \\
CG-clear glass; Br-brick; M-metal; SN-square nail; RS-rifle shell; BU-button; F-fauna
\end{tabular}

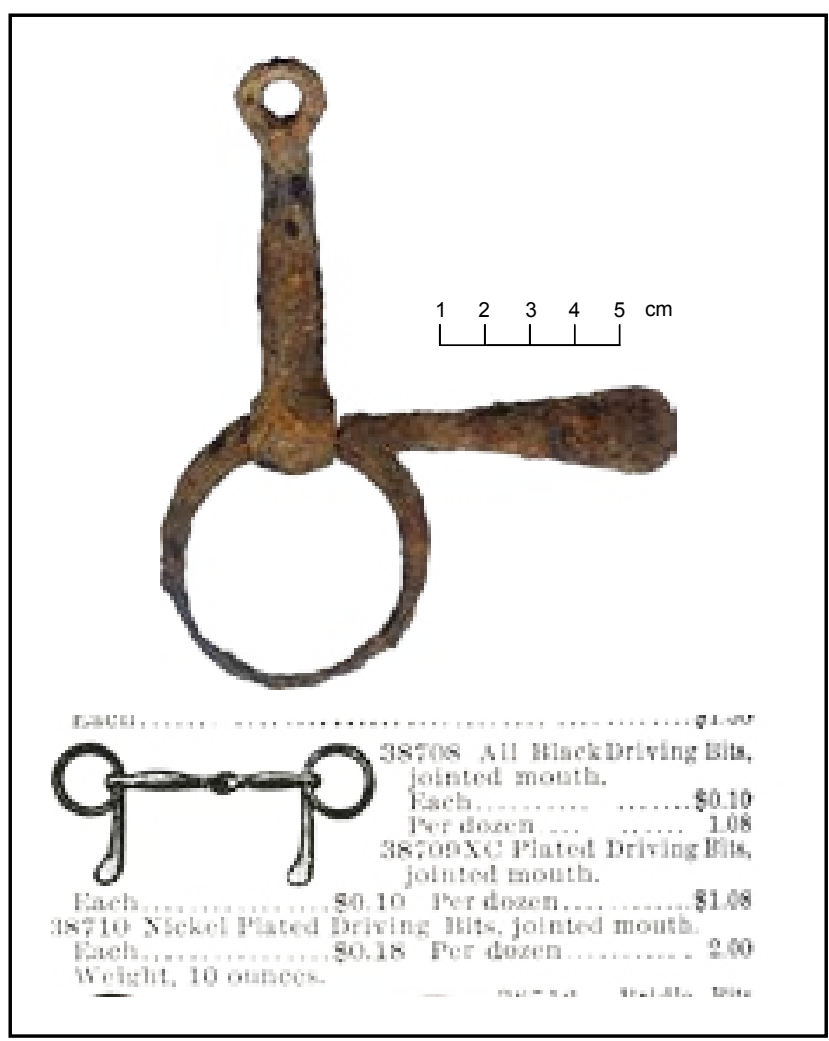

Figure 9-56. Horse bit half from 41BP773, along with replicated advertisement from 1895 Montgomery Ward Catalogue.

\section{BP775}

\section{Description}

The bulldozed remains of a house site with numerous cans and bottles are designated as 41BP775 (Figures 9-57 and 9-58). It was discovered while walking to one of the designated survey areas. The area had been recently cleared of cedar trees, and numerous push piles and deep ruts caused by tracked vehicles were common. Otherwise, pencil cacti, tall grasses, and oak trees are prevalent. The scattered artifacts and construction materials cover about $2,049 \mathrm{~m}^{2}$, with much of the trash washing down a small gully. Oak Hill Road runs $50 \mathrm{~m}$ north of the site. A nail and aluminum tag marking the site datum were attached to an oak tree $15 \mathrm{~cm}$ in diameter. This site is on land owned by Uriah Foster before the government acquired his land. Although 41BP803 (discussed below), a house site about $150 \mathrm{~m}$ to the southwest, is on the same tract of land, the artifacts suggest that 41BP803 was occupied earlier than this site.

\section{Levels of Work and Results}

Surface artifacts included approximately two dozen rusted tin cans, two 3-dot brown snuff bottles, 11 clear glass screw top bottles that had held condiments or liquor, four clear glass Mason-style jars, numerous broken clear glass jars, a brown glass bottle, and numerous red brick fragments. Archaeologists noted that all of the clear glass bottles exhibited no distinct hue, 


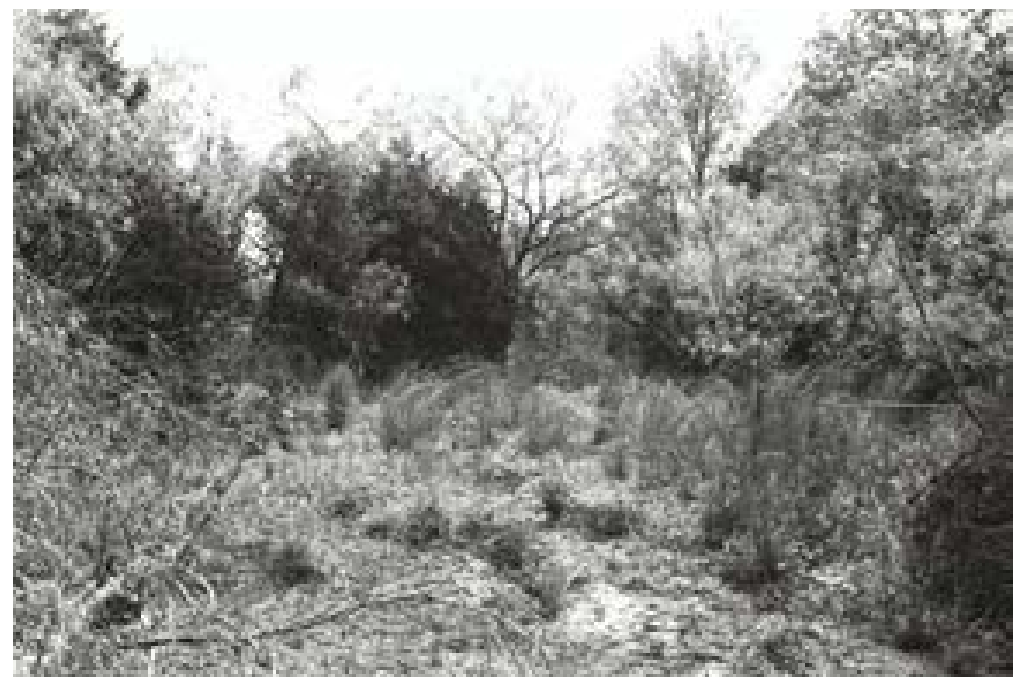

Figure 9-57. 41BP775 may be the house remains of Uriah Foster; facing west.

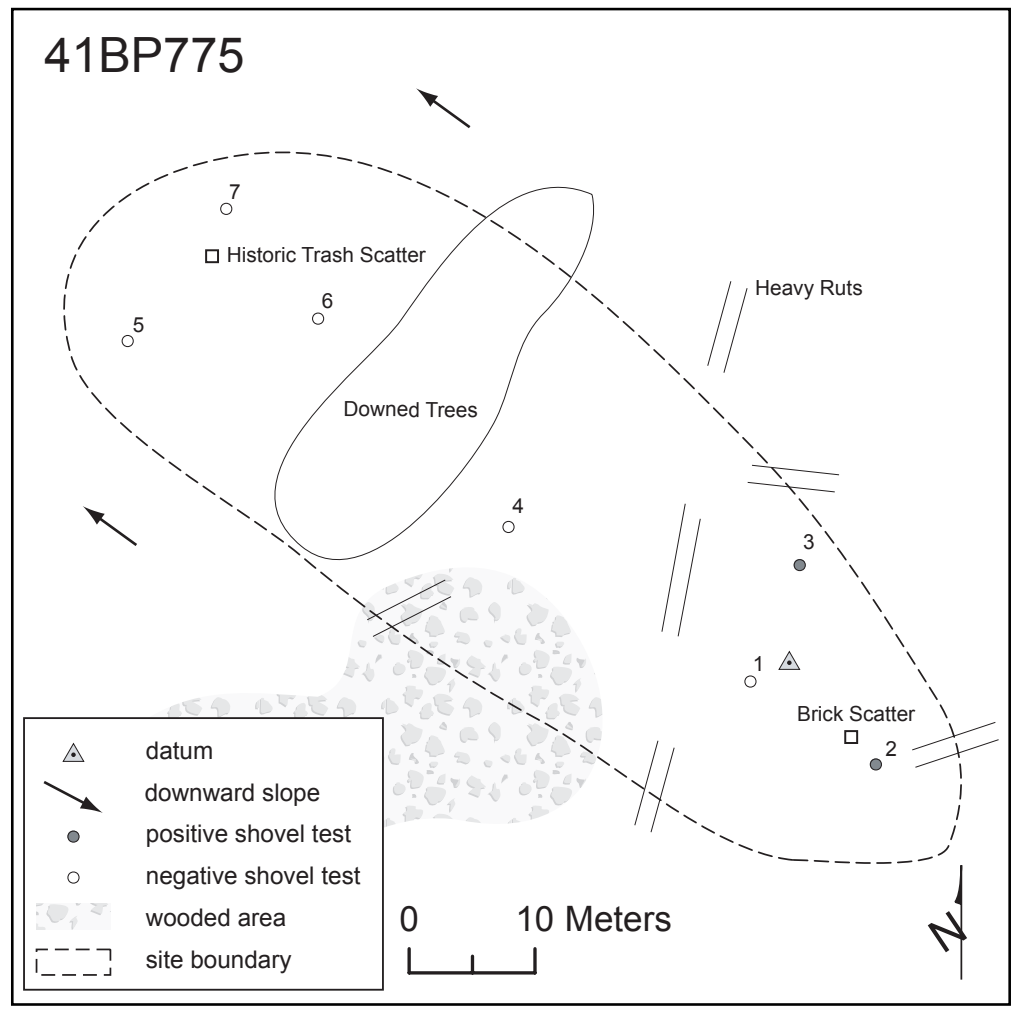

Figure 9-58. Site map of 41BP775.

were of the screw-top type, and some still had the plastic cap on them. The clear glass bottles with screw tops and plastic caps suggest a post1930 occupation. The average depth to clay in the seven shovel tests dug on the site was 13 cmbs.
Two of seven shovel tests dug on the site contained artifacts. Red brick fragments were found in ST 2, and unidentifiable metal fragments were in ST 3.

\section{Conclusions/ Recommendations}

According to Fay Pannell (personal communication 8 February 2006), this house was occupied by Uriah Foster before the government acquired the property in 1942. She thought that perhaps Albert Cottle lived there before Uriah Foster. The artifacts can be used to suggest a mid-20th century occupation. The architecture is destroyed and the general condition of the site is highly disturbed. Thus, the research value of this site is minimal, and it is not eligible for nomination to the NRHP.

\section{$41 B P 776$}

\section{Description}

This site contains both a prehistoric and a historic component (Figures 9-59 and 9$60)$. The prehistoric component is confined to the southern portion of the site and has been described in Chapter 7: New Prehistoric Component Sites. The historic component lies on the northern, elevated portion of the site. The remains of a house site occupation primarily consist of scattered ceramics, bottle glass, and dinnerware glass covering approximately $13,000 \mathrm{~m}^{2}$. The only evidence of construction found was a wrought 
iron nail and a window glass shard. The area has apparently been cleared in the past, but is now densely overgrown with cedars, mesquites, hackberries, chinaberries, prickly pear cacti, Virginia creepers, bull nettles, grapevines, poison ivy, and tall grasses. Surface visibility when CAS documented this site in September 2005 was less than five percent. The 69-acre tract where this house was located once belonged to a Mr. Hood and others in 1942, but Fay Pannell (personal communication 8 February 2006) indicated that they likely did not live on the property at that time. The site datum is marked with a nail and aluminum tag on an oak tree 25 $\mathrm{cm}$ in diameter.

\section{Levels of Work and Results}

A whiteware ceramic sherd was the only historic item observed on the surface. Seventeen of the 25 shovel tests excavated on the site were positive. Historic artifacts were recovered from nine of the 17 positive shovel tests (Table 9-11). Clear glass bottle shards with amethyst and amber hues (ca. 1880-1930) were found in two shovel tests, light green glass (pre-1900) was recovered from three shovel tests, a milk glass shard (ca. 1870s to the mid-twentieth century) (Lindsey 2005) was recovered from ST 3, and amber glass (pre-1900) was found in ST Q8. The undecorated whiteware found on the surface and

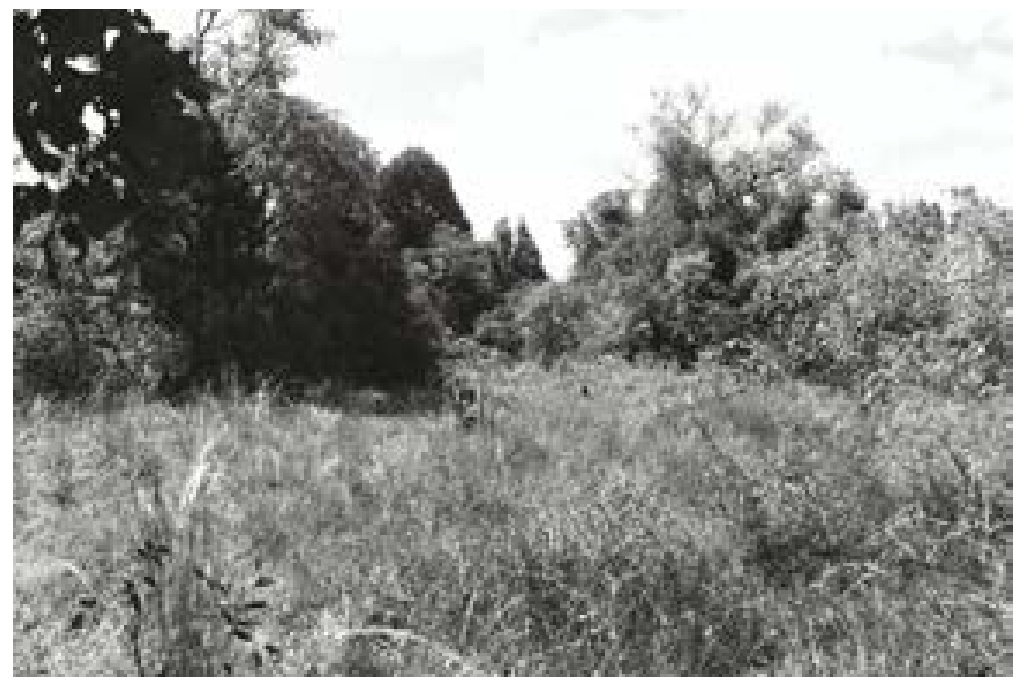

Figure 9-59. 41BP776 is a bulldozed house site; facing south.

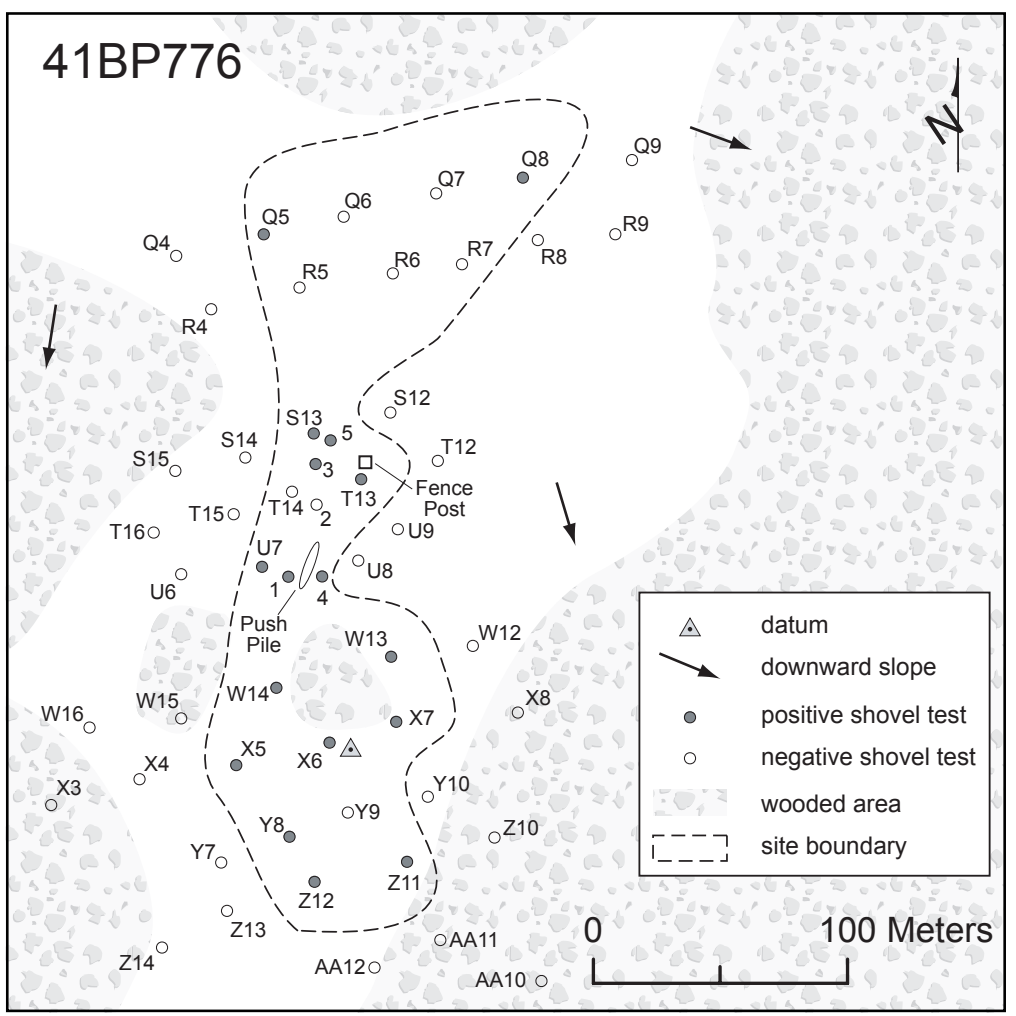

Figure 9-60. Site map of 41BP776.

in three shovel tests could date to as early as 1850 through the present. The hammered iron nail with a wrought head nail found in ST 4 implies pre-1900 construction (Nelson 1968:1-10). 


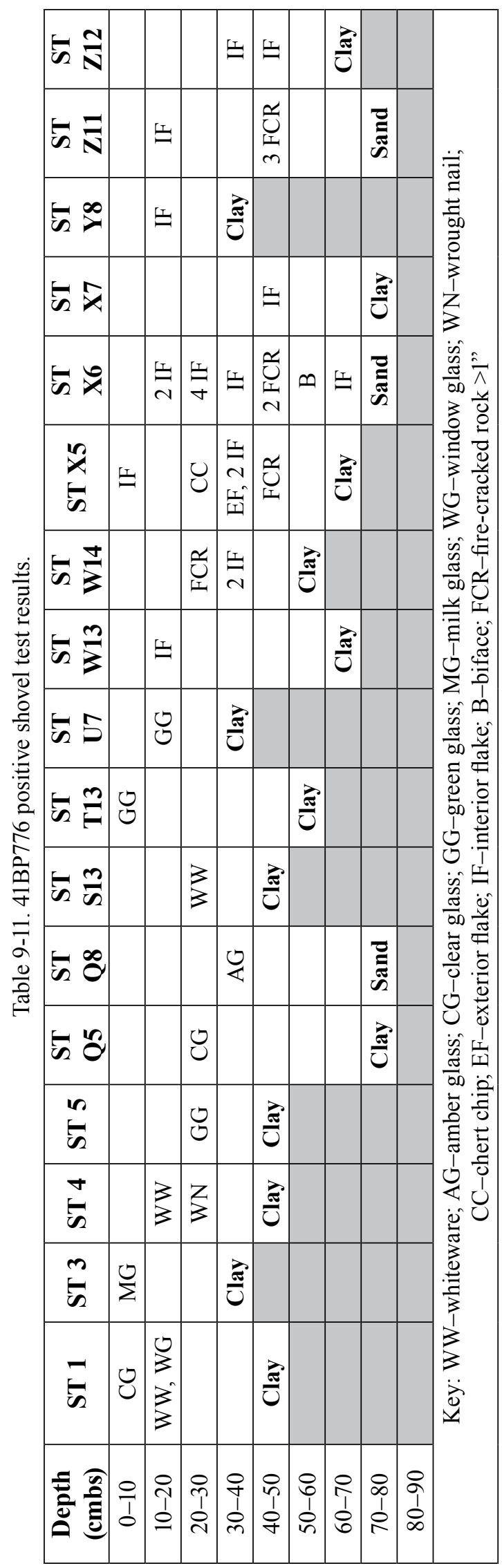

\section{Conclusions/Recommendations}

The artifact ages suggest that the house was occupied before 1900 and possibly through 1930 . The surrounding 69 acres were owned by Mr. Hood and others in 1942, but it is unknown who occupied the house before then. However, the architecture is destroyed, much of the surface has been highly disturbed, and the artifacts are mixed. Therefore, the research value of the site's historic component is minimal and it is not eligible for nomination to the NRHP.

\section{BP784}

\section{Description}

An overgrown depression believed to be a possible well led to the discovery of this farmstead site (Figures 9-61 and 9-62). A subsequent surface inspection and shovel tests indicated the site was spread over approximately $8,961 \mathrm{~m}^{2}$ of an upland knoll. The historic artifacts are mixed with a prehistoric component, discussed in Chapter 7: New Prehistoric Component Sites. The area has been extensively disturbed by earth moving equipment, with numerous push piles, treefalls, and animal burrows present. It is overgrown with mesquite, oak, cedar, and elm trees, along with cacti, beautyberries, poison ivy, assorted shrubs, and tall grasses. The site datum is marked with a nail and an aluminum tag on a 15 -inch diameter oak tree.

\section{Levels of Work and Results}

A red brick, a yellow brick with a painted face, and a clear glass shard were observed on the surface. Based upon shovel tests, it appears the house was located in the vicinity of a mott of large elm and oak trees around STs 5-8 (see Figure 9-62). Although the shallow clays and knoll setting seem an unlikely place to dig a well, the depression and dense secondary vegetation in and around it are typical of filled-in wells frequently seen on Camp Swift. 
Of the 16 shovel tests excavated within the boundaries of the site, 11 were positive. Historic artifacts were found in five of the 11 positive shovel tests (Table 9-12). Clear glass bottle shards with amethyst hue and shards with no hue (ca. 1880present) were found in four shovel tests, and cobalt blue glass shards (ca. 1840s-1930s) was recovered from ST 8. A thin, clear lantern glass shard from ST 8 could date from around 1864 (Woodhead et al. 1984), but kerosene lanterns were used through the 1930s at Camp Swift (Abner C. Scott, personal communication January 2002). A round nail found in ST 8 implies post-1890 construction (Nelson 1968:1-10). Other nail fragments were rusted beyond type recognition, and other metal fragments were unidentifiable. A yellow brick fragment was found in ST 6. Finally, a pressmolded relief whiteware stove tile with a brown to butterscotch majolica glaze was found in ST 7. Although only $1 / 4$ of the fragmented circular piece was found, it has the partial profile of a woman (Figure 9-63). The whole piece would have measured $4 \frac{1}{4}$ inches in diameter. Such items were used to decorate Victorian parlor stoves in the late 1800 s (Karen Michelle Tiles 2005).

\section{Conclusions/Recommendations}

The artifact ages presume a mode occupation period of around 1880 through 1920. However, the architecture is destroyed and the artifacts 
Table 9-12. 41BP784 positive shovel test results.

\begin{tabular}{|c|c|c|c|c|c|c|c|c|c|c|c|}
\hline $\begin{array}{c}\text { Depth } \\
\text { (cmbs) }\end{array}$ & ST 1 & ST 4 & ST 5 & ST 6 & ST 7 & ST 8 & ST 9 & $\begin{array}{c}\text { ST } \\
\text { QQ7 }\end{array}$ & $\begin{array}{c}\text { ST } \\
\text { QQ8 }\end{array}$ & $\begin{array}{c}\text { ST } \\
\text { RR11 }\end{array}$ & $\begin{array}{c}\text { ST } \\
\text { SS14 }\end{array}$ \\
\hline $0-10$ & & FCR & & $\begin{array}{c}\text { CG, } \\
\text { Br, M }\end{array}$ & WW & $\begin{array}{c}\text { CG, } \\
\text { LG, RN }\end{array}$ & CG & IF & IF & & IF \\
\hline $10-20$ & & & IF & M, IF & & M & & & & & \\
\hline $20-30$ & & Clay & BG & M & & CBG & & IF & Clay & IF & Sand \\
\hline $30-40$ & EF & & CG & Clay & Clay & CBG & & Clay & & Clay & \\
\hline $40-50$ & & & & & & Clay & & & & & \\
\hline $50-60$ & & & Clay & & & & Clay & & & & \\
\hline $60-70$ & Clay & & & & & & & & & & \\
\hline $80-90$ & & & & & & & & & & \\
\hline \multicolumn{7}{|c|}{ Key: WW-whiteware; BG-brown glass; CBG-cobalt blue glass; CG-clear glass; LG-lantern glass; } \\
Br-brick fragment; M-metal; RN-round nail; \\
EF-exterior flake; IF-interior flake; FCR--fire-cracked rock >1”
\end{tabular}

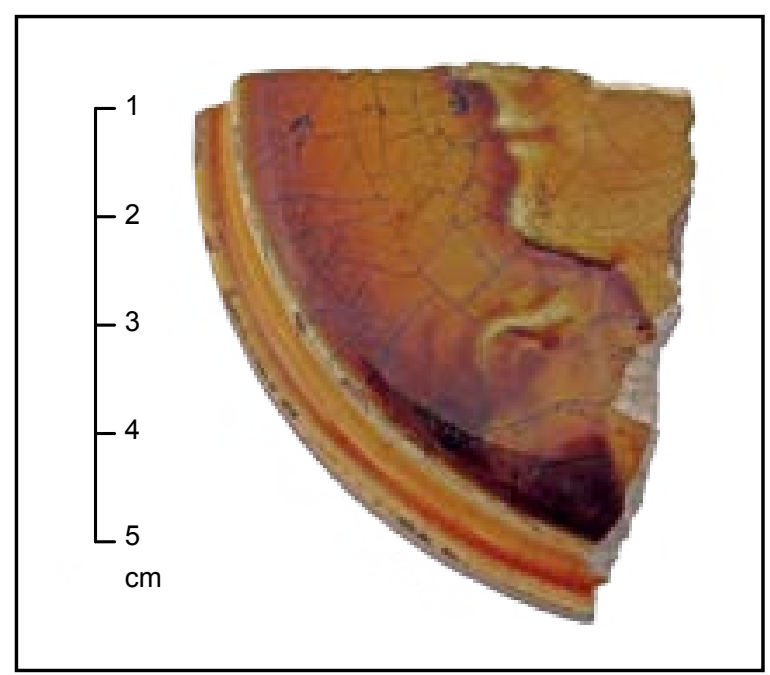

Figure 9-63. Parlor stove decorative tile piece.

\section{BP785}

\section{Description}

Sandstone foundation remains and scattered artifacts from a house site constitute 41BP785 (Figures 9-64 and 9-65). The remains cover about a $550-\mathrm{m}^{2}$ area. Mr. Hood and others owned 120 acres in this area (Bastrop County 1929). The site is located in a semi-open lower footslope now covered with shrubs and grasses, beautyberry, Virginia creeper, poison ivy, and blackberries amidst oaks, cedars, and elms. The site has been bulldozed and small push piles are present. The site datum is marked with a nail and an aluminum tag on a 4-inch diameter oak tree.

\section{Levels of Work and Results}

A cluster of six hand-hewn sandstone slabs likely represent a small house (see Figure 9-65). The only item seen on the surface was a \#3 metal washtub. All six shovel tests placed on the site were positive (Table 9-13). Clear glass bottle shards with amethyst and amber hue (ca. 1880- 


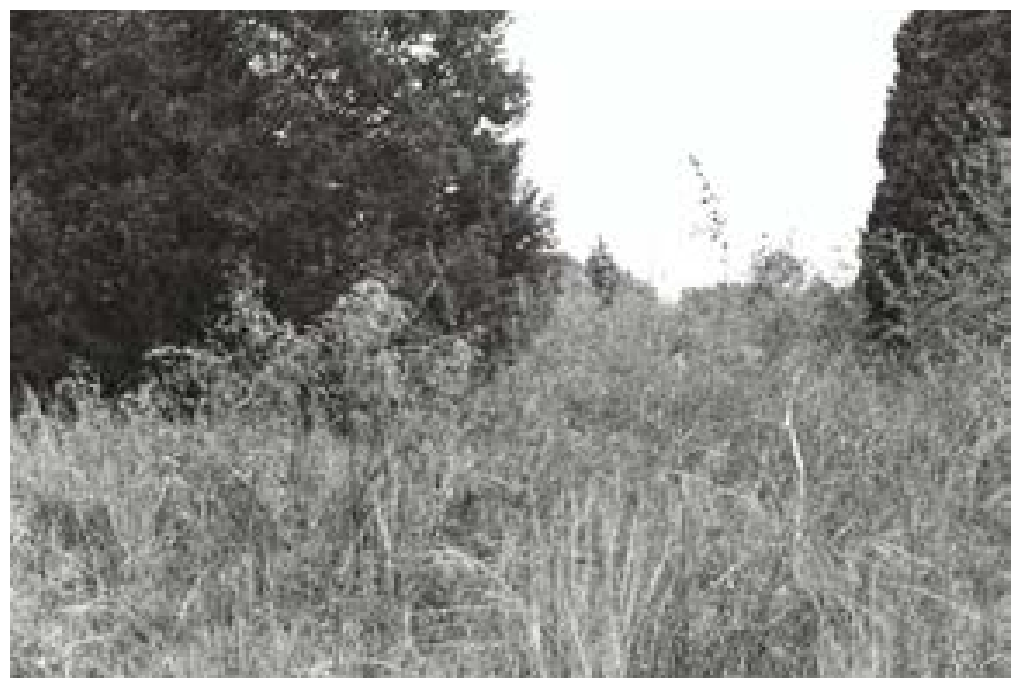

Figure 9-64. The remains of a house site constitute 41BP785; facing northeast.

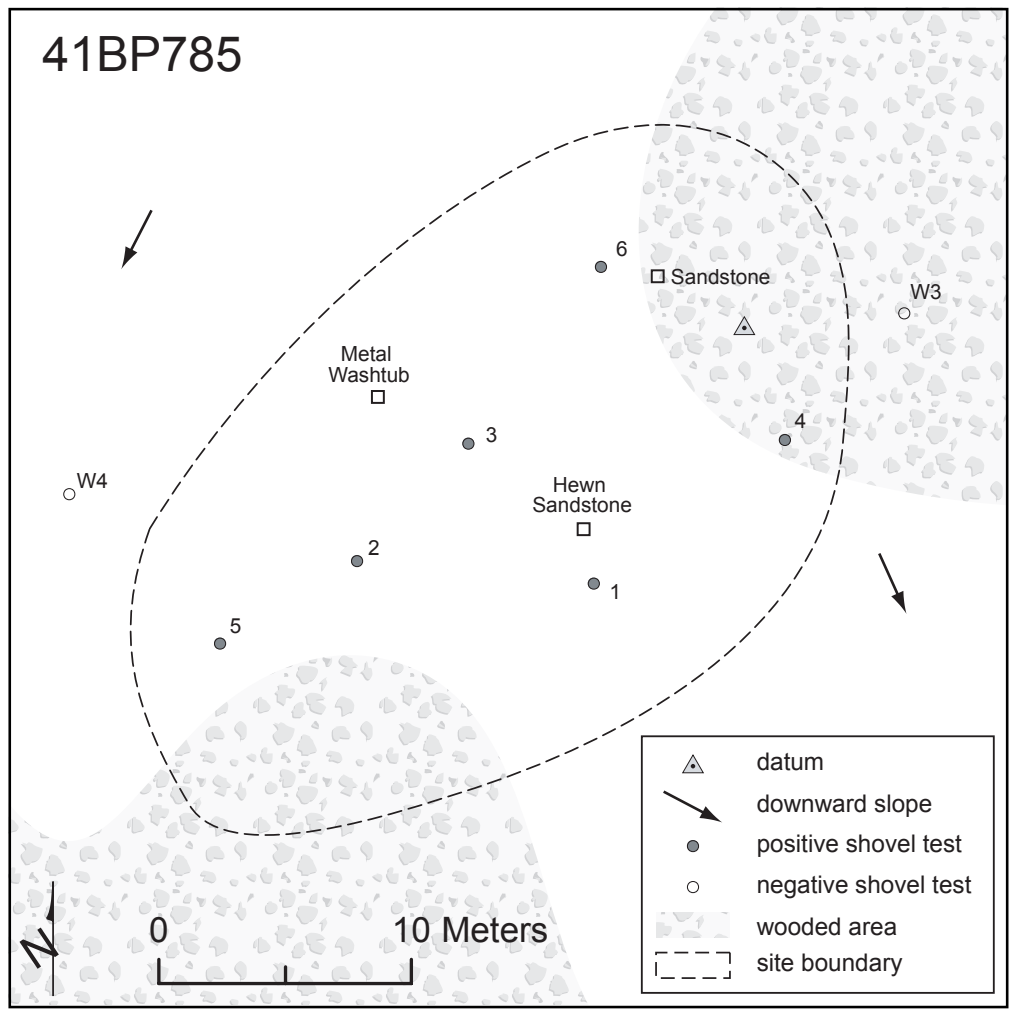

Figure 9-65. Site map of 41BP785.

1930) and shards with no hue (ca. 1880-present) were found in five of six shovel tests, and a cobalt blue glass shard (ca. 1840s-1930s) was recovered from ST 2. Thin and clear lantern glass shards in STs 2 and 3 could date from around 1864 (Woodhead et al. 1984), but as stated above (41BP784), kerosene lanterns were used through the 1930s at Camp Swift (Abner C. Scott, personal communication January 2002). An iron cooking pot rim fragment was in ST 2, and a small clock gear was in ST 4. The twoholed shell button type found at $0-10 \mathrm{cmbs}$ in ST 1 was most popular between 1880 and 1920, with a peak in popularity around 1900 (Pool 1987:277-293). It is a 22-line size appropriate for use on cloaks, jackets, or dresses (Sears, Roebuck and Co. 1993). Finally, a whiteware teacup handle (ca. 1850-present) was also found in ST 3.

\section{Conclusions/ Recommendations}

When asked about the Hoods, Fay Pannell (personal communication 8 February 2006) stated that no Hoods lived there in the 1920s through 1942. She thought that they must have owned the land for investment only. The artifact ages presume a mode occupation period of around 1880 through 1920. However, in its present bulldozed and disturbed condition, and with the lack of preserved architectural features considered, the research value of this site is minimal and it is not eligible for nomination to the NRHP. 
Table 9-13. 41BP785 positive shovel test results.

\begin{tabular}{|c|c|c|c|c|c|c|}
\hline $\begin{array}{l}\text { Depth } \\
\text { (cmbs) }\end{array}$ & ST 1 & ST 2 & ST 3 & ST 4 & ST 5 & ST 6 \\
\hline $0-10$ & $\mathrm{CG}$ & $\begin{array}{l}\text { LG, } \\
\text { BU }\end{array}$ & $\begin{array}{l}\text { WW, } \\
\text { LG }\end{array}$ & & $\begin{array}{l}\mathrm{AG} \\
\mathrm{CG}\end{array}$ & \\
\hline $10-20$ & & $\begin{array}{c}\text { CBG, } \\
\mathrm{M}\end{array}$ & $\mathrm{CG}$ & & Clay & $\mathrm{CG}$ \\
\hline $20-30$ & & Clay & $\mathrm{CG}$ & $M$ & & \\
\hline $30-40$ & Clay & & Clay & Clay & & \\
\hline $40-50$ & & & & & & Clay \\
\hline $50-60$ & & & & & & \\
\hline \multicolumn{7}{|c|}{$\begin{array}{l}\text { Key: WW-whiteware; AG-amber glass; CBG-cobalt blue glass; } \\
\text { CG-clear glass; LG-lantern glass; M-metal; BU-button }\end{array}$} \\
\hline
\end{tabular}

\section{BP791}

\section{Description}

This farmstead is situated between two intermittent drainages in a large, previously cleared field that is now overgrown with young cedar, mesquite, hackberry, oak, greenbrier, and cactus (Figure 9-66). Joe Owen owned the surrounding 200 acres from 1929 until the government acquired it, but he never lived on it (Fay Pannell, personal communication 6 February 2006). Three separate scatters of sandstone slabs likely represent three different structures (Figure 9-67). A barbed wire enclosure and wood cattle chute are located $30 \mathrm{~m}$ to the northeast of the northernmost sandstone foundation remains. The site datum is marked with a nail and an aluminum tag on a 4-inch diameter oak tree.

\section{Levels of Work and Results}

A larger depression with red brick and sandstone scattered around it on the southern portion of the site may represent either a well or cistern. The main house was likely where a pile and smaller depression are now. An old barbed wire fence leads to the northeast toward a third sandstone scatter and a probable outbuilding. Beyond it to the northeast are the barbed wire enclosure and cattle chute. The enclosure and chute are in relatively good condition, with round nails and common twostrand wire with round barbs. The only artifact seen on the surface was an undecorated whiteware sherd. Of the nine shovel tests dug on the site, only ST 4 was positive. Unidentifiable metal fragments, olive green glass (pre-1900), and clear glass were recovered from ST 4 between 0 and 15 cmbs. The average depth to red clay was $11 \mathrm{cmbs}$.

\section{Conclusions/Recommendations}

The construction material in the fenced enclosure suggests that it was used from perhaps 1929 through the early 1940s, but the age of the house and outbuilding cannot be determined. In its present bulldozed and disturbed condition, the

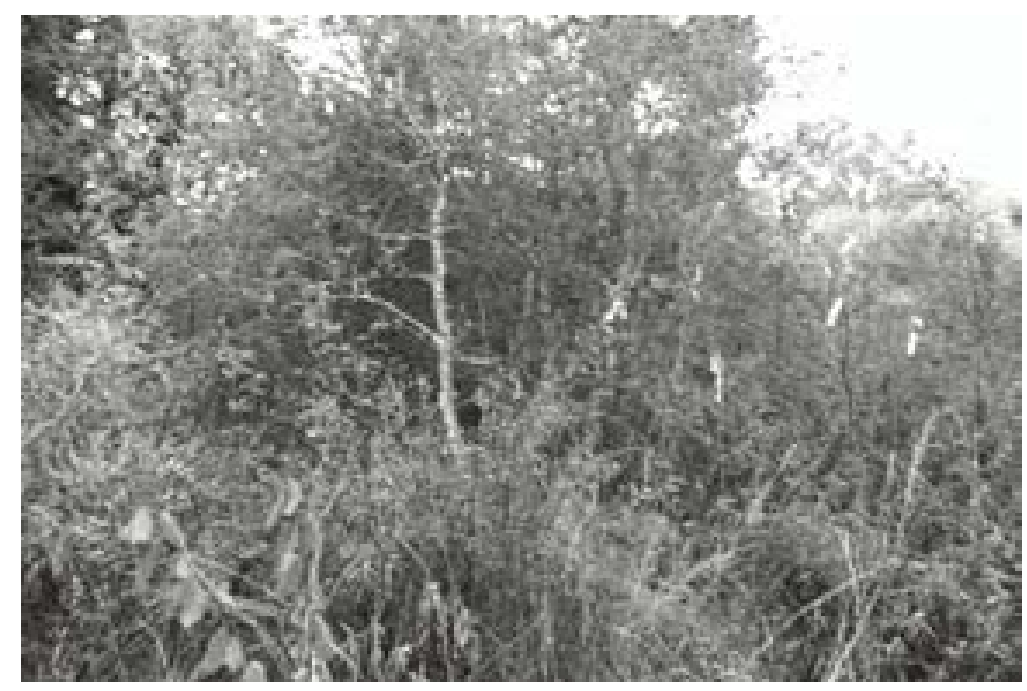

Figure 9-66. The remains of a farmstead on land owned by Joe Owens before it was acquired by the government in 1942 is designated as 41BP791; facing east. 


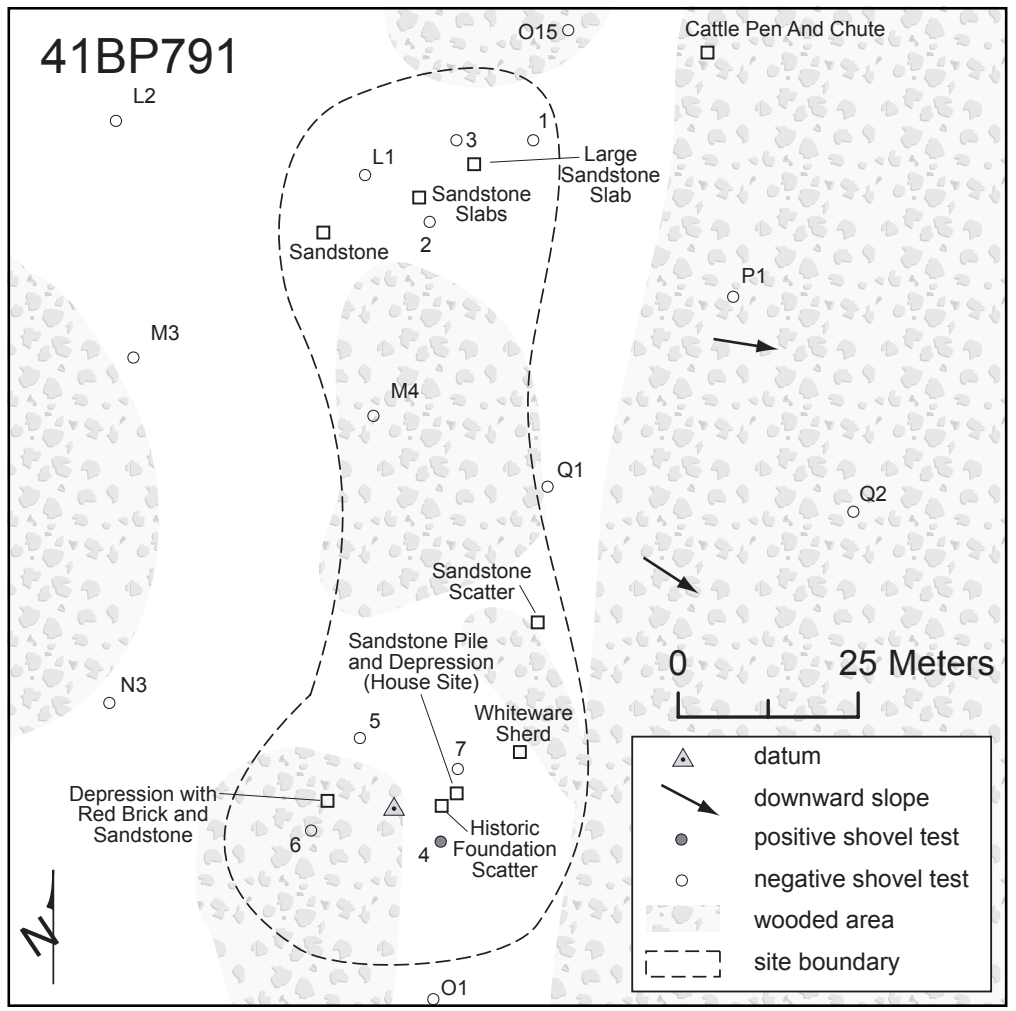

Figure 9-67. Site map of 41BP791.

research value of 41BP791 is minimal and it is not eligible for nomination to the NRHP.

\section{BP793}

\section{Description}

This barbed wire fence corral (Figures 9-68 and 969), which probably belonged to Minnie Shelton, is located $50 \mathrm{~m}$ northeast of Maneuver Road along a boundary line separating H. Washington's 111 acres and Minnie Shelton's 88 acres. It is fully overgrown with brush, secondary growth trees, weeds, and grasses. Large oaks anchor the southwestern and northeastern corners of this approximately 900-square-foot enclosure. The datum is marked with a nail and aluminum tag on facing northwest. an 8-inch diameter hackberry tree.

\section{Levels of Work and Results}

The overall condition of the posts and barbed wire suggest that it was used right up until the development of Camp Swift in 1942, and perhaps when the lands were leased for grazing in the 1950s and 1960s. Its only opening is in its northeastern corner. The wire on the corral is a common two-strand with both round and flat barbs.

\section{Conclusions/ Recommendations}

Although no artifacts were found that could associate the use of this corral to an approximated period, it can be inferred that it was used by either Minnie Shelton, or by others who leased the land in the 1950s and 1960s. Nevertheless, its research value to the history of the area is of minimal significance and it is not eligible for nomination to the NRHP.

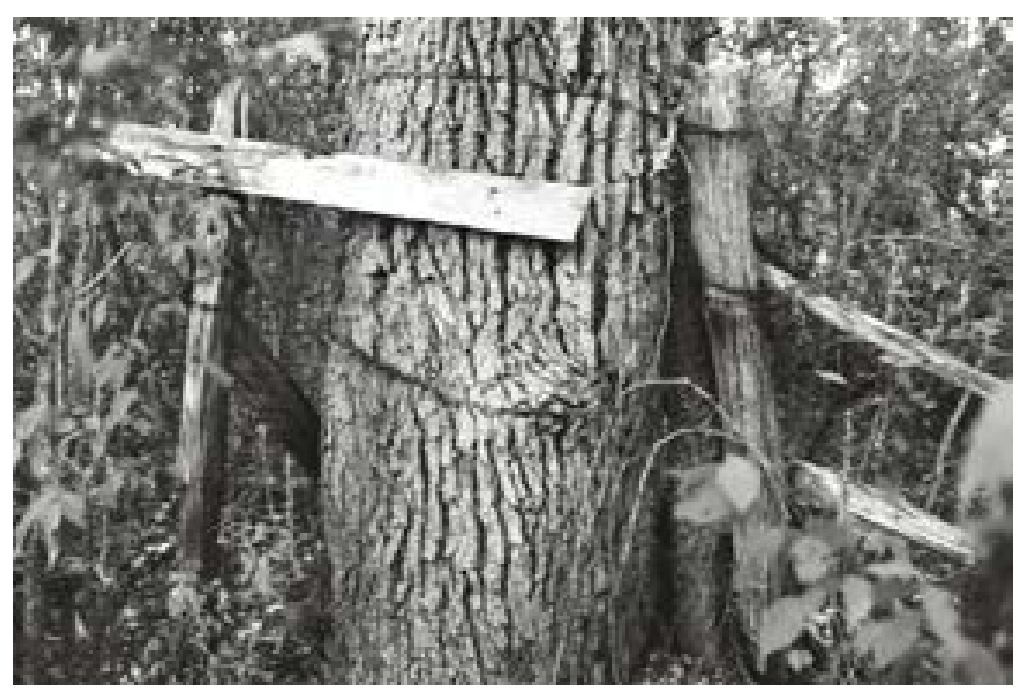

Figure 9-68. The remains of a barbed wire corral constitute 41BP793; 


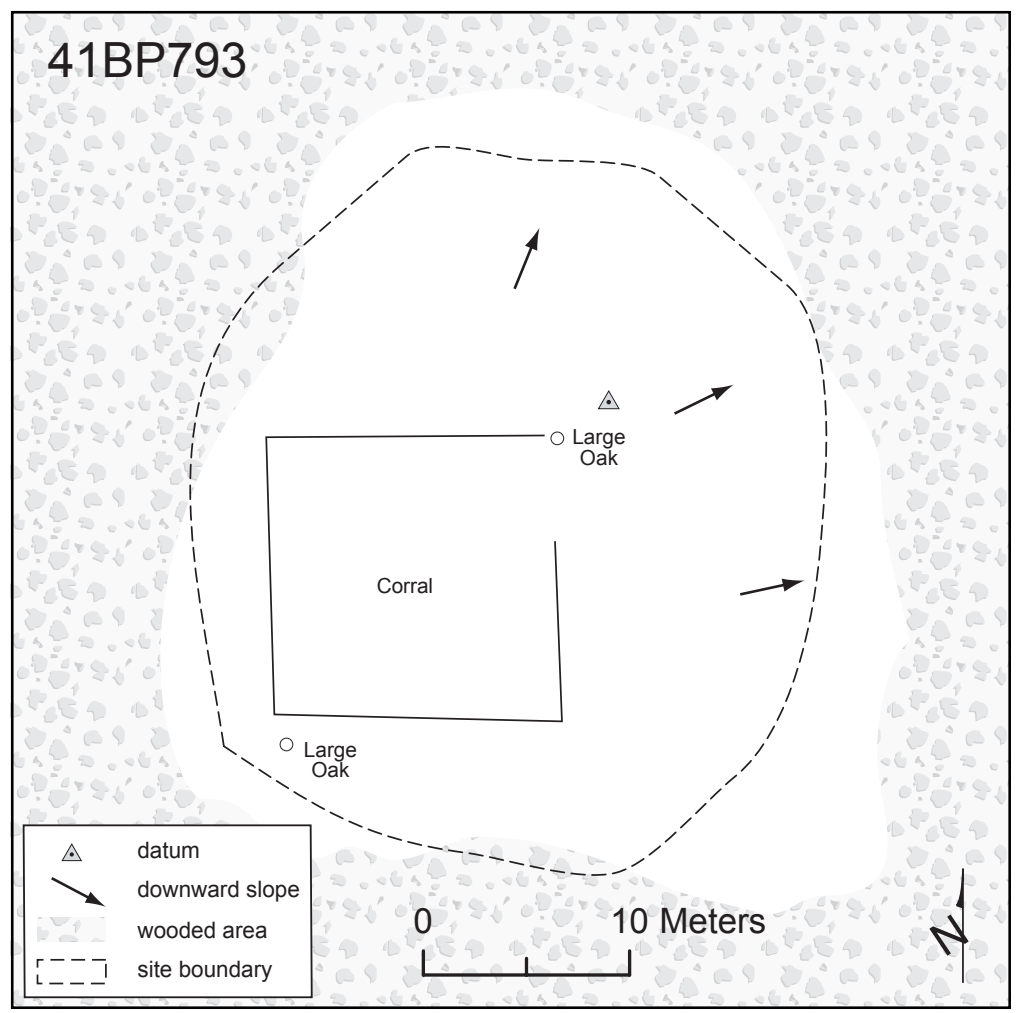

Figure 9-69. Site map of 41BP793.

\section{BP794}

\section{Description}

A barbed wire fence corral (Figure 9-70) $30 \mathrm{~m}$ west of Scott Falls Road is designated as 41BP794. It lies in the northeastern corner of a 111-acre tract that belonged to H. Washington (see 41BP795 discussion below). One portion of the fence extends to the edge of the road (Figure 9-71). The enclosure straddles a gully and covers 1,300 square feet. Oaks, cedars, elms, beautyberries, and shrubs and grasses have now over grown the site. The datum is marked with a nail and aluminum tag on a 24-inch diameter elm tree with barbed wire running through the middle of it.

\section{Levels of Work and Results}

Several sections of cedar posts remain at the site. An opening in the northeastern corner of the corral would have led to Scott Falls Road, while an opening in the southwest corner would have opened into $\mathrm{Mr}$. Washington's pastureland. Most barbed wire on the corral and fences was a common two-strand with both round and flat barbs. A very different type was found on the fence line leading west from the corral (see Figure 9-71). This is a Brock's Folded Metallic Strip with flat barbs, patented in 1884 (Clifton 1970). Although its patent date is relatively the same as most other types seen on Camp Swift, the Brock's type is rarely seen and is usually deeply imbedded within large oak or elm trees. Such is the case with this strand. It may represent the property line of Minnie Shelton, who owned the adjoining 88 acres. Four shovel tests were placed on the site but none of them contained artifacts.

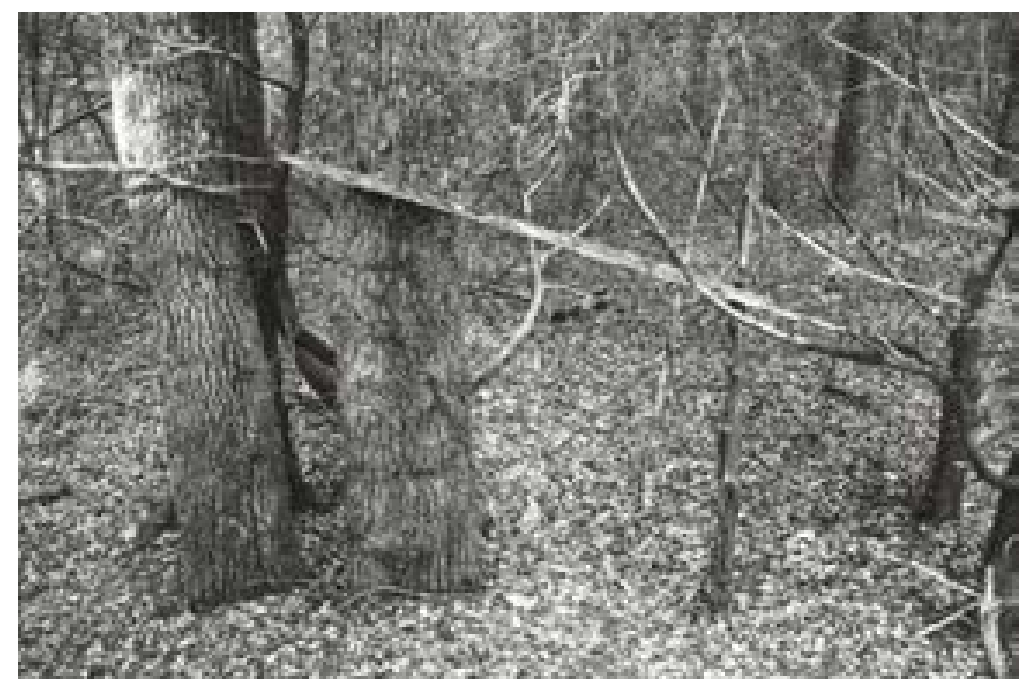

Figure 9-70. This barbed wire corral is 41BP794; facing northwest. 
FIGURE 9-71. REDACTED

Figure 9-71. Site map of 41BP794.

\section{Conclusions/Recommendations}

Although no artifacts were found that could associate the use of this corral to an approximated period, it can be inferred that it was used by Mr. H. Washington when he owned the property during the late 1800 s through about 1942. It was perhaps also used by others who leased land at Camp Swift in the 1950s and 1960s for cattle grazing. Nevertheless, its research value to the history of the area is of minimal significance and it is not eligible for nomination to the NRHP.

\section{BP795}

\section{Description}

A bladed road cuts through the farmstead remains of what may have been occupied by $\mathrm{H}$. Washington. A brick scatter probably represents the area where Mr. Washington's house was located (Figures 9-72 and 9-73). He picked the highest point on which to live, a knoll just inside the western property line of his 111 acres. The area now has numerous push piles and heavy machinery track ruts, and is overgrown with thick patches of prickly pear and pencil cactus amidst hackberries, chinaberries, oaks, cedars, and mesquites. The site datum is marked with a nail and an aluminum tag on a small mesquite tree. On the northeastern corner of Mr. Washington's property is a barbed wire fence corral (41BP794) some 550 meters away that he may have used in his farming and ranching occupation.

\section{Levels of Work and Results}

What was probably a twotrack leading to the house from Oak Hill Road is now a bladed firebreak road. No artifacts were found in the six shovel tests placed on the site, but artifacts observed on the surface (Figure 9-74) are spread across about a $4,100-\mathrm{m}^{2}$ area. An old row of fence posts mark Mr. Washington's western property boundary. Construction remains include sandstone slabs and poorly fired, broken red bricks. A barrel hoop, a metal pail the size of a milking pail, and unidentifiable metal fragments scattered throughout probably represent at least limited farming activities. Household items include the following:

- bedspring coils

- metal wash basin

- tin cans

- shallow, white enameled pan

- shallow blue and white enameled pan

- $\quad$ stoneware (Greer 1999): sherds with Bristol glaze interior and exterior (ca. 1920-1950); 


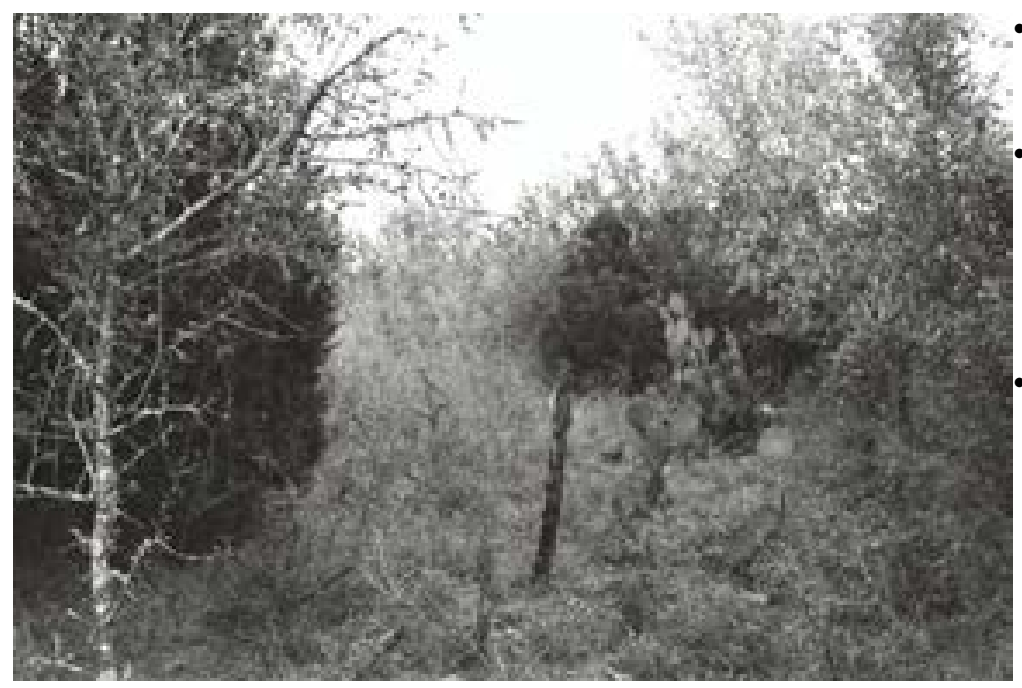

Figure 9-72. A lone fence post stands around the house that may have been occupied by $\mathrm{H}$. Washington; facing east.

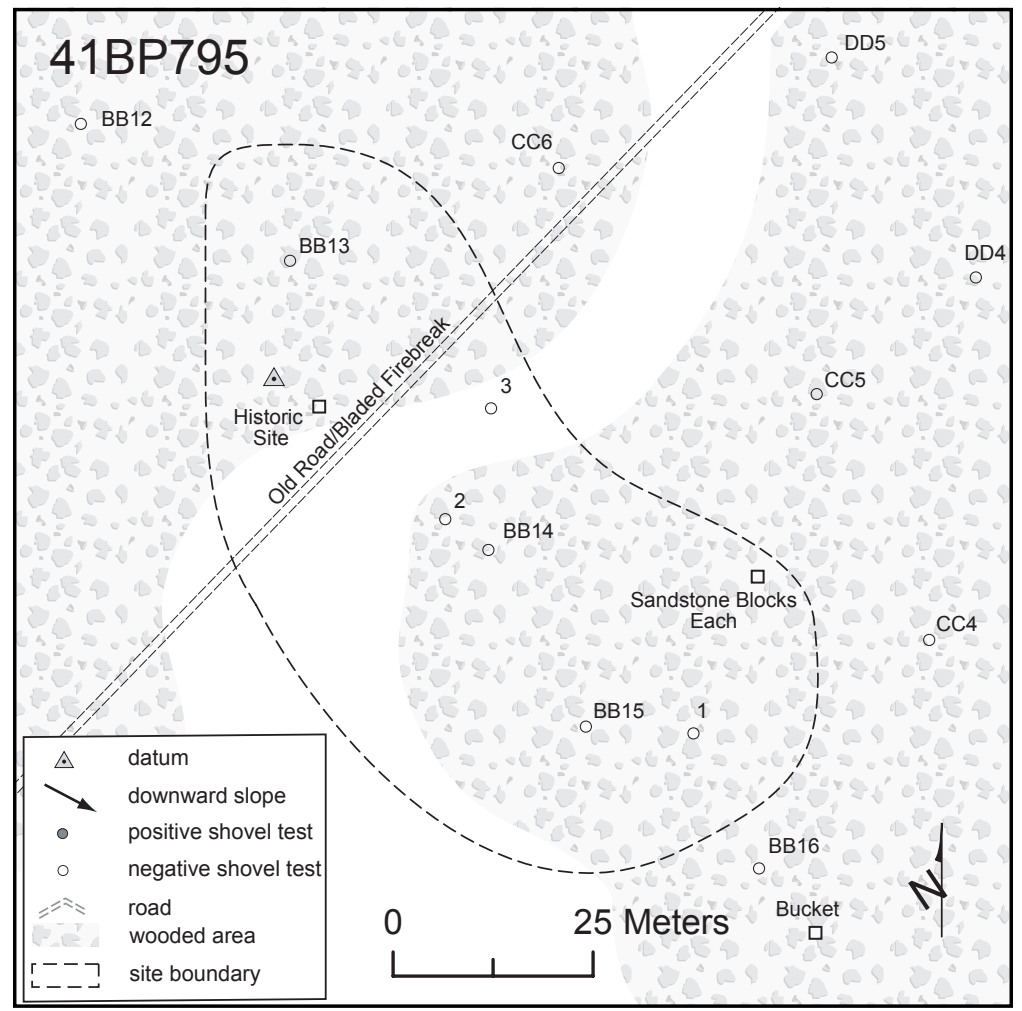

Figure 9-73. Site map of 41BP795. white enameled metal chamber pot

bottle glass (Munsey 1970): clear glass with light patina, stopper type neck (late 1800s); thick aqua lip shard (late 1800s)

bottle glass with maker's marks: Orange Crush soda bottle, clear glass, embossed ring and ribbed designs, manufactured in Bastrop, Texas ca. 1930s (Smith 1989); clear glass bottle base manufactured by HazelAtlas Glass Company sometime between 1930 and 1964 (Munsey 1970:239); clear glass body shard manufactured by the Owens Glass Company's Alton, Illinois plant in 1933 (Lockhart 2004:3).

\section{Conclusions/ Recommendations}

The overall assessment of the ages of the artifacts and archival research suggest that this site was likely occupied from the late 1800s through about 1942 when the government assumed ownership. However, there is an absence of subsurface deposits, the site has since been bulldozed, and it has little, if any, research potential. Therefore, no further work is warranted and it is not eligible for nomination to the NRHP.

broken crock pot with Leon slip interior, Leon slip top half exterior, Bristol glaze bottom half exterior (ca. 1880-1920); broken crock pot with Leon slip interior and exterior (ca. 1875-1900) 


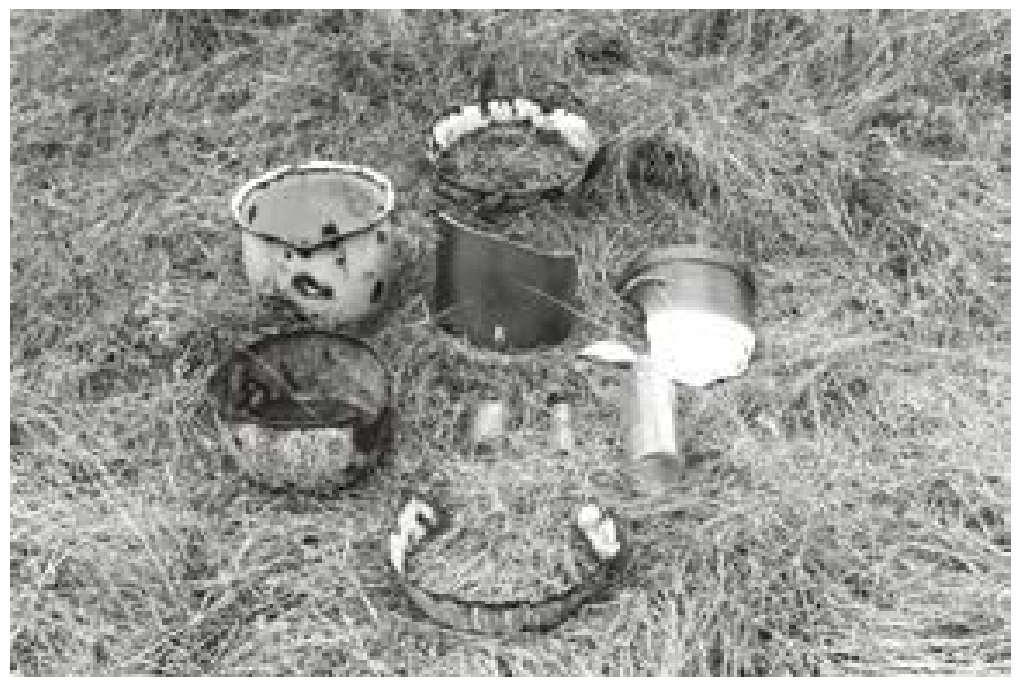

Figure 9-74. Selected artifacts from 41BP795.

\section{BP803}

\section{Description}

41BP803 consists of construction material, glass, and ceramics from a house site now scattered along two bladed trenches (Figures 9-75 and 9-76). The area has been intensively used for military training and red clay is either very near or on the surface. Push piles and hog wallows are common. CAS documented the site shortly after a controlled burn had been conducted over a large area around the site, and surface visibility was excellent. Only low brush, with a few scattered trees and sparse grasses existed during the October 2005 visit. The surface scatter covers about $1,712 \mathrm{~m}^{2}$, and lies $190 \mathrm{~m}$ south of Oak Hill Road. The nail and aluminum tag marking the site datum were attached to a mesquite tree on the north edge of the largest trench.

\section{Levels of Work and Results}

Shovel tests placed alongside the trenches and in the general area were all negative. Surface artifacts included a piece of lumber with a cut nail in it, a clear glass shard with a purple hue, a clear glass medicine bottle with no hue but a stopper type neck, red brick fragments, a single gold banded whiteware sherd, and a stoneware sherd with Leon slip interior and a salt glazed grey exterior. Modern machine cut nails could date from about 1835-1900 (Nelson 1968). Clear glass with a purple (amethyst) hue likely dates between 1880 and 1915, and clear glass medicine bottles with stopper type necks normally date before 1906 (Munsey 1970). The combination of a Leon slip interior and a salt glazed exterior on stoneware was popular from about 1850 to 1900. The gold, thin banded whiteware sherd is temporally out of context with the other artifacts and is likely from military activities in the late twentieth century.

\section{Conclusions/Recommendations}

Based upon the ages of the artifacts, this site was most likely occupied during the last quarter of the nineteenth century. Because extensive disturbance has occurred, its research value is minimal, no further work is warranted, and it is not eligible for nomination to the NRHP. 


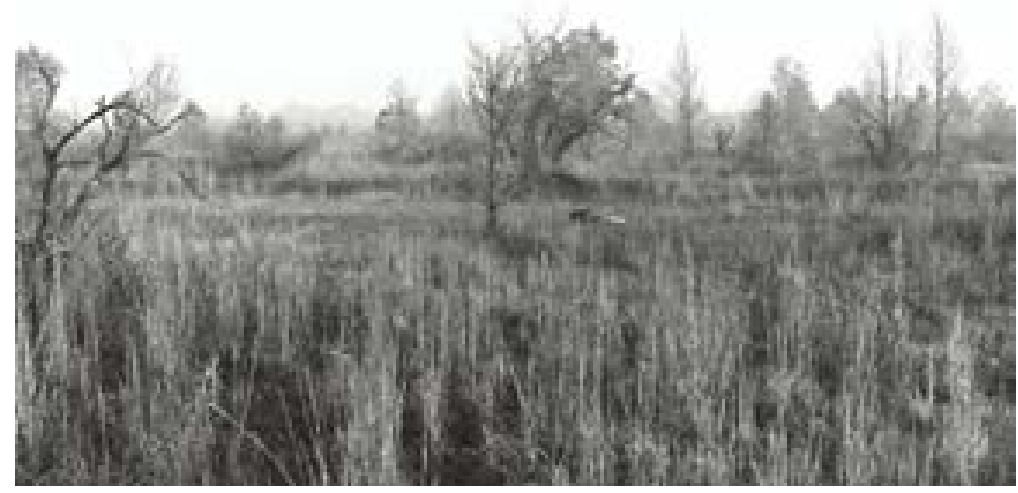

Figure 9-75. 41BP803 cosnsists of scattered house remains; facing north.

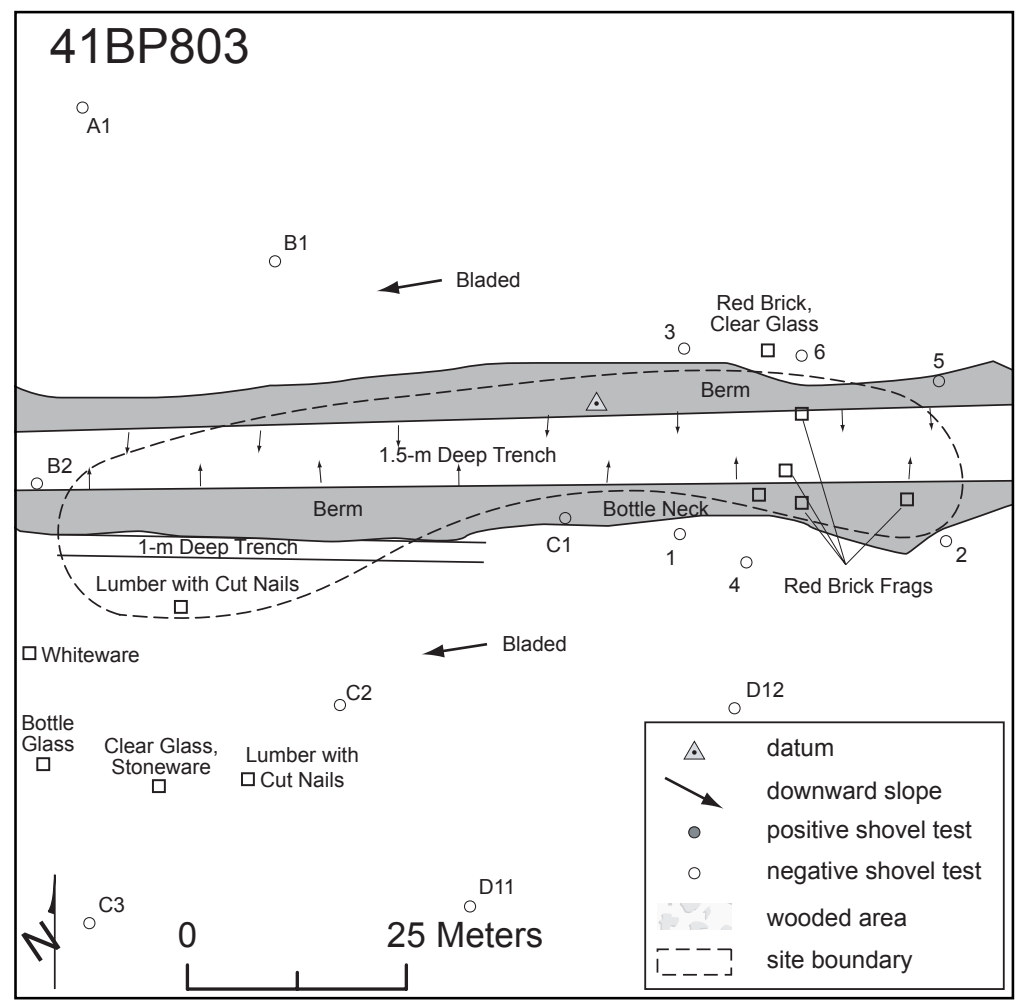

Figure 9-76. Site map of 41BP803. 


\title{
Chapter 10
}

\section{Prehistoric and Historic Isolated Finds}

\author{
By Bob Wishoff, C. Britt Bousman, David L. Nickels, and D. Emory Worrell
}

\section{Prehistoric Isolated Finds (IFs) Isolated Find 1 (IF 1)}

IF 1 is a crudely flaked biface found on the sloping and heavily eroded clay surface of a bladed two-track (Appendix B). It contained no cortex, was made of brown chert, and was approximately $5 \mathrm{~cm}$ long. Six shovel tests placed both upslope and downslope on both sides of the two-track were all negative. Average soil depth was $22 \mathrm{cmbs}$. Surface visibility on the old two-track was about 80 percent; it was about 50 percent off the two-track.

\section{Isolated Find 2 (IF 2)}

IF 2 is a quartzite fire-cracked rock measuring $9 \mathrm{~cm}$ in length. It was found in Transect ST R2 at $60-70 \mathrm{cmbs}$ on a heavily wooded sideslope. Immediately to the south of Transect ST R2 is a steep drop-off to an intermittent drainage channel. Otherwise, the terrain slopes approximately 15 degrees, suggesting that the rock was likely displaced downslope. Six shovel tests were excavated upslope; no additional artifacts were found (see Appendix B).

\section{Isolated Find 3 (IF 3)}

A single interior flake found at $20-30 \mathrm{cmbs}$ in Transect ST DDDD6 constitutes IF 3. It is situated on an upland ridge covered with oaks, cedars, and elms, with dense understory. An overgrown two-track road runs along its eastern edge (see Appendix B). Six additional shovel tests dug around Transect ST DDDD6 were all negative.

\section{Isolated Find 4 (IF 4)}

IF 4 is a single interior flake found in Transect ST C12. Transect ST C12 is in a cleared, sloping area with bladed trails (see Appendix B). Surface visibility was less than five percent in July 2005. The average soil depth in six additional shovel tests placed around Transect ST C12 was greater than 70 cmbs. All six additional shovel tests placed around Transect ST C12 were negative.

\section{Isolated Find 7 (IF 7)}

IF 7 is a single interior flake found at $0-10$ cmbs in Transect ST AAAA7. It is located in a sloping, generally cleared field that is covered with a few pine trees and dense grasses. A shallow depression south of the positive test has apparently been gouged out with heavy machinery (see Appendix B). No other artifacts were observed on the surface, and six additional shovel tests to an average clay depth of $40 \mathrm{cmbs}$ were all negative.

\section{Isolated Find 8 (IF 8)}

IF 8 is an interior flake that was recovered between the surface and $10 \mathrm{cmbs}$ deep in Transect ST WWW8 (see Appendix B). The area is a wooded ridge with cedars, oaks, shrubs, and grasses. A few rodent burrows and uprooted trees were observed. Estimated surface visibility in July 2005 was about 20 percent, but no other 
artifacts were seen on the surface. No artifacts were found in any of the six additional shovel tests placed around Transect ST WWW8, and the average depth to clay was $55 \mathrm{cmbs}$.

\section{Isolated Find 9 (IF 9)}

IF 9 is an interior flake found at $20-30 \mathrm{cmbs}$ in Transect ST L1 (see Appendix B), which was located on a semi-wooded upper sideslope. Vegetation includes cedar, pine, and mesquite, with prickly pear, grapevines, and tall grasses. Surface visibility during our August 2005 visit was less than five percent. A powerline rightof-way lies approximately $30 \mathrm{~m}$ to the east. No additional artifacts were observed on the surface, nor were any found in six additional shovel tests placed around Transect ST L1. Five of those six were dug to $70 \mathrm{cmbs}$ and did not encounter the underlying Bt horizon.

\section{Isolated Find 10 (IF 10)}

IF 10 is an interior flake that was found at $0-10 \mathrm{cmbs}$ in Transect ST DD1. It is located on a sideslope overlooking the floodplain of Dogwood Branch Creek (see Appendix B). The slope is heavily eroded with bedrock ledges exposed along the cutbank. A few fallen trees are present within the dense stand of cedars, oaks, and elms. Surface visibility was approximately 10 percent in August 2005. No additional artifacts were found either on the surface or within any of the six additional tests placed around Transect ST DD1. Soils on the slope were less than $20 \mathrm{cmbs}$ deep.

\section{Isolated Find 11 (IF 11)}

IF 11 is an interior flake found at $40-50 \mathrm{cmbs}$ in Transect ST B1 just east of Scott Falls Road (see Appendix B). Estimated surface visibility on this gentle sideslope and lower terrace was about five percent in August 2005. Riparian vegetation consists of oaks, cedars, elms, beautyberries, and thorny vines. Very nearby disturbances include an artificial berm, a bladed bar ditch, and the road. Although all were examined, no additional artifacts were found, and although the soils were deep, all six additional shovel tests dug around Transect ST B1 were negative.

\section{Isolated Find 13 (IF 13)}

A deeply buried interior flake $(60-70 \mathrm{cmbs})$ was found in Transect ST F3 (see Appendix B). It is located on a sideslope next to an upper tributary of McLaughlin Creek. Transect ST F3 is in a wooded area with oaks and cedars where a few trees had fallen and an occasional animal burrow was observed. Surface visibility during our August 2005 visit was about five percent. No artifacts were observed on the surface, and although archaeologists noted shallow roots and deep sands ( $>90 \mathrm{cmbs}$ ), no artifacts were found in any of the six shovel tests dug around Transect ST F3.

\section{Isolated Find 15 (IF 15)}

IF 15 is a bifacially flaked grey chert core measuring $14.5 \mathrm{~cm}$ long, $6 \mathrm{~cm}$ wide, and $5 \mathrm{~cm}$ thick. Approximately 80 percent cortex remains on both faces. It was found in a shallow gully on a heavily wooded slope. Three archaeologists scanned the surface up and downslope, but the only other artifact found was a medicine bottle (IF 16). The slope was heavily eroded and clay was exposed in some areas. Six shovel tests placed upslope were all negative (see Appendix B).

\section{Isolated Find 17 (IF 17)}

IF 17 consists of a shallowly buried (0-10 $\mathrm{cmbs}$ ) interior flake found on a terrace remnant of Harris Creek in Transect ST Q8. The edge of a bulldozed firing range lies about $20 \mathrm{~m}$ to the west, and an artificial berm has been pushed up about $15 \mathrm{~m}$ to the south (see Appendix B). The area is densely overgrown with hackberries, cedars, oaks, sumacs, and elms, with poison 
ivy and assorted shrubs as understory. Surface visibility was less than five percent and if any artifacts were on the surface, they could not be seen. No artifacts were found in any of the additional six shovel tests placed around Transect ST Q8. The soils here were generally less than 10 cmbs deep.

\section{Isolated Find 18 (IF 18)}

A single interior flake found in Transect ST S2 constitutes IF 18. Six additional shovel tests placed around Transect ST S2 were all negative, and soil depth averaged about $30 \mathrm{cmbs}$. They are located on a wooded sideslope on the north side of Harris Creek, and $120 \mathrm{~m}$ upstream from IF17. Cedars, oaks, vines, shrubs, and thorny brush cover the disturbed sideslope so that surface visibility was less than five percent in September 2005. The remnants of a pushed berm, probably from the construction of Range Road, are just to the north (see Appendix B).

\section{Isolated Find 19 (IF 19)}

IF 19 is an exterior flake found at $50-60 \mathrm{cmbs}$ in Transect ST C5 (see Appendix B). It is situated in an upland area south of Dogwood Branch Creek. Surface visibility in September 2005 was about 10 percent amidst tall grasses, cedars, and oaks. Bulldozed push piles were observed along the tree line, and mottled red clay was noted in the upper $30 \mathrm{cmbs}$ of the additional six shovel tests placed around Transect ST C5. No other artifacts were found either on the surface or in any of the shovel tests.

\section{Isolated Find 21 (IF 21)}

An interior, biface manufacturing flake was found in Transect ST E7 at 20-30 cmbs. Transect ST E7 is located in a semi-wooded sideslope south of an intermittent tributary of Dogwood Branch (see Appendix B). Oaks, cedars, mesquites, and scrub brush cover portions of the area. There are numerous push piles and evidently bulldozed areas. No artifacts were observed on the surface, and the results of shovel tests indicate generally shallow soils, but no additional artifacts.

\section{Isolated Find 22 (IF 22)}

IF 22 consists of a sole interior flake found in Transect ST EE1 at $0-10$ cmbs. Transect ST EE1 is located $20 \mathrm{~m}$ east of a powerline right-ofway and $20 \mathrm{~m}$ south of an intermittent drainage of Dogwood Branch (see Appendix B). This sideslope setting is generally covered with oaks, cedars, and loblolly pines. Surface visibility in September 2005 was about ten percent. No artifacts were found on the surface or in any of the six additional shovel tests dug around Transect ST EE1. Soil depth here averages 25 cmbs.

\section{Isolated Find 24 (IF 24)}

An interior flake was found in Transect ST QQ3 at $0-10$ cmbs. It is situated on the north side of a knoll 200 m south of Dogwood Branch. The immediate area has been cleared of woods and is now covered with dense grasses (see Appendix B). Surface visibility in September 2005 was less than five percent. Based upon surface observations and shovel test results, the flake in Transect ST QQ3 is the only one here. The soils here average $20 \mathrm{cmbs}$.

\section{Isolated Find 25 (IF 25)}

IF 25 is $75 \mathrm{~m}$ southwest of IF 24, on the sloping west side of the same knoll. Transect shovel tests in between these two were all negative. IF 25 is a utilized exterior flake found in Transect ST SS18. Six additional shovel tests around Transect ST SS18 were all negative (see Appendix B). The average soil depth is less than $10 \mathrm{cmbs}$. Surface visibility amidst heavy machinery two-tracks and dense grasses was about five percent; no artifacts were visible on the surface. 


\section{Isolated Find 27 (IF 27)}

IF 27 is an interior flake discovered in Transect ST O9, $20 \mathrm{~m}$ west of the M-16 rifle range, and $30 \mathrm{~m}$ east of an upper tributary of Dogwood Branch. Heavy machinery has created deep ruts throughout the cleared area, and scrub brush has overtaken an apparently previously cleared area (see Appendix B). Despite the 15-20 percent surface visibility, no artifacts were observed on the surface. Six additional shovel tests were all negative. Orange clay was encountered at an average depth of $25 \mathrm{cmbs}$.

\section{Isolated Find 28 (IF 28)}

An exterior flake discovered $20-30 \mathrm{cmbs}$ in Transect ST D4 constitutes IF 28. It is situated on a ridge west of Oak Hill Road, and between Dogwood Branch and one of its tributaries. The immediate area is semi-wooded, with scattered oak, cedar, and mesquite trees (see Appendix B). Estimated surface visibility during our October 2005 visit was about ten percent; no artifacts were visible on the surface. The results of six additional shovel tests placed around Transect ST D4 were negative and indicate that the soils average $32 \mathrm{cmbs}$.

\section{Isolated Find 29 (IF 29)}

A single exterior flake found at $60-70 \mathrm{cmbs}$ in Area 4 Transect Shovel Test U9 constitutes IF 29. This artifact was found in a wooded section in the Silstid loamy fine sand ( $\mathrm{SkC})$ soil on a steep northern facing slope on Scott Hill.

\section{Isolated Find 30 (IF 30)}

A single interior flake of amber chert found at 30-40 cmbs in Area 4 Transect Shovel Test RRR12 constitutes IF 30. This shovel test was excavated on a wooded interfluve ridge in the Robco loamy fine sand (DeC) soil.

\section{Isolated Find 31 (IF 31)}

A single interior flake found at $50-60 \mathrm{cmbs}$ in Transect Shovel Test L3 constitutes IF 31. This artifact was found in a shovel test excavated in a wooded area in the Silstid loamy fine sand (SkC) soil near a the bottom of a small valley near the dry stream channel.

\section{Isolated Finds 32, 32a and 32b (IF 32, IF 32a, IF 32b)}

A single interior flake of tan chert (IF 32) and a single specimen of quartzite fire cracked rock (IF 32a) were found at 20-30 cmbs in Transect Shovel Test E4. Three specimens of chert fire-cracked rock (IF 32b) were recovered from $60-70 \mathrm{cmbs}$ in Transect Shovel Test E4. No other artifacts were found nearby and it is not clear if the chert fire-cracked rock is cultural. These artifacts were found in Area 4 in the Judd gravelly fine sandy loam (Jef) soil on a open ridge that gently slopes to Sandy Creek.

\section{Isolated Finds 33 and 33a (IF 33, IF 33a)}

A single interior flake found at $10-20 \mathrm{cmbs}$ in Area 4 Transect Shovel Test F12 constitutes IF 33. An exterior flake (IF 33a) was recovered at 20-30 cmbs in Transect Shovel Test F12. This shovel test was excavated on a gently sloping ridge without tree cover above Sandy Creek in the Judd gravelly fine sandy loam (Jef) soil.

\section{Isolated Find 34 (IF 34)}

Isolated find 34 (IF 34) is a broken biface base made on an exterior, cortex-bearing red chert flake and was found in Transect Shovel Test A10 in Area 8. This artifact was recovered from a shovel test excavated in the Tabor fine sandy loam (TfB) soil on the base of a toe slope above McLaughlin Creek. 


\section{Isolated Finds 35 and 35a (IF 35, IF 35a)}

A one inch diameter quartzite fire-cracked rock (IF 35) was found at 50-60 cmbs in Transect Shovel Test P24. A smaller, less-than-one inch diameter specimen of quartzite fire-cracked rock (IF 35a) was found at $60-70 \mathrm{cmbs}$ within the same shovel test. These possible cultural items were found in Area 9 in the Padina fine sand (PaE) soil on a southern facing upland slope overlooking McLaughlin Creek.

\section{Isolated Find 36 (IF 36)}

A grey chert exterior flake (IF 36) was recovered at 20-30 cmbs in Transect Shovel Test P1 in Area 18. This shovel test was excavated in the Sa soil in the floodplain of McLaughlin Creek.

\section{Isolated Finds 37 and 37a (IF 37, IF 37a)}

A tan exterior flake found at $0-10 \mathrm{cmbs}$ in Transect Shovel Test N6 in Area 18 constitutes IF 37. A burned exterior flake (IF 37a) was also recovered from the same shovel test, but between 10-20 cmbs. These artifacts were recovered in the Sa soil in the floodplain of McLaughlin Creek

\section{Isolated Find 39 (IF 39)}

A tan chert interior flake (IF 39) was recovered at 10-20 cmbs in Area 21 in Transect Shovel Test A6. This artifact was found on a broad open interfluves in the Robco loamy fine sand (DeC) soil.

\section{Isolated Find 40 (IF 40)}

A single interior flake found at $0-10 \mathrm{cmbs}$ in Area B Transect Shovel Test RR-4 constitutes IF 40. This isolated find was recovered in the Uhland clay loam (Uh) soil at the edge of a small tributary channel of Dogwood Branch.

\section{Isolated Finds 41 and 41a (IF 41, IF 41a)}

A brown interior biface thinning flake (IF 41) was found at $0-10 \mathrm{cmbs}$ in Transect Shovel Test RR 10. Two heat-spalled chert flakes (IF 41a) were recovered from 20-30 cmbs during the same shovel test. This shovel test was excavated in Area B on the toe slope above the Dogwood Branch floodplain in the Uhland clay laom (Uh) soil.

\section{Isolated Finds 44 (IF 44)}

A chert interior flake (IF 44) was recovered at 0-10 cmbs in the Area J Transect Shovel Test DD1. This shovel test was excavated in a wooded mid slope of an interfluves above Dogwood Branch. The soil was Tabor fine sandy loam (TfB).

\section{Isolated Finds 45 (IF 45)}

A utilized tan chert interior flake (IF 45) was recovered at 30-40 cmbs in Transect Shovel Test L9 in Area L. The artifact was recovered in the Uhland clay laom (Uh) soil from the wooded floodplain of Dogwood Branch.

\section{Isolated Finds 46a (IF 46a)}

A chert interior pressure flake (IF 46a) was recovered at $40-50 \mathrm{cmbs}$ in Transect Shovel Test N19 in Area L. This shovel test, which also produced a historic artifact (see below) was excavated on the sideslope of a wooded interfluve overlooking Dogwood Branch in the Edge fine sandy loam (AfC2) soil.

\section{Isolated Finds 47 (IF 47)}

An oval-shaped cortex-bearing core of brown and tan color was recovered from $30-40 \mathrm{cmbs}$ in Transect Shovel Test P11 in Area Q. This shovel test was excavated in the Tabor fine sandy loam (TfB) soil on an open upland mid slope. 


\section{Historic Isolated Finds}

\section{Isolated Find 12 (IF 12)}

IF 12 is a heavily rusted horseshoe found in Transect ST E5, between 8 and $10 \mathrm{cmbs}$. Judging from its size (5 inches wide, 6 inches long), it was likely from a large draft horse. Simply because of the fact that the horse was shod suggests that it was probably used for more than just farming. Horses were more commonly shod when they were used on roads (Drew 2000:64). Its heel calkins, along with distinctive rectangular nail holes and sunken grooves to fit the nail heads, are like those manufactured in the United States today (Simmons and Turley 1980:60-67). The shoe was in a small cleared area. No other artifacts were found either on the surface or in six shovel tests placed around Transect ST E5 (see Appendix B).

\section{Isolated Find 16 (IF 16)}

IF 16 is a clear glass medicine bottle with mold seams running all the way the top of the lip, and a rusted metal screw top (ca. post-1930). It is $6^{1 / 4}$ inches long, $13 / 4$-inches wide, and $3 / 4$-inch thick. It was laying in a shallow gully on a heavily wooded slope $160 \mathrm{~m}$ northeast of the nearest historic site (41BP771). Three archaeologists scanned the surface for 45-60 $\mathrm{m}$ around the bottle, but the only other artifact found was a prehistoric core upslope (IF 15). Six shovel tests placed upslope were all negative (see Appendix B).

\section{Isolated Find 20 (IF 20)}

IF 20 is an undecorated whiteware sherd found at $0-10 \mathrm{cmbs}$ in Transect ST D2. A spent bullet casing was found in the same level. The area has been cleared of trees and apparently bladed with heavy machinery in the past. No other artifacts were found either on the surface, or in any of the six additional shovel tests dug around Transect ST D2 (see Appendix B).

\section{Isolated Find 26 (IF 26)}

IF 26 is a clear glass bottle neck with an amethyst hue, ca. 1880-1915 (Figure 10-1). It was found in Transect ST X1 between 57 and 60 cmbs. Although we closely examined the surrounding surface area and dug an additional six shovel tests around Transect ST X1, no other artifacts were found (see Appendix B). The area appeared to have been bulldozed in the past; push piles were observed. A strand of barbed wire was still attached to a nearby oak tree. The closest documented historic site is 41BP791, situated approximately $200 \mathrm{~m}$ north, which consists of house remains, a cattle chute, and a corral.

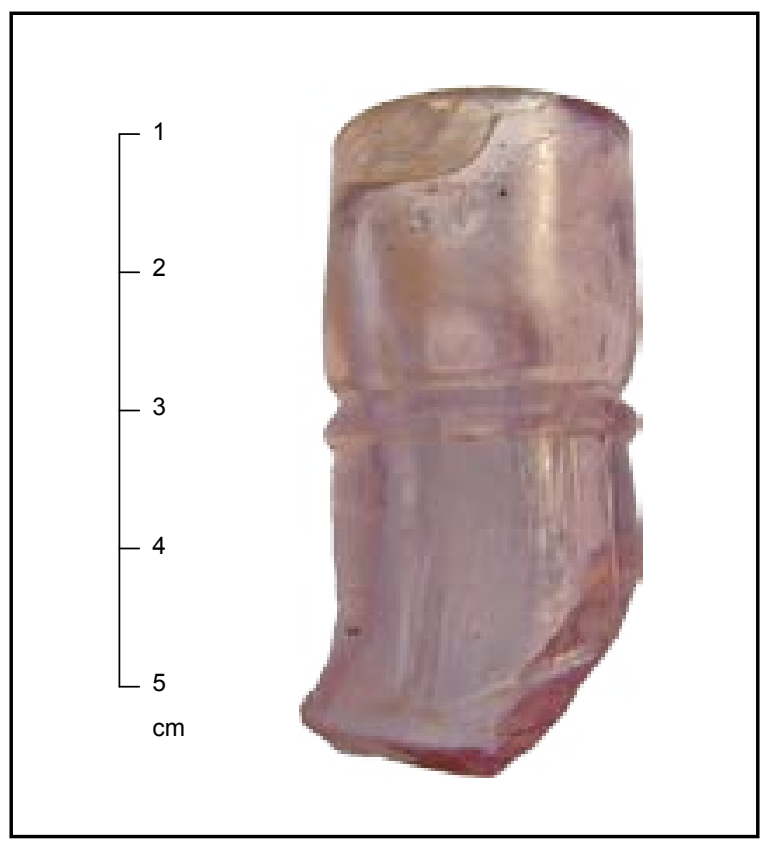

Figure 10-1. Isolated Find 26, a glass bottle neck.

\section{Isolated Finds 38 (IF 38)}

A shard of clear amber glass was found at 30-40 cmbs in an Area 19 Transect Shovel Test F10 and constitutes IF 38. This shovel test was excavated in a small eroded mid slope open area in the Robco loamy fine sand (DeC) soil. 


\section{Isolated Finds 42 (IF 42)}

A scatter of dozens of pieces of fractured brick that is probably from the same brick is described as occurring at $0-10 \mathrm{cmbs}$ in Transect Shovel Test DD12 in Area C. This was in the Edge fine sandy loam (AfC2) soil in an open upland mid slope overlooking the Dogwood Branch floodplain.

\section{Isolated Finds 43 and 43a (IF 43, IF 43a)}

Yellow brick fragments were recovered at 0-10 cmbs (IF 43) and at $10-20 \mathrm{cmbs}$ (IF 43a) in Transect Shovel Test EE12a in Area C. This shovel test was excavated on an upland mid slope in the Edge fine sandy loam (AfC2) soil and overlooking the Dogwood Branch floodplain.

\section{Isolated Finds 46b (IF 46b)}

A rifle bullet was recovered from 20-30 cmbs in Area L Transect Shovel Test N19 and constitutes IF 46. This shovel test also recovered a prehistoric artifact (see above). The shovel test was excavated into a wooded area with the Edge fine sandy loam (AfC2) soil. The setting was an interfluves sideslope above Dogwood Branch. 


\title{
Chapter 11
}

\section{Results of the Investigation and Project SUMMARY}

\author{
By C. Britt Bousman, David L. NIckels, and Damon P. Stone
}

\section{Introduction}

Chapter 4 discussed certain issues that could be addressed by this survey. Also detailed were the methods for conducting the survey so that CAS could gather the information needed to address the research issues. This chapter begins with a discussion of site density and a section relating archaeological sites to soil types and water features. Following this section is a discussion of new and unique information on the sandy mantle. Sections on prehistoric and historic occupational chronologies are also presented, and a summary concludes the chapter. During this intensive survey, a shovel test was excavated every $30 \mathrm{~m}$, covering 3,475 actual surveyed acres and resulting in the excavation of 11,015 transect shovel tests. Of these transect shovel tests, 453 were positive and 10,562 were negative. An additional 16 acres covering site boundaries outside of the survey area were further assessed with shovel tests. This resulted in a total area assessed with shovel tests of approximately 3,491 acres. During this time, CAS archaeologists encountered or searched for 168 sites, discovering 110 new sites and revisiting 54 previously recorded sites; four previously recorded historic sites could not be relocated. There are 125 prehistoric components and 58 historic components (including the four missing sites) at the 168 sites of which 15 are multi-component. For the site evaluations, 1,517 additional shovel tests were excavated within site boundaries. Of these, 477 shovel tests were positive and 1040 shovel tests were negative. In total, 12,532 shovel tests were excavated.

\section{Research Issues}

\section{Site Density}

All of the 3,475 acres surveyed during this project had been previously surveyed either in 1979 or 1997. This section compares and contrasts the density of sites discovered employing current survey methods with those used in 1979 and 1997. In 1979, Skelton and Freeman surveyed approximately 4,000 acres to be affected by a proposed lignite surface mine; these 4,000 acres had not been previously surveyed. In 1997 , Robinson surveyed a total of 5,671 acres; 4,694 acres were previously unsurveyed, while 977 acres were surveyed by Skelton and Freeman in 1979. Table 11-1 shows the various survey methodologies used during the three surveys. The results are obvious; the more intense methods used during the current project produced an increase in site density from an average of one site about every 56 acres to one site about every 21 acres.

As stated in Chapter 1, the current project focused on expected high probability areas based on the landscape and terrain features at Camp Swift. However, if one assumes that archaeological sites are dispersed in a systematic pattern across the entire landscape, then it should be that more fine-grained survey methods will result in the discovery of an increased number 
Table 11-1. Comparison of survey methodologies and results.

\begin{tabular}{|c|c|c|c|}
\hline Methods & $\begin{array}{c}\text { Skelton \& } \\
\text { Freeman 1979 }\end{array}$ & $\begin{array}{c}\text { Robinson et al. } \\
\mathbf{2 0 0 1}\end{array}$ & $\begin{array}{c}\text { Nickels et al. } \\
\mathbf{2 0 0 8} \text { (Current) }\end{array}$ \\
\hline Transect Intervals & $50-75 \mathrm{~m}$ & $30 \mathrm{~m}$ & $30 \mathrm{~m}$ \\
\hline Shovel Test Intervals & $\begin{array}{c}\text { Areas of low } \\
\text { visibility only }\end{array}$ & $150 \mathrm{~m}$ or more* & $30 \mathrm{~m}$ \\
\hline Shovel Test Diameter & $25 \mathrm{~cm}$ & unknown & $30 \mathrm{~cm}$ \\
\hline Shovel Test Depths & $50-75 \mathrm{cmbs}$ & unknown & $70 \mathrm{cmbs}$ \\
\hline Shovel Probe Intervals & NA & 30 m or more* & NA \\
\hline Shovel Probe Diameter & NA & $30 \mathrm{~cm}$ & NA \\
\hline Auger Probe Intervals & Areas of deep soils & NA & NA \\
\hline Auger Probe Diameter & $5 \mathrm{~cm}$ & NA & NA \\
\hline Auger Probe Depths & $50-75 \mathrm{cmbs}$ & NA & 3,475 \\
\hline Survey Results & & & 3,475 \\
\hline Acreage Previously Surveyed & & 4,694 & 107 \\
\hline Acreage Not Previously Surveyed & 4,000 & 5,671 & 52 \\
\hline Total Acreage Surveyed & 4,000 & & 4 \\
\hline Sites & & 58 & 163 \\
\hline New Sites Discovered in Survey Area & 73 & 42 & 21.3 \\
\hline Sites Revisited in Survey Area & & 38 & \\
\hline Sites Not Relocated in Survey Area & & 56.7 & \\
\hline Total No. Sites in Survey Area & 73 & & \\
\hline Site Density - No. Acres per Site & 54.8 & $* 00$ & \\
\hline \multicolumn{2}{|c|}{ Intervals increased when surface visibility was greater than $25 \%$} & \\
\hline & & & \\
\hline & & & \\
\hline
\end{tabular}

of sites, regardless of the landscape and terrain features. As shown in Table 11-1, the more intense survey methods used during this survey resulted in an increased number of sites. To examine whether or not the increased number of sites can be attributed more so to survey methods than variations in landscape, we compared the information from all known prehistoric sites at Camp Swift before the current survey with what we now know.

Prior to this project, 181 archaeological sites had been found on the 11,500 surveyed acres on the Camp (Nickels et al. 2005). These 181 sites were documented across all types of terrain, with no specific focus on high probability areas defined by land features or water courses. The results of these projects equate to one site every 63.5 acres for the entire camp and within the current survey boundary the previously recorded sites equaled one site for every 57 acres (61 sites previously recorded in 3,475 acres). Compare this with what was found in the current survey of 3,475-acres of one site every 21 acres (see Table 11-1), results in a more than doubling of site density.

The relatively minor difference in previous site density over the 3,475-acre high-probability areas versus the entire 11,500 acres suggests that site discovery has less to do with terrain and landscape variations and more to do with the intensity of survey. The data further suggest that if the terrain and landscape are not overriding 
influences on where sites are located, then there must be other factors involved.

The current study can be divided into smaller areas and each area assessed in terms of recovery. This study is combined with a smaller 307 acre (actually a 312 acre) survey conducted by CAS in 2004 (Nickels et al. 2005). Table 11-2 presents the data for the 2004 project's 312 acre survey and divides the current study into three areas that were selected for resurvey and identified as the Northern, Central, and Southern Areas.

The size of the different survey tracts varies from 172 acres to 1,826 acres and the number of excavated shovel tests varies from 548 to 6,814 . The number of previously and newly recorded sites varies from 4 to 121 , and the size of all sites summed for each area varies from 3.7 acres to 201.7 acres. This degree of variability makes comparisons more difficult, but one standard is the number of shovel tests excavated per acre and the Swift VI survey resulted in a narrow range from 3.2 to 3.7 shovel tests per acre, while the Swift IV survey was executed at a less intense level of 2.1 shovel tests per acre.

It should be noted that portions of the Swift IV Survey Area were assessed by backhoe trenching, but these are not included in the following analysis. Furthermore, please note that small areas of the Swift VI Southern Area and the Northern Area were already surveyed by other recent surveys and these areas were not intensively resurveyed by the current project. Also the greater density of sites in the Northern Area required a greater number of shovel tests to be excavated. These factors account for much of the variation in shovel test densities between the various areas in the Swift VI Survey.

Considering these factors, it is clear that the Swift VI Northern Area has the greatest number of sites (121 sites), but it is also the largest survey area and received the greatest density of excavated shovel tests. The Swift VI Southern Area was the smallest, had the lowest density of excavated shovel tests, and produced the fewest sites which covered the smallest area. The question that needs to be addressed is does shovel test intensity or density affect site recovery?

In order to address the above question, linear regressions between ST/Acre (shovel tests excavated per acre) and Acres per Site, and between ST/Acre and Site/Survey Area (percent of survey area covered by archaeological sites) were calculated. These show that the number of shovel tests excavated per acre does not strongly influence site density as measured by sites per acre $\left(\mathrm{R}^{2}=0.060\right)$ or the percent of the survey area covered by archaeological sites $\left(\mathrm{R}^{2}=0.012\right)$. These results can be interpreted to indicate that the northern portion of Camp Swift does have a greater site density than the areas to the south. This is reflected both by the number of sites per acre $(0.042$ and 0.066 in the northern half of Camp Swift vs. 0.032 and 0.023 in the southern

Table 11-2. Survey statistics for recent surveys at Camp Swift.

\begin{tabular}{|c|c|c|c|c|c|c|c|}
\hline Area & Acres & $\begin{array}{c}\text { Shovel } \\
\text { Tests } \\
\text { (ST) }\end{array}$ & $\begin{array}{c}\text { Number of } \\
\text { Mapped } \\
\text { Sites }\end{array}$ & $\begin{array}{c}\text { Total Site } \\
\text { Size (acres) }\end{array}$ & $\begin{array}{c}\text { Sites per } \\
\text { Acre }\end{array}$ & ST/Acre & $\begin{array}{c}\text { Site/Survey } \\
\text { size }\end{array}$ \\
\hline Swift IV & 312 & 668 & 13 & 27.6 & 0.042 & 2.1 & $8.8 \%$ \\
\hline Swift VI Northern & 1826 & 6,814 & 121 & 201.7 & 0.066 & 3.7 & $11.0 \%$ \\
\hline Swift VI Central & 1476 & 5,065 & 47 & 50.8 & 0.032 & 3.4 & $3.4 \%$ \\
\hline Swift VI Southern & 172 & 548 & 4 & 3.7 & 0.023 & 3.2 & $2.2 \%$ \\
\hline Total Swift VI & 3475 & 12.427 & 172 & 256.2 & 0.049 & 3.6 & $7.4 \%$ \\
\hline
\end{tabular}


half of Camp Swift), and the site/survey size ( 8.8 and 11.0 percent in the northern half of Camp Swift vs. 3.4 and 2.2 percent in the southern half of Camp Swift). Also, this is not a result of the density of excavated shovel tests.

Simple mathematical calculations indicate if the remaining 8,050 acres were surveyed as intensively as the 3,475 acres were during these investigations, there should be approximately one site every 20 acres. Thus, the number of additional sites that should be present within those 8,050 acres would total 403 sites. There are only 116 sites recorded within those 8,050 acres. A more intense survey would result in three and one half times as many sites than actually recorded.

\section{Prehistoric Site Density}

Since archaeologists began discovering and documenting the prehistory of Camp Swift in 1979, they have recorded 200 prehistoric sites with artifacts ranging in age from the Paleoindian period (11,500 years ago) through the Late Prehistoric period (ending 350 years ago). Archaeologists found most of these sites by digging shovel test holes in a systematic grid pattern across the landscape. These sites include campsites, where the remains of campfires, stone butchering and scraping tools, stone grinding tools, pottery, animal bones, and charred plant materials were found. At lithic procurement sites, archaeologists found the chert debris left over from chipping flakes off natural cobbles, and others fashioned into stone tools. The third kind of site is called a lithic scatter. Here, archaeologists find broken tools, as well as smaller flakes that are a result of fashioning tools into their final forms. Thus far, archaeologists have found 140 open campsites, 12 lithic procurement sites, and 47 lithic scatters.

Before this project, there were 47 prehistoric component sites documented within the 3,475- acre survey area; there are now 134. These numbers represent a 285-percent increase in discovered prehistoric sites, and a change from one site every 74 acres to one site every 25.9 acres.

\section{Historic Site Density Distribution}

Before this project, there were 33 historic component sites documented within the 3,475acre survey area; there are now 57 recorded and verified sites within this area. These numbers represent a 173-percent increase in discovered historic sites, and a change from one site every 105 acres to one site every 61 acres.

\section{Archaeological Component Distributions}

The differential distribution of prehistoric and historic component (not site) distributions can be assessed with a contingency table analysis. Table 11-3 shows the distribution of prehistoric and historic components by survey area. A chi-square test demonstrates that there is no significant variation between survey areas as the $\mathrm{p}$ value should be less than 0.05 and the extremely low adjusted residuals further confirm this inference.

\section{Archaeological Sites Relative to Soil Types and Water Features}

In a further attempt to understand where sites should be located, we examined the soil types on which known sites are located. Previous fieldwork and research provided a perception that unless prehistoric sites had strictly been used as lithic procurement sites, they were generally located in areas mapped as fine sands, and sometimes sandy loam. Historic sites, on the other hand, were generally located on areas mapped as loam or clay. Using the current 3,475 acres as a sample area, we overlaid site boundaries on soil types (see below). 
Table 11-3. Contingency table of prehistoric and historic components by survey area including Swift IV. Adjusted residuals greater than 1.96 or less than -1.96 are significant at a 0.05 level of confidence (Everitt 1992; Haberman 1978).

\begin{tabular}{|c|c|c|c|}
\hline Area & Prehistoric & Historic & total \\
\hline Swift IV & $11(0.37)$ & $4(-0.37)$ & 15 \\
\hline Swift VI Northern & $97(0.32)$ & $42(-0.32)$ & 139 \\
\hline Swift VI Central & $33(-1.00)$ & $19(1.00)$ & 52 \\
\hline Swift VI Southern & $4(1.35)$ & $0(-1.35)$ & 4 \\
\hline Total & 145 & 65 & 210 \\
\hline
\end{tabular}

The purpose of the GIS analysis was to compare distributions of sites to those of several natural landscape features. The landscape features utilized in this analysis include soils and hydrology. This study furthers our understanding of how archaeological site locations are related to the variation in landscape features or composition of subsurface material.

The combined Camp Swift IV and VI sites were used in order to expand the coverage and database over and above the Swift VI sites described in this report. The Camp Swift IV sites are described in Nickels et al. 2005. These surveys were both conducted by CAS, employed similar field methods, and are comparable. Another layer required for this analysis was the combined project boundary that simply delimits the full extent of the area covered by the Swift IV and Swift VI project boundaries. Survey boundaries, site datum points, and site boundaries were collected in the field using Trimble GPS GeoExplorer III and Trimble GPS GeoExplorer XT. Both GPS units are capable of sub-meter accuracy when the raw data are corrected by differential corrections to base station data. The Swift VI site layer currently contains 165 site boundaries with a total area of $951,528 \mathrm{~m}^{2}$ (235.12 acres) and an average site area of $5,767 \mathrm{~m}^{2}$ (1.43 acres). The Swift IV site layer contains 11 site boundaries with a total area of 79,074 $\mathrm{m}^{2}$ (19.45 acres) and an average site area of $7,189 \mathrm{~m}^{2}$ (1.78 acres). Soil distributions were compiled from Bastrop County soil maps (Baker 1979). Soil types have been identified by type and were grouped into major soil series. These include the Axtell, Crockett, Demona, Jedd, Patilo, Sayers, Silstid, Tabor, Uhland, and Wilson series. The distribution of stream courses and other hydrological features were obtained from the Texas Natural Resource Information System (TNRIS) within the combined Swift IV and 6 project survey boundaries. A comparison was made between layers by using appropriately selected ArcGIS Desktop software tools. The results of the analysis provide new information and insight into site location relative to the selected landscape features.

The specific steps that were used started with combining the separate survey boundaries (called unions in ArcGIS). Then the soil distributions were overlaid with the survey boundaries and a composite soil map covering both survey areas was created. In ArcGIS, these processes are called clipping and dissolving. Additionally, the site boundaries from Swift IV and Swift VI projects were combined by a process called merging, and project and individual site distinctions were erased (called dissolving). The sites were characterized by the overlapping soil series in a process called identification. Finally, all the site areas that overlapped with each individual soil series were combined to form a single grouping through dissolving. The final result was the distribution of each soil series and the distribution of all site areas within that soil series. This was done for every soil series.

Figure 11-1 shows the distribution of soil series and streams in the Camp Swift IV and 6 
survey areas. The associations between stream courses and specific soil series are evident. Table 11-4 shows the distribution of soil series areas, site areas, and percent of soil series covered by archaeological sites within each soil type. The chart in Figure 11-2 plots the fraction in percentages of each soil series that is covered by archaeological sites. Clearly, specific soil series have more of their areas within archaeological site boundaries than do other soil series. For example, 13.9 percent of the surface area covered by Patilo soils is within site boundaries, but only 1.7 percent of the Crockett soil series are within a site boundary. The frequency of sites is so high in the Patilo, Silstid, Demona, and Tabor soil series that future surveys should probably target these soils to increase the recovery rate of archaeological surveys. These are the sandy soils discussed in Chapter 2 and above. In fact,

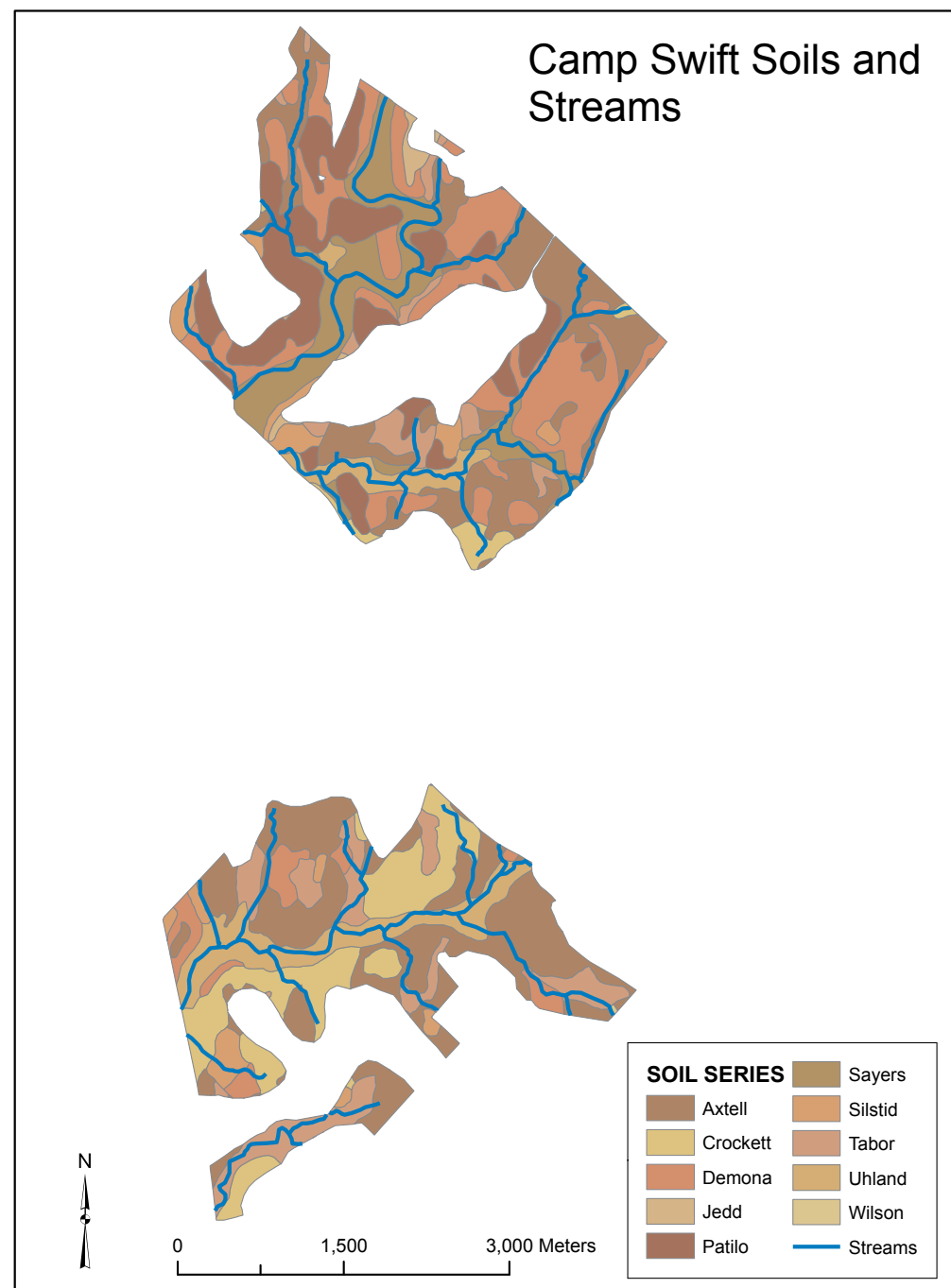

Figure 11-1. Map showing the distribution of soil series and streams at Camp Swift.

Table 11-4. Area $\left(\mathrm{m}^{2}\right)$ statistics on soil series and archaeological sites. These calculations do not include site areas outside of the survey boundary.

\begin{tabular}{|c|c|c|c|c|c|}
\hline Series & $\begin{array}{c}\text { Soil Series } \\
\left.\text { Area } \mathbf{( m}^{\mathbf{2}}\right)\end{array}$ & $\begin{array}{c}\text { Percent Soil } \\
\text { Area }\end{array}$ & $\begin{array}{c}\text { Swift IV \& VI } \\
\left.\text { Site Area } \mathbf{( m}^{\mathbf{2}}\right)\end{array}$ & $\begin{array}{c}\text { Percent Site } \\
\text { Area }\end{array}$ & $\begin{array}{c}\text { Soil Series } \\
\text { Covered by Site }\end{array}$ \\
\hline Crockett & $1,768,343$ & $11.2 \%$ & 30,643 & $3.3 \%$ & $1.7 \%$ \\
\hline Uhland & $1,237,362$ & $7.8 \%$ & 29,967 & $3.2 \%$ & $2.4 \%$ \\
\hline Sayers & $1,560,640$ & $9.9 \%$ & 58,989 & $6.3 \%$ & $3.8 \%$ \\
\hline Axtell & $4,724,618$ & $29.9 \%$ & 190,812 & $20.3 \%$ & $4.0 \%$ \\
\hline Tabor & $1,379,151$ & $8.7 \%$ & 79,669 & $8.5 \%$ & $5.8 \%$ \\
\hline Demona & $2,810,105$ & $17.8 \%$ & 239,901 & $25.5 \%$ & $8.5 \%$ \\
\hline Silstid & 570,771 & $3.6 \%$ & 57,852 & $6.1 \%$ & $10.1 \%$ \\
\hline Patilo & $1,827,083$ & $11.5 \%$ & 254,439 & $27.0 \%$ & $13.9 \%$ \\
\hline Total & $15,878,072$ & 942,271 &
\end{tabular}


67 percent of all site areas occur on these four soils, but they only compose 41.5 percent of the surveyed area. The other soil series, Crockett, Uhland, Sayers and Axtell, are likely to require much more effort to discover sites within their boundaries. It is significant that the bottomland soils, which cover 17.6 percent of the landscape, contain only 3.2 percent of the total site areas recorded. This could be due to a couple of factors. First, erosion and redeposition could account for lower site numbers. Second, the shovel tests did not penetrate below $110 \mathrm{cmbs}$, and most were excavated only to a depth of $70 \mathrm{cmbs}$. Thus sites could be deeply buried in floodplains but not discovered. The site patterns on clayey soils are not as consistent. Crockett soils cover 11.2 percent of the survey area but produced only 3.3 percent of the recorded site area; however, Axtell soils represented 29.9 percent of the surveyed area and resulted in 20.3 percent of the total site area recorded. According to these data, it would not be wise to ignore all clayey soils in future surveys, but Crockett soils might be a low priority. This analysis demonstrates that the distribution of site areas is patterned and not random.

The distribution of sites to water, determined as mapped streams, is illustrated in the bar chart in Figure 11-3. Each bar represents a 10-m distance increment. In terms of methods, individual site centroids were calculated from the site boundary files (this was done with the Feature to Point tool in ArcGIS). Then, the Switft 4 and Swift VI site databases were combined with the Merge tool. Then the distance between site centroids and stream center lines were measured with the

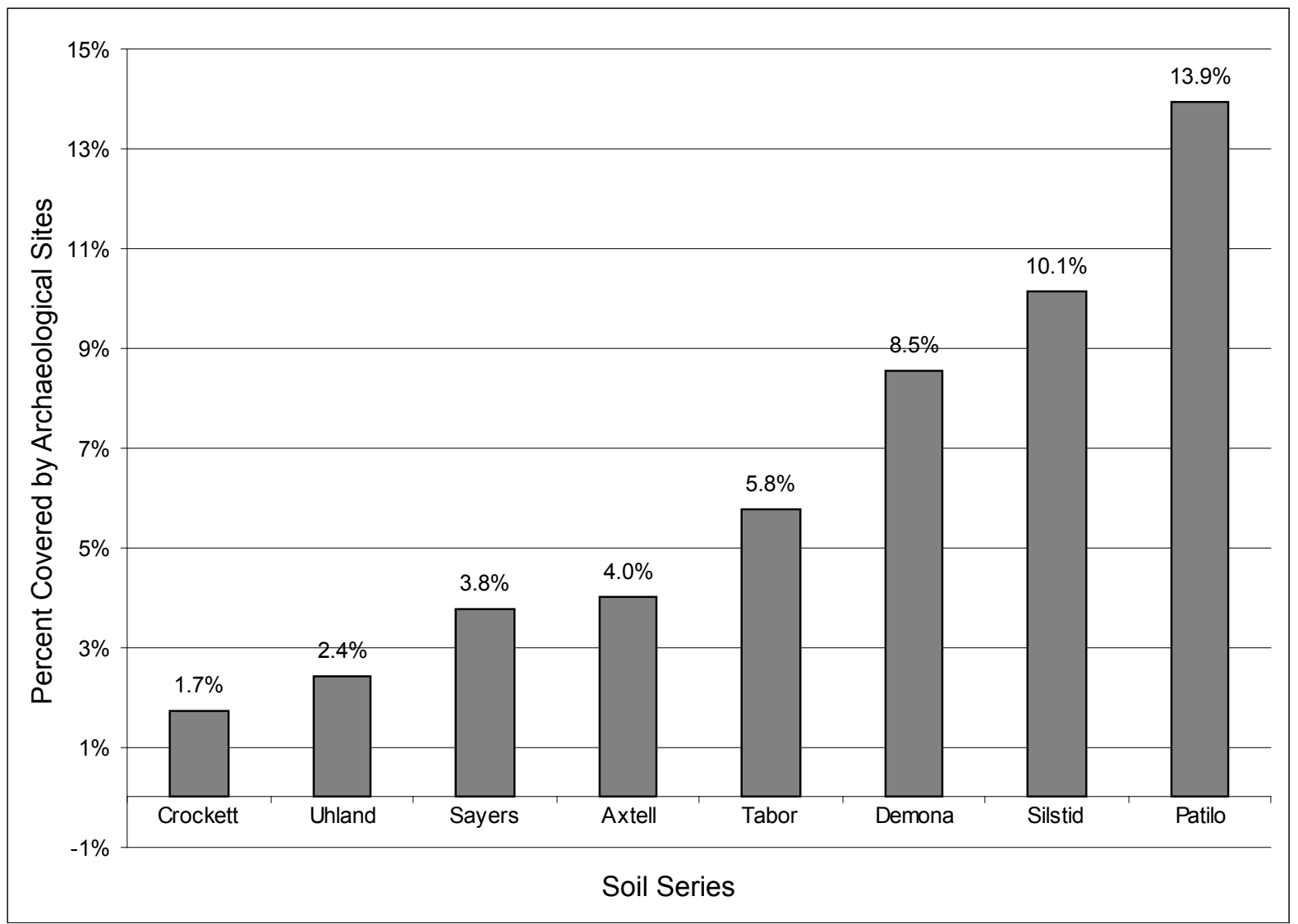

Figure 11-2. Distribution of soil series covered by archaeological sites at Camp Swift calculated by the percent of coverage. 
ArcGIS Near tool, and these data were tabulated and plotted in a graph.

A visual inspection shows that seven sites are very close to stream courses. In the remaining distributions there are multiple modes represented. The closer mode spans the distance from 20 to $80 \mathrm{~m}$ from water. There is a significant drop between 80 and $90 \mathrm{~m}$ from water, and another strong peak between 90 and $110 \mathrm{~m}$ from water. Additional peaks are visible in the bar chart, but in general terms the frequency and size of peaks diminish with increasing distance. These data correspond to the soils data, as both show that near-water locations are not productive in terms of site discovery.

\section{Depth of the Sandy Mantle}

CAS calculated the distribution of sand depths from 10,876 shovel tests excavated in systematic transects during the survey phase (not site definition phase) of the project. This is not the total number excavated, but rather the

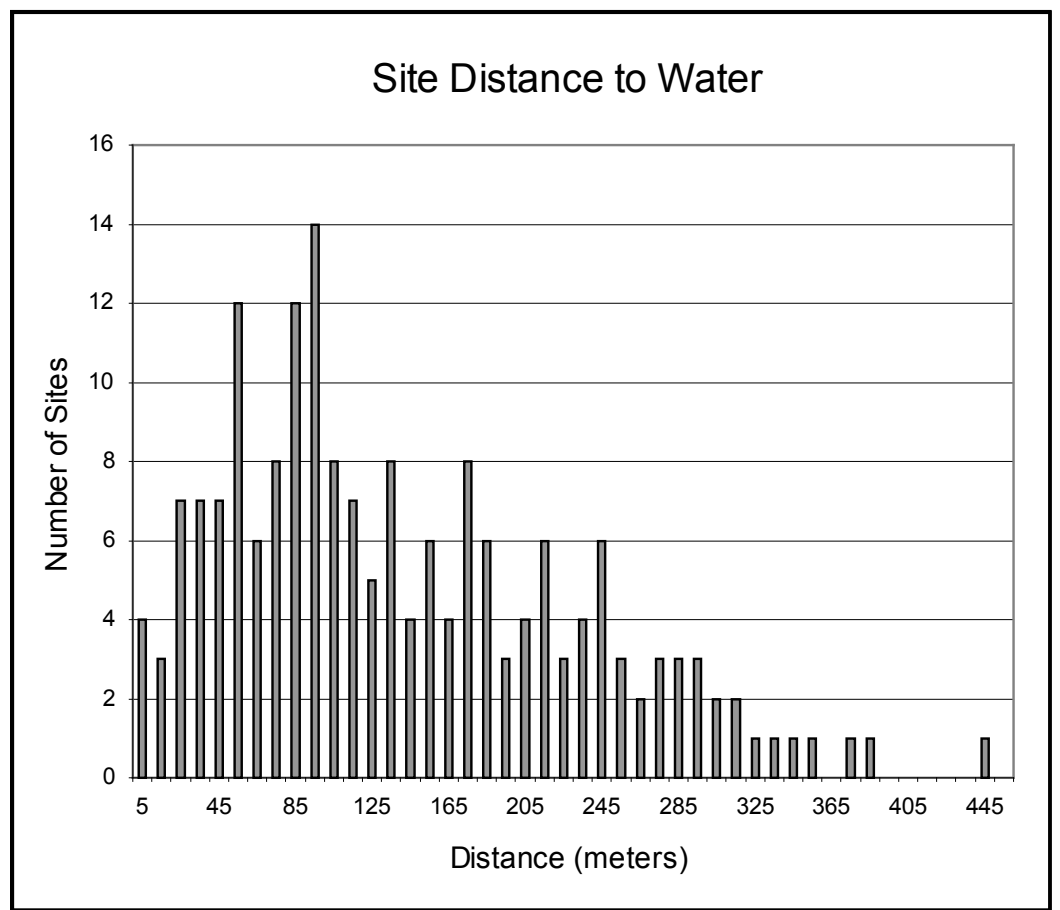

Figure 11-3. Site centroid distance to stream channel center lines. total excavated shovel tests for which there were reliable and unquestionable observations in terms of location, depth, and material. Many shovel tests were not excavated to the clayey sub-layer Bt horizon as it was too deep to reach with many shovel tests. The number of shovel tests varied slightly by survey area. In the northern area we analyzed 5,698 shovel tests, and in the southern area we analyzed 5,178 shovel tests. An isopleth (contour) map was prepared for the northern and southern areas (Figure 11-4). Five isopleths were plotted. These were combined into depth zones defined as $0-10 \mathrm{cmbs}, 10-30 \mathrm{cmbs}, 30-50$ cmbs, 50-70 cmbs, and greater than $70 \mathrm{cmbs}$. The distribution of the depth zones exhibits some striking patterns. First, sand depths are greater and form irregular meandering linear patterns near many stream courses. These distributions are expected and suggest that fluvial processes of erosion and deposition probably account for these patterns. However, in upland areas the distribution of deep sands is irregular in most areas. This suggests that erosion, at least gully erosion, is not a prime factor. This is not to say that gully erosion does not occur, because it does, but the overall pattern of sand depth does not appear to be related to erosion. However, there are areas where "islands" of shallow sands are surrounded by deep sands. This could reflect erosion of minor escarpments, but there are many other areas where deep sands are surrounded by shallow sands. These could be groundwater dissolution cavities or results of a similar pedogenic process.

The distribution of site area by the isopleth zones are 


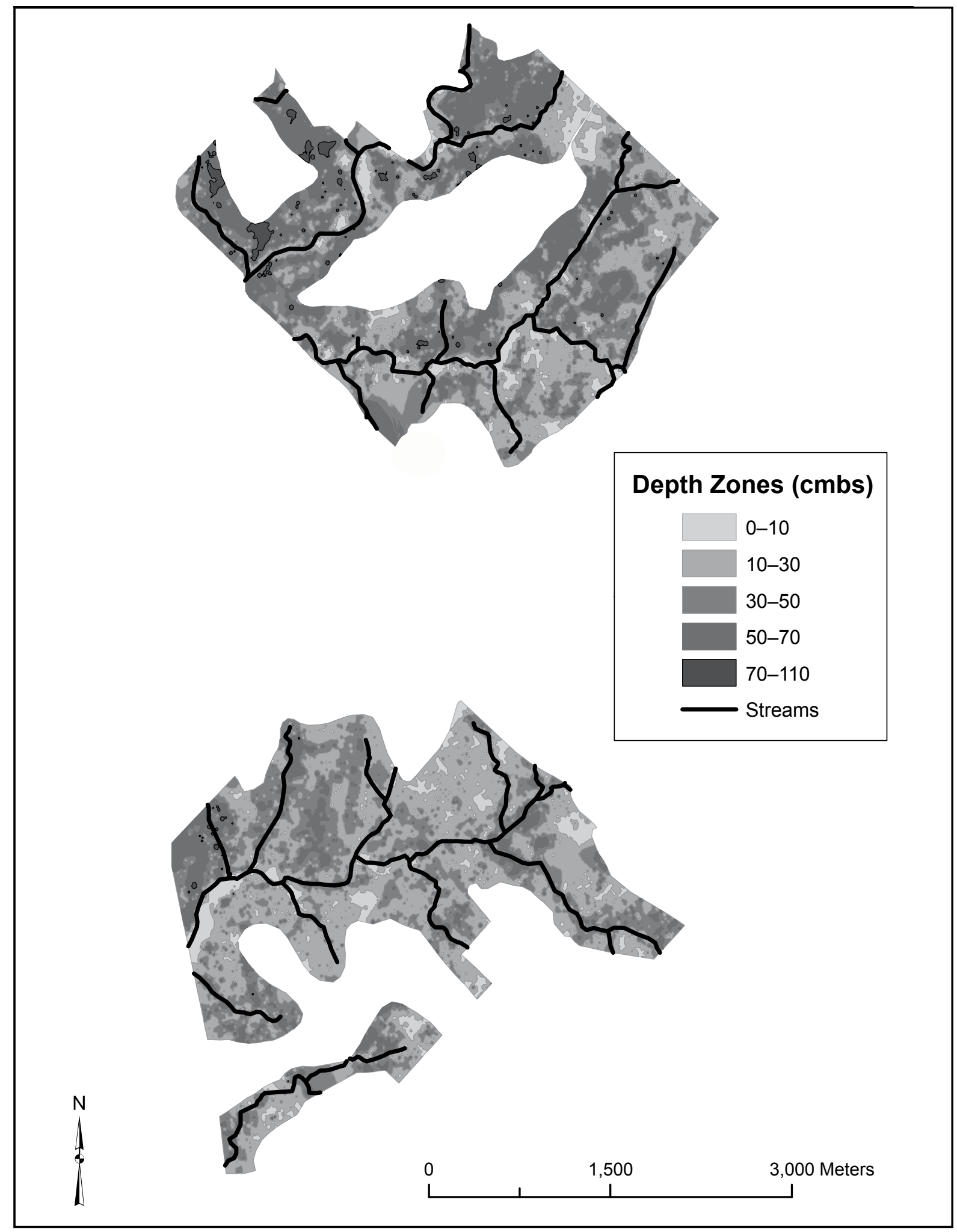

Figure 11-4. Map of the depth zones and streams in the Swift VI survey area. 
presented in Table 11-5. The area coverage for each of the depth zones is presented in square meters $\left(\mathrm{m}^{2}\right)$, and is followed by the distribution of total site area $\left(\mathrm{m}^{2}\right)$. The third column calculates the relative frequency of site areas by depth zone. The final column calculates the percent of the depth zone covered by archaeological sites. The shallow and very deep depth zones have relatively less of the total site area (11 percent and 6 percent, respectively), while medium depths $(10-70 \mathrm{cmbs})$ have higher percentages. The relative frequency is not controlled by the actual amount covered by the survey, however. When the survey area is incorporated into the calculation, there is significantly high site coverage (43.8 percent) in depth zones greater than $70 \mathrm{cmbs}$ deep. The other depth zones seem to cluster around 9 percent or 5.5 percent coverage. This suggested that very deep sands could have very high amounts of site areas associated with them. However, it is difficult to estimate where these areas are distributed without actual shovel test information. Perhaps some form of non-intrusive mapping could provide sand depth information with a reasonable amount of effort.

\section{Prehistoric Occupation of the Area Through Time}

A total of 43 projectile points have been classified according to established types or forms, with 30 of those clearly assigned a named type. This analysis does not use those 11 points categorized as Archaic, Middle Archaic, Late Archaic, or dart, as they are too generic, or could be inaccurately assigned to a chronological period. The Clear Fork gouge has been found in various temporal contexts (e.g., Boyd 1997:262264; Collins 1998; Hall 1981:340-348; Turner and Hester 1999:246-249), so we did not assign it to a specific period. The use of arrow points is more clearly defined so as to place them in the Late Prehistoric period. Another issue is where to place the Andice and Angostura points. For this analysis, both are placed in the Early Archaic.

Thus, there are 32 diagnostic stone tools (30 typed points and two arrow points) with which to evaluate the occupation of the Camp Swift area through time. There are also two sites where sandy paste, Native American pottery has been found, which can confidently place the occupation of those sites within the Late Prehistoric period. A caveat to the following discussion however, is that: 1) this data set was derived from both survey and excavations; 2) diagnostic artifacts may have been curated; 3) the recovery of diagnostic artifacts can be directly attributable to visibility; and 4) in this analysis the absence of diagnostic artifacts simply excludes the site(s) from study. Undoubtedly, an untold number more have been collected from sites at Camp Swift in historic and modern times, but this chapter works with the available database: 34 diagnostic artifacts ( 32 stone tools and two pieces of Native American

Table 11-5. Area extent and site coverage of depth zones in the Swift VI survey area.

\begin{tabular}{|c|c|c|c|c|}
\hline $\begin{array}{c}\text { Depth Zones } \\
(\mathbf{c m b s})\end{array}$ & $\begin{array}{c}\text { Depth Zone } \\
\text { Area }\left(\mathbf{m}^{\mathbf{2}}\right)\end{array}$ & Site Area $\left(\mathbf{m}^{\mathbf{2}}\right)$ & $\begin{array}{c}\text { Relative Frequency of } \\
\text { Site Area }\end{array}$ & $\begin{array}{c}\text { Percent Coverage by } \\
\text { Sites }\end{array}$ \\
\hline $0-10$ & $1,117,896$ & 103,394 & $11 \%$ & $9.2 \%$ \\
\hline $10-30$ & $5,475,415$ & 296,596 & $31 \%$ & $5.4 \%$ \\
\hline $30-50$ & $4,141,931$ & 229,729 & $24 \%$ & $5.5 \%$ \\
\hline $50-70$ & $2,852,161$ & 265,066 & $28 \%$ & $9.3 \%$ \\
\hline$>70$ & 129,694 & 56,743 & $6 \%$ & $43.8 \%$ \\
\hline Total & $13,717,097$ & 951,528 & & \\
\hline
\end{tabular}


pottery) from 21 sites. Table 11-6 lists the diagnostic artifacts recovered from Camp Swift, as well as the sites with typed points and pottery used in this analysis.

Based upon these 34 diagnostic artifacts, Figure 11-5 shows the number of temporal components per every 100-year span at Camp Swift, but standardized for the length of each temporal period. In other words, Collins' (1995:376) and Turner and Hester's (1999) chronologies of point types were used as the basis for which point types were produced in the time periods in Texas, then the number of sites with point types found for that period were divided by the number of years for that period. For example, the Late Archaic period spans a 2,800-year period, from 4000 to $1200 \mathrm{BP}$, and there are 10 sites with Late Archaic diagnostic artifacts. Therefore, $10 / 2,800=.003571$ gives the number of components per year, and when multiplied, $.003571 \times 100$ (years), one gets the number of components per 100 years (.3571); those are the values plotted in Figure 11-5.

Based upon the time-diagnostic stone tools found at Camp Swift, it appears that the area was infrequently used during the Paleoindian and Early Archaic periods, and was used much more frequently during the Late Archaic period. It was most heavily occupied during the Late Prehistoric period. No Middle Archaic, approximately 6000-4000 year-old artifacts have been found at the camp. Radiocarbon dated charcoal from excavations is shown in Table 11-7 and Figure 11-6, and the results corroborate the artifact evidence. The study of pollen and other elements in nearby peat bogs indicates that the area was extremely dry during the Middle Archaic period, and some archaeologists believe that the area may have been abandoned because of harsh climatic conditions.

\section{Historic Occupation of the Area Through Time}

The first Anglo settlers moved into the area that is now Camp Swift in the 1840s. Within a few decades after the first land grants were obtained, small communities and towns developed in the immediate and nearby areas. Oak Hill was apparently the earliest community, and at one point had a multipurpose facility that served as a school and meeting place for church congregations. Other communities were Dogwood, Wayside, Duck Pond, Spring Branch, and Piney, and the towns of Elgin, McDade, and Sayersville (Figure 11-7).

Undoubtedly, the Civil War stifled settlement here just as it did throughout Texas. Following the Civil War, returning soldiers and freed slaves sought a new life and new lands. Between 1880 and 1920, the population of Bastrop County increased nearly 242 percent. During this same 40-year period, noteworthy events that affected the development of Camp Swift lands included the closing of some mines, the opening of new mines, a flourishing brick industry, stores, newspapers, churches, schools, and practicing professionals.

The folks who lived on the land before World War II were given the option of dismantling and moving their buildings or leaving them there. Almost without exception, the military bulldozed these houses and barns when they took control of the land. Thus, most of the historic sites archaeologists found consisted only of foundations, scattered bricks, collapsed chimneys, cisterns, wells, and assorted artifacts. Left undisturbed, however, were trash dumps, cemeteries, isolated graves, and an occasional outbuilding.

Archaeologists have discovered 123 historic sites (Table 11-8; Appendix C) at Camp Swift, 


\begin{tabular}{|c|c|c|c|c|c|c|c|c|c|c|c|c|c|c|c|c|c|c|c|c|c|c|}
\hline SIBłOL & - & -- & -1 & - & - & - & - & $-1-$ & - & - & $\infty-$ & -4 & 0 & - & & $m-$ & $\theta$ & - & & -7. & $-\%$ & \\
\hline S!ฺOID & & & & & & & & & & & & & - & & & & & & & & - & \\
\hline v.InłsoŝuV & & & & & & & & & & & - & & & & & & & & & & - & ẽ \\
\hline 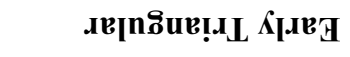 & & & & & & & & & & & & & & & & & & & & & -- & $\frac{\pi}{\pi}$ \\
\hline әэ!рuV & & & & & & & -1 & & & & & & & & & & & & & & -1 & 玨 \\
\hline әр.әәк[ng & & & & & - & & & & & & & & & & & & & & & & - & \\
\hline sә[ви.ләрәd & & & & - & & & & & & & -- & & & & & & & & & & $m$ & \\
\hline 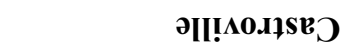 & & & & & & & & & & & & & & & & & - & & & & - & $\widehat{\theta}$ \\
\hline ІІәңиојМ & & - & & & & & & & & & & & & & & & & & & & -1 & 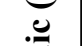 \\
\hline $0 ! \cdot 4$ & & & & & & - & & & & & & & & & & & & & & & - & 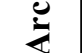 \\
\hline Josug & - & & & & & & & & & & & & & & & & - & & & & $\sim$ & 蔦 \\
\hline IIIEC & & & & & & & & & & & & & - & & & & & & & & - & \\
\hline роммәорр & & & & & & & & & & & & & & - & & & & & & & - & \\
\hline S!IIH & & & & & & & & & & & - & & & & & & & & & & - & \\
\hline мр.гемр & & & - & & & & & & & & & & & & & & & & & & - & 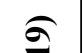 \\
\hline U.лоI|'0S & & & & & & & & 一 & & - & & - & $m$ & & & 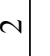 & - & & & - & $=$ & 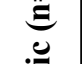 \\
\hline К.ınque.I & & & & & & & & & & & & & & & & & 一 & & & & - & 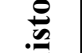 \\
\hline Кəu.snL & & & & & & & & & & & & & & & & & & & - & & - & $=$ \\
\hline słu!od Mod.IV & & & & & & & & & & & & $\sim$ & & & & & & & & & $\sim$ & $\stackrel{5}{9}$ \\
\hline 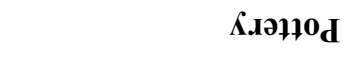 & & - & & & & & & & & & & - & -1 & & & & & & & & $\sim$ & \\
\hline 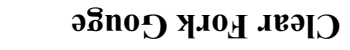 & & & & & & & & & & & & & - & & & & & & & & - & \\
\hline słu!०d ग!หपว.IV әрет & & & & & & & & & & & + & - & -1 & & & & & & & & in & $\stackrel{.}{:}$ \\
\hline słu!od ग!вчว.IV әाрp!W & & & & & & & & & & & - & & & & & & & & & & - & $\Xi$ \\
\hline słu!̣d 1.Jed & & & & & & & & _ & & & & & & & & - & -1 & - & & & $m$ & 8 \\
\hline słu!Od ग!вपว.IV & & & & & & & & & - & & & & & & & - & & & & & $\sim$ & 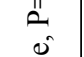 \\
\hline *əd $\kappa_{L} \partial \downarrow ! S$ & 0 & 0 & o & 2 & 0 & $\infty$ & co & ن & 2 & 0 & 0 & ن & 0 & 0 & 0 & 0 & 0 & 0 & 0 & u & u & है \\
\hline .رəqun ${ }_{N} \partial ! ! S$ & 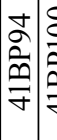 & 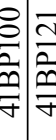 & $\vec{y}$ & $\stackrel{\infty}{\infty}$ & $\left|\begin{array}{l}\vec{\infty} \\
\tilde{\hat{n}} \\
\vec{\vartheta} \\
\vec{\gamma}\end{array}\right|$ & 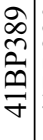 & 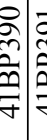 & $\frac{2}{\partial}\left(\frac{\partial}{\partial}\right)$ & $\hat{\overbrace{}}$ & 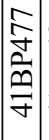 & 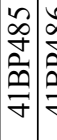 & 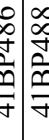 & $\begin{array}{l}0 \\
\vdots \\
\vdots\end{array}$ & 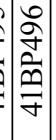 & 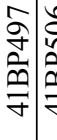 & 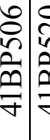 & ân & $\mid \begin{array}{l}\infty \\
\sim \\
\tilde{n} \\
\tilde{n} \\
\vec{\gamma}\end{array}$ & $\begin{array}{l}0 \\
\hat{n} \\
\hat{n} \\
\end{array}$ & 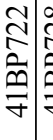 & 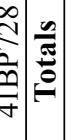 & $\bigcup_{*}^{\pi}$ \\
\hline
\end{tabular}




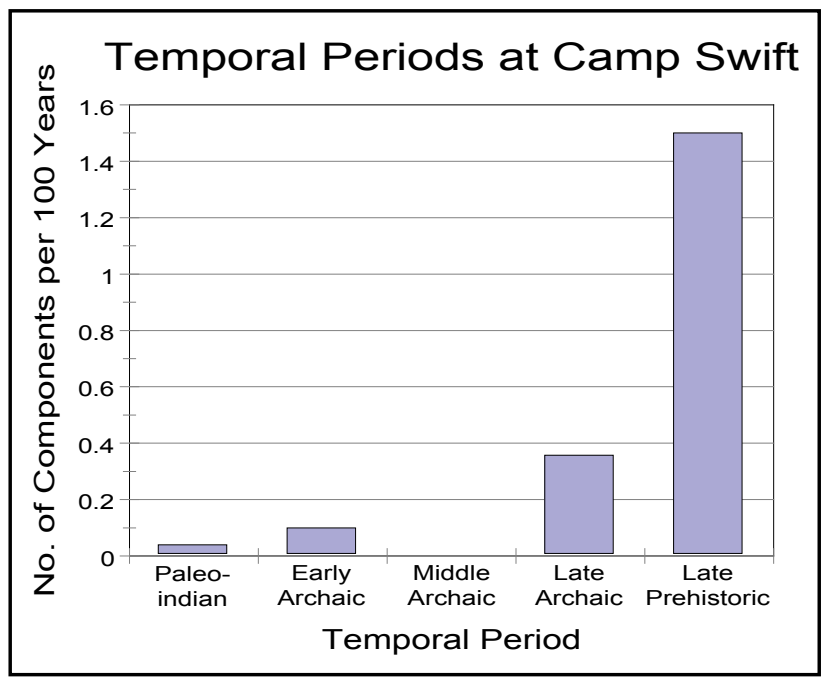

Figure 11-5. Occupation of sites through time.

and based on the ages of artifacts, deed records, and oral histories, have been able to determine the periods during which 71 house sites were likely occupied (Figure 11-8). A small dispersed population was present at Camp Swift between 1840 and 1870. Following the Civil War, an influx of white Southerners and black freedmen came to the area looking for good, cheap land. As they moved into the area, the sizes of the tracts available for purchase decreased and the number of historic sites reflect this population influx. Populations in the surrounding communities dramatically expanded from 1870 to 1900 , then generally declined in the decade after 1900 (Figure 11-9). The United States experienced an economic depression from 1893 to 1898 , endured human losses and hardships during and immediately following World War I, and then suffered the Great Depression from 1929 to 1939. Surprisingly, the 1930s witnessed an expansion of new historic sites. Nevertheless, despite towns and communities developing and then later dwindling around them, the sizes of farmsteads within the currently configured Camp Swift area decreased only slightly through the years 1880-1930 (Figure 11-10). The implications are that the area remained a closeknit and hardy rural farming community, with farms established by 1880 remaining generally unaffected by local, national, and world events. All were removed after 1942 when the Army established Camp Swift.

Table 11-7. Summary of radiocarbon dates at Camp Swift.

\begin{tabular}{|c|c|c|c|c|c|}
\hline Site & Unit & $\begin{array}{c}\text { Depth } \\
(\mathbf{c m b s})\end{array}$ & No. & Remarks (Nickels 2008b) & Date \\
\hline 41BP392 & 5 & $70-80$ & 1 & fire-cracked rock feature & $870 \pm 40$ \\
\hline 41BP485 & 9 & $90-100$ & & in association with a Pedernales point & $2430 \pm 40$ \\
\hline 41BP485 & 12 & $70-80$ & 2 & fire-cracked rock feature & $490 \pm 40$ \\
\hline 41BP488 & 5 & $80-90$ & 1 & fire-cracked rock feature & $920 \pm 40$ \\
\hline 41BP488 & 6 & 36 & 2 & fire-cracked rock feature & $770 \pm 40$ \\
\hline 41BP488 & BHT 1 & 61 & & charcoal chunk from end of trench & $640 \pm 40$ \\
\hline 41BP495 & 6 & $30-35$ & 1 & fire-cracked rock feature & $910 \pm 40$ \\
\hline 41BP495 & 5 & $120-130$ & 2 & charcoal mass & $640 \pm 40$ \\
\hline 41BP495 & 9 & $110-120$ & & in association with a Clovis preform & $930 \pm 40$ \\
\hline 41BP495 & BHT1 & $80-90$ & 1 & fire-cracked rock feature & $1630 \pm 40$ \\
\hline 41BP505 & 4 & $90-100$ & 1 & fire-cracked rock featuree & $1840 \pm 40$ \\
\hline 41BP521 & 5 & 67 & 1 & $\begin{array}{c}\text { charred hull; in association with fire- } \\
\text { cracked rock, bone, and stone tool }\end{array}$ & $1180 \pm 40$ \\
\hline 41BP529 & 2 & $110-120$ & 1 & fire-cracked rock feature & $5980 \pm 40$ \\
\hline
\end{tabular}




\section{Summary}

The information presented above provides new and important insights on the cultural resources at Camp Swift. One of the most important results of this work is that the recorded site density jumped from one site every 63.5 acres to one site every 20 acres. This is greater than a three-fold increase in density. The distribution of sites can now be analyzed with one of the bestcollected databases in Central Texas. These data show that sandy upland soils are covered by more site area than clayey soils. Sandy or clayey soils in bottomlands have the lowest percent cover by archaeological sites. This could be due to absence of sites, destruction of sites by erosion, or simply deep burial of sites to a point beyond the reach of shovel tests. The distance between streams and sites also shows this pattern of few sites near streams, and the same reasons could be in play as with the soils patterning. The mapping of sand depths is unique for the sandy mantle and the distributions show that deep sands occur along some stream courses, and form an irregular pattern in the uplands. Deep sandy areas contain the greatest site coverage.

The density of prehistoric sites climbed from one site every 80 acres to one site every 26.5 acres; again, over a three-fold increase. Very few prehistoric temporally-diagnostic artifacts were recovered, but the pattern suggests that the area had very low human populations in the Middle Holocene and had the greatest population densities during the Late Holocene in the Late Archaic and Late Prehistoric periods. The total number of recorded historic sites doubled from 30 to 61 sites. The density changed from one site every 115 acres to one site every 57 acres. The history of settlement indicates that the area was first occupied by historic peoples in the 1840s. There were peaks of construction activity between 1870 and 1900 and again between 1930 and 1940. All were abandoned by the end of 1942 .

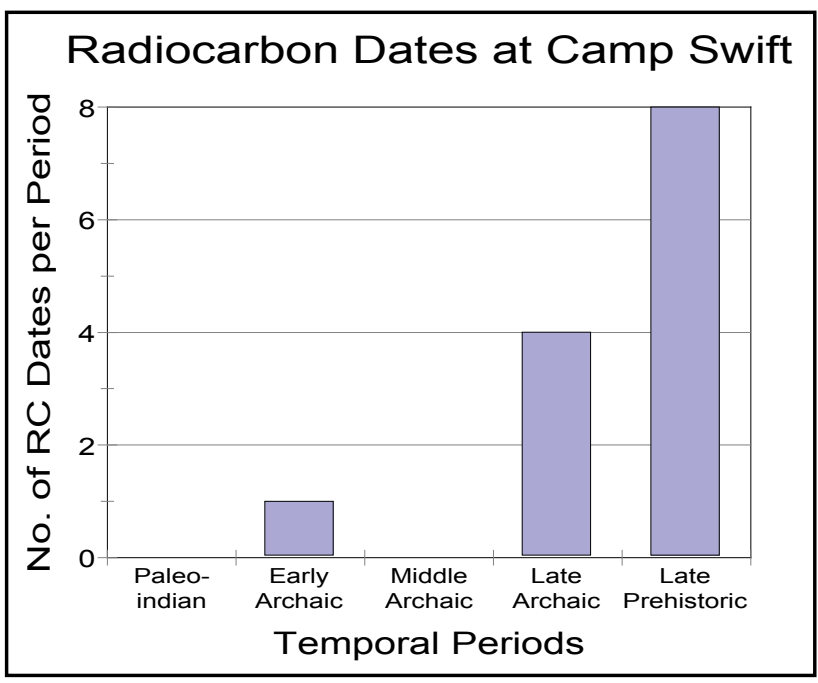

Figure 11-6. Radiocarbon dates from Camp Swift sites. 


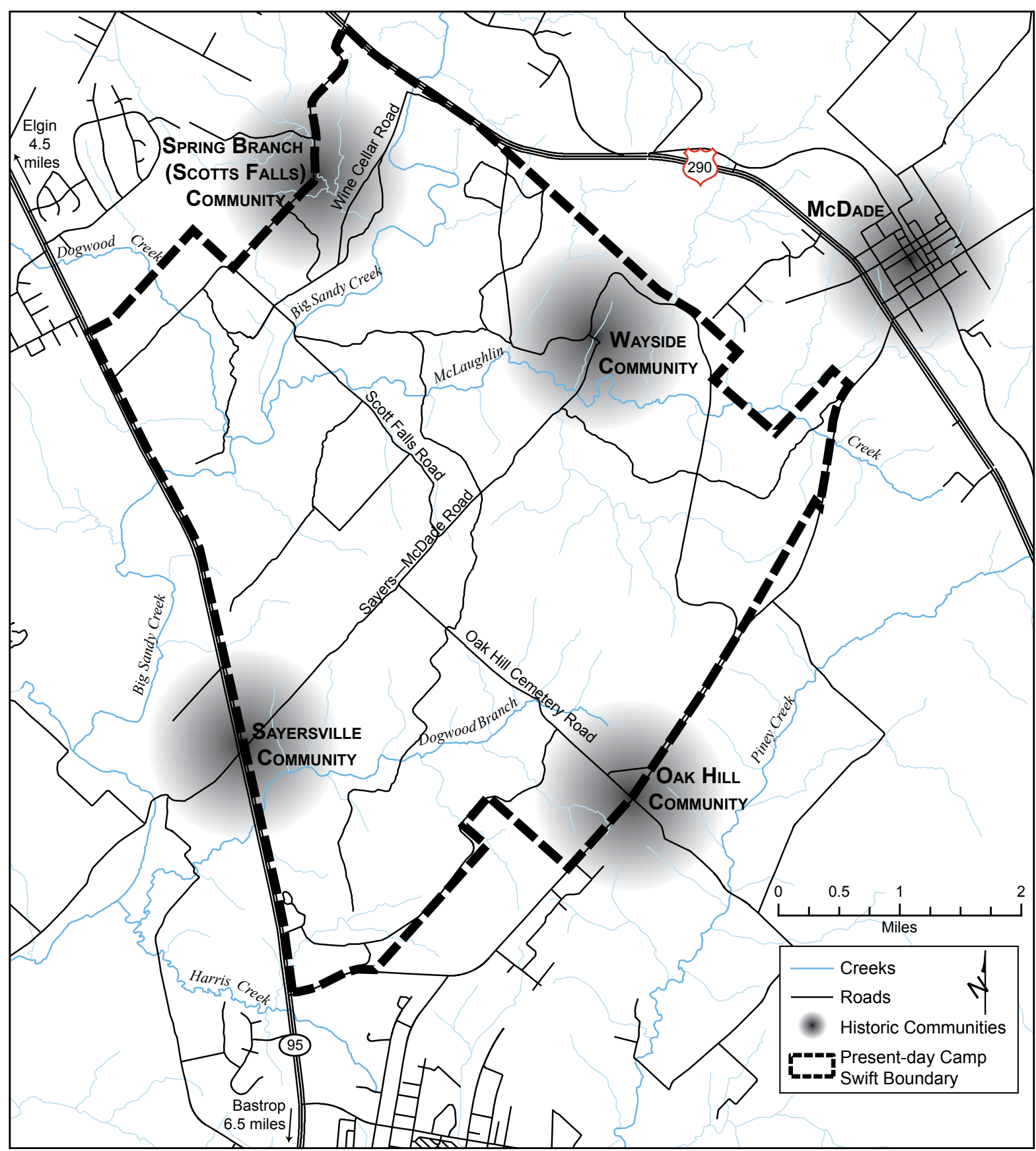

Figure 11-7. Camp Swift communities. 
Table 11-8. Historic site types discovered thus far on Camp Swift.

\begin{tabular}{|c|c|}
\hline Site Type & Number of Sites \\
\hline Agricultural (Irrigation) & 1 \\
\hline Brick Scatter & 1 \\
\hline Bridge & 6 \\
\hline Cemetery & 3 \\
\hline Corral & 5 \\
\hline House or Farmstead & 1 \\
\hline House/Fort & 1 \\
\hline House/Winery & 1 \\
\hline Industrial & 1 \\
\hline Isolated Grave & 1 \\
\hline Mine and Residences & 1 \\
\hline Outbuilding and Dam & 1 \\
\hline Quarry & 28 \\
\hline Trash Dumps/Scatters & 1 \\
\hline School & 4 \\
\hline Well & $\mathbf{1 2 3}$ \\
\hline Total & \\
\hline & 67 \\
\hline & 12 \\
\hline
\end{tabular}




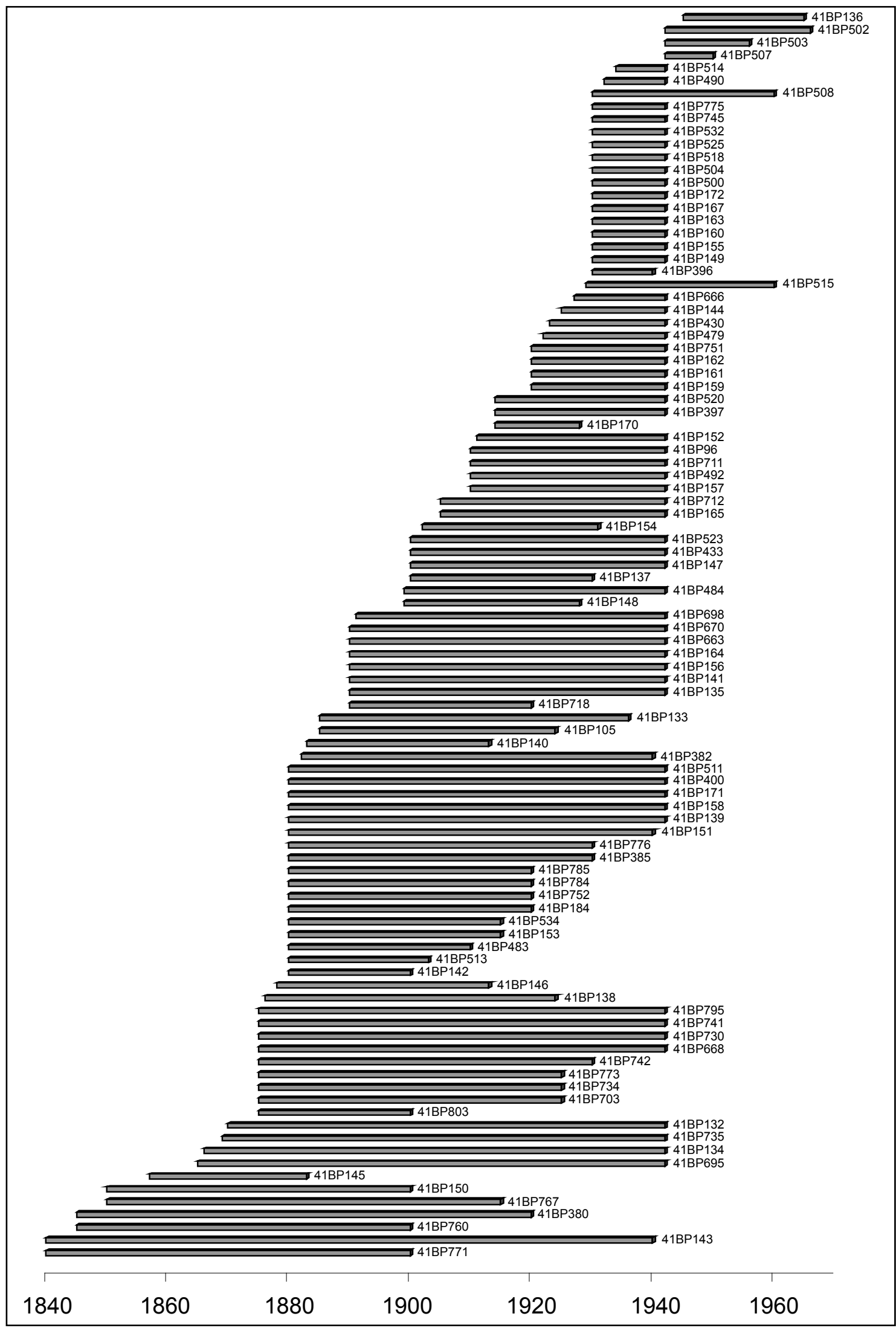

Figure 11-8. Ages of historic house sites discovered thus far on Camp Swift. 


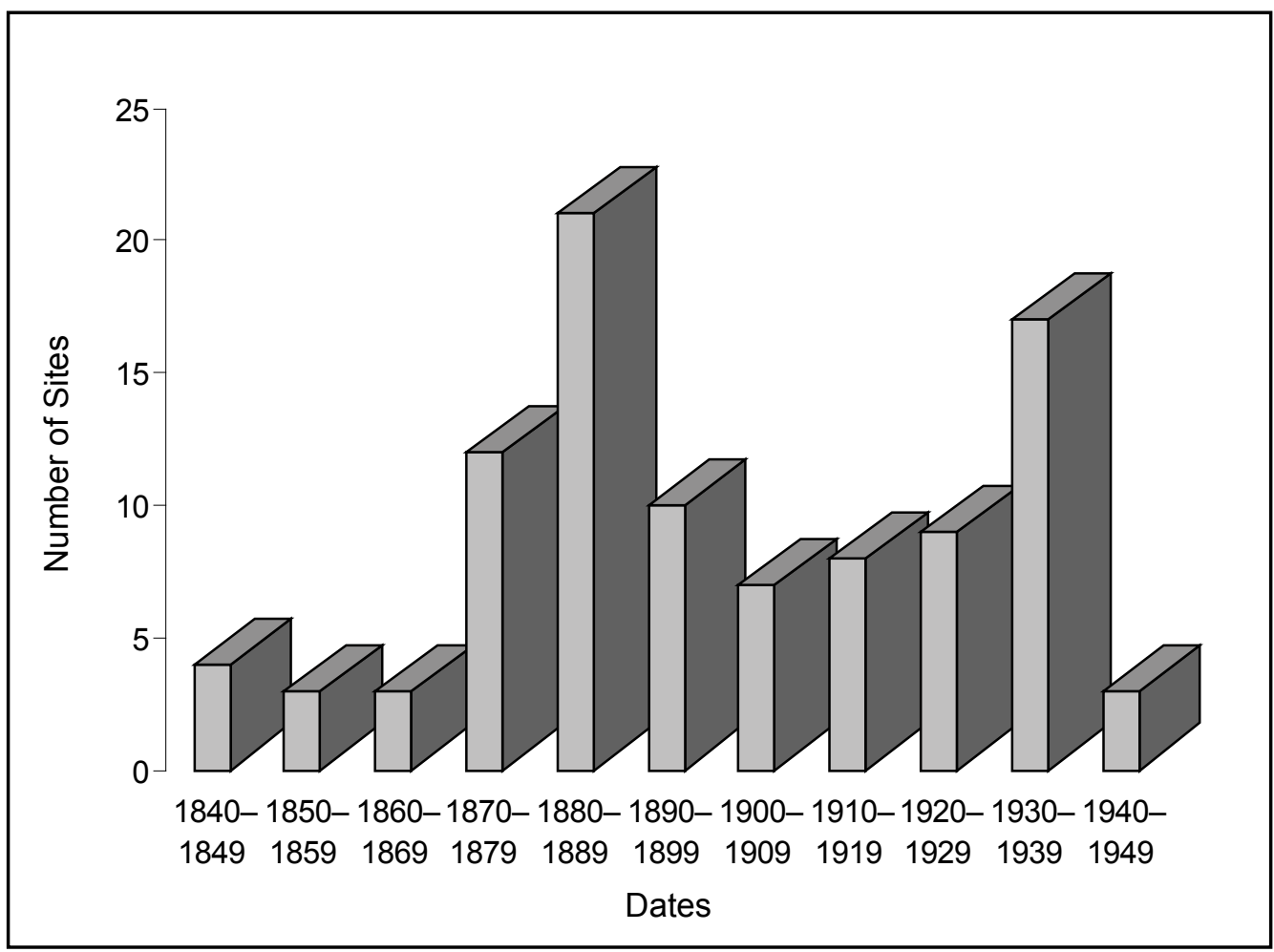

Figure 11-9. Bar chart illustrating the beginning occupation date for all known historic sites at Camp Swift.

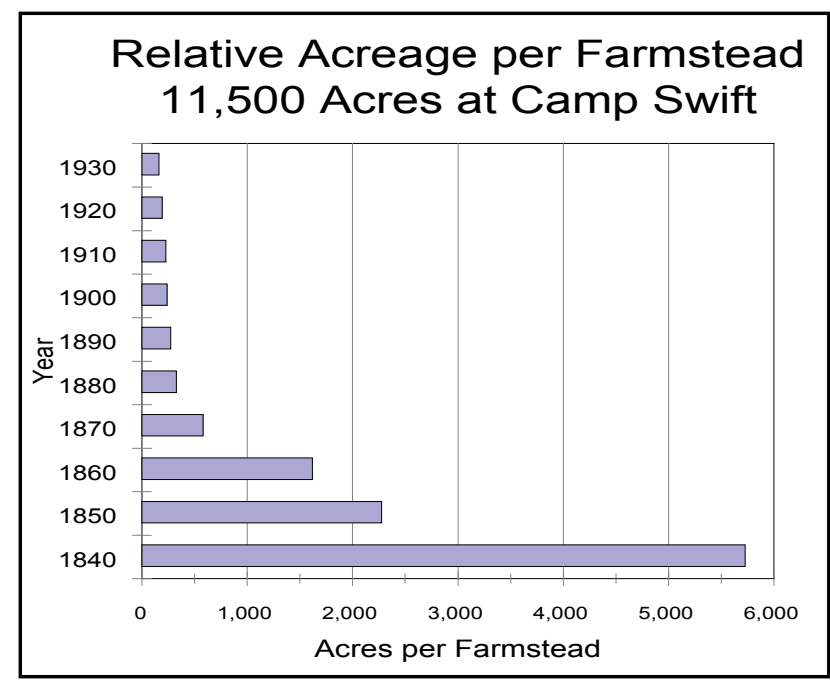

Figure 11-10. Decreasing farmstead sizes on Camp Swift through time. 


\title{
Chapter 12
}

\section{RECOMMENDATIONS}

\author{
By David L. Nickels
}

Under the terms of the contract that authorized the current project, CAS agreed to provide one of the following as recommendations for NRHP nomination eligibility: Not Eligible, Eligible, or Unknown (further investigations recommended). Tables 12-1 and 12-2 summarize the site recommendations that were discussed in Chapters 5-9.

\section{Additional Considerations}

\section{BP143 - Old Fort Site}

From the time Austin's Little Colony settlers began moving into the area in the 1830s, Bastrop County was no exception when it came to retaliatory attacks from both whites and Native Americans (Fehrenbach 1974; Richardson 1991; Wilbarger 1985 [1889]). Two District Court cases decided in 1872 and 1874 mention an "Old Fort" on the northwest bank of McLaughlin Creek (Freeman 1979:98). A significant percentage of artifacts recovered during this project suggest that site 41BP143, which is discussed in detail in Chapter 8, was occupied before 1850 . In addition to four test units, we recommend that more indepth archival investigations be conducted to determine when the fort was likely constructed, who may have constructed it, and how long it may have been used.

\section{BP154-Wayside School}

This site is recommended as unknown eligibility for nomination to the NRHP and requires very limited archival investigations.
Beginning in the 1840 s or 1850 s, there were four other schools within the confines of the current Camp Swift that preceded the Wayside School's location and construction; they were all within three miles or less of the Wayside School. The fifth school in the area, the Wayside School, was constructed here in 1902, burned in 1923, was rebuilt, and then closed in 1931 (Korges 1933:136-137). Site 41BP154 is discussed in detail in Chapter 8. Schools, churches, and cemeteries bound communities together. CAS believes more extensive archival research will reveal significant information regarding the settlement of this area that is heretofore unknown. An estimated 15 days of additional record and oral history research should be sufficient.

\section{BP724}

The consistent vertical distribution of firecracked rocks and flakes between 50 and $60 \mathrm{cmbs}$, corresponding to a buried soil zone, suggests that there may be buried burned rock features and associated material. In addition, the clearly defined differentiation in soil zones makes this site and landform ameliable to a gemorphological study. Further detail of site 41BP724 is presented in Chapter 7.

The geomorphological study should consist of two backhoe trenches. Trench walls should be profiled and described, with soil samples collected for possible further analysis in conjunction with sandy mantle formation issues. The trenches should be carefully excavated in 3-5-cm levels in 
a scraping fashion so that if features or preserved

faunal material are encountered, they can then be excavated by hand during a Phase II testing program. 
Table 12-1. Prehistoric site summary.

\begin{tabular}{|c|c|c|c|c|c|c|}
\hline Site & Type & $\begin{array}{l}\text { Maximum } \\
\text { Known } \\
\text { Depth of } \\
\text { Cultural } \\
\text { Material }\end{array}$ & $\begin{array}{c}\text { Currently } \\
\text { Assessed } \\
\text { Potential }\end{array}$ & $\begin{array}{c}\text { NRHP } \\
\text { Eligibility } \\
\text { Recommendation }\end{array}$ & $\begin{array}{l}\text { Size } \\
\left(\mathbf{m}^{2}\right)\end{array}$ & $\begin{array}{c}\text { No. of } \\
\text { Hand- } \\
\text { Excavated } \\
\text { 1-x-1-m Units } \\
\text { Recommended }\end{array}$ \\
\hline 41BР93 & Open Campsite & $90 \mathrm{cmbs}$ & Minimal & Not Eligible & 7,591 & \\
\hline 41BP94 & Open Campsite & $80 \mathrm{cmbs}$ & Unknown & Unknown & 12,500 & 12 \\
\hline $\begin{array}{l}\text { 41BP95/ } \\
\text { 41BP184 }\end{array}$ & Open Campsite & $60 \mathrm{cmbs}$ & Minimal & Not Eligible & 12,670 & \\
\hline 41BP96 & Open Campsite & Surface & Minimal & Not Eligible & 1,590 & \\
\hline 41BP97 & Lithic Procurement & Surface & Minimal & Not Eligible & 15,647 & \\
\hline 41BP99 & Lithic Procurement & Surface & Minimal & Not Eligible & 4,590 & \\
\hline 41BP100 & Open Campsite & $110 \mathrm{cmbs}$ & Unknown & Unknown & 18,070 & 11 \\
\hline 41BP101 & Lithic Procurement & Surface & Minimal & Not Eligible & 4,426 & \\
\hline 41BP103 & Open Campsite & Surface & Minimal & Not Eligible & 181 & \\
\hline 41BP105 & Open Campsite & $100 \mathrm{cmbs}$ & Minimal & Not Eligible & 7,312 & \\
\hline 41BP106 & Open Campsite & $70 \mathrm{cmbs}$ & Minimal & Not Eligible & 8,767 & \\
\hline 41BP109 & Open Campsite & Surface & Minimal & Not Eligible & 2,503 & \\
\hline 41BP111 & Open Campsite & $90 \mathrm{cmbs}$ & Unknown & Unknown & 53,607 & 2 \\
\hline 41BP112 & Open Campsite & $90 \mathrm{cmbs}$ & Unknown & Unknown & 21,622 & \\
\hline 41BP114 & Open Campsite & $70 \mathrm{cmbs}$ & Unknown & Unknown & 5,854 & 2 \\
\hline 41BP119 & Open Campsite & $20 \mathrm{cmbs}$ & Minimal & Not Eligible & 7,018 & \\
\hline 41BP120 & Open Campsite & $25 \mathrm{cmbs}$ & Minimal & Not Eligible & 40,392 & \\
\hline 41BP121 & Open Campsite & $80 \mathrm{cmbs}$ & Minimal & Not Eligible & 51,510 & \\
\hline $\begin{array}{l}\text { 41BP122/ } \\
41 \mathrm{BP} 143\end{array}$ & Open Campsite & $70 \mathrm{cmbs}$ & Unknown & Unknown & 12,344 & 2 \\
\hline 41BP123 & Open Campsite & $70 \mathrm{cmbs}$ & Minimal & Not Eligible & 3,584 & \\
\hline 41BP124 & Open Campsite & $10 \mathrm{cmbs}$ & Minimal & Not Eligible & 335 & \\
\hline 41BP127 & Open Campsite & $50 \mathrm{cmbs}$ & Minimal & Not Eligible & 775 & \\
\hline 41BP129 & Open Campsite & $30 \mathrm{cmbs}$ & Minimal & Not Eligible & 10,669 & \\
\hline 41BP130 & Lithic Scatter & $70 \mathrm{cmbs}$ & Minimal & Not Eligible & 1,174 & \\
\hline 41BP131 & Open Campsite & $40 \mathrm{cmbs}$ & Minimal & Not Eligible & 6,185 & \\
\hline 41BP366 & Open Campsite & $40 \mathrm{cmbs}$ & Minimal & Not Eligible & 1,866 & \\
\hline 41BP367 & Open Campsite & $60 \mathrm{cmbs}$ & Minimal & Not Eligible & 2,672 & \\
\hline 41BP381 & Open Campsite & $30 \mathrm{cmbs}$ & Minimal & Not Eligible & 2,237 & \\
\hline 41BP433 & Open Campsite & Surface & Minimal & Not Eligible & 11,935 & \\
\hline $41 \mathrm{BP} 436$ & Open Campsite & $70 \mathrm{cmbs}$ & Unknown & Unknown & 8,709 & 4 \\
\hline 41BP472 & Lithic Scatter & $70 \mathrm{cmbs}$ & Minimal & Not Eligible & 1,908 & \\
\hline 41BP485 & Open Campsite & $200 \mathrm{cmbs}$ & Unknown & Unknown & 23,058 & \\
\hline 41BP487 & Open Campsite & $120 \mathrm{cmbs}$ & Unknown & Unknown & 10,561 & 5 \\
\hline 41BP491 & Open Campsite & $100 \mathrm{cmbs}$ & Minimal & Not Eligible & 7,717 & \\
\hline 41BP494 & Lithic Scatter & $70 \mathrm{cmbs}$ & Minimal & Not Eligible & 10,087 & \\
\hline 41BP495 & Open Campsite & $140 \mathrm{cmbs}$ & Unknown & Unknown & 8,688 & \\
\hline
\end{tabular}


Table 12-1 Continued. Prehistoric site summary.

\begin{tabular}{|c|c|c|c|c|c|c|}
\hline Site & Type & $\begin{array}{l}\text { Maximum } \\
\text { Known } \\
\text { Depth of } \\
\text { Cultural } \\
\text { Material }\end{array}$ & $\begin{array}{c}\text { Currently } \\
\text { Assessed } \\
\text { Potential }\end{array}$ & $\begin{array}{c}\text { NRHP } \\
\text { Eligibility } \\
\text { Recommendation }\end{array}$ & $\begin{array}{l}\text { Size } \\
\left(\mathrm{m}^{2}\right)\end{array}$ & $\begin{array}{c}\text { No. of } \\
\text { Hand- } \\
\text { Excavated } \\
\text { 1-x-1-m Units } \\
\text { Recommended }\end{array}$ \\
\hline 41BP521 & Open Campsite & $170 \mathrm{cmbs}$ & Unknown & Unknown & 9,656 & \\
\hline 41BP534 & Open Campsite & $80 \mathrm{cmbs}$ & Unknown & Unknown & 22,797 & 2 \\
\hline 41BP695 & Lithic Scatter & $60 \mathrm{cmbs}$ & Minimal & Not Eligible & 4,415 & \\
\hline 41BP696 & Open Campsite & $110 \mathrm{cmbs}$ & Unknown & Unknown & 43,248 & 13 \\
\hline 41BP697 & Lithic Scatter & $70 \mathrm{cmbs}$ & Minimal & Not Eligible & 336 & \\
\hline 41BР699 & Lithic Scatter & $60 \mathrm{cmbs}$ & Minimal & Not Eligible & 393 & \\
\hline 41BP702 & Open Campsite & $70 \mathrm{cmbs}$ & Minimal & Not Eligible & 8,134 & \\
\hline 41BP704 & Open Campsite & $60 \mathrm{cmbs}$ & Unknown & Unknown & 507 & 2 \\
\hline 41BP705 & Lithic Scatter & $50 \mathrm{cmbs}$ & Minimal & Not Eligible & 76 & \\
\hline 41BP706 & Open Campsite & $90 \mathrm{cmbs}$ & Unknown & Unknown & 7,523 & 3 \\
\hline 41BP707 & Lithic Scatter & $50 \mathrm{cmbs}$ & Minimal & Not Eligible & 272 & \\
\hline 41BP708 & Lithic Scatter & $80 \mathrm{cmbs}$ & Minimal & Not Eligible & 2,245 & \\
\hline 41BP709 & Open Campsite & $60 \mathrm{cmbs}$ & Minimal & Not Eligible & 230 & \\
\hline 41BP710 & Lithic Scatter & $40 \mathrm{cmbs}$ & Minimal & Not Eligible & 115 & \\
\hline 41BP713 & Open Campsite & $90 \mathrm{cmbs}$ & Unknown & Unknown & 3,835 & 2 \\
\hline 41BP714 & Open Campsite & $50 \mathrm{cmbs}$ & Unknown & Unknown & 4,977 & 2 \\
\hline $41 \mathrm{BP} 715$ & Open Campsite & $60 \mathrm{cmbs}$ & Unknown & Unknown & 605 & 2 \\
\hline 41BP716 & Open Campsite & $70 \mathrm{cmbs}$ & Unknown & Unknown & 2,160 & 2 \\
\hline 41BP717 & Open Campsite & $60 \mathrm{cmbs}$ & Unknown & Unknown & 907 & 2 \\
\hline 41BP718 & Open Campsite & $70 \mathrm{cmbs}$ & Unknown & Unknown & 4,063 & 2 \\
\hline 41BP719 & Open Campsite & $80 \mathrm{cmbs}$ & Minimal & Not Eligible & 3,220 & \\
\hline 41BP720 & Open Campsite & $70 \mathrm{cmbs}$ & Unknown & Unknown & 3,767 & 4 \\
\hline 41BP721 & Open Campsite & $80 \mathrm{cmbs}$ & Minimal & Not Eligible & 4,715 & \\
\hline 41BP722 & Lithic Scatter & $70 \mathrm{cmbs}$ & Minimal & Not Eligible & 2,526 & \\
\hline 41BP723 & Lithic Scatter & $70 \mathrm{cmbs}$ & Minimal & Not Eligible & 195 & \\
\hline 41BР724 & Open Campsite & $70 \mathrm{cmbs}$ & Unknown & Unknown & 1,355 & 2 \\
\hline 41BP725 & Open Campsite & $70 \mathrm{cmbs}$ & Unknown & Unknown & 18,421 & 5 \\
\hline 41BP726 & Open Campsite & $50 \mathrm{cmbs}$ & Unknown & Unknown & 521 & 2 \\
\hline 41BР727 & Open Campsite & $70 \mathrm{cmbs}$ & Unknown & Unknown & 1,657 & 4 \\
\hline 41BP728 & Open Campsite & $40 \mathrm{cmbs}$ & Minimal & Not Eligible & 2,014 & \\
\hline 41BP730 & Open Campsite & $80 \mathrm{cmbs}$ & Minimal & Not Eligible & 23,401 & \\
\hline 41BP731 & Open Campsite & $70 \mathrm{cmbs}$ & Unknown & Unknown & 1,002 & 2 \\
\hline 41BP732 & Lithic Scatter & $50 \mathrm{cmbs}$ & Minimal & Not Eligible & 650 & \\
\hline 41BP733 & Open Campsite & $70 \mathrm{cmbs}$ & Unknown & Unknown & 3,789 & 7 \\
\hline 41BP734 & Lithic Scatter & $50 \mathrm{cmbs}$ & Minimal & Not Eligible & 8,688 & \\
\hline 41BP736 & Lithic Scatter & $30 \mathrm{cmbs}$ & Minimal & Not Eligible & 352 & \\
\hline 41BP737 & Lithic Scatter & $40 \mathrm{cmbs}$ & Minimal & Not Eligible & 653 & \\
\hline
\end{tabular}


Table 12-1 Continued. Prehistoric site summary.

\begin{tabular}{|c|c|c|c|c|c|c|}
\hline Site & Type & $\begin{array}{l}\text { Maximum } \\
\text { Known } \\
\text { Depth of } \\
\text { Cultural } \\
\text { Material }\end{array}$ & $\begin{array}{l}\text { Currently } \\
\text { Assessed } \\
\text { Potential }\end{array}$ & $\begin{array}{c}\text { NRHP } \\
\text { Eligibility } \\
\text { Recommendation }\end{array}$ & $\begin{array}{l}\text { Size } \\
\left(\mathbf{m}^{2}\right)\end{array}$ & $\begin{array}{c}\text { No. of } \\
\text { Hand- } \\
\text { Excavated } \\
\text { 1-x-1-m Units } \\
\text { Recommended }\end{array}$ \\
\hline 41BP738 & Lithic Scatter & $70 \mathrm{cmbs}$ & Minimal & Not Eligible & 4,599 & \\
\hline 41BР739 & Lithic Scatter & $30 \mathrm{cmbs}$ & Minimal & Not Eligible & 121 & \\
\hline 41BP740 & Open Campsite & $80 \mathrm{cmbs}$ & Unknown & Unknown & 12,274 & 4 \\
\hline 41BP742 & Open Campsite & $50 \mathrm{cmbs}$ & Minimal & Not Eligible & 4,171 & \\
\hline 41BР743 & Open Campsite & $80 \mathrm{cmbs}$ & Unknown & Unknown & 706 & 2 \\
\hline 41BР744 & Open Campsite & $70 \mathrm{cmbs}$ & Minimal & Not Eligible & 5,434 & \\
\hline 41BP745 & Lithic Scatter & $60 \mathrm{cmbs}$ & Minimal & Not Eligible & 716 & \\
\hline 41BР747 & Open Campsite & $70 \mathrm{cmbs}$ & Unknown & Unknown & 14,156 & 4 \\
\hline 41BР748 & Open Campsite & $60 \mathrm{cmbs}$ & Minimal & Not Eligible & 332 & \\
\hline 41BР749 & Open Campsite & $70 \mathrm{cmbs}$ & Minimal & Not Eligible & 1,139 & \\
\hline 41BP750 & Open Campsite & $60 \mathrm{cmbs}$ & Minimal & Not Eligible & 1,379 & \\
\hline 41BP753 & Open Campsite & $60 \mathrm{cmbs}$ & Unknown & Unknown & 5,754 & 2 \\
\hline 41BP754 & Open Campsite & $100 \mathrm{cmbs}$ & Unknown & Unknown & 1,556 & 4 \\
\hline 41BP755 & Open Campsite & $70 \mathrm{cmbs}$ & Minimal & Not Eligible & 1,309 & \\
\hline 41BP756 & Open Campsite & $50 \mathrm{cmbs}$ & Minimal & Not Eligible & 361 & \\
\hline 41BP757 & Open Campsite & $50 \mathrm{cmbs}$ & Minimal & Not Eligible & 7,976 & \\
\hline 41BP758 & Open Campsite & $40 \mathrm{cmbs}$ & Minimal & Not Eligible & 1,735 & \\
\hline 41BP759 & Open Campsite & $80 \mathrm{cmbs}$ & Unknown & Unknown & 4,000 & 3 \\
\hline 41BP761 & Open Campsite & $70 \mathrm{cmbs}$ & Unknown & Unknown & 1,559 & 2 \\
\hline 41BP762 & Open Campsite & $70 \mathrm{cmbs}$ & Minimal & Not Eligible & 1,345 & \\
\hline 41BP763 & Open Campsite & $70 \mathrm{cmbs}$ & Minimal & Not Eligible & 2,204 & \\
\hline 41BP764 & Lithic Scatter & $60 \mathrm{cmbs}$ & Minimal & Not Eligible & 1,056 & \\
\hline 41BP765 & Open Campsite & $90 \mathrm{cmbs}$ & Unknown & Unknown & 21,873 & 4 \\
\hline 41BP766 & Open Campsite & $90 \mathrm{cmbs}$ & Unknown & Unknown & 25,820 & 8 \\
\hline 41BP768 & Lithic Scatter & $50 \mathrm{cmbs}$ & Minimal & Not Eligible & 906 & \\
\hline 41BP769 & Open Campsite & $50 \mathrm{cmbs}$ & Minimal & Not Eligible & 7,483 & \\
\hline 41BP770 & Lithic Scatter & $40 \mathrm{cmbs}$ & Minimal & Not Eligible & 646 & \\
\hline 41BP772 & Open Campsite & Surface & Minimal & Not Eligible & 903 & \\
\hline 41BP774 & Open Campsite & $70 \mathrm{cmbs}$ & Minimal & Not Eligible & 73 & \\
\hline 41BP776 & Open Campsite & $70 \mathrm{cmbs}$ & Unknown & Unknown & 23,590 & 3 \\
\hline 41BP777 & Lithic Scatter & $50 \mathrm{cmbs}$ & Minimal & Not Eligible & 283 & \\
\hline 41BР778 & Open Campsite & $60 \mathrm{cmbs}$ & Unknown & Unknown & 648 & 2 \\
\hline 41BР779 & Lithic Scatter & $100 \mathrm{cmbs}$ & Minimal & Not Eligible & 190 & \\
\hline 41BP780 & Open Campsite & $70 \mathrm{cmbs}$ & Unknown & Unknown & 6,017 & 3 \\
\hline 41BP781 & Open Campsite & $40 \mathrm{cmbs}$ & Minimal & Not Eligible & 532 & \\
\hline 41BР782 & Open Campsite & $60 \mathrm{cmbs}$ & Unknown & Unknown & 34,760 & 8 \\
\hline 41BP783 & Open Campsite & $60 \mathrm{cmbs}$ & Minimal & Not Eligible & 1,048 & \\
\hline
\end{tabular}


Table 12-1 Continued. Prehistoric site summary.

\begin{tabular}{|c|c|c|c|c|c|c|}
\hline Site & Type & $\begin{array}{c}\text { Maximum } \\
\text { Known } \\
\text { Depth of } \\
\text { Cultural } \\
\text { Material }\end{array}$ & $\begin{array}{l}\text { Currently } \\
\text { Assessed } \\
\text { Potential }\end{array}$ & $\begin{array}{c}\text { NRHP } \\
\text { Eligibility } \\
\text { Recommendation }\end{array}$ & $\begin{array}{l}\text { Size } \\
\left(\mathrm{m}^{2}\right)\end{array}$ & $\begin{array}{c}\text { No. of } \\
\text { Hand- } \\
\text { Excavated } \\
\text { 1-x-1-m Units } \\
\text { Recommended } \\
\end{array}$ \\
\hline 41BP784 & Open Campsite & $40 \mathrm{cmbs}$ & Minimal & Not Eligible & 8,961 & \\
\hline 41BP786 & Lithic Scatter & $70 \mathrm{cmbs}$ & Minimal & Not Eligible & 13,682 & \\
\hline 41BP787 & Open Campsite & $60 \mathrm{cmbs}$ & Unknown & Unknown & 4,667 & 5 \\
\hline 41BP788 & Open Campsite & $70 \mathrm{cmbs}$ & Minimal & Not Eligible & 8,650 & \\
\hline 41BP789 & Open Campsite & $60 \mathrm{cmbs}$ & Minimal & Not Eligible & 555 & \\
\hline 41BP790 & Lithic Scatter & $30 \mathrm{cmbs}$ & Minimal & Not Eligible & 2,212 & \\
\hline 41BP792 & Open Campsite & $60 \mathrm{cmbs}$ & Unknown & Unknown & 3,607 & 2 \\
\hline 41BP796 & Open Campsite & $50 \mathrm{cmbs}$ & Minimal & Not Eligible & 1,384 & \\
\hline 41BP797 & Open Campsite & $70 \mathrm{cmbs}$ & Minimal & Not Eligible & 6,584 & \\
\hline 41BP798 & Lithic Scatter & $40 \mathrm{cmbs}$ & Minimal & Not Eligible & 774 & \\
\hline 41BP799 & Lithic Scatter & $30 \mathrm{cmbs}$ & Minimal & Not Eligible & 1,522 & \\
\hline 41BP800 & Open Campsite & $30 \mathrm{cmbs}$ & Minimal & Not Eligible & 1,592 & \\
\hline 41BP801 & Open Campsite & $67 \mathrm{cmbs}$ & Unknown & Unknown & 4,670 & 2 \\
\hline 41BP802 & Open Campsite & $80 \mathrm{cmbs}$ & Unknown & Unknown & 5,827 & 3 \\
\hline 41BP804 & Lithic Scatter & $50 \mathrm{cmbs}$ & Minimal & Not Eligible & 5,675 & \\
\hline & & & & & Total & 157 \\
\hline
\end{tabular}


Table 12-2. Historic site summary.

\begin{tabular}{|c|c|c|c|c|c|c|}
\hline Site & Type & $\begin{array}{l}\text { Maximum } \\
\text { Known } \\
\text { Depth of } \\
\text { Cultural } \\
\text { Material }\end{array}$ & $\begin{array}{l}\text { Currently } \\
\text { Assessed } \\
\text { Potential }\end{array}$ & $\begin{array}{c}\text { NRHP } \\
\text { Eligibility } \\
\text { Recommendation }\end{array}$ & $\begin{array}{l}\text { Size } \\
\left(\mathbf{m}^{2}\right)\end{array}$ & $\begin{array}{c}\text { No. of } \\
\text { Hand- } \\
\text { Excavated } \\
\text { 1-x-1-m Units } \\
\text { Recommended }\end{array}$ \\
\hline $\begin{array}{l}\text { 41BP95/ } \\
\text { 41BP184 }\end{array}$ & Farmstead & $50 \mathrm{cmbs}$ & Minimal & Not Eligible & 12,670 & \\
\hline 41BP96 & Trash Scatter & N/A & Minimal & Not Eligible & 1,590 & \\
\hline 41BP105 & Farming & Unknown & Unknown & Unknown & 7,312 & 6 \\
\hline 41BP132 & Farmstead & $20 \mathrm{cmbs}$ & Unknown & Unknown & 7,370 & 5 \\
\hline 41BP136 & Corral & Surface & Minimal & Not Eligible & 2,580 & \\
\hline 41BP139 & House Site & $50 \mathrm{cmbs}$ & Minimal & Not Eligible & 2,139 & \\
\hline 41BP142 & House Site & $30 \mathrm{cmbs}$ & Minimal & Not Eligible & 6,073 & \\
\hline $\begin{array}{l}\text { 41BP143/ } \\
41 \mathrm{BP} 122\end{array}$ & Farmstead/Fort & $70 \mathrm{cmbs}$ & Unknown & Unknown & 12,344 & 4 \\
\hline 41BP147 & House Site & N/A & Minimal & Not Eligible & 8,616 & \\
\hline 41BP153 & House Site & Surface & Minimal & Not Eligible & 7,252 & \\
\hline 41BP154 & School & $10 \mathrm{cmbs}$ & Unknown & Unknown & 683 & \\
\hline 41BP157 & Farmstead & $30 \mathrm{cmbs}$ & Minimal & Not Eligible & 6,479 & \\
\hline 41BP158 & Farmstead & $13 \mathrm{cmbs}$ & Minimal & Not Eligible & 1,830 & \\
\hline 41BP159 & Farmstead & $10 \mathrm{cmbs}$ & Unknown & Unknown & 1,332 & 2 \\
\hline 41BP161 & Farmstead & Surface & Minimal & Not Eligible & 9,532 & \\
\hline 41BP162 & Farmstead & $50 \mathrm{cmbs}$ & Minimal & Not Eligible & 4,968 & \\
\hline 41BP164 & House Site & Unknown & Minimal & Not Eligible & 900 & \\
\hline 41BP167 & House Site & Unknown & Minimal & Not Eligible & 580 & \\
\hline 41BP171 & House Site & $30 \mathrm{cmbs}$ & Minimal & Not Eligible & 8,920 & \\
\hline 41BP172 & House Site & $10 \mathrm{cmbs}$ & Minimal & Not Eligible & 2,986 & \\
\hline 41BP433 & House Site & $30 \mathrm{cmbs}$ & Minimal & Not Eligible & 11,935 & \\
\hline 41BP434 & House Site & Unknown & Minimal & Not Eligible & 100 & \\
\hline 41BP487 & Trash Scatter & $40 \mathrm{cmbs}$ & Minimal & Not Eligible & 10,561 & \\
\hline 41BP489 & Industrial & Surface & Minimal & Not Eligible & 1,605 & \\
\hline 41BP490 & Farmstead & $50 \mathrm{cmbs}$ & Unknown & Unknown & 4,878 & 3 \\
\hline 41BP492 & Trash Dump & N/A & Minimal & Not Eligible & 303 & \\
\hline 41BP534 & Trash Scatter & $80 \mathrm{cmbs}$ & Minimal & Not Eligible & 22,797 & \\
\hline 41BР695 & Farmstead & $100 \mathrm{cmbs}$ & Minimal & Not Eligible & 4,415 & \\
\hline 41BР698 & Brick Scatter & $\mathrm{N} / \mathrm{A}$ & Minimal & Not Eligible & 73 & \\
\hline 41BP700 & Bridge & N/A & Minimal & Not Eligible & 565 & \\
\hline 41BP701 & Bridge & N/A & Minimal & Not Eligible & 240 & \\
\hline 41BP703 & House Site & $30 \mathrm{cmbs}$ & Minimal & Not Eligible & 3,014 & \\
\hline 41BP711 & Trash Dump & N/A & Minimal & Not Eligible & 276 & \\
\hline 41BP712 & Trash Dump & $\mathrm{N} / \mathrm{A}$ & Minimal & Not Eligible & 161 & \\
\hline 41BP718 & House Site & $70 \mathrm{cmbs}$ & Unknown & Unknown & 4,063 & 3 \\
\hline
\end{tabular}


Table 12-2 Continued. Historic site summary.

\begin{tabular}{|c|c|c|c|c|c|c|}
\hline Site & Type & $\begin{array}{l}\text { Maximum } \\
\text { Known } \\
\text { Depth of } \\
\text { Cultural } \\
\text { Material }\end{array}$ & $\begin{array}{l}\text { Currently } \\
\text { Assessed } \\
\text { Potential }\end{array}$ & $\begin{array}{c}\text { NRHP } \\
\text { Eligibility } \\
\text { Recommendation }\end{array}$ & $\begin{array}{l}\text { Size } \\
\left(\mathbf{m}^{2}\right)\end{array}$ & $\begin{array}{c}\text { No. of } \\
\text { Hand- } \\
\text { Excavated } \\
\text { 1-x-1-m Units } \\
\text { Recommended }\end{array}$ \\
\hline 41BP729 & Bridge & N/A & Minimal & Not Eligible & 96 & \\
\hline 41BP730 & Farmstead & $50 \mathrm{cmbs}$ & Minimal & Not Eligible & 23,401 & \\
\hline 41BP734 & Farmstead & $60 \mathrm{cmbs}$ & Minimal & Not Eligible & 8,688 & \\
\hline 41BP735 & House Site & $60 \mathrm{cmbs}$ & Minimal & Not Eligible & 3,088 & \\
\hline 41BP741 & Trash Scatter & N/A & Minimal & Not Eligible & 685 & \\
\hline 41BP742 & House Site & $30 \mathrm{cmbs}$ & Minimal & Not Eligible & 4,171 & \\
\hline 41BP745 & House Site & Surface & Minimal & Not Eligible & 716 & \\
\hline 41BP746 & Bridge & N/A & Unknown & Unknown & 100 & \\
\hline 41BP751 & Trash Dump & N/A & Minimal & Not Eligible & 332 & \\
\hline 41BP752 & House Site & $20 \mathrm{cmbs}$ & Unknown & Unknown & 123 & 3 \\
\hline 41BP760 & Quarry & $10 \mathrm{cmbs}$ & Minimal & Not Eligible & 1,560 & \\
\hline 41BP767 & Farmstead & $20 \mathrm{cmbs}$ & Minimal & Not Eligible & 452 & \\
\hline 41BP771 & House Site & $39 \mathrm{cmbs}$ & Unknown & Unknown & 1,542 & 3 \\
\hline $41 \mathrm{BP} 773$ & Farmstead & $40 \mathrm{cmbs}$ & Minimal & Not Eligible & 1,561 & \\
\hline 41BP775 & House Site & $20 \mathrm{cmbs}$ & Minimal & Not Eligible & 2,049 & \\
\hline 41BP776 & House Site & $40 \mathrm{cmbs}$ & Minimal & Not Eligible & 23,590 & \\
\hline 41BP784 & Farmstead & $40 \mathrm{cmbs}$ & Minimal & Not Eligible & 8,961 & \\
\hline 41BP785 & House Site & $30 \mathrm{cmbs}$ & Minimal & Not Eligible & 550 & \\
\hline 41BP791 & Farmstead & $20 \mathrm{cmbs}$ & Minimal & Not Eligible & 4,236 & \\
\hline 41BP793 & Corral & N/A & Minimal & Not Eligible & 866 & \\
\hline 41BP794 & Corral & N/A & Minimal & Not Eligible & 2,810 & \\
\hline 41BP795 & Farmstead & Surface & Minimal & Not Eligible & 4,279 & \\
\hline 41BP803 & House Site & Surface & Minimal & Not Eligible & 1,712 & \\
\hline & & & & & Total & 29 \\
\hline
\end{tabular}




\section{References Cited}

Albert, Lillian Smith, and Kathryn Kent

1949 The Complete Button Book. Appledore, Stratford, Connecticut.

Arnn, John

2005 Chronology, Technology, and Subsistence: Is That All There Is? CTA Newsletter 29(2):17-28.

Bagdade, Susan D., and Alan D. Bagdade

1991 Warman's English \& Continental Pottery \& Porcelain. 2nd ed. Krause Publications, Iola, Iowa.

Baker, Frank E.

1979 Soil Survey of Bastrop County, Texas. U.S. Department of Agriculture, Soil Conservation Service, Washington, D. C.

Barnes, Virgil E.

1974 Geological Atlas of Texas, Austin Sheet. Bureau of Economic Geology, The University of Texas at Austin.

Bastrop County

1929 Map of Bastrop County, Texas. Copy on file in Bastrop County Courthouse, Deeds and Records Office. Randolph Blueprint Company, San Antonio, Texas.

Beers, John S.

2001 A Menagerie in Milk Glass. Antiques \& Art Around Florida Winter/Spring 2001:1-4. Electronic document, http://aarf.com/femilk01.htm, accessed 2005.

Bement, Leland C.

1989 Excavations at 41 BP19 the Kennedy Bluffs Site, Bastrop County, Texas. Contract Reports in Archaeology, Report Number 5. Texas State Department of Highways and Public Transportation, Highway Design Division, Austin.

Bender, Nathan E.

1986 Early $20^{\text {th }}$ Century Commercial Closures. Paper presented at the annual meeting of the Society for Historical Archaeology and Conference on Underwater Archaeology, 11 January, 1986, Sacramento, California. Copy No. 86 on file at the Center for Archaeological Studies, Texas State University at San Marcos. 
Birks, Steve

2005 Stoke-on-Trent. Electronic document, http://www.thepotteries.org/, accessed 29 November 2005.

Black, Stephen L.

1986 Clemente and Herminia Hinojosa Site, 41JW8: A Toyah Horizon Campsite in Southern Texas. Special Report No. 18. Center for Archaeological Research, The University of Texas at San Antonio.

1989a Central Texas Plateau Prairie. In From the Gulf Coast to the Rio Grande: Human Adaptation in Central, South and Lower Pecos Texas, by Thomas R. Hester, Stephen L. Black, D. Gentry Steele, Ben W. Olive, Anne A. Fox, Karl J. Reinhard, and Leland C. Bement, pp. 17-38. Research Series No. 33. Arkansas Archeological Survey, Fayetteville.

1989b Environmental Setting. In From the Gulf Coast to the Rio Grande: Human Adaptation in the Central, South, and Lower Pecos Texas, by Thomas R. Hester, Stephen L. Black, D. Gentry Steele, Ben W. Olive, Anne A. Fox, Karl J. Reinhard, and Leland C. Bement, pp. 5-17. Research Series No. 33. Arkansas Archeological Survey, Fayetteville.

1989c South Texas Plain. In From the Gulf Coast to the Rio Grande: Human Adaptation in the Central, South, and Lower Pecos Texas, by Thomas R. Hester, Stephen L. Black, D. Gentry Steele, Ben W. Olive, Anne A. Fox, Karl J. Reinhard, and Leland C. Bement, pp. 39-62. Research Series No. 33. Arkansas Archaeological Survey, Fayetteville.

Black, Stephen L., Linda W. Ellis, Darrell G. Creel, and Glen T. Goode

1997 Hot Rock Cooking on the Greater Edwards Plateau: Four Burned Rock Midden Sites in West Central Texas, 2 vols. Studies in Archeology 22. Texas Archeological Research Laboratory, The University of Texas at Austin. Archeology Studies Program, Report 2. Texas Department of Transportation, Environmental Affairs Division, Austin.

Black, Stephen L., and Al J. McGraw

1985 The Panther Springs Creek Site: Cultural Change and Continuity in the Upper Salado Creek Drainage, South-Central Texas. Archaeological Survey Report No. 100. Center for Archaeological Research, The University of Texas at San Antonio.

Blair, W. Frank

1950 The Biotic Provinces of Texas. Texas Journal of Science 2(1):93-117.

Bousman, C. Britt

1998 Paleoenvironmental Change in Central Texas: The Palynological Evidence. Plains Anthropologist 43:201-219.

2006 Before Camp Swift. In An Oral History of Camp Swift: 2004 Interviews, by Martha Doty Freeman, David L. Nickels, and Thad Sitton, Pp. 5-7. Archaeological Studies Report No. 9. Center for Archaeological Studies, Texas State University-San Marcos. 
Bousman, C. Britt, Barry W. Baker, and Anne C. Kerr

2004 Paleoindian Archeology in Texas. In The Prehistory of Texas, edited by Timothy K. Perttula, pp. 15-97. Texas A\&M Press, College Station.

Bousman, C. Britt, Michael B. Collins, Paul Goldberg, Thomas Stafford, Jan Guy, Barry W. Baker, D. Gentry Steele, Marvin Kay, Anne Kerr, Glen Fredlund, Phil Dering, Vance Holliday, Diane Wilson, Wulf Gose, Susan Dial, Paul Takac, Robin Balinsky, Marilyn Masson, and Joseph F. Powell 2002 The Paleoindian-Archaic Transition in North America: New Evidence from Texas. Antiquity 76:980-990.

Boyd, Douglas K.

1997 The Late Archaic Period, ca. 2000 B.C. to A.D. 500. In Caprock Canyonlands Archeology: A Synthesis of the Late Prehistory and History of Lake Allen Henry and the Texas Panhandle Plains, Vol. II, by Douglas K. Boyd, pp. 233-270. Reports of Investigations No. 110. Prewitt \& Associates, Austin.

Brown, Kenneth M.

1966 41BP55. University of Texas Archeological Society notes on file at the Texas Archeological Research Laboratory, The University of Texas at Austin.

Bruseth, James E., and William A. Martin

2001 OSL Dating and Sandy-mantle Sites in East Texas. Current Archeology in Texas 3(1)12-17.

Busch, Jane

1981 An Introduction to the Tin Can. Historical Archaeology 15(1):95-104.

Buder, John J.

2008 Sayersville. The Handbook of Texas Online, Texas State Historical Association. Electronic document, http://www.tshaonline.org/handbook/online/articles/SS/hrs19.html, accessed 9 May 2008.

Clifton, Robert T.

1970 Barbs, Prongs, Points, Prickers, and Stickers. University of Oklahoma Press, Norman.

Collins, Michael B.

1995 Forty Years of Archaeology in Central Texas. Bulletin of the Texas Archeological Society 66:361-400.

2004 Archeology in Central Texas. In The Prehistory of Texas, edited by Timothy K. Perttula, pp. 101-126. Texas A\&M Press, College Station. 
Collins, Michael B. (assembler and editor)

1998 Wilson-Leonard: An 11,000-year Archeological Record in Central Texas, Vols. 1-6. Studies in Archeology 31. Texas Archeological Research Laboratory, The University of Texas at Austin. Archeology Studies Program, Report 10. Texas Department of Transportation, Environmental Affairs Division, Austin.

Covey, C. (editor)

1967 Cabeza de Vaca's Adventures in the Unknown Interior of America. Collier Books, New York.

Cutrer, T. W.

1985 The English Texans. Institute of Texas Cultures, The University of Texas at San Antonio

Davis, E. Mott

1964 Investigations of C. J. McCormick Site near McDade, Bastrop County, Texas. Unpublished notes on file at Texas Archeological Research Laboratory, The University of Texas at Austin.

Dibble, David S.

1976 Results of an Archeological Survey of Areas to be Affected by a Proposed Sanitary Landfill, Camp Swift Texas. Texas Archeological Survey Technical Bulletin No. 11. The University of Texas at Austin.

Dillehay, Thomas D.

1974 Late Quaternary Bison Population Changes on the Southern Plains. Plains Anthropologist 19(64):180-196.

1979 An Archeological Reconnaissance of the Fayette Power Plant to Lytton Springs Transmission Line. Texas Archeological Survey Research Report 73. The University of Texas at Austin.

Doran, Glenn H. (editor)

2002 Windover: Multidisciplinary Investigations of an Early Archaic Florida Cemetery. University of Florida Press, Gainesville.

Durrenberger, E. Paul

1965 Anderson's Mill (41TV130): A Historical Site in Travis County, Texas. Bulletin of the Texas Archeological Society 36:1-70.

Everitt. B. S.

1992 The analysis of contingency tables. Chapman and Hill, London.

Fawcett, William B., Jr.

1975 An Archeological Survey of the Proposed Federal Youth Center, Bastrop County, Texas. Texas Archeological Survey Technical Bulletin No. 10. The University of Texas at Austin. 
Fehrenbach, Theodore R.

1974 Comanches: The Destruction of a People. Knopf Publishing, New York.

Fields, Ross C.

1995 The Archeology of the Post Oak Savannah of East Central Texas. Bulletin of the Texas Archeological Society 66:310-330.

Fox, Anne A., I. Waynne Cox, Lynne Highley, and David Hafernik, with a contribution by Robert Harrison

1989 Archaeological and Historical Investigations at the Site of the New Bexar County Justice Center in Downtown San Antonio, Texas. Archaeological Survey Report No. 184. Center for Archaeological Research, The University of Texas at San Antonio.

Frederick, Charles D., and Mark D. Bateman

2001 OSL Dating and Sandy-mantle Sites in East Texas: A Reply. Current Archeology in Texas 3:2:14-18.

Freeman, Martha Doty

1979 State of Texas Trinomial Form - 41BP157. Electronic document, http://pedernales.thc.state. tx.us, accessed 26 October 2004.

Freeman, Martha Doty, David L. Nickels, and Thad Sitton

2006 An Oral History of Camp Swift: 2004 Interviews. Archaeological Studies Report No. 9. Center for Archaeological Studies, Texas State University-San Marcos.

French's ${ }^{\odot}$

2005 French's ${ }^{\oplus}$ Mustard. Electronic document, http://www.frenchs.com, accessed 19 December 2005.

Goode, Glen T.

1989 Appendix II: Archaeological Testing and Recommendations for the Kennedy Bluffs Site, 41BP19, in Bastrop County, Texas. In Excavations at 41BP19, the Kennedy Bluffs Site, Bastrop County, Texas, by Leland C. Bement. Contract Reports in Archaeology Report 5. Texas State Department of Highways and Public Transportation, Highway Design Division, Austin.

Gould, Frank W.

1975 Texas Plants-A Checklist and Ecological Summary. Bulletin MP-585:5-14. Texas Agricultural Experimentation Station, College Station.

Greaser, Arlene, and Paul H. Greaser

1967 Homespun Ceramics. 3rd edition. Privately printed, Allentown, Pennsylvania. 
Greer, Georgeanna H.

1999 American Stonewares, The Art and Craft of Utilitarian Potters. Schiffer Publishing, Exton, England.

Haberman, Shelby J.

1978 Analysis of Qualitative Data. Volume 1. Academic Press, New York.

Hall, Grant D.

1981 Allens Creek: A Study in the Cultural Prehistory of the Brazos River Valley, Texas. Research Report 61. Texas Archeological Survey, The University of Texas at Austin.

Haslouer-Kay, Leeann

1997 State of Texas Trinomial Form - 41BP157. Electronic document, http://pedernales.thc.state. tx.us, accessed 26 October 2004.

Haslouer-Kay, LeeAnn, Dustin Kay, and Timothy M. Meade

1997 State of Texas Trinomial Form - 41BP487. Electronic document, http://pedernales.thc.state. tx.us, accessed 25 October 2005.

Hershey's

2005 The Hershey Company. Electronic document, http://www.hersheys.com, accessed 1 December 2005.

Hester, Thomas R.

1966 Daily Log, Bastrop Archeological Survey. Unpublished notes on file at the Texas Archeological Research Laboratory, The University of Texas at Austin.

2004 The Prehistory of South Texas. In The Prehistory of Texas, edited by Timothy K. Perttula, pp. 121-151. Texas A\&M Press, College Station.

Houk, Brett A., and Jon C. Lohse

1993 Archeological Investigations at the Mingo Site, Bandera County, Texas. Bulletin of the Texas Archeological Society 61:193-247.

Huebner, Jeffery A.

1991 Late Prehistoric Bison Populations in Central and Southern Texas. Plains Anthropologist 36(137):343-358.

Insulator Collectors On the Net

2005 Glass Factory Marks on Bottles. Electronic document, http://myinsulators.com/glassfactories/bottlemarks3.html, accessed 1 December 2005. 
Intermountain Antiquities Computer System (IMACS)

1992 Manual. Electronic Document, http://www.anthro.utah.edu/imacs.html, accessed 1 March 2008.

2001a 471 - Tin Cans. IMACS User's Guide August 2001. Electronic document, http://www.anthro. utah.edu/IMACs/471-TinCans.pdf, accessed 5 January 2006.

2001b 470 - Nails. IMACS User's Guide August 2001. Electronic document, http://www.anthro. utah.edu/IMACs/470-Nails.pdf, accessed 5 January 2006.

Jelks, Edward B.

1962 The Kyle Site: A Stratified Central Texas Aspect in Hill County, Texas. Archeology Series No. 5. Department of Anthropology, The University of Texas at Austin.

Johnson, LeRoy

1994 The Life and Times of Toyah-Culture Folk: The Buckhollow Encampment, Site 41KM16, Kimble County, Texas. Office of the State Archeologist Report 38. Texas Department of Transportation and Texas Historical Commission, Austin.

Johnson, LeRoy, and Glen T. Goode

1994 A New Try at Dating and Characterizing Holocene Climates, as well as Archaeological Periods, on the Eastern Edwards Plateau. Bulletin of the Texas Archeological Society 65:1-51.

Johnson, LeRoy, Dee Ann Suhm, and Curtis D. Tunnell

1962 Salvage Archaeology of Canyon Reservoir: The Wunderlich, Footbridge, and Oblate Sites. Bulletin No. 5. Texas Memorial Museum, The University of Texas at Austin.

Judson, Sheldon, and Marvin E. Kauffman

1990 Physical Geology. 8th Edition. Prentice Hall, Englewood Cliffs, New Jersey.

Karen Michelle Tiles

2005 Antique Profile \& Portrait Tiles. Electronic document, http://pages.tias.com/9513/Inventory Page/1616719/1.html, accessed 21 December 2005.

Kelley, J. Charles

1947a The Lehmann Rockshelter: A Stratified Site of the Toyah, Uvalde and Round Rock Foci. Bulletin of the Texas Archeological and Paleontological Society 18:115-128.

1947b The Cultural Affiliations and Chronological Position of the Clear Fork Focus. American Antiquity 13(2):97-109.

Kelly, Thomas C., and Erwin Roemer, Jr.

1981 Archaeological and Historical Investigations in Bastrop and Lee Counties, Texas. Archaeological Survey Report No. 101. Center for Archaeological Research, The University of Texas at San Antonio. 
Kendrick, Grace

1966 The Antique Bottle Collector. Western Printing and Publishing Company, Sparks, Nevada.

Korges, William H.

1933 Bastrop County, Texas: Historical and Educational Development, Vol. II. Unpublished Master's thesis. The University of Texas at Austin.

Kovel, Ralph, and Terry Kovel

1986 Kovels' New Dictionary of Marks: Pottery and Porcelain 1850 to the Present. Crown Publishers Inc., New York.

Leatherwood, Art

2008 Camp Swift. The Handbook of Texas Online, Texas State Historical Association. Electronic document, http://www.tshaonline.org/handbook/online/articles/CC/qbc27.html, accessed 9 May 2008.

Lehner, Lois

1988 Lehner's Encyclopedia of U.S. Marks on Pottery, Porcelain, and Clay. Schroeder Press, Paducah, Kentucky.

Leffler, John J.

2001 The History of the Camp Swift Area, 1830-1950. In An Archaeological Inventory of Camp Swift, Bastrop County, Texas, by David G. Robinson, Timothy M. Meade, LeeAnn HaslouerKay, Linn Gassaway, and Dustin Kay, pp. 153-166. Archaeological Survey Report No. 316. Center for Archaeological Research, The University of Texas at San Antonio.

Lehman, Melissa L., David L. Nickels, and Antonio Padilla

2003 Site Descriptions, Analysis, and Recommendations. In Archaeological Evaluation of 39 Category V Sites at Camp Swift, Bastrop County, Texas: 2001, by David L. Nickels, Melissa L. Lehman, and C. Britt Bousman, pp. 25-132. Archaeological Studies Report No. 3. Center for Archaeological Studies, Southwest Texas State University, San Marcos.

Leshley, Christina M.

1994 Archeological Survey for Ammunition Storage Facilities at Camp Swift, Bastrop County, Texas. Unpublished Archeological Survey Report. Adjutant General's Department of Texas, Austin.

1996 Archeological Survey for the Proposed Army Aviation Support facility at the Camp Swift Military Reservation, Bastrop County, Texas. Unpublished Archeological Survey Report. Adjutant General's Department of Texas, Austin.

Lim, Brandy G., Frederic B. Pearl, and Sue W. Moss

2000 Cultural Resources Survey of US 290; SH 95 to One Mile East of FM 696, Bastrop County, Texas. Report of Investigations No. 1. Quadrant Consultants, Inc., Houston. 
Lindsey, William

2005 Historic Glass Bottle Identification \& Information Website. Electronic document, www.sha. org/bottle/colors.htm\#Colorless, accessed 19 December 2005.

Lockhart, Bill

2004 The Dating Game. Bottles and Extras Summer 2004:2-5. Electronic document, http://www. blm.gov/historic_bottles/pdffiles/owensIll_Blockhart.pdf, accessed 1 December 2005.

Logan, Herschel C.

1959 Cartridges - A Pictorial Digest of Small Arms Ammunition. Bonanza Books, New York.

Lohse, Jon C.

1999 Lithics from the San Antonio de Valero Mission: Analysis of Materials from the 1979 Excavations of the Alamo. Bulletin of the Texas Archeological Society 70:265-279.

Lohse, Jon C., and C. Britt Bousman

2006 National Register Evaluation of Eight Sites at Camp Swift Army National Guard Training Center, Bastrop County, Texas: Swift V. Archaeological Studies Report No. 8. Center for Archaeological Studies, Texas State University-San Marcos.

Malone, James

1968 Archeological Site Survey Work in Bastrop County. Report on file, Texas Archeological Research Laboratory, The University of Texas at Austin.

Marks, Paula Mitchell

2008a Bastrop County. The Handbook of Texas Online, Texas State Historical Association. Electronic document, http://www.tshaonline.org/handbook/online/articles/BB/hcb3.html, accessed 9 May 2008.

2008b McDade. The Handbook of Texas Online, Texas State Historical Association. Electronic document, http://www.tshaonline.org/handbook/online/articles/MM/hlm45.html, accessed 9 May 2008.

2008c Elgin. The Handbook of Texas Online, Texas State Historical Association. Electronic document, http://www.tshaonline.org/handbook/online/articles/EE/hge6.html, accessed 9 May 2008.

Martin, William A., Bonnie C. Yates, and Gale J. Fritz

1988 Exploitation of Subsistence Resources within the Mountain Creek Drainage. In Late Holocene Prehistory of the Mountain Creek Drainage, edited by Duane E. Peter and Daniel E. McGregor. Joe Pool Lake Archaeological Project Vol. I. Archaeology Research Program, Southern Methodist University, Dallas. 
Mauldin, Raymond P.

2001 Assessments and Recommendations. In An Archaeological Inventory of Camp Swift, Bastrop County, Texas, by David G. Robinson, Timothy M. Meade, LeeAnn Haslouer-Kay, Linn Gassaway, and Dustin Kay, pp. 175-186. Archaeological Survey Report Number 316. Center for Archaeological Research, The University of Texas at San Antonio.

2003a Development of Burned Rock Middens at Camp Bowie. In Archaeological Testing to Determine the National Register Eligibility Status of 18 Prehistoric Sites on Camp Bowie, Brown County, Texas, 2 vols, by Raymond P. Mauldin, David L. Nickels, and Cory J. Broehm, with contributions by C. Britt Bousman, J. Philip Dering, Glenn A. Goodfriend, Linda Hodges, Jeffrey R. Francis, and Barbara A. Meissner, pp. 175-196. Archaeological Survey Report No. 334. Center for Archaeological Research, The University of Texas at San Antonio. Adjutant General's Department of Texas, Department of Facilities and Engineering, Environmental Branch, Austin.

2003b Subsistence Issues in Camp Bowie Middens. In Archaeological Testing to Determine the National Register Eligibility Status of 18 Prehistoric Sites on Camp Bowie, Brown County, Texas, 2 vols., by Raymond P. Mauldin, David L. Nickels, and Cory J. Broehm, with contributions by C. Britt Bousman, J. Philip Dering, Glenn A. Goodfriend, Linda Hodges, Jeffrey R. Francis, and Barbara A. Meissner, pp. 197-208. Archaeological Survey Report No. 334. Center for Archaeological Research, The University of Texas at San Antonio. Adjutant General's Department of Texas, Department of Facilities and Engineering, Environmental Branch, Austin.

Metcalfe, Tom Brooks

2001 McDade Pottery. The Handbook of Texas Online. Electronic document, http://www.tsha. utexas.edu/handbook/online/articles/MM/dlmdt.html, accessed 2 January 2006.

Meissner, Barbara A.

1991 Notes on the Excavation of 41BX952. Manuscript on file. Center for Archaeological Research, The University of Texas at San Antonio.

1997 Making the Man: Clothing Remains from the Alamodome Project. In Archaeology at the Alamodome: Investigations of a San Antonio Neighborhood in Transition, Vol. III, edited by Anne A. Fox, Marcie Renner, and Robert J. Hard, pp. 119-164. Archaeological Survey Report No. 238. Center for Archaeological Research, The University of Texas at San Antonio.

Moir, Randall W.

1988 Window Glass. In Historic Farming on the Hogwallow Prairies, Ethnoarchaeological Investigations of the Mountain Creek Area, North Central Texas. Joe Pool Lake Archaeological Project Vol. 2. Archaeological Research Program, Institute for the Study of Earth and Man, Southern Methodist University, Dallas. 
Montgomery Ward \& Co.

1969 Unabridged Facsimile, Catalogue No. 57, Montgomery Ward \& Co., Spring \& Summer 1895. Dover Publications, Inc, New York.

Morris, W.

1970 The Wichita Exchange; Trade on Oklahoma's Fur Frontier, 1719-1812. Great Plains Journal (9)2:79-84. Great Plains Historical Association, Lawton, Oklahoma.

Mrs. Stewart's® Bluing

2005 The History of Mrs. Stewart's ${ }^{\circledR}$ Bluing. Electronic document, http://www.mrsstewart.com/ pages/history.htm, accessed 1 December 2005.

Munsey, Cecil

1970 The Illustrated Guide to Collecting Bottles. Hawthorn Books, Inc., New York.

Nash, Michael A., Derek Green, Edward Baxter, and Russell K. Brownlow

1996 Class III Cultural Resources Inventory and Biological Survey of 4 Wellpads and Access Road Routes, Camp Swift, Bastrop County, Texas. Document No. 960561, EH\&A Job No. 17293. Espey, Huston \& Associates, Inc., Austin.

Nash, Michael A., Rick F. Taylor, and Elizabeth A. Skokan

1995 A Cultural Resources Survey of the McNeil-Bastrop 138-Kv Transmission Line Rebuild Project, Bastrop and Travis Counties, Texas. TAP No. 1487. Espey, Huston \& Associates, Austin.

Nelson, Lee H.

1968 Nail Chronology as an Aid to Dating Old Buildings. American Association for State and Local History Technical Leaflet No. 48. Nashville, Tennessee.

Nickels, David L.

2003 Historic Artifact Analysis. In Archaeological Testing of the Burleson Homestead at 41HY37, Hays County, Texas, assembled by C. Britt Bousman, David L, Nickels, pp. 49-88. Archaeological Studies Report No. 5. Center for Archaeological Studies, Texas State University-San Marcos.

Nickels, David L., and C. Britt Bousman, with contributions by James E. Barrera, John Bongino, J. Philip Dering, Tom Hallmark, Jessica L. Hurley, Lee Nordt, Barbara A. Meissner, and Antonio E. Padilla

2008 Archaeological Excavations on 20 Prehistoric Sites at Camp Swift, Bastrop County, Texas: 2002. Archaeological Studies Report No. 12. Center for Archaeological Studies, Texas State University-San Marcos. 
Nickels, David L., C. Britt Bousman, Jeff D. Leach, and Diane A. Cargill

2001 Test Excavations at the Culebra Creek Site, 41BX126, Bexar County, Texas. Archaeological Survey Report No. 265. Center for Archaeological Research, The University of Texas at San Antonio. Archeology Studies Program Report 3. Environmental Affairs Division, Texas Department of Transportation, Austin.

Nickels, David L., and Melissa Lehman

2004 Archaeological Evaluation of Sandy Mantle Prehistoric and Historic Sites at Camp Swift, Bastrop County, Texas: 2003. Archaeological Studies Report No. 5. Center for Archaeological Studies, Texas State University-San Marcos.

Nickels, David L., Melissa Lehman, and C. Britt Bousman

2003 Archaeological Evaluation of 39 Category V Sites at Camp Swift, Bastrop County, Texas: 2001. Archaeological Studies Report No. 3. Center for Archaeoolgical Studies, Southwest Texas State University, San Marcos.

Nickels, David L., Antonio Padilla, James E. Barrera, and C. Britt Bousman

2005 An Archaeological Survey of 307 Acres at Camp Swift, Bastrop County, Texas: 2003. Archaeological Studies Report No. 6. Center for Archaeological Studies, Texas State University-San Marcos.

Nightengale, Bruce A., and Henry B. Moncure

1996 Intensive Cultural Resource Survey and Monitoring at the LCRA Camp Swift Regional Wastewater Project, Bastrop County, Texas. Cultural Resources Report No. 3. Lower Colorado River Authority, Environmental Protection Division, Austin.

Nightengale, Bruce A., Dan K. Utley, C. Christopher Caran, and H. G. Wooldridge 1992 Cultural Resource and Geomorphological Investigations at the Powell Bend II Lignite Prospect, Bastrop County, Texas. Cultural Resources Report No. 1. Lower Colorado River Authority, Environmental Services Department, Austin.

Oviatt, Charles G., David B. Madsen, and Dave N. Schmitt

2003 Late Pleistocene and Early Holocene Rivers and Wetlands in the Bonneville Basin of Western North America. Quaternary Research 60(2003):200-210.

Patterson, Leland W.

1995 The Archeology of Southeast Texas. Bulletin of the Texas Archeological Society 66:239-264.

Polak, Michael

1997 Bottles Identification and Price Guide. Avon Books. New York. 
Pool, Joe C.

1987 Fanthorp Inn: A Study of Nineteenth and Twentieth Century Buttons. In Archaeological Excavations at Fanthorp Inn State Historic Site (41GM79), Grimes County, Texas, 1982, by J. David Ing, pp. 277-293. Texas Parks and Wildlife Department, Historic Sites and Restoration Branch, Austin.

Prewitt, Elton R.

1974 Archeological Investigations at the Loeve-Fox Site, Williams County, Texas. Research Report 49. Texas Archeological Survey, The University of Texas at Austin.

1981 Culture Chronology in Central Texas. Bulletin of the Texas Archeological Society 52:65-89.

1985 From Circleville to Toyah: Comments on Central Texas Chronology. Bulletin of the Texas Archeological Society 54:201-238.

1991 Burned Rock Middens: A Summary of Previous Investigations and Interpretations. In The Burned Rock Middens of Texas: An Archeological Symposium, edited by Thomas R. Hester, pp. 25-32. Studies in Archeology 13. Texas Archeological Research Laboratory, The University of Texas at Austin.

Prochnow, Shane

2001 Geoarchaeological Assessment. In An Archaeological Inventory of Camp Swift, Bastrop County, Texas, by David G. Robinson, Timothy M. Meade, LeeAnn Haslouer-Kay, Linn Gassaway, and Dustin Kay, pp. 31-37. Archaeological Survey Report No. 316. Center for Archaeological Research, The University of Texas at San Antonio.

Ray, Marcia

1974 Collectible Ceramics, An Encyclopedia of Pottery and Porcelain for the American Collector. Crown Publishing, New York.

Remington

2005 Remington Arms Company History of the Firearms Business 1816-Present. Electronic document, http//:www.Remington.com/library/history/company_history.asp, accessed 5 December 2005.

Rhodes, Sue, and Bridget Carson

2005 Fanny \& Vera's Site for New Civilians: Enamelware/Graniteware. Electronic document, http://www.shasta.com/suesgoodco/newcivilians/faq/qenamelware.htm, accessed 4 January 2006.

Richardson, Rupert N.

1991 The Comanche Barrier to South Plains Settlement. Hardin-Simmons University, Abilene, TX. 


\section{Ricklis, Robert A.}

1994 Toyah Components: Evidence for Occupation in the Project Area During the Latter Part of the Late Prehistoric Period. In Archaic and Late Prehistoric Human Ecology in the Middle Onion Creek Valley, Hays County, Texas, by Robert A. Ricklis and Michael B. Collins, pp. 207-316. Studies in Archeology 19. Texas Archeological Research Laboratory, The University of Texas at Austin.

2005 Analysis of Findings at the Buckeye Knoll Site (41VT98), Victoria County, Texas: Quarterly Report No. 5 (Through January 24, 2005). Electronic document, http://www.swg.usace.army. mil/pe/41VT98/QR/QuarterlyReport5.pdf, accessed 12 October, 2005.

Robinson, David G.

2001 Historic Contexts for Camp Swift. In An Archaeological Inventory of Camp Swift, Bastrop County, Texas, by David G. Robinson, Timothy M. Meade, LeeAnn Haslouer-Kay, Linn Gassaway, and Dustin Kay, pp. 155-159. Archaeological Survey Report No. 316. Center for Archaeological Research, The University of Texas at San Antonio.

Robinson, David G., Timothy M. Meade, LeeAnn Haslouer-Kay, Linn Gassaway, and Dustin Kay, with contributions by John J. Leffler, Shane Prochnow, Raymond P. Mauldin, and Steve A. Tomka 2001 An Archaeological Inventory of Camp Swift, Bastrop County, Texas, edited by Barbara A. Meissner. Archaeological Survey Report No. 316. Center for Archaeological Research, The University of Texas at San Antonio.

Rogers, Robert

1994 Excavations at Site 41GM224 in the Gibbons Creek Lignite Mine Permit 38A Area, Grimes County, Texas. Document No. 930476, EH\&A Job No. 14553. Espey, Huston \& Associates, Inc., Austin.

Rogers, Robert, and Steven M. Kotter

1995 Archaeological Investigations at the Chesser Site (41LE59), at the Sandow Lignite Mine, Lee County, Texas. Espey, Huston \& Associates, Inc., Austin.

Root, Matthew J., Jerry D. William, Marvin Kay, and Lisa K. Shifrin

1999 Folsom Ultrathin Biface and Radial Break Tools in the Knife River Flint Quarry Area. In Folsom Lithic Technology: Explorations in Structure and Variation, edited by Daniel S. Amick, pp. 144-168. International Monographs in Prehistory, Archaeology Series 12. University of Michigan, Ann Arbor.

Savage Arms \& Stevens FAQ

2006 How Old is a Stevens Pocket Rifle? Electronic document, http://www.faqfarm.com/Qhow_ old_is_a_Stevens_Rifle, accessed 6 January 2006. 
Schmidt, James S., Maria E. Cruse, and Russell K. Brownlow

1995 Cultural Resources Survey, Camp Swift, Bastrop County, Texas. Espey, Huston \& Associates, Inc., Austin.

Schroeder, Joseph J. (editor)

1989 Gun Collector's Digest. 5th ed. DBI Books, Inc. Northbrook, Illinois.

Schroy, Ellen T.

2000 Warman's Depression Glass: A Value \& Identification Guide. 2nd ed. Krause Publications. Iola, Wisconsin.

Sears, Roebuck and Co.

1993 Sears, Roebuck and Co., The Great Price Maker. Facsimile of the 1902 Edition, Gramercy Books, New York.

Sellards, E. H., W. S. Adkins, and F. B. Plummer

1932 The Geology of Texas: Volume I. Stratigraphy. Bulletin No. 3232. Bureau of Economic Geology, The University of Texas at Austin.

Sitton, Thad

2006 Sandyland Farmers: Life in the Countryside Before Camp Swift, 1920-1942. Archaeological Studies Report No. 10. Center for Archaeological Studies, Texas State University-San Marcos.

Skelton, Duford W.

1979 Part I. Prehistoric Resources. In A Cultural Resource Inventory and Assessment at Camp Swift, Texas, by Duford W. Skelton and Martha Doty Freeman, pp 3-80. Report No. 72. Texas Archeological Survey, The University of Texas at Austin.

Skelton, Duford W., and Martha Doty Freeman

1979 A Cultural Resource Inventory and Assessment at Camp Swift, Texas. Report No. 72. Texas Archeological Survey, The University of Texas at Austin.

Snyder, Jeffrey B.

1992 Flow Blue, A Collector's Guide to Patterns, History, and Values. Schiffer Publishing Ltd. Atglen, Pennsylvania.

Smith, Michael D.

1989 Texas Glass: An Illustrated History of the Three Rivers Glass Company, 1922-1937. Atwood Printing, New Braunfels, Texas. 
Sorrow, William M., Harry J. Shafer, and Richard E. Ross

1967 Excavations at Stillhouse Hollow Reservoir. Papers of the Texas Archeological Salvage

Project No. 11. Texas Archeological Salvage Project, The University of Texas at Austin.

Spangler, John

2005 Antique and Collectible Firearms and Militaria Headquarters. Electronic document, http//:

www.oldguns.net/q\&a12_00.htm, accessed 5 December 2005.

Steinbomer, Robert A.

1982 Brickmaking in Texas: A History of the Industry and its Product. Unpublished manuscript on file at Texas Historical Commission Library, Austin.

Story, Dee Ann

1985 Adaptive Strategies of Archaic Cultures of the West Gulf Coastal Plain. In Prehistoric Food Production in North America, edited by Richard I. Ford, pp. 19-56. Anthropological Papers No. 75. Museum of Anthropology, University of Michigan, Ann Arbor.

1990 Cultural History of the Native Americans. In The Archeology and Bioarcheology of the Gulf Coastal Plain, Vol. 1, by Dee Ann Story, Janice A. Guy, Barbara Burnett, Martha Doty Freeman, Jerome C. Rose, D. Gentry Steele, Ben W. Olive, and Karl J. Reinard, pp. 163-366. Research Series No. 38. Arkansas Archeological Survey, Fayetteville.

Stringer, Stephen S., and Alan J. Wormser

1996 Archeological Survey for Proposed Pond Improvements, Camp Swift Military Reservation, Bastrop County, Texas. Unpublished Archaeological Survey Report. Adjutant General's Department of Texas, Austin.

Suhm, Dee Ann

1957 Excavations at the Smith Rockshelter, Travis County, Texas. The Texas Journal of Science 9:26-58.

Sullo, Dawn M., and Alan J. Wormser

1996 Archeological Survey for Proposed Bradley Fighting Vehicle Training "Area A" at Camp Swift Military Reservation, Bastrop County, Texas. Unpublished Archaeological Survey Report. Adjutant General's Department of Texas, Austin.

Taylor, Anna J.

1987 Archaeological Survey of the CPS Butler Lignite Prospect, Bastrop and Lee Counties, Texas, 1984. Archaeological Survey Report No. 151. Center for Archaeological Research, The University of Texas at San Antonio.

Tera Corporation

1978 Preliminary Drafts of Selected LCRA Inputs to BLM for Camp Swift Lignite Lease. Dallas. 
Texas Historical Commission

2006 Texas Historical Sites Atlas. Electronic document, http://nueces.thc.state.tx.us/, accessed 21 March 2006.

Texas State Historical Association

2001 Big Sandy Creek. The Handbook of Texas Online. Electronic document, http://www.tsha. utexas.edu/handbook/online/articles/view/BB/rbbda.html, accessed 22 March 2006.

Toulouse, Julian $\mathrm{H}$.

1969 Fruit Jars: A Collectors' Manual. Thomas Nelson \& Sons, Camden, New Jersey

1971 Bottle Makers and Their Marks. Thomas Nelson Inc., New York.

Turner, Ellen Sue, and Thomas R. Hester

1999 A Field Guide to Stone Artifacts of Texas. 3rd ed. Gulf Publishing Co., Houston.

Tyler, Ron (editor)

1996 The New Handbook of Texas. The Texas State Historical Association, Austin.

Voellinger, Melissa

1987 Cultural Resources Investigations of Portions of the Proposed Bastrop to Elgin Waterline, Bastrop County, Texas. Document No. 870461, EH\&A Job No. 10141. Espey, Huston \& Associates, Inc. Austin.

Weir, Frank A.

1976 The Central Texas Archaic. Unpublished Ph.D. dissertation. Anthropology Department, Washington State University, Pullman.

Wilbarger, John W.

1985 [1889] Indian Depredations in Texas: Original Narratives of Texas History and Adventure,

1885. Reprinted. Eakin Press, Austin. Originally published 1889, Hutchings Printing House, Austin.

Wilding, Larry P.

2000 Classification of Soils. In Handbook of Soil Science, edited by Malcolm E. Summer, pp. E175-E-392. CRC Press, Boca Raton, Florida.

Wilmarth, M. Grace (compiler)

1938 Lexicon of Geologic Names of the United States (Including Alaska). 2 vols. Bulletin 896. Geological Survey, United States Department of the Interior. United States Government Printing Office, Washington, D.C. 
Wilson, A. M.

1930 Aerial Survey of Travis, Bastrop and Fayette Counties. Report on file, Texas Archeological Research Laboratory, The University of Texas at Austin.

Winship, G. P.

1973 [1896] The Coronado Expedition, 1540-1542. In Fourteenth Annual report of the Bureau of American Etnology 1892-1893, Part I, pp. 339-637. Government Printing Office, Washington, D. C.

Woodhead, Eileen I., Catherine Sullivan, and Gerard Gusset

1984 Lighting Devices in the National Parks Reference Collection, Parks Canada. Studies in Archaeology, Architecture, and History. National Historic Parks and Sites Branch, Parks Canada, Environment Canada, Ottawa, Ontario.

Wormington, Hannah M.

1957 Ancient Man in North America. $4^{\text {th }}$ ed. Denver Museum of Natural History, Denver.

Wormser, Alan J.

1993a Archeological Survey of Proposed Tank Ditches at the Northwest Side of Scott Hill at Camp Swift, Bastrop County, Texas. Unpublished Archaeological Survey Report. Adjutant General's Department of Texas, Austin.

1993b Archeological Survey of a Proposed Septic Field East of the Blackwell Drop Zone at Camp Swift, Bastrop County, Texas. Unpublished Archaeological Survey Report. Adjutant General's Department of Texas, Austin.

1994 Archeological Survey for Rechannelization of a Stream at the M60 Range Firing Line at Camp Swift, Bastrop County, Texas. Unpublished Archaeological Survey Report. Adjutant General's Department of Texas, Austin.

Wormser, Alan J., LeeAnn Haslouer-Kay, and Dustin Kay

1997 Archaeological Investigation of Road and Firebreak Improvements at Camp Swift, Bastrop County, Texas. Unpublished Archaeological Survey Report. Adjutant General's Department of Texas, Austin.

Wormser, Alan J., and Christina M. Leshley

1995 Archeological Survey for the Proposed $386^{\text {th }}$ Engineer Battalion Annual Squad and Platoon Training at Camp Swift, Bastrop County, Texas. Unpublished Archaeological Survey Report. Adjutant General's Department of Texas, Austin.

Wyckoff, Donald G.

1995 A Summary of the Calf Creek Horizon in Oklahoma. Bulletin of the Oklahoma Anthropological Society 42:179-210. 
Young, Vicki

2006 Wm. Rogers Silver. Centennial Antiques. Electronic document, http://www. centennialantiques.com, accessed 8 May 2006. 


\section{Appendix A Swift VI Project Site Boundaries}

By Damon P. Stone

\section{Restricted ACCess Only}

Combined USGS Quandrangle map showing site locations on Camp Swift.

Located in pocket inside the back cover. 


\section{Appendix B \\ Swift VI Project Isolated Finds}

By Damon P. Stone

\section{Restricted AcCess OnLY}

Combined USGS Quandrangle map showing isolated finds on Camp Swift.

Located in pocket inside the back cover. 


\section{Appendix C}

\section{Camp Swift Historic Sites Data}

\begin{tabular}{|c|c|c|c|c|c|}
\hline Site No. & $\begin{array}{l}\text { Earliest } \\
\text { Date }\end{array}$ & $\begin{array}{c}\text { Latest } \\
\text { Date }\end{array}$ & Site Type & 1929 Owner & Owner \\
\hline 41BP105 & 1885 & 1924 & Agricultural & $\begin{array}{c}\text { Antoine } \\
\text { Aussiloux estate }\end{array}$ & \\
\hline 41BP132 & 1870 & 1942 & House & & Floyd \\
\hline 41BP133 & 1885 & 1936 & House & & John Scott \\
\hline 41BP134 & 1866 & 1942 & House & & Abner Scott \\
\hline 41BP135 & 1890 & 1942 & House & & Fleming \\
\hline 41BP136 & 1945 & 1965 & Corral & & Otis Evans \\
\hline 41BP137 & 1900 & 1930 & House & & John Gest to Ernst \\
\hline 41BP138 & 1876 & 1924 & House/Winery & & Aussilloux \\
\hline 41BP139 & 1880 & 1942 & House & & Russell \\
\hline 41BP140 & 1883 & 1913 & House & & John Gest to W. P. Culp \\
\hline 41BP141 & 1890 & 1942 & House & & $\begin{array}{c}\text { Heinze? Brown? Amanda } \\
\text { Nicholas? }\end{array}$ \\
\hline 41BP142 & 1880 & 1900 & House & & \\
\hline 41BP143 & 1840 & 1940 & House/Fort & & \\
\hline 41BP144 & 1925 & 1942 & House & & W. H. Joiner? \\
\hline 41BP145 & 1857 & 1883 & Chandler Cemetery & & \\
\hline 41BP146 & 1878 & 1913 & Grave & & \\
\hline $41 \mathrm{BP} 147$ & 1900 & 1942 & House & & Otis Evans \\
\hline 41BP148 & 1899 & 1928 & Mine/Residences & & \\
\hline 41BP149 & 1930 & 1942 & House & & Charlie Sowell \\
\hline 41BP150 & 1850 & $1900 ?$ & House & & \\
\hline 41BP151 & 1880 & 1940 & House & & \\
\hline 41BP152 & 1911 & 1942 & House & & Gus Sowell? \\
\hline 41BP153 & 1880 & 1915 & House & & \\
\hline 41BP154 & 1902 & 1931 & Wayside School & & \\
\hline 41BP155 & 1930 & 1942 & House & & \\
\hline 41BP156 & 1890 & 1942 & House & & \\
\hline 41BP157 & 1910 & 1942 & House & & \\
\hline 41BP158 & 1880 & 1942 & House & & Beck \\
\hline 41BP159 & 1920 & 1942 & House & & Eschberger \\
\hline 41BP160 & 1930 & 1942 & Corral & & \\
\hline
\end{tabular}




\begin{tabular}{|c|c|c|c|c|c|}
\hline Site No. & $\begin{array}{l}\text { Earliest } \\
\text { Date }\end{array}$ & $\begin{array}{c}\text { Latest } \\
\text { Date }\end{array}$ & Site Type & 1929 Owner & Owner \\
\hline 41BP161 & 1920 & 1942 & House & & Cottle \\
\hline 41BP162 & 1920 & 1942 & House & & Scruggs \\
\hline 41BP163 & 1930 & 1942 & Well & & Scruggs \\
\hline 41BP164 & 1890 & 1942 & House & & \\
\hline 41BP165 & 1905 & 1942 & House & & George Thomas \\
\hline 41BP166 & Unk & Unk & Corral & & Lewis \\
\hline 41BP167 & 1930 & 1942 & House & & \\
\hline 41BP168 & Unk & Unk & Well & & Chandler? \\
\hline 41BP169 & Unk & Unk & House & & Chandler? \\
\hline 41BP170 & 1914 & 1928 & Mexican Cemetery & & \\
\hline 41BP171 & 1880 & 1942 & House & & \\
\hline 41BP172 & 1930 & 1942 & House & & \\
\hline 41BP183 & Unk & Unk & House & & \\
\hline 41BP184 & 1880 & 1920 & House & & \\
\hline 41BP379 & Unk & Unk & Trash Scatter & & \\
\hline 41BP380 & 1845 & 1920 & Trash Scatter & & \\
\hline 41BP382 & 1882 & 1940 & $\begin{array}{l}\text { New Hope } \\
\text { Cemetery }\end{array}$ & & \\
\hline 41BP385 & 1880 & 1930 & Trash Scatter & & \\
\hline 41BP396 & 1930 & 1940 & Trash Scatter & & \\
\hline 41BP397 & 1914 & 1942 & House & & C. R. Nick Branton \\
\hline 41BP400 & 1880 & 1942 & Trash Scatter & & \\
\hline 41BP430 & 1923 & 1942 & House & & \\
\hline 41BP433 & 1900 & 1942 & House & & \\
\hline 41BP434 & Unk & Unk & House & & \\
\hline $41 \mathrm{BP} 473$ & Unk & Unk & House & & J. Sanders \\
\hline 41BP479 & 1922 & 1942 & House & & Perry \& Sarah Floyd \\
\hline 41BP480 & Unk & Unk & Trash Scatter? & & \\
\hline 41BP481 & Unk & Unk & Bridge & & \\
\hline 41BP482 & Unk & Unk & Bridge & & \\
\hline 41BP483 & 1880 & 1910 & Trash Scatter & & \\
\hline 41BP484 & 1899 & 1942 & House & & John W. "Doll” Fort \\
\hline 41BP485 & Unk & Unk & Trash Scatter & & Kemp \\
\hline 41BP487 & Unk & Unk & Trash Scatter & & \\
\hline 41BP489 & Unk & Unk & Industrial & & \\
\hline 41BP490 & 1932 & 1942 & House & & $\begin{array}{l}\text { F. Gordon and B. C. \& Hettie } \\
\text { Daughtry }\end{array}$ \\
\hline 41BP492 & 1910 & 1942 & Trash Scatter & & $\begin{array}{c}\text { F. Gordon and B. C. \& Hettie } \\
\text { Daughtry }\end{array}$ \\
\hline 41BP500 & 1930 & 1942 & Trash Scatter & & T.H. \& Ada Lockett \\
\hline 41BP501 & Unk & Unk & Trash Scatter & & Amanda Owens \\
\hline
\end{tabular}




\begin{tabular}{|c|c|c|c|c|c|}
\hline Site No. & $\begin{array}{l}\text { Earliest } \\
\text { Date }\end{array}$ & $\begin{array}{l}\text { Latest } \\
\text { Dates }\end{array}$ & Site Type & 1929 Owner & Owner \\
\hline 41BP502 & 1942 & 1966 & Trash Scatter & & Florence Woods \\
\hline 41BP503 & 1942 & 1956 & Trash Scatter & & Florence Woods \\
\hline $41 \mathrm{BP} 504$ & 1930 & 1942 & Trash Scatter & & \\
\hline 41BP507 & 1942 & 1950 & Trash Scatter & & \\
\hline 41BP508 & 1930 & 1960 & Trash Scatter & & \\
\hline 41BP511 & 1880 & 1942 & House & & \\
\hline 41BP513 & 1880 & 1903 & House & & Lonnie Lane \\
\hline 41BP514 & 1934 & 1942 & Well & & \\
\hline 41BP515 & 1929 & 1960 & Trash Scatter & & \\
\hline 41BP516 & Unk & Unk & Well & & \\
\hline 41BP517 & Unk & Unk & Trash Scatter & & \\
\hline 41BP518 & 1930 & 1942 & Trash Scatter & & \\
\hline 41BP519 & Unk & Unk & Trash Scatter & & \\
\hline 41BP520 & 1914 & 1942 & House & & C.R. Nick Branton \\
\hline $41 \mathrm{BP} 523$ & 1900 & 1942 & House & & \\
\hline 41BP525 & 1930 & 1942 & House & & \\
\hline 41BP531 & Unk & Unk & Trash Scatter & & \\
\hline 41BP532 & 1930 & 1942 & House & & \\
\hline 41BP534 & 1880 & 1915 & Trash Scatter & & \\
\hline 41BP663 & 1890 & 1942 & House & & S. Vonkochneritz \\
\hline 41BP666 & 1927 & 1942 & House & & Noel Branton \\
\hline 41BP668 & 1875 & 1942 & House & & J. Sanders \\
\hline 41BP670 & 1890 & 1942 & $\begin{array}{c}\text { Outbuilding and } \\
\text { Dam }\end{array}$ & & S. Vonkochneritz \\
\hline $41 \mathrm{BP} 695$ & 1865 & 1942 & House & & Jackson S. Morgan \\
\hline 41BP698 & 1891 & 1942 & Brick Scatter & & Jackson S. Morgan \\
\hline $41 \mathrm{BP} 700$ & Unk & Unk & Bridge & & \\
\hline 41BP701 & Unk & Unk & Bridge & & \\
\hline $41 \mathrm{BP} 703$ & 1875 & 1925 & Farmstead & & C. Westbrook \\
\hline 41BP711 & 1910 & 1942 & Trash Scatter & & B. C. \& Jettie Daughtry \\
\hline $41 \mathrm{BP} 712$ & 1905 & 1942 & Trash Scatter & & B. C. \& Jettie Daughtry \\
\hline 41BP718 & 1890 & 1920 & House & & C. B. Branton \\
\hline $41 B P 729$ & Unk & Unk & Bridge & & \\
\hline $41 \mathrm{BP} 730$ & 1875 & 1942 & House & & David Scott \\
\hline $41 \mathrm{BP} 734$ & 1875 & 1925 & House & & S. Haller \\
\hline $41 \mathrm{BP} 735$ & 1869 & 1942 & House & & Jones \\
\hline 41BP741 & 1875 & 1942 & Trash Scatter & & Cynthia Floyd \\
\hline 41BP742 & 1875 & 1930 & House & & J. Evans \\
\hline $41 \mathrm{BP} 745$ & 1930 & 1942 & House & & J. Evans \\
\hline $41 \mathrm{BP} 746$ & Unk & Unk & Bridge & & \\
\hline 41BP751 & 1920 & 1942 & Trash Scatter & & J. Evans \\
\hline
\end{tabular}




\begin{tabular}{|c|c|c|c|c|c|}
\hline Site No. & $\begin{array}{c}\text { Ealiest } \\
\text { Date }\end{array}$ & $\begin{array}{c}\text { Latest } \\
\text { Date }\end{array}$ & Sity Type & $\mathbf{1 9 2 9}$ Owner & Owner \\
\hline 41BP752 & 1880 & 1920 & House & & J. Evans \\
\hline 41BP760 & 1845 & 1900 & Quarry & J. Evans & Herms \& Gest \\
\hline 41BP767 & 1850 & 1915 & House & & \\
\hline 41BP771 & 1840 & 1900 & House & J. Evans & Uriah Foster \\
\hline 41BP773 & 1875 & 1925 & House & & Hood et al. \\
\hline 41BP775 & 1930 & 1942 & House & & Hood et al. \\
\hline 41BP776 & 1880 & 1930 & House & & Joe Owens \\
\hline 41BP784 & 1880 & 1920 & House & & Minnie Shelton \\
\hline 41BP785 & 1880 & 1920 & House & & H. Washington \\
\hline 41BP791 & Unk & Unk & House & & H. Washington \\
\hline 41BP793 & Unk & Unk & Corral & & \\
\hline 41BP794 & Unk & Unk & Corral & & \\
\hline 41BP795 & 1875 & 1942 & House & & \\
\hline 41BP803 & 1875 & 1900 & House & & \\
\hline 41BP96 & 1910 & 1942 & Trash Scatter & & \\
\hline
\end{tabular}

